

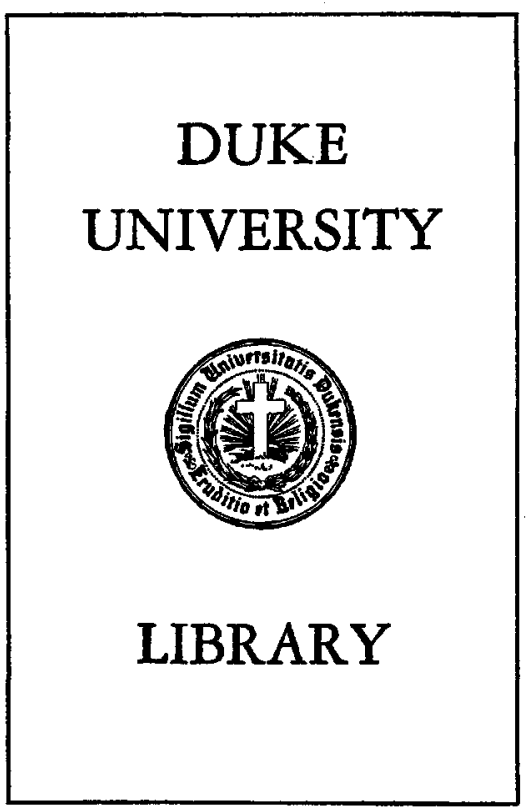








\title{
Eugenical Sterilization in the
} United States

\author{
By \\ Harry Hamilton Laughlin, D. Sc. \\ Assistant Director of the Eugenics Record Office, \\ Carnegie Institution of Washington, \\ Cold Spring Harbor, Long Island, New York, \\ and \\ Eugenics Associate of the Psychopathic Laboratory \\ of the Municipal Court of Chicago.
}

Published by the

Psychopathic Laboratory of the Municipal Court of Chicago

DECEMBER, 1922 
Copyright, 1882 ,

by the Municipal Court of Chicago.

FRED KLFIN CO. 


\section{Introduction}

Dr. Harry H. Laughlin, Eugenics Associate of the Psychopathic Laboratory of the Municipal Court of Chicago, and Eugenics Director of Carnegie Institution of Washington, Cold Springs Harbor, N. Y., has rendered the nation a signal service in the preparation of this work, "Eugenical Sterilization in the United States."

Since the rediscovery of Mendel's Law of Heredity and the recent advances made by the biologists and psychopathologists in respect to the causes of mental and physical defects in the human race, with the consequent revelation of the great role played by heredity as a producing cause, the science of eugenics has become of vital importance.

"Eugenics," says Professor Irving Fisher, "stands against the forces which work for racial deterioration, and for improvement and vigor, intelligence and moral fiber of the human race. It represents the highest form of patriotism and humanitarianism, while at the same time it offers immediate advantages to ourselves and to our children. By eugenic measures, for instance, our burden of taxes can be reduced by decreasing the number of degenerates, delinquents and defectives supported in public institutions; such measures will also increase safeguards against crimes committed against our persons or our property."

America, in particular, needs to protect herself against indiscriminate immigration, criminal degenerates, and race suicide.

The success of democracy depends upon the quality of its individual! elements. If in these elements the racial values are high, government will be equal to ail the economic, educational, religious and scientific demands of the times. If, on the contrary, there is a constant and progressive racial degeneracy, it is only a question of time when popular self-government will be impossible, and will be succeeded by chaos, and finally a dictatorship.

Dr. Laughlin is well qualified for the work he has undertaken. For twelve years he has been in immediate charge of the Eugenics Record Office (founded in 1910 by Mrs. E. H. Harriman and since 1918 a part of the Carnegie Institution of Washington), located at Cold Spring Harbor, Long Island, New York. There he is engaged in organizing and conducting eugenical investigations. $\mathrm{He}$ is, also, Expert Eugenics Agent of the Committee on Immigration and Naturalization of the House of Representatives of Washington, D. C., and recently organized the exhibits of the Second International Congress of Eugenics in New York City.

As a product of scientific research the book will have permanent value. The importance and usefulness of the work is not to be gauged by the 
extent of its circulation. Enough copies will be published to reach the leaders of the medical, legal and clerical professions, the press and members of legislative bodies.

The Municipal Court of Chicago, which has for years made an intensive study of crime prevention, punishment and suppression, feels privileged to be able to make another notable contribution in this field.

The courts have special functions to perform in the suppression of crime. The first of these is to enforce the laws impartially and justly. Incidental to this duty much original information comes to the judges of our courts, and it has been the policy of the Municipal Court to make public such incidental information, as the relationship between degeneracy and crime and their relationship to heredity, through the reports of its Psychopathic Laboratory. In the performance of this duty the Municipal Court of Chicago has pointed out the need of the permanent segregation of incorrigible defectives, which serves three purposes: First, the protection of society from the individual offender; second, the protection of the individual from himself, and, third, the restriction of propagation of the defective type due to heredity. The alternative to segregation is to continue to do what we have been doing, that is, incarcerate the offender for a time, more or less brief, and then permit him freedom to repeat his offense, and to propagate his kind.

Segregation is necessary, even though sterilization were invoked. Sterilization protects future generations, while segregation safeguards the present as well. The segregation of incorrigible defectives on farm colonies as a measure of crime prevention is urgently needed in the State of Illinois. However, in a number of states, fifteen up to the present time, experiments have been made with sterilization. The two theories of segregation and sterilization are not antagonistic, but both may be invoked.

With the intention of covering every phase of crime prevention, the Municipal Court of Chicago publishes this work as an important contribution to that cause.

We desire to make acknowledgment to the sculptor, Charles Haag, for the use of his "Fountain of the Ages," to illustrate the significance of heredity and the continuity of the blood stream.

HaRRY OLSON,

Chief Justice. 


\section{Preface}

This volume is intended primarily for practical use. It is designed to be of particular service to four classes of persons: First, to law-makers who have to decide upon matters of policy to be worked out in legislation regulating eugenical sterilization; second, to judges of the courts, upon whom, in most of the states having sterilization statutes, devolves the duty of deciding upon the constitutionality of new statutes, and of determining cacogenic individuals and of ordering their sexual sterilization; third, to administrative officers who represent the state in locating, and in eugenically analyzing persons alleged to be cacogenic, and who are responsible for carrying out the orders of the courts; and fourth, to individual citizens who, in the exercise of their civic rights and duties, desire to take the initiative in reporting for official determination and action, specific cases of obvious family degeneracy.

The work is designed also as an historical record of the several types of activities which characterized the early days of modern eugenical sterilization, and of the later working out, through legislation, litigation, experimental administration and scientific research, of a conservative state policy in reference to eugenical sterilization as an aid in protecting the country's family stocks from deterioration.

The facts here reported have been secured, and the analyses and principles here given have been worked out during the past ten years. The present study was begun by the author in 1911, as secretary of a committee appointed by the Eugenics Section of the American Breeders' Association "to Study and to Report on the Best Practical Means for Cutting Off the Defective Germ-Plasm in the American Population." Of this committee, Mr. Bleecker Van Wagenen was chairman. He reported a summary of the first year's work to the First International Congress of Eugenics in London in 1912. In February, 1914, under the authorship of the secretary, it issued bulletins 10-a and 10-b of the Eugenics Record Office, entitled respectively, "The Scope of the Committee's Work," and "The Legal, Legislative and Administrative Aspects of Sterilization."

The statistics reported in this work are brought down to January 1 , 1921, and the legal records to January 1, 1922. Great care has been taken to insure completeness and accuracy of record and fact throughout the study, and an attempt has been made to cover the whole field of policy, legality and practice.

Thanks are due for hearty co-operation in securing the facts needed for this work, to the superintendents of the custodial institutions in which eugenical sterilizing operations have been performed, to state officials 
who willingly supplied copies of official records, to judges of the courts of law before whom seven sterilization statutes have been tested, to the attorneys-at-law who have generously given legal advice and opinions, to many physicians who have been consulted in reference to the medical aspect of the problem, to the scientific field investigators of the Eugenics Record Office, to surgeons who have furnished case-records of persons sexually sterilized, and to authors and publishers of the several text-books on anatomy and surgery who have kindly permitted quotations in reference to the technique of given sterilizing operations.

Besides these many persons who have so generously aided the investigations, special obligations are due to Dr. Charles B. Davenport, Director of the Eugenics Record Office, for many constructive suggestions and for constant encouragement throughout the investigations, and to Hon. Harry Olson, Chief Justice of the Municipal Court of Chicago, for kindly writing the foreword, for rendering an opinion on the legal aspects of sterilization, which appears as Section 1 of Chapter IX, and for publishing the whole of these studies under the auspices of the Psychopathic Laboratory of his court.

Harry Hamilon Laughlin.

Cold Spring Harbor, Long Island, N. Y., January 1, 1922. 


\section{Contents}

\section{CHAPTER I.}

Chronological List of Laws, Amendments, Executive Vetoes, Repeals, Official Legal Opinions, Board Orders and Court Decisions Relating to Eugenical Sterilization Previous to January 1, 1922.

\section{CHAPTER II.}

Analysis, by States, of Sterilization Laws Enacted Prior to January 1, 1922.

1. Indiana

2. Washington.

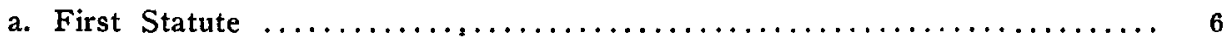

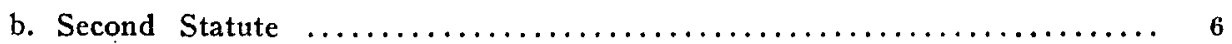

3. California.

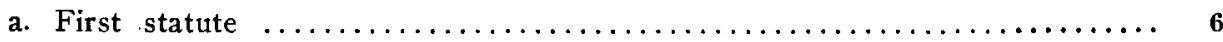

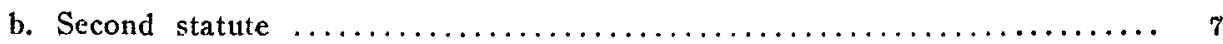

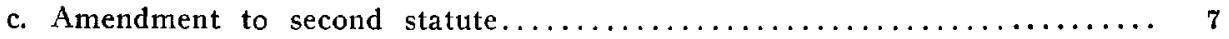

d. Sterilization provision in act establishing Pacific Colony $\ldots \ldots \ldots \ldots \ldots \ldots, 8$

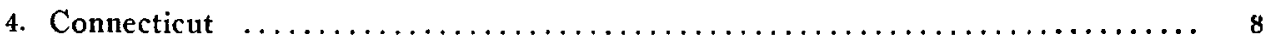

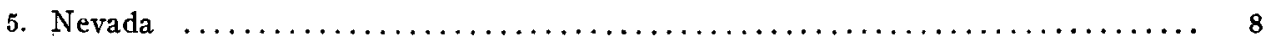

6. Iowa.

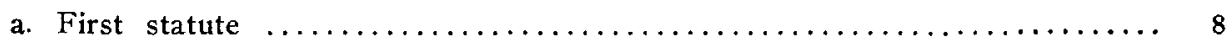

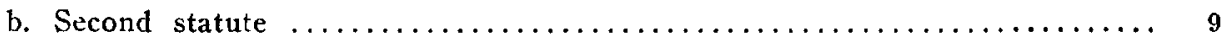

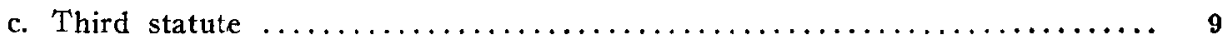

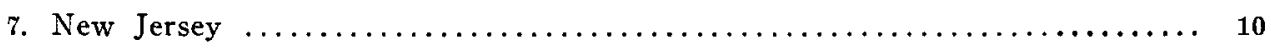

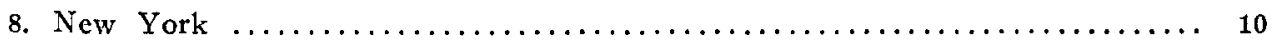

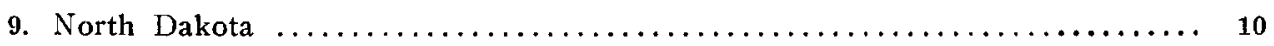

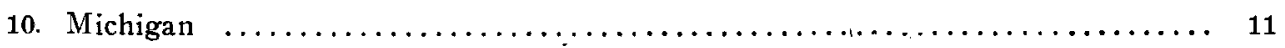

11. Kansas.

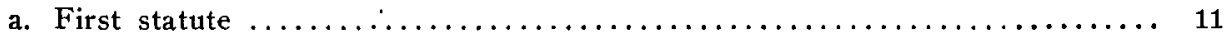

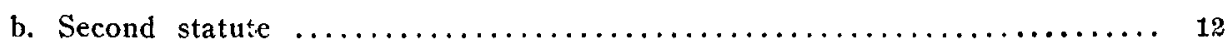

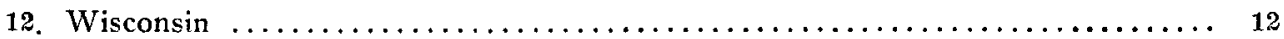

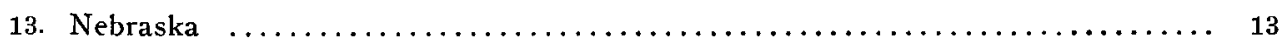

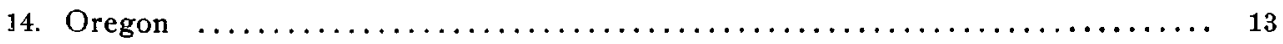

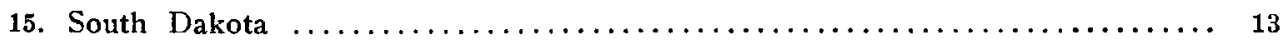

\section{CHAPTER III.}

Texts and Legislative Records of the Eugenical Sterilization Laws.

A. Laws Enacted Prior to January 1, 1922.

1. Indiana

2. Washington.

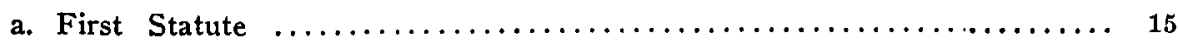

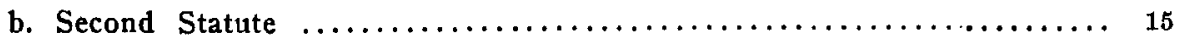


3. California. Page

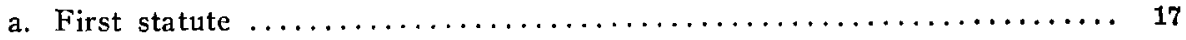

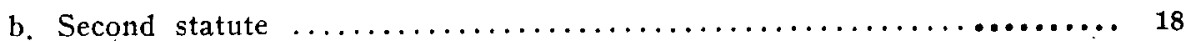

c. Amendment to second statute.......................... 18

d. Sterilization provision in act establishing Pacific Colony ............. 19

4. Connecticut.

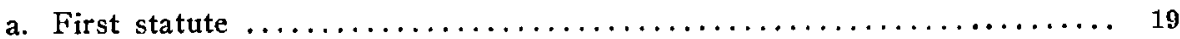

b. Sterilization provision of first statute extended to Mansfield State Training S.chool and Hospital.......................... 20

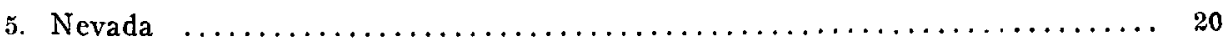

6. Iowa.

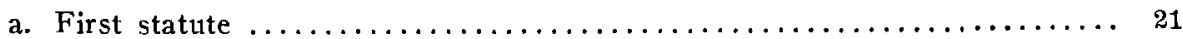

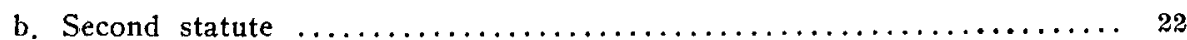

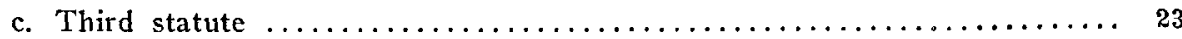

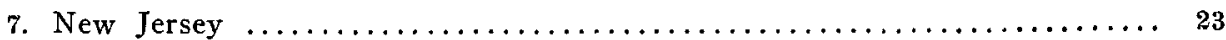

8. New York.

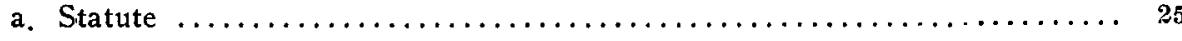

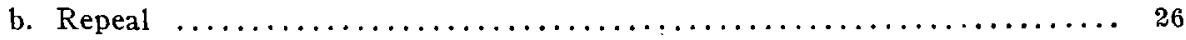

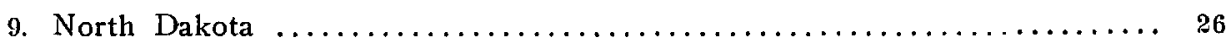

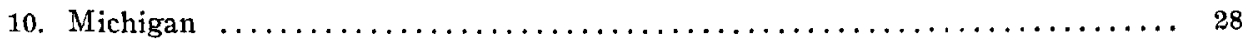

11. Kansas.

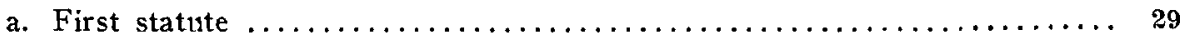

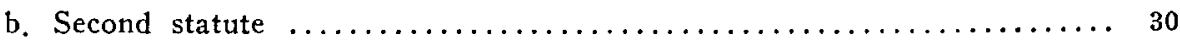

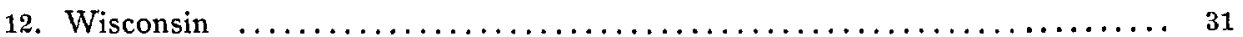

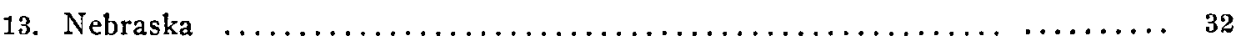

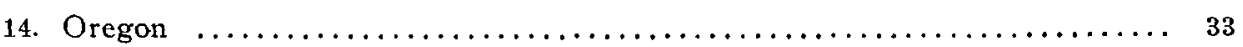

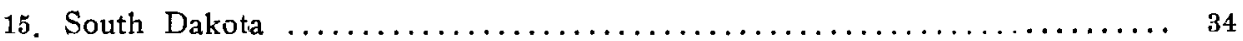

B. Eugenical Sterilization Bills Vetoed.

1. Pennsylvania.

A. Veto of $\mathbf{1 9 0 5 .}$

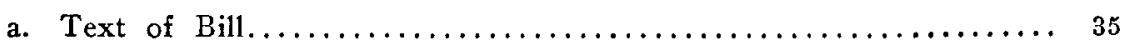

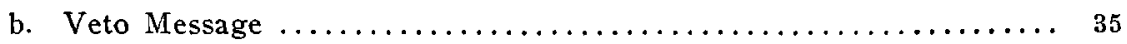

B. Veto of 1921.

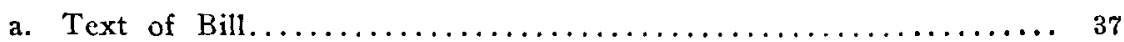

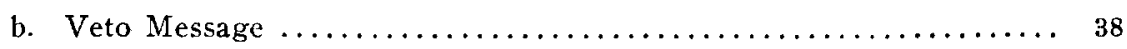

C. Notes on the Situation in Pennsylvania..................... 39

2. Oregon.

A. Bill vetoed.

a. Text of Bill................................... 40

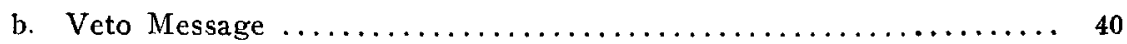

B. Law revoked by referendum.

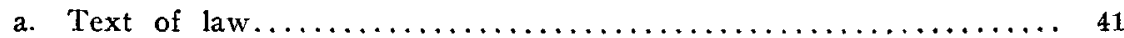

b. Legislative and referendum record $\ldots \ldots \ldots \ldots \ldots \ldots \ldots \ldots \ldots, 42$

3. Vermont.

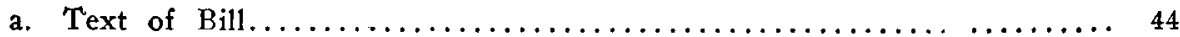

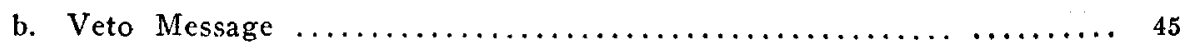

4. Nebraska.

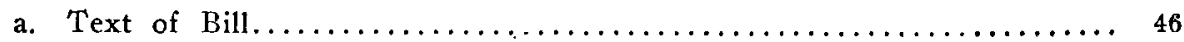

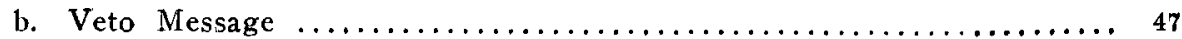


5. Idaho.

a. Text of Bill....................... 48

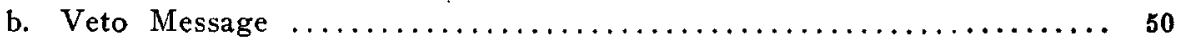

\section{CHAPTER IV.}

\section{Statistical and Descriptive Summary of Eugenical Sterilization in the Several States.}

I. Institutional Statistics and Official Reports and Opinions.

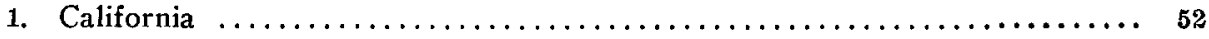

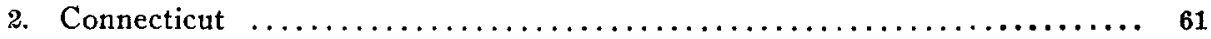

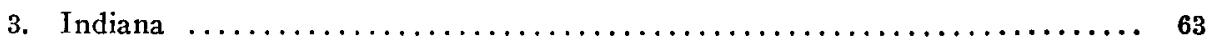

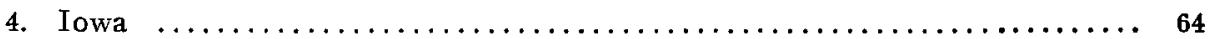

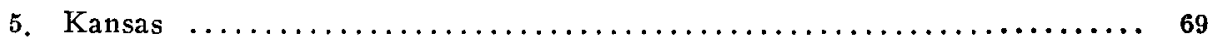

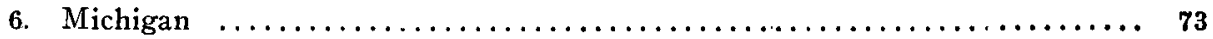

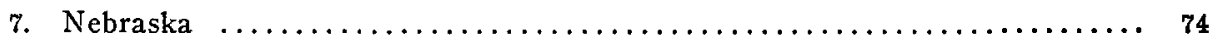

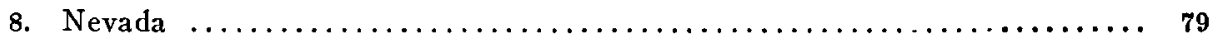

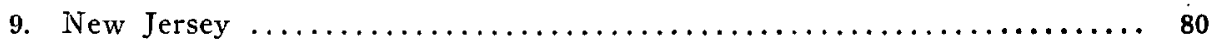

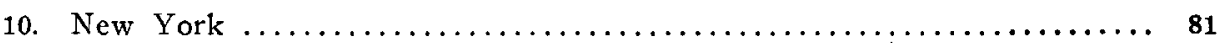

11. North Dakota ..................................... 87

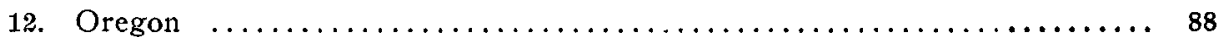

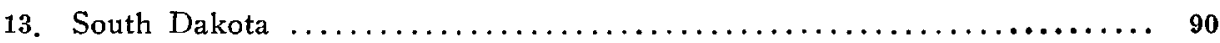

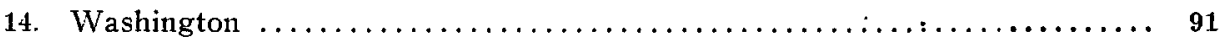

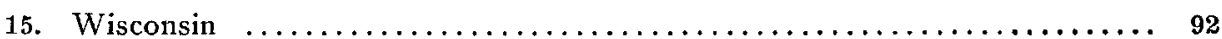

11. Summary.

A. Statistical Summary to January 1, 1921.

a. States and institutions................................. 96

b. Total number of eugenical sterilization operations in all fifteen states $\ldots \quad 96$

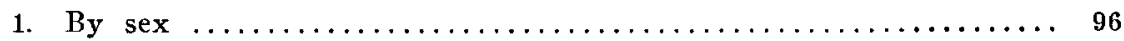

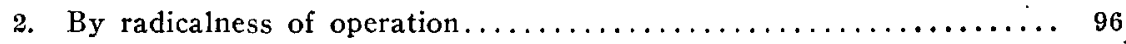

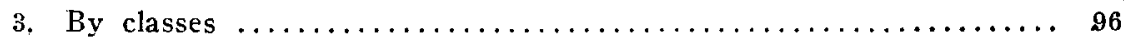

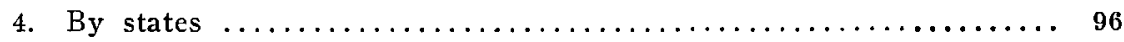

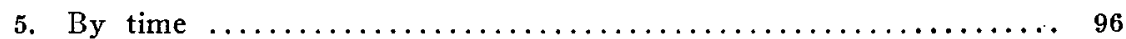

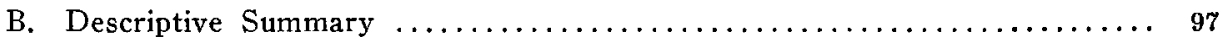

\section{CHAPTER V.}

\section{Analysis of the Eugenical Sterilization Laws by Subject.}

1. The Motives of the Sterilization Statutes.

A. The motive of heredity .............................. 99

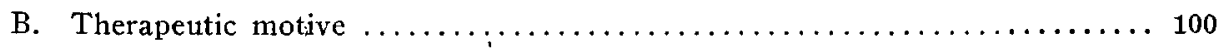

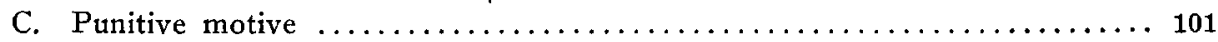

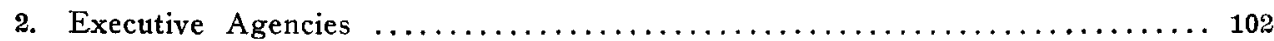

3. Provisions for Making Family History Studies.................... 104

4. Biological Criteria for Determining the Applicabilty of the Law to a Particular

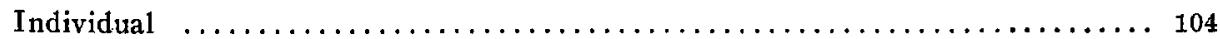

5. Court Procedure Provided by the Several Sterilization Statutes............ 107

6. Legal Counsel for the State and for Persons Nominated for the Operation.... 110

7. Is the Consent of the Patient or Guardian a Necessary Pre-requisite to Legal Eugenical Sterilization? .................................. 110

8. Type of Operation and Manner of its Performance................... 111

9. Bad Biology in the Eugenical Sterilization Statutes................... 113 
10. Mandatory and Optional Elements in the Laws....................114

11. Sexual Sterilization of Criminals.............................. 117

12. Legal Liability of Executive Agents and Surgeons................... 124

13. Punishment for Dereliction in Executing the Law................... 125

14. Punishment for the Illegal Use of Sexual Sterilization................. 125

15. The Legal Aspect of Sexual Sterilization for Therapeutic Purposes......... 127

16. The Sexual Sterilization of Inmates of Custodial Institutions Prior to

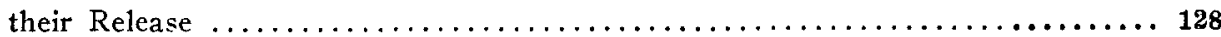

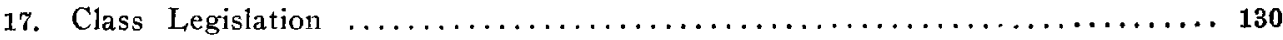

18. What Constitutes Due Process of Law in Eugenical Sterilization?......... 132

19. Records and Reports Required by Law ....................... 137

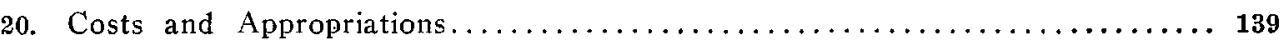

\section{CHAPTER VI.}

Analytical Outline of Litigation Growing Out of the Several Eugenical Sterilization Statutes Previous to January 1, 1922.

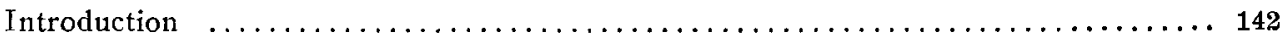

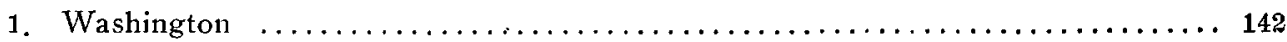

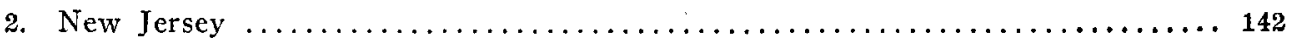

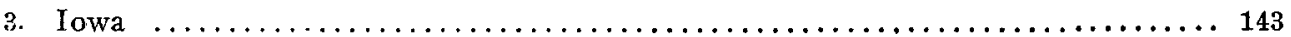

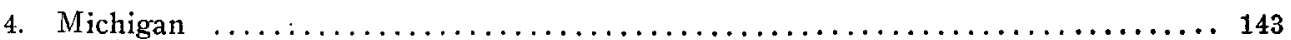

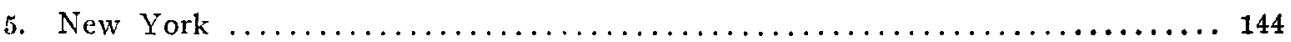

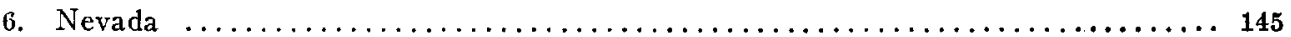

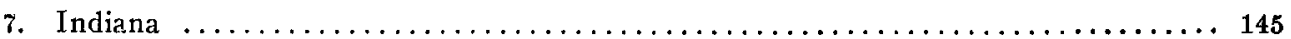

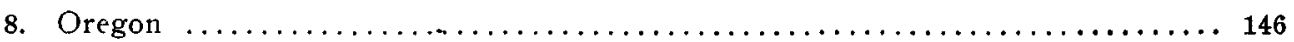

Summary: The Present Legal Status of Eugenical Sterilization............... 147

CHAPTER VII.

Detailed Review of Litigation Growing Out of the Several Eugenical Sterilization Statutes.

PART I-WASHINGTON.

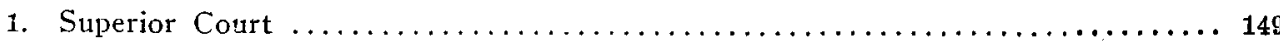

2. State Supreme Court.

a. Brief of Appellant. ...................................... 149

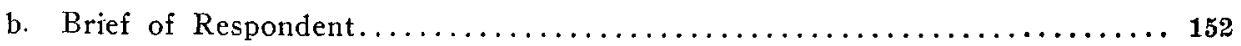

c. Decision of Supreme Court............................... 159

1. Board of Examiners.

PART II-NEW JERSEY.

a. Order for Sterilization..................................... 164

2. State Supreme Court.

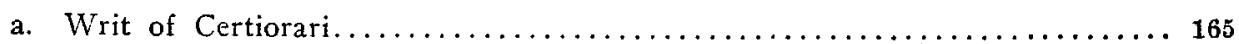

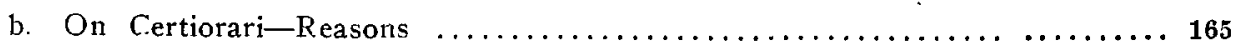

c. Brief of Appellant.................................... 166

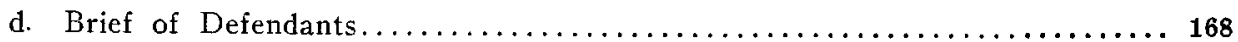

e. Brief of Elmore T. Elver, amicus curiae.................... 172

f. Decision of Supreme Court............................. 174

1. State Board of Parole.

a. Order for Sterilization. 
2. United States District Court. $\quad$ Page

a. Temporary Restraining Order.......................... 180

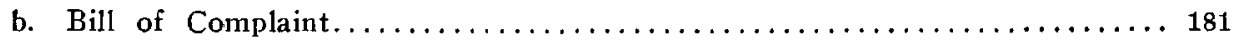

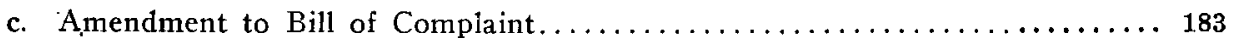

d. Reports of Attorney-General.......................... 184

e. Minutes of Meeting of Board of Parole........................ 185

f. - Decision of District Court................................. 186

g. Order for Temporary Injunction.......................... 190

3. United States Supreme Court.

a. Brief of Plaintiffs in Error.................................. 191

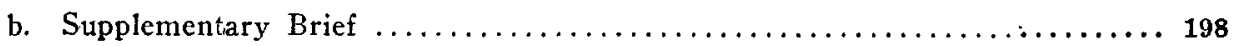

c. Decision of Supreme Court of United States.................... 200

\section{PART IV-MICHIGAN.}

1. Probate Court of Lapeer County.

a. Notice by Board of Control to Guardian........................ 203

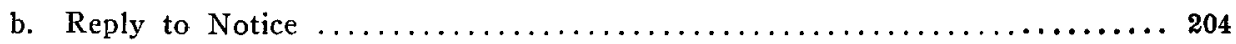

c. Petition of Superintendent............................... 204

d. Order Denying Petition................................. 205

e. Notice of Appeal..................................... 205

2. Circuit Court of Lapeer County.

a. Order Dismissing Appeal............................... 206

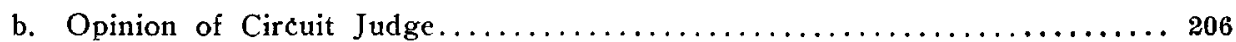

3. State Supreme Court.

a. Petition to Supreme Court.............................. 207

b. Order of Supreme Court ................................. 208

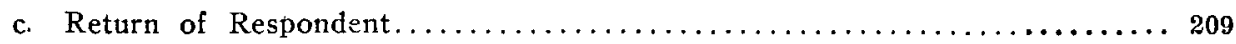

d. Brief of Attorney-General as amicus curiae..................... 209

e. Decision of Supreme Court................................ 213

\section{PART V-NEW YORK}

1. State Board of Examiners.

a. Origin of Test Casc..

2. Supreme Court, Albany County.

a. Affidavit and Order Appointing Counsel...................... 217

b. Summons and Complaint............................... 219

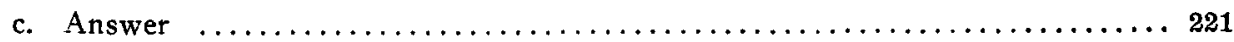

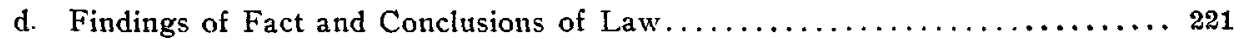

e. Exceptions of Defendant to Conclusions of Law.................. 222

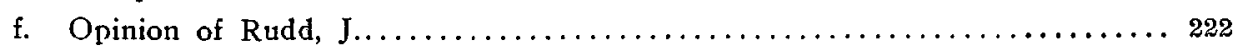

g. Judgment of Supreme Court............................ 227

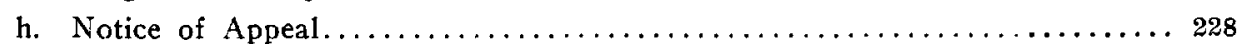

i. Stipulation for Settlement of Case............................ 228

j. Order Settling Case.................................. 229

k. Stipulation Waiving Certification........................... 229

3. Appellate Division, Supreme Court.

a. Brief for Plaintiff-Respondent............................ 229

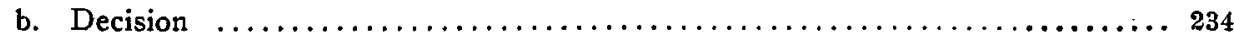


4. Court of Appeals. Page

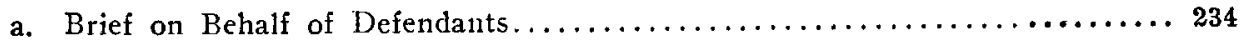

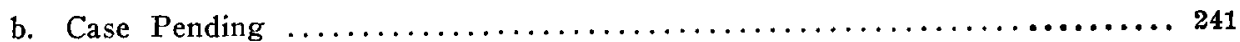

\section{PART VI-NEVADA.}

1. District Court of the Fourth Judicial District of the State of Nevada.

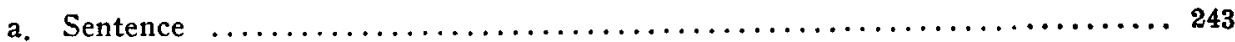

2. United States District Court in and for Nevada.

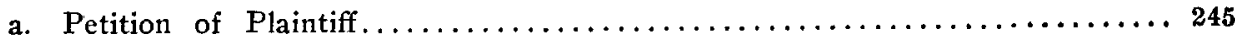

b. Orden to Show Cause and Restraining Order................... 247

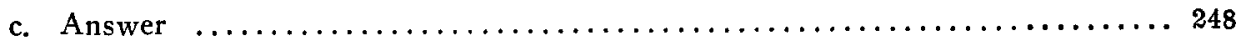

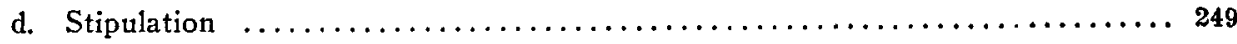

e. Plaintiff's Brief ..................................... 249

f. Decision of United States District Court...................... 250

\section{PART VII-INDIANA.}

1. Circuit Court of Clark County.

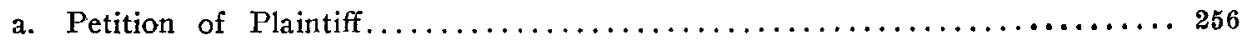

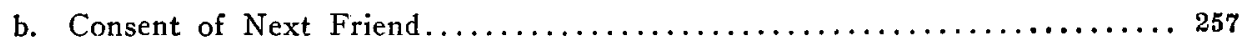

c. Demurrer Filed by Defendants............................. 257

d. Demurrer overruled and excepted $\ldots \ldots \ldots \ldots \ldots \ldots \ldots \ldots \ldots \ldots, \ldots \ldots, 257$

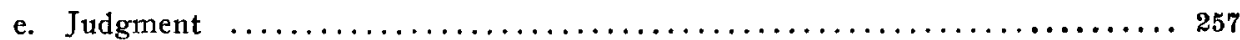

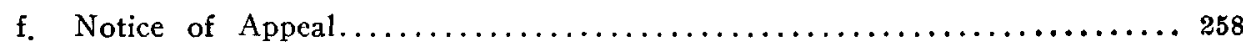

g. Praecipe for Transcript...................................... 258

2. State Supreme Court.

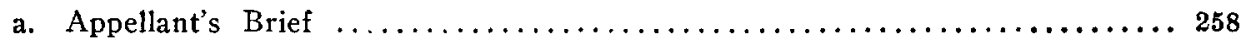

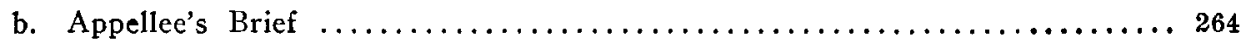

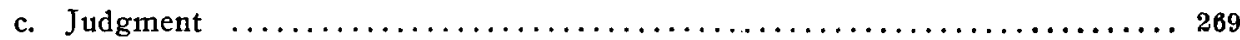

\section{PART VIII-OREGON.}

1. State Board of Eugenics.

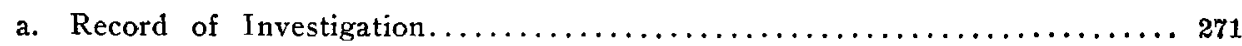

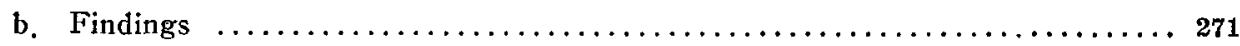

c. Order for Sterilization......................................... 272

2. Circuit Court for the County of Marion.

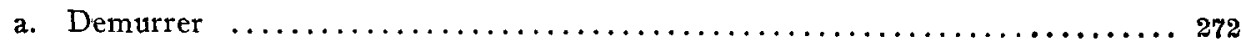

b. Brief of Defendant in Support of Demurrer.....................273

c. Points and Authorities (By Smith \& Shields, and Allan Bynon, amicus

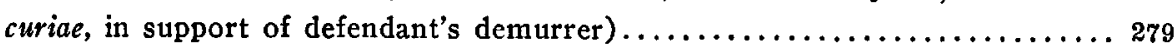

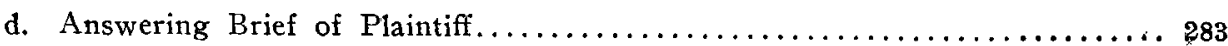

e. Opinion of Percy R. Kelly and Geo. G. Bingham, Judges.............. 287

f. Decision of the Circuit Court............................ 289

\section{CHAPTER VIII.}

Case and Family Histories of Individual Subjects of Litigation Growing Out of the Several Eugenical Sterilization Laws.

Introduction

1. Peter Feilen, moral pervert, Washington........................ 292

2. Alice Smith, epileptic and feeble-minded, New Jersey ................ 292 
Page

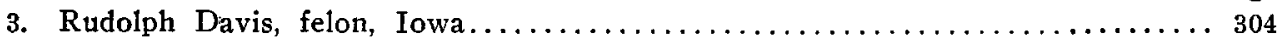

4. Nora Reynolds, feeble-minded, Michigan....................... 305

5. Frank Osborn, feeble-minded, New York....................... 305

6. Pearley C. Mickle, moral pervert, Nevada...................... 311

7. Warren Wallace Smith, moral pervert, Indiana.................... 312

8. Jacob Cline, moral pervert, Oregon......................... 318

\section{CHAPTER IX.}

\section{Legal Opinion.}

1. Opinion by Honorable Harry Olson, Chief Justice, Municipal Court of Chicago . 322

2. Official Opinion of the Attorney-General of California on the Asexualization

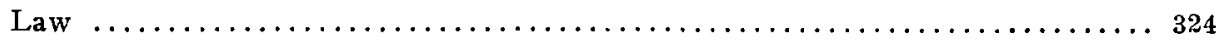

3. Opinion of the Attorney-General of Connecticut on the Asexualization Act... 328

4. Additional Opinion by the Attorney-General of Connecticut........... 333

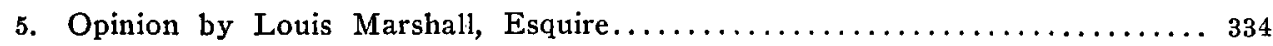

6. Brief by Charles A. Boston, Esquire........................... 336

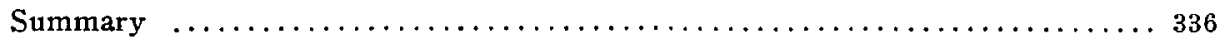

\section{CHAPTER $\mathrm{X}$.}

The Right of the State to Limit Human Reproduction in the Interests of Race Betterment.

Introduction

A. Parallel Cases of the Restriction of Personal Liberty in the Interests of the General Welfare.

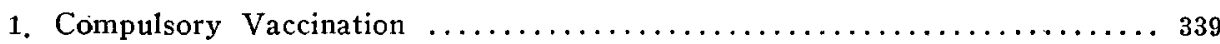

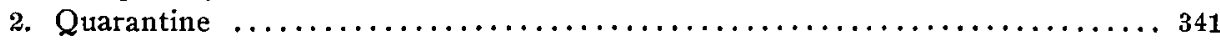

B. Legislative and Judicial Activities Regulating or Limiting Human Reproduction.

1. Limitation of Marriage................................ 342

a. List of legal limiting causes............................. 343

b. The special case of venereal and other transmissible diseases.

b1. Analysis of laws limiting marriage on account of venereal or other

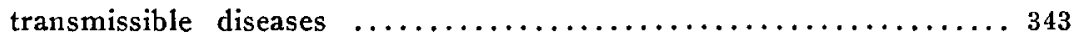

b2. Constitutionality of the Wisconsin statute requiring certificate of health for males before marriage license is issued............. 344

c. Judicial annulment of marriage in the interest of public health

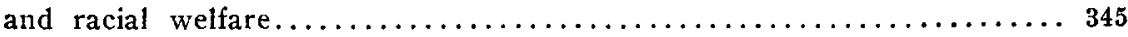

c1. Wisconsin Supreme Court........................ 345

c2. New York Court (New York County) .................. 345

c3. New Jersey Court of Chancery (concealment of insanity)......... 346

c4. New Jersey Court of Chancery (concealment of venereal disease).

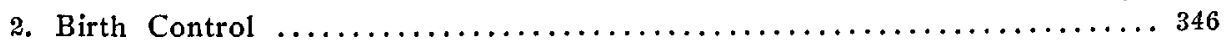

a. Review of criminal statutes on Birth Control: Judge J. C. Ruppenthal... 347

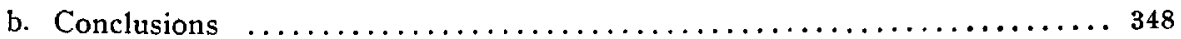

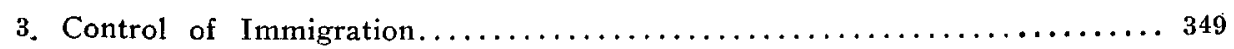

4. Institutional Segregation of Social Inadequates................... 350

a. Quotation from Dr. Henry M. Hurd..................... 350

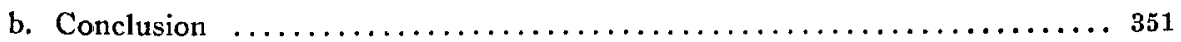


5. Eugenical Sterilization.

a. Cases of Eugenical Sterilization in States having neither authorizing

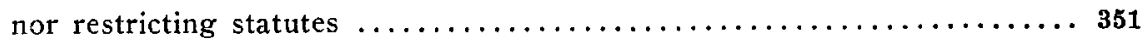

a1. Case of $\mathrm{M} \ldots \mathrm{H} \ldots$ of Massachusetts................. 352

a2. Case of " $\mathrm{X}$ " of Illinois................................ 354

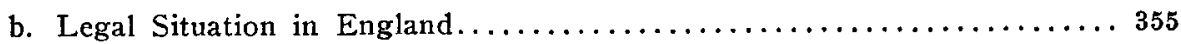

b1. Would it be lawful to sterilize?....................... 355

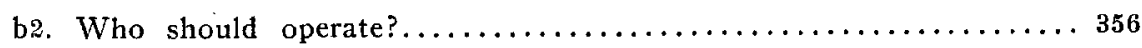

b3. Penalties for wrongfully operating $\ldots \ldots \ldots \ldots \ldots \ldots \ldots \ldots \ldots \ldots \ldots \ldots \ldots$

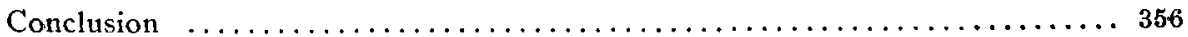

c. Possible New Fields for Eugenical Legislative Activity $\ldots \ldots \ldots \ldots \ldots \ldots \ldots \ldots$

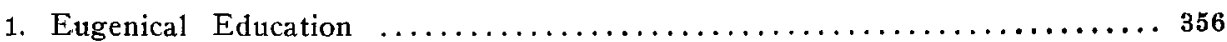

2. Compulsory Reporting of Cases of Cacogenesis................. 357

3. Registering Trained Eugenical Investigators.................... 358

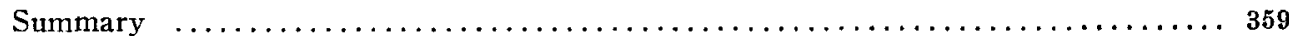

\section{CHAPTER XI.}

\section{Eugenical Diagnosis.}

A. Guiding Principles for the Determination of Potential Parenthood of Socially Inadequate Offspring.

I. General Factors of the Task............................ 362

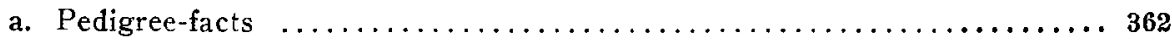

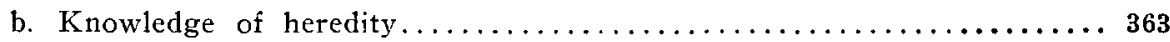

c. Application of pedigree-facts to the rules of heredity ............. 363

II. Notes on Practical Eugenical Diagnosis..................... 364

1. Divergence between personal qualities and breeding qualities......... 364

2. The individual of pure stock............................. 364

3. The individual of mixed stock......................... 364

4. Range of individual breeding qualities................... 365

5. The complexity of hereditary traits or characters.............. 365

6. Specific rules of inheritance.

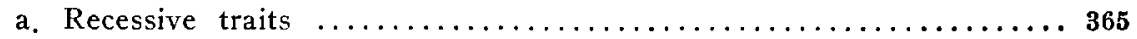

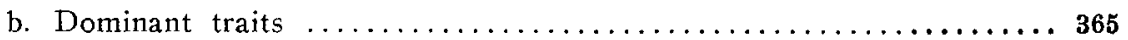

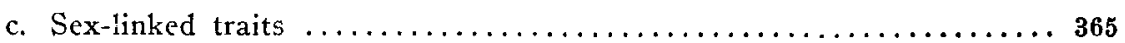

d. Other types of inheritance....................... 366

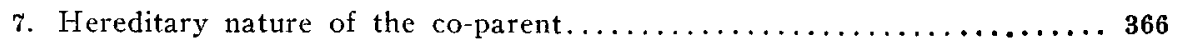

8. Eugenical salvage-the separation of good traits from bad in the same

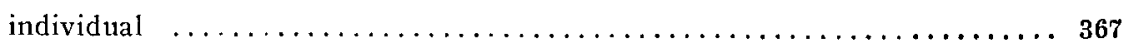

9. The factor of environment........................... 367

10. Engenica! standards.

a. The biological standard $\ldots \ldots \ldots \ldots \ldots \ldots \ldots \ldots \ldots \ldots \ldots \ldots \ldots, \ldots 68$

b. The legal standard ................................... 368

11. Types of the socially inadequate.......................... 369

12. Common sense and pedigree study $\ldots \ldots \ldots \ldots \ldots \ldots \ldots \ldots \ldots \ldots \ldots, \mathbf{3 6 9}$

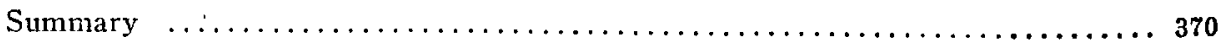

B. List of Characters in Man Classified According to Their Method of Inheritance.

I. Traits which blend in the $F_{1}$ offspring... 
II. Traits showing dominance of one condition and recessiveness of the allelomorph in the first generation and segregation in subsequent generations of offspring..$\ldots \ldots \ldots \ldots \ldots \ldots \ldots \ldots \ldots \ldots \ldots \ldots \ldots \ldots$

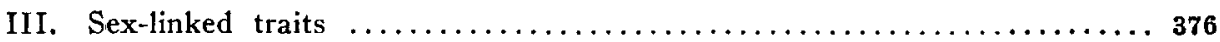

IV. Probably Mendelian, but dominance imperfect or uncertain.......... 377

V. Clearly hereditary, but rule of inheritance uncertain............. $\mathbf{3 7 7}$

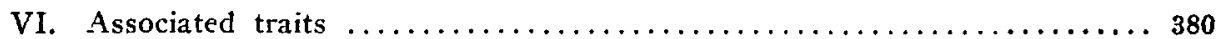

C. Tables Showing Types of Matings and Offspring.

Type a. In case the defect is recessive......................... 381

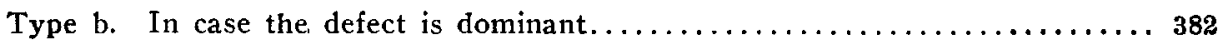

Type c. A sex-linked trait...................................

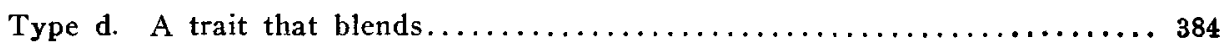

Type e. A composite trait................................ 385

D. References.

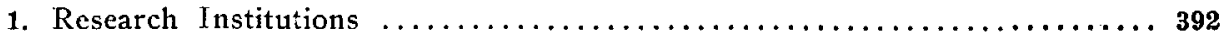

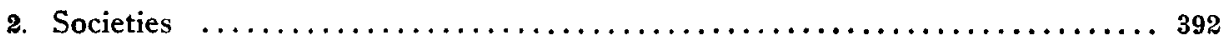

3. Universities and colleges with active departments of genetics........... 393

4. Custodial institutions for socially inadequate conducting field studies in

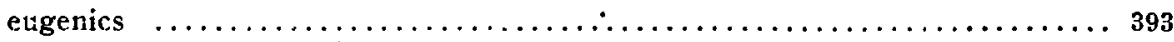

5. Courts which have undertaken scientific eugenical studies........... 394

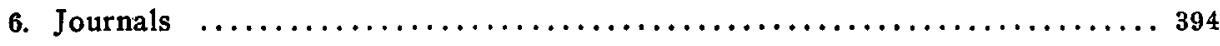

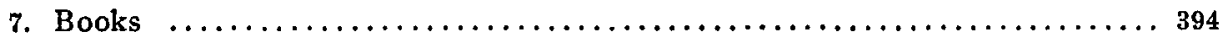

\section{CHAPTER XII.}

The Anatomical and Surgical Aspects of Eugenical Sterilization.

Section A. Anatomy, Description of the Human Male and Female Reproductive Mechanisms and an Explanation of their Functions................ 397

a. Reproductive mechanism of the human male................... 398

b. Reproductive mechanism of the human female................... 402

Section B. Surgery. The Principal Types of Surgical Operations Used in Effecting Sexual Sterilization.

1. Male.

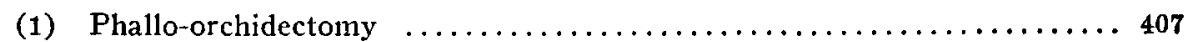

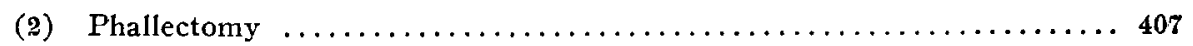

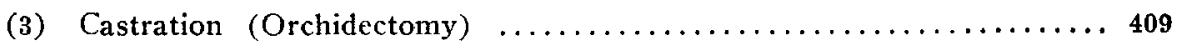

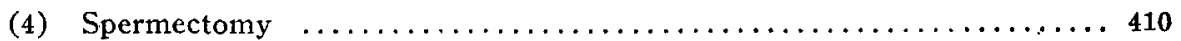

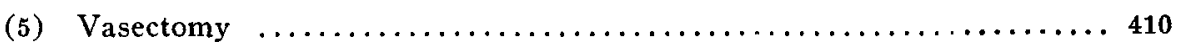

(6) Ligation of the vas deferens........................... 411

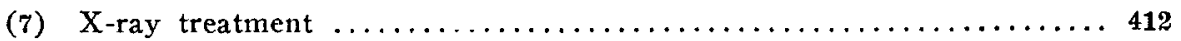

2. Female.

(1) Pan-hystero-kolpectomy $\ldots \ldots \ldots \ldots \ldots \ldots \ldots \ldots \ldots \ldots \ldots \ldots \ldots \ldots \ldots \ldots \ldots \ldots$

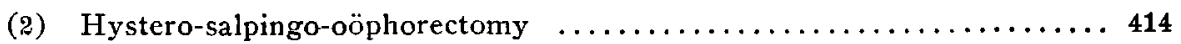

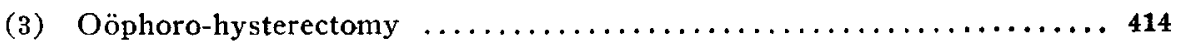

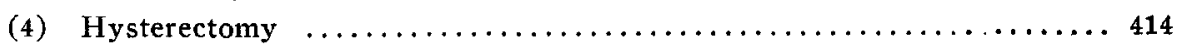

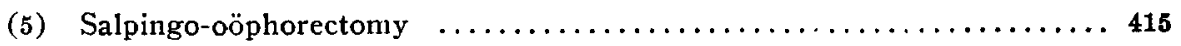

(6) Oöphorectomy (ovariectomy, ovariotomy, castration, spaying)..... 415

(7) Curetting or cauterizing the intra-uterine tubal openings.........417

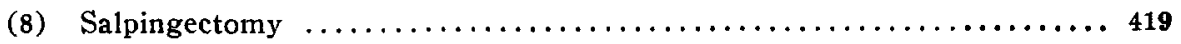

(9) Ligation of Fallopian Tubes........................ 421

(10) $\mathrm{X}$-ray treatment $\ldots \ldots \ldots \ldots \ldots \ldots \ldots \ldots \ldots \ldots \ldots \ldots \ldots \ldots \ldots \ldots, \mathbf{4 2 1}$ 
Summary.

a. Types of Eugenical Sterilization Available.

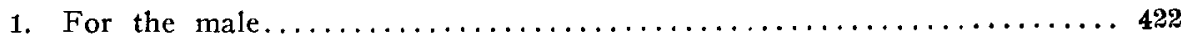

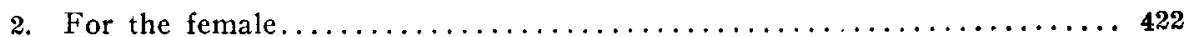

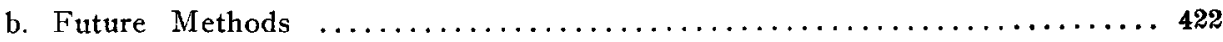

c. Weighing the Matter of Type of Eugenical Sterilization in Relation to

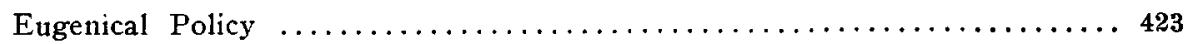

Appendix: Continence and Contraception........................ 423

\section{CHAPTER XIII.}

\section{The Physiological and Mental Effects of Sexual Sterilization.}

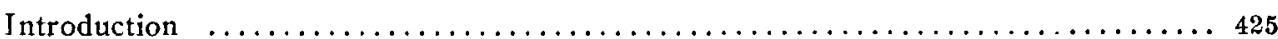

1. The Normal Course of Sexual Functions........................ 425

2. Functions of the Sex-Glands, Other than Reproduction.

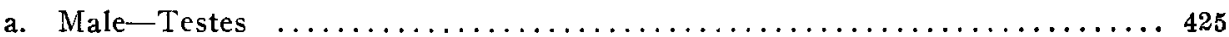

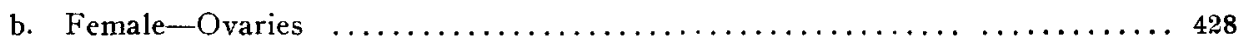

3. Classification of the Case-Histories.......................... 429

a. Type of social inadequacy ............................... 430

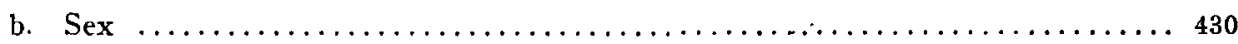

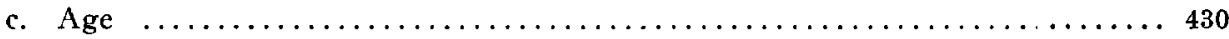

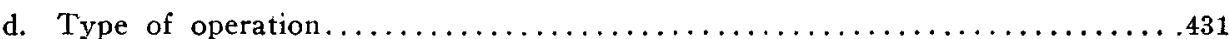

4. Testimony on the Effects of Sexual Sterilization.

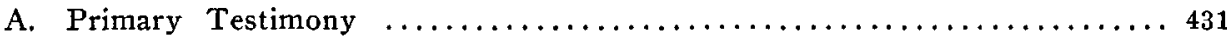

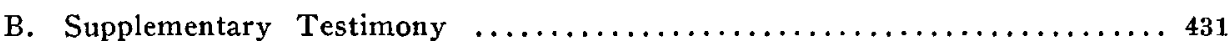

a. A. W. Wilmarth, M. D., Superintendent Wisconsin Home for Feeble-

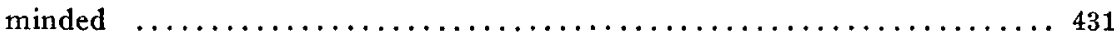

b. Havelock Ellis, from his book "The Sexual Impulse"............. 432

c. Robert Reid Rentoul, M. D., from his book "Race Culture or Race

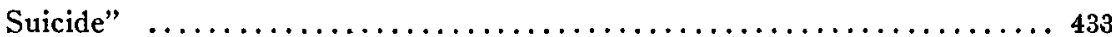

d. Martin W. Barr, M. D., in his book "Mental Defectives".......... 433

e. F. C. Cave, M. D., Journal of Psycho-Asthenics $1911 \ldots \ldots \ldots \ldots \ldots \ldots .434$

5. Summary:

A. Functions of the Sex-Glands.

B. Effects of Sexual Sterilization.

I. Anatomical and physiological effects by sex, age and type of operation.

(A) Male.

(a) Vasectomy or its functional equivalent.

(1) Before puberty .......................... 434

(2) During adolescent and adult life............... 435

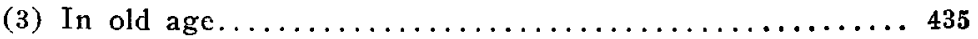

(b) Castration.

(1) Before puberty $\ldots \ldots \ldots \ldots \ldots \ldots \ldots \ldots \ldots \ldots \ldots \ldots, 435$

(2) During adolescent and adult life................435

(3) In old agc............................... 435

(B) Female.

(a) Salpingectomy or its functional equivalent.

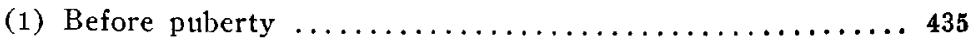

(2) During reproductive period.................. 435

(3) After the climacteric $\ldots \ldots \ldots \ldots \ldots \ldots \ldots \ldots \ldots \ldots \ldots, 435$ 
(b) Oöphorectomy.

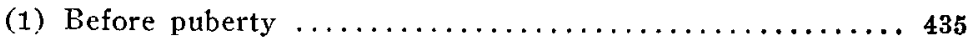

(2) During reproductive period...................435

(3) After the climacteric....................... 435

II. General Summary of Evidence on the Mental and Temperamental Effects of Sexual Sterilization..........................436

III. Summary of Evidence on Sexual Sterilization as a Therapeutic Agent... 436

CHAPTER XIV.

\section{The Legal, Biological and Practical Requirements for an Effective Eugenical} Sterilization Law.

Introduction

A. Commonly Stated Objections to the Existing Sterilization Laws.

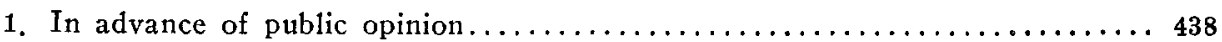

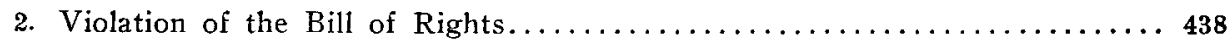

3. Ill-adapted to their implied purposes....................... 439

4. Inadequate executive machinery ........................... 439

5. Lack of coöperation among sociologists $\ldots \ldots \ldots \ldots \ldots \ldots \ldots \ldots \ldots \ldots \ldots \ldots$

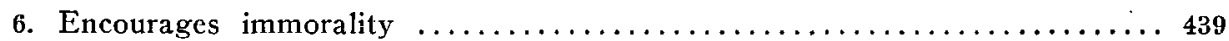

B. Requirements for an Effective Eugenical Sterilization Law.

a. Legal requirements.

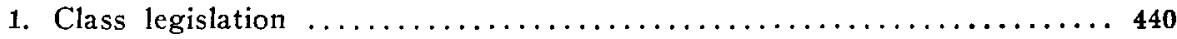

2. Due process of law.................................. 441

3. Cruel and unusual pünishment.......................... 442

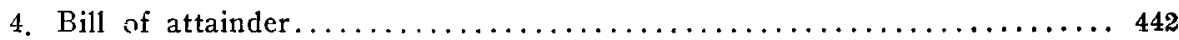

5. Twice in jeopardy of life and limb......................... 442

6. Ex post facto..................................... 442

b. Biological and eugenical requirements.

1. Standard for legal parenthood........................... 443

2. The line of demarcation between eugenic and cacogenic...........443

3. Insurance against reproduction by cacogenic persons. . . . . . . . . 443

4. Development of eugenic standards....................... 443

5. Suspension of order for eugenical sterilization.................. 443

6. Adequate evidence of cacogenesis......................... 443

c. Practical requirements.

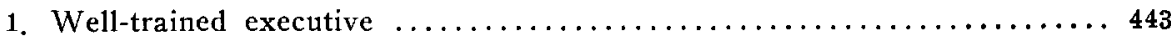

2. Due provision for prompt court procedure..................443

3. Ample funds for enforcement......................... 444

4. Due provision for modern surgical work.................... 444

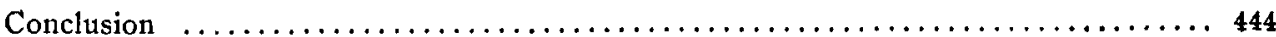

\section{CHAPTER XV.}

\section{Model Eugenical Sterilization Law.}

A. Principles Suggested for a Standard State Law...................46

B. Full Text for a Model State Law.

Section 1. Short title

Section 2. Definitions.

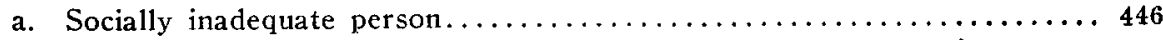

b. Socially inadequate classes......................... 446 
c. Heredity

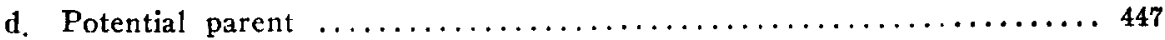

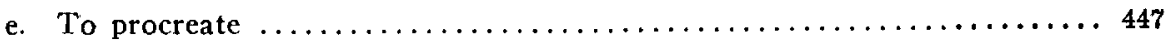

f. Potential parent of socially inadequate offspring $\ldots \ldots \ldots \ldots \ldots \ldots \ldots 447$

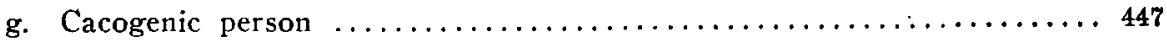

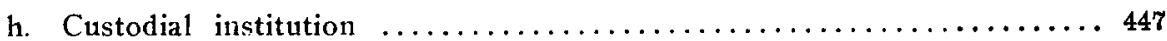

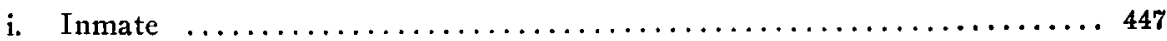

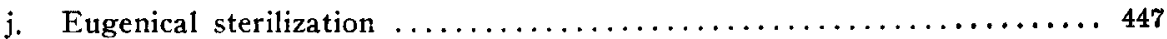

Section 3. Office of State Eugenicist........................ 447

Section 4. Qualifications of State Eugenicist.....................447

Section 5. Term of office, appointment and responsibility $\ldots \ldots \ldots \ldots \ldots \ldots \ldots, 447$

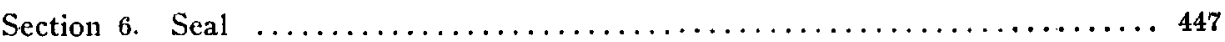

Section 7. Duties of State Eugenicist.

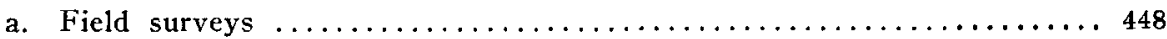

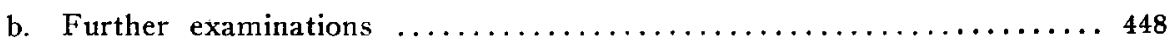

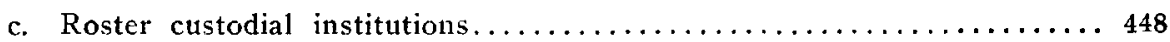

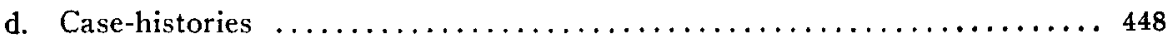

e. Records, State Eugenicist's Office....................... 448

f. Other duties ..................................... 448

Section 8. Coöperation by custodial institutions................... 448

Section 9. Power to administer oaths and make arrests.............. 448

Section 10. Opinion of State Eugenicist........................ 448

Scction 11. Appointment of date for hearing................... 449

Section 12. Notification of parties concerned.................... 449

Section 13. State's legal counsel........................... 449

Section 14. Determination by jury ......................... 449

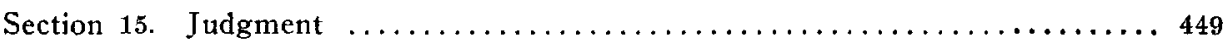

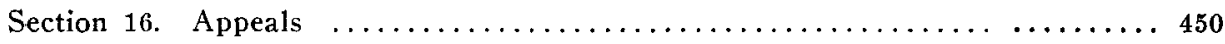

Section 17. Type of eugenical sterilization..................... 450

Section 18. Manner of consummation....................... 450

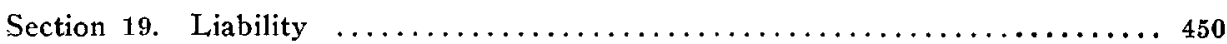

Section 20. Illegal destruction of reproductive functions.............. 450

Section 21. Punishment of responsible head of institution for dereliction.... 450

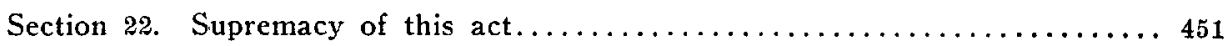

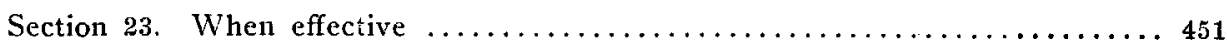

C. The Federal Government and Eugenical Sterilization.

a. Principles suggested for a Federal Statute................... 451

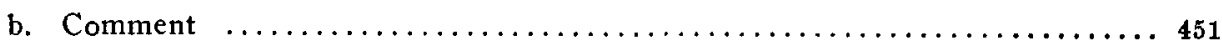

\section{CHAPTER XVI.}

\section{Explanatory Comments on the Model Sterilization Law.}

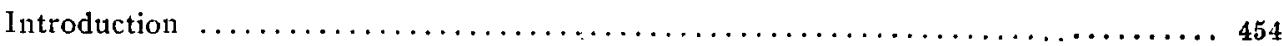

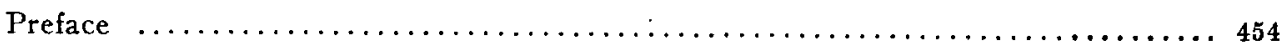

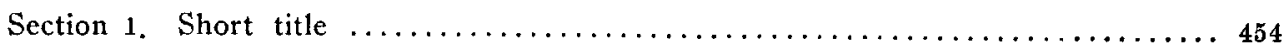

Section 2. Definitions.

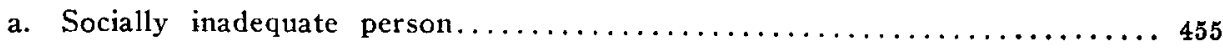

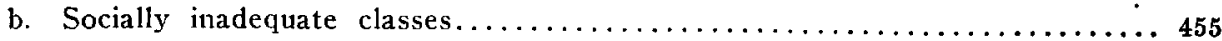

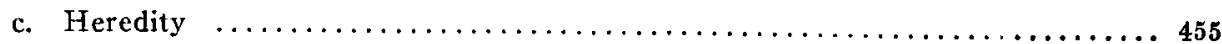

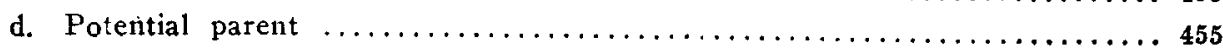


e. To procreate

f. Potential parent of sccially inadequate offspring $\ldots \ldots \ldots \ldots \ldots \ldots \ldots \ldots \ldots \ldots \ldots$

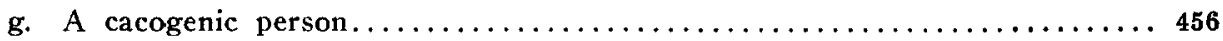

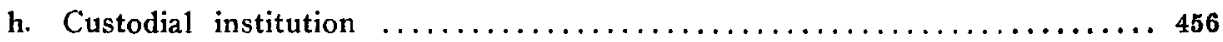

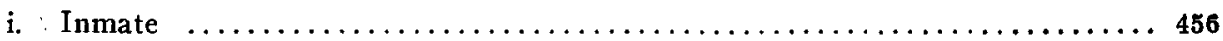

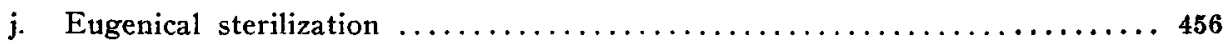

Section 3. Office of State Eugenicist............................456

Section 4. Qualifications of State Eugenicist....................... 457

Section 5. Term of office, appointment and responsibility $\ldots \ldots \ldots \ldots \ldots \ldots \ldots \ldots 457$

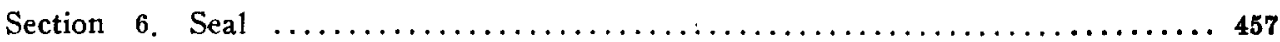

Section $\eta$ Duties of State Eugenicist.............................. 457

Section 8. Coöperation by custodial institutions..................... 458

Section 9. Power to administer oaths and to make arrests $\ldots \ldots \ldots \ldots \ldots \ldots \ldots 458$

Section 10. Opinion of State Eugenicist.............................. 458

Section 11. Appointment of date for hearing........................... 458

Section 12. Notification of parties concerned.........................458

Section 13. The State's legal counsel.............................. 459

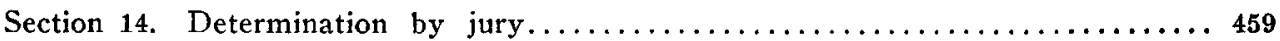

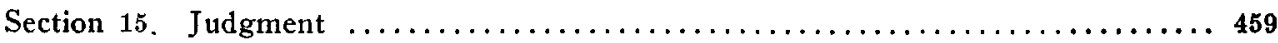

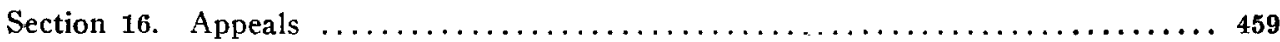

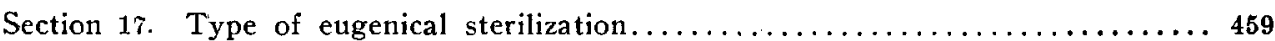

Section 18. Manner of consummation............................ 459

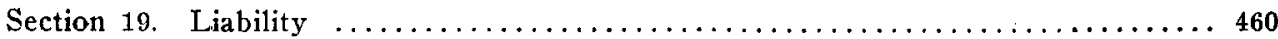

Section 20. Illegal destruction of reproductive functions................. 460

Section 21. Punishment of responsible head of institution for dereliction........ 460

Section 22. Supremacy of this act.................................460

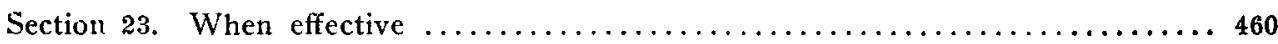

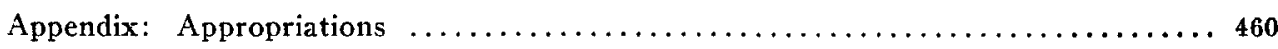

\section{CHAPTER XVII.}

Set of Forms Suggested for the Use of the State Eugenicist, the Courts, Private Citizens, and Custodial Institutions in Administering the Model Eugenical

Model Forms. Sterilization Law.

1. Case Record by State Eugenicist.......................... 464

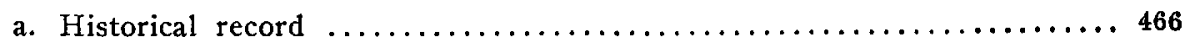

b. Record of investigation by State Eugenicist.................. $46 \mathbf{6 7}$

c. Report to State Eugenicist.......................... 467

2. Information or complaint by private citizen to State Eugenicist..........467

3. Institutional record of individual inmate prepared for State Eugenicist..... 468

4. Report of State Eugenicist (a. opinion, b. evidence, and c. petition)....... 469

5. Action begun by private citizen.........................470

a. Individual petition to court.........................470

b. Order of court denying private petition.................... 471

c. Order of court to State Eugenicist to investigate a particular case....... 471

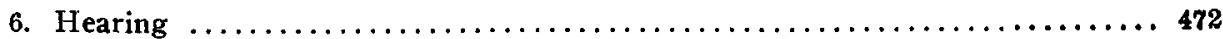

a. Proclamation appointing time and place for hearing.............472

b. Summons of propositus............................472

1. Summons to propositus in case such propositus is not an intrate of a custodial institution and is personally capable of understanding the nature of a summons............................. 47 
2. Order to guardian or custodian of propositus in case such propositus is an inmate of a custodial institution or lives under guardianship in

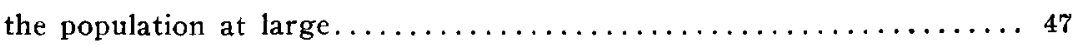

3. Order for arrest and presentation to court of the person of the propositus in case such propositus is neither an inmate of a custodial institution, nor living under guardianship in the population at large nor is capable of understanding the nature of a summons ........ 474

c. Notification to Attorney-General......................474

d. Instruction of Attorney-General to County Attorney............ 475

e. Appointment of legal counsel for the propositus............... 475

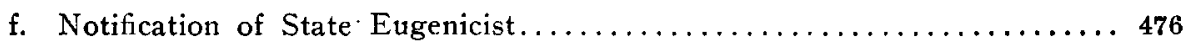

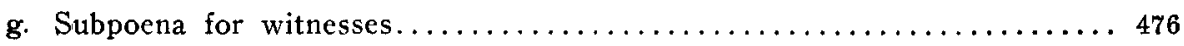

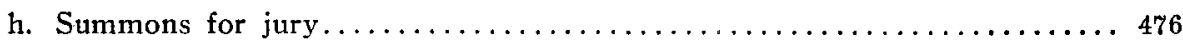

7. Judgment and order.

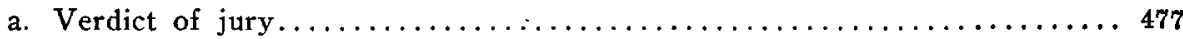

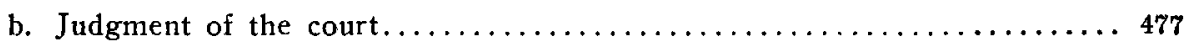

c. Order to State Eugenicist for the eugenical sterilization of a cacogenic person in the population at large....................... 478

d. Order to State Eugenicist for the eugenical sterilization of a cacogenic person who is an inmate of a custodial insitution.............. 479

e. Order to responsible head of custodial institution..............480

f. Order to State Eugenicist for the temporary suspension of an order for eugenical sterilization........................... 481

g. Order to a cacogenic person whose eugenical sterilization has been temporarily suspended, to report periodically to the State Eupenicist.... 482

h. Order to State Eugenicist for the eugenical sterilization of a cacogenic person, the original order for whose sterilization has been temporarily suspended

8. Execution of Order.

a. Contract with surgeon or physician to eugenically sterilize.

1. A cacogenic person in the population at large............... 484

2. A cacogenic person who is an inmate of a custodial institution........485

b. Report of surgeon or physician to State Eugenicist.............. 486

c. Return of State Eugenicist to court in case of the eugenical sterilization of a cacogenic person in the population at large $\ldots \ldots \ldots \ldots \ldots \ldots \ldots, \ldots$

d. Return of State Eugenicist to court in case of the eugenical stcrilization of a cacogenic person who is an inmate of a custodial institution........488

e. Semiannual return of State Eugenicist to the court in case an original order for eugenical sterilization has been temporarily suspended.........

9. Institutional data kept by State Eugenicist.

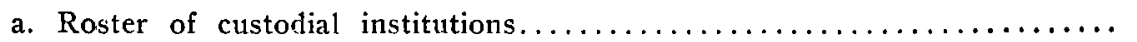

b. Monthly institutional report to State Eugenicist of accessions and

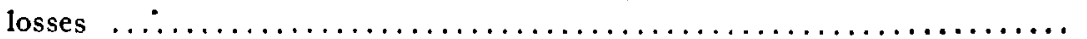

10. Record of an individual case of sterilization.

a. Case record of engenical sterilization.

11. Appropriations.

a. Working draft of appropriations section to be inserted in the proper place in the state's appropriation bills, according to the legislative practice of the particuiar state. 


\section{List of Illustrations}

Page

Figure 1. Schematic Representation of Genital Tract in the Male............. 398

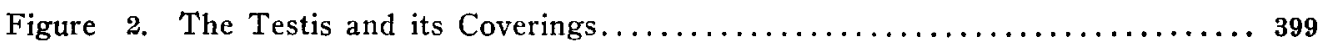

Figure 3. The Structure of the Spermatic Cord..................... 400

Figure 4. A Sectional View of the Testis........................401

Figure 5. The Development of a Human Spermatozoon..................402

Figure 6. Schematic Representation of the Genital Tract in the Female.........403

Figure 7. The Ovary, Fallopian Tube and Uterus in Place...............403

Figure 8. A Diagrammatic Section of the Human Ovary................ 404

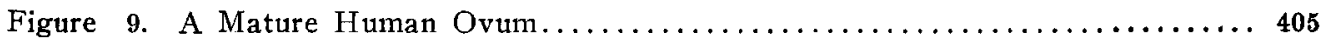

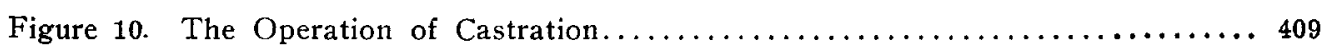

Figure 11. The Operation of Vasectomy........................ 410

Figure 12. The Abdominal Incision used in Salpingectomy and Oöphorectomy ...... 415

Figure 13. The Operation of Oöphorectomy (Kelly-Noble) $\ldots \ldots \ldots \ldots \ldots \ldots \ldots \ldots 416$

Figure 14. The Operation of Salpingectomy (Warbasse) $\ldots \ldots \ldots \ldots \ldots \ldots \ldots \ldots . \ldots 19$

Figure 15. The Operation of Salpingectomy (Margaret H. Smyth)..........420

\section{Pedigree Charts-Chapter 8}

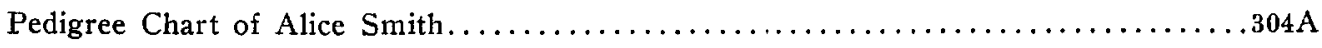

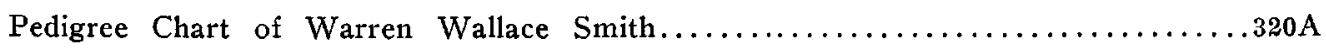

Pedigree Chart of the H... Family of Massachusetts.................. 353 

CHAPTER I.

CHRONOLOGICAL LIST

OF LAWS, AMENDMENTS, EXECUTIVE VETOES, REPEALS, OFFICIAL LEGAL OPINIONS, BOARD ORDERS, AND COURT DECISIONS RELATING TO EUGENICAL STERILIZATION PREVIOUS TO JANUARY 1, 1922.

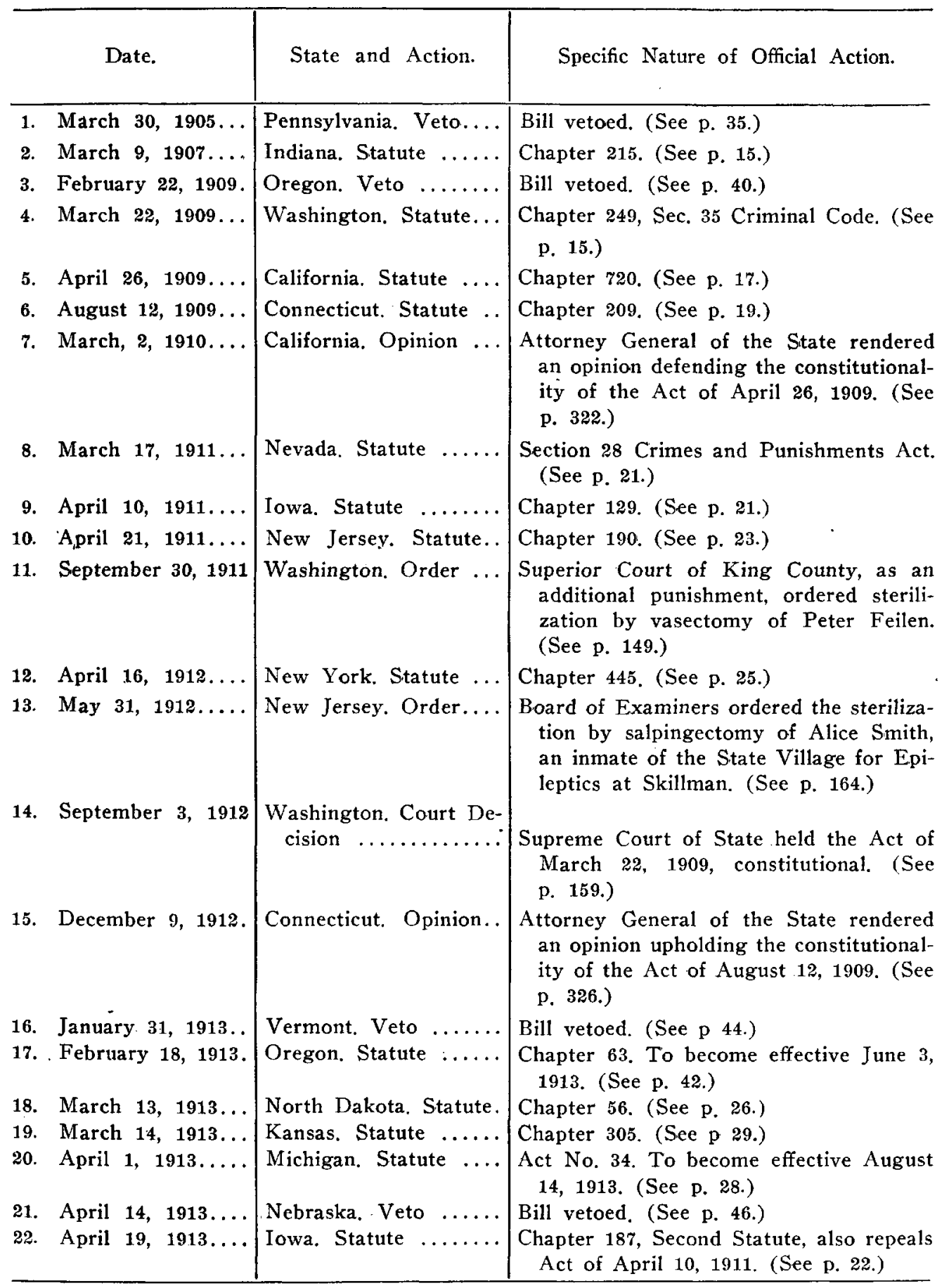




\begin{tabular}{l|l|l}
\hline Date. & State and Action. & Specific Nature of Official Action. \\
\hline
\end{tabular}

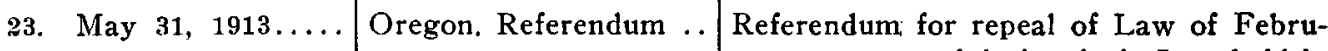
ary 19, 1913, duly invoked. Law held in abeyance until decision. (See p. 41.)

24. June $13,1913 \ldots$ California. Statute ...

Chapter 363, Second Statute, also repeals Act of April 26, 1909. (See p. 18.)

25. July 30, 1913....

26. November 4, 1913.

Wisconsin. Statute ....

Chapter 693. (See p. 31.)

Oregon, Revocation ...

Referendum duly revoked Act of February 18, 1913. (See p. 42.)

27. November 18, 1913 New Jersey. Court Decision $\ldots . . . \ldots \ldots$.

Supreme Court of the State set aside the order of the Board of Examiners of May 31, 1912, for the sterilization by salpingectomy of Alice Smith, an inmate of the State Village for Epileptics, and held the Act of April 21, 1911, "unconstitutional." (See p. 174.)

28. March 5, 1914... Iowa. Order .......

State Board of Parole ordered sterilization by vasectomy of Rudolph Davis, No. 10,406, an inmate of penitentiary at Fort Madison, twice convicted of felony. (See p. 179.)

29. June 24, 1914,... Iowa. Court Decision..

U. S. District Court, District of Southern Iowa, Eastern Division, held the Act of April 19, 1913, "unconstitutional." (See p. 186.)

30. June 1, 1915.... New York. Initiating Test Case ..........

Dr. Lemon Thompson of the Board of Examiners made application to the Supreme Court-Albany County, for the appointment of legal counsel to defend Frank Osborn, an inmate of the State Custodial Asylum, in a test case. (See p. 217.)

31. July 4, 1915..... Iowa. Statute ......

Chapter 202, Third Statute, also repeals Act of April 19, 1913. (See p. 23.)

32. July $8,1915 \ldots . .$. Nebraska. Statute ...

33. August 14, 1915... Nevada. Order ......

Chapter 237. (See p. 32.)

Fourth Judicial Court of Nevada (County of Elko) ordered as an additional punishment the sterilization by vasectomy of Pearley C. Mickle. (Seè p. 243.)

34. September 17, 1915 New York. Court Decision

State Supreme Court-Albany County, held the statute "unconstitutional and invalid" and issued an order in which the Board of Examiners was "perpetually enjoined and restrained from performing or permitting to be performed the aforesaid threatened operation." (See p. 221.) 


\begin{tabular}{|c|c|c|c|}
\hline & Date. & State and Action. & Specific Nature of Official Action. \\
\hline & May $4,1916 \ldots .$. & $\begin{array}{c}\text { Michigan. Court De- } \\
\text { cision } \ldots \ldots \ldots \ldots \ldots\end{array}$ & $\begin{array}{l}\text { Probate Court of Lapeer County denied } \\
\text { the petition of the Michigan Home and } \\
\text { Training School at Lapeer to order the } \\
\text { sterilization of Nora Reynolds, an in- } \\
\text { mate of said institution, on the ground } \\
\text { that the Act of April 1, 1913, is un- } \\
\text { constitutional. (See p. 203.) }\end{array}$ \\
\hline 36. & May $21,1917 \ldots$. & Oregon. Statute ...... & Chapter 279. (See p. 33.) \\
\hline & May 26, $1917 \ldots$. & Kansas, Statute ...... & Chapter 299. (See p. 30.) \\
\hline & July $1,1917 \ldots \ldots$ & South Dakota. Statute. & Chapter 236 (S. B. 257.) (See p. 34.) \\
\hline 39. & July $26,1917 \ldots \ldots$ & California, Statute .... & $\begin{array}{l}\text { Chapter 489, Amends the Act of June 13, } \\
\text { 1913. (See p. 18.) }\end{array}$ \\
\hline 40. & July $31,1917 \ldots$ & California. Statute $\ldots$. & $\begin{array}{l}\text { Section 42, Chapter 776. (See p. 19.) Ex- } \\
\text { tended provisions of Sterilization Law } \\
\text { to the Pacific Colony. }\end{array}$ \\
\hline & September 10,1917 & $\begin{array}{c}\text { Michigan. Court De- } \\
\text { cision } \ldots \ldots \ldots \ldots \ldots\end{array}$ & $\begin{array}{l}\text { Order of Circuit Court of Lapeer County } \\
\text { sustaining decision of Probate Court of } \\
\text { same County that the Act of April 1, } \\
1913 \text {, is "unconstitutional." (See p. 206.) }\end{array}$ \\
\hline 42. & January 15, 1917.. & Iowa. Court Decision. & $\begin{array}{l}\text { The U. S. Supreme Court reversed the } \\
\text { decision of June } 24,1914 \text {, of the District } \\
\text { Court because meanwhile (July } 4,1915 \text { ) } \\
\text { Iowa repealed the Act of April 19, 1913, } \\
\text { and enacted a new (the third) steriliza- } \\
\text { tion statute. Case not tried on its } \\
\text { merits. (See p. 200.) }\end{array}$ \\
\hline & March 8, 1918... & $\begin{array}{c}\text { New York. Court De- } \\
\text { cision } \ldots \ldots \ldots \ldots \ldots\end{array}$ & $\begin{array}{l}\text { At a Special Term, the Supreme Court of } \\
\text { Albany County sustained the findings } \\
\text { of September 17, 1915, of the same } \\
\text { court, perpetually enjoining the Board } \\
\text { of Examiners from sterilizing by vasec- } \\
\text { tomy Frank Osborn, an inmate of the } \\
\text { Rome Custodial Asylum, and holding } \\
\text { the Act of April 16, 1912 "unconstitu- } \\
\text { tional and invalid." (See p. 221.) }\end{array}$ \\
\hline & March 28, 1918.. & $\begin{array}{c}\text { Michigan. Court De- } \\
\text { cision } \ldots \ldots \ldots \ldots \ldots\end{array}$ & $\begin{array}{l}\text { State Supreme Court sustained decision } \\
\text { of Probate Court of Lapeer County of } \\
\text { May 4, 1916, and of Circuit Court of } \\
\text { the same county of September 10, 1917, } \\
\text { that the Act of April 1, 1913, is uncon- } \\
\text { stitational. (See p. 213.) }\end{array}$ \\
\hline & May 25, 1918.... & Nevada. Court Decision & $\begin{array}{l}\text { The U. S. District Court in and for the } \\
\text { District of Nevada held the Nevada } \\
\text { Act of March 17, 1911 "unconstitu- } \\
\text { tional." (See p. 245.) }\end{array}$ \\
\hline
\end{tabular}




\begin{tabular}{|c|c|c|c|}
\hline \multicolumn{2}{|r|}{ Date. } & State and Action. & Specific Nature of Official Action. \\
\hline 46. & July $1,1918 \ldots \ldots$ & $\begin{array}{c}\text { New York. Court De- } \\
\text { cision } \ldots \ldots \ldots \ldots \ldots \ldots\end{array}$ & $\begin{array}{l}\text { Supreme Court, Appellate Division, Third } \\
\text { Department. "Judgment unanimously } \\
\text { affirmed on the opinion of Rudd, J., at } \\
\text { Special Term." (See p, 234.) }\end{array}$ \\
\hline 47. & March 18, 1919... & Idaho. Veto ......... & Bill vetoed. (See p. 50.) \\
\hline 48. & April 2, $1919 \ldots$. & Connecticut. Statute .. & $\begin{array}{l}\text { Chapter } 69 \text { Public Acts of } 1919 \text { (see p. } \\
\text { 19). Extended the provisions of the } \\
\text { Sterilization Law to the Mansfield } \\
\text { State Training School and Hospital. } \\
\text { (See p. 20.) }\end{array}$ \\
\hline 49. & December 4, 1919 & Indiana. Court Decision & $\begin{array}{l}\text { Circuit Court of Clark County held } \\
\text { "Vasectomy Law" (Chap. 215, 1907) } \\
\text { unconstitutional. Judge James W. For- } \\
\text { tune. (See p. 257.) }\end{array}$ \\
\hline 50. & May $10,1920 \ldots \ldots$ & $\begin{array}{c}\text { New York. Statute Re- } \\
\text { pealed } \ldots \ldots \ldots \ldots \ldots\end{array}$ & L. 1920. Chap. 619. (See p. 26.) \\
\hline 51. & May $11,1921 \ldots \ldots$ & Indiana. Court Decision & $\begin{array}{l}\text { State Supreme Court (No. 23,709, Appeal } \\
\text { from Clark County Circuit Court) } \\
\text { Sustained the decision of the Trial } \\
\text { Court holding the "Vasectomy Law" } \\
\text { (Chap. 215, 1907) unconstitutional. (See } \\
\text { p. 258.) }\end{array}$ \\
\hline $\mathbf{5} \ddot{\mathbf{2}}$. & May $25,1921 \ldots$. & Pennsylvania. Veto ... & Bill vetoed. (See p. 38.) \\
\hline 53. & January $27,1921 .$. & Oregon. Order........ & $\begin{array}{l}\text { Oregon State Board of Eugenics ordered } \\
\text { the sterilization of Jacob Cline, an in- } \\
\text { mate of the Oregon State Penitentiary. } \\
\text { (See p. 272.) }\end{array}$ \\
\hline 54. & March $8,1921 \ldots$ & Washington. Statute .. & $\begin{array}{l}\text { Chapter } 53 \text { of the Session Laws of } 1921 \text {, } \\
\text { H. B. 190. (See p. 15.) }\end{array}$ \\
\hline 55. & December 13,1921 & Oregon. Court Decision & $\begin{array}{l}\text { Circuit Court of the State of Oregon for } \\
\text { the County of Marion held the statute } \\
\text { of February 19, 1917, unconstitutional. } \\
\text { (See p. 289.) }\end{array}$ \\
\hline
\end{tabular}




\section{CHAPTER II.}

\section{ANALYSIS, BY STATES, OF STERILIZATION LAWS ENACTED PRIOR TO JANUARY 1, 1922}

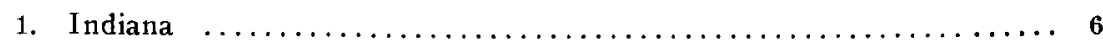

2. Washington:

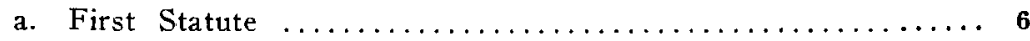

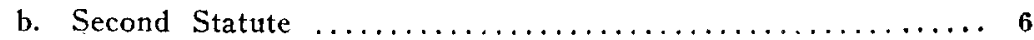

3. California:

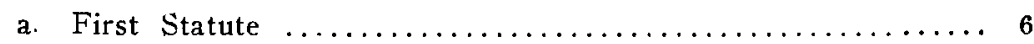

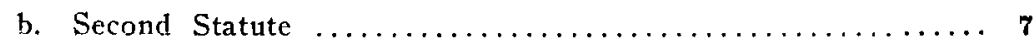

c. Amendment to Second Statute.................. 7

d. Sterilization Provision in Act establishing Pacific Colon..... 8

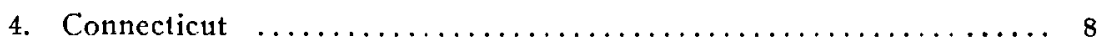

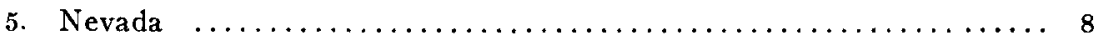

6. Iowa :

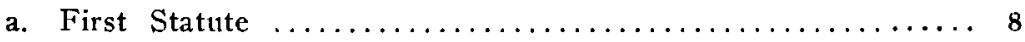

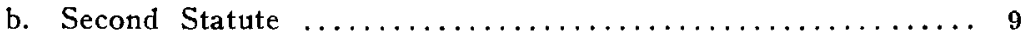

c. Third Statute $\ldots \ldots \ldots \ldots \ldots \ldots \ldots \ldots \ldots \ldots \ldots \ldots$

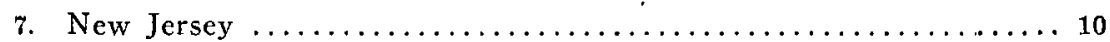

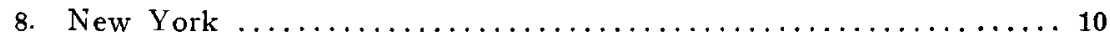

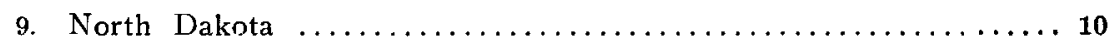

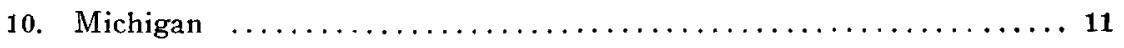

11. Kansas:

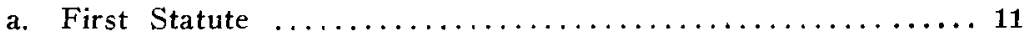

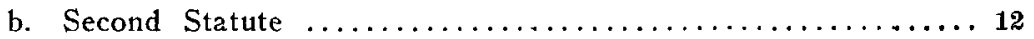

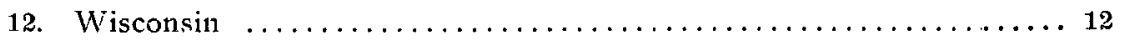

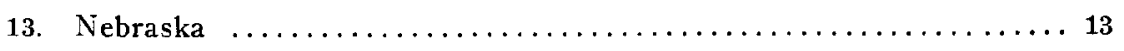

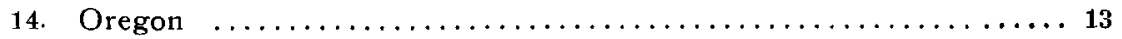

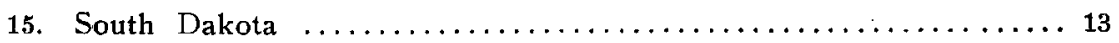




\section{INDIANA.}

Date of Approval of Statute. March 9, 1907.

Reference in State Laws. Chapter 215, Laws of 1907.

Persons Subject. Inmates of all State institutions who are deemed by a commission of three surgeons to be unimprovable, physically and mentally, and unfit for procreation.

Executive Agents Provided. For each subject institution a Committee of Experts, consisting of two skilled surgeons of recognized ability, who shall act in conjunction with the regular institution physician and Board of Managers for the particular institution.

Basis of Selection: Procedure. Inadvisability of procreation and improbability of improvement of mental and physical condition, in judgment of Committee of Experts and Board of Managers of the institution.

Type of Operation Authorized. "Such operation for the prevention of procreation as shall be decided safest and most effective."

State's Motive. Purely eugenic.

Appropriations Available for Enforcing the Act. "In no case shall the consultation fee be more than $\$ 3.00$ to each expert to be paid out of the funds appropriated for the maintenance of the institution."

Present Legal Status, January 1, 1922. After having been a dead letter since the inauguration of Governor Thomas R. Marshall in 1909, this law was tested by the courts and declared unconstitutional May 11, 1921, by decision of the State Supreme Court.

\section{WASHINGTON.}

\section{(a.) First Statute.}

Date of Approval of Statute. March 22, 1909.

Reference in State Laws. Chapter 249, Section 35, Criminal Code Statutes of 1909.

Persons Subject. Habitual criminals and persons adjudged guilty of carnal abuse of female persons under ten years of age, or of rape.

Executive Agencies Provided. The Court passing sentence for offense may in addition direct operation to be performed.

Basis of Selection: Procedure. Character of subject and his previous unsocial acts.
Type of Operation Authorized. "An operation for the prevention of procreation."

State's Motive. Purely punitive.

Appropriations Available for Enforcing the Act. No provision made for special appropriation.

Present Legal Status, January 1, 1922. Constitutional by decree of State Supreme Court September 3, 1912.

\section{(b.) Second Statute.}

Date of Approval of Statute. March 8, 1921.

Reference in State Laws. Chapter 53, of the Session Laws of 1921.

Persons Subject. Feeble-minded, insane, epileptic, habitual criminals, moral degenerates and sexual perverts (in institutions) showing hereditary degeneracy.

Executive Agents Provided. The institutional Board of Health.

Basis of Selection. Inadvisability of procreation and improbability of improvement in condition of the subject, in the judgment of said Board, after due consideration.

Basis of Procedure. Order of Board served on inmate or legal guardian. Inmate or guardian may make appeal within fifteen days to Superior Court of county in which institution is located. No operation shall be performed until expiration of time for appeal or, if appealed, until decision of court or jury.

Type of Operation Authorized. "Such surgical operation for sexual sterilization as may be specified in the order of the Institutional Board of Health" and "to be performed with due regard for the physical condition of the inmate and in a safe and humane manner."

State's Motive. Primarily eugenic and secondarily for the personal benefit of the inmate.

Appropriations Available for Enforcing the Act. "The State shall be liable only for the actual traveling expenses of the members of the Board incurred in the performance of their duties," such expenses to be paid "from the moneys appropriated for the maintenance of the institution."

Present Legal Status. January 1st, 1922. Not tested by courts.

\section{CALIFORNIA.}

\section{(a.) First Statute.}

Date of Approval of Statute. April 26, 1909. 
Reference in State Laws. Chapter 270, Statutes of 1909.

Persons Subject. Inmates of State hospitals and home for feeble-minded, and inmates of State prisons committed for life, or showing sex or moral perversions, or twice committed for sexual offenses, or three times for other crimes.

Executive Agencies Provided. Board consisting of superintendent or resident physician of each subject institution in consultation with the general superinterident of State hospitals and the secretary State Board of Health.

Basis of Selection: Procedure. Decision by entire board or any two of them that asexualization will be beneficial, or conducive to the benefit of the physical, mental or moral condition of the inmate.

Type of Operation Authorized. "Asexualization."

State's Motive. Mainly eugenic, also for the physical, mental or moral benefit of inmate, also partly punitive in certain cases.

Appropriations Available for Enforcing the Act. No provision made for special appropriation.

Legal Status, January 1, 1922. Constitutional by decree of State Supreme Court, September 3, 1912,

\section{(b.) Second Statute.}

Date of Approval. June 13, 1919. (Repeals first statute, April 26, 1909.)

Reference in State Laws. Chapter 363, Statutes of 1913.

Persons Subject. Inmates of State hospitals and home for feeble-minded and recidivisits of all prisons of the State. Act does not apply to voluntary patients in State hospitals.

Executive Agencies Provided. (a) State Commission in Lunacy, for the insane. (b) Resident Physician of the particular State prison, the general superintendent of State hospitals and secretary State Board of Health for recidivists. (c) Medical Superintendent of any State hospital, for "idiots and fools."

Basis of Selection: Procedure. Discretion of the commission before the release of persons "affected with hereditary insanity or incurable chronic mania or dementia." Discretion of resident physician of any State prison in consultation with the general superintendent of State hospitals and secretary of the State Board of Health in cases. of recidivists; provided asexualization would benefit such recidivist, and that such recidivist has been twice convicted for sexual offenses, or three times for any other crime in any State or country. Discretion of the medical superintendent of any hospital may asexualize any minor, "idiot or fool" under his care, with the written consent of the parent, or guardian if such "idiot or fool" be an adult, and said medical superintendent shall perform such operation at the request of such parents or guardians.

Type of Operation Authorized. "Asexualization."

State's Motive. Mainly eugenic, also in some cases therapeutic and punitive.

Appropriations Available for Enforcing the Act. No provision made for special appropriation.

Present Legal Status, January 1, 1922. Not tested by courts.

(c.) Amendment to Act of June 13, 1913.

Date of Approval of Statute, May 17, 1917.

Reference in State Laws. Chapter 489, Laws of 1917.

Persons Subject. . Any person who has been lawfully committed to any State hospital for the insane, or who has been an inmate of Sonoma State Home, and who is afflicted with mental disease which may have been inherited and is likely to be transmitted to descendants, the various grades of feeblemindedness, those suffering from perversion or marked departures from normal mentality, or from diseases of a syphilitic nature.

Executive Agencies Provided. State Commission in Lunacy, for the insane, Resident Physician of the respective State prisons, the general superintendent of State hospitals and secretary State Board of Health for recidivists. Medical superintendent of any State hospital for "idiots or fools."

Basis of Selection: Procedure. Discretion of Commission before release of a person afflicted with mental disease which may have been inherited and is likely to be transmitted to descendants, the various grades of feeble-mindedness, those suffering from perversion or marked departures from normal mentality or from diseases of a syphilitic nature.

Type of Operation Authorized. "Asexualization."

State's Motive. Purely eugenic.

Appropriations Available for Enforcing the Act. No provision made for special appropriation.

Present Legal Status, January 1, 1922. Not tested by courts. 
(d.) Sterilization Provision in Act establishing Pacific Colony.

Date oi Approval of Statute. June 1, 1917.

Reference in State Laws. Section 42, Chapter 776, Laws of 1917.

Persons Subject. Any inmate of Pacific Colony and who is feeble-minded or is afflicted with incurable chronic mania or dementia.

Executive Agencies Provided. Board of Trustees, on the recommendation of the superintendent approved by a clinical psychologist holding degree of Ph.D., and a physician qualified to serve under Section 19 of this Act.

Basis of Selection: Procedure. Discretion of Commission before release of a person who is feeble-minded or is afflicted with incurable chronic mania or dementia.

Type of Operation Authorized. "Sterilization."

State's Motive. Purely eugenic.

Appropriations Available for Enforcing the Act. No provision made for special appropriation.

Present Legal Status, January 1, 1922. Not tested by courts.

\section{CONNECTICUT.}

Date of Approval of Statute. August 12, 1909.

Reference in State Laws. Chapter 209, Public Acts of 1909.

Persons Subject. Inmates of State prisons and of State hospitals at Middletown and Norwich.

Executive Agencies Provided. Board of three surgeons, consisting of the resident physician and two others appointed by the superintendent of the particular institution, one member of said board appointed to perform operation.

Basis of Selection: Procedure. Decision by majority of Board, after examining the mental and physical condition of the subject, his record and family history, of the improbability of improvement of the physical and mental condition and the consequent inadvisability of procreation, or of the probability of substantial improvement of the mental and physical condition of subject thereby.

Type of Operation Authorized. ."Vasectomy or Oöphorectomy in a safe and humane manner." For operations, except as authorized by law, a fine of not more than $\$ 1,000$ or 5 years' imprisonment, or both, is provided.

State's Motive. Mainly eugenic, also therapeutic.

Appropriations Available for Enforcing the Act. Board making such examination and surgeon performing such operation shall receive from the State such compensation for services rendered as warden of State prison or superintendent of either such hospital shall deem reasonable.

Present Legal Status, January 1, 1922. Constitutional according to the opinion of the Attorney General of the State, December 9, 1912. Not tested by courts.

\section{NEVADA.}

Date of Approval of Statute. March 17, 1911.

Reference in State Laws. Section 28, Crimes and Punishment Act.

Persons Subject. Habitual criminals, and persons adjudged guilty of carnal abuse of female persons under ten years of age.

Executive Agencies Provided. The Court passing sentence for offense may in addition direct the operation to be performed.

Basis of Selection: Procedure. Character of subject and his previous unsocial acts.

Type of Operation Authorized. "An operation for the prevention of procreation, except castration."

State's Motive. Purely punitive.

Appropriations Available for Enforcing the Act. No provision made for special appropriation.

Present Legal Status, January 1, 1922. Unconstitutional by decision of Federal District Court, May 25, 1918.

\section{IOWA.}

\section{(a.) First Statute.}

Date of Approval. April 10, 1911.

Reference in State Laws. Chapter 129, Acts of 34th General Assembly, 1911.

Persons Subject. Inmates of public institutions for criminals, idiots, feeble-minded, imbeciles, drunkards, drug fiends, epileptics, syphilitics, etc.

Executive Agencies Provided. Board consisting of the managing officer and surgical superintendent of each institution with members of State Board of Parole; , the operation being performed by the surgeon of the institution. 
Basis of Selection: Procedure. Decision by a majority of board, after examining mental and physical condition of subject; of the improbability of mental or physical improvement, and the consequent inadvisability of procreation, or of the probable substantial improvement thereby, or continual evidence on part of subject of being a moral or sexual pervert.

Type of Operation Authorized. Vasectomy or salpingectomy. For operations, except as authorized by this Act, punishable by fine of "not more than $\$ 1,000$, or imprisonment in the penitentiary, not to exceed one year, or both."

State's Motive. Mainly eugenic, also punitive in cases of certain felons and sex offenders, also therapeutic.

Appropriations Available for Enforcing the Act. No provision made for special appropriation.

Present Legal Status, January 1, 1922. Repealed April 19, 1913.

\section{(b) Second Statute.}

Date of Approval. April 19, 1913. (Repeals first statute, April 10, 1911.)

Reference in State Laws. Chapter 187, Acts of 35th General Assembly, 1913.

Persons Subject. Inmates of public institutions for criminals, rapists, idiots, feebleminded, imbeciles, lunatics, drunkards, drug fiends, epileptics, syphilitics, moral and sexual perverts, and diseased and degenerate persons. Compulsory in cases of persons twice convicted of felony, or of sexual offense other than "white slavery," for which offense one conviction makes sterilization mandatory.

Executive Agencies Provided. State Board of Parole with the managing officer and physician of each institution for their respective institutions. Upon application to the Board of Parole or to any judge of the district court, by persons afflicted with syphilis or epilepsy, said board or court may authorize vasectomy or salpingectomy as the case may be. Upon submitting to such operation by one of the contracting parties and making said fact known to the second party, the law restricting marriage of such persons shall be void. Board "directed to examine annually or oftener" the mental and physical condition and family history of inmates of institutions with the view of determining the prospects of procreation by such individuals, and to report annually to the governor the proceeding "and also observation and statistics regarding its benefit."

Basis of Selection: Procedure. Decision by a majority of special board (Board of Parole, managing officer and physician of institution) that procreation by inmate would produce children with a tendency to disease, degeneracy, deformity or that physical or mental condition of inmate would be improved thereby, or that inmate is a sexual or moral pervert, operation to be performed by the physician of the institution, or by one selected by him.

Type of Operation Authorized. Vasectomy or salpingectomy. For operations, except as authorized by this Act, punishable by fine of "not more than $\$ 1,000$, or imprisonment in the penitentiary, not to exceed one year, or both."

State's Motive. Mainly eugenic, also punitive in cases of certain felons and sexoffenders, also therapeutic.

Appropriations Available for Enforcing the Act. No provision made for special appropriation.

Present Legal Status, January 1, 1922. Repealed April 16, 1915, after having been decided unconstitutional by Federal District Court, June 24, 1914.

\section{(c) Third Statute.}

Date of Approval. April 16, 1915. (Repeals second statute April 19, 1913.)

Reference in State Laws. Chapter 202, Acts of 36th General Assembly, 1915.

Persons Subject. Institutional inmates afflicted with insanity, idiocy, imbecility, feeble-mindedness, or syphilis.

Executive Agencies Provided. The superintendent of any hospital for the insane and a majority of his medical staff, with the approval of the Board of Control or a majority of the members thereof.

Basis of Selection: Procedure. Decision of superintendent and his medical staff that it is for the best interests of the patient and society, with written consent of husband or wife, parent, guardian or next of kin.

Type of Operation Authorized. Vasectomy or salpingectomy. Operations except as authorized by this Act, punishable by a fine of "not more than $\$ 1,000$ or imprisonment in penitentiary, not to exceed one year, or both."

State's Motive. Mainly eugenic, or punitive in cases of certain felons and sex offenders, also therapeutic. 
Appropriations Available for Enforcing this Act. No provision made for special appropriation.

Present Legal Status, January 1, 1922. Not tested by courts.

\section{NEW JERSEY.}

\section{Date of Approval. April 21, 1911.}

Reference in State Laws. Chapter 190, Statutes of 1911.

Persons Subject. Inmates of State reformatories, charitable and penal institutions (rapists and confirmed criminals.)

Executive Agencies Provided. Board of Examiners, consisting of one surgeon, one neurologist, each of recognized ability, appointed by the governor by and with the advice of the Senate, acting in conjunction with the Commissioner of Charities and Corrections; any person qualified under the laws of the State under direction of chief physician of institution being allowed to perform operation, orders subject to review by Supreme Court, or any justice thereof.

Basis of Selection: Procedure. Unanimous decision of board in conjunction with chief physician of the institution, after examining the mental and physical condition of subject, of the improbability of improvement of his condition and the consequent inadvisability of procreation.

Type of Operation Authorized. "Such operation for the prevention of procreation as shall be decided by said Board of Examiners to be most effective."

State's Motive. Purely eugenic.

Appropriations Available for Enforcing the Act. There shall be paid out of the funds appropriated for maintenance of such institutions to each physician of said board of examiners, a compensation of not more than $\$ 10.00$ per diem, for each day actually given to such work or examination, and his actual and necessary expenses in going to, holding and returning from such examination." The judge of Court of Common Pleas appointing any counsel under this Act may fix compensation to be paid him, and it shall be paid, as other court expenses are now paid.

Present Legal Status, January 1, 1922. Declared unconstitutional by State Supreme Court, November 18, 1913.

\section{NEW YORK.}

Date of Approval. April 16, 1912.

Reference in State Laws. Chapter 445, Laws of 1912.

Persons Subject. Inmates of State hospitals for the insane, State prisons, reformatories, and charitable institutions, and rapists, and confirmed criminals in penal institutions.

Executive Agencies Provided. Board of Examiners, consisting of one surgeon, one neurologist, one practitioner of medicine appointed by governor for five years, one of its members being appointed by the Board to perform operation. All orders shall be subject to review by Supreme Court or any justice thereof.

Basis of Selection: Procedure. Decision by majority of board, after examining mental and physical condition of subject, his record and family history, of the improbability of improvement of his condition and the consequent inadvisability' of procreation or of the probability of substantial improvement of subject's condition thereby.

Type of Operation Authorized. Any operation for the prevention of procreation. Type determined by the Board of Examiners. Except for medical necessity, unauthorized operation constitutes a misdemeanor.

State's Motive. Purely eugenic.

Appropriations Available for Enforcing the Act. "The compensation shall be $\$ 10.00$ per diem for each day actually engaged in performance of duties of the board, and their actual and necessary traveling expenses." Judge of court appointing counsel under this Act may fix compensation to be paid him. $\$ 5,000$ appropriated for 1913-14.

Present Legal Status, January 1, 1922. Declared unconstitutional by the Supreme Court of Albany County, March 5, 1918, and by Appellate Division July 1, 1918. Appeal pending before the Court of Appeals when the statute was repealed by the State Legislature, May 10, 1920. (L. 1920. Chap. 619.)

\section{NORTH DAKOTA.}

Date of Approval. March 13, 1913.

Reference in State Laws. Chapter 56, Laws of 1912.

Persons Subject. Inmates of State prisons, reform school, school for feebleminded, and asylum or hospital for insane.

Executive Agencies Provided. Board, consisting of chief medical officer of the 
particular subject institution, secretary of State Board of Health and one competent physician and surgeon of good standing and experience, who shall be appointed by State Board of Control; the latter designating some skilled surgeon, who may or may not be one of their own number, to perform the operation.

Basis for Selection: Procedure. Decision of the board or even by the chief medical officer of the institution, after examining mental and physical condition of subject of the improbability of physical or mental improvement, and the consequent inadvisability of procreation, or of the probability of substantial improvement of subject's condition thereby.

Type of Operation Authorized. "Surgical operation for sterilization."

State's Motive. Mainly eugenic, also therapeutic.

Appropriations Available for Enforcing the Act. The per diem compensation of the members appointed by the State Board of Control shall be fixed by that board in the letter of appointment, and shall not exceed $\$ 10.00$ per day, while in actual performance of their duties; and the per diem, and actual, and necessary expenses of such members shall be allowed and paid in same manner as is provided for by law for the payment of salaries and expenses of members, agents and employees of State Board of Control; also the investigation and securing, at expense of county, transcripts of records of convictions from other counties and States, and also such evidence of identification as may be obtained.

Present Legal Status, January 1, 1922. Not tested by courts.

\section{MICHIGAN.}

Date of Approval. April 1, 1913.

Reference in State Laws. Act No. 34, Public Acts of 1913.

Persons Subject. Inmates of State institutions maintained wholly or in part by public expense.

Executive Agencies Provided. Board for each institution to consist of the members of the board of control of each particular institution and the physicians or surgeons in charge thereof; such board to direct some competent physician or surgeon to perform operation. In case an institution has no physician at head, Board of Managers may hire operation performed, 30 days' notice being given subject, with option of hearing in court.

Basis for Selection: Procedure. Decision by a majority of the board, after examining physical and mental condition of subject, of the improbability of improvement of mental or physical condition, and the consequent inadvisability of procreation or of the probability of substantial improvement of the subject's condition thereby.

Type of Operation Authorized. Vasectomy or salpingectomy, in a safe and humane manner, or improvements thereon less dangerous to life. For operation, except as authorized by this Act, or for medical necessity, punishable by fine, not more than $\$ 1,000$ or imprisonment for not more than 5 years, or both.

State's Motive. Mainly eugenic, also therapeutic.

Appropriations Available for Enforcing the Act. The institution physician or surgeon performing operation shall receive no compensation therefor; if any surgeons are hired, these shall be allowed for their services the compensation fixed by the statutes, for the examination and certification of an insane person. The several sums necessary to carry out the provisions of this Act shall be paid out of general fund of State, upon the warrant of the auditor-general.

Present Legal Status, January 1, 1922. Declared unconstitutional by State Supreme Court, March 28, 1918.

\section{KANSAS.}

\section{(a) First Statute.}

Date of Approval. March 14, 1913.

- Reference in State Laws. Chapter 305, Session Laws of 1913.

Persons Subject. Inmates of all State institutions entrusted with the care or custody of habitual criminals, idiots, epileptics, imbeciles and insane; "habitual criminal" to mean "a person who has been convicted of some felony involving moral turpitude."

Executive Agencies Provided. By an authority "consisting of the managing officers of each and every institution of the State in conjunction with competent surgical assistants, who shall report its conclusions to the district court, or any court of competent jurisdiction, in or for the district, from which such inmate has been committed; the final order of sterilization lying with the court, who shall appoint one of the 'authority' to perform operation." 
Basis for Selection: Procedure. Final order of the court to which have been reported the conclusions of the "authority," after examining the physical and mental condition of the subject, his record and family history, to the effect that the subject's condition is deemed unimprovable, and consequently procreation will be undesirable; or that the subject's condition will be substantially improved thereby.

Type of Operation Authorized. Vasectomy or oöphorectomy in a safe and humane manner. For operations, except as authorized by law, or for medical necessity, fine of $\$ 1,000$, or imprisonment for one year, or both, is provided.

State's Motive. Mainly eugenic, also therapeutic.

Appropriations Available for Enforcing the Act. "The surgeon performing operation shall receive from the State such compensation for the service rendered as the Board of Administration shall deem reasonable-to be paid out of the maintenance fund of the institution in which such person is confined."

Present Legal Status, January 1, 1922. Repealed March 13, 1917.

(b) Second Statute.

Date of Approval. March 13, 1917 (Repeals Aet of March 14, 1913).

Reference in State Laws. Chapter 299. Laws of 1917.

Persons subject. Inmates of State hospitals for the insane, State hospital for epileptics, State home for feeble-minded or State school for girls.

Executives Agencies Provided. Chief medical officer of any subject institution, governing board of the institution and secretary of the State Board of Health.

Basis for Selection: Procedure. Decision of Examining Board that the mental or physical condition of any inmate would be improved thereby or that procreation by such inmate would be likely to result in defective or feeble-minded children with criminal tendencies, and that the condition of such inmate is not likely to improve so as to make procreation desirable.

Type of Operation Authorized. "Vasectomy or asexualization." "Salpingectomy or oöphorectomy." For operations, except as authorized by law, a fine of not more than $\$ 500$ and not less than $\$ 100$, imprisonment not less than 6 months and not more than 1 year.

State's Motive. Therapeutic and eugenic.

Appropriations Available for Enforcing the Act. If the physician is not connected with such institution, the governing board can make reasonable terms for compensation and such fee shall be paid from the fund provided for the maintenance of such institution in the manner provided by law.

Present Legal Status, January 1, 1922. Not tested by courts.

\section{WISCONSIN.}

Date of Approval. July 30, 1913.

Reference in State Laws. Chapter 693, Laws of 1913.

Persons Subject. Inmates of all State and county institutions for criminal, insane, feeble-minded and epileptic persons.

Executive Agencies Provided. Special Board, consisting of "one surgeon and one alienist of recognized ability." * * * "in conjunction with superintendents of the State and county institutions;" appointed by the State Board of Control. Duty of special board "to examine into the mental and physical condition of persons legally confined in all State and county institutions." It "shall meet, take evidence and examine" and shall report to the State Board of Health its findings in cases duly nominated by said Board of Control.

Basis for Selection: Procedure. Finding by unanimous vote of special board that "procreation is undesirable" by inmates whose names are submitted to said board by the State Board of Control, makes lawful the performance of operations by authority and only by authority of State Board of Control.

Type of Operation Authorized. "Such operation for the prevention of procreation as shall be decided safest and most effective."

State's Motive. Purely eugenic.

Appropriations Available for Enforcing the Act." * * * a sufficient amount of money to carry into effect the purpose of this section, not to exceed two thousand dollars." Expert's compensation by the State Board of Control, which shall not exceed ten dollars per day and expenses for days actually consumed in the performance of duty.

Present Legal Status, January 1, 1922. Not tested by courts. 


\section{NEBRASKA.}

Date of Approval. Without signature of Governor, July 8, 1915.

Reference in State Laws. Chapter 237, Laws of 1915.

Persons Subject. Feeble-minded or insane inmates of institutions for the feebleminded, hospitals for the insane, the penitentiary, reformatory, industrial schools, industrial home or other such State institution.

Executive Agencies Provided. Board of Commissioners of State Institutions shall designate five physicians from the medical staff of state institutions under their jurisdiction, three of which physicians shall be appointed from institutions for feeble-minded youth and the hospitals for the insane.

Basis for Selection: Procedure. Decision by Board of Examiners that procreation by such inmate would be harmful to society; with written consent of husband or wife, parent, guardian, or next of kin.

Type of Operation Authorized. "Such operation *** for the prevention of procreation as in the judgment of said Board of Examiners shall be most appropriate to each individual case."

State's Motive. Purely eugenic.

Appropriations Available for Enforcing the Act. "Members of said Board of Examiners shall receive no compensation for their services as such examiners, but shall be reimbursed their actual and necessary traveling expenses from funds of the respective institutions whose inmates are examined by them."

Present Legal Status, January 1, 1922. Not tested by courts.

\section{OREGON.}

Date of Approval. February 19, 1917.

Reference in State Laws. Chapter 279, General Laws of 1917.

Persons Subject. Feeble-minded, insane, epileptic, habitual criminals, moral degenerates, and sexual perverts who may be inmates of institutions maintained by public expense.

Executive Agencies Provided: State Board of Eugenics, composed of State Board of Health, Superintendent of Oregon State
Hospital, Superintendent of Eastern Oregon State Hospital, Superintendent of State Institution for Feeble-Minded and Superintendent of Oregon State Penitentiary.

Basis for Selection: Procedure: Inadvisability of procreation and no probability of improvement of mental condition in judgment of a majority of the Board.

Type of Operation Authorized. "Such type of sterilization as may be deemed best by said board."

State's Motive. For betterment of physical, mental, neural or psychic condition of inmate to protect society, and not in any manner as a punitive measure.

Appropriations Available for Enforcing the Act. "State" liable only for actual traveling expenses of members of Board, incurred in performance of their duties, and actual and necessary expense incident to the investigations of said Board and appeal therefrom.

Present Legal Status, January 1, 1922. Declared unconstitutional by Circuit Court for the County of Marion, Dec. 13, 1921.

\section{SOUTH DAKOTA.}

Date of Approval. March 8, 1917.

Reference in State Laws. Chapter 236 (S. B. 257), Law of 1917 .

Persons Subject. Inmates of State Home for Feeble-minded.

Executive Agencies Provided. State Board of Charities and Corrections, Superintendent of the subject institution, and the physician of said institution or one selected by him.

Basis for Selection: Procedure. Inadvisability of procreation and improbability of improvement of mental condition in judgment of Board and Superintendent.

Type of Operation Authorized. "The operation of vasectomy or ligation of the Fallopian tubes as the case may be."

State's Motives. Therapeutic and eugenic.

Appropriations Available for Enforcing the Act. No provision made for special appropriation.

Present Legal Status, January 1, 1922. Not tested by courts. 
A. Laws enacted prior to January 1 st 1922 .

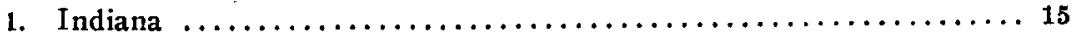

2. Washington:

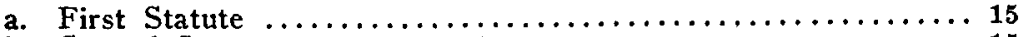

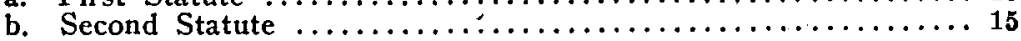

3. California:

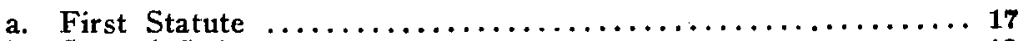

b. Second Statute $\ldots \ldots \ldots \ldots \ldots \ldots \ldots \ldots \ldots \ldots \ldots \ldots \ldots \ldots \ldots \ldots \ldots \ldots \ldots \ldots \ldots \ldots \ldots, 18$

c. Amendment to Second Statute.................... 18

d. Sterilization Provision in Act establishing Pacific Colony..... 19

4. Connecticut:

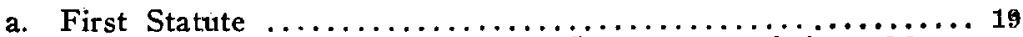

b. Sterilization Provisions of First Statute extended to Mansfield State Training School and Hospital................ 20

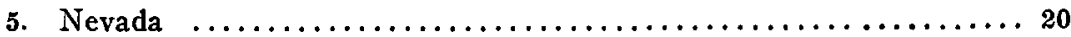

6. Iowa:

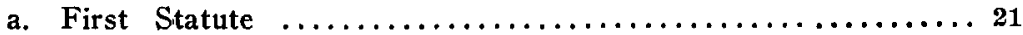

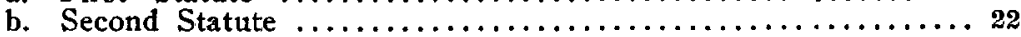

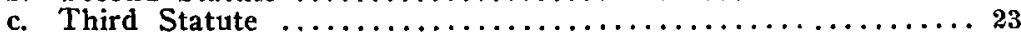

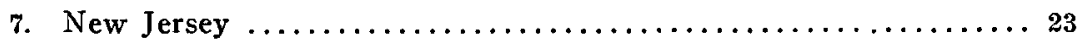

8. New York:

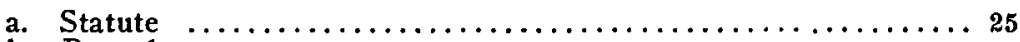

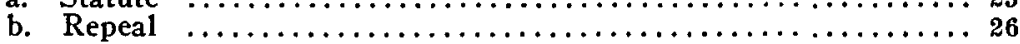

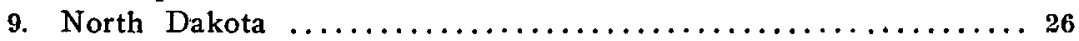

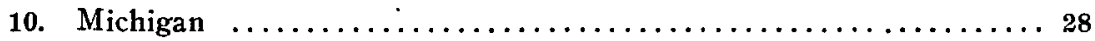

11. Kansas:

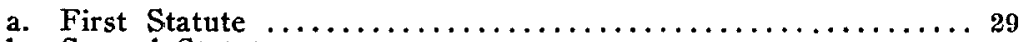

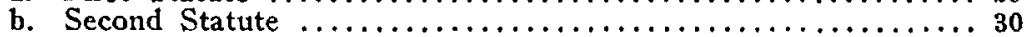

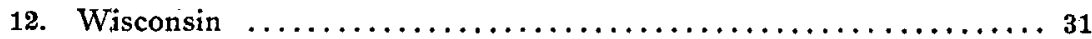

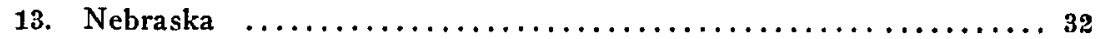

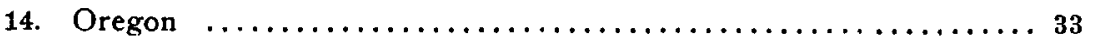

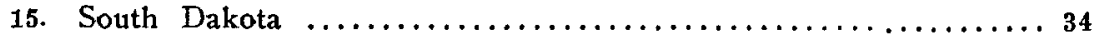

B. Eugenical Sterilization Bills Vetoed.

1. Pennsylvania :

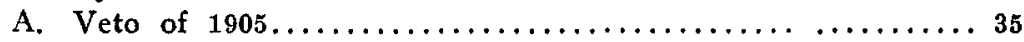

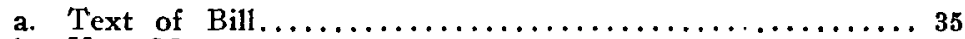

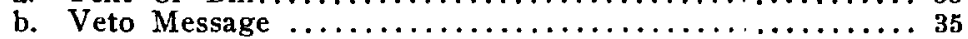

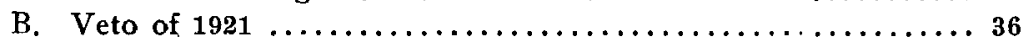

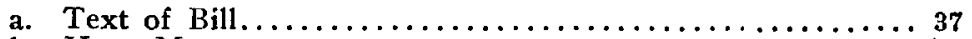

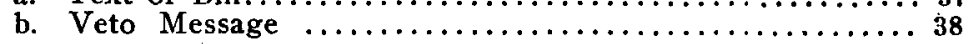

C. Notes on the Situation in Pennsylvania................. 39

2. Oregon:

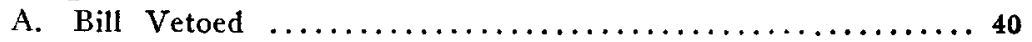

a. Text of Bill................................ 40

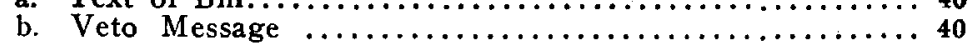

B. Law revoked by Referendum.....................41

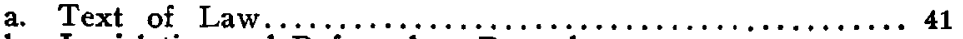

b. Legislative and Referendum Record.................. 42

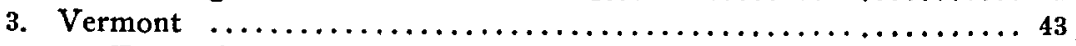

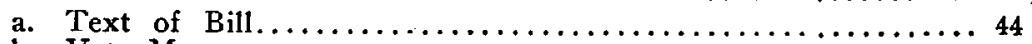

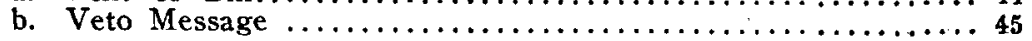

4. Nebraska:

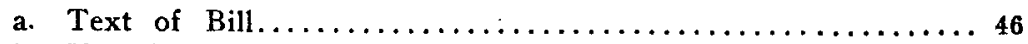

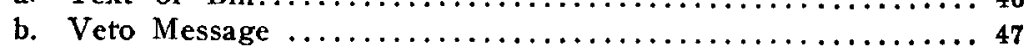

5. Idaho:

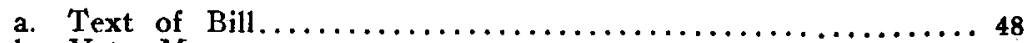

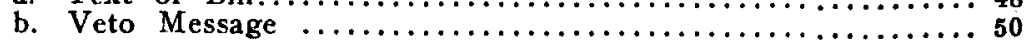




\section{A. LAWS ENACTED PRIOR TO JANUARY 1, 1922, IN VARIOUS STATES.}

\section{INDIANA.}

Date of Law: April 9, 1907.

The bill was introduced on January 29, 1.907 , by Representative Horace D. Read, of Tipton, Ind.

It passed the House February 19, 190759 ayes, 22 noes; the Senate March 6, $190 \%$ -28 ayes, 16 noes.

It was declared unconstitutional May 11, 1921, by the Supreme Court.

It appears on the Indiana laws of 1907 as Chapter 215, on page 377; Burns' Indiana Statutes 1908, sec. 2232.

AN ACT to prevent procreation of confirmed criminals, idiots, imbeciles and rapists, Providing that superintendents or boards of managers of institutions, where such persons are confined, shall have the authority and are empowered to appoint a committee of experts, consisting of two physicians, to examine into the mental condition of such inmates.

WHEREAS, Heredity plays a most important part in the transmission of crime, idiocy, and imbecility:

Therefore, be it enacted by the General Assembly of the State of Indiana, that on and after the passage of this act it shall be compulsory for each and every institution in the state, entrusted with the care of confirmed criminals, idiots, rapists, and imbeciles, to appoint upon its staff, in addition to the regular institutional physician, two (2) skilled surgeons of recognized ability, whose duty it shall be, in conjunction with the chief physician of the institution, to examine the mental and physical condition of such inmates as are recommended by the institutional physician and board of managers. If, in the judgment of this committee of experts and the board of managers, procreation is inadvisable, and there is no probability of improvement of the mental and physical condition of the inmate, it shall be lawful for the surgeons to perform such operation for the prevention of procreation as shall be decided safest and most effective. But this operation shall not be performed except in cases that have been pronounced unimprovable: Provided, That in no case shall the consultation fee be more than three dollars to each expert, to be paid out of the funds appropriated for the maintenance of stuch institution.

\section{WASHINGTON.}

\section{(a.) First Law.}

Date of Law: June 9, 1909.

The bill was introduced as a part of the criminal code which was prepared by the Code Commission.

It passed the Senate March 1, 1909; the House March 4, 1909 .

It was approved March 22, 1909, by Governor M. E. Hay.

It appears on the Washington statutes of 1909 as Chapter 249, sec. 35 Criminal Code.

PREVENTION OF PROCREATION: Whenever any person shall be adjudged guilty of carnal abuse of a female person under the age of ten years, or of rape, or shall be adjudged to be an habitual criminal, the court may, in addition to such other punishment or confinement as may be imposed, direct an operation to be performed upon such person for the prevention of procreation.

\section{(b.) Second Law.}

Date of Law: June 9, 1921.

The Bill was introduced on February 14, 1921 , by the Committee on Medicine, Surgery, Dentistry and Hygiene.

It passed the House February 17, 192168 ayes, 1.3 noes, absent or not voting 16.

It passed the Senate March 2, 1921-36 ayes, 1 no, absent or not voting 5 .

It was approved March 8, 1921, by Gov. L. F. Hart.

It appears on the Washington statutes as Chapter 53 of the Session Laws of 1921, H. B. 190.

\section{PREVENTION OF PROCREATION.}

AN ACT to prevent the procreation of feeble-minded, insane, epileptic, habitual criminals, moral degenerates and sexual perverts, who may be inmates of institutions maintained by the State, authorizing and providing for the sterilization of persons with inferior hereditary potentialities and providing for appeals to the Superior Courts in certain cases.

Be it enacted by the Legislature of the State of Washington:

SUPERINTENDENTS OF INSTITUTIONS TO MAKE REPORTS.

Section 1. It shall be and is hereby declared the duty of the superintendents of all state institutions having the care of indi- 
viduals held in restraint to report quarterly to the institutional Board of Health, all feeble-minded, insane, epileptic, habitual criminals, moral degenerates and sexual perverts, who are persons potential to producing offspring who, because of inheritance of inferior or anti-social traits, would probably become a social menace or wards of the State.

\section{STERILIZATION AUTHORIZED.}

Section 2. It shall be the duty of the Institutional Board of Health to examine into the innate traits, the mental and physical conditions, the personal records, and the family traits and histories of all persons reported so far as the same can be ascertained, and for this purpose said Board shall have the power to summon witnesses, and any member of said Board may administer an oath to any witness whom it is desired to examine; and if in the judgment of a majority of the said Board procreation by any such person would produce children with an inherited tendency to feeble-mindedness, insanity, epilepsy, criminality or degeneracy, and there is no probability that the condition of such person so examined will improve to such an exterit as to render procreation by any such person advisable, or if the physical or mental condition of any such person will be substantially improved thereby, then it shall be the duty of said Board to make an order directing the superintendent of the institution in which such inmate is confined to perform or cause to be performed upon such inmate such a type of sterilization as may be deemed best by said Board.

\section{PURPOSE.}

Section 3. The purpose of said investigation, findings and orders of said Board shall be for the betterment of the physical, mental, neural, or psychic condition of the inmate, or to protect society from the menace of procreation by said inmate, and not in ariy manner as a punitive measure; and no person shall be emasculated under the authority of this act except that such operation shall be found to be necessary to improve the physical, mental, neural or psychic condition of the inmate.

\section{NOTICE OR ORDER.}

Section 4. After fully inquiring into the condition of each of such inmates said board shall make separate written findings for each of the inmates whose condition has been examined into, and the same shall be pre- served in the records of said Board, and a copy thereof shall be furnished to the superintendent of the institution in which the inmate is confined, and if an operation is deemed necessary by said Board, then a copy of the order of said Board shall forthwith be served on said inmate, or in the case of an insane person, upon his legal guardian, and if such insane person have no legal guardian, then upon his nearest known kin within the State of Washington, and if such insane person have no known kin within the State of Washington, then upon the custodial guardian of such insane person.

\section{APPEAL.}

Section 5. Any such inmate desiring to appeal from the decision of said Board, or in the case the person is under guardianship or disability, then the guardian of said inmate may take an appeal into the Superior Court of the county in which the institution in which the inmate is confined, is located. An informal notice of appeal filed with the secretary of said board, either by the inmate or someone in his behalf, shall be all that is necessary to make the appeal: Provided, said notice shall be filed within fifteen days of the date when notice of the board's decision is served on the inmate or his guardian and said notice of appeal shall stay all proceedings of said board on said matter until the same is heard and determined on said appeal: Provided, further, that no operation shall be performed upon any inmate until the time for appeal from the decision of the board has expired.

\section{PROCEDURE ON APPEAL.}

Section 6. Upon an appeal being taken, the secretary of said board where the notice of appeal is filed, must within fifteen days thereafter, or such further time as the court or the judge thereof may allow, transmit a certified copy of the notice of appeal and transcript of the proceedings, findings and order of the board, to the clerk of the court appealed to. The trial shall be a trial de novo at law as provided by the statutes of the state, for the trial of actions at law. Upon such appeal, if the inmate be without sufficient financial means to employ an attorney, then the court shall appoint an attorney to represent the said inmate, and such attorney shall be compensated by the state upon order of the court; and it shall be the duty of the district attorney of the county wherein such trial is had to represent the said board. 


\section{ENTRY OF JUDGMENT.}

Section 7. If the court or jury shall affirm the findings of said board, said court shall enter a judgment, adjudging that the order of said board shall be carried out as herein provided; if the court fail to affirm the decision of said board appealed from, then said order shall be null and void and of no further effect.

\section{OPERATIONS.}

Section 8. Upon the receipt of the order from the Institutional Board of Health, the superintendent of the institution to which it is directed shall, after the time for appeal has expired, or in case of an appeal upon the entering of a judgment affirming the order of the board, and it is hereby made his lawful duty, to perform, or cause to (be) performed such surgical operation as may be specified in the order of the Institutional Board of Health. All such operations shall be performed with a due regard for the physical condition of the inmate and in a safe and humane manner

\section{SURGEON'S LIABILITY.}

Section 9. No surgeon performing the operation provided for in the preceding section under the direction of the superintendent, or other officer in charge of such institution, shall be held criminally liable therefor or civilly liable for any loss or damage on account thereof, except in case of negligence in the performance of such operation.

\section{PERSONS AFFECTED.}

Section 10. The criminals who shall come within the operation of this law shall be those who have been convicted three or more times of a felony and sentenced to serve in the penitentiary therefor. Moral degenerates and sexual perverts are those who are addicted to the practice of sodomy or the crime against nature, or to other gross, bestial and perverted sexual habits and practices prohibited by statute.

\section{SEX.}

Section 11. The provisions of this act shall apply to both male and female inmates of any of the institutions designated therein.

\section{EXPENSE.}

Section 12. The state shall be liable, under this act, only for the actual traveling expenses of the members of the board incurred in the performance of their duties, and the actual and necessary expense incident to the investigations of said board and an appeal therefrom, which shall be paid upon vouchers signed by the person receiving such compensation and expense from the moneys appropriated for the maintenance of the institution where such examination is held.

\section{CALIFORNIA.}

\section{a. First Law.}

Date of Law: June 25, 1909.

The bill was introduced on February 8, 1909, by Senator W. F. Price, of Santa Rosa, California.

It passed the Senate March 16, 1909-21 ayes, 1 no; the House March 22, 190941 ayes, 0 noes.

It was approved April 26, 1909, by Governor James N. Gillett.

It appears on the California statutes of 1909 as Chapter 720 on page 1093.

(It was repealed and substituted for by Chapter 363, sec. 4, June 13, 1913.)

AN ACT to permit asexualization of inmates of the state hospitals and the California Home for the Care and Training of Feeble-Minded Children and of convicts in the state prisons.

\section{The people of the State of California, rep-} resented in Senate and Assembly, do enact as follows:

Section 1. Whenever in the opinion of the medical superintendent of any state hospital, or the superintendent of the California Home for the Care and Training of Feeble-Minded Children, or of the resident physician in any state prison, it would be beneficial and conducive to the benefit of the physical, mental, or moral condition of any inmate of said state hospital, home, or state prison, to be asexualized, then such superintendent or resident physician shall call in consultation the general superintendent of the - state hospitals, and the secretary of the state board of health, and they shall jointly examine into all the particulars of the case with the said superintendent or resident physician, and if in their opinion or in the opinion of any two of them, asexualization will be beneficial to such inmate, patient, or convict, they may perform the same; Provided, that in the case of an inmate or convict confined in any of the state prisons of this state, such operation shall not be performed unless the said inmate or convict has been committed to a state prison in this or in some other state or country at least two times for some sexual offense, or at 
least three times for any other crime, and shall have given evidence while an inmate in a state prison in this state that he is a moral and sexual pervert; and provided further, that in the case of convicts sentenced to state prison for life who exhibit continued evidence of moral and sexual depravity, the right to asexualize them, as provided in this act, shall apply, whether they have been inmates of a state prison whether in this or any other state or country more than one time.

\section{b. Second Law.}

Date of Law: June 13, 1913.

This statute repeals the first sterilization law, Chapter 720 on page 1093, April 26, 1909.

The bill was introduced on Jantary 28, 1913, by Senator Edwin M. Butler, of Los Angeles, Cal.

It passed the Senate April 22, 1913-21 ayes, 4 noes; the House May 10, 1913-40 ayes, 24 noes.

It was approved June 13, 1913, by Governor Hiram W. Johnson.

It appears on the California statutes as Chapter 363; Senate Bill 881.

AN ACT to provide for the asexualization of the inmates of state hospitals for the insane, the Sonoma State Home, of convicts in the state prisons, and of idiots, and repealing an act entitled "An act to permit asexualization of inmates of the state hospitals and the California Home for the Care and Training of Feeble-Minded Children and of convicts in the state prisons", approved, April 26, 1909.

The people of the State of California do enact as follows:

Section 1. Before any person who has been lawfully committed to any state hospital for the insane, or who has been an inmate of the Sonoma State Home, and who is afflicted with hereditary insanity or incurable chronic mania or dementia shall be released or discharged therefrom, the state commission in lunacy may in its discretion, after a careful investigation of all the circumstances of the case, cause such a person to be asexualized, and such asexualization, whether with or without the consent of the patient, shall be lawful and shall not render said commission, its members, or any person participating in the operation liable either civilly or criminally.

Section 2. Whenever in the opinion of the resident physician of any state prison it will be beneficial and conducive to the benefit of the physical, mental, or moral condition of any recidivist lawfully confined in such state prison to be asexualized, then such physician shall call in consultation the general superintendent of state hospitals and the secretary of the state board of health, and they shall jointly examine into the particulars of the case with the said resident physician, and if in their opinion or the opinion of any two of them, asexualization will be beneficial to such recidivist, they may perform the same; provided, that such operation shall not be performed unless the said recidivist has been committed to a state prison in this or some other state or country at least two times for rape, assault with intent to commit rape, or seduction, or at least three times for any other crime or crimes, and shall have given evidence while an inmate of a state prison in this state that he is a moral or sexual degenerate or pervert; and provided, further, that in the case of convicts sentenced to state prison for life, who exhibit continued evidence of moral and sexual depravity, the right to asexualize them, as provided in this section, shall apply whether they shall have been inmates of a state prison in this or any other country or state more than one time or not; provided, further, that nothing in this act shall apply to or refer to any voluntary patient confined or kept in any state hospital of this state.

Section 3. Any idiot, if a minor, may be asexualized by or under the direction of the medical superintendent of any state hospital, with the written consent of his or her parent or guardian, and if an adult, then with the written consent of his or her lawfully appointed guardian, and upon the written request of the parent or guardian of any such idiot or fool, the superintendent of any state hospital shall perform such operation or cause the same to be performed without charge therefor.

Section 4. An act entitled "An act to permit asexualization of inmates of the state hospitals and the California Home for the Care and Training of Feeble-Minded Children, and of convicts in the state prisons", approved April 26, 1909, is hereby repealed.

\section{c. Amendment to the Second Law.}

Date of Amendment: July 26, 1917.

The bill was introduced on January 26, 1917, by Senator Edward J. Tyrrell of Oakland, California.

It passed the Senate March 9, 1917-26 ayes, no noes; the Assembly April 18, 1917 -42 ayes, 7 noes. 
It was approved May 17, 1917, by Governor Wm. D. Stephens.

It appears on the California statutes as Chapter 489 of the Laws of 1917.

AN ACT to amend section one of an act entitled "An act to provide for the asexualization of inmates of state hospitals for the insane, the Sonoma State Home, of convicts in the state prisons, and of idiots, and repealing an act entitled 'an act to permit asexualization of inmates of the state hospitals and the California Home for the Care and Training of Feeble-Minded Children, and of convicts in the state prisons,' approved April 26, 1919," approved June 13, 1913.

(Approved May 17, 1917.)

\section{The People of the State of California do} enact as follows:

Section 1. Section one of the act entitled "An act to provide for the asexualization of inmates of state hospitals for the insane, the Sonoma State Home, of convicts in the state prisons, and of idiots, and repealing an act entitled, 'An act to permit asexualization of inmates of the state hospitals and the California Home for the Care and Training of Feeble-minded Children, and of convicts in the state prisons,' approved April 26, 1909," approved June 13,1913 , is hereby amended to read as follows:

Section 1. Before any person who has been lawfully committed to any state hospital for the insane, or who has been an inmate of the Sonoma State Home, and who is afflicted with mental disease which may have been inherited and is likely to be transmitted to descendants, the various grades of feeblemindedness, those suffering from perversion or marked departures from normal mentality or from disease of a syphilitic nature, shall be released or discharged therefrom, the state commission in lunacy may in its discretion, after a careful investigation of all the circumstances of the case, cause such person to be asexualized, and such asexualization whether with or without the consent of the patient shall be lawful and shall not render the said commission, its members or any person participating in the operation liable either civilly or criminally.

Note: The above Section 1, as amended, differs only from Section 1 of the unamended statute in substituting the above underlined phrases for the following: "* * hereditary insantity or incurable chronic mania or dementia " * "." d. Sterilization Provision of the Law of California establishing the Pacific Colony "An institution for the care, confinement, and instruction of feeble-minded and epileptic persons."

Date of Law: July 31, 1917.

The bill was introduced on January 23, 1917, by Representative Thomas L. Ambrose of Los Angeles, California.

It passed the Assembly April 14, 191742 ayes, no noes; the Senate, April 27, 1917, -24 ayes, no noes.

It was approved June 1, 1917, by Governor Wm. D. Stephens.

It appears on the California statutes as Section 42, Chapter 776 of the Laws of 1917.

Section 42. Before any inmate who has been committed to the Pacific Colony and who is feeble-minded, or is afflicted with incurable chronic mania or dementia, shall be released or discharged therefrom, the board of trustees on the recommendation of the superintendent, approved by a clinical psychologist holding the degree of $\mathrm{Ph}$. D. and a physician qualified to serve under Section 19 of this Act, after they have made a careful investigation of all the circumstances of the case, may cause such person to be sterilized; and such sterilization, whether with or without the consent of the inmate, shall be lawful, and shall not render the said commission, or its members, or any person participating in the operation, the said trustees, the said colony, or any of its officers or employees, liable civilly or criminally.

\section{CONNECTICUT.}

(a) First Law.

Date of Law: October 1, 1909.

The bill was introduced on February 2, 1909, by Representative Wilbur F. Tomlinson, of Danbury, Conn.

It passed the House July 20, 1909-130 ayes, 28 noes; the Senate July 28, 1909.

It was approved August 12, 1909, by Governor F. B. Weeks.

It appears on the Connecticut statutes as Public Acts 1909, Chapter 209. (Substitute for House bill No. 123.) Sections 2691-2 of the General Statutes, Revision of 1918.)

AN ACT concerning operations for the prevention of procreation.

$\mathrm{Be}$ it enacted by the Senate and House of Representatives in General Assembly convened:

Section 1. The directors of the state prison and the superintendent of the state hospitals for the insane at Middletown and 
Norwich are hereby authorized and directed to appoint for each of said institutions, respectively, two skilled surgeons, who, in conjunction with the physician or surgeon in charge at each of said institutions shall constitute a board, the duty of which shall be to examine such inmates of said institutions as are reported to them by the warden, superintendent, or the physician or surgeon in charge, to be persons by whom procreation would be inadvisable. Such board shall examine the physical and mental condition of such persons and their record and family history, so far as the same can be ascertained, and if, in the judgment of a majority of said board, procreation by any such person would produce children with an inherited tendency to crime, insanity, feeble-mindedness, idiocy, or imbecility, and there is no probability that the condition of any such person so examined will improve to such an extent as to render procreation by any such person advisable, or if the physical or mental condition of any such person will be substantially improved thereby, then said board shall appoint one of its members to perform the operation of vasectomy or oöphorectomy, as the case may be, upon such person. Such operation shall be performed in a safe and humane manner, and the board making such examination and the surgeon performing such operation shall receive from the state such compensation for services rendered as the warden of the state prison or the superintendent of either of such hospitals shall deem reasonable.

Section 2. Except as authorized by this act, every person who shall perform, encourage, assist in, or otherwise promote the performance of either of the operations described in section one of this act, for the purpose of destroying the power to procreate the human species, or any person who shall knowingly permit either of such operations to be performed upon such person, unless the same shall be a medical necessity, shall be fined not more than one thousand dollars, or imprisoned in the state prison not more than five years, or both.

(b) Sterilization Provisions of Statute Extended to Mansfield State Training School and Hospital.

Chapter 69, Public Acts, 1919.

This amendment was introduced by Representative Higgins of Coventry.

It passed the House March 5, 1919; the Senate March 12, 1919; no record vote.

Approved by the Governor April 2, 1919.
AN ACT amending an Act concerning Operations to Prevent Procreation.

Be it enacted by the Senate and House of Representatives in General Assembly convened:

Section 2691 of the general statutes is amended to read as follows: The directors of the state prison and the superintendents of the state hospitals for the insane at Middletown and Norwich and the superintendent of the Mansfield State Training School and Hospital at Mansfield Depot are authorized and directed to appoint for each of said institutions two skilled surgeons, who, in conjunction with the physician or surgeon in charge at. each of said institutions, shall constitute a board the duty of which shall be to examine such inmates of said institutions as are reported to them by the warden or superintendent or the physician or surgeon in charge, to be persons by whom procreation would be inadvisable. Such board shall examine the physical and mental condition of such persons and their record and family history so far as the same can be ascertained, and if, in the judgment of a majority of said board, procreation by any such person would produce children with an inherited tendency to crime, insanity, feeblemindedness, idiocy or imbecility and there is no probability that the condition of any. such person so examined will improve to such an extent as to render procreation by any such person advisable, or if the physical or mental condition of any such person will be substantially improved thereby, then said board shall appoint one of its members to perform the operation of vasectomy or oöphorectomy, as the case may be, upon such person. Such operation shall be per-. formed in a safe and humane manner, and the board making such examination and the surgeon performing such operation shall receive from the state such compensation for services rendered as the warden of the state prison or the superintendent of either of such hospitals shall deem reasonable.

Note: This law differs from its predecessor only in extending its provisions to the newly created Mansfield State Training School and Hospital.

\section{NEVADA.}

Date of Law: January 1, 1912.

The bill was introduced March 3, 1911, by the Code Commission, not as a separate bill, but as part of the Crimes and Punishments Bill. 
It passed the Senate March 10, 1911-17 ayes, 1 no, 1 absent; the House March 14, 1911-34 ayes, 7 noes, 4 absent, 4 not voting.

It was approved March 17, 1911, by Governor Tasker L. Oddie.

It appears on the Nevada statutes as Section 28 of the Crimes and Punishments Act.

PREVENTION OF PROCREATION: Whenever any person shall be adjudged guilty of carnal abuse of a female person under the age of ten years, or of rape, or shall be adjudged to be an habitual criminal, the court may, in addition to such other punishment or confinement as may be imposed, direct an operation to be performed upon such person for the prevention of procreation; provided, the operation so performed shall not consist of castration.

\section{IOWA.}

\section{(a) First Law.}

Date of Law: July 4, 1911.

The bill was introduced on February 17, 1911, by Representative Eli C. Perkins, of Delhi, Iowa.

It passed the House March 28, 1911-64 ayes, 13 noes; the Senate April 6, 1911-32 ayes, noes 0 .

It was approved April 10, 1911, by Governor B. F. Carroll.

It appears on the Acts of the Thirtyfourth General Assembly of Iowa (1911) as Chapter 129.

(It was repealed and substituted for by Chapter 187, Acts of the Thirty-fifth General Assembly, April 19, 1913.)

AN ACT to prevent the procreation of habitual criminals, idiots, feeble-minded, and imbeciles. [Additional to title twelve (XII) of the code, relating to the police of the state.]

Be it enacted by the General Assembly of the State of Iowa:

Section 1. Unsexing of Criminals, Idiots, etc. That it shall be the duty of the managing officer of each public institution in the state, entrusted with the custody or care of criminals, idiots, feeble-minded, imbeciles, drunkards, drug fiends, epileptics, and syphilitics, and they are hereby authorized and directed to annually, or oftener, examine into the mental or physical condition of the inmates of such institutions, with a view to determining whether it is improper to allow any of such inmates to procreate; and to annually, or oftener, call into consultation the members of the state board of parole. The members of such board and the man- aging officer and the surgical superintendent of such institution shall judge of such matters. If a majority of them decide that procreation by any such inmate would produce children with a tendency to disease, crime, insanity, feeble-mindedness, idiocy, or imbecility, and there is no probability that the condition of any such inmate so examined will improve to such an extent as to render procreation by any such inmate advisable, or if the physical or mental condition of any such inmate will be materially improved thereby, or if such inmate is an epileptic or syphilitic, or gives continued evidence while an inmate of such institution that he or she is a moral or sexual pervert, then the surgeon of the institution shall perform the operation of vasectomy or ligation of the Fallopian tubes, as the case may be, upon such person. Provided that such operation shall be performed upon any convict or inmate of such institution who has been convicted of prostitution or violation of the law, as laid down in chapter two hundred and sixteen $(216)^{*}$, acts of the Thirty-third Gen-

* The full text of Chapter 216 is as follows:

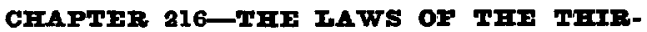

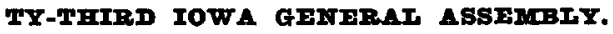
Detention or Confining of remales by Force or Intimiaation for Purposes of Prostitution. S. F. 216 .

AN ACT prohibiting the detention or confinement of any female in any house, room, building, or premises by force, false pretence, or intimidation, for purposes of prostitution or with intent to cause such female to become a prostitute, and providing a punishment for the violation thereof. [Additional to Chapter nine (9) of title twenty-four (XXIV) of the code relating to offenses against chastity, morality and decency.]

Be it enacted by the Ceneral Assembly of the State of Iowa:

Section 1. Detention or Confinement of Iemales for Prostitution Purposes. Whoever shall unlawfully detain or confine any female by force, false pretence, or intimidation in any room, house, building or premises in this state, against the will of such female, for purposes of prostitution or with intent to cause such female to become a prostitute, and be guilty of fornication or concubinage therein, or shall by force, false pretence, confinement, or intimidation, attempt to prevent any female so as aforesaid detained, from leaving such room, house, building, or premises, and whoever aids, assists, or abets by force, false pretence, confinement, or intimidation, in keeping, confining, or unlawfully detaining any female in any room, house, building or premises in this state, against the will of such female, for the purpose of prostitution, fornication, or concubinage, shall on conviction, be imprisoned in the penitentiary not less than one nor more than ten years.

Approved March 25, A. D. 1909. 
eral Assembly, or who has been twice convicted of some other sexual offense, or has been three times convicted of felony, and each such convict or inmate shall be. subjected to this same operation of vasectomy or ligation of the Fallopian tubes, as the case may be, by the surgeon of the institution.

Section 2. Penalty. Except as authorized in this act, every person who shall perform, encourage, assist in or otherwise promote the performance of either of the operations described in Section 1 of this act, for the purpose of destroying the power to procreate the human species, or any person who shall knowingly permit either of such operations to be performed upon such persons, unless the same shall be a medical necessity, shall be fined not more than one thousand $(\$ 1,000)$ dollars, or imprisoned in the county jail not to exceed one year, or both.

\section{(b) Second Law.}

Date of Law: July 4, 1913.

This statute repeals the first sterilization law, Chapter 129, Acts of the Thirty-fourth General Assembly, April 10, 1911.

The bill was introduced March 10, 1913, by Representative Col. Halgrims, of Humboldt, Iowa.

It passed the House April 17, 1913-61 ayes, 7 noes; the Senate April 18, 1913-27 ayes, 11 noes.

It was approved April 19, 1913, by Governor George W. Clarke.

It appears on the Iowa laws of 1913, Chapter 187, Acts of the Thirty-fifth General Assembly.

AN ACT to repeal the law as it appears in chapter one hundred twenty-nine (129) of the acts of the Thirty-fourth General Assembly, and to enact a substitute therefor relating to the prevention of the procreation of criminals, rapists, idiots, feeble-minded, imbeciles, lunatics, drunkards, drug fiends, epileptics, syphilitics, moral and sexual perverts, and diseased and degenerate persons.

Be it enacted by the General Assembly of the State of Iowa:

Section 1. Unsexing of criminals, idiots, etc. Board of Parole; Duties. That it shall be the duty of the state board of parole, with the managing officer and the physician of each public institution in the state, entrusted with the care and custody of criminals, rapists, idiots, feeble-minded, imbeciles, lunatics, drunkards, drug fiends, epileptics, syphilitics moral and sexual perverts, and diseased and degenerate persons, and they are hereby authorized and directed to, annually or oftener, examine into the mental and physical condition, the records and family history of the inmates of such institutions, with a view of determining whether it is improper or inadvisable to allow any of such inmates to procreate and to judge of such matters. If a majority of them decide that procreation by any such inmates would produce children with a tendency to disease, deformity, crime, insanity, feeble-mindedness, idiocy, imbecility, epilepsy, or alcoholism, or if the physical or mental condition of any such inmate will probably be materially improved thereby, or if such inmate is an epileptic or syphilitic, or gives evidence, while he is an inmate of such institution, that he or she is a moral or sexual pervert, then the physician of the institution, or one selected by him, shall perform the operation of vasectomy or ligation of the Fallopian tubes, as the case may be, upon such person. Provided that such operation shall be performed upon every convict or inmate of such institution who has been convicted of prostitution or violation of the law as laid down in chapter two hundred sixteen (216)* of the acts of the Thirty-third General Assembly, or who has been twice convicted of other sexual offenses, including soliciting, as defined in section four thousand nine hundred seventy-five-c $(4975-c)^{* *}$ of the supplement to the code, 1907 , or who has been twice convicted of a felony, and each such convict or inmate shall be subject to this same operation of vasectomy or ligation of the Fallopian tubes, as the case may be, by the physician of the institution, or one se1 , cied by him.

Section 2. Certain persons, operations upon application. Those afflicted with syphilis or epilepsy may apply to the board of parole, or any judge of the district court, and upon order of such board or judge, the operation of vasectomy or ligation of the Fallopian tubes may be performed upon such person, and any law restricting mar-

- See footnote, page 21.

* Sec. 4975-c. Sollcting for the Purpose of Prostitution-Penalty. That any person who shall ask, request, or solicit another to have carnal knowledge with any female for a consideration or otherwise, shall be punished by imprisonment in the penitentiary not exceeding five years or imprisonment in the county jall not exceeding one year, or by a fine not exceeding one thousand dollars, or both such fine and jail imprisonment. (31 G. A., ch. 165.) 
riage of such persons shall be void and of none effect, in case one of the contracting parties has submitted to such operation and the same was known to both parties before their marriage.

- Section 3. Annual report. The board of parole shall make an annual report to the governor of the state, fully covering their proceedings under the authority of this act, and also observations and statistics regarding its benefits.

Section 4. Unsexing prohibited except as authorized-penalty. Except as authorized in this act, every person who shall perform, encourage, assist in or otherwise promote the performance of either of the operations described in section one (1) of this act, for the purpose of destroying the power to procreate the human species, or any person who shall knowingly permit either of such operations to be performed upon such persons, unless the same shall be a medical necessity, shall be fined not more than one thousand dollars $(\$ 1,000.00)$, or imprisoned in the penitentiary not to exceed one year, or both.

\section{(c) Third Law.}

Date of Law: July 4, 1915.

The bill was introduced on February 18, 1915, by the Committee on Public Health (Dr. A. W. Slaught, of Ottumwa, Chairman), as a Committee Bill.

It passed the House, March 6, 1915-76 ayes, 12 noes; the Senate, April 12, 1915-31 ayes, 6 noes.

It was approved April 16, 1915, by Governor George W. Clarke.

It appears on the Iowa statutes as Chapter 202 of the Laws of the Thirty-sixth General Assembly (1915).

AN ACT to repeal the law as it appears in chapter nineteen-B (19-B) supplement to the code, 1913, and to enact a substitute therefor to prevent the procreation of the insane, idiots, imbeciles and feeble-minded.

Be it enacted by the General Assembly of the State of Iowa:

That the law as it appears in Chapter nineteen-B (19-B) of title twelve (12) supplement to the code, 1913 , be and the same is hereby repealed and the following enacted in lieu thereof:

Section 1. Sterilization Authorized. That whenever the superintendent of any hospital for the insane and a majority of his medical staff shall after investigation and examina- tion, agree that it is for the best interests of the patient and society, they are hereby authorized to perform, or cause to be performed by some capable physician or surgeon, the operation of sterilization on any such patient confined in said institution afflicted with insanity, idiocy, imbecility, feeble-mindedness or syphilis; provided that said operation is approved by the board of control or a majority thereof; and provided further, that the superintendent of the hospital shall have secured the written consent of the husband or wife, if the patient is a married person, and if an unmarried person, the written consent of the parent, guardian or next of kin, if any there be within this state, that said operation shall be performed.

Section 2. Operation Defined. The operation to be performed upon a male person shall be what is known as vasectomy, and upon a female person what is known as a section of the Fallopian tubes with implantation of the uterine muscles.

Section 3. Annual Report. The board of control shall make an annual report to the governor of the state fully covering their proceedings under the authority of this act, and also their observations and statistics regarding its benefits.

Section 4. Unauthorized OperationsPenalty. Except as authorized in this act every person who shall perform, encourage, assist in, or otherwise promote the performance of either of the operations described in section two (2) of this act for the purpose of destroying the power to procreate the human species, or any person who shall knowingly permit either of such operations to be performed upon such person unless the same shall be a medical necessity, shall be fined not more than one thousand dollars $(\$ 1,000)$, or imprisoned in the penitentiary not to exceed one year, or both.

\section{NEW JERSEY.}

Date of Law: April 21, 1911.

The bill was introduced on February 27, 1911, by Representative B. H. White, of Mount Holly, New Jersey.

It passed the House March 28, 1911-33 ayes, 6 noes; the Senate April 18, 1911-12 ayes, noes 0 .

It was approved April 21, 1911, by Governor Woodrow Wilson.

It appears on the New Jersey statutes of 1911 as Chapter 190.

AN ACT to authorize and provide for the sterilization of feeble-minded (including 
idiots, imbeciles and morons), epileptics, rapists, certain criminals and other defectives.

WHEREAS, heredity plays a most important part in the transmission of feeblemindedness, epilepsy, criminal tendencies, and other defects:

Be it enacted by the Senate and General Assembly of the State of New Jersey:

1. Immediately after the passage of this act, the Governor shall appoint by and with the advice of the Senate, a surgeon and neurologist, each of recognized ability, one for a term of three (3) years and one for a term of (5) years; their successors each to be appointed for the full term of five years, who in conjunction with the Commissioner of Charities and Corrections shall be known as and is hereby created the "Board of Examiners of Feeble-minded (including idiots, imbeciles and morons), Epileptics and other Defectives," whose duty it shall be to examine into the mental and physical condition of the feeble-minded, epileptic, certain criminal and other defective inmates confined in the several reformatories, charitable, and penal institutions in the counties and state. Any vacancy occurring in said Board of Examiners shall be filled by appointment of the Governor for the unexpired term.

2. The criminals who shall come within the operation of this law shall be those who have been convicted of the crime of rape, or of such succession of offenses against the criminal law as in the opinion of this board of examiners shall be deemed to be sufficient evidence of confirmed criminal tendencies

3. Upon application of the superintendent or other administrative officer of any institution in which such inmates are or may be confined or upon its own motion, the said board of examiners may call a meeting to take evidence and examine into the mental and physical condition of such inmates confined as aforesaid, and if said board of examiners, in conjunction with the chief physician of the institution, unanimously find that procreation is inadvisable and that there is no probability that the condition of such inmate so examined will improve to such an extent as to render procreation by such inmate advisable, it shall be lawful to perform such operation for the prevention of procreation as shall be decided by said board of examiners to be most effective, and thereupon it shall and may be lawful for any surgeon qualified under the laws of this state, under the direction of the chief physician of said institution, to perform such oper- ation; previous to said hearing the said board shall apply to any judge of the Court of Common Pleas, of the county in which said person is confined, for the assignment of counsel to represent the person to be examined, said counsel to act at said hearing and in any subsequent proceedings, and no order made by said board of examiners shall become effective until five days after it shall have been filed with the clerk of the Court of Common Pleas of the county in which said examination is held, and a copy shall have been served upon the counsel appointed to represent the person examined, proof of service of the said copy of the order to be filed with the clerk of the Court of Common Pleas. All orders made under the provision of this act shall be subject to review by the Supreme Court or any justice thereof, and said court may upon appeal from any order grant a stay which shall be effective until such appeal shall have been decided. The judge of the Court of Common Pleas appointing any counsel under this act may fix the compensation to be paid him, and it shall be paid as other court expenses are now paid.

No surgeon performing an operation under the provisions of this law shall be held to account therefor, but the order of the board of examiners shall be a full warrant and authority therefor.

4. The record taken upon the examination of every such inmate, signed by the said board of examiners, shall be preserved in the institution where such inmate is confined, and a copy thereof filed with the Commissioner of Charities and Corrections, and one year after the performing of the operation the superintendent or other administrative officer of the institution wherein such inmate is confined shall report to the board of examiners the condition of the inmate and the effect of such operation upon such inmate. A copy of the report shall be filed with the record of the examination.

5. There shall be paid, out of the funds appropriated for maintenance of such institutions, to each physician of said board of examiners, a compensation of not more than ten (\$10) dollars per diem for each day actually given to such work or examination, and his actual and necessary expenses in going to, holding and returning from such examination.

When in the judgment of the board of examiners it is necessary to secure the assistance of a surgeon outside the medical staff 
of the institution to perform or assist in said operation, the necessary expenses of such surgeon shall be paid from the maintenance account of such institution.

6. If any provisions of this act shall be questioned in any court, and the provisions of this act with reference to any class of persons enumerated therein shall be held to be unconstitutional and void, such determination shall not be deemed to invalidate the entire act, but only such provisions thereof with reference to the class in question as are specifically under review and particularly passed upon by the decision of the court.

7. This act shall take effect immediately.

\section{NEW YORK.}

\section{(a) Text of Law.}

Date of Law: April 16, 1912.

The bill was introduced on March 5, 1912, by Assemblyman Robert P. Bush, of Horseheads, N. Y.

It passed the House March 25, 1912-78 ayes, 9 noes; the Senate March 29, 1912-48 ayes, noes 0 .

It was approved April 16, 1912, by Governor John A. Dix.

It appears on the New York statutes as Public Health Law (L. 1909, Chapter 49), Art. 19 (Section 350-353), as amended by $\mathrm{L}$. 1912, Chapter 445.

AN ACT to amend the public health law, in relation to operations for the prevention of procreation.

The people of the State of New York, represented in Senate and Assembly, do enact as follows:

Section 1. Article eighteen of chapter forty-nine of the laws of nineteen hundred and nine, entitled, "An act in relation to public health constituting chapter forty-five of the consolidated laws," as renumbered article nineteen by section five of chapter one hundred and twenty-eight of the laws of nineteen hundred and eleven, is hereby made article twenty thereof, and sections three hundred and fifty and three hundred and fifty-one of such chapter are hereby renumbered sections three hundred and sixty and three hundred and sixty-one, respectively.

Section 2. Such chapter is hereby amended by inserting therein a new article, to be article nineteen thereof, to read as follows:

\section{ARTICLE 19. \\ Operations for the Prevention of Procreation.}

Section 350. Board of Examiners; compensation and expenses.
Section 351. General powers and duties of the board, persons to be operated upon.

Section 352. Appointment of counsel to persons to be operated upon.

Section 353. Unauthorized and illegal operations.

Section 350. Board of Examiners; compensation and expenses. Immediately after the passage of this act the Governor shall appoint one surgeon, one neurologist and one practitioner of medicine, each with at least ten years" experience in the actual practice of his profession, for a term of five years, to be known as the board of examiners of feeble-minded, criminals and other defectives, which board is hereby created. The compensation of the members of such board shall be ten dollars per diem for each day actually engaged in the performance of the duties of the board, and their actual and necessary traveling expenses. Any vacancies occurring in said board shall be filled by appointment of the Governor for the unexpired term.

Section 351. General powers and duties of the board; persons to be operated upon. It shall be the duty of the said board to examine into the mental and physical condition and the record and family history of the feeble-minded, epileptic, criminal and other defective inmates confined in the several state hospitals for the insane, state prisons, reformatories, and charitable and penal institutions in the state, and if in the judgment of the majority of said board procreation by any such person would produce children with an inherited tendency to crime, insanity, feeble-mindedness, idiocy, or imbecility, and there is no probability that the condition of any such person so examined will improve to such an extent as to render procreation by any such person advisable, or if the physical or mental condition of any such person will be substantially improved thereby, then said board shall appoint one of its members to perform such operation for the prevention of procreation as shall be decided by said board to be most effective.

The criminals who shall come within the operation of this law shall be those who have been convicted of the crime of rape or of such succession of offenses against the criminal law as in the opinion of the board shall be deemed to be sufficient evidence of confirmed criminal tendencies.

Section 352. Appointment of counsel to person to be operated upon. The board of 
examiners shall apply to any judge of the Supreme Court or county judge of the county in which said person is confined for the appointment of counsel to represent the person to be examined. Said counsel to act $a^{+}$a hearing before the judge and in any subsequent proceedings, and no order made by said board shall become effective until five days after it shall have been filed with the clerk of the court and a copy shall have been served upon the counsel appointed to represent the person examined and proof of service of said copy of the order to be filed with the clerk of the court. All orders made under provisions of this act shall be subject to review by the Supreme Court or any justice thereof, and said court may upon appeal from any order grant a stay, which shall be effective until such appeal shall have been decided. The judge of the court appointing any counsel under this act may fix the compensation to be paid him. No surgeon performing an operation under the provisions of this act shall be held to account therefor. The record taken upon the examination of every such inmate, signed by the said board of examiners, shall be preserved by the institution where said inmate is confined, and one year after the performance of the operation the superintendent or other administrative officer of the institution wherein such inmate is confined shall report to the board of examiners the condition of the inmate and the effect of such operation upon such inmate, and a copy of the report shall be filed with the record of the examination.

Section 353. Unauthorized and illegal operations. Except as authorized by this act, every person who shall perform, encourage, assist in, or otherwise permit the performance of the operation for the purpose of destroying the power to procreate the human species, or any person who shall knowingly permit such operation to be performed upon such person, unless the same shall be a medical necessity, shall be guilty of a misdemeanor.

Section 3. This act shall take effect immediately.

(b) The Repeal of the New York Sterilization Statute.

The New York sterilization law of 1912 was repealed May 10, 1920. The repealing bill was introduced by Senator Henry M. Sage of New York April 8th. It passed the Senate April 14th, 49 yeas, 0 nays. It passed the Assembly April 21st, 142 yeas, 0 nays, and was signed by Governor Alfred E. Smith May 10th. The repealing act appears in the statutes of New York as "L. 1920, Chap. 619." The full text of the act is as follows :

\section{AN ACT}

To repeal article nineteen of the public health law, relating to operations for the prevention of procreation.

The People of the State of New York, represented in Senate and Assembly, do enact as follows:

Section 1. Article nineteen of chapter forty-nine of the laws of nineteen hundred and nine, entitled "An act in relation to public health, constituting chapter forty-five of the consolidated laws," as such article was added by chapter four hundred and fortyfive of the laws of nineteen hundred and twelve, is hereby repealed.

Section 2. This act shall take effect immediately.

\section{NORTH DAKOTA.}

Date of Law: March 13, 1913.

The bill was introduced on February 8, 1913 , by Representative W. H. Northrup, Luverne, North Dakota.

It passed the House February 17, 191373 ayes, 20 noes; the Senate March 6, 1913a 34 ayes, 4 noes.

It was approved March 13, 1913, by Governor L. B. Hanna.

It appears on the North Dakota statutes as Chapter 56 of the laws of 1913. (Chapter 24, Sections 11429-11438, Compiled Laws of North Dakota, 1913.)

AN ACT to prevent procreation of confirmed criminals, insane, idiots, defectives, and rapists; providing for a board of medical examiners and making a provision for carrying out of same.

Be it enacted by the Legislative Assembly of the State of North Dakota:

Section 1. Whenever the warden, superintendent, or head of any state prison, reform school, state school for feeble-minded, or of any state hospital or state asylum for insane shall certify in writing that he believes that the mental or physical condition of any inmate would be improved thereby, or that procreation by such inmate would be likely to result in defective or feeble-minded children with criminal tendencies, and that the condition of such inmate is not likely to improve, so as to make procreation by such person desirable or beneficial to the community, it shall be lawful to perform a 
surgical operation for the sterilization of such inmate as hereafter provided.

Section 2. For the purpose of carrying in to effect the provisions of this act the chief medical officer of any such institution, the secretary of the state board of health and one other competent physician and surgeon, whose appointment is hereinafter provided for, shall constitute the board of examiners for such institution. The third member of such board shall be a competent physician and surgeon of good standing and of at least ten years' practice of his profession in North Dakota, who shall forthwith be appointed by the State board of control and who shall serve during the pleasure of said board of control. One such appointment may be made in each county in which any of such institutions is located, or one may be appointed to act for any two or more of such institutions to be named in the letter of appointment. The per diem compensation of such member so appointed shall be fixed by the state board of control in the letter of appointment and shall not be in excess of $\$ 10.00$ per day, a duplicate of this letter shall be filed with the state auditor, and the per diem and actual necessary expenses of such member shall be allowed and paid in the same manner as is provided for by law for the payment of the salaries and expenses of the members, agents, and employees of the state board of control.

Section 3. When the superintendent of any such institution shall deem it advisable that such operation be performed on any one or more of the inmates thereof he shall make such recommendation in writing signed by him, and file one copy thereof with the board of control and one with the chief medical officer of such institution, whereupon the chief medical officer of such institution shall forthwith call a meeting of such board of examiners, to be held at such institution at a date not less than fifteen days after the issuance of such call, and such call shall be in writing, signed by such chief medical officer, and shall clearly set forth the date and object of such meeting and shall contain the names of all inmates whose cases are to be considered at such meeting.

Section 4. At such meeting such board of examiners shall diligently inquire into the mental and physical condition of each inmate so considered, and as far as practicable into his family history, and for that purpose any member of said board may administer an oath to any witness whom it is desired to examine, and such hearing may be adjourned from day to day, and, if necessary, sessions may he held elsewhere than at such institution.

Section 5. After fully inquiring into the condition of each such person such board of examiners shall make separate written findings for each of the persons whose condition has been inquired into, and such findings shall either order that such inmate be sterilized by such operation as may be deemed best, or shall find that sterilization is not necessary or desirable, or shall continue the case to a time and place therein named or upon future call for further observation and inquiry, and such hearings shall be conducted according to the provisions of section 4 of this act. If such board in its findings order such operation upon such inmate, it shall, in such findings, designate what operation is to be performed and its purpose; and shall designate some skilled surgeon, who may not be one of their own number, who shall perform it.

Section 6. Such institutions shall keep all files in any proceedings under this act and full minutes of such meetings, and for that purpose the chief medical officer of such institution shall be the secretary of such board of examiners and custodian of its records.

Section 7. When in the opinion of the chief medical officer of any such institution such operation would be necessary or desirable upon any inmate thereof, for any of the purposes herein set forth, and such inmate requests in writing that such operation be performed, or consents thereto in writing, he may perform or procure the performance of such operation without bringing the matter to the attention of such board of examiners. When any such operation is performed under the provisions of this section it shall be the duty of the chief medical officer who performs or procures the performance of such operation to immediately report to the state board of control the details of such operation upon such blanks as the board of control may prescribe.

Section 8. Whenever the state's attorney of any county shall have reason to believe that any person who shall be convicted of felony has been twice or more previously convicted of felonies in North Dakota and elsewhere, it shall be the duty of such state's attorney to investigate and to secure at the expense of the county, transcripts of records of conviction from other counties and states 
and also such evidence of identification as may be obtained. Such proof when obtained shall be forwarded to the state board of control, who shall thereupon notify the chief medical officers of the institution to which such person is committed and the secretary of the state board of health, and such case shall be dealt with in accordance with the procedure stated in section 1 of this act.

Section 9. No surgeon who shall skillfully perform any operation as authorized by this act shall be held accountable therefor, but the findings and order of this said board of examiners or the court, or the consent of such inmate and parents or guardian shall be his full warrant and authority therefor.

Section 10. It shall be the duty of the chief medical officer of any such institution in which any sterilized inmates are confined to make careful observation of each of such inmates, particularly with the view to ascertaining the effect of such operation upon the moral, mental and physical condition of such sterilized persons, and once a year, and oftener if called for by the Governor, to make report on each of such persons in writing, keeping a copy of such report on file in such institution and furnishing copies to the Governor, the state board of control and the secretary of the state board of health.

Section 11. (Emergency.) WHEREAS, heredity plays a most important part in the transmission of crime, insanity, idiocy, and imbecility, and our institutions for degenerates are overcrowded on account of the lack of adequate means of checking the everincreasing numbers of this class; and whereas, there is now no provision in law authorizing an operation for the sterilization of defective persons, this act shall take effect and be in force from and after its passage and approval.

\section{MICHIGAN.}

Date of Law: August 1, 1913.

The bill was introduced on January 13, 1913, by Representative Arthur Odell, of Allegan, Michigan.

It passed the House February 12, 191272 ayes, 16 noes; the Senate March 19, 1913 -21 ayes, 9 noes.

It was approved April 1, 1913, by Governor Woodbridge N. Ferris.

It appears on the Michigan statutes of 1913 as Act No. 34, Public Acts 1913, page 52.

AN ACT to authorize the sterilization of mentally defective persons maintained wholly or in part by public expense in public institu- tions in this state, and to provide a penalty for the unauthorized use of the operations provided for.

The people of the State of Michigan enact:

Section 1. Authority is given to the management of any institution maintained wholly or in part by public expense, in whose custody may be held individuals who have been by a court of competent jurisdiction adjudged to be and who are mentally defective or insane, to render incapable of procreation, by vasectomy or salpingectomy or by the improvement of said surgical operation which is least dangerous to life and will best accomplish the purpose, any person who is mentally defective or insane.

Section 2. The boards of the aforesaid institutions and the physicians or surgeons in charge of each of said institutions shall for each of their respective institutions constitute a board, the duty of which shall be to examine such inmates of said institutions as are reported to them by the warden or medical superintendent to be persons by whom procreation would be inadvisable. Such board shall receive the report of insanity experts hereinafter mentioned, examine the physical and mental condition of such persons, and their record and family history so far as the same can be ascertained, and if in the judgment of a majority of said board procreation by any such person would produce children with an inherited tendency to insanity, feeble-mindedness, idiocy, or imbecility, and there is no probability that the condition of any such person so examined will improve to such an extent as to render procreation by any such person advisable, or if the physical or mental condition of any such person so examined will be substantially improved thereby, then said board shall direct a competent physician or surgeon, with such other assistants as may be necessary, to perform the operation of vasectomy or salpingectomy, or any other operation or improvement on vasectomy or salpingectomy recognized by the medical profession, as the case may be, upon such person. Such operation shall be performed in a safe and humane manner, and the board making such examination, and the institution physician or sürgeon, shall receive no extra compensation therefor; provided, that at least thirty days' notice shall be given to the parents or guardian of such person before the performing of such operation; said notice to specify the purpose, time and place of such examination; provided further, 
that when said parents or guardian object to the performance of such operation, then the question of the sanity of such person shall be referred to the probate court of the county in which the institution is located, where the question of the sanity and the necessity for this operation shall be determined as in other insane cases before such courts.

Section 3. In case an institution has no physician at its head, authority is given to the board of managers to cause such operation to be performed, to hire expert physicians to examine and report on the condition of the subject, and to perform the operation with such other assistants as may be necessary: Provided, before said operation is ordered there shall first be secured from two physicians having qualifications prescribed by law for examiners in insanity a written statement or report that such operation is desirable in the interests of the patient or the good of the community: And, provided further, that these physicians shall be allowed for their services the compensation fixed by statutes for the examination and certification of an insane person. The several sums necessary to carry out the provisions of this act shall be certified to be correct by the respective boards and shall be paid out of the general fund of the state upon the warrant of the auditor-general.

Section 4. In relation to each individual person sterilized under the provisions of this act, the board of control of the institution in which said person is an inmate shall file with the State Board of Public Health of Michigan a written record setting forth the name, age, sex, nationality, type or class of mental defectiveness of şaid person, the nature of the operation performed, the subsequent mental and physical condition as affected by said operation: Provided, that said records shall not be for public inspection, but may be open to inspection of the members of the board of control of the aforesaid institutions and of the members of the immediate family of the person operated upon, or any physician or surgeon designated by them.

Section 5. Except as authorized by this act, every person who shall perform, encourage, assist in, or otherwise promote the performance of either of the operations described in section one of this act, for the purpose of destroying the power to procreate the human species, or any person who shall knowingly permit either of such operations to be performed upon such person, unless the same shall be a medical necessity, shall be guilty of a felony, and upon conviction thereof shall be fined not more than one thousand dollars, or imprisoned in the state prison not more than five years, or both, at the discretion of the court before whom the said person or persons were so convicted.

\section{KANSAS.}

\section{(a) First Law.}

Date of Law: June 1, 1913.

The bill was introduced on February 7, 1913 , by Representative A. B. Scott, of Jetmore, Kansas.

It passed the House and the Senate March $10,1913$.

It was returned unsigned March 14, 1913, by Governor George H. Hodges, and became a law without his signature.

It appears on the Kansas statutes as Chapter 305, pages 525-526 of the Session Laws of 1913.

AN ACT to prevent the procreation of habitual criminals, idiots, epileptics, imbeciles, and insane, and providing a penalty for the violation thereof.

\section{$\mathrm{Be}$ it enacted by the Legislature of the State of Kansas:}

Section 1. That it shall be the duty of managing officers of all state institutions of this state entrusted with the care and custody of habitual criminals, idiots, epileptics, imbeciles and insane, and they are hereby authorized and directed to obtain the advice and professional services of competent surgical assistants, who, jointly with the physician or surgeon in charge of the institution in which any of such inmates shall be, shall constitute the authority whose duty it shall be to examine such inmate or inmates of the several institutions as are deemed to be improper and inadvisable to allow to procreate. Such authority shall examine the physical and mental condition of such inmate or inmates, . the history thereof so far as can be ascertained, and if, in the judgment of such authority, procreation by any such inmate or inmates would produce children with an inherited tendency to crime, insanity, feeble-mindedness, epilepsy, idiocy, or imbecility, and there is no probability that the condition of any such inmate or inmates so examined will improve to such an extent as to render procreation by any such inmate or inmates advisable, or if the physical or men- 
tal condition of any such persons will be materially improved thereby, then said authority shall report their conclusions with a recommendation to the district court or any court of competent jurisdiction in and for the district from which such inmate or inmates has been committed to such institution or institutions. The court shall thereupon hear and determine the matter, and if satisfied that the subject is an habitual criminal within the meaning of this act, or is insane, an idiot, imbecile or an epileptic, and that the purposes of this act will be accomplished by such order, shall adjudge that such operation shall be performed, and shall appoint one of the authority signing such report to perform the operation of vasectomy or oöphorectomy, as the case may be, upon such person. The county attorney of the county in which the hearing is had may be directed by the court to represent the state in the proceedings. Such operation shall be performed in a safe and humane manner, and the surgeon performing the operation shall receive from the state such compensation for the service rendered as the board of administration shall deem reasonable, to be paid out of the maintenance fund of the institution in which such person is confined. Provided, An habitual criminal within the meaning of this act shall be a person who has been convicted of some felony involving moral turpitude.

Section 2. Except as authorized by this act, every person who shall perform, encourage, assist in, and otherwise promote the performance of either of the operations described in section 1 of this act, for the purpose of destroying the power to procreate the human species, or any person who shall knowingly permit either of such operations to be performed upon such person, unless the same shall be a medical necessity, shall be fined not more than one thousand $(\$ 1,000.00)$ dollars, or imprisoned in the county jail not exceeding one (1) year, or both.

Section 3. Any managing officers herein charged with any duty specified in section 1, who shall fail, neglect or refuse for sixty days or more in the performance thereof, shall be guilty of a misdemeanor and subject to a fine of not more than one hundred dollars, or imprisonment in the county jail for not more than thirty days, or both such fine and imprisonment.
Section 4. This act shall take effect and be enforced from and after its publication in the statute book.

\section{(b) Second Law.}

Date of Law: May 26, 1917.

The bill was introduced on January 27 , 1917, by Representative W. A. S. Bird of Topeka, Kansas.

It passed the House February 14, 191778 ayes, 15 noes; the Senate March 8, 191728 ayes, 4 noes.

It was approved March 13, 1917, by Governor Arthur Capper.

It appears on the Kansas statutes as Chapter 299 of the Session Laws of 1917.

AN ACT to prevent the procreation of habitual criminals, idiots, epileptics, imbeciles and insane, and providing penalties for the violation thereof, and repealing sections 9967 , 9968, and 9969 of the General Statutes of 1915. (Chapter 305, pages 525-526, of the Session Laws of 1913.)

\section{Be it enacted by the Legislature of the State of Kansas:}

Section 1. That the warden of the State Penitentiary, the superintendent of the Hutchinson Reformatory, the superintendent of each of the State Hospitals for the Insane, the State Hospital for Epileptics, the State Home for Feeble-Minded, or the State Industrial School for Girls, shall certify in writing to the governing board of the institution of which he or she is warden or superintendent, that he or she believes. that the mental or physical condition of any inmate would be improved thereby or that procreation by any such inmate would be likely to result in defective or feeble-minded children with criminal tendencies, and that the condition of such inmate is not likely to improve so as to make procreation by such person desirable or beneficial to the state, it shall be lawful to perform a surgical operation for the sterilization of such inmate as hereafter provided, and shall not render the board of examiners, its members or any person participating in the operation liable either civilly or criminally. But before such operation shall be performed a written notice shall be served on such inmate, and guardian, if there be one, of the time and place of a meeting and hearing at least thirty days prior thereto; and said inmate shall have the right to be represented by counsel and may introduce such evidence as may be desired. 
Section 2. For the purpose of carrying into effect the provisions of this act, the chief medical officer of any such institution, the governing board of such institution, and the secretary of the State Board of Health, shall constitute a board of examiners for such institution.

Section 3. When the warden or superintendent of any such institution shall deem it advisable that such operation be performed on any one or more of the inmates, it shall be his or her duty to make such recommendation in writing, signed by him or her, to the chairman of the governing board of such institution, whereupon the chairman of such governing board shall forthwith call a meeting of such board of examiners, to be held at such institution at a date not more than fifteen days after the issuance of such call. The call shall clearly set forth the date and object of such meeting and shall contain the names of all inmates whose cases are to be considered at such meeting.

Section 4. At such meeting such board of examiners shall diligently inquire into the mental and physical conditon of each inmate so considered, and as far as practicable into his or her family history and for that purpose any member of said board may administer an oath to any witness whom it is desired to examine.

Section 5. After fully inquiring into the condition of each such person, such board of examiners shall make separate written findings for each of the persons whose condition has been inquired into, and such findings shall either order that such inmate be sterilized or not, and if the board in its findings order sterilization for the inmate, it shall, in its findings, designate what operation is to be performed and its purpose; if a male person, either the operation of vasectomy or asexualization; if a female, either the operation of salpingectomy or oöphorectomy; and shall designate some competent surgeon, who may either be connected with such institution or otherwise, who shall perform the operation. If the surgeon is not connected with such institution, the governing board can make reasonable terms for compensation and such fee shall be paid from the fund provided for the maintenance of such institution in the manner provided by law.

Section 6. Such institution shall keep all files in any proceedings under this act and full minutes of such meetings, and for that purpose the chief medical officer of such institution shall be the secretary of such board of examiners and custodian of its records.

Section 7. Except as authorized by this act, every person who shall perform, encourage, assist in or otherwise promote the performance of either of the operations described in this act, for the purpose of destroying the power to procreate the human species, unless the same shall be a medical necessity, shall be fined not less than $\$ 100.00$ nor more than $\$ 500.00$ and imprisoned in the county jail not less than six months nor exceeding one year.

Section 8. Sections 9967, 9968, and 9969 of the General Statutes of 1915 are hereby repealed.

Section 9. This act shall take effect and be in force from and after its publication in the statute books.

Note: Sections 9967,9968 and 9969 of the General Statutes of 1915 are the codified reference to Chapter 305 of the Session Laws of 1913-this being the first eugenical sterilization law of Kansas.

\section{WISCONSIN.}

Date of Law: July 31, 1913.

The bill was introduced by Senator George E. Hoyt, of Menomonee Falls, Wisconsin.

It passed the Senate July 9, 1913-24 ayes, 3 noes; the House July 25, 1913-39 ayes, 37 noes.

It was approved July 30, 1913, by Governor Francis E. McGovern.

It appears on the Wisconsin statutes as Chapter 693 of the Laws of 1913.

AN ACT to create section $561 \mathrm{jm}$ of the statutes, relating to the prevention of criminality, insanity, feeble-mindedness and epilepsy.

The people of the State of Wisconsin, represented in Senate and Assembly, do enact as follows:

Section 1. There is added to the statutes a new section to read: Section $561 \mathrm{jm}$. The state board of control is hereby authorized to appoint from time to time one surgeon and one alienist of recognized ability, whose duty it shall be, in conjunction with the superintendents of the state and county institutions who have charge of the criminal insane, feeble-minded and epileptic persons, to examine into the mental and physical conditions of such persons legally confined in such institutions. 
Section 2. Said board of control shall at such times as it deems advisable submit to such experts and to the superintendent of any of said institutions the names of such inmates of said institution whose mental and physical condition they desire examined, and said experts and the superintendent of said institution shall meet, take evidence and examine into the mental and physical condition of such inmates and report said mental and physical condition to the said state board of control.

Section 3. If such experts and superintendent unanimously find that procreation is inadvisable it shall be lawful to perform such operation for the prevention of procreation as shall be decided safest and most effective; provided, however, that the operation shall not be performed except in such cases as are authorized by the said board of control.

Section 4. Before such operation shall be performed it shall be the duty of the state board of control to give at least thirty days' notice in writing to the husband or wife, parent or guardian, if the same shall be known, and if unknown, to the person with whom such inmate last resided.

Section 5. The said experts shall receive as compensation a sum to be fixed by the state board of control, which shall not exceed ten dollars per day and expenses, and such experts shall only be paid for the actua! number of days consumed in the performance of their duties.

\section{NEBRASKA.}

Date of Law: July 8, 1915.

The bill was introduced on January 11, 1915 , by Senator H. P. Shumway, of Wakefield, Nebraska.

It passed the Senate, January 11, 191521 ayes, 12 noes; the House, April 8, 191552 ayes, 35 noes.

It became a law without the signature of the Governor, John H. Morehead.

It appears on the Nebraska statutes as Chapter 237 of the Session Laws of 1915.

AN ACT to authorize the sterilization of feeble-minded and insane inmates of state institutions, in certain cases, and to provide for the appointment of a commission, and to define their powers and duties in connection therewith.

Be it enacted by the People of the State of Nebraska:

Section 1. Hereafter no feeble-minded or insane inmate, physically capable of bear- ing or begetting offspring, shall be paroled or discharged from the institution for the feeble-minded, or the hospitals for the insane, nor paroled from the penitentiary, reformatory, industrial home, industrial schools or other such state institution, except as hereinafter provided, or by order of a court of competent jurisdiction.

Section 2. Immediately after the act shall have gone into effect the board of commissioners of state institutions shall designate five physicians from the medical staffs of the state institutions under their jurisdiction, to constitute a board of examiners of defectives, three of which physicians shall be appointed from the institution for feeble-minded youth and the hospitals for the insane. Three members of such examining board shall constitute a quorum, and every determination or order of said board must be concurred in by at least three members thereof. The members of said board of examiners shall receive no compensation for their services as such examiners, but shall be reimbursed their actual and necessary traveling expenses from the funds of the respective institutions whose inmates are examined by them. The personnel of said board of examiners may be changed from time to time by said board of commissioners of state institutions as may be found necessary or convenient.

Section 3. It shall be the duty of the examiners to examine into the innate traits, the mental and physical conditions, the personal records, and the family traits and histories of all inmates who may be subject to parole or discharge from the institution for the feeble-minded, hospitals for the insane, the penitentiary, reformatory, industrial schools, industrial home, or other such state institution, and if after a careful examination and investigation, such board of examiners find that such inmate is feebleminded, or insane, that such inmate is capable of bearing or begetting offspring, that children borne or begotten by such inmate would inherit a tendency to feeble-mindedness, insanity, or degeneracy, that such children would probably become a social menace and that procreation by such inmate would be harmful to society, and that such inmate should not be paroled or discharged, as the case may be, unless sterilized, then in every such case it shall be a condition prerequisite to the parole or discharge of such inmate that said inmate be made sterile, and that such operation be performed for the preven- 
tion of procreation as in the judgment of said board of examiners shall be most appropriate to each individual case.

Section 4. Before any such operation shall be performed, the nature, character and consequences of such operation shall be fully explained to such inmate and to the husband, wife, parent, guardian or nearest kin of such inmate and no such operation shall be performed without the written consent of such husband, wife, parent, guardian, or nearest kin, as the case may be, and the assent of such inmate so far as said inmate is capable of assenting thereto.

Section 5. Said operation shall be performed at the institution of which such person is an inmate in the presence of a member of the examining board, and either by one of the surgeons on the staff of a state institution or by some surgeon selected and paid by the husband, wife, parent, guardian or nearest of kin of said inmate.

\section{OREGON.}

Date of Law: May 21, 1917.

The bill was introduced on January 19, 1917, by Representative Arthur K. Peck, of Marshfield, Oregon.

It passed the House, February 1, 191737 ayes, 18 noes; the Senate, February 16, 1917-16 ayes, 12 noes.

It was approved February 19, 1917, by Governor James Withycombe.

It appears on the Oregon statutes as Chapter 279 of the General Laws of Oregon, 1917.

AN ACT to prevent the procreation of feeble-minded, insane, epileptic, habitual criminals, moral degenerates and sexual perverts, who may be inmates of institutions maintained by public expense, by authorizing and providing for the sterilization of persons with inferior hereditary potentialities.

\section{Be it enacted by the People of the State} of Oregon:

Section 1. There is hereby established and constituted for the State of Oregon a State Board of Eugenics which shall be composed of the State Board of Health, the Superintendent of the Oregon State Hospital, the Superintendent of the Eastern Oregon State Hospital, the Superintendent of the State Institution for Feeble-Minded, and the Superintendent of the Oregon State Penitentiary, whose duties shall be as hereinafter defined. The secretary of the State Board of Health shall serve as the secretary of said Board, and the members of said Board shall serve without compensation.
Section 2. It shall be, and it is hereby declared, the duty of the Superintendent of the Oregon State Hospital, and Superintendent of the Eastern Oregon State Hospital, and the Superintendent of the Oregon State Penitentiary to report quarterly to the State Board of Eugenics, all feeble-minded, insane, epileptic, habitual criminals, moral degenerates and sexual perverts, who are persons potential to producing offspring who, because of inheritance of inferior or antisocial traits, would probably become a social menace, or a ward of the State.

Section 3. It shall be the duty of the State Board of Eugenics to examine into the innate traits, the mental and physical conditions, the personsal records, and the family traits and histories of all persons so reported, so far as the same can be ascertained, and for this purpose said Board shall have the power to summon witnesses, and any member of said Board may administer an oath to any witness whom it is desired to examine; and if in the judgment of a majority of the said Board procreation by any such person would produce children with an inherited tendency to feeble-mindedness, insanity, epilepsy, criminality or degeneracy, and there is no probability that the condition of such person so examined will improve to such an extent as to render procreation by any such person advisable, or if the physical or mental condition of any such person will be substantially improved thereby, then it shall be the duty of said Board to make an order directing the superintendent of the institution in which the inmate is confined to perform or cause to be performed upon such inmate such a type of sterilization as may be deemed best by said Board.

Section 4. The purpose of said investigation, findings and orders of said Board shall be for the betterment of the physical, mental, neural, or psychic condition of the inmate, or to protect society from the menace of procreation by said inmate, and not in any manner as a punitive measure; and no person shall be emasculated under the authority of this Act except that such operation shall be found to be necessary to improve the physical, mental, neural, or psychic condition of the inmate.

Section 5. After fully inquiring into the condition of each of such inmates said Board shall make separate written findings for each of the inmates whose condition has been examined into, and the same shall be preserved in the records of the said Board, and 
a copy thereof shall be furnished to the superintendent of the institution in which the inmate is confined, and if an operation is deemed necessary by said Board, then a copy of the order of said Board shall forthwith be served on said inmate, or in case of an insane person upon his legal guardian, and if such insane person have no legal guardian, then upon his nearest known kin within the State of Oregon, and if such person have no known kin within the State of Oregon, then upon the custodian guardian of such insane person.

Section 6. Any such inmate desiring to appeal from the decision of the said Board, or in case the person is under guardianship or disability, then the guardian of said inmate may take an appeal to the circuit court of the county in which the institution in which the inmate is confined, is located.

An informal notice of appeal filed with the secretary of said Board, either by the inmate or someone in his behalf, shall be all that is necessary to make the appeal; provided, said notice shall be filed within fifteen days of the date when notice of the Board's decision is served on the inmate or his guardian, and said notice of appeal shall stay all proceedings of said Board in said matter until the same is heard and determined on said appeal; provided further, that no operation shall be performed, upon any inmate, until the time for appeal from the decision of the Board has expired.

Section 7. Upon an appeal being taken, the secretary of the said Board where the notice of appeal is filed, must within fifteen days thereafter, or such further time as the court or the judge thereof may allow, transmit a certified copy of the notice of appeal and transcript of the proceedings, findings, and order of the Board, to the clerk of the court appealed to.

The trial shall be a trial de novo at law as provided by the statutes of the State, for the trial of actions at law. Upon such appeal, if the inmate be without sufficient financial means to employ an attorney, then such attorney shall be compensated by the State upon order of the court; and it shall be the duty of the district attorney of the county wherein such trial is had to represent the said Board.

Section 8. If the court or jury shall affirm the findings of said Board, said court shall enter a judgment, adjudging that the order of the said Board shall be carried out as herein provided; if the court fail to affirm the decision of said Board, appealed from, then said order shall be null and void and of no further effect.

Section 9. Upon the receipt of the order from the State Board of Eugenics provided for in Section 3, the superintendent of the institution to which it is directed shall, after the time for appeal has expired, or in case of appeal upon the entering of a judgment affirming the order of the Board, and it is hereby made his lawful duty to perform, or cause to be performed, such surgical operation as may be specified in the order of the State Board of Eugenics. All operations shall be performed with a due regard for the physical condition of the inmate and in a safe and humane manner.

Section 10. The criminals who shall come within the operation of this law shall be those who have been convicted three or more times of a felony in the courts of any state and sentenced to serve in the penitentiary therefor.

Moral degenerates and sexual perverts are those who are addicted to the practice of sodomy or the crime against nature, or to other gross, bestial and perverted sexual habits and practices prohibited by statute.

Section 11. The provisions of this Act shall apply to both male and female inmates of any of the institutions designated herein.

Section 12. The State shall be liable, under this Act, only for the actual traveling expenses of the members of the Board.incurred in the performance of their duties, and the actual and necessary expense incident to the investigations of said Board and an appeal therefrom.

\section{SOUTH DAKOTA.}

Date of Law: July 1, 1917.

The bill was introduced on February 20, 1917, by Senator A. R. Labire of Doland, South Dakota.

It passed the Senate February 27, 191734 ayes, 9 noes; the House, February 28, $1917-81$ ayes, 4 noes.

It was approved March 8, 1917, by Governor Peter Worbeck.

It appears on the South Dakota statutes as Chapter 236 (S. B. 257) of the Session Laws of 1917.

\section{RELATING TO THE OPERATION OF VASECTOMY.}

AN ACT entitled, An Act for the Prevention of the Procreation of Idiots, Imbeciles and Feeble-minded Persons.

Be it enacted by the Legislature of the State of South Dakota: 
Section 1. Sterilization of Defectives. It shall be the duty of the superintendent of the State Home for Feeble-Minded Persons to examine into the mental and physical condition, the records and family history of the inmates of said institution with a view of determining whether it is improper or inadvisable to allow any such inmates to procreate, and to make an annual report of said examinations to the State Board of Charities and Corrections.

Section 2. Duty of Board. That it shall be the duty of said Board with the superintendent of said institution to carefully examine the record of each inmate and to determine whether it is improper or inadvisable to allow any such inmates to procreate, and if a majority of them, including such superintendent, decide that the procreation by any of said inmates would produce children with a tendency to disease, feeblemindedness, idiocy or imbecility, or, if the mental condition of any such inmate will probably be materially improved thereby, then the physician of the institution or one selected by him, shall perform the operation of vasectomy or ligation of the Fallopian tubes, as the case may be, upon such person.

Section 3. Record. The superintendent of the Home for Feeble-Minded shall keep a record of all inmates operated on, with statistics and notes or observations regarding its benefits, and make an annual report to the Governor of all inmates operated on, with the recorded results of said operation.

\section{B. EUGENICAL STERILIZATION BILLS VETOED.}

The Governors of Pennsylvania (1905, Pennypacker; 1921, Sprou1), Oregon (1909. Chamberlin), Vermont (1913, Fletcher), Nebraska (1913, Morehead), and Idaho (1919, Davis) have vetoed sterilization bills passed by their respective legislatures. In addition to this series of vetoes, Oregon in 1913, declined on referendum, by vote of 41,767 for and 53,319 against, to ratify a proposed sterilization law. Of these five states, however, Nebraska (1915) and Oregon (1917) finally succeeded in securing sterilization statutes which are now in force. Thus, disregarding the executive vetoes, the legislatures of eighteen different states have passed sterilization bills.

We learn also that serious legislative efforts to enact laws of this sort have been made in the legislatures of Illinois, Minnesota, New Hampshire, Ohio and Indiana.

We may make a short summary of the matter by saying that since 1907 , practically half of the several states of the Union have taken seriously legislative consideration of the possibilities of improving the natural qualities of its citizenry by means of eugenical sterilization. (See page 44, Bulletin $10 \mathrm{~B}$, Eugenics Record Office, 1914.)

The full texts of eugenical sterilization bills and veto messages follow:

\section{PENNSYLVANIA.}

\section{(A.) Veto of 1905.}

Senate Bill 35 .

Passed March 21, 1905.

Vetoed March 30, 1905.

a. TEXT OF BILL.

AN ACT for the prevention of idiocy.

Whereas, Heredity plays a most important part in the transmission of idiocy and imbecility; therefore,

Section 1. Be it enacted, etc., That on the first day of July after the passage of this bill, it shall be compulsory for each and every institution in the state, entrusted exclusively or especially with the care of idiots and imbecile children, to appoint upon its staff at least one skilled surgeon, of recognized ability, whose duty it shall be, in conjunction with the chief physician of the institution to examine the mental and physical condition of the inmates.

If, in the judgment of this Committee of Experts and Board of Trustees, procreation is inadvisable, and there is no probability of improvement of the mental condition of the inmate, it shall be lawful for the surgeon to perform such operation for the prevention of procreation as shall be decided safest and most effective; but this operation shall not be performed except in cases that have been pronounced non-improvable after one year's test in institution.

\section{b. VETO MESSAGE.}

Commonwealth of Pennsylvania

Executive Department

Harrisburg, March 30, 1905.

To the Honorable, the Senate of the Commonwealth of Pennsylvania:

Gentlemen: I return herewith, without my approval Senate Bill No. 35, entitled, "An Act for the prevention of idiocy."

This bill has what may be called with propriety an attractive title. If idiocy could be prevented by an act of assembly, we may be quite sure that such an act would have long been passed and approved in this state, and that such laws would have been enacted 
in all civilized countries. The subject of the act is not the prevention of idiocy, but it is to provide that in every institution in the state, entrusted with the care of idiots and imbecile children, a neurologist, a surgeon and a physician shall be authorized to perform an operation upon the inmates "for the prevention of procreation." What is the nature of the operation is not described but it is such an operation as they shall decide to be "safest and most effective." It is plain that the safest and most effective method of preventing procreation would be to cut the heads off the inmates, and such authority is given by the bill to this staff of scientific experts. It is not probable that they would resort to this means for the prevention of procreation, but it is probable that they would endeavor to destroy some part of the human organism. Scientists, like all other men whose experiences have been limited to one pursuit, and whose minds have been developed in a particular direction, sometimes need to be restrained. Men of high scientific attainments are prone, in their love for technique, to lose sight of broad principles outside of their domain of thought. A surgeon may possibly be so eager to advance in skill as to be forgetful of the danger to his patient. Anatomists may be willing to gather information by the infliction of pain and suffering upon helpless creatures, although a higher standard of conduct would teach them that it is far better for humanity to bear its own ills than to escape them by knowledge only secured through cruelty to other creatures. This bill, whatever good might possibly result from it if its provisions should become a law, violates the principles of ethics. These feeble-minded and imbecile children have been entrusted to the institutions by their parents or guardians for the purpose of training and instruction. It is proposed to experiment upon them, not for their instruction, but in order to help society in the future. It is to be done without their consent, which they cannot give, and without the consent of their parents " or guardians, who are responsible for their welfare. It would be in contravention of the laws which have been enacted for the establishment of these institutions. These laws have in contemplation the training and the instruction of the children. This bill assumes that they cannot be so instructed and trained. Moreover, the course it is proposed to pursue would have a tendency to prevent such train- ing and instruction. Everyone knows, whether he be a scientist or an ordinary observer, that to destroy virility is to lessen the capacity, the energy and the spirit which lead to effort. The bill is, furthermore, illogical in its thought. Idiocy will not be prevented by the prevention of procreation among these inmates. This mental condition is due to causes many of which are entirely beyond our knowledge. It existed long before there were ever such inmates of such institutions. If this plan is to be adopted, to make it effective it should be carried into operation in the world at large, and not in institutions where the inmates are watched by nurses, kept separate, and have all the care which is likely to render procreation there very rare, if not altogether impossible. In one of these institutions, I am reliably informed, there have only been three births in ten years. A great objection is that the bill would encourage experimentation upon living animals, and would be the beginning of experimentation upon living human beings, leading logically to results which can readily be forecasted. The chief physician, in charge at Elwyn, has candidly told us, in an article recently published upon "Heredity," that "Studies in heredity tend to emphasize the wisdom of those ancient peoples who taught that the healthful development of the individual and the elimination of the weakling was the truest patriotism-springing from an abiding sense of the fulfiliment of a duty to the state."

To permit such an operation would be to inflict cruelty upon a helpless class in the community which the state has undertaken to protect. However skillfully performed, it would at times lead to peritonitis, blood poisoning, lockjaw and death.

For these reasons the bill is not approved.

\section{SAML. W. PENNYPACKER.}

Note: No attempt was made to pass this bill over the Governor's veto. In fact the Governor vetoed the bill after the adjournment of the Legislature.

\section{(B.) Veto of 1921.}

SENATE BILL $\mathbf{5 6 0 .}$

Date of sterilization bill April 28, 1921.

The bill was introduced by Dr. George Woodward of Philadelphia, Pa.

It passed the Senate April 11, 1921-36 ayes, 5 noes.

It was vetoed by the Governor May 25, 1921. 


\section{a. TEXT OF BILL. AN ACT}

To provide for the sterilization of inmates of institutions having the care and custody of idiotic, imbecile, epileptics, feeble-minded and insane persons in cases where such sterilization will materially improve the mental or physical condition of such persons and in cases where owing to the idiocy, imbecility, insanity or feeblemindedness of such persons not being in permanent custody procreation by such persons would produce offspring similarly affected.

Section 1. Be it enacted by the Senate and House of Representatives of the Commonwealth of Pennsylvania in General Assembly met and it is hereby enacted by the authority of the same, That within ninety days after the first day of July one thousand nine hundred and twenty-one the board of trustees, managers or directors of each institution having the care and custody of idiots, imbeciles, epileptics, insane or feeble-minded persons which institution is supported in whole or in part by appropriations made for that purpose by the General Assembly shall constitute and appoint a commission to consist of at least one competent neurologist and one surgeon of recognized ability who may be appointed from the regular staff of such institution, the duty of which commission shall be to examine the mental and physical condition of the inmates of such institution and the. personal records and family traits and histories thereof and to determine and report in writing to the board of trustees, managers or directors of said institution from time to time.

(a) In what, if any cases, the physical or mental condition of an inmate will be materially benefited by sterilization, there being no probability that such condition of the inmates can be otherwise improved, and

(b) In what, if any cases, the condition of an inmate is such that by reason of his or her imbecility, idiocy, insanity, epilepsy or feeble-mindedness procreation by the inmate would produce offspring similarly affected and there is no probability that the condition of such inmate will improve to such an extent as to render procreation by said inmate advisable. The said Commission shall accompany said reports with specific recommendations for the sterilization of the inmates reported upon with the reasons therefor and the method of sterilization recommended in. such case.
Section 2. Upon the receipt of any such report and accompanying recommendations the said board of trustees, managers or directors of said institution shall consider the same and pass separately upon the case of each inmate recommended for sterilization, and if they approve any such recommendation by an affirmative vote of not less than three-fourths of the members of the board, they shall record upon their minutes an order for the sterilization of the inmate so recommended therefor, specifying in each case the manner in which the case shall be effected; but the sterilization of no inmate in permanent custody shall be ordered unless it shall appear from the report of the commission that the mental or physical condition of such inmate will be materially benefited thereby, and that such condition cannot probably be otherwise improved. The said board of trustees, managers or directors shall thereupon present their petition to the court of common pleas of the county wherein such institution shall be located, reciting the recommendations of said commission and the action taken thereon by said board of trustees, managers or directors, and praying for an order of said court approving the order made in each case by the said board and directing the execution thereof.

Section 3. The said court shall thereupon set a day for the hearing of said petition and order that notice in writing of the time and place and nature of such hearing shall be given to the nearest kin, guardian, committee or other legal representative of each person so ordered to be sterilized as the court may designate. If it shall appear to the satisfaction of the court that such person has no kindred, guardian, committee or other legal representative or that his or her nearest kin, guardian, committee or other legal representative is financially unable to employ counsel to represent them the court may, in its discretion, appoint counsel to represent the person ordered to be sterilized or his or her nearest kin, guardian, committee or other legal representative at such or any further hearing or proceeding and fix the compensation for the services of such counsel, which compensation shall be paid upon the order of the court by the county wherein such person so ordered to be sterilized has his or her legal settlement in Pennsylvania; or if he or she has no legal settlement therein then by the county wherein said institution is located.

Section 4. At the said hearing and the 
subsequent proceedings the board of trustees, managers or directors of said institution shall, if they so request, be represented by an assistant Attorney General. If at such hearing the court is satisfied that the persons ordered to be sterilized, or any of them, are severally potential to produce offspring, and that either

(a) Their mental or physical condition will be materially benefited by sterilization, and that such condition cannot probably be otherwise improved, or

(b) That by reason of their imbecility, idiocy, insanity, epilepsy or feeble-mindedness procreation by such persons not being in permanent custody would produce offspring similarly affected and there is no probability that the condition of such persons will improve to such an extent as to render procreation by them advisable, then

The said court shall order and direct that the order of said board of trustees, managers or directors be approved so far as the same relates to the sterilization of persons concerning the condition of which the court is satisfied as above with such modifications as may to the court seem proper and order and direct that the same be carried into execution unless an appeal from such findings and order shall be taken to the Superior Court within thirty days from the filing of the same either by the board of trustees, managers or directors presenting said petition or the representatives as above enumerated of any person directed to be sterilized by such order and the said Superior Court shall have power to review and affirm, modify or disapprove such findings and order and such appeal shall operate as a supersedeas.

Section 5. When the order of any such board of trustees, managers or directors of any such institution for the sterilization of an inmate of such institution shall have been approved by the proper court of common pleas as aforesaid and no appeal to the Superior Court shall have been taken from the order of said court approving the same within thirty days after the filing of such order or if any such appeal shall have been taken then at any time after the filing of a decree of the Superior Court affirming the findings and order of the said court of common pleas in the premises the person ordered to be sterilized in said order shall be sterilized by the surgeon member of the commission recommending such sterilization or by such other skilled surgeon as the board of trustees, managers or directors of said institution may select and designate in the manner designated in the order of said board unless otherwise directed by the court approving said order or by the Superior Court on appeal and any expense incurred thereby shall be defrayed by such institution. The aforesaid order shall constitute complete authority for the performance of said operations and no surgeon performing the same shall be held responsible in any place for the performance thereof.

Section 6. It shall be the duty of the commissions appointed by the boards of trustees, managers or directors of each of the institutions aforesaid to keep a permanent record of all cases and histories examined into and of all reports and recommendations made by them and of all orders made and received by them and all operations performed pursuant to their recommendations and to annually make a report in writing of such records to the Commissioner of Health of Pennsylvania. The cost of all legal proceedings not otherwise hereinbefore provided for shall be paid by the counties in which the inmates concerning which such proceedings are had shall have their respective legal residences or if such inmates have no legal residence then at the cost of the county in which the institution of which they are severally inmates is located.

\section{b. VETO MESSAGE.}

May 25th, 1921.

I file herewith,.in the office of the Secretary of the Commonwealth, with my objections, Senate Bill No. 560, entitled "An act to provide for the sterilization of inmates of institutions having the care and custody of idiotic, imbecile, epileptics, feeble-minded and insane persons in cases where such sterilization will materially improve the mental or physical condition of such persons, and in cases where, owing to the idiocy, imbecility, insanity or feeble-mindedness of such persons not being in permanent custody, procreation by such persons would produce offspring similarly affected."

This Bill is in clear violation of Section 1 of the Fourteenth Amendment of the Constitution of the United States, which provides that no State shall deny to any person within its jurisdiction the equal protection of the laws.

If the State of Pennsylvania has the power to pass an Act of this kind, providing for a surgical operation upon certain persons, it can only do so in the exercise of its police 
power, for such operation threatens possibly the life, and certainly the liberty, of the persons operated upon. The police power is the exercise by the Legislature of a State of its inherent sovereignty to enact and enforce whatever regulations are, in its judgment, demanded for the welfare of society at large in order to secure or to guard its order, safety, health or morality. The limitation of this power is that under our system of government the artificial enhancement of the public welfare by the forcible suppression of the constitutional rights of the individual is inadmissible. If the State, under the exercise of this police power, has the right to pass an Act to sterilize idiots, imbeciles, epileptics, and feeble-minded and insane persons who are inmates of certain institutions, it can have such right only in order to guard the health of the people of the Commonwealth. If such a power exists in the case of idiots, imbeciles, epileptics, and feeble-minded and insane persons in institutions, and is exercised for the protection of the public health it may be exercised with regard to many other diseases, for idiots, imbeciles, epileptics, and feeble-minded and insane persons are not the only persons injuriously affecting the welfare of society by procreation of offspring. If, therefore, the Legislature may, under the police power, theoretically benefit the next generation by the sterilization of persons enumerated in this Bill, it may and should pursue a like course with respect to persons affected with many other communicable diseases of a character such as to threaten the health of posterity.

Besides those afflicted with physical or mental diseases, many other persons might be undesirable citizens in the opinion of the majority of a Legislature.

This Bill is based upon a classification of such a nature that the persons included within it are not afforded the equal protection of the laws under the Fourteenth Amendment of the Constitution of the United States, which provides that no State shall deny to any person within its jurisdiction the equal protection of the laws. It relates only to those persons afflicted with the diseases enumerated in the Bill who are inmates of institutions maintained in whole or in part by the State. If the purpose to be achieved by the Bill is the sterilization - of persons afflicted with the diseases enumerated in order to prevent procreation and, therefore, protect the health of the future generations, all persons afflicted with those diseases should be included within the terms of the Bill. If the object sought for requires the sterilization of the class, then it requires the sterilization of all of that class, whether they are confined in institutions maintained in whole or in part by the State or whether they are not confined. In fact, there is more danger to be apprehended from persons afflicted with idiocy, imbecility, epilepsy, feeble-mindedness and insanity who are at large than those who are confined in institutions maintained in whole or in part by the State, who are presumed to be confined in such a manner that they have no opportunities for procreation.

For these reasons the bill is not approved.

\section{WM. C. SPROUL.}

(C.) Notes on the Situation in Pennsylvania.

(a) Legislative Record of other sterilization bills in Pennsylvania.

1911, House Bill 500.

Passed House. Passed second reading in Senate. Recommitted and died in committee in Senate.

1913, Senate Bill 367.

Died in committee.

1913, House Bill 365 .

Defeated on final passage in House.

1915, House Bill 431.

Died in committee.

1915, House Bill 420.

Died in committee.

1917, House Bill 1262.

Died in committee.

1919, House Bill 673.

Defeated on fina1 passage in House.

1919, House Bill 375.

Reported from committee with negative recommendations.

(b) Many of the institutional, medical and social authorities of Pennsylvania have been working for the enactment of a satisfactory eugenical sterilization law.

Dr. H. W. Mitchell, Secretary-Treasurer of the American Medico-Psychological Association and Superintendent of the State Hospital at Warren, Pa., prior to the veto of 1921 wrote (October 16, 1920): 
"I have recently had a long interview with Dr. Martin, the present head of the Department, who informs me, that if there can be practically unanimous support from the men interested in the conduct of insane hospitals, feeble-minded, etc., he will see that the bill is re-introduced with the backing of his Department-providing, further, that the example of other States can be cited in the legislative discussion of the proposed measure."

"In conversations with men engaged in similar work in this State, I find that few of the physicians would care to assume the sole responsibility of determining when the provision of the act should be applied to a concrete case. I should not expect any wholesale activity under the act, even if it were passed, but many cases would occur in the course of hospital operations for a year to which it could be unquestionably applied, to advantage of all concerned."

"At this hospital we are quietly using the method occasionally, with the consent of all concerned, though the surgical treatment is given in some general hospital."

James F. McCoy, Executive Secretary of the Department of Health of the Commonwealth of Pennsylvania, writes (June 8, 1921):

"Unfortunately, the Eugenical Sterilization Bill which passed the Legislature in April was vetoed by Governor Sproul. I drew the bill under the direction of the Commissioner of Health, Colonel Edward Martin, and managed to secure its final passage but the Governor took the position that it was too drastic and that the state was not prepared for it."

\section{(A.) Bill vetoed.}

\section{OREGON.}

Sterilization bill introduced by Coffey. Senate bill No. 68.

Passed by the House February 17, 1909 -50 ayes, 5 noes, absent or non-voting 5 .

Passed by the Senate February 1, 190920 ayes, 10 noes, absent or non-voting none.

Vetoed by Governor Geo. E. Chamberlain February 22, 1909.

\section{a. TEXT OF BILL.}

For an act entitled an act to prevent procreation of confirmed criminals, insane persons, idiots, imbeciles and rapists; providing that superintendents and boards of managers of institutions where such persons are confined shall have the authority and are empowered to appoint a committee of experts, consisting of two (2) physicians, to examine into the mental condition of such inmates, and to define who shall be deemed confirmed criminals within the provisions of this act.

Be it enacted by the people of the State of Oregon:

Be it enacted by the Legislative Assembly of the State of Oregon:

Section 1. From and after the passage of this act it shall be compulsory for each and every institution in the state intrusted with the care of confirmed criminals, insane persons, idiots, rapists and imbeciles, to appoint upon its staff, in addition to the regular institutional physicians, two (2) skilled surgeons of recognized ability, whose duty it shall be, in conjunction with the chief physician of the institution, to examine the mental and physical condition of such inmates as are recommended by the institutional physician and board of managers. If, in the judgment of this committee of experts and the board of managers, procreation is inadvisable, and there is no probability of improvement of the mental condition of the inmates, it shall be lawful for the surgeons to perform such operation for the prevention of procreation as shall be decided safest and most effective; but this operation shall not be performed except in cases that have been pronounced unimprovable.

The term "confirmed criminals," as contained in this act, shall be deemed to apply to and include all persons serving a third term in any penitentiary or penal institution upon conviction of a felony.

\section{b. VETO MESSAGE.}

\section{Salem, February 22, 1909.}

To the President and Members of the Senate:

I return you herewith Senate Bill No. 68, with my disapproval. It provides to make it compulsory for each and every institution in the State intrusted with the care of confirmed criminals, insane persons, idiots, rapists and imbeciles to appoint upon its staff, in addition to the regular institutional physicians, two skilled surgeons of recognized ability, whose duty it shall be, in conjunction with the chief physician of the institution, to examine the mental and physical condition of such as are recommended by the institutional physician and board of managers. If, in the judgment of this committee of experts and the board of managers, procreation is inadvisable, and there is no probability of improved mental condition of the inmate, it shall be lawful 
for the surgeons to perform such operation for the prevention of procreation as shall be decided safest and most effective, but the operation shall not be performed except in cases that have been pronounced unim-. provable.

It will be observed from a reading of the act that incurable insane criminals are so confused and confounded with each other that it is difficult to judge whether criminals are to be sterilized because they are, in fact, mentally unsound or because they are criminals who are serving a third term in the penitentiary upon conviction of a felony. The bill is not drawn to meet the conditions of institutional life in Oregon, because the penitentiary is not governed by a board of managers, but by the Governor of the State, with the assistance of a superintendent and wardens, while the asylum is under the direct supervision of a board of trustees, a superintendent and a corps of assistants. A bill departing so radically from established methods in Oregon ought to be skillfully framed and remove any ground for misunderstanding or misconstruction of its terms.

Besides these objections, I am not entirely satisfied that all of the class named in the act ought to be submitted to such harsh treatment, and if it is to become a law in this State, greater safeguards should be thrown around the unfortunate wards of the State who are mentioned in the act. Without these there might be a terrible abuse of the power attempted to be given those upon whom the duty is devolved.

I therefore return said measure to you with my veto.

\section{GEO. E. CHAMBERLAIN,}

Governor.

The Oregon bill was promoted by Dr. Owens-Adair, of Portland. After vetoing this bill, Governor Chamberlain wrote the following letter to Dr. Owens-Adair:

Doctor Owens-Adair, Portland, Oregon.

Dear Mrs. Adair:

After looking over Senate Bill Number 68 I have concluded that it is so loosely drawn and poorly safeguards the rights of the unfortunate (against whom it is directed) that I deemed it my duty to veto it.

When I first talked to you about the matter, without knowing the terms of the Bill in detail, I was disposed to favor it, but I think such a Bill ought to be so care- fully safeguarded that no abuses could be practiced against it, and I feel that this is not the case with the bill under consideration.

I have the honor to remain, Yours very respectfully, GEO. E. CHAMBERLAIN.

Note: This bill was laid on table by Senate January 20, 1911, and never acted upon.

\section{(B.) Law Revoked by Referendum, Novem-} ber 4, 1913.

a. TEXT OF LAW.

\section{AN ACT}

Entitled an act to protect the public peace, health and safety from habitual criminals, moral degenerates and sexual perverts; to require the superintendents of the Oregon State Insane Asylum, the Eastern Oregon State Hospital, the State Institution for Feeble-Minded, and the Oregon State Penitentiary to report quarterly the names, records, condition and character of all inmates of their respective institutions who are habitual criminals, moral degenerates or sexual perverts; to authorize the State Board of Health to investigate, or cause to be investigated, all such cases so reported to it; to authorize the State Board of Health, in its discretion, to direct the superintendents of the said institutions to perform or cause to be performed, such surgical operations as may be for the best interests of the public peace, health and safety.

Be it enacted by the People of the State of Oregon:

Section 1. It is hereby declared that habitual criminals, moral degenerates, and sexual perverts are menaces to the public peace, health and safety. Habitual criminals are those who have been three or more times convicted of a felony in the courts of any State and sentenced to serve in the penitentiary therefor. Moral degenerates and sexual perverts are those who are addicted to the practice of sodomy or the crime against nature, or to other gross, bestial and perverted sexual habits and practices prohibited by statute. Any person convicted of rape when the offense is committed on a female over the age of consent as fixed by Lord's Oregon Laws or on a female under the age of fourteen years with or without consent, or on a female between the age of fourteen years and the age of consent, where rape is committed as defined by Lord's Oregon Laws for rape over the age 
of consent, shall be deemed to be a moral degenerate under the terms and provisions of this act; provided, however, that in any case where the conviction of rape is secured by circumstantial evidence only, other than the evidence of the prosecutrix, this law shall not apply.

Section 2. It shall be, and is hereby declared, the duty of the superintendent of the Oregon State Insane Asylum, the superintendent of the Eastern Oregon State Hospital, the superintendent of the State Institution for Feeble-Minded, and the superintendent of the Oregon State Penitentiary to report on the first day of each quarter to the State Board of Health the names, record, character, and condition of any and all inmates of their respective institutions who may be habitual criminals, moral degenerates or sexual perverts.

Section 3. Immediately upon its receipt of the reports provided for in Section 2, the State Board of Health shall investigate, or cause to be investigated, each case so reported to it. Such investigation shall be conducted in a careful and thorough manner and in accordance with the recognized rules of medical science. A full and complete record of such investigation shall be prepared and preserved in the records of the said Board, and a copy thereof shall be furnished to the superintendent of the institution in which the inmate is confined. If the said investigation shall disclose that the inmate, so reported upon, is an habitual criminal, or is a moral degenerate or a sexual pervert the said Board shall so certify in an order to the superintendent of the institution in which the inmate is confined directing the said superintendent to perform, or cause to be performed, such surgical operation upon the said inmate as, in the opinion of the said State Board of Health, may be necessary for the protection of the peace, health and safety of the State. Any such inmate, desiring to appeal from the decision of the said Board, or in case the person is under guardianship or disability, then the guardian of said person may take an appeal to the circuit court of the county in which the institution, in which the person is confined, is located. A notice of appeal shall be all that is necessary to make the appeal. The Board shall certify to the said circuit court the report of the investigations hereinbefore described.

The trial on such appeal shall be a trial de novo at law as provided by the statutes of this State, for the trial of actions at law. If the court or jury shall find that the person accused is a habitual criminal, moral degenerate or sexual pervert, as hereinbefore defined,. said court shall enter a judgment ordering that the findings of the said Board shall be carried out as hereinbefore provided.

Section 4. Upon receipt of the order from the State Board of Health, provided for in Section 3, the superintendent of the institution to which it is directed shall, and it is hereby made his lawful duty, to perform, or cause to be performed, such surgical operation as may be specified in the order of the State Board of Health. All such surgical operations shall be performed with a due regard for the physical, mental and moral betterment of the inmate and for the protection of the peace, health and safety of the public.

Section 5. The provisions of this act shall apply to both male and female inmates of any of the institutions designated herein.

Filed in the office of the Secretary of State February 18, 1913.

\section{b. LEGISLATIVE AND. REFEREN- DUM RECORD.}

1. "The bill was introduced on January 15, 1913, by Representative L. G. Lewelling, of Albany, Oregon. It passed the Senate by a vote of 16 ayes to 11 noes; the House by 49 ayes to 8 noes. It was approved on February 18th by Governor Oswald West. It was to have appeared on the Oregon Statutes as Chapter 63, General Laws of Oregon, 1913, and was designed to take effect on June $3 d, 1913$, but the referendum was on May 31st, 1913, legally invoked for November 4th, 1913. This held the law in abeyance pending the decision of the people. In Oregon it requires the petition of 5 per cent (in this case 6,312 ) of the legal voters in order to invoke the referendum; 8,275 signers were actually secured. Such a measure is upheld if it received the indorsement in referendum of a "majority of the votes cast thereon." The vote on November 4th, 1913, was: Yes, 41,767; no, 53,319. The total Oregon vote for Governor in 1910 was 117,690 ; for President in 1912 was $137,040$. The vote was therefore apparently representative of the entire electorate.

The history of the sterilization legislation in this state is quite remarkable. A law was vetoed by Governor Chamberlain in 1909; in 1913 a new law was passed and approved by Governor West, but was revoked by a referendum before it went into effect. It is 
interesting to learn that not only was the referendum against the statute led by a woman, but that a woman physician, Dr. Owens-Adair, of Warrenton, Oregon, was the leader in the original movement for legalized eugenical sterilization, and was the author of the bill vetoed by Governor Chamberlain. So far as the committee is aware, Oregon is the only state having an organized opposition to sterilization.

The 1913 proposed law was vigorously opposed by the Anti-Sterilization League, of which Mrs. Lora C. Little is vice-president. Through the agency of this league the referendum petition was circulated, and the requisite number of signers were secured.

In their petition they state:

\section{Referendum Petition.}

This is to refer to the people of the state for their approval or rejection House Bill No. 69, passed by the Twenty-seventh Legislative Assembly of the State of Oregon, providing for sterilization of criminals, etc.

\section{Objections to the Act.}

1. The act is loosely drawn.

2. The operation is not specified, but may be whatever the State Board of Health decides upon. Cutting off an arm or leg, or trepanning the skull, would satisfy the requirements of the law.

3. Sterilization is not specified, but if intended, there are several operations possible. Some of these would not in least alter the criminal tendencies of rapists. This is the case with the operation now employed in Indiana, and might be here under this law.

4. The sterilizing operation applied to women may be a serious one endangering life.

5. Cutting of the generative organs directly affects the brain and lessens the probability of the cure of the insane. It also reduces the mental power of the feebleminded, whom the state is now seeking to raise in power by training and education.

6. The claim that such a law is necessary to protect the future of the race is unfounded and wholly disproved by the history of penal colonies. Virginia and Australia are examples. Both these communities today rank high in morals and vitality, though many of their early settlers were deported criminals. Australia had 100,000 of these as the foundation of this great commonwealth.

\section{ANTI-STERILIZATION LEAGUE,} Room 705 Swetland Building, Portland.

Phone Main 4095.

\section{A MEASURE}

To protect the public peace, health and safety from habitual criminals, moral degenerates and sexual perverts; to require the superintendents of the Oregon State Insane Asylum, the Eastern Oregon State Hospital, the State Institution for FeebleMinded, and the Oregon State Penitentiary to report quarterly the names, records, condition and character of all inmates of their respective institutions who are habitual criminals, moral degenerates or sexual perverts; to authorize the State Board of Health to investigate, or cause to be investigated, all such cases so reported to it; to authorize the State Board of Health, in its discretion, to direct the superintendents of the said institutions to perform or cause to be performed, such surgical operations as may be for the best interests of the public peace, health and safety, filed in the office of the Secretary of State February 18, 1913, to be submitted to the legal electors of the State of Oregon for their approval or rejection at the SPECIAL ELECTION to be held NOVEMBER 4, 1913, upon petition for referendum filed in the office of the Secretary of State May 31, 1913, in accordance with the provisions of Section 1 of Article IV of the Constitution of the State of Oregon.

The following is the form and number in which the measure will be printed on the official ballot:

REFERENDUM ORDERED BY PETITION OF THE PEOPLE.

STERILIZATION ACT-Referred by authority of Mrs. Lora C. Little, as VicePresident, Anti-Sterilization League, No. 7110 43d Avenue, Portland, Oregon. Its purpose is to authorize the State Board of Health to order such surgical operations as the Board shall adjudge, to be performed upon habitual criminals, moral degenerates and sexual perverts, both male and female, and defining who shall be considered as such, the same being persons confined in some State institution.

$$
\text { Vote YES or NO. }
$$

304. Yes.

305. No.

\section{VERMONT.}

Senate Bill 79.

Passed the House January 24, 1913-96 yeas, 82 nays; absent or non-voting, none. 
Passed the Senate, December 30, 1912. No roll call.

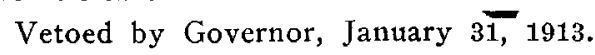

\section{a. TEXT OF BILL.}

AN ACT to authorize and provide for the sterilization of imbeciles, feeble-minded and insane persons, rapists, confirmed criminals and other defectives.

It is hereby enacted by the General sembly of the State of Vermont:

Section 1. A board of examiners of feeble-minded, criminals and other defectives is hereby created; and forthwith after the passage of this act, and biennially thereafter, the governor shall appoint one neurologist, one surgeon and one practitioner of medicine, each with at least six years' experience in the actual practice of his profession, for the term of two years from and including the first day of December of the year of appointment, as members of said board, who shall be sworn to a faithful discharge of their duties. The members of such board shall be paid ten dollars for each day actually spent in the performance of their duties, and their actual and necessary traveling expenses. A vacancy occurring in said board shall be filled by the governor for the unexpired term.

Section 2. Said board shall examine into the mental and physical condition and the record and family history of the insane, feeble-minded, epileptic, criminal and other defective inmates confined in the hospitals for the insane, state prison, reformatories, and charitable and penal institutions in the state; and if it appears to said board that procreation by any such person would produce children with an inherited tendency to crime, insanity, feeble-mindedness, epilepsy, idiocy, or imbecility, said board shall appoint a time and place for hearing thereon within the town where such person is confined, and shall deliver to such person a notice in writing of such hearing, which shall plainly state the time, place and purpose thereof, and shall be delivered to him by some member of said board not less than six nor more than thirty days before the day of said hearing. Said board shall be present at the time and place appointed for such hearing, and shall make such further examination and investigation with respect to such person as shall seem to said board necessary, and shall hear such person in his defense if he appears and requests a hearing.

Section 3. If, in the judgment of all members of said board, after said examination and hearing, procreation by such person would produce children with an inherited tendency to crime, insanity, feeble-mindedness, epilepsy, idiocy or imbecility, and if there is no probability that the condition of such person will improve to such an extent as to render procreation by such person advisable, or if, in the judgment of said board, the physical or mental condition of such person will be substantially improved thereby, and said board shall unanimously so find, said board shall order such an operation to be performed on such person for the prevention of procreation as shall be decided by said board to be safe and most effective, and shall appoint some member of said board to perform such operation, who shall perform it.

Section 4. Such order shall be in writing, signed by all members of said board, and shall bear the date of its issue, and shall contain the name of the person upon whom the operation is to be performed, the character of the operation and the name of the member of the board who is designated to perform it, and shall be filed by said board in the office of the county clerk of the county where such person resides.

Section 5. Before thus filing said order, said board shall make a copy thereof and deliver the same to the member of said board designated to perform such operation; and said order shall be his full warrant and authority for performing such operation, and no person performing an operation under the provisions of this act, in a proper and skillful manner, shall be held to account therefor in any court. But no operation so ordered shall be performed until fifteen days after the filing of said order in the office of the county clerk.

Section 6. Persons who shall come within the provisions of this law as criminals, and not otherwise, shall be those who have been convicted of the crime of rape, or of such succession of offenses against the criminal law as, in the opinion of said board, shall be deemed to be sufficient evidence of confirmed tendency.

Section 7. Said board shall keep a record of its examinations, hearings and orders, and in each case where an operation is performed under its order said board shall file with the superintendent or other administrative officer of the institution where such person is confined a copy of the record of the examination made by said board in such 
case; and one year after the performance of such operation said superintendent or other administrative officer shall report to said board the condition of such inmate and the effect of such operation upon such inmate.

Section 8. This act shall not apply to children under the age of puberty, nor to women forty-five years of age and over.

Section 9. Except as authorized by this act, a person who shall perform or assist in performing an operation for the purpose of destroying the power to procreate the human species, or a person who shall knowingly permit such operation to be performed upon him, unless the same shall be a medical necessity, shall be fined not more than one thousand dollars or be imprisoned not more than five years, or both.

Section 10. Whenever a person shall be adjudged guilty of rape, or shall be a third time convicted of felony, the court may, in addition to such other sentence as may be imposed, direct an operation to be performed upon such person for the purpose of preventing procreation, by a member of. the board of examiners of feeble-minded, criminals and other defectives to be designated by said court, and such member of said board shall perform an operation for such purpose, and the sentence and order of the court shall be his full warrant and authority therefor.

Section 11. The sum of one thousand dollars is hereby annually appropriated to carry out the provisions of this act.

Section 12. This act shall take effect from its passage.

\section{b. VETO.}

The Vermont veto was based upon an opinion rendered by the Attorney-General, Hon. R. E. Brown. The opinion follows:

Referring to Section 2 of this act, you will notice that the act applies only to those of the unfortunate classes named who are unfortunate to be actually confined "in the hospitals for the insane, state prison, reformatories and charitable and penal institutions in the state." Those equally unfortunate, except in the matter of actual confinement, including the criminals whose sentences have been completed, and all having greater opportunity to perpetuate the evil which this bill seeks to guard against, are immune from the operation of this act.

In my judgment, this is an unfair, unjust, unwarranted, and inexcusablé discrimination which ought not to be, and cannot be toler- ated under the supreme law, the Constitution of this state.

If there be anything of merit in the claims made by the advocates of this measure, and I do not attempt to say there is not, just why the feeble-minded or imbecile wife of a kind-hearted and tolerant husband should be permitted to give birth to offspring is quite beyond my comprehension, and yet instances of this kind are within the knowledge of almost every person of mature years. Instances of this kind are not confined to cases of the imbecile wife, but the suggestion applies equally to cases of the degenerate and imbecile husband of the kindhearted and tolerant wife who has sufficient means and sufficient pride to, in a measure, conceal the actual condition of her husband.

In short, the idea meant to be conveyed is, that this section contains such an unreasonable discrimination and classification as renders the act void under the Constitution of this state.

Again referring to Section 9 of this act, it is here provided that the act shall not apply to women over forty-five years of age. While it may be true that women "forty-five years of age or over," as a general rule, do not conceive and give birth to children, it is an undisputed fact, well known not only to the medical profession but in common experience, that women of that age do conceive and give birth to children. Here, again, is an unwarranted and inexcusable discrimination and classification which renders the act, in my judgment, void under our Constitution.

In this connection permit me to say that this discrimination would seem most un necessary and unwarranted because if it be true, as the act assumes, that conception in women of forty-five years or over is impossible, the execution of this law would not deprive the individual of a God-given power or function.

Again calling your attention to the provisions in Section 2, which perhaps I may be permitted to call the "machinery" for carrying the provisions of this act into effect, it seems apparent to me that these provisions are wholly inadequate, unjust, and insufficient. In this connection it ought to be sufficient to call attention to the fact that this act applies to the insane and feebleminded confined in hospitals for insane and charitable institutions of this state and that the provisions for final hearing provide only for notice in writing delivered to such insane 
or feeble-minded persons, "which shall plainly state time, place and purpose thereof," and in case the person is a minor or under guardianship, a copy of such notice shall be mailed to such parent or guardian, as the case may be, addressed to his last known residence at least six days before said hearing. There is also the further provision that the board provided for "shall hear such person in his defense, if he appears and requests such hearing. And at such hearing such person shall have a right to introduce witnesses and proofs and to be represented by counsel. Said board shall give such person a fair and impartial trial." Absolutely no provision is made to enable such insane person or persons confined in a charitable institution to appear before said board and secure such impartial trial, and the fact that such person is absolutely incapable of making a request or of performing any legal act, is utterly ignored. It is also provided that upon such proof as may be adduced said board may decide the question involved. From their decision no appeal of any kind is provided for. There is absolutely no provision regarding the quality of the evidence which said board may receive. In other words, under the provisions of this act, the decision of the board is absolute and final. In this respect an act of this kind is unheard of and unwarranted. Under such a provision, land could not be taken for a public highway, as has been repeatedly held by the Supreme Court of this state, it is not due process of law. Much less ought it to be enacted that individuals may be deprived of God-given powers, functions and rights in such manner.

Perhaps I ought also to call your attention to Section 6 of this act. It is in this section provided that "persons who shall come within the provisions of this law as criminals, and not otherwise, shall be those who have been convicted of the crime of rape or of such succession of offenses against the criminal law as in the opinion of said board shall be deemed to be sufficient evidence of confirmed criminal tendency." Under this section and the other provisions of this act, it is in effect provided that this board may inflict an additional penalty for a crime long before committed and the legal penalty of which has been already paid, and perhaps upon a person who has been reformed by the payment of such penalty, as the law presumes until further offense is committed. It seems hardly necessary to suggest that such a provision contravenes the Constitution.

But the climax of absurdity and inconsistency seems to have been reached in Section 7 of this measure. Under the provision of this section both lunatic and imbecile are permitted to do that which has never been permitted in any court of justice in this land, viz., by agreement imposed upon themselves such penalty as under this act may be imposed upon criminals after full hearing and the introduction of evidence. To say that such a provision is unwarranted and absurd is putting it mildly.

Note: An unsuccessful attempt was made to pass this bill over the Governor's veto.

\section{NEBRASKA.}

Senate Bill No. 132-33d Session.

Passed the House April 8, 1913-52 ayes, 33 noes; absent or non-voting, 15.

Passed the Senate-28 yeas, 2 nays; absent or non-voting, 3 .

Vetoed by the Governor April 14, 1913.

\section{a. TEXT OF BILL.}

\section{A BILI}

For an act to prevent the procreation of certain classes of criminals and feebleminded and other defectives; to provide for the appointment of a board of examiners by the board of commissioners of public institutions, said board of examiners to consist of two physicians and to fix their compensation, powers and duties; to provide for the appointment of counsel for the person or persons to be operated upon; to provide for the keeping of a record of the proceedings for such board of examiners and for an appeal from the order of such board; and to declare illegal all operations to prevent procreation of the human species except as authorized by this act, unless the same shall be a medical necessity, and declaring such illegal operations a felony and fixing a penalty therefor.

$\mathrm{Be}$ it enacted by the people of the State of Nebraska:

Section 1. Immediately after this act has gone into effect the board of commissioners of state institutions shall appoint two physicians, each with at least ten years' experience in the actual practice of his profession; one for a term of two years and one for a term of four years, to be known as the board of examiners of criminals, feebleminded and other defectives, which board is hereby created. The compensation of the 
members of such board shall be ten dollars per diem for each day actually engaged in the performance of the duties of the board, and the actual and necessary traveling expenses. Whenever the term of a member of the board is about to expire said board of commissioners shall appoint a physician for the ensuing term. Any vacancies occurring in said board shall be filled by appointment by said board of commissioners for the unexpired term. All appointments so made shall be of physicians with at least ten years' experience, as hereinbefore provided.

Section 2. It shall be the duty of the board to examine in to the mental and physical condition and record and family history of the feeble-minded, epileptic, criminal, and other defective inmates confined in the several state hospitals for the insane, state prisons, reformatories and charitable and penal institutions, and those for the care of defectives in the state, and if, in the judgment of said board, procreation by any such person would produce children with an inherited tendency to crime, insanity, feeblemindedness, idiocy, or imbecility, and there is no probability that the condition of any such person so examined will improve to such an extent as to render procreation by any such person advisable, or if the physical or mental condition of any such person will be substantially improved thereby, then said board shall appoint one of its members to perform such operation for the prevention of procreation as shall be decided by said board to be most effective.

The criminals who shall come within the operation of this law shall be those who have been convicted of the crime of rape or of such succession of offenses against the criminal law as in the opinion of the board shall be deemed to be sufficient evidence of confirmed criminal tendencies.

Section 3. The board of examiners shall apply to the District Court or any judge thereof at chambers in the county in which said person or persons to be examined is confined, for the appointment of counsel to represent such person or persons. Said counsel shall act at the hearing before the board of examiners and at any subsequent proceeding therein, and no order made by said board shall become effective until five days after it shall have been filed with the clerk of the District Court of said county, and a copy shall have been served upon the counsel appointed to represent the person examined and proof of service of said copy shall have been filed with the clerk of said court. All orders made under the provisions of this act shall be subject to review by the District Court or any judge thereof at chambers of the county in which the original examination took place, and said court or judge may upon the filing of such appeal grant a stay which shall be effective until such appeal shall have been decided. The judge of the court appointing any counsel under this act may fix the compensation to be paid him. No physician performing an operation under the provisions of this act shall be held to account therefor. The record taken upon the examination of every such inmate signed by the said board of examiners shall be preserved by the institution where said inmate is confined and one year after the performance of the operation the superintendent or other administrative officer of the institution wherein such inmate is confined shall report to the board of examiners the condition of the inmate and the effect of such operation upon such inmate, and a copy of the report shall be filed with the record of the examination.

Section 4. Except as authorized by this act, every person who shall perform, encourage, assist in, or otherwise permit the performance of the operation for the purpose of destroying the power to procreate the human species or any person who shall knowingly permit such operation to be performed upon such person unless the same shall be a medical necessity, shall be guilty of a felony.

Section 5. Any person found guilty under the terms of this act shall be confined in the penitentiary not less than one year nor more than five years, and shall, moreover, be liable to the suit of the party injured.

\section{b. VETO MESSAGE.}

To Honorable S. R. McKelvie, Lieutenant Governor and President of the Senate:

I herewith return, without my approval, Senate File No. 132, an act entitled:

An act to prevent the procreation of certain classes of criminals and feeble-minded and other defectives; to provide for the appointment of a board of examiners by the board of commissioners of public institutions, said board of examiners to consist of two physicians, and to fix their compensation, powers and duties; to provide for the appointment of counsel for the person or persons to be operated upon; to provide for the keeping of a record of the proceedings 
of such board of examiners and for an appeal from the order of such board; and to declare illegal all operations to prevent procreation of the human species except as authorized by this act unless the same shall be a medical necessity, and declaring such illegal operations, a felony, and fixing a penalty therefor.

This act is so far reaching in its consequences and so intimately related to the social life of mankind, that legislative action should not be taken thoughtlessly or hurriedly. This proposed legislation is new and practically untried; at best it is only an experiment and it seems more in keeping with the pagan age than with the teachings of Christianity. Man is more than an animal.

There is no urgent demand for the passage of this kind of legislation. Mutilating the human body, either as a punishment for crime or as a preventive thereof, is drastic in the extreme and there is grave doubt in my mind if it does not violate Section 9, Article I, of the Bill of Rights, which prohibits cruel and unusual punishment. I believe serious objections may be made to it because of its violation of other provisions of the Bill of Rights, and the act itself appears out of harmony with Section 11, Article III, of the Constitution, in that it contains more than one subject.

There is no valid reason why this should be made to apply to wards of the state. These wards are under the care and control of superintendents appointed by the state, the different sexes are segregated and the danger sought to be obviated by this act, is already well guarded against.

While I am heartily in favor of the provisions of Section 4 of this act and would be pleased to sign a law making it a felony for any person to perform any operation for the purpose of destroying the power to procreate the human species and making it a felony for any person to permit such an operation to be performed, still the other provisions referred to above are such that I must in conscience withhold my approval.

Respectfully submitted,

\section{JOHN H. MOREHEAD,}

Governor.

Executive Office, Lincoln, Nebraska, April 14, 1913.

Note: An attempt was made to pass this bill over the Governor's veto.
Vote in House, 35 yeas, 55 nays; absent or non-voting, 10.

Vote in Senate, 24 yeas, 7 nays; absent or non-voting, 2.

\section{IDAHO.}

Fifteenth Session Idaho Legislature.

Senate Bill No. 150.

Introduced by $T$. R. Mason from Shoshone County.

Passed the Senate March 1, 1919-31 ayes, 1 nay; absent or non-voting, 9.

Passed the House of Representatives March 6, 1919-56 ayes, 1 nay; absent or non-voting 7; excused, none.

Vetoed by Governor D. R. Davis March $18,1919$.

\section{a. TEXT OF BILL.}

AN ACT to prevent the procreation of feeble-minded, insane, epileptic, moral degenerates and sexual perverts, who may be inmates of institutions maintained by public expense, by authorizing and providing for the sterilization of persons with inferior hereditary potentialities.

$\mathrm{Be}$ It Enacted by the Legislature of the State of Idaho:

Section 1. It shall be, and it is hereby declared, the duty of the medical superintendents of the Idaho Insane Asylum, Idaho State Sanitarium and Northern Idaho State Sanitarium, to report quarterly to the Department of Public Welfare, all feebleminded, insane, epileptic, moral degenerates and sexual perverts, who are persons potential to producing offspring who, because of inheritance of inferior or antisocial traits, would probably become a social menace, or a ward of the state.

Section 2. It shall be the duty of the Department of Public Welfare to examine into the innate traits, the mental and physical conditions, the personal records, and the family traits and histories of all persons so reported so far as the same can be ascertained, and for this purpose said department shall have the power to summon witnesses, and the commissioner of public welfare shall have power to administer oaths to witnesses whom it is desired to examine; and if in the judgment of the commissioner procreation by any such person would produce children with an inherited tendency to feeble-mindedness, insanity, epilepsy or degeneracy, and there is no probability that the condition of such person so examined will improve to such an extent as to render procreation by 
any such person advisable, or if the physical or mental condition of any such person will be substantially improved thereby, then it shall be the duty of the department to make an order directing the medical superintendent of the institution in which the inmate is confined to perform or cause to be performed upon such inmate such a type of sterilization as may be deemed best by the commissioner.

Section 3. The purpose of said investigation, findings and orders of the department shall be for the betterment of the physical, mental, neural, or psychic condition of the inmate, or to protect society from the menace of procreation by said inmate, and not in any manner as a punitive measure; and no person shall be emasculated under the authority of this act except that such operation shall be found to be necessary to improve the physical, mental, neural or psychic condition of the inmate.

Section 4. After fully inquiring into the condition of each of such inmates the department shall make separate written findings for each of the inmates whose condition has been examined into, and the same shall be preserved in the records of the department, and a copy thereof shall be furnished to the medical superintendent of the institution in which the inmate is confined, and if an operation is deemed necessary by the department, then a copy of the order of the department shall forthwith be served on said inmate, or in case of an insane person upon his legal guardian, and if such insane person have no legal guardian, then upon his nearest known kin within the state of Idaho, and if such insane person have no known kin within the state of Idaho, then upon the custodian or guardian of such insane person.

Section 5. Any such inmate desiring to appeal from the decision of the said department, or in case the person is under guardianship or disability, then the guardian of said inmate may take an appeal to the District Court of the county in which the institution in which the inmate is confined is located.

An informal notice of appeal filed with the commissioner of the Department of Public Welfare, either by the inmate or someone in his behalf, shall be all that is necessary to make the appeal; provided, that said notice shall be filed within 15 days of the date when notice of the department's decision is served on the inmate or his guardian, and said notice of appeal shall stay all proceedings of said department in said matter until the same is heard and determined on said appeal: Provided, further, that no operation shall be performed upon any inmate until the time for appeal from the decision of the department has expired.

Section 6. Upon an appeal being taken, the commissioner must within 15 days thereafter or such further time as the court or the judge thereof may allow, transmit a certified copy of the notice of appeal and transcript of the proceedings, findings and order of the department, to the clerk of the court appealed to.

The trial shall be a trial de novo at law as provided by the statutes of the state for the trial of actions at law. Upon such appeal, if the inmate be without sufficient financial means to employ an attorney, then the court shall appoint an attorney to represent the said inmate, and such attorney shall be compensated by the state upon order of the court; and it shall be the duty of the prosecuting attorney of the county wherein such trial is had to represent the said department.

Section 7* If the court or jury shall affirm the findings of said department, said court shall enter a judgment, adjudging that the order of the said department shall be carried out as herein provided; if the court fail to affirm the decision of said department appealed from, then said order shall be null and void and of no further effect.

Section 8. Upon the receipt of the order from the Department of Public Welfare provided for in Section 2, the medical superintendent of the institution to which it is directed shall, after the time for appeal has expired, or in case of appeal upon the entering of a judgment affirming the order of the department, and it is hereby made his lawful duty to perform, or cause to be performed, such surgical operation as may be specified in the order of the Department of Public Welfare. All such operations shall be performed with a due regard for the physical condition of the inmate and in a safe and humane manner.

Section 9. Moral degenerates and sexual perverts are those who are addicted to the practice of sodomy or the crime against nature, or to other gross, bestial and perverted sexual habits and practices prohibited by statute.

Section 10. The provisions of this act shall apply to both male and female inmates of any of the institutions designated herein. 
Section 11. The state shall be liable, under this act, only for the actual and necessary expense incident to the investigations of said Department of Public Welfare and an appeal therefrom.

$$
\text { b. VETO MESSAGE. }
$$

\section{Robert O. Jones,}

Secretary of State.

Sir:

I return herewith Senate Bill 150, passed by the Fifteenth Session of the Idaho Legislature. Meritorious as I believe the object of the bill to be, I have determined to veto it, because, after full investigation, I am convinced that the bill will not accomplish that object.

In terms, it seeks to prevent the procreation by sterilization of feeble-minded, insane, epileptic, moral degenerates and sexual perverts, who may be inmates of institutions maintained by public expense. It does not apply to all persons in such classes, but only to those confined in public institutions-the persons in fact who by reason of such confinement are the least menace to society. By reason of this discrimination, similar acts have been held unconstitutional in other states.

Laws providing for the sterilization of the criminal and insane have been adopted in some jurisdictions and while enforced in one or two states, in most of them the law is regarded as a dead letter. The scientific premises upon which these laws are based are still too much in the realm of controversy and the results of the legislation still too experimental to justify the proposed law as wise legislation for this state.

Respectfully,

$$
\text { D. W. DAVIS, }
$$

Governor.

Office of the Chief Executive,

Boise, Idaho.

March 18, 1919.

Note: No attempt was made to pass this bill over the Governor's veto. 


\section{CHAPTER IV.}

\section{STATISTICAL AND DESCRIPTIVE SUMMARY OF EUGENICAL STERILIZATION IN THE SEVERAL STATES}

I. Institutional Statistics and Official Reports and Opinions.
1. California 52

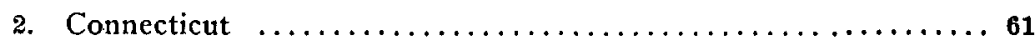

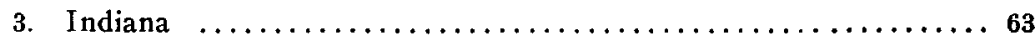

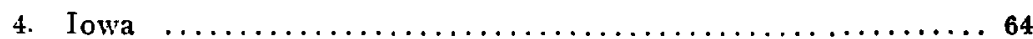

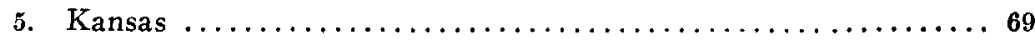

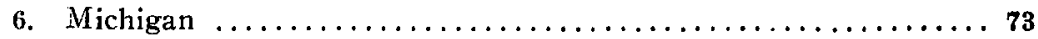

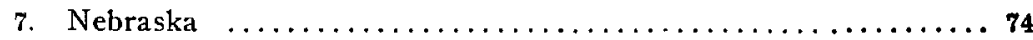
8. Nevada $\ldots \ldots \ldots \ldots \ldots \ldots \ldots \ldots \ldots \ldots \ldots \ldots \ldots \ldots \ldots \ldots$ 79
9. New Jersey $\ldots \ldots \ldots \ldots \ldots \ldots \ldots \ldots \ldots \ldots \ldots \ldots \ldots \ldots . \ldots . \ldots$

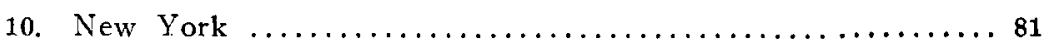
11. North Dakota ............................87
12. Oregon $\ldots \ldots \ldots \ldots \ldots \ldots \ldots \ldots \ldots \ldots \ldots \ldots \ldots \ldots \ldots$

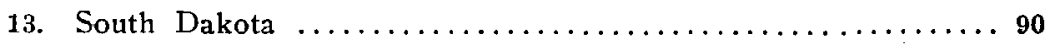
14. Washington $\ldots \ldots \ldots \ldots \ldots \ldots \ldots \ldots \ldots \ldots \ldots \ldots \ldots \ldots \ldots \ldots$

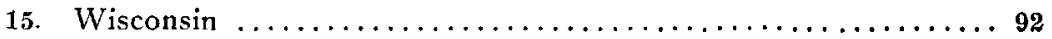

II. Summary.

A. Statistical Summary to January 1, 1921.

a. States and Institutions $\ldots \ldots \ldots \ldots \ldots \ldots \ldots \ldots \ldots \ldots \ldots$

b. Total Number of Eugenical Sterilization Operations in all fifteen

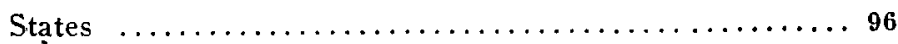

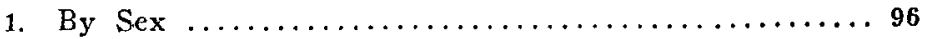

2. By Radicalness of Operation................. 96

3. By Classes ......................... 96

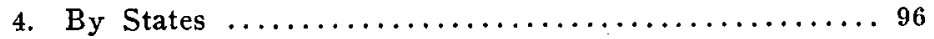

5. By Time $\ldots \ldots \ldots \ldots \ldots \ldots \ldots \ldots \ldots \ldots \ldots \ldots \ldots, 96$

B. Descriptive Summary $\ldots \ldots \ldots \ldots \ldots \ldots \ldots \ldots \ldots \ldots \ldots$ 


\section{STATISTICAL AND DESCRIPTIVE SUMMARY OF EUGENICAL STERILIZATION IN THE SEVERAL STATES.}

\section{INSTITUTIONAL STATISTICS AND OFFICIAL REPORTS AND OPINIONS.}

The existing eugenical sterilization laws are limited in their application to individuals who come into the custody of the state as social inadequates of one type or another. This chapter gives a complete statistical statement of the actual eugenical sterilization operations effected under the law from the beginning of the legal authority for such work, up to January 1, 1921.

Besides this purely statistical summary the responsible authority of every executive board or commission and of each subject institution was asked for a statement concerning:

(a) The extent of case history and pedigree records maintained by the particular institution in reference to persons sterilized, including notes on the physiological and mental effects, both immediate and remote, of the operation on the patient.

(b) The legal and administrative procedure followed in selecting cases for sterilization and in carrying out the actual operation.

(c) The changes, if any, in policy or practice in administering eugenical sterilization in the particular institution which have taken place in the course of administering the law.

(d) Suggestions concerning the improvement of the existing state statute in order to make it more effective eugenically and more practical in administration.

(e) The judgment of the executive authority in reference to the general policy of eugenical sterilization.

All of the replies to two such inquiries, one made in 1918 and one in 1921, which were received, are published in this chapter, regardless of the attitude of the particular writer toward the subject.

\section{CALIFORNIA.}

The statutes date from 1909 (second statute, 1913, third and fourth statutes, 1917). Present status (January 1, 1922): Active.
Eleven (11) state institutions are subject to the act; they have performed eugenical sterilizing operations as follows:

\footnotetext{
Vasectomy

1. State Hospital, Stockton..... 579

2. State Hospital, Napa........ 16

3. State Hospital, Agnews..... 7

4. Mendocino State Hospital, Talmage .............. 27

5. Southern California State Hospital, Patton ..........6.632

6. State Home, Sonoma........ 116

7. State Hospital, Norwalk...... 115

8. Pacific Colony, Spadra........

9. Preston School of Industry, Waterman ............ 0 10. State Prison, San Quentin.... 7 11. State Prison, Folsom....... 0 Total to January 1, 1921 . 1,492

* One hysterectomy.
}

Notes on the Enforcement of the Eugenical Sterilization Law in California.

To California must be given the credit for making the most use of her sterilization laws. The history of the application of these statutes shows an honest and competent effort to improve "the racial qualities of future generations." The work is well organized

\begin{tabular}{rcr}
\multicolumn{2}{c}{ FEMALES } & \\
Salpingectomy & Ovariotomy & Total \\
222 & 34 & 828 \\
159 & 0 & 175 \\
51 & 1 & 59 \\
& & \\
14 & 0 & 41 \\
& & \\
377 & 0 & 1,009 \\
183 & 3 & 302 \\
18 & $3^{*}$ & 137
\end{tabular}

To open March 1, 1921.

$\begin{array}{rrrr}0 & 0 & 0 & 0 \\ 0 & 0 & 0 & 7 \\ 0 & 0 & 0 & 0 \\ -1 & -1,024 & & 41\end{array}$

and is proceeding as a regular detail of institutional administration.

\section{California State Commission in Lunacy.}

Dr. F. W. Hatch, General Superintendent.

1. In the report for the two years ending June 30, 1914 (pp. 13-14). 


\section{ASEXUALIZATION.}

"Without going into definite details it may be stated that we have continued our work of sterilization and have done some 300 cases since our last biennial report. The longer we continue this work and the more study we give to it, the more convinced we become of its beneficial curative and preventive tendencies.

"Those who keep in touch with insane work must have become convinced of the increasing number of defectives and departures from normal among the fairly young people.

"The more acute maniacal forms seem to lessen, while those with disharmonies, with ill formed delusions, with the various alcoholic psychopathies, seem to increase.

"In our sterilization work we have followed the same plan of obtaining the consent of relatives, where they can be found, before operating. Especially in women we are very particular to obtain consent before undertaking the more serious operation.

"There is on the part of some writers a tendency to take it for granted that vasectomy is negligible in its effects. Such a conclusion is contrary to our experience, for we find that many of our cases show a marked clearing up a few weeks after operation. In several instances patients have applied for vasectomy after consulting with their fellows who have been operated upon and have found benefit from it. In women, who with every childbirth have a pronounced mental upset, there can be no valid objection to the work, or in those women who, while still single, continue to bring into the world children whose fathers are unknown, it would seem the part of wisdom when they become insane to cut off their reproductive ability.

"Sterilization may possibly prevent the development of a future genius once in a while, but so many who are defective or psychopathic come into the world for lack of sterilization that it is hardly profitable to discuss the question. The genius is a remote possibility, the defective is a distinct probability. Most of our cases have been between the ages of twenty and thirty years of age; quite a number are under twenty.

"Of the types of mental trouble manic depressive forms are in the majority with dementia praecox, epilepsy and alcoholic psychosis next in order.

"When you come to discuss the number of cures much latitude must be used. For instance, I have before me an unselected series of twenty-one cases, all women, in whom there was 50 per cent of restorations. In some of these cases the operation was done after decided improvement and preliminary to their discharge after consultation with their relatives as to the advisability of the operation.

"Study of the individual case and his or her potentiality for reproducing defectives is necessary and should be given."

2. In the report for the two years ending June 30, 1916 (pp. 15-16).

\section{STERILIZATION.}

"The sterilization law and the prevention of insanity work is proceeding at all of the state hospitals and at the Sonoma State Home. During the two years ending June 30th last 291 sterilizations were done-161 men and 130 women. Those operated upon were classified under the following forms of mental disease, viz:

Manic depressive......... 149

Dementia praecox......... 68

Epileptic .............. 27

Imbecility .............. 14

Drugs and alcohol........ 19

Other forms............ 14

291

The operation on women is almost uniformly a salpingectomy, except where there is organic trouble of the ovaries when one or both may be removed. Ovariotomy is occasionally done in hysteria or epilepsy with marked erotic tendencies. In the men vasectomy is the one operation, as the law does not permit us to castrate. We seldom operate upon a woman without getting the consent of her nearest relative, and that people are beginning to realize the advisability of cutting off the power of bringing children into the world by those who have become insane through inherited weaknesses is shown by the readiness with which they ordinarily give consent when the operation and its purposes are explained to them. It is not uncommon for the hospitals to have requests from patients or former patients to have sterilization done upon them. Many of our female patients who have been sterilized at the hospitals have expressed their appreciation of the work done upon them by reason of their knowledge of danger of bad inheritance in child-bearing. Among the men where there are relatives who can be found we try to obtain consent-if relatives can not be found we decide upon the work according to the history of the case, its class 
and the general character of the individual. While the results following vasectomy are by some considered negligible, it is beyond a question of doubt in many cases that there is a marked improvement both mentally and physically within thirty days after the operation, which persits until the patient is in condition to be discharged. No ill effects have followed either salpingectomy or vasectomy upon the physiological functions. That sterilization in appropriate cases should be done is undoubted. The influence of heredity, the engrafting of the weaknesses of parents upon children, perhaps in modified form, is so well established that there is no room for argument. An answer might be made that those where sterilization seemed urgent should never be discharged from the hospital but should be kept there through life; but it is easy to realize what the result would be. We would be overcrowded with the class of cases who are unfit to bring children into the world. A majority of the public would be maintaining a minority of the unfit by reason of their possession of procreative powers. Sterilization prevents the transmission of their weaknesses to children, the public is protected, and the sterilized individual can be a breadwinner but not a producer of his kind."

Miss Ethel H. Thayer, Eugenics Field Worker: "The work done in each state hospital depends upon the interest of the respective staffs. The largest number of operations has been performed at Patton and at Stockton, I believe. I know that the work is being carried on right along at Patton. The woman physician there told me that one of the most encouraging phases of the work is the ease with which they secured the consent of relatives and the coöperation of the priests to whom relatives go for advice in the matter. There seems to have been some misunderstanding about the application of the law to the feeble-minded, and operations at the Sonoma State Home have been held up for the time being. I will ask Dr. Hatch to explain this matter more fully.

"I spoke to Dr. Hafch about the investigation of the family histories of cases proposed for sterilization, and he intends to give me some such cases for study. A history that I am getting at present seems to be increasing the desire and efforts of Dr. Stocking and Judge Beasly of San Jose to secure the sterilization of two unfit individuals who are now at large and raising a family only to become county charges.
"If each hospital could have a permanent field worker, this would be an important phase of the work. Dr. Reily has this in mind, I believe, in wishing to establish the work at Patton." March 12, 1915.

Sample Letters used in Authorizing Eugenical Sterilization in California by the General Superintendent of State Hospitals and the Secretary of the State Board of Health:

\section{Stockton State Hospital.}

Stockton, California, April 26, 1921. In re MALE.

Dr. F. W. Hatch, Gen'l Supt. State Hospital,

Sacramento, California.

\section{Dear Doctor:}

MALE, admitted April 14, 1921; native Spain; age 26; white; male; from Kern County. Is afflicted with hallucinations that he is about to be submerged in water by friends-runs away with no particular aim in view; fights and threatens to fight; saw hell fire.

Diagnosis: ALCOHOLIC PSYCHOSIS: ACUTE HALLUCINOSIS.

We think this man should be operated on for sterilization as he would likely transmit to descendants.

\section{Yours truly, FRED P. CLARK,}

Medical Superintendent.

APPROVED, and authorization granted for sterilization on this 2d day of April, 1921.

$$
\text { F. W. HATCH, }
$$

General Supt., State Hospitals.

WM. DICKIE,

Secretary State Board of Hẹalth.

\section{Napa State Hospital.}

Napa, California, April 13, 1921.

Dr. F. W. Hatch,

Gen'l Supt. of State Hospitals,

Sacramento, California.

\section{RE: BERTIE S. PRUITTE.}

\section{Dear Doctor:}

We are writing to you for permission to discharge the above patient May 18, 1921, after a year's treatment in this Hospital. She was committed for two years under the Narcotic Act, but has coöperated so cheerfully in her treatment and has shown such satisfactory progress that we feel little more can be accomplished by detaining her longer.

Yours truly,

A. C. MATTHEWS, Medical Superintendent. 
Approved and authorization for discharge granted this 17th day of April, 1921.

F. W. HATCH,

General Supt., State Hospitals.

WM. DICKIE,

Secretary State Board of Health.

\section{Agnew State Hospital.}

Agnew, California, April 9, 1921.

Dr. F. W. Hatch,

Gen'l Supt., State Hospitals,

Sacramento, Calif.

\section{Dear Doctor:}

FEMALE; self-committed No. 442; from Alameda County, January 22, 1921; white; native of Kansas; female; age 32 when committed; married; housewife by occupation; diagnosis: manic-depressive.

One previous attack. Admitted June 8, 1918; discharged June 18, 1920. Present attack began two months ago; sudden in onset. Bodily condition fair. No injuries; no epilepsy; depressed. Suddenly became very much confused. No liquor, tobacco, drugs. Cause of insanity unknown.

After leaving the hospital the last time she became pregnant and had another child. Soon after this she had to be recommitted to the hospital, and I think further pregnancies would be a decided hindrance for her remaining stable when she again goes home.

Yours truly,

\section{LEONARD STOCKING,}

Medical Superintendent.

APPROVED and authority for operation of sterilization granted this 12th day of April, 1921.

\section{F. W. HATCH,}

General Supt., State Hospitals. WM. DICKIE,

Secretary State Board of Health.

\section{Mendocino State Hospital.}

Talmage, Calif., April 12, 1921.

Dr. F. W. Hatch,

Gen'l Supt. State Hospitals,

Sacramento, California.

\section{FEMALE.}

Dear Dr. Hatch:

Will you kindly grant us permission to sterilize this lady.

She has no relatives to whom we can apply. She is anxious to have this operation performed for the reason that she has had two attacks of mental trouble follow- ing pregnancies and wishes to prevent any future attacks.

Very truly yours,

ROBERT LEWIS RICHARDS,

Medical Superintendent.

APPROVED, and authorization for the operation of sterilization granted this 14th day of April, 1921.

$$
\text { F. W. HATCH, }
$$

General Supt., State Hospitals.

WM. DICKIE,

Secretary State Board of Health.

5. Southern California State Hospital.

Patton, San Bernardino County, Calif.,

April 6, 1921.

Dr. F. W. Hatch, Gen'l Supt.,

Sacramento, California.

Dear Doctor:

No. 13212; female; white; married; age 18 years; housewife by occupation. Committed November 27, 1920. Diagnosis: Manic Depressive (a.)

According to the commitment papers this patient was in the Psychopathic Ward, City Hospital, in St. Louis, Missouri, in 1916. Also that she threatened to do harm to herself and to her infant child; that her mental symptoms began at the time of the birth of her child. Patient had a maternal aunt who was insane.

As we believe this patient is afflicted with a mental disease which may have been inherited and is likely to become transmitted to descendants, we would like instructions to perform the operation of sterilization. Patient's husband asked that this operation be performed and we have his written consent.

\section{Yours very truly,}

JOHN A. REILY,

Medical Superintendent.

By order of the State Commission in Lunacy you are hereby instructed to proceed with the operation of sterilization upon the above named patient, this 8 th day of April, 1921.

$$
\text { F. W. HATCH, }
$$

General Supt., State Hospitals. WM. DICKIE,

Secretary State Board of Health.

\section{Sonoma State Home.}

Eldridge, California, April 19, 1921.

Dr. F. W. Hatch,

Gen'l Supt. State Hospitals,

Sacramento, California.

Dear Doctor: 
May we have your permission for the operation of sterilization on the following case?

REGISTER NO. 3531; FEMALE; admitted April 9, 1921. Age 24 years. Moron. This girl's parents are dead. She is paralyzed on right side. Gave birth to an illegitimate child just previous to her admission here. She gave written consent for the operation April 1, 1921, and we also have consent of her grandfather, dated April 20, 1921.

Very truly yours,

F. O. BUTLER,

Medical Superintendent.

APPROVED, and permission granted this 27th day of April, 1921, for the operation of sterilization.

\section{F. W. HATCH,}

General Supt., State Hospitals. WM. DICKIE,

Secretary State Board of Health.

\section{Norwalk State Hospital.}

Norwalk, California, April 26, 1921.

Dr. F. W. Hatch,

Gen'l Supt. State Hospitals,

Sacramento, California.

\section{Re: FEMALE STERILIZATION.}

Dear Doctor:

The above named patient was admitted to the Norwalk State Hospital from Los Angeles County, February 24, 1921.

Diagnosis: Dementia Praecox.

She was born in California twenty-eight years ago, and her mental derangement was first noticed in 1914, since that time she has been cared for at different sanitariums and at home.

From the fact that she may recover from this attack and be well enough to go home at some future date, we are asking permission to sterilize her. We have the signed permission of her mother for this operation.

Awaiting your reply in this matter, I am,

Yours very truly,

C. F. APPLEGATE,

Medical Superintendent.

APPROVED, and authorization granted to perform this operation this 29th day of April, 1921.

\section{F. W. HATCH,}

General Supt., State Hospitals. WM. DICKIE,

Secretary State Board of Health.

\section{Reports by Institution}

In response to inquiries, the following information and opinions were given:
1. Stockton State Hospital, Stockton. Dr.

Fred P. Clarke, Superintendent.

(a) From Report to State Commission in Lunacy, March, 1916 (pp. 52-53).

"Sterilizations. The results in our surgical and hydrotherapy departments have been very gratifying the past year. We have continued our work of sterilizing all patients under 45 or 50 years of age committed to the hospital. Among the women only those who have recovered, or improved to such an extent that they are able to leave the hospital, are sterilized. All the young and middle-aged men are sterilized, unless they are suffering from paresis, or some other form of dementia.

"The operations for both vasectomy and tubectomy are comparatively simple, requiring but a short time to perform. The vasectomies are done in four or five minutes under local anaesthesia; the tubectomies, when there are no complications, in less than fifteen minutes.

"Vasectomies are performed in the scrotum, the vas being picked up by the thumb and forefinger and rolled away from the tissues of the cord and fixed to the skin by tenaculum forceps. An incision is made $1 \mathrm{~cm}$ in length through the skin and sheath. The vas is drawn out and a section $1 \mathrm{~cm}$ in length is taken out. There is no bleeding and no sutures are needed except for the incision in the skin which is closed with one stitch. By this interruption in the continuity of the vas, the testicular secretion is absorbed. Since performing these operations we are led to believe, by the improvement in general and mental health, that there is a distinct beneficial result from the absorption of the testicular secretion.

"The first attempts to consciously utilize the internal secretion of the testicles were made, as is well known, by Brown-Séquard: who experimented with testicular extracts in 1889. He reported a remarkable result from the subcutaneous injection of testicular ex. tracts. They were said to increase bodily and mental vigor, etc. Many of the results claimed were evidently due to suggestion. However, since beginning these sterilization operations, we are led to believe that by the improvement in mental and general health that there is a definite beneficial effect from this operation and may lead to important findings as an organo therapeutic agent.

"The cases suffering from depression, inability to concentrate and extreme nervous- 
ness are those who are principally benefited. Men who responded to no other form of treatment, in from two to three weeks after the operation have shown marked improvement both mentally and physically and later have been discharged from the hospital in their normal mental condition and in excellent physical health. The women are benefited only by the fact that they are protected from the recurrence of their mental trouble through the nervous strain incidental to child-bearing and also the worry that they might again become pregnant, which would more than likely mean their return to the hospital, perhaps to make it their permanent home. The most important feature in these cases is that the state will not have their children, their grandchildren or their great-grandchildren to care for.

"For the tubectomy, an incision is made low down in the medium line of the abdomen so that the slight scar left is covered with pubic hair and is not noticed by the patient. The incision is made only large enough to insert the first and second fingers. The tube is then withdrawn by the fingers, a small incision is made in the isthmus (or restricted portion) of the tube, and 1 or 2 $\mathrm{cm}$ of the tube is resected. The serous covering is then sutured over with fine catgut, the tube dropped back in the abdominal cavity and the external incision closed. Patients are able to be up within three or four days after the operation. Should any pelvic disease be found present, the incision is lengthened and the condition remedied at the time of the operation.

"To my mind California-through the enactment of this law, and seeing that its provisions are carried out-is leading the world in providing that the patients committed to her various state institutions are receiving the benefits of sterilization-not alone for its curative effects-but to prevent the filling of her institutions in the future, from the offsprings of the insane who recover or partially recover and are permitted to again go out in to the world and reproduce their like-a large percentage of whom through inheritance and under unfavorable environments or dissipation, at length take the places of their ancestors in the institutions for the insane throughout the state.

"If the insane who are capable of reproducing are not sterilized before leaving the hospital, it naturally follows that we will have an ever-increasing, endless chain of insane and defective wards to care for.

"I made the rather broad statement that California was leading the world in this very important procedure. In doing so I am well aware there are several other states in which this operation is authorized, but from statistics which I have been able to gather, I feel that we, in this state, are doing more of this work than is being done elsewhere.

"I would like to see the law made broader whereby those addicted to the use of alcohol or drugs could be sterilized upon their second commitment to an insane hospital."

(b) (Quoted from letter.) "In most cases $I$ have had the consent of the relatives before operating, but this is not necessary. We have had decided beneficial results from the operation on our men patients, and many of them recover after the operation, who had shown no previous improvement under other forms of treatment. This is especially true in nervous cases, and the depressed type of manic depressive insanity. I consider the sterilization act the most important law which has been placed on the statute books as a eugenical measure. I think this law should be broadened so that alcoholics and drug habitues could be sterilized upon the second admission to a state hospital." January, 1918.

(c) Report to State Commission in Lunacy, June, 1918 (p. 41).

\section{Sterilization and Other Surgery.}

"During the past year, as in former years, we have continued to sterilize our men and women patients-under 50 years of agewho have prospects of leaving the hospital, and as stated in my former report, we have found this operation very beneficial in a great number of our men patients who have responded to no other forms of treatment."

(d) (Quoted from letter.) "I think the policy of eugenical sterilization is a very praiseworthy one, and feel that it should be more strictly enforced, not only for the prevention of the production of undesirables but for the benefit of the patients themselves.

"I would suggest that drug and inebriety cases be sterilized on their second admission to the hospital.

"Our policy is to select certain men under forty-five and women of child-bearing age for sterilization. After obtaining the permission of the General Superintendent of 
State Hospitals and of the Secretary of State Board of Health in reference to these selected cases, we perform the operation.

"We note the mental condition of patients sterilized as long as they remain in the hospital and receive reports from relatives and friends monthly from those who leave the hospital on parole. We have, however, practically no reports from those who are discharged." April 4, 1921.

\section{: Napa State Hospital, Napa.}

A. C. Matthews, Medical Superintendent. "There are no special physiological or mental effects, either immediate or remote, following sterilizations. We do not perform castration or ovariotomy for sterilization as we do not believe in the principle.

"We do not operate without obtaining first, the consent of the relatives. The cases for sterilization are carefully selected, picking out those from which there is danger of transmitting the nervous instability to offspring.

"Inasmuch as the State Sterilization Law has been declared unconstitutional in the States of New Jersey and New York, and I believe, also in Michigan, we do not care to have a test case brought into the Supreme Court of this State, fearing that a like action would be taken. This accounts for the reason that we do not sterilize any cases without first receiving the consent of the relatives.

"In the Eastern States, the law was declared unconstitutional as it was declared 'class legislation,' inasmuch as it applied only to that particular class of mental cases that were confined in the State Institutions and did not include the same class of cases outside of institutions. If a law could be so framed, and the work of such a law satisfactorily carried out as applying to mental cases, both in and out of an institution, I do not think that it would be declared unconstitutional.

"I certainly approve of the sterilization law. I feel that the movement in this direction has received a serious setback in declaring the law unconstitutionai in some of our Easterit States." Januery, 1921.

3. Agnew State Hospital, Agnew. Dr. Leonard Stocking, Medical Superintendent. (Quoted from letter.) "The sterilization law is working very satisfactorily, and without friction or objection. We almost invariably obtain the consent of the most interested relatives, or the patient, or of both. The operation is performed whenever in our judgment it is advisable. In my opinion it is of very little medical value. However, in a number of cases in performing the operation for sterilization we have found conditions necessitating more extensive operation for the good of the patient, such as removing appendix, ovary, etc. Unquestionably the statute is of great eugenical value." January, 1918.

\section{Mendocino State Hospital, Talmage.}

John Lewis Richard, Medical Superintendent. "This hospital has accurate records of the mental condition of patients sterilized since 1910. Cases which have pronounced history of hereditary feeble-mindedness or hypersexuality are selected for sterilization. Under the present law they are recommended by the Medical Superintendent for operation and permission of the State Commission in Lunacy must be secured.

"Some measure should be taken for legal protection of those authorized to perform this operation. We believe that eugenical sterilization is a desirable measure." January, 1921.

5. Southern California State Hospital, Patton. Dr. John A. Reily, Medical Superintendent.

(a) (Quoted from letter.) "Except in case of moral delinquency, we have secured the consent of the nearest relative. We have reason to believe that some physical and mental benefit is derived from the operation, and, as a means of improving the human. stock, sterilization of the defective and delinquent must, of necessity, be of great value.

"Just now we are extremely busy in applying the principles of eugenics, having sterilized in this institution alone during the month of March approximately 43 cases. Other institutions of California are doing similar work. As a matter of fact, this state is accomplishing more at this time than all of the rest of the United States combined.

"I regretted to learn recently that the Wisconsin law was declared unconstitutional. Sooner or later we will have to come to a uniform law which will stand the test of the courts and oblige all cases leaving institutions of this kind to be sterilized. Certainly, when we stop to consider the great sacrifices now being made in Europe-the sacrifice of stalwart manhood in the various nations at war-the sacrifice of the privilege of parenthood in those mentally defective dwindles into insignificance. 
"Let us hope that the proper application of sterilization, together with other principles of eugenics, will so improve the human stock that wars will be less likely in the future." April, 1918.

(b) (Quoted from letter.) "We obtain as far as possible the complete personal and family history from the patient and relatives and there is also a careful record kept of the patient's mental and physical condition before and after the operation. In most cases the consent of the relative is obtained, then a summary of the case is forwarded to the General Superintendent and his consent and the consent of the Secretary of the State Board of Health is obtained. After receiving this consent we proceed with the operation. The cases selected are those who are likely to leave the institution, and cases of women where there is a possibility of their becoming pregnant.

"During the past few months we have done very little sterilization in this institution and throughout the hospitals of California much less of this work has been done. The reason for this is that wherever a sterilization law has come before the courts in other states it has regularly been declared unconstitutional, and while our law seems to be a good one, it would possibly meet the same fate should it come before the courts.

"If our law should be declared unconstitutional it would leave us subject to the whims of those who have been sterilized and probably result in court action for damages in a number of instances. I feel, therefore, that any law should be thoroughly tested by the courts before the Superintendents of State Hospitals should be required or expected to operate under a sterilization law and that such protection should be given to the heads of hospitals that there would be no chance of their families becoming pauperized through damage suits resulting from this work.

"Undoubtedly California has accomplished more along this line than any other State and perhaps more than all other States; however, it seems quite unjust that she should stand very largely alone in this progressive effort. Certainly a court proof law should be devised, passed and put into operation in every State because, in my judgment, this is our only avenue of escape from the dreadful avalanche of defectives, delinquents and criminals which threatens our social foundations. If you can devise a method of procedure in the matter of sterilizations which would result in a universal application of this practice you would have accomplished more toward sustaining the mental stability of the human race than may be accomplished by any other means."

January, 1921.

6. The Sonoma State Home, Sonoma. Dr. Wm. J. G. Dawson, Superintendent.

(a) In answer to the inquiry: What, in your opinion, is the medical value of the statute? Dr. Dawson stated, "Some cases have shown physical improvement and are not so restless." $\mathrm{He}$ also expresses the opinion that "sex sterility would be liable to produce increased prostitution."

March, 1918.

(b) Dr. F. O. Butler, Medical Superintendent, July, 1918. Report to State Commission in Lunacy, July, 1918 (p. 77).

"Surgical work has been carried on in good order. During the last few months of the biennial period sterilization of chosen cases (particularly the moral delinquent feeble-minded type) has been started and we expect to continue this work. We find sterilization makes the patient more amenable to discipline and less restless."

In the list of operations performed, nine sterilization operations were reported.

(c) In the Twelfth Biennial Report of the State Commission in Lunacy, June 30, 1920, F. O. Butler, Medical Superintendent, reports having performed two hundred and twenty eugenical sterilizations during the biennium, of which he says: "Sterilization has been continued, but only in cases where there are no relatives or we have absolute consent and approval of responsible relatives. I am delighted to say that we are having very little difficulty in obtaining this consent. I think sterilization of a certain class of our inmates is most important; aside from the training and discipline obtained while here, the operation for sterilization renders them unable to propagate their kind; therefore, many of them are able to go on parole or be discharged and make their way in the world. This relieves the state and counties of the expense for their support as well as making them happy in the thought of being self-supporting. This procedure naturally makes more room in the institution for that class not able to cope with outside conditions, and relieves the relatives and various organizations of this burden." 
(d) (Quoted from letter from Dr. F. O. Butler, Superintendent.) "In our sterilization cases psychological examinations are made before and after the operation. Physiological tabulations are made about every six months.

"We select for sterilization (a) all cases in definitely feeble-minded class of childbearing age who may leave the institution, especially of higher mentality and immorality history, (b) border-line defectives or subnormals with a bad immoral or hereditary history who were committed here as feeble-minded. We then obtain the consent of a responsible relative and legal authority from the State Commission in Lunacy. It is our policy not to perform the operation until the inmate has been in the institution for at least one month.

"I have no further suggestion in the matter of practical administration but would think it possible to have the law so changed that it could not be declared unconstitutional as has been done in other states.

"Eugenical sterilization should be carried on in this and other states in the Union to the very fullest extent. I think it one of the greatest steps that have been taken along the eugenical line and I sincerely trust that the law will always allow us to perform such operations." January, 1921.

7. Norwalk State Hospital, Norwalk. Dr.

W. B. Kern, Medical Superintendent.

(a) (Quoted from letter.) "The rule is to acquire the written consent or approval of parent or guardian, following which the approval of the State Board of Health is obtained. The statute is of great value in helping to lessen bad heredity." February, 1918.

(b) C. F. Applegate, Medical Superintendent, 1921. (Quoted from letter.) "A report is kept of the improvement of the mental and physical condition of all cases of sterilization. Most of our cases are in young people who are about to leave the institution.

"Our procedure is as follows: First, we secure the consent of the relatives, and second, the consent of the State Lunacy Commission.

"We are firm believers in sterilization in this institution and since the question sometimes arises as to whether the matter of sterilization is legal we would suggest that proper means be taken to secure its legality." January, 1921.
8. Pacific Colony, Spadra. Dr. Fred C. Nelles, Superintendent of the Whittier State School at Whittier, reports:

"Our institution is not one of those which will come under the sterilization law. We were in a position, however, to assist in securing the passage of an act at the last session of the Legislature, creating the $\mathrm{Pa}$ cific Colony. A provision in this act makes sterilization possible. (See p. 19.)

"So far as we know, the sterilization section of the Pacific Colony law is the first to recognize the importance of the clinical psychologist in this matter. This provision is eugenic and preventive, rather than aiming at the benefit to the individual, thus differing from some state laws.

"The importance of scientific research is recognized in the establishing act of the Pacific Colony.

"Possibly segregation in the long run would work to better practical advantage than wholesale sterilization.

"* * * In the law as it applies to Sonoma, the action is taken by the State Commission in Lunacy, while with the $\mathrm{Pa}$ cific Colony it is taken on recommendation to the Trustees by the Superintendent, approved by a clinical psychologist and an M. D. qualified to serve under Section 19 of the Pacific Colony Act." February, 1918.

9. Preston School of Industry, Waterman.

Dr. C. A. Robinson, Attending Physician.

(Quoted from letter.) "We have had but one operation in three and a half years, but this one case was very satisfactory in preventing masturbation."

Dr. Robinson states, however, that in his opinion, sterilization, as a general thing, is only of slight value from a medical point of view; but from a eugenical point of view "it is very good in the insane and chronic criminals." January, 1918.

10. California State Prison, San Quentin. Mr. J. A. Johnston, Warden.

(a) (Quoted from letter.) "I desire to say that while there are many operations performed in this state in the state hospitals for the insane, there are very, very few operations in the prison. The law permits and provides for the operations in the state hospitals under certain conditions, but provides additional conditions to that part of the law applying to inmates of the state prisons. As a matter of fact it is extremely rare that we would have a case for operation under the provisions of the law. We 
perform on the average about one operation a year, and all that we have had in the past five years have been made at the inmates' requests." February, 1918.

(b) L. L. Stanley, Resident Physician, says: "The California Law is such that it is inopportune. Only a few cases of voluntary sterilization have been done. We feel that sterilization is admissible in confirmed criminals and feeble-minded persons." January, 1921.

11. State Prison, Folsom. Mr. J. J. Smith, Warden.

(a) (Quoted from letter.) "I beg to advise that the Surgical Sterilization Law of this State applies to this institution, but it has not been practiced up to date. There have been no operations performed upon any of the inmates of this institution, either under this law or for any other reasons, that have resulted in sexual sterilization. One reason for this is, that all prisoners who would be eligible for such an operation are always transferred to one of the State Hospitals for the Insane for observation and treatment. As to what operations are performed upon them there, I am unable to know." February, 1918.

(b) H. A. Clattenburg, Resident Physician. (Quoted from letter.) "Eugenical sterilization is all right under proper supervision. We wish we knew more about the statute on the subject." February, 1921.

\section{CONNECTICUT.}

The statute dates from 1909. Present status (January 1, 1922): Theoretically active, but practically a dead letter, however, the recent extension of the statute to the Mansfield State Training School and Hos- pital indicates the intention of activity. Four (4) state institutions are subject to the act. They have performed eugenical sterilization operations as follows:

Castration
0
0
0
0
0

\begin{tabular}{rr}
\hline \multicolumn{2}{c}{ FFMALES } \\
\hline Saldingectomy & Orarlotom \\
0 & 0 \\
0 & 0 \\
12 & 10 \\
0 & 0 \\
- & -10
\end{tabular}

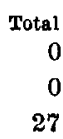

U. S. vs, Weems-in one of the recent volumes (but I cannot say which) holds to this same opinion." February, 1918.

(b) Quoted from Henry K. W. Scott, Warden: "Following the passage of Chapter 209 of the Public Acts of 1909 (Connecticut General Assembly), the Board of Directors of this prison appointed as a commission for the prevention of procreation, Drs. E. G. Fox of Wethersfield, E. J. McKnight, of Hartford, and William $H$. Carmalt, of New Haven. This commission met here at the prison on May 31, 1910, and examined the family and criminal history and mental condition of some three inmates. This was the only meeting of this commission, and to our knowledge, no operations have been performed at this institution under the provisions of this law." February, 1921.

2. Connecticut State Hospital for the Insane, Middletown. Dr. C. Floyd Haviland, Superintendent.

(a) (Quoted from letter.) "Considerable doubt exists as to the constitutionality of 
the law, and there is a strong antipathy against it. As the results of such laws appear problematical, it has never been taken advantage of in this institution. As to the medical value of the statute, I have had no personal experience, but am skeptical except in exceptional cases. Its eugenical value is limited. Such laws fail to take into account the large number of individuals capable of transmitting neurotic and psychoneurotic traits without themselves showing such manifestations." January, 1918.

(b) (Quoted from letter.) "As yet this hospital has done no work in the sterilization of patients. We now have a case under consideration in which we have obtained the consent of the family for such an operation, and which we propose to perform. While we are not under legal obligations to obtain the consent of the nearest relative, such practice is followed as a matter of policy.

"The present sterilization board of the hospital is composed of Dr. R. L. Leak, Assistant Superintendent, Dr. Henry $M$. Chandler, Senior Assistant Physician, and myself.

"Local public opinion is adverse to eugenical sterilization. In a large part this adversion seems to be of religious origin, thus the present statute is in advance of public opinion.

"The possibility of increased dissemination of venereal disease following eugenical sterilization must be considered in connection with the theoretical benefits of the latter. Sterilization requires subsequent supervision whether in or out of institutions." January, 1921.

3. State Hospital, Norwich. Dr. Henry M. Pollock, Superintendent, reports:

(a) "Five persons-two men and three women-have been under the law operated upon at this institution and two of the women have already left the hospital as they could in consequence of the operation be safely released from custodial care. Vasectomy was performed on the male cases and complete ovariotomy on the female. I also beg to advise you that at least one additional male case will shortly be reported to the Board of Trustees and that in all probability other cases will be presented within the coming year. I should like to add that due to the opposition which apparently developed at the time of the enactment of the law that upon my recommendation to the Board of Trustees they decided that no cases were to be referred to the surgical board until they had been considered by the entire medical staff of the institution and the majority of the staff had decided that such an operation would be advisable nor until a synopsis of their family and personal history had been brought before the Board of Trustees at a regular meeting and the Board had sanctioned the reference to the surgical board. This was not only with the idea of satisfying the public that the operation was not performed in a haphazard manner but only after careful study and also to properly safeguard the patients in the institution.

"I cannot agree with the statement that the law as it now stands is practically inoperable. The attorney general has decided that the law is constitutional and we anticipate more and more having the operation performed upon suitable individuals. We do not, however, expect to have the operation performed at this hospital until after each individual case has been given careful consideration. We anticipate that the field worker now at this institution will secure reliable information of the family and personal history and will thus be a great help in assisting us in deciding in regard to the advisability of the operation being performed." October 4, 1913.

(b) Quoted from Dr. F. S. Wilcox, Superintendent:

"Any case to be taken up under this law is first brought before the staff for consideration, and afterward referred to the Board of Trustees for their sanction, and then we get a signed permit from the nearest relative of the patient. Seven of these patients have been able to leave the institution and have gotten along outside, which would not otherwise have been possible. Of this number, three were married before admission and two have married since discharge." March, 1918.

(c) (Quoted from letter.) "Most of our cases of sterilization have been done recently. I think it is generally conceded that the effect is more for prevention of procreation than for any mental benefit.

"Before resorting to sterilization an examination must be made by three surgeons, one of whom must be the Superintendent of the hospital, and one of the three must perform the operation.

"Connecticut does not operate very extensively. We occasionally sterilize casesboth men and women-but we are not doing 
it vigorously as we do not wish to cause much discussion.
"I believe that eugenical sterilization meets with general approval." February, 1921.

\section{INDIANA.}

The statute dates from 1907. Present Boys' School at Plainfield and the Girls' status (January 1, 1922): Tested and de- School at Indianapolis were also subject to clared unconstitutional by the State Supreme the act but this was never officially deterCourt, May 11, 1921, after having been a mined). They performed eugenical sterilizdead letter since 1900. Seven ( 7$)$ state insti- ing operations as follows:

tutions were subject to the act (possibly the

\begin{tabular}{|c|c|c|c|c|c|}
\hline & & & & \multirow[b]{2}{*}{ Total } \\
\hline & Vasectomy & Castration & Salpingectomy & Ovariotomy & \\
\hline 1. Reformatory, Jeffersonville .. & .. 118 & 0 & 0 & 0 & 118 \\
\hline 2. State Prison, Michigan City.. & 0 & 0 & 0 & $\mathbf{0}$ & 0 \\
\hline 3. W'omen's Prison, Indianapolis & 0 & 0 & 0 & 0 & 0 \\
\hline 4. School for Feeble-Minded & & & & & \\
\hline Youth, Ft. Wayne ......... & 0 & 0 & 2 & 0 & 2 \\
\hline Colony for Feeble- & & & & & \\
\hline Minded, Butlerville .......... & $\because$ & 0 & 0 & 0 & 0 \\
\hline 6. Village for Epileptics, Newcastle & te & 0 & 0 & $\mathbf{0}$ & 0 \\
\hline 7. State Farm, Greencastle...... & 0 & 0 & $\mathbf{0}$ & 0 & $\mathbf{0}$ \\
\hline Total to January 1,1921 & & 0 & 2 & $\mathbf{0}$ & 120 \\
\hline
\end{tabular}

Notes on the Enforcement of the Eugenical

\section{Sterilization Law in Indiana. ${ }^{x}$}

Legal eugenical sterilization began in this state, following the inauguration of the practice eight years previous (1899), by the Indiana Reformatory. Beginning with the administration of Governor Thomas $R$. Marshall (1909) the law has not functioned. (For further details see Page 77, Bulletin 10b, 1914, Eugenics Record Office.)

Ex-Governor Marshall (1909) was opposed to the carrying out of sterilization of criminals and mental defectives entirely on personal grounds, that is, he himself did not believe in the theory or practice of sterilization. While governor, he instructed the authorities at Jeffersonville not to continue sterilization, otherwise he would take steps to see that the law was declared unconstitutional.

Governor James P. Goodrich (1920) is in favor of sterilization and has so notified the state institutions. There is, however, nothing contemplated in the revision of this statute until the case before the Supreme Court has been decided. There is a more or less definite feeling in the state that this law, or a correspondingly effective law, should be on the statute books.

Dr. A. H. Estabrook, Author of "The Jukes, 1915," and now (1921) investigating "The Ishmaels" of Indiana:

"Many people have stated that they deem the constitutional rights of the individual to include the power of sexual intercourse, and many of these think that the operation of sterilization prevents sexual intercourse; for this reason alone they are opposed to the sterilization. It is not the restriction of child bearing that makes them antagonistic to the sterilization operation, but it is a feeling that the constitutional rights of the individual have been taken away. They readily appreciate the rights of society and not of the individual to prevent child bearing, and when the matter is explained to them that the sterilization operation merely prevents reproduction and does not prevent normal sex relations, a great majority of these people have taken a different attitude. I am suggesting this to you as $I$ feel it is one of the most important things to incorporate in your report on sterilization. Some, however, have felt that feeble-minded women who have been sterilized will have more promiscuous sex relations than before, knowing that pregnancy will not occur. That, of course, is a debatable question, but my own feeling is that there will not be much increase in illegitimate sex-relations under these conditions." March, 1921.

(b) In response to inquiries the following information and opinions were given:

1. Indiana Reformatory, Jeffersonville.

Dr. G. E. Mowrer, Physician.

(Quoted from letter.) "The sterilization statute is of the highest good socially. It will eliminate those who are unfit to become parents, both from mental and physical standpoints." January, 1918.

${ }^{1}$ Institutions 5 and 6 did not supply historical comment. 
2. Indiana State Prison, Michigan City.

Edw. J. Fogarty, Warden.

(Quoted from letter.) "Relative to the appointment of a Sterilization Board under the Act of March 9, 1907, I would say that we have never appointed any Board in compliance with this act. In an institution like ours it is all 'bunk'." February, 1921.

3. Indiana Women's Prison, Indianapolis.

Margaret M. Elliott, Superintendent.

(a) (Quoted from letter.) "We have never yet taken advantage of this law." January, 1918.

(b) (Quoted from letter.) "We have never appointed a Sterilization Board in this institution." February, 1921.

4. Indiana School for Feeble-minded Youth,

Fort Wayne. Dr. George S. Bliss,

Superintendent.

(a) (Quoted from letter.) "Governor Marshall told the institution not to apply the law, which has since become inactive. Medically the statute is of small value, because public sentiment is not yet educated up to it. Eugenically, if it could be generally applied to high grade imbeciles and morons, it ought to be of greatest value." January, 1918.

(b) Melvin Druckemiller, Acting Superintendent, writes:

"Cases suitable for discharge are selected for sterilization before leaving the institution. Before resorting to sterilization we secure a family history which sorts out abnormal relatives as far back as the grandparents, and beyond that whenever it is possible to secure the information.

"There should be a State Agent in each county and a County Committee to look after and sterilize all married mental defectives after one or more children at least.

"No doubt I am radical but I think that most penal cases should be sterilized and that all feeble-minded school inmates who are about to be discharged or run away should be sterilized as soon as there is evidence of their permanent mental disability.

"We have sterilized one girl this summer and will operate on another this week. We performed a few operations in 1908 just after the law was passed." February, 1921.

7. Indiana State Farm, Greencastle. Mr. C. E. Talkington, Superintendent.

\section{IOWA.}

The - statutes date from 1911 (second statute, 1913; third statute, 1915). Present status (January 1, 1922): Theoretically active under volunteer system; practically, it (a) (Quoted from letter.) "The Indiana State Farm has never sterilized any prisoners up to the present. While the statute of 1907 seems to give us power, there have been some objections raised to our performing the operation, and we are still undecided in the matter." February, 1918.

(b) (From letter.) "The Indiana State Farm is a prison for misdemeanants and does not sterilize prisoners." February, 1921.

Indiana Boys' School, Plainfield. Geo. A. H. Shideler, Superintendent, says:

"We understand that the statute permits surgical operations as pertaining to inmates and patients as you describe, but they are not performed or carried out at this institution in any way. *** We believe in the proposition under proper control and think it will aid materially in the prevention of crime. After several years' experience with these derelicts, I am of the firm opinion that sterilization should be practiced with care and good judgment for the betterment of social conditions." April, 1918.

Indiana Girls' School, Indianapolis. Dr.

Kenosha Sessions, Superintendent, writes:

"Mr. Amos W. Butler, Secretary of Board of State Charities, in answer to inquiries concerning application of the sterilization law, states: 'I think perhaps our law is broad enough to include all the state institutions for certain things, and also all of the county institutions. So far as we know, the law has not been put into operation regarding the latter. Some of the hospitals for the insane have considered applying it. It is likely in the matter of confirmed criminals the lawyers would say that it applied to the Indiana Reformatory at Jeffersonville, the Indiana State Prison at Michigan City, the Indiana Women's Prison at Indianapolis, and the Indiana State Farm at Putnamville. Perhaps it would also apply to such persons in county jails. It would NOT apply to that class in the Indiana Girls' School or the Indiana Boys' School, but it might apply there in the case of rapists or mental defectives. It is left for each institution to construe it as seems to be its needs until it has been interpreted by the courts." February, 1918.

has fallen into disuse. Six (6) state institutions are now (since 1915) subject to the act. They have performed eugenical sterilizing operations as follows: 


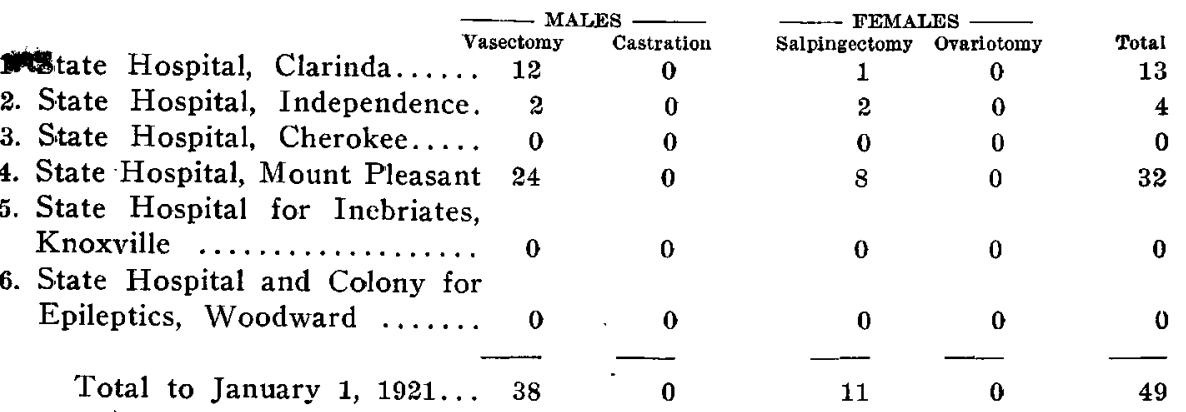

Notes on the Enforcement of the Eugenical Law in Iowa.

Formerly the six state institutions for the criminalistic were subject to the sterilization law but following litigation growing out of the second statute (1913) its application was, by new legislation, limited to the above listed institutions. As in several other states, activity under the sterilization statute in Iowa depends upon the interest of the superintendent of the particular subject institution.

Excerpts from Reports of the Iowa Board of Parole, the Board of Control of State Institutions and from the Department of Health and Medical Examiners:

\section{1. (a) From the Report of the Iowa Board of Parole:}

"At Cherokee State Hospital the board for that institution ordered that the operation of vasectomy be performed on ten males, and the operation of ligation of the fallopian tubes be performed on four females. At the Independence State Hospital the board for that institution ordered that the operation of vasectomy be performed on two males, and the operation of ligation of the fallopian tubes on two females. At the Mount Pleasant State Hospital the board for that institution ordered that the operation of vasectomy be performed on twenty-four males, and the operation of ligation of the fallopian tubes in the cases of nine females. At the Clarinda State Hospital the board for that institution ordered the operation of vasectomy to be performed in the case of four males, and the operation of ligation of the fallopian tubes in the cases of twelve females.

"Of the cases in which operations were ordered, there were performed and reported to the board as follows: At Cherokee thirteen, at Independence three, at Mount Pleasant twenty-two, at Clarinda thirteen.

“* * * This board is of the opinion that Chapter 187 of the Acts of the Thirty-

fifth General Assembly is not operable. We think that it should be provided in the statute authorizing the sterilization of mental and moral defectives that after the conclusion has been reached that the good of society requires sterilization of the individual, notice should be given, the case examined by the board as a tribunal with authority to take testimony offered to contradict the facts found by the board, and to enter the order for sterilization, or refuse it, as should be determined from the facts found. We do not favor the right of appeal to any other tribunal. We submit the administration of the law providing for the sterilization of inmates of state institutions which are under the jurisdiction of the State Board of Control, other than the penal institutions, should be given the Board of Control and the superintendent and the physician of each institution; in other words, that the Board of Control should be in such institutions substituted for the Board of Parole. The Board of Control must make frequent visits to these institutions and thus would there be financial saving. Besides, that board is in constant communication with the officers of such institutions, and also in possession of much information concerning the inmates. The Board of Parole, however, is in much better position than the Board of Control to know the record of the prisoners in the reformatory and penitentiary; to know of their physical, mental and moral conditions both before their conviction and after their incarceration, than is the Board of Control. The law, therefore, as to the penal institutions should remain as it is in this respect.

"The sterilization of mental and physical deficients is, as it seems to us, for the purpose of protecting the State from the increase of its mentally and physically defective population; and not only that, but also to prevent the suffering and misery that will be the result entailed on the children of

1 Institution 4 did not supply historical comment. 
such persons, and on relatives and friends on whom they must be dependent. This in no sense is a punishment, either when applied to the inmates of Hospitals for the Insane, or such like institutions, or to the penal institutions.

"The classes included in any mandatory provision would be certain to include some individuals of whom it could not be said there was a liability in procreation resulting in children with a tendency to the defects justifying the operation. For this reason we do not favor a law which makes mandatory the operation in cases of either mental, physical or moral defectives.

"In conclusion, we recommend:

"First. That Chapter 187 of the acts of the Thirty-fifth General Assembly be amended or repealed, and a substitute enacted providing for the sterilization of the classes therein included, and for the reasons therein stated.

"Second.' That it shall be provided that an order of sterilization be entered only after hearing on notice, and that there shall be no appeal from the order entered, giving only the right of review by the higher court as provided by law.

"Third. That the administration of the law remain in the tribunal now authorized, except as above pointed out.

"Fourth. That inmates of jails and county homes or such like institutions should not be included.

"Fifth. That the performance of the operation should not be made mandatory in any case.

"Respectfully submitted this 31st day of December, 1914.

$$
\begin{aligned}
& \text { "W. H. BERRY, } \\
& \text { "J. E. HOWE, } \\
& \text { "D. C. MOTT, } \\
& \text { "Iowa Board of Parole." }
\end{aligned}
$$

1913-14.

This report was accompanied by four letters addressed to the State Board of Parole. They appear as follows:

$$
\text { Exhibit "A." }
$$

Cherokee, Iowa, November 29, 1914.

Hon. W. H. Berry,

Chairman Board of Parole,

Des Moines, Iowa.

My Dear Sir: To begin with, I desire to go on record as one who is very much in favor of the so-called Perkins Law. While the law as it now stands may need a few changes, I am not prepared at this time to make any suggestions.

Of the cases operated on in this institution, five have left on parole. I should have hesitated very much recommending any of these cases for a parole prior to sterilization. I believe I can truthfully say also, that in many cases operated on there has been a noticeable change for the better, both in their mental as well as their physical condition. I am inclined to think that the law as it now stands is rather too broad in its application, so far as the insane cases are concerned, and it may be advisable to make a change in this respect. The writer hopes that the present law, with possibly a few changes, will at least be given further trial. I am of the opinion, too, that public sentiment in favor of the law will have a tendency to become more and more favorable.

\section{Sincerely yours,}

M. N. VOLDENG, Superintendent.

\section{Exhibit "B."}

Mount Pleasant, November 30, 1914.

Hon. W. H. Berry,

State Board of Parole,

Des Moines, Iowa.

Dear Sir: I have your letter of the 28th, and in reply will say we are very anxious to have the law so worded or changed, that there will be no question about the liability in sterilizing the patients in our state hospitals for the insane and the institution for the feeble-minded.

I believe that the authority for ordering the sterilization of these patients in our hospitals for the insane particularly, and I believe also in the institution for the feebleminded, should be left to the superintendent of the institution, and the Board of Control, and I suggest you make this recommendation in your report to the governor.

The Board of Control visits the institutions each month, and is in close touch with the patients themselves, as well as a great many of the relatives of these patients. They are in position to advise what is best for the patients, not only the patient himself, but also the relatives. It is confusing to the relatives to have the superintendent and the Board of Control encouraging the sterilization of certain patients in our institution, and then have the Board of Parole come and pass upon these cases; in other words, the relatives and the patients get confused concerning the two boards, so I am in favor 
that the Board of Control, who, as stated above, is in close touch with the patients and relatives, have the authority to order the sterilization of certain patients.

I am in hopes that the law may be so changed as to not have to have the consent of the relatives for the sterilization of certain patients between the ages of fourteen and fifty years. I would like to have it arranged so that the Board of Control can pass upon these cases during the semi-annual visits in the spring and fall of each year, and issue orders to the superintendent that certain patients be sterilized.

I am anxious that you recommend to the governor the enforcement of this law in our state hospitals for the insane and the institution for the feeble-minded. The law, in my opinion, is a good one, and this work should be encouraged, as it is an advancement in the right direction.

I shall be glad, indeed, to see Iowa take. a stand on this question and continue this work. Good results have already been accomplished, and there has not been a single bad result following the sterilization of any of these fifty or more cases, which we have operated on in this institution. In my opinion nothing but good can come from the sterilization of the young men and women committed to this institution as insane. I am glad to make this report to your board, and I hope you will do all you can to get proper legislation this coming winter on this most particular matter of sterilization of the insane and feeble-minded.

Very truly yours, C. F. APPLEGATE,

Superintendent. Exhibit "C."

Clarinda, Iowa, November 30, 1914.

Iowa Board of Parole,

Des Moines, Iowa.

Gentlemen: Your letter of recent date by Judge W. H. Berry is at hand. As to my views relative to the matter of operations performed on various patients here, namely, vasectomy, I can only repeat what I said to you on your last visit.

In the cases tried, it seems to have had a beneficial influence. One patient has since gone home to a neighboring county, and from all we can learn there has been no complaint of him whatever, and he is getting along nicely. Other young patients on whom we operated have become more orderly and quiet and, while defective in mental development, which could not be improved by any treatment, the influence of the operation seems to have been favorable. Considering such slight experience as we have had, I am favorable to further operations in suitably selected cases.

Sincerely yours,

MAX E. WITTE,

Superintendent.

Exhibit "D."

Independence, Iowa, Dec. 4, 1914.

Iowa Board of Parole,

Des Moines, Iowa.

Gentlemen: Replying to your letter dated the 28th ult., signed by Chairman Berry, the following is a brief report of the progress made at this institution under the sterilization law enacted by the last session of the General Assembly:

At the Independence State Hospital the sterilization law has been utilized in the case of three patients, two males and one female. J. H. No. 11808, a male patient, single, aged fifty-one on admission January 23, 1912. The mental derangement was diagnosticated as sexual perversion with dementia praecox. The patient was born in Chicago in 1861, attended the Lincom and Wells schools in that city, leaving school at fourteen. He was in the eighth grade doing common fractions and decimals at the time he discontinued school. $\mathrm{He}$ worked at various occupations, was dissipated and spent his time from Saturday evening until Sunday night in the company of prostitutes. He had gonorrhea when sixteen years of age. The blood serum reacted negatively to the Wasserman test. $\mathrm{He}$ admits bestiality, having performed the act of sodomy with a gelding. He was sentenced to the Fort Madison prison for sodomy in 1905 . This patient was sterilized about January 25, 1914, the operation being vasectomy.

J. H., No. 11336, male, single, age twentyseven years on admission April 22, 1910, diagnosis precocious dementia. The patient was transferred from the insane department of the reformatory at Anamosa, having been convicted of manslaughter and committed to prison. The patient claims that he did not know anything of his crime while engaged in the act, but that he has always been subject to spells of excitement when he would not realize what he was doing. The patient was usually quiet and well behaved, but occasionally would undergo an 
attack, apparently of a hysterical nature, during which time he would attack attendants and patients indiscriminately, and was with difficulty overpowered and controlled. This patient was sterilized about February 7,1914 , the operation being vasectomy.

M. T., No. 12015, a female, single, admitted November 28, 1912, age sixteen. Form of mental derangement epileptic insanity. The patient is a native of Iowa and has one brother younger than herself. The brother seems all right mentally. This patient was not considered bright as a child, but was healthy. She had very little education and of late years has been considered queer. She was never sociable and has not had any severe illness or injury. She has no bad habits and was employed in house work which she performed rather indifferently. The menstrual periods were painful, so that it was necessary for her to go to bed at these times. The epileptic seizures usually appeared during the monthly periods. When seven years old she showed evidence of something wrong with her mind, was quite queer, although she was not thought to be insane. Just before coming to the hospital she was confused. This condition followed severe seizures. This patient was rendered asexual about February 13, 1914, by the operation of ligation of the fallopian tubes.

These three patients are all in the hospital at the present time. We are not able to determine that the operation has influenced the mental state of any one of them, either favorably or unfavorably. Should they be discharged or escape from the institution they would not be able to propagate their kind. The sterilization of the unfit is, we believe, in accord with advanced scientific thought. There is considerable opposition, however, to the practical application of such enactments on the part of friends of the patients. We doubt the advisability of making such acts mandatory, until the public shall have been more thoroughly educated along these lines. It is difficult, if not impossible, to enforce the laws that are not supported by public opinion.

Very sincerely yours,

W. P. CRUMBACKER,

Superintendent.

\section{(b) The Board of Parole, Des Moines.}

Winfield S. Withrow, Chairman of the Board, writes: "The original act pertaining to sterilization passed by the General Assembly of the State of Iowa was held un- constitutional in the Federal Court and was thereafter repealed by Chapter 365 of the Thirty-sixth General Assembly. The original act passed by the Thirty-fifth General Assembly was amended by the Thirty-sixth General Assembly authorizing such operations in insane hospitals only, where the superintendent and the majority of his medical staff believed it to be for the best interest of the patient and also provided that the operation be first approved by the Board of Control and with the written consent of the husband or wife of the patient if married, and if not by the guardian or next of kin.

"The Board of Parole has since that time had no connection with that work and we have no records bearing upon it." February, 1921.

\section{Report of Board of Control of State} Institutions, 1916 (pp. 39-40):

"The law of the Thirty-fifth General Assembly empowering the Board of Parole to sterilize certain described inmates in the hospitals for the insane, as well as those at the Reformatory and State Penitentiary, was, by the Thirty-sixth Assembly, repealed, and in its stead a law was passed authorizing the superintendent and his medical staff, by a majority vote, by and with the approval of the Board of Control of State Institutions, to sterilize such of the inmates of the insane hospitals as they might direct, after the husband, or wife, parents, or nearest of kin had given their consent. Very few cases have been acted upon, since the adoption of the law of the Thirty-sixth General Assembly, from the hospitals and the board is not in shape to offer any suggestions as to the operation of the new method. The few operations that have been performed, we learn from the superintendents, have been followed by beneficial results." 1916.

\section{F. S. Treat, Secretary, Board of Control of} State Institutions:

"Originally, the law was administered by the Board of Parole, but this has been changed so that it is now in our hands. Amendments to the law, however, have so modified it that its operation is practically confined to the hospitals for the insane, and at these institutions nothing can be done without the consent of the husband, wife or nearest kin. The law, as it pertained to the criminal, was declared unconstitutional. A few operations have been performed at the hospitals for the insane, and previously at 
the institution for the feeble-minded, but as amended, the law is practically a dead letter." March, 1918.

\section{Department of Health and Medical} Examiners, Des Moines. Guilford H. Sumner, M. D., Secretary-Executive Officer, reports:

"The law of 1913 was unconstitutional because it provided a cruel and unusual punishment, because it denied to the prisoner to be operated upon due process of law, and because it is in effect a 'bill of attainder' in that it provides for the infliction of a punishment for past offenses by legislative act without jury trial. Davis vs. Berry, 216 Fed. 413." January, 1921.

\section{Institutional Reports.}

In response to inquiries the following information and opinions were given:

1. State Hospital, Clarinda. Dr, M. E. Witte, Superintendent, writes:

"The influence of the operation was good in selected cases - feeble-mindedness and insanity with erotic tendencies. The eugenical value of the statute is excellent. Several of the young men sterilized are out and make a living. Same is true of the young woman, and this without danger of procreating defective children." January, 1918.

\section{State Hospital, Independence.}

(a) Dr. W. P. Crumbacker, Superintendent, writes: "The sterilization statute is not very popular with the public as yet. The patients and relatives also object to it in many cases. We have had so few operations that we feel incompetent to make a definite statement concerning its medical value. However, eugenically it is probably valuable in preventing the propagation of undesirable citizens." January, 1918.

(b) R. A. Stewart, Superintendent, writes: "The only way sterilization can now be done in Iowa is for the relatives to obtain the consent of the Board of Parole. This Board met at the hospital, organized a State Sterilization Board which interviewed the selected patients and went. into their heredity, form of psychosis and number of previous attacks and voted on action as prescribed by the Law of 1913.
"Sterilization is the only method to eradicate insanity but public opinion is still divided on this subject and $I$ regret that the members of the American Medico-Psychological Association did not indorse it in 1913 at Niagara Falls." January, 1921.

3. State Hospital, Cherokee. George Donohoe, M. D., Superintendent, says:

"At present eugenical sterilization is in abeyance pending legislation which needs to be made clear and operative.

"Theoretically, sterilization is good; practically, of doubtful value in insane patients, except in a few instances." January, 1921.

\section{State Hospital for Inebriates, Knoxville.}

Dr. M. C. Mackin, Superintendent, writes:

"I do not interpret the present sterilization law as applying to this institution. The previous law which applied to all institutions, as I understand it, under the control of the Board of Control of State Institutions, came under a former act which was repealed.

"A convict of the penitentiary at Ft. Madison, some few years ago, brought action against the Board of Parole to prevent the carrying out of the intent of the law as it applied to him. The matter was carried to the Supreme Court, which decided that the law was unconstitutional. The next General Assembly enacted the present law.

"There is no doubt in my mind that a great many of our patients should be emasculated. A certain percentage of them are marked degenerates and they should not be permitted to propagate their kind. I am a firm believer that this law should be enforced wherever conditions warrant it." January, 1918.

6. State Hospital and Colony for Epileptics, Woodward. M. N. Voldeng, M. D., Superintendent, writes:

"Nothing is being done in Iowa along this line for the reason that the first law enacted was deemed unconstitutional.

"Generally speaking, we are favorable to the policy. While I was superintendent of the Cherokee State Hospital we performed a number of operations during the first year after the law was enacted." January, 1921.

\section{KANSAS.}

The statutes date from 1913 (second statute 1917). Present status (January 1, 1922): Theoretically active, but practically a dead letter. Ten (10) state institutions are subject to the act. They have performed eugenical sterilizing operations as follows: 


\begin{tabular}{|c|c|c|c|c|c|}
\hline & \multicolumn{2}{|c|}{ - } & \multicolumn{2}{|c|}{ _ WEMATIRS —_ } & Tutal \\
\hline 1. State Hospital, Topeka....... & . 7 & 4 & 23 & 19 & 53 \\
\hline 2. State Hospital, Osawatomie. . & 0 & 0 & 0 & 0 & 0 \\
\hline 3. State Hospital for Epileptics & & & & & \\
\hline Parsons $\ldots \ldots \ldots \ldots \ldots \ldots$ & 0 & 0 & 0 & 0 & 0 \\
\hline 4. School for Feeble Minded & & & & & \\
\hline Winfield $\ldots \ldots \ldots \ldots \ldots \ldots$ & 0 & 1 & 0 & 0 & 1 \\
\hline 5. State Penitentiary, Lansing... & 0 & 0 & 0 & 0 & 0 \\
\hline 6. State Hospital, Larned...... & 0 & 0 & 0 & 0 & 0 \\
\hline r. Industrial Reformatory, & & & & & \\
\hline Hutchinson $\ldots \ldots \ldots \ldots$ & 0 & 0 & 0 & 0 & 0 \\
\hline 8. Industrial School for Girls & & & & & \\
\hline Beloit $\ldots \ldots \ldots \ldots \ldots \ldots$ & 0 & 0 & 0 & 0 & 0 \\
\hline ๑. Industrial School for Boys, & & & & & \\
\hline Topeka $\ldots \ldots \ldots \ldots \ldots \ldots \ldots$ & 0 & 0 & $\mathbf{0}$ & 0 & 0 \\
\hline $\begin{array}{l}\text { 10. Industrial Harm for women, } \\
\text { Lansing } \ldots \ldots \ldots \ldots \ldots \ldots \ldots\end{array}$ & . & 0 & 0 & 0 & 0 \\
\hline 'Total, January $1,1921$. & 7 & 5 & 23 & 19 & 54 \\
\hline
\end{tabular}

Notes on the Enforcement of the Eugenical Sterilization Law in Kansas. ${ }^{1}$

Like Indiana, Kansas practiced eugenical sterilization on the responsibility of an interested institution before the practice was authorized by law. About 1898 the State School for Feeble-Minded at Winfield inaugurated this work. The "red tape" of the present law is complained against by several institutions.

In response to inquiries the following information and opinions were given:

1. State Hospital, Topeka. Dr. M. L.

Perry, Superintendent, writes:

"Patients who plainly should not bear children and who are discharged not restored are sterilized. They leave the institution as soon as they recover from the operation.

"During the past two years a more aggressive policy is being pursued. We have a good working statute and $I$ am in favor of it." April 8, 1921.

2. State Hospital for Insane, Osawatomie. Dr. F. A. Carmichael, Superintendent, writes:

(a) "The statute is ambiguous and involved, and smothered in red tape to a degree that makes it practically inoperative."

Dr. Carmichael reports performing only three operations in two years, and says that the medical value of the statute is "practically nil," and that its eugenical value is "slight." January, 1918.

(b) "Legislation in this state is so vague in its application that sterilization is not undertaken with reference to the criminal insane or defective classes, except as it may be carried out in conjunction with some other operative procedure.

"The recognition of the need of some such measure is fully apparent but unfortunately it has been impossible to affect legislation that would adequately protect those responsible for the selection of such cases." February, 1921.

3. State Hospital for Epileptics, Parsons. O. S. Hubbard, Superintendent, writes: "We have considered practically no cases for eugenical sterilization in our institution. Public opinion is not ready for it. The sterilization of institution inmates is often of little value; it should come earlier to be of value and that at present is impracticable." January, 1921.

4. State Home for Feeble-Minded, Winfield.

(a) Dr. F. C. Cave, Superintendent, says: "The only institution in the State as far as I know that has ever done any sterilizing upon its inmates is this Home at Winfield. That was twenty years ago and the Superintendent at that time was a Dr. Pilcher who was assisted in the work by Dr. Emerson. About fifty cases were operated on, half girls and half boys, the operation being the complete removal of the testicles in the boys, and complete removal of ovaries in the girls. Since that time nothing has been done except in diseased conditions of these organs or in cases of congenital hernia where operative procedures were instituted to remedy the defect and no attention given to the enclosed testicle, removing it with the hernial sac. A

Institution 7 did not supply historical comment. 
storm of protest was raised at that time and the populace were thinking of burning Dr. Pilcher at the stake, or at least they wanted to. Probably some of the noise they made was due to politics, as these stigmata were rife at that time, and the fellow who had a job had to be uprooted and turned out every two years or at least every time they changed faith.

"Since then nothing has been done, the various superintendents, of whom I am one, were afraid to start anything and particularly so during the past few years when the Legislature made laws pertaining to the measure, and if the red tape wasn't followed to the letter, it meant a penal offense and a fine that would take all our loose change. In 1913 such a law started, but the Governor didn't sign it, and it became a law by being kept on his desk for several days without being returned to the House. However, lawyers didn't take long to discover that it was not drawn properly, couldn't be put in effect, and besides it had so much red tape to it that getting alcohol free of tax was a picnic compared to it. The last Legislature tried its hand at the same thing and produced an enactment that looked a whole lot better, yet it had plenty of red tape to it, and our present Board in consultation with experts, including some of our older Superintendents, decided for the present it wasn't a wise thing to put the law into effect. I haven't been advised as to why they deemed it best to be so conservative.

"So far, that is as far as Kansas has gore in the matter, but I presume eventually the measure will crop out and be put in tangible form, so that it will be of some value to the State, the individual and the community."

In response to further inquiry, Superintendent Cave wrote that "he was of the opinion that both the medical and eugenical values of the existing sterilization law were high, and that he intended applying the operation to a considerable number of the moron group in his institution." March, 1918.

(b) T. E. Hinshaw, M. D., Physician to the School: "I wish to say that the single case of castration was not done under the auspices of this institution. The inmate's parents took him to their home town where the operation was done. In this institution nothing has been attempted in the line of sterilization as the operation is now so hedged about with legal technicalities and difficulties that no one cares to try it.

"I would cut the red tape so as to make it possible to castrate those who are a menace to society. I think that the general policy of stcrilization (by that I mean castration) is correct." January, 1921.

5. State Penitentiary, Lansing. S. L. Axford, M. D., Deputy State Health Officer, says:

"As you perhaps know, we have a sterilization and castration law in Kansas; so far as I know, it has never been used. Some two years ago the Secretary of the State Board and one or two members of the Board and a psychiatrist from the University examined some prisoners with this end in view, but I have never seen a report that was made and I am certain no operations have been performed at the penitentiary." January, 1921.

6. (a) Larned State Hospital, Larned, Dr. L. R. Sellers, Superintendent.

In answer to the question, What, in your opinion, is the medical value of the sterilization statute? wrote: "It is a handicap. Its provisions of a public trial for each case in the District Court discourages the operation." In further reply to the question, What is its eugenical value? he said: "It would be great. The unfit should not be permitted to procreate."

Excerpts from letters of Dr. Sellers: "Prior to the enactment of eugenical sterilization statute of 1913 , I have no data of the number of cases operated upon in the state, nor an accurate history of the patients, prior and subsequent to the operation. These operations were not performed on account of eugenic reasons, but for the benefit of the patient. The operations, so far as I know, were upon two classes-masturbators and rapists.

"I was, prior to January 1,1915 , a member of the medical staff of the Osawatomie State Hospital fifteen years. During that time we unsexed by castration seven or eight patients (men). I regret that I am unable to give you the kind of a report of these cases that you would wish. At that time we were agitating the matter of preventing the marriage of degenerates, but little was said of sterilizing degenerates.

"During the last six years the people of our state have been taking a lively interest in the matter of protecting posterity by sterilization of the unfit. When there was no statute bearing on this procedure, the 
friends of the patient readily gave consent to have the operation performed; I do not recall an instance of a refusal.

"It would appear that our law of 1913 was enacted to protect the degenerate against the doctors, whom they evidently regard as a bloodthirsty gang. If a Superintendent of one of our hospitals wishes to unsex a degenerate with a view of preventing the procreation of the unfit, he must begin a suit in the District Court of the county from which the patient was committed (sometimes this is more than two hundred miles distant), go in person and back the prosecution. There are not many superintendents who would care to go to all this extreme trouble. Therefore this 1913 statute completely blocks sterilization in Kansas.

"In addition to the cases operated on at Osawatomie, I am of the belief that patients were castrated at the hospitals of Topeka and Parsons. But $I$ think this work was all done prior to enactment of the law mentioned.

* * * "There has recently been a great awakening of interest along the line of eugenics in Kansas. The women's clubs of the state have everywhere discussed the subject. But should we operate without going through the court procedure, we would be liable to heavy costs; therefore I think it likely that most superintendents will see to saving the costs." February, 1918.

Replying to questionnaire, Dr. Sellers writes: "Prior to 1913, the Superintendents of our state insane hospitals, after obtaining the consent of patient's family, would order his Medical Staff to sterilize a patient. But little trouble was ever encountered in securing consent of family. Since the enactment of the 1913 law, there is a heavy penalty for sterilizing without going through a form in the District Court, and consequently I expect less work has been done along this line than was done prior to the legislative enactment. Under the old method of sterilizing by castration, the patients were deprived of glands that impaired to some extent their nutrition. Yet for the good of posterity the operation was justified.

"No such objection can be urged against vasectomy or section of tube. Our degenerates are rapidly increasing, and an effort must soon be made to remedy this. It is hoped that our next legislature will so amend the sterilization law that physicians in our state institutions may have a free hand to do what is needed to stop the propagation of degenerates." February, 1918. (b) (Quoted from letter written by Dr. L. R. Sellers, Superintendent.) "We have done no work in the line of sterilization for six or more years. Some twelve or fifteen years ago, I was a member of the Medical Staff of the Osawatomie Hospital and at that time there was no statute against, or regulating sterilization. We performed the operation on many of our patients. In each case we first obtained the consent of the nearest kin, and then without any publicity operated. The results were satisfactory in every particular. Then the legislature of our state enacted a law, providing that before sterilization could legally be performed, the patient must have his day in court. The procedure was about as follows: The superintendent must take the patient to the county from which he was sent, and have hearing of the case. The superintendent would appear before a jury (often summoned from the livery stables, and court house loafers). This jury of incompetents would hear the evidence that the superintendent gave, then pass upon it. You can readily see how enthusiastic the superintendents would be in complying with the law. I think this act stopped the work of sterilization in Kansas. The 1917 Legislature repealed this law and enacted another providing that in case a superintendent of a hospital desired to sterilize a patient he must first make an application to the Board of Administration, who would hold a meeting at the institution, and then grant or refuse the request. This procedure gives much publicity about the institution and is, therefore, objectionable. What we need is an act making it obligatory on the superintendents of our institutions for the insane to sterilize all female patients before sending them out on parole, provided they have not passed the childbearing period, and all male patients of any age. I would object to castration in either sex, on account of the nutritional function of the ovary and testicle.

"The present statutes on this subject are too complicated. I would have this whole matter decided by the patient's friends and the hospital staff, and then the work would be done in a quiet manner without publicity. I would have the sterilization produced by vasectomy, or section of tube in female. Like begets like, the insane and epileptic will continue to beget degenerate children. The stream of degeneracy is growing wider and deeper. Sterilization will stop- the stream at its fountain head.

"All patients should be sterilized before 
sending them to their homes. This work should be obligatory on the superintendent. Friends of patients would gladly give consent. It is absolutely necessary to stop procreation of the unfit."

8. Industrial School for Girls, Beloit.

(a) Lillian M. Mitchner, Superintendent, in response to the inquiry, What, in your opinion, is the eugenical value of the sterilization statute? wrote: "It seems to me that if it were enforced in our institutions for feeble-minded and subnormal men and women, boys and girls, it would be of incalculable value along eugenical lines."

(b) Etta Joe McCoy, Superintendent, wrote: "This state has a law for sterilization, but nobody seems to have had the nerve to do very much with it. Personally, I have been greatly interested in that phase of reform work and that means of checking the oncoming tide of paupers and delinquents ever since they first tried to pass the law in Oregon a number of years ago, as I happened to be in the state at that time and watched with much interest the discussions through the state legislature.

\section{MICHIGAN.}

The statute dates from 1913. Present status (January 1, 1922): Inoperative, declared unconstitutional by state courts. 1918. Eight (8) state institutions (and others "maintained wholly or in part by public

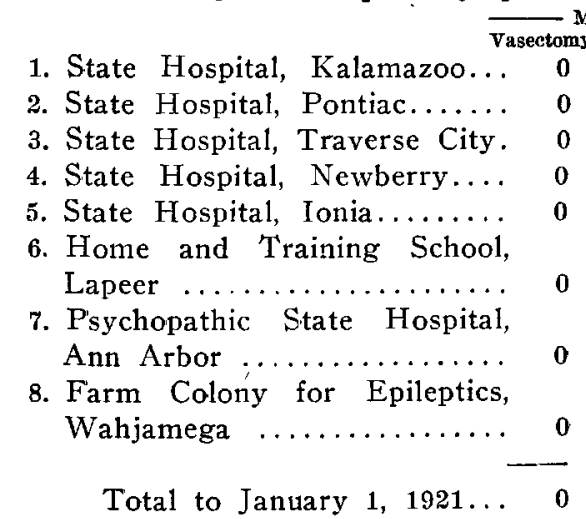

Notes on the Enforcement of the Eugenical Sterilization Law in Michigan.

Executive authorities in Michigan considered the sterilization law as of doubtful constitutionality from the first and the first attempt to use it resulted in a test case, in the course of which litigation the courts held the law unconstitutional.

In response to inquiries the following information and opinions were given:

1. State Hospital, Kalamazoo. Dr. Herman Ostrander, Superintendent, wrote:

Institutions 2 and 4 did not supply historical comment
"However, I have been superintendent of the institution here at Beloit for only about fifteen months, and before coming from the East I visited eight or ten different institutions, mostly juvenile reformatories. I found that most superintendents believe in the measure, but very few use it on account of public sentiment and 'kinks' in state laws. So far as I know, there has never been an operation of this kind performed on an inmate of the Beloit School.

"I am firmly convinced that if I stay in this type of work I shall use every known means of curing physical delinquency and disease." January, 1921.

9. Industrial School for Boys, Topeka.

H. W. Charles, Superintendent, wrote:

"This law has been regarded as a dead letter in this state. The provisions contained in it are such that it has been deemed utterly impracticable. It was intended that this law should apply to this institution as well as others, but for the reasons above given, no operations have been undertaken in this institution, and, so far as I know, none in the state." January, 1918.

expense") were subject to the act; one eugenical sterilizing operation was performed under it. The eight state institutions are as follows:

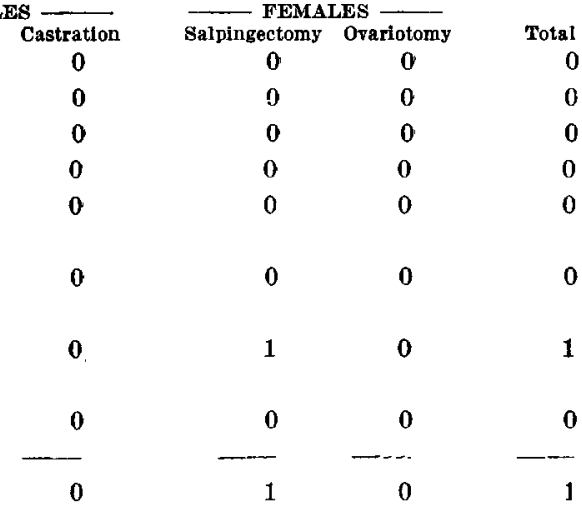

"If the statute could be fully carried out, I believe it would be of considerable value. Unfortunately there would be considerable opposition for the sterilization of ManicDepressive cases, who are the most dangerous." January, 1918.

3. State Hospital, Traverse City. James D. Munson, Medical Superintendent, wrote:

"I am not aware that any of the State Hospitals in Michigan have felt justified in performing any of the operations that have 
been suggested to produce sterility. There was a law passed in 1913, I believe, but the same was so worded that it was practically impossible to carry it out. I do not regard sterilization as of any value except with reference to patients who are likely to leave the hospital.

"Although this hospital has never done sterilization on any of its patients, those of procreative age about to be discharged might. rightfully be considered with great care and some should doubtless be sterilized if the laws could be enacted in states so as to protect the hospital. The Michigan law offers no such protection." January, 1921. 5. State Hospital, Ionia.

Dr. Robert H. Haskell, Superintendent, writes that there have been no operations under this law in his institution, and that his opinion as to the medical or eugenical value of this-statute would be purely theoretical. January, 1918.

6. Michigan Home and Training School.

Lapeer. Dr. H. A. Haynes, Medical

Superintendent, wrote:

"I petitioned to have a number of -our patients operated upon, as provided by the sterilization law, but their parents or guardians objected, and the matter was taken before various courts, and at present is before the Supreme Court for an opinion on its constitutionality." January, 1918.

7. (a) Psychopathic State Hospital, Ann

Arbor. Dr. Albert M. Barrett, Superintendent, wrote:

"The constitutionality of this law has been questioned, and the matter is now before the Supreme Court of this state for decision. The penalty attached to this law deters one from performing any operation of this sort. It undoubtedly could be done as a medical measure without the law. The present statute is, in my opinion, too cumbersome and complicated. So many formalities must be complied with that one is often disinclined to take up the matter of operation. Its value as a eugenical measure is unquestioned, but the desired end could be accomplished by a much simpler statute." January, 1918.

(b) "The sterilization statute of this state has been declared unconstitutional and since this, has been in abeyance. At the present time it seems impossible to frame any statute that would permit of general sterilization for eugenical purposes. It is our intention to present a new mental deficiency bill to the present legislature. In this is a provision for sterilization in the following way: Any feeble-minded person who will submit to sterilization will not be debarred from contracting marriage. I do not see how we can go much further than this in Michigan at the present time." January, 1921.

8. Farm Colony for Epileptics, Wahjamega. Dr. Robert L. Dixon, Superintendent, wrote:

"The sterilization has no medical value not available under former acts. It is of eugenical value in preventing reproduction, but a poor substitute for isolation or colonization.

"We have six females and one male who are sterile as a result of operations before coming to this institution; but we have had no operations in this institution." January, 1918.

\section{NEBRASKA.}

The statute dates from 1915. Present tions are subject to the act; they have perstatus (January 1, 1922): Active under formed eugenical sterilizing operations as volunteer system. Nine (9) state institu- follows:

1. Institute for Feeble-Minded

$$
\text { Vasectomy MALES Castration }
$$

FEMALES
Salpingectomy Ovarlotomy

Total

Youth, Beatrice ............

2. Hospital for Insane, Norfolk. 30

3. Hospital for Insane, Itigleside 27

4. Hospital for Insane, Lincoln. 28

5. Penitentiary, lincoln ....... 0

6. Industrial School for Boys, Kearney ................. 0

7. Industrial Home, Milford.... 0

8. Girls' Industrial School, Geneva 0

9. Industrial Farm for Women,

York ................. 0

Total to January $1,1921 \ldots \overline{87}$

$\begin{array}{rrrr}0 & 5 & 0 & 7 \\ 0 & 8 & 0 & 38 \\ 0 & 5 & 0 & 3 \% \\ 0 & 44 & 6 & 78 \\ 0 & 0 & 0 & 0 \\ & & & \\ 0 & 0 & 0 & 0 \\ 0 & 0 & 0 & 0 \\ 0 & 0 & 0 & 0\end{array}$

$\begin{array}{rrrr}0 & \frac{0}{62} & 0 & 0 \\ 0 & 6 & \frac{155}{155}\end{array}$


Notes on the Enforcement of the Eugenical Sterilization Law in Nebraska. ${ }^{2}$

In the character of the law and the competency of its application, Nebraska shares with California, Washington and Oregon the claim to the most business-like and scientific administration of eugenical sterilization.

1. Biennial Report of the Board of Examiners of Defectives.

(a) First Biennial Report, 1916.

To His Excellency, Honorable John $H$. Morehead, Governor, and to the Honorable Members of the Board of Commissioners of State Institutions, Howard Kennedy, Henry Gerdes and Silas A. Holcomb:

"Gentlemen:

"We, the members of the Board of Examiners of Defectives, desire to submit our report covering the period of time from the creation of the Board to the 30 th day of November, 1916.

"It has been the policy of the Board of Exanniners of Defectives to adopt a conservative policy in dealing with all applicants for sterilization. We have ever kept in mind the contention of the critics to sterilization, that the so-called geniuses are sometimes victims of acute neurosis.

"In each of our institutions we observe the criminal, the delinquent and otherwise defective individual, a ward of the state through no fault of his, but by reason of an endowment the product of faulty mating and ancestral defection. This fact has convinced the Board that a certain duty confronts us in each applicant for sterilization; first, to determine in the ancestral strain the tendency to insanity or feeble-mindedness; second, to carefully weigh the probable result of procreation and its effect upon the coming generation and to act with the thought of protecting the individual and safeguarding the interests of the state.

"We recognize the feeble-minded class as the most prolific class and potentially the most dangerous from the standpoint of race standards. We have, therefore, unhesitatingly authorized the sterilization of the male feeble-minded wherever application was made. With the female feeble-minded we have recognized complications which made the task of disposing of these applicants less simple. In the first place the surgical procedure is much more complicated and after sterilization the social problem is a compli-

Institutions 5, 6, 7 and 8 did not supply historical comment. cated one as such individuals may become prostitutes and carriers of venereal diseases. We have, therefore, advocated custodial care rather than sterilization in the case of the feeble-minded female. In the applicants in which the condition was one of frank insanity we have been guided largely by the wishes of the patient and relatives in authorizing sterilization. We have refused sterilization or parole in other instances and have permitted some cases to be paroled without sterilization, being guided by the family history as well as the specific form of mental alienation from which the applicant was suffering.

"We are pleased to report that universal good results have been obtained in all cases sterilized. In each institution extreme care has been exercised and in no instances have difficulties or complications arisen. We include herewith a table which will reveal in a general way the efforts of the Board.

"Respectfully submitted,

"B. F. WILLIAMS, Chairman.

"W. S. FAST, Secretary.

"GEORGE E. CHARLTON,

"D. G. GRIFFITHS.

"H. WINNETT ORR."

Table Containing Patients Coming Under the Observation of the Board of Examiners of Defectives for the Period Ending November 30, 1916:

Whole number of patients

passed upon...........40 $40 \quad 49 \quad 89$

Number ordered sterilized.. $15 \quad 20 \quad 35$

$\begin{array}{lllll}\text { Sterilized according to law.. } & 9 & 6 & 15\end{array}$

Number authorized paroled

without sterilization...... $20 \quad 26 \quad 46$

Number examined, action de-

ferred $\ldots \ldots \ldots \ldots \ldots \ldots \ldots, 5 \quad 3 \quad 8$

No patient examined from the penitentiary, either of the industrial schools or industrial home. November, 1916.

(b) Second Biennial Report, 1918:

"To his Excellency, Honorable Keith Neville, Governor, and to the Honorable Members of the Board of Commissioners of State Institutions, Henry Gerdes, Silas A. Holcomb, and Eugene O. Mayfield.

"Gentlemen:

"We submit herewith the Second Biennial Report of the Board of Examiners of Defectives, covering the period beginning December 1, 1916, and ending November 30, 1918. This Board was created and appointed by the Board of Commissioners of State Institutions complying with Chapter 237, 
Laws of Nebraska, 1915, entitled 'An Act to authorize the sterilization of feeble-minded and insane inmates of state institutions, in certain cases, and to provide for the appointment of a commission, and to define their powers and duties in connection therewith.'

"There have been ten meetings of the Board of Examiners of Defectives held during the past two years. Meetings are called by the chairman on request of the superintendents of the different state hospitals. Appended to this report will be found five tables: Table I, referring to the Ingleside Hospital for the Insane; Table II, the Nebraska Hospital for the Insane; Table III, Hospital for the Insane of Nebraska; Table IV, Nebraska Institution for Feeble-Minded Youth; Table V, combined report of the action of the Board as it pertains to all of the institutions. There was a total of 235 patients examined in four state institutions. The institutions were given authority to sterilize 77 patients before parole or discharge be granted, 43 patients have been sterilized, the remaining 34 patients still remain residents of the institutions, they being as yet unable mentally to take their former place in society.

"Section 1 of the law! governing this Board reads as follows: 'Sterilization of feeble-minded or insane inmates of state institutions.-Hereafter no feeble-minded or insane inmate, physically capable of bearing or begetting offspring, shall be paroled or discharged from the institution for the feeble-minded, or the hospital for the insane, nor paroled from the penitentiary reformatory, industrial home, industrial schools or other such state institutions, except as here- inafter provided, or by order of a court of competent jurisdiction.'

"It will be noted that the Board has not been called upon to examine any patients from the State Penitentiary, the Nebraska Industrial Home, State Industrial School, nor the Girls' Industrial School. All patients examined were from the three hospitals for the insane and the institution for feebleminded.

"The Board has adopted and followed a conservative policy in dealing with applicants for sterilization. No controversies have been invited nor entered into, prejudices in most cases have been overcome and religious scruples have always been respected. No patients have been sterilized without full consent of the relatives and the consent of the patient himself. Authority to sterilize has not been given in any case until after careful consideration of the personal and family history of the patient and the Board convinced that the patient was capable of bearing or begetting offspring and that the offspring "would inherit a tendency to feeble-mindedness, insanity, or degeneracy, and that such children would probably become a social menace and that procreation by such inmate would be harmful to society.' In every case operated upon, recovery was prompt and complete.

"Respectfully submitted,

"W. S. FAST, Chairman.

"D. G. GRIFFITHS, Secretary.

"G. E. CHARLTON.

"J. D. CASE.

"B. A. FINKLE."

(c) Statistical Report of Board of Examiners of Defectives:

\section{INGLESIDE HOSPITAL FOR THE INSANE, INGLESIDE, NEBRASKA}

Table of Patients Coming Under the Observation of the Board of Examiners of Defectives for the Biennium Ending November 30, 1918.

TABLE I.

\begin{tabular}{|c|c|c|}
\hline & M & $\mathrm{F}$ \\
\hline Number examined .... & 50 & 44 \\
\hline $\begin{array}{l}\text { Authority given for sterilization before parole } \\
\text { or discharge } \ldots \ldots \ldots \ldots \ldots \ldots \ldots \ldots \ldots\end{array}$ & 12 & 4 \\
\hline $\begin{array}{l}\text { Authority given to parole or discharge with- } \\
\text { out sterilization } \ldots \ldots \ldots \ldots \ldots \ldots \ldots \ldots\end{array}$ & 24 & 30 \\
\hline Action deferred & 14 & 10 \\
\hline$\cdots \cdots \cdots \cdots \cdots_{*} \cdots_{*} \cdots_{*} \cdots$ & 50 & $4 t$ \\
\hline Sterilized according to law............ & 12 & 1 \\
\hline
\end{tabular}


NEBRASKA HOSPITAL FOR THE INSANE, LINCOLN, NEBRASKA

Table of Patients Coming Under the Observation of the Board of Examiners of Defectives for the Biennium Ending November 30, 1918.

TABLE II.

\begin{tabular}{|c|c|c|c|}
\hline & & & \\
\hline & $\mathrm{M}$ & $\mathrm{F}$ & $\mathrm{T}$ \\
\hline Number examined $\ldots \ldots \ldots \ldots \ldots \ldots \ldots \ldots \ldots \ldots$ & 36 & 46 & 82 \\
\hline $\begin{array}{l}\text { Authority given for sterilization before parole } \\
\text { or discharge } \ldots \ldots \ldots \ldots \ldots \ldots \ldots \ldots \ldots \ldots \ldots\end{array}$ & 15 & 16 & 31 \\
\hline Authority given to parole or discharge with- & & & \\
\hline Action deferred $\ldots \ldots \ldots \ldots \ldots \ldots \ldots \ldots \ldots \ldots$ & 13 & 22 & 35 \\
\hline Action deterted & 8 & 3 & 16 \\
\hline Total & 36 & 46 & 39 \\
\hline
\end{tabular}

Sterilized acording to law............. $4 \quad 10 \quad 14$

HOSPITAL FOR THE INSANE OF NEBRASKA, NORFOLK, NEBRASKA

Table of Patients Coming Under the Observation of the Board of Examiners of Defectives for the Biennium Ending November 30, 1918.

TABL,E III.

\begin{tabular}{|c|c|c|c|}
\hline & & & \\
\hline Number examined $\ldots \ldots \ldots \ldots \ldots \ldots$ & 35 & 21 & 56 \\
\hline Authority given for sterilization before parole & & & \\
\hline or discharge $\ldots \ldots \ldots \ldots \ldots \ldots \ldots \ldots \ldots$ & 23 & 4 & 23 \\
\hline $\begin{array}{l}\text { Authority given to parole or discharge with- } \\
\text { out sterilization } \ldots \ldots \ldots \ldots \ldots \ldots \ldots \ldots \ldots \ldots\end{array}$ & 5 & 16 & 21 \\
\hline Action deferred $\ldots \ldots \ldots \ldots \ldots \ldots \ldots \ldots$ & 7 & 1 & 8 \\
\hline & - & - & \\
\hline Total & 35 & 21 & 56 \\
\hline & & & \\
\hline Sterilized according to law.. & 10 & 3 & 13 \\
\hline
\end{tabular}

NEBRASKA INSTITUTION FOR FEEBLE-MINDED YOUTH, BEATRICE, NEBRASKA

Table of Patients Coming Under the Observation of the Board of Examiners of Defectives for the Biennium Ending November 30, 1918.

TABLE IV.

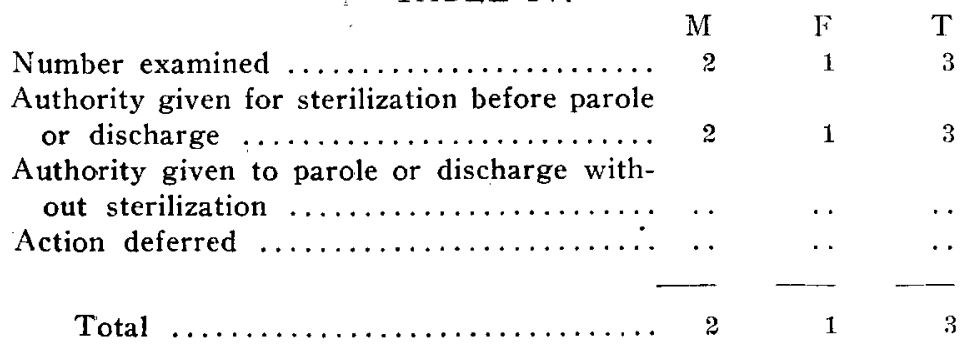

Sterilized according to law 


\section{Combined Tables of Patients from the Ingleside Hospital for the Insane, Nebraska Hospital for the Insane, Hospital for the Insane of Nebraska, and the Nebraska Institution for Feeble-Minded Youth, Coming under the Observation of the Board of Examiners of Defectives for the Biennium Ending November 30, 1918.}

\begin{tabular}{|c|c|c|c|}
\hline & M.:. & $\because F$ & $\mathrm{~T}$ \\
\hline $\begin{array}{l}\text { Number examined } \ldots \ldots \ldots \ldots \ldots \ldots \ldots \ldots \ldots \ldots \\
\text { Authority given for sterilization before parole }\end{array}$ & 123 & 112 & 235 \\
\hline 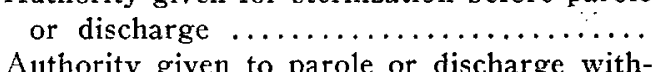 & 52 & 25 & 77 \\
\hline out sterilization $\ldots \ldots \ldots \ldots \ldots \ldots \ldots \ldots \ldots$ & 42 & 68 & 110 \\
\hline Action deferred & 29 & 19 & 48 \\
\hline $\begin{array}{l}2 \ldots \ldots \ldots \ldots \ldots \ldots \\
* * * * *\end{array}$ & 123 & 112 & 23 \\
\hline terilized according to law. & & 15 & 43 \\
\hline
\end{tabular}

\section{Institutional Reports.}

In response to inquiries the following information and opinions were given:

1. Nebraska Institution for Feeble-Minded Youth, Beatrice.

(a) Dr. D. G. Griffiths, Superintendent: "The Nebraska sterilization law applies only to inmates of state institutions, and only then when they are about to be discharged during the child-bearing period. As far as it goes the law has been very satisfactory in our state. The operations under it are limited in number, and have been entered into at all times with a great deal of precaution. I think the act was not passed on a medical basis, but for its eugenical value." April, 1918.

(b) J. A. Buford, M. D., Assistant Superintendent: "The State of Nebraska has a Board for examination of mental defectives. Before being discharged from this institution, patients must appear before this Board, and upon their recommendation, they are ordered sterilized and discharged. This work is done at the State Orthopedic Hospital, Lincoln, Nebraska.

"Our suggestions have been embodied in certain bills introduced in the Legislature by request of the Nebraska Children's Code Commission.

"I am heartily in favor of it and urge the adoption of some such measure under proper supervision and regulation." January, 1921.

2. Hospital for Insane, Norfolk. G. E. Charlton, Superintendent.

"I would do away with that part of the sterilization statute requiring the consent of the nearest relative." January, 1921.
3. State Hospital, Ingleside. W. S. Fast, Superintendent.

"All patients of child-bearing age, otherwise eligible for parole or discharge, are passed upon by the Sterilization Board. There have been no changes in this law which has been in effect for a period of five years, nor have $I$ any changes to suggest. The law should always be administered by conservative physicians. Personal and family histories, individual characteristics, etc. etc., should be taken into consideration in determining whether or not patients should be sterilized." February, 1921.

4. Nebraska Hospital for the Insane, Lincoln. (a) Dr. Lawrence B. Pilsbury, Superintendent.

"You will notice by the enclosed report that we have sterilized in this institution three men and six women under the statute of 1915; one of the men being a high grade imbecile and the other patients all being insane.

"One of them was an epileptic, but I suppose that when a patient is both epileptic and insane you would have such patient classified as insane. The analytic table does not seem to provide for this contingency, nor does it provide for hysterectomy, panhysterectomy nor the removal of tube on one side and ovary on the other, although all of these procedures are sterilizing operations.

"Of the men sterilized, one, H. C., was a high grade imbecile with a record of repeated thefts. He left the hospital in good physical condition and $I$ have heard nothing of him since. Another, U. T., was a case of manic- 
depressive insanity and had apparently entirely recovered from his attack when he left the hospital recently. He has a history of repeated attacks of insanity, and the sterilizing operation seemed to have no influence one way or the other on his recovery. The other male patient, W. S., had also a history of repeated manic-depressive attacks and ran away from the hospital recently without full recovery. The operation had no effect on. his mental condition.

"Of the women, one, E. B., was a case of dementia praecox on a defective basis. Both tubes were removed and the patient is still in the hospital and shows slight mental improvement. Another, K. A., also a dementiapraecox patient, had the right tube and left ovary removed. She left the hospital soon afterward and her present condition is unknown.

"Another woman, G. D., sister of the preceding, a manic-depressive case, had both tubes removed and left the hospital somewhat improved mentally. Another, A. B., diagnosed as dementia praecox, had both tubes removed and is now in the hospital in about the same condition.

"P. E., a case of manic-depressive insanity, had both tubes resected, but she had practically recovered from her attack before the operation was performed. She left the hospital later and is still away on parole.

"A sixth woman, G. K., is an insane epileptic and in her case a hysterectomy was performed. She is still in the hospital in an unimproved condition."
In response to inquiry, Dr. Pilsbury stated that, in his opinion, the medical value of the statute was probably very little, but that, theoretically, the eugenical value should be considerable, so far as reducing the incidence of insanity and feeble-mindedness is concerned; but that custodial segregation would, in time, of course, bring about the same result. March, 1918.

(b) J. D. Case, Superintendent: "Heredity, age, civil condition, physical condition all are taken into consideration in cases passed upon by the Board of Examiners of Defectives, consisting of five specialists in nervous and mental diseases.

"Eugenical sterilization is very important if carefully applied in cases which are carefully selected by a competent board." January, 1921.

\section{Industrial Farm for Women, York.} Dr. Alma J. Chapman, Superintendent.

"When Hazel Scott was ready to be paroled she came before the Sterilization Board and they recommended sterilization. This was done at the Orthopedic Hospital, Lincoln, Nebraska. She had had a child at the Nebraska Industrial Home at Milford, Nebraska, and has spent most of her life in institutions. So we had her examined before the Sterilization Board. Her sister signed a paper giving her consent.

"I am in favor of sterilization, especially for patients paroled from insane asylums." January, 1921.

\section{NEVADA.}

The statute dates from 1911 . Present status (January 1, 1922): Inoperative; declared unconstitutional by Federal Court, 1918. One (1) state institution was, by order of the criminal courts, subject to the act, but performed no eugenical sterilizing operations under it.

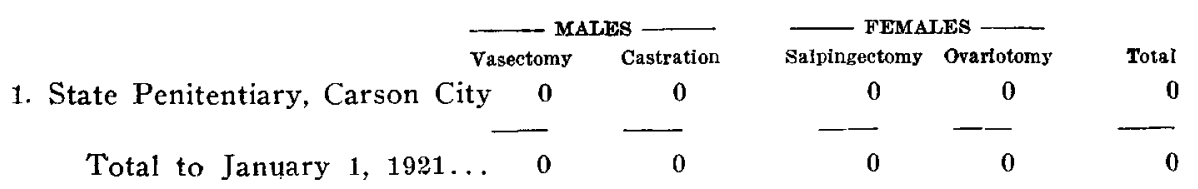

\section{State Penitentiary, Carson City 0}

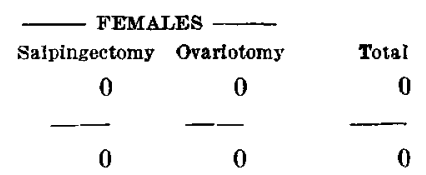

Notes on the Enforcement of the Eugenical Sterilization Law in Nevada.

In this state eugenical sterilization existed solely as a punishment and its first attempted use resulted in the federal courts declaring it "cruel and unusual."

In response to inquiries the following information and opinions were given:
1. Nevada State Penitentiary, Carson City. (a) R. B. Henrichs, Warden.

"There is a Sterilization Law in this state, but as the only sentence imposed was mever carried out, but was taken to the Supreme Court and is still pending, I am not in a position to make a report." January, 1918.

(b) "I do not believe in sterilization." January, 1921. 


\section{NEW JERSEY.}

The statute dates from 1911. Present status (January 1, 1922): Declared unconstitutional by state courts, 1913. Ten (10) state institutions, also the several county

\begin{tabular}{|c|c|c|c|c|c|}
\hline & & \multicolumn{2}{|c|}{ _ FEMALES $\multimap$} & \multirow[b]{2}{*}{ Total } \\
\hline & Vasectomy & Castration & Salpingectomy & Ovariotomy & \\
\hline 1. State Prison, Trenton........ & .0 & 0 & 0 & 0 & 0 \\
\hline 2. Reformatory, Rahway ...... & 0 & 0 & 0 & 0 & $\mathbf{0}$ \\
\hline 3. Home for Girls, Trenton..... & 0 & 0 & 0 & $\mathbf{0}$ & $\mathbf{0}$ \\
\hline 4. Home for Boys, Jamesburg... & 0 & 0 & 0 & 0 & 0 \\
\hline 5. State Hospital, Trenton....... & 0 & 0 & 0 & 0 & 0 \\
\hline 6. State Hospital, Morris Plains. & 0 & 0 & 0 & 0 & 0 \\
\hline 7. State Village for Epileptics & & & & & \\
\hline Skillman $\ldots \ldots \ldots \ldots \ldots \ldots$ & 0 & 0 & 0 & 0 & $\mathbf{0}$ \\
\hline 8. Colony for Feeble-Minded & & & & & \\
\hline Males, New Lisbon.......... & 0 & 0 & $\mathbf{0}$ & $\mathbf{0}$ & 0 \\
\hline 9. Reformatory for Women, & & & & & \\
\hline Clinton $\ldots \ldots \ldots \ldots \ldots \ldots$ & 0 & 0 & 0 & 0 & 0 \\
\hline 10. Institution for Feeble-Minded & & & & & \\
\hline Women, Vineland $\ldots \ldots \ldots \ldots$ & 0 & 0 & 0 & 0 & 0 \\
\hline Total to January 1,192 & 0 & 0 & - & 0 & 0 \\
\hline
\end{tabular}

Notes on the Enforcement of the Eugenical Sterilization Law in New Jersey."

The first attempted use of the statute (by the State Village for Epileptics at Skillman) in this state resulted in a test case before the courts which declared it to be class legislation so far as epileptics are concerned. This adverse decision, while not specifically applying to subject institutions for other types of the socially inadequate, resulted in their declining to make use of the statute for fear of similar prevention by the courts so that this law has always been a dead letter.

In response to inquiries the following information and opinions were given:

3. State Home for Girls, Trenton. Elizabeth V. H. Mansell, Superintendent.

"One of the first acts of Governor Wilson was to sign the sterilization bill, but it was immediately afterward pronounced unconstitutional." January, 1918.

4. Home for Boys, Jamesburg. Rudolph

W. Remser, Resident Physician.

"I believe with Dr. August Hoch that this, in general, is a matter of education of the public conscience in regard to the great responsibility of marriage and parenthood rather than legislation, especially in juveniles in whom the percentage of definite psychoses is so small." January, 1921.

\section{State Hospital, Trenton.}

Dr. Henry A. Cotton, Superintendent, reports that no operations were performed under this law, which was declared unconstitutional; but that, in his opinion,

both the medical and eugenical values of such a statute would be good. February, 1918.

6. State Hospital, Morris Plains. (a) Dr.

Britton D. Evans, Medical Director.

"I have to advise you that the Sterilization Statute was declared unconstitutional in this State, and as no patients have ever been reported upon, I can give you no data on the subject." February, 1918.

(b) Marcus A. Curry, Superintendent. "I am of the opinion that eugenical sterilization properly safeguarded and supervised would be a valuable agent in decreasing the supply of the socially unfit.

"If the present statute had not been declared unconstitutional it might have been practical and effective, but without actual testing it is impossible to state." January, 1921.

\section{Colony for Feeble-Minded Males, New Lisbon.}

J. Frank Macomber, Superintendent, gave it as his opinion that the principal value of the sterilization law was experimental; that it was the proper thing for feeble-minded males, but its value was very questionable when applied to females. January, 1918.

10. Institution for Feeble-Minded Women, Vineland. Geo. B. Thorn, Superintendent.

"We have not taken advantage of the Sterilization Law which is in effect in this state. 
"We feel it would be a wonderful help in the administration of this institution were we able to avail ourselves of this statute, as there has been some difference of opinion as to the legality of same.

"A test case had been tried in one of the courts where a patient was operated on, at Skillman, N. J., and from their standpoint,

\section{NEW YORK.}

The statute dates from 1912. Present status (January 1, 1922): Repealed 1920, after having been declared unconstitutional by the lower state courts in 1918. Thirty

1. State Prison, Auburn........ Vasectomy Castration

2. Clinton State Prison, Dannemora ................ 0

3. Sing Sing Prison, Ossining...

4. Great Meadow Prison, Comstock .................. 0

5. Farm for Boys, Valatie...... 0

6. Reformatory, Elmira ....... 0

7. Eastern New York Reformatory, Napanoch ........... 0

8. Agricultural and Industrial School, Industry ............

9. Training School for Girls, Hudson ..................

10. Western House of Refuge for Women, Albion ............

11. Reformatory for Women. Bedford Hills...$\ldots \ldots \ldots \ldots$. 0

12. Institution for Feeble-Minded Children, Syracuse ........ 0

13. Newark State School, Newark

14. Custodial Asylum, Rome....

15. Craig Colony for Epileptics,

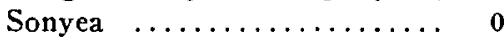

16. Letchworth Village, Thiells.. 0

17. Matteawan State Hospital, Beacon ................ 0

18. State Hospital, Utica....... 0

19. State Hospital, Willard...... 0

20. Hudson River State Hospital, Poughkeepsie ........... 0

21. State Hospital. Middletown... 0

22. State Hospital, Buffalo...... 0

23. State Hospital, Binghamton.. 0

24. St. Lawrence State Hospital, Ogdensburg ...............

25. State Hospital, Rochester....

26. Gowanda State Hospital, Collins

27. State Hospital, Kings Park...

28. State Hospital, Central Islip..

29. Long Island State Hospital, Brooklyn ............... 0

30. Manhattan State Hospital, Ward's Island, N. Y......... was declared unconstitutional. The law affecting this institution is not the same, but we have not made a test case as yet. We are having considerable discussion in New Jersey as to how to have this law amended so that it will be constitutional." January, 1921.

(30) state institutions were subject to the act before its repeal; they performed eugenical sterilizing operations as follows:

\begin{tabular}{|c|c|c|c|c|}
\hline tomy & Castration & Salpingectomy & Ovarlotomy & Total \\
\hline 1 & 0 & 0 & 0 & 1 \\
\hline 0 & 0 & 0 & 0 & 0 \\
\hline 0 & 0 & 0 & 0 & 0 \\
\hline 0 & 0 & 0 & 0 & 0 \\
\hline 0 & 0 & 0 & 0 & 0 \\
\hline 0 & 0 & 0 & 0 & 0 \\
\hline 0 & o & 0 & 0 & 0 \\
\hline 0 & 0 & 0 & 0 & 0 \\
\hline 0 & 0 & 0 & 0 & 0 \\
\hline 0 & 0 & 0 & 0 & 0 \\
\hline 0 & 0 & 0 & 0 & 0 \\
\hline 0 & 0 & 0 & 0 & 0 \\
\hline 0 & 0 & 0 & 0 & 0 \\
\hline 0 & 0 & 0 & 0 & 0 \\
\hline 0 & 0 & 0 & 0 & 0 \\
\hline 0 & 0 & 0 & 0 & 0 \\
\hline 0 & 0 & 0 & 0 & 0 \\
\hline 0 & 0 & 0 & 0 & 0 \\
\hline 0 & 0 & 0 & 0 & 0 \\
\hline 0 & 0 & 0 & 0 & 0 \\
\hline 0 & 0 & $\mathbf{0}$ & 0 & 0 \\
\hline 0 & 0 & 12 & a & 12 \\
\hline 0 & 0 & 0 & 0 & 0 \\
\hline 0 & 0 & 0 & 0 & 0 \\
\hline 0 & 0 & 0 & 0 & 0 \\
\hline 0 & 0 & 24 & 5 & 29 \\
\hline 0 & 0 & 0 & 0 & 0 \\
\hline 0 & 0 & 0 & 0 & 0 \\
\hline 0 & 0 & 0 & 0 & 0 \\
\hline 0 & 0 & 0 & 0 & 0 \\
\hline 1 & $\overline{0}$ & $\overline{36}$ & $\overline{5}$ & $\overline{42}$ \\
\hline
\end{tabular}


Notes on the Enforcement of the Eugenical Sterilization Law in New York. ${ }^{1}$

The State of New York in its Eugenical Sterilization Statute provided for a "Board of Examiners of Feeble-Minded Criminals and other Defectives," and appropriated $\$ 29,825.00$ for the execution of the statute. The money appears to have been spent large$1 y$ for fees and traveling expenses, ${ }^{2}$ and no printed report was ever issued, nor, from the detailed reports of institutions, did the Board of Examiners ever attempt any serious study or accomplish anything other than to bring a test case before the State courts. It appears also that the law was originally passed, not at the instance of persons interested in eugenics, but for the primary purpose of creating a commission for "deserving friends." The statute was copied almost bodily from the New Jersey law, and no effort was made to improve or adapt it. In short, the history of this law in New York State is a record of politics, incompetency and discredit. It has set back eugenical progress among the state's institutions more than ten years.

The two institutions in this state which practice eugenical sterilization, namely, the State Hospitals at Buffalo and at Collins, operate under their own responsibility. They did not attempt to use the sterilization statute when it was in force.

(a) Excerpts from correspondence of Hon. Francis M. Hugo, Secretary of State for New York, and from that of Dr. Lemon Thomson, Member of the Board of Examiners of Feeble-Minded 'Criminals and other Defectives, together with a Statement of Appropriations and Expenditures of said Board furnished by Comptroller Eugene $M$. Travis:

Hon. Francis M. Hugo, Secretary of State. "We give below the names, addresses, dates of appointment, expirations of terms, etc., of persons who were appointed on the Board of Examiners of Feeble-Minded Criminals and other Defectives, which is the Commission you referred to and which was established by 'Chapter 445 of the Laws of 1912.'

1 Institutions 3, 4, 5, 8, 17, 18, 19, 24, 25 and 29 did not supply historical comment.

2 See p. 83 "Comptroller's Report," and p. 139

"Costs and Appropriations."
"Charles H. Andrews, M. D., of Buffalo, N. Y., appointed August 26, 1912; no expiration of term given.

"Lemon Thomson, M. D., of Glens Falls, N. Y., appointed August 26, 1912; no expiration of term given.

"Charles C. Duryee, M. D., of Schenectady, N. Y., appointed August 26, 1912; no expiration of term given.

"John V. Hennessy, of Albany, N. Y., appointed March 9, 1914, for a term to expire August 26, 1917; Vice Duryee, resigned.

"William J. Wansboro, M. D., of Albany, N. Y., appointed July 22, 1914; no expiration of term given; to succeed John V. Hennessy, M. D., deceased.

"According to our records the present Members of the Board are as follows:

"Charles H. Andrews, M. D., of Buffalo, N. Y.

"Lemon Thomson, M. D., of Glens Falls, N. Y.

"William J. Wansboro, M. D., of Albany, N. Y." February, 1918.

Dr. Lemon Thomson, Glens Falls, N. Y. "I regret to state that our work on the board of examinations of feeble-minded, etc., resulted in a total fizzle. We spent more time with the Legislature to get an appropriation to carry on the work than we were spending on the work itself. Finally we got a case before the court for a legal decision, and it is now more than two years since the closing of the case. Attorneys failed to put in their briefs, consequently we had no hope of getting a decision. A little more than a year ago, having become disgusted with the whole affair, I wrote to the Secretary of the Governor as to whether Governor Whitman favored further investigation in that direction. Not hearing from the Governor's Secretary, I threw up the whole matter in disgust, as I did not feel like spending my money on work in which we could not get a decision. It is a disgrace to the State that they have taken no amount of interest in the same.

"As to reports I do not know where to put my hand on them, but if they would be of any service to you, I will gladly look up same and forward them to you, but we did not get so far as to have any printed reports." February, 1918. 


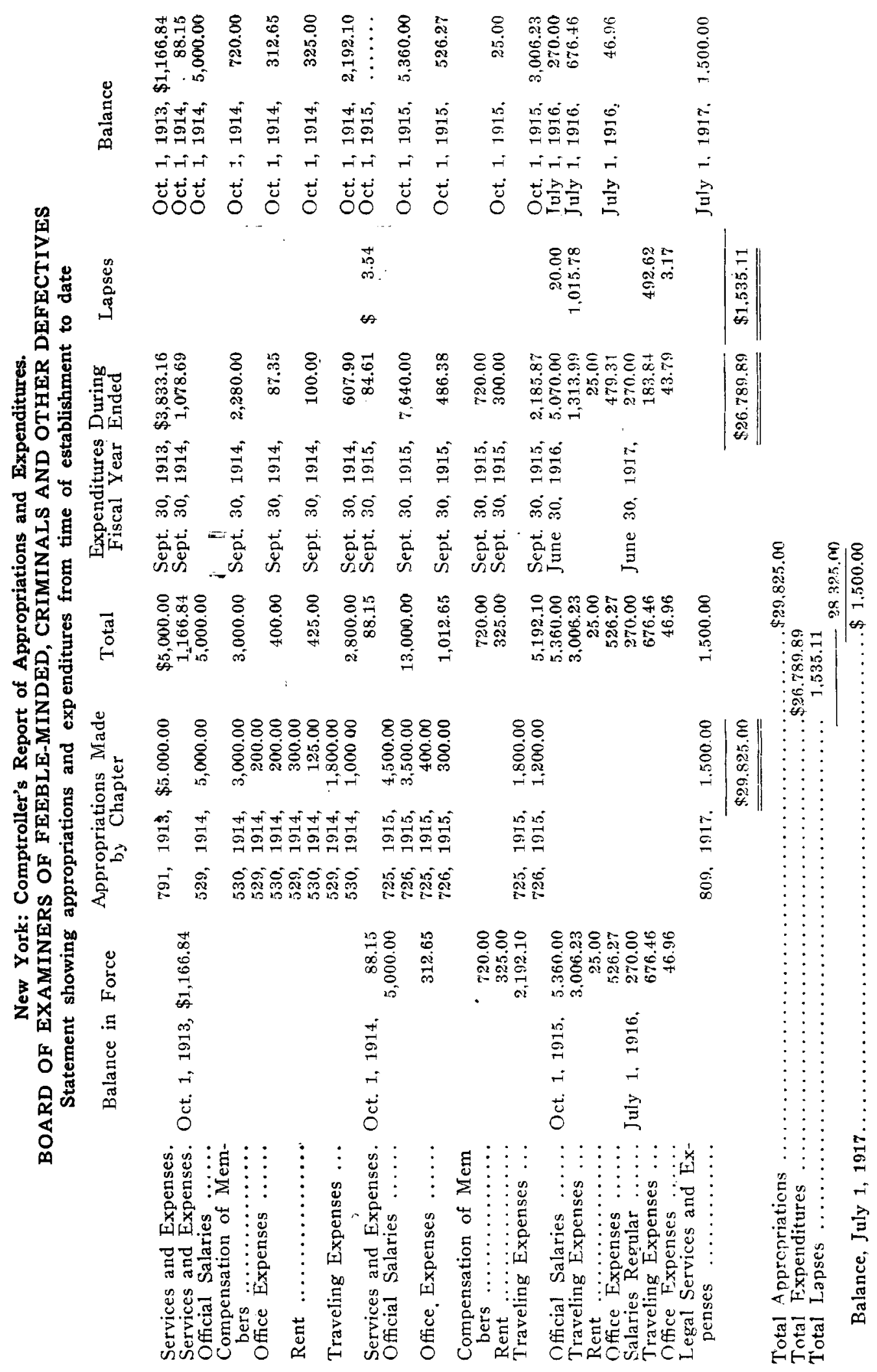


(b) National Christian League for Promotion of Purity (New York). Elizabeth B. Grannis, President, March 9, 1921, writes:

"Some people should be segregated, but not more than one-quarter or one-third of those who now occupy public institutions, and are supported by public funds. If the economic phase of this question could be properly understood a multitude of sensible people would come to the front in behalf of sterilization.

"We have had a number of cases that ought to be known to every intelligent individual. One young man whom I took out of the idiot asylum on Randall's Island, pronounced incurable (there was nothing the matter with him but silly, contemptible parentage who didn't know enough to manage him)-he was given to self-indulgence, and pronounced by the boy doctors, incurable. In a few weeks after I took him out he was sterilized, and in a very few weeks became so self-responsible and self-respecting, no longer a cowered, machine-made nervous wreck that he had been, $* * *$ we obtained a position for him with the Remington Typewriter Co, at $\$ 3.50$ per week. His salary was raised every few weeks until within a very few months he was getting seven dollars a week. He is now a fullfledged United States soldier, with never a symptom of any feeble-mindedness having occurred to any federal authority who examined him. Another young man who had been in the Binghamton Asylum five years is now in camp with excellent record, having been pronounced incurable by the young doctors, and in my repeated correspondence it was stated by the superintendent that it was not probable that he could ever become self-supporting. The first position he obtained was as elevator man with $\$ 40.00$ a month income for his service. Today both of these young men are attending night school, but both in camp, displaying wholesome ambition, with promises to fit themselves for business and to be always a credit to those who helped in securing their discharge. The one who was in five years attended one of our meetings in which he made an address, stating, 'Today $I$ am a free man, walking the streets like any other citizen instead of being behind bars and locked in, with no freedom of individual action.'

"I could mention a case of a young woman" sent home from every boarding school for improper conduct. Sterilization settled her, and prevented serious distress and misfortune."

(c) In response to inquiries the following information and opinions were given:

1. Auburn State Prison, Auburn. (a) Dr. Frank L. Heacox, Physician. "The State Commission made a special study of a few cases, but no recommendations were made as to the cases investigated. One operation of double vasectomy was performed on one patient at his own and his family's request. The patient was a youth twenty years of age, who was suffering from tubercular testicles." Dr. Heacox stated that, in his opinion, the medical value of the statute was very little, but that eugenically it was invaluable. March, 1918.

(b) "Our one case of eugenical sterilization was a voluntary one." January, 1921.

2. Clinton State Prison, Dannemora. Dr. John R. Ross, Medical Superintendent. "There is no doubt in my mind that this operation, if carried out extensively among the insane, feeble-minded and certain of the criminal type, would be of great eugenical value. I feel, however, that it would be impossible to perform this operation to any extent until there has been an educational campaign among the public." February, 1918.

6. New York State Reformatory, Elmira. Frank E. Christian, Superintendent.

(a) "Several cases were examined by the Commission, but nothing more accomplished. Medically the statute was excellent in selected cases, and eugenically it was a good measure." January, 1918.

(b) "The New York Sterilization Law, now repealed, was never popular enough to be enforced. A number of our segregable defective delinquents ought to come under the jurisdiction of a practical sterilization law. We believe it to be practical in cases of extreme degeneracy." January, 1921.

7. Eastern New York Reformatory, Napanoch. (a) Dr. W. N. Thayer, Jr., Physician, reported that no operations had been performed there, that the institution had never been visited by the Committee; that he would not care to offer an opinion concerning the medical value of the statute, but that its eugenical value was good, if applied to cases of feeble-mindedness and recurrent insanity. Dr. Thayer did not consider crime hereditary. January, 1918.

(b) "Eugenical sterilization is not necessary in cases requiring permanent custody 
but it should be done in cases of feebleminded individuals not in custody." January, 1921.

9. Training School for Girls, Hudson. Dr. Hortense V. Bruce, Superintendent. "We have never attempted to do anything under the authority of the Sterilization Law as we understood that the matter would have to come into the courts. In fact, the Commissioners sought to have us select a patient only in order to have a test case to bring into court. Therefore, this institution has nothing but a negative report." February, 1918.

10. Western House of Refuge for Women, Albion. Dr. D. E. Ollswang, Physician. "I think that the Sterilization Law is excellent, and certainly ought to be carried out in all institutions of this nature. It would greatly decrease the number of feeble-minded and inferior children born." January, 1918.

\section{Reformatory for Women, Bedford} Hills.

(a) Mary C. Conant, Physician. While four cases were reported, Dr. Conant, resident physician, states that "none of the four cases were primarily for sterilization. In the first case tubes were diseased, and the other three cases were Caesarian sections for contracted pelves. Under the circumstances sterilization seemed desirable." Doubtless these operations would have been performed under due course of professional practice, regardless of the so-called Sterilization Law.

Superintendent Helen A. Cobb writes: "My understanding of the Sterilization Law in this state is that it has not got beyond the statute books in Albany. No operations primarily for this purpose have been performed in this institution." January, 1918.

(b) O. M. Grover, M. D., Resident Physician. "I think all mental defectives who are custodial charges should be sterilized." January, 1921.

12. (a) Institution for Feeble-Minded Children, Syracuse. Dr. O. H. Cobb, Superintendent. "The medical and eugenical values of the sterilization statute are nil." January, 1918.

(b) "We have done none of this at this institution and from our viewpoint this procedure is notl practicable in New ;York State at this time." January, 1921.

13. Newark State School, Newark. Dr. Ethan A. Nevin, Superintendent. "The State Commission made some preliminary investi- gations but no cases from this institution were recommended for operation. I understand, through the failure of the legislature to provide funds for this commission, that it has practically become extinct. I have not had sufficient evidence presented to me to convince me that this is a wise method of dealing with this proposition." February, 1918.

14. Custodial Asylum, Rome. Dr. Charles Bernstein, Superintendent, from whose institution the test case for the New York statute arose, reported that there had been no operations under the law in his institution; that he could not in the ordinary course of professional practice perform any operation under this law that would be forbidden or illegal without it; that, in his opinion, there was no medical value in the statute; and that, instead of being of eugenical value, the statute was a eugenical hindrance." January, 1918.

15. Craig Colony for Epileptics, Sonyea. Dr. Wm. T. Shanahan, Superintendent. "The Commission visited the Colony, but nothing was done in the way of attempting to enforce the Act." Dr. Shanahan reported that, in his opinion, the statute was of doubtful medical and eugenical values. January, 1918.

16. Letchworth Village, Thiells. Dr. Charles S. Little, Superintendent. "The Sterilization Law in this state has not been put in practice, and I doubt if it ever will be, although I do not know of any good reason why it should not be done, if public sentiment would be favorable to it." February, 1918.

20. Hudson River State Hospital, Poughkeepsie. Dr. Walter G. Ryon, Superintendent. "No cases have been sterilized on account of the prejudice existing against the operation on the part of patients and their relatives. The hospital's policy is not to antagonize them. Some have been given the alternative' in seeking discharge, but have not accepted it." Superintendent Ryon gave it as his opinion that if an operation is for purely sterilizing purposes, he could under the law perform operations which would be illegal without it. In answer to inquiry concerning the medical and eugenical values of the statute he wrote: "The eugenical value is great. The medical value consists in increasing the propriety, and therefore, the frequency of paroling and discharging convalescent insane." February, 1918. 
21. State Hospital, Middletown. Dr. M. C. Ashley, Superintendent, reported that while they had not performed any operations in his hospital because funds had not been provided for the purpose, stili, in his opinion, both the medical and eugenical possibilities of the statute were excellent. January, 1918.

\section{State Hospital, Buffalo.}

(a) Dr. Arthur W. Hurd, Superintendent, in answer to inquiries, reported that he was doubtful whether the law, as it stood before tested in the courts, was applicable to inmates of the hospitals for the insane. He stated also that in reference to the medical value to the institution: "That it may be of a great deal of value in selected cases, as child-bearing, for instance, brings on recurrent attacks of insanity. Eugenically the statute is of much value in preventing the propagation of defectives."

“* * * Since 1912 six sterilizations have been done in this institution on women to produce sterility on account of the mental condition, which made it unwise that the patients should have any more children, and in two instances where the mental condition was in unmarried insane women and was accompanied by immoral tendencies. In each one of the cases we obtained the written consent of the relatives, which was filed in the case before such an operation was undertaken. We have always felt that indiscriminate sterilization among the insane was not indicated, but believe very strongly in it, and think it is of very great value in decreasing the number of people who would be born with a bad heredity, and also in saving the strength of women, for instance: If continued child-bearing would weaken the system, and in that way increase the tendency to mental breakdown." February, 1918.

(b) F. W. Parsons, Superintendent. "There have not been any untoward mental or physical effects resulting from our cases of salpingectomy, as the menstruation has continued uninterrupted. Before operating we obtain and file the written consent of husband, parent or guardian. Several defectives of bad moral tendencies were sterilized before they were allowed to go on parole, also a number of insane women with good intelligence and who had repeated attacks of insanity during pregnancy or the puerperium.

"The sterilization act is not in force in
New York State. The hospital assumes the responsibility." January, 1921.

23. Binghampton State Hospital, Binghampton. Dr. Charles G. Wagner, Medical Superintendent.

(a) "We have never performed any operations for sterilization and do not contemplate any such operations. You, of course, appreciate that the State Hospital Commission - with headquarters at Albany, N. Y., has charge of all of the State hospitals in New York State and we have received no instructions from the Commission regarding the application of eugenical sterilization statute to which you refer." February, 1918.

(b) "Approve of the theory but the practice has not been applied in this state." January, 1921.

26. Gowanda State Hospital, Collins. Dr. C. A. Potter, Superintendent.

(a) In answer to inquiry concerning the medical and eugenical values of the statute, Dr. Potter replied: "If properly amended, the law would be of very great value in preventing recurrence of attacks of insanity, one of our cases has proven this conclusively. If enforced, after amendment, its eugenical value would be greater than any law of recent years which applies to institutions." February, 1918.

(b) "We note that several of our patients who have been sterilized have had no mental breakdown since the operation and have been able to fill their places in the household since they have not been exposed to pregnancy. Those cases which became insane on account of child-bearing or have a bad heredity but who could remain outside if not exposed to frequent child-bearing, are selected for sterilization and written consent is obtained from the husband or legal guardian, or nearest relative, the whole process and reasons therefor having been thoroughly explained.

The public should be shown that insane, epileptics, feeble-minded and criminals have no right to procreate, from an economic standpoint as well as from the point of eugenics. The insane, feeble-minded, epileptics and criminals of child-bearing age should be sterilized." January, 1921.

27. State Hospital, Kings Park. Dr. Wm. A. Macy, Superintendent (deceased).

(a) "I am not familiar enough with the statute to form a positive opinion as to its medical value, but a statute of this sort is of 
value only when public opinion is educated to an appreciative point. With sufficient public support behind a law it should prove of value, especially in paroled or discharged cases of chronic insanity, mental deficiency and frequently recurring cases of mental disorder." January, 1918.

(b) Wm. C. Garvin, Superintendent. “(1) Sterilization of patients in institutions seems superfluous. (2) In extramural cases or in cases about to be paroled or discharged we have not been able to convince ourselves that compulsory sterilization would be justified in the absence of indications for commitment to an institution." January, 1921.

28. State Hospital, Central Islip. Dr. G. A. Smith, Superintendent, writes that no surgical sterilization of inmates has been performed in his institution, and that he is uncertain as to whether in the ordinary course of professional practice he could perform any operation under the sterilization law which would be forbidden or illegal without it. He responded, also, that in his opinion the law had no direct medical value,

11. NORTH

The statute dates from 1913. Present status (January 1, 1922): Active. Four (4) state institutions are subject to the act.

1. Reform School. Mandan.... Vasectom

$$
\text { Vasectomy MALES Castration }
$$

2. State Penitentiary, Bismarck. 0

3. Hospital for Insane, Jamestown 11

4. Feeble - Minded Institution, Grafton ............... 4

Total to January $1,1921 \ldots \overrightarrow{15}$

Notes of the Enforcement of the Eugenical Sterilization Law in North Dakota. ${ }^{\text {' }}$

Like Connecticut, North Dakota is acting conservatively under her sterilization statute. The further use of it is a matter of education and increased interest.

In response to inquiries the following information and opinions were given:

3. Hospital for Insane, Jamestown.

(a) Dr. Wm. M. Hotchkiss, Superintendent. "I have had no difficulty in securing the consent of parent or relative when patient refuses to have the operation performed. The statute is of inestimable eugenical value, because of its possibilities in eliminating defective hereditary influences. Since the law has been in effect we have sterilized thirty males and two females; but we have Institutions 1 and 2 did not supply historical comment. but that it was of eugenical value in cases of idiots, imbeciles, mental defectives and epileptics confined in institutions. March, 1918.

30. Manhattan State Hospital, Ward's Island, New York City.

(a) Dr. Marcus B. Heyman, Superintendent, stated that, in his opinion, there was no medical value in the sterilization statute, but that its eugenical value consisted in the possibility of preventing procreation by constitutionally defective individuals. February, 1918.

(b) "There has never at any time been any patients in this hospital sterilized with a view to eugenics. It is not the policy of this hospital to make such recommendations. This question does not seem to be a medical question but rather a moral and ethical question.

"I am of the opinion that the New York State Law authorizing sterilization was repealed, although $\mathrm{I}$ am not positive of this. In any event the law was so cumbersome that it was impractical." January, 1921.

They have performed eugenical sterilizing operations as follows:

\begin{tabular}{c} 
Castration \\
0 \\
0 \\
0 \\
0 \\
\hline 0
\end{tabular}

$\begin{array}{ccr}\text { Salpingectomy } & \text { Ovariotomy } & \text { Total } \\ 0 & 0 & 0 \\ 0 & 0 & 0 \\ 7 & 0 & 18 \\ 1 & 0 & 5 \\ - & -- & -23\end{array}$

done much less than contemplated, because the lack of finance prevented the hiring of surgical nurses. We have eleven cases of females who are to be operated on when possible." March, 1918.

(b) A. W. Ogden, M. D., Assistant Superintendent. "The present State Board of Administration of North Dakota do not favor eugenical sterilization and there are many relatives of patients who oppose it, and on account of these facts there has been nothing done along this line for some time." February, 1921.

4. The Institution for the Feeble-Minded, Grafton.

(a) Dr. A. R. T. Wylie, Superintendent. "We have as yet had no operations which came strictly under this law. One member of the Medical Board is opposed to such action from moral standpoints and this has 
somewhat hindered its application here. However, we have performed a number of operations but with the consent of the parents.

"The law is quite broad, and we think we can perform operations under it which would be forbidden otherwise.

"The law has some medical value in that operations of this sort have resulted in

\section{OREGON}

The statute dates from 1917. Present status (January 1, 1922): Active. Four (4) state institutions are subject to the act.

1. State Hospital,* Salem...... 1

2. Eastern Oregon State Hospital, Pendleton ............ 0

3. Institution for Feeble-Minded, Salem ................

4. State Penitentiary, Salem.... 1 Total January $1,1921 \ldots \ldots 2$ Notes on the Enforcement of the Eugenical

\section{Sterilization Law in Oregon.}

Oregon is the only state which has a State Board of Eugenics acting under that specific title. The law is functioning satisfactorily in all of the institutions to which it applies. Along with California and $\mathrm{Ne}-$ braska, this state is developing her sterilization policy scientifically and progressively.

The Oregon law provides for a State Board of Eugenics. According to section one of the statute, this Board is entirely ex-officio, and serves without compensation.

"The State Board of Eugenics is composed of the State Board of Health, the Superintendents of the Oregon State Hospital, Eastern Oregon State Hospital, and the Institution for the Feeble-Minded, and the Warden of the State Penitentiary. The Secretary of the Board of Health is also Secretary of the Eugenics Board. The present members are:

Dr. W. B. Morse, President, Salem.

Dr. C. J. Smith, Vice-President, Portland.

Dr. Andrew C. Smith, Portland.

Dr. F. M. Brooks, Portland.

Dr. George E. Houck, Roseburg.

Dr. J. H. Rosenberg, Prineville.

Dr. R. E. Lee Steiner, Salem.

Dr. W. D. McNary, Pendleton.

Dr. J. N. Smith, Salem.

Mr. L. H. Compton, Salem.

Dr. Frederick D. Stricker, Secretary, Portland.

* February 14, 1921, twelve cases pending before the State Board of Eugenics. mental and physical improvement in certain of our cases. In my opinion, in eugenical value, the law is good." February, 1918.

(b) "The operation of sterilization is usually preliminary to discharge. It is our policy to secure the consent of the parent. We approve of such operations in properly selected cases." January, 1921.

They have performed eugenical sterilizing operations as follows:

\begin{tabular}{cccr}
\hline $\begin{array}{c}\text { Castration } \\
32\end{array}$ & $\begin{array}{c}\text { Salpingectomy } \\
\text { Ovariotomy }\end{array}$ & Total \\
32 & 30 & 11 & 74 \\
& & 8 & 40 \\
0 & 0 & 0 & 10 \\
2 & 10 & 0 & 3 \\
- & 0 & -19 & 127
\end{tabular}

"The law is working satisfactorily in this State but we feel that it is too soon to say of just how much value it is going to be." February, 1921.

(a) Excerpts from letters of the State Board of Eugenics, and State Board of Health:

State Board of Eugenics: "In answer to your inquiry, while this law was passed in 1917 very little has been done as yet and no report has been issued. At the last meeting of the Board in December, about twenty persons were ordered sterilized. In two instances the patients appealed from the decision of the Board. Owing to lack of information we are now at a loss how to handle these appealed cases. Our AttorneyGeneral is unable to enlighten us on the subject and if you can supply us with any information or advise us where we could secure such information, we would appreciate it very much." ROBERT E. L. HOLT, STATE HEALTH OFFICER. March, 1918.

State Board of Health: "Your favor of August 22d received in which you request a recent report of our eugenical sterilization law. I regret to inform you that this work has not been published but the facts are essentially as follows:

"The Eugenics Board is composed of the State Board of Health and the Superintendents of the insane asylums and the feebleminded institutions of the State. The Secretary of the Board of Health is also Secretary of the Eugenics Board. 
"The Board meets at such intervals as necessary to examine cases needing sterilization. At the present time cases which come under this class are purely institutional, and resolve themselves into those insane who are sterilized for their physical well-being, and the other class of the cyclic type who are paroled from the insane asylums and those feeble-minded cases which are paroled or sent to their homes for vacation periods or any other reason, and are sterilized prior to their discharge. Public sentiment in this way has not been aroused and the work is moving smoothly.

"We have not decided yet to adopt a policy of doing widespread sterilization; by widespread I mean civic cases which come into court or are apprehended in other ways.

"Upon our compilation of data, we will be pleased to send you a printed copy." DAVID N. ROBERG, M. D., STATE HEALTH OFFICER. September, 1919.

(b) In response to inquiries the following information and opinions were given:

1. State Hospital, Salem. Dr. R. E. Lee Steiner, Superintendent. (a) "Cases are recommended to the State Board of Eugenics, who meet at the institution to examine the patients and go over their histories. The Board then decides what shall be done, and notifies relatives or guardians concerning their decision. Fifteen days are allowed - for appeal to the Circuit Court." Dr. Steiner stated that he considered the law valuable as an educational measure, which might lead to more practical legislation, that its possible eugenical value was limited as the law now stands, but that it opens the way to amendments in the future, which would be of great eugenical value. All of the 12 males who were operated upon in his institution were castrated. In all four female cases the ovaries were removed. All of the 16 cases, both males and females, were flagrant masturbators or sex perverts. January, 1918.

(b) "We have been operating for four years with a great many cases considered and a great many unsexed and sterilized with splendid results. For obvious reasons we are not advertising, but are continuing to do the best work possible. We will be able to show a remarkably fine statement in due course of time." From the Fourth Biennial Report of the Oregon State Board of Control for the biennial period ending September 30, 1920, Dr. Steiner says: "It will be noticed that thirty operations for sterilization have been done. All of these were by the direction of the State Board of Eugenics. No untoward or unfavorable results have occurred, and the operations have been beneficial in all cases. It has been rather difficult for the public as well as the patients and relatives to get the right point of view and appreciate the immediate and remote benefits to be derived from this means of preventing the increase of insanity; but I think there is reason to hope that their increasing enlightenment will cause these operations to be resorted to much more extensively in the future." January, 1921.

(c) L. F. Griffiths, First Assistant Physician. "We maintain full clinical history of patients sterilized, together with notes added a few months after the operation. In carrying out the law prospects are selected by the staff who submit the patients together with their clinical history and reasons for sterilization, to the State Board of Eugenics. If the Board favors the operation they notify relative or guardian and give time for appeal which may be taken through the regular courts.

"We believe great good can finally be accomplished but that only such cases should be selected, regarding which there can be no doubt of its advisability." January, 1921.

\section{Eastern Oregon State Hospital, Pen-} dleton.

(a) Dr, W. D. McNary, Superintendent. "The application of this law was placed in the hands of the State Board of Health and the heads of several state institutions. But it has been found to be rather impractical in application, as it was so framed as to make it difficult to apply to the class or cases that it was most desirable to reach. The consent of relatives or guardian was required and appeal to the courts provided for, and after attempting to utilize it in a few cases at the Oregon State Hospital at Salem and meeting with protest and annoying complications it was decided not to do anything further toward its enforcement." April, 1918.

(b) "We maintain the usual case, personal and family history. Cases are selected by the superintendent, referred to the State Board of Eugenics, examined and passed on by the Board and if favorable, the superintendent is ordered to operate. Relatives are notified.previous to operation and have redress by appeal to courts. 
"Eugenical sterilization is a proper, justi-. fiable and beneficial procedure." January, 1921.

3. Institution for Feeble-Minded, Salem. (a) Dr. J. N. Smith, Superintendent, stated that no operations had been performed in his institution under this Act, and its medical value was unknown. $\mathrm{He}$ held that its eugenical value was considerable. January, 1918.

(b) "We have performed ten cases of eugenical sterilization and have twelve cases now pending before the State Board of Eugenics." February, 1921.

\section{Oregon State Penitentiary, Salem.}

(a) Charles A. Murphy, Warden. In the Oregon State Penitentiary there was, up to the time of this report, one case of eugenical sterilization.

Exhibit A.

(Report of Warden to Board of Eugenics.) OREGON STATE PENITENTIARY.

Salem, Oregon, June 28, 1917.

In re Chester Vanderpool,

Prisoner No. 6770.

CRIME: Larceny in dwelling.

COUNTY: Multnomah.

SENTENCE: 1 to 7 years.

RECEIVED: February 3, 1913.

Age 23.

"This fellow has served two terms in the Oregon Reform School; he escaped from here June 10, 1913, and was returned June 11, 1915; he escaped again January 28, 1917, and was returned June 7,1917 .

"It appears that the prisoner is the victim of unfortunate ancestral conditions from which he can never escape; hị mother is feeble-minded, and his career has been one of continuous difficulty; sometimes not criminal in its tendency but always disobedient and unmanageable. I believe his case should be considered by the Board of Eugenics.

"CHAS. A. MURPHY, Warden." Exhibit B.

(Order of Sterilization.)

STATE BOARD OF EUGENICS. Selling Building.

Portland, Oregon, Jan. 7, 1918.

To Chas. A. Murphy, Warden,

State Penitentiary,

Salem, Oregon.

I.N RE CHESTER VANDERPOOL PRISONER NO. 6770.

At a regular meeting of the Oregon State Board of Eugenics, held December 20, 1917, and after full and complete examination of the above named inmate, it is the decision of the Board that he be sterilized by vasectomy. This notice constitutes an order to that effect, said order to be carried out as provided in Section 9, Chapter 279, Session Laws of 1917 .

(Signed): ROBERT E. L. HOLT, Secretary.

In reply to the question, What are the medical and eugenical values of the statute? Mr. Murphy wrote: "This statute prevents the bringing into the world of mental defectives by feeble-minded persons and those of criminal tendencies that are very pronounced. Regarding its eugenical value, the law has been in operation so short a time that 1 am unable to say." March, 1918.

(b) L. H. Compton, Warden. "Cases for sterilization are referred to the State Board of Eugenics by the Warden. The prisoners are then given a hearing before this Board. The two prisoners recently castrated were released shortly after the operation and we have had no chance to study the effects.

"I believe this is the only way to handle feeble-minded, insane, sexual perverts, etc. It stops the breed, which is the desired result although its effect on the individual is usually very beneficial." January, 1921.

\section{SOUTH DAKOTA.}

The statute dates from 1917. Present status (January 1, 1922): Inactive. One (1) state institution is subject to the act, but eugenical sterilizing operations have not yet been instituted. The institution subject to the act is:

1. State Institution for Feeble-

$$
\text { Vasectomy MALES }
$$$$
\text { _... FEMALES }
$$$$
\text { Salpingectomy Orariotomy }
$$

Total Minded, Redfield .......... Total to January $1,1921 \ldots \overline{0}$

$L_{0}^{0}$

$\begin{array}{cc}0 & 0 \\ - & 0\end{array}$




\section{Notes on the Enforcement of the Eugenical} Sterilization Law in South Dakota.

In this state the law applies to one institution only but the administrative authority of this institution has never made use of it.

In response to inquiry the following information and opinion were given:

In South Dakota the sterilization statute is applicable only to:

\section{WASHINGTON.}

The statutes date from 1909. Second statute, 1921. Present status (January 1, 1922): Theoretically operative, having been sustained by the State Supreme Court in 1910, but practically a dead letter. Second statute
1. State Institution for Feeble-Minded, Redfield. Dr. J. K. Kutnewsky, Superintendent, reported that as yet nothing had been done about the enforcement of this law, because there was some question concerning its constitutionality. He declined to comment upon its eugenical value, and stated that its medical value was questionable. May, 1918.

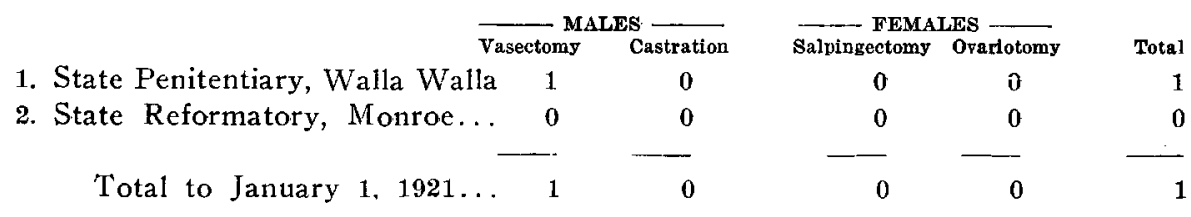

Notes on the Enforcement of the Eugenical Sterilization Law in Washington.

The sterilization law of 1909 in this state is like the law of Nevada, for which it served as a model, purely punitive in its motives and application, but unlike the case in Nevada, the Supreme Court of the State of Washington upheld its constitutionality.

In Washington the first sterilization law was applicable only to criminal court cases, and only by implication to the custodial institutions-the State Penitentiary and the State Reformatory which are the executive agents of the court orders.

The second law, that of 1921, is of much wider scope, applying to inmates of institutions for the feeble minded and insane as well as of the State Penitentiary and State Reformatory. It is purely eugenic and therapeutic in its motives.

In response to inquiry the following information and opinions were given:

1. Washington State Penitentiary, Walla Walla.

Superintendent Henry Drum says: "In the case of Peter Feilen no action has been taken as yet to carry into effect that provision of the sentence calling for vasectomy; the status of the case being that it has been held in abeyance until the expiration of the time for appeal to the United States Supreme Court, which, as I understand it, will be in September of this year. There are petitions from friends of this man who do not believe he was justly convicted or that the crime, not tested by court. Two (2) state institutions, as the executive agents of the criminal courts, are subject to the first act. They have performed eugenical sterilizing operations as follows:

of which he was convicted, ever occurred. What the final result will be cannot at this time be determined.

"We have one other case here-that of a young man of doubtful normal mental condition. In this case the commitment contains an order that an operation be performed upon the said William Henry Harrison Revenue for the prevention of procreation, and said operation not to be performed until further order from the Court.' It might appear that the intention of the Court, in making the provision that the operation should not take place until further orders of the Court, was that it should be a saving clause in the event that the young man, now under a life sentence, should be discharged from prison." August 23, 1913.

\section{State Reformatory, Monroe.}

(a) Donald B. Olson, Superintendent. "Section 35 of 1909 Laws of Washington has not been carried out as far as it affects the inmates of this institution. We have no authority from the courts to perform such an operation, consequently none has been performed. I am in favor of the law when carefully worked out." February, 1918.

(b) P. H. Raymond, Chaplain. "I am heartily in favor of the sterilization statute, if worked out with judicial care. I am also anxious to know if the law has been operated in other states and with what results, and if within your powers to supply any information concerning it, I would appreciate your sending it." February, 1918. 
(c) Geo. P. Dubuque, Secretary. "Although we believe in sterilization it has never been done at this institution." January, 1921.

\section{IN THE COURTS.}

Honorable George B. Holden, Judge of the Superior Court, County of Yakima, State of Washington, makes the following statement of two cases recently before his court :

(a) "The case in question is that of State of Washington vs. John Hill, upon whom I suspended judgment and suggested an operation for the prevention of procreation. This, however, was merely a suggestion, and not a part of the judgment in the case.

"On January 30, 1922, John Hill pleaded guilty to the crime of grand larceny. The theft was of a number of hams, which he took by stealth because of his impoverished condition; their value, however, being more than $\$ 25.00$, he was guilty of grand larceny and subject, under our indeterminate sentence law, to not less than six months, nor more than fifteen years, imprisonment in the state penitentiary, which was the judgment of the court and the judgment was suspended during good behavior. The facts of the case, which led to the suggestion that he submit to a voluntary operation for the prevention of procreation, and to which suggestion he assented after the details of the operation (vasectomy) and its results were explained to him, are as follows:

"Hill is a Russian beet sugar laborer, with a wife and five children, all under the age of eleven years. He is robust physically, about forty years of age, and his wife some years his junior. Hill, his wife and five children are all mentally subnormal, even for their situation in life. For many months the children have been half starved and half clothed. It was apparent that he could not provide them with the common necessities of life, to say nothing of giving them any sort of advantages in the world by way of education or other preparation to battle for themselves. He was forced to steal to prevent them from starvation, or to apply for public aid. The case was brought to the attention of the authorities through the dis- covery of the theft of the hams, since which time he and his family are partially dependent upon public charity, and without the addition of more children to the family, will undoubtedly continue to be more or less a public charge; with more children, the extent of demand for public charity will be increased. Under these conditions, the operation was suggested to him and after explanation, as before stated, he consented."

(b) "I had occasion to order such an operation upon the defendant in the case of State vs. Chris McCauley on the 12th day of December, 1921. The history of this case, so far as is known, is as follows:

"McCauley was convicted in King County, Washington, February 25, 1918, under the name of Harry Taylor, of the crime of burglary in the second degree, and sentenced to the State Reformatory, at Monroe, Washington. Some time subsequent to his sentence, it was learned by the Board of Control, that he had previously been convicted of a felony in connection with dynamiting a store at Cle Elum, Washington, and had served five years in the State Penitentiary at Walla Walla, for this offense; thereupon he was ordered transferred from the State Reformatory to the State Penitentiary, at Walla Walla, from which latter institution he was later paroled, and on September 17, 1921, he was convicted in this (Yakima) county of the crime of grand larceny. Thereupon he was informed against as an habitual criminal and convicted by a jury on November 30, 1921, and sentenced by me on December 12, 1921, to the State Penitentiary, at Walla Walla, for a period of not more than twenty years, nor less than ten years, and an operation was directed to be performed upon him by the warden of the penitentiary for the prevention of procreation.

"This man, about 35 years of age, is subnormal mentally and has every appearance and indication of immorality. $\mathrm{He}$ has a strain of negro blood in his veins and has a lustful and disgusting appearance.

"The subject of sterilization is one that must receive more attention from the American public." March 10, 1922.

\section{WISCONSIN.}

The statute dates from 1913. Present status (January 1, 1922). Active. Eleven (11) state institutions, also the several county institutions of the same types, are subject to the act (see p. 31, chapter III), although the State Board of Control feels that neither institutions 6,7 or 8 below listed, should be thus included. The state institutions have performed eugenical sterilizing operations as follows: 


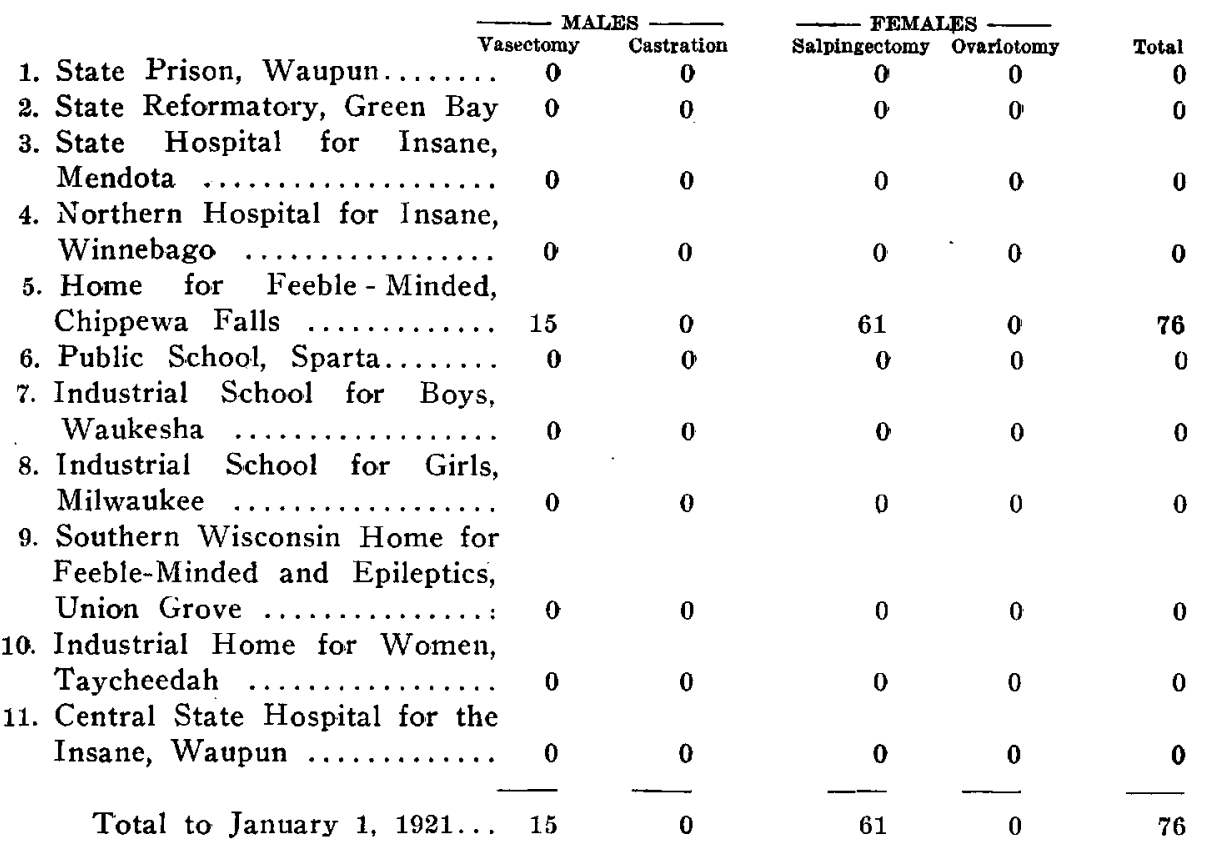

Notes on the Enforcement of the Eugenical Sterilization Law in Wisconsin.'

Although the Wisconsin law is applicable to several types of institutions, the State Board of Control has thus far used it only in cases in the State School for the FeebleMinded at Chippewa Falls. In this they are acting conservatively and because it is generally recognized that so far as degeneracy is concerned, feeble-mindedness is more readily diagnosed than insanity and also when the problem of social menace due to worthless offspring is involved, feeblemindedness deserves to be dealt with before insanity. The extension of this law to other institutions is a matter of conservative development and doubtless will be made when the state administrative system is prepared for it. The law seems to be working intelligently and effectively.

From the Report of the Wisconsin State Board of Control, 1917-1918, pp. 6 and 7.

"At various times since the legislature gave such authority; operations have been performed on inmates of both sexes of the Home for Feeble-Minded. There have been but few objections by the parents or relatives, and frequently the parents have requested that the operation be performed. Fifty-eight inmates have been sterilized, divided about equally between the sexes. Many of these, especially the females, have

Institutions 4, 8 and 10 did not supply historical comment.

been paroled, and most of them are doing well. But few have been returned to the home.

"It is the intention of the Board to continue these operations."

\section{Excerpts from letters of the State Board} of Control.

"I note that there is a question upon which you want information, about which you did not write me before; that you are receiving returns from a good many of the state institutions of Wisconsin, which are subject to the sterilization law, but that this state differs from many others having such laws, in that the law is applicable to county institutions.

"Under the sterilization law of Wisconsin we have power to sterilize any chronic insane inmate of a county asylum. We have thirtyfive county asylums in this state with a population of about 6,200 . Up to the present time none of the classes which we have power to sterilize have been sterilized except the feeble-minded.

"The Board did not think it wise to proceed with too much haste in the sterilization of mental defectives and it was thought best to sterilize at different times a number of feeble-minded patients and wait until it was determined what effect the operation had upon them. We find that it has little or no effect upon their mental condition.

"We are now placing out in homes some of the feeble-minded persons who have been sterilized. This is done as an experiment to 
determine whether it is advisable and safe to place these persons in homes. Those that have been placed out have only been a short time in homes and it is yet difficult to determine whether the plan is going to be a success. If it is successful, we in time will have quite a large number of feeble-minded persons placed out in homes.

"No report has yet been made upon the sterilization of defectives, except the reports by the superintendent of the Home for the Feeble-Minded and the report which is included in our last biennial report.

\section{“M. J. TAPPINS, Secretary." \\ February, 1918.}

"Since the date of the last report we have caused about one hundred and fifty persons to be sterilized. All of these were inmates of the Home for the Feeble-Minded and divided about equally between the sexes. A number of those that had been sterilized have been released from the Home, especially females. There have been no bad results from the operations; so far as we can determine, the operation has little or no effect upon the mentality of the individual.

"It is the intention of the Board to continue to exercise the authority given by statute to perform these operations. We have not yet extended it to the criminal classes; but that will probably be done in the. future. M. J. Tappins, Secretary." February, 1919.

"The correct number of operations for sterilization that have been performed is $\mathbf{7 6}$, of which 16 were males and 60 females. There was an error in our report of 1918 in the number.

"During the war period practically no operations were performed because the surgeon who did the operating was engaged in war work, A number of the inmates who were sterilized have been placed out in homes and are getting along reasonably well, and thus far the result of the operations has been satisfactory to the Board. Of course, the operation results in little or no change in the mental condition of the person operated upon.

"Thus far no action has been brought in the courts to determine the constitutionality of the sterilization law, and we hope that no such action will be brought, because in many of the states where actions have been brought the law has been declared unconstitutional. We do not want such a result here in Wisconsin because we believe that the sterilization of mental defectives will have a tendency to reduce the number in this class. M. J. Tappins, Secretary." February, 1920.

"With reference to the organization of Sterilization Boards which may have been appointed or are now authorized to enforce the Sterilization Law in Wisconsin, you are advised that no permanent board has been created."

"The State Board of Control from time to time appoints one surgeon and alienist who together with the Superintendent of the institution act as a board in making a physical and mental examination upon the inmates committed to our Wisconsin Home for the Feeble-minded and upon their findings and recommendations, this board authorizes that an operation for the prevention of procreation may be performed."

H. W. WILLIAMS, Statistician,

February, 1921.

"Although the act authorizes this Board from time to time to appoint one surgeon and an alienist whose duty it shall be in conjunction with the Superintendent of Institutions having charge of the criminal insane, feeble-minded and epileptic to examine into their mental and physical condition and report as to the advisability of performing the operation for the prevention of procreation, we have not as yet carried these investigations beyond the inmates of our Wisconsin Home for the Feeble-Minded and at the present time it is the policy of this Board not to go beyond this class of people in the sterilization of mental defectives."

"Since this law has been in effect there has been no legal action introduced in any of the Courts or any adverse opinions rendered by the Attorney General of this state, which would in any way have a tendency to defeat the operation of the law." H. W. WILLIAMS, Statistician.

February, 1921.

In response to inquiries the following information and opinions were given:

1. State Prison, Waupun. Wisconsin State Prison (only signature given) "Take our name from your inquiry list." January, 1921.

2. State Reformatory, Green Bay. Dr. C. O. Latham, Physician, reports that, medically he has had no opportunity to follow case histories, but that eugenically the statute is of undoubted value. January, 1918. 
3. State Hospital for Insane, Mendota. F. I. Drake, M. D., Superintendent. When asked concerning his judgment in reference to the general policy of eugenical sterilization, Dr. Drake's laconic reply was: "Excellent." January, 1921.

5. Home for Feeble-Minded, Chippewa Falls. (a) Dr. A. W. Wilmarth, Superintendent. "*** I might add that the statute legalizing sterilization in this state was passed.for the following reasons:

"It was found that the high-grade imbecile almost invariably cohabited with those who were also defective to some degree. Sometimes this was legalized by marriage, sometimes not. In every case, the offspring were generally defective. It was found that these physically strong and mentally cunning defectives could not be sequestrated successfully without curtailing their freedom of action more than was desirable. Many elope, others are discharged by that "court of last resort," a jury of laymen who know nothing about them. Parole was followed, more often than not, by the birth of more children. The operation here is primarily to prevent conception. No organ is removed except if found actually diseased, so that the health of the patient demands it. A small oortion is removed from the cord, or tube, sufficient to make conception impossible. In that way, we hope, and expect, to be able to parole some to their friends where they can live a broader life than here, and where in case of a single indiscretion, should they escape the vigilance of their guardians, it would not be followed by the birth of offspring whose whole life would be a tragedy." February, 1918.

(b) “*** Some of these operations were made at the request of parents, and none of them against the relatives' wishes. Where objections were filed, no operation has been performed.

"*** The cases are so uniform that I can see no advantage in taking time for separate reports. The operation was limited to section, and ligating of both ends of the spermatic cords in the males, and the tubes in the females.

"In the brief time which has elapsed, we have seen no change in the mental or physical characteristics of these cases, nor do we see any reasons for expecting any.

"The sole reason for operation is to prevent conception; many of our wards, coming from reasonably good homes, with par- ents who can, to a considerable extent, guard their children. This operation will prevent the serious results which may occur from even a single indiscretion. ***" February, 1918.

(c) In response to inquiry concerning the medical and eugenical values of the statute, Dr. Wilmarth replied: "No operations were undertaken that were not primarily for the purpose of sterilization. After operations we do not expect these cases to be able to turn over to the public ten sub-normal children, as one women has in this state. Some families have sent four and five. We hope to diminish the number who need care, until it more nearly approaches the number we are able to care for. We expect no other results." February, 1918.

(d) A. L. Beier, M. D. Superintendent. "The procedure as outlined in the provisions of the Wisconsin Sterilization Act is followed in this institution. The production of sterility in mental defects by surgical methods is the most powerful and effective means that we have at our disposal to prevent their propagation."

"During the last biennial period or from July 1, 1918 to June 30, 1920, 17 inmates were operated upon for the prevention of procreation under the Sterilization Act. In each case their recovery from the operation was satisfactory and complete and as was expected no marked change was noted in their mental condition." February, 1921.

6. 'Public School, Sparta. L. H. Prince, Superintendent. "I have no suggestions to make at the present time, but $I$ am in favor of the general policy of eugenical sterilization." January, 1921.

7. Industrial School for Boys, Waukesha. Oscar Lee, Superintendent. "Sterilization is not practiced in this institution."

January, 1921.

9. Southern Wisconsin Home for FeebleMinded and Epileptics, Union Grove. $H$. C. Werner, Superintendent. "No cases were selected in this institution for sterilization because we have at present no hospital facilities for such work. It is advisable in selected cases only." January, 1921.

11. Central State Hospital for the Insane. Waupun. Dr. Rock Sleyster, Superintendent. "This is to advise you that our State Board of Control has not ordered any of this work applied to this institution. The only place in Wisconsin where anything has been done is the Home for the Feeble- 
Minded at Chippewa Falls." February, 1918.

Milwaukee County Hospital for Mental Diseases. Wauwatosa. Dr. A. W. Young, Superintendent, reports that there have been no operations under this Act in his institution. He holds the opinion that the medical value of the statute is good, and that eugenically it would work out for the benefit of humanity. January, 1918.

\section{SUMMARY OF EUGENICAL STERI- LIZATION IN THE SEVERAL STATES.}

\section{A. Statistical Summary to January 1, 1921.}

(a) States and Institutions.

1. Total number of states which have or have had eugenical sterilization laws

(a) Number of states with laws still

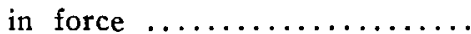

(b) Number of states in which the courts have held the sterilization laws unconstitutional.....

(c) Number of states which have repealed their sterilization laws, after having been declared unconstitutional

2. Number of states in which sterilization bills have been vetoed or sterilization laws revoked by referendum. .

3. Total number of state* institutions which are or have been legally entitled to practice eugenical sterilization $\ldots \ldots \ldots \ldots \ldots \ldots \ldots \ldots . . . . . .$.

4. Number of state institutions at present legally entitled to surh practice.

5. Number of such state institutions which, to a greater or less extent have practiced legalized eugenical

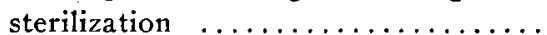

6. Number of state institutions which were or are entitled to such practice but which have not made use of it.

7. Greatest number of operations performed by any one institution (Southern California State Hospital, Patton) $\ldots \ldots \ldots \ldots \ldots \ldots \ldots \ldots \ldots \ldots \ldots, 009$

8. Number of states having eugenical sterilization laws unattacked by the courts but which have made no use of them (South Dakota) ..........

9. Number of states in which all of the state institutions authorized to practice eugenical sterilization have made use of it. (Oregon).............. (b) Total number of Eugenical Stcrilj. zation Operations in all Fifteen (15) States from beginning of legalized operations, in 1907 , to January $1,1921 \ldots \ldots \ldots \ldots \ldots \ldots ., 233$

1. By Sex.

Males (vasectomy 1,781; castration

72) $\ldots \ldots \ldots \ldots \ldots \ldots \ldots \ldots \ldots \ldots \ldots, 853$

Females (salpingectomy 1,280; ovari-

otomy 100$) \ldots \ldots \ldots \ldots \ldots \ldots \ldots \ldots \ldots \ldots \ldots \ldots \ldots \ldots \ldots, 380$

Total $\ldots \ldots \ldots \ldots \ldots \ldots \ldots \ldots, 233$

2. By Radicalness of Operation.

Less Radical (vasectomy 1,781 ; salpingectomy 1,280$) \quad \ldots \ldots \ldots \ldots \ldots 3,061$

More Radical (castration 72; ovariotomy 100$) \ldots \ldots \ldots \ldots \ldots \ldots \ldots, 172$

Total $\ldots \ldots \ldots \ldots \ldots \ldots \ldots \ldots, \overline{3,233}$

3. By Classes.

In Institutions for the

1. Feeble-minded $\ldots \ldots \ldots \ldots \ldots, 403$

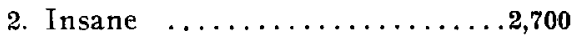

3. Criminalistic $\ldots \ldots \ldots \ldots \ldots \ldots, 130$

Total $\ldots \ldots \ldots \ldots \ldots \ldots \ldots \ldots . . ., 233$

4. By States.

1. California $\ldots \ldots \ldots \ldots \ldots \ldots \ldots, 2,558$

2. Connecticut $\ldots \ldots \ldots \ldots \ldots \ldots \ldots, 27$

3. Indiana $\ldots \ldots \ldots \ldots \ldots \ldots \ldots .120$

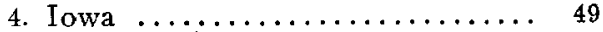

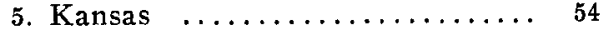

6. Michigan $\ldots \ldots \ldots \ldots \ldots \ldots \ldots \ldots$ 1

7. Nebraska ................. 155

8. Nevada .................. 0

9. New Jersey $\ldots \ldots \ldots \ldots \ldots \ldots \ldots$. 0

10. New York ............... 42

11. North Dakota ............... 23

12. Oregon $\ldots \ldots \ldots \ldots \ldots \ldots \ldots \ldots, 127$

13. South Dakota ............... 0

14. Washington $\ldots \ldots \ldots \ldots \ldots \ldots \ldots$

15. Wisconsin ............... 76

Total $, \ldots \ldots \ldots \ldots \ldots \ldots \ldots \ldots, 233$

5. By Time.

Prior to January 1, 1919:

Males (vasectomy 1,376; castration 25) $\ldots \ldots \ldots \ldots 1,401$

Females (salpingectomy 836 ; ovariotomy 80$) \ldots 916$

Between January 1, 1919 and

January 1, 1921:

Males (vasectomy 405; castration 47) .......4 452

Females (salpingectomy 444 ; ovariotomy 20)... 464

Total since beginning, in 1907, of legalized sterilization..... 3,233
* In Michigan, New Jersey and Wisconsin, certain types of county and other municipa institutions are, or were, subject to the act. 


\section{B. Descriptive Summary.}

Among the fifteen states which have enacted eugenical sterilization statutes the law is still on the statute books, unattacked by the courts and therefore still available for use, in the following nine states: California, Connecticut, Iowa, Kansas, Nebraska, North Dakota, South Dakota, Washington, and Wisconsin. California, Connecticut, Kansas, Iowa, and Washington, have each enacted more than one eugenical sterilization statute.

In California and Nebraska the law is functioning in a very satisfactory manner. In Connecticut, North Dakota and Wisconsin, similarly, the law is being applied without challenge in a satisfactory manner but to a very limited extent. In Washington and Nebraska special executive machinery of proven competency is entrusted with the enforcement of the sterilization law. In Kansas and Iowa it has fallen into disuse. In South Dakota the statute is practically a dead letter.

In Iowa the law of 1913 was declared unconstitutional; it was repealed and re-enacted in new, and apparently constitutional form, in 1915. In New York the law was declared unconstitutional by the courts (1918) and repealed (1920), but has not yet been re-enacted by the Legislature. In New Jersey, Nevada, Michigan, Indiana, and Oregon, the laws were declared unconstitutionl by the courts but are still on the statute books, dead letters. In the State of Washington litigation resulted in upholding the constitutionality of a very drastic eugenical and punitive sterilization law.

Eugenical sterilization laws have been vetoed by the Governors of Pennsylvania (1905, 1921), Oregon (1909), Vermont (1913), Nebraska (1913), and Idaho (1919), subsequently, however, Oregon (1917), and Nebraska (1915) enacted successful laws. In Oregon also, a former sterilization law was revoked (1913) by referendum.
In analyzing the tables of this chapter it will be noticed that under the law thus far there have been eugenical sterilizations in only State Institutions for the (1) insane, (2) feeble-minded and (3) criminalistic. No eugenical sterilization operations have thus far been performed in-

(a) State Institutions for the (1) inebriates, (2) diseased, (3) blind, (4) deaf, (5) deformed, (6) dependent, (7) epileptic, nor in

(b) County, Municipal or Private Institutions for any type of the socially inadequate, nor

(c) Among the socially inadequates and cacogenic individuals in the population at large.

\section{PRACTICAL ASPECTS.}

The extension of the provisions of the sterilization law to all cacogenic persons of a given legal standard, whether within custodial institutions or in the population at large, is both a legal and a practical requirement for eugenical effectiveness.

In the matter of legal authorization and control of eugenical sterilization it may be safely concluded that the experimental period is rapidly passing. It is now known what attitude the courts generally will take toward specific elements in laws authorizing sterilization. Also the practical eugenical standard for sterilization is fairly well established. In any particular case this standard can be scientifically applied in a satisfactory manner by medical diagnosis and eugenical field work. In such 'cases it remains, of course, for the courts to determine the legal validity of the facts thus presented and to order or to refuse the application of the law. The nature of administrative machinery which will work and which will fail is, from the experiments already made, fairly well known, so that if the principle of eugenical sterilization has public support, practically any state legislature can, if it chooses, enact a functioning law. (See Model Sterilization Law, Chapter XV.) 


\section{CHAPTER V.}

\section{ANALYSIS OF THE STERILIZATION LAWS BY SUBJECT.}

1. The Motives of the Sterilization Statutes.......................... 99

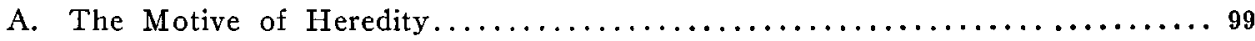

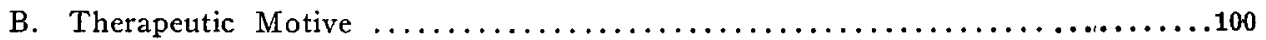

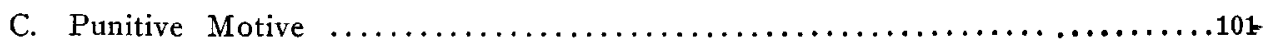

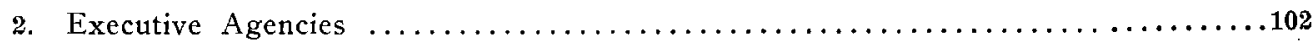

3. Provisions for Making Family History Studies....................... 104

4. Biological Criteria for Determining the Applicability of the Law to a

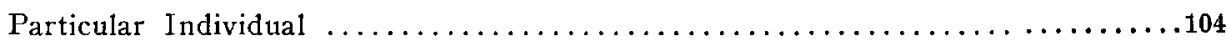

5. Court Procedure Provided by the Several Sterilization Statutes..............107

6. Legal Counsel for the State and for Persons Nominated for the Operation ..........110

7. Is the Consent of the Patient or Guardian a Necessary Pre-requisite to

Legal Eugenical Sterilization?...............................110

8. Type of Operation and Manner of its Performance....................111

9. Bad Biology in the Eugenical Sterilization Statutes...................113

10. Mandatory and Optional Elements in the Laws........................

11. Sexual Sterilization of Criminals............................

12. Legal Liability of Executive Agents and Surgeons......................

13. Punishment for Dereliction in Executing the Law....................125

14. Punishment for the Illegal Use of Sexual Sterilization....................125

15. The Legal Aspect of Sexual Sterilization for Therapeutic Purposes............127

16. The Sexual Sterilization of Inmates of Custodial Institutions Prior to

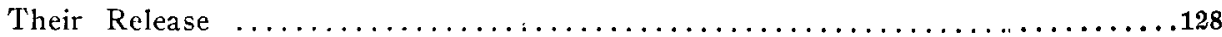

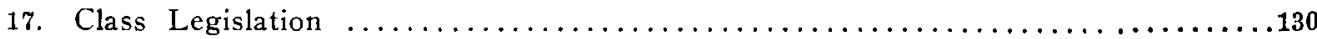

18. What Constitutes Due Process of Law in Eugenical Sterilization?............132

19. Records and Reports Required by Law .........................

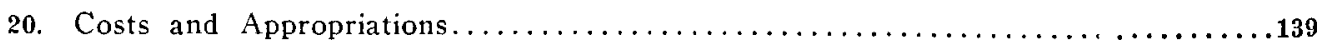


1. THE MOTIVES OF THE STERILIZATION STATUTES.

By implication all of the sterilization statutes are eugenical. Still the three motives of eugenical betterment, therapeutic value to the patient, and punishment for crimes involving moral turpitude or confirmed criminalistic tendencies, are, in different statutes, variously combined, while in one state, Nevada, the law is purely punitive. Also in Washington the first statute, 1909, was purely punitive, but the second, 1921, is primarily eugenical. The motive of human sterilization as authorized by law should be purely eugenical-that is, it should seek to improve the racial qualities of future generations.

\section{A. The Motive of Heredity.}

So far as the recognition of heredity as a factor in determining social adequacy on the part of individuals is concerned, we find the following provisions in the statutes:

1. INDIANA. (Preface) "An act to prevent procreation of confirmed criminals, idiots, imbeciles and rapists $*^{* * \prime}$ “*** Whereas, heredity plays a most important part in the transmission of crime, idiocy, and imbecility: ***"

2. WASHINGTON. First Law: No reference.

Second Law (Preface) "An Act to prevent the procreation of feeble-minded, insane, epileptic, habitual criminals, moral degenerates and sexual perverts ***"

(Section 1.) “*** who are persons potential to producing offspring who, because of inheritance of inferior or anti-social traits, would probably become a social menace or wards of the State."

3. CALIFORNIA. Second Law: This statute applies to inmates of state institutions who are afflicted with hereditary insanity or incurable chronic mania or dementia.

Amendment to Second Sterilization Law: This amendment emphasizes the relation of heredity to social degeneracy by including in reference to the specifications of inmates of institutions subject to the act the following new phrases: (Section 2) "**** who is afflicted with mental disease which may have been inherited and is likely to be transmitted to descendants, the various grades of feeblemindedness, those suffering from perversion or marked departures from normal mentality or from disease of a syphilitic nature * * *"

4. CONNECTICUT. (Section 1) "**** if in the judgment of a majority of said board procreation by any such person would produce children with an inherited tendency to crime, insanity, feeble-mindedness or imbecility ***."

5. IOWA. First Law (Preface) "AN ACT to prevent the procreation of habitual criminals, idiots, feeble-minded and imbeciles ***" (Section 1) "*** that procreation by any such inmate would produce children with a tendency to disease, crime, insanity, feeble-mindedness, idiocy or imbecility $* * *$ "

Second Law (Preface) "*** relating to the prevention of the procreation of criminals, rapists, idiots, feeble-minded, imbeciles, lunatics, drunkards, drug-fiends, epileptics, syphilitics, moral and sexual perverts, and diseased and degenerate persons $* * *$ "

(Section 1) “*** that procreation by any such inmates would produce children with a tendency to disease, deformity, crime, insanity, feeble-mindedness, idiocy, imbecility, epilepsy, or alcoholism ***”

Third Law (Preface) "**** to prevent the procreation of the insane, idiots, imbeciles and feeble-minded ***" (Section 1) "*** that it is better for the interests of *** and society ***"

6. NEW JERSEY (Préface). "WHEREAS, heredity plays a most important part in the transmission of feeble-mindedness, epilepsy, criminal tendencies and other defects ***"

7. NEW YORK (Section 351). Referring to the inmates of institutions and examinations of them by the board, the law provides, "*** if procreation by any such person would produce children with an inherited tendency to crime, insanity, feeble-mindedness, idiocy or imbecility ***"

8. NORTH DAKOTA (Preface). "AN ACT to prevent procreation of confirmed criminals, insane, idiots, defectives, and rapists ***" (Section 1) "**** or that procreation by such inmate would likely result in defective or feeble-minded children with criminal tendencies ***" (Section 11) "Whereas, heredity plays a most important part in the transmission of crime, insanity; idiocy, and imbecility, and our institutions for degenerates are overcrowded on account of the lack of adequate means of checking the ever-increasing numbers of this class; and whereas, there is now no provision in law authorizing an operation for the sterilization of defective persons, this act shall take effect and be in force from and after its passage and approval," 
9. MICHIGAN (Section 2). “*** if procreation by any such person would produce children with an inherited tendency to insanity, feeble-mindedness, idiocy or imbecility $* *^{*} *$ "

10. RANSAS. First Statute (Preface). "An act to prevent the procreation of habitual criminals, idiots, epileptics, imbeciles, and insane, and providing a penalty for the violation thereof." (Section 1) "*** procreation by any such inmate or inmates would produce children with an inherited tendency to crime, insanity, feeble-mindedness, epilepsy, idiocy, or imbecility ***."

Second Statute (Preface) "An act to prevent the procreation of habitual criminals idiots, epileptics, imbeciles and insane ***" (Section 1) “*** procreation by any such inmate would be likely to result in defective or feeble-minded children with criminal tendencies $* * * "$

11. WISCONSIN. This statute is eugenical by implication in that its preface states: "An act ${ }^{*} *$ relating to the prevention of criminality, insanity, feeble-mindedness, epilepsy $* * * "$

12. NEBRASKA. (Section 3) “*** that such an inmate is capable of bearing or begetting offspring, that children borne or begotten by such inmate would inherit a tendency to feeble-mindedness, insanity, or degeneracy, that such children would probably become a social menace and that procreation by such inmate would be harmful to society $* * * \cdots$

13. OREGON. (Preface) "An act to prevent the procreation of feeble-minded, insane, epileptic, habitual criminals, moral degenerates and sexual perverts ***" (Section 2) "*** who are persons potential to producing offspring, who, because of inheritance of inferior or antisocial traits, would probably become a social menace, or a ward of the State."

14. SOUTH DAKOTA. (Preface) "An act entitled, An Act for the Prevention of the Procreation of Idiots, Imbeciles and FeebleMinded Persons. (Section 2) “*** that the procreation by any of said inmates would produce children with a tendency to disease, feeble-mindedness, idiocy, or imbecility ***"

B. The Therapeutic Motive."

If for sound medical reasons the physicians and surgeons of a custodial institution find that an operation involving the

i See also page 127. destruction of the reproductive functions would be beneficial to any particular inmates, certainly in no state in the Union would it be legally beyond the province of the authorities of the particular institution to order such an operation or treatment, provided the ordering of operations or treatments of equally serious surgical sequence, but which do not involve the destruction of reproductive functions, might legally be ordered by such same authority. Nevertheless the statutes have often seen fit to add a therapeutical motive to the eugenical one which actuates most of the laws in relation to sexual sterilization.

1. INDIANA. No direct reference.

2. WASHINGTON. First. Law: No direct reference.

Second Law (Section 3) "*** no person shall be emasculated under the authority of this act except that such operation shall be found to be'necessary to improve the physical, mental, neural or psychic condition of the inmate."

3. CALIFORNIA. First Law (Section 1) "*** would be beneficial and conducive to the benefit of the physical, mental or moral condition of any inmate ***"

Second Law (Section 2) " *** it will be beneficial and conducive to the benefit of the physical, mental or moral condition of any recidivist ***”.

4. CONNECTICUT. (Section 1) “*** if the physical or mental condition of any such person will be substantially improved thereby ***"

5. NEVADA. No direct reference.

6. IOWA. Second Law (Section 1) "** * or if the physical or mental condition of any such inmate would probably be materially improved thereby ***"."

Third Law (Section 1) " **** that it is for the best interests of the inmate ** "."

7. NEW JERSEY. No direct reference.

8. NEW YORK. (Section 1) “*** or if the physical or mental condition of any such person will be substantially improved thereby ***",

9. NORTH DAKOTA. (Section 1) "*** whenever the warden, superintendent *** shall certify in writing that he believes the mental or physical condition of any inmate would be improved thereby ***"

10. MICHIGAN. (Section 2) "**** or if the physical or mental condition of any such person would be improved thereby * * "." 
11. KANSAS. First Law (Section 1) “*** or if the physical or mental condition of any such person will be materially improved thereby ***"

Second Law. No direct reference.

12. WISCONSIN. No direct reference.

13. NEBRASKA. No direct reference.

14. OREGON. (Section 3) "**** or if the physical or mental condition of any such person will be substantially improved thereby ****,

15. SOUTH DAKOTA. (Section 2) "*** or if the mental condition of any such inmate will probably be materially improved thereby ***"

\section{Punitive Motive.}

1. INDIANA. No reference.

2. WASHINGTON. First Law ** ** the Court may, in addition to such other punishment or confinement as may be imposed, direct an operation to be performed upon such person for the prevention of procreation $* * * \cdots$

Second Law: Although this law is primarily not punitive in its motive, it applies to (Section 10) $"{ }^{* * * *}$ criminals, who have been convicted three or more times of a felony and sentenced to serve in the penitentiary therefor."

3. CALIFORNIA. First Law: It is doubtful whether the application to criminals of sterilization under this statute is punitive, or is meant only to establish a criterion for locating persons who are constitutional degenerates. (Section 1) "Provided, that in the case of an inmate or convict confined in any of the state prisons of this state, such operation shall not be performed unless the said inmate or convict has been committed to a state prison in this or in some other state or country at least two times for some sexual offense, or at least three times for any other crime, and shall have given evidence while an inmate in a state prison in this state that he is a moral and sexual pervert; and provided further, that in the case of convicts sentenced to state prison for life who exhibit continued evidence of moral and sexual depravity, the right to asexualize them, as provided in this act, shall apply, whether they have been inmates of a state prison either in this or any other state or country more than one time."

Following the ruling of the Federal Court in the Iowa case, it is probable that if the above reference were punitive in any degree, it would be declared to be a bill of attainder, and would render the act unconstitutional.

Second Law. (Section 2) "*** provided, that such operation shall not be performed unless the said recidivist has been committed to a state prison in this or some other state or country at least two times for rape, assault with intent to commit rape, or seduction, or at least three times for any other crime or crimes, and shall have given evidence while an inmate of a state prison in this state that he is a moral or sexual degenerate or pervert; and provided, further that in the case of convicts sentenced to state prison for life, who exhibit continued evidence of moral and sexual depravity, the right to asexualize them, as provided in this section, shall apply whether they shall have been inmates of a state prison in this or any other country or state more than one time or not; ***"

The same comment which accompanies the provisions similar to these in the first California law apply equally well to these provisions. The fact that this law in California is functioning so splendidly and that no test case has arisen under it, leads one to incline toward the belief that the above reference to criminals who are subject to the act is meant not to be punitive, but only to establish a criterion for hereditary degeneracy.

4. CONNECTICUT. No reference.

5. NEVADA. "*** the court may, in addition to such other punishment or confinement as may be imposed, direct an operation to be performed upon such person for the prevention of procreation ***"

6. IOWA. First Law (Section 1) "Provided that such operation shall be performed upon any convict or inmate of such institution who has been convicted of prostitution or violation of the law, as laid down in chapter two hundred and sixteen, acts of the thirty-third general assembly, or who has been twice convicted of some other sexual offense, or has been three times convicted of felony, and each such convict or inmate shall be subjected to this same operation of vasectomy or ligation of the Fallopian tubes, as the case may be ***."

Second Law." (Section 1) "Provided that such operation shall be performed upon every convict or inmate of such institution who has been convicted of prostitution or violation of the law as laid down in chapter 
216 of the acts of the thirty-third general assembly, or who has been twice convicted of other sexual offenses, including soliciting, as defined in section 4975 -c of the supplement to the code, 1907 , or who has been twice convicted of a felony, and each such convict or inmate shall be subject to this same operation of vasectomy or ligation of the Fallopian tubes, as the case may be ***."

These provisions were the ones which caused the Federal District Court to declare the Iowa statute a bill of attainder, and a denial of equal protection of the laws. It assumes here that these provisions are purely punitive. Had they been looked upon as in no manner punitive, but as establishing in place of the usual pedigree studies criteria for the determination of that degree of hereditary degeneracy which the state forbids to reproduce itself, then a different outcome might have resulted from the litigation, but the Court took the view that the motive was punitive, and consequently the act was declared unconstitutional.

Third Law. This statute, which repeals the law of 1913 , because the latter was declared unconstitutional, does not apply to inmates of prisons, and furthermore applies only to inmates of hospitals for the insane, and then only with the consent of the patient or his guardian or next of kin.

7. NEW JERSEY. This statute in reference to its applicability to criminals was not tested by the courts, therefore it is difficult to determine whether section 2 is punitive or is meant only to establish a criterion for determining hereditary degeneracy. Section 2 reads: "The criminals who shall come within the operation of this law shall be those who have been convicted of the crime of rape, or of such succession of offenses against the criminal law as in the opinion of this board of examiners shall be deemed to be sufficient evidence of confirmed criminal tendencies."

8. NEW YORK. The situation here is the same as in New Jersey. A part of section 351 reads: "The criminals who shall come within the operation of this law shall be those who have been convicted of the crime of rape or of such succession of offenses against the criminal law as in the opinion of the board shall be deemed to be sufficient evidence of confirmed criminal tendencies."

9. NORTH DAKOTA. No reference.
10. MICHIGAN. No reference.

11. KANSAS. First Law: No reference Second Law: No reference.

12. WISCONSIN. No reference.

13. NEBRASKA. No reference.

14. OREGON. (Section 4) "The purpose of said investigation, findings, and orders of said Board shall be for the betterment of the physical, mental, neural, or psychic condition of the inmate, or to protect society from the menace of procreation by said inmate, and not in any manner as a punitive measure; * * " (Section 10) "The criminals who shall come within the operation of this law shall be those who have been convicted three or more times of a felony in the courts of any state and sentenced to serve in the penitentiary therefor."

It is evidently the intention of this law, as shown in Section 10, to act not as a punitive measure, but as a criterion for locating inmates of prisons who are hereditarily de. generate.

15. SOUTH DAKOTA. No reference.

Sterilization laws should of course apply to degenerates and defectives who have been convicted of crime on the same terms as to persons equally degenerate or defective who have not been sentenced to prison. But the location among prisoners of such individuals should be effected by modern pedigree studies rather than by the rules based upon the number of commitments and the type of crime for which punishment is being meted out; because the latter criterion is not nearly so effective as the pedigree method, but on the other hand most certain in many cases to be mistaken for a punitive measure.

\section{EXECUTIVE AGENCIES.}

The location of persons who are potential parents of socially inadequate offspring and the securing of case history and family pedigree evidence sufficient for legal proof of such parenthood, is such an involved and arduous task that the principal executive agent of a sterilization statute should be a professional eugenicist who should devote all of his time and attention to the duties of his office, and who should be aided by an ample corps of assistants. This officer, the State Eugenicist, would be expected to invoke the operation of the law in particular cases by nominating to the courts of competent jurisdiction certain individuals for eugenical sterilization. When such cases are contested, expert testimony 
must be available for just decisions, at which time trained psychologists, eugenicists, anthropologists and physicians each, within his particular realm of specialization, may be considered competent witnesses. The greatest error which a legislature could make in enacting a just eugenical sterilization statute would be to delegate its enforcement and execution solely. to physicians and surgeons, entirely ignoring the other fields of expert knowledge equally pertinent to the problems in hand with the skill possessed by the practitioner of medicine.

If a sterilization law is meant to be taken seriously, it must contain mandatory features, and consequently its enforcement is much more apt to be effectively carried out if entrusted to particular persons whose principal business is the enforcement of such a statute, than if made an extra duty of an existing body of officers who can give only a portion of their time and attention to the tasks imposed by the new statute.

In examining the sterilization statutes of the 15 states which have thus far enacted such laws, we find the following executive agencies provided:

1. INDIANA. For each subject institution a Committee of Experts, consisting of two skilled surgeons of recognized ability and the regular institution physician. Appointment of committee compulsory.

2. WASHINGTON. First Statute. Judge of the Criminal Court in cases adjudged guilty of carnal abuse of female persons under ten years of age, or of rape.

Second Statute. An institutional Board of Health.

3. CALIFORNIA. First Statute. Board, consisting of superintendent or resident physician, with the general superintendent of state hospitals, and the secretary of the State Board of Health.

Second Statute. (1) For the insane, the State Commission in Lunacy. (2) For recidivists, the resident physician of the particular prison, the general superintendent of state hospitals, and the secretary of the State Board of Health. (3) For "idiots and fools", the medical superintendent of any state hospital.

Third Statute. Same as under the Second Statute.

Fourth Statute. Board of Trustees of Pacific Colony, on a recommendation of the superintendent thereof, "approved by a clinical psychologist holding the degree $\mathrm{Ph}$. D., and a physician qualified to serve" under the act establishing said colony.

4. CONNECTICUT. For each subject institution a board of three surgeons, one of whom is the resident physician of the particular institution. Appointment of board compulsory but not compulsory to bring cases before them.

5. NEVADA. The Criminal Court, in passing sentence for carnal abuse of a female person under ten years of age, or for rape.

6. IOWA. First Statute. Board consisting of the managing officer and surgical superintendent of each institution, with members of State Board of Parole.

Second Statute. Board consisting of the managing officer and surgical superintendent of each institution, with members of State Board of Parole.

Third Statute. Superintendent of any hospital for the insane, and a majority of his medical staff, with the approval of the Board of Control thereof.

7. NEW JERSEY. Board of Examiners consisting of one surgeon, one neurologist, and the State Commissioner of Charities and Corrections.

8. NEW YORK. Board of Examiners consisting of one surgeon, one neurologist, and the State Commissioner of Charities and Corrections.

9. NORTH DAKOTA. For each subject institution, a Board consisting of the chief medical officer of the particular institution, the secretary of State Board of Health, and one competent physician and surgeon.

10. MICHIGAN. For each subject institution, the Board of the particular institution and the physician or surgeon in charge thereof.

11. RANSAS. First Statute. Managing officers of the particular institution in conjunction with competent surgical assistants.

Second Statute. For each subject institution, the chief medical officer of the particular institution, the governing board thereof, and the'secretary of State Board of Health.

12. WISCONSIN. Special Board consisting of one surgeon and one alienist in conjunction with the superintendent of the institution and the State Board of Control.

13. NEBRASKA. Five physicians appointed by the Board of Commissioners of State Institutions from the medical staffs of 
the state institutions, of whom three shall be from the institutions for the feeble-minded and the insane.

14. OREGON. State Board of Eugenics, composed of the State Board of Health, and the superintendents of the several subject state institutions. Secretary of the State Board of Health is ex officio the Secretary of the State Board of Eugenics.

15. SOUTH DAKOTA. State Board of Charities and Corrections, the superintendent of the single subject institution, and the physician thereof.

\section{PROVISIONS (EITHER DIRECT OR IMPLIED) IN THE SEVERAL STATUTES FOR MAKING FAMILY HISTORY OR PE DI GREE STUDIES OF THE PERSONS SELECTED FOR EUGEN- ICAL STERILIZATION.}

Connecticut Law of 1909 (Chapter 209, Section 1). "**** shall examine the physical and mental condition of such persons and their record and family history.

New York Law of 1912 (Chapter 445, Section 2). "*** to examine into the mental and physical condition and the record and family history of the feeble-minded, epileptic, criminal and other defective inmates. * * *"

North Dakota Law of 1913 (Chapter 56, Section 4). "*** shall diligently inquire into the mental and physical condition of each inmate so considered, and as far as practicable into his family history. * * * "

Kansas Law of 1913 (Chapter 305, Section 1). "*** * shall examine the physical and mental condition of such inmate or inmates, the history thereof so far as can be ascertained. * * *

Michigan Law of 1913 (Act No. 34, Section 2). "*** * shall examine the physical and mental condition of such persons and their record and family history so far as the same can be ascertained.

Iowa Law of 1913 (Chapter 187, Acts of the Thirty-fifth General Assembly, Section 1.) “*** to examine into the mental and physical condition, the records and family history of the inmates.

California Law of 1913 (Chapter 363, Section 1). "**" $*$ and who is afflicted with hereditary insanity. * * *"
Nebraska Law of 1915 (Chapter 237, Section 3). “**** to examine into the innate traits, the mental and physical conditions, the personal records, and the family traits and histories of all inmates. * **"

Oregon Law of 1917 (Chapter 279, Section 3). "** * * to examine into the innate traits, the mental and physical conditions, the personal records, and the family traits and histories of all persons so reported as far as the same can be ascertained. ***"

Kansas Law of 1917 (Chapter 299, Section 4). "*** * shall diligently inquire into the mental and physical condition of each inmate so considered, and as far as practicable into his or her family history.

South Dakota Law of 1917 (Chapter 236, Secton 1). "**** to examine into the mental and physical condition, the records and family history of the inmates.

California Law of 1917 (Chapter 489, Section 1). "*** and who is afflcted with mental disease which may have been inherited and is likely to be transmitted to descendants. * * *"

Washington Law of 1921 (Chapter 53, Section 2). "**** to examine into the innate traits, the mental and physical conditions, the personal records, and the family traits and histories of all persons so reported, so far as the same can be ascertained ***,"

\section{THE BIOLOGICAL CRITERIA FOR DETERMINING THE APPLICABIL- ITY OF THE LAW TO A PAR- TICULAR INDIVIDUAL.}

All of the laws state with more or less precision what natural classes are to be included within their scope, but as with all laws, the determination of the application in particular cases must be entrusted to executive and judicial machinery. The law also must lay down certain rules for the guidance of its executive agents in determining what individual persons fall within this class.

The logical plan for determining the eugenical necessity for sexual sterilization is of course to require pedigree studies, and to provide further for the analysis of such studies by persons skilled in the modern science of human genetics. A person within the classes named and who by such a procedure is demonstrated to be a potential parent of defectives, and who is to remain 
in the population at large, should be subjected to eugenical sterilization. It would remain only for the administrative body to determine the facts, after which the application of the law should be automatically effected by court orders.

Most of the existing laws leave much to the discretion and judgment of their executive agents, without requiring pedigree studies. An examination of the several sterilization statutes reveals the following situation:

1. INDIANA. "If, in the judgment of this committee of experts and the board of managers, procreation is inadvisable, and there is no probability of improvement of the mental and physical condition of the inmate, it shall be lawful.

2. WASHINGTON. First Law: Sterilization may be ordered by the court in certain cases, in its discretion. No standards of hereditary degeneracy are laid down.

Second Law: " $* * *$ if in the judgment of a majority of the said Board (institutional Board of Health) procreation by any such person would produce children with an inherited tendency to feeble-mindedness, insanity, epilepsy, criminality or degeneracy, and there is no probability that the condition of such person so examined will improve to such an extent as to render procreation by any such person advisable, or if the physical or mental condition of any such person will be substantially improved thereby, then it shall be the duty of said Board to make an order directing $* * *$ to perform $* * *$ such a type of sterilization as may be deeme best ***",

3. CALIFORNIA. First Law: The Superintendent of an institution, at his discretion, calls into consultation the superintendent of the state hospitals and the secretary of the state board of health, who examine into the particulars of the case, "and if in their opinion, or in the opinion of any three of them, asexualization will be beneficial * * * they may perform the same. * *" (Section 1.)

Second Law: Section 1 requires the careful investigation of all circumstances of the case, and provides for the same consultation and opinion as the earlier statute.

Amendment to: Second Law: This establishes additional standards for limiting the selection of inmates for sterilization to those suffering from certain types of hereditary diseases.
The law establishing the Pacific Colony in California permits the operation upon the recommendation of a superintendent, approved by a clinical psychologist and a qualified physician.

4. CONNECTICUT. In Connecticut the board "*** shall examine the physical and mental condition of such persons and their record and family history, so far as the same can be ascertained, and if the judgment of a majority of said board, procreation by any such person would produce children" of a certain degenerate nature, “** * * then said board shall appoint one of its members to perform the operation * * *." (Section 1.)

5. NEVADA. The court may, in its discretion, in passing sentence for certain crimes, add the punishment of sterilization. There are no legal requirements as to evidence of hereditary degeneracy.

6. IOWA. First Law: This statute calls upon the heads of institutions to examine into the mental and physical condition of the inmates "*** * with a view to determining whether it is improper or inadvisable to allow any of such inmates to procreate * * ", and to call into consultation the members of the state board of parole. "The members of such board and the managing officers and the surgical superintendent of such institutions shall judge of such matters." (Section 1.)

Second Law: This statute follows the first law of 1913 in this respect.

- Third Law: Whenever the superintendent of any hospital for the insane, and the majority of his medical staff, after investigation and examination, agree that it is best "** " said operation shall be performed." (Section 1.)

7. NEW JERSEY. According to this statute, the superintendent of an institution or the board of examiners itself may “** * take evidence and examine into the mental and physical condition of such inmates ***" as are selected for the particular examination. If the board unanimously finds "*** that procreation is inadvisable, it shall be lawful to perform *** an operation of sterilization.

(Section 3.)

8. NEW YORK. The board of examiners must "*** examine into the mental and physical condition and the family history" of the inmates of institutions, "**** and 
if in the judgment of a majority of said board procreation * * * by any particular inmate would produce defectives, the operation is authorized. (Section 351.)

9. NORTH DAKOTA. Whenever the executive officer of an institution certifies in writing "*** that he believes that the mental or physical condition of any inmate would be improved * * * by sterilization, or that procreation by such inmate would produce defective children, it shall be lawful to sterilize the particular inmate. (Section 1.)

10. MICHIGAN. The board of the particular institution "*** shall receive the report of insanity experts, *** examine the physical and mental condition of such persons and their, record and family history so far as the same can be ascertained, and if in the judgment of a majority of said board procreation by such person would produce . * *" defective offspring, the board may direct sterilization.

11. KANSAS. The managing authority of the institution shall examine the physical and mental condition of the inmates and the history thereof, so far as it can be ascertained, and if in the judgment of such authority procreation by any such inmate or inmates would produce children" of a degenerate nature, the said authority shall report “* * * their conclusions with a recommendation to the District court ****. The court shall thereupon hear and determine, the matter whether **** the purposes of this act will be accomplished by such order ***" for sterilization, and "* * shall adjudge that such operation shall be performed." (Section 1.)

Second Law: The superintendent of a custodial institution may certify in writing to the governing board of the institution that he "believes that the mental or physical condition of any inmate would be likely to be improved" by sterilization, and that the offspring of such inmate would be likely "to result in defective or feeble-minded children with criminal tendencies." The board of "examiners shall then "diligently inquire into the mental and physical condition of each inmate so considered and as far as practicable into his or her family history, and for that purpose any member of said board may administer an oath to any witness whom it is desired to examine." (Sections 1 and 4.)

12. WISCONSIN. In this state the board of control submits to a body of experts the names of such inmates of institutions "whose mental and physical condition they desire examined, and said experts and the superintendent of said institution shall meet, take evidence and examine into the mental and physical condition of such inmate **** If such experts and superintendent unanimously find that procreation is inadvisable, it shall be lawful to perform such operation * * *" of sterilization. (Sections 2 and 3.)

13. NEBRASKA. The board of examiners are directed to "examine into the innate traits, the mental and physical conditions, the personal records and the family traits and histories" of all inmates who are about to be discharged or paroled from state institutions, "*** and if after a careful examination and investigation such board of examiners find that such inmate" is capable of bearing or begetting children who would probably "inherit a tendency to feeble-mindedness, insanity or degeneracy, that such children would probably become a social menace, and that procreation by such inmate would be harmful to society * * *," sterilization may be ordered. (Section 3.)

14. OREGON. This statute requires that the executive officers of institutions report quarterly to the State Board of Eugenics all inmates $" * * *$ who are persens potential to producing offspring, who because of the inheritance of inferior or antisocial traits, would probably become a social menace, or a ward of the State." The State Board of Eugenics shall "examine into the innate traits and the mental and physical conditions, the personal records and the family traits and histories of all persons so reported * * *" and shall have power to summon witnesses and administer oaths, "and if in the judgment of a majority of the said Board procreation by any such person would produce children ** *" of a degenerate nature, "*** then it shall be the duty of said Board to make an order directing" the sterilization of the particular inmate.

15. SOUTH DAKOTA. In this state the law requires that the superintendent of the state home for the feeble-minded "examine into the mental and physical condition, the records and family history of the inmates of said institution with a view of determining whether it is improper or inadvisable to allow any such inmate to procreate, and to make an annual report of said examinations to the State Board of Charities and Corrections." It is then the duty of the board to 
examine into the matter for the purpose of determining "whether it is improper or inadvisable to allow any such inmates to procreate ** *." The decision and order is based upon the vote of the majority of the board.

The Michigan statute recognizes the necessity of expert examination and analysis of reports in order to determine proper subjects for eugenical sterilization. It also recognizes the necessity of performing the actual sterilizing operation by trained experts. (Section 3.) "In case an institution has no physician at its head, authority is given to the board of managers to cause such operation to be performed, 'to hire expert physicians to examine and report on the condition of the subject, and to perform the operation with such other assistants as may be necessary: Provided, Before said operation is ordered there shall first be secured from two physicians having qualifications prescribed by law for examiners in insanity a written statement or report that such operation is desirable in the interests of the patient or the good of the community; and, provided further, that these physicians shall be allowed for their services the compensation fixed by the statutes for the examination and certification of an insane person. The several sums necessary to carry out the provisions of this act shall be certified to be correct by the respective boards and shall be paid out of the general fund of the State upon the warrant of the auditor-general."

It is interesting to observe that in several instances the law expects members of the board of examiners, by investigating the mental and physical condition of an inmate, to be able to determine the nature of his hereditary qualities. This, of course, is impossible. Not only must the individual be given a thorough examination, but his pedigree must be studied before, under the existing stage of genetical knowledge at least, it is possible to determine the hereditary nature of the propositus, and consequently possible to designate any particular degenerate as a proper subject for eugenical sterilization. Provisions for the calling of witnesses and the passing of expert opinion are valuable, but the principal stress should be laid upon requirements for family history studies and their analysis by experts, in order to determine whether a particular individual is, within the definition of the standards set by the law, a potential parent of socially inadequate offsprinx.

\section{COURT PROCEDURE PROVIDED BY THE SEVERAL STERIL- IZATION STATUTES.}

As elsewhere stated in these studies, the executive agents of the several sterilization laws have been given three types of procedure: First, executive or ministerial discretion. Second, hearing before or examination by a board or commission in a quasijudicial manner. Third, hearing and trial before an established court of law.

Court procedure is provided by the statutes as follows:

1. INDIANA. No provision.

2. WASHINGTON. First Law: Sterilization may be imposed as an additional sentence in certain criminal cases.

Second Law: The law requires that, after careful investigation into the condition of the subject inmate, the examining board make separate written findings of each case to be preserved in the records of the board and a copy thereof furnished to the superintendent of the institution where such inmate is confined, upon which a copy of the order of said board shall be served on such inmate or his legal guardian. Any such inmate or his guardian desiring to appeal from the decision of the board may take an appeal into the Superior Court, after filing an informal notice thereof with the secretary of said board within fifteen days of the date when notice of the board's decision was served. (Section 6.)

"Upon an appeal being taken, the secretary of the said board where the notice of appeal is filed, must within fifteen days thereafter, or such further time as the court or the judge thereof may allow, transmit a certified copy of the notice of appeal and transcript of the proceedings, findings and order of the board, to the clerk of the court appealed to. The trial shall be a trial de novo at law as provided by the statutes of the state, for the trial of actions at law ***." (Section 7.)

"If the court or jury shall affirm the findings of said board, said court shall enter a judgment, adjudging that the order of said board shall be carried out as herein provided; if the court fail to affirm the decision of said board appealed from, then said order shall be null and void and of no further effect."

3. CALIFORNIA. First Law: No provision.

Second Law: No provision.

Amendment to Second Law and 
Sterilization Provisions of Law Establishing Pacific Colony. No provisions.

4. CONNECTICUT. No. provisions.

5. NEVADA. Sterilization may be imposed as an additional sentence in certain criminal cases.

6. IOWA. First Law. No provisions.

Second Law. Section 2: "Those afflicted with syphilis or epilepsy may apply to the board of parole, or any judge of the district court, and upon order of such board or judge, the operation of vasectomy or ligation of the fallopian tubes may be performed upon such persons."

Third Law. No provisions.

7. NEW JERSEY. The law provides for the examination of inmates of particular institutions by a board of examiners who may in their discretion find that procreation by the particular inmate would be inadvisable. The law continues: (Section 3.) "** * previous to said hearing the said board shall apply to any judge of the Court of Common Pleas, of the county in which said person is confined, for the assignment of counsel to represent the person to be examined, said counsel to act at said hearing and in any subsequent proceedings, and no order made by said board of examiners shall become effective until five days after it shall have been filed with the clerk of the Court of Common Pleas, of the county in which said examination is held, and a copy shall have been served upon the counsel appointed to represent the person examined, proof of service of the said copy of the order to be filed with the clerk of the Court of Common Pleas. All orders made under the provisions of this act shall be subject to review by the Supreme Court or any justice thereof, and said court may upon appeal from any order grant a stay which shall be effective until such appeal shall have been decided. The judge of the Court of Common Pleas appointing any counsel under this act may fix the compensation to be paid him, and it shall be paid as other court expenses are now paid.

8. NEW YORK. The law provides that the board of examiners shall investigate the particular cases and, if such board determines upon sterilization, the following procedure is provided: (Section 352.) "The board of examiners shall apply to any judge of the Supreme Court or county judge of the county in which said person is confined for the appointment of counsel to represent the person to be examined. Said counsel to act at a hearing before the judge and in any subsequent proceedings, and no order made by said board shall become effective until five days after it shall have been filed with the clerk of the court and a copy shall have been served upon the counsel appointed to represent the person examined and proof of service of said copy of the order to be filed with the clerk of the court. All orders made under provisions of this act shall be subject to review by the Supreme Court or any justice thereof, and said court may upon appeal from any order grant a stay which shall be effective until such appeal shall have. been decided. The judge of the court appointing any counsel under this act may fix the compensation to be paid him. No surgeon performing an operation under the provisions of this act shall be held to account therefor. The record taken upon the examination of every such inmate, signed by the said board of examiners, shall be preserved by the institution where said inmate is confined, and one year after the performance of the operation the superintendent or other administrative officer of the institution wherein such inmate is confined shall report to the board of examiners the condition of the inmate and the effect of such operation upon such inmate, and a copy of the report shall be filed with the record of the examination."

9. NORTH DAKOTA. No provisions.

10. MICHIGAN. In this state the statute provides for investigations and, under certain conditions, for the order for sterilization, after which the procedure is as follows: (Section 2.) "The boards of the aforesaid institutions and the physicians or sur. geons in charge of each of said institutions shall for each of their respective institutions constitute a board, the duty of which shall be to examine such inmates of said institutions as are reported to them by the warden or medical superintendent to be persons by whom procreation would be inadvisable. Such board shall receive the report of insanity experts hereinafter mentioned, examine the physical and mental condition of such persons and their record and family history so far as the same can be ascertained, and if in the judgment of a majority of said board procreation by any such person would produce children with an inherited tendency to insanity, feeble-mindedness, 
idiocy, or imbecility, and there is no probability that the condition of such person so examined will improve to such an extent as to render procreation by any such person advisable, or if the physical or mental condition of any such person will be substantially improved thereby, then said board shall direct a competent physician or surgeon, with such other assistants as may be necessary, to perform the operation of vasectomy or salpingectomy or any other operation or improvement on vasectomy or salpingectomy recognized by the medical profession, as the case may be, upon such person. Such operation shall be performed in a safe and humane manner, and the board making such examination, and the institution physician or surgeon, shall receive no extra compensation therefor; Provided, That at least thirty days' notice shall be given to the parents or guardian of such person before the performing of such operation; said notice to specify the purpose, time and place of such examination; Provided further, That when said parents or guardian object to the performance of such operation, then the question of the sanity of such person shall be referred to the probate court of the county in which the institution is located, where the question of sanity and the necessity for this operation shall be determined as in other sanity cases before such courts."

11. KANSAS. First Law. This statute provides for investigation by the managing officers of institutions and, in case they find sterilization applicable in the particular case, under the statute, then (Section 1) “** said authority shall report their conclusions with a recommendation to the district court or any court of competent jurisdiction in and for the district from which such inmate or inmates has been committed to such institution or institutions. The court shall thereupon hear and determine the matter, and if satisfied that the subject is an habitual criminal within the meaning of this act, or is insane, an idiot, imbecile or an epileptic, and that the purposes of this act will be accomplished by such order, shall adjudge that such operation shall be performed, and shall appoint one of the authority signing such report to perform the operation of vasectomy or oöphorectomy, as the case may be, upon such person. The county attorney of the county in which the hearing is had may be directed by the court to represent the state in the proceedings."
Second Law. No provisions.

12. WISCONSIN. No provisions.

13. NEBRASKA. No provisions.

14. OREGON. In this state the applica. tion of the law is ministerial, unless the inmate nominated for sterilization desires to appeal from the decision of the state board of eugenics, in which case the statute makes the following provisions: (Sections 6, 7 , and 8.) "Any such inmate desiring to appeal from the decision of the said Board, or in case the person is under guardianship or disability, then the guardian of said inmate may take an appeal to the circuit court of the county in which the institution, in which the inmate is confined, is located.

"An informal notice of appeal filed with the secretary of said Board either by the inmate or some one in his behalf, shall be all that is necessary to make the appeal; provided, said notice shall be filed within 15 days of the date when notice of the Board's decision is served on the inmate or his guardian, and said notice of appeal shall stay all proceedings of said Board in said matter until the same is heard and determined on said appeal; provided further, that no operation shall be performed, upon any inmate, until the time for appeal from the decision of the Board has expired.

"Upon an appeal being taken, the secretary of the said Board where the notice of appeal is filed, must within fifteen days thereafter, or such further time as the court or judge thereof may allow, transmit a certified copy of the notice of appeal and transcript of the proceedings, findings, and order of the Board, to the clerk of the court appealed to.

"The trial shall be a trial de novo at law as provided by the statutes of the State, for the trial of actions at law. Upon such appeal, if the inmate be without sufficient means to employ an attorney, then such attorney shall be compensated by the State upon order of the court; and it shall be the duty of the district attorney of the county wherein such trial is had to represent the said Board.

"If the court or jury shall affirm the tindings of said Board, said court shall enter a judgment, adjudging that the order of the said Board shall be carried out as herein provided; if the court fail to affirm the decision of said Board, appealed from, then said order shall be null and void and of no further effect." 
15. SOUTH DAKOTA. No provisions. 6. LEGAL COUNSEL FOR THE STATE AND FOR PERSONS NOMINATED FOR THE OPERATION UNDER THE STERILIZATION STATUTES.

1. NEW JERSEY. For the Defendant. The board of examiners may apply to any judge of the court of common pleas of the county in which the defendant is confined for the appointment of counsel to represent such person. Compensation for such counsel is fixed by the judge appointing him.

2. NEW YORK. For the Defendant. The board of examiners may apply to any judge of the supreme court or county judge of the county in which the person nominated for sterilization is confined for appointment of counsel to represent such person. The compensation for such counsel to be determined by the judge appointing him.

3. NORTH DAKOTA. In this state the procedure is ministerial rather than judicial, nevertheless provision is made for the aid of the state's law officers as follows: (Section 8) "Whenever the state's attorney of any county shall have reason to believe that any person who shall be convicted of felony has been twice or more previously convicted of felonies in North Dakota and elsewhere, it shall be the duty of such state's attorney to investigate and to secure at the expense of the county, transcripts of records of conviction from other counties and states and also such evidence of identification as may be obtained. Such proof when obtained shall be forwarded to the state board of control, who shall thereupon notify the chief medical officers of the institution to which such person is committed and the secretary of the state board of health, and such case shall be dealt with in accordance with the procedure stated in section 1 of this act."

4. MICHIGAN. No provisions.

5. KANSAS. (Section 1) “**** the county attorney of the county in which the hearing is had may be directed by the court to represent the state in the proceedings ***"

\section{WISCONSIN. No provisions.}

7. OREGON. The procedure is ministerial in uncontested cases, but when contested cases may be finally determined by the courts of the state. The state board of eugenics "* * shall have power to summon witnesses and any member of said board may administer an oath to any witness whom it is desired to examine * **"

For the Defendant. In case the matter comes before the courts for final decision (Section 7) " ** * if the inmate be without sufficient means to employ an attorney, then such an attorney shall be compensated by the state upon the order of the court."

For the State. (Section 7) " *** *and it shall be the duty of the district attorney of the county wherein such trial is had to represent said board. ***"

By implication, by custom, and by other statutes governing the representation of the state in contested cases, the attorney-general or the county attorneys of the states and counties interested act as legal counsel in upholding the statutes and the boards or officers seeking to enforce it.

In the Model Law provision is made for the appointment of legal counsel by the court in case the person nominated for sterilization is financially unable to provide such counsel. The State Eugenicist and the state's interests in applying the law are 'well looked out for, so far as legal counsel is concerned, by the attorney-general and the county attorney of the county in which the particular case arises.

8. WASHINGTON. The law of 1921 provides for legal counsel only in cases of appeal.

For the Defendant. (Sec. 6) "6*** if the inmate be without financial means to employ an attorney, then the court shall appoint an attorney to represent said inmate and such attorney shall be compensated by the State upon order of the court."

For the State. "**** it shall be the duty of the district attorney of the county wherein such trial is had to represent the said board."

\section{IS THE CONSENT OF THE PA- TIENT OR GUARDIAN A NECES- SARY PREREQUISITE TO LEG- AL EUGENICAL STERILIZA- TION?}

Second California Law, 1909. (Chapter 363, Sec. 1) "whether with or without the consent of the patient ***"

Michigan Law, 1913. (Act No. 34, Public Acts, Sec. 2) "Provided, That at least thirty days' notice shall be given to the parents or guardian of such person before the performing of such operation; said notice to specify the purposer, time and place 
of such examination; Provided further, That when said parents or guardian object to the performance of such operation, then the question of the sanity of such person shall be referred to the probate court ***"

Wisconsin Law, 1913. (Che. ter 693, Sec. 4.) "Before such operation s: " be performed it shall be the duty of the sta hoard of control to give at least ti.. 'nves ine in writing to the husband or wi guardian, if the same shall be know.., if unknown, to the person with whom such inmate last resided."

Third Iowa Law, 1915 (Chapter 202, 36th General Assembly, Sec. 1) "*** * and provided further, that the superintendent of the hospital shall have secured the written consent of the husband or wife, if the patient is a married person, and if an unmarried person, the written consent of the parent, guardian or next of kin, if there be within this state, that said operation shall be performed."

Nebraska Law, 1915. (Chapter 237, Sec. 4) "Before any such operation shall be performed, the nature, character and consequences of such operation shall be fully explained to such inmate and to the husband, wife, parent, guardian, or nearest of kin of such inmate and no such operation shall be performed without the written consent of such husband, wife, parent, guardian, or nearest kin, as the case may be, and the assent of such inmate so far as said inmate is capable of assenting thereto."

Amendment to the Second California Law, 1917. (Chapter 489, Sec. 1) "whether with or without the consent of the patient $* * *$ "

California Law Establishing Pacific Colony, 1917. (Chapter 776, Sec. 42) "whether with or without the consent of the inmate ***"

Oregon Law, 1917. (Chapter 279, Sec. 5) “*** and if an operation is deemed necessary by said Board, then a copy of the order of said Board shall forthwith be served on said inmate, or in the case of an insane person upon his legal guardian, and if such insane person have no legal guardian then upon his nearest known kin within the State of Oregon, and if such person have no known kin within the State of Oregon, then upon the custodian guardian of such insane person * *"

Kansas Law, 1917. (Chapter 305, Sec. 1) "**** but before such operation shall be performed a written notice shall be served on such inmate, and guardian, if there be one, of the time and place of a meeting and hearing at least thirty days prior thereto; and said inmate shall have the right to be represented by counsel and may introduce such evidence as may be desired * * *"

Washington Law, 1921 (Chapter 53, Sec. 4). “***ifi,n maratinn is deemed neces-

$\therefore \quad 3 \circ$

itilits

$\therefore \quad$ i 11 jijts

persori, .r.?

insane person...

D Iegaı guardian, then upon his nearest known kin within the State of Washington, and if such insane person have no known kin within the State of Washington, then upon the custodian guardian of such insane person."

\section{TYPE OF OPERATION AND MANNER OF ITS PER- FORMANCE.}

In eugenical sterilization the principal object is permanently to destroy the reproductive function of the individual. In the male, there are two common operationsfirst, the less serious one known as vasectomy, which consists in removing a short section of each of the vasa deferentia. This may be performed without anæsthetic in a few minutes by a competent surgeon, with less pain to the subject than accompanies the pulling of a tooth. With local anxsthetic it is accompanied by practically no pain or distress to the patient. Second, the more radical operation is castration; this requires hospital attention and consists in the complete removal of the testes.

In the female the surgical operations for sexual sterilization are much more serious than in the male, because all the former operations require the opening of the abdominal cavity. Consequently the sterilization of the female calls for much more skill and care, and also for more time for convalescence, than are required in sterilizing the male. The less radical of the operations in sterilizing the female is known as salpingectomy, which consists in removing a section of the Fallopian tubes (oviducts.) The more radical operations are known as oöphorectomy (or ovariotomy) and uterectomy (or hysterectomy.) The former consists in removing the ovaries; the latter in removing the uterus.

If the sole object of these operations is eugenical, that is, no subsidiary therapeutic 
value is sought, logically enough the operation should be of the minimum radicalness required under the existing stage of surgical advance, permanently to destroy the reproductive functions. Such operations consist in the male of vasectomy, and in the female of salpingectomy. A simpler operation could hardly be desired for the male, but for the female it is grestin on he hoped that in a less erility may -ation is much more wavus surgically w the female than in the male, there is one compensation. Much more frequently in the female than in the male the need for abdominal surgery for therapeutic purposes is present, consequently quite often in the female the therapeutic value of an abdominal operation may be achieved as an accompaniment to sexual sterilization.

It is suggested that scarifying the horns of the uterus and thus effecting sterilization by occluding the terminal openings of the Fallopian tubes may be developed surgically to the point of practicability. Because such an operation, would not involve the opening of the abdominal cavity, it would provide for females an operation comparable in simplicity with vasectomy in the male.

$\mathrm{X}$-rays, which are known to destroy certain tissues, are being successfully employed experimentally for sexual sterilization. But, like scarifying the horns of the uterus, surgical technique has not yet developed this agency to the point of general practical value. Thus while surgical science is working upon the problem, it has as yet produced nothing practicable that is simpler than vasectomy in the male and salpingectomy in the female. But even if much simpler methods should be developed, it would appear the part of wisdom to write the law wide enough to permit the application of that particular method for effecting sterility which in each case would be best adapted to the therapeutic needs of the individual, and which in the light of the existing methods of approved surgery, would in each case prove the least serious surgically.

Many of the laws quite properly require that the operation of sexual sterilization be effected "in a safe and humane manner." This again is a provision which might well be included within the model sterilization statute, because it is an additional safe-guard around the rights of the particular individuals who are subjected to actual sterilizing operations.
The following is a series of literal abstracts of the several statutes in reference to the surgical type of operation !and the manner of its performance:

1. INDIANA. " $* * *$ it shall be lawful for the surgeons to perform such an operation for the prevention of procreation as shall be decided safest and most effective."

2. WASHINGTON. First Law. “*** an operation *** for the prevention of procreation."

Second Law “*** such surgical operation as may be specified in the order of the Institutional Board of Health. All such operations shall be performed with a due regard for the physical condition of the inmate and in a safe and humane manner."

3. CALIFORNIA. First Law, Section 1. “*** if in their opinion *** asexualization will be beneficial to such inmate, patient or convict, they may perform the same; ***"

Second Law, Section 1. “*** the state commission in lunacy may $* * *$ cause such a person to be asexualized ***"

4. CONNECTICUT. Section 1. “** said board shall appoint one of its members to perform the operation of vasectomy or oöphorectomy *** . Such operation shall be performed in a safe and humane manner ***”

5. NEVADA. “** direct an operation to be performed upon such person for the prevention of procreation; provided the operation so performed shall not consist of castration."

6. IOWA. First Law, Section 1. “*** then the surgeon of the institution shall perform the operation of vasectomy or ligation of the Fallopian tubes, as the case may be, upon such person."

Second Law, Section 1. "*** then the physician of the institution, or one selected by him, shall perform the operation of vasectomy, or ligation of the Fallopian tubes, as the case may be, upon such person."

Third Law, Section 1. "“*** they are hereby authorized to perform or cause to be performed by some capable physician or surgeon, the operation of sterilization ***"

Section' 2. "The operation to be performed upon a male person shall be what is known as vasectomy, and upon a female person what is known as a section of the Fallopian tubes with implantation in the uterine muscles." 
7. NEW JERSEY. Section 1. “*** it: shall be lawful to perform such operation for the prevention of procreation as shall be decided by said board of examiners to be most effective ***"

8. NEW YORK. Section 351. " "* * * then said board shall appoint one of its members to perform such operation for the prevention of procreation as shall be decided by săid board to be most effective ***"

9. NORTH DAKOTA. Section 1. "*** it shall be lawful to perform a surgical operation for the sterilization of such inmate ***"

Section 5. "*** shall designate some skilled surgeon, who may not be one of their own number, who shall perform it."

10. MICHIGAN. Section 1. “*** to render incapable - of procreation by vasectomy or salpingectomy, or by the improvement of said surgical operation which is least dangerous to life and will best accomplish the purpose, ***"

Section 2. "*** then said board shall direct a competent physician or stirgeon, with such other assistants as may be necessary, to perform the operation of vasectomy or salpingectomy, or any other operation or improvement on vasectomy or salpingectomy recognized by the medical profession, ***. Such operation shall be performed in a safe and humane manner, ***",

11. KANSAS. First Law, Section 1. "*** and shall appoint one of the authority signing such report to perform the operation of vasectomy or oöphorectomy, as the case may be, ***. Such operation shall be performed in a safe and humane manner, ***"

Second Law, Section 5. " $* * * *$ if a male person, either the operation of vasectomy or asexualization; if a female, either the operation of salpingectomy or oöphorectomy; and shall designate some competent surgeon, who may either be connected with such institution or otherwise, who shall perform the operation."

12. WISCONSIN. Section 3. “*** "that such operation be performed for the prevention of procreation as shall be decided safest and most effective ***"

13. NEBRASKA. Section 3. “* ** that such operation be performed for the prevention of procreation as in the judgment of said board of examiners shall be most appropriate to each individual case."
14. OREGON. Section 3 . “*** to perform or cause to be performed upon such inmate such a type of sterilization as may be deemed best by said board."

Section 4. "**** and no person shall be emasculated under the authority of this Act except that such operation shall be found necessary to improve the physical, mental, neural, or psychic condition of the inmate."

Section 9. "*** all operations shall be performed with due regard for the physical condition of the inmate, and in a safe and humane manner."

15. SOUTH DAKOTA. Section 2. "** then the physician of the institution, or one selected by him, shall perform the operation of vasectomy or ligation of the Fallopian tubes, as the case may be ***"

\section{BAD BIOLOGY IN THE EUGENI- CAL STERILIZATION STATUTES.}

In many of the sterilization laws there is a phrase evidently intended to throw an additional safeguard around the individual in securing him against unjust and uneugenical sterilization. It is that phrase which implies that an individual may, because of his condition, be today a potential parent of defectives and undesirables, and in the future, on account of some recovery, may become so changed that parenthood on his or her part becomes desirable for the state. This is equivalent to saying that an individual may be a mongrel today and a thoroughbred tomorrow, which, of course, is contrary to all practical observation and to all biological teaching. There may be medical and social reasons why a person is an undesirable procreator today and a desirable one tomorrow-in such cases there should be medical or social treatment, not eugenical sterilization-but so far as hereditary traits are concerned, there is no such change. Eugenical sterilization can be justified only on the grounds of hereditary and constitutional degeneracy. Once a degenerate, so far as hereditary qualities are concerned, always a degenerate.

If both the literal and implied motives of these laws were purely therapeutic, then, because an individual who is diseased today might recover so as to make procreation medically or hygienically desirable on his part, the phrase would be understandable, but even in such cases it would have no legal use because no surgeon now hesitates, on account of legal restraint, to perform, for 
purely therapeutical reasons, an operation which incidentally results in procreative sterility.

The phrases run as follows:

Indiana Law of 1907 (Chapter 215) “*** and there is no probabilty of improvement of the mental and physical condition of the inmate ***"

Connecticut Law of 1909. (Chapter 209, Sec. 1) “*** and there is no probability that the condition of any such person so examined will improve to such an extent as to render procreation by any such person advisable * *"

Iowa Law of 1911. (Chapter 129, Thirtyfourth General Assembly, Sec. 1) "**** and there is no probability that the condition of any such inmate so examined will improve to such an extent as to render procreation by any such inmate advisable. ${ }^{* * *}$ "

New Jersey Law of 1911. (Chapter 190, Sec. 3) " $" * *$ and there is no probability that the condition of such inmate so examined will improve to such an extent as to render procreation by such inmate advisable **"*

New York Law of 1912. (Chapter 49, Laws of 1909, as amended by Sec. 351 of Chapter 445.) "“*** and there is no probability that the condition of any such person so examined will improve to such an extent as to render procreation by any such person advisable ***"

North Dakota Law of 1913. (Chapter 56, Sec. 1) " $* * *$ and that the condition of such inmate is not likely to improve so as to make procreation by any such person desirable or beneficial to the community ***"

Kansas Law of 1913. (Chapter 305, Sec. 1) " *** and there is no probability that the condition of any such inmate or inmates so examined will improve to such an extent as to render procreation by any such inmate or inmates advisable * **"

Michigan Law of 1913. (Public Act 34, Sec. 2) "*** and there is no probability that the condition of such person so examined will improve to such an extent as to render procreation by any such person advisable ***"

Oregon Law of 1917. (Chapter 279, Sec. 3) "*** and there is no probability that the condition of such person so examined will improve to such an extent as to render procreation by any such person advisable **"
Kansas Law of 1917. (Chapter 299, Sec. 1) $" * * *$ and that the condition of such inmate is not likely to improve so as to make procreation by such person desirable or beneficial to the state ***"

Evidently this false idea and objectionable expression have been copied from statute to statute. Because they are founded on biological misconceptions they should be dropped from future laws. The matter of human heredity is much more deeply seated than a passing condition which may make an individual a parent of good pedigree today and one of undesirable hereditary traits tomorrow.

\section{THE MANDATORY AND OPTION-}

\section{AL ELEMENTS IN THE SEVER-}

\section{AL STERILIZATION LAWS.}

If a law is meant to be compulsory, then of course there must be no gaps in its chain of mandates, which begins with the order for the appointment of executive officers, and ends with the actual surgical operation of sterilization. A single "may" inserted in the chain of execution makes the whole procedure an optional, or at least a non-compulsory one. The principal elements in the chain are: (1) The appointment of executive agents: (2) the examination of individuals alleged to be subject to the act; (3) the determination of the facts in particular cases, whether the particular person is subject to eugenical sterilization; (4) the order for the actual sterilizing operation.

Which statutes require eugenical sterilization, and which make it optional on the part of the executive agents? By thus comparing what the laws order, with what their executive agents have done, we arrive at a judgment concerning the effectiveness of the execution of the law in different states, and may be able also to locate the particular weak points in the chain of statutory order and practical execution. Finally, such an analysis may aid in drafting a successful act whose intent is mandatory.

1. INDIANA, 1907. The law provides for the compulsory appointment of a committee of experts in each institution, whose duty it shall be to examine the condition of inmates recommended for sterilization. If this committee decides in favor of the sterilization of the inmate, " *** it shall be lawful for the surgeons to perform such operation for the prevention of procreation as shall be decided safest and most effective." Chap. 215, Laws of 1907. 
2. WASHINGTON, 1909. As a punitive measure for criminals and rapists, "the court may direct an operation to be performed upon such a person for the prevention of procreation-_." Chap. 240, sec. 35, Criminal Code, Laws of 1909.

Second Sterilization Law, 1921. "It shall be and is hereby declared the duty of the superintendents of all state institutions having the care of individuals held in restraint to report quarterly to the Institutional Board of Health, all feeble-minded, insane, etc., *** then it shall be the duty of said Board to make an order directing the superintendent of the institution in which such inmate is confined to perform or cause to be performed upon such inmate such a type of sterilization as may be deemed best by said Board."

But, like the law of Oregon, this statute provides for a possibility of such inmate, his legal guardian or nearest kin to appeal from the decision of the Board within fifteen days from date of notice served upon him.

3. CALIFORNIA. (a) First Sterilization Law, 1909, provides that a resident physician of an institution, together with the superintendent of the institution and the secretary of the state board of health, may constitute a board to determine whether asexualization will be of physical, mental, or moral benefit to an inmate; if they decide in favor of asexualization, "- they may perform the same-_" Chap. 720, Sec. 1, Laws of 1909.

(b) Second Sterilization Law, 1913, Chap. 363.

Sec. 1 provides that the state commission in lunacy "-may- cause to be asexualized__ before his or her release or discharge from an institution, any person in a state hospital for the insane afflicted with hereditary insanity or incurable chronic mania or dementia.

Sec. 2 applies to convicts in state prisons, and provides that in the case of recidivists who, in the judgment of a board of physicians, will be benefited by such operation, the board "- - may perform the same-_"

Sec. 3 provides that any idiot, if a minor, "may be asexualized__." If an adult, by the consent or request of the parent or guardian of such idiot, the superintendent of a state hospital "- shall perform such operation-_."

(c) Amendment to Second Sterilization Law, 1917. Sec. 1 provides that the state commission in lunacy "-may-cause to be asexualized__-" before his or her release or discharge from a state hospital for the insane, any person of the class described, comprising those afflicted with hereditary mental disease, feeble-mindedness or syphilis. (Chapter 489, Sec. 1, Laws of 1917.)

(d) Sterilization Provision establishing the Pacific Colony, Sec. 42, Chapter 776, Laws of 1917. This provides that before the release or discharge of an inmate of the Pacific CoTony who is feeble-minded or afflicted with incurable chronic mania or dementia, the board of trustees, etc., after a careful investigation, "- may cause such person to be sterilized; and such sterilization —-shall be lawful__.".

4. CONNECTICUT, 1909. The state prison and the hospitals for the insane are directed to appoint boards of examination, and in the case of inmates by whom procreation is judged inadvisable, "-said board shall appoint one of its members to perform the operation-." (Chap. 209, sec. 1, Public Acts 1909.)

5. NEVADA, 1911. In punishment for the crime of rape, "- the court maydirect an operation to be performed upon such person for the prevention of procreation." (Section 28 of the Crimes and Punishment act.)

6. IOWA. (a) First Sterilization Law, 1911. The state board of parole, in conjunction with the managing officer or superintendent of each institution, shall examine into the condition of inmates of these institutions, and if they decide that procreation is inadvisable, or that an operation will be beneficial, "- - the surgeon of the institution shall perform the operation_- Also certain classes of convicts or inmates of institutions, as prostitutes, sexual offenders, etc., "—- shall be subjected to this same operation-' (Chapter 129, Sec. 1, Acts of the Thirty-third General Assembly.)

(b) Second Sterilization Law, $1913 \mathrm{Sec}$. 1 provides as above for a board of examiners and provides that, when such a board shall determine a person to be unfit to procreate, "- then the physician of the institutionshall perform the operation-upon such person-—."

Sec. 2 is in regard to operations upon application, and provides that those afflicted with syphilis or epilepsy —- "may apply to the board of parole__" "_-and upon or- 
der-the operation-may be performed upon such person-_." (Chap. 187, Acts of the Thirty-fourth General Assembly.)

(c) Third Sterilization Law, 1915, provides that when the superintendent and majority of the staff of a hospital for the insane agree that it is for the best interests of the patient and society, and provided that the individual and his or her family consent, "—- they are hereby authorized to perform-- the operation of sterilization on any such patient-_.."(Chap. 202, Section 1, Laws of the Thirty-sixth General Assembly.)

7. NEW JERSEY, 1911. If, after examination, the board of examiners and chief physician of an institution find that procreation on the part of an inmate is inadvisable, "-it shall be lawful to perform such operation-." But first the law provides for appointment of counsel, etc., and makes the order of the board of., examiners subject to review by the Supreme Court. (Chap. 190, Sec. 1, Laws of 1911.)

8. NEW YORK, 1912. The law provides for the appointment of a board of examiners with authority to determine whether an inmate of an institution should, either for his own good or that of society, be sterilized. If procreation in the case of such inmate is deemed inadvisable, "- said board shall appoint one of its members to perform such operation for the prevention of procreation-_." Here as in the New Jersey law, the appointment of counsel is provided for. (Article 19 of Chapter 49, Laws of 1909 , as amended by Chapter 445 , Laws of 1912.)

9. NORTH DAKOTA, 1913. Chapter 56, Sec. 1, provides that when procreation by an inmate of a state institution shall be deemed inadvisable, "—_it shall be lawful to perform a surgical operation for the sterilization of such inmate as hereafter provided."

The law further provides for a board of examiners, and in Section 5 provides that if this board order such operation, "it-__-shall designate some skilled surgeon--who shall perform it."

Section 7 deals with inmates who request the performance of such operation, or give their consent thereto in writing, and provides that in such cases the chief medical officer of an institution "——— may perform - such operation without bringing the natter to the attention of such board of examination-_."
10. MICHIGAN, 1913. Act No. 34, Public Acts 1913.

Section 1 authorizes the operation to prevent procreation to be performed on mentally defective or insane inmates of public institutions.

The boards and physicians of such institutions shall determine what inmates are persons by whom procreation would be inadvisable, and in such cases "_- said board shall direct a competent physician or surgeon- to perform the operation -_upon such person-_-." (Section

2.)

\section{KANSAS.}

(a) First Sterilization Law, 1913 (Chap. 305, pp. 525-526.) Section 1 of this act provides that the managing officers of all state institutions shall, with the assistance of competent surgeons, examine inmates who in their opinion should not be allowed to procreate, and report the result of such examination to a court, with a recommendation to such court. If the court, after a hearing, determines that the purpose of the act will be fulfilled by such an operation, they "-__-shall adjudge that such operation shall be performed, and shall appoint one of the authority- - to perform the operation._-

(b) Second Sterilization Law, 1917. (Chap. 299.)

Section 1 provides that in the case of inmates of institutions whose physical or mental condition would be likely to result in defective or feeble-minded children with criminal tendencies, "____ it shall be lawful to perform a surgical operation for the sterilization of such inmate___."

Section 5 provides that the board of examiners, after making full inquiry into the condition of the inmate, if sterilization be ordered, "—_- shall_- designate what operation is to be performed—__and shall designate some competent surgeonwho shall perform the operation-_-"

12. WISCONSIN, 1913. (Chap. 693, Sec. 3.) The law in this state provides that the state board of control shall appoint a committee of experts to examine inmates of institutions, and if such experts and the superintendent of the institution find procreation to be inadvisable on the part of an inmate, "—_ it shall be lawful to perform such operation for the prevention of procreation as shall be-_afest and most effective-_.." 
23. NEBRASKA, 1915. (Chap. 237.) Before the discharge or parole of any inmate of an institution for feeble-minded or insane, a board of examiners shall determine "whether or not procreation by such inmate vould be harmful to society, and if such s decided to be the case, "—_ it shall be is condition prerequisite to the parole or discharge of such inmate that said inmate be mad sterile, and that such operation be performed for the prevention of procreation ." (Sec. 3.)

14. OREGON, 1917. (Chap. 279.) This statute provides for the establishment of a State Board of Eugenics, to whom the superintendents of state institutions shall report all inmates who are in their judgment potentially capable of producing offspring likely to become a social menace or wards of the State. The State Board of Eugenics shall examine such reported inmates, and when they consider procreation inadvisable, they shall order the superintendent of the institution in which such inmate is confined to "___perform or cause to be performed upon such inmate such a type of sterilization as may be deemed best by said Board." (Sec. 3.) But before such order can be carried out, a copy shall be served on said inmate, or his guardian, and fifteen days shall be allowed for the inmate to appeal from the decision of said Board (Sec. 6). After the time for appeal has expired, or in case the inmate has appealed and the order has been affirmed by a judgment of the court, "—_-it is hereby made his (the superintendent of the institution's) lawful duty to perform_-such surgical operation as may be specified-_-" (Sec. 9.)

15. SOUTH DAKOTA, 1917. (Chap. 236.) The State Board of Charities and Corrections, together with the superintendent of the State Home for Feeble-Minded Persons, shall determine whether any inmates should not be allowed to procreate, and in such cases "—_ the physician of the institution - shall perform the operation-_-upon such person." (Sec. 2.)

\section{SEXUAL STERILIZATION OF CRIMINALS.}

It would be unfortunate indeed if criminologists, the public, or the courts associated cugenical sterilization more closely with criminalistic individuals than with the insane, the feeble-minded, or any other of the ten types of socially inadequate individuals which comprise the whole range of socially unadapted types. A criminal is a person who has been convicted of crime. Crime is arbitrarily defined by the legislative authority of the State. A criminal may, or may not, be a degenerate. On the other hand the term criminalistic is biological and social rather than legal. It means an individual who, regardless of the nature of the statutory laws of the state or the freedom or incarceration of the subject himself, is antisocial in his instincts and conduct to a degree which renders him a willful or at least a careless menace to the community.

If one could prove that a given individual youth, before puberty, would upon maturity become a rapist or a sexual pervert, and that such tendencies were hereditary, society would be justified in sterilizing such individual, as a preventive measure, because the removal of the sex-gland before puberty stops the development of sex-impulses. Eugenical interests would be served if, in such cases degenerate inheritance lines were cut off, and current society would be protected against the anti-social conduct of the individual operated upon. But, to vasectomize or castrate an adult for the purpose of destroying his or her sex impulses is without purpose, because such operations upon adults destroy neither the sex-impulses nor the capacity for coitus.

The science of internal secretions is still in its infancy. Ultimately this department of physiology may have something to contribute which will be of service to criminologists and social agencies which seek to govern impulses by controlling internal secretions. Thus, the therapeutic promise of sterilization is not great enough to justify its widespread use. There is, however, a modicum of control over the impulses to be derived from castration, which small personal and social benefit could be well considered as a secondary matter in determining upon the particular type of sterilization in a given case in which eugenical sterilization has been decided upon. For this reason in the model law the State Eugenicist is given authority to decide upon the particular type of sterilizing operation or treatment, in order that he may, in consultation with medical authorities, select that particular type which, as the law states, will give due consideration to possible therapeutic benefit.

For eugenical purposes the legal term criminal carries little meaning, but criminalistic connotes an hereditary degenerate make-up. Only those persons who constitute the latter 
class should be included within the operation of a eugenical sterilization statute. The lack of a clean-cut understanding of the distinction between criminal and criminalistic, but at the same time a vague appreciation of its truth, has caused several states to attempt to apply eugenical sterilization to a certain type of criminals determined, not by scientific pedigree studies, but by a certain number and kind of convictions under the criminal laws. The enactments of the several states in this regard follow:

1. INDIANA: The law applies to institutions "entrusted with the care of confirmed criminals, idiots, rapists and imbeciles." There is no special reference to the expectation of criminalistic tendencies on the part of the potential offspring of such inmates.

2. WASHINGTON: The first law in Washington meant to reach degenerates by applying to habitual criminals and to persons "adjudged guilty of carnal abuse of a female person under ten years of age, or of rape."

The Second Statute of Washington applies to habitual criminals, who have been convicted three or more times of a felony, moral degenerates and sexual perverts. In this second law the application to criminalistic persons is not punitive, but this class are included when, in particular cases, they are shown to be hereditary degenerates.

3. CALIFORNIA: The first California statute selected for sterilization from the state prisons inmates committed for life, and those showing sexual or moral perversions, or twice committed for sexual offense, or three times for other crimes.

The second California statute makes any recidivist lawfully confined in a state prison liable to the asexualization act.

4. CONNECTICUT: 'In Connecticut the law legalizes the sterilization of inmates of the state prison and insane hospitals "if, in the judgment of the majority of said board, procreation by any such person would produce children with an inherited tendency to crime * * *."

5. NEVADA: The Nevada statute follows the wording of that of Washington by applying to habitual criminals and persons "adjudged guilty of carnal abuse of a female person under ten years of age, or of rape."

6. IOWA: The second Iowa statute made sterilization mandatory in case of persons twice convicted of felony, or of sexual offense other than white slavery, for which latter offense one conviction was sufficien. to make sterilization compulsory.

The third sterilization law of Iowa omits all reference to institutions for the criminal classes, and criminalistic tendencies in possible offspring.

7. NEW JERSEY: In New Jersey th criminals who come within the operation of the law are "those who have been gonvicted of the crime of rape, or of such succession of offenses against the criminal law as in the opinion of the board of examiners shall be deemed to be sufficient evidence of confirmed criminal tendencies."

8. NEW YORK: The New York statute in reference to criminals follows the exact wording of the New Jersey law.

9. NORTH DAKOTA: The sterilization law of North Dakota applies to the inmates of state institutions for the feebleminded, insane and criminal classes, procreation by whom would, in the opinion of the board, "be likely to result in defective or feeble-minded children with criminal tenden$\operatorname{cies} * * * "$

10. MICHIGAN: The Michigan statute makes no direct reference to criminals or criminalistic tendencies.

11. KANSAS: The first sterilization law applies to state institutions for the insane, feeble-minded, epileptic, and habitual criminals, and authorizes the sterilization of the particular inmates of such institutions by whom, in the judgment of the authorities, procreation would "produce children with an inherited tendency to crime * * *."

The second sterilization law of Kansas follows the wording of the first in reference to criminality.

12. WISCONSIN: The statute is applicable to criminals on the same basis as to the insane, feeble-minded and epileptic, with no special reference to criminalistic tendencies expected in the potential offspring.

13. NEBRASKA: The law applies to feeble-minded and insane inmates of penitentiaries, reformatories and industrial schools on the same terms as to inmates of institutions for the feeble-minded and insane.

14. OREGON: The law applies to habitual criminals, moral degenerates and sexual perverts on the same terms as to other classes of the socially inadequate, and includes among the types of possible children, the birth of which it seeks to prevent, those with an inherited tendency to "criminality or degeneracy." 
15. SOUTH DAKOTA: The statute makes no reference or allusion to institutions for the criminal classes, nor to criminality.

The application of sterilization to criminals in any manner which partakes in the least of the nature of punishment is repugnant to the spirit of American institutions, and is apt to work eugenical injury as well as eugenical benefit. The inmates of institutions for the criminal classes should be subject to eugenical sterilization laws on the same terms as inmates of institutions for all other types of custodial care, and members of the population at large, who, as the result of scientific pedigree studies, are proven to be potential parents of socially handicapped or unadapted offspring.

\section{Comment: Crime and Sterilization}

In Iowa the law was declared to be a bill of attainder because it selected by legislative enactment for punishment certain individuals of a very limited class. It was ex post facto because it was apparently applicable to persons twice convicted of certain offenses in which cases one of the offenses at least might have been committed before the enactment of the law. It placed the individual "twice in jeopardy of life or limb" because it applied to criminals as an additional punishment, after they had been duly convicted of crime. If sterilization in Iowa had been ordered as a part of the original judgment and sentence, then the only basis for attack under the bill of rights would have been "cruel and unusual punishment."

In Nevada the law was not attacked on the grounds which rendered the Iowa statute invalid, but was declared unconstitutional because the constitution of Nevada forbids "cruel and unusual punishment."

In Washington the first law (exactly the same as that in Nevada), was upheld because the constitution of Washington forbids only "cruel punishment." Sterilization in America, if not cruel, is certainly unusual.

The second law applies to criminals as a degenerate class, and is not carried out as a punitive measure, nor connected with any sentence.

There is always danger in these specialized sterilization laws applicable only to limited criminal classes, that the provision forbidding "class legislation" will be transgressed. Eugenical sterilization must, moreover, eliminate all signs and suggestions of punishment. Its motive is solely race betterment. It is highly probable that no court in the land would declare a sterilization statute unconstitutional on the grounds of "class legislation" if it applies to potential parents of socially inadequate offspring and goes further to provide adequate means for demonstrating such potential parenthood, and further applies with equal force to all of the generally recognized classes of socially handicapped and unadapted. Such a statute would be well within the police power of the state, because the good, which it would do the general welfare, would amply justify the restriction of so-called "personal rights," which restriction is, of course, inherent in every statutory provision. There must, however, always be a justifiable return commensurate with the extent of the invasion of personal rights. The eugenicist must demonstrate to the legislatures and to the courts that eugenical sterilization is a social remedy well within such limitations.

In the "Journal of the American Institute of Criminal Law and Criminology" the matter of sterilization has received attention from time to time:

1. 1911-1912, Vol. 2, p. 141.

A note signed A. M. reviews an article by Dr. A. Good, a Swiss authority on sterilization, who had a short time previously written a paper for the Schweizerische Zeitschrift für Strafrecht, in which he urged the adoption of the sterilization provision in the Swiss criminal code. The note continues: "The legally sanctioned domain of the physician is briefly discussed, including the sacrifice of the foetus to save the life of the mother, transfusions, transplantation, and scientific experiments. Sterilization (preferably by the application of the X-ray) is in the interest of the social body and is designed to make unnecessary more objectionable measures of prevention of conception and artificial abortion. The definition of legal justification of operations and medical duty should include the interest of the commonwealth, as well as that of the individual, wherever medical science recognizes the indications as justified in principle. The mediaeval church doctrine and popular prejudice naturally demand some precaution to prevent the animosity aroused by vaccination and prophylactic measures."

2. 1911-12, Vol. 2, p. 428.

A note signed $F$. G. reviews briefly a pamphlet by Dr. Harry C. Sharp, formerly a surgeon of the Indiana State Penitentiary, who began performing vasectomy in that institution in 1899, and had up to the time of the publication of the pamphlet operated upon 456 cases. 
3. 1911-1912, Vol. 2, p. 965.

Dr. Adolf Meyer reviews a paper, "Kastration und Sterilisation von Geisteskranken in der Schweiz Von Dr. Emil Oberholzer, Juristisch-psychiatrische Grenzfragen. VIII. Band, Heft 1-3, pp. 25-144." This paper records the case histories of 19 persons who were either castrated or sterilized, or for whom these operations were seriously considered but not carried out after due consideration by the medical authorities. After reviewing these cases, Dr. Meyer says: "Taking it all in all, the frankly recorded material shows the conditions for sterilization, but also the fact that a great deal of judgment is required which cannot easily be formulated in the words of a statute. It is of interest to note that among the parents of these patients hardly one of them would have offered sufficient provocation and opportunities for legal sterilization before the birth of these victims. We thus are not yet dealing with a panacea, but the problem deserves more extensive casuistic study, rather than mere figures of the hundreds of cases which have been operated on without any account or further analysis of the reasons and results."

4. 1912-1913, Vol. 3, p. 269.

Here a letter by $\mathrm{H}$. Havelock Ellis to the Editor of the Lancet is quoted in full. In this letter the writer considers the moral, the legal, and the eugenical aspects of sterilization.

5. 1913-1914, Vol. 4, p. 297.

A note signed R. H. G. quotes the recently enacted sterilization law of Michigan.

6. 1913-1914, Vol. 4, pp. 326-358.

A protest against laws authorizing the sterilization of criminals and imbeciles by Charles A. Boston. This article reviews the sterilization legislation up to date, and opposes the principle on the following grounds: "Before advocating such laws, I would wish to be assured that the interests of the community demand them; that the assumed principle of heredity be true; that the safeguards of liberty are not to be thrown aside for a merely imaginary good; that they be preserved as far as possible and that crude legislation (and in my view it is all crude) be avoided."

7. 1913-1914, Vol. 4, p. 420.

Arthur J. Todd of the University of Illinois makes reference to six articles recently published in German periodicals on the subject of sterilization. He writes:
"Sterilization of Criminals and Defectives. -The question of 'sterilization' has passed nearly through its academic stage. It is no longer to be regarded merely as the aberration or idiosyncrasy of some 'crank' warden, doctor or alienist. I was told last summer by the conservative secretary of a Western State Board of Charities that the only trouble with sterilization is that it is not used often enough! But when we begin to find serious notice taken by European scientific workers of American applications of sterilization we may safely presume that the principle has arrived! The German publication, Juristisch-psychiatrische Grenzfragen (Vol. III), last year contained two notable articles on this subject. One from Dr. Hans W. Maier, on the North American laws against the inheritance of crime and insanity and their application; the other from Dr. Emil Oberholzer, on castration and sterilization of the insane in Switzerland. Dr. Löffler, editor of the Österreichische Zeitschrift für Strafrecht (Heft. 6, 1912), notes these articles and gives a very fair resume of the problems involved. Other recent treatments of the sterilization question from different angles are to be found in Archiv f. Kriminal-Anthropologie, etc., XXXIX, 32; Zeitschrift f. die gesamte Strafrechtswissenschaft, XVIII, 446; Monatschrift f. Kriminal Psychologie und Strafrechtsreform, V, 734-743. Dr. Ernst Rosenfeld, in writing of his impressions as a delegate to the last International Prison Congress (Blätter f. Gefängniskunde, $45: 286-9$ ), concludes unfavorably on the practice of sterilization at least as he saw it in Indiana. Auf mich hat der Vorgang einen abscheulichen Eindruck gemacht, he says. But another distinguished foreign delegate, Dr. Gennat, Director of Prisons at Hamburg, recently expressed himself as favoring 'emasculation,' at least of men convicted of crimes against decency. We need not multiply examples. Enough has been said to warrant the criminologist or the lawyer in treating the sterilization question seriously in formulating his science or his project for legal reform."

8. 1913-1914, Vol. 4, p. 733.

The full decision of the Supreme Court of New Jersey on the sterilization law.

9. 1913-1914, Vol. 4, p. 747 .

Dr. Henry B. Hemenway, of Eyanston, Illinois, presents a criticism of Mr. Boston's paper above reported. He says: "Mr. Boston seems far from satisfactory from the 
biological point of view. He evinces more of the contentiousness of a barrister than the critical analysis of a judicial mind. He is perfectly justified in suggesting that the sterilization laws have originated more among sociologists and amateur reformers than among scientific students of biology. $\mathrm{His}$ reference to telegony is unfortunate because it is one of the exploded theories of unscientific breeders; and he seems to have rather overworked his references to 'undesirable citizens.",

10. 1913-1914, Vol. 4, p. 757.

A note signed $R$. H. G. refers to the decision of the Supreme Court of New Jersey in setting aside the sterilization law of that state.

11. 1913-1914, Vol. 4, pp. 804-814.

"Sterilization Laws from a Legal Standpoint," by Frank A. Fenning. The author is a member of the bar of the District of Columbia. This paper reviews sterilization legislation. The author says: "The social and the medical view, closely allied as they are, have been brought to the attention of the public far more often than the legal view. In the last analysis, however, it is the view that the courts will take which must influence and control the zeal of the social worker, as well as the activity of the surgeon." After reviewing the recent medical and psychopathic research he concludes: "Out of all of this patient research, this life work of men of marked attainments, we indulge in the expectation that we will be able to give treatment instead of punishment to the criminal, and to the weak-minded and the epileptic hold out that same ray of hope which shines now for many who in years bygone would have seen no light."

12. 1913-1914, Vol. 4, p. 934.

Dr. Bernard Glueck reviews "Sterilisation und Kastration als Hilfsmittel im Kampfe gegen das Verbrechen. Von Dr. Friedr. Ludw. Gerngross. J. F. Lehmann's Verlag, München, 1913, pp. 39 M. 1.20." The reviewer finds that "The idea that society has a right to, and should, protect itself against its anti-social members, so warmly agitated at the present time is by no means a new one."

"Already in the ancient Greek and Roman states there was a recognition of this principle, but we of today shudder at the mere mention of the methods used by the ancients."

Dr. Glueck then refers to the discussion of the legal phases of the problem which the original paper presented, but it did not lend itself to brief abstraction.

13. 1914-1915, Vol. 5, p. 5.

Arthur J. Todd, in a note entitled, "Sterilization and Criminal Heredity," approves of recent criticisms of the sterilization laws and says: "The critics of such legislation are right in asserting that criminal inheritance remains yet to be proved. They may be wrong, however, in going on to conclude that sterilization is a 'cruel and unusual punishment,' and of no practical utility." *** "And it is surely within the rights of the state to prevent habitual criminals and defective delinquents from procreating children at all, since they are manifestly unfit for rearing them. It is not germs of criminality we ought to fear, but lack of constructive parental capacity. It would be well if future discussions kept this aspect of the problem clearly in view."

14. 1914-1915, Vol. 5, pp. 364-370.

"Marriage, Sterilization and Commitment Laws Aimed at Decreasing Mental Deficiency," by Jessie Spaulding Smith. The writer, who is a teacher of special classes in Oakland, California, recognizes the high fecundity of many degenerate families, and advocates asexualization as an aid to the custodial care of feeble-minded persons in controlling the general problem in hand. She enumerates the existing sterilization laws.

15. 1914-1915, Vol. 5, pp. 419-425.

This article gives in full the decision of the District Court of the United States for Southern Iowa (Eastern District), relating to the sterilization law of Iowa.

16. 1914-1915, Vol. 5, pp. 514-539.

"Sterilization of Criminals" (Report of Committee H. of the Institute, Joel D. Hunter, (hairman).

17. 1916-1917, Vol. 7, pp. 373-378.

"Sterilization of Criminals" (report of Committee F. of the Institute, Joel D. Hunter, Chairman).

18. 1916-1917; Vol. 7, p. 591.

A letter to the Editor of the "Journal of Criminal Law and Criminology," written by W. F. Gray, in which the writer favors the sterilization of certain classes. He believes that the conditions are such "that something should be done to check the rapid increase of the insane, feeble-minded, and degenerate persons." He has approved for the State of Illinois a proposed legislative act modeled from the one which originally appeared in Bulletin 10-b of the Eugenics Record Office. 
19. 1916-1917, Vol. 7, p. 611.

A draft of the proposed sterilization law for Illinois above referred to.

20. 1916-1917, Vol. 7, p. 753.

A letter to the Editor of the "Journal of Criminal Law and Criminology," written by Dr. William S. Sadler of Chicago. The writer favors sterilization as a eugenical measure. After a general discussion he reaches the topic of immigration, and says: "Even our immigration laws are based on finances and education, and not on blood and taint. We should keep out of this country all classes who are eugenically unsound and let in the eugenically sound immigrant, whether he can read or write or has a dollar. We can teach him to read and make money after he reaches our shores." Continuing to the subject of feeble-mindedness, Dr. Sadler says: "When it comes to sterilization, I am interested in just one fundamental proposition, and that is feeble-mindedness with its second cousins, epilepsy and insanity. I am decidedly opposed to this agitation for the sterilization of criminals, paupers, prostitutes and inebriates. I believe that considerably more than 75 per cent of public prostitutes are feeble-minded. I believe that more than half of our criminals are feeble-minded, subnormal or otherwise falling in the category of moronism. I believe statistics bear out the assertion that almost 90 per cent of our paupers belong to this group. As to the per cent of feeble-minded among confirmed drunkards, I am not aware that we are in possession of anything reliable in the way of statistics."

21. 1917-1918, Vol. 8, page 449.

"Sterilization of Criminals" (Report of Committee " $F$ " of the Institute and a minority report, William A. White, Chairman).

The Survey (Nov. 24, 1917) commented editorially on this report.

22. 1917-1918, Vol. 8, p. 126.

A draft of the proposed law for the sterilization of criminals, feeble-minded, insane, etc., in Pennsylvania.

\section{Other Pertinent References.}

1. From the "Proceedings of the Fourth Annual Meeting of the American Institute of Criminal Law and Criminology and of the Wisconsin Branch," Milwaukee, Aug. 29-31, 1912, pp. 191-216. "Sterilization of Criminals and Defectives," being the Report of Branch Committee "D."

2. "Sterilization of Criminals" (report of Committee " $\mathrm{H}$ " of the Institute, Joel D.
Hunter, Chairman, 1915). "The American Bar Association Journal," Vol. 2, No. 1, January, 1916, pp. 128-134.

3. "Hereditary Criminality," Judge Warren W. Foster, Pearson's Magazine, November, 1909. An article approving of the policy of legalizing eugenical sterilization.

4. "Sterilization of the Unfit," New York Law Journal, October 8, 1912 (Vol. XLVIII, No. 7, p. 136). A commentary on the decision of the Supreme Court of Washington State v. Feilen, in which the court upheld the constitutionality of the punitive sterilization statute.

The commentator says:

"It seems highly probable that under the police power as now radically exercised by legislatures with judicial sanction, statutes of this general purpose will be held as protective expedients for society. And the decision of the Supreme Court of Washington is of wide significance because dealing favorably with a constitutional question incidental and tributary to the main one. Persons guilty of rape and habitual criminals if not insane or feeble-minded, must be dealt with on the theory of punishment for crime. By holding sterilization not to be an unconstitutional punishment the Washington court assures a wide scope to the statute for social improvement of future generations."

5. Harvard Law Review, Vol. XXVI, No 2, December, 1912, pp. 163-165.

"The Constitutionality of the Compulsory Asexualization of Criminals and Insane Persons.-On the theory that modern scientific investigation has demonstrated that idiocy, insanity and criminality are hereditary, several states have recently passed statutes providing for the compulsory asexualization of the inmates of insane asylums and state prisons in cases where it seems advisable to a board of medical examiners.1 The application of this provision to others besides criminals and the manner and purpose of its imposition makes it clear that it should not be regarded as a punishment but as an exercise of the police power. This power certainly enables the state to take some measures to protect itself against the birth of undesirable citizens, since limitations on the right to marry have been upheld on this ground.2 Furthermore, the fact that this purpose is achieved by performing an operation is not a fatal objection, for it is clear that a state can inflict physical injury on individuals for the protection of society. 
Compulsory vaccination laws, for instance, have been upheld, 3 and the operation of vasectomy, at least, is hardly more serious than vaccination.4 If, therefore, there is a probability that the persons to be operated upon will produce insane or degenerate offspring, the statutes are constitutional. Since the insanity of lunatics is generally inherited, the statutes, in so far as they apply to lunatics, would thus seem to be valid.s

"With regard to criminals, however, the statutes are less easy to sustain. The researches of criminologists have demonstrated that a large number of criminals have an inborn and hereditary tendency to crime, 7 but such criminals probably form only a minority of the inmates of penal institutions.s Therefore mere conviction of crime is insufficient to justify society in taking this drastic means of protecting itself against the criminal. Asexualization can only be justified in the case of born criminals, and unfortunately in the present state of scientific knowledge it seems impossible to distinguish most born criminals from criminals by acquired habit.10 Therefore born criminals who cannot be proved to be such must be granted immunity. However, there are probably some criminals whose degenerate character can be ascertained, and if a statute can be so drawn as to limit its operation to such as these it should be constitutional.11

"It is possible, however, for a legislature to change the aspect of the constitutional question by imposing sterilization as a punishment for crime.12 As such it is not unconstitutional unless $s_{13}$ cruel and unusual. A recent case holds that vasectomy is not a cruel punishment for statutory rape.14 State v. Feilen, 126 Pac. 75 (Wash.). The scope of the provision against cruel punishment has never been clearly defined, but it certainly prohibits torture,, 15 and, looked at apart from its purpose, vasectomy is a mild form of torture. The fact that there is a rational purpose behind it makes it doubtful, however, if it can be said to shock public feeling, which has sometimes been laid down as the test of cruel punishment.18 Yet, in the case of those convicted of some of the crimes included in.the Washington statute, the act authorized the asexualization of persons against whom society is not in need of this protection.17 As to them the punishment seems cruel, and the statute which imposes it unconstitutional. At all events, it is thoroughly objectionable, since it imposes as a penalty for certain classes of crime a treat- ment which is justified, if at all, only by the physical nature of certain criminals."

1. Ind., Laws, 1907, c. 215; Conn., Pub. Acts, 1909 c. 209 ; Cal., Stat., 1909 c. 720 ; Ia., Laws, 1911 c. 129.

2. Lonas v. State, 3 Heisk. (Tenn.) 287; State v. Gibson, 36 Ind. 389; Gould v. Gould, 78 Conn. 242, 61 Atl. 604 .

3. Morris v. Columbus, 102 Ga. 792,30 S. E. 850; Jacobson v. Massachusetts, 197 U. S. 11, 25. Sup. Ct. 358 .

4. See 27 Medico-Legal Journal, 134. Vasectomy is a comparatively simple and painless operation consisting of the cutting into and binding up of a small portion of the vas deferens. It effectively sterilizes the subject but does not impair his health or take away his sexual instincts.

5. See Lombroso, Crime: Its Causes and Remedies, 168 .

6. The right of the state to confine insane persons in asylums is clearly established. Dowdell petitioner, 169 Mass $387,389,47$ N. E, 1033, 1034. This right has sometimes been based on state's authority to care for the helpless. See Dowdell, petitioner, supra; Chavannes v. Priestly, 80 Ia. 316, 320, 45 N. W. 766,768 . In some cases, however it is certainly based also on the state's right to protect society. See Shenango v. Wayne, $34 \mathrm{~Pa}$. St. 184, 186; Keleher v. Putnam, 60 N. H. 30 31. Preventing the procreation of lunatics is merely another method of exercising this right of social protection.

7. See Ferri, Criminal Sociology, 28; Lom. broso, Crime: Its Causes and Remedies, 151 Dugdale, The Jukes.

8. Ferri estimates that born and habitual criminals together form about forty per cent of the total. See Ferri, Criminal Sociology, 18 .

9. The only objection which can be made to the legitimate children of habitual criminals is that they are likely to be reared in an atmosphere of crime. This is merely an inference, and if it proves correct the state can take them from the custody of their parents. See Van WaIters v. Board of Children's Guardians, etc., 132 Ind. $567,569,32$ N. E. 568,569 . The legislature clearly has no power to enact laws based on the principle that no one has a right to have children unless he can bring them up in an ideal environment.

10. See Saleilles, Individualization of Punishment, 129 .

11. Inasmuch as it is very difficult to restrain the powers of the medical examiners within proper limits, the attempt to pass this sort of legislation at present seems inadvisable. The common provision that the operation may be performed whenever a majority of the examiners "decide that procreation would produce children with a tendency to disease" would seem to give dangerously wide powers to examiners who held extreme views as to the hereditary nature of crime; and yet it is hard to suggest a more satisfactory phraseology.

12. Although the purpose of the statute is not to avenge or prevent a particular crime, but rather to reduce the number of criminals, it would seem that since it provides for sterilization as part of the sentence imposed upon conviction of crime it must be regarded as punishment. Cf. State v. Ray, 63 N. H. 406 . See People ex rel. Bradiey v. Illinois State Reformatory, 148 I1l $413,419,36$ N. E. 76, 78 Contra, Prescott v. State, 19 Oh. St. 184.

13. "The word "unusual" which is generally linked with "cruel" is not in the Washington constitution. Wash. Const. Art 1 \& 14 . Its omission is not important. since it is always construed with cruel. Storti v. Commonwealth, 178 Mass. 549,60 N. E. 210 .

14. The precise crime of which the defendant was convicted was "the carnal abuse of a female person under the age of ten years." Wash., Rem. \& Bal. Code, \$ \$2287, 2436 .

15." See Wilkerson v. Utah, 99 U. S. 130, 136; State v. Willams, 77 M'o. 310, 312. Some courts hold that a punishment may also be cruel because excessive. State v. Driver, 78 cruel because excessive. State v. Driver, 78 
349, 30 Sup. Ct. 544. Contra, Aldridge v. Commonwealth, 2 Va. Caf. 447. Since rape may be punished by death, sterilization can hardly be regarded as an excessive penalty. Rayna v. State, 75 S. W. 25.

16. See Cooley, Constitutionl Limitations, 473; State v. Becker, 3 S. D. 29, 41. Furthermore, the apparent theory of the statute that the crime of which the defendant was convicted is strong evidence of his degenerate character seems reasonable, although it has been asserted that such crimes are mainly due to the effect of civilization. See Lombroso, Crime: Its Causes and Remedies, 256.

17. The act authorizes the sterilization of habitual criminals. Wash., Rem. \& Bal. Code, 8287. Habitual criminals include those who have been three times convicted of petit larceny. Wash. Rem. \& Bal. Code, \$ 2286. Larceny is common among born criminals. See Lombroso, Crime: Its Causes and Remedies, 154. Nevertheless, the fact that a man has been found guilty of three small thefts is insufficient evidence of his degeneracy. This objection is hardly lessened by the fact that the sterilization of such persons is discretion. ary with the court, since this discretion may be exercised arbitrarily.

The matter of sterilization applicable to the criminal classes is summed up from the eugenical point of view as follows:

1. The criminalistic classes and inmates of institutions for criminals should be subject to the eugenical sterilization statutes of the states without favor or discrimination upon exactly the same terms to which all other inhabitants of the state are subjected, namely, the proof by pedigree studies of the potential parenthood of socially handicapped or unadapted offspring on the part of a given individual.

2. No element or suggestion of punishment should enter into a sterilization statute, because eugenical sterilization has for its sole purpose the improvement of racial qualities.

3. If, however, a state desires to enact a statute providing for the sexual sterilization of all criminals on a purely punitive basis, it is legally essential that the order for sterilization be made part and parcel of the original sentence passed by the court. If sterilization is ordered on all inmates of certain institutions, which inmates have previously been sentenced for a given crime, then such order, as in the Iowa case, will doubtless be held to constitute a bill of attainder. Moreover, this Iowa decision implies that sterilization is a serious thing, requiring in each case due process of law. Finally, punitive sterilization is not in any degree a simple therapeutic detail, such as vaccination, which has been settled by the courts of the country as being well within the provisions of administrative and executive powers granted under legislative authority, and not requiring court procedure in each particular case. But it seems probable that, in a majority of the states at least, a purely or partly punitive statute authorizing sexual sterilization would be held to constitute cruel and unusual punishment, and therefore, would be held unconstitutional and of no effect.

4. No appreciable mitigation of vicious sex-tendencies results fron sterilization, except in the removal of the sex-gland before puberty.

5. Criminologists generally have not contended that sterilization is a reformatory measure.

REFERENCES.

P. Näcke, "Die Kastration bei gewissen Klassen von Degenerirten als ein Wirksamer Socialer Schutz," Archiv. für Eriminalanthropologie, Bd, III, 1899, p. 58; Id. "Kastration in Gewissen Fällen von Geisteskrankheit," Psychistrisch - Nenrologieche Wochenschrift, 1905 , No. 29 .

Angelo Zuccarelii, "Assessualizzazione o sterilizzazione dei Degenerati," I'Anomalo, 1898-99, No, 6; id." "Sur la nécessité et sur les Moyens d'empécher la Réproduction des Hommes les plus Dégénérés," International Congress Criminal Anthropology, Amsterdam, 1901.

Näcke, Treurologisches Centralblatt, March 1 , 1909. The original account of these operations is reproduced in the PsychiatrischTourologische wochenschrift, No. 2, 1909 , with an approving comment by the editor, Dr. Bresler.

Flood, "Castration of Idiot Children," American Jourmal Psychology, Jan., 1899; also Alientst and Neurologist, Aug., 1909, p. 348. Havelock Ellis, Sex in Relation to Society (Vòl. VI of Studies in the Psychology of Sex), pp. 614-615, Castration and Negative Eugenics.

Millant, Castration Criminelle et Maniaque, 1902 .

\section{LEGAL LIABILITY OF EXECU- TIVE AGENTS AND SURGEONS IN EXECUTING THE SEVERAL EUGENICAL STERILIZATION LAWS.}

The responsibility for eugenical sterilization, or sterilization for therapeutic motives must, of course, rest entirely with the law. It would be not only unfair, but also quite illogical to hold the executive agents of the statute personally or criminally liable for executing both the letter and the spirit of the law in cases which undoubtedly fall within the scope of the statute itself. However, some of the sterilization laws have deemed it fitting to make special provisions in reference to the immunity from criminal liability on the part of the particular executive agents.

1. INDIANA. No reference.

2. WASHINGTON. First Law: No reference.

Second Law: (Sec. 9.) "No surgeon performing the operation provided for in the 
preceding section under the direction of the superintendent, or other officer in charge of such institution, shall be held criminally liable therefor or civilly liable for any loss or damage on account thereof, except in case of negligence in the performance of such operation."

3. CALIFORNIA. First law. No reference.

Second Law-Section 1. “*** Asexualization, whether with or without the consent of the patient, shall be lawful and shall not render said Commission, its members or any person participating in the operation, liable either civilly or criminally."

Sterilization Provision of law of California establishing Pacific Colony. This statute follows the exact wording of the second California statute, in reference to freedom from civil or criminal liability.

4. CONNECTICUT. No reference.

5. NEVADA. No reference.

6. IOWA. First Law, No reference.

Second law-no reference.

Third law-no reference.

7. NEW JERSEY. Section 3. "** No surgeon performing an operation under the provisions of this law shall be held to account therefor, but the order of the Board of Examiners shall be a full warrant and authority therefor."

8. NEW YORK. Section 352 . "*** No surgeon performing the operation under the provisions of this Act shall be held to account therefor."

9. NORTH DAKOTA. Section 9. “*** No surgeon who shall skillfully perform any operation as authorized by this Act shall be held accountable therefor, but the findings and order of this said Board of Examiners by the court, or the consent of such inmate and parents or guardian shall be his full warrant and authority therefor."

10. MICHIGAN. No reference.

11. KANSAS. First Law. No reference. Second Law-no reference.

12. WISCONSIN. No reference.

13. NEBRASKA. No reference.

14. OREGON. No reference.

15. SOUTH DAKOTA. No reference.

13. PUNISHMENT FOR DERELICTION IN EXECUTING THE LAW.

Most of the sterilization statutes present so many dangers in the mandatory chain between the legislative enactment and the actual sterilization of the particular subject that the effect of such laws is to make them an optional agency in the hands of their executive agents. However, after certain preliminary processes have, on the option of their executive agents, been got through with, one of the statutes makes mandatory, under pain of fine or imprisonment, the further execution of the law. An examination of the statutes reveals the following situation in this regard:

KANSAS. First Sterilization Law, Chapter 305, Laws of 1913, Section 3. "Any managing officers herein charged with any duty specified in section 1 , who shall fail, neglect or refuse for sixty days or more in the performance thereof, shall be guilty of a misdemeanor and subject to a fine of not more than one hundred dollars, or imprisonment in the county jail for not more than thirty days, or both such fine and imprisonment."

Doubtless the laws governing administrative officers generally, in many other states, would be applicable to officers who are derelict in enforcing the sterilization statute. It would seem that in a model sterilization statute little need would be found for this particular provision, but that great care should be taken by legislative provision to insure the appointment of competent and honest men. The laws of the state covering executive derelicts generally should be depended upon to insure competent activity on the part of a particular executive agent.

\section{PUNISHMENT FOR THE ILLE- GAL USE OF SEXUAL STERILI- ZATION.}

With the advent of eugenical sterilization and the spread, among surgeons of practice and skill in sterilizing operations, and further with the spread of the knowledge that many physicians and surgeons possess a relatively simple method of making individuals sexually sterile, there will doubtless be an appeal to the medical and surgical profession on the part of certain irresponsible and sexually indulgent individuals to be made sexually sterile, in order that they may ply their trade or indulge their sexual appetites more freely and with less danger of parenthood than is possible in the case of persons who are sexually fertile. It is probable that the hereditary moral qualities of such persons would be found to be of such low value to the state that the perpetuation 
of their kind would be of little value. Still there is the moral and hygienic aspect of unbridled license, and the matter of tampering illegally with a function, so vital to the interests of the state as the reproductive pow$\mathrm{er}$, is of such moment that several of the sterilization statutes have sought to control the illegal use of surgical sexual sterilization by devoting a section of the statute to defining what constitutes the illegal use of sexual sterilization and prescribing punishments for breach of the law.

In reviewing these statutes we find the following provisions:

1. CONNECTICUT. Sterilization Statute, Chapter 209, Public Acts 1909, Section 2: "Except as authorized by this act, every person who shall perform, encourage, assist in, or otherwise promote the performance of either of the operations described in section one, of this act, for the purpose of destroying the power to procreate the humane species, or any person who shall knowingly permit either of such operations to be performed upon such person, unless the same shall be a medical necessity, shall be fined not more than one thousand dollars, or imprisoned in the state prison not more than five years, or both."

2. IOWA. First Sterilization Law, Chapter 129, Acts of 34th General Assembly, Section 2: "Except as authorized in this act, every person who shall perform, encourage, assist in or otherwise promote the performance of either of the operations described in Sec. 1 of this act, for the purpose of destroying the power to procreate the human species, or any person who shall knowingly permit either of such operations to be performed upon such persons, unless the same shall be a medical necessity, shall be fined not more than one thousand $(\$ 1,000.00)$ dollars, or imprisoned in the county jail not to exceed one year, or both."

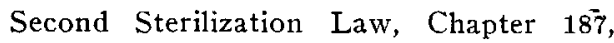
Acts of 35th General Assembly, Section 4: "Except as authorized in this act, every person who shall perform, encourage, assist in or otherwise promote the performance of either of the operations described in section one of this act, for the purpose of destroying the power to procreate the human species, or any person who shall knowingly permit either of such operations to be performed upon such persons, unless the same shall be a medical necessity, shall be fined not more than one thousand dollars, or im- prisoned in the penitentiary not to exceed one year, or both."

Third Sterilization Law, Chapter 202, Acts of 36th General Assembly, Section 4: "Except as authorized in this act, every person who shall perform, encourage, assist in, or otherwise promote the performance of the operations described in section two of this act for the purpose of destroying the power to procreate the human species, or any person who shall knowingly permit either of such operations to be performed upon such person, unless the same shall be a medical necessity, shall be fined not more than one thousand dollars, or imprisoned in the penitentiary not to exceed one year, or both."

3. NEW YORK. Public Health Law, 1912, Article 19, Sec. 353: "Except as authorized by this act, every person who shall perform, encourage, assist in, or otherwise permit the performance of the operation for the purpose of destroying the power to procreate the human species, or any such person who shall knowingly permit such operation to be performed upon such person, unless same shall be a medical necessity, shall be guilty of a misdemeanor."

4. MICHIGAN. Public Acts 1913, Act No. 34, Section 5: "Except as authorized by this act, every person who shall perform, encourage, assist in, or otherwise promote the performance of either of the operations described in section one of this act, for the purpose of destroying the power to procreate the human species, or any person who shall knowingly permit either of such operations to be performed upon such person, unless the same shall be a medical necessity, shall be guilty of a felony, and upon conviction thereof shall be fined not more than one thousand dollars, or imprisoned in the state prison not more than five years or both, at the discretion of the court before whom the said person or persons were so convicted."

5. KANSAS. First Law, Chapter 305, Session Laws of 1913, Section 2: "Except as authorized by this act, every person who shall perform, encourage, assist in, or otherwise promote the performance of either of the operations, described in section 1 of this act, for the purpose of destroying the power to procreate the human species, or any person who shall knowingly permit either of such operations to be performed upon such a person, unless the same shall 
be a medical necessity, shall be fined not more than one thousand dollars, or imprisoned in the county jail not exceeding one year, or both."

Second Law, Chapter 299, Session Laws of 1917, Section 7: "Except as authorized by this act, every person who shall perform, encourage, assist in or otherwise promote the performance of either of the operations described in this act, for the purpose of destroying the power to procreate the human species, unless same shall be a medical necessity, shall be fined not less than $\$ 100.00$ nor more than $\$ 500.00$, and imprisoned in the county jail not less than six months nor exceeding one year."

6. WISCONSIN. Chapter 693, Laws of 1913. Section 3. “*** provided, however, that the operation shall not be performed except in such cases as authorized by the said board of control."

Because of the liabilities of abuse of surgical sexual sterilization if the practice becomes widespread for eugenical purposes, it would appear wise to include in future statutes provisions against the illegal use of this method of preventing human reproduction.

\section{THE LEGAL ASPECT OF SEXUAL STERILIZATION FOR THERA- PEUTIC PURPOSES. ${ }^{1}$}

To each of the 124 state institutions for the various types of the socially inadequate classes which are or have been subject to the several sterilization laws, the following questions were put:

1. Can you, in ordinary course of your professional practice, perform any operation under this law that would be forbidden or illegal without it?

Answers:

Institution not under the law $\ldots \ldots, 16$

No:........................ 25

Yes:....................... 15

Must have consent of patient,

or State Board of Health, etc.... 7

Law declared unconstitutional..... 8

No cases................... 20

Law specifies classes............ 2

Applicable only to parole cases.... 1

Don't know.................. 8

No such law................. 4

No answer:................. 18

Total................ 124

1 See also page 100 .
2. What in your opinion is the medical value of the statute?

Answers:

Decided value:............... 21

Slight value.................. 8

No opinion to offer:............ 20

No value................... 8

No answer:...............67

Total................ $\overline{124}$

3. What is the eugenical value of the law?

Answers:

Decided value:.............. 50

Doubtful ..................... 5

No opinion.................. 6

No value.................... 2

No answer:................, 61

Total................. 124

For therapeutic purposes it would appear that the existing laws may be regarded as superfluous , because they grant no new authority and impose no additional responsibility. It is true that many of the sterilization statutes permitted the sterilization of certain inmates on the grounds that such operation might benefit the physical and mental condition of the particular inmate. It seems probable, however, that the laws controlling the medical and surgical treatment of inmates of institutions generally cover surgical operations which were based upon sound medical reasons, and which operations incidentally involve the destruction of the reproductive functions of the individual. Just as the attempt to make sexual sterilization a punishment for crime has proven to be entirely repugnant to our institutions, and of little eugenical value, the authority granted to use sterilizing operations for therapeutic purposes is entirely superfluous and of no eugenical value. Eugenical sterilization has but one purpose, the cutting off of the descent lines of individuals with defective and degenerate hereditary traits. Punishment for crime, and remedies for physical ailments of the particular individual, are problems not for eugenics, but respectively for eriminology and for medicine.

Many cases are reported in different states in which surgeons, without regard to statutes in reference to eugenical sterilization, but apparently entirely safe-guarded by other laws controlling surgical practice, have by surgical means sexually sterilized their 
patients. In these cases several motives have been reported: first, to forestall possible future pregnancies which would be apt to be obstetrically difficult; second, oth. er cases which would be especially burdensome economically or socially; and third, on account of eugenical desirability. It is here pertinent to call attention to the fact (p. 86, Chapter IV) that the Buffalo State Hospital practices eugenical sterilization on its own responsibility.

But in even more cases sexual sterilization has been performed as an accompaniment, surgically unnecessary but desirable for one or more of the above stated reasons, of gynecological operations. In such cases it appears that sexual sterilization was not justified on its own account, but was made a by-product of operations having other primary purposes.

\section{THE SEXUAL STERILIZATION OF INMATES OF CUSTODIAL INSTITUTIONS, PRIOR TO THEIR RELEASE.}

No eugenical purpose would be served by the sexual sterilization of inmates of our larger custodial institutions unless such inmates are to be released into the population at large while still in the reproductive period. It is true that in some of the smaller alms-houses and ill-managed custodial institutions, female inmates are known to give birth to children who were conceived while the particular inmate was still in the institution, or while away on short parole, or at intervals between the commitment periods. But such occurrences are becoming rarer. If segregation in modern custodial institutions were general in the case of potential parents of degenerates, and such custodial care in all cases continued until the end of reproductive period of the particular inmates, there would be no object in eugenical sterilization. But the inmates of the custodial institutions and the potential parents of socially inadequate offspring are not in any state to any great degree one and the same class. Inmates of institutions are of two classes-potential parents of degenerate offspring, and persons who are not such. Similarly the same two classes exist in the population at large. This is the reason why eugenical sterilization laws which apply only to the inmates of institutions constitute "class legislation" in that such statutes create an unnatural and arbitrary sub-class within a larger natural class, some of which natural class are in institutions and some of whom are in the population at large. $B$ ut to this entire general natural class, not to its arbitrary sub-class, the law, in order to be constitutional on the grounds of "equal protection of the laws" must apply.

The superintendents of some of the larger custodial institutions oppose sterilization because they feel that sterilization if extensively used would cause society to diminish its support of extensive segregation of inadequates. They fear that it is proposed to apply sterilization to socially incapable and degenerate individuals, then turn such persons on their own resources and on charity in the population at large. They point out that if individuals of low natural inhibitory powers are sexually sterile, the knowledge of such sterility will break down the last modicum of self-restraint which these unfortunates possess in reference to sexual matters; that as a result sexual license, accompanied by moral deterioration and in the spread of venereal disease, would be greatly increased.

But here there is a confusion of the functions of a custodial institution and eugenical sterilization. Custodial segregation, if continued long enough in a modern institution, will safely take the place of sexual sterilization. But sexual sterilization cannot take the place of custodial care of a degenerate or defective individual. It would appear then that the statute should apply to the potential parents of defectives who are in institutions, but that the actual performance of the sterilizing operation or treatment may, in the case of the inmates of the institutions, be well suspended until the particular inmate is about to be released into the population at large. And if in the meantime the particular inmate has, due to disease or medical treatment or old age, lost the reproductive function, then of course there would be no eugenical object, even upon release of such an inmate, in executing the legal order for destroying the reproductive functions.

With those laws which permit sexual sterilization for punitive or therapeutic, rather than for eugenical purposes, the application of the operation to inmates of institutions, regardless of their prospect of release or parole while still potential parents, is quite logical; but with the passing of punitive sterilization, and the superfluous nature of special legislation permitting sterilization for 
therapeutic purposes, the eugenical motive alone remains. This logically calls for sexual sterilization of potential parents of degenerates, who are inmates of custodial institutions, only in case such inmates are to be released or discharged while still capable of procreation.

The laws in reference to the relation between the termination of custodial care and the time set for sterilizing the particular inmate are summarized as follows:

1. INDIANA. The law applies only to the inmates of certain institutions. There is no provision for suspending the order for execution in the case of life prisoners, nor is there any authorization for sterilizing potential parents of defectives in the population at large.

2. WASHINGTON. In Washington the first law is punitive and applies equally at the discretion of the judge in case of conviction for rape to a person committed for life and one committed for the minimum period.

The second law applies generally to defective and criminal individuals in institutions. Its intent is absolutely eugenical and therapeutic.

3. CALIFORNIA. The first statute applies generally to inmates of non-punitive institutions, but in the case of convicts sentenced to a state prison for life, and who exhibit continued evidence of moral and sexual depravity, the right to asexualize them shall apply. This last provision must be purely therapeutic in its intent; certainly it has no eugenical bearing.

Second California statute applies only to inmates of institutions, with the same provision as the first statute for application to life prisoners. This statute, however, implies a more logically eugenical meaning by authorizing the state commission in lunacy, after consideration, to cause inmates of institutions to be asexualized before the release or discharge of such persons from institutional custody.

The third and fourth statutes modify in no manner the provisions of the second in reference to the time of application of authorized sterilization.

4. CONNECTICUT. The law applies only to inmates of institutions, with no provision for excepting individuals who are committed for life, or who are not potential parents.

5. IOWA. The first law applies only to inmates of institutions, with no provision in reference to the probable length of period of commitment or potential parenthood.

The second statute applies to the inmates of institutions, and also permits the board of parole or a district court to authorize the sterilization of persons at large who are afflicted with syphilis or epilepsy.

The third sterilization law of Iowa applies only to inmates of institutions, with no provision for excepting the inmates apparently to be confined for life, and who are not po. tential parents.

6. NEW JERSEY. The law applies only to the inmates of the institutions, with no provision for excepting individuals apparently to be confined for life, or who are not potential parents.

7. NEW YORK. The law applies only to the inmates of institutions, with no provision for excepting individuals apparently to be confined for life, or who are not potential parents.

8. NORTH DAKOTA. This law applies only to the inmates of institutions, with no provision for excepting individuals apparently to be confined for life, or who are not potential parents.

9. MICHIGAN. The law applies only to the inmates of institutions, with no provision for excepting inmates apparently to be confined for life, or who are not potential parents.

10. KANSAS. The first and second statutes of Kansas apply to the inmates of institutions, with no provision for excepting inmates, apparently to be confined for life, or who are not potential parents.

11. WISCONSIN. The law applies only to the inmates of institutions, with no provision for excepting inmates apparently to be confined for life, or who are not potential parents.

12. NEBRASKA. The sterilization statute of Nebraska was the first in letter and spirit to recognize the eugenical purpose of the Act by modifying its application of sterilization to the inmates of institutions. It applies only to such inmates as are "physically capable of bearing or begetting offspring," and provides further that if after the investigation of the "family traits and history of all inmates who may be subject to parole or discharge from the institution," it is found "that such inmate is capable of bearing or begetting offspring," “*** that such children would probably become a so- 
cial menace, and that the procreation by such inmate would be harmful to society, and that such inmate should not be paroled or discharged, as the case may be, unless sterilized, then in every such case it shall be a condition prerequisite to the parole or discharge of such inmate, that said inmate be made sterile."

13. OREGON. The law applies only to the inmates of institutions, with no provision for excepting individuals apparently to be confined for life, or who are not potential parents.

14. SOUTH DAKOTA. The law applies only to the inmates of institutions, with no provision for excepting individuals apparently to be confined for life, or who are not potential parents.

Twenty-two laws in reference to sterilization have been written on the statute books of American states. In only one instance was the law made applicable to persons in the population at large. This exception is to a very limited class authorized to be eugenically sterilized by the second sterilization law of Iowa (1913, Chap. 187, Acts of the 35th General Assembly, Sec. 2) "Those afflicted with syphilis or epilepsy may apply to the board of parole, or any judge of the district court, and upon order of such board or judge, the operation of vasectomy or ligation of the Fallopian tubes may be performed upon such person, and any law restricting marriage of such person shall be void and of none effect, in case one of the contracting parties has submitted to such operation and the same was known to both parties before their marriage."

The student of eugenics, in making this particular analysis of the laws with reference to their attitude toward applying eugenical sterilization only to those potential parents of defective offspring who are inmates of institutions and who are to be discharged into the population at large while still physically able to bear or to procreate young, finds that the Nebraska statute stands out as the only law which has at all grasped the eugenical purpose of applying a sterilization statute to the inmates of custodial institutions for the several types of socially unadapted.

\section{CLASS LEGISLATION}

Section 1 of the XIVth Amendment to the Constitution of the United States provides that "no State shall make or enforce any law which shall abridge the privileges or immunities of citizens of the United States; nor shall any State deprive any person of life, liberty, or property without due process of law, nor deny to any person within its jurisdiction the equal protection of the laws." The violation of the latter provision of this section, the denial of equal protection of the laws, constitutes what is called "class legislation." The law must, of course, establish certain standards and specifications for the application of the law. In so doing it creates legal classes, but these classes must, under this provision, be natural classes. They must not be too much subdivided or too artificial or arbitrary in their inclusions and limitations. In other words, the law, in depriving individuals of life, liberty, or property, must apply with equal force and without favor or hindrance to all persons within the state who conform to the general specifications set by the statute.

Five of the eugenical sterilization statutes, Indiana (Chapter 215, Laws of 1907), New Jersey, (Chapter 190, Session Laws of 1911), Iowa, (Chapter 187 Session Laws of 1913), New York (Chapter 445, Session Laws of 1912) and Michigan, (Act No. 34 Sessions Laws of 1913)-have been declared unconstitutional, among other objections, in four cases on the ground that the statute, as drawn, constituted "class legislation." The judges in rendering their opinions in some cases criticised the expediency of the law and the effectiveness of its administration, matters which, of course, should be attended to by the legislative and executive departments, respectively. But in each case, finally, the court exercised its undoubted judicial prerogative in passing upon the constitutionality of the act.

There is another specification which custom demands of our American state legislation, and that is that there be a reasonable adaption of the means which the statute provides for effecting the desired end. There must be a compensation in benefit to the general welfare for the intrusion upon what might be called personal or natural rights of the citizen. Thus, if vaccination had been proven to be of no avail, doubtless the courts would have refused to uphold the constitutionality of a statute which so invaded the rights of the citizen to a great extent and still offered no return to the general welfare. But vaccination having proved its medical worth, the courts quite generally have sustained the most radical provisions for compulsory vaccination. 
In relation to eugenical sterilization, what is the natural class to which the remedy must be applied, without constituting "class legislation" or denying the equal protection of the laws to all residents within the jurisdiction of a given state? The New Jersey court held that to apply sterilization to epileptic inmates of an institution and not to the epileptics of the same degree of degeneracy in the population at large constituted "class legislation." The court in this case moreover suggested that the limits of undesirable parenthood would be difficult to establish, that if the principle of sterilization of degenerates were upheld, there would be no logical termination for its application. This latter opinion was of course not that of students of the socially indequate classes who had canvassed the whole field of socially handicapped and had learned that the classification of social inadequates and definitions which set them off quite sharply from the normal population are generally agreed upon by sociologists and eugenicists.

If a particular state seeks to limit its sterilization laws to natural classes of degenerates, may it not contend that its segregation and commitment laws are so thorough that only in institutions are persons of degenerate stock who logically fall within the eugenical ban to be found? Could it not also contend that the sterilization of all feeble-minded persons of a certain degree of mental defect constitute a natural class to whom eugenical sterilization could be logically applied without any possibility of denying equal protection of the laws to all citizens of the state. It might even be argued that there is so much hereditary salvage in the insane classes, and so many types of the insane-indeed modern institutions often show thirty classes in their diagnosis reports-that the inclusion of the insane in the same category with the feebleminded would be illogical and would work eugenical harm in many cases. If in future cases the courts uphold the narrower view of "class legislation" which has been upheld by the four cases above mentioned, then doubtless the states will be found bereft of a power for race betterment which they may in the future care to exercise.

The model sterilization statute, however, has no quarrel with "class legislation" because it applies to all individuals in the state, whether in institutions or in the population at large, who conform to a certain standard stated in the statute of degenerate parenthood, regardless also of the particular type of defectiveness, whether feeble-minded, insane, criminalistic, or with gross physical defects. The law must thus, in order to be logical, not subject persons who are individually. handicapped mentally or physically to sexual sterilization if their individual handicap is the result of accident or environment circumstances, and is not based upon hereditary qualities. This distinction is certainly sound biologically, and its application helps to define more sharply the natural classes which the law holds should be made the basis for legislation. A court, in seeking to avoid discrimination by including all the insane persons within the scope of a sterilization law, would defeat its own purpose by not making the exceptions above described.

A canvass of the statutes finds the following limitations of the application of eugenical sterilization, that is, individuals are selected for sterilization within these classes.

1. INDIANA. Inmates of institutions entrusted with the care of confirmed criminals, idiots, rapists and imbeciles.

2. WASHINGTON. First Law. Those adjudged guilty of carnal abuse of a female person under ten years of age, or rape.

Second Law. Inmates of State custodial institutions who are feeble-minded, insane, epileptic, habitual criminals, moral degenerates and sexual perverts.

3. CALIFORNIA. First Law. Inmates of the state hospitals and the California Home for the Care and Training of FeebleMinded Children, and convicts in the state prisons.

Second Law. Inmates of state hospitals for the insane, the Sonoma State Home, convicts in state prisons, and idiots.

Amendment to the Second Law. No extension of classes.

Law establishing the Pacific Colony. Application of sterilization statutes to inmates of the Pacific Colony.

4. CONNECTICUT. Inmates of the state prison and the state hospitals for the insane at Middletown and Norwich.

5. NEVADA. Those adjudged guilty of carnal abuse of a female person under ten years of age, or of rape.

6. IOWA. First Statute. Inmates of each public institution in the state entrusted with the care of criminals, idiots, feebleminded, imbeciles, drunkards, drug-fiends, epileptics and syphilitics.

Second Law: All public institutions in the state entrusted with the care of crimi- 
nals, rapists, idiots, feeble-minded, imbeciles, lunatics, drunkards, drug-fiends, epileptics, syphilitics, moral and sexual perverts, and diseased and degenerate persons; also persons in the population at large who are afflicted with syphilis or epilepsy and who may voluntarily apply to a district court.

Third Law. Inmates of the state hospitals for the insane.

7. NEW JERSEY. Feeble-minded, epileptic, and other defective inmates confined in the several reformatories, charitable and penal institutions in the counties and state, criminals who have been convicted of the crime of rape or of such succession of offenses against the criminal law as in the opinion of the board of examiners shall be deemed to be sufficient evidence of confirmed criminal tendencies.

8. NEW YORK. Feeble-minded, epileptic, criminal and other defective inmates confined in the several state hospitals for the insane, state prisons, reformatories and charitable and penal institutions in the state, including criminals who have been convicted of the crime of rape, or of such succession of offenses against the criminal law as in the opinion of the board shall be deemed sufficient evidence of confirmed criminal tendencies.

9. NORTH DAKOTA. Inmates of the state prison, reform school, state school for feeble-minded, and the state hospitals and asylums for the insane.

10. MICHIGAN. Inmates of all institutions maintained wholly or in part by public expense, who have been adjudged by a court of competent jurisdiction to be mentally defective or insane.

11. KANSAS. First Law. Inmates of all state institutions entrusted with the care and custody of habitual criminals, idiots, epileptics, imbeciles, and insane.

Second Law: Inmates of the state penitentiary, the Hutchinson Reformatory, the state hospitals for the insane, the state hospitals for epileptics, the state Home for Feeble-Minded, and the state Industrial School for Girls.

12. WISCONSIN. Inmates of state and county institutions for the criminal, insane, feeble-minded and epileptic classes.

13. NEBRASKA. Inmates of institutions for the feeble-minded and insane, the penitentiary, reformatory, industrial home and industrial schools.
14. OREGON. Inmates of the Oregon state hospitals and the Oregon penitentiary, who are feeble-minded, insane, epileptic, habitual criminals, moral degenerates and sexual perverts.

15. SOUTH DAKOTA. Inmates of the state home for feeble-minded persons.

This canvass shows a rather limited application of the principle of eugenical sterilization, but as the principles which govern the determination of degenerate parenthood and practical methods of gathering pedigree evidence are still not widely diffused among the social and eugenical workers of the country, these laws may be considered safe and sound in that they apply to such individuals who by due process of law have been declared to be socially unadapted to a degree which constitutes them a social menace. The decisions of the court in reference to their limited application, together with wider spread of the knowledge of human pedigree studies, will justify the correction of this objection of so limited an application that the statutes are apt to be held to constitute "class legislation."

\section{WHAT CONSTITUTES DUE PRO- CESS OF LAW IN EUGENICAL STERILIZATION?}

Whenever a law commands that something be done in reference to individuals of a certain class, the members of which present a given legally defined condition, and the execution of the thing ordered is, or may be, distasteful or objectionable to the particular individuals affected, such a law is always considered an infringement of the personal liberty of the individuals affected by it. But this is the nature of all law-to command what shall be done and what shall not be done. A democracy permits such infringement of personal rights only in case the law applies without favor or discrimination to all members of the natural class presenting the legally defined conditions.

In applying such a statute in America there must always be due process of law. This may be effected by requiring court procedure in cases involving a relatively great infringement on personal liberty, or by entrusting the application of the law to executive agents who in their discretion may decide summarily that the law applies or does not apply in a particular case. Obviously enough, this latter type of summary administration is applicable only to the less serious infringements on personal liberty, 
and the rights of persons affected by the laws are further safe-guarded by providing for appeals to the courts in case of apparent or supposed abuse of power.

In reference to eugenical sterilization, the following questions arise: Is sterilization a surgical operation, and in compulsory cases an infringement on personal liberty to such an extent that it should be ordered only as a result of court procedure in which the individual propositus has a right to be heard, or may it be classed with those lesser infringements or intrusions on personal liberty which are entrusted in their execution to the arbitrary discretion of executive agents? Does the fact that sterilization results in the inability of the individual operated upon to produce young have any bearing on the matter, or will the law take into consideration only the danger to life of the surgical operation itself, and in the case of young persons the physiological consequences in development? Will all sterilizing operations come under the same class as to requiring due process of law-that is, will vasectomy, or even castration, in the male, and sterilization by scarifying and $\mathrm{X}$-rays in the female, be classed as not endangering life, and therefore be ordered by an executive agent, whereas those operations upon the female which involve the opening of the abdominal cavity be classed with those dangerous to life, and therefore be ordered only with the consent of the patient, or by court order, after hearing and trial?

The arguments for requiring court procedure in each case may be summed up as follows:

(a) The destruction of the reproductive powers will effect directly the character of the next generation, and consequently is a matter of great social importance.

(b) So far as the individual and the family are concerned, sterilization cuts most deeply into the most fundamental of all natural functions.

(c) There is no necessity for haste in eugenical sterilization, as in the case of vaccination for an impending epidemic of smallpox, or the commitment of the insane who are momentarily in danger of committing serious anti-social acts.

(d) The determination of defective parenthood is a matter which requires careful, extensive and technical study, and cannot be effected summarily and without due investigation.
Eugenical sterilization lays a safe and sane democratic foundation for laws which will in the future govern not only the interests of race betterment, but be used to limit the human race, due to the prospect of overpopulation. If summarily applied, such limitation would be fraught with the greatest possibility for wrong to the individual and the race. The necessity, while population is still relatively sparse, for developing an effective and just court procedure for the determination of defective parenthood is very great.

The arguments for entrusting eugenical administration to executive or administrative discretion are:

(a) Potential parenthood of defectives is defined by legislative authority, and its execution should be entrusted to scientific and honest agents who will, as in the case of vaccination, determine the necessity for the application to individual cases.

(b) An honest executive agent is much more apt to make a thorough and expeditious examination than is a court, which often permits cases to drag on for years; meanwhile the potential parent of defectives would be reproducing his or her defective stock.

(c) Quarantine rests on individual executive discretion under a general statute, and not on court procedure in each case.

(d) The commitment of insane to institutions, which involves as great an invasion of liberty as can be imagined, is entrusted to executive agents who are not required to conduct court procedure in order to make commitment legal.

(e) In institutional cases, vaccination, dental work, operations for rupture, and many other surgical and medical treatments are permitted on the discretion of the superintendent, regardless of the consent of the individual, and certainly without court order. Even in punitive cases wardens and principals of prisons and reform schools are permitted considerable latitude in administering disciplinary punishment. If sterilization is for the benefit of the individual, should it not fall within this same category of remedial agencies placed at the disposal of superintendents of institutions?

There are two groups of statutes in reference to their attitude toward the seriousness of eugenical sterilization as an invasion of personal freedom. The first group consists of those laws in which due process of law is achieved by making eugenical sterilization 
the subject of ministerial discretion, and not requiring court procedure in each case. In the second group are those statutes which evidently hold that eugenical sterilization is so fraught with possibilities for wrong to the individual in depriving him of life or liberty or of natural functions that if due process of law be effected, it is necessary in each case to provide court procedure, with the right to be heard, and the application of the order for sterilization as a result of the law and the evidence. It may even be held that the facts of the case may be determined legally by jury.

All of this does not, of course, imply that the state has not the right to impose eugenical sterilization upon defective families, but that in the orders for particular cases there is a difference of opinion in this early period of sterilization legislation concerning what constitutes due process of law.

Under the term executive discretion are included all of those means of determination other than court procedure. Many states have sought to insure justice and efficiency: by setting up a sort of semi-judicial commission, or entrusting the final determination to a board of directors. The essential feature of proceedings under such boards is, however, non-judicial in that the right of the person nominated for sterilization to be heard directly or by a mixed friend and attorney, and the application of the law solely upon the facts and the evidence, is lacking.

It is clear that a state may effect legal eugenical sterilization, so far as satisfying due process of law, either through (a) the summary discretion of an administrative officer, or (b) a semi-judicial board of examiners or commission, or (c) court procedure based on law and evidence. In the model law which accompanies this study, procedure is provided as follows:

A trained eugenicist acts in the executive capacity by securing evidence relative to socially inadequate parenthood, then brings the evidence before courts of competent jurisdiction who determine upon sterilization in accordance with the law and the evidence. If the law is properly drawn, court procedure may after the first few cases be expedited almost as promptly as under purely executive procedure. Thus in every case the people of the state will be assured that the most punctilious regard has been had for the rights of the particular individual nominated for sterilization, and the opportunity for abuse of authority in executing a law fraught with such responsibilities to the state is reduced to a minimum.

There are three groups of states in reference to their attitude in regard to what constitutes due process of law in ordering eugenical sterilization:

GROUP I. States which effect due process of law through administrative discretion, or quasi-judicial boards or commissions.

There is, of course, nothing to prevent the stbject about to be operated upon, to appeal to the court for a hearing, but such appeal must be made and decided on the general laws of the state and not in accordance with a specific provision of the sterilization statute.

GROUP II. States which provide for the investigation and ordering of eugenical sterilization by an administrative quasi judicial board or commission, but which provide, also, for an easy and convenient appeal to the courts by the subject.

GROUP III. States which require court procedure in each particular case.

\section{GROUP I.}

\section{Administrative Discretion.}

1. INDIANA. The executive board consists of the regular institutional physician and two skilled surgeons, who make recommendations to the board of managers of the institution:" "If, in the judgment of this committee of experts and the board of managers, procreation is inadvisable * * * it shall be lawful for the surgeons to perform such operations * * *."

2. CALIFORNIA. First Law: "Whenever in the opinion of the medical superintendent *** it would be beneficial and conducive to the benefit of the physical, mental or moral condition of any inmate * * * he shall call in consultation the general superintendent * * * they may perform the same."

Second Law: "**** the state commission in lunacy may in its discretion, after a careful investigation of all the circumstances, cause such a person to be asexualized * * *"

Amendment to the Second Law of California: "Before any person who has been lawfully committed to any state hospital for the insane *** shall be released or discharged therefrom, the state commission * * * may * * * after examination: 
cause such person to be asexualized, and such asexualization whether with or without the consent of the patient shall be lawful * * *"

Law establishing the Pacific Colony. Section 42: "Before any inmate *** shall be released or discharged therefrom, the board of trustees on the recommendation of the superintendent *** may cause such person to be sterilized; and such sterilization, whether with or without the consent of the inmate, shall be lawful **"."

3. CONNECTICUT. The institutional physician and two skilled surgeons "*** * shall constitute a board, the duty of which shall be to examine such inmates of said institutions *** and if, in the judgment of a majority of said board, procreation by any such person would produce children with an inherited tendency to crime * * * then said board shall appoint one of its members to perform the operation * * * *

4. IOWA. First Law: "The members of such board and the managing officer and the surgical superintendent of such institution shall judge of such matters."

Second Law: "If a majority of them decide that procreation by any such inmates would produce children with a tendency to disease *** then the physician of the institution *** shall perform the operation."

Third Law: “*** that whenever the superintendent and a majority of his medical staff shall * * agree that it is for the best interests of the patient and society, they are hereby authorized to perform the operation of sterilization *** and provided further that the superintendent of the hospital shall have secured the written consent of the husband or wife, if the patient is a married person, and if an unmarried person, the written consent of the parent, guardian or next of kin, if any there be within this state ***"

5. NORTH DAKOTA. "If such board in its findings order such operation upon such inmate, it shall, in such findings, designate what operation is to be performed **". (Section 5.).

6. KANSAS. Second Law: The second sterilization law of Kansas differs from the first largely in that the first statute required court procedure in each particular case, whereas the second statute, that of 1917, organizes a board of examiners who may make final disposition of cases nominated to them by the authorities of the different institutions. (Section 1.) "But before such operation shall be performed a written notice shall be served on such inmate, and guardian, if there be one, of the time and place of a meeting and hearing at least thirty days prior thereto; and said inmate shall have the right to be represented by counsel and may introduce such evidence as may be desired."

7. WISCONSIN. (Section 3.) "If such experts and superintendent unanimously find that procreation is inadvisable, it shall be lawful to perform such operation * * *."

8. NEBRASKA. The board of commissioners of state institutions designate a board of examiners consisting of five institutional physicians, three of whom constitute a quorum. "A determination or order of said board must be concurred in by at least three members thereof." This board, after an investigation, may order that (Section 3) "6*** it shall be a condition prerequisite to the parole or discharge of such inmate that said inmate be made sterile * * *." (Section 4). "Before any such operation shall be performed, the nature, character and consequences of such operation shall be fully explained to such inmate and to the husband, wife, parent, guardian or nearest kin, as the case may be, and the assent of such inmate so far as said inmate is capable of assenting thereto."

9. SOUTH DAKOTA. In this state the superintendent of the institution for feebleminded persons makes a nomination to the State Board of Charities. (Section. 2) "** * that it shall be the duty of said board *** to determine whether it is improper or inadvisable to allow any such inmates to procreate ***" If the board so decide "** * * then the physician of the institution *** shall perform the operation * * *."

\section{GROUP II.}

\section{Administrative Discretion with Provisions for Easy and Convenient Appeal to Court Procedure.}

1. MICHIGAN. Authority is given to the management of any institution maintained wholly or in part by public expense $1 * * *$ to render incapable of procreation *** any person who is mentally defective or insane ** *" Provision is made for the notification of the parent or guardian of 
such person at least thirty days before performing the operation. " **** when said parents or guardian object to the performance of such operation, then the question of the sanity of such person shall be referred to the probate court of the county in which the institution is located, where the question of the sanity and the necessity for this operation shall be determined as in other insane cases before such courts."

2. OREGON. In Oregon the State Board of Eugenics makes an investigation of the personal and family history of inmates reported to it by the superintendents of custodial institutions. This Board then prepares its findings in writing, and in case of operation deemed necessary, serves a copy of the order "*** on said inmate, or in case of an insane person upon his legal guardian, and if such insane person have no legal guardian, then upon his nearest known kin within the State of Oregon, and if such person have no known kin within the State of Oregon, then upon the custodian guardian of such insane person."

Section 6. "Any such inmate desiring to appeal from the decision of the said Board, or in case the person is under guardianship or disability, then the guardian of said inmate may take an appeal to the circuit court of the county "* *."

3. WASHINGTON. According to the second law, the duty of investigating into and reporting upon the family history and conditions of the inmate and decision upon the operation are entrusted into the hands of the institutional board of health, however, "** * Any such inmate desiring to appeal from the decision of said board, or in the case the person is under guardianship or disability, then the guardian of said inmate may take an appeal into the superior court of the county in which the institution, in which the inmate is confined, is located."

"** Provided said notice shall be filed within fifteen days of the date when notice of the board's decision is served on the inmate or his guardian, and said notice of appeal shall stay all proceedings of said board on said matter until the same is heard and determined on said appeal: Provided, further, That no operation shall be performed, upon any inmate until the time for appeal from the decision of the board has expired." (Sec. 5.)

“* * * The trial shall be a trial de novo at law as provided by the statutes of the state, for the trial of actions at law." (Sec. 6.)

"** * If the court or jury shall affirm the findings of said board, said court shall enter a judgment, adjudging that the order of said board shall be carried out as herein provided; if the court fail to affirm the decision of said board appealed from, then said order shall be null and void and of no further effect." (Sec. 7.)

\section{GROUP III.}

\section{Court Procedure Required in Each Case Before Sterilization.}

1. NEW JERSEY. Section 3: “*** previous to said hearing the said board shall apply to any judge of the Court of Common Pleas *** for the assignment of counsel to represent the person to be examined ***. All orders made under the provisions of this act shall be subject to review by the Supreme Court or any justice thereof, and said court may upon appeal from any order grant a stay which shall be effective until such appeal shall have been decided."

2. NEVADA. "Whenever any person shall be adjudged guilty of carnal abuse of a female person under the age of ten years, or of rape, or shall be adjudged to be an habitual criminal, the court may, in addition to such other punishment or confinement as may be imposed, direct an operation. to be performed upon such person for the prevention of procreation * * *."

3. NEW YORK. Section 352: "The board of examiners shall apply to any judge of the Supreme Court or county judge of the county in which said person is confined for the appointment of counsel to represent the person to be examined. * * * All orders made under the provisions of this act shall be subject to review by the Supreme Court or any justice thereof, and said court may upon appeal from any order grant a stay, which shall be effective until such appeal shall have been decided ***"

4. KANSAS. First Law: The managing authorities of the custodial institutions make investigations concerning the inadvisability of allowing certain of their inmates to procreate. (Section 1) "**** then said authority shall report their conclusions with a recommendation to the District Court or any court of competent jurisdiction in and for the district from which such inmate or inmates has been committed ${ }^{*} *^{*}$. The 
court shall thereupon hear and determine the matter."

5. WASHINGTON. "Whenever a person shall be adjudged guilty of carnal abuse of a female person under the age of ten years, or of rape, or shall be adjudged to be an habitual criminal, the court may, in addition to such other punishment or confinement as may be imposed, direct an operation to be performed upon such person for the prevention of procreation."

\section{RECORDS AND REPORTS REQUIRED BY LAW.}

It seems obvious that a thing so important to the welfare of the state as eugenical sterilization should be accompanied by permanent reports and records which should remain the property of the state. However, many of the statutes are by text or implication optional so far as their enforcement is concerned, and perhaps on this account in many cases no provision has been made for adequate records of case and family histories, the procedure of selection, and the actual sterilizing operations performed. If in America a body of professional eugenicists and expert field workers is to be developed for the purpose of enforcing the sterilization statutes, then certainly the keeping of accurate records would aid greatly in the efficiency of the work of the persons entrusted with the investigations demanded by the statutes, and in the actual application of the law to particular cases.

Perhaps one reason for omitting legislative demands for permanent records is that often the person entrusted to enforce the law is an ex officio executive agent whose principal interests and duties are with some other state enterprise and who would be expected to include an account of his activities in enforcing this particular statute with an account of his primary business.

The laws of the several states in this regard may be summarized as follows:

1. INDIANA. No reference to records.

2. WASHINGTON. First Law. No reference to records, but since the order for steriliźation may be imposed only as a part of a sentence in a court of record, the evidence concerning the particular convict's history and personality and records of his order for sterilization would be permanently on file in the court archives.

Second Law. (Sec. 4.) After fully inquiring into the condition of each of such inmates said board shall make separate written findings for each of the inmates whose condition has been examined into, and the same shall be preserved in the records of said board, and a copy thereof shall be furnished to the superintendent of the institution in which the inmate is confined, and if an operation is deemed necessary by said board, then a copy of the order of said board shall forthwith be served on said inmate, or in the case of an insane person, upon his legal guardian, and if such insane person have no legal guardian, then upon his nearest known kin within the State of Washington, and if such insane person have no known kin within the State of Washington, then upon the custodian guardian of such insane person.

3. CALIFORNIA. First Statute: No provision for records.

Second Statute: No provision for records.

4. CONNECTICUT. No provision for records.

5. NEVADA. As in Washington, a record of the history and personality of the individual convict and the order for his sterilization would automatically be recorded in the court's archives.

6. IOWA. First Law: No reference to records.

Second Law: No reference to records.

Third Law. Section 3: "The board of control shall make an annual report to the governor of the state fully covering their proceedings under the authority of this act, and also their observations and statistics regarding its benefits."

7. NEW JERSEY. (Section 4.) "The record taken upon the examination of every such inmate, signed by the said board of examiners, shall be preserved in the institution where such inmate is confined, and a copy thereof filed with the Commissioner of Charities and Corrections, and one year after the performing of the operation the superintendent or other administrative officer of the institution wherein such inmate is confined shall report to the board of examiners the condition of the inmate and the effect of such operation upon such ininate. A copy of the report shall be filed with the record of the examination."

8. NEW YORK. (Section 352.) "The record taken upon the examination of every such inmate, signed by the said board of examiners, shall be preserved by the institution where said inmate is confined, and one year after the performanc of the operation 
the superintendent or other administrative officer of the institution wherein such inmate is confined shall report to the board of examiners the condition of the inmate and the effect of such operation upon such inmate, and a copy of the report shall be filed with the record of the examination."

9. NORTH DAKOTA. (Section 3.) "When the superintendent of any such institution shall deem it advisable that such operation be performed on any one or more of the inmates thereof he shall make such recommendation in writing signed by him, and file one copy thereof with the board of control and one with the chief medical officer of such institution, whereupon the chief medical officer of such institution shall forthwith call a meeting of such board of examiners, to be held at such institution at a date not less than fifteen days after the issuance of such call, and such call shall be in writing, signed by such chief medical officer and shall clearly set forth the date and object of such meeting and shall contain the names of all inmates whose cases are to be considered at such meeting."

(Section 5.) "After fully inquiring into the condition of each such person such board of examiners shall make separate written findings for each of the persons whose condition has been inquired into ***."

(Section 6.) "Such institutions shall keep all files in any proceedings under this act and full minutes of such meetings, and for that purpose the chief medical officer of such institution shall be the secretary of " such board of examiners and custodian of its records."

10. MICHIGAN. (Section 4.) "In relation to each individual person sterilized under the provisions of this act, the board of control of the institution in which said person is an inmate shall file with the State Board of Public Health of Michigan a written record setting forth the name, age, sex, nationality, type or class of mental defectiveness of said person, the nature of the operation performed, the subsequent mental and physical condition as affected by said operation: Provided, That said records shall not be for public inspection, but may be open to inspection of the members of the board of control of the aforesaid institutions and of the members of the immediate family of the person operated upon, or any physician or surgeon designated by them."
11. KANSAS. First Law: No reference to records.

Second Law. (Section 6.) "Such institution shall keep all files in any proceedings under this act and full minutes of such meetings, and for that purpose the chief medical officer of such institution shall be the secretary of such board of examiners and custodian of its records."

12. WISCONSIN. No reference to records.

13. NEBRASKA. No reference to records.

14. OREGON. (Section 5.) "After fully inquiring into the condition of each of such inmates said Board shall make separate written findings for each of the inmates whose condition has been examined into, and the same shall be preserved in the records of the said Board, and a copy thereof shall be furnished to the superintendent of the institution in which the inmate is confined, and if an operation is deemed necessary by said Board, then a copy of the order of said Board shall forthwith be served on said inmate, or in case of an insane person upon his legal guardian, and if such insane person have no legal guardian, then upon his nearest known kin within the State of Oregon, and if such person have no kin within the State of Oregon, then upon the custodian guardian of such insane person."

15. SOUTH DAKOTA. (Section 1.) "It shall be the duty of the superintendent of the State Home for Feeble-Minded Persons to examine into the mental and physical condition, the records and family history of the inmates of said institution *** and to make an annual report of said examination to the State Board of Charities and Corrections."

Inquiries addressed to the executive agents of the different sterilization laws have elicited the fact that records of their doings are for the most part very meager. Indeed, in some cases, especially those in which the law is a dead letter, absolutely no record of any sort appears to have been prepared or preserved on account of business pertaining to the execution of the sterilization statute. In other cases where there was some executive activity, the records are most meager.

It would seem fitting that the future sterilization statutes should order their executive agents to prepare and to preserve as the property of the state complete records of 
their own transactions as well as of the case and family history investigations and the analysis of pedigree records, and not trust to incidental and fragmentary records as preserved in the archives of courts and minutes prepared as memoranda for temporary use.

\section{COSTS AND APPROPRIATIONS.}

No sterilization statute can be expected to function unless its executive agents are supplied with ample funds or salaries, and field and office expenses. The existing laws for the most part either make the execution of the law an ex officio duty of a given official, and give no additional compensation therefor, or provide a small fee system quite inadequate to the purpose. In no case is there an appropriation provided for the necessary pedigree studies. The only funds mentioned in the statutes are those available for legal defense of an individual nominated for sterilization, and small surgical fees for the actual performance of the operation. New York made a special appropriation of $\$ 29,825.00$, and New Jersey of $\$ 500.00$ for the expenses of their respective commissions.

An analysis of the statutes shows the following situation:

1. INDIANA: "Provided that in no case shall the consultation fee be more than three dollars to each expert, to be paid out of the funds appropriated for the maintenance of such institutions." Chap. 215, Laws of 1907.

2. WASHINGTON. "The state shall be liable, under this act, only for the actual traveling expenses of the members of the board incurred in the performance of their duties, and the actual and necessary expense incident to the investigations of said board and an appeal therefrom, which shall be paid upon vouchers signed by the person receiving such compensation and expense from the moneys appropriated for the maintenance of the institution where such examinaton is held." Section 12, Chap. 53, Law of 1921.

3. CALIFORNIA: “* * * the superintendent of any state hospital shall perform such operation or cause the same to be performed without charge therefor." Section 3, Chap. 363, Laws of 1913.

4. CONNECTICUT: "** * * and the surgeon performing such operation shall receive from the state such compensation for services rendered as the warden of the state prison or superintendent of either of such hospitals shall deem reasonable." Section 1, Chap. 209, Public Acts 1909.

5. NEW JERSEY. In case the person nominated for sterilization is not able to pay for legal counsel (Section 3, Chapter 190, Laws of 1911) " **** the judge of the Court of Common Pleas appointing any counsel under this act may fix the compensation to be paid him, and it shall be paid as other court expenses are now paid."

"There shall be paid out of the funds appropriated for maintenance of such institutions to each physician of said board of examiners, a compensation of not more than ten (\$10) per diem for each day actually given to such work or examination, and his actual and necessary expenses in going to, holding and returning from such examination.

"When in the judgment of the board of examiners it is necessary to secure the assistance of a surgeon outside the medical staff of the institution to perform or assist in said operation, the necessary expenses of such surgeon shall be paid from the maintenance account of such institution." Section 5, Chap. 190, Laws of 1911.

6. NEW YORK: "Immediately after the passage of this act the Governor shall appoint one surgeon, one neurologist and one practitioner of medicine, each with at least ten years' experience in the actual practice of his profession, to be known as the board of examiners of feeble-minded, criminals and other defectives, which board is hereby created. The compensation of the members of such board shall be ten dollars per diem for each day actually engaged in the performance of the duties of the board, and their actual and necessary traveling expenses." Section 350 , Chapter 445, Laws of 1912.

In case the person nominated for sterilization is not able to pay for legal counsel, "the judge of the court appointing any counsel under this act may fix the compensation to be paid him." Section 352, Chapter 445, Laws of 1912.

7. NORTH DAKOTA: Referring to the member of the board who by statute must be a physician or surgeon, Section 2 of Chapter 56 of the Laws of 1913 , says: "The per diem compensation of such member so appointed shall be fixed by the state board of control in the letter of appointment and shall not be in excess of $\$ 10.00$ per day, a duplicate of this letter shall be filed with the 
state auditor, and the per diem and actual necessary expenses of such member shall be allowed and paid in the same manner as is provided for by law for the payment of the salaries and expenses of the members, agents and employees of the state board of control."

8. MICHIGAN: In this state the boards and officers of the institutions constitute the boards which examine inmates of their particular institutions, with the view to determining upon eugenical sterilization. Section 2. "*** * and the board making such examination, and the institution physician or surgeon, shall receive no extra compensation therefor." "Provided further, that these physicians shall be allowed for their services the compensation fixed by statutes for the examination and certification of an insane person. The several sums necessary to carry out the provisions of this act shall be certified to be correct by the respective boards and shall be paid out of the general fund of the State upon the warrant of the auditor-general." Section 3, Act 34, Public Acts 1913.

9. KANSAS: First Law, Chapter 305, Laws of 1913, Section 1, "**" and the surgeon performing the operation shall receive from the state such compensation for the service rendered as the board of administration shall deem reasonable, to be paid out of the maintenance fund of the institution in which such person is confined."

Second Law, Chapter 299, Laws of 1917, Section 5. "If the surgeon is not connected with such institution, the governing board can make reasonable terms for compensation and such fee shall be paid from the fund provided for the maintenance of such institution in the manner provided by law."

10. WISCONSIN: Chapter 693, Laws of 1913, Section 5. "The said experts shall receive as compensation a sum to be fixed by the state board of control, which shall not exceed ten dollars per day and expenses, and such experts shall only be paid for the actual number of days consumed in the performance of their duties."

11. NEBRASKA: In this state the board of commissioners of state institutions designate members from their medical staffs to constitute a board of examiners.' * * The members of said board of examiners shall receive no compensation for their services as such examiners, but shall be reimbursed their actual and necessary traveling expenses from the funds of the respective institutions whose inmates are examined by them. The personnel of said board of examiners may be changed from time to time by said board of commissioners of state institutions as may be found necessary or convenient." Section 2, Chap. 237, Laws of 1915.

12. OREGON: In this state the members of the Board of Eugenics are ex officio, and "*** the members of said Board shall serve without compensation." Section 1, Chapter 279, Laws of 1917.

"The State shall be liable, under this Act, only for the actual traveling expenses of the members of the Board incurred in the performance of their duties, and the actual and necessary expense incident to the investigations of said Board and an appeal therefrom." Section 12, Chapter 279, Laws of 1917.

\section{COMMENT: COSTS AND APPROPRI- ATIONS ${ }^{1}$}

The principal lesson to be learned from correlating these legislative facts with the practical working out of the statutes is that in order to function as designed, the enforcement of the law must be delegated to an expert official who is paid a reasonable salary, and who must devote his entire time and attention to the duties of his office, The payment for field investigations, for the expenses incurred in court procedure, and for the actual surgical operations should be covered by an appropriation to be expended at the direction of the State Eugenicist.

\footnotetext{
${ }^{1}$ See form 11a p. 494.
} 


\section{CHAPTER VI.}

\section{ANALYTICAL OUTLINE OF LITIGATION GROWING OUT OF THE SEVERAL EUGENICAL STERILIZATION STATUTES PREVIOUS TO JANUARY $1,1922$.}
(Including a statement of the resulting legal status of each statute affected.)

Introduction

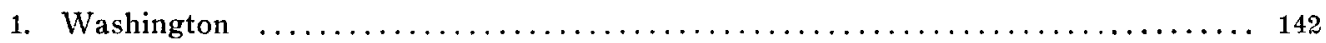

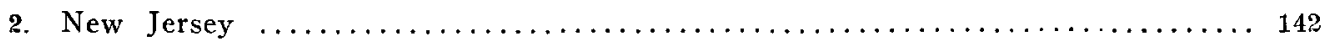

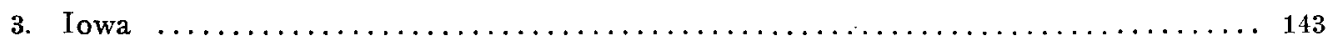

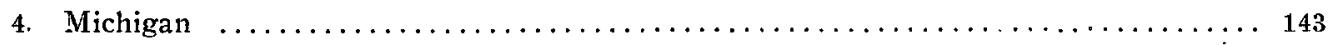

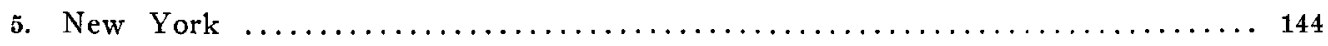

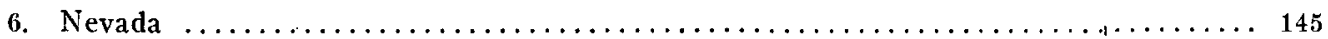

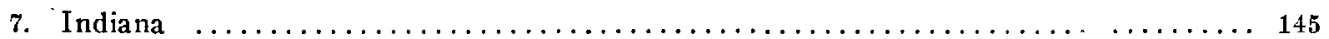

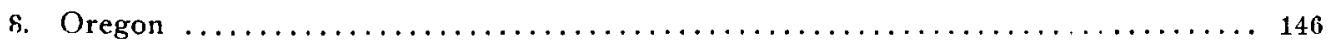

Summary: The Present Legal Status of Eugenical Sterilization.............. 147 


\section{INTRODUCTION.}

Since 1907 fifteen different states have enacted statutes authorizing or commanding that sexual sterilization of one type or another be applied to certain inmates of various state and other public institutions for the socially inadequate, or to persons duly convicted of certain crimes.

In the following named states these statutes had been tested by the courts prior to January 1, 1922:

1. Washington, 1911-1912.

2. New Jersey, 1912-1913.

3. Iowa, 1914-1917.

4. Michigan, 1916-1918.

5. New York, 1915-1920.

6. Nevada, 1915-1918.

7. Indiana, 1919-1921.

8. Oregon, 1921-1922.

1. WASHINGTON.

A. NATURE OF STATUTE.

Date and Reference. First Statute. March 22, 1909, Chapter 249, Section 35, Criminal Code.

Motive. Purely punitive.

Applicability. Habitual criminals or those adjudged guilty of rape.

Mandatory Feature. Optional with court as additional punishment.

Legal Viewpoint. Court procedure necessary in each case.

Type of Operation Authorized. An operation for the prevention of procreation.

B. EXTENT OF OPERATIONS.

One case only. (Peter Feilen.)

C. LITIGATION.

1. TRIBUNAL. The Superior Court of King County.

Case. State of Washington vs. Peter Feilen ( 7 Wash., 65.)

Date of Decision. September 30, 1911.

Decision. Ordered sterilization by vasectomy of Peter Feilen as a punishment for rape.

Reason. Validity of statute, guilt and moral turpitude of defendant.

Resulting Legal Status of Statute. Statute is apparently functioning. Trial Court may order sterilization as a part of the punishment for certain crimes.

2. TRIBUNAL. Supreme Court of the State of Washington.

Case. State of Washington vs. Peter Feilen (126 Pacific Reporter, 75.)

Date of Decision. September 3, 1912.
Decision. Sustained decision of Superior Court of King County.

Reason. Statute not contrary to constitutional provision of State which forbids cruel punishment. No provision in state constitution against unusual punishment.

Resulting Legal Status of Statute. The statute is valid.

Note: The second Washington statute, March 8,1921 , which is principally eugenical in its motives, has not yet been the subject of litigation.

\section{NEW JERSEY.}

A. NATURE OF STATUTE.

Date and Reference. April 21, 1911, Chapter 190.

Motive. Purely eugenical.

Applicability. Certain feeble-minded, epileptic, criminal and other defective inmates of state and. county reformatory, charitable and penal institutions.

Mandatory Feature. Selection optional with Commission after hearing Counsel for inmate appointed by Court of Common Pleas.

Legal Viewpoint. Administrative function subject to court review.

Type of Operation Authorized. "Such operation for prevention of procreation as shall be decided by said Board of Examiners to be most effective."

B. EXTENT OF OPERATIONS.

No one was ever actually sterilized under this law.

\section{LITIGATION.}

1. TRIBUNAL. Board of Examiners of feeble-minded (including imbeciles, idiots and morons), epileptics, criminals and other defectives.

Case. Alice Smith, an epileptic, inmate of the State Village at Skillman.

Date of Decision. May 31, 1912.

Decision. Operation of salpingectomy ordered to be performed upon the said Alice Smith.

Reason. An epileptic in the case of whom procreation is inadvisable with no probability of improvement to the extent to render procreation advisable.

Resulting Legal Status of Statute. Statute is apparently functioning.

2. TRIBUNAL. Supreme Court.

Case. Alice Smith vs. Board of Examiners of Feeble-Minded (88 At1. 963.)

Date of Decision. November 18, 1913. 
Decision. Reversed the decision of the Board of Examiners and held the statute unconstitutional.

Reason. Denies to epileptics in state institutions protection of the laws equal to that afforded epileptics who are not institutional charges, thus violating Section 1, Article XIV of the United States Constitution.

Resulting Legal Status of Statute. Statute is unenforceable so far as its application to epileptics is concerned. Apparently the law is still applicable to social inadequates other than epileptics in county and state institutions.

\section{IOWA.}

\section{A. NATURE OF STATUTE.}

Date of Reference. April 19, 1913, Chapter 187 , second statute on subject.

Motive. Mainly eugenical, partly punitive and partly therapeutic.

Applicability. Inmates of certain state institutions for the insane, criminalistic and feeble-minded. Volunteer applicants with epilepsy or syphilis.

Mandatory Features. Compulsory for inmates twice convicted of felony, or sexoffense, or for one offense of white slavery.

Legal Viewpoint. Administrative function of State Board of Parole acting with institution officers.

Type of Operation Authorized. "Operation of vasectomy or ligation of the Fallopian tubes."

\section{B. EXTENT OF OPERATIONS.}

Under all three statutes forty-nine cases (thirty-eight vasectomies and eleven salpingectomies) have been performed up to January 1, 1921. All of these are from institutions for the insane.

C. LITIGATION.

1. TRIBUNAL. Board of Parole.

Case. Rudolph Davis, No. 10,406, an in-. mate of the penitentiary at Fort Madison, twice convicted of felony.

Date of Decision. March 5, 1914.

Decision. Operation of vasectomy ordered to be performed upon said Rudolph Davis.

Reason. An inmate of the State Penitentiary who was twice convicted of felony.

Resulting Legal Status of Statute. Statute is apparently functioning.

2. TRIBUNAL. United States District Court, Southern Iowa, Eastern Division.

Case. Rudolph Davis vs. William H. Berry, et al. (216 Fed. Rep. 419).
Date of Decision. June 24, 1914, Reversed decision of the District Court.

Reason. 1. No provision for due process of law, thus violating Section 1, Article XIV United States Constitution. 2. Cruel and unusual punishment. 3. Bill of attainder.

Resulting Legal Status of Statute. Statute is unenforceable.

3. TRIBUNAL. United States Supreme Court.

Case. William H. Berry et al. vs. Rudolph Davis (United States Report, Vol. 242, pages 468-470).

Date of Decision. January 15, 1917.

Decision. Reversed the decision of June 24, 1914, of the District Court.

Reason. Because meanwhile (July 4, 1915) the State of Iowa repealed the Act of April 19, 1913, thus the case was not tried on its merits.

Resulting Legal Status of Statute. Statute repealed July 4, 1915.

\section{MICHIGAN.}

A. NATURE OF STATUTE.

Date and Reference. April 1, 1913, Act No. 34.

Motive. Mainly eugenical, also therapeutic.

Applicability. Inmates of state institutions maintained wholly or in part by public expense, duly adjudicated mentally deficient or insane.

Mandatory Features. Selection optional with management of institution.

Legal Viewpoint. Administrative function, subject to court review if parents or guardian object.

Type of Operation Authorized. "Operation of vasectomy or salpingectomy or any other operation or improvement on vasectomy or salpingectomy as the case may be."

B. EXTENT OF OPERATIONS.

One case only, a salpingectomy by the psychopathist of the State Hospital at Ann Arbor.

\section{LITIGATION.}

1. TRIBUNAL. Probate Court of Lapeer County.

Case. In the matter of Nora Reynolds, a mentally defective inmate of the Michigan Home and Training School.

Date of Decision. May 4, 1916.

Decision. The statute is unconstitutional. Reason. Denies equal protection of the law. 
Resulting Legal Status of Statute. Statute is unenforceable.

2. TRIBUNAL. Circuit Court of Lapeer County.

Case. In Re Nora Reynolds, a Mentally Defective Person. Appeal from Probate Court.

Date of Decision: September 10, 1917.

Decision. Statute (Act 34 of the Public Act of 1913).

Reason. Class legislation; applied to too limited a portion of the feeble-minded population.

3. TRIBUNAL. Supreme Court of the State of Michigan.

Case. H. A. Haynes, Superintendent of the Michigan Home and Training School, Relator vs. William B. Williams, Circuit Judge, respondent (N. 28, 151), (166 N. W. Rep. 938).

Date of Decision. March 28, 1918.

Decision. Sustained the decisions of the inferior courts.

Reason. The statute is unconstitutional because it does not afford those affected by it equal protection under the law.

Resulting Legal Status of Statute. Statute is not valid.

\section{NEW YORK.}

\section{A. NATURE OF STATUTE.}

Date and Reference. April 16, 1912, Chapter $\mathbf{4 4 5}$.

Motive. Mainly eugenical, partly therapeutic.

Applicability. Inmates of certain institutions in state for insane, feeble-mindet, and rlependent, also confirmed criminals.

Mandatory Features. Selection optional with Commission. Counsel for inmate appointed by Supreme Court or County Judge.

Legal Vewpoint. Administrative orders subject to court review.

Type of Operation Authorized. "Such operation for prevention of procreation as shall be decided by said board to be most effective."

\section{B. EXTENT OF OPERATIONS.}

In all forty-two eugenical sterilization operations were performed in New York State Institutions while the statute was in force, but none of them was performed under this statute; all were performed by special arrangement with the patients and their families under the laws and customs governing ordinary surgical operations. Of these forty-two operations, one was vasectomy performed by the Auburn State Prison; twelve salpingectomies by the Buffalo State Hospital; and twenty-four salpingectomies and five ovariotomies by the Gowanda State Hospital at Collins. Neither the litigation nor the repeal of the law on April 10, 1921, is affecting these operations.

\section{LITIGATION.}

1. TRIBUNAL. Board of Examiners of feeble-minded (including idiots, imbeciles and morons), epileptics and other defectives.

Case. Frank Osborn, feeble-minded inmate of Rome Custodial Asylum. Informal understanding between the Board of Examiners and the Superintendent of the asylum that the above named inmate be selected for a test case. No records.

Date of Decision. June 1, 1915. Petition of Lemon Thomson of the Board of Examiners to the Supreme Court of Albany County to appoint counsel for Frank Osborn.

Decision. No order for vasectomization of Frank Osborn was issued.

Reason. Not given.

Resulting Legal Status of Statute. Statute is apparently functioning.

2. TRIBUNAL. Supreme Court of Albany County.

Case. Frank Osborn vs. Lemon Thomson, Charles H. Andrews, William J. Wansboro, composing Board of Examiners of Feeble-Minded, criminals and other defectives. (169 N. Y. Sup. 638)

Date of Decision. September 17, 1915.

Decision. Held the statute "unconstitutional and invalid" and issued an order in which the Board of Examiners was "perpetually enjoined and restrained from performing or permitting to be performed, aforesaid threatened operation."

Reason, Not stated.

Resulting Legal Status of Statute. Statute is unenforceable.

3. TRIBUNAL. Special Term of the Supreme Court-Albany County.

Case. Frank Osborn vs. Lemon Thomson, Charles H. Andrews, William J. Wansboro, composing Board of Examiners of feeble-minded, criminals and other defectives. (103 Misc. Rep. 123), (171 N. Y. Sup. 1094.)

Date of Decision. March 8, 1918.

Decision. Sustained findings of September 17, 1915, of the same court perpetually 
enjoining the Board of Examiners from sterilizing by vasectomy, Frank Osborn, inmate of Rome Custodial Asylum, and holding the statute unconstitutional and invalid.

Reason. The statute denies equal protection of the laws guaranteed by Section 1, Article XIV, of the Constitution of the United States.

Resulting Legal Status of Statute. Statute is unenforceable.

4. TRIBUNAL. Supreme Court of the State of New York, Appellate DivisionThird Judicial Department. (185 App. Div. 902.)

Case. Frank Osborn, Plaintiff-Respondent vs. Lemon Thomson, et al., composing Board of Examiners, Defendants-Appellants.

Date of Decision. July 1, 1918.

Decision. "Judgment unanimously affirmed on the opinion of Rudd; J., at special term."

Reason. Same as above.

Resulting Legal Status of Statute. Statute is unenforceable.

5. TRIBUNAL. Court of Appeals.

Case. Frank Osborn, Plaintiff-Respondent vs. Lemon Thomson, et al., composing Board of Examiners, Defendants-Appellants.

Date of Decision. Case pending. (Advance Sheets No. 950, March 15, 1919)

Resulting Legal Status of Statute. Pending decision by the Court of Appeals, the statute is unenforceable in the test case, and by implication generally, by decision ( July 1, 1918) of the Supreme Court of the State of New York, Appellate Division, Third Judicial District. Upon the repeal of the statute on May 10, 1920 (Chap. 619 of Laws of 1920), the questions involved became academic and the appeal in the Court of Appeals was withdrawn.

6. NEVADA.

A. NATURE OF STATUTE.

Date and Reference. March 17, 1911, Section 28, Crime and Punishments Act.

Motive. Purely punitive.

Applicability. Habitual criminals or those adjudged guilty of rape.

Mandatory Features. Optional with the court as additional punishment.

Legal Viewpoint. Court procedure necessary in each case.

Type of Operation Authorized. "Operation for prevention of procreation provided the operation so performed shall not consist of castration."
B. EXTENT OF OPERATIONS.

No operations were performed under this law.

\section{LITIGATION.}

1. TRIBUNAL. District Court of the 4th Judicial District of Nevada, Elko County.

Case. State of Nevada vs. Pearley C. Mickle.

Date of Decision. August 14, 1915.

Decision. Ordered sterilization by vasectomy of Pearley C. Mickle as additional punishment.

Reason. 1. Statute not contrary to constitutional provisions of state which prohibit cruel and unusual punishment.

2. Moral turpitude of defendant.

Resulting Legal Status of Statute. Statute is apparently functioning.

1. TRIBUNAL. United States District Court, District of Nevada.

Case. State of Nevada vs. Pearley C. Mickle. (Not published)

Date of Decision. May 25, 1918.

Decision. Statute is unconstitutional.

Reason. Provides an unusual punishment and is therefore contrary to Section 6, Article 1 , of the Constitution of Nevada, which forbids "cruel or unusual punishment."

(Constitution of Washington forbids only cruel punishment.)

Resulting Legal Status of Statute. Statute is not valid.

\section{INDIANA.}

A. NATURE OF STATUTE.

Date and Reference. March 9, 1907, Chapter 215, Laws of 1907.

Motive. Purely eugenic.

Applicability. Inmates of all state institutions charged with the case of "confirmed criminals, idiots, imbeciles and rapists" deemed by a commission of three surgeons to be unimprovable, physically and mental$l y$, and unfit for procreation.

Mandatory Feature. Compulsory to appoint commissions but not compulsory to present cases for their consideration.

Legal Viewpoint. Administrative procedure by commission.

Type of Operation Authorized. "Such operation for the prevention of procreation as shall be decided safest and most effective."

\section{B. EXTENT OF OPERATIONS.}

Indiana was a pioneer state in eugenical sterilization. All such operations in this state were performed by Dr. Harry C. Sharp, 
Surgeon of the Jeffersonville Reformatory on male inmates of that institution. Beginning in 1899, eight years before the enactment of the Sterilization Act in 1907, he performed one hundred seventy-six vasectomies on men who desired the operation upon being discharged from state custody. After the law was enacted he performed one hundred eighteen additional operations. All such operations, however, ceased upon the inauguration of Governor Thomas R. Marshall in 1909. Since that date and until the initiation of the present test case this statute has been a dead letter.

\section{LITIGATION.}

1. TRIBUNAL. Circuit Court of Clark County.

Case. Warren Wallace Smith, by Lincoln E. Lankford, his next friend, vs. Charles F. Williams, as Chief Physician of the Indiana Reformatory, et al. (September 25, 1919)

Date of Decision. December 4, 1919.

Decision. Permanent injunction granted against the enforcement of the act against the plaintiff.

Reason. Act of 1907 (Chapter 215) is unconstitutional because it denies those persons subject to it the right to free administration of justice in open court, that is, it does not provide adequately for due process of law.

Resulting Legal Status of Statute. Action under the law suspended pending the decision of the Supreme Court of the State to which the case was appealed by the defendant.

2. TRIBUNAL. Supreme Court of the State of Indiana.

Case. Charles F. Williams, as Chief Physician of the Indiana Reformatory, and Joseph E. Hennings, Alvin Padgett, John $H$. Weathers, and Thomas A. Daily, as members of the Board of Managers of the Indiana Reformatory, Appellants, vs. Warren Wallace Smith, by Lincoln E. Lankford, his next friend, Appellee.

Date of Decision. May 11, 1921.

Decision. Sustained the decision of the trial court, which granted a permanent injunction against the enforcement of the act by the defendant against the plaintiff.

Reason. The Act of 1907 (Chapter 215) is unconstitutional because it is "in violation of the 14th amendment to the Federal Constitution in that it denies appellee due process."

Resulting Legal Status of Statute. The statute is not valid.

\section{OREGON.}

\section{A. NATURE OF STATUTE.}

Date and Reference. February 19, 1917. Chapter 279, General Laws of 1917.

Motive. Purely eugenical and therapeutic.

Applicability. Feeble-minded, insane, epileptic, habitual criminals, moral degenerates and sexual perverts, who may be inmates of institutions maintained by public expense.

Mandatory Feature. Compulsory with State Board of Eugenics to examine into all cases of inmates, procreation by whom would produce children with degenerate hereditary traits.

Legal Viewpoint. Administrative function of State Board of Eugenics, subject to appeal by inmate or his legal guardian.

Type of Operation Authorized. "**** such type of sterilization as may be deemed best by said Board."

\section{B. EXTENT OF OPERATIONS.}

Under this statute 127 cases (2 vasectomies, 66 castrations, 40 salpingectomies and 19 ovariotomies) have been performed up to January 1,1921 ; 114 of these were from institutions for the insane, 10 from the institution for feeble-minded and 3 from the State Penitentiary at Salem.

\section{LITIGATION.}

1. TRIBUNAL. Oregon State Board of Eugenics.

Case. Jacob Cline, a feeble-minded, insane, epileptic, habitual criminal and sexual pervert, committed to the Oregon State Penitentiary to serve from four to ten years for rape.

Date of Decision. January 27th, 1921.

Decision. That operation of sterilization by emasculation be performed on said Jacob Cline.

Reason. For the betterment of the physical, mental, neural and psychic condition of the said Jacob Cline, and not in any manner as a punitive measure.

Resulting Legal Status of Statute. Statute is apparently functioning.

2. TRIBUNAL. Circuit Court of the State of Oregon for the County of Marion.

Case. Jacob Cline vs. Oregon State Board of Eugenics.

Date of Decision. December 13, 1921.

Decision. Proceeding against Jacob Cline ordered dismissed.

Reason. Statute held unconstitutional and void because it violates that Clause of Section 1 of the 14th Amendment of the U. S. 
Constitution which provides that no State "shall deprive any person of life, liberty or property without due process of law."

Resulting Legal Status of Statute. Statute unenforceable.

\section{SUMMARY :}

\section{THE PRESENT LEGAL STATUS OF EUGENICAL STERILIZATION.}

The legal situation in reference to the power of the State to enact eugenical sterilization is summarized as follows:

1. A state may, in the proper and constitutional exercise of its police power, enact practical and enforceable eugenical sterilization laws, devoid of punitive features, but which may include criminals, and which have for their sole purpose the improvement of the natural hereditary physical, mental and moral endowment of future generations; provided, (a) that such laws are not so unduly discriminatory in their application as to constitute the denial of equal protection of the laws guaranteed by Section 1, Article XIV, of the Constitution of the United States, to all of the citizens of all the states, and (b) that such statutes provide for due process of law in their administration.

2. A law which defines a natural class of undesirable parents without unnatural subclassification and commands that eugenical sterilization be applied to all of the members of the general class who are sexually fertile, or who are approaching the reproductive period with prospects of sexual fertility, most probably would not be declared unconstitutional by any of our states on the grounds either of (a) an unwarranted extension of the police power in the interests of the general welfare, nor, (b) as constituting "class legislation" in the denial of equal protection of the laws.

3. It is probable that eugenical sterilization made applicable to one sex only would not on account of such limitation be held unduly discriminatory, and consequently "class legislation," in any of our states, a1though no sound eugenical reason can be advanced for limiting sexual sterilization to cacogenical persons of either sex.

4. It remains to be decided from future litigation whether the constitutional pro- vision against "class legislation" will be violated by applying eugenical sterilization to a natural class, such as the hereditary feeble-minded, who are inmates of institutions, unless persons who are members of the same natural class-that is, those who are equally feeble-minded from defective heredity-in the population at large be equally subject to the same statutory provisions. (See N. J. Case p. 174; N. Y. Case p. 234, Mich. Case p. 213.)

5. Although supported by the courts of the State of Washington, it is probable that punitive sterilization will be forbidden by the courts as repugnant to the spirit of our constitutional provisions against cruel and unusual punishment. (Sec Wash. Case p. 159; Nev. Case p. 245; Iowa Case pp. 186, 200.

6. Surgical operations primarily for sound medical reasons, which incidentally and not purposely involve the destruction of the reproductive functions, are amply controlled by the existing statutes governing medical and surgical practice.

7. It is probable that compulsory and involuntary eugenical sterilization will be considered by the courts of most of our states to be of such import both to society and to the individual that "due process of law" will be held to involve court procedure, with the right to be heard, and a decision based solely upon the law and the evidence. The chronic nature of cacogenesis, implying ample time for exact determination, as opposed to the acute necessity arising in the case of needed vaccination and quarantine, is an additional reason why sound eugenical policy and justice should demand court procedure in each case of compulsory sterilization. In the long run conservative court procedure will, doubtless, prove to be the safest and most practical policy.

On the other hand, it appears that in the case of eugenical sterilization by the consent of a patently cacogenic individual or his or her family or legal guardian, "due process of law" will be held to be satisfied by ministerial discretion not involving court procedure in each particular case. (See the Third Iowa [voluntary] Law, p. 23, and litigation. growing out of the Second [compulsory] Iowa Law p. 22.) 


\section{CHAPTER VII.}

\section{DETAILED REVIEW OF LITIGATION GROWING OUT OF THE SEVERAL EUGENICAL STERILIZATION STATUTES.}

\section{PART I. WASHINGTON.}

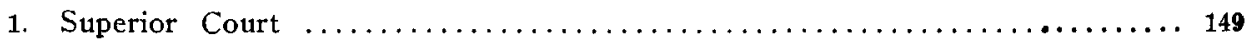

2. State Supreme Court
a. Brief of Appellant

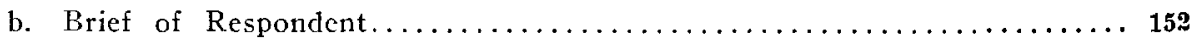
c. Decision of Supreme Court.......................... 159 
I. WASHINGTON. (Chapter 249, Section 35, Criminal Code, March 22, 1909.)

The first Washington sterilization statute is purely punitive, consequently it applies only to persons who have been duly convicted of certain crimes. In such cases it is obvious that the order for sterilization must be made a part and parcel of the punishment set forth in the sentence, otherwise if imprisonment be a part of the punishment it would constitute a second punishment for the same offense to order sterilization at a later date. This feature of the sentence was regular enough, but the law was tested on the ground of its providing for a "cruel and unusual" punishment.

\section{SUPERIOR COURT.}

September 30, 1911, the Superior Court of King County ordered as an additional punishment to his life imprisonment sentence the sterilization by vasectomy of Peter Feilen, duly convicted of carnal abuse of a female child under ten years of age. (7 Wash., 65.)

\section{STATE SUPREME COURT.}

September 3, 1912, the Supreme Court of the state sustained the decision of the Superior Court of King County, thus upholding the constitutionality (state) of the sterilization statute, which is purely punitive. The effect of this decision is, that in the state of Washington vasectomy as a punishment, executed in response to due process of law, is not a cruel punishment. The constitution of Washington forbids cruel punishment, but says nothing about unusual punishment. (126 Pac. Rep. 75)

The principal documents in the case follow:

(a) Brief of Appellant.

IN THE SUPREME COURT OF THE STATE OF WASHINGTON.

The State of Washington,

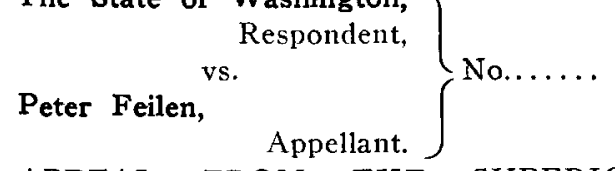

APPEAL FROM THE SUPERIOR COURT OF KING COUNTY. JOHN F. MAIN, Judge.

\section{BRIEF OF APPELLANT.}

Statement of the Case.

The appellant was charged by information in the court below with having carnally known and abused one Lois Cleaves, a fe- male child of the age of 8 years on the 12 th day of June, 1911. He was tried before the Hon. John F. Main, one of the Judges of the Superior Court of King County, sitting with a jury, and a verdict of guilty as charged was returned. Thereafter a motion for a new trial was interposed on the statutory grounds, and after argument, denied by the court; thereupon the court sentenced the defendant to the state penitentiary at Walla Walla for life, and, in addition, ordered that an operation be there performed upon him which would prevent future procreation. From the judgment of the court this appeal is prosecuted.

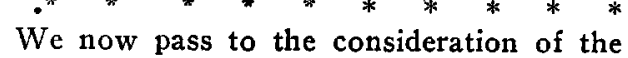
sentence imposed; this sentence is in two parts, one of which imposed a life term in the state penitentiary, and the other a surgical operation of some sort to prevent future procreation. In the light of the testimony as to what took place, the sentence of a life term in the state penitentiary was grossly excessive. The child sustained neither temporary or permanent injury at the hands of the appellant; there was no laceration of her private parts; no brutality used toward her person generally; even the hymen, situated barely an inch from the outer lips of the vagina, was found intact; nothing, in fact, shown except a lascivious fondling of a child of tender years by the appellant.

In the case of State vs. Patchen, 37 Wash. p. 24, the defendant was convicted of the crime of rape upon a female child of the age of ten years; the evidence established beyond all question that the defendant had been guilty of the crime charged, and established, in addition, that the defendant had been guilty of similar offenses towards several other small children, playmates of the girl named in the information. The trial court sentenced the defendant to a term of twentyone years in the state penitentiary. On appeal to this court the judgment of the trial court was affirmed, but the court in commenting upon the sentence imposed, used this language: "Complaint is made of the severity of the sentence. The sentence seems unduly severe, in view of the advanced age of the appellant, and the character of the prosecuting witness and associates as disclosed at the trial, but this question is not subject to review by this court."

In the case of State vs. Van Waters, 36 Wash. 358, the defendant was convicted of a similar offense and sentenced to a term of 
twenty-five years in the state penitentiary; on appeal the judgment of the trial court was affirmed, but this court held that the sentence imposed was excessive. We quote the following from the opinion of the court: "The sentence imposed by the court, while within the limitations of the statute, seems to us unnecessarily severe, in the light of the evidence. If we felt it was within our recognized power we would direct a modification of it, reducing the period to five years, but our investigations have led us to doubt the authority of an appellate court to reduce or modify a sentence which is within the discretion of the trial court to impose, and we mention the matter here in the hope it may aid the appellant in inducing the pardoning power to exercise its clemency in his behalf after he has served a reasonable time."

Under the authority of these cases we submit that the sentence imposed upon the appellant was grossly excessive, and should not be permitted to stand. We appreciate that, in the same cases, this court has held that the extent of the sentence is within the discretion of the trial judge, and ordinarily will not be interfered with by this court on appeal, but in the present case there is interwoven and connected with this part of the sentence another part which is clearly unconstitutional and vitiates the entire sentence. This brings us to a consideration of that part of the sentence which calls for a surgical operation upon the person of the appellant.

In 1909 the Legislature of the State of Washington passed what is known as the "Criminal Code." This code was the outcome or outgrowth of a conference between the prosecuting attorneys from the various counties in the state, most of whom were new to practice, and were elected to their official positions so that they could get suffcient experience at the expense of the public to engage in the practice of law subsequently on their own account. When Justinian conceived the idea of codifying the Roman laws he called into conference Tribonian, the greatest lawyer of ancient times, and committed to his hands the contemplated task. Tribonian gathered about him the greatest lawyers and judges of his time, and they spent over ten years in formulating what has since been known as the Code Justinian, or civil code. When Napoleon conceived the idea of revising the ancient Roman code he placed the matter in the hands of the greatest lawyers and jurists of France, Italy, Belgium and Spain, and for six years they labored upon the herculean task allotted to them before they gave to the world what has since been known as the Code Napoleon. The present criminal code of the State of Washington was formulated by a number of inexperienced prosecuting attorneys in a period of less than sixty days, and rushed through the legislature in the closing days of its session, without critical consideration of its contents. Among the freak enactments included in this code is the one involved in the present case, and is as follows: "Whenever any person shall be adjudged guilty of carnal abuse of a female person under the age of ten years, or of rape, he shall be adjudged to be an habitual criminal, and the court may, in addition to such other punishment or confinement as may be imposed, direct an operation to be performed upon such person for the prevention of procreation." (Laws 1909, p. 899.) This law was enacted on the theory, evidently, that men who commit rape, or become habitual criminals, are physically and mentally unfit to procreate their species, and that society will be benefited by castrating them or otherwise operating upon them so as to prevent them from bringing offspring into the world. Many criminals are possessed of bodies, both physically and mentally, which better qualify them for parentage than others who have never transgressed the criminal statutes. Some criminals are merely misdirected geniuses, and would make much better parents, so far as society at large is concerned, than the man who passes the contribution box at church on Sunday and talks morality to the children at Sunday school one day of the week, and collects interest at the rate of five per cent per month from his unfortunate fellow man during the remainder of the week, or who preaches temperance and morality in public and rents his property privately for grog shops and houses of prostitution. It has been demonstrated by study and observation that feeble-minded people produce feeble-minded offspring. Why not apply the operation of castration or vasectomy to this class of people? Paupers invariably marry among their own kind and produce pauper children, and these in turn do the same, and the support of these pauper offspring is thrown upon the public as an additional charge. Why not castrate the paupers, if it is a good thing? In many parts of this country there are people who 
will not work, even when employment is offered, but are indolent, shiftless, and incompetent; and these are permitted to marry without interference and produce children of like character and tendencies. Why not operate upon this type and so protect society?

The writer of this brief has been unable to find any decisions bearing upon this question, although similar enactments have been passed in Indiana, New Jersey and California. However, with the indulgence of the court we will refer to an article in the March, 1912, number of Current Literature, and briefly quote therefrom: "Few misconceptions are more general, according to the famed English student of eugenics, Sir James Barr, than the notion that criminals should, just because they are criminals, be prevented from becoming parents. Nevertheless, legislation has in certain parts of the world done the human race the injury of sterilizing all habitual criminals. This is to overlook the fact that there are certain criminals, such as the burglar, who are very clever-gifted with personal qualities of a high order. If we are to breed men and women for intelligence it would be a bad thing to exclude the burglar from parenthood. The same may be said for other classes of criminals-highwaymen, for instance, and forgers. Many burglars are misdirected geniuses. They are frequently more honest than financiers, especially financiers connected with the promotion of companies. It would be better from the standpoint of eugenics to sterilize the financiers than to sterilize the burglars, some of whom would make magnificent administrators. The fallacy underlying the notion that habitual criminals, just because they are habitual criminals, should be debarred from parenthood, rests upon an incapacity to distinguish between qualities of advantage to the race. Many burglars have qualities of immense advantage to the human race-qualities that should not be lost, although they should, of course, be better directed."

In the issue of Law Notes for June, 1911, there is a discussion on page 47 of the Indiana Sterilization Act, and the writer takes the position that such legislation is not only unconstitutional but illogical and absurd. From the article in question we quote one brief paragraph: "Can they lawfully castrate one whom they have adjudged to be a 'confirmed criminal' and beyond the probability of improvement, instead of performing the simple operation of vasectomy? The Indiana Constitution provides that 'cruel and unusual punishment shall not be inflicted.' By the ancient common law of England one who committed mayhem by castration 'was sentenced to lose the like part.' But even this limited employment of castration as a punishment 'went out of use * * * partly because, upon a repetition of the offense, the punishment could not be repeated,' says Blackstone, 4 Black. Comm. 206. 'Any punishment, which, if ever employed at all, has become altogether obsolete, must certainly be looked upon as unusual,' said the distinguished chief justice and author of 'Constitutional Limitations,' Cooley Const. Lim. (6th Ed.) 403. The common-law felony of mayhem is a very grave statutory offense in Indiana. We have read Chief Justice Baldwin's expressions of opinion, as quoted in the New York Tribune for May 14. Nevertheless, if a board of physicians and surgeons shall contemplate operating by castration upon criminals, under the supposed authority of the Indiana Act of $190 \%$, we think that common prudence would advise them to consult an Indiana lawyer for confirmation of the foregoing authorities for his opinions of their potency."

The Constitution of this state provides, Article I, Sec. 14, that "Excessive bail shall not be required, excessive fines imposed, or cruel punishment inflicted." We believe that the punishment inflicted in the present case is such a cruel punishment as is inhibited by that constitutional provision. Of course, it will be argued, as it was argued before the trial court by the attorney for the State, that the operation contemplated is not cruel in its nature, that all that is necessary to do to prevent procreation is to perform the operation of vasectomy or some equally innocuous operation, and in the event of the unfortunate criminal being pardoned, or later development disclosing his innocence of the crime for which he was convicted and sentenced, the severed tube could be reunited and nature's functions happily restored. Frankly, we don't believe there is anything simple or harmless about such an operation, and certainly do not believe that after long disuse of the normal functions of the male necessary to procreate his species there could be a complete restoration. Aside from this, however, the provision of the code in question does not necessarily contemplate any alleged innocuous operation. It provides merely that the court, if he thinks the de- 
fendant is not a fit subject for parentage, shall "direct an operation to be performed upon such person for the prevention of procreation." The best known and most used operation to prevent procreation, both in ancient and modern times, has been the operation of castration, and the trial judge, if he desired to make assurance doubly sure, under the provisions of this act, could order castration in place of vasectomy, and if the law is constitutional the poor unfortunate defendant would be castrated. If anything further be needed to show the cruel nature of the punishment imposed, it may be found in Deuteronomy, Chap. 23, Sec. 1: "He that is wounded in the stones or hath his private member cut off shall not enter into the assembly of Jehovah."

We submit that this provision of the law is in conflict with the constitutional provision above quoted, in that it is cruel and inhuman, and vitiates the entire judgment of the court in the present case.

We respectfully submit that the conviction of the defendant should be set aside and the cause remanded to the trial court, with directions to discharge the appellant from custody.

Respectfully submitted, SIDNEY WILLIAMS, and WILLIAM BELL, Attorneys for Appellant.

(b) Brief of Respondent.

IN THE SUPREME COURT OF THE STATE OF WASHINGTON.

The State of Washington,

vs.
Respondent.
Peter Feilen, No.......

APPEAL FROM THE SUPERIOR COURT OF KING COUNTY.

JOHN F. MAIN, Judge.

\section{BRIEF OF RESPONDENT.}

Statement of the Case.

This appellant was charged by information filed in the Superior Court of King County, with the crime of carnal knowledge of one Lois Cleaves, a female child of the age of 8 years. He was tried before the Hon. John F. Main, sitting with a jury, and a verdict of guilty as charged returned. A motion for a new trial boing made and overruled, he was sentenced by the court to life imprisonment in the state penitentiary at Walla Walla. And pursuant to Section 2287 Rem. \& Bal. Code it was the judgment of the court that an operation be performed upon the appellant for the prevention of procreation.

From such judgment and sentence this appeal is prosecuted.

Appellant in his statement of the case has incorporated an epitomized statement of the evidence which is not entirely accurate, but in view of the fact that he has assigned as error the submission of the case to the jury which raises the question of the sufficiency of the evidence, we will notice the evidence under that head and controvert such statements of the appellant as we deem inaccurate.

The last three of appellant's assignments of error concerning the sentence of the trial court appellant groups in subdivision two, and we will consider them as so grouped by him.

The sections of the statute (Rem. \& Bal. Code) pursuant to which the sentence was imposed are as follows:

Section 2436. "Every person who shall carnally know and abuse any female child under the age of eighteen years, not his wife, shall be punished as follows:

(1) When such child is under the age of ten years, by imprisonment in the state penitentiary for life;

(2) When such child is ten and under fifteen years of age, by imprisonment in the state penitentiary for not less than five years;

(3) When such child is fifteen and under eighteen years of age, and of previously chaste character, by imprisonment in the state penitentiary for not more than ten years, or by imprisonment in the county jail for not more than one year."

Section 2287: "Whenever any person shall be adjudged guilty of carnal abuse of a female person under the age of ten years, or of rape, or shall be adjudged to be an habitual criminal, the court may, in addition to such other punishment or confinement as may be imposed, direct an operation to be performed upon such person, for the prevention of procreation."

The judgment of the court against this appellant is as follows:

"The prosecuting attorney, with the defendant Peter Feilen, and his counsel, came 
into court on the 9th day of September, 1911, and after argument by respective counsel, the matter of the sentence of the defendant was taken under advisement by the court until the 16th day of September, 1911, at which time it was continued until the 23d day of September, 1911. All parties being present, the defendant was duly informed by the court of the nature of the information found against him for the crime of carnal knowledge of a child, committed on the 12th day of July, 1911, of his arraignment and plea of not guilty to the offense charged in the information, of his trial and the verdict of the jury on the 6th day of September, 1911, of guilty. The defendant was then asked if he had any legal cause to show why judgment should not be pronounced against him, to which he replied that he had not, and no sufficient cause being shown or appearing to the court thereby, the court rendered its judgment that, whereas said defendant having been duly convicted in this court of the crime of carnal knowledge of a female person under the age of ten years, to-wit, of the age of eight years, it is therefore ordered, adjudged and decreed that the said defendant, Peter Feilen, is guilty of the crime of carnal knowledge of a female person under the age of ten years, and that he be punished by confinement at hard labor in the penitentiary of the State of Washington for the term of his natural life.

"And it is further ordered, adjudged and decreed that an operation be performed upon said Peter Feilen for the prevention of procreation, and the warden of the penitentiary of the State of Washington is hereby directed to have this order carried into effect at the said penitentiary by some qualified and capable surgeon by the operation known as vasectomy; said operation to be carefully and scientifically performed.

"The said defendant is remanded to the custody of the sheriff of King county to be by him detained and delivered into the custody of the proper officials for transportation to said penitentiary.

"Done in open court this 30th day of September, 1911, as of September 23, 1911.

"JOHN F. MAIN, Judge."

It is first contended by appellant that the sentence of a life term in the penitentiary is grossly excessive, but we submit that any prayer for relief in that behalf should be addressed to the legislature of this state.

It will be noted that Section 2436 Rem. \&
Bal. Code, supra, provides that when the carnal knowledge is of a child under the age of ten years, the punishment shall be by imprisonment in the state penitentiary for life. Such section leaves the trial court no alternative but to impose sentence as directed by the statute.

As was held in the case of People vs. Morris, 80 Mich. 637, 8 L. R. A. 685: "It is not the province of the court to deal with the policy of the law as that belongs to the legislature, which is composed of the representatives of the people, who alone have the right to voice the sentiments of the people in public enactments, and when such sentiments are enacted into law, the only province of the court is to determine their validity under the Constitution."

And in State vs. Becker, 3 S. D. 29, "It devolves upon the legislature to fix the punishment for crime, and in the exercise of their judgment great latitude must be allowed and courts may reasonably interfere only when the punishment is so unreasonable or so cruel, as to meet the disapproval and condemnation of the conscience and reason of men generally."

It is the duty of a state to protect the good order, peace, and happiness of its citizens by enacting such laws as will tend to prevent practices that lead to vice and crime and punish those who violate such laws. The one thing that justifies punishment for crime more than anything else is the deterrent effect it has upon those who, unrestrained, would resort to violence, vice and chicanery. The punishment of the individual, though well deserved and justly meted out, would be of little benefit to society were it not for the example that it sets to those who are not endowed with inherent righteousness.

So pursuant to the duty of a commonwealth to protect its citizens the legislature is entrusted with the power and discretion to enact such laws as are adequate, and necessary for such purposes, and to impose and regulate punishments, taking into consideration the object they are designed to accomplish, the degree of criminality of the offense or the illegality or impolicy of the act they are intended to punish or prevent. Necessarily crimes are punished to a degree commensurate with their gravity, and the gravity is determined by the effect the commission of this crime or that crime has upon society as gathered from the accumulated experience and observation of mankind. 
The crime of rape has for the longest time within the memory of man been considered one of exceeding gravity. As has been said, "Female chastity, justly recognized as the foundation for the superstructure of family and state, has been hedged by civilized nations, ancient and modern, with but few notable exceptions, by all the safeguards within the power of jurists to devise, and from the earliest times the heaviest penalties have been placed upon its forcible violation."

Under the Mosaic law, it was punished by death if the woman was betrothed and by a fine of fifty shekels paid to the father, and she was to be the wife of the ravisher all the days of his life without the power of divorce, if she was not betrothed. Deuteronomy, Chap. 23-25. The Roman law which was even more severe visited the offender with death and confiscation of goods, and taking the chivalric view that the man is always the responsible party, made the penalty the same whether consent was given or not. The Saxons held chastity in like esteem, and punished rape with death, as did also the old Gothic or Scandinavian constitution. With the advent of William the Conqueror, the penalty imposed by the Saxons was changed to castration and loss of eyes.

And in some of our southern states the penalty of death of the common law is still adhered to. So taking into consideration the degree of criminality of such offense, the effect of its commission upon society, and the desire of the people for protection from its perpetration, the enactment making the violation of a female child under the age of ten years punishable by life imprisonment is well within the discretion of the legislature, and being so it cannot be held that such sentence so imposed by a court is excessive.

Nor is it within the province of this court to interfere where the sentence imposed was within the discretion of the trial judge.

State vs. Douglass, 24 Wash. Dec. 27.

State vs. Van Waters, 36 Wash. 358.

In the case of State vs. Berzman, 10 Wash. 277, a case similar to this case under consideration, where complaint was made of the severity of the sentence, it was said:

"Considering the case with a view to the actual injury done, it must strike any one as a severe punishment, but looking at it as an exhibition of abandoned and wicked lust which would not hesitate to ruin the life oi innocent ehildren, we are not prepared to say that the sentence was legally excessive. If there be anything in the theory that society has a right to relieve itself of the presence of dangerous criminals, to protect itself from their further depredations, there is no place that it can make a better beginning than with those reckless libertines who would corrupt and debauch its womankind before they are old enough to think of protecting themselves."

The cases cited by appellant, State vs. Van Waters, 36 Wash. 358, and State vs. Patchen, 37 Wash. 24, while holding that this court has no power to interfere with the sentence imposed intimate that the sentence in those cases might seem excessive, but it will be noted that the circumstances were different in those cases, for in the Patchen case they said: "The sentence seems unduly severe in view of the advanced age of the appellant, and the character of the prosecuting witness and her associates" as disclosed at the trial.

And in the Van Waters case they said, in substance, that the sentence seemed severe in the light of the evidence. It is therefore probable that there was some such circumstance in the Patchen case.

Nor could the sentence be held to be cruel. "The word 'cruel' when considered in relation to the time when it found place in the Bill of Rights meant, not a fine or imprisonment or both, but such as that inflicted at the whipping post, in the pillory, burning at the stake, breaking on the wheel and the like. The word, according to modern interpretation, does not affect legislation providing imprisonment for life, or for years or the death penalty by hanging or electrocution, and if it did, the laws for the punishment of crime would give no security to the citizen."

Hobbs vs. State, 133 Ind. 404, 408.

"And it may be stated that in cases involving such grave offenses as rape, imprisonment in the penitentiary has been virtually upheld even though such sentence may amount to the maximum of a legal penalty."

State vs. Hilsabeck, $132 \mathrm{Mo} .348$.

"The punishment of imprisonment for life under Statute 1893, Chapter 466, for criminal intimacy with a female child under the age of sixteen years, is not in violation of the constitutional provision against cruel or unusual punishments." 
Commonwealth vs. Murphey, 165 Mass. 66.

It is further contended by the appellant that that part of the judgment which orders a surgical operation known as-vasectomy to be performed upon the person of appellant is unconstitutional and that it therefore vitiates the entire sentence.

We cannot agree with this contention. Were we to contend that such aforesaid part of the sentence was unconstitutional and void, it is entirely separable from the other part of the sentence, and its vitiation would therefore have no effect upon the remaining part.

"The weight of the authority sustains the proposition that where the court imposes a punishment in excess of its power such sentence is valid to the extent that the court had power to impose it, although void as to the excess, where such erroneous sentence is severable into parts."

12 Cyc. 782 and cases cited.

We submit however that the sentence is in no respect erroneous or void.

"The power over the whole subject of punishment for crime is vested in the legislature, and the only limitation upon its exercise is the inhibition against the infliction of cruel and unusual punishments which are held to mean those of a barbarous character and unknown to the common law, the first object of punishment being the protection of society, the reformation of prisoners being only subsidiary and incidental to it."

\section{State vs. McCauley, 15 Cal. 429-455.}

In the exercise of this power, with the distinct view to protecting society, the legislature passed Section 2287 Rem. \& Bal. Code, supra.

From an examination of said section, it will be noted that it is the inherent quality of the individual, the congenital defect that scientific observation has determined may be transmitted to his offspring, that said law is aimed to correct. Its application to habitual criminals is indicative of such intention.

The object of such law may properly be said to be twofold. It can be recognized that such a law would have little effect as a deterrent upon the class of habitual criminals and sexual perverts that it is aimed primarily to reach, for with such class the ability to restrain their criminal tendehcy is either absent or inert. Its object, therefore, with regard to such class is to prevent the perpetuation of their species. But the sexual crime is not infrequently committed by those whose vicious tendency is under restraint only in proportion to their fear of punishment.

The object of the law in regard to this class is to make the punishment of such a nature as to accomplish the maximum effect as a deterrent, and to give the maximum protection to existing society.

The legislature being limited in the exercise of its power to prescribe punishment for crime only by the constitutional inhibition against cruel punishment, does the section herein above quoted come within such prohibition?

The word cruel as used in this respect has been judicially defined in numerous decisions as follows:

"The word 'cruel' as used in a mandatory article of the constitution was intended to prohibit a resort to the process of torture, resorted to for so many centuries, as a means of extorting confessions from suspected criminals, under the sanction of the civil law, but was never designed to abridge or limit the selection by the law making power of such kind of punishment as was deemed most effective in the punishment and suppression of crime."

Garcia vs. Territory, 1 N. W. 415-418.

"The interdict of the constitution against the infliction of cruel and unusual punishments applies to such punishments as amount to torture, or such as would shock the mind of every man possessed of common feeling, such as drawing and quartering the culprit, burning him at the stake, cutting off his nose, arms, or limbs, starving him to death, or such as was inflicted by the act of the English parliament in the 22d year of the reign of Henry VIII whereby the prisoner was ordered to be thrown into boiling water and boiled to death for the offense of poisoning."

State vs. Williams, 77 Mo. 310 .

In Whitten vs. State, $47 \mathrm{Ga}$. 297, it was said that "the clause of the Georgia constitution which declares that cruel and unusual punishments shall not be inflicted, was intended to prohibit the barbarities of quartering, hanging in chains and such punishments."

"Cruel and unusual punishment means some cruel and degrading punishment not 
known to the common law or a punishment so disproportionate to the offense as to shock the sense of the community."

In Re Bayard, 25 Hun. 546.

"Whatever is greater than has ever been described or known or inflicted must be cruel and unusual punishment."

State vs. Dower, 78 N. C. 423-426.

"Const. Art. 6, Section 23, in prohibiting the inflicting of cruel and unusual punishments, meant those which are so excessive or so cruel as to meet the disapproval or condemnation of the conscience and reason of men generally."

State vs. Becker, 51 N. W. 1018; 3 S. D. 29.

Appellant has argued to some length upon the point that if the court could order the operation of vasectomy, it could as well order full castration of the defendant, in view of the fact that the statute provides for an operation to prevent procreation. But even though such contention may be well founded, it cannot be said that such enactment comes within the prohibition of the constitution. For it cannot be said that the operation of castration performed with the skill known to surgical science in this modern age would be cruel. But would not the statute be construed to mean that stich operation for the prevention of procreation be the mildest one known to surgical science, and the one that would cause the minimum of suffering or inconvenience to the subject.

It is a general rule of statutory construction that where a statute is susceptible of two constructions one of which would be constitutional, courts will adopt that construction which is consistent with the constitutionality of the statute.

"The legal presumption is that the legislature intends nothing unconstitutional, and when an act is susceptible of two constructions that one must be adopted which is constitutional."

French vs. Teschermaker, 24 Cal, 518.

It might, with equal logic, be argued that Sec. 140, Chapter 249, Laws 1909, is unconstitutional because the penalty of "death" therein provided might perchance be inflicted by drawing and quartering or other torture. Yet if the court directed hanging thereunder it would hardly be contended that the judgment was void because it might have directed death by torture, but did not.
And pursuant to the spirit of the statute, the court in this case ordered that the operation known as vasectomy be performed.

The operation of vasectomy has long been in use as a substitute for castration in prostatic diseases, but so far as we have been able to ascertain was first made use of in penal institutions in Indiana by Dr. Sharpe.

We quote from Vol. II of page 283, Penal and Reformatory Institutions, prepared for the Eighth International Prison Congress, in relation to such operation and its use in connection with criminals generally, as follows:

"Since October, 1899, I (Dr. Sharpe) have been performing an operation known as vasectomy, which consists of ligating and resecting a small portion of the vas deferens. This operation is indeed very simple and easy to perform. I do it without administering an anesthetic either general or local. It requires about three minutes' time to perform the operation, and the subject returns to his work immediately, suffering no inconvenience, and is in no way impaired for the pursuit of life, liberty and happiness, but is effectively sterilized. I have been doing this operation for over nine years. I have 456 cases that have afforded splendid opportunity for post operative observation, and I have never seen any unfavorable symptom. There is no atrophy of the testicle, there is no cystic degeneration following, but on the contrary, the patient becomes of a more sunny disposition, brighter of intellect, ceases excess masturbation, and advises his fellows to submit to the operation for their own good. And here is where this method of preventing procreation is so infinitely superior to all others proposed-that it is endorsed by the subjected persons. All the other methods proposed place restrictions, and therefore punishment, upon the subject; this method absolutely does not. There is no expense to the state, no sorrow or shame to the friends of the individual as there is bound to be in carrying out the segregation idea.

"There is a law providing for the sterilization of defectives in effect in Indiana, and it is being carried out in the Indiana Reformatory. I regret very much that it is not being followed up in the other institutions of the state, but there is no doubt that it will come in a very short time.

"After observing nearly five hundred males, in whom I had severed the vas 
deferens, I am prepared to state that there is not only a diminution of the muscular and nervous fatigue resulting from muscular exertion, but also a lessening of fatigue sensation and a decided increase of energy and well being. I have observed splendid results in cases of neurasthenia.

"If my information is correct there have been over 800 persons subjected to this operation, 200 of this number at their own request, and the results in all cases are said to have been good. As a result of Dr. Sharpe's experimental operations the legislature of Indiana, in March, 1909, passed a bill, the text of which is as follows, giving legal status to the operation:

"'Preamble-Whereas, heredity plays a most important part in the transmission of crime, idiocy and imbecility,

" "Therefore, be it enacted by the General Assembly of the State of Indiana, that on and after the passage of this act it shall be compulsory for each and every institution in the state entrusted with the care of confirmed criminals, idiots, rapists and imbeciles, to appoint upon its staff, in addition to the regular institutional physicians, two skilled surgeons of recognized ability, whose duty it shall be, in conjunction with the chief physician of the institution, to examine the mental and physical condition of such inmates as are recommended by the institutional physician, and board of managers. If, in the judgment of the committee of experts, and the board of managers, procreation is inadvisable and there is no probability of improvement of the mental condition of the inmate, it shall be lawful for the surgeons to perform such operation for the prevention of procreation as shall be decided safest and most effective. But this operation shall not be performed except in cases that have been pronounced unimprovable.'

"The State of Oregon in 1909 enacted a similar law, and California and Connecticut have also passed laws to this effect. In the early part of 1909 the General Assembly of the State of Illinois was asked to pass a bill legalizing the sterilization of criminals of certain types, and although the bill was endorsed by the Chicago Medical Society, the Physicians' club, Chicago, and the South Side Medical Society, it failed to become a law. This subject has also been agitated in other states, and has been a topic of discussion in many organizations interested in criminological and medical matters.
"Penal and Reformatory Institutions, Vol. 2, prepared for the Eighth International Prison Congress, p. 283. Russell Sage Foundation.

"It will be seen by the work already done, and the number of states that have passed the law legalizing the sterilization of criminals that it has passed beyond the speculative and theoretical stage and has become an important feature in modern criminology."

"The advocates of the sterilization of criminals after the manner indicated justify the operation and assert the necessity as follows:

(1) "The fact of the great number of public charges recruited from the defective classes.

(2) "That defects physical and mental are transmitted to the offspring.

(3) "That, if a defective marries a defective, the children will inherit the stigmata of both parents, and be of a more defective type still. The natural tendency is for the abnormal to mate with the abnormal, consequently defectives are rapidly increasing in numbers as well as becoming more pronounced in type.

(4) "That a large number of this class fail to respond to moral or intellectual influences, are lacking in self-restraint and inhibitory power, and while they may have full knowledge of the nature of an offense and comprehend that it is morally wrong, still have not the will power to resist the impulse to commit the act.

(5) "That this class of persons is prolific, as they know no law of self-restraint, and refuse to take into consideration their ability to care for their offspring. It is also claimed that these ranks are recruited from those suffering from nervous, mental or physical disease, included in this class the children of syphilitics and of victims of alcoholic and drug habits or immoral excesses.

(6) "That the restriction of propagation is necessary for the relief of this condition. It is observed that the moral force of an educated public opinion or law, opposed to the marriage of defectives, cannot prevent the propagation of defective offspring, for while there might be fewer marriages of this type, sexual intercourse would not be discontinued, the procreation would not be prevented to any appreciable degree, and offspring would be illegitimate as well as defective. Laws have been made in various states to restrict the marriage of defectives. 
In Minnesota no woman under the age of forty-five years or a man of any age, except he marry a woman over forty-five years of age, either of whom is epileptic, imbecile, feeble-minded or afflicted with insanity, may intermarry or marry any other person. Michigan, Delaware, Connecticut, Indiana, New Jersey and North Dakota have also passed such laws, but they have not proved satisfactory or effective, and do not furnish the remedy for the evil.

(7) "That the absolute segregation in colonies and industrial refuges of so great a number of existing defectives would necessitate the expenditure of enormous sums of money."

Mr. Henry M. Boies, in his book, Prisoners and Paupers, gave voice to much the same line of reasoning in support of castration for defectives, which applies equally to vasectomy. We quote from $\mathrm{Mr}$. Boies as follows:

"By carefully providing for its degenerates and abnormals in comfortable prisons, asylums and almshouses, giving them the advantage of the highest knowledge and science of living, society unwittingly aggravates the evil it seeks to alleviate. It maintains alive those who would perish without its aid. It permits their reproduction and multiplication. It fosters with more attention than it gives to better types, the establishment and increase of an abnormal and defective class. It not only perpetuates by care, but encourages by permitting unrestricted 'breeding in' among them the unnatural spread and growth of a social gangrene of fatal tendencies. It is assuming alarming and oppressive proportions which begin to be felt in the whole social organization. In terror our advancing civilization begins to inquire if there be no way of counter action consistent with its highest benevolence, by which the abnormality of abnormalism may be avoided, criminality and pauperism restored to natural proportions, or to that ratio of increase which may be the inevitable result of ignorance and excess in living.

"The abnormal does not want children, has no affection for them, and gets rid of them as soon as possible if they come. If this were not so, their offspring, being abnormal, weak, sickly, diseased, deformed, idiotic, insane or criminal, due to a burdensome and suffering existence or an early death, are a curse rather than a comfort to their parents; so that in no sense could the deprivation of these organs inflict injury or damage to criminal or pauper. On the contrary, they would be enabled thereby to enjoy many comforts and privileges and be relieved from many restraints at present necessarily imposed upon them.

"The remedy we suggest would certainly be effectual, and of immeasurable benefit to the human race, the exercise of an inherent right which really injures none, and moreover, it appears to have become an imperative duty which society owes to its own preservation, which may not be neglected without actual $\sin$.

"Society arrests and confines the leper, the victim of smallpox, yellow fever, cholera, or typhoid, and treats them according to its own will, with or against their consent. It does not hesitate to remove a gangrened limb, a diseased organ from a person if it be necessary; it shuts up the insane, the imbecile, the criminal for public protection, it inflicts punishments of various degrees, compels men to labor without pay, for its good, in durance, even deprives them of life if it pleases; assumes arbitrary control of life, liberty and happiness of an individual, if it considers it necessary for the public welfare; and no reasonable being questions its right or duty to do these things. At the same time it allows its deformed and diseased in mind and body and soul to disseminate social leprosy and cancer with impunity, while the skill of its surgeons could prevent the infection by an operation almost as simple as vaccination. It seems inexplicable that the remedy should have been so long delayed."

From the foregoing it seems certain that the operation as ordered, could in no way be held to be cruel. Nor according to the definitions hereinbefore set out, could such operation be said to be such as would shock the mind of every man possessed of common feeling or such as would amount to torture. More truly could it be said that such punishment was to some extent commensurate with the gravity of an offense which would only be committed by one who had sunk to the lowest degeneracy, and whose abandoned and wicked lust amounts to inherent depravity.

It is of the utmost importance to the continued integrity of society that the possibility of commission of crimes of this nature be as nearly eliminated as possible, and such remedies as seem most effective for that purpose should be adopted. As has been 
stated hereinbefore, the greatest good resulting from punishment for crime is the deterrent effect it has upon the commission thereof.

Reformation of the individual is humane, and a subject for intelligent cultivation, but absolutely undesirable and poor sociological economy if at the expense of the rights of organized society.

Rape was clearly recognized as a crime most dangerous to society, and its commission was drastically punished as has already been referred to, yet legislation in this connection has at all times kept pace with advancing civilization. Experiments have been tried upon the theory that punishment for such offense was more severe than necessary with the invariable result that a lessening of the penalty caused an increase in the crime.

Quoting again from Witthaus and Becker, Medical Jurisprudence, Vol, II, page 660, it is said:

"With the advent of William the Conqueror, the penalty imposed by the Saxons was changed to castration and loss of eyes (Saxon penalty was death). In the $3 \mathrm{~d}$ Edward $I$ this was judged too severe; rape became a trespass only, punishable by two years' imprisonment, but the prevalence of the offense made such rapid strides that in the 13th Edward $I$ it was again made a felony, and has so continued in that country, and this. During the reign of Victoria by the 4 th and 5 th Victoria, c. 56, section 3, imprisonment or penal servitude for a term of years has been substituted for the prevailing death penalty, with a resultant increase in the crime from fifty to ninety per cent over statistics for preceding years in four years."

Such punishment as has been devised has not eliminated entirely the crime of rape, nor will it ever be totally eliminated. But society is entitled to such protection from this class of criminals as the legislature can give, and the discretion of the legislature is practically unlimited in determining the adequacy of the punishment for crime. They are presumed to know the popular sentiment and to express it by their enactments. We assume that they have done so by the statute, and we submit that such statute measured by the humane standard of modern civilization, by the judicial definitions heretofore set out, and by the object that it seeks to accomplish does not come within the constitutional prohibition sought to be invoked by the appellant.

And as to said statute prescribing punishment which might be said to be unusual, we submit that our constitution makes no prohibition against unusual punishment and appellant's citation from Cooley's Constitutional Limitations is therefore not applicable. See Art I, Sec. 14, Constitution State. of Washington, as follows:

"Excessive bail shall not be required, excessive fines imposed, nor cruel punishment inflicted."

For the foregoing reasons we respectfully submit that the judgment is right and just, and should be affirmed.

Respectfully submitted,

JOHN F. MURPHY, HUGH M. CALDWELL, H. B. BUTLER,

Attorneys for Respondent.

c. Decision of the State Supreme Court. (No. 70 Wash.; 126 Pacific Rep. 75.)

THE STATE OF WASHINGTON, Respondent v. PETER FEILEN, Appellant.; Rape-Evidence: Sufficiency.

Same-Evidence: Corroboration.

Criminal Law-Appeal; Review; Verdict; Rape; Sentence and Punishment.

Criminal Law-Cruel or Unusual Punishment-Constitutional Law.

Appeal from a judgment of the Superior Court of King County, Main. J., entered September 30, 1911, upon a trial and conviction of rape. Affirmed.

Sidney J. Williams and William R. Bell, for appellant.

John F. Murphy, Hugh M. Caldwell, and H. B. Butler, for respondent.

CROW, J.-The defendant was convicted of the crime of statutory rape upon the person of a female under the age of ten years, and was sentenced to imprisonment for life in the state penitentiary. The final judgment and sentence from which he has appealed further ordered, adjudged and decreed that:

"An operation be performed upon said Peter Feilen for the prevention of procreation, and the warden of the penitentiary of the state of Washington is hereby directed to have this order carried into effect at the said penitentiary by some qualified and capable surgeon by the operation known as vasectomy; said operation to be carefully and scientifically performed." 
By his first assignment, appellant contends that the trial judge erred in submitting the case to the jury, for the reasons (1) that no degree of penetration was shown, and (2) that the testimony of his victim, the prosecuting witness, was not corroborated by such other evidence as tended to convict him of the crime charged. We find no merit in these contentions. The evidence will not be discussed or stated in this opinion, as no good purpose could be thereby served. We are convinced that, under the rule announced in State vs. Kincaid, 27 Wash. Dec. 114, 124 Pac. 684, the evidence was sufficient to comply with the requirements of Rem. and Bal. Code, 2437. We are also satisfied that the evidence afforded that degree and character of corroboration required by $\mathbf{2 1 5 5}$, Rem. and Bal., and from all of the evidence we conclude that the only verdict that should have been returned was the one that the jury did return. The case was for the jury, and their verdict will not be disturbed.

Appellant was prosecuted under Rem. and Bal. Code, 2436, and the penalty of life imprisonment was properly imposed. Rem. and Bal. Code, 2287, provides that:

"Whenever any person shall be adjudged guilty of carnal abuse of a female person under the age of ten years, or of rape, or shall be adjudged to be an habitual criminal, the court may, in addition to such other punishment or confinement as may be imposed, direct an operation to be performed upon such person for the prevention of procreation."

It was under the authority of this section that the trial judge ordered the operation of vasectomy, and appellant, by his remaining assignments, contends that it is unconstitutional in that an operation for the prevention of procreation is a cruel punishment prohibited by Art. I, Sec. 14 of the state constitution, which directs that "excessive bail shall not be required, excessive fines imposed, nor cruel punishment inflicted." As the statute does not prescribe any particular operation for the prevention of procreation, the trial judge ordered that the operation known as vasectomy be carefully and skillfully performed. The question then presented for our consideration is whether the operation of vasectomy, carefully and skillfully performed, must be judicially declared a cruel punishment forbidden by the constitution. No showing has been made to the effect that it will in fact subject appellant to any marked degree of physical torture, suf- fering or pain. That question was doubtless considered and passed upon by the legislature when it enacted the statute. Appellant further contends that the imposition of the alleged cruel punishment as a part of the sentence necessitates a reversal of the judgment. This would not be true, even though we were to hold the operation to be an infliction of cruel punishment, as the judgment of conviction would have to be affirmed with directions to enforce the penalty of life imprisonment. When a sentence is legal in one part and illegal in another, it is not open to controversy that the illegal, if separable, may be disregarded and the legal enforced. United States vs. Pridgeon, 153 U. S. 48; State vs. Williams, 77 Mo. 310-313.

The crime of which appellant has been convicted is brutal, heinous and revolting, and one for which, if the legislature so determined, the death penalty might be inflicted without infringement of any constitutional inhibition. It is a crime for which, in some jurisdictions, the death penalty has been imposed; 33 Cyc. 1518. If for such a crime death would not be held a cruel punishment, then certainly any penalty less than death, devoid of physical torture, might also be inflicted. In the matter of penalties for criminal offenses, the rule is that the discretion of the legislature will not be disturbed by the courts except in extreme cases.

"It would be an interference with matters left by the constitution to the legislative department of the government, for us to undertake to weigh the propriety of this or that penalty fixed by the legislature for specific offenses. So long as they do not provide cruel and unusual punishments, such as disgraced the civilization of former ages, and make one shudder with horror to read of them, as drawing, quartering, burning, etc., the constitution does not put any limit upon legislative discretion." Whitten vs. State, 47 Ga. 297.

On the theory that modern scientific investigation shows that idiocy, insanity, imbecility, and criminality are congenital and hereditary, the legislatures of California, Connecticut, Indiana, Iowa, New York, New Jersey and perhaps other states, in the exercise of the police power, have enacted laws providing for the sterilization of idiots, insane, imbeciles, and habitual criminals. In the enforcement of these statutes vasectomy seems to be a common operation. Dr. Clark Bell, in an article on hereditary criminality and the asexualization of criminals, found at 
page 134, Vol. 27, Medico-Legal Journal, quotes with approval the following language from an article contributed to Pearson's Magazine for November, 1909, by Warren W. Foster, senior judge of the Court of General Sessions of the Peace of the County of New York:

"Vasectomy is known to the medical profession as 'an office operation' painlessly performed in a few minutes, under an anaesthetic (cocaine) through a skin cut half an inch long, and entailing no wound infection, no confinement to bed. 'It is less serious than the extraction of a tooth,' to quote from Dr. William D. Belfield, of Chicago, one of the pioneers in the movement for the sterilization of criminals by vasectomy, an opinion that finds ample corroboration among practitioners. *** There appears to be a wonderful unanimity of favoring the prevention of their future propagation. The Journal of American Medical Association recommends it, as does the Chicago Physicians' Club, the Southern District Medical Society, and the Chicago Society of Social Hygiene. The Chicago Evening Post, speaking of the Indiana law, says that it is one of the most important reforms before the people, that 'rarely has a big thing come with so little fanfare of trumpets.' The Chicago Tribune says that the sterilization of defectives and habitual criminals is a measure of social economy.' The sterilization of convicts by vasectomy was actually performed for the first time in this country, so far as is known, in October, 1899, by Dr. H. C. Sharp, of Indianapolis, then physician to the Indiana State Reformatory at Jeffersonville, though the value of the operation for healing purposes had long been known. He continued to perform this operation with the consent of the convict (not by legislative authority) for some years. Influential physicians heard of his work, and were so favorably impressed by it that they endorsed the movement, which resulted in the passage of the law upon the Indiana statute books. Dr. Sharp has this to say of this. method of relief to society: 'Vasectomy consists of ligating and resecting a small portion of the vas deferens. This operation is indeed very simple and easy to perform; I do it without administering an anaesthetic, either general or local. It requires about three minutes' time to perform the operation and the subject returns to his work immediately, suffers no inconvenience, and is in no way impaired for his pursuit of life, liberty, and happiness, but is effectively sterilized." "

Must the operation of vasectomy, thus approved by eminent scientific and legal writers, be necessarily held a cruel punishment under our constitutional restriction when applied to one guilty of the crime of which appellant has been convicted? Cruel punishments, in contemplation of such constitutional restriction, have been repeatedly discussed and defined, although we have not been cited to, nor have we been able to find, any case in which the operation of vasectomy has been discussed. In State vs. Woodward, $68 \mathrm{~W}$. Va. 66, 69 S. E. 385, a recent and well-considered case which may be consulted with much profit, Brannon, Justice, said:

"The legislature is clothed with power well nigh unlimited to define crimes and fix their punishments. So its enactments do not deprive of life, liberty or property without due process of law and the judgment of a man's peers, its will is absolute. It can take life, it can take liberty, it can take property, for crime. 'The legislatures of the different states have the inherent power to prohibit and punish any act as a crime, provided they do not violate the restrictions of the state and federal constitutions; and the courts cannot look further into the propriety of a penal statute than to ascertain whether the legislature had the power to enact it;' 12 Cyc. 136. 'The power of the legislature to impose fines and penalties for a violation of its statutory requirements is coeval with government.' Mo. P. R. Co. v. Humes, 115 U. S. 512. The legislature is ordinarily the judge of the expediency of creating new crimes, and of prescribing penalties, whether light or severe. Commonwealth vs. Murphy, 165 Mass. 66; Southern Express Co. vs. Commonwealth, 92 Va. 66. For such a fundamental proposition I need cite no further authority. *** What is meant by the provision against cruel and unusual punishment? It is hard to say definitely. Here is something prohibited, and in order to say what this is we must revert to the past to ascertain what is the evil to be remedied. Within the pale of due process the legislature has power to define crimes and fix punishments, great though they may be, limited only by the provision that they shall not be cruel or unusual or disproportionate to the character of the offense. Going back to ascertain what was intended by this constitutional provision the history of the law tells us of 
the terrible punishment visited by the ancient law upon convict criminals. In our days of advanced Christianity and civilization this review is most interesting, yet shocking and heartrending."

The learned jurist then proceeds with the narration of the cruel punishments mentioned in 4 Blackstone, at pages 92,327 , and 377 , and after citing and discussing the English Bill of Rights; Whitten vs. State, 47 Ga. 301; Aldrige Case, 2 Va. Cases, 447; Wyatt's Case, 6 Rand 694; In re Kemmler, 136 U. S. 436, 446; Wilkerson vs. Utah, 99 U. S. 130, 135; Cooley, Const. Lim. (4th ed.), 408; Wharton, Crim. Law (7th Ed.), 3405; Hobbs vs. State, 133 Ind, 404, 32 N. E. 1019, $18 \mathrm{~L}$. R. A. 774 ; State vs. Williams, $77 \mathrm{Mo}$. 310; Weems vs. United States, 217 U. S. 349; O'Neil vs. Vermont, 144 U. S. 323, and other cases, says:

"In short, the text writers and cases say that the clause is aimed at those ancient punishments, those horrible, inhuman, barbarous inflictions."

In re O'S'hea, 11 Cal. App. 568, 105 Pac. 777, the California Court of Appeals for the First district, said:

"Cruel and unusual punishments are punishments of a barbarous character and unknown to the common law. The word, when it first found place in the Bill of Rights, meant not a fine or imprisonment, or both, but such punishment as that inflicted by the whipping post, the pillory, burning at the stake, breaking on the wheel, and the like; or quartering the culprit, cutting off his nose, ears or limbs, or strangling him to death. It was such severe, cruel, and unusual punishments as disgraced the civilization of former ages, and made one shudder with horror to read of them. Cooley on Constitutional Limitations (7th ed.), p. 471 et seq. State vs. McCauley, 15 Cal. 429; Whitten vs. State, 133 Ind. 404, 32 N. E. 1019; State vs. Williams, 77 Mo. 310 . The legislature is ordinarily the judge of the expediency of creating new crimes, and prescribing the punishment, whether light or severe. Commonwealth vs. Murphy, 165 Mass. 66, 42 N. E. 504, 52 Am. St. Rep. 496, 30 L. R. A. 734; Southern Express Co. vs. Com., 92 Va. 59, 22 S. E. 809,41 L. R. A. 436."

Guided by the rule that, in the matter of penalties for criminal offenses, the courts will not disturb the discretion of the legislature save in extreme cases, we cannot hold that vasectomy is such a cruel punishment as cannot be inflicted upon appellant for the horrible crime of which he has been convicted.

The judgment is affirmed.

PARKER, CHADWICK, and GOSE, JJ. concur. 


\section{CHAPTER VII. (Continued)}

\section{PART II. NEW JERSEY.}

1. Board of Examiners

a. Order for Sterilization.............................. 164

2. State Supreme Court

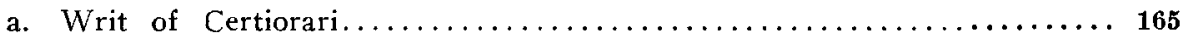

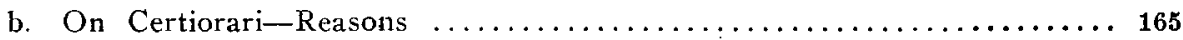

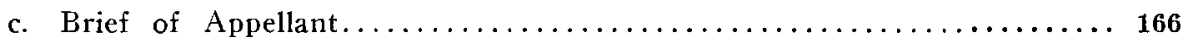

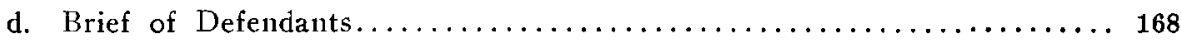
e. Brief by Elmore T. Elyer, amicus curiae................... 172

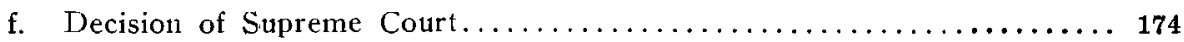




\section{II.-NEW JERSEY. (Chapter 190, April} 21, 1911.)

The New Jersey law makes it the duty of the Board of Examiners "to examine into the mental and physical condition of the feeble-minded, epileptic, certain criminals and other defective inmates confined in the several reformatories, charitable and penal institutions in the counties and state. * * Criminals who come within the operation of this law shall be those who have been convicted of the crime of rape, or of such succession of offenses against the criminal law as in the opinion of this Board of Examiners shall be deemed to be sufficient evidence of confirmed criminal tendencies." The law then provides that "the superintendent or other administrative officer of any institution in which inmates are or may be confined, or upon its own motion the said Board of Examiners may call a meeting to take evidence and examine into the mental and physical condition of such inmates confined as aforesaid." If this Board of Examiners and the chief physician of an institution unanimously find that procreation is inadvisable "it shall be lawful to perform such operation for the prevention of procreation" as may be deemed advisable. But before an order for sterilization may become effective "a judge of the Court of Common Pleas of the county in which said person is confined" must pass upon the case.

It is clear that in New Jersey, while the motive of the statute is not punitive in any sense, and is purely for the protection of society against the procreation of defectives, sterilization is considered of sufficient consequence in relation to a possible invasion of personal rights that a court of law must pass on each case.

1. The nomination by the Board of Examiners May 31, 1912, for the sterilization of Alice Smith, an inmate of the Village for Epileptics at Skillman, gave rise to a test of the constitutionality of the statute.

1. BEFORE THE BOARD OF EXAMINERS OF FEEBLE-MINDED (INCLUDING IDIOTS, IMBECILES AND MORONS), EPILEPTICS,
CRIMINALS AND OTHER DE-
FECTIVES.

The principal document in the case follows:

a. Order for Sterilization of Alice Smith.

In the matter of the hearing in the case of Alice Smith, an inmate of the New Jersey State Village for Epileptics, held at the
Administration Building, State Village for Epileptics; May 31, 1912.

\section{ORDER.}

The Board of Examiners of FeebleMinded (including Idiots, Imbeciles and Morons), Epileptics, Criminals and other Defectives, together with David F. Weeks, the Chief Physician of the New Jersey State Village for Epileptics, having on the thirtyfirst day of May, 1912, regularly convened at the Administration Building at the New Jersey State Village for Epileptics (according to the provisions of Chapter 190, page 353 , of the Laws of 1911, Statutes of the State of New Jersey), and at that time, in the presence of Azariah M. Beekman, Counsel regularly appointed to represent Alice Smith, an inmate of said Village, committed thereto on August 19, 1902, by Alfred F. Skinner, Judge of the Court of Common Pleas of Essex County, application for the appointment of said counsel having been made to and the appointment having been made, previous to the holding of said hearing, by the Judge of the Court of Common Pleas of the County of Somerset, in which county the institution in which the said Alice Smith is an inmate is located, having examined into the mental and physical condition of the said Alice Smith, do find and declare her to be an epileptic person within the meaning of the said Act; and : said Board together with the Chief Physician of said institution having unanimously found in the case of said Alice Smith, that procreation by her is inadvisable, and that there is no probability that the condition of said Alice Smith, so examined, will improve to such an extent as to render procreation by said Alice Smith advisable.

It is, therefore, on this the thirty-first day of May, nineteen hundred and twelve, ORDERED, That the operation of Salpingectomy, as the most effective operation for the prevention of procreation, be performed upon the said Alice Smith in accordance with the motion at said hearing unanimously adopted.

JOSEPH P. BYERS,

Commissioner of Charities and Corrections, Chairman.

HENRY B. COSTILL,

Surgeon and Member Board of Examiners.

ALEX. MARCY, JR., Neurologist and Member Board of Examiners.

DAVID F. WEEKS,

Chief Physician of the Institution. 
2. The case was submitted to the Supreme Court of New Jersey on July 3, 1913, and decided November 19, 1913 . The opinion of the Court was delivered by Mr. Justice Garrison, in which he held the Act of April 21, 1911, unconstitutional because it denied epileptics in the state institutions the protection of the laws equal to that afforded to members of this same class of unfortunates who are not institutional charges, thus violating Section 1, Article XIV, of the Constitution of the United States. Theoretically, this Act in New Jersey is still applicable to the "Feeble-minded (including idiots, imbeciles and morons), rapists, certain criminals and other defectives," because Section 6 of the Act provides that: "If any provisions of this act stall be questioned in any court, and the provisions of this act with reference to any class of persons enumerated therein "st.t be held to be unconstitutional and void, sud determination shall not be deemed to inulidate the entire act, but only such pro$v$ vis ons the reof with reference to the class in g*estion ais are specifically under review and $7 x$. Licularly passed upon by the decision of the court." (88 At1. Rep. 968.)

The principal documents in the case follow:

\section{STATE SUPREME COURT.}

a. 'Writ of Certiorari Served on the Attorney General December 26, 1912.

\section{NEW JERSEY SUPREME COURT.}

\section{THE STATE, Alice Smith,}

Prosecutor. vs.

\section{Board ot Examiners of}

Feeble-Minded (Including Idiots, Imbeciles, and Morons), Epileptics, Criminals and other Defectives,

\section{Defendants.}

\section{WRIT OF CERTIORARI.}

STATE OF NEW JERSEY; to-wit: State of New Jersey, to Joseph P. Byers, Henry B. Costill, Alexander Marcy, Jr., and David F. Weeks, acting as the "Board of Fxaminers of Feeble-Minded (including Idiwts, Imbeciles and Morons), Epileptics, Criminals and other Defectives;" by which order it was by said board adjudged and determined that the said Alice Smith is an epileptic person within the meaning of Chapter 190, page 353 of the Laws of
1911, Statutes of the State of New Jersey; and that procreation by her is inadvisable and wherein it is further ordered that the operation of Salpingectomy be performed upon said Alice Smith in accordance with the provisions of said act, do command you that the said order, together with all matters and proceedings touching the same and had thereupon, and each of them, you do certify and distinctly and openly send, together with this our writ, to our Justice of the Supreme Court of Judicature, at Trenton, on the thirty-first day of December, instant, that we may further cause to be done what of right and according to the laws of the State should be done.

WITNESS: Wm. S. Gummere, Chief Justice of our Supreme Court, this the fourteenth day of December, nineteen hundred and twelve (1912).

JOSEPH TUMULTY, Clerk.

A. M. BEEKMAN,

Attorney.

\section{b. On Certiorari-Reasons.}

THE STATE, Alice Smith,

Prosecutor. vs.

\section{Board of Examiners of}

Feeble-Minded (Including

Idiots, Imbeciles, and Morons), Epileptics, Criminals and other Defectives,

Defendants.
On

Certiorari

Reasons.

\section{ON CERTIORARI-REASONS.}

The said prosecutor, by Azariah M. Beekman, her attorney, comes and prays that the order made by the defendants whereby the surgical operation of Salpingectomy is directed to be performed upon the person of the prosecutor, may be set aside and reversed, and for nothing holden, for the following reasons:

1. The act of the Legislature by authority of which the defendants acted in making said order is unconstitutional and in derogation of the civil rights of the prosecutor as a citizen of the State of New Jersey and the United States.

2. There is and was no authority or power conferred upon the defendants by the act of the Legislature (Chapter 190, page 353 of the laws of 1911, Statutes of the State of New Jersey) under which said order 
can be made nor does the said act authorize and empower the defendants or any board, person or persons to perform the operation of Salpingectomy upon a citizen of the State.

3. The statute (Chapter 190, Laws 1911) under which the said order purports to have been made essentially provides for the corporal punishment and physical injury of a particular class of sitizens without their consent and without pretense that such punishment is inflicted as a penalty for any crime or misdemeanor committed by the victim, but solely upon the authority of a commission or board of varying complexion and of transitory character, invested with no statutory or constitutional powers to pronounce sentence or inflict punishment.

4. The statute in question is unconstitutional because it provides for cruel and unusual punishment without a trial by jury or the adjudication of a court of competent jurisdiction; and because it is in effect class. legislation and beyond a reasonable exercise of the power of the Legislature to enact and prescribe police regulations on the ground of putlic policy.

5. The said order should be set aside and for nothing holden because the making thereof and the hearing and proceedings upon which the order is founded was not in conformity to the statutory provisions of the act of the Legislature, known as Chapter 190, page 353 of the Laws of 1911, Statutes of the State of New Jersey.

\section{A. M. BEEKMAN, Attorney of Prosecutor.}

\section{c. Brief of Azariah M. Beekman, On Behalf of Appellant.}

NEW JERSEY SUPREME COURT.

THE STATE, Alice Smith,

$$
\text { Prosecutor, }
$$

Board of Examiners of Feeble-

Minded (Including Idiots, Imbeciles and Morons), Epileptics, Criminals and Other Defectives,

Defendants.)

Brief.

The chief ground relied upon in this appeal is the unconstitutionality of the statute upon which the entire procedure rests. Unless this statute is a constitutional exercise of that legislative function known as "police power" incident to governmental authority there is no tenable argument to support its legality or the legality of any act or procedure thereunder.

DEFINITION: "Police power, in its broadest acception, means the general power of a government to preserve and promote the public welfare even at the expense of private rights."

A. and Eng. Ency. of Law, 1st Ed., Vol 18, page 739 .

It is, therefore, apparent that in the exercise of this governmental function private rights may be involved and trespassed upon and the question as to what extent secms unsettled and debatable.

"Many attempts have been madi: in this court and elsewhere to define the police power, but never with entire success. always easier to determine whether a part ${ }^{2}$ lar case comes within the general scope of the power than to give an abstract definition of the power itself which will in all respects be accurate."

Stone vs. Mississippi, 101 U. S. Reץ jrts 814.

It is a well recognized right of the state to confine its subjects who are suffering from contagious or infectious diseases. or insanity, the public safety requiring it. th

"The confinement of a violent lunatic is as defensible as the punishment of a criminal. The reason for both police regulations is the cause, viz: to insure the safety of the public."

Tiedeman's Limitations of Police Power, page 105.

But it seems that the danger in any of these cases must be immediate and not contingent and remote, for the State has no right to speculate where the liberty of an individual is involved.

"It would be unlawful exercise of police power if government officials should attempt to confine one in a hospital for medical treatment whose disease did not render him dangerous to public health," * * * "The remote or contingent danger to society from the inheritance of disease by his children would be no ground for interference The danger must be immediate."

Ibid, page 1003.

"In this respect the insane asylum bears the same relation to the public as the ho; pital does. As long as coercion is not employed, there would seem to be no limit 
to the power of the State to provide for medical treatment of lunatics."

Ibid, page 105.

The title of the act in question, "AN ACT TO AUTHORIZE AND PROVIDE FOR THE STERILIZATION OF FEEBLE-MINDED ( I N C L U D I N G IDIOTS, IMBECILES A D MORONS), EPILEPTICS, RAPIS' $I$ CERTAIN CRIMINALS AND OT.. DEFECTIVES" (Laws of 1911, Chapter 190, page 353 , clearly indicates the character of the undertaking embraced in this statute, the classification of the person to be effected in all cases embraces the idea included in the defective, the feeble-minded. Idiots and lunatics are specifically included.

This classification alone dispenses with the possibility of legal consent and the general purpose of the act and the problem with which it undertakes to deal eliminates any idea that the subjects of its operation have the right or power to exercise any volition.

In order to carry out the provisions of the art, physical violence must be inflicted (Section 3, page 354, Laws 1911), upon the determination and decision of a board of examiners created to act in the premises.

In the case at bar an order has been made (page 44, State of Case) that the operation of salpingectomy be performed upon the person of the prosecutrix, to-wit: The removal of the fallopian tubes by excision, involving physical pain and suffering and permanent impairment of the sexual functions of the prosecutor, who is now unmarried (page 9, State of Case) has no desire to be a mother (page 41, State of Case) and is confined in a State institution, therefore, in this instance the possibility of injury to society in general is particularly remote, and the danger, if any, is not immediate. The facts in this case present a fair example of the actual working-of an unusual attempt to extend the law making power upon the theory of police regulation in the interest of the general public good.

Owing to the indefinite attitude of the courts upon this important matter it seems permissible to express personal notions upon the feasibility of such a law and to comment upon the social aspects of the situation presented.

Medicine is admittedly an uncertain science, it is to a large degree experimental, and theoretical, for it deals with the mystery of life, death and the infinite phenomena of physical production and reproduction and nothing short of infinite knowledge should be taken as absolute authority when we undertake to finally determine the source of human imperfections, mental and physical.

There is and can be no guarantee that this or that disease is incurable, and never wili be curable, or is necessarily transmittable from one generation to another.

There can be no definite line drawn to mark a division line between the healthy and the unhealthy, the normal and the abnormal, for no human is perfect either in mind or body. We are sick or well, sane or insane by comparison only.

This act applies only to those confined in institutions of the State and does not include any of its subjects who may be similarly afflicted who are at lasge. It is, therefore, directed at a particular class of unfortunates who by reason of their confinement alone are denied the usual pursuits of happinessand the ordinary opportunity of procreation and sexual enjoyment. They, however, have forfeited no constitutional right.

There is no immediate danger to society, for owing to their present situation the possibility of the social evil in mind is remote and contingent. It seems a dangerous innovation to give any board or constituted authority, created by legislative enactment only, the power to physically harm one of the State's subjects, under less safeguard and formality than is required to inflict a penalty upon criminals who have violated the rules of society and forfeited its protection.

The victims of the operation of this law are unfortunates merely-the heirs, perhaps, of the transgression of others. They have not wronged society, they bear the penalties of an effete civilization, are mentally and physically helpless, the wards of the State.

Since science is uncertain, and the courts are not definite, should not due regard be paid to the spirit of the provisions of our State Constitution and its generally accepted intent?

Article I, Section 1. "All men are by "nature free and independent, and have "certain natural and unalienable rights, "among which are those of enjoying and "defending life and liberty; acquiring, pos"sessing and protecting property, and of "pursuing and obtaining safety and happi"ness."

"The right to a trial by jury shall remain inviolate, but the legislature may authorize 
the trial of civil suits, when the matter in dispute does not exceed fifty dollars, by a jury of six men."

Paragraph 7, Article I, State Constitution.

"In all criminal prosecutions the accused shall have the right to a speedy and public trial by an impartial jury."

Paragraph 7, Article I, State Constitution.

"No person can be deprived of the right to manage his own affairs or of his personal liberty, without the intervention of a jury."

In the matter of Runey Day, 1 Stockton. 9 Equity, page 185.

The right to pursue safety and happiness must certainly include the right of personal security.

DEFINITION: "Personal security has been defined to include security of life, limb, body, health and reputation."

'2d Ed. Am. \& Eng. Ency. Law, Vol. 6, p. 1008.

The statute in question provides no trial by jury, but if given force and operation, there would be vested in a board created by the legislature the right to decree a physical violence to a distinct class of persons, including criminals who have been convicted of rape or of a succession of offenses sufficient to indicate confirmed criminal tendency. The act applies only to "inmates corfined in the several reformatories, charitable and penal institutions in the counties and State."

(Section 1, Chapter 1, Laws 1911. page 353.)

This may not open the statute to the charge that it is class legislation, but the tendency would be, on the part of those nut confined in public institutions to avoid subjecting themselves or their relatives to the hazards of the law which does not apply to those outside of such institutions.

To this extent the law itself would defeat its object.

Respectfully submitted,

AZARIAH M. BEEKMAN,

Attorney for Prosecutors.

d. Brief of Defendants.

NEW JERSEY SUPREME COURT.

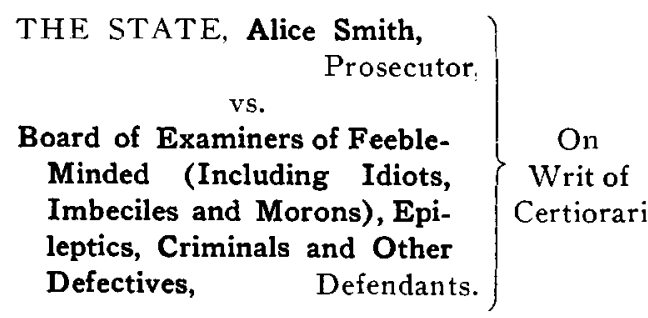

\section{BRIEF OF NELSON B. GASKILL, Attorney-General, \\ ON BEHALF OF THE DE- FENDANTS.}

The writ presents for review an order of the State Board of Examiners of FeebleMinded (including Idiots, Imbeciles and Morons), Epileptics, Criminals and Other Defectives, which Board is constituted and operates by virtue of the authority conferred by Chapter 190, Laws of 1911, page 353 .

\section{1.}

\section{THE STATUTE.}

The essential parts of the statute are as follows:

"An Act to authorize and provide for the sterilization of feeble-minded (including idiots, imbeciles and morons), epileptics, rapists, certain criminals and other defectives.

WHEREAS, Heredity plays a most important part in the transmission of feeblemindedness, epilepsy, criminal tendencies, and other defects:

BE I'T ENACTED by the Senate and General Assembly of the State of New Jersey:

1. Immediately after the passage of this act, the Governor shall appoint by and with the advice of the Senate, a surgeon and a neurologist, each of recognized ability, one for a term of three (3) years and one for a term of five (5) years, their successors each to be appointed for the full term of five years, who in conjunction with the Commissioner of Charities and Corrections shall be known as and is hereby created the 'Board of Examiners of Feeble-Minded (including idiots, imbeciles and morons), Epileptics, Criminals and other Defectives,' whose duty it shall be to examine into the mental and physical condition of the feeble-minded, epileptic, certain criminal and other defective inmates confined in the several reformatories, charitable and penal institutions in the counties and State. Any vacancy occurring in said Board of Examiners shall be filled by appointment of the Governor for the unexpired term.

2. The criminals who shall come within the operation of this law shall be those who have been convicted of the crime of rape, or of such succession of offenses against the criminal law as in the opinion of this Board of Examiners shall be deemed to be sufficient evidence of confirmed criminal tendencies. 
3. Upon application of the superintendent or other administrative officer of any institution in which such inmates are or may be confined, or upon its own motions, the said Board of Examiners may call a meeting to take evidence and examine into the mental and physical condition of such inmates confined as aforesaid, and if said Board of Examiners, in conjunction with the chief physician of the institution, unanimously find that procreation is inadvisable, and that there is no probability that the condition of such inmate so examined will improve to such an extent as to render procreation by such inmate advisable, it shall be lawful to perform such operation for the prevention of procreation as shall be decided by said Board of Examiners to be most effective, and thereupon it shall and may be lawful for any surgeon qualified under the laws of this State, under the direction of the chief physician of said institution, to perform such operation; previous to said hearing the said board shall apply to any judge of the Court of Common Pleas, of the county in which said person is confined, for the assignment of counsel to represent the person to be examined, said counsel to act at said hearing and in any subsequent proceedings and no order made by said Board of Examiners shall become effective until five days after it shall have been filed with the clerk of the Court of Common Pleas, of the county in which said examination is held, and a copy shall have been served upon the counsel appointed to represent the person examined, proof of service of the said copy of the order to be filed with the clerk of the Court of Common Pleas. All orders made under the provisions of this act shall be subject to review by the Supreme Court or any justice thereof and said court may upon appeal from any order grant a stay which shall be effective until such appeal shall have been decided. The judge of the Court of Common Pleas appointing any counsel under this act may fix the compensation to be paid him and it shall be paid as other court expenses are now paid.

No surgeon performing an operation under the provisions of this law shall be held to account therefor, but the order of the Board of Examiners shall be a full warrant and authority therefor ***.

6. If any provisions of this act shall be questioned in any court, and the provisions of this act with reference to any class of persons enumerated therein shall be held to be unconstitutional and void, such determination shall not be deemed to invalidate the entire act, but only such provision thereof with reference to the class in question as are specifically under review and particularly passed upon by the decision of the court."

\section{II.}

\section{THE FACTS EXHIBITED BY THE STATE OF THE CASE.}

The prosecutor, Alice Smith, is an inmate of the New Jersey State Village for Epileptics, above the age of twenty-one years, and was committed to the said institution by an order made by the Judge of the Court of Common Pleas of the County of Essex, on August 19th, 1902, as indigent epileptic. (State of the Case, pages 5, 6, 7, 8 and 9.)

In addition to the stipulation of facts, and the appearance of the record formally adjudging the prosecutor to be an epileptic, the certificate of original records, the history and condition of the prosecutor are exhibited in pages of the State of the Case, 9 to $\mathbf{4 5}$. It is impossible to consider this evidence without being led inevitably to the result that the prosecutor is, in fact, an epileptic. In fact, this is not denied.

The hearing, and the order of the Board following the hearing (page 44), indicate that the statutory procedure was properly followed.

\section{III.}

The act in question was.passed by the Legislature of nineteen hundred and eleven, and became a law, with the approval of the Executive. The legislative policy, therefore, is established and declared. This policy follows established belief upon the subject treated, as is evidenced by the laws of other states.

\section{Indiana, Laws 1907, C-215; \\ Connecticut, Public Acts 1909, C-209; \\ California, Statutes 1909, C-720; \\ Iowa, Laws 1911, C-129.}

The underlying principle upon which such legislation is based, and its justification, must be found in the police power of the States. It is to be observed that nothing in the act now under consideration indicates that its operation is conceived or intended to be within that part of the police power of the State which deals with crime by administering punishment. The act belongs rather to the administrative, regulative phase of the police power, intended to promote the general welfare, not only of the presently exist- 
ing group of citizens, but their successors throughout the continuation of the State as such. The tests to be applied to this statute, therefore, are not those by which a punitive statute is measured.

Since the limits of the police power have never been encompassed within a single definition, but must be judged inevitably by the circumstances of each individual case as presented, so this case stands without absolute precedent.

So far as information runs in the several States in which similar legislation has been passed, either the operation of the act has received some assent from the individuals affected, or has been put into operation without objection or subsequent determination by the Court in a test case. For there is no decision which counsel has been able to find dealing directly with the questions now presented.

The statute of the State of Washington, which was under review in State v. Feilen, 126 Pac. Rep. 75, is a statute somewhat similar, but in which the operations of the statute were clearly and specifically directed at punishment for crime, and, as has been stated above, no such purpose can be found in the statute now under review. The question, therefore, of double punishment, or cruel or unusual punishment is not involved.

The Legislature has declared the scope of the statute as applied to certain described classes. It seems to be settled that the declaration of the Legislature prohibiting certain acts of restraint of previously existing liberties, as harmful to the public welfare, disposes of the subject matter, as far as the Court is concerned, with the problem of whether the acts referred to are or are not harmful, and, therefore, to be prohibited. This is the burden of the decision in the case of the State Board of Health vs. Diamond Mills Paper Company, reported in 63 Eq., at p. 11. The only question, therefore, before the Court can be, not whether the Legislature is justified in the conclusion which it has reached, but whether, having reached that conclusion, it has, in enforcing it, or in the declaration of the statute, encroached upon any of the rights or privileges of the individual guaranteed by the organic law, beyond the power of legislative invasion.

It must be conceded that the growing tendency of judicial decision is toward a liberal interpretation of the guarantees of personal rights, as contained in the State and Federal Constitutions, subjecting the rights of the individual to restriction in favor of the general welfare.

As Mr. Justice Holmes said, in rendering the opinion in Noble State Bank vs. Haskell, 219 U. S., p. 104:

"Many laws which it would be vain to ask the court to overthrow could be shown, easily enough, to transgress a scholastic interpretation of one or another of the great guarantees in the Bill of Rights. They more or less limit the liberty of the individual or they diminish property to a certain extent. We have few scientifically certain criteria of legislation, and as it often is difficult to mark the line where what is called the police power of the State is limited by the Constitution of the United States, judges should be slow to read into the latter a nolumus mutare as against the law-making power."

The novelty of the statutory proceeding, and the broad scope of the statutory forecast must, therefore, be dismissed, and search made, since there is no absolute precedent, for decisions which will, at least, act as lines of direction.

It is well settled that the right of marriage is subject to limitations by the State. It is true that the State has never regarded the marriage ceremony as a legal, as distinguished from a religious ceremony, as is the case under the civil law, but the regulation and the restriction of the right of marriage has long since been established. These restrictions include protection to the State against the marriage of classes of persons distinctly upon the ground that the birth of undesirable citizens will be detrimental to the State welfare.

\section{Lonas vs. State, 3 Heisk (Tenn. 287); \\ State vs. Gibson, 36 Ind. 389 ; \\ Gould vs. Gould, 78 Conn. 242.}

The statutes of this State regulating marriage, including prohibition against the marriage of epileptics, have not received consideration at the hands of the Court, seeming to have been accepted without protest. It is true that this limitation upon the right of marriage does not include, or has not yet included, infliction of physical injury upon individuals for the protection of society. Yet there are not wanting decisions which indicate the right of the State to campel physical injury upon unwilling individuals for the general protection. The discovery of vaccination, and its successful use, led to the adoption of compulsory vaccination laws. 
These were resisted, as infringing the rights of personal liberty, due process of law, etc., and were sustained as a valid exercise of the police power.

Morris vs. Columbus, $102 \mathrm{Ga}$. 792; 30 S. E. Rep. 850;

Jacobson vs. Mass., 197 U. S. 11.

It results, therefore, since the State may protect itself against the birth of undesirable citizens by placing restrictions upon the right of marriage; and may inflict physical injury on individuals for the protection of society, that these two rights may properly be joined to accomplish the end which the Legislature has declared to be necessary and proper.

The severity of the operations required by this statute, and their possible effect, are dealt with elsewhere in the brief submitted.

So, too, the right of the State to segregate certain classes of individuals, not as criminals, but in defense of the right of the State to care for the helpless, and to protect society, has been established.

\section{In re Dowdle, 169 Mass. 387-389;}

Chevannes vs. Priestly, 80 Iowa 316-320;

Shenango vs. Wayne, $34 \mathrm{~Pa}$. St. 184-186;

Keleher vs. Putnam, 60 N. H. 30-31.

Thus it appears that the right of restraint may be joined to the infliction of physical injury, for the protection of society.

It may be well to consider here the force and effect to be given to paragraph six of the act under review, which is as follows:

"6. If any provision of this act shall be questioned in any court, and the provisions of this act with reference to any class of persons enumerated therein shall be held to be unconstitutional and void, such determination shall not be deemed to invalidate the entire act, but only such provisions thereof with reference to the class in question as are specially under review and particularly passed upon by the decision of the court."

This clearly indicates that the Legislature, in dealing with this subject, was not unaware of the difficulty which might lie in the path of accomplishment of its purpose, and called upon the Court thereby to consider the act as applicable in the legislative mind, not only to all of the classes involved, but to any of them to which the provisions of the statute might be held to be constitutionally applicable.

It appears that the act includes the feebleminded, epileptic and other defective inmates corfined in the several reformatory, chari- table and penal institutions in the counties and the State, and the criminals defined by paragraph two. The application of the act, therefore, is to certain classes generally referred to as defectives, and to others generally classified as criminals. There may be, possibly, more ground for objection to the reason for the application of the provisions of the act to criminal classes than to defective classes, because of the difficulty of properly determining the propriety of the procedure of the act in criminal cases. To this it may be suggested that the Legislature has disposed, by its declaration, of the question of propriety, when it has included certain criminals within its declaration of those to whom the act shall, in the protection of the public welfare, be applied, so that this question as to whether the act ought to include any criminal classes is not within the jurisdiction of the Court, unless the criminal classes so included may be shown to have some additional guarantee beyond that of the other classes involved, which is, of course, possible.

Or, it may be suggested that this phase of the act is not brought before the Court by the present proceedings, which deal with one of the so-called defective classes, and that, therefore, the possible application of the act to the criminal classes is one which the Court is not called upon to decide, and, further, it appears that if the Court should be of the opinion that, as applied to criminal classes, the act is unconstitutional, this provision may be exscinded, under the legislative sanction, and the remainder of the act stand intact.

If, however, the Court shall be of the opinion that the provisions of paragraph two indicate an intention on the part of the Legislature to make this act applicable to the criminal classes therein defined, as a punishment for crime, rather than to designate the classes of individuals to whom the act is to be applicable, then it may be suggested that this phase of the act falls within the authority of State vs. Feilen, above referred to.

The act of the State of Washington, there under review, dealt with habitual criminals.

The reasons filed are somewhat indefinite, but they do not indicate any objection to the form of the statute. Insofar as the five distinct reasons have not been dealt with in the general argument preceding, it seems to be sufficient to say that reason number two is answered by paragraph three of the statute, provided it be sustained, and the pro- 
ceedings seem to be, in all respects, in conformance with the statute, and reason number five failing to disclose wherein the proceedings are alleged to be defective, no specific answer can be made thereto.

In conclusion, counsel begs to present to the Court the brief of the Honorable Elmore T. Elver, of the Wisconsin bar. This brief deals so fully and capably with certain phases of the legislation now under review, that no attempt has been made to present the same subject matter, or to deal with it in any different form. Mr. Elver's brief is respectfully submitted to the Court for its consideration and attention, with the request that $\mathrm{Mr}$. Elver be considered as admitted to this bar pro hac vice.

Respectfully submitted,

NEILSON B. GASKILL,

Assistant Attorney-General.

c. Brief by Elmore T. Elver, Esq., of the Wisconsin Bar, as amicus curiae, upholding the constitutionality of the New Jersey Sterilization Act.

This brief was submitted with that of Hon. Nelson B. Gaskill, Assistant AttorneyGeneral of New Jersey. The author reviews very carefully the legal, medical and biological authorities on sterilization and related social remedies. He then concludes that:

THE ACT IN QUESTION HAVING BEEN PASSED FOR THE PROMOTION OF THE PUBLIC HEALTH, SAFETY AND WELFARE, WE CONTEND NO CONSTITUTIONAL QUESTION (OTHER THAN THE ONE DISCUSSED UNDER THE NEXT HEADING) IS INVOLVED, FOR THE REASON THAT THE PASSAGE OF THE ACT IS THE VERY ESSENCE OF THE EXERCISE BY THE LEGISLATURE OF THE POLICE POWERS.

Hoboken vs. Goodman, 68 N. J. L. (39 Vr.) 217; 51 Atl. 1092;

Bryant, Com'r vs. Skillman Hardware Co., 76 N. J. L. (47 Vr.) 45 ;

Meeham vs. Excise Com., 75 N. J. L. (46 Vr.) 557;

Passaic vs. Patterson Bill Posting Co., 71 N. J. L. (42 Vr.) 75; 58 Atl. 342;

Hopper vs. Stack, 69 N. J. L. (40 Vr.) 562 ; 56 Atl. 1;

Jacobson vs. Massachusetts, 25 Sup. Ct. Rep. 358; 197 U. S. 11; 49 L. ed. 643 (Compulsory Vaccination Law);
Noble State Bank vs. Haskell, 219 U. S. $104 ; 55$ L. ed. 112 ; 31 Sup. Ct. Rep. 186.

In the Meeham case it is said:

"Police regulations of this character must (Bishop's law, regulating places at which intoxicating liquors are sold), in the absence of clear evidence to the contrary, be deemed to be based upon facts within the possession of the Legislature rendering such legislation proper, if not necessary: See Hopper vs. Stack, 40 Vr. 562."

And again in the Hopper case the Court says, at page 556 et seq., of the opinion:

"Apart, however, from these considerations, the matter as an. incident of police regulation is clearly within the legislative province, as will appear when the subject of its police power is considered.

"Under this branch of the relator's argument a number of provisions are criticized upon the ground that they tend to constrain the otherwise untrammeled conduct of citizens when seeking to give expression to their political preferences, which is said to be one of their natural rights. Assuming that specific instances of this have been shown, no constitutional question is involved, for the reason that it is of the very essence of the exercise by the Legislature of its police powers that citizens may for the public good (which is what the word 'police' means in this context) be constrained in their conduct even with respect to matters in themselves, natural and otherwise right. Limitations of strictly natural rights and reasonable regulation of general constitutional rights are not incompatible with the valid exercise of the police powers."

"Every exercise of police power involves; of necessity, the determination by the lawmaker of some fact quite apart from the exercise of any legislative discretion concerning it. The contrary is not conceivable. Thus it is not conceivable that an act to protect passengers upon railways could have been enacted without the determination by the Legislature that railways existed and that passengers were carried by them-whether such passengers required protection, and, if so, of what sort would be the discretionary element in such legislation. Similarly, the act upon their statute book to protect worshippers at camp-meetings could not have been enacted without a determination of the fact of the existence of such asscicia- 
tions, the objects of those so associated and the further fact that such objects included immunity from interference by persons having a hostile or even an alien purpose. This elemental proposition is stated only to emphasize the difference between such determinations by the Legislature of conditions of this already in being and enactments by the Legislature that bring into existence conditions that provisionally had not, and but for such legislation would not have, any existence. This distinction is vital in its bearing upon the argument before us, since it marks the distance that scparates an act passed for the regulation of conduct upon which citizens had already embarked from the creation by the Legislature of institutions that compel citizens to a course of conduct upon which they had not voluntarily entered. Thus, to take the previous illustration, there is a wide difference in a constitutional sense between a statute that recognized the existence and objects of camp-meetings and affords protection to those who adopt that form of worship, and an act that instituted such gatherings and compelled persons to associate for the purposes prescribed by such act. Repeated illustration cannot make this distinction more plain or add to the force of its application to the present argument. If in place of camp-meetings we read political parties, and if for the avowed object of such religious gatherings we substitute the known purposes of such political associations, we shall have in its simplest form the domain of fact which the legislation in question must have recognized as subsisting before exercising over it the regulative and protective features of the statute under review. Thus the Legislature must have recognized as a fact the existence of political parties of varying numerical strength by which candidates for public election were placed in nomination upon party tickets and platforms. It must likewise have determined that in the selection of such nominees each of these political parties invited the co-operation of voters who were in practical affiliation with it, and resented attempts at participation by or interference from those not so in sympathy. The Legislature must, further, have decided that the purposes of these party proceedings were so far public purposes that those engaged in them ought to be protected in what they had undertaken, and that to this end the police power of the State should be exercised.
These matters of fact being established, the element of legislative discretion entered to determine the measure of such regulation and the mode of its exercise. In all of this there is no calling of anything into existence, no creation of political parties or of primary meetings, no prescription of the terms of membership-in fine, no initiation of any essential matter, but only the recognition of an existing state of facts and a determination to throw over them the protection of police regulation. With the wisdom or efficiency of this latter determination the judicial branch of the government has nothing whatsoever to do, nor does the preliminary determination of fact concern it when, as in the present case, neither in argument nor in proof is there any suggestion that such determination was not in accord with fact. What the attitude of the courts would be toward legislation of the palpably illusive character suggested by some of the illustrations used upon the argument need not be discussed, not only because the question is not in the case, but also because in no case does one department of the government presume unworthy conduct on the part of a co-ordinate branch."

In the Haskell case, page 110, Justice Holmes uses the following language:

"It may be said in a general way that the police power extends to all the great public needs. Camfield vs. United States, 167 U. S. 518, 42 L. ed. 260, 17 Sup. Ct. Rep. 864. It may be put forth in aid of what is sanctioned by usage, or held by the prevailing morality or strong and preponderant opinion to be greatly and immediately necessary to the public welfare."

VIEWED FROM A PUNITIVE STANDPOINT, WE CONTEND THAT STERILIZATION AS A PUNISHMENT WOULD NOT BE CRUEL AND UNUSUAL. WE DO NOT FEEL THAT WE CARE TO DISCUSS THIS PROPOSITION AT LENGTH ON ACCOUNT OF THE DECISIVE STAND OF THE COURTS, AND MERELY DIRECT ATTENTION TO THE FOLLOWING AUTHORITIES:

State vs. Gedkiche, 43 N. J. L. 86 ;

State vs. Feilen (Washington), 126 Pac. Rep. 75;

United States vs. Weems, 217 U. S: 349 ; 54 L. ed. 793. 
For the reason hereinbefore set forth, we respectfully submit that the order should not be set aside and reversed.

Respectfully submitted,

ELMORE T. ELVER, For the Defendant.

\section{f. Decision of the New Jersey Supremie Court.}

NEW JERSEY SUPREME COURT. June Term, 1913.

\section{THE STATE, Alice Smith, Prosecutrix, vs. \\ Board of Examiners of Feeble- Minded (Including Idiots, Imbeciles and Morons), Epi- leptics, Criminals and Other Defectives,}

$$
\text { Defendants. }
$$

\section{Submitted July 3, 1913. \\ Decided November 18, 1913.}

Held, That the statute in question was based upon a classification that bore no reasonable relation. to the object of such police regulation, and hence denied to the individuals of the class so selected the equal protection of the laws guaranteed by the Fourteenth Amendment of the Constitution of the United States.

Before Justices GARRISON, TRENCHARD AND MINTURN.

For the prosecutrix, Azariah M. Beekman.

For the defendant, Nelson B. Gaskill, Assistant Attorney-General.

(Elmore T. Elver, Esq., of the Wisconsin Bar, on the brief.)

The opinion of the Court was delivered by GARRISON, $J$.

The question propounded is whether or not the statute, under, which the order now before us was made, is a valid exercise of the police power. The statute, it will be observed, applies to criminals, in which aspect it does not now concern us since the prosecutrix is an epileptic, an unfortunate person but not a criminal.

The order is made by the Board of Examiners provided by the Act of April 21st, 1911 (P. L., p. 353). Briefly stated, the order after reciting that Alice Smith is an epileptic inmate of a State charitable institution, that procreation by her is inadvisable, and that there is no probability that her condition will improve to such an extent as to render procreation by her advisable, orders that the operation of Salpingectomy be performed upon the said Alice Smith.

Salpingectomy is the incision or excision of the Fallopian tube, i. e., either cutting it off or cutting it out. The Fallopian tube is an essential part of the female reproductive system and consists of a narrow conduit some four inches in length that extends on each side of a woman's body from the base of the womb to the ovary upon that side. These three organs, i. e., the ovary, the Fallopian tube and the uterus, are all concerned in normal child-bearing, the relation between them being that the unfecundated ovum which is periodically produced in the ovary passes down through the Fallopian tube into the body of the uterus where, if fecundation by the male seed takes place, or has taken place, the embryo is formed and developed into the foetus or unborn child.

The statute is broad enough to authorize an operation for the removal of any one of these organs essential to procreation. These organs are in pairs on either side of the body excepting the uterus, which is a single organ lying deep in the pelvis back of the bladder. The operation of Salpingectomy, therefore, to be effective must be performed in both sides of the body, and hence is in effect two operations, both requiring deep-seated surgery under profound and prolonged anaesthesia, and hence involving all of the dangers of life incident thereto, whether arising from the anaesthetic, from surgical shock or from the inflammation or infection incident to surgical interference with the peritoneal cavity. These ordinary incidents and dangers of such an operation are not lessened where the operation is not sought by the patient, but must be performed upon her by force at least to the extent of the production of such anaesthesia as shall completely destroy all liberty of will or action. The order is addressed to no one and is silent as to the person by whom this operation is to be performed, and the statute likewise is silent upon this subject, excepting that when an order is made, "thereupon it shall be and may be lawful for any surgeon qualified under the laws of this State, under the direction of the chief physician of said institution, to perform such operation."

The prosecutrix falls within the classification of the statute in that she is an inmate of 
the State Village for Epileptics, a State charitable institution, "the objects of which," as stated in the act creating it, are "to secure the humane, curative, scientific and economical care and treatment of epilepsy." (4 Comp. Stat., p. 4961.)

The prosecutrix has been an inmate of this charity since 1902 , and for the five years last past she has had no attack of the disease. From this statement of the facts it is clear that the order with which we have to deal threatens possibly the life and certainly the liberty of the prosecutrix in a manner forbidden by both the State and Federal Constitutions, unless such order is a valid exercise of the police power. The question thus presented is, therefore, not one of those constitutional questions that are primarily addressed to the Legislature, but a purely legal question as to the due exercise of the police power which is always a matter for determination by the courts.

This power, stated as broadly as the argument in support of the order requires, is the exercise by the Legislature of a State of its inherent sovereignty to enact and enforce whatever regulations are in its judgment demanded for the welfare of society at large in order to secure or to guard its order, safety, health or morals. The general limitations of such power, to which the prosecutrix must appeal, is that under our system of government the artificial enhancement of the public welfare by the forceable suppression of the constitutional rights of the individual is inadmissible.

Somewhere between these two fundamental propositions the exercise of the police power in the present case must fall and its assignment to the former rather than to the latter involves consequences of the greatest magnitude. For while the case in hand raises the very important and novel question whether it is one of the attributes of government to essay the theoretical improvement of society by destroying the function of procreation in certain of its members who are not malefactors against its laws, it is evident that the decision of that question carries with it certain logical consequences having far-reaching results. For the feeble-minded and epileptics are not the only persons in the community whose elimination as undesirable citizens would, or might in the judgment of the Legislature, be a distinct benefit to society. If the enforced sterility of this class be a legitimate exercise of gove-nmental power, a wide field of legislative activity and duty is thrown open to which it would be difficult to assign a legal limit.

If in the present case we decide that such a power exists in the case of epileptics, the doctrine we shall have enunciated cannot stop there. For epilepsy is not the only disease by which the welfare of society at large is injuriously affected; indeed, not being communicable by contagion or otherwise, it lacks some of the gravest dangers that attend upon such diseases as pulmonary consumption or communicable syphilis. So that it would seem to be a logical necessity that, if the Legislature may, under the police power, theoretically benefit the next generation by the sterilization of the epileptics of this, it both may and should pursue the like course with respect to the other diseases mentioned with the additional gain to society thereby arising from the protection of the present generation from contagion or contamination. Even when these and many other diseases that might be named have been included, the limits of logical necessity have by no means been reached.

There are other things besides physical or mental diseases that may render persons undesirable citizens or might do so in the opinion of a majority of a prevailing legislature. Racial differences, for instance, might afford a basis for such an opinion in communities where that question is unfortunately a permanent and paramount issue. Even beyond all such considerations it might be logically consistent to bring the philosophic theory of Malthus to bear upon the police power to the end that the tendency of population to outgrow its means of subsistence should be counteracted by surgical interference of the sort we are now considering. - Evidently the large and underlying question is how far is government constitutionally justified in the theoretical betterment of society by means of the surgical sterilization of certain of its unoffending but undesirable members. 1 If some, but by no means all, of these illustrations are fanciful, they still serve their purpose of indicating why we place the decision of the present case upon a ground that has no such logical results or untoward consequences.

$\Gamma$ Such a ground is presented by the classification upon which the present statute is based, which is of such a nature that the persons included within it are not afforded the equal protection of the laws under the Fourteenth Amendment of the Constitution 
of the United States, which provides that "no State shall deny to any person within its jurisdiction the equal protection of the laws." Under this provision it has been uniformly held that a State statute that bears solely upon a class of persons selected by it must not only bear alike upon all the individuals of such class, but that the class as a whole must bear some reasonable relation to the legislation thus solely affecting the individuals that compose it.

"It is apparent," said Mr. Justice Brewer in Gulf, Colorado, Etc., R. R. Co. vs. Ellis (165 U. S., p. 150), after a review of many cases, "that the mere fact of classification is not sufficient to relieve a statúte from the reach of the equality clause of the Fourteenth Amendment, and that in all cases it must appear, not only that a classification has been made, but also that it is one based upon some reasonable ground-some difference which bears a just and proper relation to the attempted classification-and is not a mere arbitrary selection."

This summarizes a mass of cases that might be cited.

Turning our attention now to the classification on which the present statute is based and laying aside criminals and persons confined in penal institutions with which we have no present concern, it will be seen that -as to epileptics, with which alone we have to do-the force of the statute falls wholly upon such epileptics as are "inmates confined in the several charitable institutions in the counties and State." It must be apparent that the class thus selected is singularly narrow when the broad purpose of the statute and the avowed object sought to be accomplished by it are considered. The objection, however, is not that the class is small as compared with the magnitude of the purpose in view, which is nothing less than the artificial improvement of society at large, but that it is singularly inept for the accomplishment of that purpose in this respect, viz., that if such object requires the sterilization of the class so selected, then fortiori does it require the sterilization of the vastly greater class who are not protected from procreation by their confinement in State or county institutions.

The broad class to which the legislative remedy is normally applicable is that of epileptics, i. e., all epileptics. Now, epilepsy, if not, as some authorities contend, mainly a disease of the well-to-do and over-fed, is at least one that affects all ranks of society, the rich as well as the poor. If it be conceded for the sake of argument that the Legislature select one of these broadly defined classes, i. e., the poor, and may legislate solely with reference to this class, it is evident that by the further sub-classification of the poor into those who are, and those who are not, inmates in public charitable institutions, a principle of selection is adopted that bears no reasonable relation to the proposed scheme for the artificial betterment of society. For not only will society at large be just as injuriously affected by the procreation of epileptics who are not confined in such institutions as it will be by the procreation of those who are so confined, but the former vastly outnumber the latter and are in the nature of things vastly more exposed to the temptation and opportunity of procreation, which indeed in the cases of those confined in a presumably well conducted institution is reduced practically to nil.

The particular vice, therefore, of the present classification is not so much that it creates a sub-classification based upon no reasonable basis, as that having thereby arbitrarily created two classes, it applies the statutory remedy to that one of those classes to which it has the least, and in no event a sole application, and to which indeed, upon the presumption of the proper management of our public institutions, it has no application at all. When we consider that such statutory scheme necessarily involves a suppression of personal liberty and a possible menace to the life of the individual who must submit to it, it is not asking too much that an artificial regulation of society that involves these constitutional rights of some of its members shall be accomplished, if at all, by a statute that does not deny to the persons injuriously affected the equal protection of the laws guaranteed by the Federal Constitution.

The suggestion that the classification might be sufficient, if the scheme of the statute were to turn the sterilized inmates of such public institutes loose upon the community and thereby to effect a saving of expense to the public, is not deserving of serious consideration. The palpable inhumanity and immorality of such a scheme forbids us to impute it to an enlightened Legislature that evidently enacted the present statute for a worthy social end upon 
the merits of which our present decision upon strictly legal lines is in no sense to be regarded as a reflection.

The conclusion we have reached is that, without regard to the power of the State to subject its citizens to surgical operations that shall render procreation by them impossible, the present statute is invalid in that it denies to the prosecutrix of this writ the equal protection of the laws to which under the Constitution of the United States she is entitled.

The order brought up by this writ is set aside.

NOTE:

At the time of the above given decision (November, 1913) the attorney for the Board of Examiners announced their intention of carrying the case to higher Courts, but the matter was allowed to lapse. Up to March, 1919, nothing further had been done. 


\title{
CHAPTER VII. (Continued)
}

PART III. IOWA.

\author{
.f Parole \\ erilization
}

istrict Court.

'estraining Order......................... 180

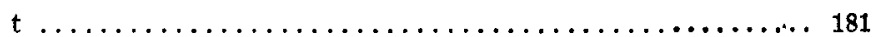

f Complaint...................... 183

$-1, \ldots \ldots \ldots \ldots \ldots \ldots \ldots \ldots \ldots \ldots, 184$

- Parole.................... 185 


\section{IOWA.}

(Chapter 189, April 19, 1913.)

The Iowa statute provided for a consideration of family history studies in order to determine pedigree values, and without recourse to court procedure in each case. It authorizes the sterilization of such inmates of "each public institution in the state entrusted with the care and custody of criminals, rapists, idiots, feeble-minded, imbeciles, lunatics, drunkards, drug fiends, epileptics, syphilitics, moral and sexual perverts, and diseased and degenerate persons," as a majority of the Board of Parole may deem potential parents of defectives. The Federal Court appears to have assumed jurisdiction in the matter on account of the statute's alleged violation of the Fourteenth Amendment to the Federal Constitution, which provides that no state shall deny to any of its citizens the equal protection of the laws.

The test case arose in the person of Rudolph Davis, an inmate of the Iowa Penitentiary. He had been twice convicted of felony, and the case here took on a punitive aspect. The applicability of the following items on the Bill of Rights were considered: Bill of Attainder, ex post facto law, twice in jeopardy of life or limb, and due process of law. The statute was held unconstitutional by Judge Smith McPherson because in his opinion it violated the fundamental qualities in each of the above-named particulars.

Honorable W. R. C. Kendrick, Assistant Attorney-General of Iowa, under date of February 21, 1918, supplied the following information:

"On March 11, 1914, a bill of equity was filed in the District Court of the United States for the Southern District of Iowa, Eastern Division, at Keokuk, being the April Term, 1914, of said court, by Rudolph Davis, plaintiff, against William $H$. Berry, et al., constituting the Board of Parole of Iowa; James C. Saunders, Warden of the Penitentiary at Fort Madison; and Austin F. Philpott, physician of said institution, asking for a writ of injunction restraining defendants from performing the operation of vasectomy upon the plaintiff, who was a convict in said penitentiary.

"Defendants were proceeding to act under Chapter 187, Acts of the 35th General Assembly (Laws of 1913), by the provisions of which the State Board of Parole was directed and commanded to examine the inmates of all public institutions in the state, and if they decided that procreation by any such inmates would probably result in the birth of children with a tendency toward venereal disease, deformity, crime, imbecility, idiocy, insanity, and the like, then and in that event the Board of Parole was authorized to order the physician of the institution to perform the operation which would result in sterilization. As applying to inmates of the state penitentiaries, the law commanded the board to order such operation performed upon every inmate who had been twice convicted of a felony.

"After the filing of said bill the attorneygeneral of Iowa gave an opinion to the Board of Parole that Chapter 187 did not apply to any inmate who had not been twice convicted of a felony, since the law went into effect, and recommended that the board rescind and cancel their order for sterilization. Acting upon that opinion the board cancelled their former order, and the attorney-general, acting as counsel for the Board, moved the court to dismiss complainant's bill. However, the court overruled said motion, issued a temporary writ, and on June 24, 1914, entered judgment and decree, holding Chapter 187 void, as being in violation of the Constitution which prohibits the infliction of cruel and inhuman punishment. The lower court's decision will be found in 216 Fed. Rep. 419 . The case was appealed to the Supreme Court of the United States, and the judgment of the lower court reversed, not, however, for error in misstating the law by the lower court, but for the reason that pending the appeal the Iowa Legislature repealed the law under which suit was brought, and, therefore, the injunction was superfluous and the higher court had practically nothing to decide. This case is reported in Davis vs. Berry, 242 U. S. 468."

\section{STATE BOARD OF PAROLE.}

On March 5, 1914, the Iowa State Board of Parole ordered the sterilization by vasectomy of Rudolph Davis, an inmate (No. 10406) of the State Penitentiary at Fort Madison.

(a) Order of the Board directing operation on Rudolph Davis, No. 10406, an inmate of the Penitentiary at Fort Madison.

"To Managing Officer of the Penitentiary at Fort Madison:

"At a meeting of the Board anthorized by Chapter 187 of the Acts of the ThirtyFifth General Assembly of the State of 
Iowa, held at the said penitentiary in Fort Madison, Iowa, on the 14th day of February, 1914, said Board examined into the mental and physical condition, the records and family history of Rudolph Davis, No. 10406, an inmate of said penitentiary, and found said Rudolph Davis, No. 10406, to be an inmate of the said penitentiary; that he has been twice convicted of a felony, the last conviction being for a crime committed since the 4 th day of July, 1913. He is now serving under sentence on the last conviction, and that the operation of vasectomy should be performed on said Rudolph Davis, because he has been twice convicted of a felony.

"It is therefore ordered that the operation of vasectomy be performed on said Rudolph Davis, No. 10406, an inmate of said penitentiary, and that A. F. Philpott, physician of said penitentiary, be and is authorized and directed to forthwith perform said operation of vasectomy, or have same performed by some one selected by him, and make return hereon to the Iowa Board of Parole.

"All done under authority given in Chapter 187 of the Acts of the Thirty-Fifth General Assembly of the State of Iowa, and in pursuance of the findings and order of the local board of said penitentiary as above recited.

"In testimony whereof the undersigned Chairman of the Board of the Penitentiary organized and acting in pursuance of the provisions of Chapter 187 of the Acts of the Thirty-Fifth General Assembly of the State of Iowa, hereto attaches his signature.

"Signed this 5th day of March, 1914.

$$
\begin{aligned}
& \text { "W. W. BERRY, } \\
& \text { "Chairman. }
\end{aligned}
$$

"(Endorsed:) Filed March 11, 1914. Wm. C. McArthur, Clerk, by Frank Wahlgren, Deputy."

\section{JUNE 24, 1914, THE UNITED} STATES DISTRICT COURT OF SOUTHERN IOWA, Eastern Division; held the Iowa Act of April 19, 1913 (the second sterilization statute of this state), contrary to Section 1, Article XIV of the Constitution of the United States, because said statute provides for cruel and unusual punishment, constitutes a bill of attainder, and does not provide for due process of law in inflicting punishment. (216 Fed. Rep. 419.)

The principal documents in the case follow:

\section{(a) Temporary Restraining Order.}

"In the District Court of the United States in and for the Southern District of Iowa, Eastern Division, at Keokuk.

$$
\text { No. 9-A. Equity. }
$$

RUDOLPH DAVIS, Plaintiff, vs.

"WILLIAM H. BERRY, JOHN E. HOWE, and DAVID C. MOTT, Constituting the Board of Parole of Iowa; James C. Sanders, Warden and Managing Officer of the Penitentiary at Fort Madison, Iowa, and Austin F. Philpott, Physician of said Penitentiary.

\section{TEMPORARY RESTRAINING ORDER.}

"Whereas, in the above named suit it has been made to appear upon the verified bill of the plaintiff, filed herein that a temporary restraining order preliminary to the hearing for an interlocutory injunction is proper, and that prima facie the plaintiff is entitled thereto. Now, on motion of said plaintiff, it is ordered that the defendants appear before the District Court of the United States, for the Southern District of Iowa, in the Eighth Circuit, at the court room of said Court at Council Bluffs, upon the 21st day of March, 1914, at 9 o'clock a. m. of said day, and then and there show cause, if any they have, why the interlocutory writ of injunction therein prayed for should not issue, and it appearing to the undersigned that there is danger of irreparable injury being caused to the plaintiff before the hearing of said application for the preliminary interlocutory writ of injunction can be heard unless the said defendants are, pending such hearing, restrained as hereinafter set forth. And it appearing that if notice of this hearing should be given that the threatened danger complained of would occur, and that it is necessary and proper that this order be made without notice. Therefore plaintiff's application for such temporary restraining order is granted without bond.

"Now, therefore, it is ordered that you, the said William H. Berry, John E. Howe, and David C. Mott, constituting the Board of Parole of Iowa; James C. Sanders, Warden and Managing Officer of the Penitentiary at Fort Madison, Iowa, and Austin F. Philpott, Physician of said Penitentiary, defendants herein, your agents, servants and employees, and all persons acting by or under your authority or direction be, and you are hereby specially restrained and enjoined from performing, or causing the operation 
of vasectomy to be performed upon the plaintiff, and the said defendant, Austin F. Philpott, as Physician of the penitentiary at Fort Madison, Iowa, is especially restrained from designating any other person to perform said operation upon the plaintiff until the further order of this Court.

"It is further ordered that a copy of this order, certified under the hand of the Clerk and the seal of this Court, be served on each of the defendants by registered mail.

"Dated at Council Bluffs, in the Southern District of Iowa, this 11th day of March, 1914.

\section{(Signed "SMITH McPHERSON,}

"District Judge in and for the Southern District of Iowa.

"(Indorsed:) Filed March 11, 1914. Wm. C. McArthur, Clerk, by Frank Wahlgren, Deputy."

\section{b. Bill of Complaint.}

In the District Court of the United States for the Southern District of Iowa, Eastern Division, at Keokuk, April Term, A. D. 1914.

In Equity. No. 9-A.

RUDOLPH DAVIS, Plaintiff. vs.

WILLIAM H. BERRY, JOHN E. HOWE, AND DAVID C. MOTT, Constituting the Board of Parole of Iowa; James C. Sanders, Warden and Managing Officer of the Penitentiary at Fort Madison, Iowa, and Austin F. Philpott, Physician of said Penitentiary, Defendants.

To the Honorable Judge of the United States District Court for the Southern District of Iowa :

Rudolph Davis, the plaintiff, complains and says:

1st. That the plaintiff is a citizen and resident of the State of Louisiana, temporarily confined in the Iowa State Penitentiary, at Fort Madison, in the County of Lee and State of Iowa, and within the Southern Judicial District of Iowa.

2d. That the defendant, William $H$. Berry, is a citizen of the State of Iowa, and a resident of Indianola, Warren County, in the State of Iowa, within the Southern Judicial District of Iowa; the defendant, John E. Howe, is a citizen of the State of Iowa, and a resident of Adair County, in the State of Iowa, within the Southern Judicial District of Iowa; the defendant, David C.
Mott, is a citizen of the State of Iowa, and a resident of Iowa County, in the State of Iowa, within the Northern Judicial District of Iowa; the defendant, James C. Sanders, is a citizen of the State of Iowa, and a resident of the County of Lee, in the State of Iowa, within the Eastern Division of the Southern Judicial District of the State of Iowa; and the defendant, Austin F. Philpott, is a citizen of the State of Iowa, and a resident of the County of Lee, in the State of Iowa, within the Eastern Division of the Southern Judicial District of Iowa.

3d. That the plaintiff is a convict, No. 10406 , in the said penitentiary, under a judgment of the District Court in and for Linn County, Iowa, made and entered on the 27th day of August, 1913, sentencing him to not exceeding ten years, for the crime of breaking and entering.

4th. That the defendants, William $H$. Berry, John E. Howe and David C. Mott, are members of, compose and constitute the Board of Parole of the State of Iowa; that the defendant, James C. Sanders, is the warden and managing officer of the Iowa State Penitentiary at Fort Madison, Lee County, Iowa; and the defendant, Austin F. Philpott, is the physician of said penitentiary, which is a public institution of the State of Iowa.

5th. That acting under Chapter 187 of the Acts of the Thirty-fifth General Assembly of the State of Iowa, a copy of which is hereto attached, marked Exhibit "A," and made a part hereof, the defendants, acting as the board of said penitentiary, organized under said Chapter 187 , did, on the 14th day of February, 1914, decide by an unanimous vote that the operation of vasectomy should be performed on this plaintiff; that the minutes of said board in the plaintiff's case read as follows:

"The case of Rudolph Davis, No. 10406, was presented and on examination it was found that Rudolph Davis had been twice convicted of a felony, the last conviction being for a crime committed since the 4 th day of July, 1913. He is now serving under the sentence on last conviction, and is a prisoner in the penitentiary at Fort Madison. It was moved that the operation of vasectomy be performed on Rudolph Davis, No. 10406, and said motion prevailed unanimously."

6th. That on the 5th day of March, 1914, the said Board, through its chairman, the 
defendant, William $\mathrm{H}$. Berry, issued its mandate to the defendant, James C. Sanders, as managing officer of said penitentiary, ordering that the operation of vasectomy be performed on this plaintiff, and directing the defendant, Austin F. Philpott, as physician of said penitentiary, to forthwith perform said operation on this plaintiff, or have same performed by some one selected by him. A copy of said mandate is hereto attached, marked Exhibit " $B$," and made a part - hereof.

7 th. That the defendant, Austin F. Philpott, threatens to immediately designate some person to forthwith perform said operation on this plaintiff, and will do so unless restrained by this Honorable Court.

8th. That the operation of vasectomy consists in the resection or incision of the vas deferens, and would sterilize this plaintiff and render him incapable of procreation.

9th. That said Chapter 187 of the Acts of the Thirty-Fifth General Assembly of the State of Iowa violates and is contrary to Section 10, Article I, of the Constitution of the United States and is, therefore, void and of no effect; that as applied to this plaintiff it is ex post facto in that it was approved April 19, A. D. 1913, and became effective July 4, 1913; that he has not been twice convicted of a felony since July 4, 1913, and never has been twice convicted of a felony in the State of Iowa.

10th. That said Chapter 187 of the Acts of the Thirty-Fifth General Assembly of the State of Iowa violates and is contrary to Article I, Section 21 of the Constitution of Iowa, and is therefore void and of no effect in that as applied to this plaintiff it is ex post facto for the reasons set forth in the 9 th paragraph of this bill.

11th. That said Chapter 187 of the Acts of the Thirty-Fifth General Assembly of the State of Iowa is contrary to Section 10 of Article I of the Constitution of the United States, which forbids any state to pass a Bill of Attainder in that it is a legislative act inflicting punishment without a judicial trial; that the said Act creates a new offense under the laws of Iowa, prescribes a punishment therefor, sentences the plaintiff and all other convicts who have been twice convicted of a felony, and orders the execution of the sentence without indictment, information or trial, and without giving the convict an opportunity to defend himself, without requiring legal evidence, and without giving the convict the benefit of counsel. 12th. That said Chapter 187 of the Acts of the Thirty-Fifth General Assembly of the State of Iowa is contrary to Article I, Section 21 of the Constitution of Iowa, for the reasons set forth in paragraph 11 of this bill.

13th. That said Chapter 187 of the Acts of the Thirty-Fifth General Assembly of Iowa is contrary to Section 1 , Article $I$, of the Constitution of Iowa, for the reason that it deprives the plaintiff of his inalienable right to enjoy life and liberty and to pursue and obtain safety and happiness.

14th. That said Act of the General Assembly of Iowa is contrary to Section 9, Article I, of the Constitution of Iowa, which provides that the right of a trial by jury shall remain inviolate in that the said Act prescribes the punishment of vasectomy for a convict twice convicted of a felony without requiring the fact of such convictions to be determined by a jury but leaves the determination of that question to the Board of Parole, the managing officer of the prison, and the prison physician, and plaintiff further avers that the indictment against him in Linn County, Iowa, under which he was convicted and sentenced to the said penitentiary, and under which judgment he is now confined did not refer to the alleged former conviction of the plaintiff; that no evidence of a former conviction was introduced and the jury did not specially find that this plaintiff had been formerly convicted.

15th. That said Act of the General Assembly of Iowa is contrary to the Fourteenth Amendment of the Constitution of the United States, which provides "that no state shall deny to any person within its jurisdiction the equal protection of the laws," in that it applies only to persons who have been twice convicted of felonies and are inmates of the penitentiary, while it does not apply to persons who have been twice convicted of felonies but are not inmates of the penitentiary.

16th. That said Act of the General Assembly of the State of Iowa is contrary to the Fourteenth Amendment of the Constitution of the United States for the reason that it abridges the privileges and immunities of this plaintiff as a citizen of the United States and deprives him of this liberty without due process of law.

17th. That said Act of the General Assembly of Iowa is contrary to Section 9, Article I, of the Constitution of Iowa for the reason that it deprives the plaintiff of liberty without due process of law. 
18th. That said Chapter 187 of the Acts of the Thirty-Fifth General Assembly of Iowa is contrary to Section 17, Article I, of the Constitution of Iowa, which provides that cruel and unusual punishment shall not be inflicted, for the reason that the operation of vasectomy is a cruel and unusual punishment.

19th. That plaintiff is without adequate remedy at law; that plaintiff will suffer irreparable loss and damage unless a temporary restraining order is granted without notice restraining the defendants or any of them, and any one acting under their authority or designation, from performing said operation of vasectomy upon him.

20th. That the amount in controversy in this action exceeds, exclusive of interest and costs, the sum or value of Three Thousand $(\$ 3,000.00)$ Dollars.

21st. That plaintiff is without means and is unable to give an injunction bond.

Wherefore, to the end that he may obtain the relief to which he is justly entitled in the premises, the plaintiff prays the court:

First: To grant him your writ of subpœena, directed to William H. Berry, John E. Howe and David C. Mott, constituting the Board of Parole of Iowa; James C. Sanders, Warden and Managing . Officer of the penitentiary at Fort Madison, Iowa, and Austin F. Philpott, Physician of said penitentiary, requiring and commanding all of them, and each of them, to appear and answer this bill of plaintiff at the next April term, 1914, of said court, in and for the Eastern Division at Keokuk, but not under oath, answer under oath being expressly waived.

Second. To grant an interlocutory writ of injunction commanding the said defendants, and each of them, their servants, agents, employees, and all persons under their authority, direction or control, to absolutely desist and refrain from performing the operation of vasectomy upon this plaintiff, and commanding the said defendant, Austin F. Philpott, to refrain from designating any other person to perform said operation on this plaintiff, and that upon the final hearing and determination of this suit that said injunction be made perpetual, and that plaintiff may have such other and further relief, preliminary and final, as to the court may seem meet and proper, and which equity may require, and for costs.

Third. That the Court grant unto your plaintiff a temporary restraining order, without notice, restraining the said defendants, and each of them, their servants, employees, and agents and all persons under their authority, direction or control, from performing, or causing the operation of vasectomy to be performed on this plaintiff, and restraining the said defendant, Austin F. Philpott, as physician of said penitentiary, from designating any other person to perform said operation upon this plaintiff until such time as your Honor shall direct and appoint a hearing herein.

(Signed) GEORGE B. STEWART, Solicitor and Counsel for Plaintiff.

\section{STATE OF IOWA,}

\section{Lee County, ss:}

I, Rudolph Davis, on my oath depose and say that I am the plaintiff in the above entitled suit; that I have heard the foregoing Bill of Equity read over and that the facts and allegations therein stated are true as I verily believe.

(Signed) RUDOLPH DAVIS.

Subscribed and sworn to before me by the said Rudolph Davis this 10th day of March, A. D. 1914.

- (Signed) JESSE SCHLARBAUM, [Seal] Notary Public in and for Lee County, Iowa.

(Endorsed:) Filed March 11, 1914. Wm. C. McArthur, Clerk, by Frank. Wahlgren, Deputy.

\section{c. Amendment to Bill of Complaint.}

In the District Court of the United States for the Southern District of Iowa, Eastern Division, at Keokuk, April Term, A. D. 1914.

\section{RUDOLPH DAVIS, Plaintiff,} vs.

WILLIAM H. BERRY, JOHN E. HOWE, AND DAVID C. MOTT, Constituting the Board of Parole of Iowa; James C. Sanders, Warden and Managing Officer of the Penitentiary at Fort Madison, Iowa, and Austin F. Philpott, Physician of said Penitentiary, Defendants.

\section{AMENDMENT TO BILL.}

Now comes the plaintiff and amends his bill heretofore filed in the manner following:

1. He withdraws paragraph 14 of said bill and inserts in lieu thereof the following: That said Act of the General Assembly of Iowa is contrary to Section 9 of Article I of the Constitution of Iowa, which provides that the right to a trial by jury shall remain inviolate in that the said act prescribes the 
punishment of vasectomy for a convict twice convicted of a felony without requiring the fact of such conviction to be determined by a jury, or even by the Board created by said act, but arbitrarily and peremptorily orders said operation to be performed on convicts twice convicted of a felony, and plaintiff further avers that the information against him in Linn County, Iowa, under which he was convicted and sentenced to said penitentiary, and under which judgment he is now confined, did not refer to the alleged former conviction of the plaintiff; that no evidence of a former conviction was introduced and that the jury did not specially find that this plaintiff had been formerly convicted; that an exemplified copy of said information is hereto attached, marked Exhibit " $\mathrm{C}$ " and made a part hereof.

2. Plaintiff avers that he has been twice convicted of a felony; once in Linn County, Iowa, and once in Pulaski County, in the State of Arkansas, in the year 1909.

(Signed) GEORGE B. STEWART, Solicitor and Counsel for Plaintiff.

\section{UNITED STATES OF AMERICA,} Southern District of Iowa.

\section{STATE OF IOWA,}

\section{Lee County, ss:}

I, Rudolph Davis, on my oath depose and say that $I$ am the plaintiff in the above entitled suit; that I have heard the foregoing amendment to the Bill in Equity in said suit read over, and that the facts and allegations therein stated are true as I verily believe.

\section{(Signed) RUDOLPH DAVIS.}

Subscribed and sworn to before me by the said Rudolph Davis this 9th day of April, A. D. 1914 .

(Signed) JESSE SCHLARBAUM,

[Seal] Notary Public in and for Lee County, Iowa.

(Endorsed:) Filed April 14th, 1914. Wm. C. McArthur, Clerk, by Frank Wahlgren, Deputy.

\section{d. Reports of Attorney-General to Board of Parole, October 21, 1913:}

Dear Sir: I am in receipt of your communication directing my attention to Chapter 187, Acts of the Thirty-Fifth General Assembly, relating to the prevention of the procreation of certain delinquents and defectives, and requesting to be advised:

1st. As to whether the act applies to prisoners confined in the penal institutions referred to in said act who were convicted prior to the taking effect of said act; that is to say prior to the 4 th day of July, 1913; and,

2d. Does the act include persons convicted of misdemeanors and confined in jails and minor prisons of the state.

First. The question is not free from diffculty. In this question is involved (a) the intention of the legislature, that is to say, whether or not the legislature intended the act to apply to persons confined or convicted prior to the taking effect of the act; and (b) if the legislature did so intend, is the act constitutional.

Assuming then that the legislature intended the act to apply to persons convicted or sentenced prior to the taking effect of said act, the same would be unconstitutional as being ex post facto, if it may be considered as a means of punishment or even if it contained directly an element of punishment. If, however, it is looked upon wholly as a sanitary and police measure in the interest of society at large, and directly in the interest of the possible offspring of the persons referred to in the act, then it would clearly not be unconstitutional.

It is a cardinal principle of construction that every act should be so construed as to relieve it of grave constitutional questions if possible. This being true, and it also being uncertain as to whether it was the intention of the General Assembly to make the act apply to persons convicted of crime prior to the taking effect of the act, I am of the opinion that the act should be construed to apply only to those persons who have been convicted of crime subsequent to the taking effect, of said act.

Second. After a careful consideration of the entire act I am clearly of the opinion that it was not the intention of the legislature to include therein misdemeanants or persons confined in county and city jails.

Respectfully submitted, (Signed) GEORGE COSSON, Attorney-General.

October 21, 1913.

Hon. W. H. Berry, Chairman Board of Parole, Des Moines, Iowa.

REPORT OF APRIL 1, 1914.

Gentlemen: On the 17th of July, 1913. your board submitted the following questions to the Department of Justice with a request for an official opinion thereon: 
1st. "Do the prisoners confined in the prisons named above whose crime was committed before the taking effect of the act referred to, come under the provisions thereof?"

2d. "Does the act include persons convicted of misdemeanors confined in jails and minor prisons of the state?"

On the 21st of October, 1913, an official opinion was given in which it was held that the act did not include misdemeanants or persons confined in county and city jails. In discussing the first proposition it was said:

"The first question is not free from difficulty. In this question is involved (a) the intention of the legislature; that is to say, whether or not the legislature intended the act to apply to persons confined or convicted prior to the taking effect of the act; and (b) if the legislature did so intend, is the act constitutional?"

In discussing the question I there said that "Assuming that the legislature intended the act to apply to persons convicted or sentenced prior to the taking effect of said act, the same would be unconstitutional, as being ex post facto, if it may be considered as a means of punishment or even if it contained directly an element of punishment;" and that "It is a cardinal principle of construction that every act should be so construed as to relieve it of grave constitutional questions if possible;" and that, "This being true, and it also being uncertain as to whether it was the intention of the General Assembly to make the act apply to persons convicted of crime prior to the taking effect of the act, I am of the opinion that the act should be so construed as to apply only to those persons who have been convicted of crime subsequent to the taking effect of said act."

The precise question now presented by the complaint filed by George B. Stewart on behalf of Rudolph Davis seems not to have been passed upon in that opinion. viz: Was it the intention of the legislature that both convictions should be subsequent to the taking effect of the act?

It will be noticed as the language used by the General Assembly is general in its nature, and after a careful consideration of the act, I am of the opinion that the act should be so construed as to require that both convictions of a felony must be subsequent to the passage of the act. This being true, and there now being no person confined in the penitentiary who has been twice convicted of felony since the passage of Chapter 187, acts of the Thirty-Fifth General Assembly, it follows that the order made by the Board of Parole designating Rudolph Davis and others should be cancelled and that no prisoners should be designated by the commission named upon whom the operation should be performed who has not been twice convicted of a felony subsequent to the passage of the act. Since the act does not make it clear whether both convictions should be had in the State of Iowa, and as it is well known that what is a felony in one state may be a misdemeanor in another state, and vice versa, and since the Thirty-Sixth General Assembly will convene on the second Monday in January, 1915, I suggest that no further action be taken under this particular section of the act until the General Assembly has an opportunity to make the provision in question more specific.

This opinion is limited to the construction to be placed upon the single phrase under consideration, viz., a prisoner "who has been twice convicted of a felony."

(Signed) GEORGE COSSON, Attorney-General of Iowa.

April 1, 1914.

Honorable Board of Parole.

\section{e. Minutes of Meeting of Board of Parole} et al., April 15, 1914.

MINUTES OF MEETING OF THE BOARD FOR THE ADMINISTRATION OF THE LAW AS FOUND IN CHAPTER 185 OF THE ACTS OF THE THIRTY-FIFTH GENERAL ASSEMBLY:

The Board of Parole, together with J. C. Sanders, Warden of the Penitentiary at Fort Madison, and A. F. Philpott, Physician of said Penitentiary, met at Des Moines, Iowa, April 15, 1914, called to order, and on motion of J. E. Howe, the following preamble and resolution was adopted:

Whereas, at a meeting of this board held at Fort Madison, Iowa, on February 14, 1914 , it was ordered that the operation of vasectomy be performed by the physician of said prison on the following named prisoners confined in said Penitentiary, to-wit:
No. 10405-Harry Delmar
No. 10406-Rudolph Davis
No. 10409-W. J. McArtor
No. 10414-John Ryan
No. 10434-Jake Mann 
No. 10440-Peter Stark

No, 10441-D. O. Martin

No. 10448-Ed Turnipseed

No. 10453-William O'Gara

No. 10455-S. H. Keeler

No. 10462-Fred Trask

No. 10464-Charles King

No. 10473-William Kinney

No. 10475-Charles Davis

No. 10477-Claude Brasher

No. 10478-David Dyer

No. 10481-Thomas Burns

No. 10485-Charles Reide

No. 10491-Joe Murphy

No. 10492-Fred Carson

No. 10494-John Singleton

No. 10497-Oscar Carlson

No. 10499-Frank Sanders,

all for the reason that each of said prisoners had been twice convicted of a felony and for that reason under the Act of the ThirtyFifth General Assembly of the State of Iowa providing for sterilization of prisoners should be sterilized; and,

Whereas, in each of said cases one of such felonies had been committed since the taking effect of said Act, and in each of said cases one of the felonies of which the prisoner had been convicted was committed before the taking effect of said Act; and,

Whereas, the Attorney-General of Iowa now has filed with this board his written opinion, holding that the proper construction of the provisions of said act which requires that the operation of vasectomy should be performed on every prisoner in the Penitentiary of Iowa who has been twice convicted of a felony, would require that both of the crimes of which he was convicted must have been committed since the taking effect of said Act, and therefore does not apply in any of the above named cases;

Therefore, resolved, that because of the construction of said Act by the AttorneyGeneral of Iowa, we reconsider the motion by which the operation of vasectomy was ordered to be performed in each of the above cases.

Moved.by A. F. Philpott that the motion made February 14, 1914, that the operation of vasectomy be performed on

No. 10405-Harry Delmar

No. 10406-Rudolph Davis

No. 10409-W. J. McArtor

No. 10414-John Ryan

No. 10434-Jake Mann

No. 10440-Peter Stark
No. 10441-D. O. Martin

No. 10448-Ed Turnipseed

No. 10453-William O'Gara

No. 10455-S. H. Keeler

No. 10462-Fred Trask

No. 10464-Charles King

No. 10473-William Kinney

No. 10475-Charles Davis

No. 10477-Claude Brasher

No. 10478-David Dyer

No. 10481-Thomas Burns

No. 10485-Charles Reide

No. 10491-Joe Murphy

No. 10492-Fred Carson

No. 10494-John Singleton

No. 10497-Oscar Carlson

No. 10499-Frank Sanders,

be laid on the table. The motion prevailed.

Moved by D. C. Mott that the board be now adjourned, subject to the call of the chairman. The motion prevailed.

The board adjourned.

(Signed) W. H. BERRY,

Chairman.

A. F. PHILPOTT,

Secretary.

A notice of appeal was filed by the Attorney-General of the State of Iowa on August 19, 1914, which was followed by an order signed by Judge Smith McPherson on August 20, 1914, duly allowing the appeal.

f. Decision of the District Court of the United States in and for the Southern District of Iowa, Eastern Division.

No. 9-A. Equity.

RUDOLPH DAVIS, Complainant, against

WILLIAM H. BERRY, JOHN F. HOWE, DAVID C. MOTT, JAMES C. SANDERS and AUSTIN F. PHILPOTT, Defendants.

\section{OPINION.}

George B. Stewart of Fort Madison, Iowa, for Complainant; George Cosson of Des Moines, Iowa, Attorney-General of Iowa, for Defendants.

Before Walter I. Smith, Circuit Judge; John C. Pollock and Smith McPherson, District Judges.

\section{Smith McPherson, District Judge:}

The complainant is a prisoner in the Iowa penitentiary. Defendants Berry, Howe, and Mott constitute the Iowa Board of Parole; Sanders is the warden, and Philpott is the physician of the penitentiary. 
The case is one of diversity of citizenship, with federal questions presented by a Bill of Equity with an application for a temporary injunction to restrain defendants as state officers from enforcing Chapter 187 of the acts of the Thirty-fifth General Assembly (1913), authorizing a surgical operation called vasectomy on idiots, feeble-minded, drunkards, drug fiends, epileptics, syphilitics, moral and sexual perverts, and mandatory as to criminals who have been twice convicted of a felony.

Complainant has been twice convicted of a felony, one of which was prior to the enactment of the statute in question (and in another state), and the other since (in this state), and for the latter he is now imprisoned. The defendant Board of Parole in February, 1914, made an order that the operation should be performed upon certain designated prisoners, including the complainant. This action was brought by the complainant for the purpose of enjoining each and every one of the defendants from subjecting him to the operation. Since the action was instituted the Board of Parole under a written opinion of the attorney-general of the state has rescinded its order, and they and the prison physician say they will observe such opinion. The opinion of the attorney-general is based upon the proposition that the statute is ex post facto if either of the convictions was for an offense committed prior to the enactment of the statute. Complainant's counsel in argument conceded the statute is not an ex post facto one.

The attorney-general was in error when he advised the Board of Parole that the statute in question is void by reason of it being ex post facto, except only as to prisoners who have been twice convicted for felonies committed since the enactmert of the statute. The statute under any construction is not an ex post facto one. State of Iowa ex. rel. Gregory vs. Jones, 128 Fed. Rep. 626; Kelly vs. People, 115 Ill. 583 (4 N. E. 644); Commonwealth vs. Graves, 155 Mass. 163 (29 N. E. 579); Sturtevant vs. Commonwealth, 158 Mass. 598 (33 N. E. 648); In re Miller, 68 N. W. 990 (Michigan); Blackburn vs. State, so Ohio State, 428 (36 N. E. 18) ; Moore vs. State of Missouri, 159 U. S. 673; Cooley's Constitutional Limitations, 7th Ed. 382; State vs. Dowden, 137 Iowa, 573; Graham vs. West Virginia, 224 U. S. 616. He is not being subjected to the operation for that which was by him done prior to the enactment of the statute, but because he voluntarily brings himself within a class covered by the statute, and he does this subsequent to the enactment of the statute.

The attorney-general also advised the Board of Parole that the statute should be so construed as to be applicable only to prisoners who have been twice convicted of felonies committed since the enactment of the statute. Section 26, Article III, of the Iowa Constitution provides that a statute shall take effect July 4 th following its enactment, or, if enacted at a special session, then at the expiration of ninety days after adjournment; or, in case of a declared emergency, by the publication thereof. But the attorney-general to maintain the proposition that the law is ex post facto as applied to one who was convicted the one time prior to the statute is doing violence to the state constitution by contending that the statute would be effective only as to any prisoner many years after its enactment.

The defendant Board of Parole by rescinding the order subjecting complainant to the surgical operation, and the defendant warden and physician through the attorney-general now insist that an injunction should not issue because it will serve no purpose. There are two answers to this: death, resignation, and expiration of terms of office will bring other men into the positions now held by the defendants who may not entertain the same views as these defendants. The opinion of the attorney-general is advisory only and is not at all binding on either these defendants or their successors in office.

Again, the statute in question provides that certain persons may be subjected to the surgical operation; but the latter part of Section 1 provides that such operations shall be performed upon prisoners who have been twice convicted of a felony, such as the complainant.

It is the duty of an officer to follow the mandates of the statute. Of course, every officer must act at his peril under a statute that another party claims to be unconstitutional and void; but where a person will suffer an irreparable injury if the statute is carried out, the presumption is that such statute will be observed and that an injunction should issue to enjoin the enforcement of a void statute. Williams vs. Boynton, 147 N. Y. 426 (42 N. E. 184); Osborne vs. Blank, 9 Wheaton, 739,$840 ; 2$ High on Injunctions (4th edition), Section 310. 
Complainant in his verified bill alleges that the statute is in violation of the United States Constitution in that it is in effect a Bill of Attainder in that there is to be no indictment or trial; that the statute abridges his privileges, and that he is denied the equal protection of the laws; that he is denied due process of law; that the statute is in conflict with the Iowa Constitution in that the statute denies the inalienable right to enjoy life, liberty and to pursue and obtain safety and happiness; that there is no jury trial awarded him, and that the statute provides cruel and unusual punishment.

The case presents important questions. Statutes like this are of recent years, the first one upon the subject enacted less than fifteen years ago. The question has been before Appellate courts but twice. In one case, that of State of Washington vs. Feilen, 126 Pac. Rep. 75 (41 L. R. A., N. S., 418), the statute was upheld. The court held that the punishment was not cruel or unusual in the constitutional sense. That case involved a most heinous offense, that of the ravishment of a female child, and the statute provided that in addition to life imprisonment the jury and the court might determine whether he should be subjected to the operation of vasectomy. So that on the question now presented there was due process of law in that the matter was judicially determined. The other case, by the Supreme Court of New Jersey, was that of Smith vs. Board of Examiners, 88 Atl. Rep. 963. In that case the operation was to be performed upon a woman who was an epileptic, an inmate of a state charitable institution, and that court held that the statute was based upon an unreasonable police regulation and denied to her and persons of her class the equal protection of the laws as guaranteed by the Fourteenth Amendment.

The sole purpose of the operation is to destroy the power of procreation. The operation as originally performed was that of castration. In the twelfth century Henry II. declared it treason for any person to bring over any mandate from the pope or any one in authority in church affairs. This he made punishable as to secular clergymen by the loss of their eyes and by castration. Goldsmith's History of England, Volume 1, page 38 . In Weems vs. United States, 217 U. S. 349,377 , the fact that castration was once inflicted is recognized-and see the case of Whitton vs. Georgia, 47 Georgia, 301.
There is a difference between the operation of castration and vasectomy; castration being physically more severe than the other. But vasectomy in its results is much the coarser and more vulgar. But the purpose and result of the two operations are one and the same.

When Blackstone wrote his Commenta ries he did not mention castration as one of the cruel punishments, quite likely for the reason that with the advance of civilization the operation was looked upon as too cruel and was no longer performed. But each operation is to destroy the power of procreation. It is of course to follow the man during the balance of his life. The physical suffering may not be so great, but that is not the only test of cruel punishment; the humiliation, the degradation, the mental suffering are always present and known by all the public and will follow him wheresoever he may go. This belongs to the dark ages.

As, of course, all persons concede that it would be better for society if some men did not beget children; diseased, deformed, mentally weak children and criminally inclined, are brought into the world oftentimes to their own shame and against the interest of the public. But are they not at the minimum? And must the marriage relation be formed under these newly-conceived laws based upon the brutalities of many centuries since and be allowed to take the place of the marriage relation formed along the true lines? Must the marriage relation be based and enforced by statute according to the teachings of the farmer in selecting his male animals to be mated with certain female animals only?

It is somewhat difficult to define with precision what is cruel and unusual punishment in the constitutional sense. Usually the length of imprisonment following a conviction is within the discretion of the legislative body, and we have an extreme case in O'Neil vs. Vermont, 144 U. S. 323, in which the judgment of the lower court was affirmed and the statute upheld. But quite a per cent of the bar of the country are of the opinion that the dissenting opinion by Justice Field (concurred in by Justice Brewer and Harlan) was the stronger.

No doubt delegates to the conventions, in providing against cruel punishment, had largely in mind what Blackstone had then recently written in volume 4 , page 376 , such as being drawn or dragged to the place of 
execution, emboweling alive, cutting off the hands or ears, branding on the face or hand, slitting the nostrils, placing the prisoner in the pillory, the ducking, the rack, and the torture, and, as in Spanish countries, crucifying. In a very few states of the Union the whipping post has been retained as a constitutional mode of punishment. But it will be found that the courts in those states have construed the statute thus imposing such punishment in the light of their history, and what had been done and was being done at the time of the adoption of their constitution. No one can doubt but that under our present civilization if castration were to be adopted as a mode of punishment for any crime, all minds would so revolt that all courts without hesitation would declare it to be a cruel and unusual punishment. As we understand it, castration was never inflicted after the revolution of 1688 . So that if, as some now contend, it is now competent for a legislature to impose such punishment as existed by the common law, the validity of the statute providing for castration could not be upheld because that punishment was one imposed back of the time of the common law as, generally speaking, it comes down to us. In O'Neil vs. Vermont, 144 U. S. 323 , and Weems vs. United States, 217 U. S. 349 , and in re Kemler, 136 U. S. 436 , all phases of the question are so presented as to leave nothing further to be said.

While it is true that there are differences between the two operations of castration and vasectomy, and while it is true that the effect upon the man would be different in several respects, yet the fact remains that the purpose and the same shame and humiliation and degradation and mental torture are the same in one case as in the other. And our conclusion is that the infliction of this penalty is in violation of the Constitution which provides that cruel and unusual punishment shall not be inflicted.

This statute not only allows but commands the operation of vasectomy to be performed upon all twice convicted of a felony. A felony in Iowa is not only murder, arson, rape, counterfeiting, and other serious crimes known as felonies at the common law, but they have been much extended under the Iowa statute, and some things are now felonies which until recently were misdemeanors with trials before a justice of the peace, or else no crime at all; wife abandonment, cutting electric light wires, breaking an electric globe, obstructing highway, unfastening a strap in a harness, and other things. So that if a person commits two or more of these, he is to be subjected to the operation if this statute is enforced.

And it is of no importance in argument whether the prison physician does this on his own motion or under an order of the State Board of Parole. The hearing is by an administrative board or officer. There is no actual hearing. There is no evidence. The proceedings are private. The public does not know what is being done until it is done. Witnesses are not produced, or if produced they are not cross-examined. What records are examined is not known. The prisoner is not advised of the proceedings until ordered to submit to the operation. And yet in many cases there will be involved a serious controverted question of fact. The records of two convictions may show the same name of the party or parties convicted; but there are many men of the same name, but which is no proof that the person in the one case is the same person convicted in the other case. It is common knowledge that many prisoners take assumed names. Who is to determine whether the various names represent one and the same person? And if one of the convictions was in another state, the question will arise whether it was for a felony.

These inquiries that must be held in the open, with full opportunities to present evidence and argument for and against. To uphold this statute it must be affirmed that the Board of Parole or prison physician must hear the evidence and examine laws of other states without notice and in the prisoner's absence and determine these questions. And if determined adversely, the prisoner has no remedy but must submit to the operation.

In the case at the bar, the hearing was a private hearing, and the prisoner first knew of it when advised of the order. Due process of law means that every person must have his day in court, and this is as old as magna charta: that sometime in the proceedings he must be confronted by his accuser and given a public hearing. Or as was stated in Leeper vs. Texas, 139 U. S. 642 :

"Law, in its regular course of administration through courts of justice, is due process, and when secured by the law of the state the constitutional requirement is satisfied."

Under the habitual criminal laws of the state, if a prior conviction is relied on, the 
same must be pleaded and established by the evidence. But we have cases, this one included, in which the prior conviction has not been judicially established. But in Hayes vs. Missouri, 120 U. S. 68 , it was said that due process of law and the equal protection of the laws were secured if the laws operated on all alike and that all persons subject to the laws are treated alike under the limitations imposed. And the same holding was made in Duncan vs. Missouri, 152 U. S. 377. And see Lowe vs. Kansas, 163 U. S. 88; Jones vs. Brim, 15 U. S. 184; Magoun vs. Illinois Trust, 170 U. S. 294; Railroad vs. Matthews, 174 U. S. 105.

The cases are numerous and without conflict as to such holdings, and further citations need not be made.

But assuming that the prior convictions all appear of record, and assuming there is no conflict in the testimony and no difficulty in reaching the conclusion, but little or no advance is made in determining the question. If it be said that the statute automatically decides the question and nothing remains for the prison physician to do but to execute that which is already of record, then the statute becomes a Bill of Attainder. One of the rights of every man of sound mind is to enter into the marriage relation. Such is one of his civil rights, and deprivation or suspension of any civil right for past conduct is punishment for such conduct, and this fulfills the definition of a Bill of Attainder, because a Bill of Attainder is a legislative act which inflicts punishment without a "jury trial, as is fully discussed and held in the case of Cummings vs. Missouri, 71 U. S. 277, The Federalist, No. 44, by Madison; Justice Samuel F. Miller on the Constitution, 584; Watson on the Constitution, 733738.

We hold the statute to be void, and unite in holding that a temporary writ of injunction should be issued as prayed.

Keokuk, Iowa, June 24, 1914.

\section{Smith, Circuit Judge, concurring:}

The foregoing opinion is supported by a wealth of historical and other references and I do not wish to dissent from any portion of it. But the Iowa law does not provide for a judicial investigation of the identity of the prisoner with the one previously convicted of a felony as did the law in Washington construed in State vs. Feilen, referred to in the foregoing opinion. The Fourteenth Amendment to the Federal Constitution provides that no state shall deprive any person of life, liberty or property without due process of law. It seems to manifest to me that the law which provides that such operation (vasectomy or ligation of the Fallopian tubes) shall be performed by the physician of the institution or one selected by him upon any convict or inmate who has twice been convicted of a felony deprives the party in question of due process of law that it can scarcely be discussed. Suppose a person had been twice convicted of a felony and has served his entire time and should subsequently be an inmate of the penitentiary unconvicted of any crime, but simply held there for safe keeping, this law in its strictness would require the prison physician to perform the operation upon him in person or by some person selected by such physician. It seems to me that the victim of this operation is so clearly deprived under this statute of due process of law that an injunction must issue, and I therefore express no opinion upon the other interesting questions presented.

(Endorsed:) Filed June 24, 1914. Wm. C. McArthur, Clerk, by Frank Wahlgren, Deputy.

g. Order for Temporary Injunction.

IN THE DISTRICT COURT OF THE UNITED STATES IN AND FOR THE SOUTHERN DISTRICT OF IOWWA, EASTERN DIVISION.

No. 9-A. Equity.

RUDOLPH DAVIS, Complainant, against

WILLIAM H. BERRY, JOHN J. HOWE, DAVID C. MOTT, JAMES C. SANDERS, and AUSTIN F. PHILPOTT, Defendants.

\section{ORDER.}

This case was heretofore presented by an application of complainant for a temporary injunction. Thereupon the resident judge of said court by written order designated Walter I. Smith, one of the United States Circuit judges for this, the Eighth circuit, and John C. Pollock, the United States District judge for the District of Kansas, to sit with and assist him in the determination of said application for a temporary injunction herein.

After said designations had been made and made of record herein, the said application came on for hearing in open court at Keokuk, Iowa, viz., April 17, 1914, the com- 
plainant appearing by George B. Stewart, Esq., his solicitor, and the same defendants all appearing by George Cosson, Esq., attorney-general of Iowa.

And after full argument the said application was fully submitted on the said application and the pleadings and was by the court taken under advisement.

And now at this time the court being fully advised, files a written opinion herein with a concurring opinion, each and both of which are now ordered of record and made a part hereof.

And it is further ordered that a temporary writ of injunction issue under the seal of this court restraining and enjoining the said William H. Berry, John F. Howe, and David C. Mott, members of and composing the Iowa State Board of Parole; James C. Sanders, the warden of the Iowa State Penitentiary at Fort Madison, Iowa, and Austin F. Philpott, the physician of said penitentiary, and the successors in office of each and every one of said officers aforesaid from performing the operation of vasectomy on the said complainant, the Iowa Statute Chapter 187, Acts of the Thirty-fifth General Assembly, Laws of Iowa, being unconstitutional, null and void.

And this order and the whole thereof will be and remain in full force until final hearing.

Witness our official signatures this June 24th, A. D. 1914.

(Signed) WALTER I. SMITH, United States Circuit Judge. (Signed) JOHN C. POLLOCK, United States District Judge. (Signed) SMITH McPHERSON, United States District Judge.

(Endorsed:) Filed June 24th, 1914. Wm. C. McArthur, Clerk, by Frank Wahlgren, Deputy.

\section{UNITED STATES SUPREME COURT.}

January 15, 1917. The United States Supreme Court reversed the decision of June 24, 1914, of the District Court, because meanwhile (July 4, 1915) Iowa repealed the Act of April 19, 1913, and enacted a new (the third) sterilization statute. (See Transcript of Record. Supreme Court of the United States, October Term, 1916, No. 47. Filed October 20, 1914, No. 24,409.) (242 U. S. 468.)

\section{PRINCIPAL DOCUMENTS.}

a. Brief for Plaintiffs in Error, filed with the Supreme Court of the United States on
August 30, 1916, by George Cosson, Attorney-General of Iowa.

Statement of the Case.

Statute.

Errors Relied Upon.

\section{I.}

The court erred in holding that it had jurisdiction of the subject matter involved in this cause.

II.

The court erred in holding that Chapter 187, Acts of the Thirty-fifth General Assembly of Iowa, applied to all convicts now confined in the penitentiary of the State of Iowa who have been twice convicted of felony, even though such convicts have not been twice convicted of felony within the State of Iowa subsequent to the enactment of said chapter.

III.

The court erred in holding that Chapter 187. Acts of the Thirty-fifth General Assembly of Iowa, applied to all convicts now confined in the penitentiary of the State of Iowa who had been twice convicted of felony, even though one of said convictions was in a state other than the State of Iowa, and even though one of such convictions occurred prior to the time said Chapter 187 became a law.

\section{IV.}

The court erred in overruling and disregarding the opinion of the Board of Parole of the State of Iowa and of the attorneygeneral of the State of Iowa in their interpretation of Chapter 187, Acts of the Thirtyfifth General Assembly of the State of Iowa, holding that said chapter only applied to those convicts now confined in the penitentiary of the State of Iowa who had been twice convicted of felony in the State of Iowa subsequent to the going into effect of said Chapter 187.

\section{V.}

The court erred in holding that the facts as shown by the record presented such a state of facts as would entitle complainant to a temporary injunction or to any other relief.

VI.

The court erred in passing upon the constitutionality of Chapter 187, Acts of the Thirty-fifth General Assembly of Iowa.

\section{VII.}

The court erred in holding Chapter 187, Acts of the Thirty-fifth General Assembly unconstitutional and void. 


\section{VIII.}

The court erred in not dismissing plaintiff's complaint as prayed for by defendants in their motion to dismiss said Bill of Complaint.

\section{IX.}

The court erred in issuing the temporary injunction and restraining order as shown by the record.

$$
\mathrm{X} \text {. }
$$

The court erred in entering the order and decree, holding the said Chapter 187 unconstitutional and in entering the temporary injunction and restraining order.

\section{ARGUMENT.}

The court erred in granting a temporary injunction.

It is such a fundamental and cardinal principle of law that no one is entitled to a temporary injunction unless he is about to suffer irreparable injury and that such injury is imminent, and that he has no legal remedy, that a discussion of the proposition or a citation of authorities is not only unnecessary, but seems almost a reflection upon the court.

This is especially true where the defendant in the presence of the chancellor or court proposes to do what the plaintiff asks in his bill.

Behn vs. Young, $21 \mathrm{Ga} .207$ at 213.

And the mere fact that the act is unconstitutional does not suffice to warrant the court in granting the injunction unless it is shown that the injury is irreparable, the danger imminent and that no legal remedy is available.

Shelton vs. Platt, 139 U. S., 591;

Allen vs. Pullman Palace Car Co., 139 U. S. 658; 339;

Pacific Express Co. vs. Siebert, 142 U. S.

Pittsburgh, etc., Ry. Co. vs. Board of Public Works, 172 U. S., 32;

Arkansas Building and Loan Association vs. Madden, 175 U. S., 269.

There is not one discordant note in the unbroken line of authorities and this is true not only with reference to this court but the inferior federal courts, the state courts and the text writers.

The learned authority on "Injunctions" (see Section 1329-a of the 4th Edition of High on Injunctions) states the doctrine as follows:

"Where relief is sought against the enforcement of an unconstitutional statute, either state or federal, the unconstitutionality of the law is not alone sufficient to justify the granting of the writ, but irreparable injury must also be alleged and clearly proven, or some other special circumstance must be shown which brings the case under some recognized head of equity jurisdiction. And where the plaintiff fails to make such a showing, the relief will be denied and he will be left to his remedy at law."

The court in the case of Bigelow vs. Hartford Bridge Co., 14 Conn. 565, held that a state of things from which the plaintiff apprehends injurious consequences to himself, but which neither actually exists nor is threatened by the defendants, nor is inevitable, is not a sufficient ground for an injunction. That "it is obviously not fit that the power of the court should be invoked in this form for every theoretical or speculative violation of one's rights."

And in the very well considered case of The People of the State of New York, complainants, vs. Canal Board of the State of New York, respondents, 55 N. Y. 391, the court said:

"It is not enough that the canal board is a public body composed of state officers, charged with important duties affecting the public, and that they may act in hostility to the public interests under a void law, or that the attorney-general is apprehensive that they may so act; if it is not made to appear that they are acting or threatening to act, that is, if a state of facts does not actually exist which calls for relief by injunction, it will not be granted. *** Injury, material and actual, not fanciful or theoretical, or merely possible, must be shown as the necessary or probable results of the action sought to be restrained."

It is equally fundamental that if a change of circumstances after the commencement of the suit relieves the defendant of the immediate injury, no temporary injunction should issue.

Behn vs. Young, 21 Ga. 207;

Foster's Federal Practice, Vol. 1, p. 751;

In Re Jackson, 9 Fed. 493;

In Re Pitts, 9 Fed. 542.

So also must the injunction be denied where defendant states that he has no intention of doing the acts in question, and there is not a substantial or a preponderance of the evidence which shows to the contrary.

Benton vs. Budd, 120 Cal. 329;

Lambert vs. Alcorn, 144 Ill. 313;

Whalen vs. Dalahsmutt, 59 Md. 250. 
This proposition was announced by the Illinois court notwithstanding four witnesses testified to an assertion of the defendant to the contrary.

\section{Lied vs. Henderson, 991 Ill. 282.}

The plain facts are that the court's opinion is based upon a wholly erroneous conception of the record in the case. The very basis of the granting of the temporary injunction is founded upon misconceptions. The court in its opinion (see page 33 of the transcript) falls into the first error when he states:

"The opinion of the attorney-general is based upon the proposition that the statute is ex post facto if either of the convictions was for an offense committed prior to the enactment of the statute."

And again the court mis-stated the opinion of the attorney-general when he states (pages 33 and 34 of the transcript):

"The attorney-general was in error when he advised the Board of Parole that the statute in question is void by reason of it being ex post facto, except only as to prisoners who have been twice convicted for felonies committed since the enactment of the statute."

The opinion of the attorney-general was based upon no such proposition, and the attorney-general gave no such opinion either official or unofficial, oral or in writing. Before this controversy arose and before any suit was instituted, the Board of Parole submitted to the attorney-general a request for an opinion as to whether the act in question applied to all persons in the penitentiary who had been twice convicted of a felony, and regardless of whether their convictions, that is to say, both convictions, were prior to the passage of the act, and it was in response to that request for an opinion that the attorney-general transmitted to the said Board of Parole an official opinion with reference to whether the act applied to all prisoners confined in the penal institutions of the state who were convicted prior to the taking effect of the act in which he said:

"The question is not free from difficulty. In this question is involved (a) the intention of the legislature, that is to say, whether or not the legislature intended the act to apply to persons confined or convicted prior to the taking effect of the act; and (b) if the legislature did so intend, is the act constitutional?

"Assuming then that the legislature intended the act to apply to persons convicted or sentenced prior to the taking effect of said act, the same would be unconstitutional as being ex post facto if it may be considered as a means of punishment or even if it contained directly an element of punishment. If, however, it is looked upon wholly as a sanitary and police measure in the interest of society at large, and directly in the interest of the possible offspring of the persons referred to in the act, then it would clearly not be unconstitutional." (Transcript, pages 26 and 2\%.)

The attorney-general then had under consideration whether the act contemplated the wholesale operation of every man in the penal institutions of the state who had been twice convicted of a felony, the convictions taking place prior to the passage of the act, and even then it was clearly pointed out that unless the act was punitive in its nature it would not be ex post facto assuming that both convictions were had prior to the passage of the act.

What the attorney-general held in that opinion was that the legislature never intended the law to apply to persons who were convicted prior to the passage of the act. Undoubtedly every one would concede the soundness of the opinion of the attorneygeneral, to-wit: That if the law applied to persons convicted prior to the passage of the act, both convictions I mean, and second that the act was punitive in its nature, it would be ex post facto. But as before stated, the attorney-general held that the law never contemplated that persons previously convicted should be subject to the provisions of the act in question.

Subsequently, however, and without further consultation with the attorney-general, the Board of Parole assumed that one conviction subsequent to the passage of the act would bring the prisoner under the purview of the statute and proceeded to make the order including the defendant herein. After the institution of the suit by the plaintiff in error, the Board of Parole then submitted to the attorney-general the question as to whether both convictions must be had subsequent to the passage of the act.

In response to that request, the attorneygeneral called attention to his first opinion that the legislature never intended the act to apply to persons convicted prior to the taking effect of the act, and that the precise question as to whether both convictions should be subsequent to the taking effect of the act was not then considered, and concluded as follows: 
"It will be noticed that the language used by the General Assembly is general in its nature, and after a careful consideration of the act, I am of the opinion that the act should be so construed as to require that both convictions of a felony must be subsequent to the passage of the act. This being true, and there now being no person confined in the penitentiary who has been twice convicted of felony since the passage of Chapter 187, Acts of the Thirty-fifth General Assembly, it follows that the order made by the Board of Parole designating Rudolph Davis and others should be cancelled and that no prisoner should be designated by the commission named upon whom the operation should be performed who has not been twice convicted of a felony subsequent to the passage of the act." (Exhibit B, Transcript pages 27-28.)

Read the copy of the official opinion which was the basis of the board's action in cancelling the orders, it being designated as Exhibit B and copied in full on pages 27 and 28 of the official transcript, and not a line or suggestion is made with reference to the act being ex post facto if the last conviction were had subsequent to the passage of the act.

The attorney-general was perfectly familiar with the well settled doctrine that one conviction subsequent to the passage of the act was sufficient to relieve the act in question of any objection upon the ground of being an ex post facto act. This question has been passed upon numberless times in those states having habitual criminal acts.

See Revised Laws, Mass., 1902, Vol. 2, Sec. 21, Chapter 220;

McDonald vs. Mass., 180 U. S. 311;

Graham vs. West Virginia, 224 U. S. 616.

There are some very well reasoned cases by the Massachusetts courts, but in the Massachusetts statutes it made it very clear that one conviction subsequent to the taking effect of the law would be sufficient and in the Massachusetts statutes it was also designated that a previous conviction in that or any other state, which was punished by a sentence in the penitentiary of a given time should satisfy the requirements of the act; whereas the Iowa statute is merely general in its terms, does not say whether the convictions must both be in Iowa, and this in addition to the fact, as before stated, that what is a penitentiary sentence in one state calls for only an insignificant punishment in another state, prompted the attorney-general to hold that the Iowa statute drawn in such general language, without any reference where the convictions should be had, should be construed as to require that both convictions should be subsequent to the passage of the act.

This construction is for the purpose of effectuating the intent of the legislature and not because of any supposed unconstitutionality of the act, it being well known that a more severe punishment is justified against one whose previous conduct is bad than against another whose previous conduct has been good.

If the court had taken the trouble to have read the opinions of the attorney-general, it would not have fallen into such grievous error.

The court was also in error in holding that there was no duty upon the administrative officers to follow the opinion of the attorney-general. The official opinion of the attorney-general, when called for by a state department and received upon a matter of official business, is binding until overruled by the court, the legislature or some other official manner.

The attorney-general of the State of lowa is a constitutional officer. (See Article V, Section 12 of the Code of Iowa.)

The powers of the several attorneysgeneral of the states are similar in their respective spheres to the powers of the attorney-general of the United States, and the duties and authority of the attorney-general of the United States and the attorneygeneral of each state are similar to the powers of the chief law officer of England, where the attorney-general is and has been from the time the memory of man runneth not to the contrary the chief law officer of the government.

\section{Am. \& Eng. Enc. of Law, page 475;}

Enc. Laws of England, Vol. 1, page 624;

4 Reeves Hist. Eng. Law, Chapter 26, page 151;

\section{People vs. Miner, 2 Lans., 396-398.}

In the case of the People vs. Miner, 2 Lans., 396 on page 399, the Supreme Court of New York held that the attorney-general has all "the powers belonging to the office at common law and such additional powers as the legislature has seen fit to confer upon him."

To the same effect see State ex rel Young vs. Robinson, 101 Minn. 277. 
Section 208, Supplemental Supplement, 1915, of the Code of Iowa, provides in part that "There shall be at the seat of government a department to be known as the department of justice, and the attorney-general shall be the head thereof."

Ard Section 208 provides in part that " $\mathrm{He}$ shall give his opinion in writing upon all questions of law submitted to him by the General Assembly, or either house thereof, the governor, lieutenant governor, speaker of the house *** and to the heads of any other state departments now existing or hereafter created."

Both as a matter of law and as a matter of custom, the state department of the several states and the departments of the federal government follow the opinions of the attorney-general until they are overruled by some superior authority.

We then have this situation: the attorneygeneral in an official opinion held that the law did not apply to the defendant in question or any person in the penitentiary, because neither the defendant nor any other person had been twice convicted of a felony subsequent to the passage of the act. The Board of Parole in a formal, official resolution cancelled their previous order and declared their intention of being governed by the official opinion of the attorney-general. In addition to that the warden who has actual charge of the penitentiary, and the prison physician, who would have personally directed the operation in the event that one was performed, both declared under oath that neither at the time nor at any time in the future would the operation be performed, and that the official opinion of the attorneygeneral would be followed, and the attorneygeneral on behalf of the state filed in court his resistance saying that no action either at the time or at any time in the future would ever be taken pursuant to the provisions of said act.

Considering then both the facts and the law, there was not one substantial reason for the court granting this temporary injunction. The court entirely misconceived the position taken by the attorney-general. There was no threatened injury, either present or prospective. As soon as the Board of Parole discovered they had wrongfully construed the statute, they immediately cancelled their order, the Board of Parole, the warden and the prison physician all announced in the most solemn manner that they would follow the opinion of the attorney-general and had no intention at the time or at any time in the future of performing said operation. And in spite of the fact that a temporary injunction or interlocutory decree is issued only for the purpose of holding matters in statu quo until there can be a hearing on the merits of the case, the court granted a temporary injunction.

In our dual form of government, and in view of the state and interstate nature of our commerce, in the very nature of things, this court and inferior federal courts must have authority to hold statutes unconstitutional, but as this court has said over and over again, this will never be done unless the statute is so clearly and palpably unconstitutional as to leave no reasonable doubt.

This court has zealously guarded the rights of the states but so great has been the abuse of the inferior federal courts that almost every important state statute covering fundamental reforms to meet industrial changes and additional abuses growing up under our modern civilization, has been held unconstitutional by some inferior federal court. It was because of this unwarranted usurpation of power that action was taken by the National Association of AttorneysGeneral looking toward congressional relief, and in response to this action congress passed an act forbidding the granting of an injunction against any state officer upon the ground of the unconstitutionality of a state statute unless three judges were sitting, one of whom must be an associate justice of the Supreme Court of the United States or a United States Circuit judge. (Act of Congress, June 18, 1910, Section 17.)

Section 266, 61st Congress, U. S. Statutes at Large, p. 1162.

Ex Parte Metropolitan Water Co., 220 U. S. 539.

The court therefore having erred in granting the temporary injunction, it is unnecessary to consider the constitutionality of the act in question upon its merits.

The state frankly admits that there is serious doubt as to the constitutionality of the act; however, since no act of a legislature should be stricken down as unconstitutional unless it is clearly so beyond all reasonable doubt, we contend that in any event the act was not so clearly unconstitutional as to warrant the court in striking it down as being in contravention of the fundamental law. Especially is this true on a hearing 
upon a temporary injunction. We, therefore, submit the following in support of the constitutionality of the act:

\section{PART II.}

It is the contention of the plaintiffs in error that the lower court erred in holding that the statute in question was unconstitutional, deciding that the statute was a Bill of Attainder, provided for the infliction of cruel and unusual punishment, and deprived persons of life, liberty or property without due process of law.

While there has been a great deal of discussion during the past few years in the newspapers and in legal, scientific and other periodicals concerning the subject of sterilization of criminals and defectives by vasectomy, the question of the constitutionality of statutes of this kind has not been passed upon by this court. The only reported decisions in which the matter has been judicially discussed are in the cases of:

State vs. Feilen, 70 Wash. 65; 126 Pac. Rep. 75;

Smith vs. Board of Examiners, 85 N. J. Law, 46; 88 Atl. Rep. 963.

The object of the performance of this operation is to prevent the procreation of criminals, defectives and other degenerates, and this is based upon the theory that criminality or weakness of mind is inheritable, and should be resorted to as a protection to society against the generation of moral degenerates and mental incompetents. If habitual criminality connotes inheritable degeneracy as claimed by the most eminent scientific and legal writers, vasectomy of habitual criminals should be upheld as a measure for the protection of society against the procreation of criminals and degenerates without regard to the aspect of punishment. In fact, the sterilization of criminals and degenerates by vasectomy is not a punishment at all inflicted upon the person subjected to the operation but is a measure resorted to for the protection of society.

The Supreme Court of the State of Washington, in the case of State vs. Feilen, 70 Wash., 65, 126 Pac. Rep. 75; 41 L. R. A. (N. S.) 418, in upholding the constitutionality of the statute of that state providing for the sterilization of criminals by means of vasectomy, says:

"On the theory that the modern scientific investigation shows that idiocy, insanity, imbecility and criminality are congenital and hereditary, the legislatures of California (Stat.
1909, p. 1093, Chap. 720), Connecticut (Pub. Laws 1909, Chap. 209), Indiana (Laws 1907, Chap. 215), Iowa (Laws 1911, Chap. 129), New Jersey (Laws 1911, Chap. 190), and perhaps other states, in the exercise of the police power, have enacted laws providing for the sterilization of idiots, insane, imbeciles and habitual criminals. In the enforcement of these statutes vasectomy seems to be a common operation. Dr. Clark Bell, in an article on hereditary criminality and the asexualization of criminals, found at page 134, Vol. 27, Medico-Legal Journal, quotes with approval the following language from an article contributed to Pearson's Magazine for November, 1909, by Warren W. Foster, senior judge of the Court of General Sessions of the Peace of the County of New York:

" "Vasectomy is known to the medical profession as "an office operation," painlessly performed in a few minutes, under an anesthetic (cocaine), through a skin cut half an inch long, and entailing no wound infection, no confinement to bed. "It is less serious than the extraction of a tooth," to quote from Dr. William D. Belfield, of Chicago, one of the pioneers in the movement for the sterilization of criminals by vasectomy, an opinion that finds ample corroboration among practitioners. ${ }^{* * *}$. There appears to be a wonderful unanimity of favoring opinion as to the advisability of the sterilization of criminals and the prevention of their further propagation. The Journal of American Medical Association recommends it, as does the Chicago Physicians' Club, the Southern District Medical Society, and the Chicago Society of Social Hygiene. The Chicago Evening Post, speaking of the Indiana law, says that it is one of the most important reforms before the people, that "rarely has a big thing come with so little fanfare of trumpets." The Chicago Tribune says that "the sterilization of defective and habitual criminals is a measure of social economy." The sterilization of convicts by vasectomy was actually performed for the first time in this country, so far as is known, in October, 1899 , by Dr. H. C. Sharp, of Indianapolis, then physician to the Indiana State Reformatory, at Jeffersonville, though the value of the operation for healing purposes had long been known. He continued to perform this operation with the consent of the convict (not by legislative authority) for some years. Influential physicians heard of his work, and 
were so favorably impressed with it that they indorsed the movement, which resulted in the passage of the law now upon the Indiana statute books. Dr. Sharp has this to say of this method of relief to society: "Vasectomy consists of ligating and resecting a small portion of the vas deferens. This operation is, indeed, very simple and easy to perform; I do it without administering an anesthetic, either general or local. It requires about three minutes' time to perform the operation, and the subject returns to his work immediately, suffers no inconvenience, and is in no way impaired for his pursuit of life, liberty and happiness, but is effectively sterilized." "

It is apparent from the reading of the foregoing opinion upon the constitutionality of the Washington statute that the sterilization of criminals by means of vasectomy is not a cruel punishment under our constitutional restriction, but is a measure for the protection of society and, is in fact, no punishment at all. The constitutional inhibition against cruel and unusual punishments has reference to those ancient, horrible, inhuman, and barbarous inflictions and punishments like the whipping post, the pillory, burning at the stake, breaking on the wheel, quartering the culprit, cutting off the nose, ears or limbs, or strangling the victim to death, and not to statutes enacted in these advanced days of civilization providing for the sterilization of habitual criminals and defectives by the painless operation of vasectomy in order to protect society against procreation of criminals and degenerates.

It is difficult to define with precision just what is meant, in a constitutional sense, by the words "cruel and unusual punishment." On this subject we respectfully call the court's attention to the following authorities:

O'Neill vs. Vermont, 144 U. S. 323;

In Re O'Shea, 11 Cal. App. 575; 105 Pac. 779;

Cooley, Const. Lim., 7th ed., pp. 471 et seq.;

State vs. McCauley, 15 Cal. 429;

Whitten vs. State, $47 \mathrm{Ga} .297$;

State vs. Williams, 77 Mo. 310;

Aldridge vs. Com., 4 Va. Cas. 447;

Wyatt's Case, 6 Rand. (Va.) 694;

In Re Kemmler, 136 U. S. 436, 444, 34 L. ed. 519, 523, 10 Sup. Ct. Rep. 930;

Wilkerson vs. UUtah, 99 U. S. $130,135,25$ L. ed. 345, 347;

Cooley, Const. Lim. 4th ed. 408;
Wharton, Crim. Law, 7th ed., Sec. 3405;

Hobbs vs. State, 133 Ind. 404; 18 L. R. A. $774 ; 32$ N. E. 1019 ;

Weems vs. United States, 217 U. S. 349, 54 L. ed. 450, 12 Sup. Ct. Rep. 693.

The trial court in deciding this cause on the application of the defendant in error (the complainant) for a temporary injunction held that the statute in question was a Bill of Attainder. In this the court was in error. A Bill of Attainder is a legislative act which inflicts punishment on a person without a judicial trial.

Cummings vs. State of Missouri, 71 U. S. 277 at 323.

Can it be said that the painless operation of vasectomy which is approved by the most eminent scientific and legal writers, is a punishment? It is, indeed, no punishment at all. It is simply a means resorted to, in the case of habitual criminals, idiots, lunatics and other defectives, as a measure for the protection of society against the procreation of moral delinquents and mental incompetents.

If then the statute in question is not properly considered punitive in its nature, but wholly in the interest of society, the defendant has not been deprived of any of his fundamental rights without due process of law. If the plaintiff in error considers the statute mischievous in its tendencies, the answer is made by this court in the case of Atkins vs. Kansas, 191 U. S. 223, wherein the court said:

"So, also, if it be said that a statute like the one before us is mischievous in its tendencies, the answer is that the responsibility therefor rests upon legislators, not upon the courts. No evils arising from such legislation could be more far-reaching than those that might come to our system of government if the judiciary, abandoning the sphere assigned to it by the fundamental law, should enter the domain of legislation, and upon grounds merely of justice or reason or wisdom annul statutes that had received the sanction of the people's representatives."

We submit that even on a permanent hearing the court would not be warranted in granting an injunction, but in view of the official opinion of the attorney-general, the sworn statement of the warden and prison physician, and the official action of the Board of Parole, no reasonable ground whatever existed for the granting of the temporary injunction. 
It was this very abuse in the granting of temporary injunctions which necessitated congressional action. It is significant to note that whereas it requires three judges to sit in considering the granting of a temporary injunction, two of whom must concur, one judge alone may hear the case upon its merits and grant a permanent injunction.

Seaboard Air Line Ry. vs. R. R. Com. of Ga., 213 Fed. 27 at 29.

In that case the court said: "There is no requirement in the Judicial Code, Section 266 , that three judges should hear the case when submitted for final decree on the pleadings and evidence. The three judges are only required to pass on the question of granting the interlocutory injunction."

The decision of the lower court should be reversed, the order granting the temporary injunction should be annulled and the temporary injunction dissolved.

Respectfully submitted, GEORGE COSSON,

Attorney-General of Iowa, For Plaintiffs in Error.

\section{ROSS R. MOWRY,} Of Counsel.

\section{b. Supplementary Brief.}

On December 24, 1916, the attorneygeneral of lowa filed the following stupplementary brief with the Supreme Court:

\section{c. Decision of the Supreme Court of the United States.}

IN THE SUPREME COURT OF THE UNITED STATES.

October Term, 1916.

$$
\text { No. } 47 \text {. }
$$

WILLIAM H. BERRY, JOHN E. HOWE, and D. C. MOTT, constituting the Board of Parole of Iowa, et al.,

Plaintiffs in Error. vs.

RUDOLPH DAVIS,

Defendant in Error.

\section{APPEAL FROM THE DISTRICT COURT OF THE UNITED STÁTES FOR THE SOUTHERN DIS- TRICT OF IOWA.}

SUPPLEMENTAL BRIEF ON BEHALF OF PLAINTIFF IN ERROR.

\section{STATEMENT OF THE CASE.}

On the 4th day of December, 1916, this court made an order directing attention to the fact that Chapter 19-B, Supplement to the Code, 1913, Section 2600-p, et seq., was repealed and re-enacted. See Chapter 19-B, Supplemental Supplement, 1915, 2600-s1 to 2600-s5, inclusive, page 238 of said Supplemental Supplement to the Iowa Code, 1915, and gave permission to the state to point out why the case in question should not be dismissed because of the repeal and re-enactment of the said act.

Speaking broadly and generally, the state is protesting and appealing against the wrongful granting of a temporary injunction, and the state's rights in this particular are not different because the statute has been repealed and re-enacted than though it had remained in precisely the same language as when the cause was heard and when the appeal was taken.

It should be kept clearly in mind that the state is not asking this court to pass upon the constitutionality of the statute in question which has been repealed and re-enacted. If it were so, to that extent the case would be a moot case; rather, the state is coming before this court insisting that inferior federal courts shall not indulge in moot and academic questions by passing upon the constitutionality of statutes when every right of complainant may be protected without passing upon the constitutionality of the law. Therefore the purpose of the appeal is first, to obtain relief from the wrongful granting of a temporary injunction; second, to reestablish the principle that state statutes are not to be stricken down as unconstitutional when complainant's rights may be fully protected without passing upon the constitutionality of the act; and, third, for the purpose of overruling an erroneous decision which, if it stands without reversal, may create untold mischief.

See Davis vs. Berry, 216 Fed., 413.

\section{ARGUMENT.}

The state contends that this case is governed by the doctrine announced in Southern Pacific Terminal Company vs. Interstate Commerce Commission and Young, $219 \mathrm{U}$. S., 498; and that of United States ys. TransMissouri Freight Association, 166 U. S., 290 at 308 , and cases therein cited and Boise City In. Co. vs. Clarke, 131 Fed. 415, rather than Richardson vs. McChesney, 218 U. S., 487, and Jones vs. Montague, 194 U. S., 147.

There is nothing better settled in the entire jurisprudence of this country than that a person is not entitled to ask that a court shall 
strike down as unconstitutional a statute, unless it is shown that he himself will be injured by the unconstitutional law. It is not only the doctrine of every state in the Union and every text writer, but the doctrine of this court.

This court in the case of Hooker vs. Burr, 194 U. S., 415, speaking through Mr. Justice Peckham, page 419, announced the doctrine as follows:

"We have lately held (therein following a long line of authorities) that a party insisting upon the invalidity of a statute, as violating any constitutional provision, must show that he may be injured by the unconstitutional law before the courts will listen to his complaint. Tyler vs. Judges, etc., 179 U. S., 405; Turpin vs. Lemon, 187 U. S., 51, 60. If, instead of showing any injury, the plaintiff shows that he cannot possibly be injured, he cannot, of course, ask the interference of the court."

And this court said in the comparatively recent case of McCabe vs. A., T. \& S. F. Ry. Co., 235 U. S., 151, that before an injunction would be granted, the complainant must show a personal need and an absence of adequate remedy at law, and "the fact that some one else, although of the same class as complainant, may be injured, does not justify granting the remedy."

And in that case it was held that colored men were not entitled to have the statute of Oklahoma held unconstitutional in the absence of a showing that they personally had been discriminated against because of the certainty that some other colored man would be discriminated against if the statute was permitted to remain as a valid act of the legislature of Oklahoma. The court, on page 164, said:

"The desire to obtain a sweeping injunction cannot be accepted as a substitute for compliance with the general rule that the complainant must present facts sufficient to show that his individual need requires the remedy for which he asks."

It is further a cardinal principle of constitutional law that a court will not pass upon a constitutional question if the case can be otherwise decided.

In the case of Light vs. United States, 220 U. S., 523, this principle is again affirmed and announced, the court refusing to pass upon the constitutional questions involved because unnecessary, and citing Siler vs. Louisville \& Nashville R. R., 213 U. S., 175.
We then have this situation: complainants in the court below filed a bill asking for certain relief. Defendants granted the relief in toto and made it absolutely certain that no possible injury would result to them. This being true, complainant's bill should have been dismissed and the court should have declined to have passed upon the constitutionality of the act. When the court, however, proceeded in spite of this fact to file an opinion upon the constitutionality of the act, they entered into an academic discussion which was not necessary in order to protect any rights of the complainants. The decision then of the inferior federal court became both academic and moot, and it is this very decision which the state is protesting against in this court. Instead of this appeal being dismissed as moot, the bill of the complainants should be dismissed as moot with costs. If the appeal is dismissed, then the erroneous decision, carelessly written, containing misstatements as to the record and fundamental errors of law, will stand as a precedent. For this reason a public question is involved and a public interest attaches to the decision in question.

We desire to repeat what we said in the main argument, not by way of criticism, but as a conservative statement of the fact, that almost every law looking toward social or moral reform, which has been passed by the several states in the Union in the last decade, has been held unconstitutional by some inferior federal or state court. This abuse by the federal courts, and the other inferior courts, had a far-reaching effect upon the thought of this country. This protest was manifest in several ways. The recall of the judiciary was demanded-indeed, not only demanded but incorporated in the constitution of at least six of the states of the Union.

See Constitution of Oregon, Art. II, Sec 18;

Constitution of California, Art. XXIII;

Constitution of Colorado, Art. XXI, and amendments to Art. VI, Sec. 1;

Constitution of Arizona, Art. VIII, Sec. 1;

Constitution of Nevada, Art. II, Sec. 9;

Constitution of Kansas, Art. IV, Sec. 3, 4 and 5 .

Ohio, however, and I think some other states incorporated into their constitution a much more practical remedy. Article IV of the Constitution of Ohio requires the concurrence of all but one of the seven judges of the Supreme Court of that state in order 
to hold a law of the state unconstitutional, except in affirming a judgment of the Court of Appeals holding a law invalid.

The National Association of AttorneysGeneral started an agitation which resulted in the act of congress which prohibited one United States judge from granting a temporary injunction upon the ground of the unconstitutionality of a state statute, and required that before such an injunction should issue, there must be three judges sitting, two of whom must concur and one of such judges must be an associate justice of the Supreme Court of the United States or a United States Circuit judge. Acts of Congress, June 18, 1910, Section 17. Section 266, 61st Congress, U. S. Statutes at Large, page 1162; Ex Parte Metropolitan Water Co., 220 U. S., 539.

It is perfectly elementary that an appeal may be had from the wrongful granting of a temporary injunction. It was the abuse of wrongfully granting temporary injunctions which congress sought to correct. It is this abuse incorporated in the form of an opinion entitled, Davis vs. Berry, and recorded in 216 Fed, pages 413-419, inclusive, which the state is insisting should be overruled so that it will not stand as a sign board pointing in a wrong direction to other judges of the United States and to state courts.

The case ceased to have any personal consideration from the very moment that the state offered to give the complainants in the court below full relief, but the state is vitally concerned with these two fundamental propositions: the constitutionality of an act should not be passed upon by either a federal or a state court unless the rights of the parties to the suit make it imperative.

Light vs. United States, 220 U. S., 523 at 538;

Silver vs. Louisville \& Nashville R. R., 213 U. S., 175;

Cyc. on Constitutional Law, Vol. 8, p. 98, Par. 3-b.

And no injunction shall be granted on the complaint of any one unless he himself will suffer injury.

McCabe vs. A., T. \& S. F. Ry. Co., 235 U. S., 151.

To dismiss the appeal would be to encourage inferior courts to go beyond the necessities of the case and render academic and moot decisions on constitutional questions. To sustain the appeal and dismiss complainants' original bill, or overrule the decision of the inferior court, will be in harmony with the jurisprudence of this and every civilized country of the world, and will be to discourage academic and moot discussions of constitutional law and place a check upon the abuse of power of inferior courts in exceeding the necessities of the case. It will likewise be in exact harmony with the act of congress previously referred to.

Let me again state that this is not a case where the state is asking this court to pass upon the constitutionality of a statute which has been repealed, but the state is asking that the decision recorded in the Federal $\mathbf{R e}$ porter wrongfully granting a temporary injunction should be overruled and the doctrine reaffirmed that no injunction shall be granted to a complainant, much less a temporary injunction, unless he shows that he himself will suffer injury in the absence of the granting of such an injunction, and that the constitutionality of an act shall not be passed upon unless the rights of the parties to the suit make it imperative.

We respectfully submit that the state's appeal should be sustained and that complainant's original bill should be dismissed with costs.

\section{GEORGE GOSSON, Attorney General of Iowa. For the Plaintiffs in Error.}

\section{DECISION OF THE SUPREME COURT OF THE UNITED STATES.}

(See U. S. Report, Vol. 242, pp. 468-470.) BERRY ET AL,, CONSTITUTING THE BOARD OF PAROLE OF IOWA, ET AL., VS. DAVIS. ${ }^{1}$

Appeal from the District Court of the United States for the Southern District of Iowa. No. 47.

Submitted October 26, 1916;

Decided January 15, 1917.

When injunctive relief against action by state officials granted in the court below becomes superfluous and the case moot

\footnotetext{
${ }^{1}$ On December 4, 1916, the Chief Justice made the following announcement:

"Attention is directed to the fact that the statute of Iowa of April 19, 1913, Supplement to Iowa Code, 1913, p. 1082, concerning which the appellee complained and the enforcement of which by the Board of Parole he sought by his suit to enjoin, has been repealed during the pendency of the case in this court (see Act of 1915 , Supplemental Supplement to Iowa Code, 1915, p. 238). In view of this fact permission is given the State through its Attorney-General on or before January 1, 1917, by printed brief to point out the reasons, if any, which exist why the appeal in this case should not be dismissed."
} 
because of subsequent state legislation passed while the case is here pending, this court will reverse and remand with directions to dismiss the bill without costs.

216 Fed. Rep. 413, reversed.

The case is stated in the opinion.

Mr. George Cosson, Attorney-General of the State of Iowa, and Mr. Ross R. Mowry, Assistant Attorney-General of the State of Iowa for appellants.

No appearance for appellee.

MR. JUSTICE HOLMES delivered the opinion of the court.

This is a bill to enjoin the State Board of Parole and the warden and physician of the state penitentiary at Fort Madison from performing vasectomy upon the plaintiff, the defendant in error, in pursuance of an Iowa statute approved April 19, 1913; 35 G. A., c. 187 , Sec. 1. Supplement to Code 1913, c. $19-\mathrm{B}$, Sec. $2600-$ p. This act among other things directed the operation to be performed upon convicts in the penitentiary who had been twice convicted of felony, and on February 14, 1914, the Board had ordered it, upon the ground that the plaintiff had been twice so convicted. The bill was filed on March 11, 1914. On April 15, 1914, following an opinion of the Attorney-General that both felonies must have been committed after the passage of the act, the order was laid on the table, and the warden and physician made affidavits, filed on April 22, that the operation would not be performed by them. Nevertheless, three judges, disregarding the foregoing opinion and action, proceeded to issue a preliminary injunction as prayed in the bill; 216 Fed. Rep. 413.

An appeal was taken to this court in 1914. In 1915 the Act of 1913 was repealed, and the substituted act does not apply to the plaintiff. Supplemental Supplement to the Code of Iowa, 1915, c. 19-B, Sec. 2600-s1. All possibility or threat of the operation has disappeared now, if not before, by the act of the State. Therefore, upon the precedents. we are not called upon to consider the propriety of the action of the District Court, but the proper course is to reverse the decree and remand the cause with directions that the bill be dismissed without costs to either party. United States vs. Hamburg-Amerikanische Packetfahrt-Actien Gesellschaft, 239 U. S. 466, 475, 478; Jones vs. Montague, 194 U. S. 147, 153; Dinsmore vs. Southern Express Co., 183 U. S. 115, 120; Mills vs. Green, 159 U. S. 651, 658.

Decree reversed. Bill to be dismissed without costs to either party. 


\section{CHAPTER VII. (Continued)}

PART IV. MICHIGAN.

1. Probate Court of Lapeer County.
a. Notice by Board of Control to Guardian.
b. Reply to Notice. 204
c. Petition of Superintendent..............................204
d. Order Denying Petition.................................. 205
e. Notice of Appeal................................... 205

2. Circuit Court of Lapeer County.

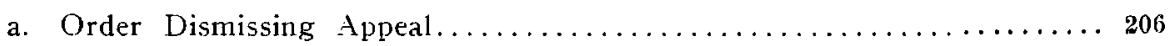

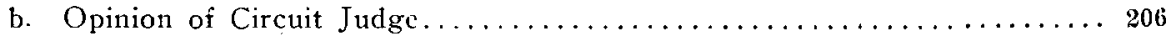

3. State Supreme Court.

a. Petition to Supreme Court......................... 207

b. Order of Supreme Court............................... 208

c. Return of Respondent.............................. 209

d. Brief of Attorney General as amicus curiae.................... 209

e. Decision of Supreme Court ...........................213 


\section{(IV.) MICHIGAN.}

(Act 34, April 1, 1913.)

The Michigan statute is applicable to the inmates (Sec. 1) "*** of any institution maintained wholly or in part at public expense, and who have been by a court of competent jurisdiction adjudged to be, and who are mentally defective or insane." The method of selecting such inmates for sterilization is as follows:

(Section 2) "*** The boards of the aforesaid institutions and the physicians and surgeons in charge of each of said institutions shall for each of their respective institutions constitute a board." This board examines such inmates "*** as are reported to them by the warden or medical superintendent to be persons by whom procreation would be inadvisable." "“* ** if in the judgment of the majority of said board procreation by any such person would produce children with inheritance of insanity, feeble-mindedness, idiocy, or imbecility ***, then said board shall direct a competent physician or surgeon *** to perform the operation ***"

There is a provision in the statute for notifying the parent or guardian of a person nominated for sterilization. The opinion of the legislators evidently was that, in case no objection is raised, the matter is one well within the administrative functions of its state institutions, and would not, in such cases, involve court procedure in order to effect due process of law.

This statute was tested in the case of Nora Reynolds, an inmate of the Michigan Home and Training School, at Lapeer. The final opinion was written by Mr. Justice Steere of the Supreme Court of Michigan, and filed March 28, 1918, the case having passed through the probate and circuit courts of Lapeer County, both of which had maintained the unconstitutionality of the act, on the ground of "class legislation," specifically denying the equal protection of the laws to feeble-minded persons within custodial institutions and within the population at large.

\section{THE PROBATE COURT OF LA- PEER COUNTY.}

May 4, 1916. The Probate Court of Lapeer County denied the petition of $\mathrm{H}$. A. Haynes, Superintendent of the Michigan Home and Training School to order the sterilization of Nora Reynolds, an inmate of said institution, on the ground that the Act of April 1, 1913, is "unconstitutional." In rendering this decision the court did not state whether the constitution of the State of Michigan or of the United States was violated, nor was the particular provision violated named.

The principal documents in the case follow:

a. Notice by the Board of Control of the Michigan Home and Training School to John Roach, guardian ad litem of Nora Reynolds, an inmate of said school. To:

\section{John Roach,}

Guardian or parents of Nora Reynolds, mentally defective, an inmate of the Michigan Home and Training School, at Lapeer, Michigan.

YOU WILL PLEASE TAKE NOTICE THAT, Whereas, it has been reported to the Board of Control of the said Michigan Home and Training School by the superintendent thereof that the said Nora Reynolds is a person by whom procreation would be inadvisable; and, whereas, upon report of experts and examination of the physical and mental condition of the said Nora Reynolds, together with her family history, in the judgment of the said Board of Control, procreation by the said Nora Reynolds would produce children with an inherited tendency to insanity, feeble-mindedness, idiocy or imbecility, and that there is no probability that the condition of the said Nora Reynolds will improve to such an extent as to render procreation by her advisable; therefore, it has been ordered by the said Board of Control that a surgical operation known as salpingectomy be performed upon the said Nora Reynolds by some competent surgeon employed for that purpose, at the hospital of the said Michigan Home and Training School at Lapeer, on the 7 th day of June, 1915, and that due notice of the time and place of such surgical operation be given to you at least thirty days before the performance of the same as provided by law. Said operation to be in accordance with Act No. 34 of the Public Acts of the State of Michigan for the year 1913. And that you are further notified that if you desire to make objection to the performance of the said operation of salpingectomy upon the said Nora Reynolds you are to file your objection with $\mathrm{H}$. A. Haynes, Medical Superintendent of the said Michigan Home and Training School at Lapeer, Michigan, on or before the day of the operation aforesaid.

Dated, Lapeer, May 13, 191.5. 
BOARD OF CONTROL OF THE MICHIGAN HOME AND TRAINING SCHOOL.

By Norman Flowers, President. By John S. Smith, Secretary.

b. The reply of John Roach, guardian ad litem of Nora Reynolds:

To:

THE BOARD OF CONTROL OF THE MICHIGAN HOME AND TRAINING SCHOOL.

Having been duly notified by the President and Secretary of the Board of Control of the Michigan Home and Training School that said Board of Control has ordered that a surgical operation known as salpingectomy be performed upon one Nora Reynolds, a mentally defective inmate of said institution on the rth day of June, 1915, and having been notified that the said operation would be performed in accordance with and under Act 34 of the Public Acts of the State of Michigan for the year 1913, I hereby, as guardian ad litem of the said Nora Reynolds, enter my objection to said operation for the following reasons to-wit:

1st. That it is unconstitutional in that it is in violation of Article VIII, Declaration of Rights, Constitution of the United States, which reads as follows:

"Excessive bail shall not be required nor excessive fines imposed, nor cruel or unusual punishment inflicted."

And also Article II, Section 15, Constitution of the State of Michigan, which reads as follows:

"Excessive bail shall not be required; excessive fines shall not be imposed; cruel and unusual punishment shall not be inflicted nor shall witnesses be unreasonably detained."

2d. That it is unconstitutional in that it is in violation of Article XIV, Section 1, Declaration of Rights, Constitution of the United States, which reads as follows:

"All persons born or naturalized in the United States and subject to the jurisdiction thereof, are citizens of the United States and of the State wherein they reside. No State shall make or enforce any law which shall abridge the privileges or immunities of citizens of the United States, nor shall any State deprive any person of life, liberty, or property without due process of law, nor deny to any person within its jurisdiction the equal protection of its laws."
And also in that it is in violation of Section 2, Article IV of the Constituton of the United States, which reads as follows:

"The citizens of each State shall be entitled to all privileges and immunities of citizens in the several States."

3d. That it is unconstitutional in that it is not only in violation of the above mentioned acts but it is in violation of the spirit of the Constitution both State and Federal, which extends to all citizens regardless of their imperfections, the equal protection of the law.

By JOHN ROACH,

Guardian ad litem of the above named Nora Reynolds.

c. Petition of Superintendent H. A. Haynes of the Michigan Home and Training School, to the Probate Court of Lapeer County:

\section{STATE OF MICHIGAN, THE PROBATE COURT FOR THE COUNTY OF LAPEER.}

\section{IN THE MATTER of Nora}

Reynolds, a Mentally Defective Inmate of The Michigan Home and Training School.

\section{I.}

Your petitioner, H. A. Haynes, respectfully represents that he resides in the City' of Lapeer, in said county, that he is interested in said matter and makes this petition as medical superintendent of the Michigan Home and Training School and for and in behalf of the Board of Control of the said Michigan Home and Training School.

\section{II.}

Your petitioner further represents that it has been reported to the Board of Control of said Michigan Home and Training School by the superintendent thereof that said Nora Reynolds is a person by whom procreation would be inadvisable and upon the report of experts and from the examination of the physical and mental condition of said Nora Reynolds together with her family history in the judgment of the said Board of Control procreation by the said Nora Reynolds would produce children with an inherent tendency to insanity, feeble-mindedness and idiocy or imbecility, and that there is no probability that the condition of the said Nora Reynolds will improve to such an extent as to render procreation by her advis- 
able, therefore, it has been ordered by the said Board of Control that a surgical operation known as salpingectomy be performed upon said Nora Reynolds by some competent surgeon employed for that purpose.

\section{III.}

Your petitioner further represents that upon the 23d day of April, 1915, John Roach of the City of Lapeer was duly appointed by the Probate Court of said County of Lapeer as guardian of said Nora Reynolds. IV.

Your petitioner further shows that the 7 th day of June, A. D. 1915, was the date fixed by the said Board of Control of the Michigan Home and Training School for said operation, and that thirty days before the time fixed for said operation notice was duly served upon John Roach, the guardian of said Nora Reynolds, at the City of Lapeer, in said County of Lapeer, a copy of which notice is hereto annexed and marked Exhibit "A," and that before the time fixed. in said notice for said operation, the said John Roach, as guardian of said Nora Reynolds, filed with the said Board of Control of the said Michigan Home and Training School written objections to the performance of said operation, a copy of said objections is hereto attached and marked Exhibit "B."

Your petitioner therefore prays that a time be fixed for hearing of this petition before the said Probate Court for the County of Lapeer as is provided in Section 2 of Act 34 of the Public Acts of the State of Michigan for 1913, and at such hearing this court shall determine the mental defectiveness or insanity of said Nora Reynolds and the necessity for said operation.

And your petitioner will ever pray.

\section{H. A. HAYNES.}

\section{d. Order of the Probate Court of Lapeer County Denying Petition.}

\section{STATE OF MICHIGAN, \\ THE PROBATE COURT FOR THE COUNTY OF LAPEER.}

At a session of said court, held at the Probate Office in the City of Lapeer, in said County, the 4th day of May, A. D. 1916.

Present, Hon. Daniel F. Zuhlke, Judge of Probate.

In the matter of Nora Reynolds, a mentally defective inmate of the Michigan Home and Training School.

H. A. Haynes, Medical Superintendent of the said Michigan Home and Training
School, having for and in behalf of the Board of Control of the said Michigan Home and Training School filed in said court his petition praying that a time be fixed for hearing of his said petition before said Probate Court for the County of Lapeer, as provided in Section 2 of Act No. 34 of the Public Acts of the State of Michigan for the year 1913, and that at such hearing this Court shall determine the mental defectiveness or insanity of the said Nora Reynolds, and the necessity for an operation as provided in said Act No. 34 of the Public Acts of 1913. After reading and considering said petition, this Court believing that the said Act No. 34 of the Public Acts of 1913 is unconstitutional, and this Court therefore refuses to hear said petition.

It is Ordered, That the prayer of said petition be denied and the said petition be and is hereby dismissed.

\section{[Seal] DANIEL F. ZUHLKE,}

\section{e. Notice of Appeal to Circuit Court:} STATE OF MICHIGAN, THE PROBATE COURT FOR THE
COUNTY OF LAPEER.

To the Probate Court for said County:

In the matter of Nora Reynolds, a mentally defective inmate of the Michigan Home and Training School.

I, H. A. Haynes, respectfully represent that $I$ reside in the City of Lapeer, in said County, and am interested in said matter as medical superintendent of the Michigan Home and Training School, acting for and in behalf of the Board of Control of said Michigan Home and Training School.

I further represent that I am aggrieved by the order of said court made on the 4th day of May, A. D. 1916, and I hereby give notice of an appeal to the Circuit Court for said County from the said order for the following reasons, viz:

1. That the said court erred in refusing to determine the mental defectiveness or insanity of Nora Reynolds, and the necessity for an operation as provided by Act 34 of the Public Acts of 1913.

2. That the court erred in refusing to hear the petition fled in accordance with Act 34 of the Public Acts of 1913.

3. That the court erred in denying the prayer of said petition and in dismissing the same. 
4. That the court erred in holding Act 34 of the Public Acts of 1913 unconstitutional.

5. That Act 34 of the Public Acts of 1913 violates no provision of the constitution of the United States.

6. That Act 34 of the Public Acts of 1913 violates no provision of the Constitution of the State of Michigan.

Dated this 19 th day of May, A. D. 1916.

\section{H. A. HAYNES,}

Medical Superintendent of the Michigan Home and Training School.

The appeal was duly allowed by Hon. Daniel F. Zuhlke, Judge of Probate, on May 20,1916 .

\section{CIRCUIT COURT OF LAPEER COUNTY.}

September 10, 1917, the Circuit Court of Lapeer County sustained the decision of the Probate Court, on the ground that the Act of April 1, 1913, is contrary to Section 1, Article XIV of the Constitution of the United States, and is class legislation.

\section{PRINCIPAL DOCUMENTS:}

a. Order of Circuit Court of Lapeer County dismissing the appeal from the Probate Court:

STATE OF MICHIGAN, THE CIRCUIT COURT OF THE COUNTY OF LAPEER.

In Re Nora Reynolds, a Men- ?

tally Defective Person.

At a session of said court held at the Court House, in the City of Lapeer, on the 10th day of September, 1917.

Present: Hon. William B. Williams, Circuit Judge.

In this cause an appeal was taken from an order of the Probate Court to the effect that Act 34 of the Public Acts of 1913 is unconstitutional. After due consideration of the briefs of counsel for the respective parties, it appearing to my satisfaction that said Act is unconstitutional in that it is in violation of Section 1 of Article XIV of the Constitution of the United States, and is class legislation, it is ordered that said appeal be, and the same is hereby dismissed, and the order of the Probate Court is affirmed, but without costs to either party.

WILLIAM B. WILLIAMS, Circuit Judge. b. Opinion of William B. Williams, Cir. cuit Judge:

STATE OF MICHIGAN,

THE CIRCUIT COURT FOR THE COUNTY OF LAPEER.

In Re Nora Reynolds, a Mentally Defective Person. OPINION.

This is a proceeding to test the constitutionality of Act 34, Public Acts of 1913. Nora Reynolds is an inmate of the Michigan Home and Training School. The Board of Control of said institution took the proper preliminary steps to determine whether the operation of salpingectomy should be performed on her, the object of said operation being to make it impossible for her to bear children.

On the hearing in the Probate Court, Act 34 was held unconstitutional, and an appeal was taken to the Circuit Court. I am of the opinion that the act in question is clearly in violation of Section 1 of Article XIV of the Declaration of Rights of the Constitution of the United States. That it is class legislation, and therefore, unconstitutional.

The object of the statute is clear and the result sought to be reached is much to be desired but the statute so limits the class of feeble-minded persons who may be brought within its provisions as to almost entirely subvert its object and make it clearly class legislation.

It will be observed that the Act is only applicable to that class of feeble-minded persons who are inmates of institutions maintained wholly or in part at public expense. The same reason obtains for sterilizing feeble-minded persons who are inmates of private institutions, and it is certainly more imperative for sterilization of feebleminded persons who are under no restraint in any institution, either public or private, yet this statute makes it a felony to sterilize such persons.

A similar statute has recently been held unconstitutional by the Supreme Court of New Jersey: Smith vs. Board of Examiners of Feeble-Minded, 88 Atl. 963. The rẹasons there given why the Act is unconstitutional seem to me so conclusive that I am content to base my conclusion on the reasoning of that case.

I have not considered the question whether the Act might be upheld as a proper police regulation if it applied to all feeble-minded persons. 
An order may be entered, therefore, dismissing the appeal, but without costs, thus affirming the order of the Probate Court.

WILLIAM B. WILLIAMS,

Circuit Judge.

\section{STATE SUPREME COURT.}

March 28, 1918, the State Supreme Court denied the writ of mandamus and sustained the decision of May 4, 1916, and of the Circuit Court of the same County of September 10, 1917, that the Act of April 1, 1913, is unconstitutional. (166 N. W. Rep, p. 938.)

\section{PRINCIPAL DOCUMENTS:}

a. Petition of Superintendent $H$. A. Haynes of the Michigan Home and Training School, to the Supreme Court of Michigan, to issue writ of mandamus commanding Circuit Judge William B. Williams to show cause why a peremptory mandamus should not be issued to compel said circuit judge to vacate the order mentioned in the petition and to try appeal upon its merits:

\section{STATE OF MICHIGAN.}

\section{Supreme Court.}

To the Honorable Supreme Court of the

State of Michigan:

Your petitioner, H. A. Haynes, respectfully shows that he is the medical superintendent of the Michigan Home and Training School, duly appointed and qualified as such.

\section{I.}

That Nora Reynolds is and has been for some years past an inmate of the Michigan Home and Training School, having been duly committed to that institution as a mentally defective person.

\section{II.}

That on the 23d day of April, A. D. 1915, John Roach of the City of Lapeer was appointed guardian of the said Nora Reynolds, and duly qualified as such.

\section{III.}

That, pursuant to the provisions of Act 34, of the Public Acts of 1913, it was made to appear to the Board of Control of the Michigan Home and Training School that the said Nora Reynolds was a person by whom procreation would not be advisable, and upon the report of experts and from an examination of the physical and mental condition of the said Nora Reynolds, together with her family history, in the judgment of the said Board of Control, procreation by the said Nora Reynolds would produce defective and feeble-minded children with an inherent tendency to feeble-mindedness, imbecility and insanity, and that there was no probability that the condition of the said Nora Reynolds would improve to such an extent as to render procreation by her advisable. Whereupon said Board of Control ordered that the surgical operation, known as salpingectomy, should be performed upon the said Nora Reynolds by some competent surgeon employed for that purpose, pursuant to the provisions of Act 34 of the Public Acts of 1913.

\section{IV.}

That on the 7th day of June, A. D. 1915, was the day fixed by the said Board of Control of the Michigan Home and Training School for the performance of said operation. and that thirty days prior to the time fixed for said operation notice was duly served on John Roach, the guardian of said Nora Reynolds, at the City of Lapeer, in the County of Lapeer, a copy of which notice is hereto annexed and marked "Exhibit A," and that before the time fixed in the said notice for said operation the said John Roach, as guardian of the said Nora Reynolds, filed with the said Board of Control of the Michigan Home and Training School written objections to the performance of said operation, a copy of which objections are hereto attached and marked "Exhibit B." Whereupon petitioner filed a petition in the Probate Court for the said County of Lapeer praying that the said court determine the mental defectiveness or insanity of the said Nora Reynolds, and the necessity for performing said operation, a copy of which petition being hereto attached and marked "Exhibit C."

\section{V.}

That afterwards, on the 22d day of July. A. D. 1915 , a hearing was had on said petition and an order made and entered by the said Probate Court dismissing said petition. a copy of said order being hereto attached and marked "Exhibit D."

\section{VI.}

That an appeal was duly made to the Circuit Court for the County of Lapeer from the said order dismissing said petition, a copy of the notice and reasons for the appeal. the order allowing said appeal and the proof of service of the same being hereto attached and marked "Exhibit E."

\section{VII.}

That afterwards, on the 16th day of June. A. D. 1916, John Roach, the guardian of the 
said Nora Reynolds, made and filed a motion in said court to dismiss said appeal, a true copy of said motion being hereto attached and marked "Exhibit F." That said motion was heard on the 10th day of September, A. D. $191 \%$, and an order entered by said court on the 10th day of September, A. D. 1917, dismissing said appeal, a true copy of said order being hereto attached and marked "Exhibit G." The reasons for making said order being set forth in the opinion of the court, a copy of which opinion is hereto attached and marked "Exhibit H."

\section{VIII.}

Your petitioner further shows that the Honorable William B. Williams is the circuit judge of said court and presided as such upon the hearing of said motion and made the order therein set forth, and in making the same committed error because:

(a) Act 34 of the Public Acts of 1913 is not unconstitutional.

(b) Act 34 of the Public Acts of 1913 is not class legislation.

Wherefore, your petitioner prays:

(a) That an order to show cause may be issued out of and under the seal of this honorable court directed to the said William B. Williams, circuit judge, requiring said William B. Williams, circuit judge, to show cause why a writ of mandamus should not issue out of this court commanding the said William $B$. Williams to vacate and set aside said order dismissing said appeal and to proceed with the hearing of said appeal upon the merits.

(b) Upon failure of said William B. Williams, circuit judge, to show cause satisfactorily to this court that the said order dismissing said appeal should not be vacated and set aside, that a peremptory writ of mandamus issue out of this court directed to the said William B. Williams, circuit judge, commanding the said William B. Williams to vacate and set aside said order dismissing said appeal and proceed to the hearing of said appeal upon the merits.

And your petitioner will ever pray.

\section{H. A. HAYNES.}

\section{STATE OF MICHIGAN,}

County of Lapeer, ss:

On the 29th day of September, 1917, personally appeared the above named petitioner and made oath that he has read the foregoing petition and knows the contents thereof and that the same is true of his own knowledge except as to those matters therein stated to be on information and belief and as to those matters he believes it to be true.

HARRY S. EVANS,

Notary Public Lapeer County, Mich. [Seal] Commission expires April 9, 1919.

b. Order of Supreme Court commanding Circuit Judge William B. Williams to show cause why a peremptory mandamus should not be issued to compel said circuit judge to vacate the order mentioned in the appeal and try the case upon its merits.

\section{THE SUPREME COURT OF THE} STATE OF MICHIGAN.

At a session of the Supreme Court of the State of Michigan, held at the Supreme Court Room, in the Capitol, in the City of Lansing, on the 4th day of October, in the year of our Lord one thousand nine hundred and seventeen.

Present:

The Hon. Franz C. Kuhn, Chief Justice;

John W. Stone,

Russell C. Ostrander,

John E. Bird,

Joseph B. Moore,

Joseph H. Steere,

Flavius L. Brooke,

Grant Fellows,

Associate Justices.

H. A. HAYNES, Superintendent of the Michigan Home and Training School,

$\left.\begin{array}{rrr} & \text { Relator: } \\ \text { WILLIAM } & \text { Bs. } & \text { WILLIAMS, } \\ \text { Circuit Judge, } & \text { Ro. } 28151 . \\ & \text { Respondent. }\end{array}\right\}$

On the reading and filing the petition and accompanying affidavits of relator above named and on motion of Alex J. Groesbeck, Attorney-General, and Clare Retan and L. W. Carr, Assistant Attorneys-General, attorneys for relator, ordered that said respondent, said William B. Williams, circuit judge, do show cause to this court on the $23 \mathrm{~d}$ day of October, 1917 , why a peremptory mandamus should not be issued out of and under the seal of this court to compel him, the said William B. Williams, circuit judge, to vacate and set aside the order referred to in said petition, whereby he, the said William B. Williams, dismissed relator's appeal from an order of the Probate Court of the County of Lapeer, in the matter of Nora Reynolds, 
a mentally defective inmate of the Michigan Home and Training School, and to proceed to hear said appeal upon the merits.

And it is further ordered that a certified copy of this order together with a copy of the petition and, affidavits aforesaid and upon which this order is founded be served upon the said respondent at least ten days before the time herein limited for showing cause.

\section{STATE OF MICHIGAN, ss:}

I, Jay Mertz, Clerk of the Supreme Court of the State of Michigan, do hereby certify that the foregoing is a true and correct copy of an order entered in said Court in said cause; that I have compared the same with the original, and that it is a true transcript therefrom, and the whole of said original order.

In Testimony Whereof, I have hereunto set my hand and affixed the seal of said Supreme Court at

[Seal.] Lansing, this fourth day of October, in the year of our Lord one thousand nine hundred and seventeen.

\section{JAY MERTZ,}

Clerk.

\section{c. Return of Respondent.}

SUPREME COURT. STATE OF MICHIGAN,

\section{Supreme Court.}

H. A. HAYNES, Superintendent of the Michigan Home and Training School, s.

WILLIAM B. WILLIAMS, Circuit Judge, Respondent.)

\section{RETURN OF RESPONDENT TO ORDER TO SHOW CAUSE.}

Answer of the above named respondent to the order to show cause heretofore issued in said cause and to the petition of the relator on which said order was based, respectively, shows to this honorable court:

\section{I.}

The allegations of paragraph one of the petition are admitted.

\section{II.}

The allegations of paragraph two of the petition are admitted.
III.

The allegations of paragraph three of the petition are admitted.

IV.

The allegations of paragraph four of the petition are admitted.

$\mathrm{V}$.

The allegations of paragraph five of the petition are admitted.

VI.

The allegations of paragraph six of the petition are admitted.

VII.

The allegations of paragraph seven of the petition are admitted.

\section{VIII.}

Answering paragraph eight respondent admits that he is circuit judge and presided as such upon the hearing of said motion and made the order therein set forth, but denies that he committed error in making the same, for the reasons set forth by the relator in said paragraph eight.

IX.

Respondent denies that the relator is entitled to the writ of mandamus as prayed for, and therefore asks that this petition be dismissed.

WILLIAM B. WILLIAMS, Circuit Judge.

\section{STATE OF MICHIGAN,}

County of Lapeer, ss:

On the 6th day of October, 1917, personally appeared the above named respondent, William B. Williams, Circuit Judge, and made oath that he has read the foregoing answer and knows the contents thereof and that the same is true of his own knowledge except as to those matters therein stated to be on information and belief and as to those matters he believes it to be true.

THERESA B. BUTTS,

Notary Public, Lapeer Co., Mich. My commission expires Sept. 12, 1918.

\section{d. Brief of Attorney-General as Amicus Curiae.}

Statement of facts.

Preliminary statement.

SPECIFICATION OF ERROR.

The court erred in holding that Act No. 34 of the Public Acts of 1913 is in violation of Section 1 of Article XIV of the Declaration of Rights of the Constitution of the United States of America. 


\section{ARGUMENT.}

The only case we have been able to discover which is in point with the case at bar is Smith vs. Board of Examiners of FeebleMinded, 88 Atl. 963. The facts in that case are as follows:

The Board of Examiners of FeebleMinded of the State of New Jersey ordered an effective operation for the prevention of procreation to be performed upon one Alice Smith. This order was made by virtue of the authority conferred upon said Board by provisions of P. L. of 1911, page 353. The title and pertinent parts of said statute read as follows:

"An act to authorize and provide for the sterilization of feeble-minded (including idiots, imbeciles and morons), epileptics, rapists, certain criminals and other defectives.

"Whereas, heredity plays a most important part in the transmission of feeble-mindedness, epilepsy, criminal tendencies and other defects:

"Be it enacted by the Senate General Assembly of the State of New Jersey:

"1. Immediately after the passage of this act, the Governor shall appoint by and with the advice of the Senate, a surgeon and a neurologist, each of recognized ability, one for a term of three (3) years and one for a term of five (5) years, their successors each to be appointed for the full term of five years, who in conjunction with the commissioner of charities and corrections shall be known as and is hereby created the 'Board of Examiners of Feeble-Minded (including idiots, imbeciles and morons), Epileptics, Criminals and other Defectives,' whose duty it shall be to examine into the mental and physical condition of the feeble-minded, epileptic, certain criminal and other defective inmates confined in the several reformatories, charitable and penal institutions in the counties and state.

"2. The criminals who shall come within the operation of this law shall be those who have been convicted of the crime of rape, or of such succession of offenses against the criminal law as in the opinion of this Board of Examiners shall be deemed to be sufficient evidence of confirmed criminal tendencies.

3. Upon application of the superintendent or other administrative officer of any institution in which such inmates are or may be confined, or upon its own motion, the said Board of Examiners may call a meeting to take evidence and examine into the mental and physical condition of such inmates confined as aforesaid, and if said Board of Examiners, in conjunction with the chief physician of the institution, unanimously find that procreation is inadvisable, and that there is no probability that the condition of the inmate so examined shall improve to such an extent as to render procreation by such inmate advisable, it shall be lawful to perform such operation for the prevention of procreation as shall be decided by said Board of Examiners to be most effective, and thereupon it shall and may be lawful for any surgeon qualified under the laws of this state, under the direction of the chief physician of said institution, to perform such operation."

From the order of said board Alice Smith brought certiorari. It was urged upon the part of the State that the act in question was a valid exercise of the police power of the State. On behalf of the plaintiff it was urged that the act was in violation of the Fourteenth Amendment to the Constitution of the United States. The court sustained defendant's contention, saying:

"This (police) power, stated as broadly as the argument in support of the order requires, is the exercise by the Legislature of a state of its inherent sovereignty to enact and enforce whatever regulations are in its judgment demanded for the welfare of society at large in order to secure or to guard its order, safety, health or morals. The general limitation of such power to which the prosecutrix must appeal is that under our system of government the artificial enhancement of the public welfare by the forceable suppression of the constitutional rights of the individual is admissible.

"Somewhere between these two fundamental propositions the exercise of the police power in the present cause must fall, and its assignment to the former rather than to the latter involves consequences of the greatest magnitude. For while the case in hand raises the very important and novel question whether it is one of the attributes of government to essay the theoretical improvement of society by destroying the function of procreation in certain of its members who are not malefactors against its laws, it is evident that the decision of that question carries with it certain logical consequences, having farreaching results. For the feeble-minded and epileptics are not the only persons in the community whose elimination as undesirable 
citizens would, or might in the judgment of the Legislature, be a distinct benefit to society. If the enforced sterility of this class be a legitimate exercise of governmental power, a wide field of legislative activity and duty is thrown open to which it would be difficult to assign a legal limit.

"If in the present case we decide that such a power exists in the case of epileptics, the doctrine we shall have enunciated cannot stop there. For epilepsy is not the only disease by which the welfare of society at large is injuriously affected, indeed, not being communicable by contagion or otherwise, it lacks some of the gravest dangers that attend upon such diseases as pulmonary consumption or communicable syphilis. So that it would seem to be a logical necessity that, if the Legislature may, under the police power, theoretically benefit the next generation by the sterilization of the epileptics of this, it both may and should pursue the like course with respect to the other diseases mentioned, with the additional gain to society thereby arising from the protection of the present generation from contagion or contamination. When these and many other diseases that might be named have been included, the limits of logical necessity have, by no means, been reached.

"There are other things besides physical or mental diseases that may render persons undesirable citizens, or might do so in the opinion of a majority of a prevailing Legislature. Racial differences, for instance, might afford a basis for such an opinion in communities where that question is unfortunately a permanent and paramount issue. Even beyond all such considerations it might be logically consistent to bring the philosophic theory of Malthus to bear upon the police power to the end that the tendency of population to outgrow its means of subsistence should be counteracted by surgical interference of the sort we are now considering.

"Evidently the late and underlying question is, how far is government constitutionally justified in the theoretical betterment of society by means of the surgical sterilization of certain of its unoffending but undesirable members? If some, but by no means all, of these illustrations are fanciful, they still serve their purpose of indicating why we place the decision of the present case upon a ground that has no such logical results or untoward consequences.
"Such a ground is presented by the classification upon which the present statute is based, which is of such a nature that the persons included within it are not afforded the equal protection of the laws under the Fourteenth Amendment of the Constitution of the United States, which provides that 'no state shall deny to any persons within its jurisdiction the equal protection of the laws.' Under this provision it has been uniformly held that a state statute that bears solely upon a class of persons selected by it must not only bear alike upon all the individuals of such class, but that the class as a whole must bear some reasonable relation to the legislation thus solely affecting the individuals that compose it.

"'It is apparent,' said Mr. Justice Brewer in Gulf, Colorado, etc., R. Y. Co. vs. Ellis, 165 U. S. 150, 17 Sup. Ct. 255, 41 L. Ed. 666, aifter a review of many cases, 'that the mere fact of a classification is not sufficient to relieve a statute from the reach of the equality clause of the Fourteenth Amendment, and that in all cases it must appear, not only that a classification has been made, but also that it is one based upon some reasonable ground-some difference which bears a just and proper relation to the attempted classification-and is not a mere arbitrary selection.'

"This summarizes a mass of cases that might be cited.

"Turning our attention now to the classification on which the present statute is based, and laying aside criminals and persons confined in penal institutions with which we have no present concern, it will be seen that -as to epileptics, with which alone we have to do-the force of the statute falls wholly upon such epileptics as are inmates confined in the several charitable institutions in the counties and state.' It must be apparent that the class thus selected is singularly narrow when the broad purpose of the statute and the avowed object sought to be accomplished by it are considered. The objection, however, is not that the class is small as compared with the magnitude of the purpose in view, which is nothing less than the artificial improvement of society at large, but that it is singularly inept for the accomplishment of that purpose in this respect, viz., that if such object requires the sterilization of the class so selected, then a fortiorari does it require the sterilization of the vastly greater class who are not pro- 
tected from procreation by their confinement in state or county institutions.

"The broad class to which the legislative remedy is normally applicable is that of epileptics, i. e., all epileptics. Now, epilepsy is not, as some authorities contend, mainly a disease of the well to do and overfed, but is at least one that affects all ranks of society, the rich as well as the poor. If it be conceded, for the sake of argument, that the Legislature may select one of these broadly defined classes, i. e., the poor-and may legislate solely with reference to this class, it is evident that, by the further subclassification of the poor into those who are and those who are not inmates of public charitable institutions, a principle of selection is adopted that bears no reasonable relation to the proposed scheme for the artificial betterment of society. For not only will society at large be just as injuriously affected by the procreation of epileptics who are not confined in such institutions as it will be by the procreation of epileptics who are so confined, but the former vastly outnumber the latter, and are in the nature of things, vastly more exposed to the temptation and opportunity of procreation, which indeed in cases of those confined in a presumably wellconducted institution is reduced practically to nil.

"The particular vice, therefore, of the present classification is not so much that it creates subclassification, based upon no reasonable basis, as that having thereby arbitrarily created two classes, it applies the statutory remedy to that one of those classes to which it has the least and in no event sole application and to which, indeed, upont the presumption of the proper management of our public institutions it has no application at all. When we consider that such statutory scheme necessarily involves a suppression of personal liberty and a possible menace to the life of the individual who must submit to it, it is not asking too much that an artificial regulation of society that involves these constitutional rights of some of its members shall be accomplished, if at all, by a statute that does not deny to the persons injuriously affected the equal protection of the laws guaranteed by the Federal Constitution ***.

"The conclusion we have reached is that without regard to the power of the state to. subject its citizens to surgical questions that shall render procreation by them impossible, the present statute is invalid, in that it denies the prosecutrix of this writ the equal protection of the laws to which under the Constitution of the United States, she is entitled."

The State vs. Feilen, $126 \mathrm{~Pa}$. 75, 4 L. R. A. (N. S.) 419. Plaintiff was prosecuted under Section 2436 of Rem. and Bal. Code and properly convicted. The trial court ordered that the operation of vasectomy be performed upon plaintiff under the authority of Section 2287 Rem. and Bal. Code.

Plaintiff contended that the performance of this operation was cruel and unusual punishment, and that this section of the code authorizing said operation was unconstitutional. The court held that the performance of the operation of vasectomy for the punishment of crime was not a cruel and unusual punishment, and the statute in question was a valid one.

In Davis vs. Berry, 216 Fed. 413, the court had under consideration a statute of Iowa which authorizes the performance of the operation of vasectomy on persons twice convicted of a felony. The court held the statute unconstitutional on the ground that it amounted to a denial of due process of law to the person convicted of one of the class of crimes for which the operation was performed as a penalty, the statute in question making no provision for a judicial determination of the identity of the person affected. The court discussed at length the proposition whether or not the performance of such an operation for the punishment of crime is cruel and unusual punishment, and it is clearly apparent from reading the opinion that no doubt existed in the mind of the court but that the performance of such an operation as this for the punishment of crime was cruel and unusual punishment.

Davis vs. Berry and State vs. Fei'en, supra, can, of course, be distinguished from the case at bar, the question involved in those cases being whether or not the performance of the operation of vasectomy for a crime amounted to cruel and unusual punishment while in the instant case the operation is not performed as a part of the penalty inflicted for the punishment of a crime.

The foregoing are all the cases we have been able to discover involving statutes authorizing the performance of the operations of salpingectomy or vasectomy either as a punishment for crime or for the purpose of preventing procreation by that class of persons whose condition is such that the legislature deems procreation by them inadvisable. 
ALEX. J. GROESBECK, Attorney-General;

CLARE RETAN, Assistant Attorney-General;

L. W. CARR, Assistant Attorney-General.

3. March 28, 1918. The Supreme Court of Michigan sustained the decision of the Probate Court of Lapeer County of May 4, 1916, and the Circuit Court of the same county of September 10, 1917, that the Act of April 1, 1913, is unconstitutional because it violates the constitutional guarantee of equal protection under the laws, and is class legislation.

\section{e. Decision of the Supreme Court:}

\section{STATE OF MICHIGAN.}

\section{H. A. HAYNES, Superintend-} ent of Michigan Home \& Training School,

$$
\text { Plaintiff (or Relator). }
$$
vs.

$\left.\begin{array}{rrr}\text { WILLIAM } & \text { B. } & \text { WILLIAMS, } \\ \text { Circuit Judge, } & \\ & \text { Defendant } \\ \text { (and Respondent). }\end{array}\right\} 1918$.

BEFORE: The Full Bench, except Fellows, J.

Steere, J.:

In this proceeding by mandamus plaintiff seeks review and reversal of an order of the Circuit Court of Lapeer County sustaining an order of the Probate Judge of that county refusing to entertain jurisdiction on plaintiff's petition for a hearing in the Probate Court to determine the question of sanity of an alleged incompetent named Nora Reynolds, confined in the Michigan Home and Training School at Lapeer, in said county, and the necessity of performing upon her the operation of salpingectomy "as in other insane cases before such courts," under the provisions of Act No. 34 of the Public Acts of 1913.

The Probate Court dismissed said petition and on appeal the Circuit Court sustained the order of dismissal on the ground that said act is unconstitutional.

The statute in question is entitled, "An Act to authorize the sterilization of mentally defective persons maintained wholly or in part by public expense in public institutions of this state and to provide a penalty for the unauthorized use of the operations provided therefor."
The operations provided for in the act are (on the male) vasectomy and (on the female) salpingectomy, "or any other operation or improvement on vasectomy or salpingectomy recognized by the medical profession, as the case may be, upon such person."

By Section 5 of the act, except as authorized therein, such operations "unless the same shall be a medical necessity," are made a felony punishable by five years' imprisonment in the state prison or a fine not to exceed one thousand dollars, or both in the discretion of the court.

Briefly summarized this act authorizes the management of any publicly maintained institution of the state authorized to hold in custody individuals who have been adjudicated by a court of competent jurisdiction mentally defective or insane, to render incapable of procreation by the operations mentioned inmates determined to be proper subjects for such treatment. The state boards and physicians and surgeons in charge of each of said institutions are constituted a special board with authority to examine such inmates as are reported by the warden, or medical superintendent, to be persons by whom procreation would be inadvisable and upon the report of insanity experts examine into the physical and mental condition of such persons, etc., determine the advisability of such operation upon them. At least 30 days' notice of the proceeding must be given the parent or guardian of such mentally defective person before performing the operation, such notice specifying the purpose, time and place of such examination. If the parent or guardian object, the matter must be referred to the Probate Court of the county in which the institution is located, which is then required to determine as in other cases the question of sanity and necessity of the operation. When authorized the operation is to be performed either by the physician of the institution or an expert employed by the board for that purpose after a report has been secured from two qualified physicians that such operation is desirable in the interest of the patient or the good of the community. A record, not for public inspection, is required to be made in relation to each individual so operated upon and filed with the State Board of Public Health.

Acting under the provisions of this act the Board of Control of the Michigan Home and Training School and plaintiff, its medical superintendent, as a special board for 
that purpose, took the proper steps and made the requisite determination for performing the operation of salpingectomy upon said Nora Reynolds. Notice of such proceedings was served upon John Roach, her guardian, who interposed written objections contending that the act was unconstitutional and void on various grounds. Petition was thereupon filed in the Probate Court by plaintiff as superintendent of said institution asking that the sanity of said inmate and necessity for the proposed operation be there determined, with the result already stated.

As appears by return to the order to show cause issued from this court the learned Circuit Judge, in an opinion sustaining the refusal of the Probate Court to take jurisdiction, expressed the view that the results sought to be reached by the act were commendable and to be desired but as framed and enacted it "so limits the class of feebleminded persons who may be brought within its provisions as to almost entirely subvert its object and make it clearly class legislation," and therefore unconstitutional.

The only brief filed or argument offered in this proceeding is by the Attorney-General as amicus curiae, apparently conceding the unconstitutionality of the act and concurring in the views expressed by the Circuit Judge that the validity of the legislation cannot be sustained in its present form because of the narrow and arbitrary classification adopted.

The only question argued or raised in this proceeding against the validity of the law being that it is capricious and discriminating class legislation, there is no occasion to dwell or pass upon any suggested underlying medico-legal questions to which the indicated purpose of the law points and which within constitutional limits are for legislative rather than judicial consideration. That line of inquiry in the field of forensic medicine has only incidental relation to the question here involved.

It is elementary that legislation which, in carrying out a public purpose for the common good, is limited by reasonable and justifiable differentiation to a distinct type or class of persons is not for that reason unconstitutional, because class legislation if germane to the object of the enactment and made uniform in its operation upon all persons of the class to which it naturally applies; but if it fails to include and affect alike all persons of the same class, and extends immunities or privileges to one portion and denies them to others of like kind, by unreasonable or arbitrary sub-classification, it comes within the constitutional prohibition against class legislation. For the purpose of this case we need go no further into the subject of class legislation than to point out this distinction. For an -able amplification of the topic, with abundant citation of sustaining cases, reference may be made to Vol. 6 of Ruling Case Law, subpage 373 et seq.

Plainly stated, the manifest purpose and only justification for this legislation is to promote, under the police power of the state, the general welfare of the human race by a step in the line of selective breeding to be effected through sterilization of those found and adjudicated by a designated tribunal to be hopelessly insane and mentally defective to such an extent that, in connection with their personal record and family history, procreation by such persons is inadvisable and inimical to public welfare.

Conceding, for the purpose of this inquiry, that such legislation is a proper governmental function and within the police power of the state, the question naturally ariseswhat logical connection with the object sought by this enactment has a classification which carves a class out of a class and applies the proposed curative treatment, which it is found the public weal demands and justifies, only to those of the type requiring such exclusive legislation who, by reason of their sequestration under public control, are presumably helpless to work upon those now in being or posterity the mischief which the law is framed to eliminate?

"The legislature cannot take what might be termed a natural class of persons, split the same in two and then designate the dissevered factions of the original unit as two classes, and thereupon enact different rules for the government of each."-6 R. C. L., p. 383.

In this enactment the legislature selected out of what might be termed a natural class of defective and incompetent persons only those already under public restraint, leaving immune from its operation all others of like kind to whom the reason for the legislative remedy is normally and equally, at least, applicable, extending immunities and privileges to the latter which are denied to the former.

While legislation is to be found in a few other jurisdictions providing for sterilization 
of designated abnormal classes by whom procreation is deemed inadvisable, either because mentally defective or of certain confirmed criminal tendencies, but two cases are cited or found where the subject has been before a court of last resort.

In State v. Feilen, 126 Pac. Reporter, 75 (41 L. R. A. [N.S.] 419), defendant was convicted in a trial court of the state of Washington of statutory rape upon a female child and sentenced under authorizing statutes of that state to imprisonment in the penitentiary for life, and in addition thereto that the operation of vasectomy, for prevention of procreation, be performed upon him by some qualified and capable surgeon, "carefully and scientifically" under procurement by the Warden of the penitentiary. The constitutionality of the statute authorizing this portion of the sentence was attacked on the ground that it provided for cruel and unusual punishment. In a carefully considered review of the subject the Court reached the conclusion that such operation when properly performed involved little pain and danger, was not of that class of "severe, cruel and unusual punishments as disgraced the civilization of former ages," and declined to hold the law unconstitutional.

That case, while illuminating in some respects, involved primarily a question foreign to the issue before us, and is of but remote application, for under the statute involved here the proposed operation is not provided as a penalty in punishment of crime.

A sterilization law was enacted in the state of New Jersey in 1911, to which our act (No. 34 of 1913) is analogous in purpose and similar in various provisions, although that law extends the scope of its provided curative treatment to convicted rapists and other criminals convicted of such a succession of crimes as in the opinion of the authorized determining board are found stamped with confirmed criminal tendencies. It was entitled "An act to authorize and provide for the sterilization of feeble-minded (including idiots, imbeciles and morons), epileptics, rapists, certain criminals and other defectives." As particularly in point here, its operation was confined to inmates of the "several reformatories, charitable and penal institutions in the various counties and state." The constitutionality of the law was attacked on various grounds in a case involving the proposed operation of salpingectomy on an epileptic female named Alice Smith, an inmate of one of the designated institutions, found by the board to be permanently so afflicted that procreation by her was inadvisable. The court of last resort in that state held the law unconstitutional for the same reason urged in this inquiry. Smith v. Board of Examiners of Feeble-Minded, 88 At1. 963. Passing by certain reflections and moot suggestions in that case which need not be endorsed or considered for the purpose of the question before us, the following clearly stated reasons for holding the law invalid as discriminating class legislation are well in point.

"It must be apparent that the class thus selected is singularly narrow when the broad purpose of the statute and the avowed object sought to be accomplished by it are considered. The objection, however, is not that the class is small as compared with the magnitude of the purpose in view, which is nothing less than the artificial improvement of society at large, but that it is singularly inept for the accomplishment of that purpose in this respect, viz., that if such object requires the sterilization of the class so selected, then a fortiorari does it require the sterilization of the vastly greater class who are not protected from procreation by their confinement in state or county institutions. The broad class to which the legislative remedy is normally applicable is that of epileptics, i. e., all epileptics. *** If it be conceded, for the sake of argument, that the legislature may select one of these broadly defined classes-i. e., the poor-and may legislate solely with reference to this class, it is evident that, by the further sub-classification of the poor into those who are and those who are not inmates in public charitable institutions, a principle of selection is adopted that bears no reasonable relation to the proposed scheme for the artificial betterment of society. For not only will society at large be just as injuriously affected by the procreation of epileptics who are not confined in such institutions as it will be by the procreation of those who are so confined, but the former vastly outnumber the latter, and are, in the nature of things, vastly more exposed to the temptation and opportunity of procreation, which indeed in cases of those confined in a presumably well conducted public institution is reduced practically to nil."

For the foregoing reasons we are constrained to concur in the opinion of the learned Circuit Judge that this law as framed does not afford, in its scope, those affected by it that equal protection under the laws guaranteed by the constitution, and so limits the class of defectives covered by its provisions as to be clearly class legislation without substantial distinction within constitutional inhibition.

The writ of mandamus prayed for is therefore denied. 


\section{CHAPTER VII. (Continued)}

\section{PART V. NEW YORK.}

1. State Board of Examiners.

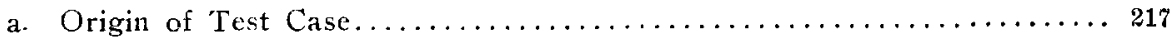

2. Supreme Court, Albany County.

a. Affidavit and Order Appointing Counsel.................... 217

b. Summons and Complaint............................ 219

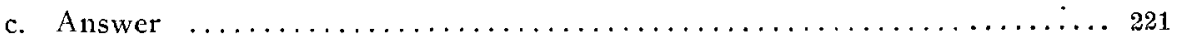

d. Findings of Fact and Conclusions of Law................... 221

e. Excep ions of Defendant to Conclusions of Law............... 222

f. Opinion of Rudd, J. ............................... 222

g. Judgment of Supreme Court........................ 227

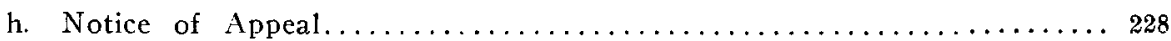

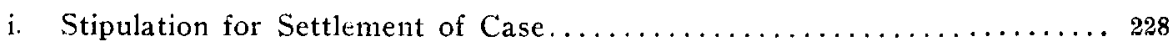

j. Order Settling Case............................ 229

k. Stipulation Waiving Certification....................... 229

3. Appellate Division, Supreme Court.

a. Brief for Plaintiff-Respondent. . . . . . . . . . . . . . . . . . 229

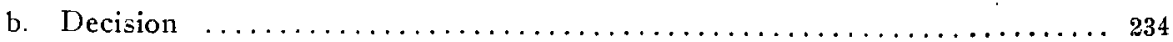

4. Court of Appeals.

a. Brief on Behalf of Defendants........................... 234

b. Case Pending at Time of Repeal of Statute................... 241 


\section{(V.) NEW YORK.}

(Chapter 445, April 16, 1912.)

Similarly to the New Jersey statute, the New York law required a court review of each particular case nominated for sterilization.

\section{STATE BOARD OF EXAMINERS.}

In the spring of 1915, the Board of Examiners of Feeble-minded (including Idiots, Imbeciles and Morons), Epileptics and Other Defectives, made their first move. No records were kept of their meetings, nor were the members upon formal request able to supply any data from memory. The only documentary evidence of their official activity prior to the court procedure in the test case was found in the auditors' records of their expenditures.

a. Origin of Test Case. Litigation grew out of informal agreement made in the Spring of 1915 between the Board of Examiners of Feeble-minded (including Idiots, Imbeciles and Morons), Epileptics and Other Defectives on the one part, and the Rome Custodial Asylum on the other, that Frank Osborn, a feeble-minded inmate of said asylum, about 22 years of age, and known to belong to a family of degenerates, be made the subject of a test case. The trial was begun September 17, 1915, and hearings were had at intervals covering a period of several months.

\section{SUPREME COURT, ALBANY COUNTY.}

On March 5, 1914, Mr. Justice Rudd of the Supreme Court, Albany County, handed down an opinion declaring the Act unconstitutional on the ground that "the provisions of the Federal Constitution, to which this law is offensive, is that part of the Fourteenth Amendment which declares 'that no state *** shall deny to any person within its jurisdiction the equal protection of the laws.'" The opinion reviewed the testimony of the witnesses, and Judge Garrison's decision on the New Jersey law. In reference to a possible punitive aspect Mr. Justice Rudd held "the operation upon feebleminded is in no sense in the nature of a penalty, and therefore, whether it is unusual and cruel punishment, is not involved."

The principal documents of the case follow:

\section{SUPREME COURT, ALBANY COUNTY.}

(103 Misc. Rep. 23.)

(169 N. Y. Sup. 638.)

(171 N. Y. Sup. 1094.)

\section{a. Affidavit and Order Appointing Counsel.}

In the Matter of the Application of LEMON THOMSON, M. D., and CHARLES H. ANDREWS, M. D., and WILLIAM J. WANSBORO, M. D., Composing the Board of Examiners of Feebleminded, Criminals and Other Defectives, Appointed Pursuant to Section 350 of the Public Health Law of the State of New York, for the Appointment of Counsel to Represent FRANK OSBORN, a Person to be Examined Pursuant to Section 352 of the Public Health Law.

On reading the annexed affidavit of Lemon Thomson, M. D., by which it appears that the State Board of Examiners of Feebleminded Criminals and other Defectives have examined into the mental and physical condition of Frank Osborn, now confined in the Rome Custodial Asylum, and have decided that it is advisable to perform an operation upon him for the prevention of procreation, and in pursuance to Sections 351 and 352 of the Public Health Law, I hereby appoint Ellis J. Staley, Esq., counselor at law, of the City of Albany, N. Y., to represent said Frank Osborn, and said Staley is to act at a hearing before me and in any subsequent hearings, for said Frank Osborn, which hearing I fix for the 12th day of June, 1915, at ten thirty o'clock in the forenoon, or as soon thereafter as I can hear counsel, at the place for holding special term in the City Hall, Albany, N. Y.

I direct that this order be filed with the clerk of Albany County and a copy served upon said Staley, counsel appointed to represent said Frank Osborn, within ten days from this date, and that proof of service of a copy of the order be served on the said Staley.

The compensation to be allowed said counsel shall be twenty dollars a day, while he is actually engaged in this matter.

Dated, June 2, 1915.

\section{ALDEN CHESTER,}

Justice Supreme Court. 


\section{SUPREME COURT,}

\section{ALBANY COUNTY.}

In the Matter of the Application of LEMON THOMSON, M. D., CHARLES H. ANDEWS, M .D., and WILLIAM J. WANSBORO, M. D., Composing the Board of Examiners of Feebleminded Criminals and Other Defectives, Appointed Pursuant to Section 350 of the Public Health Law of the State of New York, for the Appointment of Counsel to Represent FRANK OSBORN, a Person to be Examined Pursuant to Section 352 of the Public Health Law.

\section{STATE OF NEW YORK,}

\section{County of Albany, ss:}

Lemon Thomson, being duly sworn, says: I reside in the City of Glen Falls, N. Y. I was appointed by the Governor of the State of New York a member of the Board of Examiners of Feeble-minded Criminals and other Defectives, pursuant to Chapter 445 of the Laws of 1912 , which law has become Article XIX of the Public Health Law. The other members of the Board are Charles H. Andrews, M. D., and William J. Wansboro, M. D., and said Andrews, Wansboro and myself are now acting members of said Board of Examiners.

Section 351 of the Public Health Law prescribes the general powers and duties of our Board. It authorizes us to examine into the mental and physical condition and the record and family history of the feebleminded, epileptic, criminal and other defective inmates confined in the several State hospitals for the insane, state prisons, reformatories and charitable and penal institutions in the State and if, in the judgment of the majority of said Board, procreation by any such person would produce children with an inherited tendency to crime, insanity, feeble-mindedness, idiocy or imbecility, and there is no probability that the condition of any such person so examined will improve to such an extent as to render procreation by any such person advisable, or that the physical or mental condition of any such person will be substantially improved thereby, then our Board shall appoint one of its members to perform such operation for the prevention of procreation as shall be decided by said Board to be most effective.
By Section 352 of the same law, before any such operation is performed, our Board is required to apply to any judge of the Supreme Court or county in which such person is confined, for the appointment of counsel to represent the person to be examined, said counsel to. act at a hearing before the judge and in any subsequent proceedings, and no order made by said Board shall become effective until five days after it shall have been filed with the clerk of the court and a copy shall have been served upon the counsel appointed to represent the person examined, and proof of service of said copy of the order to be filed with said clerk of the court.

The Board came into existence by the appointment of its members in 1912. Dr. Andrews and myself have continued as members of the Board of Examiners since its inception. Dr. Wansboro succeeded Dr. Hennessey, and Dr. Hennessey succeeded Dr. Duryee. No operations have ever been performed pursuant to said Sections 351 and 352 and no application has ever been made to the court for the appointment of counsel to represent persons to be operated upon, and so far as I know, the law has never been passed upon by the courts of this State.

The Board has made an examination of one Frank Osborn, who is about twenty-two years of age, and was sent to the Rochester Industrial Institution in 1907, and from there to the Rome Custodial Asylum, at Rome, where he is now confined. He has cost the State, while in its institutions, approximately $\$ 2,000$, up to October 1,1914 , and since that time has been an expense. to the State of about $\$ 175$ per year. After a careful examination by the Board we have learned that said Frank Osborn comes from a family of degenerates. $\mathrm{He}$ is one of sixteen children, eight of whom are dead. Five brothers and sisters besides himself are confined in State institutions for the feeble-minded; one, a feeble-minded brother, lives with a farmer and is intemperate, incapable and untrustworthy; one sister, the brightest of the family, lives with and keeps house for a man to whom she is not married, though she has a husband living. She is immoral and has been an inmate for two years of a house of prostitution. Of his dead brothers and sisters one died in an institution for feebleminded and seven died before becoming one year of age. The father of said Frank Osborn was feeble-minded and the son of a man who was an epileptic and who lost his 
mind before death. Said Frank Osborn's mother is living, is feeble-minded and comes from a family of defectives. Her mother was feeble-minded and one sister and two brothers of Frank's mother were feebleminded.

The family of Osborn, from which Frank Osborn comes, have always been a charge to either the county or the State, and they have cost the State approximately $\$ 10,000$ since they became State charges.

The sources of our information are examinations of individual records, examination of said Frank Osborn and members of his family, relatives and neighbors who have been intimately acquainted with his family during their lifetime.

The said board have carefully examined into said Frank Osborn's mental and physical condition and it is the judgment of a majority of said board that procreation. by said Frank Osborn would produce children with an inherited tendency to feeble-mindedness, and there is no probability that his condition will improve to such an extent as to render procreation advisable. His physical condition is such that no harm will come to him, so far as the board is able to ascertain, from the operation.

If said Frank Osborn was operated upon so that he could not procreate, in my opinion he would be able to earn his living if placed in the care and custody of some other person, but without such an operation, it would be inadvisable to release him, even under such circumstances.

Before the operation is performed on said Frank Osborn, your board asks, in accordance with the provisions of said Section 352 of the Public Health Law, that the court appoint counsel to represent him.

I also ask that a hearing be had before the judge who signs the order for which I am now applying and that said counsel be instructed to represent said Frank Osborn upon such hearing.

I therefore apply for an order in accordance with said Section 352 of the Public Health Law.

No previous or other application has been made to any judge for the order herein asked for.

LEMON THOMSON.

Subscribed and sworn to before me this $1 \mathrm{st}$ day of June, 1915.

W. M. THOMAS,

Notary Public,

Albany, N. Y. b. Summons and Complaint.

SUPREME COURT, COUNTY OF ALBANY.

FRANK OSBORN,

\section{against}

LEMON THOMSON, CHARLES

H. ANDREWS and WILLIAM

J. WANSBORO, composing the

Board of Examiners of Feeble-

Minded, Criminals and other De-

fectives,

\section{Defendants.}

To the Above-named Defendants:

You are hereby summoned to answer the complaint in this action, and to serve a copy of your answer on the plaintiff's attorney within twenty days after the service of this summons, exclusive of the day of service; and in case of your failure to appear or answer, judgment will be taken against you by default for the relief demanded in the complaint.

Trial to be held in the County of Abany. Dated, July 19, 1915.

\section{ELLIS J. STALEY, Plaintiff's Attorney.}

Office and Postoffice address: 95 State St., Albany, N. Y.

SUPREME COURT,

ALBANY COUNTY.

FRANK OSBORN,

\section{against}

LEMON THOMSON, CHARLES

$H$. ANDREWS and WILLIAM

J. WANSBORO, composing the

Board of Examiners of Feeble-

Minded, Criminals and other De-

fectives,

\section{Defendants}

The plaintiff, complaining of the defendants, alleges, upon information and belief:

First: That the plaintiff is a resident of the State of New York, a citizen of the United States of America and of the age of twenty-two years.

Second: That on or about the 16th day of April, 1912, a certain bill which had been theretofore duly passed by the Senate and Assembly of the State of New York, was signed by the Governor of said State and 
filed in the office of the Secretary of State as an Act of the Legislature, being known as Chapter 445 of the Laws of 1912, a copy of which said Act is hereunto annexed marked "Schedule A."

Third: That pursuant to the provisions of said Chapter 445 of the Laws of 1912, Lemon Thomson, M. D., Charles H. Andrews, M. D., and William J. Wansboro, M. D., were appointed as members of the Board of Examiners of Feeble-minded, Criminals and other Defectives, and at all the times hereinafter mentioned did, and now do, compose the said Board of Examiners of Feeble-minded, Criminals and other Defectives.

Fourth: That the said Act, Chapter 445 of the Laws of 1912, in many respects violates the Constitution of the United States and does not secure the blessings of liberty to the citizens of the United States and their posterity as therein guaranteed, and is therefore, unconstitutional and void, and particularly in that it violates Section 10 of Article $I$ thereof in being a Bill of Attainder and an ex post facto law; subdivision 3 of Section 2 of Article III in depriving citizens of the right to trial by jury; Section 2 of Article IV in depriving citizens of the State of New York of privileges and immunities to which citizens of other states are entitled; Article $\mathrm{V}$ of the amendments to said Constitution in compelling a citizen to be a witness against himself and depriving citizens of life, liberty and property, without due process of law; Article VIII of said amendments in authorizing the infliction of cruel and unusual punishment; Section 1 of Article XIV of said amendments in abridging privileges and immunities of citizens and depriving persons of life, liberty and property without due process of law and denying to persons within its jurisdiction the equal protection of the laws.

Fifth: That the said Act, Chapter 445 of the Laws of 1912, in many respects violates the Constitution of the State of New York and does not secure the blessings of freedom to the people of said State, as therein guaranteed, and is therefore, unconstitutional and void, and particularly in that it violates Section 1 of Article I thereof in depriving citizens of rights and privileges without the law of the land; Section 2 of Article 1 thereof in depriving citizens of the right to trial by jury; Section 5 of said Article I thereof in authorizing the infliction of cruel and un- usual punishment; Section 6 of said Article I thereof in depriving persons of life, liberty and property, without due process of law, and Section 1 of Article VI thereof in conferring upon a board or commission and a justice of the Supreme Court or certain county judges, powers exclusively vested in the Supreme Court.

Sixth: That this plaintiff is, and for several months last past, has been, confined in the Rome Custodial Asylum, a State charitable institution, at Rome, N. Y., and that while so confined therein was examined by the defendants herein, and that said defendants composing the said Board of Examiners, threatened to have performed, and are about to perform, an operation upon this plaintiff for the prevention of procreation pursuant to the power and authority so attempted to be conferred as aforesaid, by the provisions of said Act, known also as Article XIX of the Public Health Law; and that in pursuance of its said purpose so to perform said operation upon this plaintiff, the said defendants presented through the Attorney-General of the State of New York, an application to the Hon. Alden Chester, a justice of the Supreme Court, for the appointment of counsel to represent this plaintiff pursuant to Section 352 of said Act, and that an order was accordingly made thereon by said justice appointing Ellis J. Staley, counselor at law, of the City of Albany, N. Y., as such counsel.

Seventh: That unless said defendants are enjoined and restrained from so performing, or causing to be performed, the said threatened operation, this plaintiff will suffer irreparable injury and damage for which no adequate remedy at law exists.

Wherefore, the plaintiff demands judgment that the said defendants, composing the said Board of Examiners, and each of them, and their successors in office, be perpetually enjoined and restrained from performing or permitting to be performed the aforesaid threatened operation and that during the pendency of this action the said defendants be enjoined and restrained from performing, or permitting to be performed, said threatened operation; and that plaintiff may have such other or other and further relief as may be just, together with costs of this action.

\section{ELLIS J. STALEY,} Attorney for Plaintiff.

Office and Postoffice Address: 95 State St., Albany, N. Y. 
STATE OF NEW YORK, COUNTY OF ALBANY, ss:

Ellis J. Staley, being duly sworn, says that he is the attorney for the plaintiff herein; that he has read the foregoing complaint and knows the contents thereof, that the same is true of his own knowledge except as to the matters therein stated to be alleged upon information and belief and that as to those matters he believes it to be true.

Deponent further says, that the reason why this verification is made by deponent and not by the plaintiff is that the plaintiff is not now within the County of Albany, which is the county within which deponent resides and has his office, and that the sources of deponent's information and grounds of his belief are an examination of an affidavit of the defendant Thomson verified June 1, 1915, and filed in the Albany County Clerk's office, and conversations had by a representative of deponent with the plaintiff relating to the matters set forth in said complaint.

ELLIS J. STALEY.

Sworn to before me this 19th day of July, 1915.

\section{G. LEROY BUTLER, Notary Public, Albany, N. Y.}

c. Answer.

- SUPREME COURT, ALBANY COUNTY.

FRANK OSBORN,

\section{against}

\section{Plaintiff,}

LEMON THOMSON, CHARLES

H. ANDREWS and WILLIAM

J. WANSBORO, composing the

Board of Examiners of Feeble-

Minded, Criminals and other De-

fectives,

Defendants.

The defendants for an answer to the complaint of the plaintiff herein:

First: Deny upon information and belief the allegations set forth in paragraphs "Fourth," "Fifth," and "Seventh" of the complaint.

Wherefore, defendants demand judgment dismissing the complaint, with costs.

Dated, September 2, 1915.

EGBURT E. WOODBURY,

Attorney-General and

Attorney for the Defendants.

Office and Postoffice Address: Capitol, Albany, N. Y.

\section{STATE OF NEW YORK,}

COUNTY OF ALBANY, ss:

Lemon Thomson, being duly sworn, says: I am one of the defendants in the above entitled action. I have read the foregoing answer and know the contents thereof, and the same is true of my knowledge except as to the matter therein stated to be alleged upon information and belief, and that as to those matters I believe it to be true.

\section{LEMON THOMSON.}

Sworn to before me this 7th day of September, 1915.

FLORENCE E. BUSHWELL, Notary Public, Albany County.

\section{d. Findings of Fact and Conclusions of Law.}

At a Special Term of the Supreme Court of the State of New York held at the City of Albany, N. Y., on the 17th day of September, 1915.

Present: HON. WILLIAM P. RUDD, Justice.

SUPREME COURT, COUNTY OF ALBANY.

FRANK OSBORN,

$$
\text { against }
$$

\section{Plaintiff,}

LEMON THOMSON, CHARLES

H. ANDREWS and WILLIAM

J. WANSBORO, composing the Board of Examiners of FeebleMinded, Criminals and other Defectives,

\section{Defendants.}

The issues in this action coming on to be tried by the court at the above Special Term held by the undersigned, without a jury, and having been tried commencing on the 17 th day of September, 1915, and the allegations and evidence of the parties having been heard; now, after hearing Ellis J. Staley, attorney for plaintiff, and J. Sheldon Frost of counsel and Wilber W. Chambers, Deputy Attorney-General of counsel for the defendants; due deliberation having been had; I find and decide as follows:

\section{FINDINGS OF FACT.}

First: That the plaintiff is a resident of the State of New York, a citizen of the United States of America, and of the age of twenty-two years.

Second: That on or about the 16th day of April, 1912, a certain bill which had been 
theretofore duly passed by the Senate and Assembly of the State of New York, was signed by the Governor of said State and filed in the office of the Secretary of State as an Act of the Legislature, the same being known as Chapter 445 of the Laws of 1912.

Third: That pursuant to the provisions of said Chapter 445 of the Laws of 1912, Lemon Thomson, M. D., Charles H. Andrews, M. D., and William J. Wansboro, M. D., the defendants herein, were appointed as members of the Board of Examiners of Feeble-Minded, Criminals and other Defectives, and now compose the said board of examiners of feeble-minded, criminals and other defectives.

Fourth: That said Frank Osborn is, and since 1907 has been confined as an inmate in the Rome Custodial Asylum, a State charitable institution located at Rome, New York, and is a person physically strong but mentally defective and in the class known as feeble-minded, possessing a mental capacity according to the Binet test of about eight years.

Fifth: That shortly prior to the commencement of this action the said Board of Examiners pursuant to the said act examined into the mental and physical condition and the record and family history of said Frank Osborn and determined that procreation by him would produce children with an inherited tendency to feeble-mindedness; that there was no probability that this condition would improve to such an extent as to render procreation advisable and prepared for the performance of the operation of vasectomy upon him.

Sixth: That the said Board of Examiners, unless restrained by this court, will cause to be performed upon said Frank Osborn, the aforesaid operation.

\section{CONCLUSIONS OF LAW.}

First: That the plaintiff, Frank Osborn, has no adequate remedy at law for the aforesaid threatened injuries and damage.

Second: The Chapter 445 of the Laws of 1912, known as Article XIX of the Public $\mathrm{H}$ alth Law, is unconstitutional and invalid.

'I hird: That the defendants, Lemon Thomson, Charles H. Andrews and William J. Wansboro, composing the Board of Examiners of feeble-minded, criminals and other defectives, and each of them and their agents, representatives and successors in office be perpetually enjoined and restrained from performing or permitting to be performed the aforesaid threatened operation.

Fourth: That the plaintiff recover of the defendants the costs and disbursements of this action to be taxed by the clerk.

Judgment in accordance with the foregoing is hereby directed.

WM. P. RUDD, Justice Supreme Court.

\section{e. Exceptions of Defendant to Conclusions of Law.}

\section{SUPREME COURT, COUNTY OF ALBANY.}

FRANK OSBORN,

Plaintiff,

against -

LEMON THOMSON, CHARLES

H. ANDREWS and WILLIAM

J. WANSBORO, composing the

Board of Examiners of Feeble-

Minded, Criminals and other De-

fectives,

Defendants.

The defendants hereby except to the conclusions of law made by Hon. William P. Rudd, Justice of the Supreme Court, and filed in the office of the clerk of the County of Albany on the 8th day of March, 1918, as follows:

First: Except to the conclusion of law marked "First."

Second: Except to the conclusion of law marked "Second."

Third: Except to the conclusion of law marked "Third."

Fourth: Except to the conclusion of law marked "Fourth."

Dated, March 10th, 1918.

Yours, etc.,

MERTON E. LEWIS,

Attorney-General and Attorney for Defendants.

Office and Postoffice Address: Capitol, Albany, N. Y.

To:

HON. ELLIS J. STALEY,

Attorney for Plaintiff, 93 State St., Albany, N. Y.

HON. LUTHER C. WARNER,

County Clerk of Albany County.

f. Opinion of Rudd, J.

SUPREME COURT,

ALBANY COUNTY. 
In the Matter of the Application of LEMON THOMSON, M. D., CHARLES H. ANDREWS, M. D., and WILLIAM J. WANSBORO, M. D., composing the Board of Examiners of Feeble- Minded, Criminals and Other Defectives, appointed pursuant to Section 350 of the Public Health Law of the State of New York, for the appointment of counsel to represent Frank Osborn, a person to be examined pursuant to Section 352 of the Public Health Law.

Merton E. Lewis, Esq., Attorney-General, for the Applicants.

Wilber W. Chambers, Esq., Deputy Attorney-General, of Counsel.

Ellis J. Staley, Esq., Attorney for Respondent.

J. Sheldon Frost, Esq., of Counsel.

\section{SUPREME COURT,}

\section{ALBANY COUNTY.}

FRANK OSBORN,

\section{against}

LEMON THOMSON, CHARLES

H. ANDREWS and WILLIAM

J. WANSBORO, composing the

Board of Examiners of Feeble-

minded, Criminals and Defectives,

\section{Defendants.}

Ellis J. Staley, Esq., Attorney for Plaintiff. J. Sheldon Frost, Esq., of Counsel.

Merton E. Lewis, Esq., Attorney-General, for the Defendants.

Wilber W. Chambers, Esq., of Counsel.

Trial had before William P. Rudd, Justice of the Supreme. Court, at Special Term, under Stipulation signed by the Attorneys representing the respective parties.

\section{MEMORANDUM.}

Rudd, J.: Chapter 445 of the Laws of 1912 is an act amending the Public Health Law by adding Section 19 thereto, in relation to operations for the prevention of procreation. It provides in substance as follows:

1. The appointment of a Board of Examiners consisting of one surgeon, one neurologist and one practitioner of medicine to be known as the Board of Examiners of Feebleminded, Criminals and other Defectives.
2. Making it the duty of this board to examine into the mental and physical condition and the record and family history of the feeble-minded, epileptic, criminals and other defectives confined as inmates in the several State hospitals for the insane, State prisons, reformatories, and charitable and penal institutions of the State, and if, in the judgment of the majority of said board, procreation by any such person would produce children with an inherited tendency to crime, insanity, feeble-mindedness, idiocy or imbecility, and that there is no probability that the condition of any such person will improve to such an extent as to render procreation by any such person advisable, or if the physical or mental condition of such person will be substantially improved thereby, that then the board shall appoint one of its members to perform such operation for the prevention of procreation as shall be decided by said board to be most effective.

The criminals who shall come within the operation of this law shall be those who have been convicted of the crime of rape or of such succession of offenses against the Criminal Law as in the opinion of the board shall be deemed in the criminal examined to be sufficient evidence of confirmed criminal tendencies.

3. It is the duty of this board to apply to any Judge of the Supreme Court or County Judge of the county in which said person is confined for the appointment of counsel to represent the person to be examined. The counsel shall act for such person at a hearing before the judge or in any subsequent proceedings, and no order made by the board shall become effective until five days after it shall have been filed with the clerk of the court and a copy shall have been served upon the counsel appointed to represent the person examined. Orders made by the board are subject to review by the Supreme Court or any justice thereof.

Under this law a Board of Examiners was appointed consisting of the petitioners herein. Such board determined to perform the operation known as vasectomy upon Frank Osborn, an inmate of the Rome Custriial Asylum, 22 years of age, strong physically, who has been an inmate of that institution for several years, and who is in the class known as feeble-minded.

As indicated by the title above, Frank Osborn through counsel appointed by $\mathrm{Mr}$. Justice Chester, began action against the members constituting the Board of Exam- 
iners asking a permanent injunction restraining the carrying out of the determination of the board with reference to an operation upon him; and in the action thus brought are raised questions as to the constitutionality of the act.

We have under consideration the questions which have arisen in review of the determination of the board and those which result from the challenge by the counsel of Frank Osborn, against the constitutionality of the act. We will first consider the determination of the board.

Dr. Lemon Thomson, one of the Board of Examiners, testified in substance that the board had selected Frank Osborn after learning as to his family and after submitting him to a somewhat superficial examination physically and mentally; and that such selection was made because in the opinion of the commission Osborn could not probably procreate normal offspring. $H$ is was what the Board of Examiners thought a bad case.

Dr. Thomson says that he has never performed the operation of vasectomy for sterilization; that in his opinion no benefit would come to the patient from the operation so far as rendering him free from the dangers of the infection of a venereal disease; that the operation would not weaken in Frank Osborn the tendency of the rapist.

Dr. Andrews, a member of the Board of Examiners, testified that he had never performed the operation, and that he had never seen it performed; and while the statute required that the board should determine upon the operation which would be most effective, he stated that vasectomy would not be the most effective operation but, on the other hand, that castration would be. He further testified that he had not given any study to any particular phase of this question.

Dr. Wansboro, of the Board of Examiners, was not called.

Dr. Bernstein, superintendent of the Rome Custodial Asylum, where Frank Osborn has been, as an inmate, since 1907, and in which there are cared for over 1,300 patients, testified that Osborn was of a higher grade of feeble-mindedness; that the actual number of feeble-minded in our state had not proportionately increased in 25 years; that because of the demands of society there developed many social failures; that there had been a persistent demand for the removal of such individuals from temptations in the community; and these social failures are forced upon the attention of the state, and it has been accepted as a principle that the state must care for defectives; that such people should not be looked after by any social or political division of the state. The doctor testified that he had observed $\mathbf{5 , 0 0 0}$ feeble-minded patients; that Osborn could not earn his living outside of the institution if he were turned out into the world; that he had an "eight year" mental capacity; that all patients in the institution are segregated; and upon the question of Osborn being able to procreate normal children he said: "We are taught that the dominant traits appear in one-quarter, when the parentage is mixed as regards traits; that it is only in cases of feeble-mindedness of both parents that yor would look generally for an increase of feeble-mindedness among offspring."

In other words, that when one parent is feeble-minded and the other of norma: mental capacity that the tendency is recessive, that is, towards the normal.

The doctor testified that vasectomy would not change any of the criminal tendencies of the feeble-minded at all; it would only eliminate the one element of procreation; that in his opinion one of the conditions which would result from a general enforcement of the law, as is here determined, would be to tend to create a class of people by themselves who would feel that they were so different from normal humanity that they would go back to promiscuous sexual relations and that there would be known places where these people were harbored and there they would tend to collect. That among a class of such persons upon whom the operation of sterilization has been performed you would find increased sexual intercourse, and that such increased illicit intercourse is a promoter of disease and general demoralization.

Dr. Bernstein, knowing Frank Osborn as an inmate of the institution of which he was superintendent, testified that he was not in favor of the operation upon Osborn which has been recommended. $\mathrm{He}$ further said that he did not know of one case in the 1,300 in the institution that it would be desirable to operate upon, giving as a reason that it would not help the boy, and it would not help society. Osborn will have to be supervised and cared for just as well and just as much after the operation as before; after the operation of vasectomy he will want to go where the girls are just as much as he does now; that society needs protection from 
the raping of little girls and the frightening of them just as much as it wants protection from a future generation of dependents and delinquents. That vasectomy upon Osborn is not going to give us the thing society wants to have, protection from his possible ravages. In the doctor's opinion this legislation is in advance of our enlightenmentwe don't know today what we are dealing with; that a careful and scientific study of ductless glands and their secretions shows that when such secretions forming in the body are interfered with, physiological teaching indicates that conditions are created which affect the brain and the nervous system; and that such interference with the secretions does not cause or bring about a cure or a remedy such as is sought.

Frank Osborn testified. He did a small sum in addition; knows the days of the week; knows his age; but said he did not know what this inquiry or proceeding meant.

Dr. Davenport, a biologist, testified that he agreed with the statements made by Dr. Sharp of Indianapolis in an article entitled, "Vasectomy as a means of preventing procreation in defectives," in the statement there contained that "defective persons are not necessarily to become a public charge, for included within this class are to be found the most gifted as well as the most vicious, weakest and ordinarily the most unhappy of mankind," and mentioning a few of such instances in the names of Chatterton, Goldsmith, Coleridge and Charles Lamb.

This statute grows out of studies and efforts of those who are interested in the subject of eugenics, which has to do with the improvement of the population by taking advantage of laws of heredity; with improving through better breeding. It deals with the inheritance of traits; with changes in population through differential fecundity; the greater or less fecundity of the different classes of population; with changes of population from emigration; or better or worse strains, with hereditary basis of the traits of population. That there is to be found much of good in the most degenerate families known in our land, mentioning the Jukes and the Nams.

The doctor testified that he has not advocated the operation of vasectomy, and that in his opinion segregation of the sexes would be better.

Mr. Van Wagenen, who has studied and written upon the problems of eugenics, testified that it would be well if voluntary accept- ance of such an operation could be had; that when such operations have been done against the will of the patient the psychic effects have been bad; that he would never recommend such an operation except upon those who consented.

Dr. Coakley, a specialist in vivisection, testified as to the danger of infection because of the retained secretions in the body; that in the operation the vas deferens is severed, but that it can be reunited even after a considerable length of time, and therefore, nothing is accomplished.

Dr. Fernald, superintendent of the school for feeble-minded in Massachusetts, testified that he had never seen an authorized medical statement based upon actual facts which would justify claims made for the results in Indiana where such a law is in operation; that the operation of vasectomy does not in the slightest interfere with the physical act of sex intercourse; that illicit intercourse would result, and the effect thereof would be the exchanging of the burden of feeblemindedness for the burden of sex immorality or sex diseases and of insanity resulting in that condition which would be quite as serious and would affect people who are producers and burden bearers. It would prejudice many right-thinking persons who are interested in those who are afflicted against institutions, when it is known that under the law such an operation would be possible against the wishes of the person upon whom the operation is to be made.

The testimony shows that the operation of vasectomy upon the male is simple in its character; that it can be done without anaesthesia, quite painless. That upon the female is is serious in its character, requiring an abdominal section and the risks incident thereto.

A well authenticated case upon the records shows that in the case of a woman having been sterilized because of feeble-mindedness she was freed from any danger incident to childbirth, was therefore freely inclined to improper sexual relations, and her lack of moral character becoming generally known she was the victim of constant sexual relations with the boys and men of the little village where she lived; that she became diseased resulting in an epidemic of venereal disease in the locality.

The court has set forth sufficient of the testimony and of that portion of it which is practically uncontradicted to indicate that the determination of the Board of Examiners 
to cause the operation of vasectomy upon Frank Osborn is not justified either upon the facts as they today exist or in the hope of benefits to come.

The members of the Board of Examiners apparently know very little about the subject. They have given it no particular study. They are not, in the opinion of the court, justified in the determination which they have reached, and, therefore, upon review of the determination which the board has made, this court reverses the same.

The action above entitled was brought by Frank Osborn against the defendants as members of the Board of Examiners for an injunction restraining the board from causing to be performed an operation upon him to prevent procreation.

It is claimed that the law in question violates the Constitution of the United States in many respects; that it is a Bill of Attainder; that it is depriving citizens of a trial by jury; and also of the privileges or immunities to which citizens of other states are entitled; that it is compelling a citizen to be a witness against himself, and depriving him of life, liberty and property without due process of law; that it permits infliction of a cruel and unusual punishment; that it abridges the privileges and immunities of citizens in depriving persons of life, liberty and property without due process of law, and denying to persons within its jurisdiction the equal protection of the law.

It is conceded that the proper form of raising the question of unconstitutionality herein involved, is by an action asking a permanent injunction.

A similar law has been declared unconstitutional by the Supreme Court of New Jersey in the case of Smith against the Board of Examiners, 88 Atlantic Reporter, 963, in an opinion written by Judge Garrison.

The New Jersey statute gave to the Board of Examiners discretion to determine the form of operation most effective, as does the New York Law.

It was thus given to the board to do almost anything which in their opinion would effectively destroy the power of procreation in Frank Osborn, or of any male or female feeble-minded inmate of a State hospital.

The statute seems to vest in the board the discretion to do what Judge Garrison said of the New Jersey Law:

"The statute is broad enough to authorize an operation for the removal of any one (in the female) of these three organs, that is the ovary, the fallopian tube and the uterus, which are essential to procreation."

The subject of the operation in the New Jersey case was an inmate of the State Village for Epileptics, and the New Jersey court said: "While the case in hand raises the very important and novel question whether it is one of the attributes of government to essay the theoretical improvement of society by destroying the function of procreation in certain of its members who are malefactors against its laws, it is evident that the decision of that question carries with it certain logical consequences, having farreaching results. For the feeble-minded and epileptics are not the only persons in the community whose elimination as undesirable citizens would or might in the judgment of the legislature, be a distinct benefit to society. If the enforced sterility of this class be a legitimate exercise of governmental power, a wide field of legislative activity and duty is thrown open to which it would be difficult to assign a legal limit."

Frank Osborn is not a malefactor. $\mathrm{He}$ is mentally deficient. He is defective without personal responsibility for such defect. It must be assumed that he is poor in the sense that there are no parents or friends to give him a home and provide for him, and so he becomes a ward of the state to be cared for and treated and strengthened and developed, if possible. He is no different from many others running no doubt into the thousands in our state who are not within the confines of a State institution, and who together taken with those who are in institutions and similarly situated, mentally and physically, make up a large class of mentally deficient people.

Can it be said that the law can direct the physical mutilation of the bodies of those who are in the State's care, and not be concerned with the same class of persons who are in the world at large?

The laws of our State which have been sustained by our courts as a proper exercise of the police power are not found to be a justification of this law.

The statute under consideration concerns certain classes of criminals as well as defectives. In the consideration of the question here we have properly confined our thoughts to the facts which have developed in the testimony, and those facts only relate to the feeble-minded.

The operation upon the feeble-minded is in no sense in the nature of a penalty, and 
therefore, whether it is an unusual and cruel punishment is not involved.

The entire purpose of the enactment seems to be to save expense to future generations in the operation of eleemosynary institutions organized by the people of the State to care for those who are afflicted; the theory being that if the Board of Examiners should conclude that every feeble-minded inmate of a public institution should be operated upon either by the operation known as vasectomy or the more radical operation of castration that then the State woud be justified in turning all the people of this class at large to find their own way, trusting that they, in accordance with the theory of the law, could no longer procreate; the State being thus relieved of their care during their lives and freed from the danger of the burden in the future of their abnormal offspring.

Such does not seem to this court to be the proper exercise of the police power. It seems to be a tendency almost inhuman in its nature. The subject of this inquiry is, according to the testimony of physicians, physically strong. The same witnesses testified that if turned out into the world after or without the operation he could not care for himself or make a living; that at present, situated as he is, he works and helps the State in meeting the burden upon it in his care:

The last section of the statute under consideration provides that "Except as authorized by this act every person who shall perform, encourage, assist in or otherwise permit the performance of the operation for the purpose of destroying the power to procreate the human species, or any person who shall knowingly permit such operation to be performed upon such person, unless the same shall be a medical necessity, shall be guilty of a misdemeanor."

It seems clear that Frank Osborn is not given the equal protection of the laws, having in mind many others situated as he is who are not within the walls of a public institution, to which equal protection he is entitled with them. There is afforded to the young man similarly situated as to his physical and mental makeup, who is cared for by his parents in his own home, whose sexual tendencies and capacity may be the same as Osborn's, the protection of the law which makes it a misdemeanor for any person to assist or take part in the operation of vasectomy upon such a subject, while Frank Osborn, because he is an inmate of a State hospital, is not only not protected, but he is subject to such operation without his consent when determination is reached by the board created under this statute.

It seems, therefore, that the provisions of the Federal Constitution to which this law is offensive is that part of the Fourteenth Amendment which declares "that no state *** shall deny to any person within its jurisdiction the equal protection of the laws."

The law certainly denies to some persons of a class and similarly situated the protection which is afforded to others of the same class.

The State has power, many times sustained by the courts, to protect the health, morals and welfare of the people, but such protection cannot be afforded unless it applies to all alike.

The courts have sustained the laws which prohibit the marriage contract between epileptics within certain ages, enacted for the same purpose and to accomplish the same end as the law we are considering, but such laws thus sustained have related to all epileptics, they do not alone relate to the unfortunates within hospitals.

Our attention is called to an interesting and most readable opinion by the AttorneyGeneral of California.

$\mathrm{His}$ conclusion is "as regards the castration of confirmed criminals and rapists, and those guilty of sexual crimes, I am of the opinion that these are grave constitutional questions" but "as restricted to the sterilization of the inmates of prisons and hospitals by the method of vasectomy, I am of the opinion that there are no legal inhibitions upon this enlightened piece of legislation which is an awakening note to a new era and a great advance toward that day when man's inhumanity to man will have acquired a meaning beyond mere frothy sentiment."

Why sterilization by vasectomy of patients in a hospital, who are grouped as a class with rapists in a State prison, strikes an awakening note in a new era and will lead to the day to which the Attorney-General so poetically refers, is beyond the comprehension of this court and is not enlightening.

Our conclusion is that the statute is unconstitutional and therefore invalid.

Judgment may be entered accordingly.

\section{g. Judgment of Supreme Court.}

At a Special Term of the Supreme Court of the State of New York, held at the City 
of Albany, N. Y., on the 17th day of September; 1915.

Present: HON. WM. P. RUDD, Justice.

\section{SUPREME COURT,} COUNTY OF ALBANY.

FRANK OSBORN,

$$
\text { against }
$$

LEMON THOMSON, CHARLES

H. ANDREWS and WILLIAM

J. WANSBORO, composing the

Board of Examiners of Feeble-

Minded, Criminals and other Defectives,

\section{Defendants.}

The defendant above named having voluntarily generally appeared in this action by Hon. Egburt E. Woodbury, Attorney-General, as their attorney and having served an answer herein; and the issues raised thereby having been duly brought on for trial at the above Special Term and a trial thereof having been had before the undersigned, without a jury, commencing on the 17th day of September, 1915; and the plaintiff having appeared upon said trial by Ellis J. Staley, his attorney, and by J. Sheldon Frost, of counsel, and the defendants having appeared by Hon. Wilber W. Chambers, Deputy Attorney-General, of counsel; and a decision containing a statement of the facts found and the conclusions of law thereon and directing judgment as hereinafter set forth having been duly made and this day filed herein; and the plaintiff's costs and disbursements having been duly taxed at the sum of one hundred and eight dollars. Now, upon filing the summons, complaint and answer, and upon the decision filed herein as aforesaid, it is, on motion of Ellis J. Staley, attorney for plaintiff,

Adjudged and decreed as follows:

First: That the defendants, Lemon Thomson, Charles H. Andrews and William J. Wansboro, composing the Board of Examiners of Feeble-minded Criminals and other Defectives, and each of them and their agents, representatives and successors in office, be perpetually enjoined and restrained from performing or permitting to be performed upon said Frank Osborn the operation of vasectomy.

Second: That the plaintiff, Frank Osborn, recover of the defendants, Lemon Thomson, Charles H. Andrews and William J. Wans- boro, composing the Board of Examiners of Feeble-minded Criminals and other Defectives, the sum of one hundred and eight dollars, his costs and disbursements of this action.

Judgment entered this 8th day of March, 1918.

L. C. WARNER,

WILLIAM P. RUDD, Justice Supreme Court. Clerk.

h. Notice of Appeal. SUPREME COURT, ALBANY COUNTY.

FRANK OSBORN, Plaintiff-Respondent, against

\section{LEMON THOMSON, CHARLES}

H. ANDREWS and WILLIAM

J. WANSBORO, composing the

Board of Examiners of FeebleMinded Criminals and other Defectives,

\section{Defendants-Appellants.}

PLEASE TAKE NOTICE that the above named defendants hereby appeal to the Appellate Division of the Supreme Court for the Third Department, from the judgment of the Supreme Court herein entered in this action in the office of the clerk of Albany County on the 8th day of March, 1918, wherein it was adjudged that the defendants be perpetually enjoined and restrained from performing an operation on plaintiff, and the said defendants appeal from each and every part of said judgment as well as from the whole thereof.

Dated, March 26, 1918.

$$
\begin{aligned}
& \text { MERTON E. LEWIS, } \\
& \text { Attorney-General and } \\
& \text { Attorney for the Defendarit. }
\end{aligned}
$$

Office and Postoffice Address: Capitol, Albany, N. Y.

To:

HON. ELLIS J. STALEY, Attorney for Plaintiff, 95 State Street, Albany, N. Y.

HON. LUTHER C. WARNER, Clerk of the County of Albany.

\section{i. Stipulation for Settlement of Case.}

It is hereby stipulated that the foregoing case contains all the evidence given in the trial of this action, and may be settled as hereinbefore set forth and signed and ordered 
filed by the justice before whom this case was tried.

Dated, May 1, 1918.

\section{MERTON E. LEWIS, Attorney-General; Attorney for Appellant. ELLIS J. STALEY, Atţorney for Respondent.}

\section{j. Order Settling Case.}

The foregoing case contains all the evidence given and proceedings had upon the trial of this action, and is hereby settled and signed by the undersigned, before whom this action was tried without a jury, and ordered filed in the office of the Clerk of Albany County.

Dated, May 1, 1918.

$$
\text { WILLIAM P. RUDD, }
$$

Justice.

\section{k. Stipulation Waiving Certification.}

It is hereby stipulated by the attorneys for the respective parties herein that the foregoing summons and complaint, answer, order appointing. counsel, minutes of trial, findings of fact and conclusions of law, exceptions to conclusions of law, and opinion of Mr. Justice Rudd, judgment and notice of appeal therefrom are true and correct copies of the originals thereof, and of the whole of such originals, and certification of the same is hereby waived.

Dated, May 1, 1918.

$$
\begin{aligned}
& \text { MERTON E. LEWIS, } \\
& \text { Attorney-General; } \\
& \text { Attorney for Appellant. } \\
& \text { ELLIS J. STALEY, } \\
& \text { Attorney for Respondent. }
\end{aligned}
$$

3. APPELLATE DIVISION OF THE SUPREME COURT OF THE STATE OF NEW YORK FOR THE THIRD DEPARTMENT. (185 App. Div. 902.)

PRINCIPAL DOCUMENTS.

a. Brief for Plaintiff-Respondent, by his Attorney, Ellis J. Staley. Argued by J. S. Frost, Albany, N. Y.

FRANK OSBORN, against

Plaintiff-Respondent,

\section{LEMON THOMSON, CHARLES}

H. ANDREWS and WILLIAM

J. WANSBORO, composing the

Board of Examiners of FeebleMinded, Criminals, and Other Defectives,

Defendants-Appellants.
The defendants, composing the Board of Examiners of Feeble-minded, Criminals and other Defectives, have appealed from the judgment of the Special Term whereby they were perpetually restrained from performing the operation of vasectomy upon Frank Osborn, the plaintiff in this action. (Case on Appeal, fol. 1074.)

The trial was had before Mr. Justice Rudd at the Albany Special Term. The opinion of the Special Term is printed at folios 9951066.

The act under which the operation is proposed to be performed was passed in 1912 and is known as Chapter 445 of the laws of that year. No operations have been performed thereunder (fol. 76) and the application for the appointment of counsel and for a hearing in respect to the proposed enforcement of such law was not made until June, 1915. (Fol. 86.)

The selection of Frank Osborn as the subject for such operation was the first made by the Board (fol. 177) and this action was thereafter brought in order that all questions might be presented in a manner recognized by established procedure. Evidence was received without technical objection in order that the fullest presentation of facts and of the opinions of those who had made a study of the transmission of mental qualities might be had.

A very clear and comprehensive statement of the facts is to be found in the opinion of the learned Special Term.

The benefit of the proposed operation, assuming the same might be so effective as to prevent subsequent restoration of procreative powers, in this particular instance is clearly of a financial nature only. It is undisputed that Osborn would be unable to maintain himself were he left to his own resources, possessing as he does, a mental development, according to established tests, of an eight-year-old child. (Fols. 410, 420, 965-967, 978.)

Dr. Thomson, the chairman of the Board, testified at folio 234:

"Q. The sole benefit then it is claimed by "your board for this operation is that it "prevents procreation of persons liable to "feeble-mindedness?" A. "Yes, sir."

Bleeker Van Wagenen, who as appears from the testimony has given much study to the subject of sterilization, testified at folio 781 :

"I have seen cases where the operation has been performed compulsorily under the 
state law against the will of the individual, and against his violent protest, where the psychic effect has been bad. And along with that there has seemed to be some measure of bad effect physically as well as mentally."

Dr. Fernald testified at folio 929 , in speaking of persons upon whom the operation of castration had been performed, as follows:

" $Q$. Have you observed as to whether or not those persons were treated generally as a class by themselves, in a sense? A. Well, my own patients have been jeered at and have been ridiculed.

"Q. What have you observed with respect to the confidence of the patient himself after the operation, with respect to his dealings with the public? A. Well, the male patients who have been castrated had very much less self-confidence-why, less selfrespect and confidence, I think, expresses it fully."

Dr. Bernstein testified, upon examination by the court beginning at folio 20 :

"By the Court:

"Q. Referring to the situation that the counsel just mentioned, are you in favor of taking this step with reference to Frank Osborn? A. No. Q. Why? A. This step of vasectomy you mean? $Q$. Yes. Why? A. Because it won't help the boy; it won't help society. The boy will have to be. supervised and cared for just as well and as much as if he had the operation as if he does not have the operation. I have the personal history of the boy here showing his tendency to go where the girls are, showing that he has had to be disciplined several times for it. After the operation of vasectomy he will want to go where the girls are just as much as he does now. Now society wants protection from the raping of little girls and frightening them just as they want protection from a future generation of dependents and delinquents."

Osborn is now a State charge, segregated from persons of the opposite sex. He would be a public charge were the operation performed. It is not apparent wherein the State would be financially benefited by the performance of the proposed operation, but, assuming that it might be thus benefited, the question resolves itself into this: Is mutilation of the person of an innocent but physically unfortunate human being permissible to that, or any, end?

Dr. Charles Bernstein, who for twelve years has been the stperintendent of the Rome State Custodial Asylum where Osborn is held as a patient, testified to having observed approximately five thousand cases of feeble-mindedness (fol. 408) and under whose direction seven operations of vasectomy had been performed (fol. 444), described the method of operation as consisting of opening the skin directly on the groin and a few tissues below the skin bringing to view the spermatic cord, consisting of the artery and veins to the testicle, the vas deferens which carry the spermatic fluid or nerve supply to the testicle and some other tissue; then the vas deferens, which is tortuous or worm-like and two or three times as long as the artery, veins and nerves which are associated with it, is selected from this mass of tissue and about an inch thereof cut out, tying the ends and sewing the wound together. Sometimes the tissue of the scrotum is pulled up to the groin and the cut made through the skin so as not to have a scar appear in the groin, but in either event the tissues under the skin are opened above the groin. (Fols. 445-449.)

That but little force is to be given to the assertion of the chairman of the Board of Examiners that the operation is of a most simple and safe character will be manifest from an examination of his testimony upon this subject appearing at folios 204-230.

Dr. Coakley testified that while the operation could be performed with one incision, it would be better to make two incisions and that any incision in the human body involves elements of danger. (Fol. 873.) $\mathrm{He}$ said "there is always danger of infection regardless of the most positive asepsis and the danger of shock can not be explained at all."

There is no evidence to show that Osborn possesses the reproductive plasm (spermatozoa). It is here proposed to perform the operation upon the mere presumption of the possession of such powers. In a normal person and in matters of property or matrimonial rights, indulgence in such presumption might be, and doubtless is, permitted; but it should not be assumed in the case of a defective where physical mutilation is involved.

Dr. Bernstein testified at folio 459:

"What we need to know is in what percentage of our feeble-minded cases are spermatozoa present at the present time and in how many of these will it reappear after one or two years following the vasectomy.

"Q. In other words, in your opinion, Doctor, there may exist among the feebleminded patients under the charge of the 
State a considerable number who might be correctly described as being sterile at the present time? A. Yes, sir."

The operation of vasectomy does not necessarily prevent procreation. Dr. Bernstein found the presence of spermatozoa nearly a year after the operation had been performed (fol. 455), and he stated at folio 457 , referring to cases where the operation had been performed under his direction: "The real unfortunate situation here is that these cases should have been studied as regards the presence or absence of spermatozoa in the ejaculated fluid before as well as after the operation."

Dr. Coakley testified that the vas deferens could be reunited after the operation. (Fol. 843.)

Dr. H. C. Sharp, of Indiana, under whose direction most of the operations were performed in that state, on October 6, 1915, wrote to the counsel for the respondent a letter which is here inserted by permission of the counsel for the appellants and of which the following is a copy:

"The operation to which you refer of reuniting the severed ends of the vas is possible, although a delicate but very simple operation. However, I have never done this operation but in one case, and I did this for the purpose of demonstrating that it was possible."

Mr. Boston states that sterilization is a punishment unless a benefit results. (See Appendix.)

Mr. Justice Rudd, in his very able opinion, says, at folio 1148: "Frank Osborn is not a malefactor. He is mentally deficient. He is defective without personal responsibility for such defect."

The proposition of Justice Rudd is that of an undisputed fact; the proposition of $\mathrm{Mr}$. Boston is manifestly correct. This court may and should assume the accuracy of both. If both are true, no authority can be found for the performance of the proposed operation unless it appears from the record that Osborn is to be benefited thereby. We respectfully submit that the appellants have failed in such respect.

To deprive an individual of all hope of progeny, where he has been guilty of no offense, is at least a close approach to cruel and untusual punishment. The case of State v. Feilen (70 Wash., 65, 126 Pac. 75), from which the appellants quote at considerable length, was one where the defendant had been convicted of the crime of rape com- mitted upon a child under ten years of age, sentenced to imprisonment for life and to have the operation of vasectomy "carefully and scientifically performed." The court said the nature of the crime would permit the death penalty had the legislature so determined and concluded as follows: "We can not hold that vasectomy is such a cruel punishment as can not be inflicted upon appellant for the horrible and brutal crime of which he has been convicted."

The assertion would seem to be justified that vasectomy might not be cruel punishment when applied to one convicted of a brutal sexual crime, but as applied to any other crime, much less to an innocent, it becomes cruel and inhuman.

Cruel and unusual punishment under the Philippine Bill of Rights was held in Weems vs. United States, 217 U. S. 349; 30 Sup. Ct. Rep. 544, to invalidate a sentence of carrying during the term of imprisonment a chain at the ankle hanging from the wrist and perpetually disqualifying from the exercise of political rights. In connection with the review by the Court of a considerable number of cases it is said: "In the application of a constitution, therefore, our contemp? ation cannot be only of what has been, but of what may be. Under any other rule a constitution would indeed be as easy of application as it would be deficient in efficacy and power."

The New York State statute here in question assumes to authorize the prevention of procreation by such operation "as shall be decided by said board to be most effective." Under the rule stated by the Supreme Court of the United States in the recent case above cited, it is permissible for this court to consider the possibility of the amputation of the sexual organ or even, as was said by Governor Pennypacker of Pennsylvania in his veto message of March 30th, 1905, of a similar statute: "It is plain that the safest and most effective method of preventing procreation would be to cut the heads off the inmates and such authority is given by the bill to this staff of scientific experts."

In Fisher Co. vs. Woods (187 N. Y., 90), Haight, J., in writing the unanimous opinion of the court, said, at page 95 :

"The legislative determination as to what is a proper exercise of the police power, is subject to the supervision of the court and in determining the validity of an act it is its duty to consider not only what has been done under the law in a particular instance, but 
what may be done under and by virtue of its authority. Liberty, in its broad sense, means the right not only of freedom from servitude, imprisonment or restraint, but the right of one to use his faculties in all lawful ways; to live and work where he will, to earn his livelihood in any lawful calling and to pursue any lawful trade or avocation." (Citing numerous cases.)

The testimony of Dr. Walter E. Fernald, for twenty-eight years Medical Superintendent of the Massachusetts School for FeebleMinded, and who has had under his charge during the past ten years an average of over 1,000 patients, is entitled to very great consideration because of his high standing in his profession and his knowledge gained from specific cases. He states that in the New York Hospitals for the Insane from twelve to twenty-five per cent are public charges because of mental diseases caused by syphilis. (Fol. 948, 930.)

$\mathrm{He}$ further states that some thirty to thirty-five per cent of his patients are not of the hereditary class. (Fol. 953.)

In his opinion, in which Dr. Bernstein concurs, the unsexing of the individual leads to more promiscuous illicit intercourse.

Beginning at folio 934, he says:

"I feel that sterilization would enormously increase the likelihood of illicit sex intercourse. I believe that with the female the fear of impregnation, in the case of very many-I say this without disrespect-but in the case of very many women is a deterrent to illicit sex intercourse, and with that restraint removed $I$ believe there would be an enormous increase in the intercourse of women so operated upon. In fact, that has been before the committees of our legislature for the last six or seven years, and I have given that as my principal reason, or one of the principal reasons, for my opposition to the whole principle of sterilization. On the other hand, the sterilization of male patients which renders them incapable of impregnating women would have the same effect in that it would cause girls and women to feel that intercourse with that man was absolutely safe and could be indulged in without any of the fear of detection, which is within a certain class of women the only thing which keeps them from promiscuous sex relations. ** $*$ I had one female patient who was a girl of 17 , who was taken home by the overseer of the poor of a certain town and subjected to the operation of ovariotomy. She had been a public charge up to the time because of the fear of the town officials that she would bring other children into the world. After the operation she was turned over to her mother and told that as there was no longer any danger of her having children the town would no longer assume responsibility. That girl immediately-her mother was a working woman and was not able to safeguard her and not able to watch her-and I was visited in about three months by the clergyman and physician of that village, who told me that that morning their children, a boy of five and a girl of seven, had peeped through a picket fence, with other children, and watched a line of boys who in turn had sex intercourse with this sterilized feeble-minded girl. The physician told me that he thought that very many of the boys and young men in that town had intercourse with her. That she had acquired gonorrhea and that she transmitted gonorrhea to a very large number of the boys, who in turn had infected other girls and women, and that there was an epidemic of gonorrhea in that little village from the sex relations with this one girl. That was a rather remarkable opportunity to judge of some of the possibilities of the presence in the community of women who were known to be incapable of becoming pregnant. Of course that is partly social. The fact that she was sterile made the authorities feel that it was not a matter for them. I have no doubt that that fact influenced her mother somewhat in being willing to allow her to be exposed as she was. I have no doubt it was a factor in making those boys and men feel that intercourse with her was fairly safe. I have always felt that the danger of the transmission of venereal diseases would be enormously increased if we should sterilize large numbers of boys and girls, men and women, and allow them to be at large, for those reasons."

Supporting the observation of Dr. Fernald, Dr. Bernstein testified at folios 478-479:

" $Q$. Has it been your observation, Doctor, that the probability of offspring is deterrent to illicit intercourse? A. Yes, sir.

"Q. So that among a class of persons such as you describe, namely, persons among whom the operation of sterilization has been performed, you would expect to find increased intercourse, would you not? A. Oh, decidedly.

"Q. And increased illicit intercourse is a promoter of disease and of idleness, is it not? A. It is very commonly recognized as that." 
On cross-examination, Dr. Thomson, of the Board of Examiners, testified, beginning at folio 230 :

"Now, Doctor, the performance of the operation of vasectomy is not an interference with the sensation incident to cohabitation? A. It is not.

"Q. So that a feeble-minded individual or any other individual upon whom the operation of vasectomy might be performed would be equally desirous to have intercourse? A. He would be deprived absolutely of nothing than power to procreate.

" $Q$. And one of the purposes of the performance of this operation upon inmates of State charitable institutions is that they may be safely allowed their liberty and not kept in enforced segregation from females? A. Yes, sir.

"Q. There is a menace to society from illicit intercourse and from intercourse between individuals under unsanitary conditions, is there not? A. Yes, sir.

" $Q$. And that condition, and that of venereal diseases is a serious menace to the future of the race, is it not? A. Why, yes, sir; those who get it.

"Q. Then so far as any benefit might come in the direction of the venereal disease wouldn't be affected one way or the other by this operation? A. No effect whatever.

"Q. The sole benefit then it is claimed by your Board for this operation is that it prevents procreation of persons liable to feeblemindedness? A. Yes, sir."

Manifestly an increase of illicit intercourse means an increase in venereal and other diseases, including syphilis, with the resulting increase in the number of feeble-minded. On this phase, Dr. Fernald testified, at folio 930:

"The evidence which has been obtained by the use of the modern blood reactions show that different observers have found from ten to thirty per cent of the inmates of our institutions for the feeble-mindeded are feebleminded because of the congenital syphilis which they inherited from their parents."

In matter of Jacobs ( $98 \mathrm{~N}$. Y., 98 ) a statute entitled, "An Act to improve the Public Health by prohibiting the manufacture of cigars and the preparation of tobacco in any form in tenement houses in certain cases and regulating the use of tenement houses in certain cases," was held unconstitutional upon the ground that the court was not able to see in the law a sufficient adaptation to the end claimed.
In other words, the proposition resolves itself into this: Is not the proposed remedy fraught with more danger than the disease itself?

It seems quite certain that the right to trial by jury is denied by this statute. The procedure is not clearly indicated therein. Apparently a majority of the Board may appoint one of its members to perform the operation on a selected criminal or defective inmate of state institutions after an examination into the mental condition, record and family history. The Board then applies to a judge of the Supreme Court or a county judge to appoint counsel; such counsel "to act at a hearing before the judge and in any subsequent proceedings." Then an order may be made by the Board for the operation, which orders are subject to review "by the Supreme Court or any justice thereof." In what manner this review is to be had is not set forth in the statute, but in the absence of any provision for submitting the questions to be reviewed to a jury it would seem that the method must be either by appeal or by certiorari based upon the "record taken upon the examination." The absence of the right to trial by jury would seem to make this statute objectionable as being a Bill of Attainder.

The important decisions dealing with the general question of constitutionality of laws of this character are:

Smith vs. Board of Examiners, 85 N. J. Law, 146; 88 Atlantic Rep., 963.

Davis vs. Berry, 216 Fed. Rep., 413.

The only other decision, so far as we have been able to ascertain, is that of State vs. Feilen (70 Wash., 65; 126 Pac. Rep., 75.) An examination of this last case shows that the only constitutional question considered is that of cruel and unusual punishment, and for reasons heretofore pointed out in this brief, it seems wholly inapplicable to Osborn's situation.

The respondent refrains from a discussion of the first two cases above, not because of a belief in their lack of importance, but because of a belief that by reason of their very great importance this court will desire to examine the reported decisions in their entirety, rather than to accept such portions thereof as counsel might select for insertion within the limitations of a brief of reasonable length.

Among the cases upon which the appellants rely are Matter of Viemeister (179 N. Y., 235), and Jacobson vs. Commonwealth 
of Massachusetts (197 U. S., 11). These cases deal with vaccinations as a health proposition and to avoid the spread of a contagious disease involving no loss or destruction of natural power, physical ability or of a function of life.

We submit the following taken from the brief filed by the complainant in Smith vs. Board of Examiners (supra):

"Medicine is admittedly an uncertain science, it is to a large degree experimental and theoretical, for it deals with the mystery of life, death and the infinite phenomena of physical production and -reproduction and nothing short of infinite knowledge should be taken as absolute authority when we undertake to finally determine the source of human imperfections, mental and physical.

"There is and can be no guarantee that this or that disease is incurable and never will be curable or is necessarily transmittible from one generation to another.

"There can be no definite line drawn to make a division line between the healthy and the unhealthy, the normal and the abnormal, for no human is perfect either in mind or body. We are sick or well, sane or insane by comparison only.

"This act applies only to those confined in institutions of the State and does not include any of its subjects who may be similarly afflicted who are at large. It is, therefore, directed at a particular class of unfortunates who, by reason of their confinement alone, are denied the usual pursuits of happiness, and the ordinary opportunity of procreation and sexual enjoyment. They, however, have forfeited no constitutional right.

"There is no immediate danger to society for owing to their present situation the possibility of the social evil in mind is remote and contingent. It seems a dangerous innovation to give any board or constituted authority, created by legislative enactment only, the power to physically harm one of the State's subjects under less safeguard and formality than is required to inflict a penalty upon criminals who have violated the rules of society and forfeited its protection.

"The victims of the operation of this law are unfortunates merely-heirs, perhaps, of the transgressions of others, they have not wronged society, they bear the penalties of an effete civilization, are mentally and physically helpless, the wards of the State."

An article written by Mr. Charles A. Boston of the New York Bar and published in the Journal of Criminal Law and Criminology, in the issue of September, 1913, contains such an able, interesting and exhausting argument upon the question of sterilization that we take the liberty of attaching the same as an appendix to this brief.

The respondent contends that the judgment of the Special Term should be affirmed, with costs.

Respectfully submitted, ELLIS J. STALEY, Attorney for Plaintiff-Respondent.

J. S. FROST,

Of Counsel.

b. Decision of Appellate Division of Supreme Court.

July 1, 1918.

"Judgment unanimously affirmed as the opinion of Rudd, J., at special term."

4. COURT OF APPEALS. (Adv. Sheets No. 950, March 15, 1919.

PRINCIPAL DOCUMENTS.

a. Brief on Behalf of Defendants-Appellants, by Merton E. Lewis, AttorneyGeneral. Argued by Wilber W. Chambers, Deputy Attorney-General.

\section{IN THE}

\section{COURT OF APPEALS \\ OF THE}

STATE OF NEW YORK.

FRANK OSBORN,

$$
\text { against }
$$

Plaintiff-Respondent,

LEMON THOMSON, and others, composing the Board of Examiners of Feeble-Minded Criminals and other Defectives,

\section{Defendants-Appellants.}

This is an appeal by the Board of Examiners of Feeble-Minded, Criminals and other Defectives from the judgment of the Appellate Division of the Supreme. Court, entered herein in the office of the clerk of said Appellate Division on July.5, 1918, affirming a judgment entered in this action on March 8,1918 , in the office of the clerk of Albany County, perpetually enjoining and restraining the defendants from performing an operation on plaintiff for the prevention of procreation (fols. 1068-1075, 1079-1080, 10981107).

Chapter 445 of the Laws of 1912, which is now Article XIX of the Public Health Law, Sections $350-353$, created a Board of 
Examiners of Feeble-Minded Criminals and other Defectives.

The defendants in the above-entitled action compose the said Board.

This action was brought by plaintiff against the defendants for an injunction restraining them from performing or causing to be performed an operation upon him to prevent procreation which it is alleged they had threatened to perform.

The complaint alleges that Chapter 445 of the Laws of 1912 in many respects violates the Constitution of the United States, particularly in that it violates Section 10 of Article I, being a Bill of Attainder, and an ex post facto law; subdivision 3 of Section 2 of Article III in depriving citizens of a trial by jury; Section 2 of Article IV in depriving citizens of the State of New York of the privileges and immunities to which citizens of other states are entitled; Article V of the amendments to the State Constitution in compelling a citizen to be a witness against himself and depriving citizens of life, liberty and property without due process of law; Article VIII of said amendments in authorizing the infliction of cruel and unusual punishment; Section 1 of Article XIV of said amendment in abridging privileges and immunities of citizens and depriving persons of life, liberty and property without due process of law, and denying to persons within its jurisdiction the equal protection of the laws.

In the proceeding which was instituted under said statute, Mr. Ellis J. Staley was appointed by the court as required by statute, to represent said Frank Osborn, and the court fixed a day in the order made on June 2,1915 , for a hearing on the advisability of performing an operation for the prevention of procreation, in pursuance of said statute.

This action and the proceeding under the statute were consolidated by agreement between the attorneys for the respective parties. The stipulation to this effect provided:

"That any and all evidence there produced upon said hearing and upon said trial-shall be deemed to have been taken and received so far as the same may be properly applicable thereto in both of said hearings and upon said trial, and that both said hearings and said action may be prosecuted by filing a determination in the same manner as if such evidence had been separately taken and received therein."
The question involved is one of law. The testimony was taken in order that the court might have the benefit of the opinions of men who had made a study of the subject.

Mr. Justice Rudd, at Trial Term, wrote an opinion (pp. 202-216) in which he reached the conclusion that Osborn was denied the equal protection of the laws.

\section{POINT I.}

THE WEIGHT OF EVIDENCE PRODUCED UPON THE TRIAL IS TO THE EFFECT THAT THE OPERATION PRESCRIBED IN THE STATUTE WILL BE BENEFICIAL TO SOCIETY AND THE PERSON OPERATED UPON AND WOULD PROBABLY SAVE THE STATE A VAST AMOUNT OF MONEY.

On this head the evidence of Dr. Thomson, a member of the Board of FeebleMinded Examiners, was to the effect that he had made a careful examination of Osborn (fols. 118-120) and his family history (fols. 120-153-154), and that from his investigation, the Osborn family alone had cost the State upwards of $\$ 10,000$ to maintain (fol. 154).

He further testified, as did also Dr. Andrews, that no harm would come to Osborn from the operation (fols. 156-157, 290-292).

Doctors Thomson and Andrews very carefully described the operation which they intend to perform on Osborn-that of vasectomy, which is the operating for sterilizing males to prevent procreation. It is a minor operation in a male and not serious, and from observation, no ill effects come from it (fols. 157-168, 288-290).

The weight of the evidence is to the effect that vasectomy would absolutely prevent procreation (fols. 249-252, 288), and that it is a desirable thing to do in cases of feebleminded persons.

Dr. Bernstein testified that the proportion of feeble-minded in this State is one to every five hundred or one to every three hundred and fifty persons. That is, there is one mental defective to every five hundred or every three hundred and fifty normal individuals, and there are over 32,000 feebleminded persons in this State (fols. 371-372). There are 10,000 feeble-minded persons under State care, and it costs the State $\$ 1,766,000$ to care for them, or at the rate of $\$ 176.60$ per person (fol. 372-373). Dr. Bernstein said that there were not as many as 10,000 cared for in New York in State institutions, but 
there were 6,000 in State and county institutions, and that the cost of these was from $\$ 150$ to $\$ 225$ a person (fols. 374-375). In his institution alone there were 1,570 patients.

Dr. Davenport, who is connected with the Carnegie Institution of Washington, and who has made a study of heredity and feeblemindedness (fol. 580), testified:

"I have long felt that sterilization laws as they have been enacted by the different states, are premature, because in advance of public sentiment now. On the other hand, I would say, on broad theoretical grounds, I think that the state has a right to prevent procreation, as it has, or does, the right of every one of the functions of the individual, including his life and his liberty. A state which limits itself in its control of the individual is weak, and such limitations tend to destroy society. I' hold it to be a loftier duty of the state to protect the happiness of the children and adults of the next generation than to protect from assault adults of this generation. I am inclined to think it better, now that the law has been put on the statute books, to retain or amend it, and act conservatively under it."

Dr. Bleecker Van Wagenen, who testified on behalf of Osborn, said that he was in favor of the operation, where he would get the consent of those who were to be operated upon. He said:

"I don't say that I would continue that always and forever, but at this present state, to my mind, it is of the utmost importance to the future, that it should for the present. Now, that does not necessarily mean that they cannot do any cases. Quite to the contrary, some hundreds of cases have been done and are continuing to be done under that basis in California, on various types of insane, feeble-minded and epileptics, and so far as I have been informed, at this comparatively late date, they have not performed compulsory operations, but several hundred of the kind through first investigating the family line, *** and persuading them all, including where it is possible the patient himself or herself, whatever the case may be, that that is a good thing to do, and then performing the operation." (Fols. 813814).

Dr. Fernald, called on behalf of Osborn, in speaking of the effect of the operation on the patient, testified:

"I doubt if the operation of vasectomy, if it was safeguarded by proper mental prepara- tion, which would undoubtedly be given, would have any effect whatsoever, so far as that is concerned." (Fol. 923.)

So, in the main, the doctors and experts agree that the operation, which is known as a minor one, and which merely consists, ir the male, of severing the spermatic duct, is a simple operation, not necessary to give an anæsthetic, and could be performed withour the use of cocaine even, and the patient suffers no more pain than that of a pinch. The patient would not be confined to his bed.

In the female, the operation is not 'sc simple, but would not be attended with seriousness (Fols. 166-167). The operation in the female is performed by the excision of a small portion of the heel of the Fallopian tube and is not severe. The evidence established that the operation does prevent, as Dr. Thomson testified, procreation.

\section{POINT II.}

THE STATUTE DOES NOT VIOLATE THE CONSTITUTIONAL RIGHTS OF THE PERSON UPON WHOM THE OPERATION IS TO BE PERFORMED.

In our researches we have been able to find only three cases on the subject. Two seem to be against the validity of the law, while one is in favor of it. The AttorneysGeneral of both California and Connecticut have upheld the constitutionality of such a law in opinions (see appendix to this brief).

The cases we have in mind are Smith vs. Board of Examiners, 85 N. J. Law, 146; Davis vs. Berry, 216 Fed. Reporter, 413. Those two are against similar legislation.

The case of the State vs. Feilen, 41 Lawyers' Reports (N. S.), 418, also reported in 70 Wash. 65, 165 Pacific, 75, favors the law.

But these cases, we urge, are not decisive of the question here. It seems to us that the constitutionality of the statute should be upheld, as being a proper exercise of the police power, in promotion of the health laws of the State.

In the case of Davis vs. Berry, supra, the court had before it an Act of the Iowa legislature, requiring the performance of the operation of vasectomy on criminals who had been twice convicted of a felony. The District Court distinctly held that the law in question was not void by reason of its being ex post facto, but did condemn the law 
because it denies the right of a hearing, and that depriving him of the right to be heard took away the right he had under the Constitution to have his day in court, which meant due process of law. The law was not absolutely condemned more than to say that it was the opinion of the court that vasectomy provided the infliction of a cruel and unusual punishment.

In the case of Smith vs. Board of Examiners of Feeble-Minded Persons, of New Jersey, the court condemned the law, which provided for surgical operations for the prevention of procreation upon feeble-minded persons, because the statute was based upon a classification that bore no reasonable relation to the subject of police regulation, and hence denied to the individual of the class so selected the equal protection of the law, granted by the Fourteenth Amendment to the Constitution of the United States. The condemnation of the law as being an improper classification was directed against that part of it which required the operation to be performed upon inmates confined in the several charitable institutions in the counties and State.

The learned judge pointed out that, "If such object requires the sterilization of the class so selected, then a fortiori does it require the sterilization of the vastly greater class who are not protected from procreation by their confinement in state or county institutions."

The learned judge concluded: "The conclusion we have reached is that, without regard to the power of the State to subject its citizens to surgical operations, that shall render procreation by them impossible, the present statute is invalid, in that it denies to the prosecutrix of this writ the equal protection of the laws to which, under the Constitution of the United States she is entitled."

In the case of the State vs. Feilen, the court upheld the right of the State to sterilize by means of vasectomy persons convicted of statutory rape, and the learned judge who wrote for the court has covered the ground so thoroughly that we quote liberally therefrom:

"On the theory that modern scientific investigation shows that idiocy, insanity, imbecility, and criminality are congenital and hereditary, the legislatures of California (Stat. 1909, p. 1093, Chap. 720), Connecticut (Pub. Laws 1909, Chap. 209), Indiana (Laws 1907, Chap. 215), Iowa (Laws 1911. Chap.
129), New Jersey (Laws 1911, Chap. 190), and perhaps other states, in the exercise of the police power, have enacted laws providing for the sterilization of idiots, insane, imbeciles, and habitual criminals. In the enforcement of these statutes vasectomy seems to be a common operation. Dr. Clark Bell, in an article on hereditary criminality and the asexualization of criminals, found at page 134, Vol. 27, Medico-Legal Journal, quotes with approval the following language from an article contributed to Pearson's Magazine for November, 1909, by Warren W. Foster, senior judge of the Court of General Sessions of the Peace of the County of New York: "Vasectomy is known to the medical profession as "an office operation," painlessly performed in a few minutes, under an anæsthetic (cocaine), through a skin cut half an inch long, and entailing no wound infection, no confinement to bed.' 'It is less serious than the extraction of a tooth,' to quote from Dr. William D. Belfield, of Chicago, one of the pioneers in the movement for the sterilization of criminals by vasectomy, an opinion that finds ample corroboration among practitioners. ***There appears to be a wonderful unanimity of faroring opinion as to the advisability of the sterilization of criminals and the prevention of their further propagation. The Journal of the American Medical Association recommends it, as does the Chicago Physicians' Club, the Southern District Medical Society, and the Chicago Evening Post; speaking of the Indiana Law, says that it is one of the most important reforms before the people, that 'rarely has a big thing come with so little fanfare of trumpets.' The Chicago Tribune says that 'the sterilization of defectives and habitual criminals is a measure of social economy.' The sterilization of convicts by vasectomy was actually performed for the first time in this country, so far as is known, in October, 1899, by Dr. H. C. Sharp, of Indianapolis, then physician to the Indiana State Reformatory, at Jeffersonville, though the value of the operation for healing purposes had long been known. He continued to perform this operation with the consent of the convict (not by legislative authority) for some years. Influential physicians heard of his work and were so favorably impressed with it that they indorsed the movement, which resulted in the passage of the law now upon the Indiana statute books. Dr. Sharp has this to say of this method of relief to society: 'Vasectomy consists of ligating 
and resecting a small portion of the vas deferens. This operation is, indeed, very simple and easy to perform; I do it without administering an anæsthetic, either general or local. It requires about three minutes' time to perform the operation, and the subject returns to his work immediately, suffers no inconvenience, and is in no way impaired, for his pursuits of life, liberty, and happiness, but is effectively sterilized.'

"Must the operation of vasectomy, thus approved by eminent scientific and legal writers, be necessarily held a cruel punishment under our constitutional restriction, when applied to one guilty of the crime of which appellant has been convicted? Cruel punishments, in contemplation of such constitutional restriction, have been repeatedly discussed and defined, although we have not been cited to, nor have we been able to find, any case in which the operation of vasectomy has been discussed."

The court held the punishment was not cruel and inhuman and upheld the law.

Appended to this brief, the court will find the opinion of Attorney-General Webb of California by his deputy, R. C. Van Fleet, upholding the constitutionality of the Sterilization law of that state (Stat. 1909, p. 1093, Chap. 720) and the opinion of AttorneyGeneral Light of Connecticut, in favor of the constitutionality of the same kind of law of that state (Pub. Laws Connecticut, 1909, Chap. 209).

These opinions so fully cover the ground that we use them as a part of our brief and in that way simplify the extent of our argument.

\section{POINT III.}

THE LAW IN QUESTION IS A VALID EXERCISE OF THE POLICE POWER AND DOES NOT OFFEND THE CONSTITUTION.

For the convenience of the court we shall divide this point into various subheads.

\section{(1) POLICE POWER.}

The police power is an attribute of sovereignty which is possessed by every sovereign state and is a necessary attribute of every civilized government.

Judge Cooley defines police power of a state as that which "embraces its whole system of internal regulation, by which the state seeks not only to preserve the public order and to prevent offenses against the state, but also establish for the intercourse of citizens with citizens those rules of good manners and good neighborhood which are calculated to prevent conflict of rights, and to insure to each the uninterrupted enjoyment of his own so far as is reasonably consistent with a like enjoyment of the rights of others."

This definition has been quoted with approval many times.

Hathorn vs. Natural Carbonic Gas Co. 194 N. Y., 326, p. 344.

By means of this power the Legislature exercises supervision over matters involving the common weal and enforces the observance by each individual member of society of the duties which he owes to others and to the community at large.

People vs. King, 110 N. Y. 418.

The courts have been unable or unwilling to definitely describe a rule that may be followed which will cover all cases, but instead have determined as each case is presented whether it falls within or without the appropriate limits.

People vs. Budd, 117 N. Y. 1.

With this very brief reference to the police power, suffice it to say that it has been defined as the law of necessity and as the power of self protection on the part of the community.

State of Wis. vs. Redmon, 14 L. R. A. (N. S.), 229.

(2) OVER WhAt SUBJECTS GENERALLY THE POLICE POWER EXTENDS.

One of the most important fields of legislation in which the State may enact measures under the police power, consists of regulations in the interest of public health and safety.

Jacobson vs. Massachusetts, 197 U. S. 1: For instance, it has been held that law: may be passed providing for drainage ans sewer systems. (New Orleans Gas Light Co. vs. Drainage Com., 197 U. S. 453).

Requiring the owners of a lot which has been declared to be dangerous to the public health to fill it up to a certain level. (Charlestown vs. Werner, 38 S. C. 488.)

Making it a penal offense to discharge any refuse matter in a running stream. (People vs. Hupp, 53 Colo., 80, 123 Pac. 651.)

Forbidding a riparian owner on a pond from which a municipal water supply is taken, to bathe in the pond. (State vs. Morse, 84 Vermont 387.)

For bidding any one to make use of, for the purpose of drinking, of polluted water 
supply. (State Board of Health vs. St. Johnsbury, 82 Vermont, 276.)

Providing for the collection and removal of refuse in thickly populated cities. (State vs. Robb, 100 Me. 180.)

Establishing quarantine regulation notices to owners of live stock. (Kimmish vs. Ball, 129 U. S. 217.)

Providing for the destruction of noxious weeds. (St. Louis vs. Galt, 179 Mo. 8.)

Providing for the destruction of trees attacked by incurable infectious diseases. (State vs. Main, 69 Conn. 123.)

For regulation in behalf of public morals like the suppression of gambling. (Ah Sun vs. Wittman, 198 U. S. 500.)

For the prevention of fraud and deceit. (People vs. Freeman, 242 I11. 373.)

To regulate skill and learning in professions. (Dent vs. State of W. Va., 129 U. S. 114.)

To enact laws in the promotion of the general welfare. (Chicago, B. and Q. R. R. Co. vs. Illinois, 200 U. S. 561.)

It may enact laws to preserve and promote the public welfare even at the expense of private rights. (Walker vs. Jameson, 114 Ind. 591.)

An important class of statutes sustained as tending to promote the public welfare are those which relate to physical welfare of the members of the body politic. It has been said that it is to the interest of the State to have strong, robust, healthy citizens, capable of self-support, of bearing arms and adding to the resources of the country. Laws for this purpose are made for the protection of citizens from overwork and requiring a general day of rest to restore his strength and preserve his life for the obvious protection of the public welfare.

Holden vs. Hardy, 169 U. S. 366.

People vs. Havnar, 149 N. Y. 195.

And so we might go on with many more cases which cover the police power, and which cases have been held to be valid.

(3) THE - ACT IN QUESTION DOES NOT OFFEND BECAUSE IT IS AN EX POST FACTO LAW.

This was clearly held in Davis vs. Berry (supra).

The Relator Says It Deprives Him of His Life and Liberty Without Due Process of Law.

But it is fundamental that the possession and enjoyment by the individual of all of his rights, even that of liberty itself, are subject to such reasonable regulations and restraints as are essential to the preservation of health, safety and the welfare of the community.

\section{People vs. Morse, 84 Vermont 387.}

(4) THE RELATOR SAYS IT DEPRIVES HiM OF HIS LIBERTY AND THE EQUAL PROTECTION OF THE LAWS.

It has been repeatedly said that the guarantee of equal protection of the laws means that no persons or classes of persons shall be denied the same protection of the laws which is enjoyed by other persons or other classes under like circumstances and their rights, liberty and property, and in the pursuit of happiness.

Santa Clara County vs. So. Pacific R. R. Co., 118 U. S. 394.

Moore vs. Missouri, 159 U. S. 673.

The act in question operates against all feeble-minded, epileptics, criminals and other defective inmates confined in State institutions.

It has been held that the State may classify persons and objects for the purpose of legislation so long as the classification is based on proper and justifiable distinction.

Chicago, M. and St. Paul R. R. Co. vs. Westby, 178 Fed. 619.

And the legislature has a right to discriminate amongst those persons and to limit the application of its laws to a portion of them only.

Grainger vs. Douglass Park Jockey Club, 148 Fed. 513.

The law will be upheld so long as it operates alike on all persons and property similarly situated.

Barbier vs. Connell, 113 U. S. 27.

It does so operate here-on all persons confined in State institutions, etc.

Therefore, it seems to us the classification is reasonable and should be held to not offend the provisions of the Constitution denying relator the equal protection of the laws.

(5) THE STATUTE DOES NOT DEPRIVE OSBORN OF. HIS LIFE, LIBEETY AND PROPERTY WITHOUT DUE PROCESS OF THE LAW.

The statute specifically gives him notice and opportunity to be heard through an attorney to be appointed by him and to thus defend the proceedings.

That is all that the law requires to be done. 
Simon vs. Craft, 182 U. S. 427.

We urge that the law in question may be likened unto that which requires compulsory vaccination as a condition of the privilege of attending public schools. Such legislation has been upheld.

Matter of Viemeister, 179 N. Y. 235.

Jacobson vs. Massachusetts, 197 U. S. 11. In the case of Matter of Viemeister (supra), Section 210 of the Public Health Law which excluded children and persons not vaccinated from the public schools until vaccinated, was attacked on the ground that it violated the constitution.

To sustain the law in question here we call the court's attention to the decision of the Court of Appeals in that case in an able opinion written by Judge Vann in 1904. The attack on the law was that it violated the Constitution which guarantees the rights, privileges and liberties of its citizens, but the Court of Appeals sustained the statute as a valid exercise of police power.

Judge Vann said (p. 238):

"The police power, which belongs to every sovereign state, may be exerted by the legislature subject to the limitations of the Constitution, whenever the exercise thereof will promote the public health, safety or welfare. The power of the legislature to decide what laws are necessary to secure these objects is subject to the power of the courts to decide whether an act purporting to promote the public health or safety has such a reasonable connection therewith as to appear upon inspection to be adapted to that end. A statute entitled a health law must be a health law in fact as well as in name, and must not attempt in the name of the police power to effect a purpose having no adequate connection with the common good. As we have recently said, it 'must tend in a degree that is perceptible and clear towards the preservation of the *** health *** or welfare of the community, as those words have been used and construed in the many cases heretofore decided.' (Health Dept. of N. Y. vs. Rector, etc., 145 N. Y. 32, 39.) When the sole object and general tendency of legislation is to promote the public health, there is no invasion of the Constitution, even if the enforcement of the law interferes to some extent with liberty and property. These principles are so well established as to require no discussion, and we cite but a few of many authorities relating to the subject.
"The fact that the belief is not universal is not controlling, for there is scarcely any belief that is accepted by every one. The possibility that the belief may be wrong and that science may yet show it to be wrong is not conclusive, for the legislature has the right to pass laws which, according to the common belief of the people, are adapted to prevent the spread of contagious diseases. In a free country where the government is by the people through their chosen representatives, practical legislation admits of no other standard of action, for what the people believe is for the common welfare must be accepted as tending to promote the common welfare, whether it does in fact or not. Any other basis would conflict with the spirit of the Constitution and would sanction measures opposed to a republican form of government.

"While we do not decide and cannot decide that vaccination is a preventive of smallpox, we take judicial notice of the fact that this is the common belief of the people of the State and with this fact as a foundation, we hold that the statute in question is a health law, enacted in a reasonable and proper exercise of the police power. It operates impar. tially upon all children in the public schools and is designed not only for their protection but for the protection of all the people of the State. The relator's son is excluded from school only until he complies with the law passed to protect the health of all, himself and his family included. No right conferred or secured by the Constitution was violated by that law or by the action of the school authorities based thereon."

We respectfully submit that that part of the health law in question tends to promote the welfare of the community and protect the public health and hence, is a valid exercise of the police power.

In deciding the questions here involved, we call the court's attention to the fact that in a number of cases the judicial branch of our government has held that the presumption is always in favor of the constitutionality of the statute.

People vs. West, 106 N. Y. 293.

And the courts have gone so far as to pronounce that in no doubtful case should they determine legislation to be contrary to the Constitution.

Munn vs. Illinois, 94 U. S. 113. 
And that the courts will resolve every reasonable doubt in favor of the validity of the enactment.

Sinking Fund Cases, 99 U. S. 700, on p. 718.

POINT IV.

THE JUDGMENT APPEALED FROM SHOULD BE REVERSED AND THE STATUTE HELD CONSTITUTIONAL.

Dated, September 30th, 1918.

Respectfully submitted,

MERTON E. LEWIS,

Attorney-General,

Attorney for Defendants.

WILBER W. CHAMBERS,

\section{Deputy Attorney-General,} Of Counsel.
Appendix:

This brief was accompanied by the opinion of the Attorney-General of California upholding the validity of the sterilization statute of that state. (For full text of the opinion see Chapter IX, Sec. 1.)

b. Case pending at time of repeal of statute.

Pending decision by the Court of Appeals, the legislature of the State of New York repealed the statute on May 10, 1920 (Chapter 619 of the Laws of 1920).

Upon this repeal the questions involved became purely academic and the appeal in the Court of Appeals was withdrawn. Thus the litigation in the matter of eugenical sterilization in the State of New York, based upon the Law of 1912 (Chapter 445), never received a final judicial opinion of the highest court of the state. 


\section{CHAPTER VII. (Continued)}

PART VI. NEVADA.

1. District Court of the Fourth Judicial District of the State of Nevada.

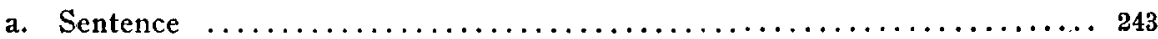

2. United States District Court in and for Nevada.
a. Petition of Plaintiff.
b. Order to Show Cause and Restraining Order 247
c. Answer 248
d. Stipulation. 249
e. Plaintiff's Brief 249
f. Decision of United States District Court. 250 


\section{(VI.) NEVADA.}

(Section 28, Crimes and Punishments, Act March 17, 1911.)

The Nevada statute is copied after the first law of the State of Washington. The fact that the first Washington statute was upheld and that of Nevada held invalid was due to differences in the constitutions of the two states; that of Washington forbids cruel punishment while the Nevada Constitution forbids cruel and unusual punishment.

\section{DISTRICT COURT OF THE FOURTH JUDICIAL DISTRICT OF THE STATE OF NEVADA.}

On August 14, 1915, in the District Court of the Fourth Judicial District of the State of Nevada, in and for Elko County, Pearley C. Mickle was sentenced to sterilization as a punishment for rape.

The principal documents in the case follow:

a. Sentence. August 14, 1915.

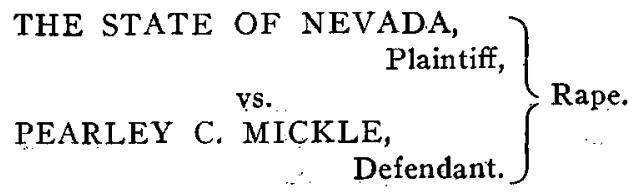

BE IT REMEMBERED, That on the 12th day of August, 1915, same being a regular judicial day of the District Court of the Fourth Judicial District of the State of Nevada, in and for Elko County, the aforementioned court being duly convened, with the regular officers thereof present, and the State represented by E. P. Carville, Esq., District Attorney, and C. A. Cantwell, Esq., Assistant District Attorney, the above mentioned defendant was duly brought before the court and sentenced by Hon. E. J. L. Taber, Judge of said court.

COURT: This is the time set for pronouncing judgment in the case of the State of Nevada, plaintiff vs. Pearley C. Mickle. Mr. Mickle, you may stand up. As you were informed before today, the District Attorney filed an information against you today charging you with the crime of rape, alleged to have been committed in the County of Elko, State of Nevada, on the 10th day of August, 1915. The information states that at that time and place you forcibly had carnal knowledge of a female, Mrs. George W. Fox, against her will and without her consent; you being then and there an adult male person. Upon your arraign- ment this morning you entered a plea of guilty to this information, and your plea was entered on the minutes of the court, and with your consent this was the time set for pronouncing judgment or sentence. Have you any legal cause to show why judgment should not now be pronounced against you?

DEFENDANT: No, sir, I haven't.

COURT: Is there anything you want to say, Mr. Mickle?

DEFENDANT: No, sir.

COURT: Will you state how old you are?

DEFENDANT: Nineteen.

COURT: Have you the discharge papers showing his age?

CARVILLE: Twenty-two; he was born in '93.

DEFENDANT: I enlisted when I was fifteen, but enlisted as eighteen. My mother and father has the birth certificate.

COURT: Your folks are living, $\mathrm{Mr}$. Mickle?

DEFENDANT: Yes, sir.

COURT: Where do they live?

DEFENDANT: Mother lives in Portland, Oregon, and father in New York.

COURT: Will you state what your father does?

DEFENDANT: A wagon maker.

COURT: Your mother is a good woman, is she?

DEFENDANT: Yes, sir.

COURT: How did you come to commit such a crime as this?

DEFENDANT: By drinking steady, and was just sobering up. When $\mathrm{I}$ am sobering up it drives me crazy. Whisky and wine puts me off my head.

COURT: You mean to say you were just sobering up after having been drunk?

DEFENDANT: Yes, sir, just sobering up.

COURT: Have you ever done anything of this kind before.

DEFENDANT: No, sir.

COURT: Anything like it at all?

DEFENDANT: No, sir, your Honor.

COURT: Have you always been a healthy person?

DEFENDANT: Yes, sir.

COURT: Did you ever have fits of any kind?

DEFENDANT: Epileptic fits.

COURT: Do you wish to vouch to me for that?. Do you assure me that is the truth? 
DEFENDANT: Yes, sir, that is the truth; I can prove it.

COURT: How long since you had one?

DEFENDANT: The last one I had was last March.

COURT: How many have you had?

DEFENDANT: I have had ten, I guess, in the last four years.

COURT: Anything like that in your family before, your father or mother?

DEFENDANT: Not that I know of. I have a cousin that has them.

COURT: You don't claim to be insane, do you, Mr. Mickle?

DEFENDANT: No, sir.

COURT: You don't pretend to be crazy: DEFENDANT: No, sir.

COURT: Well, now, I want to be perfectly fair with you. A man in your condition is under a strong temptation to tell lies.

DEFENDANT: I am not telling any lies, your Honor; I am telling the straight truth.

COURT: Sometimes a man tells a lie when he thinks it will help him, when it is against him and that may be the case with your epilepsy.

DEFENDANT: I can prove that.

COURT: Would you make that statement that you have epileptic fits if you knew it was going to hurt you with me instead of helping you?

DEFENDANT: No, sir, I wouldn't.

COURT: You mean you would tell a lie about it if you thought it would help you with me?

DEFENDANT: No, sir, I wouldn't.

COURT: Perhaps you do not understand me. Supposing you knew by telling me you had epileptic fits that I would punish you more than I would otherwise. That might seem strange to you, but supposing you knew that, would you still say you had them?

DEFENDANT: I have. That is the truth; hope to God to die.

COURT: Of course, Mr. Mickle, I wouldn't have you understand what the punishment is, but I don't mean to say when I remind you the court might inflict the death penalty on you, because the court cannot do it in this case, but it might affect you injuriously in some other way. And no matter whether it does or not, you still say that is the truth?
DEFENDANT: That is the truth, nope to God to die.

COURT: -Is there any place I could investigate your father or mother, or anybody else you would be willing to have me inquire of whether this is true or not?

DEFENDANT: Yes, sir.

COURT: Will you tell me their address?

DEFENDANT: Yes, sir, Mrs. Jennie Pounds, Ceres, New York.

COURT: Is that a small town or village?

DEFENDANT: A small village.

COURT: You don't need any street address?

DEFENDANT: No.

COURT: Is that your mother?

DEFENDANT: My aunt.

COURT: She knows that you had fits?

DEFENDANT: Yes, sir, I was there last March when $I$ had these fits.

COURT: And she is living, so far as you know, at this time?

DEFENDANT: She is living, as far as I know, at this time.

COURT: The court now considers and adjudges that you, by reason of your plea of guilty to this information, are guilty of the crime of rape, as therein alleged, and I do now pronounce the judgment and sentence of this court that for that crime you be imprisoned and confined in the state prison of this State, and the court fixes as a minimum of such confinement a period of five years; and the court fixes as a maximum the term and duration of your natural life. And at this time, by virtue of the provisions of 6293 Revised Laws-

Mr. Mickle, I am going to order that an operation be performed upon you. I want to tell you it is not the operation of castration. Do you know. what that means? It is not that: It is an operation which many hundreds of men have undergone and that we call baseptomy (vasectomy?) The operation does not take away the power of sexual intercourse, but it does take away the power of begetting children. I was not going to pronounce that sentence until $I$ found from you that you were subject to epileptic fits And I am going to put it in my judgment. I am going to give considerable time for that to be done, so it need not be done in a hurry, so the authorities at Carson will have plenty of time to investigate and see if you have told the truth. If they find that 
you have told the truth the operation may be performed. While I do not think you are entitled to very much sympathy, still I want to be fair with you and tell you that that operation is not one that causes much pain; in fact, the doctors say it is not so serious as having a tooth pulled, so far as the pain is concerned. Furthermore, they do not open your body to any extent; it is less than half an inch, and is an operation performed in a very few minutes. It doesn't have any such result upon you as castration would. I tell you this in advance so you may know the sentence the court is going to pronounce upon you.

The court further pronounces judgment, and orders, adjudges and decrees that an operation be performed upon you for the prevention of procreation; that said operation be performed within one year of the date of your incarceration in the state prison of this State by virtue of this judgment; that the operation to be performed, as hereby ordered, shall be the operation known to medical science as baseptomy (vasectomy?) or such other operation as shall be determined upon by the surgeon or surgeons who shall be designated to perform the same. And the warden of the said State Prison of the State of Nevada, is hereby directed to have this order and judgment carried into effect at the said state prison by some qualified and capable surgeon or surgeons; that said operation shall not consist of castration. And the court further orders that said operation shall be performed scientifically and with the greatest care and humanity possible.

Mr. Mickle, this court would not have ordered this operation if it had not been for your own statement that you are subject to epileptic fits. And I want you to understand further, that horrible and loathsome as your crime has been, that this operation is not ordered by this court for the purpose of increasing your punishment. The reason this court makes this order is that epileptic fits are hereditary and it is for' that reason. The court wishes to protect society against any offspring from you, is why this order is made. Is there anything you wish to say, Mr. Mickle?

DEFENDANT: No, sir.

COURT: Defendant is remanded.

\section{CERTIFICATE.}

I do hereby certify that on the 12th day of August, 1915, I was duly appointed, qualified and acting reporter of the Fourth Judicial District Court of the State of Nevada, in and for Elko County; that as such reporter, on said date, I took down in shorthand the proceedings had in the pronouncing of judgment and sentence on the defendant in the case of The State of Nevada vs. Pearley C. Mickle; that the foregoing, consisting of seven pages, inclusive, is a full, true, and correct transcript of said proceedings.

Dated, at Elko, Nevada, this 14th day of August, 1915.

B. H. WALTERS, Official Reporter.

ENDORSED: FOURTH JUDICIAL DISTRICT COURT OF STATE OF NEVADA, IN AND FOR ELKO COUNTY. THE STATE OF NEVADA, PLAINTIFF, VS. PEARLEY C. MICKLE, DEFENDANT. SENTENCE. TRANSCRIPT.

\section{THE UNITED STATES DISTRICT COURT.}

May 25, 1918. The United States District Court in and of Nevada held that the Nevada Act of March 17, 1911, provides for an unusual punishment and is therefore contrary to Section 6, Article I of the Constitution of Nevada.

PRINCIPAL DOCUMENTS.

a. Petition of Plaintiff.

Sentence of State District Court:

IN THE DISTRICT COURT OF THE UNITED STATES, IN AND FOR THE DISTRICT OF NEVADA.

PEARLEY C. MICKLE, vs. Plaintiff,

D. S. DICKERSON, as Warden of the Nevada State Prison, and DONALD T. MCLEAN, as Physician of the Nevada State Prison,

Defendants.)

Comes Pearley C. Mickle, the plaintiff above-named, by and through his attorneys, Woodburn \& Bartlett, Esqrs., and respectfully shows unto the above entitled court, the following:

I.

That the plaintiff is a citizen and resident of the State of Pennsylyania. 
II.

That the above-named defendants, D. S. Dickerson and Donald T. McLean, are respectively the warden and physician of the Nevada State Prison at Carson City, Nevada, and are citizens and residents of the State of Nevada.

\section{III.}

That on the 14th day of August, A. D. 1915, plaintiff herein was convicted in the Fourth Judicial District Court of the State of Nevada, in and for the County of Elko, of the crime of rape, and on said date was sentenced by the Hon. E. L. Taber, the judge of said court, to an indeterminate sentence of not less than five years in the Nevada State Prison; that at the time of pronouncing said sentence said court further ordered and directed, under the supervision and direction of the defendant, D. S. Dickerson, as warden of the said Nevada State Prison, that within one year from said date an operation be performed upon the person and body of the plaintiff herein to prevent procreation; said operation, as plaintiff is informed and believes, being commonly known and called the operation of vasectomy.

\section{IV.}

That said operation of vasectomy which will prevent procreation, was, by said Fourth Judicial District Court of the State of Nevada, in and for the County of Elko, ordered to be performed upon the person and body of petitioner under and by virtue of the provisions of Section 6293 of the Revised Laws of the State of Nevada, said section being as follows:

"Whenever any person shall be adjudged guilty of carnal abuse of a female person under the age of ten years, or of rape, or shall be adjudged to be an habitual criminal, the court may, in addition to such other punishment or confinement as may be imposed, direct an operation to be performed upon such person, for the prevention of procreation; provided, the operation so directed to be performed shall not consist of castration."

\section{V.}

That there is no other pretended authority, statutory or otherwise, in the State of $\mathrm{Ne}$ vada, permitting or authorizing the performance of said operation to prevent procreation upon the person and body of plaintiff, except as contained in said Section 6293 of the Revised Laws of the State of Nevada.
VI.

That petitioner is informed and believes, and upon such information and belief states the fact to be, that said operation of vasectomy so ordered by said Fourth Judicial District Court of the State of Nevada, in and for the County of Elko, consists of the ligation of the fallopian tube of the human body.

\section{VII.}

That said Section 6293 of the Revised Laws of the State of Nevada authorizing the performance of said operation which will prevent procreation is void and of no effect, and violates Section 6, of Article I of the Constitution of the State of Nevada, in that the punishment therein permitted and authorized is cruel and unusual; said Constitutional provision being as follows:

"Sec. 6: Excessive bail shall not be required, nor excessive fines imposed, nor shall cruel or unusual punishments be inflicted, nor shall. witnesses be unreasonably detained."

\section{VIII.}

That by virtue and in pursuance of the said order of said Fourth Judicial District Court of the State of Nevada, in and for the County of Elko, the defendant, D. S. Dickerson, as warden of said Nevada State Prison, has ordered and directed the defendant, Donald T. McLean, as physician of said Nevada State Prison, to perform said operation of vasectomy to prevent procreation upon the body and person of petitioner on the 31st of July, A. D. 1916, and petitioner alleges that said defendants will perform said operation unless restrained from so doing.

\section{IX.}

Plaintiff further shows to the court, and as an additional ground why said operation should not be performed, that the Honorable E. L. Taber, the judge of said Fourth Judicial District Court of the State of Nevada, in and for the County of Elko, ordered and directed the performance of said operation to prevent procreation, not as punishment of the crime of rape, as authorized by said Section 6293 of the Revised Laws of the State of Nevada, but for the reason that said defendant was an epileptic.

\section{$\mathrm{X}$.}

That there is no authority, statutory or otherwise, authorizing the performance of an operation to prevent procreation upon epileptics. 


\section{XI.}

That petitioner was never formally charged with being an epileptic, but was adjudged and decreed to be an epileptic without due process of law in contravention of the Fourteenth Amendment to the Constitution of the United States.

\section{X.II.}

That if said operation is performed, plaintiff will suffer great and irreparable injury.

WHEREFORE, plaintiff prays for an order restraining and enjoining the abovenamed defendants from the performance of said operation of vasectomy, or any other operation to prevent procreation upon the person and body of the plaintiff herein, and for such other and further relief as to this Honorable Court may seem meet and proper in the premises.

\section{WOODBURN \& BARTLETT,} Solicitors for Petitioner.

United States of America,

$\left.\begin{array}{l}\text { State of Nevada, } \\ \text { County of Washoe, }\end{array}\right\}$ ss:

William Woodburn, being first duly sworn, deposes and says that he is one of the solicitors for the plaintiff named in the foregoing petition; that he has read the said petition and knows the contents thereof, and that the statements therein made are true, according to his best information and belief; that he makes this affidavit because of the fact that the said Pearley C. Mickle, plaintiff above named, is absent from the County of Washoe, State of Nevada, and is now an inmate of the Nevada State Prison at Carson City, Nevada.

WILLIAM WOODBURN.

Subscribed and sworn to before me this 29th day of July, 1916 .

(Notarial Seal)

JONATHAN PAYNE,

b. Order to Show Cause and Restraining Order.

IN THE DISTRICT COURT OF THE UNITED STATES, IN AND FOR THE DISTRICT OF NEVADA.

Pearley C. Mickle, vs. Plaintiff,

D. S. Dickerson, as Warden of the $\mathrm{Ne}$ vada State Prison, and Donald T. McLean, as Physician of the Nevada State Prison,

Defendants.
On petition of the plaintiff, duly verified, it is

ORDERED, That the said defendant, D. S. Dickerson, as warden of the Nevada State Prison, and the said defendant, Donald $T$. McLean, as physician of said Nevada State Prison, show cause before this court, at Carson City, Nevada, on the "7th day of August, 1916, at ten o'clock a. m. of said day, why an injunction should not be granted restraining the said defendant, D. S. Dickerson, as warden of the Nevada State Prison, and the said Donald T. McLean, as physician of the Nevada State Prison, from performing an operation of vasectomy, or any other operation to prevent procreation upon the person and body of Pearley C. Mickle, and for such other and further relief as may seem meet and proper in the premises.

And it is further ORDERED, That said defendants, their agents, deputies and employes be, in the meantime, restrained from performing an operation of vasectomy, or any other operation to prevent procreation, upon the person and body of said Pearley $C$. Mickle on the thirty-first day of July, 1916, or at any other time, until further order of this court.

It is further ORDERED, That a copy of the petition filed herein, attached to a copy of this Order, be served upon the said defendant, D. S. Dickerson, as warden of the Nevada State Prison, and the said Donald T. McLean, as physician of the Nevada State Prison, from performing an operation of vasectomy, or any other operation to prevent procreation upon the person and body of Pearley C. Mickle, and for such other and further relief as may seem meet and proper in the premises.

And it is further ORDERED, that said defendants, their agents, deputies and employes be, in the meantime, restrained from permorming an operation of vasectomy, or any other operation to prevent procreation, upon the person and body of said Pearley $C$.

Mickle on the thirty-first day of July, 1916, or at any other time, until further order of this Court.

It is further ORDERED that a copy of the petition filed herein, attached to a copy of this Order, be served upon the said defendant, D. S. Dickerson, as Warden of the Nevada State Prison, and upon the said Donald T. McLean, as Physician of the said Nevada State Prison.

E. L. FARRINGTON,

Dated, July 29th, 1916. 
ANSWER.

\section{c. Answer of Defendants.}

IN THE DISTRICT COURT OF THE UNITED STATES, IN AND FOR THE DISTRICT OF NEVADA.

PEARLEY C. MICKLE, Plaintiff,
vs.

D. S. DICKERSON, as Warden of the Nevada State Prison, and DONALD $T$. McLEAN, as Physician of the Nevada State Prison, Defendants.

ANSWER.

Come now D. S. DICKERSON and DONALD T. McLEAN, defendants herein, by their attorney, GEO. B. THATCHER, Attorney-General of the State of Nevada, and for answer to the complaint herein admit, deny and aver as follows, to-wit:

I.

Admit all the matters and things contained in paragraphs I and II of said complaint.

\section{II.}

Admit that on the date mentioned in paragraph III of said complaint that plaintiff was convicted of the crime of rape as alleged in said paragraph, but allege that the sentence of said court was for not less than a minimum of five years and a maximum of life imprisonment, and admit all the other matters and things contained in said paragraph III of said complaint.

\section{III.}

Admit all the matters and things contained in paragraphs IV and V of said complaint.

\section{IV.}

In answer to paragraph VI of said complaint these defendants deny that the operation of vasectomy consists of the ligation of the fallopian tube of the human body, but allege that said operation is a resection of the vas deferens.

\section{V.}

In answer to paragraph VII of said complaint these defendants deny that the performance of said operation is a cruel and unusual punishment within the meaning of Section 6 of Article I of the Constitution of the State of Nevada.
VI.

Admit all the matters and things contained in paragraph VIII of said complaint.

\section{VII.}

Deny all the matters and things contained in paragraphs numbered IX, X, and XI of said complaint.

\section{VIII.}

Deny all the matters and things contained in paragraph XII of said complaint, and state that if said operation is performed, defendant will not suffer great or irreparable injury, or any injury at all.

IX.

Further answering said complaint, these defendants allege that the plaintiff herein has not legal capacity to bring this action for the reason that it appears from said complaint and defendants in this Answer allege that the plaintiff is an inmate of the Nevada State Prison and is lawfully confined therein under a judgment and sentence of a court of competent jurisdiction upon a criminal charge, which said sentence may extend in duration to the end of the natural life of said plaintiff, and that therefore the said plaintiff is civilly dead and is not entitled to sue, a full and true copy of which judgment and sentence is hereto attached, marked "Exhibit $A$ " and made a part hereof.

THEREFORE, having fully answered said complaint, these defendants pray that the restraining order herein may be vacated and set aside, and that they have judgment for costs in this behalf expended.

\section{Attorney-General.}

Attorney for Defendants.

State of Nevada,

County of Ormsby, ss:

DONALD T. McLEAN, being first duly sworn on oath, deposes and says: That he is one of the defendants herein; that he has read the above and foregoing Answer and that the same is true of his own knowledge, except as to the matters which are therein stated to be on information and belief, and as to those matters, he believes it to be true.

Subscribed and sworn to before me this ....... day of August, A. D. 1916.

Notary Public. 


\section{d. Stipulation.}

IN THE DISTRICT COURT OF THE UNITED STATES, IN AND FOR THE DISTRICT OF NEVADA.

PEARLEY C. MICKLE,
Plaintiff,
vs.
D. S. DICKERSON, as
Warden of the Nevada
State Prison, and DON- Stipulation.
ALD T. McLEAN, as
Physician of the Nevada
State Prison, Defendants.

It is hereby stipulated and agreed by and between the parties hereto that this action is submitted for determination by the judge of the above entitled court upon the sole question of the constitutionality of Section 6293, Revised Laws of Nevada, 1912.

It is further stipulated and agreed that if the judge of said court shall determine that said section of said laws is constitutional, then the above action be dismissed.

Signed by the Attorney for Plaintiff, and the Attorney for Defendant.

\section{e. Plaintiff's Brief.}

\section{CRUEL AND UNUSUAL PUNISH- MENT.}

It is not the barbarous or cruel or torturous bodily punishment, or its severity, but I wish to address myself more particularly to the unusual character of the punishment which is just as much within the prohibition of the constitutional provision as "cruel punishment."

The case upon which petitioner mainly relies, is that of Davis vs. Berry, 216 Federal, at pages 413 and 416 . Here the court lays down the rule in plain and unmistakable terms, that the operation of vasectomy, insofar as it offends the sense of decency and propriety of society, is on a par with castration.

The operation of castration was first provided in the Twelfth Century by Henry II, as a punishment for bringing any mandate from the Pope, or one in authority in church affairs, which was declared an act of treason.

Other similar punishments were the barbarities of quartering, hanging in chains, burning, acts similar to those provided by the Spanish Inquisition, all of which were intended by the framers of our Constitution to be banished for all time.

In the Berry case the court mentioned the fact that Blackstone made no mention in his Commentaries of the performance of the operation of castration for punishment, very likely, as the court stated, for the reason that even at that date, with the advance of civilization, it was so revolting and repugnant as to have no place in the cruel punishments of even that day.

In the Berry case reference is made to the case of State vs. Feilen, 126 Pacific, 75, which sustains the contention of defendant. Two grounds were raised in the Berry case, viz: That the Constitution was offended not only as to the cruel and unusual punishment clause; but that it also offended the due process of law clause.

The court, in the Berry case, in its reference to the Feilen case, merely distinguished it from the case under consideration as to the due process of law feature, and then, as will be observed, proceeded to hold the statute unconstitutional as being repugnant to the cruel and unusual clause.

(Quote from Whitten vs. State, 47 Ga., 297; cited in Weems vs. United States, 54 Law Ed. 813.)

"So long as they do not provide cruel and unusual punishments, such as disgraced the civilization of former ages and made one shudder with horror to read of them-quartering, burning, etc., the Constitution does not put any limit upon the legislative discretion."

State vs. White (Kans), 25 Pac. 33, cited in Weems vs. U. S., supra.

"Is the punishment usual in the community-seems to be the test. The provision goes to kind of punishment, not duration."

State vs. White, supra. Cited in Weems vs. U. S., supra.

In the cases above cited, it will be observed that the mere infliction of pain, or any act calculated to cause physical suffering is not the test. Independent of the inhibition against cruelty, the provision also mentioned the term "unusual."

It will be observed in the case of State vs. Feilen, that the Constitution of the State of Washington merely refers to the word "cruel," and the decision was based upon that ground.

I make the following suggestions of painless acts which, yet, would undoubtedly come within the terms of the constitutional inhibi- 
tion: Tattooing the brow; removal of an eye under an anæsthetic.

Again, it is clear that the infliction of capital punishment by means of hanging; although possibly causing some pain to the victim, yet is not unusual, and is not, according to the authorities, within the prohibition. However, to first chloroform the victim, and then burn him, would unquestionably be considered so revolting that no court would hesitate to pronounce it unconstitutional.

"The punishment of offenses by stripes is certainly odious, but cannot be said to be unusual."

Commonwealth vs. Wyatt, 6 Rand (Va.), 694.

Defendant's List of Authorities on Constitutionality of Punishment:

\section{Mickle vs. Dickerson,}

8 R. C. L., Section 268-

State vs. Feilen, 7 Wash,, 65.

41 L. R. A. ns. 418.

126 Pac. 75.

Ann. Cas. 1914, B. 512, 515.

Dec. Dig. Criminal Law, Sec. 1213.

State vs. Woodward.

30 L. R. A. ns 1004.

Davis vs. Berry, 216 Fed., 413.

Dutton vs. State, 91 Atl., 417.

Collins vs. Johnston, 35 S. C. R. 649.

Smith vs. Board, 88 Atl., 963.

Weems vs. U. S., 217 U. S., 349.

\section{ADDITIONAL MEMORANDUM.}

As to electrocution see

Storti vs. Commonwealth, 52 L. R. A. 520.

People ex rel Kemmler vs. Dorston,

$$
\begin{aligned}
& 119 \text { N. Y., 569, } \\
& 136 \text { U. S., 436, } \\
& 7 \text { L. R. A., } 715 .
\end{aligned}
$$

\section{f. Decision of the United States District Court.}

IN THE DISTRICT COURT OF TÍtE UNITED STATES, IN AND FOR THE DISTRICT OF NEVADA.

PEARLEY C. MICKLE, Plaintiff vs.

RUFUS B. HENRICHS, as Warden of the Nevada State Prison, and DONALD $T$. McLEAN, as Physician of the Nevada State Prison, Defendants
WOODBURN \& BARTLETT, for Plaintiff. GEO. B. THATCHER, Attorney-General of Nevada, and

E. T. PATRICK, Assistant Attorney-General, for Defendants.

FARRINGTON, District Judge:

Mickle having pleaded guilty to the charge of rape, was sentenced to be imprisoned in the Nevada State Penitentiary for an indeterminate period of not less than five years. It was also ordered as a part of the judgment that an operation be performed on his person sufficient to deprive him of the power of procreation. This suit is brought against the warden and the physician of the Nevada State Prison to procure a decree of this court restraining them from carrying the order of the court into effect. All questions as to jurisdiction have been expressly waived. The operation directed is known as vasectomy, and is authorized by Section 6293 of the Revised Laws of Nevada, which reads as follows:

"Whenever any person shall be adjudged guilty of carnal abuse of a female person under the age of ten years, or of rape, or shall be adjudged to be an habitual criminal, the court may, in addition to such other punishment or confinement as may be imposed, direct an operation to be performed upon such person, for the prevention of procreation; provided, the operation so directed to be performed shall not consist of castration."

Plaintiff claims that the statute violates Section 6 of Article I of the Constitution of Nevada, "in that the punishment therein permitted and authorized is cruel and unusual."

The section referred to is as follows:

"Excessive bail shall not be required, nor excessive fines imposed, nor shall cruel or unusual punishments be inflicted."

Under this provision, if the punishment is either cruel or unusual, it is prohibited.

It was agreed by counsel that the operation could be performed in such a manner as to be painless, and such was the effect of the testimony. The operation, under a local anaesthetic, occupies but a few minutes. The person operated on may at once thereafter resume his ordinary avocatioti and physical activities, without serious discomfort. The power to beget offspring is taken away, without impairing the desire and capacity for sexual enjoyment. 
It appears from the record that Mickle is an epileptic. That fact was accorded considerable weight by the court in pronouncing judgment.

Possibly in the exercise of its police power, it may be lawful for the legislature to adopt reasonable measures, adequate and sufficient to prevent degenerates and persons afflicted with transmittable mental defects, physical disease, or criminal tendencies from begetting children, but legislation of that character must operate alike on all unfortunates of the same class, and the classification must operate reasonably with relation to the end sought to be accomplished.

The courts of New Jersey recently refused to uphold a state statute providing for the sterilization of certain feeble-minded, epileptic and criminal defectives confined in penal and charitable institutions of that State. Much stress was laid on the fact that an epileptic confined in a penal institution is less likely to transmit his infirmity to children than an epileptic who is not so confined. It was pointed out by the court that the statute creates two classes, viz: those who are, and those who are not, unfortunate enough to be the inmates of such institutions, and it applies its remedy to the former class only; that the classification has no relation whatever to the eradication of epilepsy; it is purely arbitrary and artificial, and denies to those least able to protect themselves, equal protection of the law.

Smith vs. Bd. of Exmrs. of Feeble-Minded, 88. Atl. 963:

If the purpose of the Nevada statute be to prevent the transmission of criminal tendencies, it must be noted that it does not apply to all convicted offenders, not even to all who are habitual criminals, or to all persons adjudged guilty of rape or carnal abuse of female children; but only to such habitual criminals and persons guilty of rape, as the court in the exercise of a discretion, which is in no wise directed by the statute, may designate.

It is a notorious fact that many judges do not regard mutilation as a wise or lawful method of punishment. It is only those of the contrary opinion who will prescribe vasectomy as a part of the punishment for this offense.

Again, it is doubtful whether our penal institutions contain more than a small minority of those undesirables who are inclined to lawlessness and crime. It is easy to imagine that a brute guilty of rape, or who has a tendency to commit such a crime, might regard it rather to advantage than otherwise, to be sterilized, As a prevention of this crime vasectomy is without effect. Once free, the convict who has been so punished, is still physically capable of committing the offense.

These considerations, however, are beside the issue. There is, no attempt by defendants to support the judgment on the ground that vasectomy is calculated to promote general welfare. It is conceded that cruel and unusual punishments are prohibited, regardless of any and all theories of race culture.

Whether the operation performed as punishment is violative of the constitutional injunction against cruel and unusual punishment, is the question. This provision in slightly varying form is to be found in the Federal Constitution, and in all but three of the State Constitutions. In Washington the inhibition is against "cruel punishment;" in the Federal Constitution it is against "cruel and unusual punishment;" in Nevada it is against "cruel or unusual punishment;" and in Massachusetts it is directed expressly to the judiciary: "No magistrate or court of law shall *** inflict cruel or unusual punishment."

The Federal courts have never attempted a precise definition of either "cruel" or "unusual," as used in the Constitution. The prohibition first appeared in the English Bill of Rights of 1688 , and was there directed to modes of punishment which to the modern mind seem barbarous and inhuman, such as the pillory, the thumb-screw, the rack, disemboweling the living victims, drawing, quartering, burning and boiling.

The decisions are not altogether harmonious. Some hold that as used in the earlier Constitutions, including that of the United States, the restriction applies only to those ancient punishments which seem so shocking in this more enlightened age.

Whitten vs. State, 47 Ga. 297, 301.

Judge Storey intimates that such limitations on the power to punish are unnecessary because resort to atrocious punishment is hardly possible by the government of a free people. In support of this view attention is called to the fact that even before the Revolutionary War the modes of punishment mentioned had been practically discarded, not.only in the Colonies, but in England; and as originally drafted and adopted, the Federal Constitution contained no such re- 
strictions. It was only in response to a strong popular demand that it became a part of the organic law of the nation as the Eighth Amendment. It is unreasonable to believe that it was adopted solely as a shield against obsolete abuses.

In other and more recent cases there are strong expressions as to the effect that imprisonment, though not in itself cruel or unusual, may become so if the term of confinement is grossly disproportionate to the offense.

McDonald vs. Commonwealth, 173 Mass. 322.

Weems vs. United States, 217 U. S. 349.

In the latter case the Supreme Court of the United States seems to have committed itself to the more humane and liberal doctrine that the English Amendment is a regulation of sufficient vitality and adaptability to restrain cruel innovations in the way of punishment.

The Nevada Constitution was not adopted until 1864, a comparatively recent date. Neither then nor at any other time within the history of the State prior to the date of the act in question, had mutilation of the person been a recognized mode of punishment.

It is to be noted that the Nevada Constitution forbids punishments either "cruel or unusual." The terms are used disjunctively. If accorded their usual significance, it is evident that the purpose was to forbid newly devised as well as cruel punishments.

In Cooley on Constitutional Limitations ( 6 ed.) p. 402 , it is said that

"Those degrading punishments which in any State had become obsolete before its existing Constitution was adopted, we think may well be held forbidden by it as cruel and unusual. We may well doubt the right to establish the whipping post and the pillory in states where they were never recognized as instruments of punishment, or in states whose Constitutions, revised since public opinion had banished them, have forbidden cruel and unusual punishment. In such states the public sentiment must be regarded as having condemned them as 'cruel,' and any punishment which, if ever employed at all, has become altogether obsolete, must certainly be looked upon as 'unusual.'"

In Hobbs vs. State, 18 L. R. A., 774, 777, the court says that "unusual" as used in the Constitution, means a class of punishments which never existed in the State, or that class which public sentiment must be regarded as having condemned.

It may be said as questioning the accuracy of this definition that the courts have repeatedly upheld statutes authorizing electrocution, but in those cases death was the punishment; electrocution was merely the means adopted to reach that end as swiftly and as painlessly as possible.

Stroti vs. Commonwealth, 52 L. R. A. 520.

In State vs. Feilen, $126 \mathrm{Pac}$. 75 , the Supreme Court of Washington came to the conclusion that a statute authorizing vasectomy was not unconstitutional. This decision was rendered under a Constitution which prohibited cruel punishment only. In this it differs from the Nevada Constitution, which prohibits cruel and unusual punishment.

I am not inclined to adopt the view that the two provisions mean substantially the same thing.

The same question came up in the case of Davis vs. Berry, 216 Fed. 413. There Judges Smith, Pollock and Smith McPherson had under consideration an Iowa statute directing the operation of vasectomy to be performed upon convicts in the state prison who had been twice convicted of a felony. After going in to the history of similar punishments, the court says:

"When Blackstone wrote his Commentaries he did not mention castration as one of the cruel punishments, quite likely for the reason that with the advance of civilization the operation was looked upon as too cruel, and was no longer performed. But each operation is to destroy the power of procreation. It is, of course, to follow the man during the balance of his life. The physical suffering may not be so great, but that is not the only test of cruel punishment; the humiliation, the degradation, the mental suffering are always present and known by all the public, and will follow him wheresoever he may go. This belongs to the Dark Ages. *** Our conclusion is that the infliction of this penalty is in violation of the Constitution, which provides that cruel and unusual punishment shall not be inflicted."

Vasectomy in itself is not cruel; it is to be classed with branding, the amputation of a finger, the slitting of a tongue, or the cutting off of an ear; when resorted to as a punishment, it is ignominious and degrading, and in that sense it is cruel. Certainly it would be unusual in Nevada. 
It may well be that it came to the minds of the men gathered in the Constitutional Convention of this State that there could be unwise punishment without the infliction of physical pain; that legislators under the stress of unusual conditions and peculiarly atrocious crime, might hastily adopt strange methods of repression, unknown to our criminal practice and harmful to the State.

Reformation of the criminal is a wise and humane purpose of punishment, to be disregarded only when the death penalty is inflicted. It needs no argument to establish the proposition that degrading and humiliating punishment is not conducive to the resumption of upright and self-respecting life. When the penalty is paid, when the offender is free to resume his place in society, he should not be handicapped by the consciousness that he bears on his person, and will carry to his grave, a mutilation which, as punishment, is a brand of infamy. True, rape is an infamous crime; the punishment should be severe; but even for such an offender the way to an upright life, if life is spared, should not be unnecessarily obstructed. It will not do to argue that inasmuch as the death penalty may be inflicted for this crime, vasectomy, or any other similar mutilation of the body, cannot be regarded as cruel, because the greater includes the less. The fact that the extreme penalty is not exacted is evidence that the criminal is considered worthy to live, and to attempt reformation. For him, and for society, a fair opportunity to retrieve his fall is quite as important as the eugenic possibilities of vasectomy.

A decree will be entered in favor of the plaintiff, restraining the warden and the physician of the Nevada State Prison from performing the proposed operation of vasectomy on the person of the plaintiff. 


\section{CHAPTER VII. (Continued).}

\section{PART VII. INDIANA.}

1. Circuit Court of Clark County.

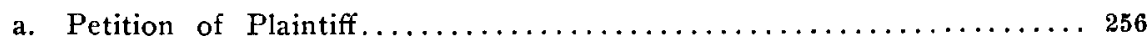

b. Consent of Next Friend............................... 257

c. Demurrer Filed by Defendants........................... 257

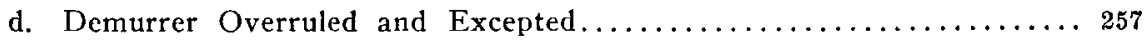

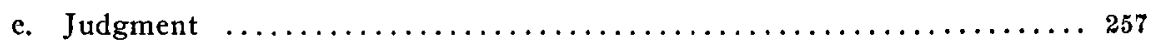

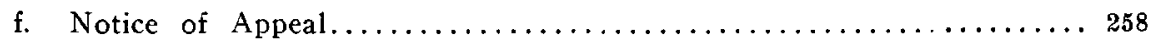

g. Praecipe for Transcript.............................. 258

2. State Supreme Court.

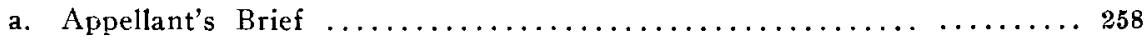

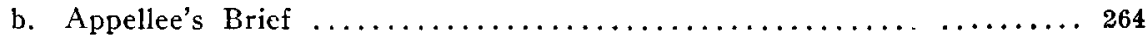

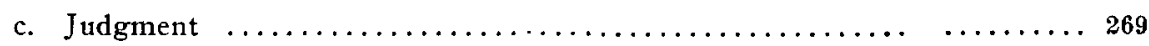




\section{(VII.) INDIANA.}

In Indiana legalized sterilization began in 1907 by the enactment of Chapter 215 of the Acts of 1907. For a number of years previously (since 1899), Dr. H. C. Sharp, physician of the Reformatory at Jeffersonville, had practiced vasectomy under the general laws governing surgical practice in the state. His motives were purely eugenical. Thus the so-called vasectomy act had for its purpose the legalization and regulation of the specific type of surgical operation, which has for its purpose motives not indicated by pathological conditions.

With the administration of Governor Thomas R. Marshall, who was opposed to the practice, the statute fell into disuse and remained a dead letter until the administration of Governor James P. Goodrich, who asked the institutions of the state to avail themselves of the provisions of the so-called vasectomy act. The Reformatory at Jeffersonville appointed a Sterilization Board, but the (the following quotation from a letter by Dr. A. H. Estabrook of April 29, 1921) "institutional officials, especially the physicians involved, were more or less fearful because of the seeming unconstitutionality of the act, and so were rather afraid to go ahead merely on the Governor's wish, so he took some money from his contingent fund, secured a very good lawyer from Jeffersonville as counsel for plaintiff, instructing the lawyer to test the constitutionality of the act on every possible ground of there being any errors in the same. The lawyer selected was Wilmer $T$. Fox, a high type man of good intellectual and social traits."

"Warren Wallace Smith, the subject in this case, was selected as the plaintiff in the case, because he had been convicted of incest and sent to the Reformatory, coming under the classification of rapist in the act."

"It was explained to Smith that he was chosen for the case, that the act of sterilization was not going to be carried out, that this was to be a test case and he agreed to the proposition. It was found that he was under the age of twenty-one, so Lincoln $\mathrm{E}$. Lankford, as his next friend, was chosen to act in the case. In view of the fact that this test case is a:friendly case, and there was to be no argument about the facts, I feel that you will not need any particular data concerning Smith's career in the Reformatory. However, Smith is probably a high grade imbecile, coming from a more or less de- generate family in Wayne County, was sent to the Reformatory as stated above, for incest on his half-sister, from Wayne County, February 13, 1919, for two to twenty-one years, received at the Reformatory the same day. He had been arrested previously for petit larceny, by occupation a laborer, education second grade. At the present time he is working at outside work in the Reformatory at unskilled tasks. I question whether he has any comprehension that he is a subject of an interesting legal case, as he is mentally too incapable of understanding anything of that sort."

"Mr. Fox saw Smith and filed the case as requested by the Governor, in his complaint covering every legal possibility for error in the act, being based more or less primarily upon the plea that the plaintiff had not had his day in court before an impartial body of men and that the operation would be cruel and inhuman treatment."

"I had a long discussion with Mr. Fox concerning the act and his general views on the sterilization problem; who said that unquestionably the law of Indiana was faulty in several respects, that it did not state the law was on eugenic grounds, that it did not give the person concerned a hearing before an impartial board, that only selected groups were taken and not all the groups that are more or less anti-social in nature, and that certain classes only of criminals are included and not all classes of criminals that should be eliminated from society on general grounds. *** He stressed the point that the medical profession is not yet agreed on diagnoses in the mental field and also they do not agree on the effects of sterilization, and implied that the judiciary must protect the people until such an agreement takes place."

"The attitude of several of the constitutional lawyers seems to be that the Indiana law creates increased punishment with no court action, which is contrary to the Constitution of the State."

Honorable Wilmer T. Fox, attorney for Smith, in a letter to the author (February 12,1921 ), says:

"The injunction suit was filed primarily for the purpose of testing the statute. The members of the Board of Trustees of the Indiana Reformatory seriously doubted whether the statute, in the form in which it had been enacted in Indiana, was constitutional and they did not care to take the re- 
sponsibility either for enforcing or not enforcing it until the courts had passed on the question. The first time that they had a typical case up they arranged for the inmate to bring an injunction suit to test the validity of the act."

Dr. A. H. Estabrook, in a letter of August 9, 1921, to Mr. A. W. Butler, Secretary of the Indiana State Board of Charities and Corrections, says:

"In view of the preamble of Chapter 215, Acts 1907 , the Sterilization Act, which says, whereas, 'Heredity plays a most important part in the transmission of crime, idiocy and imbecility,' it would seem that Warren Wallace Smith, Indiana Reformatory, No. 10734, was not the best person to be chosen as a test person for questioning the constitutionality of this act, as, on the basis of their data, as exhibited in their letter of July 29, the Reformatory officials had no information as to the family history of this boy to indicate whether or not he came from a mentally defective strain. The said Smith is feeble-minded as shown by his behavior at the Reformatory, and the rapist or incest act was one of chance because of the feeblemindedness rather than any rapist-criminal behavior, deliberately carried out as a criminal act other than that of a feeble-minded person.

"Further, the half-sister with whom Warren had sexual relations did not become pregnant by him as stated by Warren to the Reformatory officials.

"It would seem, then, that the provisions of a sterilization law, such as the Indiana law, should have been carried out with due reference to the present day methods of eugenics; that is, with a complete family history study before any authorization for sterilization be made."

George A. H. Shideler, Superintendent of the Reformatory, stated that Smith was chosen: "First, because he had incestuous relations with his half-sister, Smith stating that she was pregnant; second, that his behavior at the Reformatory showed that he was feeble-minded, in that he did not have any conception of the rules of the institution, and further that he did not recognize the wrongfulness of his act."

1. December 4, 1919. Judge James W. Fortune of the Circuit Court of Clark County granted a permanent injunction against Charles F. Williams, as Chief Physician of the Indiana Reformatory, and various mem- bers of the Board of Managers of said institution, against the performance of the operation of vasectomy or any other operation for sterilization of the plaintiff, Warren Wallace Smith, an inmate of the Reformatory at Jeffersonville. The injunction was directed against the members of the Board of Managers of said Reformatory-the ground for the decision being that the statute (Chap. 215 of the Acts of 1907) is unconstitutional because it denies to the persons subject to it the right to free administration of justice in open court.

\section{CIRCUIT COURT OF CLARK COUNTY.}

The principal documents in the case follow:

a. Petition of the Plaintiff, September 25, 1919:

STATE OF INDIANA, COUNTY OF CLARK, ss:

In the Clark Circuit Court September Term, 1919.

W A R R E W A L L A E SMITH, by LINCOLN E. LANKFORD, his $\mathrm{next}$ friend,

vs.

CHARLES F. WILLIAMS, as Chief Physician of the Indiana Reformatory, and Joseph E. Hennings, Alvin Padgett, John H. Weathers and Thomas A. Dailey, as Members of the Board of Managers of the Indiana Reformatory.

No. 12018 Complaint.

(Here follows appellant's brief, page 3 , "The plaintiff___ through to page 6, "WILMER T. FOX, Attorney for Plaintiff." Sec. p. 259 of this book.)

Attached to this complaint is the "TERM TIME SUMMONS."

STATE OF INDIANA, CLARK COUNTY, ss:

The State of Indiana to the Sheriff of Clark County, Greeting:

You are hereby commanded to summon Charles F. Williams, as Chief Physician of the Indiana Reformatory, and Joseph E. Hennings, Alvin Padgett, John $\mathrm{H}$. Weathers and Thomas A. Dailey, as members of the Board of Managers of the Indiana Reformatory, to appear in the Clark Circuit Court before the judge thereof on the 9th day of 
October, 1919 , the same being the...... judicial day of the September term of said court, at the Court House, in Jeffersonville, in said County, to answer the complaint of Warren Wallace Smith by Lincoln E. Lankford, his next friend.

Witness the Clerk of said Court, and the seal thereof hereunto affixed at Jeffersonville, Indiana, the 25th day of September, 1919.

\section{ERNEST E. JACOBS,}

Clerk.

Certificate to Term Time Summons in the following statement:

"I certify that I have served this summons on the 29 th day of September, 1919, by reading the same to Charles F. Williams.

"The other within named witnesses not found in my bailiwick.

\section{"JOHN H. DILLINGER."}

Stamped on back of complaint is: Filed in open court September 25, 1919.

\section{ERNEST E. JACOBS.}

Also referring to complaint:

"Plaintiff fixes the 9th day of October, 1919 , as the day defendant shall appear in this action and requests that summons be issued to the Sheriff of Clark County, Indiana.

\section{WILMER T. FOX, Attorney for Plaintiff.}

\section{b. Consent of Next Friend:}

STATE OF INDIANA, COUNTY OF CLARK, ss:

In the Clark Circuit Court, September Term, 1919.

W A R R E WALLACE
SMITH, by LINCOLN E.
LANKFORD, his n x t
friend,
vs.
CHARLES F. WILLIAMS, 12018
Consent of
as Chief Physician of the
Indiana Reformatory, et al. Friend.

The undersigned hereby consents to act as next friend in the above entitled cause for said Warren Wallace Smith, an infant under the age of twenty-one years.

LINCOLN E. LANKFORD.

Dated September 24, 1919.

\section{c. Demurrer filed by Defendants:}

STATE OF INDIANA, COUNTY OF CLARK, ss:

In Clark Circuit Court. September Term, 1919.

WARREN WALLACE SMITH, by LINCOLN E. LANKFORD, his next friend, vs.

No. 12018.

CHARLES F. WILLIAMS, as

Chief Physician of the Indiana

Reformatory, et al.

"The defendants, and each of them, in the above entitled cause demur to plaintiff's complaint therein, and for grounds of demurrer say that said complaint does not state facts sufficient to constitute a cause of action against them or any of them."

\section{ELE STANSBURY, Attorney-General. Defendant's Attorney.}

\section{EDWARD M. WHITE, Of Counsel.}

Following the demurrer, on next page, is "Memorandum" found in plaintiff's brief, page 7, "Defendants say_____ through to page 8 , "submitting to it." (See p. 260 of this book.)

Respectfully submitted, ELE STANSBURY, Attorney-General.

EDWARD M. WHITE, Of Counsel.

\section{d. Demurrer overruled and excepted:}

Appellant's demurrer was overruled by the court and to such ruling appellants at the time excepted. (Tr. p. 10, 1.1 to 1.9.)

Thereupon the court ruled and ordered that appellant should plead over to appellee's complaint. Appellants then refused to plead further, but elected to stand upon their demurrer. (Tr. p. 10, 1.21 to 1.28.)

\section{e. Judgment:}

"In default of answer and upon appellants" refusal to plead further, the court on December 4, 1919, found for appellee upon his complaint, and adjudged and decreed that the appellants be and they were enjoined from performing or causing to be performed the operation of vasectomy or any other operation for appellee's sterilization and that the appellants pay the cost of such action. (Tr. p. 11, 1.1. to 1.13.)" 


\section{f. Notice of Appeal:}

Notice of appeal was then given and service acknowledged by appellee as follows:

"To Warren Wallace Smith, Appellee, and Wilmer T. Fox, his Attorney, and Ernest E. Jacobs, Clerk of Clark Circuit Court.

"You are hereby notified that appellants, in the above entitled cause hereby appeal to the Supreme Court from the judgment rendered in your favor against them, namely, Charles F. Williams, as Chief Physician of the Indiana Reformatory, Joseph E. Hennings, Alvin Padgett, John $H$. Weathers and Thomas A. Dailey as members of the Board of Managers of the Indiana Reformatory on the day of December, 1919 , by the Claik Circuit Court in the cause numbered 12018, entitled Warren Wallace Smith by Lincoln E. Lankford, his next friend, vs. Charles F. Williams, et al.

"Dated, this 12th day of January, 1920. "ELE STANSBURY,

"Attorney-General.

"EDWARD M. WHITE,

"Deputy Attorney-General.

"Attorneys for Appellants.

"On behalf of the appellee, Warren Wa1lace Smith, by Lincoln E. Lankford, his next friend, I hereby acknowledge service of the above and foregoing notice this 12th day of January, 1920.

$$
\begin{aligned}
& \text { "WILMER T. FOX, } \\
& \text { "Attorney for Appellee. }
\end{aligned}
$$

"I acknowledge service of above notice this 12 th day of January, 1920.

$$
\begin{aligned}
& \text { "ERNST E. JACOBS, } \\
& \text { "Clerk of Clark Circuit Court." }
\end{aligned}
$$

\section{g. Praecipe for Transcript:}

Appellants then filed with the Clerk of the Clark Circuit Court their praecipe for transcript to be used on appeal to the Supreme Court (Tr. p. 12) which praecipe is as follows:

"To Ernest E. Jacobs, Clerk of Clark Circuit Court: The defendants in the above entitled cause request you to prepare and properly certify, for use on appeal to the Supreme Court of Indiana, a full, true and complete transcript of the proceedings, papers on file, and judgment in the above entitled cause."

\section{STATE SUPREME COURT.}

May 11, 1921. The Associate Judge of the Supreme Court, Hon. Howard L. Town- send, in an opinion and judgment of the State Supreme Court, confirmed the judgment of the Trial Court, enjoining the institution from performing or causing to be performed the operation of sterilization of any type upon Warren Wallace Smith, the defendant. The statute was held to be a plain violation of the Fourteenth Amendment to the Federal Constitution, in that it denied due process of law. The statute thus becomes void and unenforceable.

The principal documents and records in the case follow:

\section{a. Appellant's Brief:}

\section{IN THE}

\section{SUPREME COURT OF INDIANA.}

\section{Appeal from the Clark Circuit Court.}

\section{CHARLES F. WILLIAMS, as Chief Physician of the Indiana Reformatory, and Jo- seph E. Hennings, Alvin Padgett, John H. Weathers and Thomas A. Dailey, as members of the Board of Managers of the Indiana No. 23709. Reformatory, vs. \\ Appellants, \\ WARREN WALLACE SMITH, by LINCOLN E. LANKFORD, his next friend, \\ Appellee.}

\section{APPELLANT'S BRIEF.}

\section{I.}

\section{NATURE OF THE ACTION.}

This is a suit to enjoin appellants from performing an operation known as vasectomy upon appellee, who is a prisoner in the Indiana Reformatory, for the purpose of sterilizing him, under and pursuant to the provisions of the Act of 1907 (Acts 1907, p. 377).

II.

\section{THE ISSUES.}

Appellee filed his complaint in the Clark Circuit Court to enjoin appellants as officers of the Indiana Reformatory from sterilizing appellee. Appellants appeared to the action and demurred to the complaint upon the ground that it did not state facts sufficient to constitute a cause of action against them. 
III.

HOW THE ISSUES WERE DECIDED, AND JUDGMENT.

The demurrer of appellants to appellee's complaint was submitted to the court and the court overruled the same to which ruling appellants at the time excepted ( $\mathrm{Tr}$. p. 10) and the court ordered appellants to plead over. Appellants refused to plead further and elected to stand upon their demurrer. The court then, for want of answer, found for appellee, that the act of 1907 , p. 377, was unconstitutional and ordered, adjudged and decreed that the defendants be enjoined from performing or causing to be performed the operation of vasectomy or any other operation for the sterilization of appellee and entered judgment against appellants for costs. (Tr. p. 10, 1.17, to p. 11, 1.12.)

IV.

ERRORS RELIED ON FOR REVERSAL.

The error assigned and relied on for reversal is:

That the trial court erred in overruling appellants' demurrer to appellee's complaint. (Tr. p. 14, 11.1 to 25.)

\section{$\mathrm{V}$.}

\section{STATEMENT OF THE RECORD.}

The sole question here for determination is as to the legal sufficiency of appellee's complaint. The complaint, omitting its formal parts, is as follows:

"The plaintiff in the above entitled cause complains of the defendants in said cause and says that said Charles F. Williams is now, and was at all the times hereinafter mentioned, the duly qualified and acting Chief Physician of the Indiana Reformatory, and that the defendants, Joseph E. Hennings, Alvin Padgett, John $H$. Weathers and Thomas D. Dailey, are now ${ }_{2}$ and were at all times hereinafter mentioned, the duly qualified and acting members of the Board of Managers of said Indiana Reformatory.

"Plaintiff further says that he is now, and has been at all times mentioned herein, a citizen of the United States and of the State of Indiana, and that he is now, and has been at all times mentioned herein, an inmate of said Indiana Reformatory serving therein a sentence for the crime of incest.

"Plaintiff further says that on the - day of August, 1919, Charles F. Williams, as Chief Physician of said Indiana Reformatory, and said Joseph E. Hennings, Alvin Padgett, John H. Weathers and Thomas A. Dailey, acting as said Board of Managers of the Indiana Reformatory, recommended that this plaintiff be examined as to his mental and physical condition; that thereafter, on the - day of September, 1919, pursuant to said recommendation, this plaintiff was examined by said Charles F. Williams, institutional physician of said Indiana Reformatory, and by two surgeons whose names this plaintiff does not know. That thereafter said committee of physicians and surgeons and said Board of Managers entered and ordered finding that the physical and mental condition of this plaintiff was such that, in their judgment, procreation was inadvisable, and that there was no probability of the improvement of the mental condition of this plaintiff. That thereupon said Board of Managers ordered and directed said Charles F. Williams, as Chief Physician of said Indiana Reformatory, to perform on this plaintiff the operation known as vasectomy, for the prevention of procreation on the part of this plaintiff, and that said Charles F. Williams, as such physician, and said Board of Managers, will proceed to carry into execution the finding and order aforesaid, thereby causing the plaintiff great and irreparable injury, unless restrained and enjoined.

"Plaintiff further says that he has not been given a public trial by an impartial jury as to his mental and physical condition or as to the necessity of said operation, nor has arry provision been made by said defendants, or by any other persons or tribunal, for plaintiff to be heard on such questions, in person and by counsel, nor has plaintiff been furnished the accusation against him, given the opportunity to meet the witnesses against him, or compulsory process for obtaining witnesses in his favor, but that said finding and order have been entered pursuant to, in the manner provided by, and in reliance upon the provisions of Chapter 215 of the Acts of the Sixty-fifth Regular Session of the General Assembly of the State of Indiana, being Acts of 1907, pages 377 and 378 , and without further authority or warrant. That the operation ordered as aforesaid, if performed, will sterilize this plaintiff and forever deprive him of the power to enter into the marriage relation, and will degrade and humiliate plaintiff.

"Plaintiff further says that the finding and order aforesaid are illegal and void, and that said Act of 1907 is unconstitutional and void, in this: 
“a) That said finding, order and Act of 1907 deny to this plaintiff the free administration of justice, in open court, guaranteed to him by Section Twelve of Article One of the Constitution of the State of Indiana.

"(b) That said finding, order and Act of 1907 deny to this plaintiff the right to a public trial by an impartial jury, the right to be heard by himself and counsel, the right to demand the nature and cause of the accusation against him and to have a copy thereof, the right to meet the witness face to face, and the right to have compulsory process for obtaining witnesses in his favor guaranteed to him by Section Thirteen of Article One of the Constitution of the State of Indiana.

"(c) That said finding, order and Act of 1907 deprive this plaintiff of life, liberty and property without due process of law, contrary to Section One of Article Fourteen of the Constitution of the United States of America, commonly known as the Fourteenth Amendment to said Constitution.

"(d) That said finding, order and Act of 1907 provide for the infliction on this plaintiff of cruel and unusual punishment contrary to Section Sixteen of Article One of the Constitution of the State of Indiana.

"(e) That said Act of 1907 is a Bill of Attainder and that said finding, order and Act are contrary to Section Ten of Article One of the Constitution of the United States of America.

"(f) That said Act of 1907 embraces more than one subject and embraces matters not expressed in the title, contrary to Section Nineteen of Article Four of the Constitution of the State of Indiana.

"WHEREFORE, plaintiff asks that said defendants, and each of them, be enjoined from carrying into execution the finding and order aforesaid, be enjoined from performing or causing to be performed the operation of vasectomy or any other operation for the sterilization of this plaintiff, and that said Act of 1907 be declared unconstitutional and void, and all other proper relief.

\section{"WILMER T. FOX, "Attorney for Plaintiff."}

(See p. 255 of this book.)

In support of their demurrer, appellants filed the following memorandum, to-wit:

"Defendants say that the above demurrer to plaintiff's complaint should be sustained for the following reasons:

"1. The Act of 1907 (Acts 1907, p. 37) under which defendants propose to perform the operation known as vasectomy upon plaintiff as alleged in the complaint is a valid enactment and is not violative of either the Federal or State Constitutions.

"(a) The plantiff has had his day in court. Due process of law was accorded to him and he was convicted of the crime of incest, which carries with it, under the provisions of the Act of 1907, the right of the defendants to cause him to be examined and if it be found that there is no probability of improvement of his mental condition, and that it is inadvisable for him to procreate, to operate upon him and sterilize him; and the complaint shows that all steps have been properly taken by defendants looking to that result.

"(b) Plaintiff has not been deprived of the equal protection of the laws. He belongs to a class of confined criminals who are equally protected and the basis of the classification is a reasonable one.

“(c) Plaintiff can not be heard to assert that because the act in question applies also to 'idiots, rapists and imbeciles' who are not convicted criminals and does not apply to idiots and imbeciles not confined, that such confined idiots and imbeciles are deprived of the equal protection of the laws, for plaintiff by his averments is not an idiot or an imbecile. He can not attack the constitutionality of the act as it applies to them.

"(d) The Act of 1907 complained of in plaintiff's complaint does not provide cruel or unusual punishment such as is prohibited by Section 16 of Article I of the Indiana Constitution. The operation is practically painless and is completed in a few minutes, without effect except to prevent procreation.

"(e) It is within the police power of the State to provide, as it has in the Act of 1907 , for the sterilization of persons where society will be benefited by such a course; and a person thus sterilized is not deprived of any right which he may not legally be deprived of in the interest of society.

"( $f)$ The Act of 1907 is not a Bill of Attainder, for it does not inflict punishment without a judicial trial. Plaintiff had a jury trial or could have had one if he desired, to determine whether he was guilty of incest, and, therefore, to be placed in confinement where he was subject to be operated upon.

"(g) The operation of vasectomy is neither a punishment or an injury to one submitting to it." 
(Here follow Appellants' Demurrer, Judgment, Notice of Appeal, and Praecipe for Transcript. See p. 257 of this book.)

\section{TRANSCRIPT MÁDE AND FILED.}

Pursuant to appellants' praecipe therefor, the clerk made a transcript of the record and appended his certificate thereto.

This transcript of the record with appellants' assignment of error made thereon was duly filed in this court on January 13th, 1920.

\section{POINTS AND AUTHORITIES.} I.

(Error in overruling Appellants' Demurrer.)

(A) It is not cruel or unusual punishment for appellants to sterilize appellee by means of the operation known as vasectomy.

State vs. Feilen, 70 Wash. 65 (41 L. R. A. (N. S.) 418).

(B) Punishments are cruel only when they involve torture, or a lingering death, and it is held the punishment of death is not cruel within the meaning of the Constitution prohibiting cruel or unusual punishments.

Rice vs. State, 7 Ind. 332;

Hobbs vs. State, 133 Ind. 404, 408;

Re Kermuler, 136 U. S. 436.

(C) The constitutional provisions prohibiting cruel or unusual punishments have special reference to barbarities such as drawing, quartering, burning, etc., permitted under the old law of felony.

Hobbs vs. State, 133 Ind. 404, 408;

Robinson vs. Miner, $68 \mathrm{Mich}$. 549 ;

State vs. Williams, 77 Mo. 310;

Whitten vs. State, 47 Ga. 297.

(D) The Act of 1907 (Acts 1907, p. 377) does not provide punishment at all.

\section{II.}

The act under which appellants propose to sterilize appellee is as follows:

(Here follows the text of the Indiana Sterilization Act. Chap. 215, 1907.)

(A) The above act is the first law enacted on this subject. California and Connecticut enacted similar laws in 1909 (California Stats. 1909, p. 1093), (Connecticut Acts 1909, Chap. 209), and New Jersey and Iowa enacted similar laws in 1911 (New Jersey Laws 1911, Chap. 190), and (Iowa Laws 1911, Chap. 129).

(B) The Washington statute differs from the Indiana statute somewhat. It is as follows:

"Whenever any person shall be adjudged guilty of carnal abuse of a female person under the age of ten years, or of rape, or shall be adjudged to be an habitual criminal, the court may, in addition to such other punishment or confinement as may be imposed, direct an operation to be performed upon such person for the prevention of procreation."

(C) The constitutionality of the Washington, New Jersey and Iowa acts have been attacked in the courts in the following three cases and these are the only adjudications on this subject ever made anywhere in the world, so far as I have been able to ascertain. I refer to the cases of:

State vs. Feilen, 70 Wash. 65 (41 L. R. S. (N. S.) 418;

Davis vs. Berry, 216 Fed. Rep. 413; (Iowa Statute) appealed to U. S. Supreme Court (242 U. S. 468);

Smith vs. Board, etc., 88 Atl. 963 (New Jersey Act).

(D) The Washington statute was upheld, the court holding that the operation of vasectomy was not cruel or unusual and that the act did not violate the Constitution of the State or of the United States.

In deciding the case the court referred to the Indiana law of 1907 and said:

"The sterilization of convicts by vasectomy was actually performed for the first time in this country, so far as is known, in October, 1899 , by Dr. H. C. Sharp, of Indianapolis, then physician to the Indiana State Reformatory, at Jeffersonville, though the value of the operation for healing purposes had long been known. He continued to perform this operation with the consent of the convict (not by legislative authority) for some years. Influential physicians heard of his work, and were so favorably impressed with it that they indorsed the movement, which resulted in the passage of the law now upon the Indiana statute books. Dr. Sharp has this to say of this method of relief to society: 'Vasectomy consists of ligating and resecting a small portion of the vas deferens. This operation is, indeed, very simple and easy to perform; I do it without administering an anesthetic, either general or local.

"'It requires about three minutes' time to perform the operation, and the subject returns to his work immediately, suffers no inconvenience, and is in no way impaired for his pursuit of life, liberty, and happiness, but is effectively sterilized.'"

(E) The New Jersey act provided for the sterilization of idiots, feeble-minded persons, epileptics and certain classes of criminals and 
other defectives confined in the several reformatories, charitable and penal institutions in the state and its counties. The defendant in the action was an unfortunate woman who had committed no offense but who was subject to epilepsy and was confined in an institution. The court held the act invalid as to her because it deprived her of the equal protection of the laws. This was correct because the act did not require epileptics not confined in a state or county institution to be sterilized.

Smith vs. Board, etc., 88 Atl. 963.

(F) The above case is not decisive in this case because appellee does not belong to the class to which Miss Smith belonged. $\mathrm{He}$ is a convicted criminal and can not contend that the Indiana act is unconstitutional as to idiots, epileptics, etc., because it discriminates against the confined ones, because he is not of that class. He can only complain if as a convicted criminal he is deprived of the equal protection of the laws.

(G) The Iowa suit was decided in the United States District Court of South Dakota, that court holding that the Iowa law providing for the performance of the operation of vasectomy on criminals twice convicted of a felony is unconstitutional as providing a cruel and unusual punishment and as a deprivation of due process of law. The court in deciding this case took the mistaken notion that vasectomy like castration deprived the person of sexual desire, which according to medical men is not true. The court said: "There is a difference between the operation of castration and vasectomy: castration being physically more severe than the other. But vasectomy in its results is much the coarser and more vulgar." The district court enjoined the operation and while the cause was taken to the United States Supreme Court on a writ of error, no decision was made in that court, owing to the fact that the Iowa act had then been repealed and the question had therefore become a moot one.

Berry vs. Davis, 242 U. S. 468.

\section{III.}

Is the Indiana Act of 1907 violative of our State or Federal Constitutions?

(A) The Indiana act does not provide sterilization as a punishment for crime, but in the exercise of the police power, it seeks to remove the cause of crime. It has been held that it is the duty of the State to promote and protect the peace and good order and happiness of the citizens by enacting adequate laws to prevent practices that lead to vice and crime.

Harper vs. Commonwealth, $93 \mathrm{Ky} .290$.

(B) The right to procreate should be subject to the more important right of society to prevent procreation by persons morally and physically unfit.

(C) The Act of 1907 is based upon the State's police power, and the subject of preventing procreation is a proper and reasonable subject for the exercise of such power in the interest of the general welfare of the people and the Constitution can only prevent the exercise of such power when it is exercised in an arbitrary or oppressive manner.

McLean vs. Arkansas, 211 U. S. 539.

(D) The right of freedom of contract is held not to be unlimited in its nature and when the right to contract or carry on business conflicts with laws declaring the public policy of the State, enacted for the protection of the public health, safety or welfare, such laws may be valid notwithstanding they have the effect to curtail or limit the freedom of contract.

Holden vs. Hardy, 169 U. S. 366 ;

Knight \& Jillson vs. Miller, 172 Ind. 27.

(E) While the police power of the State is not unlimited, and is subject to judicial review where the rights of the citizens are unnecessarily and arbitrarily interfered with or destroyed, still the legislature being familiar with local conditions is primarily the juidge of the necessity of such enactments and they will not be struck down because the court may differ with the legislature in its views of public policy.

Jacobson vs. Mass., 197 U. S. 11;

Mugler vs. Kansas, 123 U. S. 623.

(F) If the Act of 1907 has a reasonable relation to the protection of the public health, safety or welfare it should not be set aside.

(G) If liberty of contract which is protected against hostile state legislation is not universal, but is subject to legislative restrictions in the exercise of the police power of the State why should not the right to procreate be restricted by legislation in the interest of public safety and the public welfare.

McLean vs. Arkansas, 211 U. S. 539.

$$
\text { IV. }
$$

(A) Under the police power statutes enacted to prevent the formation of combinations to restrict trade are upheld, notwith- 
standing the right to contract is guaranteed by the Constitution.

Knight \& Jillson vs. Miller, 172 Ind. 27.

(B) Under this power cities may regulate the heighth of buildings notwithstanding the private ownership of the property.

Welch vs. Swazey, 214 U. S. 91.

(C) Under the police power the operations of railroad trains may be controlled.

Southern Ry. Co. vs. King, 217 U. S. 524.

(D) Under this same power, our statute providing for the elevation of railroad tracks does not violate the Fourteenth Amendment.

Morris vs. Indianapolis, 177 Ind. $369,394$.

(E) A statute requiring railroad companies to destroy weeds and which does not require other land owners to do so, is not a denial of the equal protection of the laws.

Chicago, etc., R. R. Co. vs. Anderson, 182 Ind. 140, 143 .

(F) The section of the Constitution prohibiting the granting of special privileges or immunities does not apply as against the exercise of a purely police power for the protection of the public.

Ayres vs. State, 178 Ind. 453, 457;

Chicago, etc., R. R. Co. vs. Anderson, 182 Ind. 140 .

\section{V.}

It is contended by appellee that by his sterilization under the Act of 1907 he is deprived of a right he has to a public trial, to demand the nature and cause of the accusation against him and have a copy thereof, to be heard by himself and counsel, to meet the witnesses face to face, and to have compulsory process for obtaining witnesses guaranteed to him by Section Thirteen of Article One of the Indiana State Constitution.

The answer to all this is, that he is not now accused of anything. That he was accused in a public court with the crime of incest, had a public trial, had his day in court, had counsel, a chance to face the witnesses and had compulsory process to procure his witnesses, and he was convicted and sentenced to the reformatory.

He knew when accused of incest that if he was convicted and sentenced he would thereby be put in a class liable to be examined by the prison physicians and to be sterilized by order of the trustees of the prison and he must be said to have contemplated such probabilities when he was tried on a charge of incest. He has had his day in court.
(A) Appellant must now submit to sterilization not as a punishment for crime, for imprisonment is his punishment, but in obedience to the exercise of the State's police power as declared by the General Assembly of 1907 , in the interest of the common welfare and because by his conviction after a trial at which he was deprived of no constitutional right, he has placed himself in a class subject to such operation.

(B) If the classification is a fair one and to prevent procreation by him is reasonably necessary for the general welfare, then having been convicted of the crime of incest as appellee has, and having been examined by the officers of the Reformatory designated to examine that class of convicts and by them it is found that there is no hope of improvement in his mentality, he should not be heard to assert that the act is unconstitutional as to him, even though it might be so as to epileptics confined in public institutions because those not so confined are not required to be sterilized and hence those confined might be held to be deprived of the equal protection of the laws.

The appellee contends that the finding and order for his sterilization and the Act of 1907 authorizing it, is unconstitutional and void because:

"(a) That said finding, order and Act of 1907 deny to this plaintiff the free administration of justice, in open court, guaranteed to him by Section Twelve of Article One of the Constitution of the State of Indiana.

"(b) That said finding, order and Act of 1907 deny to this plaintiff the right to a public trial by an impartial jury, the right to be heard by himself and counsel, the right to demand the nature and cause of the accusation against him and to have a copy thereof, the right to meet the witnesses face to face, and the right to have compulsory process for obtaining witnesses in his favor guaranteed to him by. Section Thirteen of Article One of the Constitution of the State of Indiana.

"(c) That said finding, order and Act of 1907 deprive this plaintiff of life, liberty and property without due process of law, contrary to Section One of Article Fourteen of the Constitution of the United States of America, commonly known as the Fourteenth Amendment to said Constitution.

"(d) That said finding, order and Act of 1907 provide for the infliction on this plaintiff of cruel and unusual punishment contrary 
to Section Sixteen of Article One of the Constitution of the State of Indiana.

"(e) That said Act of 1907 is a Bill of Attainder and that said finding, order and Act are contrary to Section Ten of Article One of the Constitution of the United States of America.

"(f) That said Act of 1907 embraces more than one subject and embraces matters not expressed in the title, contrary to Section Nineteen of Article Four of the Constitution of the State of Indiana."

(A) If the exercise of the State's police power in the interest of the general welfare, when not exercised oppressively or arbitrarily is independent of and not curbed by our State Constitution as held by authorities cited herein under Point 3 , then the above contention of appellee can not be sustained.

(B) To establish that the operation known as vasectomy is not cruel or unusual. See authorities cited by appellant under Point 1 of this brief.

(C) Very clearly the title of the Act of 1907 (Acts 1907, p. 377) is sufficient upon which to base the provisions of the act authorizing the appointment of skilled surgeons in addition to the regular institutional physician and the action to be taken by such appointees in examining convicts and reporting the results of such examination to the trustees of the Reformatory.

The title of said Act is as follows:

"An Act entitled an act to prevent procreation of confirmed criminals, idiots, imbeciles, and rapists; providing that superintendents and boards of managers of institutions where such persons are confined shall have the authority and are empowered to appoint a committee of experts, consisting of two (2) physicians, to examine into the mental condition of such inmates."

The general subject of the Act was to prevent procreation and the matters connected therewith consisted of the provisions for the appointment of persons to examine prisoners, etc. This is a sufficient title.

State.vs. Gerhardt, 145 Ind. 439.

\section{ARGUMENT.}

Appellants submit that the Act of 190\%, here in question and claimed by appellee to violate both the State and Federal Constitutions, is a police measure in the interest of the general welfare. That the subject of procreation by persons convicted of incest or rape is a proper subject for the exercise of the State police power and that the General
Assembly, by the Act, has designated the chief physician and his scientific assistants and the trustees of penal institutions to carry out the policy declared by it to be necessary for the general welfare and safety of the public and that the means employed to accomplish the purposes of the Act are neither arbitrary or oppressive. That the operation, known as vasectomy, resulting in sterilization, is not cruel or unusual punishment-is not punishment at all-and that the trial court erred in holding such Act to be unconstitutional, such judgment should be reversed.

Respectfully submitted,

ELE STANSBURY, Attorney-General.

EDWARD M. WHITE,

Of Counsel.

\section{b. Appellee's Brief:}

\section{NATURE OF THE ACTION.}

The appellant's brief states correctly the record and nature of the action. It was a suit to enjoin appellants from performing an operation known as vasectomy upon appellee, who is a prisoner in the Indiana Reformatory, for the purpose of sterilizing him under and pursuant to the provisions of the Act of 1907 (Acts 1907, p. 377).

\section{THE ISSUES.}

Appellee filed his complaint in the Clark Circuit Court to enjoin appellants, as officers of the Indiana Reformatory, from sterilizing appellee. In his complaint appellee alleges that he is a citizen of the United States, and of the State of Indiana; that he is an inmate of the Indiana Reformatory and that on the day of September, 1919, pursuant to the recommendation of Trustees and Chief Physician of that institution (appellants herein) he was examined by appellant, Williams, institutional physician, and by two surgeons whose names appellee does not know. That as a result of such examination said physicians and trustees entered an order finding that the physical and mental condition of appellee was such that, in their judgment, procreation was inadvisable, that there was no probability of the improvement of the mental condition of appellee, and that appellant Williams should perform on appellee the operation known as vasectomy, which he will proceed to perform if not enjoined.

Appellee attacks the constitutionality of Chapter 215, of Acts of 1907 (pages 377 and 
378), under which the officers of the Reformatory are proceeding and alleges that he was not given a public trial by an impartial jury as to his mental and physical condition or as to the necessity of such operation, nor was any provision made by appellants, or by any other persons or tribunal, for plaintiff to be heard on such questions, in person and by counsel, nor was plaintiff furnished the accusation against him, given the opportunity to meet the witnesses against him, or compulsory process for obtaining. witnesses in his favor. That the operation ordered, if performed, will sterilize appellee and forever deprive him of the power to enter into the marriage relation and will degrade and humiliate him.

Appellee alleges that the Act of 1907 is unconstitutional (for the reasons assigned in his Points and Authorities herein) and the complaint concludes with a prayer for injunctive relief. The demurrer of appellants was overruled, and on their refusal to plead further, judgment was rendered in favor of appellee and the injunction granted as prayed for.

\section{POINTS AND AUTHORITIES.}

\section{FIRST ASSIGNMENT OF ERROR.}

The court did not err in overruling appellants' demurrer to appellee's complaint for the following reasons:

1. The Act of 1907 (Chapter 215, at pages 371 and 378 ) denies appellee the free administration of justice in open court guaranteed to him by Section 12 of Article I of the Constitution of Indiana. (Sec. 57, Burns, R. S., 1914.)

a. An inquiry as to whether an inmate of a prison should be sterilized must be in the open with full opportunities to present evidence and argument for and against. An examination before an administrative board or officers where witnesses are not produced or cross-examined does not give a citizen his day in court.

Davis vs. Berry, 216 Fed. 413, 418;

12 Corpus Juris 1188-1193 (Sec. 956-957); 12 Corpus Juris 1202 (Sec. 970).

2. The Act of 1907 denies appellee the right to a public trial by an impartial jury, the right to be heard by himself and counsel, the right to demand the nature and cause of the accusation against him and to have a copy thereof, the right to meet the witnesses face to face, and the right to have compulsory process for obtaining witnesses in his favor guaranteed to him by Section 13 of Article $I$ of the Constitution of Indiana (Sec. 58, Burns, R. S., 1914).

a. Appellee is accused (by necessary implication, if not in direct terms) of being such a menace to society that fine or imprisonment alone is not sufficient punishment, but that he must have performed upon him a serious operation. Such a charge is a criminal prosecution which can be determined only by public trial in due form of law.

Davis vs. Berry, 216 Fed. 413, 418;

Cummings vs. Missouri, 71 U. S. $277,320-$ 332 ;

Gillett on Criminal Law, Section 27 .

b. A public trial benefits the accused by permitting the public to see that he is fairly dealt with and not unjustly condemned, the presence of interested spectators keeping his triers keenly alive to a sense of their responsibility and to the importance of their functions.

Cooley's Constitutional Limitations (6th ed.), page 379 .

3. The Act of 1907 deprives appellee of life, liberty and property without due process of law and denies appellee the equal protection of the laws, contrary to the Fourteenth Amendment to the Constitution of the United States.

a. Due process of law means a law which hears before it condemns, which proceeds on inquiry and renders judgment only after trial.

12 Corpus Juris 1190-1191 (Sec. 956).

b. A hearing before an administrative board, such as is provided in Acts of 1907, is not due process of law.

Davis vs. Berry, 216 Fed. 413, 418.

c. A law which singles out "confined" criminals, idiots, rapists and imbeciles for operation and ignores all others of deficient mental and physical condition, does not proceed upon a reasonable classification and denies the class enumerated the equal protection of the laws.

Smith vs. Board of Examiners, 85 N. J. L. 46 (88 At1. 963, 966);

Osborn vs. Thomson, 169 N. Y. Supp. 638, 664.

4. The Act of 1907 provides for the infliction on appellee of cruel and unusual punishment contrary to Section 16 of Article I of the Constitution of Indiana.

a. While vasectomy is physically less severe than castration, in its results it is much the coarser and more vulgar, and is equally cruel and inhuman. 
Davis vs. Berry, 216 Fed. 413, 416-417.

b. Performance of the operation of vasectomy is a punishment, whether it be expressly made one of the penalties for certain crimes, or whether it be disguised and veneered as a beneficent protection to society.

Cummings vs. State of Missouri, 71 U. S. 277,320 ;

Davis vs. Berry, 216 Fed. 413, 417;

Rem. \& Bal. Washington Statutes, Sec. 2287;

State vs. Feilen, 70 Wash. 65; 126 Pac. $75,78$.

c. Deprivation of any rights, civil or political, previously enjoyed, may be punishment.

Cummings vs. State of Missouri, 71 U. S. 277,320 .

5. The Act of 1907 is a Bill of Attainder and contrary to Section 10 of Article I of the Constitution of the United States.

a. One of the rights of every man of sound mind is to enter into the marriage relation. Such is one of his civil rights and deprivation or suspension of any civil right for past conduct is punishment for such conduct and falls within the definition of a Bill of Attainder.

Davis vs. Berry, 216 Fed. 413, 419;

Cummings vs. State of Missouri, 71 U. S. $277,320$.

6. The Act of 1907 embraces more than one subject and embraces matters not expressed in its title, contrary to Section 19 of Article 4 of the Constitution of Indiana.

a. Every act must have a title and designate a single subject, expressed in the title.

Indiana Ry. vs. Potts, 7 Ind. 681.

7. Though every officer acts at his peri] under a statute which another claims is unconstitutional and void, where a person will suffer irreparable injury if the statute is enforced, it will be presumed that it will be enforced, and an injunction should enjoin its enforcement, if invalid.

Davis vs. Berry, 216 Fed. 413, 415.

\section{ARGUMENT.}

That the Act of 1907 deprives the appellee of life, liberty and property without due process of law and that it fails to give him the free administration of justice in open court-his day in court-contrary both to the State and Federal Constitutions, seems to counsel for appellee to be so elementary as to require no extended research or argument. Special emphasis on this glaring defect in the statute was laid by counsel in argument in the lower court, and the decision of that court in favor of appellee was in part based on that very ground, yet the honorable Attorney-General has been unable to cite a single authority in support of the star chamber proceedings permitted by the Act of 1907 and makes no allusion to this important feature of the case other than casually on page nineteen of his brief. The conclusion is not unwarranted that no such decision can be found and that the statute can not be defended in that respect.

Due process of law means a law which hears before it condemns, which proceeds on inquiry, and renders judgment only after trial (12 Corpus Juris 1190). In a criminal proceeding due process of law requires a law defining the offense, a court of competent jurisdiction, accusation in due form, notice and opportunity to answer the charge and a trial according to the settled course of judicial proceeding (12 Corpus Juris 1202). Measured by these accepted standards, the Act of 1907 is wholly insufficient. This act defines no offense and provides for no hearing. Its language, condensed, is that three physicians shall examine the mental and physical condition of certain confined criminals, idiots, rapists and imbeciles, and, if in the judgment of these physicians and the Board of Managers procreation is inadvisable and there is no probability of improvement of the mental condition of the inmate, they shall perform such operation for the prevention of procreation as shall be decided safest and most effective. Although dealing with the right of the appellee to enter the marriage relation, not to mention his future health and happiness, not a single safeguard against unwarranted, unjust, arbitrary or oppressive judgment is thrown around appellee. When procreation is inadvisable is left to the judgment of seven men without the creation of a single standard, medical or otherwise, by which their decision is to be governed. Neither the physicians nor the appellee may know with certainty, to a common intent, when and under what circumstances procreation is inadvisable. It is a constitutional right that the charge should be preferred with certainty. (Gillett on Criminal Law, Sec. 27.) -

The exact question was decided in Davis vs. Berry, 216 Fed. 413. The Iowa statute provided for the operation called vasectomy on idiots, feeble-minded, drunkards, drug fiends, epileptics, syphilitics, moral and sexual perverts, and made it mandatory as 
to criminals who had twice been convicted of a felony. Davis instituted an injunction proceeding to enjoin the performance of the operation on him because of his second conviction of a felony, and the District Court in an unanimous decision paid their respects to the lack of due process of law in the following language:

"The hearing is by an administrative board or officer. There is no actual hearing. There is no evidence. The proceedings are private. The public does not know what is being done until it is done. What records are examined is not known. The prisoner is not advised of the proceedings until ordered to submit to the operation. ${ }^{* * *}$ These are inquiries that must be held in the open with full opportunities to present evidence and argument for and against. $* *$ Due process of law means that every person must have his day in court, and this is as old as Magna Charta; that some time in the proceedings he must be confronted by his accuser and given a public hearing."

There is no occasion for piling authority upon authority to prove this elementary proposition of constitutional law. It is well to bear in mind, however, a potent reason for public trials enunciated by Judge Cooley in his work on Constitutional Limitations (6th ed., page 379), in which he states:

"The requirement of a public trial is for the benefit of the accused; that the public may see he is fairly dealt with and not unjustly condemned, and that the presence of interested persons may keep his triers keenly alive to a sense of their responsibility and to the performance of their functions."

The Act of 1907 is subject to other objections that will now be considered. To date such laws have been declared invalid in the following decisions:

Davis vs. Berry, 216 Fed. 413;

Smith vs. Board, 85 N. J. L. 46, 88 Atl. 963;

Osborn vs. Thomson, 169 N. Y. Supp. 638;

Haynes vs. Williams, Mich., $166 \mathrm{~N}$. W. 938, 1918 D. L. R. A. 233.

One state only, Washington, has upheld such a law, viz: State vs. Feilen, 70 Wash. 65; 126 Pac. 75; 41 L. R. A. (N. S.) 418.

It should be noticed that the question of due process of law did not enter into the Washington case, for the reason that the statute defining the offense of carnal abuse expressly made sterilization one of the penalties. The accused knew what penalty might be imposed upon him and had the oppor- tunity during his day in court to introduce evidence and submit argument as to why the full penalty should not be inflicted upon him. No such right is to be found in the Indiana statute.

The Fourteenth Amendment to the Constitution of the United States is also violated in another particular by the Act of 1907 . The classification is so narrow as to deny appellee the equal protection of the laws. The Act of 1907 applies only to "confined criminals, idiots, rapists and imbeciles," but protects the young man similarly situated as to his physical and mental make-up, who is unconfined, whose sexual tendencies and capacity may be the same as appellee. The law certainly denies to some persons of a class and similarly situated the protection which it affords to others of the same class. Under the police power the protection of the health, morals and welfare of the people can be afforded only by laws that apply to all alike. Sterilization laws of New York, New Jersey and Michigan have been held invalid because of such a narrow classification.

Osborn vs. Thomson, 169 N. Y. Supp. 638, 644-645;

Smith vs. Board, 85 N. J. L. 46,88 Atl. 963 , 965-967;

Haynes vs. Williams, - Mich. -; 166 N. W. 938, 1918, D. L. R. A. 233.

No matter what disguise or veneer may be applied by the Act of 1907, the operation provided for is punishment.

"One of the rights of every man of sound mind is to enter into the marriage relation. Such is one of his civil rights."

Davis vs. Berry, 216 Fed. 413, 419.

"The deprivation of any rights, civil or political, previously enjoyed, may be punishment; the circumstances attending and the causes of the deprivation determining the fact."

Cummings vs. Missouri, 71 U. S. 277, 320; 18 L. Ed. 362.

In the only state in which a sterilization statute has been upheld the legislature expressly denominates the operation to be a punishment in these words:

"The court may, in addition to such other punishment or confinement as may be imposed, direct an operation to be performed."

Sec. 2287, Rem. \& Bal. Washington Statutes,

and the court throughout its opinion considers the penalty in the light of a punishment. 
The operation provided for in the Act of 1907 is not only a punishment, but is cruel and inhuman within the meaning of the constitutional provision.

"There is a difference between the operation of castration and vasectomy, castration being physically more severe than the other. But vasectomy in its results is much the coarser and more vulgar. But the purpose and result of the two operations are one and the same. When Blackstone wrote his commentaries he did not mention castration as one of the cruel punishments, quite likely for the reason that with the advance of civilization the operation was looked upon as too cruel, and was no longer performed. But each operation is to destroy the power of procreation. It is, of course, to follow the man during the balance of his life. The physical suffering may not be so great, but that is not the only test of cruel punishment: the humiliation, the degradation, the mental suffering are always present and known by all the public, and will follow him wheresoever he may go. This belongs to the Dark Ages. * * Our conclusion is that the infliction of this penalty is in violation of the Constitution, which provides that cruel and unusual punishment shall not be inflicted."

Davis vs. Berry, 216 Fed. 413, 416-417.

The physical effects of the operation are discussed at length in Osborn vs. Thomson, 169 N. Y. Supp. 627, 640-642, its cruelty clearly established, and its baneful effects both on the individual and upon society established from its practical workings.

The Act of 1907 is likewise a Bill of Attainder, for one of the rights of every man of sound mind is to enter into the marriage relation. Such is one of his civil rights, and deprivation or suspension of any civil right for past conduct is punishment for such conduct and it fulfills the definition of a Bill of Attainder.

Davis vs. Berry, 216 Fed. 413, 419;

Cummings vs. Missouri, 71 U. S. 277, 320.

Counsel for appellants seek to uphold the validity of the Act of 1907 as an exercise of the police power in behalf of the public health, safety and welfare. Without entering into a detailed discussion of this broad subject, it is sufficient to observe that where this question has been considered the courts have invariably held the sterilization statute not to be a valid exercise of the police power.

Justice Rudd, in Osborn vs. Thomson, 169 N. Y. Supp. 638 , at page 644 , in considering a sterilization law as an exercise of the police power, says :

"Such does not seem to this court to be the proper exercise of the police power. It seems to be a tendency almost inhuman in its nature."

Justice Harrison, in Smith vs. Board, 82 N. J. L. 46, 88 Atl. 963, 965-966, says:

"The question thus presented is therefore not one of those constitutional questions that are primarily addressed to the Legislature, but a purely legal question as to the due exercise of the police power, which is always a matter for determination by the courts. *** The feeble-minded and epileptics are not the only persons in the community whose elimination as undesirable citizens would, or might in the judgment of the Legislature, be a distinct benefit to society. If the enforced sterility of this class be a legitimate exercise of governmental power, a wide field of legislative activity and duty is thrown open to which it would be difficult to assign a legal limit. If in the present case we decide that such power exists in the case of epileptics, the doctrine we shall have enunciated cannot stop here. For epilepsy is not the only disease by which the welfare of society at large is injuriously affected. ** There are other things, besides physical or mental diseases, that may render persons undesirable citizens, or might do so in the opinion of a majority of a prevailing legislature. Racial difference, for instance, might afford a basis for such an opinion. $* * *$

"How far is government constitutionally justified in the theoretical betterment of society by means of the surgical sterilization of certain of its unoffending, but undesirable, members? If some, but by no means all, of these illustrations are fanciful, they still serve their purpose of indicating why we place the decision of the present case upon a ground that has no such logical results or untoward circumstances."

It is respectfully submitted that the judgment of the Clark Circuit Court should be affirmed because:

(a) Appellee is not given his day in court by the Act of 1907;

(b) That, if viewed as a punishment, the operation of vasectomy is a cruel and inhuman punishment and the Act of 1907 is a Bill of Attainder;

(c) If viewed merely as an exercise of the police power for the public welfare, the classification of this act is not only so narrow as to deny appellee the equal protection of 
the law, but any sterilization law that might be framed is so repulsive and from its very nature so susceptible to abuse, that it is unlikely that a valid law could be framed.

WILMER T. FOX, Attorney for Appellee.

\section{c. Judgment:}

\section{SUPREME COURT OF INDIANA.}

November Term, 1920.

On the 11th day of May, 1921, being the 147 th judicial day of said November Term, 1920.

Case No. 23709. Appealed from the Clark Circuit Court.

Opinion and judgment pronounced by Associate Judge Hon. Howard L. Townsend.

Appellants were enjoined from performing vasectomy on appellee, who is a prisoner in the Indiana Reformatory.

The Chief Physician, Board of Managers and two chosen surgeons were proposing to act pursuant to the following:

(Here follows the full text of the Indiana sterilization statute. Chapter 215 of the Acts of 1907, page 377 . See p. 15 of this book.)

In Davis vs. Berry et al. (U. S. District Court, S. D.), 216 Fed. Rep. 413, in passing on an Iowa statute similar to the one here in question, on page 218 , the court uses this language:

"The hearing is by an administrative board of officers. There is no actual hearing. There is no evidence. The proceedings are private. The public does not know what is being done until it is done. Witnesses are not produced, or, if produced, they are not cross-examined. *** The prisoner is, not advised of the proceedings until ordered to submit to the operation. ** Due process of law means that every person must have his day in court, and this is as old as Magna Charta; that some time in the proceeding he must be confronted by his accuser and given a public hearing."

In the instant case the prisoner has no opportunity to cross-examine the experts who decide that this operation should be performed upon him. He has no chance to bring experts to show that it should not be performed; nor has he a chance to controvert the scientific question that he is of a class designated in the statute. And wholly aside from the proposition of cruel and unusual punishment, and infliction of pains and penalties by the legislative body through an administrative board, it is very plain that this act is in violation of the Fourteenth Amendment of the Federal Constitution in that it denies appellee due process.

The case of Davis vs. Berry, supra, is interesting in its discussion of questions other than due process. It also cites the adjudicated cases in other states on similar statutes.

The trial court was correct in enjoining appellant from performing, or causing to be performed, the operation of vasectomy upon appellee.

Judgment of the trial court is therefore affirmed. 


\section{CHAPTER VIl. (Concluded)}

\section{PART VIII. OREGON.}

1. State Board of Eugenics.

a. Record of Investigation................................... 27

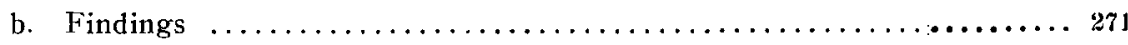

c. Order for Sterilization............................ 272

2. Circuit Court for the County of Marion.

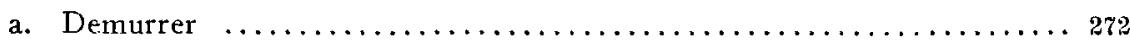

b. Brief of Defendant in Support of Demurrer................ $2 r 3$

c. Points and Authorities (by Smith \& Shields and Allan Bynon, amicus curiae, in Support of Defendant's Demurrer) ........ 279

d. Answering brief of Plaintiff.......................... 283

e. Opinion of Percy R. Kelly and Geo. G. Bingham, Judges......... 287

f. Decision of the Circuit Court.........................289 


\section{(VIII). OREGON.}

(Chapter 279 General Laws of Oregon, 1917.)

In Oregon the duty of examing into the innate traits, the mental and physical condition and the personal records. family traits and histories of defectives and degenerates confined in state institutions is vested in the State Board of Eugenics. It is the duty of the superindendents of the Oregon State Hospitals and the Oregon State Penitentiary to report quarterly to the Board of Eugenics all inmates who are $* * *$ "persons potential of producing offspring, who, because of inheritance of inferior or antisocial traits would probably become a social menace or a ward of the State." Upon decision of this Board of the inadvisability of procreation by such defective or degenerate person, the law requires the Board of Eugenics to issue an order to the superintendent of the institution in which such person is confined, to perform or cause to be performed an operation for sterilization.

The order of the Board of Eugenics. January 27th, 1921, for sterilization of Jacob Cline, an inmate of the Oregon State Penitentiary, convicted for the crime of rape. gave rise to a test of the constitutionality of the statute.

The principal documents in the case follow:

\section{STATE BOARD OF EUGENICS.}

In the Matter of Jacob Cline.

\section{a. Record of Investigation.}

On the 27th day of January, 1921, the State Board of Health met with the Superintendents of the following Institutions:

Mr. L. H. Compton, Warden, State Penitentiary; tal;

Dr. R. E. Lee Steiner, Supt. State Hospi-

Dr. J. N. Smith, Supt. Institution for Feeble-Minded;

the same, together, constituting the State Board of Eugenics, said meeting being held in the city of Salem, County of Marion, State of Oregon, pursuant to, and as required by, law. Said meeting was held for the purpose, among other things, of examining into the innate traits, the mental and physical condition, the personal records and the family traits and history of JACOB CLINE; said Jacob Cline having been previously reported on the 1 st day of January 1921, by L. H. Compton, the Warden of the Oregon State Penitentiary as being a person feeble minded, insane, epileptic, habitually criminal, morally degenerated or sexually perverted, towit:

Sexually perverted, and a potential parent of offspring who, because of inheritance of inferior or antisocial traits, would probably become a social menace or a ward of the State.

Among other things, the State Board of Eugenics did carefully examine into the innate traits, the mental and physical condition, the personal record, and the family traits and histories of the said Jacob Cline so far as the same can be ascertained, and for this purpose the State Board of Eugenics summoned and examined the following witnesses:

$\mathrm{Mr}$. Compton, and $\mathrm{Mr}$. Lewis, assistant Warden who under oath testified before the State Board of Eugenics in substance as follows:

Seems to have mania for sexual intercourse with little girls. Committed to Penitentiary for rape.

(Signed) ANDREW C. SMITH, Secretary State Board of Health. Secretary State Board of Eugenics.

\section{b. Findings.}

Based upon the examination of Jacob Cline as shown by the record of investigation in the above entitled matter, in the judgment of a majority of the members of the State Board of Eugenics, towit: Dr. A. C. Smith, Dr. F. M. Brooks. Dr. W. B. Morse, Dr. C. I. Smith, Dr. Geo. E. Houck, Dr. J. H. Rosenberg, Dr. R. E. L. Steiner, Dr. J. N. Smith and Mr. L. H. Compton; procreation by the above named Jacob Cline, who is now confined in the State Penitentiary would produce children with an inherited tendency to feeble-mindedness, insanity, epilepsy, criminality or degeneracy towit: Degeneracy, and there is no probability that the condition of said Jacob Cline will improve to such an extent as to render procreation by said Jacob Cline advisable, and that the physical. metal, neutral or psychic condition, to wit: the physical and psychic condition of said Jacob Cline will be substantially improved by sterilization in the following manner, towit: Emasculation.

Dated at Salem, Oregon, this 2rth day of January 1921 .

(Signed) ANDREW C. SMITH.

Secretary State Board of Health. Secretary State Board of Eugenics. 


\section{c. Order.}

To L. H. Compton, Warden of the Oregon State Penitentiary.

\section{Greeting:}

Based upon the investigation conducted at Salem, Oregon, on the 27th day of January, 1921, as shown by the record thereof, a copy of which is hereto attached, and upon the result of such investigation, as shown by the Findings of the State Board of Eugenics, a copy of which is hereto attached. you are hereby directed to perform, or cause to be performed, upon JACOB CLINE above named, an operation, sterilizing the said JACOB CLINE by emasculation, which is deemed best by the State Board of Eugenics.

The purpose of this order, and of the investigation and findings of the State Board of Eugenics, is for the betterment of the physical, mental, neural or psychic condition of the said Jacob Cline and not in any manner as a punitive measure.

Dated at Salem, Oregon, this 2ith day of Januàry, 1921.

(Signed) W. B. MORSE, Chairman. (Signed) ANDREW C. SMITH,

Secretary State Board of Health.

Secretary State Board of Eugenics.

\section{CIRCUIT COURT FOR THE COUNTY OF MARION.}

a. Demurrer.

IN THE CIRCUIT COURT OF THE STATE OF OREGON, FOR THE COUNTY OF MARION.

$\left.\begin{array}{c}\text { STATE BOARD OF } \\ \text { EUGENICS, } \\ \text { vs. Plaintiff, } \\ \text { JACOB CLINE, } \\ \text { Defendant. }\end{array}\right\} \begin{aligned} & \text { No. 15442. } \\ & \text { DEMURRER. }\end{aligned}$

Comes now Jacob Cline, the above named defendant, through his attorney, Tom Garland, and demurs to the Order and Findings of the "State Board of Eugenics" and to the entire proceedings herein, on the grounds that the facts stated do not constitute a crime, and do not state sufficient to constitute a cause of action, or suit, and the said board has no lawful right to make said Order or Findings; that the law creating the said Board, and under and by virtue of which these proceedings are had is unconstitutional and void for the following reasons. and upon the following grounds:

1st. That the Act and particularly Sections 85 to 96 inclusive of Chapter 264, 1919
Session Laws, creating the said Board of Eugenics, violates the provisions of the Fourteenth Amendment of the United States Constitution in that said Sections and Law are a denial to this defendant of the equal protection of the laws guaranteed to him under said 14th Amendment, and that the alleged classification in which he is placed is a most unreasonable classification and is of such a general nature as to be ambiguous and unreasonable, and is not based upon reasonable grounds; and is an unjust discrimination against this defendant as it unreasonably singles certain classes of which this defendant is alleged to be one, of a vast number of similar classes that would come within the purview of the attempted legislation, and is a denial to certain classes of citizens, and to this defendant of the same rights given to others; that it is unduly oppressive upon the individual; that it constitutes an unwarranted assault upon his person, and is an inhuman, an unnatural and cruel mutilation and is an unreasonable infringement upon his personal rights, guaranteed him by the said 14th Amendment to the United States Constitution.

That said law, Chapter 264, 1919 Sessions Law, and particularly Sections 85 to 96 inclusive thereof, violates this defendant's rights under

2nd. Article I, Section 12, Constitution of Oregon which provides,

"No person shall be put in jeopardy

twice for the same offense..."

and violates this defendant's rights under

3rd. Article I, Section 13, Constitution of Oregon which provides,

"No person arrested or confined in jail shall be treated with unnecessary rigor"

and violates this defendant's rights under

4th. Article I, Section 15, Constitution of Oregon which provides,

"Laws for the punishment of crime shall be founded upon the principles of reformation and not of vindictive justice"

and violates this defendant's rights under

5th. Article I, Section 16, Constitution of Oregon, which provides,

“. . . cruel and unusual punishment shall not be inflicted, but all penalties shall be in proportion to the offense" and violates this defendant's rights under 6th. Article I, Section 20, Constitution of Oregon, viz: 
"No law shall be passed granting to any citizen or class of citizens, privileges or immunities which, upon the same terms shall not equally belong to all citizens"

and violates this defendant's rights under

7th. Article 1, Section ${ }^{*} 15$, Constitution of Oregon, viz:

"No conviction shall work corruption of blood or forfeiture of estate."

8th. That the said legislative enactment namely Chapter 264, 1919 Session Laws, and Sections 85 to 96 , inclusive, under which these proceedings are brought EMBRACES MATTER NOT PROPERLY EXPRESSED IN THE TITLE in this:

So much of the Act as provides for 'emasculation' and for 'such a type of sterilzation as may be deemed best by said Board' constitutes matters which are not properly connected with the subject expressed in the Title, since the Title mentions merely sterilization, and gives no hint of any provision for emasculation, or any other operation except sterilization, and therefore conflicts with Section 20 of Article IV of the Constitution of the State of Oregon, and hence is unconstitutional and void.

9th. That the aforesaid Act and Law under which these proceedings are brought EMBRACES MORE THAN ONE SUBJECT AND INCLUDES MATTERS NOT PROPERLY CONNECTED THEREWITH, and therefore conflicts with Section 20 of Article IV of the Constitution of the State of Oregon, and hence is unconstitutional and void.

10th. That the aforesaid Act under which these proceedings are brought IS BROADER THAN THE TITLE OF SAID ACT, and therefore conflicts with Section 20 of Article IV of the Constitution of the State of Oregon, and hence is unconstitutional and void.

11th. That said act creating said Board of Eugenics is unconstitutional and void because as is shown upon its face, it blends the executive or administrative departments of government with the judicial, and shows that persons charged with official duties under one of these departments are exercising functions of another, and therefore contravenes Article III, Section I, of the Constitution of Oregon.

Attorney for Defendant. TOM GARLAND.
I, Tom Garland, Counsel for defendant Jacob Cline, hereby certify that in my opinion the foregoing demurrer is well founded in Law,

\section{TOM .GARLAND.}

I, Tom Garland, attorney for Jacob Cline, the within named Defendant, do hereby certify that I served the within Demurrer on John H. Carson, Esq., District Attorney for Marion County, State of Oregon, Attorney for the within State Board of Eugenics, by mailing to said John H. Carson at his office at Salem, Oregon, a true copy thereof, duly certified with postage fully prepaid thereon, on the 27 th. day of June, 1921.

TOM GARLAND, Attorney for Defendant.

b. Brief of defendant in support of demurrer.

IN THE CIRCUIT COURT OF THE STATE OF OREGON, FOR THE COUNTY OF MARION.

\section{STATE BOARD OF No. 15442. EUGENICS, Plaintiff, BRIEF OF DE- FENDANT IN vs. JACOB CLINE,
Defendant. SUPPORT OF DEMURRER.}

The FIRST and SIXTH grounds of Demurrer is, that the Sections of this Act, creating the State Board of Eugenics (Sec. 85 to 96 inclusive. Chapter 264,1919 , S. L.) denies to this defendant, and a certain a1leged class of citizens, the "Equal protection of the laws" guaranteed by the 14th Amendment of the U. S. Constitution and Art. 1, Sec. 20, Constitution of Oregon, in that, the alleged class, to which it is claimed he belongs, is an arbitrary discrimination and an unreasonable classification.

While the defendant recognizes that it is difficult to determine whether a particular classification is unreasonable or reasonable, and that no definite rule can be laid down in this regard, the general rule seems to be, and it is clearly logical and just, that the Court must be able to say, that there is no fair reason for the law that would not require, with equal force, its extension to others whom it leaves untouched; that the PURPOSE of the Law must be taken into consideration, and all persons in like situation and circumstances relative to the particular legislation, undistinguishable from those of the members of the class, must be brought under the influence of the Law. A 
class cannot be carved out of a class nor a class split. In other words, there must not be a mere ARBITRARY selection, making the law apply only to certain persons, while the PURPOSE of the law would not be carried out without including other persons in like situation,

In the case at bar, the whole purpose of the Enactment is to insure offspring who will not bear hereditary traits which would weaken the human race. That is the SOLE purpose; it says, it is not as a punitive measure, but to protect posterity from hereditary diseases. It then proceeds to arbitrarily classify insanity, epileptics, criminality and degeneracy as being such a classification as would accomplish this purpose.

A just and proper classification would be ALL persons affected with diseases that cannot help but be transmitted to offspring, and of such a nature as would be a material detriment to the production of healthy, sane, normal individuals.

It is a matter not only of medical knowledge, but of general notoriety, that tuberculosis, syphilis and cancer are diseases that are surely transmitted to the offspring, with often weakening results, much more so than epilepsy; and that a tendency to criminality is not only not transmitted to posterity, but is often cured in the individuals. Criminality certainly is not transmitted to posterity; as an example, Australia was settled up by and was used as a colony for English criminals and their descendants, and is now one of the most progressive and substantial countries in the world.

The defendant submits that the attempted classification would apply to such a small number of persons, that keeping in view the PURPOSE of the legislation, as to amount to a nullity, towards accomplishing its ends; and simply means a denial to this limited number of persons of the "Equal protection of the laws."

AUTHORITIES for 1st and 6th Points.

"No definite rule can be laid down as to determine whether a Classification is reasonable or unreasonable." -6, R. C. L.. Sec. 373-374.

"If it attempts to create distinctions and classifications between the citizens of this State, the basis of such a classification must be natural and not arbitrary."-Stratton vs. Morris, 89 Tenn. 497. (12 L. R. A. 70.)

"The classification must be upon reasonable grounds, it cannot be a mere arbitrary selection."-Gulf vs. Ellis, 165 U. S. 150.
"There must be SUCH A DIFFERENCE between the situations and circumstances of ALI the Members of the class, and the situation and circumstances of ALL OTHER members of the STATE IN RELATION TO THE SUBJEC'TS of the discriminatory legislation as presents a just, natural reason for the difference made in their liabilities and burdens, and in their rights and privileges." -6 R. C. L., Sec. 374. State vs. Sherman, 18 Wyo. 169. State vs. Chicago, M. \& St. P. R R. Co., 114 Minn. 122; 105 P. A. C. 392; 130 N. W. 545.33 L. R. A. (N. S.) 494. 1912 B. ANN Cas. 1030

"In order that a statute may comply with the necessary requirements as to due process of law, it MUST NOT VIOLATE the limitations as to classification iniposed by the Constitutional inhibition as to the denial of the equal protection of the law." $-6, \mathrm{R}$. C. L., Siec. 369.

"... all who are in a situation and circumstances relative to the subjects of the discriminatory legislation indistinguishable from those of the members of the class must be brought under the influence of the law and treated in the same way as are the members of the class." -15 ANN Cas. 849.

"The only case besides the reported case that appears to have passed on the validity of an asexualization statute is Smith vs. Board of Examiners of Feeble-Minded (N. J.) $88 \mathrm{Atl}$. 963. It appeared in that case that the board of examiners, created by 'an act to authorize and provide for the sterilization of feeble-minded, including idiots, imbeciles and morons, epileptics, rapists, certain criminals and other defectives,' (N. J. P. L. 1911, p. 353), ordered that the operation of salpingectomy be performed on an epileptic inmate of a state charitable institution as the most effective operation for the prevention of procreation. The Court held that the statute in question was based on a classification that bore no reasonable relation to the object of such police regulation, and hence denied to the individuals of the class so selected the equal protection of the laws guaranteed by the fourteenth amendment to the Constitution of the United States. The Court said: "The prosecutrix falls within the classification of the statute in that she is an inmate of the State Village for Epileptics, a state charitable institution, 'the objects of which,' as stated in the act creating it, are 'to secure the humane, curative, scientific and economical care and treatment of epilepsy,' 4 Comp. Stat. p. 4961. The prosecutrix has 
been an inmate of this charity since 1902, and for the five years last past she has had no attack of the disease. From this statement of the facts it is clear that the order with which we have to deal threatens possibly the life, and certainly the liberty of the prosecutrix in a manner forbidden by both the state and federal constitutions, unless such order is a valid exercise of the police power. The question thus presented is therefore not one of those constitutional questions that are primarily addressed to the legislature; but a purely legal question as to the due exercise of the police power. which is always a matter of determination by the courts. This power, stated as broadly as the argument in support of the order requires, is the exercise by the legislature of a state of its inherent sovereignty to enact and enforce whatever regulations are in its judgment demanded for the welfare of society at large in order to secure or guard its order, safety, health, or morals. The general limitation of such power to which the prosecu'rix must appeal is that under our system of government the artificial enhancement of the public welfare by the forcible suppression of the constitutional rights of the individual is inadmissible. Somewhere between these two fundamental propositions the exercise of the police power in the present case must fall, and its assignment to the former rather than to the latter involves consequenkes of the greatest magnitude. For while the case in hand raises the very important and novel question whether it is one of the attributes of government to essay the theoretical improvement of society by destroying the function of procreation in certain of its members who are not malefactors against its laws, it is evident that the decision of that question carries with it certain logical consequences of the greatest magnitude. For the feeble-minded and epileptics are not the only persons in the community whose elimination as undesirable citizens would, or might in the judgment of the legislature, be a distinct benefit ta society. If the enforced sterility of this class be a legitimate exercise of governmental power, a wide field of legis. lative activity and duty is thrown open to which it would"be difficult to assign a legal limit. If in the present case we decide that such a power exists in the case of epileptics, the doctrine we shall have enunciated cannot stop there. For epilepsy is not the only disease by which the welfare of society at large is injuriously affected; indeed, not being communicable by contagion or otherwise, it lacks some of the gravest dangers that attend upon such diseases as pulmonary consumption or communicable syphilis. So that it would seem to be a logical necessity, that if the legislature may, under the police power, theoretically benefit the next generation by the sterilization of the epileptics of this, it both may and should pursue the like course with respect to the other diseases mentioned, with the additional gain to society thereby arising from the protection of the present generation from contagion or contamination. Even when these and many other diseases that might be named have been included, the limits of logical necessity have, by no means, been reached. There are other things besides physical or mental diseases that may render persons undesirable citizens, or might do so in the opinion of a majority of a prevailing legislature. Racial differences, for instance, might afford a basis for such an opinion in communities where that question is unfortunately a permanent and paramount issue. Even beyond all such considerations it might be logically consistent to bring the philosophic theory of Malthus to bear upon the police power to the end that the tendency of population to outgrow its means of subsistence should be counteracted by surgical interference of the sort we are now considering. Evidently the large and underlying question is, how far is government constitutionally justified in the theoretical betterment of society by means of the surgical sterilization of certain of its unoffending, but undesirable, members? If some, but by no means all, of these illustrations are fanciful, they still serve their purpose of indicating why we place the decision of the present case upon a ground that has no such logical results or untoward consequences. Such a ground is presented by the CLASSIFICATION upon which the present statute is based, which is of such a nature that the persons included within it are not afforded the equal protection of the laws under the Fourteenth Amendment of the Constitution of the United States, which provides that 'no state shall deny to any person within its jurisdiction the equal pro. tection of the laws.' Under this provision it has been universally held that a state statute that bears solely on a class of persons selected by it must: not only bear alike upon all individuals of such class, but that the class as a whole must bear some reasonable relation to the legislation thus solely affect- 
ing the individuals that compose it. 'It is apparent,' said Mr. Justice Brewer in Gulf, etc., R. Co. vs. Ellis, 165 U. S. 150, 17 S. Ct. 255, 41 U. S. (L. ed) 666, after a review OF MANY CASES, 'that the mere fact of classification is not sufficient to relieve a statute from the reach of the equality clause of the Fourteenth Amendment, and that in all cases it must appear, not only that a classification has been made, but also that it is one based upon some reasonable ground-some difference which bears a just and proper relation to the attempted classification-and is not a mere arbitrary selection. 'This summarizes a mass of cases that might be cited. Turning our attention now to the classification on which the present statuie is based, and laying aside criminals and persons confined in penal institutions with which we have no present concern, it will be seen that-as to epileptics, with which alone we have to do-the force of the statute falls wholly upon such epileptics as are inmates confined in the severa! charitable institutions in the counties and state.' It must be apparent that the class thus selected is singularly narrow when the broad purpose of the statute and the avowed object sought to be accomplished by it are considered. The objection, however, is not that the class is small as compared with the magnitude of the purpose in view, which is nothing less than the artificial improvement of society at large, but that it is singularly inept for the accomplishment of that purpose in this respect, viz., that if such object requires the sterilization of the class so selected, then a fortiorari does $i^{2}$ require the sterilization of the vastly greater class who are not protected from procreation by their confinement in state or county institutions. The broad class to which the legislative remedy is normally applicable is that of epileptics; i. e.. all epileptics. Now. epilepsy, if not, as some authorities contend, mainly a disease of the well to do and overfed, is at least one that affects all ranks of society, the rich as well as the poor. If it be conceded, for the sake of argument. that the legislature may select one of these broadly defined classes-i. e., the poor-and may legislate solely with reference to this class, it is evident that, by the further subclassification of the poor into those who are and those who are not inmates in pulslic charitable institutions, a principle of selection is adopted that bears no reasonable relation to the proposed scheme for the artilicial better- ment of society. For not only will society at large be just as injuriously affected by the procreation of epileptics who are not confined in such institutions as it will be by the procreation of those who are so confined, but the former vastly outnumber the latter, and are, in the nature of things, vastly more exposed to the temptation and opportunity of procreation, which indeed in cases of those confined in a presumably well-conducted public institution is reduced practically to nil. The particular vice, therefore, of the present classification is not so much that it creates a subclassification, based upon no reasonable basis, as that, having thereby arbitrarily created two classes, it applies the statutory remedy to that one of those classes to which it has the least, and in no event a sole, application, and to which indeed upon the presumption of the proper management of our public institutions it has no application at all. When we consider that such statutory scheme necessarily involves a suppression of personal liberty and a possible menace to the life of the individual who must submit to it, it is not asking too much that an artificial regulation of society that involves these constitutional rights of some of its members shall be accomplished, if at all, by a statute that does not deny to the persons injuriously affected the equal protection of the laws guaranteed by the Federal Constitution."

Note: State vs. Feilen, (Wash.) ANN. CASES. 1914 B. 515.

The EIGHTH ground of Demurrer is that the Act EMBRACES MATTERS NOT PROPERLY EXPRESSED IN THE TITLE.

"The title must not be a cover for surreptitious legislation, but the subject or object of every law must be so expressed in the title as to give notice of the contents of the law."-R. C. Law. p. 848. Sec: 94.

"The title of an act defines its scope. It can contain no valid provisions beyond the range of the subject there stated."-Peterson vs. Lewis, 78 Ore. 641. 654 .

And as stated in 26 A. \& E. Encyc. of Law, (2nd Ed.), 589, 590.

"Where the language employed in the title is such as would lead a reasonable man to suppose that the legislature intended to restrict the scope of the act within certain limits specified in the title, such act is unconstitutional so far as concerns any provisions outside of the limits thus marked 
out, even though such provisions might properly have been included in the act under a broader title."

So much of the act as provided for "emasculation" and for "such a type of sterilization as may be deemed best by said Board" constitutes matters which are not properly expressed in the Title, since the Title mentions merely "sterilization" and gives no hint of any provision for "emasculation".

"Sterilization"-Act or process of sterilizing; also, state of being sterile.

"Emasculate"-To deprive of virile or procreative power, to castrate; geld, to render effeminate.-Websters International Dictionary. (New) G. \& C. Merriam Co. 1911.

"Words and Phrases" has no definition for sterilization or emasculation. "Sterilization" is generally recognized, and has a POPULAR meaning as an operation consisting of ligating and resecting a small portion of the vas deferens. It is very simple and easy to perform and may be done without administering an anaesthetic, either general or local. It requires only a few minutes time to perform the operation and the subject returns to his work immediately, and is effectively STERILIZED. It does not affect the physica1 capacity of the individual to perform the sexual act, but merely destroys the ability to procreate.

"EMASCULATE" is to castrate; and is a serious surgical operation, often endangering the subject's life, particularly like the case at bar where the defendant is a man of advanced years. The operation renders the individual effeminate, changes his voice, skin. hair, weight, and renders his mind dull and rapidly causes a complete deterioration of all the subject's faculties, as an example. A convict in Salem named Fagan was recently emasculated, that is castrated, and the papers were full of how he was placed upon the operation table as he had consented to being sterilized, under a promise of release: and when he came out from under the anæsthetic and found he had been castrated he rapidly became insane, and when released shot a man near the Dalles and attempted to kill the family and he was shot by the officers.

Men charged with FORGERY, LARCENY, BURGLARY AND EVERY known crime, to the number of Sixty, it is stated, have been slated for castration in the Oregon State Penitentiary. A wholesale butchery of these poor unfortunate individuals, simply to satisfy the obsession of some well meaning but narrow minded reformers will blot the fair name of Oregon.

Emasculation was not mentioned in the Title of the Act. The title is a restrictive one.

The NINTH and TENTH grounds of Demurrer are that the Act EMBRACES MORE THAN ONE SUBJECT AND INCLUDES MATTERS NOT PROPERLY CONNECTED THEREWITH, and is broader than the title of said act.

Article IV, Sec. 20, Constitution of Oregon provides:

"Every act shall embrace BUT ONE SUBJECT, and matters properly connected therewith which subject shall be expressed in the title."

But if any subject shall be embraced in an act which shall not be expressed in the title, SUCH ACT shall be void only to so much thereof as shall not be expressed in the title.

"It is not essential that the Legislative title to an act shall specify with particularity all the different provisions of the act. It is sufficient, if the general subject of the act be contained in the title and is a fair index to the legislative purpose and if all the provisions of the act are germane to such subject and do not relate to mat,ters wholly foreign thereto." - In re Willow Creek-74 Ore. 615.

"The object of this provision was to prohibit embracing in bills matters having no relation to each other, wholly incongruous and of which the title gives no notice, thus securing the adoption of measures by fraud without attracting attention, or combining subjects representing diverse interests, in order to unite the members of the legislature who favored either in support of all."State vs. Shaw, 22 Ore. 288. Clemensen vs. Peterson, 35 Ore. 47. State vs. Levy, 76 Ore. 63. State vs. Perry, 77 Ore. 266.

The title of this act purports primarily to create "A State Board of Health". It is a restrictive title. If it were an Act "Relating to the Public Health" it might properly include a good many of the subjects embraced in this act, but not all of them, as some of the subjects embraced in this act are not even germane to or properly connected with that subject. It is simply an attempt to bunch a lot of different subjects.

The EIEVIENTH ground of Demurrer is, that the Act shows on its fae that persons charged with official duties under one of the departments, the administrative, which 
is a branch of the executive, is exercising functions of another, that is of the judicial.

Article III, Sec. 1, Constitution of Oregon, provides:

"The powers of the Government shall be divided into separate departments, the legislative, the executive, including the admiristrative, and judicial; and no person charged with official duties under one of these departments shall exercise any of the functions of another except as in this Constitution expressly provided."

"under Article VII.-1. A, as amended. the Legislature was authorized to confer judicial power upon the State Accident Commission, ...... since under the Amendment the legislature or the people may confer judicial powers upon any tribunal selected, SO J_ONG AS THE DIFFERENT DEPARTMENTS OF GOVERNMENT ARE NOT MADE TO ENCROACH UPON EACH OTHER.-Evanhoff vs. State Industria! Accident Commission, 78 Ore. 515.

"What is Judicial power within Constitutional Theory as to separation of Powers of Government."-Note in 1913 E. Ann. Cas. 1097.

\section{Section 85 of the Act provides:}

"There is hereby established and constituted for the State of Oregon a 'State Board of Eugenics,' which shall be composed of the State Board of Health, the Sup't of the Oregon State Hospital, the Sup't of the Eastern Oregon State Hospital, the Sup't of the State Institution for Feeble-Minded, and the Sup't of the Oregon State Penitentiary, whose duties shall be as hereinafter defined."

These are ALL Administrative Officers of the State of Oregon, and are appointees of the Executive.

Now our inquiry is, do they perform Judicial functions under the Act in question.

Sec. 86 provides that the above Administrative Officers shall report to the "State Board of Eugenics" (that is report to themselves) all persons who they think PROBABLY come under the law.

Sec. 87 provides in substance, that they shall then examine into "the innate traits, the mental and physical conditions, the personal records, and the family traits and histories. of all persons so reported as far as the same can be ascertained."

The Board has power to summon witnesses.
To administer oaths.

To DETERMINE “IF IN THE JUDGMENT" of a majority of said Board procreation by any such person would produce children with an inherited TENDENCY to feeble-mindedness, insanity, epilepsy, criminality and degeneracy,-or if the physical or mental conditions of any such person will be substantialiy improved thereby-then it shall be the duty of said Board TO MAKE AN ORDER DIRECTING THE STATE HEALTH OFFICER TO PERFORM OR CAUSE TO BE PERFORMED UPON SUCH PERSON SUCH A TYPE OF STERILIZATION AS MAY BE DEEMED BEST BY SAID BOARD. Sec. 88 -and no person shall be "Emasculated" under the authority of this act except that such operation shall be found to be necessary to improve the physical, mental, neural or psychic condition of such person. Such person shall be served with a copy of the written findings and orders of said board.

The person then has a right to an appeal to the Circuit Court. If no appeal is taken in 15 days the operation SHALL be performed. Sec. 91. provides that upon appeal "the trial shall be a trial de novo at law as provided by the Statutes of the State for trials of actions at law."

Trial de novo means "A new; a fresh; a second time," in other words a second trial.

"To constitute a delegation to a ministerial officer of judicial powers, it is not necessary that the adjudication be conclusive of the rights of the parties put in issue; but if the officer is clothed with the power of adjudicating on and protecting the rights and interests of contending parties and the adjudication involves the construction and application of the law and effects the rights and interests of the parties, although not finally determining the rights it is a judicial pro ceeding, or the exercise of a judicial func tion."-6 R. C. L. Page 172.

Now to apply the above formally to the matter under discussion:

1. The contending parties are the state and the person reported upon.

2. The Board is clothed with the power to protect the rights of the parties; and for this purpose may summon witnesses and examine them under oath.

3. The Board construes the law as to what kind of an operation shall be performed, and applies it as to whether the person is subject to it or not. 
The writer is not unmindful that there are decisions which hold that administrative boards have the right to "determine a fact" and that then the law operates independent of the administrative board as to the consequences following the ascertainment of the facts. In the Act under discussion the board not only ascertains a fact but then determines "what form of operation is best" and orders that it shall be carried out.

The state board of Eugenics is given power under the act of determining who will "probably" (Sec. 86) come under the provisions of the classification. Then after ascertaining this fact (that is if ascertaining the probability of a thing is ascertaining a fact) they are vested with the further discretionary power ("if in the judgment Sec. 87 ") of construing the law; $i$. e., of deciding what kind of operation is to be performed ("such a type of sterilization as may be deemed best by said board.") It is analogous to the proposition that if a board were to have power to determine if a certain person probably came within the class of say vagrants, and further deciding (such a type of imprisonment as may be deemed best by said board) imprisonment for one day, or one year.

If a board composed of administrative officers can determine that a person's classification is so and so; and further can assess a punishment to this type or that, in their discretion, then what are our Courts for? If this is not using judicial power, what is it?

No Right of Appeal to the supreme court.

As this is a special proceeding-neither civil nor criminal-there is grave doubt as to the right of an appeal to the Supreme Court, in fact the framers of the act would not have allowed an appeal to this Court if they could have helped it-but they were afraid to go that far just yet.

As to right of appeals-from boards,Smith Securities Co. vs. Mult. County, 98 Ore. 419.

\section{Demurrer.}

The act does not provide for any procedure in the Circuit Court, so Sec. 3 L. O. L. applies; which provides the "Means to be used by Court to execute its Powers," therefore a demurrer herein is proper.

\section{Latest enactment.}

Chapter 279, 1917 S. L. attempted to legislate upon the same subject, but this present law Chapter 264, 1919, S. L. is the later law, and by implication and time supersedes and repeals the older law.

\section{IN CONCLUSION}

The greatest menace to the liberty of the American people, today, is the assumption of power, by boards and commissions, that is absolutely unwarranted under our Constitution. An open enemy we can fight-usurpation of Judicial functions by commissioners and boards, with their arbitrary decisions, is the fear of every lover and student of our Constitution. We are fast becoming a government by functionaries, rather than a government by laws.

I respectfully submit to your Honor, that the Demurrer herein should be sustained.

(Signed) TOM GARLAND, Attorney for Jacob Cline.

\section{c. Points and authorities.}

IN THE CIRCUIT COURT OF THE STATE OF OREGON. FOR THE COUNTY OF MARION.

Department No. 1.

$\begin{array}{cr}\text { State Board of Eugenics, } & \text { Plaintiff, } \\ \text { Jacob Cline, } & \\ & \text { BUPIEF IN } \\ \text { SUPORT OF } \\ \text { DEFENDANT'S } \\ \text { DEMURRER. }\end{array}$

Points and Authorities.

I.

That Sections 8448 to 8459 , both inclusive, Oregon Laws, are unconstitutional and void as class legislation.

14th Amendment of the Constitution of the U. S.

Article 1, Section 20, Constitution of Oregon.

Smith vs. Board of Examiners, $85 \mathrm{NJL} 47$.

Mickle vs. Henrichs, 262 Fed. Rep. 688.

Haynes vs. Williams 166 N. W. 938-L.R.A.

1918 D. 233, 6 R. C. L. Page 383, Sec. 375.

Osborn vs. Thomson, 169 N. Y. S. 638.

State vs. Goodhue, 63 Ore. 11\%.

Altschul vs. State 72 Ore. 591.

Ideal Tea Co. vs. Salem, 77 Ore. 182.

Sterett et al vs. Portland, 79 Ore, 260, 272. Chan Sing vs. Astoria, 79 Ore. 411.

Monroe vs. Whitycombe, 84 Ore. 328.

\section{II.}

That the above referred to sections, Oregon Laws, are unconstitutional and void in that they constitute and provide for cruel and unusual punishment.

Article 1, Section 16, Constitution of Oregon.

Davis vs. Berry, 216 Fed. Rep. 413.

Mickle vs. Henrichs, 262 Fed. Rep. 687.

Osborn vs. Thompson, 169 N. Y. S. 638. 


\section{III.}

That the above referred to sections. Oregon Laws, are unconstitutional and void in that they violate the constitutional requirement that no Court shall be secret, but justice shall be administered openly and without purchase, completely and without delay and that in all criminal prosecutions, the accused shall have the right to public trial by an impartial jury, in the county in which the offense shall have been committed, to be heard by himself and counsel, to demand the nature and cause of the accusation against him, and to have a copy thereof; to meet the witnesses face to face, and to have compulsory process for obtaining witnesses in his favor.-Art. 1, Sec. 10 and 11, Constitution of Oregon. Davis vs. Berry, 216 Fed. Rep. 413.

\section{IV.}

That the above referred to sections, Oregon Laws, are unconstitutional and void in that they constitu'e and provide for a bill of Attainder and a Bill of Pains and Penalties.-Art. 1, Sec. 9, Constitution of the U. S. Art. 1. Sec. 25, Constitution of Oregon. Davis vs. Berry, 216 Fed. Rep. 413.

Note: The case of Davis vs. Berry, supra, was reversed by the Supreme Court of the United States January 15, 1917, without reference to the merits of the case, for the reason. as announced by the Chief Justice. that the original state enactment appealed from had meanwhile been repealed by the Iowa State Legislature and that the case had become moot for that reason, the Court directed that the case be reversed and remanded, with directions to dismiss the bill without costs.-Berry et al vs. Davis $242 \mathrm{U}$. S. 468 .

\section{ARGUMENT.}

\section{Class Legislation.}

The Legislature in 1917 enacted a law. now codified, 2887 to 2898 , both inclusive, Oregon Laws, which provided in substance for the establishment and personnel of a Sta ${ }^{2}$ e Board of Eugenics; for the report of the Superintendent of the Oregon State Hospital, the Superintendent of the State Insitution for Feeble-Minded and the Superintendent of the Oregon State Penitentiary, to the State Board of Eugenics, of certain persons within these state institutions who are persons potential to producing offspring who would probably become a social menace or ward of the State: for the sterilization of habitual criminals and for the details of administra- tion of the said Board of Eugenics, covering the procedure necessary to effect a performance of surgical operations on the said subjects of the enactment; the enactment also defined who shall come within the operation of this law, therein defining criminals and moral degenerates; providing that the act applies to males and females alike.

This law, so patently unconstitutional as contravening the proscription against class legislation, in that it applied only to inmates of state institutions, was somewhat doctored up and patched up and the attempt was made to supply the missing supports, in order to safely and effectively execute the purposes of this measure, by the enactment of a similar law by the 1919 Legislature. This latter enactment is now codified as Sections 8448 to 8459 , both inclusive. Oregon Laws. and an inspection of the latter enactment discloses:

I. In Section 8449, the addition of the State Health Officer to the several superintendents of Oregon state institutions, as a. member of the Board of Eugenics. This State Health Officer doubtless was added in order that he might cover all persons living in the State of Oregon outside of the mentioned state institutions. Section 8458 shows the same attempt to patch up the manifestly unconstitutional enactment of 1917 , by stating that "the provisions of the foregoing ten sections of this act shall apply to all persons within the State of Oregon...." But, the zealous guardian of the people's destiny, who framed this legislation, forgot in his haste to sufficiently befog his true purposes. by disclosing in other sections that what was really intended was what the 1917 enactment expressly declared, namely, óperations on persons presently held in Oregon state institutions. The examination of Section 8456 is all that is necessary to show that this is true. This section states that "upon the receipt of the order from the State Board of Eugenics, provided for in Sec. 8450 , the Superintendent of the institution to which it is directed shall, after the time for appeal has expired. or in case of appeal, upon entering of a judgment affirming the order of the Board, and it is hereby made his lawful duty, to perform, or cause to be performed. such surgical operation as may be specified in the order of the State Board of Eugenics. All such operations shall be performed with a due regard for the physical condition of the inmate and in a safe and humane manner." 
The closest inspection of the 1919 enactment fails to disclose any provision for, or the modus operandi, taking any person in the State of Oregon, not an inmate of an Oregon institution, into custody for the surgical operation so necessary to preserve the race. How does the private citizen come into confinement and under the authoritiy of the Board of Eugenics for this operation? It was never intended by the framers of this legislation that a person outside of an Oregon State institution should be the object of the State's beneficence.

But, granting, for the sake of argument, that the law, as it stands, does provide for and cover the entire population of this State, the logical conclusions which must be drawn immediately disclose the utter viciousness of such class legislation. What constitutional power is this that thus permits the Sitate Health Officer to arbitrarily single out John Doe and to permit Richard Roe, perhaps twice as vicious and morally degenerate as John Doe, to go unscathed? There is no power nor method prescribed for requiring the State Health Officer to report to the State Board of Eugenics any man, no matter how vicious, unless it suits his whim or caprice. Should fifteen days from the date of the secret or closed session and findings of the Board go by before John Doe appeals from the mandate of the Board, then what power can prevent his suffering an irremediable and final damage? Surely this places more arbitrary power in the hands of any one man than any other piece of legislation that has ever been foisted upon an unsuspecting people, under the guise of the police power.

This is class legislation of the most: revolutionary character, for here the class to be affected is not even defined by the Legislature, but left to the arbitrary whim of an appointive administrative officer. For instance, this officer could order castrated all baldheaded degenerates, and leave the rest without competition, and still no remedy would exist, for there is no way to compel such officer to report any particular person to the Board.-See Beveridge vs. Lewis, 67 Pac. Rep, 1040.

Another fatal element which is patently class discrimination is found in Section 8451 . Here the law says "..... and no person shall be emasculated under the authority of this act except that such operation shall be found necessary to improve the physical, mental, neural or psychic condition of such person." Emasculation, by every authority known, means castration, and cannot be held to include any other than male persons. This is discriminatory and class legislation.

\section{Cruel and Unusual Punishment.}

Defendant contends that the enactment provides for a law which is both cruel and unusual, con arary to our organic law. Numerous cases have sustained this position. It will be noted in the case of Osborn vs. Thomson, 169 N. Y. S. 638, in which case the Court has, fortunately, set out at length the testimony of the doctors called before the Court in the hearing of this cause, that the doctors uniformly testified to the falsity of hope placed in the operation known as vasectomy. They urged that castration is the only certain operation to be performed on the male to realize the ends sought. Medical history is replete with instances and records of the deleterious and destructive effects resulting from this operation. The whole soma changes, enthusiasm, interest in life, the will to sustain position sufficient to make a living. is undermined; mental changes soon occur and the robbing of these or any other glands is permanently and irreparably harmful to the loser.

"No one can doubt but that under our present civilization, if castration were to be adoptied as a mode of punishment for any criminal, all minds would so revolt that all Courts without hesitation would declare it to be a cruel and unusual punishment. As we understand it, castration was never inficted after the Revolution of 1688 . So that if, as some now contend, it is now competent for a Legislature to impose such punishment as existed by the common law, the validity of the statute providing for castration could not be upheld because that punishment was one imposed back of the time of the common law as, generally speaking, it comes down to us."-Davis vs. Berry, 216 Fed. Rep. 417.

Whatever may be said as to vasectomy being a minor matter so far as the immediate pain and immediate effect of the operation is concerned, it cannot be denied that grave and serious consequences result because of it.

a. "......that a careful and scientific study of ductless glands and their secretions shows that when such secretions forming in the body are interfered with, that physiological teaching indicates that conditions are created which affect the brain and the nerv. ous system;--" 
b. "..... that when such operations have been done against the will of the patient the psychic effects have been bad;....."

c. "..... Dr. Coakley, a specialist in vivisection, testified as to the danger of infection because of the retained secretions in the body. ...."-Osborn vs. Thomson, $169 \mathrm{~N}$. Y. C. 641.

It will doubtless be conceded that the operation of vasectomy is of itself a matter of minor consequence, but the like operation performed on the female, known as salpingectomy, is serious in its character, requiring an anaesthesia, an abdominal section and the risks incident thereto. It will be seen from Section 8450 that the State Board of Eugenics is duty bound to make an order directing the State Health Officer to perform or cause to be performed upon such person such a type of sterilization as may be deemed best by said Board.

"The statute is broad enough to authorize an operation for the removal of any one (in the female) of these three organs, that is, the ovary, the Fallopian tube and the uterus, which are essential to procreation."-Os. born vs. Thomson, 169 N. Y. S. 643.

Surely, then, Salpingectomy, a major operation, and castration, both so far-reaching in physical and mental and moral effect, are dangerous and cruel and unusual punishments.

III. and IV. Due Process of Law; Bill of Attainder and Bill of Pains and Penalties.

In view of the able manner in which our contentions in these regards are set out in Davis vs. Berry, 216 Fed. Rep. 413, we deem more than passing comment an affront to the intelligence of the Court, and altogether unnecessary. Suffice it to say that the 1919 enactment, attacked herein, provides for so elastic a procedure, so loosely confined to the established practices of determining issues under the American system of government that it contravenes the controlling spirit of "due process of law," as we understand it. No opportunity is given the accused. to face his accusers. There is no public trial; certainly there is no impartial jury. The hearing is not had before the accused nor is he represented by counsel. His right "to demand the nature and cause of the accusation against him and to have a copy thereof" is shelved until after the Board has reached its findings. And as to meeting the witnesses face to face, and as to having compulsory process for obtaining witnesses in his favor, these requirements seem to have been altogether forgotten by the framers of this bill, to whom selective breeding means more than our Constitution.

A Bill of Attainder has been defined as a legislative act which inflicts punishment without a jury trial.-The Federalist, No. 44 by Madison, Watson Const. 733-738.

Section 8451 tells $u$ s that the deprivation and forcible ravishment of the genital organs of the male or female, as the case may be, is not in any manner a punitive measure. This is sweet sop to all save the victim of the surgeon's knife. He knows what has happened to him and that it is a punishment. In Section 8457, we note that the additional punishment, namely, sterilization by vasectomy, salpingectomy, castration or some other violent and dangerous operation shall be awarded any person

(1) who has been committed and is an in mate of any institution for feebleminded or hospital for insane, maintained by the State of Oregon,

(2) or is a criminal who has been convicted three or more times of a felony in the courts of any state and sentenced to serve in the penitentiary therefor, or

(3) is a moral degenerate or sexual pervert who is addicted to the practice of sodomy or the crime against nature or to other gross, bestial or perverted sexual habits and practices prohibited by statute,

because such incarceration, commitment or addiction is arbitrarily made by statute prima facia evidence that procreation by any such person would produce children with an inherited tendency to feeble-mindedness, insanity, epilepsy, criminality or degeneracy. The mere fact that the framers of this act stamped the enactment "not punitive" does not efface and destroy its punitive effect. "A rose by any other name would smell as sweet." The clause in the Constitution prohibiting Bills of Attainder includes Bills of Pains and Penalties.-Story Const. Sec. 1338. Hare Am. Const. L. 549. Cummings vs. Missouri, 4 Wall. (U. S.) 323.

Respectfully submitted, (Signed) SMITH \& SHIELDS ALI.AN BYNON. Amicus Curiae. 


\section{d. Answering brief of plaintiff.}

IN THE CIRCUIT COURT OF THE STATE OF OREGON FOR THE COUNTY OF MARION.

$\left.\begin{array}{cr}\text { State Board of Eugenics, } \\ \text { Plaintiff, } \\ \text { Jacob Cline, } & \\ \text { vs. } & \text { Defendant. }\end{array}\right\} \begin{gathered}\text { No. 15,442 } \\ \text { ANSWERING } \\ \text { BRIEF OF } \\ \text { PLAINTIFF } \\ \text { AGAINST DE- } \\ \text { MURRER OF } \\ \text { DEFENDANT. }\end{gathered}$

Of the various grounds suggested by the defendant in support of demurrer, relative to the constitutionality of sections 85 to 96 , inclusive, of chapter 264, Laws of 1919 , there appears the objection that the title of the act is defective. The part of the title relating expressly to that part of the health code under consideration in this case reads as follows:

"Providing the powers and duties of the State Board of Health and for the establishment of a State Board of Eugenics, and their powers and duties; providing for sterilization of certain classes and for appeal from the orders of the State Board of Health and State Board of Eugenics in relation thereto, and appointment of attorneys to defend certain cases, defining moral degenerates and sexual perverts."

A cursory examination of the title to said chapter discloses an attempt to index the various provisions of a health code, which, of course, is unnecessary, it having been held In $\operatorname{Re}$ Willowcreek, 74 Or. 615, that

"It is sufficient if the general subject of the act be contained in the title and is a fair index to the legislative purposes, and if all the provisions of the act are germane to such subject and do not relate to matters wholly foreign thereto."

It should not, however, be held that this title is so imperfect as to render the act unconstitutional merely because of its undue length. Considered as a whole it is a fair index to the legislative purpose, and the provisions of the act are germane to it. The matters in the bill are essentially health measures and all pertain to a health code; an examination of them will show that they are not incongruous or representative of diverse interests.

"The history and object of this constitutional provision, and the mischief against which it was aimed should be kept steadily in view by the courts in its construction and application. It was intended to prevent the practice, common in legislative bodies not thus restricted, of embracing in the bill matters having no relation to each other, wholly incongruous, and of which the title gives no notice, thus securing the adoption of measures by fraud and without attracting attention; or combining subjects representing diverse interests, in order to unite the members of the legislature who favored either in support of all. These combinations being corruptive of the legislature and dangerous to the state, are prohibited in most, if not all, the states by constitutional provision similar to ours. This provision was not designed to embarrass legislation, but to put an end to legislation of the vicious character referred to, and has been always liberally construed to sustain legislation not within the mischief."--State vs. Shaw, 22 Or. 288.

The unconstitutionality of the act is urged on the further ground that it denies to the class to which defendant belongs equal protection of the laws afforded under the Fourteenth Amendment of the Constitution of the United States, and Article I, Section 20 of the constitution of the State of Oregon, because the act arbitrarily classifies insane, epileptics, criminals and degenerates as the only types, the elimination of which would decrease the number of state dependents and charges.

These are not precisely the classifications made by the act as an examination of section 86 will disclose. That section reads as follows:

"It shall be, and it is hereby declared, the duty of the superintendent of the Oregon State Hospital, the superintendent of the Eastern Oregon state hospital, the superintendent of the state institution for feebleminded, and the superintendent of the Oregon state penitentiary and the state health officer to report quarterly on the first of January, April, July and October, to the state board of eugenics, all feeble-minded, insane, epileptic, habitual criminals, moral degenerates and sexual perverts, who are persons potential to producing offspring who, because of inheritance of inferior or antisocial traits, would probably become a social menace, or a ward of the state."

In section 88 the purpose of the act is declared to be for the betterment of the physical, mental, neural or psychic condition of the person or to protect society from the menace of procreation by said person. Insofar as its provisions call for sterilization for the purpose of elininating hereditary dis- 
abilities, it is of broader effect as to the persons to whom it applies than as to the persons upon whom operations for the purpose of emasculation are permitted to be performed. As to the first, it apparently seeks protection against a constantly increasing number of state charges, while as to the latter, its purpose is declared to be for the inprovement of the physical, mental, neural or psychic condition of the person operated upon.

The classes of persons to whom the statute applies are capable of endangering the safety and morals of the community and adding greatly to the sum of human suffering. The classifications are not confined to inmates of the State institutions, nor made to apply arbitrarily to the poor to the exclusion of the rich and are not otherwise unreasonably restricted or limited. Beyond these considerations the courts are not concerned. The propriety, wisdom and expediency of legislation is exclusively a legislative question.-McCrary vs, U. S., 195 U. S. 27.

Similar laws have been passed by various states: California and Connecticut in 1909, Indiana in 1907, New York, Michigan. Kansas. Wisconsin, North Dakota in 1912 and 1913. These acts are in exercise of the police power to protect the state against the constantly increasing burden of the support and maintenance of feeble-minded, ingsane and criminal persons. They all proceed upon the theory that the duty of society to protect and preserve itself is higher than its duty to protect and preserve individuals who are a menace to society and who will procreate their own kind.

The constitutionality of statutes passed for the purpose of protecting the state against the birth of undesirable citizens by prohibiting the marriage of a white person to a negro and of epileptics under the age of forty-five have been upheld.-Lonas v. State. 3 Heisk (Tenn.) 287; State v. Gibson, 36 Ind. 389; Gould v. Gould, 78 Conn. 242.

In the case of Gould v. Gould the classification in a statute prohibiting marriage in certain cases of epileptics was considered by the court as follows:

"One mode of guarding against the perpetuation of epilepsy obviously is to forbid sexual intercourse with those afflicted by it, and to preclude such opportunities for sexual intercourse as marriage furnishes. To impose such a restriction upon the right to contract marriage, if not intrinsically unreasonable, is no invasion of the equality of all men before the law, if it applies equally to all under the same circumstances who belong to a certain class of persons, which class can reasonably be regarded as one requiring special legislation either for their protection or for the protection from them of the community at large. It cannot be pronounced by the judiciary to be intrinsically unreasonable, if it should be regarded as a determination by the General Assembly that a law of this kind is necessary for the preservation of public health, and if there are substantial grounds for believing that such determination is supporter by the facts upon which it is apparent that it was based. Holden v. Hardy, 169 U. S. 366, 398; Bissell v. Davison, 65 Conn. 183, 192. There can be no doubt as to the opinion of the General Assembly, nor as to its resting on substantial foundations. The class of persons to whom the statute applies in not one arbitrarily formed to suit its purpose. It is certain and definite. It is a class capable of endangering the health of families and adding greatly to the sum of human offspring. Between the members of this class there is no discrimination, and the prohibitions of the statute cease to operate when, by the attainment of a certain age by one of those whom it affects, the occasion for the restriction is deemed to become less imperative."

The right of the state to inflict physical injury on individuals for the protection of society has been upheld authoritatively in cases relating to statutes requiring compulsory vaccination.

Morris v. Columbus, 102 Georgia 792; Jacobson vs. Massachusetts, 197 U. S, 11.

The decision in Morris v. Columbus, supra, is particularly interesting in its discussion of the right of the state to submerge individual rights to public welfare. It reads in part as follows:

"There can be no question that this is a reasonable exercise of the power conferred upon the city authorities by the legislature. With the wisdom or policy of vaccination the courts have nothing to do. We do not propose to enter into a discussion as to whether or not it is a preventive of smallpox. That question is not proper subject-matter for review by the courts. The legislature has seen fit to adopt the opinion of those scientists who insist that it is efficacious, and this is conclusive upon us. Our only province is to see that none of the rights guaranteed to the plaintiffs in error by the fundamental law are infringed. 'What is for the public good, 
and what are public purposes, and what does properly constitute a public burden, are questions which the legislature must decide upon its own judgment, and in respect to which it is vested with a large discretion which cannot be controlled by the courts except, perhaps, where its action is clearly evasive, and where, under pretense of lawful authority, it has assumed to exercise one that is unlawful.' Cooley's Const. Lim. 155. See also Powell v. Pa, 127 U. S. 678. No law which infringes any of the natural rights of man can long be enforced. Under our system of government the remedy of the people, in that class of cases where the courts are not authorized to interfere, is in the ballot-box. Any law which violates reason, and is contrary to the popular conception of right and justice will not remain in operation for any length of time. but courts have no authority to declare it void merely because it does not measure up to their ideas of abstract justice. The motive which doubtless actuated the legislature in the passage of the act now under consideration was that vaccination was for the public good. In this the General Assembly is sustained by the opinion of a great majority of the men of medical science both in this country and in Europe.

"The General Assembly conferred this authority upon the City of Columbus in the exercise of its police power, by which, says Tiedeman, 'State, persons, and property are subjected to all kinds of restraints and burdens, in order to secure the general comfort, health, and prosperity of the State.' The Supreme Court of Illinois has said of this power that it is 'coextensive with self-protection, and is not inaptly termed "the law of overruling necessity." It is that inherent power in the State, which enables it to prohibit all things hurtful to the comfort and welfare of society.' Lakeview vs. Rose Hill Cemetery, 70 III. 192. The Court of Appeals of New York says: "The police power extends to the protection of persons and property within the State. In order to secure that protection they may be subjected to restraints and burdens by legislative acts. If the act is a valid and reasonable exercise of the police power of the State, then it must be submitted to, as a measure designed for the protection of the public and to secure it against some danger, real or anticipated, from a state of things which modifications in our social or commercial life have brought about. The natural right to life, liberty, and the pursuit of happiness is not an absolute right. It must yield whenever the concession is demanded by the welfare, health, or prosperity of the State. The individual must sacrifice his particular interest or desires, if the sacrifice is a necessary one, in order that organized society as a whole shall be benefited.'-People vs. Warden of City Prison, 39 N. E. Rep. 686."

The brief of defendant quotes at length from an opinion by the Supreme Court of New Jersey in which a eugenics measure of that state was declared unconstitutional in an attempted application to an inmate of a hospital for epileptics maintained by the state. The analysis of that case (Smith vs. Board of Examiners, 88 At1. 963) discloses that the New Jersey Statute was essentially different in its classification than the Oregon act in that its application was confined to feeble-minded, epileptic, criminal and defective persons confined in reformatories, charitable and penal institutions maintained by the public. This restriction to the inmates of public institutions was the sole ground stated by the court as a basis of its decision as may be observed from that part of the decision which reads as follows:

"Turning our attention now to the classification on which the present statute is based, and laying aside criminals and persons confined in penal institutions with which we have no present concern, it will be seen that-as to epileptics, with which alone we have to do-the force of the statute falls wholly upon such epileptics as are "inmates confined in the several charitable institutions in the counties and state.' It must be apprrent that the class thus selected is singularly narrow when the broad purpose of the statute and the avowed object sought to be accomplished by it are considered. The objection, however, is not that the class is small as compared with the magnitude of the purpose in view, which is nothing less than the artificial improvement of society at large, but that it is singularly inept for the accomplishment of that purpose in this respect, viz., that if such object requires the sterilization of the class so selected, then a fortiorari does it require the sterilization of the vastly greater class who are not protected from procreation by their confinement in state or county institutions. ***

"The conclusion we have reached is that without regard to the power of the state to subject its citizens to surgical operations that shall render procreation by them im- 
possible the present statute is invalid, in that it denies to the prosecutrix of this writ the equal protection of the laws to which, under the Constitution of the United States, she is entitled."

The defendant raises the further objection that the duties imposed upon the State Board of Eugenics require said board to exercise judicial functions, that because section 87 provides that the board shall examine into the innate traits, the mental and physical condition, the personal record and the family traits and histories of all persons so reported, and make an order directing the Board of Health to perform or cause to be performed upon any person who is deemed by the board to be within the scope of the act, such type of operation as may be considered best by the board, that thereby the. board is vested with judicial powers.

The case in re Willowcreek, 74 Ore. 615, cited by defendant's brief, is most decidedly against the conclusion drawn by the defendant. In that case it was contended that the act of 1909, known as the Water Code, was a violation of section 1, Article 7 of the state constitution in that it undertook to vest judicial power in a tribunal and officers not recognized by the constitution. The supreme court of this state, in passing upon said question, used the following language:

"The statute prescribing the duties to be, performed by the water board and its members in their respective official capacities in a determination of water rights does not confer judicial powers or duties upon the board or such officers in any sense as indicated by the constitution. Their duties are executive or administrative in their nature. In proceedings under the statute the board is not authorized to make determinations which are final in character. Their findings and orders are prima facie final and binding until changed in some proper proceeding. The findings of the board are advisory rather than authoritative. It is only when the courts of the state have obtained juris. diction of the subject-matter and of the persons interested and rendered a decree in the matter determining such righ's that, strictly speaking, an adjudication or final determination is made. It might be said that the duties of the water board are quasi judicial in their character. Such duties may be devolved by law on boards whose principal duties are administrative. As said in Reetz vs. Michigan, 188 U. S. 505, 507, 23 Supt. Ct. 390, 391 ( +7 L. ed. 563): 'Indeed, it not infrequently happens that a full discharge of their duties compels boards, or officers of a purely ministerial character, to consider and determine questions of a legal nature. Due process is not necessarily judicial process.' Many executive officers, even those commonly known as purely administrative offcers, act judicially in the performance of their official duties, and in so doing do not exercise judicial powers as the words are commonly used and as they are used in the organic act in conferring judicial powers upon specified tribunals. State vs. Corvallis \& E. R. R. 59 Ore. 450, 117 Pac. 980; Patterson vs. N. W. Co. 170 Ill. Ap. 501, 511; People vs. Hasbrouck, 11 Utah 291, 39 Pac 918. In Washington the public utilities act was held not to confer judicial or legislative powers upon administrative officers. State vs. Superior Court, 67 Wash. 37, 120 Pac. 861, Ann. Cas. 1913 D, 78. In Wisconsin the industrial commission was held to be an administrative body, the court saying: 'It is an administrative body or arm of the government, which in the course of its administration of a law is empowered to ascertain some questions of fact and apply the existing law thereto, and in so doing acts quasi judicially; but it is not therehy vested with judical power in the constitutional sense.' Borgnis vs. Falk Co. 147 Wis. $358,133 \mathrm{~N}$. W. 219,37 L. R. A. (N. S.) 489. See Stettler vs. O'Hara, 139 Pac. 743. The duties of the Board of Control are similar to those of a referee appointed by the court. The powers and duties of the three principal divisions of the state government, legislative, executive and judicial, are necessarily sometimes blended to a limited extent. The preservation of lines between them is the fundamental idea in the organic act, and the continuance of regulated liberty depends or maintaining these boundaries. Willoughby on the Constitution, vol. 2, Sec. 742; Biggs vs. McBride. 17 Ore. $640,648,21$ Pac. 878, 5 L. R. A. 115. Delegation of powers to boards or commissions has generally been sustained by the courts throughout the country. O. R. \& N. Co. vs. Campbell (C. C.) 173 Fed. 957; Portland Ry. L, \& P. Co. vs. Railroad Commission, 56 Ore. 468, 105 Pac $709,109 \mathrm{Pac}$. 273. The separation of the powers, both state and national, has not been complete. The practical necessities of efficient government prevent a complete defined division. It has been necessary to vest in each department certain powers which primarily should not belong to it. Courts 
establish rules of practice to govern procedure therein, and thereby in a certain sense exercise legislative functions; they appoint officers, in reality executive acts. Courts have no hesitation in performing ministerial acts if such are incidental to the exercise of their proper judicial functions. Legislation of recent years creating commissions for various purposes such as regulating rates of public utilities is a familiar instance of the overlapping of governmental functions. In many respects these acts pro. vide for the performance of duties by administrative boards judicial in their nature or quasi judicial,"

In State, ex. rel. vs. Hawkins, 44 Ohio State, 98, it is said:

"What is judicial power cannot be brought within the ring-fence of a definition. It is undoubtedly power to hear and determine, but this is not peculiar to the judicial office. Many of the acts of administrative and executive officers involve the exercise of the same power."

In conclusion, it may be urged that the presumption is in favor of the constitutionality of the act. It has been held by the Supreme Court of this state, as well as by the Supreme Court of every state in the Union, and also by the Supreme Court of the United States, that every act is presumed to be constitutional until the contrary has been shown beyond a reasonable doubt. In other words, where reasonable minds might: differ as to the constitutionality of an act, the doubt is resolved in favor of its constitutionality. In State vs. Cochran, 55 Ore. 157, Mr. Justice McBride refers to the presumption above stated as follows:

"In conclusion we will add that under any point of view it is manifest, from the various constructions placed by eminent counsel upon Article VII, however different they may be, in view of the legislative in:erpretation thereof, that, under light most unfavorable to the act in question, no one can say the constitution is free from ambigit ty on the subject, or that such act under consideration is beyond a rational doubt unconstitutional. Placed therefore under the most damaging scrutiny possible, there is no escape from the conclusion that the legislative assembly did not, in the enaciment of the law in question, exceed its constitutional powers. To hold otherwise would be to disregard, as hereinbefore disclosed, the well-settled rules of construction heretofore promulgated by an unbroken line of deci- sions by this court from the earliest history of our State."

Mr. Justice Eakin, in delivering a concurring opinion, said:

"The Legislature has all power not taken away by the constitution. Before a statute is declared unconstitutional, its repugnancy should be clear and free from doubt. In Simon vs. Northrup. 27 Ore. 495, (40 Pac. 561; 30 L. R. A. 1.11), Mr. Chief Justice Bean says:

" "The courts will never exercise the extraordinary power of declaring an act of the Legislature unconstitutional unless there is a plain, palpable, and clear conflict between the statute and the constitution.' In re Wellington, 16 Pick. (Mass.) 87, (26 Am. Diec. 631). In Sinking Fund Cases, 99 U. S. 718 (25 L. ed. 496) it is sajd: 'Every possible presumption is in favor of the validity of a statute, and this continues until the contrary is shown beyond a rational doubt. One branch of the government cannot encroach on the domain of another without danger. The safety of our institutions depends in no small degree on a strict observance of this salutary rule.' Every doubt must be resolved in favor of the legislative act. Every intendment must be given in favor of its constitutionality, and we are not justified in holding that the legislative act, increasing the number of justices of the Supreme Court to five is unconstitutional."

On the same subject see the following cases:

Libby vs. Olcott, 66 Ore. 124.

State vs. Standard Oil Co. 61 Ore. 438, at 449 .

Pac. Elevator Co. vs. Portland, 65 Ore. 349 , at 384 .

In re Willow Creek, 144 Pac. 505.

Respectfully submitted.

Attorneys for Plaintiff.

e. Cpinion of Percy R. Kelly and Geo. G. Bingham, Judges.

IN THE CIRCUIT COURT OF THE STATE OF OREGON FOR MARION COUNTY.

Department No. 1.

State Board of Eugenics,

In re Jacob Cline.

This proceeding arises because of the action of the State Board of Eugenics directing an operation sterilizing Jacob Cline by cmasculation. Following this action, Mr. Tom Garland in behalf of Cline. by a letter 
to the Secretary of the Board, caused the filing herein of a transcript of the proceedings of the Board. The questions confronting us have been heard upon a demurrer in behalf of Cline to the action of this Board.

It is urged by counsel for Cline, and by a brief filed by Messrs. Allan Bynon and Smith \& Shields, attorneys, as amici curiae, that various provisions of the state and federal constitutions have been violated by the statute upon which the action of the Board is predicated.

Two statutes upon the subject have been enacted in this state, and appear in the codification of Oregon Laws for 1920. The first was passed in 1917, being Chapter 279 of 1917 Session Laws, and Sections 2887 to 2898 inclusive of Oregon Laws. The second was passed in 1919 , being Sections 85 to 96 inclusive of Chapter 264 of 1919 Session Laws and Sections 8448 to 8459 inclusive, Oregon Laws.

We are of the opinion that the 1917 Statute is uriconstitutional because it clearly violates the provisions of the state and federal constitution prohibiting class legislation, for the reason that it is confined in its operation to the inmates of certain state institutions. In our opinion, the enactment of the latter statute constitutes legislative construction of the former supporting this view.

We cannot concur in the suggestion that the latter statute is unconstitutional as unwaranted class legislation or as providing for cruel and unusual punishment.

We are convinced, however, that the latter statute is unconstitutional because it violates the clause of Section 1 of the 14th Amendment of the U.S. Constitution providing that "no state shall deprive any person of life, liberty or property without due process of law."

Judge Field has construed the term, lif $\epsilon$, as here used, saying that it means something more than mere animal existence. "The inhibition against its deprivation," he says, "extends to all those limbs and fact1ties by which life is enjoyed. The deprivation, not only of life, but of whatever God has given to everyone with life, for its growth and enjoyment is prohibited by the provision in question." Munn vs. Illinois $9 t$ U. S. 113 at 142. Following this construction of the term thus employed in the constitutional provision mentioned, clearly the operation proposed herein would constitute deprivation of life.

Judge Cooley has said that: "Due process of law in each particular case means such an exertion of the powers of government as the settled maxims of law permit and sanction and under such safeguards for the protection of individual rights as those maxims prescribe for the class of cases to which the one in question belongs." Cooley Const. Lim. Sec. 356.

Unquestionably this case belongs to the class requiring strict rules of procedure fot it is in the class providing the direct con sequences, namely: deprivation of life. In such cases, the settled maxims of law require the application of the rule of evidence demanding at every stage of the proceeding, proof beyond a reasonable doubt. The statute in question, however, beyond declaring that it is not in any manner a punitive measure, is silent as to the rules of evidence applicable thereto. It is true that there is a provision to the effect that after appeal the trial shall be a trial de novo at law as provided by the statutes of the state for the trial of actions at law; but it nowhere indicates whether it shall be tried as a criminal action or as a civil action. Besides the rules of evidence, the method of joining the issues, the manner of forming the jury, the number of peremptory challenges, the grounds for challenges for cause, the number of concurring jurors necessary to warrant the return of a verdict are all uncertain and unprescribed. There is no provision for complaint, information or indictment, motion, demurrer, answer or plea, and none expressly imposing the affirmative of the issue upon either party.

The provision that an informal notice of appeal filed with the secretary of said board either by the person or someone in his behalf shall be all that is necessary to make the appeal, impresses us as an indication that the matter should be treated informally and without the safeguards demanded by the importance of the issue to be determined.

Moreover, the statute does not state what court shall entertain an appeal. It merely states that: "Any such person *** may take an appeal to the circuit court." There are many circuit courts in the state. No method is provided by statute for determining which one is the appellate tribunal in these cases.

We realize that if a trial, after due notice, before an impartial judicial tribunal having 
competent jurisdiction is provided, even by way of appeal only, the constitutional guaranty is preserved, and that an appeal from the judgment rendered after such trial, need not be prescribed; but in a case of such importance as this, every judicial impulse inclines to the wisdom of providing for such an appeal to the highest court of this state.

In a case originating in the justice's court, provision is made for the formulation of the issues, for the manner of selecting a jury. procuring and hearing witnesses, hearing counsel, returning a verdict, and entering judgment; and thirty days are given within which an appeal may be taken to the Circuit Court of the county wherein the judgment is given. In a case originating in or appealed to the circuit court, though it involves only a trivial interest in property, the rights of the parties litigant are similarly protected and safeguarded and sixty days are given the litigants within which to appeal to the Supreme Court; but in the cases treated by the statute in question, no opportunity at all is given the person most vitally affected to make his position known, either by witnesses, counsel or in person at the time of the hearing before the Board. Only fifteen days are given for the exercise of the right of appeal, and no appeal from the judgment of the circuit court is expressly prescribed.

As showing the trend of judicial thought, we are impressed by the fact that of seven decided cases upon statutes providing for such operations as are contemplated by the statute under consideration six of these cases hold the respective statutes unconstitutional.

Davis vs. Berry, 216 Fed. Rep. 417, s. c. 242 U. S. 468.

Osborn vs. Thomson, 169 N. Y. S. 638.

Smith vs. Board of Examiners; 85 N. J. L. $46 ; 88$ At1. 963.

Haynes vs. Williams, 166 N. W. 938.

Mickle vs. Henrichs, 262 Fed. Rep. 688.

Williams vs. Smith, 131 N. E. 2.

And the one upholding the law, (State vs. Feilen, 70 Wash. 65, 126 Pac. 75) is easily distinguishable from the case at bar because it construes a statute undeniably punitive, and one wherein the safeguards of due process of law have not been omitted or overlooked.

Believing that within the adjudicated meaning of the clause of the 14th Amendment of the U. S. Constitution referred to, the statute in question, if enforced might have the effect of depriving any resident of Oregon of life, and being of the opinion that it does not provide due process of law as a safeguard against its unjust and unwarranted enforcement, we hold it unconstitutional and void, insofar as it attempts to provide for operations of sterilization.

(Signed) PERCY R. KELLY,

(Signed) GEO. G. BINGHAM,

Judges.

\section{f. Decision of the Circuit Court.}

IN THE CIRCUIT COURT OF THE STATE. OF OREGON FOR THE COUNTY OF MARION. ${ }^{1}$

Department No. 1.

No. 15442.

In the Matter of Jacob Cline the State Board of Eugenics $\}$

The above entitled matter having been heard upon the above named Jacob Cline's demurrer to the record filed herein of the proceedings of said State Board of Eugenics, the said State Board of Eugenics appearing by Hon. John H. Carson, its attorney, and district attorney for Marion County, the said Jacob Cline appearing by Mr. Tom Garland, his attorney, and Captain Allan Bynon and Messrs. Smith \& Shields, attorneys at law, appearing as amici curiae, at which hearing it was stipulated that written briefs should be filed and said written briefs having now been filed,

IT IS ORDERED that said demurrer of said Jacob Cline to said proceedings of said State Board of Eugenics be and the same is hereby sustained;

AND IT: IS HEREBY FURTHER ORDERED that this proceeding be and the same is hereby dismissed.

\section{PERCY R. KELLY, \\ GEO. G. BINGHAM,} Judges.

Filed December 13, 1921.

1 Following the decision (December 13, 1921) of the Circuit Court of the County of Marion, the Oregon State Board of Eugenics ordered the Oregon state Board to the State Supreme court.

(Quoted from letter) "There has been no appeal from the judgment of the Circuit Court of the State of Oregon in the Case of Oregon State Board of Eugenics vs. Jacob Cline (No. 15442), for the reason that the statute of this state does not authorize an appeal from this state does not authorize an appeal from of case." I. H. Van Winkle, Attorney-General. June 23, 1922. 


\section{CHAPTER VIII.}

\section{CASE AND FAMILY HISTORIES OF INDIVIDUAL SUBJECTS OF LITIGATION GROWING OUT OF THE SEVERAL EUGENICAL STERILIZATION LAWS.}

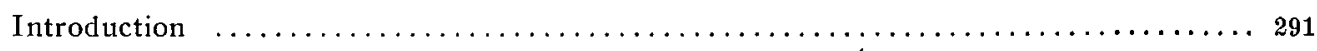

1. Peter Feilen, moral pervert, Washington......................... 292

2. Alice Smith, epileptic and feeble-minded, New Jersey................. $2 q_{2}$

3. Rudolph Davis, felon, Iowa ................................... 304

4. Nora Reynolds, feeble-minded, Michigan........................ 305

5. Frank Osborn, feeble-minded, New York......................... 305

6: Pearley C. Mickle, moral pervert, Nevada....................... 311

7. Warren Wallace Smith, moral pervert, Indiana $\ldots \ldots \ldots \ldots \ldots \ldots \ldots \ldots \ldots \ldots \ldots \ldots \ldots$

8. Jacob Cline, moral pervert, Oregon........................... 318 


\section{INTRODUCTION.}

In investigating the institutional and court records in the matter of case and family histories, we find that there is a wide variation in the type of record provided, and also in the extent of individual case histories, but most of all a great difference is found in the quality and extent of the pedigree records. The investigation finds in the cases of $\mathrm{W}_{\mathrm{ar}}$ ren Wallace Smith, an inmate of the Reformatory at Jeffersonville, Indiana, and of Alice Smith, an inmate of the New Jersey State Village for Epileptics at Skillman, who were the subjects of the test cases in their respective states, the most complete and valuable pedigree studies. The first study was contributed by Dr. A. H. Estabrook of the Eugenics Record Office, and the second was made under the direction of Dr. D. F. Weeks, Superintendent of the Skillman Village. These records are commended as models for executive agents of eugenical sterilization laws. They are pedigree records which set forth the family distribution of natural traits in a manner adequate to the determination of the hereditary qualities of the particular individual. If records as complete and scientific as these can be obtained for individuals nominated for eugenical sterilization under a statute, there need be no doubt concerning the principal question of fact, namely, whether the particular individual is, so far as hereditary endowment is concerned, a potential parent of socially inadequate offspring.

The importance of providing thorough pedigree studies before deciding upon the sterilization of an individual for eugenical purposes cannot be overestimated. Any sterilization law which seeks to be eugenically effective must of necessity not only demand that investigation of the pedigree or hereditary traits of the individual be made as the basis for determining upon sterilization in each particular case, but the statutes must also provide adequate facilities whereby its executive agents may secure the desired facts.

The Subjects of the Test Cases are as follows:

\begin{tabular}{|c|c|c|}
\hline Subject of Test Case & State & $\begin{array}{c}\text { Test Case, Date and Where } \\
\text { Originated }\end{array}$ \\
\hline 1. Peter Feilen, Moral Pervert & Washington & $\begin{array}{l}1911 \text { Superior Court of King Coun- } \\
\text { ty, Seattle, Washington }\end{array}$ \\
\hline $\begin{array}{l}\text { 2. Alice Smith, Epileptic and } \\
\text { Feeble-minded }\end{array}$ & New Jersey & $\begin{array}{l}\text { 1912 N. J. State Village for Epilep- } \\
\text { tics, Skillman, N. J. }\end{array}$ \\
\hline 3. Rudolph Davis, Felon & lowa & $\begin{array}{l}1914 \text { State Penitentiary, Fort Ma- } \\
\text { dison, Ja. }\end{array}$ \\
\hline 4. Nora Reynolds. Feeble-minded & Michig & $\begin{array}{l}1916 \text { Michigan Home and Training } \\
\text { School, Lapeer, Mich. }\end{array}$ \\
\hline 5. Frank Osborn, Feeble-minded & New York & $\begin{array}{l}1915 \text { Rome State Custodial Asylum. } \\
\text { Rome, N. Y. }\end{array}$ \\
\hline 6. Pearley C. Mickle, Moral Pervert & Nevada & $\begin{array}{l}1918 \text { District Court of the Fourth } \\
\text { Judicial District, Elko County, } \\
\text { Elko, Nevada }\end{array}$ \\
\hline $\begin{array}{l}\text { 7. Warren Wallace Smith, Moral } \\
\text { Pervert }\end{array}$ & Indiana & $\begin{array}{l}1919 \text { Circuit Court of Clark County, } \\
\text { Jeffersonville, Indiana }\end{array}$ \\
\hline 8. Jacob Cline, Moral Pervert & Oregon & $\begin{array}{l}1921 \text { Circuit Court for the County } \\
\text { of Marion, Oregon }\end{array}$ \\
\hline
\end{tabular}

Of these eight cases, two, those in Washington and Nevada, originated in the criminal courts in connection with sentences for crimes, the statutes in these two states being purely punitive in their motive. The other six cases originated in custodial institutions -in New Jersey in an institution for the epnleptic; in Iowa and Oregon, prisons; in Michigan and in New York, institutions for the feeble-minded; in Indiana, in a men's reformatory. 
CASE AND FAMILY HISTORIES.

The facts concerning the individual nominated for eugenical sterilization, and his or her family history or pedigree, so far as such facts are obtainable from the official institution and court records, follow:

1. PETER FEILEN, Moral Pervert. Case originated in the Superior Court of King County, Seattle, Washington.

The records in this case are extremely meager, so far as they concern the constitutional make-up of the individual, and neither is any record found descriptive of his pedigree.

Under date of June 28, 1919, John D. Carmody, Deputy Prosecuting Attorney of King County, Washington, writes:

"Feilen was a man about forty years of age; was constable of Kirkland, a little town a few miles from Seattle; was a man of family, and respected in his community. We know of no criminal antecedents, nor are we able to find any indication of degeneracy in any of his family."

Under date of February 18, 1919, Henry Drum, Superintendent of the State Penitentiary at Walla Walla, where Feilen was imprisoned, says:

"In view of the fact that there was grave doubt as to Feilen's guilt, he having a great number of the best people in that vicinity behind him, protesting his innocence, he was pardoned on December 27th, 1916."

"Feilen spent the active years of his life, up to about forty, as a locomotive engineer, and met with an accident in a collision that gave him a severe brain concussion, and acquaintances say that he has never been so clear-minded or forceful since the accident. I am convinced that he never was guilty as charged."

(See also Chapter VII, Sec. 1, Washington.)

2. ALICE SMITH, Epileptic and Feebleminded. An inmate of the State Village for Epileptics at Skillman, N. J.

Not only are the individual case histories of the institution at Skillman very complete, but no institution in the country has a more complete set of pedigree-records, secured at first-hand by trained field workers, than has this same institution. The result is that when the New Jersey Supreme Court issued a writ of certiorari, the institution at Skillman was able to supply personal and pedigree records adequate to the needs of determining the particular question of degenerate hereditary constitution, or more directly the potentiality of the particular patient as a parent of socially inadequate offspring.

\section{Case History of Alice Smith. ALICE SMITH.}

\section{Consecutive Number 79.}

Admitted to the New Jersey State Village for Epileptics, August 20th, 1902.

Single, white, female.

No occupation, very little education.

Committed under date of August 19th 1902, by Alfred F. Skinner, a judge of the Court of Common Pleas of the County o: Essex.

Residence previous to admission, Newark (N. J. S. B. of C. Guardians).

Age at time of admission, 17 years, 11 months and 17 days.

Age on May 31st, 1912, 27 years, 8 months and 17 days.

Duration of treatment at the New Jersey State Village for Epileptics, up to May 31st, 1912, 9 years, 9 months and 11 days.

A native of New Jersey, who was continuously a resident of the State prior to admission.

The petitioner for her admission was $\mathrm{Mr}$. Hugh F. Fox, President of the New Jersey State Board of Children's Guardians, with address at 629 Commercial Trust Building, Jersey City, N. J.

At the time of admission was given as having "no occupation," no children.

During her residence in this institution has been employed at housework, school and kitchen work.

At present (May 31, 1912), she is employed as an assistant in the care of the officers' dining room at Bergen Cottage.

Presented before the Board of Managers of Feeble-minded (including Idiots, Imbeciles and Morons), Epileptics, Criminals and other Defectives, held at the New Jersey State Village, Skillman, February 29th, 1912, and May 31st, 1912.

\section{Family History.}

Patient's father is living, and at the present time (1912) is about 78 years old. $\mathrm{He}$ is mentally deficient, and at the present time is demented, so that he comes under the cate 
gory of those commonly known as "halfwitted." He was a sailor, and is a veteran of the Civil War. He had a brother who died from epileptic attacks at the age of 12 years. For full details of father's fraternity see Hereditary History and Charts.

Patient's mother is an epileptic, and has been the victim of epileptic seizure manifestations since the age of 14 years. She is mentally deficient to a fairly marked degree. She is alive, and at the present time about 70 years of age. Her mother (patient's grandmother) was epileptic, and she (patient's mother) had one sister and one brother each epileptic, and one brother and one sister each feeble-minded. See hereditary chart and history for complete information concerning patient's maternal ancestors.

The patient had four brothers and three sisters. Five of the children reached maturity, five of whom are patients at the New Jersey State Village for Epileptics.

\section{Personal History.}

Patient was sixth in line of birth of a family of eight, and was born September, 1884. Patient is supposed to have been born at term, after a normal labor and natural -delivery.

She was a breast-fed child, and said to have had "spasm" from birth. Because of the low mentality of patient's parents, and their station in life, little is recorded or remembered concerning this patient's infancy and early childhood. It is known, however, that she had difficult dentition, and some of the diseases of childhood.

The patient attended school very little, and had practically no home, training. Her parents lived in an alley way, in a section of the city which is the habitat of negroes. The father's paternal interest in this patient as well as all his children, was directly in proportion to their earning capacity. Many times, in fits of anger, he would turn his daughters out of his house, and they would seek refuge among the negroes about the neighborhood. The patient, Alice, was at one time a pupil in the New Jersey Training School for Feeble-minded Children.

She gives a history of having worked at one time at general housework for a private family, and that during this employment she was favored with only nocturnal manifestations of epilepsy.

Patient states that one evening when she was returning home, about 9 p. m., she was met by a, negro, whom she accompanied to a vacant lot nearby, where they indulged in sexual intercourse.

She became pregnant, and in 1901 was delivered of a female offspring. At this time she was cared for during her accouchement in the almshouse. After she came from childbed she returned to her father's home and kept the baby until it was taken by the Chi'dren's Guardians' Society, who later placed it in a private family, but it died at the age of two years and three months of pneumonia.

So far as can be learned from the patient, and from the parents, she has always been healthy, save for her epilepsy, and this statement has been borne out since her admission to this institution. Patient states that about a year previous to her admission here, she had an attack of smallpox, but there are no objective sequelae present, or is there mention mạde of it, in her history previous to admission.

\section{Onset and History of Epilepsy.}

The patient is stated in admission papers as having been afflicted with epilepsy since birth. There is no detail mentioned, or attacks described. No cause was assigned, and the history of this patient's epilepsy, prior to her admission, at best is vague and indistinct.

The patient herself states that the onset of her seizures did not occur until the age of thirteen years, and that they followed after she had visited the home of a friend, and therein witnessed a young girl in the thralls of an epileptic seizure. The patient herself describes this as the cause of her epilepsy.

Patient states that with her attacks she had an aura, which consisted chiefly of dizziness which occurred sufficient time before impairment of consciousness to allow her to seek a place of safety, and that as a rule she reclined in a chair. From her knowledge of her one time epileptic attacks, they were, no doubt, grand mal, but of the mild grand mal variety.

She denied biting her tongue, or loss of bladder or rectal control. After attacks she experienced, as a rule, moderate frontal headache, which on one occasion was so severe as to require rest in bed, and medical attention.

At times her attacks occurred in their majority by night, then again by day, but at no time, according to patient's memory, did the nocturnal attacks occur to the exclusion of the diurnal attacks, or vice versa. For 
some time previous to her admission she stated that her attacks averaged one on alternate days.

At one time, prior to her admission, there is alleged to have occurred an attack, or a series of attacks, which lasted twenty-four hours. This information is most unreliable, as it was given by a party almost completely ignorant of the facts of the case, is contradicted by the patient's statements, and is improbable as judged by the subsequent history and course of her epilepsy.

During the forepart of her admission to this institution, she was irregularly afflicted with attacks, which on one occasion prostrated her. Hysteria from the history since admission appeared to alternate with epilepsy, and as time has gone on her convulsive phenomena gradually ceased, and she has manifested her epilepsy by her moods and emotions. Fairly frequent have been periods during which she was depressed, abstained from the intake of nourishments, and at times manifested complete dissatisfaction with her surroundings.

In the interim she manifested a fairly pleasant and cheerful disposition. She has been regularly employed, and has been, except as previously noted, most faithful in the discharge of her duties.

In speculating as to the cause of this patient's epilepsy, there seems, after a careful perusal of her family history, only two factors to consider in the production of her epilepsy. First, that this patient is congenitally defective, and also inherited the epileptic tendency from her parents.

It is now generally conceded that epilepsy may be classed with and accounted for in the same category with feeble-mindedness, so that these problems, though to a degree separated, can profitably be studied together. The emotional shock, which the patient ascribes as the cause of her epilepsy, if present, was simply the exciting cause, which destroyed the equilibrium of a brain from birth defective and abnormal in its makeup. The one great causative factor in this patient's case is beyond doubt her bad heredity. It is not at all difficult to understand how this girl, born with a nervous system that

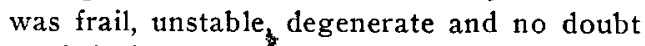
weak in its structural composition and force, had the soil most fertile for the creation and growth of epileptic manifestations. The question of this patient at the present time, due to her remission for years, being placed in the group of cures, is one most worthy of consideration. This especially is most important from the eugenics point of view.

To begin with, what definition describes. a "cure" in epilepsy? Is the simple arrest of seizures for a period of one, two, nine or fifteen years, sufficient to place the individual on the recovered list? We all admit that long remissions, induced by regular life, anc successful hygienic treatment, as favor pa. tients cared for in separate Colonies or Vil. lages, are common, and give a certain prog. nostic value, but are not synonyms of cure. To consider the case in question, this patient's seizures were not, according to her own description, of the classical grand mal type. This is strengthened by the distinctness of her aura, the fairly marked period of time between her prodromata and her impairment of consciousness, both of which are in inverse proportion to the severity of seizure types. Her tongue was never bitten, she has not the epileptic facies (scars from repeated wounds, usually received by falls during attacks), which are so prevalent among those essentially grand mal epileptics. There seems every proof to justify the conclusion that she had the minor form of epilepsy, which is not as amenable to treatment as the major variety. Careful observation of over 3,000 clinical histories of epileptics treated in special institutions, has disclosed the fact that major attacks of epilepsy are more amenable to treatment than minor ones, next coming major and minor forms combined, and lastly minor attacks alone. Surely this girl does not belong to the class of recoverable cases, even in the face of the long remission of her attacks. Sex also has been found to play some little part in the prognosis of epilepsy, and in that it favors the male side. What epileptologist can state with assurance, that even after a patient for twenty years has been free from attacks, but that the next day, hour or moment, he will not be hurled to the ground in the classical throes of his or her one-time active disease?

To discharge such a case as this one as cured, and allow her to return to her usual walks in life, would be a crime against society. To withdraw each and every person who has at any time displayed epileptic tendencies, in any degree whatever, from the community, is the only rational course left open. It would be indeed most wasteful to the nation and State to allow this defective to wander about, as it would entail perpetuation of her kind, and other eviis due to this lack of proper care and segregation. From 
now on the chief treatment of this particular case lies in preventing the reproduction of her kind, as not one case is known of normal offspring coming from two neuropathic parents. $U p$ to the present time this is the first tentative conclusion as to the application of Mendelian laws to human heredity.

\section{PHYSICAL EXAMINATION AND AMANUENSIS.}

Physically at the time of this patient's admission, and at the present time, she is fairly well developed and nourished and generally enjoys good health.

Her vital organs are negative to signs of disease, and she presents no marked stigmata or malformations.

Objectively, her deep reflexes are sluggish, and there are some superficial varicosities, and subjectively she complains of headache and vertigo. Neither of these are severe, or accompanied by prostration. Since her residence in this institution she has once been confined to bed with an attack of influenza of about five days' duration.

In November, 1906, she entered our regular school and could not read or write, she being reported, however, as anxious to learn. At this time she could not count or read figures. By June of the following year she was able to read words of four or five letters, and could write from copy, also could slightly compose. She spelt very poorly, but knew the addition tables. She did not retain that which she learned. Her lack of advancement was thought sufficient reason for withdrawing her from school at the expiration of the school year.

In November, 1910 , she entered the Industrial Class, as taught in the Cottage in which she lived, and was taught embroidery. She progressed very slowly, showed a disposition to left-handedness, worked from right to left, and displayed little interest in her work and apparently liked to be urged and coaxed. At the end of this year she was able to do a button-hole stitch and some hemstitch. She was at the expiration of this year permanently withdrawn from school work.

At the present time she is employed in the Cottage wherein she resided, and is a fair worker along domestic lines. Rather moody and.indifferent to her surroundings, and is suspected of being a masturbator.

Her menstrual life is negative.

Since her admission, according to the treatment of those who have most closely observed her, she has deteriorated to some degree mentally, and is becoming more habituated to attacks of sullenness and discontent. Rather indifferent in matters of personal adornment.

\section{MENTAL STATUS IN THE CASE OF ALICE SMITH.}

\section{General Appearance and Attitude.}

Patient is a young woman with a pleasant facial expression, very kind and obliging in manner and a very good and steady worker. She has a special fondness for children. Upon the several occasions that she was examined she co-operated very well, and willingly answered all questions.

\section{Speech.}

This is somewhat defective, as she has a congenital defect in her pronunciation, which is a family trait, only one sister being entirely free from it. Her vocabulary is poor and she does not express herself well.

\section{Consciousness and Orientation.}

Her consciousness is clear, and she is perfectly oriented as to time, place and person.

\section{Memory.}

For remote events it is very poor; patient is unable to give any clear history of her previous life, remembering only the most prominent features. The idea of chronological occurrence is absolutely unknown to her. She remembers fairly well the outlines of recent events, but she is unable to give a connected, detailed account of the happenings. Impressibility for numbers is poor. Five numbers, even without distraction, are not remembered. The maximum of syllables which she is able to repeat is sixteen, the record for a child of six years.

\section{Attention.}

Generally speaking this is good. Attention tests meet with good results.

\section{Range of Information.}

Patient is extremely ignorant. She never attended school previous to her coming to the Village; benefited but little in the Village school which she attended for some time. She is an analphabet, and can hardly count. She has no knowledge of the most elementary geographical and historical facts of her own country. In spite of the fact that her father is a Civil War veteran, she knows nothing about this war.

\section{Judgment and Conclusion.}

She is perfectly satisfied with her confinement at the Village, and realizes that it is necessary on account of her convulsions. She does not realize, however, that the dis- 
ease is due to heredity, as "she never had any fits before she grew up." When asked for explanation why all her brothers and sisters have that disease, she confessed ignorance; she was told that it was on account of her mother having that disease, but she can't see how it could be possible, as her mother only had them after a fall. She does not see the reason why her parents should not have had children, as the doctor at home never told them that her disease was due to heredity. She considers herself now cured; denies any desire to marry, "because men are no good; they marry you and then they leave you after a few months." She would not, however, be afraid to have children, as she considers herself cured, and, therefore, she could not transmit the disease. Of her sexual experience with the negro some years ago, she speaks quite indifferently. She professes ignorance of the culprit. One night at $9 \mathrm{p} . \mathrm{m}$. when she was returning from her work, this colored man offered her his company, and while they were near an empty lot, he dragged her in and there committed rape upon her. She never notified the police because she could not have described the man. She, however, told her father of the occurrence.

\section{Emotions and Volition.}

During the examination she did not show any sign of nervousness or any other sign of abnormal emotionality. Her daily conduct is uniform, but if something occurs to her dislike, she gets despondent and moody, remaining so for two or three days, refusing to take food, and it was only recently that she had to be compelled to consume her meal.

\section{Associations.}

Her free associations show a marked mental inhibition, and the controlied ones a poverty of ideas.

According to the Binet-Simon scale she grades between nine and ten years, which indicates that her mentality is allied to moronity. Other tests, such as Healy's puzzle tests, show that she is unable to learn by experience, which fact is also apparent from her life history. According to the Bechterew test she shows impairment of the ability for observation and of memory, while the ability for combination and synthesis is in the limits of normal mental capacity.

\section{Diagnosis and Prognosis.}

Patient is an epileptic with a congenital mental deficiency. She belongs to a fraternity consisting entirely of epileptics. Her mother is also afflicted and her father, being feeble-minded, is possibly a potential epileptic, as his brother was a victim of epilepsy: thus his feeble-mindedness may be only a sign of latent epilepsy.

The patient is no doubt congenitally deficient as the differential tests which we applied, clearly prove, but this congenital defect is no doubt due to the same factor which causes her epileptic seizures. The latter disease, however, did not do any further damage with the exception of memory impairment.

She was always a good natured and obliging girl, with the hypersexuality which is common in defectiveness. This patient did not possess the normal aversions of a white girl to a colored man, who was perhaps nice to her. We can disregard her version of being raped, as the specialists on this subject have proven in extensive literature that it is practically impossible for one man to commit this crime unless the victim is insensible, which latter state did not take place.

The patient is very fond of children, she is hypersexual, as even now she is given to masturbation, and no doubt when at large she would soon fall victim to another unscrupulous man. The seriousness of her disease, its hereditary character, does not seem to dawn upon her, and she would therefore be a social danger, as she would be the cause of a new generation of epileptics and imbeciles. With the heredity chart at hand, showing the disastrous effect of aggregated heredity, her offspring would have practically no chance to escape a similar fate. The fact of her not having any seizures does not justify the fact of her being cured. Even though this cure had taken place, the hereditary aspect would not lose anything of its danger, as the disposition of the disease is carried in the germ plasm, on which the influences of individual life are without effect.

Society, therefore, should take any permissible step to prevent her having children.

\section{Seizure Record in the Case of Alice Smith.} Consecutive Number 79.

(Copied from Original Records.)

Year 1903-3 Petit $m a 1$ seizures.

2 Grand mal seizures.

Year 1904-1 Petit mal attack.

Year 1905-No seizures.

Year 1906-No seizures.

Year 1907-No seizures.

Year 1908-2 Grand mal seizures.

Year $1909-$ No seizures.

Year $1910-$ No seizures.

Year 1911-No seizures.

Year 1912-No seizures, up to May 31. 
THE NEW JERSEY STATE VILLAGE FOR EPILEPTICS A'T SKILLMAN.

\section{Physical Examination.}

Name-Alice Smith.

Cottage-Bergen.

Consecutive No.-79.

General Appearance-Good.

Nutrition-Good.

Physical Condition - (Good, Impaired,

Feeble, Critical) Good.

Mental Condition-Feeble-minded.

Disposition-Good.

Habits-Cleanly.

Height -5 feet $1 / 8$ inches.

Weight-119 pounds.

Complexion-Light.

Expression of Face:

Face-Happy.

Eyes-Blank.

Mouth-Cheerful.

Skin-Light.

Color of Hair-Light Brown.

Speech-Answers Questions, Lisps, Voluble, Coherent, Voice Lisps.

Eyes-Light.

Pupils-Equal.

Pupil Reaction-Light O. D., Accommodation $O$. D., Light O. S., Accommodation O. S.
Pupils-Contracted
O. D., Contracted

O. S.

Lids-Oedematous; Conjunctiva, Cloudy; Cornea, etc., Clear.

Ophthalmoscopic Examination-Not made.

Muscular Anomalies-None.

Ears-Small.

Hearing-R., Normal; L., Normal; Discharges, Pains, etc., None.

Nose-Large.

Taste and Smell-Both Impaired.

Mouth-Good Condition.

Teeth-Good Condition.

Gums-Thickened.

Odor-Foul.

Mu. Mem.-Normal.

Palate-Normal.

Tonsils-Normal.

Pharynx-Normal.

Tongue-Normal.

Appetite and Bowels-Excessive Appetite;

Bowels, Normal.

Thorax-Shallow and Narrow.

Spinal Column-Kyphotic.

Lungs-Poorly Developed.

Heart-Strong but Slow.

Vessels and Pulse-Volume, Full; Rhythm,

Regular; Rate, 76; Comparison, etc., Normal.
Abdomen and Viscera (Size, shape, position of organs, tenderness, pulsations, etc.) Slightly Enlarged.

Condition of Reproductive OrgansNormal.

Rectum-Normal.

Reflexes (Superficial and Deep)-Both Nearly Absent.

Headache, Vertigo, Fêver, General Symptoms, etc.-Headache and Vertigo.

Paralysis-None.

Memory-Recent, Fair Only, Remote.

Sleep-Good.

Dreams-None.

Evidences of Injury-Loss of Members, Marks, Scars, Ruptures, Varicose Veins, etc.

Varicose Veins-On outside of both lower legs; below knee, also on lower inner left thigh.

Gait-Swinging.

Station-Good.

General Coordination-Good.

Muscular Twitchings, etc.-Good.

Sensation, Tactile, Thermal, Muscular Sense, etc.-All Normal.

Electrical Examination-Not Made.

Stigmata of Degeneration-None.

(See also Chapter VII, Sec. 2, New Jersey.)

Additional light is thrown upon the constitutional makeup of the propositus by the following cross-examination, which took place at the meeting of the Board of Examiners of Feeble-minded (including Idiots, Imbeciles, and Morons), Epileptics, Criminals and other Defectives, held at the New Jersey State Village for Epileptics on May 31, 1912.

\section{CASE PRESENTED-ALICE SMITH.}

Dr. Weeks: I identify this patient as Alice Smith, whose record I read before she entered the room.

Dr. Costill: Alice, what is your name? Alice: Alice Smith.

Dr. C.: What is your father's name? A. George Smith.

Dr. C.: Do you know how old your father is? A. He will be 77 tomorrow.

Dr. C.: How many brothers and sisters have you, Alice? A. Five here altogether.

Dr. C.: Five here; well, how many of you were there altogether? A. There were eight of us altogether.

Dr. C.: Where did you live before you came here? A. In Newark.

Dr. C.: Alice, did you ever have a child before you came here? A. Yes, sir, I did. 
Dr. C.: What was its father's name? A. I don't know, sir.

Dr. C.: You don't know the name of your child's father? A. No, sir.

Dr. C.: Do you know whether he was black or white? A. No, sir.

Dr. C.: Can't you remember? A. No, sir.

Dr. C.: Do you know how old the baby was before you came here? A. Two years old.

Dr. C.: Did you ever have an attack of small pox, Alice? A. Yes, sir.

Dr. C.: How old were you when you had your first epileptic attack? A. Thirteen years old.

Dr. C.: Did these attacks occur in the day time or at night? A. In the morning.

Dr. C.: Did you know when these attacks were to come on? A. Yes, sir; I always knew.

Dr. C.: How did you know? A. I got dizzy in the head.

Dr. C.: Have you had any attacks lately? A. It's ten years since I had one.

Dr. C.: Do you then consider yourself cured? A. Yes, sir, I do myself.

Dr. C.: Would you like to leave here? A. Yes, sir, I would.

Dr. C.: What would you do if you left here? A. I would go home to pop and mom.

Dr. C.: Well, who do you think would take care of you; could you work? A. Oh, yes.

Dr. C.: What kind of work? A. House work or minding children.

Dr. C.: Would you like to have any more children? A. No, sir, no married life for mine.

Dr. C.: Do you think you would have children if you did? A. No, they might have the same disease as I have.

Dr. C.: Then you don't want any more children? A. No, sir, I don't.

Dr. C.: You would live with your father? A. Yes, sir.

Dr. C.: Did you ever go to school, Alice? A. I did go when I was home; I went to school here once.

Dr. C.: Did you ever go to the Industrial School here? A. No, sir.

Dr. C.: Didn't you ever go to school here and learn to sew? A. No.

Dr. C.: How old are you, Alice? A. Twenty-six years old.

Dr. C.: How old were you when you came here? A. Twenty-one years old.
Mr. Byers: Alice, why wouldn't you like to have children? A. They might have the same disease that I have.

Mr. B.: Did your mother have this trouble? A. Yes, sir.

Mr. B.: Any of your brothers? A. Yes, sir.

Dr. C.: Didn't you tell one of the doctors here that you thought you were cured, and that if you had children they wouldn't have epilepsy? A. I don't remember.

Dr. C.: How would you keep from having children? A. Stay home with pop and mom.

Dr. C.: Well, how did you happen to have that other child? A. Oh, that wouldn't happen again.

Dr. C.: How would you prevent it? A. Get pop to come and meet me when I came home from work.

Dr. C.: Do you think you could take care of yourself if you had no one to take care of you? A. I might.

\section{PATIENT IS SHOWN PICTURES OF SISTERS AND BROTHERS.}

Mr. Byers: Alice, do you know who that is? A. George Smith.

Mr. B.: Is he any relation to you? A. My brother.

Mr. B.: Where is he? A. Over in Smith (Cottage).

Mr. B.: Is he an inmate here? A. Yes, sir.

Mr. B.: Why is he here? A. Because he has convulsions.

Mr. B.: Who is that? A. Dorretta Smith.

Mr. B.: Any relation to you? A. My sister.

Mr. B.: Where does she live? A. Over in "J."

Mr. B.: In this institution? A. Yes, sir.

Mr. B.: Who is that? A. Russel Smith.

Mr. B.: Is he any relation to you? A. Yes, sir; my brother.

Mr. B.: Where does he live? A. Over to Garrison.

Mr. B.: Why is he over there? A. Because he has spells, too.

Mr. B.: Whose picture is that? A. That's Emma Smith.

Mr. B.: Any relation to you? A My sister.

Mr. B.: Does she live here, too? A Yes, sir.

Mr. B.: Who is that? A. Why that is me. 
Mr. B.: Where do you live? A. In the Children's Building.

Mr. B.: Are you here for the same reason as your brothers and sisters? A. Yes, sir; for the same reason.

Mr. B.: Alice, do you like the men? A. No, sir.

Mr. B.: Not at all? A. Not at all.

Mr. B.: You don't see many men here; didn't you like the men before you came here? A. No, indeed.

Mr. Beekman: Suppose you could have an operation performed upon you which would prevent your having any more children, would you submit to this? A. I would.

Mr. B.: You are so anxious not to have any children on account of this disease, that you would be willing to submit to an operation? A. Yes, sir.

Mr. Byers: Alice, have you any bad habits? A. No, sir.

Mr. B.: Are you sure? A. Yes, sir.

Mr. B.: Sometimes women and sometimes men have bad habits which they practice when they are alone. Do you do anything of that sort? A. No, sir.

\section{PEDIGREE OR FAMILY HISTORY RECORD.}

Consecutive Number-79.

Cottage-Bergen.

Name-Alice Smith.

\section{Source of Information. April, 1911.}

Mr. George Smith, the patient's father, 1. Henry Place, Bloomfield.

Mrs. Susan Smith, the patient's mother, 1 Henry Place, Bloomfield.

Mrs. Margaret Bender, the patient's mother's sister, Bloomfield; Nathan Conklin, the patient's mother's brother, 14 Railroad street, Bloomfield.

Mrs. Jessie Van Riper, the patient's father's cousin, 292 Littleton avenue, Newark.

Mrs. Moses Bender, the patient's mother's sister's son's wife, Bloomfield.

Mrs. Wilson, the patient's mother's sister's daughter, Bloomfield.

Mr. Lewis Bender, the patient's mother's sister's son, Bloomfield.

Charles Penn, the patient's mother's maternal cousin, Upper Montclair.

Caleb Riker, the patient's mother's mother's brother, Dodd street, Orange.

Mrs. Caleb Riker, the patient's mother's mother's brother's wife, Dodd street, Orange.

Mrs. Kraushu, the patient's mother's sister's daughter, Hedges Alley, Newark.
Moses Bender, the patient's mother's son, Bloomfield.

Mr. Lind, Overseer of the Poor, Blomfield.

A newspaper reporter resident in Bloomfield.

Policeman, Montclair.

Mrs. Thompson, matron of the Children's Home, Montclair.

\section{The Patient and Her Home.}

The patient's family is well known in the town, as they are generally spoken of as being half-witted. They have always lived in the poorer parts of the town, for the most part in the vicinity of the railroad, in an alley known as "Washerwoman's Alley," where the houses are in poor condition and are occupied by negroes. At present the family is living in a house in the rear of Henry street. The children never had any home training and were not able to learn much at. school; their parents were too feeble-minded to give them the care they needed or to see the necessity of keeping them in school regularly. The father abused the family, and has often turned the girls out of the house, at such times they were obliged to take refuge in the homes of their negro neighbors. When their illegitimate children were born, Alice and Emma went to the Poor House.

Neighborhood-At present fair, formerly very bad.

Housing-Rear house in poor condition; there are four families in the house. It is located in the rear of Henry street, which is a good street. The family has two rooms on the first floor and $a$ kitchen and store room in the basement. They pay $\$ 6.00$ a month rent.

Home Treatment-Very bad and neglectful.

Number in the Household-The patient's father and mother; one is feeble-minded and the other is epileptic.

Financial Condition-Very poor. The mother gets help regularly from the town and the father has a pension of $\$ 20.00$ a month. They were at one time cared for at the Home for Disabled Soldiers in Vineland.

Education-All the children went to school but very little. Alice and Russell were at one time pupils at the New Jersey Training School at Vineland, and Emma was at one time in the Home of the Good Shepherd at Newark.

The Patient's Fraternity - There were eight children in the fraternity, five of these 
grew up and of these five four are patients at the New Jersey Village for Epileptics at Skillman.

The first was a boy, 2-IV-23. He was drowned when he was only seven years old.

The second was Dorretta, 2-IV-25. She was born in 1873, and is a patient at the New Jersey State Village for Epileptics. Morally she is said to have been the best in the family.

The third was George, 2-IV-26. He is an epileptic and so feeble-minded that he is not allowed by the law to marry. At present he is working on a farm in Verona. Papers are on file for his admission to the State Village, but his father decided not to have him admitted as long as he was able to work.

The fourth was a girl, 2-IV-27, who died in infancy.

The fifth was Emma Jane, 2-IV-28. She was born in 1882. While living in Bloomfield she had an illegitimate child, a girl, 2-IV-13. The child was born in the Almshouse and died when it was a few weeks old.

The sixth was Alice, 2-IV-29. She was born 1884. She had an illegitimate child, 2 -IV-13, by a colored man whose name is said to have been Washington, 2-IV-32. At first the child was said to have been put in an orphan asylum for colored children at Bayonne, but it was learned later that the child, after having been placed with a private family, died at the age of six months.

The seventh was a boy, 2-IV-24. He died when he was four years old. His death was due to injuries received from a fall out of a second story window.

The eighth was Russell, 2-IV-30. He was born 1886. He was brought to the State Village from the New Jersey Training School at Vineland.

THE PATIENT'S FATHER AND HIS FRATERNITY.

His name is George Smith, 3-III-55. He was born somewhere in Connecticut, 1834, and was brought to New Jersey when only a small child, and has lived in this State ever since. $\mathrm{He}$ is mentally deficient, has an ugly disposition and an ugly temper. $\mathrm{He}$ has a very exalted idea of himself and his own accomplishments, in short, considers himself quite above the average. He claims to have been an engineer at one time; was a sailor and is a veteran of the Civil War. At present he does nothing but draw his pension. A few years ago he tried to act as flagman on the railroad, but for some reason lost the job. He has been an inmate of the Home for Dis- abled Soldiers at Kearney, N. J., and at another time was at the Home for Disabled Soldiers and Wives at Vineland, but they had to leave there because his wife is an epileptic.

$\mathrm{He}$ is the oldest in a family of nine children.

The second was Caroline, 1-III-34. She married a man by the name of Smith, of South Norfolk, Conn. They had three children, two daughters, 1-IV-7, 8, and a son, Fred Smith, 1-IV-9. One of the daughters lives in Kansas City and one in Bridgeport, Conn. Their names are unknown. Fred is said to be an engineer or a machinist and lives somewhere in Connecticut.

The third was a boy, 2-III-53, who was killed by a horse at the age of seventeen.

The fourth was a boy, 2-III-54, who died at the age of 12 of epileptic attacks.

The fifth and eighth were both boys, 2-III-52, 51. The one died at the age of nine, cause unknown; and the other died in infancy, cause unknown.

The sixth was Delia, 1-III-32. She died at 27 of childbirth. The child did not live, and she had no others before this. Her husband's name was William Waiters, 1-III-136.

The seventh was Sarah, 1-III-34. She married Henry Brown, and died at the age of 23. All of her life she was subject to very severe headaches. The cause of her death is unknown. She had two daughters, one of them, 1-IV-6, who married Harvey Mills, died of what was supposed to be consumption at the age of 29. She never had any children. The other daughter was Jessie, 1-IV-6. She married a man by the name of Van Riper and lives at 292 Littleton avenue, Newark. She is of a very nervous temperament, but otherwise seems to be normal. She has had seven children, six boys and one girl. Four of the boys, 1-V-2, $5,6,7$, and the girl, $1-V-8$, are living. One boy died in infancy and the other, $1-\mathrm{V}-4$, died at three of spinal meningitis. The two oldest boys appear to be normal; they are both in school; the others are too young yet to go to school.

The ninth and youngest in the fraternity was Russell, 1-III-33. $\mathrm{He}$ is said to have been a heavy drinker and is thought to have died of cancer of the stomach. He had four children, three daughters and one son. The son, 1-IV-1, died at the age of 31 of consumption. The girls are all living somewhere in Newark; they are Ada, Ida and Josephine. Josephine is said to be sexually 
immoral, and had one illegitimate child which she is supposed to have smothered. The girls are 1-IV-2, 4.

By his first wife the patient's father had a daughter who died in infancy.

\section{PATIENT'S FATHER'S FATHER AND} HIS FRATERNITY.

His name was - Smith. He was a heavy drinker, and died at the age of 88 of paralysis. He at one time lived in a soldiers' home. He had three brothers and five sisters, all of whom are dead except possibly Sarah Sherwood.

Burr Smith, 1-II-1, is said to have ived to be 81 and to have died then of heart trouble. He had three daughters and one son, all of whom are dead except one daughter, Elmira, 1-III-1; she married a man by the name of Worster, and lives in Newark. See additional information.

Allen Smith, 1-II-2, died at the age of 37 . The cause of his death is unknown. He had two sons and one daughter, 1-III-27, 29. The daughter is thought to be living in Goshen, N. Y., but nothing is known about the others, and her name is not known.

Harry Smith, 1-II-3, lived to be about 82 . $\mathrm{He}$ had eight children, two of whom died in infancy. There were two daughters and three sons supposed to be still living, 1-III-5, 9, one of them, George Burr Smith, lives at Westport, Conn., but it is not known where the others are.

Sarah Smith, 1-II-5, married a man by the name of Sherwood. She is supposed to be still living in Westport, Conn. She had one son.

Mary Smith, 1-II- 7 , married George Gorman, and lived in Goshen, N. Y. She had five sons and two daughters.

Delia Smith, 1-II-6, married Patrick Riley. She had one son and one daughter. The son, 1-III-31, lives in Southport, Conn., and the daughter, who married a merchant by the name of Hay, lives in Upper Norfolk, Conn.

Caroline Smith, 1-II-4, married

Brown. She had five children. The last sister, 1-II-8, married Harvey Keeler. She had three sons and two daughters. The daughters, 1-III-22, 21, married brothers by the name of Allen, and live in Westport, Conn.

THE PATIENT'S FATHER'S FATHER'S PARENTS, 1-I-1, 2.

They both lived to be old. The mother was a great smoker and is said never to have been without her clay pipe.

\section{THE PATIENT'S FATHER'S MOTHER} AND HER FRATERNITY.

Her maiden name was Sarah Ball, 2-II-10. She lived to be over 70 years old Her death is said to have been due to dropsy. For over 35 years she kept a boarding house.

She had three brothers and one sister.

Aaron Ball, 2-II-11, was killed in the war. He was married and had had one daughter.

Celie Ball was a shoemaker, 2-II-12. He was a hard drinker. He had two sons and one daughter. One of the sons, William Ball, travelled in a minstrel show and was killed in a railroad accident. The other son, 2-III-14, was a soldier, and like his father, was alcoholic. He died in some soldiers. home.

Amzie Ball, 2-II-14, died from stomach trouble. He had two children, who died early in life, and three who grew up, William, Theodore and Jesse. William and Theodore are said to be living near Plainfield.

Angelina Kiddie was the sister, 1-II-13. She died in 1899 in the Old Ladies' Home in Orange. She never had any children.

The patient's father's mother's parents are said to have lived to be very old, but nothing more is known about them.

\section{THE PATIENT'S MOTHER AND HER FRATERNITY, 2-III-56.}

Her maiden name was Susan Ann Conklin. She was born in New Jersey but could not tell the name of the town, neither could she tell how old she is, but thinks that she is about 66 years old. Since she was about 14 years old she has been subject to epilepsy and claims that it was caused by a fall on the stairs.

She is the fourth in line of birth of seven children.

Nathan, 2-III-61, is the first in line of birth. He never was married, and lives alone in a miserable room on Railroad street, Bloomfield. $\mathrm{He}$ is very feeble-minded. $\mathrm{He}$ served in the Civil War, and now draws a pension which his sister, Margaret Bender, and her daughter, Mrs. Wilson, manage to spend for him.

Catherine, 3-III-70, was the second in the family. She was said to have been deficient mentally and was given to the use of alcohol. She died of paralysis of the throat. Her husband was Thomas Hewett; he was a very hard drinker and died of heart trouble in 1890 . They had thirteen children. The oldest was Thomas. He, while trying 
to hold a man up on the road, was killed. The man whom he tried to rob shot in selfdefense. The second was Johanna, 4-IV-r2. She had one illegitimate child and is now said to be married to a man by the name of Rice, in Chicago. She is said not to have been very bright. The third was Libby, 4-IV-73. She has been married twice, and is now living somewhere in Vermont. Her first husband's name was Shepherd, and the second was Gramling. By her first husband she had one son. The fourth is Moses, 3-IV-53. $\mathrm{He}$ is living at Jerome Place, Bloomfield, and has two sons and two daughters. The fifth was Edward. $\mathrm{He}$ is living somewhere in Connecticut, 3-IV-52. The sixth is James. $\mathrm{He}$ is married but has no children. He is living somewhere in Orange, and is by trade a hatter. $\mathrm{He}$ is a hard drinker. The seventh is Esther, 3-IV-56. She married a man by the name of Martin, and now lives in Bridgeport, Conn. They have two sons and two daughters. The eighth is Susan, 40-IV-74. She married - Nicholson, who is now dead. She is sexually immoral and is alcoholic. She has three daughters and two sons, all of whom are in a home in Brooklyn. The ninth was John, 3-IV-50. He never married, is mentally deficient, and it is not known where he is. The tenth is Jennie Peters. She lives in Bloomfield, near Brookside Place, 3-IV-49. She has no children, and is said to have some kind of kidney trouble. The eleventh is Mrs. Kershu, 4-IV-75. She lives on the second floor in a miserable house in what is known as Hedges Alley in Newark. She is nervous and in very poor physical condition, probably due to poverty. She has had three children, a son seven years old and a girl five years, are living. There was a boy who only lived twelve hours. There were two other children of Catherine who died early in life.

Margaret, 2-III-5\%, is the third in the patient's mother's fraternity. She married Jacob Bender. He was a drunkard and died in the Home for Soldiers at Kearny. It is said he had softening of the brain. Margaret is an epileptic, and is feeble-minded like her sister, and she has a growth of some kind on her face; a hard bunch on the jaw near the ear; it is as large as her fist. Her epilepsy is said to have been caused by measles. She had in all ten children, of these five sons and one daughter died in infancy. Of the four who grew up there is Libby Wilson, who lives on Glenwood avenue,
Bloomfield. She, 2-IV-13, has spells which seem to be petit mal attacks of epilepsy. She neglects her children and is a very poor housekeeper. Her first husbald's name was Steele, and by him she had three sons. Her oldest son is 14 years old; and is in the sixth grade at school. The next is not very bright. $\mathrm{He}$ is 11 years old and is in the second grade at school. $\mathrm{He}$ is also crosseyed. The other is 9 years old, and is also in the second grade at school. Her second husband's name was - Arnold. She had no children by him. Her third husband, the present one, is shiftless and a hard drinker. By him she has had one daughter, 2-V-15, born 1909. The other children of Margaret are Lewis, Moses and Louise.

Lewis Bender is mentally deficient, 3-IV46 , and so is his wife. They have four children living, all under six years old, and one other who died when about two years of age. Lewis lives in Bloomfield and drives a wagon for a meat market. At one time he was a hard drinker, but has been leading a sober, industrious life since he joined the Salvation Army. Moses Bender, 3-IV-47, is janitor of the Watsessing School. $\mathrm{He}$ is deficient mentally, though a good worker and faithful in all that he is supposed to do, but he must be told each time what to do. His wife is apparently normal and a good housekeeper. Her maiden name was ___ They have six children: Lewis, born 1894, 3-IV-19. He left school at 16 and was then in the third grade. He could do good manual work and was reliable, but otherwise he could not learn. William, born 1895 , passed the fourth grade, but he could not go any further. $\mathrm{He}$ was lazy and rough and could not be relied upon. Maggie, born 1898, is in the fourth grade, and has been there for two years. Lillian, born 1896 , is in the kindergarten, and has been a very troublesome child. Louise, the other daughter of Margaret, 3-IV-48, married Michael Quinn. $3-\mathrm{V}-59$. He was a drunkard and died from consumption in the almshouse. Louise is sexually immoral, and while living in Bloomfield was arrested several times for disturbing the peace. She is said by her relatives to be a "perfect devil." She had four children, three of whom grew up: John, Michael and James, 3-V25, 28. John, the eldest, is about 18 . They were all brought up in orphan asylums.

Moses Elias, 2-III-59, was the fif $h$ in the patient's mother's fraternity. He died at the age of three of King's evil. 
The sixth was a boy, 2-III-58, who died in infancy.

The last was an epileptic boy, 2-III-60. He died before he was 10 years old.

\section{THE PATIENT'S MOTHER'S FATHER AND HIS FRATERNITY.}

Her father was Moses Conklin, 3-II-21. $\mathrm{He}$ was deficient mentally, was a drunkard and of a very brutal disposition. He would sell anything that be could get his hands on for a drink, even to his wife's clothes. Once he and his wife went to Ohio, and they walked all of the way back. $\mathrm{He}$ was killed at Morristown at a Fourth of July celebration. $\mathrm{He}$ was intoxicated and his death was due to his own act. He had two sisters who married brothers by the name of Mope. They are all dead now.

\section{THE PATIENT'S MOTHER'S MOTHER AND HER FRATERNITY.}

Her maiden name was Johanna Riker. She was an epileptic and lived to be 85 years old. Most of her life she took in washing. She had four sisters and six brothers, all of whom are dead now except Caleb Riker. $\mathrm{He}$ is over 80 years old, and is living on Dodd street, near Park avenue, in Orange.

Susan, 4-II-33, a sister of Johanna, married John Penn. He was backward, and so was his brother, Joseph $h_{p}$ 4-II-39, 40. Susan had eight children. The oldest was David, 4-III-93. He was a hard drinker and his wife was feeble-minded. They are both dead now. The next was John. His children live somewhere in Doddville. He died from an accident. Charlie is the third, 1-III-90. He lives on the Mountain Road in Upper Montclair. He is feeble-minded, but reliable. He works regularly for a family by the name of —_ in Upper Montclair. He has been married twice. His first wife, 4-III-97, died from consumption. By her he had six children, two of them, 4-IV, 69,71 , died of consumption. The oldest was Sarah, she lives in Arlington, and married a ma by the name of George Davenport. She was considered feeble-minded. The next was Charles. He was said to have been queer and could not learn. He wandered away from home when he was 14 years old, and was never heard of again. The next was Alice, 4-IV-68. She married a man by the name of Macon and has one son Chester Macon. She is now living somewhere in Newark. After her came George, 4-IV-70. He was a musician. About ten years ago he left his wife and two children and has not been heard of since. His son's name was Clarence Penn, and his daughter was Mary Penn. She married a man who is a keeper in some boys' home. Charlie's second wife is Ann Penn, 4-III-96. She is sexually immoral, alcoholic, criminalistic, and is now in jail in Newark. By her he had four children, two of them were still born. The other two, a boy and a girl, are living. The girl, who is somewhat backward, is in school at Montclair Heights School, on the Mt. Hebrew Road. She is said to be a nice child, 4-IV-64, who is kept at home a good deal to take care of the house. The boy is Walter, 4-IV-65. He was born in 1905, but appears to be no more than three or four years old. He is now in the Children's Home at Montclair. When he was brought to the Home he was in a very bad condition, due to neglect. His nose was sore and the odor was vile, due to continuous colds, and the bone had been partly eaten away and had to be removed.

Mary, 4-II-34, was the next in the fraternity. She is dead now, and the cause of death is unknown. She married David Thoma, and lived in Albany. She had three sons, John, David, and Henry, and one daughter.

Jeannette, 4-II-31, died from dropsy. Her husband's name was Abraham Brown, and by him she had two children. Her second husband's name was Simpson, and by him she had one child.

Israel, 3-II-27, was the oldest of the boys in the patient's mother's mother's fraternity. He lived to be 83 , and died of some kind of stomach trouble.

David, 4-II-32, lived to be 93 . He had six sons and five daughters. One of his sons named David, 4-III-72, is in the State Hospital for the Insane at Morris Plains. David's wife was killed by lightning. One of their sons, Charles, is living at West Orange. Of their daughters, Liza, Harriet, and Irene are still living; Liza is living in Bergen County. She had four sons. She married.

Matthew, 4-II-44, was found dead in bed. He was never married.

William, 4-II-35, lived in the West. $\mathrm{He}$ had lost one arm in an accident. He had three daughters and one son. The son was killed in a mining accident.

Elisha, 4-II-45. He died from Bright's disease.

Caleb, 3-II-23, is the youngest and he is normal, and so is his wife. They have had six children, three sons and three daughters. 
There was one son who died before he was two of brain fever, 3-IV-67. A son and a daughter died of scarlet fever. One was 11 and the other $\%$. Of the two daughters living, one is Martha Bryan. She lives in Dover. She has six sons and two daughters, all living, except one daughter. Her husband is dead. The other daughter is Minerva Fifield. She lives in Newark and has one son and three daughters. Caleb's son is named Emmons, 3-III-56. He is married but has no children. $\mathrm{He}$ is normal.

Johanna Riker, the patient's' mother's mother, was married when she was but 14 years old, and her husband, Moses Conklin, 3-II-31, was her first cousin. His mother, 3-I-6, and her father, 3-I-7, were brother and sister.

\section{THE PATIENT'S MOTHER'S MOTH- ER'S PARENTS.}

Her father died at 85 from erysipelas, and her mother, whose maiden name was Surch, died from dropsy, and her mother, whose maiden name was Rose, died from a cancer.

\section{ADDITIONAL INFORMATION CON- CERNING THE PATIENT AND HER FRATERNITY.}

Source-Emma, Alice and Dorretta Smith, patients at the New Jersey State Village.

They each declared the following to be true, separately and independently.

The oldest in the fraternity, 2-IV-23, was subject to epileptic attacks and his death occurred during a seizure when he fell into the water and was drowned.

The seventh, 2-IV-24, was also subject to epilepsy, and it was while he had a seizure that he fell out of a window and was killed.

\section{RUDOLPH DAVIS, Felon. No. 10406.}

An inmate of the State Penitentiary, Fort Madison, Iowa.

Rudolph Davis was one of twenty-three inmates of the Penitentiary at Fort Madison, Iowa, who, because they had been twice convicted of felony were, under the provisions of Chapter 187 of the Acts of the Thirty-fifth General Assembly, ordered by the Board of Parole of the State of Iowa to be vasectomized by the phyisician of said prison. It thus appears that an order for sterilization was issued not on the evidence of the constitutional makeup of the individual, nor of his hereditary potentialities as determined by the pedigree study of his family.

Neither the court nor the penitentiary officials were supplied with the facts concerning the hereditary makeup of this man, but the Board of Parole on April 24, 1919, supplied the following data:

"This man was committed to our State Penitentiary at Fort Madison on August 28th, 1913, having been convicted of the crime of breaking and entering, he having broken into a laundry, stealing therefrom a considerable quantity of clothing and other property. At that time he was twenty-two years of age.

"From what we were able to learn we concluded that he was born in the State of Mississippi; that when he was an infant his father and mother separated and soon thereafter he was removed by his mother to New Orleans; that he attended school but very little, only reaching the third grade and quitting at the age of nine years; that he was neglected and at an early age in his history acquired the habit of using intoxicating liquors; that he was frequently arrested for intoxication and served several jail sentences for that offense.

"When about ten years of age he went to Little Rock, Arkansas, and when about fifteen years of age he burglarized three different places there and received a sentence of four years in the State Penitentiary at Little Rock. After serving about three years he was released from there and about a year thereafter, or in August, 1913, he committed the offense in Iowa above referred to.

"It was in February, 1914, that the operation of vasectomy was ordered. This matter was heard in the Federal Court and an injunction granted preventing the operation from being performed.

"It may be interesting to note that this man made a fairly good record in prison and that on July 13th, 1917, nearly four years after his sentence, and when he still had over two years to serve, if he had remained in prison, this Board then paroled him, securing him a good position working in a round house, which was work that he was qualified to do and which was agreeable to him.

"A very few days after he reached his employment his employer reported to us that he was very hard to get along with owing to his uncontrollable temper and that it had been necessary to change him from one place to another. Soon thereafter he 
absconded and was later arrested in San Francisco but was not returned to our penitentiary."

(See also Chapter VII, Sec. III, Iowa.)

4. NORA REYNOLDS. Feeble-minded. An inmate of the Michigan Home and Training School, Lapeer, Michigan.

In a letter dated February 14, 1919, Dr. H. A. Haynes, Medical Superintendent of the Michigan Home and Training School, at Lapeer, wrote:

"Replying to your letter of the 4 th relative to history of Nora Reynolds, would say that I have very little history of the case. I have no record of any of her relatives and it appears that very little is known of her history at the State Public School where she was admitted when a little girl. She was placed in several homes and failed to make good, therefore was returned to the school and eventually was transferred to this institution."

The institutional records of Nora Reynolds follow:

Date of birth: June 15, 1883.

\section{INSTITUTIONAL HISTORY.}

Nora came to the institution March 27, 1907. At that time few institutional records were kept. In the latter part of 1908 or the early part of 1909 made her escape from the institution. When she was returned she was found to be pregnant, and November 11, 1909, she gave birth to a female child. (From office record.)

March 22, 1911-Mental examination gave approximate mental age of 11 years.

June 18, 1912-Nora Reynolds about 1 a. $m$. escaped from cottage soon after Mrs. - nightwatch, made her 12 o'clock rounds. The patient was apprehended the following morning. She says she climbed out of a window and had no one to help her. She was dressed in a night dress, shoes, and a dress. She was bareheaded and had on no underwear. She says she saw no one after she left the cottage.

August 13, 1912-Patient made her escape from the cottage during the night. She took a suit case with a few things in it. She is believed to have had assistance.

September 11, 1912-Dr. H. notified that R. D. - of township has in his house Nora Reynolds. She was returned to the institution.

September 11, 1912-Mr. F——, night watch of cottage, arrested at 9:30 for being implicated in getting patient out. Mr. F. confessed to helping her out and is in jail at present awaiting trial. Nora says she is pregnant.

October 23 and 25, 1912-Nora taken to court when Mr. F. was having his trial for carnal relations with Nora. $\mathrm{He}$ was found guilty.

March 25, 1913-Patient taken by Miss A. of her cottage to hospital at $12: 30$ A. M. Gave birth to a female child at 1:00 A. $\mathrm{M}$.

November 14, 1914-Patient has recently been ugly toward other patients in the cottage and today assaulted ___ slapping her quite severely.

January 17, 1916-Punished her little girl unjustly and was impudent and violent when remonstrated by her attendant.

March 28, 1917-Wassermann negative.

October 23, 1917-Mental examination by Terman Stanford Revision of Binet Test9 years, 3 months.

November 21, 1918-Patient obtained possession of a master key and let herself out through the fire escape of the third floor. She let herself in again and denied having the key. When she was searched none was found, but the following morning the master key was found outside of her window.

\section{Additional Information.}

An undated letter from patient to an outof-town man was intercepted. This letter planned meeting him every morning.

Another letter dated 10-14-11 asks another out-of-town man to meet her in Flint, as she is about to escape from the institution.

A letter from the State Agent states that Nora was given when a very little girl to Mrs. Who later died and in turn gave her to $\mathrm{Mr}$. and Mrs. F- From this home she went to the State Public School. She was admitted to the Michigan Home and Training School from the State Public School. Mr. and Mrs. F___ are unknown and there are no records of adoption.

(See, also Chapter VII, Sec. IV, Mich1gan.)

5. FRANK OSBORN, feeble-minded, an inmate of the Rome State Custodial Asylum, Rome, N. Y.

It appears that there was no detailed nor extensive family history study made in this case, as was secured in the case of Alice 
Smith, in New Jersey. However, considerable evidence concerning the constitutional make-up and the pedigree of the subject of this particular case is secured by examining the court records in the matter and extracting from them such references as may throw light upon the particular question in hand. The following extracts are taken from the RECORD ON APPEAL, Supreme Court of the State of New York, Appellate Division, Third Department, in the Case of Osborn vs. Board of Examiners:

"The board has made an examination of one Frank Osborn, who is about twenty-two years of age, and was sent to the Rochester Industrial Institution in 190\%, and from there to the Rome Custodial Asylum, at Rome, where he is now confined. $\mathrm{He}$ has cost the State while in its institutions, approximately $\$ 2,000$, up to October 1,1914 , and since that time has been an expense to the State of about $\$ 175$ per year. After a careful examination by the board we have learned that said Frank Osborn comes from a family of degenerates. He is one of sixteen children, eight of whom are dead. Five brothers and sisters besides himself are confined in State institutions for the feebleminded; one, a feeble-minded brother, lives with a farmer and is intemperate, incapable and untrustworthy; one sister, the brightest of the family, lives with and keeps house for a man to whom she is not married, though she has a husband living. She is immoral and has been an inmate for two years of a house of prostitution. Of his dead brothers and sisters one died in an institution for feeble-minded and seven died before becoming one year of age. The father of said Frank Osborn was feebleminded and the son of a man who was an epileptic and who lost his mind before death. Said Frank Osborn's mother is living, is feeble-minded and comes from a family of defectives. Her mother was feeble-minded and one sister and two brothers of Frank's mother were feeble-minded.

"The family of Osborn, from which Frank Osborn comes, have always been a charge to either the county or the State, and they have cost the State approximately $\$ 10,000$ since they became State charges.

"The sources of our information are examinations of individual records, examination of said Frank Osborn and members of his family, relatives and neighbors who have been intimately acquainted with his family during their lifetime.
"The said board have carefully examined into said Frank Osborn's mental and physical conditon and it is the judgment of a majority of said board that procreation by said Frank Osborn would produce children with an inherited tendency to feeble-mindedness, and there is no probability that his condition will improve to such an extent as to render procreation advisable. His physical condition is such that no harm will come to him, so far as the board is able to ascertain, from the operation." (From Affidavit and Order appointing Counsel, pp. 18, 19.)

From Testimony of Lemon Thomson for Applicants-Direct. pp. 26-33. (See also Chapter VII, Sec. V, New York.)

Q. Now, you are acquainted with a young man by the name of Frank Osborn, who is an inmate of the Rome Custodial Asylum? A. Yes, sir.

Q. He is here in court now, is he? A. Yes, sir.

Q. Do you recognize him? A. Yes, sir.

Q. Did you make some examination of Osborn? A. I did.

Q. When did you make an examination of him, about when? A. Within the past year.

Q. Did you make more than one? A. I have examined him more than once.

Q. Did you make a careful examination of him, A. I did.

Q. The examination you made of him was both physical and mental? A. Yes, sir.

Q. And did you make inquiry into his family history? A. I did; quite extensively.

Q. Did you inquire from others who knew Osborn as to his family history? A. I did.

Q. Did you examine any other members of his family? A. I did.

Q. State, will you please, doctor, what members of his family you recall you examined? A. His mother, his sister, one sister, Harriet.

Q. And did you make inquiry from them about their family history? A. I did.

Q. As a result of this examination of Osborn and his family history what did you ascertain? If you can't recall, read your notes. A. I am permitted to use my notes, am I?

Q. Yes. 
Mr. Chambers. You (Mr. Frost) haven't any objection to that?

Mr. Frost. No.

Q. I want you to state in detail just exactly what you found both as to his history and his family history. A. The information I received came besides from his family, from records, from neighbors, people who had been acquainted with the family, and from affidavits, records from societies that had investigated Frank, as one of sixteen children.

Q. Now just excuse me for interrupting you. About what is his age, did you learn? A. About 21. I think he is more than 21 now. I have his exact age. There are eight living.

Q. Eight brothers and sisters, eight children? A. Eight children, brothers and sisters, living. Three are now confined in the State Institution for Feeble-Minded at Syracuse; Frank and his brother at the State Institution at Rome; one is in the Institution for Feeble-minded at Newark, N. Y.; one formerly an inmate at the Industrial School, the old school at Rochester, is now on a farm at East Palmyra, where he was taken by the father of the present man who has him; one sister Harriet is living at New Haven, N. Y., with a man not her husband. She had been previously married, lived with her husband for a few weeks. He enlisted in the navy a few weeks after the marriage. They had parted before the enlistment. She then went to a house of prostitution in Syracuse, remained there about two years. From there she went to live with the man she is now living with. This part of the information came from Harriet herself.

Q. Now, go right on, doctor, and state any other information that you know about the family. I might ask, is his mother feeble-minded in your opinion? A. Yes, sir. Shall I finish up with the children?

Q. Yes, go ahead. A. One child died in the orphan asylum at Rome, one other died in the institution for feeble-minded at Syracuse. The mother is living at 419 East Adams street, Syracuse. The father is dead, died about 1902 .

The mother some time afterward claimed she married a man by the name of Van Hueyser, who lives with her winters and deserts her summers. She cannot write. She can read a very little bit, very little.

Now shall I give you some evidence which I get from records from the Society for the Prevention of Cruelty to Children. Q. Yes.

Mr. Chambers-Some of it may be hearsay, judge.

Mr. Frost-Yes, but I do not regard this as going to the merits of the question, and assume the situation is as you represent it, so I will not object to your giving whatever line you desire.

Q. Go ahead and give all you learned. A. The mother's name was Aurilla Guernsey before marriage.

Q. G-u-e-r-n-s-e-y? A. G-u-e-r-n-s-e-y. Shall I read right off here what I have copied there?

Q. Yes, to save time. A. Copy of report of S. P. C. C., Onondaga Orphan Asylum, April 2, 1904.

Family of Aurilla Osborn, commonly called "Rilly" Osborn, living in town of Lysander on the direct road between Baldwinsville and Lysander, "Fenner district," near northwest corner of Mud Lake. (This gives seven children; there are eight.)

Fannie, about 17 years; James, about 15 years; Frank, about 12 years; Henry, about 14 years; Louise, about 8 years; Alice, about 9 years; Florence, about 5 years.

They are all "about."

Q. Now, you learned that there was still another? A. There is still another, and, I think, after I spoke about it, is mentioned here.

The mother is the widow of Charles Osborn, who died three years ago in a condition of indescribable filth and neglect. The mother is vicious, immoral, filthy in person, truculent and a terror, nuisance and offense to all the region about. The children, three boys and four girls at home (one of the girls, Hattie, away at work) range in ages from 17 years to 5 years. They have all been to school excepting the youngest, but are so dull and careless and unmanageable that they cannot learn anything; none can read writing and in a very labored and limited way can they read print.

They have come to school so filthy in person and so foul smelling as to be unendurable and have been ordered out by the teacher, Miss Grace Mason, who openly declared that if they were not kept out of school she, the teacher, would instantly quit her job when they entered.

There is now one of the boys, Henry, aged 14, so ill that he is likely to die any hour. (I will say this one is the boy at East 
Palmyra.) The physician attending, Dr. Dout, of Lysander, says he is dying of consumption, starvation and neglect. The mother is so impotent and careless that he gets no nursing, no food properly prepared and even the nutriment provided by compassionate neighbors and the medicine lef by the doctor are given in a very uncertain way. The mother is described as being not only gravely ignorant and slatternly, but ugly and dangerous as well when interfered with. She is a short, stout woman.

Complaint was made by Mr. L. B. Russ, a near neighbor, who was accompanied to our office by Mr. A. B. Borden, another near neighbor. They also refer to other neighbors, F. W. Fenner and H. L. Huntington, school trustee, and J. W. Iosette.

The overseer of the poor, Hiram Patchett, is willing to co-operate and will probably consent to pay for the children in an institution.

The oldest girl, Hattie, is reported as being immoral The same fate, beyond a doubt, awaits the younger sisters as they approach maturity As an illustration of their manner of living, Mr. Russ states that they observe no decency or cleanliness. They make no use of a closet, but make convenience of the door yard, the floors, the beds. Old bedding is sometimes thrown out so rotten that it falls to pieces and is an offense to passersby.

Osborm, the husband, is reported by neighbors as having died in a wallow of filth indescribable.

The family now receive a weekly allowance of $\$ 3$ from the overseer of the poor for groceries, but nothing is properly cooked or prepared and the wonder is how they manage to live. They are very careless and wasteful, sleep in their clothes, all in one room.

They have burned all the loose wood obtainable, the cellar door and steps, the outhouse-have torn out the cellar walls in pure mischief. In short, their indecencies of living are almost beyond belief.

The nearest justice of the peace is Fred H. Morgan, Little Utica.

Charles Edward Osborn, the father of the family, has one sister, or had one sister. (This should all have been in the past when I say "has".) One sister living at Baldwinsville. One sister is dead. Charles was shiftless, neglectful as to his personal appearance, unable to accumulate before and after marriage; was considered feeble-minded. $\mathrm{He}$ was the son of a man who had epilepsy. for fifteen years previous to his death.

Aurilla, the mother, had four sisters and three brothers. Two of the brothers are markedly feeble-minded One died a little more than a year ago. They had been men who had worked for farmers, as they term it, had done "chores" for their living. They were bashful. The one who died was a drinking man whenever any one woud treat him, never having anything to buy for himself.

The other brother was respectably considered, though he has had his experience in taking things that did not belong to him and had been arrested for it.

The sisters have nothing particular in regard to them excepting one. One was reported to be a "bad actor," were the words given, or prostitute.

Q. No other proceeding has been brought, doctor, since you have been a member of this board to test the constitutionality of this law that you know of? A. No, sir.

Q. You have made no official operation on any inmate of an institution? A. No, sir.

Q. Now, did you learn that it cost the State a good deal of money to support the Osborn family in those institutions? A. I did.

Q. Did you learn it cost the State approximately $\$ 2,000$ to maintain Frank Osborn in an institution? A. It has.

Q. And that it cost the State approximately $\$ 10,000$ to maintain or have such members of his family in institutions? A. It has.

Q. (The Court)-Does cost them? A. It has cost them and is costing them at present.

Q. That is, I mean cost the State or counties, some of that was perhaps the counties? A. A little of it the counties; most of it the State. No record is made of the cost to the several towns or to the town of Lysander.

Q. Now from the examination which you made of Osborn, is it your opinion that procreation by said Osborn would produce children with an inherited tendency to feeblemindedness? A. It is.

Q. Would you say whether his condition will or will not improve after an operation? A. I would say it would not.

Q. Is his physical condition such that no harm would come to him from such an operation? A. It is. 
Q. Now what kind of an operation, doctor, does the Board contemplate performing on him, if one is performed? A. Vasectomy.

\section{Cross-examination by Mr. Frost:}

Q. Doctor, the case of Frank Osborn was the first selection made by the Board of Examiners in this State under the Act of 1912, for the performance of an operation, was it not? A. We had considered several; that was the one we selected among the many.

Q. And did you make that selection before or after obtaining the information relative to his family and the history and habits of his family? A We made it after; the definite selection.

Q. (By the Court.) Excuse me, I didn't understand that. You made it after the definite selection? A. Yes, sir.

Q. You mean by that you made the examination after the definite selection? A. No, sir, we made the examination of the family histories-

Q. (Interrupting.) After? A. Previous to the selection.

Q. Oh, previous? A. Yes, sir. We made the selection of Frank Osborn after.

Q. After you had examined him and after you had inquired into his family history? A. Yes, sir.

Q. (By Mr. Frost.) At the time of the investigation into the family history of $\mathrm{Mr}$. Osborn there were confined in the Rome Custodial Asylum about how many persons whom you would classify as feeble-minded? A. I think all of them classified as feebleminded. I think they have about some 1,300 approximately.

Q. What particular fact was it which led you to select Frank Osborn as the first subject of the application of this law? A. A good, big husky fellow, had lots of color, and we have got to make a start.

Q. But you had already investigated his family history, had you not? A. We had.

Q. Had you investigated the family history also of the other 1,300 or $1,400 \mathrm{pa}$ tients? A. Oh, no.

Q. When you determined to take up for consideration the selection of a subject for the performance of this operation what was your first step in making such selection, that is, it was an examination of the family history, was it not? A. The family history and then the individual.
Q. And you first examined the family history, did you? A. Yes, sir.

Q. And after an examination of the family history then you made a physical examination of the subject? A. We did.

Q. Did the question of the family history of the proposed subject bear any relation to the probable effect upon his physical system of the proposed operation? A. The history of the family bear any relation to the physical effect?

Q. Yes. A. No, sir, I think not; no, sir.

Q. Or any relation to the probable mental effect? A. No, sir.

Q. Then the only relation which the family history bore in the determination reached by your board of the selection of a patient was to get a patient who had a bad family record, isn't that the fact? A. No.

Q. Well, now, what other relation then did the family history have to the selection of a patient? A. The selection of a patient who could by no possibility procreate a normal mental individual from the stock from which he came.

Q. Then if you had a patient who was feeble-minded to a degree equal to that of Frank Osborn and you as a member of this board had to determine the question whether or not the operation should be performed would you be influenced in your determination by the family history of that patient? A. I would.

Q. So that the degree of feeble-mindedness which you may find in a patient will not be the determining fact with you in a question of this character? A. Not to start with; would be more cautious; we don't wish to get anyone that there could be any possible doubt as to his ability to precreate normal individuals mentally.

Q. Well, did your board in making this selection consider the question of the selection of a patient with what may be termed a bad family record? A. Why, not particularly. We talked that over. We had several to select from.

Q. Well, didn't you as a matter of fact select a patient with a bad family record as came under your observation? A. It is bad enough.

\section{Testimony of Charles Bernstein for Defend- ant-Direct, p. 83-4.}

(Superintendent of Rome Custodial Asylum)

Q. You know Frank Osborn here in this proceeding? A. Yes, sir. 
Q. And how long has he been in your institution? A. I believe since April, 1907.

Q. Have you personal knowledge of the work which he performs? A. Yes, sir.

Q. What does he do? A. At the present time he works in the laundry sorting clothing, both before and after washing.

Q. Have you had him performing other work? A. Yes, sir.

Q. Have you observed him to an extent as to enable you to say as to whether or not he will be able to earn his livelihood after he got his freedom? A. He could not.

$Q$. What do you say as to his physical condition? A. In general he is fairly well developed physically, over-tall for his age and weight.

Q. His health is generally good?

A. Yes, sir.

Q. What have you observed with reference to his ability to read and write? $\mathrm{A}$. $\mathrm{He}$ can read and write.

Q. What would you say was his present age with reference to his mental development? A. According to the Binet test about eight years mental capacity.

\section{Testimony of Frank Osborn-Direct,} pp. 111-115.

Mr. Frost-I would like the Court to observe Mr. Osborn and I will call him as a witness.

The Court-Can the oath be administered to him?

Dr. Bernstein-He doesn't appreciate what it means.

The Court-Will you take his statement without the oath?

The respective counsel so agreed.

The Court-I do not want to make light of the oath. It is consented that Frank Osborn be examined, but without being sworn.

Frank Osborn, examined (not sworn), testified:

\section{Examined by Mr. Frost:}

Q. What is your name? A. Frank Osborn.

Q. How old are you? A. Twenty-two.

Q. Where do you live now? A. Syracuse.

Q. Where did you come from today? A. Rome.

Q. You came from Rome? A. Yes.

Q. Where do you stay in Rome? A. In the institution.

Q. When you say you live in Syracuse what do you mean? A. That is my home.
Q. And that is where your father lives? A. Yes.

Q. And your mother? A. Yes.

Q. Is it your mother who lives in Syracuse? A. Yes.

Q. And is it your own father who lives in Syracuse? A. No, stepfather.

Q. Stepfather? A. Yes, sir.

Q. Did you ever go to school, Frank? A. Yes, sir.

Q. Can you read? A. A little bit.

Q. (Showing paper to witness.) Take that newspaper and see if you can read something to us, read up here in this corner (indicating), can you read that? A. (Examining same.) Yes.

Q. Read that. (Witness does not read at first.)

Q. What does that say, Frank? Can you read it? A. Yes.

Q. What does it say?

Mr. Chambers-Let him read it.

Q. Read it aloud, read it to us.

Dr. Bernstein-Read it. Don't be afraid.

Q. Read it to us or anything. Look at the paper and find anything you can read there and read it to us just a line or two. A. (Reading same.) "Do you enjoy your meals this hot weather? There is no reason why you should not."

Q. Now, Frank, will you take a pencil and sign your name right here to this paper, sign your name right up there? (Witness does so.)

Mr. Frost--Before I ask him that question I offer in evidence so much of the matter printed in the newspaper as was read by the witness, and reads as follows: "Do you. enjoy your meals this hot weather? There is no reason why you should not."

Q. What is that you have written, Frank? A. My name.

Q. And write under it your age? A. (Witness does so.)

Mr. Frost-I offer this slip in evidence.

The same was received in evidence and marked "2-J. E. K."

Following is a copy of same:

"Mr. frank Osborne

I be 22 this november $20 . "$

Q. Do you know the days of the week, Frank? A. Yes.

Q. Name them just, please. What is the first day of the week? A. Monday.

Q. Go on, name the rest of them. A. Tuesday, Wednesday, Thursday, Friday, Saturday and Sunday. 
Q. How many days are there in the week, Frank? A. Seven.

Q. And the first one you say is what? A. Monday.

Q. And the last day of the week is what? A. Sunday.

Q. Do you know who the Governor of the State of New York is? What is his name? Do you know or can't you think now, which is it, Frank? You don't know, do you? (Witness shakes his head negatively.)

Q. How much do you weigh? A. One hundred and fifty-six.

Q. And how tall are you? A. Six foot one.

Q. Can you add; do you know how to add? A. Not very well.

Q. (Presenting same.) I show you a paper. See if you can add those figures. (Handing same to witness.) A. (Witness does so.)

Q. Mr. Frost: I offer this slip in evidence.

The same was received in evidence and marked "3-J. E. K."

Following is a copy of same:

$$
\begin{aligned}
& \text { "4642 } \\
& \frac{3122}{7764 "}
\end{aligned}
$$

Q. Did you ever work for anyone who paid you by the day or by the week for your work? A. No, sir.

Q. You never did that? A. No, sir.

$Q$. Do you know how much a man gets for working on a farm? A. No.

Q. You don't know whether he gets a dollar a day or $\$ 2$ a day or $\$ 5$ a day? A. No, sir.

Q. Didn't anyone ever tell you? A. No.

Q. You haven't any idea how much he gets? A. No.

Q. How many cents are there in a dollar? A. One hundred.

$Q$. If you had half a dollar that would mean how many cents? A. Fifty.

Q. And if you had a quarter that would mean how many cents? A. Twenty-five.

Q. And if you had three quarters in your pocket how much money would that be? A. Seventy-five.

Q. And if you had a dollar and you paid twenty-five cents for some cigars, how much money would you have left? A. Seventyfive.

Q. And if you paid forty cents for cigars out of a dollar how much would you then have left? A. Sixty-five.
Q. How much? A. Sixty-five.

Cross-Examination by Mr. Chambers:

Q. Let me ask you a few questions, you needn't be afraid because nothing is to be done here except ask you questions: Frank, do you know what this is that we are doing here? A. No.

Q. Did you read something about it in the paper? A. Yes.

Q. You did? A. Yes.

$Q$. Did you know what kind of an operation was going to be performed? A. I didn't understand what it was going to be.

$Q$. If you don't understand it you don't know whether you want it done or not? A. No.

Q. Is that it? (No answer.)

6. PEARLEY C. MICKLE, Moral Pervert.

Case originated in the District Court of the Fourth Judicial District, Elko County, Elko, Nevada.

The only evidence relative to the personality and pedigree of Pearley C. Mickle is that which is secured from the court record. After this man had been declared guilty of rape, the following examination took place:

From the Minutes of the District Court of the Fourth Judicial District of the State of Nevada, in and for Elko County. (See also further evidence in Chapter VII, Sec. VI, Nevada.)

Court: Have you any legal cause to show why judgment should not be pronounced against you?

Defendant: No, sir, I haven't.

Q. Is there anything you want to say, Mr. Mickle?

A. No, sir.

Q. Will you state how old you are?

A. Nineteen.

Q. Have you the discharge papers showing his age?

Carville: Twenty-two; he was born in '93.

Defendant: I enlisted when I was fifteen, but enlisted as eighteen. My mother and father has the birth certificate.

Q. Your folks are living, Mr. Mickle?

A. Yes, sir.

Q. Where do they live?

A. Mother lives in Portland, Oregon, and father in New York.

Q. Will you state what your father does?

A. A wagon maker.

Q. Your mother is a good woman, is she?

A. Yes, sir. 
Q. How did you come to commit such a crime as this?

A. By drinking steady and was just sobering up. When $I$ am sobering up it drives me crazy. Whiskey and wine puts me off my head.

Q. You mean to say you were just sobering up after having been drunk?

A. Yes, sir, just sobering up.

Q. Have you ever done anything of this kind before?

A. No, sir.

Q. Anything like it at all?

A. No, sir, your Honor.

Q. Have you always been a healthy person?

A. Yes, sir.

Q. Did you ever have fits of any kind?

A. Epileptic fits.

Q. Do you wish to vouch to me for that?

Do you assure me that it is the truth?

A. Yes, sir, that is the truth; I can prove it.

Q. How long since you had one?

A. The last one I had was last March.

Q. How many have you had?

A. I have had ten, I guess, in the last four years.

Q. Anything like that in your family before, your father or mother?

A. Not that I know of. I have a cousin that has them.

Q. You don't claim to be insane, do you, Mr. Mickle?

A. No, sir.

Q. You don't pretend to be crazy?

A. No, sir.

Q. Well, now, I want to be perfectly fair with you. A man in your condition is under a strong temptation to tell lies.

A. I am not telling any lies, your Honor. I am tell the straight truth.

Q. Sometimes a man tells a lie when he thinks it will help him, when it is against him and that may be the case with your epilepsy.

A. I can prove that.

Q. Would you make that statement that you have epileptic fits if you knew it was going to hurt you with me instead of helping you?

A. No, sir, I wouldn't.

Q. You mean you would tell a lie about it if you thought it would help you with me?

A. No, sir, I wouldn't.

Q. Perhaps you do not understand me. Supposing you knew by telling me you had epileptic fits that I would punish you more than I would otherwise. That might seem strange to you, but supposing you knew that, would you still say you had them?

A. I have. That is the truth; hope to God to die.

Q. Of course, Mr. Mickle, I wouldn't have you understand what the punishment is, but I don't mean to say when I remind you the Court might inflict the death penalty on you, because the Court cannot do it in this case, but it might affect you injuriously in some other way. And no matter whether it does or not, you still say that is the truth?

A. That is the truth; hope to God to die.

Q. Is there any place I could investigate your father or mother, or anybody else you would be willing to have me inquire of whether this is true or not?

A. Yes, sir.

Q. Will you tell me their address?

A. Yes, sir, Mrs. Jennie Pounds, Ceres, New York.

Q. Is that a small town or village?

A. A small village.

Q. You don't need any street address?

A. No.

Q. Is that you mother?

A. My aunt.

Q. She knows that you had fits?

A. Yes, sir, I was there last March when I had these fits.

Q. And she is living, so far as you know, at this time?

A. She is living, as far as I know, at this time.

\section{$\because$ WARREN WALLACE SMITH, Moral}

Pervert. An inmate of the State Reformatory at Jeffersonville, Indiana.,

Case originated in the Circuit Court of Clark County, Ind.

Neither the Reformatory nor the Board of Examiners, who selected Smith as the subject of the test case, made any serious attempt to secure Smith's family history in accordance with the common eugenical practice, for the purpose of throwing light upon the hereditary traits of the subject. This essential task, however, was accomplished by private enterprise, which had the hearty support of all parties concerned in the case.

Dr. A. H. Estabrook, scientific investigator on the Staff of the Eugenics Record Office, after consulting with the authorities of the Reformatory at Jeffersonville, with the attorneys in the case and with the family of the subject, reported the following: 


\section{a. Abstract.}

Notes regarding Warren Wallace Smith, Test Case for Indiana Sterilization Law. Born 1903, Indiana Reformatory No. 10734, rated as mentally dull, physically fair, sentenced to Indiana Reformatory 2-13-19, term two to twenty-one years for incest; received at Reformatory same date. Conviction in Wayne County (Richmond). Warren probably born Henry County, second grade schooling, never attended church, left home about the age of 16 , occupation laborer; previous arrest for petty larceny. His father, Henry Smith, belongs to the Mission Church, pecuniary condition, poor; mother, Lena K. Smith, also member of the Mission Church, father and mother being separated. Warren has one half-sister, Letha Marie, born 11-18-07; on 6-19-16 made a ward of Shelby County, Board of Children's Guardians; 5-5-17 placed out in private home; $3-28-18$ returned to father; immoral relations with brother Warren, and on 2-8-19 committed to Wayne County Board of Children's Guardians, and transferred from there same date to Indiana Girls' School. Brother Arthur C. Smith born 11-10-09, sent to Shelby County Orphans' Home 6-19-16, same time as sister; returned 3-20-18 to father; 2-8-19, at time of breaking up of family because of incest charge against Warren, made ward of Wayne County Board of Children's Guardians; transferred 2-27-19 to White's Institute, correctional institute for juveniles (private organization); 8-30-19 returned to parents; 9-2-19 placed in private home; 4-8-20 sent to Home for Friendless and Orphans' Home in Richmond, Indiana.

Smith was selected as subject for sterilization case merely because he came under the classification of rapist in sterilization law of 1907; that he was not selected because of feeble-mindedness, although he is probably a high-grade imbecile, and neither was he selected because a member of a feeble-minded, degenerate, anti-social family of the State.

Smith has had a normal record at the institution, is employed at outside work, unskilled labor, caring for lawns, etc., about institution. He is not able to carry responsibility at any time, and his parole from institution will probably be a matter of form after his minimum sentence has been carried out. He was placed in school for a time, but it was found of no use. The chaplain states that he has not been unmanageable in any way.

\section{b. Detailed Family History. (See Family} Pedigree Chart, p. 312A.) Warren Wallace Smith, the Subject of the Test Case of the Indiana Sterilization Law.

Governor James P. Goodrich of Indiana, during his term of office, 1917 to 1920 , had felt that the provision of the Indiana sterilization law should be carried out in the different State institutions where applicable. The trustees of the Indiana Reformatory on the other hand had decided to discontinue the sterilization of certain Reformatory in- mates on the ground that they thought the law unconstitutional. Hence Governor Goodrich decided that the validity of the law should be determined and requested the Reformatory officials to start a case, and secured Wilmer T. Fox, of Jeffersonville, Ind., a practicing attorney, to act as attorney for the plaintiff to enjoin the sterilization and follow the case through to the Supreme Court of Indiana. This study of the SmithKisker family was made because Warren Wallace Smith, age nineteen, was chosen as the subject in the test case in the Clark County Circuit Court to decide upon the constitutionality of the Indiana sterilization law.

\section{THE SMITH FAMILY (PATERNAL LINE).}

Warren Wallace Smith, 10734, at the Indiana Reformatory, was selected for the following reasons: $\mathrm{He}$ had been convicted of incest with his half sister, "The inability of this boy to comprehend the wrongfulness of such an act, and his tendency for sexual intercourse by consent or forcibly, seemingly making no difference to him. His behavior while at the Reformatory was that of a weak-minded boy, he having no conception or regard for the rules of the institution. His mental age is about eight years."-Letter of G. A. H. Shideler, Superintendent of the Indiana Reformatory, 7-29-1921. Warren was received at the Reformatory on February 13,1919 , for two to twenty-one years, on the charge of incest, from Wayne County, and was transferred as No. 8535 to the Indiana State Prison on May, 1921.

In view of these facts it seems desirable to know something of the family history of this boy, to ascertain whether he is a member of a defective strain of people and the incidence of mental defectiveness in the family group.

Warren Wallace Smith was born about 9-13-1902, in Henry County, Ind., though there is a dispute as to the exact date. It is stated that at the time of the birth of the child, the mother had a severe epileptic seizure but that the birth otherwise was normal. He was always dull and apathetic as a child. His mother died when he was about three years old and although his father married again shortly and kept a home, Warren lived around with his relatives a larger part of the time. His aunts who have had the care of him, say that Warren is not 
difficult to control. He attended school for a time but he could not learn and never went beyond the second grade. As he grew older he was in trouble several times, accused of annoying people on the streets, petty larceny, etc. At that time it was suggested to Warren's father by the authorities to have him sent to the Indiana School for the Feebleminded at Fort Wayne but the father objected and nothing came of the suggestion. Warren was then twelve years old. He has never been employed. At seventeen, Warren was arrested for incest with his halfsister then twelve years old. This relationship had been going on for about four months previous to its discovery. Warren was then committed, $2-13-1919$, to the Indiana Reformatory for two to twenty-one years and received at the Reformatory the same date. On April 30, 1921, he was transferred to the Indiana State Prison along with about three hundred others from the Reformatory. At the same time that Warren was sent away his sister, Letha Marie, was sent to the Indiana Girls' School.

Warren's mother, Lena Kisker, born 1884; Terre Haute, had some schooling and could read and write. At the age of thirteen she had convulsive seizures accompanied by loss of consciousness and these attacks were soon recognized as grand-mal epilepsy. These occurred from the age of thirteen on, as many as several attacks in a week at times. After marriage, which took place at the age of sixteen, they were not as frequent. She married Henry Smith and had by him two children, Warren and Marion, born 1904, who died of summer complaint at the age of six months. Marion was dull as a baby and paid no attention to anything. Lena died at the age of twenty of typhoid fever, in 1904. She was then living near Spiceland, in Henry County, Indiana. It is said that Lena was a good housekeeper and took good care of her children and always bore a good reputation.

Henry Smith, the father of Warren, was born about 1879 in Indiana. He had a little schooling of several months, and can neither read nor write. $\mathrm{He}$ has always worked as a common laborer and has been steadily employed all his life with the exception of the present time. Now, 1921, he is buying a house and lot on payments at 1009 S. J. street, Richmond. Due to lack of work this past summer he has fallen behind on payments but hopes to make this up as soon as he can get work. He has always had a good repu- tation for honesty and general character. Henry has a mental age about ten years, is industrious, has some planning ability and foresight, a desire to do well and be respected. He has some comprehension of the mental condition of his son, Warren. He has always lived in either Henry or Wayne Counties, Indiana. His first wife was Lena Kisker and he married her when he was twenty years old. After her death, five years later, he married Edna Lamb, of Dunreith, born 1892, with some schooling, a hard worker, married at the age of fifteen, having two children by Henry and dying at the age of twenty, in 1912. These two children are Letha Marie, and Arthur Smith. The girl, born 11-18-1907, in Henry County, Indiana, was sent at the age of nine to the Shelby County Orphans' Home as a ward of the court because of no home. On 3-20-1918 she was returned to her father. Some time after this incestuous relations began with her half-brother, Warren, as stated above. After this had been discovered Warren was sent to the Reformatory and Letha Marie to the Indiana Girls' School, 2-18-1919, where she is at the present time. At the age of fourteen she tests thirteen years and six months mental age, is somewhat emotional in her reactions and seems mentally capable of high school training. The boy, Arthur, born 11-8-1910, was sent to the Shelby County Orphans' Home, 6-19-1916, at the same time as the sister, Letha. On 2-20-1918 he was returned to his father with whom he remained until he was sent to the Wayne County Board of Children's Guardians at the time of Warren's arrest and conviction. $\mathrm{He}$ was immediately transferred to White's Institute at Wabash, Ind., a semi-correctional private institution for children. He was later placed in a foster home and on 4-20-1920, returned to Wayne County Board of Children"s Guardians and then to the father, where he now is. At eleven he is in grade $4 \mathrm{~A}$ in the Hibbard School, Richmond.

Henry's third wife was Florence Riley, born 1890, daughter of William Riley of Stricklett, Lewis County, Ky. Her first husband was Charles Smith, brother of Henry, whom she is supposed to have divorced. She had one child by Henry which died. About 1916 she left Henry, taking her children with her and lived with another man as his wife. It is not known where she is at the present time. Nothing is known of the specific traits of Florence other than that she was "from Kentucky, and bad." 
Henry's father, John Smith, paternal grandfather of case, born 1854 in Kentucky, has been a day laborer all his life. At one time he owned a small farm near Dunreith, which was sold at the time of his wife's death. He is uneducated and ignorant, but so far as is known was never in trouble and has always borne a fair reputation. His wife was Dulcina Scarboro, born 1861, Madison County, Ky. She was a woman of no education, unable to read and write, married young and always poor. She had ten children by John Smith ard died at the age of 55 of strangulation of the bowels. The children of John and Dulcina besides Henry are Hulda, Minnie, Charles, Eva, Ezra, Elizabeth and Lillian.

Hulda, aunt of the case, born 1882, is a woman of no education, has worked hard all her life and at the present time does plain dressmaking. She keeps a neat house and maintains a fair standard of living. It is reputed that her one living child is illegitimate, having been born before she came to Ingalls, Ind, and before she married Bert Lockridge, of Greensboro, her first husband. Hulda, however, states that Luva is the child of Bert. Her first husband, Bert, a follower of shows, died of tuberculosis soon after marriage. Her second husband, Oscar Stratton, was a common laborer, somewhat intemperate, and was the father of four boys by her, all of whom died young. These two later separated and a divorce was secured, Hulda later marrying James Byser, a laborer and at present a shoe cobbler, by whom she has had no children. They live at 1415 South 18th street, Newcastle, Ind. Hulda's one child, Luva, takes the name Stratton, and was born in 1901. She attended. school through the eighth grade when her health became poor and she stopped. She has worked at the piano factory in Newcastle tuning pianos in process of manufacture and has studied music, especially the piano. She is bright mentally and has a quiet, refined manner which seems out of place in the home of her mother and not at all like her unpolished mother and step-father. She lives with her mother in Newcastle.

Minnie, the next child of John and sister of Hulda, paternal aunt of the case, born 1884, is an ignorant, somewhat apathetic woman who has worked hard all her life. She married, when young, Luther Tungee, a laborer, and both have worked out since then and have made a poor living. It is stated that Luther, the husband, has been intemperate and treated his family poorly. They have three children; a boy, nineteen, slow in school, working now in the Hoosier factory in Newcastle, but not very promising, and two girls, one fifteen in the first year high school, and one twelve in the sixth grade in the regular school in Newcastle. They live at Stop 30 on the Newcastle Traction line, about two miles west of Newcastle.

William, a barber, an ignorant, semi-efficient man, in Port Clinton, Ohio, is the next child of John Smith and uncle of the case. He married Ida Kisker, a sister of the woman his brother Henry married. He has seven children, described under Ida, the wife, in the Kisker description.

Charles, the next son of John and brother of Hulda, paternal uncle of case, born 1887, is a barber by trade. He now resides at 1172 Warman avenue, Indianapolis. His first wife was Florence Riley, by whom he had two children, one Parma Irene, about nine, still living, the other one being dead. Florence left Charles for his brother Henry. After a divorce he married Hazel Hines with whom he is at the present time. Charles had little schooling and outside of his unsuccessful marriage, the first time, has borne so far as known a fair reputation though he has only had a fair standard of living in his home. $\mathrm{He}$ has no children by his second wife.

Eva, the sister of Charles, and paternal aunt of case, born about 1890, had some schooling, married when young and has had two children. She has attended church in Newcastle and has borne a good reputation. She is mentally slow, has had little schooling and is not of a high grade of intelligence. The husband, Ralph Arnold, is a laborer and is now living at Indianapolis with the brother-in-law, Charles Smith. Their oldest child, now eight, is in grade three in school. Ezra, the twin of Eva, is an unindustrious, shiftless fellow with little education. He was a soldier during the World War. He has recently married but does not get along well with his wife, and it is reported that he is disagreeable to her and they have continual quarrels. He lives in Fremont, Ohio, where he works as a laborer when employed.

Elizabeth, born 1893, sister of Ezra and Henry, aunt of case, is recognized by her own family and others as mentally defective and irresponsible. She has been married three times, but as her brother says, "Her husbands just won't stay with her." She has been associating lately with a fourth man and has left Newcastle, her last home, about 
a month ago with this fourth "husband" and gone to Port Clinton, Ohio, to stay with her brother, William. She has been doing housework for the past few years in Newcastle but is shiftless and has no ambition. She has been under treatment the past year in the Public Health Clinic for venereal disease and is known as a prostitute in Newcastle.

Lillian, born 1899, Indiana, the last child of John Smith, aunt of case, is a weak-willed woman of little education and intellectual ability. She married at nineteen a young man of twenty who had no property and was a discharged soldier, with tuberculosis. She now has one child by him, aged two years. They live on his disability pay of $\$ 95$ per month from the government and he takes no interest in the rehabilitation work offered him by the government, thinking it easier to get along with just his allowance. They live in Newcastle, Indiana.

Summary of the Paternal (Smith) Branch.

The Smith family group shows a degree of intellectual development slightly below the average of the general population. The earlier generation has had little schooling but the last has and in general is doing fair work in the schools. The industrial level of its members has been low. The Smith family has two defectives: Elizabeth Smith Kendall, a high grade moron, and Warren W. Smith, a low grade moron. The incidence of defectiveness in the Smith family is low and there are no particularly undesirable mental traits appearing in any strength. This Smith family then cannot be considered a cacogenic group to the extent that its germ plasm should be cut off. As will be seen later, it is probable that Warren's condition was the result of the nervous taint in the mother's family added to the low average mental and nervous makeup of the Smith group. The other case of mental defectiveness in the Smith family is probably incidental in that type of germ plasm which is so near to the border line mentality as that presented here.

\section{KISKER FAMILY (MATERNAL LINE).}

On the case's maternal side, the Kisker. family is much like the Smith family in its general social and intellectual level. Lena Kisker, as stated earlier, is the mother of the subject of this sketch. She was born in $\mathbf{1 8 8 4}$ and later had some schooling. She developed epilepsy at about the age of thirteen and died at twenty, as stated. Both her parents were born in Germany. They were married in
Germany and came to this country after the birth of their second child.

Fred Kisker, Lena's father, maternal grandfather of case, was born in 1854 in Germany. He had little schooling but could read and write. He came to this country about thirty-seven years ago and here worked as a day laborer. He has always been considered "eccentric, peculiar and hot-tempered and irritable, pig headed." In 1904 he was committed to the Indiana State Hospital for the Insane at Richmond, diagnosis: paranoia, and is still in an asylum; at present he is in the Central Hospital at Indianapolis. His wife, Anna Fox, born 1859, in Germany, married there and came to this country later. She uses the English language readily but with a German accent. She has some schooling and can read and write. She has always worked and for the last twenty years, since her husband has been in the hospital for the insane, has done housework and taken in washings to support herself. She is small in stature and thin. She is of fair intellectual mental ability but slightly below the average. She now lives around with her various daughters in Anderson, Ind., and has done this for the past twenty years. The oldest Kisker child was born in Germany. She came to this country when young and received some schooling in this country. Anna married at about the age of seventeen Alvin Bloomer, born 1870. He was a laborer and farm hand and very intemperate. $\mathrm{He}$ has separated from his wife several times but has always returned to her. During these separations he has associated with other women and about ten years ago acquired syphilis. Two years ago he became irritable, depressed, and unable to work. On 1-271921, he was admitted to the Madison County Poor Asylum as "epileptic" though the condition existing then was the beginning of general paresis. On 5-9-1921, he was sent to the Central Hospital for the Insane at Indianapolis as a general paretic and is still there, deteriorating very rapidly. Alvin was a fair provider in his home when not drinking. Anna, the wife, therefore, has always worked taking in washing and doing housework for the support of the children. She has led a hard life, always poor but has borne a fair reputation and now keeps her house quite neat considering her lack of adequate support. Recently, October, 1921, her children were made wards of the court of Madison. County and the Board of Children"s Guardians of that county is giving $\$ 30.00$ of 
relief per month to the mother for the care of these children in her own home. She lives at 916 Laurel street, Anderson, in a house badly in need of repair, and is paying $\$ 9$ rent a month. She is a woman slightly below the average in intellectual ability. She has six children. The oldest, Bernice, born 1900 , was a prostitute at fourteen and continued so until her marriage in 1919 to Robert Huntsberger of Kokomo, where she now lives. Since marriage she has borne a good reputation. She attended school until the fifth grade but after leaving school has not worked except at short periods. The next child, Roscoe, born 1906, is in the 6A grade in school in Anderson but is capable of only average $5 \mathrm{~A}$ grade work. He is irregular in attendance, due to frequent illnesses, is mentally slow and somewhat listless. It is evident that this boy needs medical attention and treatment. The other children of Anna are William, born 1912, grade $3 \mathrm{~B}$ in school, with poor eyes; Harold, born 1914, grade 2B; Marion, born 1915, and Lawrence, born 1917. These last five children are now wards of the Madison County Board of Children's Guardians and live with the mother at 916 Laurel street, Anderson, Ind.

Mary, maternal aunt of case, born 1882, Germany, is the second child of the Kiskers. She is an active woman, the smartest of the family and stands out among them as being of average intelligence. She has had some schooling, is industrious and has planning and managing ability. She married when young Albert Abrams of Anderson, and has had four children by him. In recent years they have had marital difficulties and after his discharge from the army in 1919, she secured a divorce from him. She now supports herself by taking in washing and the care of boarders and maintains a very fair standard of living and keeps herself and family neat and clean. Her children are: Bessie, born 1902, married to Eugene Reed of Anderson, but now separating from her husband; Merle, born 1905, at work; Willis, born 1909, grade 5 in school, and Viola, born 1912, now in grade 3 in school. They live at 1009 Central avenue, Anderson, Ind.

Ida, the next child of Fred and Anna, maternal aunt of case, born 1889 , can read and write but has had little schooling. She is below the average mentally and her standard of living in the home is very poor. She married when young William Smith, already mentioned, an industrious but semi-efficient man of mediocre intellectual ability. They have seven children. The oldest, Gladys, born 1905, is unable to do fair work in grade five, is slow mentally and not interested in school work. At sixteen she is on the streets at night with men and boys in Port Clinton, Ohio, her home. Violet, born 1907, is below the average in school work, being in grade $4 \mathrm{~A}$ at the age of fourteen. She, too, is associating promiscuously with boys on the streets at night. Edgar, born 1911, is doing poor work in school in grade $3 B$ while his next younger sister, Doris, age eight, is doing average work in grade $3 B$ now. The other children are small. They are all with the parents in Port Clinton, Ohio.

The last three children in the Kisker family are boys: Ernest, John and James Edward, maternal uncles of case. Ernest, born 1891, is a tall, thin young man now learning the plumbing trade as a helper. As a young boy he had "mad spells or fits" but he seems now to have outgrown them. He had some schooling. He has been a laborer until recently. $\mathrm{He}$ is now with his sister, Mary, in Anderson, John, born 1895, was a soldier in the last war and now is working as a laborer in a gravel pit near Anderson. He recently married but is separated from his wife. James, born 1897, the last of the Kisker fraternity, was also in the army and is now working as a day laborer. The boys spend their money freely and recklessly and do not assist their mother who has no support other than what she earns. None of these boys has ever been in trouble or arrested so far as known.

\section{Simmary of the Maternal (Kisker) Branch.}

The Kisker family has a mediocre grade of intelligence much like that of the Smith family. The mental and nervous disturbance in this family shows in the grandfather, a paranoic, one daughter, an epileptic and her feeble-minded child. No other nervous or mental disease appears in this group. The disease conditions here are very circumscribed and apparently not carried extensively in the germ plasm as no other defects appear outside of the three mentioned.

\section{Eugenical Findings.}

The Smith-Kisker group then has four cases of extreme mental defectiveness in a total of 47 persons, or a rate of 8 per cent of mental disease, only four times the amount of defectiveness in the general population. From the eugenic viewpoint then it would be a question whether the germ- 
plasms of this group should be cut off. Conservative restriction of the reproduction should be carried out only in those germplasms which are giving forth a large percentage of defectives, on the average, much larger than that found here in these peoples. It seems certain that the cutting off of the germ-plasm is recommended from the scientific standpoint, and expedient from the public view only when a family is reproducing practically all mental defectives.

Author's rote: This family history investigation is typical of the scientific studies that should be made, and required by law as a matter of routine in connection with every case proposed for eugenical sterilization. This sort of study for the purpose in hand, namely. the determination of the kind and degree of hereditary degeneracy possessed by the propositus, is also equally important as a factor in scientific psychiatric diagnosis, which is a prerequisite to commitment to custodial institutions.

The author does not agree with Dr. Estabrook in reference to his extreme conservatism. Dr. Estabrook thinks that, given inferior family stock, four times the average frequency of family degeneracy found in the population as a whole is insufficient to justify the eugenical sterilization of an individual who is a feeble-minded moral pervert. The author, too, is very conservative in these matters, but he feels that Dr. Estabrook's criterion is much too low. The difference is this: Estabrook's standard for eugenical sterilization is a degenerate from 100 per cent degenerate near kin. The author's criterion is an individual proven by pedigree analysis to be a potential parent of offspring, at least 25 per cent of whom would be hereditary degenerates, or at least 50 per cent of whom would be carriers of degenerate blood. It is the duty of the law and the court to determine the kind and degree of degeneracy which should constitute the criterion for eugenical sterilization. Radicalness of selection is justified only in proportion to the supply of adequate scientific pedigree investigation in the particular case. (See Sec. $2 f$ Model Sterilization Law, p. 445, and Chapter XI Eugenical Diagnosis, pp. 362.$)$

8. JACOB CLINE a moral pervert and rapist, inmate of the Oregon $S^{2}$ ate Penitentiary at Salem, Oregon.

Records, so far as they pertain to the family history and pedigree of the subject, are very scant. Jacob Cline had been convicted of rape and sentenced to serve from 4 to 10 years therefor at the Oregon Penitentiary, and subsequently was ordered by the State Board of Eugenics to be vasectomised under the provisions of Chapter 279 of the General Laws of Oregon of 191\%. This order was issued on the evidence of his personal, constitutional, degenerate make-up.
The official description of Jacol Cline as secured from the Oregon State Penitentiary follows:

\section{OREGON STATE PENITENTIARY.}

Description of Prisoner. No. 7,939.

Name: Jacob Cline. Received: June 1, 1919. Alias: None.

Crime: Rape. County: Douglas. Sentence: 4 to 10 years. Age: 64 . Color: White. Complexion Light. Eyes: Blue. Hair: Grey. Weight 140. Height: 5 feet 5 inches, Build Medium. Occupation: Farmer and preacher. Nativity: Oregon. Parentage: American. Live in Oregon: Life time. Education: Poor Married or single: Married. Creed: Protcstant. Name and address of relatives: Mrs. Jessie Cline (wife) Glendale, Oregon. Phy sical condition: Good. Disease or infirmity: None. Financial circumstances: Fair. Conjugal relations: Pleasant. No. of children: 'Two. Character of Home: Good. Age when lcft home: 27. Character of associates: Good. Age at death of father: 33. Age at death of mother: 55. Nativity of father: Pennsylvania. Occupation of father: Carpenter. Financial condition of father: Fair. Character of father: Good. Education of father: Poor. Religion of father: None. Nativity of mother: Ohio. Occupation of mother: Housewife. Financial conditon of mother: Fair. Character of mother: Good. Education of mother: Poor. Religion of mother: Adventist. Conjugal relations of parents: Pleasant. Relatives or ancestors intemperate: No. Relatives or ancestors delinquent or deficient: No. Criminal Record: Apparently none. Temperate: Yes. Use tobacco: No. Use drugs: No.

\section{Statement of District Attorney, Douglas County, Based Upon the Report of the Parole Officer of the Oregon State Penitentiary.}

To the Parole Officer, Oregon State Penitentiary,

Salem, Oregon.

"My dear Sir :

In compliance with Section 6, of our Parole Law, I am writing you for information concerning Jacob Cline, who was committed to this institution from your county May 31, 1919, to serve a 4 to 10 years' sentence, convicted of rape. You are in a position to know many things about this man which will be of great importance to 
us to deal wisely and justly with him. We are making this request of you while the facts are fresh in your mind, and will file this report, which will be of special value when the question of parole or executive clemency comes up.

Will you please give us, as you are able, your personal knowledge of this prisoner, his family, his habits of life and his past reputation?

'Moved to Douglas County about 10 years ago. Prior to that time lived near Portland, Oregon. Claims to have become converted and was called by the Spirit of God to preach the Gospel to the populace, and therefore frequently has taken extended trips to preach his doctrine called "The Crooked Way Made Straight." He was divorced from his former wife and his grown children left him.'

Give, please, a brief statement of his crime.

'Married a second wife and when he moved to Douglas County he adopted Maude May Morris from the Oswego Catholic Home, an orphan about 5 years old. Shortly after he moved to Douglas County he began to abuse the little girl's body, and when she reached the age of 9 he first had sexual intercourse with her. and then continually until she became 16 years of age, telling her that it was not wrong in the eyes of God to do this, and exercised complete control and management over the little girl during this time. Was convicted by a jury after a most vigorous defense by his counsel.'

Are there extenuating circumstances in either side of his case?

'There are none. It appears that his own daughter by his first wife was taken from him when she was 12 years old and sent :o the Boys and Girls Aid Society, for the reason that he had occupied the same bed with her. However, this statement is purported to have been made by the defendant himself. The evidence showed the mos: depraved acts committed by the defendant upon this little girl, and that from the time that she was about 7 years old until she became 12 or 13 he slept with her at different times. He has two children by his second wife, two boys, ages 7 and 9 years, respectively.'

In your judgment, should he be given a chance at the expiration of his minimum?

'No, for some other little girl will fall a victim to his lust.'

(Signed) GEORGE NEUNER, Jr.,

District Attorney.
Report to Parole Board, State of Oregon.

(Required by Section 1, Chapter 302, page 624, General Laws of Oregon, 1917.)

In Re: State of Oregon vs. Jacob Cline.

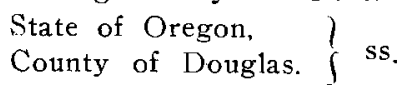

I, J. W. Hamilton, Judge of the Circuit Court of the State of Oregon for the County of Douglas, before whom (Jacob Cline) was convicted of the crime of rape and was sentenced to the Oregon State Penitentiary for a term of not less than (4) years nor more than (10) years, submit the following data relating to the history of said prisoner and his crime:

Personal Characteristics, Moral, Mental, Physical: $\mathrm{He}$ is some sort of a preacher. Seems to be a man fairly well educated. An attendant of church and Sunday school. He is 65 years of age.

Names, Addresses, General Character of Closest Associates: He seems to have had no other associates than his family, consisting of a wife and two little boys.

General Statement of Crime: The little girl was taken by him from the Sisters' Home, and adopted by him. The evidence shows that he has been practicing sexual intercourse with her since she became about 12 years old. The case was corroborated by three other witnesses who testified to having seen him in compromising position with the child.

Suggestions as to Treatment; Being an old man. I suggest that his treatment as adop:ed should take that fact into consideration.

\section{(Signed) J. W. HAMILTON, Judge. \\ Oregon State Penitentiary. \\ Statement to the Governor of Prisoner Seeking Parole.}

May 121920.

To the Governor of Oregon,

Salem, Oregon.

Name: Jacob Cline Alias:......... Prison

No. 7939 .

Age: 65. Crime: Rape.

Where was your home at the time? Near Glendale.

Give other places of residence: Sauvies Island.

What business, occupation or calling did you follow? Farming.

Were you occupied or idle preceding the commission of your crime? Occupied.

Have you a wife and children? Yes.

Have you parents living? Where are they? How are they situated? No. 
What education have you had? Fair.

Tell the story of your crime: Was gone from home and another man raped my adopted daughter and got her to lay the blame on me. She did it for love and money.

Are you guilty of the crime? No.

What did you plead at the trial? Innocence.

Are you justly imprisoned according to the evidence? No.

Date of crime? 24 of May 1918.

What were your relations to the complaining witness? Foster father.

What was her action in the case; fair or otherwise? Unfair.

What is the present attitude of complainant toward you? Good.

Have you the promise of work if paroled? What are your prospects in this connection? Good, have a farm.

Have you ever previously been convicted of crime? How many times? No.

Have you ever previously served jail, or prison sentence? No.
If so, when and where and for what crime?

Are you addicted to the use of liquor? No.

Give names and addresses of two nearest relatives or friends. If relatives, give relationship: 2 sisters.

Mrs. Bell Cook, Svenson, Oregon.

Mrs. Sm. Tunstall, West Union, Oregon.

Give name of sentencing Judge: Hon. Hamilton.

Give name of Sheriff: George K. Quine. (Signed) JACOB CLINE.

Report by the Warden of the Oregon State Penitentiary to the State Board of Eugenics.

To the State Board of Eugenics, Greeting:

I hereby report to you Jacob Cline, a feeble-minded, insane, epileptic, habitual criminal, moral degenerate or sexual pervert, towit: a Sexual Pervert-who is a person potential to producing offspring who, because of inheritance of inferior or antisocial traits, would probably become a social menace, or a ward of the State.

Dated, this first day of January, 1921.

(Signed) L. H. COMPTON, Warden, Oregon State Penitentiary. 


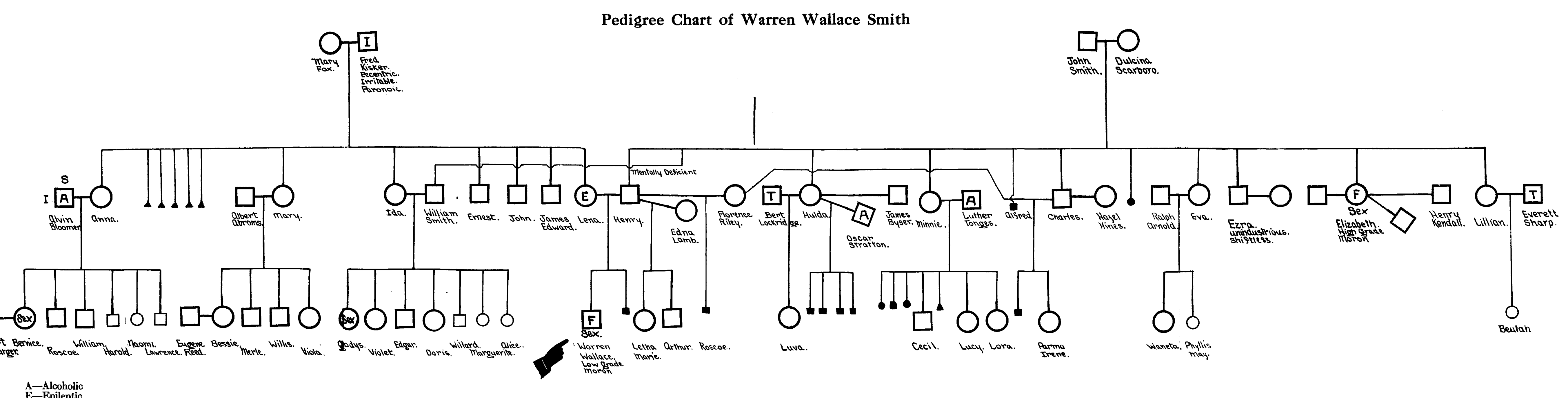
A-Alcoholic
E-Epilieptic
F-Febleminded
I-Insane 



\section{CHAPTER IX. \\ LEGAL OPINION.}

1. Opinion of the Honorable Harry Olson, Chief Justice, Municipal Court of Chicago

2. Official opinion of the Attorney-General of California on the asexualization law

3. Opinion of the Attorney-General of Connecticut on the asexualization act....... 328

4. Additional opinion of the Attorney-General of Connecticut................ 333

5. Opinion by Louis Marsha1l, Esquire............................. 334

6. Brief by Charles A. Boston, Esquire............................... 336

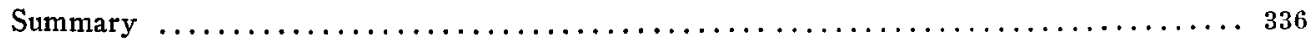


1. OPINION OF THE HONORABLE HARRY OLSON, CHIEF JUSTICE, MUNICIPAL COURT OF CHICAGO.

\author{
Chicago, Ill., Nov. 1, 1922.
}

\section{My dear Prof. Laughlin:}

You have asked me for my opinion of the constitutionality of the eugenics sterilization law which you have proposed.

The constitutionality of such a law has been so well and ably discussed by others, who have rendered their opinions, and you have quoted from so many decided cases, that I feel there is nothing more that can profitably be said on the subject.

I believe the model law, which you propose, will be held constitutional by the courts. It meets objections which have been made by the courts to legislation enacted by several states. Such legislation has often violated the bill of rights, which guarantees to all citizens an equal protection of the laws, "the due process of law" clause, the provision against cruel and unusual punishment, the bill of attainder clause, the ex post facto and the twice in jeopardy provisions of the constitution.

The model act applies the law to the population generally, outside of institutions, as well as inmates thereof.

"The due process of law" clause in the constitution is not infringed by the model act, which provides for a hearing in court with due notice, the right of a jury trial and the right of appeal.

The model act has no element of punishment in it, and thus the question of the constitutional inhibition against cruel and unusual punishment will not arise.

The elimination of the punitive element in the model act also removes the possibility of a question arising under a bill of attainder, twice in jeopardy provisions, or the ex post facto clause of the constitution.

The model act places the burden of proof upon the state to establish that the person designated for sterilization is a menace to the next generation by reason of degenerate hereditary qualities. Legal objections to sterilization in certain cases are, so far as I can see, eliminated from this model act. I prefer, therefore, to discuss the need of such legislation rather than its legality. The efficacy of such a law will turn upon questions of fact, and its enforcement upon public policy.

If the science of eugenics has so far advanced, as seems to be the fact, that it can be determined that certain individuals are afflicted with physical, nervous, and mental disorders that are hereditary and will reappear in the next or later generations, and threaten the safety of society, and that by a simple, and practically painless operation, such persons can be rendered sterile, then there can be no question but that legislation contemplated by the model act will be an effective protection to future generations, and will be in furtherance of a sound public policy. Indeed, if society can prevent degenerate stocks from multiplying, it is its supreme duty to do so, and when such prevention can be brought about in a humane manner, there will be no hesitancy on the part of an informed public in enacting and enforcing legislation to that end.

The efforts of all who appreciate the necessity of such biological legislation, as you propose, must be directed toward spreading information of the hereditary character of serious nervous and mental disorders, and of some physical defects. That such education is badly needed is evident from the fact that a speaker, in an address before no less important a body than the American Bar Association a few years ago, challenged the idea that there was any possibility of inheriting anything from one's ancestors:

"Heredity," said he, "aside from living parental example, has nothing to do with the matter. $*^{* *}$ Usually, the criminal is from an honest father and mother."

The right and the duty of self defense applies no less to nations than to individuals. The menace of the world war through the elimination of dominant stocks of all nations engaged therein was a tremendous set-back to the progress of these nations, but, even so, it was not so serious a handicap to their future welfare as is the fact that defective and degenerate stocks were spared the destruction of war to people the future with their own kind.

Not only must nations defend their future against racial degeneration from within, but they must limit immigration of defective stocks from all other lands. Because we have received an abundance of valuable and well-bred stock through immigration, our government has been lax and careless in its immigration legislation and administration, while the authorities of other nations, better informed, have made of us an asylum and a dumping ground for their own vagabond, drunken, degenerate, feebleminded, dementia praecox, epileptic, and criminalistic classes. That this is so has been demonstrated again and again in the Psychopathic Laboratory of the Municipal Court of Chicago, where whole families drift soon after arrival in America and Chicago. The government immigration authorities have been on the lookout for physical defects, eye defects, etc., but have not understood intellectual and emotional defects, especially the latter. The feeblemindedness or low mentality of certain immigrants has been concealed from the authorities by the mask of a foreign tongue, and the emotional defect by the smoke screen of actual or apparent in- 
telligence. Our Laboratory has demonstrated that where the emotions are absent, there is no conscience, and such a defect governs behavior far more than the intellect. Hence the dementia praecox type of deficiency when accompanied by a twelve year old intelligence has had easy admission into America without understanding or objection from our authorities. Early defective immigration has added to our native element of this type. Our criminal courts are full of dementia praecox cases. They commit most of the fundamental crimes, such as robbery, burglary, rape and murder. They constitute sixty-five per cent of the inmates of insane asylums. Their care entails a vast expense to the state, in some states thirty-three per cent of the total assessed taxes. Our asylums and penitentiaries are increasing in population, and the expense of their care is mounting. Laws for the punishment of crime have no real deterrent effect upon mental defectives, and there has been a failure to check crime by law enforcement against this type of offender. Our Psychopathic Laboratory records show that, out of 779 cases in the Boys Court, there were 654 suffering from dementia praecox, or about 84 per cent; 109 psychopathic constitution, or about 13 per cent, and 10 epilepsies, or less than 1 per cent. In the Morals Court, out of 464 cases of females, 260 or 36 per cent, were dementia praecox; 92 psychopathic constitution, or 19 per cent, and 4 epilepsies, or less than 1 per cent.

Out of 359 cases of males in the Morals Court, 107 were dementia praecox, 110 psychopathic constitution, and 4 epilepsies. Out of 657 cases of males in the Domestic Relations Court, 236 were dementia praecox, 295 psychopathic constitution, and 3 epilepsies. In the outside criminal branches, of 270 males, 107 were dementia praecox, 68 psychopathic constitution, and 5 epilepsies. Out of 152 females, 84 were dementia praecox, 41 psychopathic constitution, and 1 epilepsy. Observe, therefore, that dementia praecox plays the highest role and is the criminal psychosis par excellence.

Life has become unsafe by reason of the presence of this type in society, despite industrial precaution and efforts of police and courts. Their early and rapid multiplication increases the threat to civilization. All this is known to intelligent editors, physicians, lawyers, judges, and social workers. When these facts become common knowledge protective legislation will be enacted. In Chicago we have sought to educate the public, by publishing accurate and scientific diag- noses of this type, made by a highly trained and competent expert, when they have been brought into court and convicted of serious crimes. The Chicago public now refer to dementia praecox for an explanation of brutal and gross criminal conduct, indicating absence of the normal emotions of the average person. Our press advocated and our legislature passed legislation for the segregation of mental defectives guilty of their second crime. The legislation was vetoed by the governor on the principal ground that no farm colony had been provided by the legislature. Such legislation, I am confident, will be passed by the next Illinois legislature.

Progress is being made in other states also. Psychopathic laboratories connected with the criminal courts of our large cities are rapidly disclosing to the public that hereditary mental defects lie at the bottom of most fundamental crimes. Industrial accidents due to mental deficiency are common enough to place the manufacturing, railroading, and building industries on their guard. The increasing cost of maintenance of the insane and mental defectives has attracted the notice of the taxpayer. The physician is being drafted into public office and his special knowledge of the havoc worked in our civilization by hereditary defectives will be reflected in the legislation and administration to curb the menace of inferior stock.

Books like "The Racial Prospect" by S. K. Humphrey, "The Revolt Against Civilization" by Lothrop Stoddard, and "Is America Safe for Democracy" by William McDougal, have had a wide public influence.

The publication of this volume, written by you as the result of long investigation along scientific lines, and especially Chapter XI, entitled "Eugenical Diagnosis," wherein the workings of Mendel's law of heredity are demonstrated, will prove to be sensational, not only in our own country, but in all other civilized lands.

"The Rising Tide of Color," by Lothrop Stoddard, warns us of danger to the white race, but this book of yours warns humanity of the menace to all races-to the entire human race-of racial degeneracy. Nor do you stop with this warning, but in addition, you point out the direct and effective remedy. You have rendered humanity a great service by your painstaking labors for which future generations will cherish your name.

Sincerely yours,

HARRY OLSON, Chief Justice. 
2. OFFICIAL OPINION OF THE ATTORNEY-GENERAL OF CALIFORNIA ON THE ASEXUALIZATION LAW.

State of California, Office of the Attorney-General.

San Francisco, March 2, 1910.

Hon. F. W. Hatch, General Superintendent of State Hospitals, Sacramento, California.

Your favor of October 25, 1909, in relation to the asexualization of a certain class of insane and convicts, duly received. The statute to which you refer is as follows:

"Whenever in the opinion of the medical superintendent of any State Hospital, or the superintendent of the California Home for the Care and Training of Feeble-minded Children, or of the resident physician in any state prison, it would be beneficial and conducive to the benefit of the physical, mental, or moral condition of any inmate of said state hospital, home or state prison, to be asexualized, then such superintendent or resident physician shall call in consultation the general superintendent of state hospitals and the secretary of the State Board of Health, and they shall jointly examine into all the particulars of the case with the said superintendent or resident physician, and if in their opinion, or in the opinon of any two of them asexualization will be beneficial to such inmate, patient or convict, they may perform the same; provided, that in the case of an inmate or convict confined in any of the state prisons of this state, such operation shall not be performed unless the said inmate or convict has been committed to a state prison in this or some other state or country at least two times for some sexual offense, or at least three times for any other crime, and shall have given evidence while an inmate in a state prison in this state that he is a moral or sexual pervert; and provided, further, that in the case of convicts sentenced to state prison for life who exhibit continued evidence of moral and sexual depravity, the right to asexualize them, as provided in this act, shall apply, whether they have been inmates of a state prison either in this or any other state or country more than one time." (Statutes 1909, p. 1093.)

I may as well state at the outset that in my opinion the question of the castration of rapists and confirmed criminals presents some grave constitutional aspects, and I fear that in a statute of the nature of the one before us, the constitutional guarantees are not entirely preserved.

There are no recorded cases arising under a statute similar to this one, as Indiana and California are the pioneer states in this legislation. A consideration of the Indiana statute, however, came before the annual meeting of the National Prison Association held in Chicago in September, 1907, and very full argument was indulged therein. The Attorney-General of Indiana, Mr. Bingham, doubted the soundness of the principle of emasculating a perfectly sane person, unless it is imposed as a part of a penalty; in other words, that this operation should be a matter of punishment adjudged by the court. This view seemed to be concurred in by other attorneys there present. It was suggested that such a punishment would be unsafe in the hands of the court and the modern jury, and should only be applied after the investigation of experts. There is no doubt of the soundness of this idea, but we are restricted in this country by our system of government which excludes many of the acts of paternalis $m$ not having the sanction of law. What I have said, however, applies to the operation known as castration. But there is another operation, for the prevention of procreation, upon the inmates of institutions intrusted with the care of confined criminals, idiots, rapists and imbeciles, and to the extent that the operation is part of a necessary medical treatment, the act would be undoubtedly valid. This is also the opinion of the attorneys who were present at the meeting of the National Prison Association where this question was discussed. (See transactions National Prison Association, 1907, pp. 177-194.)

In treating upon this subject, it must be borne in mind that medical opinion is now convinced that degeneracy is a defect, and that a defect differs from a disease, in that it can not be cured. Degeneracy is the term applied when the nervous or mental construction of the individual is in a state of unstable equilibrium. Degeneracy means that certain areas of brain cells or nerve centers of the individual are more highly or imperfectly developed than the other brain cells, and this causes an unstable state of the nerve system, which may manifest itself in insanity, criminality, idiocy, sexual perversion, or inebriety. Most of the insane, epileptic, imbecile, idiotic, sexual perverts; many of the confirmed inebriates, prostitutes, tramps, and criminals, as well as the habitual paupers, 
found in our country poor-asylums; also many of the children in our orphan homes, belong to the class known as degenerates. For this condition to go on unchecked eventually means a weakening of our nation. It is as Herbert Spencer once said, "To be a good animal is the first requisite to success in life, and to be a nation of good animals is the first condition to national prosperity."

\section{Marriage Restrictions Not Sufficient.}

Idiots, imbeciles, and degenerate criminals are prolific, and their defects are transmissible. Each person is a unit of the nation, and the nation is strong and pure and sane, or weak and corrupt and insane, in the proportion that the mentally and physically healthy exceed the diseased. This grave danger has consumed the thought of great and good men in recent years. Much restrictive legislation has been suggested, and many states have passed marriage Taws for the purpose of regulating, as far as possible, the propagation of degenerates through the marriage relation. Minnesota has a law providing that no woman under the age of fortyfive years, or a man of any age, except he marry a woman over forty-five years of age either of whom is epileptic, imbecile, feebleminded, or afflicted with insanity, shall intermarry or marry any other person within the bounds of the state. Michigan, Delaware, Connecticut, New Jersey, and North Dakota have all passed laws for the purpose of preventing marriage among defectives; but, unfortunately, matrimony is not always necessary to propagation, and the tendency of these several different laws is to restrict procreation only among the more moral and intelligent class, while the most undesirable class goes on reproducing its kind, the only difference being that illegitimacy is added to degeneracy.

Castration is another means that has been suggested for the purpose of preventing the propagation of the unfit. But there is still too much conflict among experts as to the result of this drastic measure, and observation of its data has not been sufficiently thorough to warrant any definite deductions. Castration sometimes causes death, and it can readily be seen that one subjected to it would in all probability become morose and downcast on account of the deformity. Besides the organs involved have a double function, that of an internal as well as an external secretion, and the organism can not maintain a normal condition when robbed of this internal secretion.
The same results, however, in the prevention of degeneracy can be obtained by a method of treatment less objectionable and less severe. This operation is known as vasectomy, which consists of ligating and resecting a small portion of the vas deferens. Of this operation, Dr. H. C. Sharp, physician in the Indiana Reformatory, who was one of the first to apply it, as early as the year 1899 , says:

"This operation is, indeed, very simple and easy to perform. I do it without administering an anesthetic, either general or local. It requires about three minutes' time to perform the operation, and the subject returns to his work immediately, suffers no inconvenience, and is in no way impaired for his pursuit of life, liberty, and happiness, but is effectively sterilized. I have been doing this operation for nine full years. I have two hundred and thirty-six cases that have afforded splendid opportunity for post-operative observation, and $I$ have never seen any unfavorable symptoms. There is no atrophy of the testicles, there is no cystic degeneration, there is no disturbed mental or nervous condition following, but, on the contrary, the patient becomes of a more sunny disposition, brighter of intellect, ceases excessive masturbation, and advises his fellows to submit to the operation for their own good. And here is where this method of preventing procreation is so infinitely superior to all others proposed-that it is endorsed by the subjected persons. All the other methods proposed place restrictions, and, therefore, punishment upon the subject; this method absolutely does not. There is no expense to the state, no sorrow or shame to the friends of the individual as there is bound to be in the carrying out of the segregation idea."

\section{Additional Protection to Marriage.}

There is a law providing for the sterilization of defectives in effect in Indiana, and our law follows it very closely. Under the provisions of the law women may be subjected to sterilization as well as men, and the operation on women is almost as simple, for it consists of simply ligating the fallopian tube.

If, under the Constitution, the state may so far interfere with the right to contract as to prohibit the marriage of epileptics, it would peem that, considering this measure solely as a preventive and health measure, it would to no greater extent violate the Federal Constitution or the Civil Rights Bill. It may 
also be considered as an additional protection to the marriage relation, for intercourse under the sanction of the marriage relation is the only intercourse between the sexes recognized by the law, and, if the state may absolutely prohibit such intercourse between epileptics in the marriage relation, it would seem that it would have the power for the protection of society to take these absolutely preventive measures, especially as their effects upon the subject are innocuous.

Marriage is undoubtedly the supreme product of human social evolution. Every advance made in the ethics of marriage has been at the expense of a battle with natural law and animal impulse. The integrity and moral plane of the family are the keynote of our social fabric, but the struggle to maintain monogamy has been a fierce one, and is still going on beneath the surface.

It is on these broad grounds that the courts have upheld statutes preventing the marriage of defectives. I call your attention particularly to the case of Gould vs. Gould, 78 Conn. 242 (61 Atl. 604), wherein the court says:

Was the statute a valid act of legislation? It forbade the marriage of certain classes of persons under any circumstances. One of these, only, it is now necessary to considerthat of epileptic. The provisions of the act of 1895 were separable with respect to the different classes of persons with whom it deals, and, so far as this action is concerned, it is enough if it can be supported as to marriages contracted after its enactment by those in the condition of the defendant: Pub. Acts. 1895, Chap. 325, p. 667. The constitution of this state (preamble and article 1, section 1) guarantees to its people equality under the law in the rights to "life, liberty and the pursuit of happiness": State vs. Conlon, 65 Conn. 478, 489, 491, 31 L. R. A. 55, 48 Am. St. Rep. 227, 33 Atl. 519. One of these is the right to contract marriage; but it is a right that can only be exercised under such reasonable conditions as the legislature may see fit to impose. It is not possessed by those below a certain age. It is denied to those who stand within certain degrees of kinship. The mode of celebrating it is prescribed in strict and exclusive terms: Gen. Stat. 1902, Sec. 4538. The universal prohibition in all civilized countries of marriages between near kindred proceeds in part from the established fact that the issue of such marriages are often, though by no means always, of an inferior type of physical or mental development. That epilepsy is a disease of a peculiarly serious and revolting character, tending to weaken mental force, and often descending from parent to child, or entailing upon the offspring of the sufferer some other grave form of nervous malady, is a matter of common knowledge, of which courts will take judicial notice. State vs. Main, 69 Conn. 123, 135, 36 L. R. A. 623, 61 Am. St. Rep. 30, 37 Atl. 80. One mode of guarding against the perpetuation of epilepsy obviously is to forbid sexual intercourse with those afflicted by it, and to preclude such opportunities for sexual intercourse as marriage furnishes. To impose such a restriction upon the right to contract marriage, if not intrinsically unreasonable, is no invasion of the equality of all men before the law, if it applies equally to all, under the same circumstances, who belong to a certain class of persons, which class can reasonably be regarded as one requiring special legislation either for their protection or for the protection from them of the community at large. It can not be pronounced by the judiciary to be intrinsically unreasonable if it should be regarded as a determination by the general assembly that a law of this kind is necessary for the preservation of public health, and if there are substantial grounds for believing that such determination is supported by the facts upon which it is apparent that it was based: Holden vs. Hardy, 169 U. S. 366, 398, 42 L. ed. 780, 18 Sup. Ct. Rep. 383; Bissell vs. Davison, 65 Conn. 183, 192, 29 L. R. A. 251, 32 Atl. 348. There can be no doubt as to the opinion of the general assembly, nor as to its resting on substantial foundations. The class of persons to whom the statute applies is not one arbitrarily formed to suit its purpose. It is certain and definite. It is a class capable of endangering the health of families and adding greatly to the sum of human suffering. Between the members of this class there is no discrimination, and the prohibitions of the statute cease to operate when, by the attainment of a certain age by one of those whom it affects, the occasion for the restriction is deemed to become less imperative. While Connecticut was the pioneer in ths country with respect to legislation of this character, it no longer stands alone. Michigan, Minnesota, Kansas and Ohio have, since 1895 , acted in the same direction: 2 Howard, Matrimonial Institutions, 400, 479, 480; Ohio Sess. Laws 1904, p. 83. Laws of this kind may be regarded 
as an expresion of the conviction of modern society that disease is largely preventable by proper precautions, and that it is not unjust in certain cases to require the observation of these, even at the cost of narrowing what in former days was regarded as the proper domain of individual right. It follows that the statute in question was not invalid, as respects marriages contracted by epileptics, after it took effect.

If there is the power to thus guard agains the perpetuation of epilepsy and preclude such opportunities for sexual intercourse as marriage furnishes, then, by the same course of reasoning, the state would have the power to preclude any opportunity for such intercourse in the manner herein prescribed, in asmuch as the measures provided for have no harmful results.

Considered, then, as a health measure, and as a rational and undoubted protection to society, without any elements of torture accompanying its execution, it appears to me that the sterilization of degenerates by the method which I have described would not violate our constitutional guarantee.

\section{Common Law Must Keep Pace with Scien- tific and Social Advances.}

We are living in a quick and active age of scientific progress and achievement that atrophies the power of surprise. The individual finds himself in the midst of a bewildering panorama of uses and activities, and he needs a superb equipment to meet them. The age must furnish him with the equipment, mental and physical, as well as with the activities. The art of healing and preventive medicine, in particular, has achieved great triumphs in emancipating the race from the old terrors of virulent dis ease. This it has done by dealing with the science of causes, instead of results alone. It has now turned its penetrating light upon race degeneracy, with its train of accompanying evils, criminality, prostitution, pauperism, inebriety, and insanity. Modern thought is being swayed by these immortal pioneers of science who have stood for the liberation of humanity from ignorance, dog$\mathrm{ma}$, and superstition. The dealing with crime from the standpoint of its causes, heredity and degeneracy, congenital and acquired, is a modern science. Lombroso's great work appeared in 1876. Already ar. enlightened criminology has had its results in our modern reformatories; the growing sentiment in favor of classification of criminals; the establishment of juvenile courts, and the separation of youthful and adult criminals; the parole system, and the increasing favor with which the indeterminate sentence is regarded. These are but rays of light which filter down into our slough of ignorance. We can not but be profoundly convinced that the day of fruition in the treatment of the criminal and insane is at hand. Science has taken its masterful grasp of this subject, and the precious results will as surely follow as the discovery of anæsthesia, or any of the boons which have attended the triumphant march of scientific thought, and the measures here proposed will undoubtedly become universal in the treatment of defectives. Shall it be said that the supreme flower of Anglo-Saxon civilization, the common law, does not keep pace with the beneficent ideas of the age? Is it not adequate to the ever-varying needs of our social development? Mr. Justice Mathews says, in Hurtado vs. California, that this flexibilty and capacity for growth and adaptation is the peculiar boast and excellence of the common law. The Constitution of the United States was ordained, it is true, by the descendants of England, who inherited the traditions of English law and history; but it was made for an undefined and expanding future and for a people gathered, and to be gathered, from many nations and many tongues There is nothing in Magna Charta, rightly construed, as a broad charter of right and law, which ought. to exclude the best ideas of all systems and of every age; and as it was the characteristic principle of the common law to draw its inspiration from every foundation of justice, we are not to assume that its sources of supply have been exhausted On the contrary, we should expect that the new and various experiences of our own situation and system will mould and shape it into new and not less useful forms. (Hurtado vs. California, 110 U. S. 530.)

\section{Vasectomy Leaves Liberty and Life.}

Whether considered as an additional punishment, or as an invasion of the right to procreate, involved in the right to life, liberty and happiness, the measures proposed are no more radical than the measures for the suppression of crime now in vogue, which do not show any particular sensitiveness on the part of society as to the criminal's rights. The law does not hesitate to hang the murderer, despite the fact that, upon the average, the murderer is of all criminals the least dangerous to society. Liberty is the 
right of man, which can not be gainsaid, yet the law does not hesitate to imprison for life on occasion. Life imprisonment not only takes away liberty, but practically infringes upon the right to live, the right to marry, and the right to procreate. In imprisonment for life, or capital punishment, it would be somewhat difficult to see any conservation of the rights of the criminal's posterity from the sentimentalist's standpoint.

Sterilization of criminals for the protection of the public against a degenerate posterity in no way compares in severity with capital punishment or imprisonment for life, for it does not interfere with either liberty or life.

As to the difficulty of determining whether a person is a congenital criminal or not before applying the measures proposed, a noted specialist has this to say:

It is not necessary to demonstrate a criminal anthropological type in order to prove the value of measures tending to prevent the procreation of children by criminals. Whether there is a definite anthropologic type, or not, the fact remains that a certain more or less definite proportion of our population is composed of criminals by instinct and by profession-these individuals are degenerates, and the degeneracy that is responsible for their own criminality may indubitably be transmitted to their descendants. Any measure that prevents this class of individuals from having descendants is necessarily preventive of crime. To demand that all criminals should be cast in a definite mould, the finished product of which he who runs may read, is begging the question. It is not necessary to determine whether "any given convict is a member of an hereditary criminal group" in order to show that the prevention of his procreating will be preventive of crime.

It is obvious that the application of sterilization to the crime class would require some discrimination, and should be made under strictly scientific supervision.

So far as the typic or habitual criminal is * concerned, the method should be universally applied. In other cases, careful study and selection should be made, society in all cases being given the benefit of the doubt. There is this to be said in favor of sterilization, viz., if performed under strict scientific supervision, as a method of preventing crime only, and not for the purpose of punishment-it being directed against the criminal and not against the crime that he has committed-comparatively few mistakes would be likely to be made, and those mistakes by no means so serious in results as many that are made by courts of law in the correction and punishment of the innocent.

As restricted to the sterilization of the inmates of prisons and hospitals by the method of vasectomy, I am of opinion that there are no legal inhibitions upon this enlightened piece of legislation which is an awakening note to a new era and a great advance toward that day when man's inhumanity to man will have acquired a meaning beyond mere frothy sentiment.

\section{Castration Presents a Constitutional Question.}

As regards the castration of confirmed criminals and rapists, and those guilty of sexual crimes, I am of the opinion that there are grave constitutional questions at stake, and that such measures should not be taken until an adjudication is had in a court of law.

(Signed) U. S. WEBB, Attorney General. By R. C. Van Fleet, Deputy.

\section{THE OPINION OF THE ATTOR- NEY-GENERAL OF CONNECTI- CUT, ON THE ASEXUALIZATION ACT.}

The Act Authorizing Operations for the Prevention of Procreation Is Constitional.

Hartford, December 9, 1912.

Ward A. Garner, Esq.,

Warden of Connecticut State Prison.

Dear Sir-You request my opinion on behalf of the Board of Directors of the Connecticut State Prison as to the constitutionality of Chapter 209 of the Public Acts of 1909, being an act entitled "An Act Concerning Operations for the Prevention of Procreation."

The act in question reads as follows:

"Section 1. The directors of the state prison, and the superintendents of the state hospitals for the insane at Middletown and Norwich are hereby authorized and directed to appoint for each of said institutions respectively two skilled surgeons, who, in conjunction with the physician or surgeon in charge at each of said institutions, shall constitute a board the duty of which shall be to examine such inmates of said institutions as are reported to them by the warden, superintendent, or the physician or surgeon in charge, to be persons by whom procreation would be inadvisable. Such board shall ex- 
amine the physical and mental condition of such persons and their record and family history so far as the same can be ascertained, and if, in the judgment of a majority of said board, procreation by any such person would produce children with an inherited tendency to crime, insanity, feeble-mindedness, idiocy, or imbecility, and there is no probabilty that the condition of any such person so examined will improve to such an extent as to render procreation by any such person advisable, or if the physical or mental condition of any such person will be substantially improved thereby, then said board shall appoint one of its members to perform the operation of vasectomy or oöphorectomy, as the case may be, upon such person. Such operation shall be performed in a safe and humane manner, and the board making such examination and the surgeon performing such operation shall receive from the state such compensation for services rendered as the warden of the state prison, or the superintendent of either of such hospitals shall deem reasonable

Sec. 2. Except as authorized by this act, every person who shall perform, encourage, assist in, or otherwise promote the performance of either of the operations described in section one of this act, for the purpose of destroying the power to procreate the human species, or any person who shall knowingly permit either of such operations to be performed upon such person, unless the same shall be a medical necessity, shall be fined not more than one thousand dollars, or imprisoned in the state prison not more than five years, or both."

This statute is clearly a police regulation, therefore its constitutionality must depend upon whether the regulations prescribed are kept within the proper bounds of the police powers of the State.

\section{Woodruff v. N. Y. \& N. Eng. R. R. Co., 59 Conn., 85.}

It has been universally conceded that under the broad and comprehensive rule of public policy, States may do any thing necessary to protect the people, which is not in conflict with the constitution.

It has been repeatedly held that the State may regulate, and even prohibit, marriage under certain conditions, and the legislature may authorize municipal corporations, or boards of education, to exclude unvaccinated children from public schools, even in the absence of smallpox.
Gould v. Gould, 78 Conn., 242.

Bissell v. Davidson, 65 Conn., 183.

Our constitution does not impose any specific limitations on the exercise of legislative power, except some slight restrictions in one or two amendments, but our Bill of Rights constitutes the fundamental condition on which all powers of government may be exercised. It guarantees to the people equality under the law in their rights to "life, liberty, and the pursuit of happiness."

\section{Preamble and Article First.}

State v. Conlen, 65 Conn., 48.

Among these rights may be mentioned the right to contract marriage, and the right to beget children, but these rights can only be exercised under such reasonable conditions as the legislature may see fit to impose.

The right to contract marriage is not possessed by those below a certain age, and it is frequently denied to those who stand within certain degrees of kinship. The law has fixed the mode of celebrating it in strict and exclusive terms.

A few years ago our legislature passed a law forbidding man or woman, either of whom is epileptic, imbecile or feeble-minded, to intermarry, or live together as husband and wife, when the woman is under fortyfive years of age, and made it a state prison offense to violate, or to attempt to violate, any provision of the act. Our Supreme Court held this statute to be constitutional.

In speaking for the Court in Gould v. Gould, 78 Conn., 244, Mr. Justice Baldwin said:

"The universal prohibition in all civilized countries of marriages between near kindred proceeds in part from the established fact that the issue of such marriages are often, though by no means always, of an inferior type of physical or mental development.

"That epilepsy is a disease of a peculiarly serious and revolting character, tending to weaken mental force, and often descending from parent to child, or entailing upon the pffspring of the sufferer some other grave form of nervous malady, is a matter of common knowledge, of which courts will take judicial notice. State vs. Main, 69 Conn., 123, 135. One mode of guarding against the perpetuation of epilepsy obviously is to forbid sexual intercourse with those afflicted by it, and to preclude such opportunities for sexual intercourse as marriage furnishes. To impose such a restriction upon the right to contract marriage, if not intrinsically un- 
reasonable, is no invasion of the equality of all men before the law, if it applies equally to all under the same circumstances who belong to a certain class of persons, which class can reasonably be regarded as one requiring special legislation either for their protection or for the protection from them of the community at large. It cannot be pronounced by the judiciary to be intrinsically unreasonable, if it should be regarded as a determination by the General Assembly that a law of this kind is necessary for the preservation of public health, and if there are substantial grounds for believing that such determination is supported by the facts upon which it is apparent that it was based. Holden v. Hardy, 169 U. S., 366, 398; Bissell v. Davidson, 65 Conn. 183, 192. There can be no doubt as to the opinion of the General Assembly, nor as to its resting on substantial foundations. The class of persons to whom the statute applies is not one arbitrarily formed to suit its purpose. It is certain and definite. It is a class capable of endangering the health of families and adding greatly to the sum of human suffering. Between the members of this class there is no discrimination, and the prohibitions of the statute cease to operate when, by the attainment of a certain age by one of those whom it affects, the occasion for the restriction is deemed to become less imperative.

"While Connecticut was the pioneer in this country with respect to legislation of this character, it no longer stands alone. Michigan, Minnesota, Kansas and Ohio, have, since 1895 , acted in the same direction. 2 Howard on Matrimonial Institutions, 400, 479, 480; Laws of Ohio, 1904 , p. 83 . Laws of this kind may be regarded as an expression of the conviction of modern society that disease is largely preventible by proper precautions, and that it is not unjust in certain cases to require the observation of these, even at the cost of narrowing what in former days was regarded as the proper domain of individual right."

The principles laid down by Mr. Justice Baldwin in said case apply with equal force to the statute under consideration.

Society owes to itself the duty of preventing procreation by persons who would produce children with an inherited tendency to crime, insanity, feeble-mindedness, idiocy, or imbecility.

Dugdale's history of the Jukes shows where the single ancestor "Max" was the progenitor of more than 1,200 social derelicts.

In view of such history the sterilization of criminals must stand within the police power of the State upon the same footing with the sterilization of idiots, feeble-minded and imbeciles.

Such an operation should not be considered punishment any more than the imposition of vaccination is a punishment. In one case, society seeks to prevent the spread of an infectious disease, and in the other, the disastrous spread of crime, insanity, feeble-mindedness, idiocy and imbecility.

In his work entitled "Mental Defectives," Dr. Barr says:

"Let asexualization be once legalized, not as a penalty for crime, but a remedial measure preventing crime and tending to future comfort and happiness of the defective; let the practice once become common for young children immediately upon being adjudged defective by competent authority properly appointed, and the public mind will accept it as an effective means of race preservation. It would come to be regarded, just as quarantine, simply as protection against ill."

Dr. H. C. Sharp of the Indiana Reformatory, in his pamphlet on "The Sterilization of Degenerates," says:

"Since October, 1899, I have been performing an operation known as vasectomy, which consists of ligating and resecting a small portion of the vas deferens. This operation is indeed very simple and easy to perform, I do it without administering an anesthetic either general or local. It requires about three minutes' time to perform the operation and the subject returns to his work immediately, suffers no inconvenience, and is in no way impaired for his pursuit of life, liberty and happiness, but is effectively sterilized. I have been doing this operation for nine full years. I have had two hundred and thirty-six cases that have afforded splendid opportunity for post operative observation and $I$ have never seen any unfavorable symptom. . . And here is where this method of preventing procreation is so infinitely superior to all others proposed-that it is endorsed by the subjected persons. All the other methods proposed place restrictions and, therefore, punishment upon the subject; this method absolutely does not."

It has been conclusively proven by the experience of the medical world that the operation of vasectomy and oöphorectomy is comparatively painless, and therefore cannot be 
esteemed cruel, though it may be unusual, but everything new is unusual.

The constitution does not contemplate that the State should be restricted in the exercise of protective measures to the forms of evil that existed at the time the constitution was adopted.

In the case of Weems v. United States, 217 U. S., page 373, Mr. Justice McKenna, in delivering the opinion of the Court, said:

"Legislation, both statutory and constitutional, is enacted, it is true, from an experience of evils, but its general language should not, therefore, be necessarily confined to the form that evil had theretofore taken. Time works changes, brings into existence new conditions and purposes. Therefore a principle, to be vital, must be capable of wider application than the mischief which gave it birth. This is peculiarly true of constitutions. They are not ephemeral enactments, designed to meet passing occasions. They are, to use the words of Chief Justice Marshall, 'designed to approach immortality as nearly as human institutions can approach it.' The future is their care, and provision for events of good and bad tendencies of which no prophecy can be made. In the application of a constitution, therefore, our contemplation cannot be only of what has been, but of what may be. Under any other rule a constitution would indeed be as easy of application as it would be deficient in efficacy and power. Its general principles would have little value, and be converted by precedent into impotent and lifeless formulas. Rights declared in words might be lost in reality. And this has been recognized. The meaning and vitality of the constitution have developed against narrow and restrictive construction."

Modern scientific investigation has shown clearly that idiocy, insanity, imbecility, and criminality are hereditary, and congenital, and, on the strength of this information, Indiana, California, Connecticut, New Jersey, Iowa, New York, Nevada, and Washington, in the exercise of the police power, have enacted laws providing for the sterilization of certain persons likely to produce children with an inherited tendency to crime, insanity, feeble-mindedness, idiocy or imbecility.

The State of Washington had a statute which read as follows:

"Whenever any person shall be adjudged guilty of carnal abuse of a female person under the age of ten years, or of rape, or shall be adjudged to be an habitual criminal; the court may, in addition to such other punishment or confinement as may be imposed, direct an operation to be performed upon such person, for the prevention of procreation."

One Peter Feilen was convicted before the Superior Court, King County, in the State of Washington, of the crime of statutory rape, committed upon the person of a female child under the age of ten years, and was sentenced to imprisonment for life, in the state penitentiary, and in addition to such punishment, acting under the authority given in said statute, the court further ordered an operation to be performed upon said Peter Feilen for the prevention of procreation, and the warden of the penitentiary of the State of Washington was directed to have the order carried into effect by some qualified and capable surgeon by the operation known as vasectomy.

The defendant appealed from the judgment to the Supreme Court of the State, and contended that the law is unconstitutional, in that an operation for the prevention of procreation is a cruel punishment, prohibited by Article 1, Section 14, of the State Constitution, which directs that "excessive bail shall not be required, excessive fines imposed, nor cruel punishment inflicted." The court (State v. Feilen) rendered its decision September 3, 1912, holding the law to be constitutional, and that the operation of vasectomy is not cruel punishment. Among other things, the court said:

"As the statute does not prescribe any particular operation for the prevention of procreation, the trial judge ordered that the operation known as vasectomy be carefully and skillully performed. The question, then presented for our considertation is whether the operation of vasectomy, carefully and skillfully performed, must be judicially declared a cruel punishment forbidden by the Constitution. No showing has been made to the effect that it will in fact subject appellant to any marked degree of physical torture, suffering or pain. That question was doubtless considered and passed upon by the legislature when it enacted the statute. . .

"The crime of which the appellant has been convicted is brutal, heinous, and revolting, and one for which, if the legislature so determined, the death penalty might be inflicted without infringement of any constitutional inhibition. It is a crime for which in some jurisdictions the death penalty has 
been imposed. 33 Cyc., 1518. If for such a crime death would not be held a cruel punishment, then certainly any penalty less than death, devoid of physical torture, might also be inflicted. In the matter of penalties for criminal offenses, the rule is that the discretion of the legislature will not be disturbed by the courts, except in extreme cases. It would be an interference with matters left by the Constitution to the legislative department of the government for us to undertake to weigh the propriety of this or that penalty fixed by the legislature for specific offenses. So long as they do not provide cruel and unusual punishments, such as disgraced the civilization of former ages, and make one shudder with horror to read of them, as drawing, quartering, burning, etc., the constitution does not put any limit upon legislative discretion. Whitten $v$. State, 47 Ga., 297.

"In State v. Woodard, 68 V. 66,69 S. E. 385,30 L. R. A. (N. S.), 1004, a recent and well considered case which may be consulted with much profit, Brannon; Justice, said: . . The legislature is clothed with power well nigh unlimited to define crimes and fix their punishment. So its enactments do not deprive of life, liberty, or property without due process of law, and the judgment of a man's peers, its will is absolute. It can take life, it can take liberty, it can take property for crime. The legislatures of the different states have the inherent power to prohibit and punish any act as a crime, provided they do not violate the restrictions of the state and federal constitutions; and the courts cannot look further into the propriety of a penal statute than to ascertain whether the legislature had the power to enact it.' 12 Cyc., 136. 'The power of the legislature to impose fines and penalties for a violation of its statutory requirements is coeval with government. Mo. P. R. Co. v. Humes, 115 U. S., 512 ( 6 Sup. Ct. 110, 29 L. Ed., 463). The legislature is ordinarily the judge of the expediency of creating new crimes, and of prescribing penalties, whether light or severe. Commonwealth v. Murphy, 165 Mass., 66 (42 N. E., 504, 30 L. R. A., 734, 52 Am. St. Rep., 496); Southern Express Co. v. Commonwealth, 92 Va., 66 (22 S. E., 41 L. R. A., 436). For such a fundamental proposition I need cite no further authority.

"Guided by the rule that, in the matter of penalties for criminal offense, the courts will not disturb the discretion of the legislature, save in extreme cases, we cannot hold that vasectomy is such a cruel punishment as cannot be inflicted upon appellant for the horrible and brutal crime, ; which he has been convicted."

The foregoing is the only case bearing upon any feature of a sterilization law, and that is confined to the constitutionality of the punishment provided.

The statutes of the states of Washington (first law) and Nevada both limit the operation to an habitual criminal, any person adjudged guilty of the carnal abuse of a female person under the age of ten years, or of rape, and contemplate the imposition of such operation as further punishment, while Indiana, California, Connecticut, New Jersey, Iowa, and New York have laws which provide for performing the operation upon all such persons confined in the state prison, and other state institutions, who are likely to produce children with an inherited tendency to crime, insanity, feeble-mindedness, idiocy or imbecility.

The New Jersey and New York laws are expressly limited in their application to criminals, as follows:

"The criminals, who shall come within the operation of this law shall be those who have been convicted of the crime of rape, or of such succession of offenses against the criminal law as in the opinion of this Board of Examiners shall be deemed to be sufficient evidence of confirmed criminal tendencies."

And each statute provides for the appointment of counsel to represent the person to be examined at the hearings of the board, and in any subsequent proceedings, and permits an appeal from any order of the board to the Supreme Court, or any Justice thereof, and the court may, on appeal, grant a stay which shall be effective until such appeal shall have been decided.

The other state laws make no provision for the appointment of counsel, or an appeal from any order of the board.

The laws of Connecticut, New York and Iowa, prohibit the performance of the operation, except as authorized by the respective acts, unless the same shall be a medical necessity. Therefore the only persons eligible for the operation in those states are the persons confined in the institutions named.

This prohibition is based upon the police powers of the State, and the legislature doubtless justified it upon the theory that it 
would be dangerous to society to permit healthy men and women to cause themselves to be deprived: of the natural power of procreation. I $a n$ of the opinion, however, that some board stould have the authority to permit such operation to be performed upon any individual, whenever such individual is able to satisfy the board that his purpose is to prevent producing children with an inherited tendency to crime, insanity, disease, feeblemindedness, idiocy, or imbecility. It is illogical to limit the application of the law to the inmates of prisons and asylums, and to make it a penal offense to perform the operation on anyone else. The law should provide for a state board with power to examine individual applicants, as well as the inmates of state institutions, and order the operation performed in every case where the person examined would be likely to produce children with any of the above tendencies.

Many persons inherit a tendency to insanity or disease, who may desire to avoid transmitting such tendency to their children, and they should be permitted to obtain legal sanction for submitting to the operation of vasectomy.

Some features of our statute, in my judgment, are objectionable and should be changed, but I find nothing intrinsically unreasonable in the law. It applies equally to all of certain classes of persons, which persons may be regarded as requiring special legislation for the protection from them of the community at large. It may be taken as a determination by the General Assembly that a law of this kind is necessary for the preservation of public health and morals, and no one at all familiar with the facts will question the essential justice of such determination. The classes of persons to which the statute applies are capable of endangering the health, morals and good character of our people and adding greatly to the sum of human suffering. There is no discrimination among the members of such classes. The principles laid down in such cogent language by Chief Justice Baldwin, in the case of Gould v. Gould, supra, are capable of a wider application than the mischief which gave them birth; they may reach as far as the needs of society.

There are no individual rights under the Constitution superior to the common welfare. The whole of society is greater than any of its parts. No man is permitted to claim the right to beget children with an inherited tendency to crime, insanity, feeblemindedness, idiocy, or imbecility.
In determining the constitutionality of such a law, there may be ground for some distinction between different classes of individuals embraced within its terms. No one will question that the sterilization of idiots and imbeciles may be regarded within the police power of the state, but some may doubt whether the sterilization of criminals can be supported on the same ground. I believe that the sterilization of such criminals as are included within the purview of our statute may be. The inmates of the institutions named in the act are brought by penal and police regulations into the custody and care of the State, and constitute a special class. The State assumes under the law an obligation to this class and to the public which does not obtain in relation to any other class of our citizens, therefore the application of the sterilization law to this class alone is reasonable and it cannot be said to deprive such class of "the equal protection of the law" vouchsafed by the Fourteeenth Amendment of the Constitution of the United States.

For the foregoing reasons, I am of the opinion that the statute in question is constitutional.

Respectfully submitted, JNO. H. LIGHT, Attorney-General.

\section{ADDITIONAL OPINION BY THE ATTORNEY-GENERAL OF CON- NECTICUT.}

\section{The Act Authorizing Operations for the Prevention of Procreation Is Not in Conflict with the Fourteenth Amend- ment of the Constitution of the United States.}

Hartford, January 8, 191 .

Dean Henry Wade Rogers,

Law Department Yale University, New Haven, Conn.

My Dear Mr. Rogers-This is the first opportunity I have had to reply to your favor of the 30 th ult.

I have given an opinion to the Directors of the Connecticut State Prison through Warden Garner in which I hold that Chapter 209 of the Public Acts of 1909, being "An Act Concerning Operations for the Prevention of Procreation," is constitutional. I have requested my secretary to send you a copy of the opinion.

At first blush I thought that the act was unconstitutional, but after a careful examination of the provisions of the act and nu- 
merous authorities, I came to the conclusion that the act is constitutional.

The Fourteenth Amendment of the Constitution of the United States gave me considerable pause. I considered very carefully whether the State through this law would "deprive any person of life, liberty or property, without due process of law; or deny to any person within its jurisdiction the equal protection of the laws."

I understand the essential elements of "due process of law" are notice and opportunity to defend. But due process does not require any particular form of proceedings to be observed, but only that the same shall be regular proceedings, in which notice is given of the claim asserted and opportunity afforded to defend against it.

Smith v. State Board of Medical Examiners, 117 N. W., 1116. It appears to me that no member of the class enumerated in the statute can claim the right to produce children with an inherited tendency to crime, insanity, feeble-mindedness, idiocy, or imbecility; therefore, the statute is a reasonable police regulation for the protection of the health, morals and safety of the people, and the discrimination rests upon a proper basis. Within constitutional limits, the legislature is the sole judge as to what laws should be enacted for the protection and welfare of the people and as to when and how the police power of the State is to be exercised.

State v. Drayton, 117 N. W., 768; N. J. Ch., 1908.

The public policy of the State is the creature of the legislature and the courts have nothing to do with forming it and can only recognize it like any other matter of public law.

The "equal protection of the law" means equal security or burden under the law to all similarly situated, and the law must bear alike on all individuals, classes and districts which are similarly situated, the real purpose of the amendment being to prevent arbitrary and capricious legislation; therefore, to constitute equal protection of the law, it is only necessary that there be equality among those similarly situated.

I think that the inmates of the State Prison and the Insane Hospitals at Middletown and Norwich are essentially in a class by themselves, and the State necessarily assumes a different relationship to them than to any other classification of a part of our people.
I believe, however, that the law is defective and should be amended. In my opinion the power to examine and order an operation of vasectomy or oöphorectomy should belong to the State Board of Health, and the Directors of the State Prison, and the Superintendents of the State Hospitals at Middletown and Norwich, might be authorized to have any inmate examined with a view of having said operation performed, and in such case the inmate to be examined should be privileged to have an attorney appointed to appear for him at the expense of the State.

And, furthermore, any individual should have the right to make application to the Board to be examined, and in case sufficient reason be shown, to be authorized to have said operation performed on himself or herself.

I shall be pleased to aid in any possible way the Social Hygiene Society in obtaining such amendments to the law as may be thought desirable.

$$
\begin{aligned}
& \text { Sincerely yours, } \\
& \text { JNO. H. LIGHT, } \\
& \text { Attorney-General. }
\end{aligned}
$$

\section{OPINION BY LOUIS MARSHALL, ESQ., OF THE NEW YORK BAR.}

The following opinion is rendered by Louis Marshall, Esq., in a letter to Hon. Warren W. Foster, Judge of the Court of General Sessions of New York City.

Guggenheimer, Untermeyer \& Marshall, No. 37 Wall Street, New York.

April 12, 1912.

\section{Dear Judge Foster:}

I am in receipt of your several letters, in which you ask my opinion with respect to the constitutionality of legislation which has been proposed for the sterilization of criminals and degenerates by means of the operation of vasectomy. I regret that $I$ have been so situated as to be unable to give the subject the careful study to which it has been entitled. It has been my intention to do so, but you are apparently desirous of an immediate expression of my views, and I will therefore state them in mere outline, without elaboration or argument.

Doubtless the state has the power, in the administration of punishment to offenders and in dealing with those who may imperil the safety of the public, to segregate them and to exercise a general supervision over them. The exercise of this function comes 
strictly within the police power of the state, since it affects the public safety and welfare. In the case of criminals the state has the power to impose more drastic punishment upon second offenders and upon habitual criminals than it sees fit to impose upon first offenders. It has likewise the power to impose indeterminate sentences upon those convicted of crime.

Except so far as prohibited by the constitutional prohibition against the imposition of cruel and unusual punishment, I believe that it is within the power of the state to inflict the death penalty in such cases as at common law were subject to that punishment, and to impose imprisonment up to the limit of incarceration for life, due regard being had to the nature and character of the crime sought to be punished.

The prohibition against the infliction of cruel and inhuman punishment is difficult of precise definition. It is generally understood to have reference to the imposition of torture, of a punishment which is barbarous and wanton and repugnant to the public conscience. Electrocution has been held not to constitute cruel and unusual punishment within the inhibition of the Constitution, in People ex rel Kemmler vs. Durston, 119 N. Y. 569 , affd. 136 U. S. 436,446 . The decapitation of the hand of a kleptomaniac, the branding of one who has committed the crime of burglary or the amputation of the sexual organs of one guilty of adultery would doubtless, in this age, be deemed cruel and inhuman punishment.

The most recent decision on the subject is to be found in Weems vs. United States, 217 U. S. 349, where the Supreme Court held a provision of the Penal Code of the Philippine Islands to impose cruel and inhuman punishment insofar as it prescribed for an offense by an officer of the government who made false entries in public records, the obligation to pay a large fine, imprisonment during twelve years, with accessories such as the carrying of chains, the deprivation of civil rights during imprisonment, perpetual disqualifications to enjoy political rights, to hold office thereafter, and the subjection to constant surveillance. In the dissenting opinion of Mr. Justice White, in which $\mathrm{Mr}$. Justice Holmes concurred, there are collated a large number of precedents, which indicate the extent to which courts have sustained statutes imposing drastic penalties even though they were claimed to be cruel and unusual.
I understand that the operation of vasectomy is painless and has no effect upon the person upon whom it is imposed other than to render it impossible for him to have progeny. If it could be said that such a punishment would only be inflicted in the case of confirmed criminals, there would be strong reasons, founded on considerations of the public welfare, which would justify its imposition. The danger, however, is that it might be inflicted upon one who is not an habitual criminal, who might have been the victim of circumstances and who' could be reformed. To deprive such an individual of all hope of progeny would approach closely to the line of cruel and unusual punishment. There are many cases where juvenile offenders have been rendered habitual criminals who subsequently became exemplary citizens. It is true that these cases are infrequent, and yet the very fact that they exist would require the exercise of extreme caution in determining whether such a punishment is constitutional.

Although not entirely certain as to this phase of the case, I have no doubt that the imposition of such a penalty by a commission or state board, or by any tribunal other than a court which is to determine the penalty for the offense of which one charged with crime has been convicted, would be unconstitutional. The determination that such an operation shall be performed necessarily involves the infliction of a penalty. Unless justified by a conviction for crime, it would be a wanton and unauthorized act and an unwarranted deprivation of the liberty of the citizen. In order to justify it the person upon whom the operation is to be performed has, therefore, the right to insist upon his right to due process of law. That right is withheld if the vasectomy is directed, not by the court which imposes the penalty for the crime, but by a board or commission, which acts upon its own initiative or which, under a general provision of law, undertakes to determine whether or not the operation shall be performed on a specific individual.

In this aspect of the case it seems to me that the decision of the Court of Appeals in People ex rel Barone vs. Fox, 202 N. Y. 616, which adopted the dissenting opinion of Mr. Justice Clarke in 144 App. Div. 611, is conclusive. In that case it was held that Section 79 of Chapter 659 of the Laws of 1910 , authorizing the physical examination by a physician of a woman convicted of disorderly conduct in that she is a common 
prostitute, in order to discover whether she is afflicted with any communicable venereal disease and authorizing the magistrates of inferior courts of criminal justice in the City of New York to commit her to a public hospital for treatment for such disease for a certain period not exceeding one year or until she shall be cured, is unconstitutional, since the magistrate is bound by the report of the physician so that the convicted person is deprived of her right to have the fact of the existence of the disease officially determined by the magistrate.

So in regard to the legislation which you now have under consideration, it is my firm opinion that the court which imposes the sentence upon the prisoner can alone impose the penalty of vasectomy, the prisoner being first accorded an opportunity to be heard by the court on the question as to whether or not such penalty shall be inflicted.

To go further than to lay down these general principles, and to attempt to formulate a statute which would fully cover the various questions which may arise in respect to the application of this remedy, is at present impossible for me. I shall continue to consider the subject, which is intensely interesting and important, and if any further ideas suggest themselves to me I shall be very glad to communicate them to you.

I fear that the public is not as yet prepared to deal with this problem; it requires education on the subject. I cannot, however, refrain from expressing the general opinion that the movement is one which is based on sound considerations. The difficulty is, however, in adopting proper safeguards to ade-. quately protect those who are not hopelessly confirmed criminals, degenerates, or defectives.

It is my recollection that I have recently seen a case decided by the Supreme Court of Indiana which has a strong bearing upon this question, but I cannot for the moment lay my hands on it. If I find it I shall send you a reference to the decision.

Very truly yours, (Signed) LOUIS MARSHALL.

HON. WARREN W. FOSTER,

32 Franklin Street, New York City.

\section{BRIEF BY CHARLES A. BOSTON,} ESQ., OF THE NEW YORK BAR, Contending that the Recent Sterilization Laws are Unconstitutional.

On December 14, 1911, Charles A. Boston, Esq., of the New York Bar, addressed the Society of Social and Moral Prophylaxis at the New York Academy of Medicine, on the subject, "A Protest Against Laws Authorizing the Sterilization of Criminals and Imbeciles." A copy of his notes on the subject are on file at the Eugenics Record Office. They constitute essentially a lawyer's brief against sexual sterilization as an invasion of the Bill of Rights. These notes were organized into an article under the above-named title, which appeared in the "Journal of the American Institute of Criminal Law and Criminology", (1913-1914, Volume IV, Number 3,.pp. 326-358.)

\section{SUMMARY:}

1. Legal opinion is divided more on the subject of the policy of eugenical sterilization than upon its constitutionality.

2. If due provision is made for respecting the so-called "Bill of Rights," there is practical unanimity of legal opinion in support of the power of the State in the normal exercise of its police authority, to enact laws providing for the sexual sterilization of certain natural classes of defectives or degenerates in the population of the State.

\footnotetext{
1 Brief abstracts of all references to sterilization which appeared in this Journal are given in Section 11 of Chapter V, pp. 117, of this book, under the subject "The Sexual sterilization of Criminals."
} 


\section{CHAPTER X. \\ THE RIGHT OF THE STATE TO LIMIT HUMAN REPRODUCTION IN THE INTERESTS OF RACE BETTERMENT.}

Introduction

A. Parallel Cases of the Restriction of Personal Liberty in the Interests of the General Welfare.

1. Compulsory vaccination

2. Quarantine

B. Legislative and Judicial Activities Regulating or Limiting Human Reproduction.

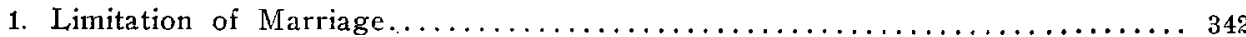

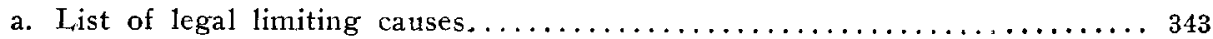

b. The special case of venereal and other transmissible diseases.

b1. Analysis of laws limiting marriage on account of venereal or other transmissible diseases.......................... 343

b2. Constitutionality of the Wisconsin statute requiring certificate of health for males before marriage license is issued............. 344

c. Judicial annulment of marriage in the interests of public health and

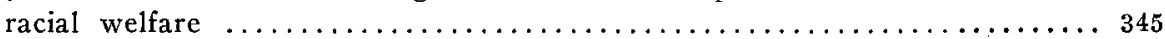

c1. Wisconsin Supreme Court...................................... 345

c2. New York Supreme Court (New York County) ................. 345

c3. New Jersey Court of Chancery (Concealment of insanity).......... 346

c4. New Jersey Court of Chancery (Concealment of venereal

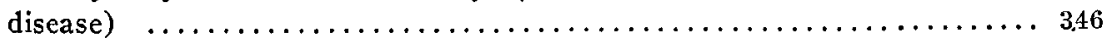

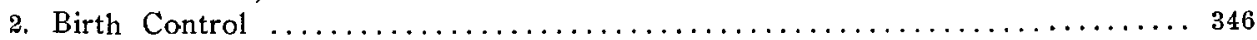

a. Review of criminal statutes on Birth Control: Judge J. C. Ruppen-

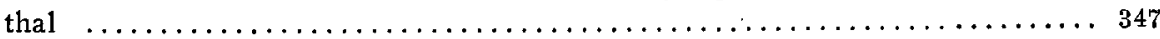

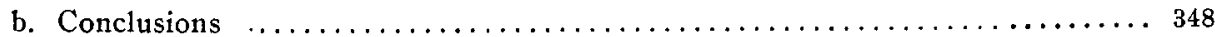

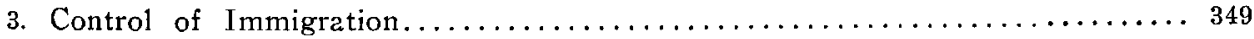

4. Institutional Segregation of Social Inadequates.................... 350

a. Quotation from Dr. Henry M. Hurd ........................ 350

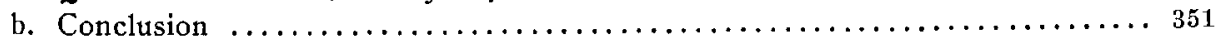

5. Eugenical Sterilization.

a. Cases of eugenical sterilization in states having neither authorizing

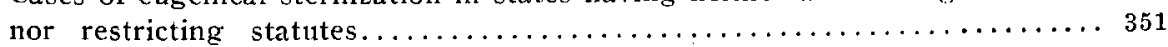

a1. Case of M... H... of Massachusetts.................. 352

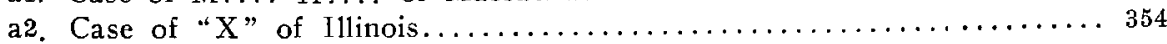

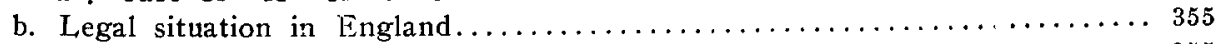

b1. Would it be lawful to sterilize?........................... 355

b2. Who should operate?..................................... 356

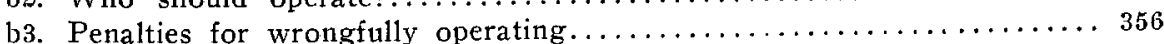

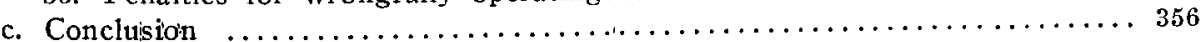

C. Possible New Fields for Eugenical Legislative Activity ................. 356

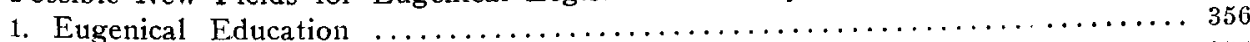

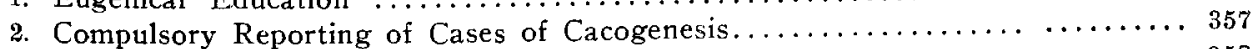

3. Registering Trained Eugenical Investigators $\ldots \ldots \ldots \ldots \ldots \ldots \ldots \ldots \ldots \ldots \ldots$

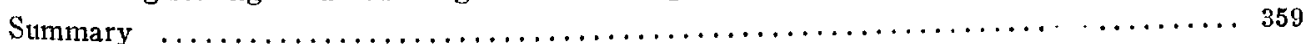




\section{INTRODUCTION.}

The proposal to enact eugenical sterilization laws naturally calls up the question of the constitutionality of the statutes under which the state, through the exercise of its police power, would extend its control over human reproduction to the extent of seizing certain individuals proven by pedigree-study to be potential parents of degenerate or defective offspring, and by surgical operation or medical treatment, destroying their reproductive powers.

Although eugenical sterilization is a very ancient means of conscious effort to conserve and improve certain human races, still the proposal to use this means on an extensive scale by the authority of statutory law is a relatively new ${ }^{1}$ principle in American legislation. The bolstering up of our defective strains by the recent great development of American custodial institutions ${ }^{2}$ for the insane, feeble-minded, criminalistic and other types of the socially inadequate, has created a problem in race-conservation, the degree of which we have not heretofore been compelled to face. Our states are devoting from $5.4 \%$ (Alabama, 1915) to $30.5 \%$ (Massachusetts, 1915) of their total state expenditures to maintaining state institutions for the socially inadequate. American states, in the interest of the general welfare, have exercised many novel and radical police functions, quite as extreme and no more beneficial than eugenical sterilization. Generally such activities are justified and upheld by the courts, if they can be directed by laws not running counter to the bill of rights, and have for their purpose the improvement of the well-being of the state, and can demonstrate their fitness in accomplishing their stated purpose. Many of them seek directly to benefit the natural physical, mental and moral qualities of the nation.

A state does not hesitate in the interests of organized society to take the life of an individual. This in modern practice is always in punishment for crime, but crime is not the only type of anti-social or of socially ineffective conduct. Crime is, it is true, the only type of such behavior which carries blame with it. But the other types of social inadequacy equally destructive to the security and vigor of the nation, while not carrying blame, carry pity, shame, chagrin, ineffectiveness, and degeneracy.
At this point mention might well be made of military conscription. Every soverign state claims this right, although it involves most arbitrarily the control of the conduct and services of the citizen, and places him in great jeopardy of life. It is absolutely non-punitive, but is demanded by the principle that, in the long run, the welfare of the commonwealth is of vastly more importance to the sum total of human happiness than is the temporary freedom and personal security of the individual. Personal jeopardy is highly preferable to injury to the state. If we compare the right and duty of military conscription with the right and duty of the state to control human reproduction in the interests of the common welfare, we find that the latter impinges not more upon individual freedom, but with fully as much ultimate common benefit.

Within modern times, civilized states have resorted to banishment as a means of protecting their organized society. At present in American states those types of social inadequacy, other than crime, which destroy the effectiveness of the individual and the peace and prosperity of the state, are taken care of in a humane manner by custodial institutions. In such institutions the liberty of the individual is just as completely taken away as in the case of imprisonment for crime. The state may restrain its irresponsible members, under the undoubted exercise of its police power, which permits the most severe practice, if in the end the general welfare of the organized social life of the community is promoted.

Euthanasia is not resorted to in our most highly civilized states, but in some of the less advanced communities of the world, especially those in which the population crowds closely upon the food supply, it is common to remove, often by non-punitive death, the members least necessary to the life of the tribe. The direct means of controlling the racial quality of future generations available to our more enlightened and humane states are the legal control of immigration and of marriage; social punishment for illegitimacy; the regulation of attempts at birth-control, abortion, and infanticide; teaching the better classes the truth concerning human heredity and the necessity of fit

1 First bill vetoed 1905, Pennsylvania. First law enacted 1907, Indiana.

2 See Statistical Directory of State Institutions for the Defective, Dependent and Delinquent Classes, H. H. Laughlin, Bureau of the Census, 1919. 
and fertile matings among those with the best natural endowments; and finally the limitation of reproduction of degenerates by eugenical sterilization. The novelty of the proposal cannot militate against its legality, if it is proven effective for the purpose proposed. When in capital punishment electrocution was found to be more humane than hanging, it was readily adopted by a number of states. Vaccination may seem harsh and cruel, but when humanely applied the courts have quite universally held that the state is well within the exercise of its undoubted police power in ordering its compulsory application.

Ultimately the state must find a biologically, socially, morally, and economically superior substitute for war, pestilence, and famine in culling the human species of its defective strains. Also the state must find eugenically the means to undo the racial ill innocently done the nation by society's charitably fostering defective individuals up to parenthood, and encouraging their reproduction. Such pampering has been done by the recent great development of outside charity and hospitalization. The principle here to be applied should be: By all means aid, to the full extent of society's ability, the poor, the unfortunate and the suffering, but permit only those individuals most splendidly endowed by nature, with socially valuable physical, mental and moral qualities, to reproduce.

Thus a democracy, in order to live, must be willing to investigate new social remedies, to try them out and to accept those which prove adequate to promoting national effectiveness and racial vigor-the general welfare, it is called in law. The principal guide in trying out novel social legislation is that the activity provided for shall not transgress our Bill of Rights, which we have built up through the centuries at so great an effort. Measures for race improvement must, of course, be effected through due process of law and without denying the equal protection - of the laws to all of the inhabitants of the state: Except in cases involving crime, there must be no element of punishment in them. Every measure designed for promoting the gerieral welfare must stand the practical test of being an effective agency for promoting the good of the race to a degree entirely in keeping with the severity or radicalness of the remedy.

With all species, including man, the life and well-being of the race or nation, as a whole, are vastly more important than the unrestricted and unsocial conduct of the individuals who compose the race, because experience has proven that in the long run individual effectiveness and happiness is assured and promoted only by individual subordination and occasional personal sacrifice. The sum total of human freedom and human happiness will be greatly promoted, in the long run, by eugenical processes which call for the elimination of degenerate and handicapped strains, from the racial stocks, and the increase of numbers of citizens highly endowed by nature with splendid mental, physical, and moral qualities. The state, then, must exercise its undoubted right and duty to control human reproduction along the lines of race betterment, and in so doing is fully justified in putting into effect such measures as, in keeping with the Bill of Rights and humane principles, will bring about the desired ends.

\section{A. PARALLEL CASES OF THE RE- STRICTION OF PERSONAL LIB- ERTY IN THE INTERESTS OF THE GENERAL WELFARE.}

Since the proposition to sterilize eugenically involves the taking away, in the interests of the state, of a natural endowment of an individual, namely, the reproductive power, it is pertinent to cast about for legislation and court decisions which relate to processes bearing an analogy to some aspects of eugenical sterilization. In compulsory minor surgical treatment and in infringement upon personal liberty, in the interests of the general welfare, the state's work in vaccination and quarantine is found to be pertinent.

1. Compulsory Vaccination is analogous to compulsory eugenical sterilization to the extent that both are non-punitive and that both involve the seizure of the individual and subjecting him or her to surgical treatment. Both vaccination and sterilization are done supposedly for the public good. Vaccination protects the individual and his associates from a serious and loathsome disease in the more immediate future; eugenical sterilization protects society from racial degeneracy in the more remote future. Vaccination, however, in its operative seriousness and pathological possibilities, greatly exceeds vasectomy, but not castration, in the male, but may not on the average be said to equal in seriousness sterilization of the female by any known process except possibly by $\mathrm{X}$-rays. 
The following brief history of legislation and litigation, however, sustains the view that the State may, in the interests of public welfare, impose compulsory vaccination upon its residents.

From Public Health Bulletin No. 52, published in January, 1912, and written by J. W. Kerr, Assistant Surgeon General, we quote from page 16:

"Questions relating to vaccination have been brought before the judicial branch of the Government under all possible aspects. The courts have been called upon to decide the constitutionality of statutes requiring vaccination, the power of the legislature to delegate authority to require vaccination, the validity of local ordinances or regulations enforcing vaccination, the price of vaccination, the responsibility for the expenses of vaccination, the form of the certificates used, what vaccination is, wher fallure to vaccinate a child constitutes negligence, etc.

"Power of States to Enact Compulsory Vaccination Iaws.-All disputes regarding the right of State legislatures, in the exercise of the police power, to enact statutes making vaccination compulsory were definitely settled by the decision of the supreme Court of the United States in the case of Jacobson $v$. Massachusetts (197 U. S., 11). The highest tribunal of the land had already as an obiter dictum in Lawton v. Steele (152 U. S. 136) enunciated the principle that the State might order the compulsory vaccination of children, but the Massachusetts case was the first instance in which the validity of a state law requiring vaccination was questioned before the Supreme Court on constitutional grounds, the court ruling that the police power of the State covered such cases, and it was for the legislature and not for the courts to determine whether vaccination was or was not the best preventive measure against smallpox.

"Similar conclusions have been reached or assumed by a number of state courts with respect to compulsory vaccination or making vaceination a condition of attendance at school, signally, in Abeel v. Clark (84 Cal. $226)$; State Bd. of Health v. Board of Trustees (110 Pac., 137); 143 Cal., 658; Bissell v. Davidson (65 Conn., 183); Harris v. Cox, D. C. Law No. 53015; Morris v. Eolumbus (102 Ga., $792)$; Blue v. Beach (115 Ind., 121); Osborn v. Russell (64 Kans., 507); Com. v. Pear and Com. v. Jacobson (183 Mass., 212); Viemeister v. White (179 N. Y, 235); re Smith (146 N. Y., $68)$; State v. Hay (126 N. C., 999); Field v. Robinson (198 Pa., 638); Stull v. Reber (215 Pa., 156); McSween v. Bd. of School Trustees (129 S. W. R., 206); State v. Shorrock (55 Wash., 208); the case of State v. Burdge (95 Wis., 390) being the only one in which the court refused to commit itself to the validity of such legislation, taking the view that the question was not presented by the record.

"Delegation of Authority.-The doctrine that State legislatures have power to delegate their authority to enforce vaccination to local authorities has been maintained in Morris v. Columbus (102 Ga., 792); Com. v. Pear (183
Mass., 242); re Smith (146 N. Y., 68); State v. Board of Education ( 81 N. E. R., 568); and somewhat more reservedly in Osborn v. Russell (64 Kans., 507); and Mathews v. Board of Education (127 Mich., 530).

"Power of Iocal Authorities in the Absence of Iegislation.-There is a decided lack of harmony in the decisions of the courts regarding the power of State or local authorities to make vaccination a condition to school attendance when no specific authority has been granted by the legislature. The exercise of this power has been upheld in Austin v. School Board (83 Ark., 431); Blue v. Beach (155 Ind., 121); 157 Ind., 25; State v. Zimmerman (86 Minn., 353); re Rebenack (62 Mo. Ap., 8); State v. Cole (220 Mo., 697); Hutchins v. Durham (137 N. C., 68); Duffield v. School District (162 Pa., 476); Glover v. Board of Education (14 S. D., 139); McSween v. Board of School Trustees (129 S. W. R., 206); and State v. Board of Education (21 Pac., 401); while the use of this power has been animadverted against and its legality denied in Morris $v$. Columbus (102 Ga., 792); Potts v. Breen (167 II1., 67); Lawbaugh v. Board of Education (177 I11., 572); 234 Ill., 422; Usborn v. Russell (64 Kans. 507); Mathews v. Board of Education (127 Mich., 530); and State v. Burdge (95 Wis., 390 ). Although in some of these cases, notably in the Illinois and Michigan cases, the opinion was expressed that during epidemics or as an emergency measure unvaccinated children might be excluded from school

"Mention must be made of the fact that after the decisions in the cases of State $v$. Zimmerman (86 Minn,, 353); Glover v. Board of Education (14 S. D., 139); and State v. Board of Education (21 Utah, 401), acts were promptly passed by the State legislatures of Minnesota, South Dakota, and Utah forbidding compulsory vaccination."

We quote two decisions, the first by the California District Court of Appeal, First District, in the case of Williams vs. Wheeler (Dec. 31, 1913) (138 Pacific Reporter, 937).

"The history of the legislation on the subject shows that the State of California stands committed to the policy of requiring vaccination as the best preventive means known to medical science for lessening the liability to infection with a dreaded and dangerous disease.

"The board of regents of the University of California has the right to make and enforce reasonable rules requiring vaccination as a condition of admission to the university.

"The general health is one of the subjects over which the State legislature has control through the police power, and in the exercise of that control it has the power to pass general laws, in the nature of health regulations, requiring that persons admitted to educational institutions shall be vaccinated.

"The rules of the board of regents of the University of California required vaccination as a prerequisite to the admission of students to the university. A general state law required that students entering educational institutions in the State must be vaccinated, but a provision of the law made an exception in 
cases where the students or their parents or guardians were conscientiously opposed to vaccination. The court held that this provision of the law was not a health regulation and not within the general police powers of the legislature, and that, in view of the broad powers given to the board of regents of the State university by the constitution, the provision in the State law did not nullify or alter the rule of the board of regents."

The following is a decision of the Kentucky Court of Appeals in the case of the Trustees of Highland Park School District vs. McMurtry (Apr. 13, 1916) (184 Southwestern Reporter, 390).

In Kentucky the State board of health and the local boards of health are both charged, independently, with the preservation of the public health, and they have power to take such action as in the exercise of a reasonable discretion may be deemed necessary to suppress and prevent the spread of any infectious or contagious diseases.

Under the laws of Kentucky, when a smallpox epidemic is threatened, it is within the power of a local board of health to require all children attending school to be vaccinated.

A PLEA FOR COMPULSORY VACCINATION IN DEFENSE OF ASSEMBLY BILL NO. 474 ENTITLED, "AN ACT REGULATING. VACCINATION IN THE STATE OF NEW YORK."

By CYRUS EDSON, M. D.

Health Department, City of New York. 1889 .

Page 1. (In listing the reasons).

No. 2. "That compulsory vaccination is an invasion of personal liberty."

Pages 5-6 (In reply):

"It is alleged that the compulsory vaccination is an invasion of personal liberty. To a certain extent it is. But is not enforced isolation, removal to the so-called pest-house, a much greater invasion of liberty?

"It is my duty to remove to the smallpox hospital all cases of the disease that occur in tenements, apartment houses, hotels, boarding-houses, etc., in New York City. I have seen the babe taken from the arms of its heart-broken mother. Is not this a much greater invasion of personal liberty? It is authorized by the health laws. Compulsory vaccination will do more to effect the prevention of such cases than any other measure that can be devised. We have in New York City a class, mostly Bohemians, who are a source of danger to the rest of the people by reason of their prejudice of vaccination.
When smallpox appears among them it is almost impossible to stamp it out. Compulsory vaccination will enable us to compel these people to be protected against smallpox. They will yield only to the strong hand of the law."

\section{PENNSYLVANIA STATE VACCINA- TION COMMISSION. \\ Report and Dissenting Reports. March, 1913.}

Pages 136-7.

Vaccination Laws in Other Lands:

In practically all of the armies and navies of the civilized world, vaccination and revaccination are compulsory.

(The following list is given of countries having compulsory vaccination laws).

Germany, 1875; Japan, 1885; Hungary, May, 1887; Italy, March, 1892; Roumania, 1894; France, 1902. Sweden requires that children must be vaccinated "before the age of three." Norway has indirect compulsion, requiring the vaccination of all school children.

Denmark, by royal decree, April 3, 1810, made attendance at school, permission to receive confirmation, and to be married in the church, dependent on proof of vaccination. It also decreed compulsory vaccination in time of smallpox epidemics. Children must be vaccinated before the age of seven.

Belgium. Indirect compulsion through vaccination of school children.

Holland. 1892.

England: The present law requires that every child shall be vaccinated before reaching the age of six months; the penalties of this law may, however, be avoided by a declaration under oath of conscientious objection to vaccination.

\section{Conclusion.}

The legal aspects of the vaccination problem may be summed up as follows: In the absence of constitutional provision to the contrary, a state may, in the exercise of its police power, enact compulsory vaccination laws. Their enactment is a matter of policy wholly within the discretion of the legislature.

2. Quarantine. Quarantine involves a suspension of the right of a diseased or exposed individual or household to move about in the community, or in any other manner to come in close contact with fellow citizens who are not suffering from or have not been exposed to the same disease. It is analogous to 
eugenical sterilization in that both are nonpunitive, and that both appear to be abridgments of personal liberty of a most serious nature.

Quarantine is found to be such a valuable agency in protecting the public from the menace of the spread of contagious diseases that the state has assumed the rights to make suitable quarantine regulations and the courts have sustained their respective states in the reasonable and sound exercise of such authority. In the present connection it is pertinent to learn whether, in each particular case, a ministerial or administrative agency, duly established by legislative enactment, may, of its own discretion, impose the quarantine restriction on a given individual, or whether the removal of such natural liberty as the quarantine involves requires in each particular case court procedure with the right possibly to trial by jury.

The Illinois Supreme Court, in the case of the People vs. Tait (Dec. 17, 1913), handed down the following decision:

"The legislature may, in the exercise of the police power of the state, create ministerial boards with power to prescribe rules and impose penalties for their violation, and provide for the collection of such penalties, and the exercise of this power by the legislature is not a delegation of legislative power.

"Rules and regulations of boards of health must be written, adopted in an official manner, and duly entered of record.

"An Illinois law authorized county boards of health to make and enforce rules and regulations to check the spread of communicable diseases. The defendant was charged with failing to comply with quarantine regulations established by the County Board of Health, and was convicted in the lower court, but the Supreme Court reversed the judgment because it did not appear that the rule or regulation under which he was convicted was in writing and had been regularly adopted by the Board of Health and duly entered of record."

\section{Conclusion.}

Quarantine is so demonstrably adapted to promoting the health of the people that, despite its non-punitive taking away of personal liberty, it is undoubtedly constitutional in each of the several states. The balance of private inconvenience against public welfare is in each case decided in favor of the latter.

\section{B. LEGISLATIVE AND JUDICIAL ACTIVITIES REGULATING OR LIMITING HUMAN REPRODUC- TION.}

There are many ways in which the people of a state, either through the pressure of an aroused public opinion acting directly in influencing custom, or acting through its representatives in the legislature by enacting statutory laws, may deny the right of reproduction to certain proved defectives or degenerates.

The marriage and reproduction mores of a people are so deeply seated in their life that in a self-governing country no statutory law affecting them which has not the support of public opinion may be expected to accomplish its stated purpose. If, however, public opinion is behind the statute, a modern state by statute may successfully resort to the means described in this chapter, and possibly others, in its legislative efforts to limit or control the reproduction of individuals social$1 y$ inadequate from defective heredity.

\section{Limitation of Marriage.}

The power of the state to limit marriage ${ }^{x}$ in the interests of race betterment is undoubted. Practically any rule having a sound biological, medical or social foundation may be enacted into statutory law limiting marriage, provided that such limitation applies impartially to all residents of the state who present the given set of limiting conditions. These given conditions, however, must be descriptive of a natural class logically and justly set apart. They must not establish an artificial class in an unfair or discriminatory manner. The purpose must be laudable, and its means of attainment must be reasonable. The principal point, therefore, which the courts insist upon is that such laws shall not constitute class legislation, that is, they shall not deny to any natural group or class of citizens the equal protection of the laws guaranteed to the inhabitants of all of the states by the Fourteenth Amendment to the Constitution of the United States.

1 See 1. American Marriage Laws in Their Social Aspects: Hall and Brooke. Russell Sage Foundation, 1919.

2. State Laws Limiting Marriage Selection, Examined in the Light of Eugenics: Davenport, Chas. Benedict. Bulletin No. 9, Eugenics Record Office, 1913 .

3. Marriage and Divorce Laws of the World: Ringrose. Musson-Draper Co., 1911 .

4. Summary of Laws of Several States Governing Marriage and Divorce of FeebleMinded, Epileptic and Insane: Smith, Wilkinson \& Wagoner: Bulletin No. 82, University of Washington, 1914 .

5. Legal Status of Negro-White Amalgamation in the United States: A. E. Jenks, Am. Jr. Sociology, March, 1916, pp. 666-678. 


\section{a. List of Legal Limiting Causes.}

As a matter of fact, state laws limiting marriage vary in different states on different subjects with the varying strength and particular direction of public pressure. Legal limitations exist in reference to the following subjects: (1) age, (2) parental consent, (3) license, (4) ceremony, (5) bigamy and previous marriage, (6) consanguinity, (7) marriage by force, menace, duress, or false personation, (8) miscegenation, (9) venereal and other communicable diseases, (10) insanity, feeble-mindedness, epilepsy and other forms of hereditary degeneracy, (11) criminality, (12) alcoholism and narcoticism. On each of these subjects the right of the state to legislate is undoubted. All states have limitations of some sort, among the most eugenical of which are those relating to certain types. of miscegenation and those denying marriage to the insane, feebleminded and other constitutional degenerates or defectives. The present laws deny marriage to individuals personally defective; but, if modern human pedigree studies have proven anything, it is that in individuals personally normal hereditary degeneracy can be located only by family history study. The location of such degeneracy is a difficult task, but is necessary as a foundation for the intelligent purging of the race.

In those states with the highest percentage of literacy and the greatest development of state institutions, it would be equally logical to limit marriage to persons who can demonstrate the possession in their family trees of socially valuable mental, physical and temperamențal qualities. This at present may be a little in advance of public opinion, but as the eugenical sciences make advance and the teachings of biology, medicine and sociology permeate more deeply into the life of the American people, the demand for the limitation of marriage to persons of demonstrated natural worth will doubtless be made, and judging by analogy, when such time arrives and such laws have been enacted with due regard for the Bill of Rights, we may logically expect that the courts will sustain them, and that the people will demand their enforcement.

b. The Special Case of Venereal and Other Transmissible Diseaes.

Analysis of only one of these basic factors for limiting marriage will be made here. The possession of venereal or other transmissible diseases as a legal bar to marriage is now being actually developed by the several states, so that its legal status and the processes and vicissitudes of its attainment become especially instructive. These laws restrict the marriage license to otherwise qualified individuals who can show a clean bill of health so far as venereal infection is concerned. Some of them apply to males only, others to both sexes. This is a new social remedy which medicine and social hygiene have developed, which the legislatures have adopted and which the courts appear to be supporting because it is demonstrated to be an effective means for promoting general public health. The fact that it is a new remedy does not appear to destroy its efficiency nor its constitutionality.

b1. Analysis of Lazes Limiting Marriage on Account of Venereal or Other Transmissible Diseases (rozo).

Since 1905 thirteen states have, in response to the recent awakening in social hygiene, enacted laws limiting marriage on account of venereal or other transmissible diseases. The following table gives an analysis of their essential features:

\section{LAWS LIMITING MARRIAGE LI- CENSE ON ACCOUNT OF VENER- EAL DISEASES.}

1920.

1. ALABAMA. General Laws, Regular Session of 1919 , No. 178 , applicable to males only.

2. INDIANA. Chapter 126, Acts of 1905, applicable to both sexes.

3. MICHIGAN. Chapter 83 , R. S. 1846 , and Act 128 P. A. 1887 (see C. L. 1915), applicable to both sexes.

4. NEW JERSEY. Chapter 23, Laws of 1917, applicable to both sexes.

5. NEW YORK. Domestic Relations Law, Article III, 1917-18, applicable to males of any age and females under 45 years.

6. NORTH DAKOTA. Chapter $207 \mathrm{~S}$. L. 1913, and Chapter 237 S. L. 1919, applicable to males of any age and females under 45 years.

7. OREGON. Chapter 187 S. L. 1913, applicable to males only.

8. PENNSYLVANIA. P. L. 1013, 1913, applicable to both sexes.

9. UTAH. Title 46, Chapter I. C. L. $191 \%$, applicable to both sexes. 
10. VERMONT. P. A. 198, 1918; P. A. 238, 1917; and P. A. 179, 1919, applicable to both sexes.

11. VIRGINIA. Chapter 300 , Acts of the Assembly, 1918, applicable to both sexes.

12. WASHINGTON. Chapter 174 Session Laws 1909, and Chapter 16, House Bill No. 27, Extraordinary Session 1909, applicable to males of any age and females under 45 years.

13. WISCONSIN. Chapter 107, Laws of 1917, applicable to males only.

b2. Constitutionality of the Wisconsin Statute Requiring Certificate of Health from Males Before Marriage License is Issued.

Perhaps the most far-reaching decision in reference to one of this particular series of statutes (erroneously called "The Eugenics Laws") is that of the Wisconsin Supreme Court in the case of Peterson vs. Widule (June 16, 1914) (140 Northwestern Reporter, 966). The court (Winslow, C. J.) held:

"*** The power of the State to control and regulate by reasonable laws the marriage relation, and to prevent the contracting of marriage b.y persons afficted with loathsome or hereditary diseases, which are liable either to be transmitted to the spouse or inherited by the offspring, or both, must on principle be regarded as undeniable.

"*** When the legislature passes a constitutional law, that law establishes public policy. upon the subjects covered by it, and that policy is not open to question by the courts.

"*** An argument is made that the law is void because the classification is unreasonable, arbitrary, and discriminatory, in that it singles out men about to marry and makes a class of them; there being, as it is argued, no substantial differences which suggest the propriety of different legislative treatment between men who are about to marry and women who are about to marry. Theoretically the argument is strong. Women who marry and transmit a loathsome disease to their husbands do just as much harm as men who transmit such a disease to their wives; if women were, in fact, doing this thing as frequently or anywhere nearly as frequently as men, the argument could hardly be met. The medical evidence in the case, however, corroborates what we suppose to be common knowledge, namely, that the great majority of women who marry are pure, while a considerable percentage of men have had illicit sexual relations before marriage, and conse- quently that the number of cases where newly married men transmit a venereal disease to their wives is vastly greater than the number of cases where women transmit the disease to their newly married husbands. Classification is not to be condemned because there may be occasional instances in which it does not fit the situation; it is proper if the great mass of situations to which the law applies justify the formation of a class and the application of some special or different legislative provisions to that class. Classification can rarely be mathematically exact. The question is not whether in some individual instance there is any perceptible distinction, but 'whether there are characteristics which in a greater degree persist through the one class than in the other,' and which justify the different treatment. (State vs. Evans, 130 Wis., $381 ; 110$ N. W., 241.) That there are such characteristics in the class of unmarried men is as certainly true as it is discreditable to the male sex.

"It follows that legislation directed against males alone for the purpose of preventing the transmission of venereal diseases is clearly within the police power and just as clearly is not discriminatory. The only question to be considered is whether the law which attempts to accomplish the purpose is unreasonable or unduly invades constitutional rights in its methods of enforcement.

“* * * For my part I have no sympathy with this statute. I think it tends to discourage marriage rather than to prevent the spread of venereal diseases ${ }^{* * *}$.

“*** But the ineffectiveness of the law, or its folly, if it be foolish, or the fact that it was passed in a modern spirit of legislating first and investigating afterwards, is quite remote from the question of its constitutionality. The people must learn to hold their legislators responsible for the enactment of laws which, however unwise and absurd, are still within the constitutional power of the legislature. It will be for the benefit of both the people and the legislature to recognize this responsibility and to know that they can not look to the Supreme Court for relief in every case of an objectionable but constitutional law. So long as the legislature believed there was enough venereal disease in this State to justify the enactment of the statute in question, we can not gainsay it, for that was a matter for the legislature to decide. Assuming the prevalence of venereal disease, its contagious nature, and 
its communicability by contact, it was within the power of the legislature to enact statutes wholly or partially preventive of the spread of this disease. If the legislature libeled the people of this State by making it to appear that venereal diseases were prevalent here, when in fact they. were not, the members of that body must for such error answer to the electors and not to the Supreme Court. If I concede, as I must, the power to require a marriage license, I must also concede the power to require of the licensee reasonable qualifications, and it can not be said to be unreasonable that he be free from venereal disease.

"I can not imagine how this law can be said to interfere with freedom of worship or liberty of conscience. The notion that marriage was a sacrament, not a civil contract creating a status, once vigorously asserted, has long since passed away. A point is made that, requiring the prospective husband to submit to the examination without making the prospective wife do so, conflicts with the Fourteenth Article of the United States Constitution, which forbids the States to deny the equal protection of the law. But the men desiring to marry form a very definite class quite germane to the object sought to be accomplished by the statute. And we read in the learned medical treatises that, while the primary source of venereal infection is usually the prostitute, still such diseases are generally brought into the family by the husband rather than by the wife. The legislature was justified in so deciding ****

"*** I find no ground for holding that part of the statute here involved unconstitutional ***",

This decision is upheld by Barnes, J., and Timlin, J, (concurring). The dissenting opinions are expressed by Marshall, J., and Vinje, J.

The foregoing decision in reference to the most recently adopted specific legal limitations to marriage is a type of those involving other fields of legal limitation which amply sustain the power of the state to limit marriage in the interests of the hereditary physical, mental and moral endowment of offspring, which may result from particular contemplated marriage unions. In this particular Wisconsin case the extent and flexibility of the state's legislative authority is exemplified by its power to apply the remedy in hand to one sex only, if such limitation is found desirable. c. Judicial Annulment of Marriage in the Interests of Public Health and Racial Welfare.

In the matter of annulling marriages on account of the development or discovery of mental defect or transmissible disease in one of the marriage mates, in states having no specific statutes covering the matter the courts have varied widely in sustaining or annulling the legality of the marriage contract, as the following recent court decisions quoted from the United States Public Health Reports ${ }^{1}$ indicate:

c1. WISCONSIN SUPREME COURT, Venereal Disease. Ground for Annulment of Marriage.

$$
\text { C- vs. C- }
$$

"One party to a marriage was infected with gonorrhea at the time of the marriage. Upon discovering this fact the other party ceased marital relations. The court held that the facts were sufficient to warrant the annulment of the marriage.

"The plaintiff (the wife) sued for divorce. The husband filed a counterclaim, asking that the marriage be annulled.

"The court found from the evidence that at the time of the marriage plaintiff. knew that she was infected with gonorrhea and that she infected her husband. After his infection the defendant severed marital relations with the plaintiff. The Circuit Court entered judgment annulling the marriage." (148 Northwestern Reporter, 865.)

\section{c2. NEW YORK SUPREME COURT, SPECIAL TERM, NEW YORK COUNTY.}

\section{Marriage-Tuberculosis-Annulment of Marriage Because of Fraud in Concealing Disease. Sobol vs. Sobol}

(Dec. 7, 1914.)

"It is proper for a court, in view of the widespread prevalence of tuberculosis and the disastrous consequences to those who suffer from it, to take judicial notice of its infectious character and the fact the close association with a person afflicted with that disease, unless attended with great care, occasions danger of infection to those coming into close contact with such person.

\footnotetext{
1 Cases 1 and 2 quoted from Reprint No. 342 from the Public Health Reports, pp. 69 and 70 Cases 3 and 4 quoted from Reprint No. 410 from the Public Health Reports, pp. 69 and 71 .
} 
"The fraudulent concealment of material facts concerning the condition of his health by one party to a marriage contract justifies the legal annulment of the marriage at the instance of the other party.

"The defendant knew before marriage that he was suffering from tuberculosis. He concealed this fact from the plaintiff, and represented that certain symptoms of the disease were the result of a cold. Upon discovery of the facts the plaintiff ceased to cohabit with him. No offspring resulted from the marriage. The court annulled the marriage on the ground of fraudulent concealment and misrepresentation." (150 New York Supplement, 248.)

\section{c3. NEW JERSEY COURT OF CHANCERY.}

Marriage-Concealment by One Party of Insanity in Family Not Ground for Annulment.

Allen vs. Allen, 95 At1. Rep., 363. (Sept. 20, 1915.)

"In order to enable a court of equity to annul a marriage on the ground of fraud in concealing disease, the proof of the diseased condition of the defendant must be clear and convincing.

"A marriage can not be annulled by a court of equity for fraudulent concealment by one party of his or her physical condition uniess the disease is of such a nature as to render contact seriously dangerous to the other party.

"Plaintiff (the wife) asked the court to annul the marriage on the ground that the husband concealed from her the fact that he was afflicted with a taint of hereditary insanity. Some years after the marriage the husband had become insane. The court refused to annul the marriage because (1) It was not clearly proved that the insanity was hereditary; and (2) the concealment of insanity in the family was not such a fraud as would justify the court in annulling the marriage."

\section{c4. N.EW JERSEY COURT OF CHANCERY.}

Venereal Disease-Annulment of MarriageEvidence Not Sufficient to Prove That Defendant Knew That He Was Suffering from Syphilis and Fraudulently Concealed That Fact.

Kaufman vs. Kaufman. (April 1, 1916.)
"The fact that one party to a marriage was afflicted with syphilis at the time of the marriage is not sufficient to enable a court to annul the marriage.

"Complainant sought to have her marriage annulled on the ground that the defendant (her husband) had fraudulently concealed from her the fact that at the time of the marriage he was suffering from syphilis. The court decided that the evidence was not suffcient to prove that the defendant knew when the marriage occurred that he had syphilis and that he had fraudulently concealed that fact." (97 Atlantic Reporter, 490.)

\section{Birth Control.}

All laws of a state which concern sexmorality have a bearing, either directly or indirectly, upon human reproduction. Therefore a consideration of the existing anti-birth control laws, so-called, is pertinent.

It is conceivable that the term, birthcontrol, might have developed a connotation equivalent to eugenics, but as a matter of fact as the term is used at present, birthcontrol implies the limitation of the number of offspring of a given mother. Primarily, in accordance with the family's economic status, that is, its ability to provide properly for the rearing and training of all of its children. The term implies, also, that this end could be easily accomplished, if the present laws limiting and denying the giving and publication of information concerning the use of mechanical appliances to prevent conception were repealed. The contention is made that, whereas the more favored economic classes, through wider access to medical literature and advice, have an easier means of securing the desired information and of procuring the mechanical contrivances; but, on the other hand, the poorer classes, not having such ready access to physicians, medical supplies, and standard medical literature, are, because of the laws forbidding the dissemination of birth control instruction and the sale of contraceptives, denied equal opportunity. At present the laws regulating the publication and dissemination of knowledge concerning contraception and controlling the distribution and sale of mechanical contrivances adapted to preventing conception are inextricably woven in with the laws against lewdness, obscenity, criminal abortion, prostitution and fornication, which laws have for their prime motives the prevention of sex-immorality. 
According to a recent school of advocates of birth control a clean cut separation should be made between birth control and seximmorality, and in consequence the dissemination of instruction in birth control methods, and the manufacture, distribution and sale of mechanical contraceptives be made free from criminal liabilify. Their opponents oppose this proposal, contending that the present laws are based upon the proper foundation, and that birth control teaching and appliances should continue to be classed legally with criminal abortion and obscenity.

\section{a. Review of Criminal Statutes on Birth} Control. Judge J. C. Ruppenthal:

"In the United States, laws relating to birth control seem to have been developed since about 1870. Congress, the legislatures of nineteen states and Porto Rico, and the commission of the Canal Zone, have enacted statutes that clearly and definitely refer to the prevention of conception in women as a practice to be declared a crime by such laws. In Canada, at least Ontario has such a law. Twenty-two more states of the Union, and also Hawail have statutes which the courts, with liberality of construction or strictness, hold to apply or not apply criminally to the matter of birth control, at least through prevention of conception, or "contraception." The District of Columbia, and the states of Rhode Island and Florida have kindred enactments, relating in the states to causing miscarriage of a pregnant woman, and in the District to abortion. Four states, Georgia, New Hampshire, New Mexico, and North Carolina, and also Alaska, appear to have no legislation that either certainly or possibly may be held to apply to birth control. All the forty-nine sets of enactments referred to are found in the statute books under "obscenity" and "offenses against morals," as headings. In most cases the phraseology relating to contraception is found embedded among many clauses relating to pornographic or non-mailable matter, to indecent and immoral printing, writing, painting and the like. Colorado, Indiana and Wyoming mention "self-pollution," and Massachusetts names "self-abuse" along with abortion and prevention of conception.

"Clear and definite laws on contraception are found on the statute books of the states of Arizona, California, Colorado, Connecticut, Idaho, Indiana, Iowa, Kansas, Massachusetts, Minnesota, Montana, New Jersey, N'ew York, North Dakota, Ohio, Oklahoma, Washington and Wyoming-eighteen-as well as Porto Rico, Ontario, the Canal Zone and the United states. The federal laws are quite full in expression, and perhaps served as model for most of the states.

"If a court regards written matter relating to contraception or means to accomplish this, as "obscene, vulgar and indecent," then laws apply also in the states of Alabama, Arkansas, Delaware, Hawail, Illinois, Kentucky, Louisiana, Maine, Maryland, Michigan, Missis- sippi, Missouri, Nebraska, Pennsylvania, Nevada, Oregon, South Carolina, South Dakota, Tennessee, Texas, Utah, Vermont, Virginia, West Virginia and Wisconsin-twenty-five in number. In some states a limitation as "if they manifest a tendency to corrupt the morals of youth," or morals generally.

"'Articles and instruments of immoral use or purpose" are denounced, but no specific purpose or object of such is set out, in the laws of Connecticut, Illinois, Kentucky, Louisiana, Michigan, Mississippi, Missouri, Nebraska, Oregon, Pennsylvania, Rhode Island and Utah. In Maryland 'obscene and indecent' books are mentioned, and 'obscene' matters in South Carolina, with no more specific designation. In Ontario the law very widely includes the assertion or warranty of the offender, as the language is 'any article intended or represented as a means of preventing conception or causing abortion.' To make prosecutions more easy, Idaho provides that the complaint need not set out any portion of the language alleged to have been unlawfully used. To aid in capture of contraband articles, instruments and literature or other things, search warrants or seizure, or both, are authorized in Arizona, California, Colorado, Idaho and Nevada.

"Where advice or information as to abortion is forbidden, though some states, as Minnesota and New York, carefully discriminate against 'unlawful abortion,' others, as Kansas and Iowa, say, 'procuring abortion,' with no intimation that such could, in any case, be lawful. Kansas, however, in another statuteas to manslaughter of a woman pregnant or her child-excepts 'when it shall be necessary to save the life of the mother, and thus inferentially distinguishes acts of two classes.

"While some statutes are word for word alike in several states, most of them vary in scope. Among the forbidden acts, in connection with articles, instruments, books, papers, etc., are to 'exhibit' (United States law and Colorado); 'bring into the state' (Alabama); 'import' (Hawaii); 'buy,' 'sell,' 'lend,' 'keep for sale,' 'have in possession,' (Iowa); 'have in possession with intent to sell,' 'have possession with or without intent to sell' (Indiana); 'advertise,' 'distribute' (New York); 'manufacture (Missouri and New York); 'has possession with intent to utter or express to view or to sell,' 'for gratuitous distribution' (ii Ohio, drug or nostrum; in Kansas, literature) 'conveying notice, hint or reference to, unde: 'real or fictitious name' (Rhode Island); 'give information orally' (New York, Minnesota, In. diana); 'write, compose, or publish' (notice o; advertisement, in Arizona); 'manifesting a tendency to the corruption of the morals of youth or of morals generally,' (Hawaii); 'cautions females against its use when in preg-

${ }^{1}$ Criminal Statutes on Birth Control: J. C. Ruppenthal, Judge of the Twenty-third Judicial District of Kansas; Judge Advocate U. S. Army. Journal of Crim. Law and Criminology, May, 1919, pp. 48-50.

See also: Abstract of the Criminal Laws of the U. S., the Several States thereof, and Canada, Relating to Birth Control. J. C. Ruppenthal, Jour. C
May, 1919, pp. 51-61. 
nancy' (Ohio); 'drug or nostrum purporting to be exclusively for the use of females' (Ohio). To meet the ingenuity of evasive devices, New Jersey includes all persons 'who shall in any manner, by recommendation against its use or otherwise give or cause to be given, or aid in giving any information, how or where any of the (literature, instruments, medicines, etc.) may be had or seen or bought or sold.' Whatever is prohibited directly to anyone is usually expanded in terms to include aiding in any way toward the forbidden end.

"A few exceptions from the sweeping provisions are incorporated. In Ontario the offense must be 'knowingly, without lawful excuse or justiflcation;' in New Jersey, 'without just cause.' In some states the law provides that it 'shall not be construed to affect teaching in medical colleges' (Colorado, Indiana, Ohio); 'nor standard medical books' (Colorado, Indiana, Kansas, Ohio); "nor the practice of regular practitioners of medicine and druggists (Colorado) in their legitimate business' (Ohio); "nor works of scientific character, or on anatomy, surgery or obstetrics' (Kentucky); 'article or instrument used or applied by physicians is not ... indecent.' In Connecticut possession of the things forbidden is unlawful 'unless with intent to aid in their suppression or in enforcing the provisions' of the law.

"Almost everything denounced under any of these laws is non-mailable under the laws of the United States, Colorado, Illinois, Indiana, Iowa, Missouri, Nebraska, Ohio and New York. Delivery of such to express or railroad companies is forbidden by the United States, Illinois, Indiana, and New York. Besides forbidding the deposit of such matters in the mails, Colorado adds or with any person.'

"From the foregoing it may be seen that no general principle runs through the statutes of all the states, etc. As with laws everywhere that impinge upon sex matters in any way, there is more of tabu and superstition in the choice and chance, the selection and caprice, the inclusions and exclusions of these several enactments than any clear, broad, well-defined principle or purpose underlying them. Without such principle, well-defined and generally accepted, the various laws must remain largely haphazard and capricious."

\section{b. Conclusions.}

The dissemination of birth control, so called, instruction, and manufacture, distribution and sale of mechanical contraceptives is in most states prohibited by laws seeking to prevent sex-immorality.

The present anti-birth control criminal laws, which exist in nearly all of the states, are entirely prohibitive or restrictive, and consequently may have worked out in. favor of a higher birth rate.

All good citizens must approve laws which promote public and personal morality and which forbid and destroy obscenity and prostitution, but the present anti-birth control laws, so-called, do not appear to be well designed to accomplish their desired ends.

As a remedy for over-population, which is probably one of the several great causes of modern war, birth control might be effective by decreasing the numbers of citizens in particular nations, but unless such reduction took place where the population pressure was greatest, it would not operate in the desired manner. Moreover, its operation in preventing war would be eugenically equivalent to preventing war by reducing the population of a nation by famine, or pestilence, which strike down individuals and remove them from parenthood, on a basis, for the most part, indifferent to hereditary worth. Overpopulation presents a field for eugenical activity, which calls for building the next generation in numbers equal to the optimum quantitative demand of the nation, and in quality descended from the best blood.

Eugenicists criticise birth control, socalled, because of its shortsightedness in favoring birth restriction principally on an economic basis. . Birth control becomes then, in a sense, an anti-baby strike. Whereas eugenics favors the restriction of reproduction by the hereditarily less able mental, moral and physical parents, but demands a higher birth rate by those parents possessing the soundest hereditary traits. Thus eugenics makes good blood the primary, and present economic status a secondary consideration, because there is no constant and high correlation between economic status and hereditary worth.

From the analysis of the legal situation it is apparent that a state, in the exercise of its undoubted police authority, may enact statutes in reference to birth control information and appliances, and sex-immorality, which statutes influence very greatly the quality and quantity of human reproduction. In the enactment of such laws, however, the state should take care not to substitute the criterion of economic condition in place of that of inborn physical, mental and moral quality, in encouraging and limiting birth rate.

It is doubtful whether the court interpretation of any existing laws would prevent reputable physicians from advising their patients in reference to means of preventing conception, or a standard medical work from publishing facts in reference to the matter. But when birth control is talked and practiced in the spirit of obscenity and lewdness, 
the law would be expected to restrain its perverters.

The legislative and legal world is in need of a new set of guiding principles which shall determine the policy of the state in suppressing obscenity and in regulating birth control information and practice in their relation to the immediate public health and morality and to racial welfare, because the present principles and activities are not duly co-ordinated in the interests of the general welfare.

3. Control of Immigration. ${ }^{1}$ The control of immigration is a matter of the greatest eugenical import, because whenever two races have lived for long periods of time in the same geographical range of personal acquaintances and contact, racial fusion to some extent has resulted. Therefore the laws controlling immigration have indirectly, and often remotely in time, but nevertheless very definitely a strong governing influence upon the quality of human reproduction.

In the United States the authority to control immigration is vested by the Constitution in the Federal government. For the most part present social and economic motives have guided our immigration statutes, but it is undeniably within the power of the Federal government to deny admission to immigrants on the basis of cacogenesis, that is the possession of degenerate or undesirable personal hereditary traits. At present besides limiting immigration annually to 3 per cent of the foreign-born of the United States as shown by the Census of 1910, distributed among the several nations according to their respective quotas, admission is denied certain members of the dependent and defective classes, but the denial of admission is limited to individuals personally defective or degenerates. The matter of pedigree, or blood, which determines the quality of their offspring, has not yet been made a matter of serious legislative concern.

- It is clear that the eugenical principle applied to immigration control would, in substance, read as follows:

Admission as immigrants shall be denied sexually fertile foreigners who, regardless of their personal social adequacy, cannot establish to the satisfaction of definitely established tests and standards, that in each case the would-be immigrant is equal in the natural worth of his or her hereditary mental, physical and temperamental traits, to the standard which the American people are willing to constitute a considerable portion of its future population.

But before such a rule can be enforced, the science of human heredity must make more progress, and above all, must lay down and demonstrate the validity of specific rules for determining breeding quality. Obviously the task of determination in a specific case involves family history study, and is consequently expensive, for such study must be carried out in the home territory of the subject. At first statutes providing for such determinations would, of necessity, have to be experimental, and would apply only to the most patent and easily demonstrated cases; later, as the science of pedigree-study progressed, and the administrative arm of the law became more effective, the statute could be drawn more rigidly.

At present both the United States and many of the several states have laws providing for the deportation of certain individuals who are, or who within a definite period of time following admission become, defective in personality, and who consequently are thrown upon public charity for their maintenance. Many people of this sort, despite the immigration and quarantine restrictions, find their way past the Federal immigration offcials, and settle in different states. The nation deports such persons to the country of origin, while the state may deport only to the state of origin. The present restriction of the migration of degenerates, and the possible future restriction of the immigration of cacogenical persons, tend to throw upon the communities which permit the reproduction of such anti-social persons the responsibility for their care, and thus ultimately is logically to be expected to cause the particular community to seek a more efficient solu-

1 See Annual Report of the CommissionerGeneral of Immigration for year ending June 30, 1919, which gives the immigration data for the first hundred years (1819-1919), during which the United States has kept immigration statistics. Govt. Print. Off.

Also Annual Report of the Commissioner General of Immigration for year ending June 30, 1921: "The Percentum Limit Act" of May 19, 1921, entitled "An Act to limit the immigration of aliens into the United States" as extended by Public Resolution No. 55, 67th Congress, approved May 11, 1922.

Senate Reports of the Immigration Commission presented by Mr. Dillingham, Vols. 1 to 41 (1911). Govt. Print. Off.

The Immigration Problem: Jenks \& Lauck, Funk \& Wagnalls Co., 1917.

Immigration Laws (Act of Feb. 5, 1917) and Rules of May 1, 1917. (Third Edition, March, 1919.) Govt. Print. Off.

Treaty, Laws and Rules Governing Admission of Chinese-Rules of May 1 , 1917. (Second Edition, Nov,, 1917.) Govt. Print. Off. 
tion of its handicap by forbidding certain degenerates to reproduce.

Thus the immigration policy of a nation is inextricably tied up with its etgenical problems, but fortunately no one denies the right of a sovereign nation to control by law and treaty its own emigration and immigration policy.

\section{Institutional Segregation of Social}

\section{Inadequates.}

The state may seek out and segregate ${ }^{1}$ in custodial institutions those individuals of its population who are temporarily or permanently socially inadequate.

But the state finds that the control of the reproduction of certain types of degenerates cannot be effected solely through the control of the marriage relation, because many of the degenerates of the state are not amenable to law-that is, they are anti-social, the marriage laws do not govern their reproduction, hence illegitimacy runs high among them. In such cases the only practicable means of preventing their reproduction is through segregating them in custodial institutions during the reproductive period, or if they remain at large, subjecting them to eugenical sterilization so that they., shall not be physiologically able to reproduce. Both segregation and eugenical sterilization involve the taking away of the personal liberty without the element of punishment, but liberty is nevertheless taken away, just as completely as is done in the case of a criminal who breaks the criminal law and who, by due process of law, is sent to prison. Both in commitment and sterilization the principal motive is the protection of society, the secondary motive the protection of the particular individual. This latter motive is doubtless stronger in commitment than in sterilization. There must, of course, in compulsory vaccination, in quarantine, and in commitment to custodial institutions, as well as in imprisonment for crime, be due process of law. But due process of law in the case of crime always implies court procedure, which in turn implies the right to be heard and the assurance of judgment in accordance with the law and the evidence, whereas in case crime is not involved, but a medical or psychiatric or eugenical situation is found, the state may provide due process of law in another manner. It may delegate the enforcement of the non-punitive types of taking away personal liberty in the interests of the public welfare to ministerial or administra- tive bodies or officers, who are authorized to use their own discretion in each particular case. Such laws, of course, cannot prevent recourse to the courts in case of abuse of power. In the case of these social and therapeutic remedies involving the limitation of personal liberty, the public will co-operate in due proportion to the exigencies of the case and to its enlightenment and patriotism. Thus, in many states, for most of these processes-vaccination, quarantine, commitment to custodial institutions, and eugenical sterilization-the co-operation of the families concerned has been so great that the enforcement of the law has been greatly supported by the voluntary element on the part of the persons directly affected. If in each case the individual resisted as in the case of punishment for crime, these social, therapeutic and eugenical remedies would not have such a bright outlook, nor would their present effectiveness be very great.

\section{a. Quotation from Dr. Henry M. Hurd.}

Dr. Hurd says, ${ }^{2}$ in reference to due process of law in commitment of the insane (Vol. 1 , pp. 335-6):

"Many persons have contended that unless the insane are committed by jury trial, they are restrained of their liberty 'without due process of law, but it has been clearly pointed out by Ordronauz and others that 'due process of law' means the law of the land, so that any law which is properly placed upon the statutes must be considered 'due process of law.'

"In examining the laws of commitment and the procedures under them, I find that in five states of the Union, viz., Colorado, Kentucky, Mississippi, Texas and Wyoming, it is imperative that the commitment of patients shall be after a verdict by a jury.

"In four others, viz., Alabama, Massachusetts, Missouri and Wisconsin, a jury is not

1 See Summaries of State Laws Relating to the Insane: Koren, Familton \& Haber, 1917.

Summaries of State Laws Relating to the Feebie-minded and Fpileptic: Hamilton \& Haber, 1917. Both works published by the $\mathrm{Na-}$ tional Committee for Mental Hygiene, N. $Y$.

Summary of State Laws Relating to Dependent Classes: 1913. U. S. Bureau of Census.

Statistical Directory of State Institutions for Defective, Dependent and Delinquent Classes: II. H. I aughlin, 1919. U. S. Bureau of Census.

Annual Census of the Insane, Feeble-minded, Epileptics and Inebriates in Institutions in the U S.: January 1, 1918. H. M. Pollock, Edith M. Furbush. The National Committee for Mental Hygiene, N. $\mathbf{Y}$.

2 The Institutional Care of the Insane in the United States and Canada. Four Volumes. Johns Hopkins Press, 1916. 
imperative, but may be impaneled at the discretion of the court. In five states, viz., Georgia, Kansas, Maryland, Michigan and Washington, a jury must be impaneled when demanded by the patient or his counsel.

"In one state, Illinois, a jury or a commission must determine the question of insanity and the presence of the insane person in court is at the discretion of the judge.

"In several states, when an appeal is taken from the decision of the judge of probate that a person is insane, the appeal must be tried before a jury.

"In ten states, viz., Iowa, Kansas, Louisiana, Minnesota, Nebraska, North Dakota, Oklahoma, Pennsylvania, South Dakota and Virginia, the question of insanity is determined by a commission-usually a county commission.

"In twenty-four states, viz., Arizona, Arkansas, California, Connecticut, Delaware, District of Columbia, Florida, Idaho, Indiana, Maine, Nevada, New Hampshire, New Jersey, New Mexico, New York, North Carolina, Ohio, Oregon, Rhode Island, South Carolina, Tennessee, Utah, Vermont and West Virginia, no mention of a jury is made in the law."

In the same work (p. 344) in reference to the voluntary admission of patients we read:

"No section of any law seems more vague and lacking in uniformity than that governing the admission of voluntary patients to institutions for the insane, as now found in the statutes of the various states.

"Out of the 48 states and the District of Columbia, the following 17 states and the District of Columbia already have provisions of law permitting the admission of voluntary patients, viz., California, Colorado, Connecticut, District of Columbia, Illinois, Maryland, Massachusetts, Michigan, Minnesota, New Jersey, New York, North Carolina, Ohio, Pennsylvania, Rhode Island, Vermont. Wisconsin and Virginia."

\section{b. Conclusion.}

The state undoubtedly possesses the legal right to enact statutes which provide for the punitive imprisonment of persons convicted of crime, and also the involuntary non-punitive commitment and custody of persons who because of their social inadequacy are unable properly to care for themselves, or are a public menace. The effective institutional custody of a person prevents, of course, parenthood during the period of commit- ment, and to such an extent the state thus exercises, indirectly but surely, a limited legal control over human reproduction.

\section{Eugenical Sterilization.}

Regardless of the virtues and defects of the eugenical sterilization statutes already enacted, and in the absence of specific constitutional denial, legal opinion and judicial decision support the power of a state to resort to compulsory eugenical sterilization, if it so chooses and expresses its choice in welldrawn statutes. Neither analysis nor abstract of the evidence supporting this statement will be given here, because this special phase of the subject was extensively treated in the accompanying chapters. ${ }^{1}$

a. Cases of Eugenical Sterilisation in States Having Neither Authorizing nor Restraining Statutes.

There have been a number of instances in which sexual sterilization has been put into effect for purely eugenical reasons. As a rule, this has been accomplished on the responsibility of a physician, or by the suggestion or at least with the co-operation of the family of the individual sterilized, or in some cases by the action of a court of law. It appears that in 1893 Dr. F. E. Daniel, ${ }^{2}$ of Texas, was one of the earliest of the recent eugenicists to propose sexual sterilization for the purpose of race improvement. Beginning in 1898, Dr. F. Hoyt Pilcher, of the Institution for Feeble-minded Children at Winfield, Kansas, performed a number of operations (58 boys castrated) for avowed eugenical purposes. This aroused considerable opposition, but also brought support to his program. Indeed his trustees, by resolution, formally upheld his work in seeking in this manner to purge the race of certain defective strains.

Dr. Martin W. Barr, Superintendent of the Pennsylvania Training School for Feebleminded, at Elwyn, Pa., and Dr. Everett Flood, Superintendent of the Monson State Hospital for Epileptics at Palmer, Mass., also were early advocates and testers of eugenical

${ }^{1}$ Chapter VI. Analytical Outline of Litigation Growing Out of the Several Sterilization Statutes.

Chapter VII. Detailed Review of Litigation Growing out of the Several Sterilization Statutes.

Chapter IX. Legal Opinion.

: F E Daniel, Pres. State Med. Association of Tex. "Should Insane Criminals, or Sexual Perverts Be Allowed to Procreate?" Medicolegal Journal, Dec., 1893; id., "The Cause and Plevention of Rare." 'Texas Medical Journal, May, 1904. 
'sterilization. In 1899 Dr. H. C. Sharp, surgeon of the Reformatory at Jeffersonville, Indiana, began the operation of vasectomy for purely eugenical purposes. He continued these operations for at least eight years before they were legalized (1907) in Indiana. In the Cantonal Asylum at Wil, ${ }^{1}$ Switzerland, with the consent of the civil authorities, two men and two women were sterilized for purely eugenical purposes. There are doubtless many other instances not here recorded, in which the eugenical principle has either operated independently or has been joined with the therapeutic purpose in determining upon operations which have resulted in sexual sterilization. With the rise of modern studies in human heredity, the possibility of using this remedy for preventing the procreation of certain degenerates has made substantial progress.

The fact that cases of eugenical sterilization have been performed without the sanction of the law, and that no legal recourse was had, nor even desired, nor most probably was possible, points the way for energetic administrative and judicial officers to advance eugenical measures. But a measure so wrought with possibilities for good or for evil and so liable to be perverted in arbitrary, unskillful or designing hands, should be directed and limited by law. It is, however, a wise law that encourages the co-operation of the person designated for eugenical sterilization, and of his or her family in carrying out a legally arrived at decision to sterilize.

A review of two actual cases of eugenical sterilization in states having no statute on the subject follows:

$$
\text { a1. The Case of } M-H \longrightarrow \text { of }
$$
Massachusetts.

This case was reported by Dr. Henry $P$. Frost, Superintendent of the Boston State Hospital for the Insane.

In filing this report Doctor Frost writes: "*** I am sending you an abstract of one of my cases, a man on whom we recently performed vasectomy in the interest of eugenics-a very feeble step in what you and I agree is the right direction * *"."

\section{BRIEF OF VASECTOMY CASE.}

$\mathrm{M}$ - $\mathrm{H}$ - was admitted to the Psychopathic Ward for observation November 13, 1911 (Psyco. No. 546). He was discharged from there and committed to the Boston State Hospita1, November 14, 1911. (Case No. 10302.)
Family History: Shows no history of insanity or alcoholism.

Personal History: Age at admission 42 years. Went to school in Ireland from 6 to 14 years of age, said that all the schoolmasters in Ireland could not put anything into his head. Was in a hospital for insane in Ireland about 17 years ago, for about 18 months. Came to this country at the age of 34 , and married two years later. Is of good habits; a steady worker.

Present Attack: Wife says he has always been as well as at present time, and she considers him in his normal condition. On Sunday while wife was in labor she noticed that he was not right, he sang religious songs, prayed, etc. Exciting cause-pregnancy of wife, who was alone in the house. The patient was alone with wife when babies were born.

Summary of Physical Examination: Tall, middle aged, white, male, emaciated, poorly developed, speech defect, pupils irregular, do not react to light, eyeball prominent and protruding.

Summary of Mental Condition on Admission: Was excited, disturbed, restless, resistive and noisy; religious and exhilarated; appeared confused. Showed loquaciousness and distractability. Orientation and memory unimpaired. Insight, negative. Hears the voice of God and has religious delusions based upon this hallucination which he has had for thirty years. Venereal history, negative. Probably no excessive use of alcohol.

I Sixteenth Annual Report, 1907 (See also "Sterilization of Unfit" by" Havelock Ellis, Eugenics Review, 1909-10. Vol. I, page 203.)

In Switzerland, Swiss Cantonal Asylum at Wil (Berne), there were 4 inmates-2 men, 2 women-mentally abnormal though not insane, and medical authorities wished to discharge them.

(1) Woman, 25 years, epileptic, liable to attacks of insanity. She had had two children who were epileptic idiots and a charge on community. She was strong and anxious to work.

(2) Woman, 36 years, weak-minded with occasional attacks excitement. She had had two illegitimate children, who were charge on community. She was skillful worker.

(3) Man, 31 years, physically well built, psychically a degenerate and frequently coming into conflict with the law.

(4) Man, 32 years, mentally superior but sex pervert, held for offenses againgt minors.

Sex inclination strong, all four.

Municipal authorities opposed to their liberation; four children already had to be provided for; if liberation took place the number could not fail to be increased.

Deadlock! Sterilization by castration the solution eagerly accepted by all. Operated and set at large.

(1) Has been at work ever since and expresses herself as content with her condition.

(2) Able to earn her own living.

(3) Still commits thefts at times but has not been guilty of any sex offenses.

(4) Same condition as No. 3 . 


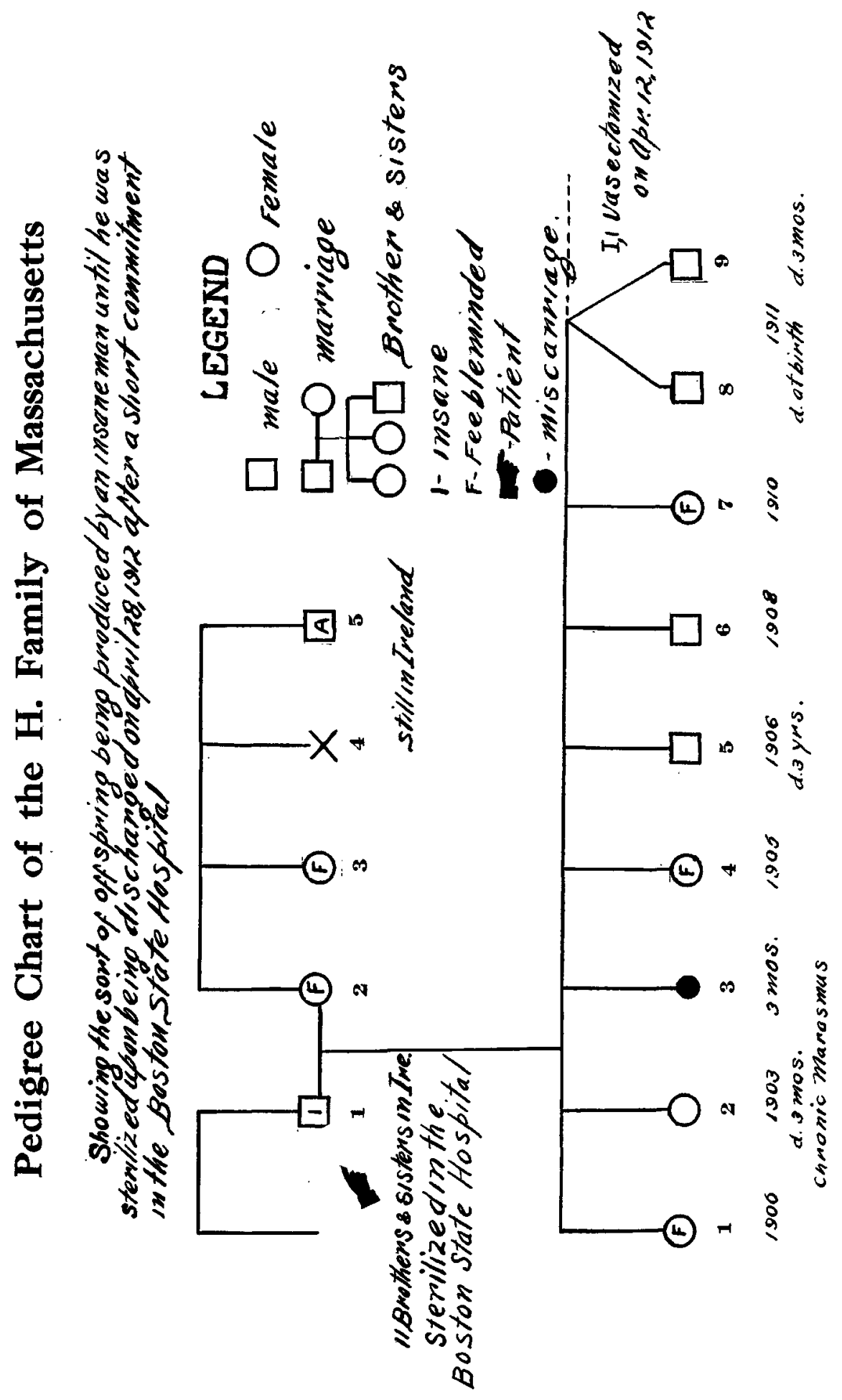


While here he gradually became quiet and tractable and talked relevantly. Was evasive about delusions but probably less prominent than before. Ate and slept well. Conduct and behavior good.

January 22, 19I2. Was presented at the staff meeting for diagnosis and discharge. It was found that he retains the delusions although he is very quiet and has nothing to say about them. The consensus of opinion was that he belonged in the Allied to Manic Depressive classification, and that he probably has never recovered since his early attack 17 years ago; that he is rather below the average naturally. As to his condition if allowed to go home, he would be discharged capable of self-support, as he has been self-supporting nearly all his life. The obstacle to his going is the question of an insane man and a defective woman propagating children and raising a family. No decision was arrived at as to his discharge, but the matter was referred to the social service worker to investigate home conditions and report.

Social Service Report in Brief: Investigation showed:-

Wife of the patient to be of decidedly inferior make-up, but fond of her children and a good mother, keeping them and the house in a clean, orderly condition. Said that they had all the children they could provide for, that she did not want any more, but realized that there would probably be more.

Family History:

\section{Pedigree Chart of H. Family of Mass.}

\section{Children:}

(See Chart on preceding page.)

First, a girl, 11 years of age. Defective, manner silly and nervous. Has been to school for four years and is now in the first grade.

Second, a girl, 8 years of age. Case of retarded development recommended for $\mathrm{Wa}$ verly. Appearance of feebleminded child. Now in kindergarten. At times has been untidy in habits.

Third, a boy, 4 years of age. Of normal mental and physical activity.

Fourth, a girl, 2 years of age. Does not walk or talk yet. Of anaemic appearance.

Fifth and Sixth, twins born just before patient's admission. One died at birth. The other, sickly, died recently.

Three others have died in infancy.

Sources of Family Incone:
Patient has been receiving $\$ 10$ per week for low grade work in a shipping department. Was said to be a steady but not a very intelligent worker. Employers said that he could probably obtain his old position on discharge from the hospital. Mother's entire time taken up with care of children. During patient's residence at the hospital, the family was receiving aid from the church, the city and the Associated Charities. Relatives would not help. It was questionable as to how long outside help would be continued.

Summary of Report:

Mother-inferior, but a good provider and home maker.

Father-insane, but harmless and capable of providing for the family. His wife became pregnant before marriage and they were married in the police station.

Children-two or three defective, one normal.

Subsequently to Report: It was suggested that the patient be sterilized before allowing him to go home, and the matter was proposed to him, also the Physician, Dr. Wornell (city doctor in district of patient's home). The patient did not take kindly to the suggestion, but the doctor thought it would be an excellent idea and agreed to consult with Mrs. $H$. and advise her, if possible, to persuade Mr. H. that it would be the best solution in the case.

About April 9 the patient was visited by wife, and together they consented to vasectomy.

Vasectomy was performed April 18.

The patient went home on trial visit April 28, 1912.

\section{a2. The Case of $X$, of Illinois.}

Another example of eugenical sterilization brought about through the intervention of a State official, this time a judge of a criminal court in a state in which there is no law either directing, authorizing, forbidding or controlling eugenical sterilization, is reported in The Survey (Oct. 28, 1916, p. 78) as follows:

\section{"SENTENCED TO PRISON OR} STERILIZATION.

"One of the most respected and experienced judges in the criminal court at Chicago set a precedent, which is said to be the first of its kind, in giving a prisoner the choice between going to prison for a crime of which he was convicted by a jury or of submitting to sterilization. In offering this alternative from the bench, Judge Marcus 
A. Kavanaugh said to the prisoner, sixtyfive years of age and a married man with children:

"'If I sent you to the penitentiary it means death to you in your present health. At the same time I dare not turn you loose upon the public, for fear this mania with which you seem to be affected may cause you to attempt a similar crime, and then I would be at fault. If you will submit to an operation, with the choice of the best surgeons by next Saturday, I will set aside your sentence. I cannot compel you to submit and you will have a week to think the matter over. If you decide to do this, it will mean that you do not have to begin your sentence of from one to twenty years in the penitentiary.'

"The prisoner subsequently decided to be sterilized.

"In commenting on the case the judge said he presumed he would be criticized for his proposition to the prisoner, but he wished neither to commit him to what really would be a death sentence, nor to expose the public to a repetition of his heinous offenses against little girls.

"'One of my reasons for rendering the decision," he added, "was to draw public attention to a situation which has been disregarded too long. I believe all morons, the criminal insane and habitual criminals, both men and women, should be so treated. To my mind it is a crime against society that this class should be permitted to propagate their kind. As for those who commit outrages against women and female children, I advocate even more drastic measures, which would make repetition of the acts impossible. It is my hope that public interest may be aroused.'"

Under date of June 8,1918 , in response to an inquiry on the part of the Eugenics Record Office, Judge Kavanaugh, responded:

"The case happened over a year ago. The prisoner consented to the operation. It may be that the result was purely psychological, but at any rate it has effected an entire change for the better in his disposition, which after all I think is preferable to sentencing him to the penitentiary. If he had gone to prison he probably would have been released by this time and returned to absolute freeciom with lis evil disposition intensified. While this alternative ought not be offered in every case, still I think that a major operation should accompany every imprisonment of men who commit outrages upon women or children."

\section{b. The Legal Situation in England.}

No one doubts the legality of the power of the British Parliament to enact a statute regulating the use of compulsory eugenical sterilization, and for forbidding the illegal or immoral use of the operation. In the absence of such statutes, the legality of eugenical sterlization would probably depend upon the powers and customs of the Lunacy Commissioners, as supported by their respective County Councils, the volunteer element in securing the coopperation of those to be operated upon, and existing laws gor erning ordinary strrgical operations.

Dr. R. R. Rentoul ${ }^{2}$, of Liverpool, who has made a survey of the eugenical sterilization problem in Great Britain, says:

"b1. Would it be Lawful to Sterilize? This question can best be answered by referring to precedents, etc. As our references refer chiefly to "castration," they may be taken to illustrate the law and custom as it would now beat upon a much less serious operatior. -namely, dividing and ligaturing either the vasa deferentia, spermatic cords, or fallopiar tubes.

"I have elsewhere referred to the making of eunuchs in Old and New Testament times, and to the action of Mohammedan countries; to the legality of our present custom of castrating thousands of animals in the United Kingdom, and to ordinary surgical operations upon the ovaries and testes.

"With reference to the bearing of the English law upon the subject of surgical operations generally, the law provides that nc surgeon is empowered by law to perform any surgical operation upon any person Every operation is legally an assault, and consequently the consent of the patient, or the relatives, or the guardian is secured before operating. The law does not even empower any surgeon to kill the child in the womb with the view of saving the life of the pregnant woman. Sir J. F. Stephen, in his Digest of the Criminal Law, Arts. 204 205 and 206 , says that every person has the right to consent to a surgical operation upon himself, or upon his child; that if the person is incapable of giving consent to a surgical operation, it is not a crime to operate with-

1 Race Culture or Race Suicide: Robert Reid Rentoul, M. D. The Walter Scott Publishing Co., Ltd., 1906. pp. 146-148. 
out consent; that every person has a right to consent to the infliction of bodily harm, not amounting to a maim. He states that castration is a "maim." It follows, I think, that all operations when necessary to the saving of life, or in the improving of the person's health, is a justifiable "maim." Further, I would contend that sterilizing a person so as to save him begetting mental degenerates is a necessary, and therefore, a lawful operation.

"b2. Who Should Operate? No person shotld perform the operation of sterilization for the purpose of preventing the begetting of degenerates, without the official permission of the Lunacy Commissioners of England, Scotland, or Ireland; and the Commissioners should inquire into the history of the person to be operated upon, and take any other step they consider necessary. No person should operate except those specially appointed by the Commissioners. The result of each operation should be communicated to the Commissioners by the person who operated. 'A report containing full and complete details should be laid annually before both Houses of Parliament. If the Lunacy Commissioners refuse to act, then each County Council, through its Asylum Committee, should sanction the operation.

"b3. Penalties for Wrongfully Operating, etc. If any person sterilize any person for the purpose of the prevention of the begetting (or the conceiving) of offspring, without the consent of the Lunacy Commissioners; or if any person operate for any immoral or unlawful purpose; or if any person issue a permit to marry, or join in marriage, or marry any sterilized person without first notifying the fact of sterilization to the nonsterilized person, a penalty of fifteen years' penal servitude should follow conviction in a Court of Law. If a sane husband or sane wife, or the sane man and woman about to become husband and wife, wish to be sterilized, such persons must first obtain the consent of the Lunacy Commissioners."

c. Conclusion: Not only may a state enact statutes authorizing and regulating eugenical sterilization, but in the absence of such statutes, the courts of law and the custodial institutions, by securing the consent of the subjects, may, without legal interference, cause certain of their prisoners and charges to be eugenically sterilized.

\section{POSSIBLE NEW FIELDS FOR EUGENICAL LEGISLATIVE AC - TIVITY.}

Neither the science of eugenics, nor the practical application of eugenical principles to legislation generally, has advanced far enough to warrant the compilation of an eugenical code. But, if in the future eugenical considerations modify legislation in many of its several fields of activity, it is logical to look forward to such a code, comparable, for example, in many respects to the sanitary codes recently compiled and enacted.

While not treating the non-eugenical aspects of the subjects, an eugenical code would over-rule, and in some cases repeal, incidental eugenical provisions in statutes on many widely different subjects, and would systematize the legislation of the state, having for its purpose the conservation and improvement of the natural or hereditary mental, moral and physical constitution of the people. The specific subjects for such treatment, because they have an essential eugenical bearing, are as follows: Marriage and divorce; regulation of the immoral aspect of human reproduction, such as obscenity, lewdness, fornication, prostitution, criminal abortion, and birth control (so-called); illegitimacy; differential taxation in favor of number and quality of children; maternal pensions and aid; institutional segregation-of sexually fertile defectives and inadequates; human pedigreeregistry; immigration; compulsory reporting of cases of cacogenesis; eugenical education, and doubtless many more.

At present legislation on any of the abovenamed topics which does not take into consideration the relation of the specific matter to human reproduction, and consequently to the differential birth-rate which largely determines the future quality of the human stock of the nation, will not function in the greatest interests of the general welfare. Moreover, the nation which by wise legislation conserves its better stock, by directing and encouraging its reproduction along etigenical lines, will stand a better chance of success in future international competition.

Although most of the above-named subjects are themes for future development and legislation, two of them might well be promoted by immediate legislation.

1. Eugenical Education. A state may enact laws providing for eugenical education 
in its schools. Such instruction could be effectively given in the elementary grades in connection with the study of history, geography, nature study and physiology. In the high schools and colleges eugenics. if not made the subject of a separate course, may be successfully treated in courses devoted primarily to biology, physiology, psychology and sociology, economics and statistics. Such instruction, if properly planned, would include, in a manner appropriate to the age and abilities of the students, the facts of human heredity, the relation between hereditary constitution and the success and achievements of the individual and the race, analysis of the factors of heredity and environment, and practical pedigree-studies, also other factors of eugenical import, such as mate selection. differential migration, differential birth-rate, and differential survival.

Logically such instruction would be expected in a generation to react in the demand for and the support of legislation directly ordering eugenical measures. A case in point is the influence of the compulsory teaching of the deleterious effects of alcohol on the human system. Laws providing for full instruction were enacted a generation ago as "sops" to the temperance faction. They have borne fruit today as important factors in the success of constitutional prohibition.

2. Compulsory Reporting of Cases of Cacogenesis. Doubtless a state may legally require licensed charity, social, medical and eugenical field-workers, parole officers, custodial institutions and physicians to report cases of social inadequacy and of defective parenthood. Such legislation would be supplementary to more direct measures which the state may enact to handle such cases after they are reported.

Recent laws of several states, which have been supported by the courts, demonstrate the legal authority of the state to require licensed physicians to report certain diseases. Such authority is justified because its exercise tends toward the betterment of the general welfare, by protecting the people against ill health. By logical analogy the state could expect to exercise, without successful attack in the courts, authority requiring certain licensed social, medical, charity and eugenics workers to report cases of cacogenesis in the interests of protecting the nation against hereditary degeneracy. Such orotection is certainly an essential element in conserving the general welfare.

The United States Public Health Service recently published a bulletin entitled "The Right of the Community to Require Physicians to Report Cases of Disease coming under their Observation, the Purposes thereof and Reasons therefor as stated by Courts of Last Resort." Although laws requiring the notification of cases of disease are of comparatively recent origin, they have been sustained by the courts because they have proven to be effective agencies in protecting the public health, and when properly drawn they do not violate any of the constitutional provisions of the so-called "bill of rights," nor other constitutional limitations upon legislation. Quoting the above-named bulletin:

"The Supreme Court of the United States in Dobbins v. Los Angeles (195 U. S., 223, at p. 235) said:

"It may be admitted that every intendment is to be made in favor of the lawfulness of the exercise of municipal power making regulations to promote the public health and safety, and that it is not the province of courts, except in clear cases, to interfere with the exercise of the power reposed by law in municipal corporations for the protection of local rights and the health and welfare of the people in the community.'

"The opinion of the same court in California Reduction Co. v. Sanitary Works (199 U. S. 306, at p. 318) contains the following statement:

" 'It may be taken as firmly established in the jurisprudence of this court that the States possess, because they have never surrendered, the power-and therefore municipal bodies, under legislative sanction, may exercise the power-to prescribe such regulations as may be reasonable, necessary, and appropriate, for the protection of the public health and comfort. *** Equally well settled is the principle that if a regulation. enacted by competent public authority avowedly for the protection of the public health. has a real, substantial relation to that object. the courts will not strike it down upon grounds merely of public policy or expediency." "

While the law makes it the duty of the licensed physician to report without compensation cases of certain diseases, the physician himself is protected by the law from liability to damage which may grow out of such reporting, even though the report itself 
may later be proven to be based upon false diagnosis. (Brown v. Purdy, 8 N. Y. St. Rep., 143). Quoting further the abovenamed report:

"The leading court decision regarding the reporting of cases by physicians is state $v$. Wordin (56 Conn., 216), which was decided December 1, 1887. In that case a physician was prosecuted for the violation of an ordinance of the city of Bridgeport, Conn., which provided that physicians must report cases of 'infectious or pestilential disease.' The defendant was charged with neglecting to report a case of diphtheria which he attended. He was found guilty and fined.

"He appealed, claiming that the ordinance was inoperative and void because (among other reasons) it was unjust and unreasonable, inasmuch as it took professional knowledge for which it paid nothing, interfered with the physicians' lawful business, and imposed a public burden upon a class.

"The court (Pardee, J) said:

"In conferring authority upon the legislature of the city to pass the ordinance the legislature of the State was in the performance of its duty and in the exercise of its power to protect its citizens from exposure to contagious, fatal diseases.

"Of absolute necessity this power inheres in every organized community; otherwise there would be only organized suicide. It takes unwritten precedence of all provisions for the protection of rights of property and includes the right to require as much of the services or property of each as may be necessary to the preservation of the lives of all, without provision for payment therefor. $* * *$

"Is an ordinance which requires one to lose a small portion of his time that the lives of many may be saved offensive to the constitution? An ordinance requiring the person who in the night season should first discover a dwelling house in the city to be on fire to turn aside and arouse the inmates and sound the alarm without compensation would not shock anyone. Nor, we think, does one requiring the person who first discovers in a crowded street the presence of a contagious, fatal disease to notify without compensation the official charged with the duty of preserving health and protecting life therein. If to compel this gratuitous service is to violate the principles of the social compact, it would be better to dissolve and reorganize. $* * *$

"In his concession that the ordinance would be valid in the ravages of pestilence, under presence of an overwhelming necessity to prevent public calamity, the defend- ant concedes the whole case. An ordinance of this character must be intensely practical; a proper regard for human life demands that a contagious, fatal disease shall be barred rather than driven out.

"The inequality of burden of which the defendant complains is only in seeming Persons offering their services to the public as healers of diseases and requiring pecuniary compensation therefor, thereby assert their ability to detect the presence of it when the great mass of the people can not The people accede to the truth of their assertion, and in the matter of life surren. der themselves to their keeping. Of course an ordinance in the interest of life must detect the presence of a fatal contagious disease at the earliest possible moment. Therefore with impartial action it compels that member of the community who is the first to have sight and knowledge of it to give note of warning to others from whom its presence is hidden. It would be idle to require, indeed there would be danger in accepting, this service from those who can not see or do not know. The burden is made to rest upon every member of the only class which is in a condition to contribute anything to the accomplishment of the purpose of the ordinance."

Conclusion: Judging from the foregoing court decisions sustaining the power of the state to compel physicians, in the interest of the general health of the community, to report cases of communicable diseases, well drawn laws or ordinances requiring medical, social and eugenical field-workers, in the interest of the hereditary soundness of future generations, to report cases of hereditary degeneracy would be upheld.

\section{Registering Trained Eugenical Investi- gators.}

There are several types of social field work now being conducted in the United States. Each type has its own aims, methods and ideals, and requires specific talents and training, and has thus become a specialized occupation. However no state has, as yet, registered or licensed these workers, who, like physicians, come in close contact with families. This contact is engineered entirely by diplomatic skill on the part of the worker. Legal registration would make much simpler the relation between field investigators and the person or family supervised, aided, or studied, and would also insure the public 
against abuse of those confidences which are given to the field investigator.

The legal registration of nurses has proven to be of considerable use to the nurses themselves, to the medical profession. and to the community at large. A similar benefit would be expected to arise from the registration of social workers. At present, and until the several types of social work become still more highly stabilized and professionalized, the general title "registered social worker" should suffice for all types of social workers. In the future perhaps special legal provisions for registration and certification of eugenical field workers will become desirable. Certainly the latter class of investigators constitute a specially trained group of persons, who, in order to do their work effectively, must enjoy certain privileges and must be held to certain responsibilities, especially in the homes of families which have one or more members in a custodial institution of one type or another, and from which the field investigator may be working.

There is also the matter of professional standard to be maintained, and a certain professional contact between field workers and the better and highly talented families. which latter are the subjects of eugenical field investigations quite as often as are degenerates. These constructive studies are, but in another way, just as important to the state as are researches into the family qualities of the socially inadequate.

A bill recently introduced into the legislature of California by Senator Gates is entitled "An act to provide for the examination and registration of social workers, creating an examining body therefor, and providing for an association for registered social workers." This is a general bill which lists the several types of investigations which come under the term "social work." It would doubtless be satisfactory to eugenical investigators to have family history investigations specifically listed as one of the several items under social work, for the purpose of certification and registration. By this bill, it would be illegal for anyone not registered after examination, to describe himself or herself as a "registered social worker." For persons who might do so, the bill provides punishment by fine upon conviction.

There is another aspect of legal registration and certification of field investigators which is quite important. Registration would probably enable the properly trained and certified person to testify in court as an expert in matters involving an analysis of human pedigrees. Honorable Harry Olson, Chief Justice, Municipal Court of Chicago, (November 3, 1921) said, "Field workers will always be permitted to testify as to the facts, but as to the significance of these facts, especially where they involve mental diseases, I think they will never be licensed as physicians are now. Physicians will be called in that field while the eugenical worker will be called only for the facts as investigation has disclosed them, but, of course, the legislature can lay down standards, which when made, would qualify an individual as an expert in that particular field."

In the matter of reporting cases of hereditary degeneracy or cacogenesis, the state would find its system working much more effectively if, besides requiring such reports of licensed physicians, it were to register all types of social investigators, and were to require reports on cacogenesis from them also. The reporting of hereditary degeneracy is as essential an element in purging the state of its degenerate family strains as the compulsory reporting of contagious diseases is a necessary factor in protecting the people of the state from pestilence.

\section{SUMMARY}

1. The doctrine of adequate social remedy.

A living democracy must believe in and exercise the doctrine of adequate social remedies. In the absence of specific constitutional prohibition, the courts have generally sustained the power of the state legislative authority to apply any sound and reasonable social remedy for the general betterment. The principal concern of the courts in such cases has been to prevent violation of the bill of rights, especially undue discrimination or class legislation as it is sometimes called.

\section{The state's control of life and liberty of criminals.}

As just and fitting punishment for crime, the state has always exercised, in the interests of the public welfare, the right not only to take away a person's liberty by imprisonment, but also in extreme cases to take the life of the individual.

\section{Non-punitive control of conduct.}

But the large group of legal, social or therapeutic remedies which impinge upon personal freedom have no element of punishment in them. Among such remedies are 
vaccination, quarantine, commitment to hospitals for the insane, the feeble-minded, and other types of the socially inadequate, and limiting marriage in the interest of normal, healthy and socially valuable offspring.

4. Control of emigration and immigration.

Every sovereign state holds, as an elemental necessary function, the right to decide who of its citizens shall be permitted to leave the country as emigrants, and who among aliens, shall be permitted to enter as visitors or immigrants. This principle bears greatly upon the immediate welfare of the state, but in the long run, if the immigrants be potential parents, it bears vastly more upon the welfare of the state by influencing the character of the inborn qualities of future generations.

\section{Military conscription.}

In demanding military service, the state exercises its undoubted sovereign authority, under the principle that present individual welfare, convenience and personal safety are subordinate to the ultimate common welfare of the nation and state.

\section{Birth-Control.}

The laws governing birth-control in the United States are still chaotic and unharmonized with the protection of public morals and in promoting eugenical welfare. The application of a new legislative and judicial principle is needed in this field. Such a principle calls first, for the control of human reproduction on the basis of encouraging high fertility by sound stock, and forbidding reproduction by degenerate stock, regardless of present economic status; second, the element of the possibility of immorality should be cared for by legal response to the means and spirit exercised in promoting birthcontrol.

\section{Compulsory reporting of hereditary de- generacy.}

Because of the similarity in method and purpose to the compulsory reporting of certain diseases, the state can, if it so desires, require the compulsory reporting of cases of hereditary degeneracy by licensed physicians and professional social field investigators.

It is clear, also, that the state may legally permit private citizens to report cases of apparent or presumed family degeneracy.

\section{Legalized eugenical sterilization.}

Both by many close and logical analogies, and by a few direct and specific eugenical sterilization statutes enacted and tested by the courts, the several states of the American Union are demonstrated to possess the power to enact and to enforce statutes which provide for the destruction of the reproductive powers of individuals, provided such particular measures are designed for and proven to be effective in promoting the soundness of the hereditary physical, mental and moral qualities of future generatons. 


\section{CHAPTER XI.}

\section{EUGENICAL DIAGNOSIS.}

A. Guiding Principles for the Determination of Potential Parenthood of Socially Inadequate Offspring.

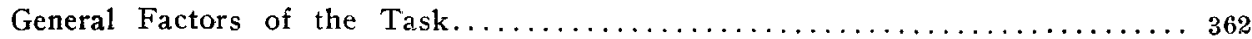

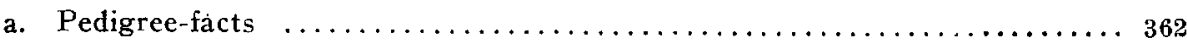

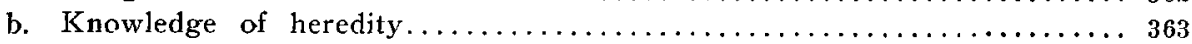

c. Application of pedigree-facts to the rules of heredity $\ldots \ldots \ldots \ldots \ldots \ldots \ldots 363$

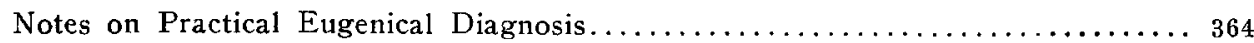

1. Divergence between personal qualities and breeding qualities......... 364

2. The individual of pure stock............................ 364

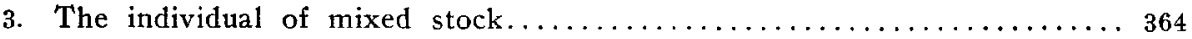

4. Range of individual breeding qualities....................... 365

5. The complexity of hereditary traits or characters $\ldots \ldots \ldots \ldots \ldots \ldots \ldots, 365$

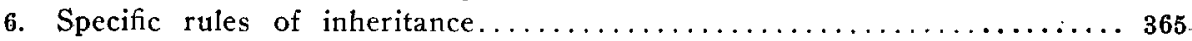

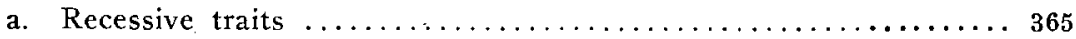

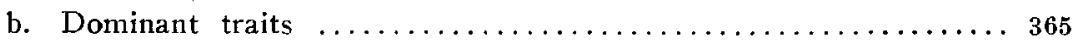

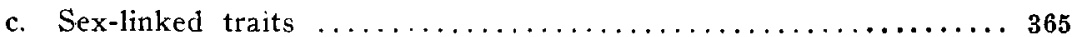

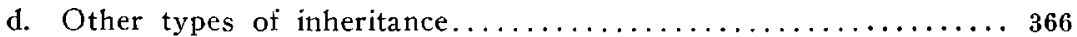

7. Hercditary nature of the co-parent...........................66

8. Eugenical salvage-the separation of good traits from bad in the

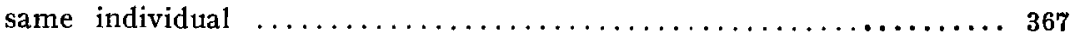

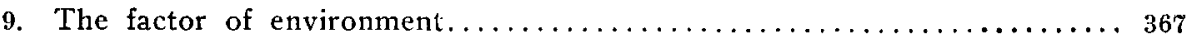

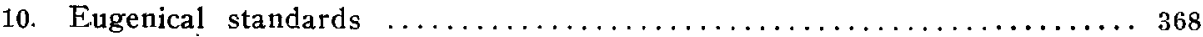

a. The biological standard ............................ 368

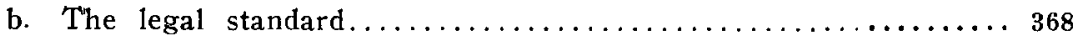

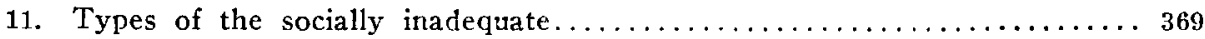

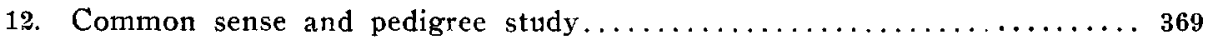

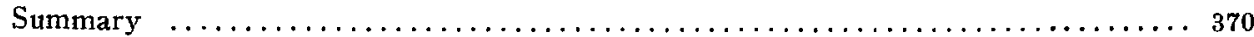

B. List of characters in man classified according to their method of in-

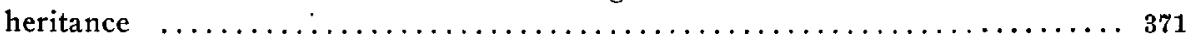

I. Traits which blend in the $F_{i}$ offspring...................... 372

II. Traits showing dominance of one condition and recessiveness of the allelomorph in the first generation and segregation in subsequent generations of off'spring.................... 372

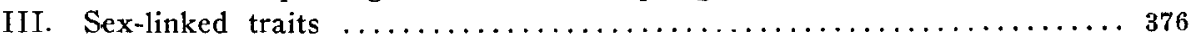

IV. Probably Mendelian, but dominance imperfect or uncertain........... 377

V. Clearly hereditary, but rule of inheritance uncertain............. 377

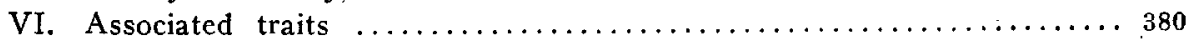

C. Tables showing types of matings and offspring. $\ldots \ldots \ldots \ldots \ldots \ldots \ldots \ldots \ldots \ldots$

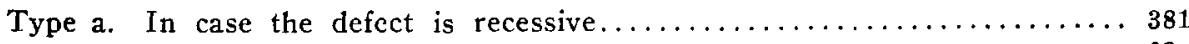

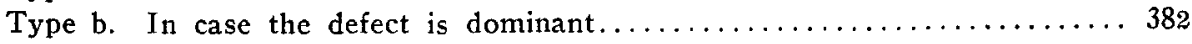

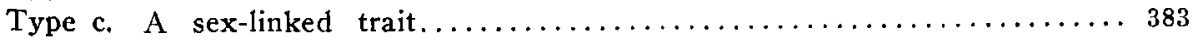

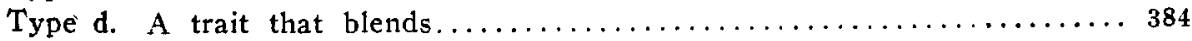

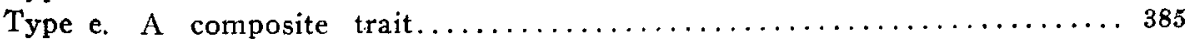

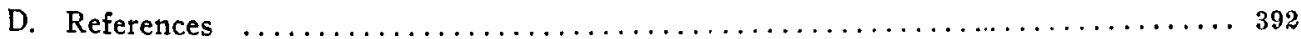

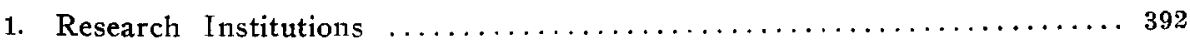

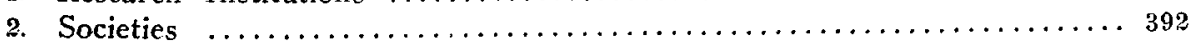

3. Universities and colleges with active departments or genetics.......... 393

4. Custodial institutions for socially inadequate conducting field studies in eugenics..................................... 393

5. Courts which have untertaken scientific eugenical studies............. 394

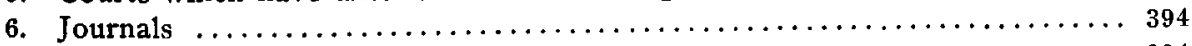

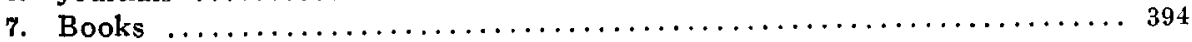


EUGENICAL DIAGNOSIS.

\section{A. GUIDING PRINCIPLES FOR THE DETERMINATION OF POTENTIAL PARENTHOOD OF SOCIALLY IN- ADEQUATE OFFSPRING.}

Eugenical diagnosis is the determination, by case-records and pedigree-analysis, of the mental, physical and temperamental traits which a given potential parent may transmit either patently or latently to his or her possible offspring. Such diagnosis includes not only the determination of the limits and possibilities of quality of a given character. istic, but also must indicate the distribution and combinations of the traits in question among the possible offspring.

Pedigree-analysis is here taken to include also the study of the constitutional makeup of the propositus ${ }^{1}$ because the possession of specific traits by the propositus, when studied in relation to the family distribution of these given qualities, is an important factor in genetical determination.

Eugenical diagnosis is equally useful in the determination of the breeding ${ }^{2}$ qualities of sterling as well as of degenerate individuals. It is clear that the whole task of constructive breeding in man is dependent upon the success of such diagnosis. While not stated in so many words, the principal end of research and the purpose of books and papers on the subject of human heredity is, in its practical aspect, to enable predictions in hereditary behavior to be made.

General Factors of the Task. Eugenical diagnosis is not an exact science like mathematics. nor yet even so exact as astronomy or engineering, but it is a biological science the success of which, in general, depends upon the application of scientific principles, wide experience and common sense. Specifically its operation involves three fundamental factors: first, the pedigree-facts in the particular case: second, the knowledge of rules governing the inheritarce of the traits in question; and third, the scientific skill with which the two foregoing factors are considered in connection with each other.

Parenthetically, it should be here stated that, in practical eugenics, the physician has an important part to play before it is necessary for the eugenicist to act, namely, the physician must determine whether the propositus is a potential parent, that is, sexually fertile now or prospectively. Of course, no individual can be a "potential parent of socially inadequate offspring" unless he or she is first of all a potential parent. If the physician demonstrates that an individual is a potential parent, then the eugenicist must find out whether the possible offspring of the particular propositus would, according to the established pedigree-facts, the laws of heredity, and within the quality and percentage standards set by law, be social inadequates.

(a) Pedigree-facts. It has been demonstrated many times in practical breeding experiments with plants and animals, and in family history study in man, that selection for parenthood on the basis solely of qualities which show in the individual has never resulted in great racial progress. On the other hand, even though the facts of heredity are still imperfectly understood, the selection for parenthood on the basis of both individuality and pedigree has resulted in the last two hundred years in the building up, by the civilized nations of the world, of a wonderfully superior group of highly specialized and highly successful domestic plants and animais.

By pedigree-facts are meant authentic records which describe in detail the specific traits under consideration, and the distribution of these traits among the several members of the family-tree to which the particular propositus belongs. Consorts not bloodkin to the propositus are not to be considered unless such consorts are parents of children who carry blood common with the propositus. To be of practical use, pedigreefacts must be so marshalled that the analyst can by their use trace the descent and recombination of given hereditary traits in the family-tree under consideration.

How to secure adequate pedigree-facts is the first practical problem which the eugenicist meets. It is being solved in the United States at the present time in a satisfactory manner by the training of a corps of professional eugenical field workers. There are now (1922) more than one hundred and fifty such investigators in this country. Their business consists in starting with a given individual, called the propositus; then, after

\footnotetext{
1 For definitions se Chap. XV (p. 446).

"The word "breeding" is an elegant one, and, contrary to a connotation which it conveys to many minds, it is not to be inferred that its use in connection with eugenics is lowering the methods and standards of human reproduction to those of plants and animals. To persons acquainted with the subject, breeding connotes the process of improvement in natural qualities due to careful mate selection.
} 
securing a thorough case-history of this particular individual, and securing records of medical examination, psychiatrical and anthropological tests, the worker goes to the home territory of the propositus. There from first-hand evidence the family connections of the individual are established, and then, in order to present the family relations to the analyst, clearly and conveniently, a family-tree is plotted in pedigree or genealogical fashion. The field worker next proceeds to secure case-histories and biographical records of the various members of the family-tree, with particular emphasis upon those persons closest in blood and kin to the propositus, and upon those traits which are being diagnosed genetically in the propositus.

In this work of establishing kinships and individual relationships, the student of human affairs has an advantage over the plant and animal breeders, for the latter, if exact pedigrees are not kept, except for a few facts of relationship-evidence reconstructible from the evidence furnished by the traits of the individual, loses all hope of restoring them; but in the case of man there are such wide acquaintances and so many records of births, marriages, deaths, and newspaper accounts. church and town records, and often genealogical trees maintained by the family, and in addition the facts of individual traits, that the field worker, if he be a specialist in his work, is in most cases able to restore to a satisfying degree of completeness the family-tree and individual analyses of its several members. It is the experience of field workers that practically all of the custodial institutions, societies for community betterment, and especially child welfare and charities-and-corrections organizations, are particularly anxious to aid the investigators in ferreting out the truth, when sought for the purpose of eugenical diagnosis. Officers of the law also have proven uniformly coopperative. The evidence is that sources of information and social and individual coöperation are abundant to enable the restoration of adequate records of a large percentage of social inadequates who are thought to be cacogenic. The use of these sources and coöperative aids depends upon the skill and diplomacy of the field worker, which is but one reason why the field worker must be especially adapted and trained to the task of gathering first-hand pedigreedata in the field. There are of course some individual cases concerning whom no family connections can be established, but these are surprisingly few in relation to the whole numbers of social inadequates found in American communities and custodial institutions.

Except for the aid of officers of the law and charitable institutions, the method of restoring accurate pedigrees of anti-social and of highly social individuals, or members of the so-called better families, is essentially the same. In both cases the field worker must go to the source of information. Experience has shown that there is not very much difference in the difficulties met in working out these two kinds of pedigrees. If the better families often have more printed records of a genteel nature, such as genealogies, the histories of the more degenerate have, in compensation, records of the courts of law and of aid rendered by individuals and social organizations.

b. Knowledge of Heredity. The second factor, the knowledge of the inheritance of particular traits, is one which is becoming much more exact as time passes. Even now, as a result of eugenical and genetical research, the hereditary formulas for many human traits are known. The promising thing about the situation is that by the modern system of investigation the secrets of nature in reference to human heredity yield themselves readily. We cannot here give an account of all of these investigations. It must therefore suffice to give references ${ }^{1}$ to some of the more important books and papers in which the records of these investigations appear. The eugenicist is an expert legal witness, like the physician and the engineer, and must keep abreast of the times by constant reference to the latest literature and current researches in his profession. The sources of research and record which may be of use to the eugenicist are research institutions, scientific societies, the genetical departments of certain universities, the eugenical departments of certain of the greater custodial institutions for the socially inadequate, and a growing number of books and journals.

c. Application of pedigree-facts to the rules of heredity. The third factor consists

1 A short, practical bibliography covering a few references to this subject of use to the eugenicist appears at the end of the present chapter. In connection with this bibliography there is given also a list of research institutions, university departments, custodial institutions and scientlfic societies which are working on the problems of eugenics and human heredity. 
of the scientific application of the pedigreefacts of the particular case to the demonstrated laws of heredity which govern the particular human qualities in question. Just as the trained eugenical field worker has the task of gathering at first-hand the pedigreematerial, and the investigator the task of analyzing pedigrees for the purpose of deducing the laws of human heredity, the practical eugenicist in a given case has the task of critically and scientifically coördinating the facts presented by the foregoing two types of workers, to the end that a definite eugenical diagnosis or prediction may be made and demonstrated.

Although eugenical diagnosis is made on a purely biological basis, without regard to what the statutory law may set up as the legal eugenical standard, as soon as the biological diagnosis is completed, an application of the demonstrated biological facts to the statutory provisions governing the determination of cacogenesis must be made. The standards of the law are arbitrarily and definitely established, but supposedly reason and logic prevail in their enactment. If in the sum of his hereditary qualities an individual is legally proven to fall below the statutory line or zone of demarcation, such individual may then be legally declared to be a cacogenic person. Thus the eugenicist, so far as law is concerned, is called upon to perform the services of an expert witness, to apply general rules and principles of science to the facts established in the particular case. Upon the expert testimony of this nature should depend the decision of the court whether the particular individual is, as alleged, a cacogenic person in the eyes of the law, and must therefore be sterilized, or whether the individual is not cacogenic, and therefore may not by state order be made sexually sterile.

\section{NOTES ON PRACTICAL EUGENICAL DIAGNOSIS.}

While there is much to be learned concerning human heredity, still science has found out a number of principles which appear to be fundamental in pedigree analysis. These principles and their accompanying explanations which follow may be used as practical guides, so far as such guides are at present possible, in determining the genetic or hereditary make-up of a given individual, and consequently in predicting the hereditary qualities which the person in question will, under given conditions, transmit to his or her offspring

1. The Divergence between personal qualities and breeding qualities. If the resemblance between the breeding qualities of a given individual and his or her personality were exact, there would, of course, be no biological need for genealogical records in man, nor for pedigree-registry associations for domestic animals and plants. The fact that the germ-plasm carried by the individual is not, except in the case of those few who are thoroughly homozygous, or "purebred," an exact reflection of the inborn personal traits, makes the determination of the specific breeding qualities of the selected individual a difficult and complex task, to be achieved only by scientific and painstaking analysis and authentic records. The great problem of the eugenicist, as of the constructive breeder of animals and plants, is to indicate as fit for parenthood those individuals who, regardless of their own personalities, carry in their germ-cells the determiners for desirable physical, mental and temperamental qualities, sufficient in number and quality to insure, with proper mates, socially valuable offspring.

2. The individual of pure stock. Whether a plant, an animal, or a human being, a pure-bred individual is one in which, or in whom, all of the essential breed characteristics are carried in the germ-plasm, and only those qualities which show in the personality of the individual are capable of being transmitted to the offspring of the particular individual. Such purity of blood is obtained, especially among mixed races, only after many generations of prolific breeding properly directed and accompanied by radical culling, and even then, in many of the arbitrarily indicated non-essentials, it is highly probable that even the most pure individuals will be found to be highly complex or mongrel. But relatively speaking the individual of pure stock "breeds true."

3. The individual of mixed stock. A mongrel is an individual generally of an undesirable combination of characters, whose body and personality on the one hand, and whose qualities as a sire or a dam on the other, are far apart. Such a person, animal or plant will not "breed true". In order to determine the breeding qualities of an individual of mixed ancestry, it is all the more necessary to secure and to analyze most carefully accurately kept and extensive pedigree-records. Without 
such records the breeder can only guess concerning the nature of a mongrel's offspring.

4. Range of individual breeding qualities. ${ }^{1}$ The potential parent, whether purebred or mongrel, carries in the germ-plasm and may pass on to his or her offspring the determiners for at least all of the hereditary qualities which show in his or her body and personality, and. in addition, may carry the determiners for many qualities which are not patent in the individual; but not all of these potentialities will necessarily pass to the same offspring. Furthermore, the determiner for given quality may pass to a given offspring. but if it be recessive to its allelomorph, or hereditary complement, which is contributed by the coparent, it will not show in the first generations, and thus may remain submerged for a number of generations, until a favorable mating permits it to become patent.

5. The complexity of hereditary traits or characters. In his constitutionzl make-up, an individual is a composite of hereditary traits. These traits are qualities or characteristics to which we give names. They may be (a) simple natural unit traits, for which the rules of inheritance are very clear; or they may be (b) arbitrary unions associated only in name, in which case they are composed of several genetically independent qualities; or they may be (c) hereditary complexes associated in the germplasm and into each of which in an inseparable manner many hereditary qualities enter. It is highly probable that a large majority of the hereditary traits in man to which we give names are of this latter highly complex nature. There are also doubtless many such natural complexes which are as yet not named.

6.. Specific rules of inheritance. ${ }^{2}$ If a trait possessed by the propositus is a single unit of inheritance, it is a relatively easy task to make an eugenical diagnosis in reference to the capacities and limitations of its possessor in passing it on to his offspring. From the standpoint of the rules of inheritance, there are three principal types of single unit traits. These deserve special consideration because they are representative of the elementary principles underlying the great bulk of natural inheritance. and into such simple behavior entities the science of genetics seeks to analyze the more complex characteristics.

a. Recessive Traits. These characters are called recessive because if an individual possessing one of them is mated with a member of a race not possessing the same character, the trait disappears in the first generation. $\left(\mathrm{F}_{1}\right)$ We shall not here go further into the details of genetics other than to call attention to the fact that a recessive trait may skip one or more generations; that on the average, in mixed stock. a relatively small number of the members of the family are apt to be affected; that affected persons carry the ability to reproduce this particular trait, but not its complement: that a normal member of a family in which the incidence of recessive trait is high may carry a germ-plasm "taint" which can be determined only by many matings, hence with recessive traits there is much more danger of insidiously contaminating the germ-plasm of the family, than is the case with dominant traits; and. finally, if both parents are unaffected and the trait is demonstrably a recessive one, it is sufficient evidence, if it appears in the offspring, that it came from both sides of the house.

b. Dominant Traits. The dominant trait is the complement of the recessive. In a first generation cross between pure races, one of which possesses the trait and the other does not, the dominancy of one of the contrasted traits over its mate is demonstrated by the former's appearance in all of the first generaton $\left(F_{1}\right)$ offspring. Practically a dominant trait is recognized because it behaves as follows: It does not skip a generation; on the average. in mixed stock, a relatively large number of members of the family are affected by it; a person who is free individually from the trait cannot carry the "taint" in his blood, and, therefore, with dominant traits, there is less danger of insidiously contaminating the germ-plasm of the race than is the case with recessive traits.

c. Scx-linked Traits. There are a number of human traits, such as color-blindness and hemophilia, which are dominant in males and recessive in females. Their rule of inheritance is as follows: An affected man may marry a woman of unaffected stock, in which case none of their children will show the trait, and indeed none of the sons will carry it latently in their germ-plasm, but half of the daughters of such a union, while not showing the trait in their bodies, will

\footnotetext{
${ }^{1}$ See pp. 371-380.

2 See Section B of this chapter. A few characters in man classified according to their method of inheritance. Also Tables showing types of matings and offspring.. Section $\mathrm{C}$
} of this chapter. 
possess the potentiality of passing it on to the next generation. If such a "tainted" daughter marries a man who is unaffected, one half of their sons will show the trait personally, the other half will be free from it; while none of their daughters will show the trait, but one half of them will carry it in the same manner as their mother, while the other half will be entirely free from it, both personally and in their hereditary capacities.

If in an exceptional case an affected man marries a woman who carries the trait in her germ-plasm, half of their sons will show the trait like the father, the other half will be free from it. Of their daughters, one half will carry the determiner for the trait in all of their germ-cells, and may or may not be exceptional by showing it in their own bodies. The other half of the daughters will, like the mother, not show the trait, but carry it in half of their germ-cells.

d. Other types of inheritance. The three rules of transmission of unit-traits above described are fundamental in their nature, but in the process of transmission from one generation to another the determiners for these traits often undergo a special series of hazards which destroy the usual simple mathematical calculations known as Mendelism. When such disturbances occur, there are corresponding modifications in the rules of inheritance above outlined. The physical basis ${ }^{1}$ for such changes is found in such phenomena as linkage, crossing-over, interference, non-disjunction, lethal factors, and the like. It is probable also that evolutionary changes both of an advantageous or progressive nature and a disadvantageous or degenerative nature are caused by chemical changes in the germ-plasm (the chromosomes) in the process of transmission from one generation to another. Such changes are known as mutations.

Gradually the laws governing different traits and trait-complexes are being worked out in plants, animals and man. It is necessary in each case not only to know whether the basic element in the character being studied is dominant, recessive or sex-linked, but the diagnostician must also be acquainted with the inheritance of the particular quality as it behaves in the particular family to which the propositus being subjected to eugenical diagnosis belongs.

7. Hereditary nature of the co-parent. In eugenical diagnosis an individual is or is not a potential parent of socially inade- quate offspring, regardless of the hereditary nature of an actual or possible co-parent. A constitutional degenerate will contaminate the race more surely and just as extensively through mating with a sterling as with a mongrel parent, fertility being equal in the two matings. The results of degeneracy may not be so patent in the first generation as when a degenerate mates with a degenerate, nevertheless it can be mathematically and biologically demonstrated that they are just as definite and extensive. A co-parent of good quality may raise the standard of the lower parent in the offspring, but the better qualities are pulled down in accomplishing this mediocre result. While the principles of segregation and recombination of traits insure that, if enough such mediocre families intermarry, hereditary qualities will again segregate themselves into many grades and types of individuals, still such an original mixture is retrogressive from the standpoint of racial progress, because it complicates and delays the centering of degenerate qualities in single individuals, which centering is essential to culling, unless indeed all contaminated as well as all thoroughly degenerate stock is to be denied the privilege of reproduction.

If a potential parent of socially inadequate offspring be already a parent, his or her offspring will serve the useful purpose of aiding eugenical diagnosis of the particular parent, just as in every mating, regardless of its fitness or of the quality of the parents, if children result, their constitutional characters throw light upon the genetic makeup of the parents.

In objecting to the estimation of eugenical values without regard to the nature of the co-parent, it is often pointed out that in domestic animals the pure-sire method, in which the sire is of the desired stock and the dam may be a mongrel, racial progress is very rapid. This is one case in which the analogy between practical animal breeding and practical eugenical processes in the human race does not hold good. If we are to set up different standards of eugenesis for the two sexes, we must as a logical corollary establish a system of polygamy. Moreover the evidence of history shows that in man the so-called pure-sire method of asssimilating a lower race into a higher one

I The Physical Basis of Heredity, by Thomas H. Morgan, gives the latest evidence on the correlation between the behavior of chromatin and of hereditary traits, as they pass from one generation to another. 
has worked out successfully only in nations in which illegitimacy and polygamy are common. In like manner, within the same race, the process of assimilating a lower stock into a higher one by the pure-sire method is not practical in nations in which polygamy and illegitimacy are not permitted, but among whose people the marriage relation is held sacred. It must therefore be universally acknowledged that the eugenesis or cacogenesis of an individual is independent of the nature of the co-parent, although the natural traits of the co-parent throw much light on the unborn qualities of the propositus.

8. Eugenical salvage-the separation of good traits from had in the same individual. Theoretically the unit of eugenesis, and likewise of cacogenesis, is the hereditary unit-quality or trait, becatuse natural hereditary qualities are proven in family history descent to be subject to segregation and recombination. The individual, which in most cases is personally an inseparable complex of good and bad hereditary characteristics, is also an eugenical or cacogenical unit, depending upon the predominance of valuable or degenerate natural traits. Still more extensive than the individual is the family or strain possessing to a large degree the same hereditary constitution. Thus organized society, in seeking to purge the race of its degenerate qualities, would wish. if it were possible, to eliminate only the degenerate traits and to retain the valuable. But practically the law cannot proscribe certain unit-traits in an individual by ordering "that traits ' $a$ ' and ' $b$ ' shall not be permitted to reproduce themselves because they are degenerate, but that the good qualities ' $c$ ' and ' $d$ ', carried by the same individual who possesses ' $a$ ' and ' $b$ ', shall be permitted to reproduce". The process by which traits are carried from generation to generation does not permit so clean-cut a system of segregation. If society is to be extremely radical in its culling system, it may proscribe whole families as comprising stock which is undesirable. But the student of pedigrees has learned that in practical eugenics the unit of selection for reproduction or denial of reproduction is not the trait by itself, nor the family, but the individual. It is thus apparent that eugenical selection must involve the destruction of some good qualities along with the bad in the individual whose descent lines are cut off, but it is fortunate that eugenica! selection does not of necessity involve the eugenical destruction of a whole family because certain of its individuals are proven cacogenic.

This necessity of a clean-cut decision as to whether a given individual, with his whole repertoire of hereditary qualities, good and bad, may be permitted to reproduce, presents one of the most. serious problems to the eugenicist, as it has done in all ages to the constructive breeders of plants and animals. The particular question is always this: We have here a given individual of mixed desirable and degenerate hereditary qualities. In the long run, would the race be better off if this mixed personality be denied the right to reproduce, or are some of his sterling qualities so valuable that the race can well afford to permit him to reproduce, meanwhile trusting to the principle of segregation and recombination of traits in later offspring to concentrate the valuable qualities in one set of inviduals and the degenerate in another? The answer to this problem depends, of course, upon the relative social values of the good and bad in the original mixed personality. It is thus obvious that until the biological sciences of medicine, anthropology and genetics make much more progress, it will be impossible to lay down specific rules for governing the salvage of good hereditary qualities when mixed with bad in the same individual. At present, at one end of the series a person possessed of many valuable traits with but few undesirable ones calls for conservation and reproduction; at the other end of the series an individual characterized by many degenerate qualities with but few good ones calls for denial of reproduction. In the middle of this series there is a wide zone which neither the science of heredity nor the statutory law may as yet succesfully attack. Therefore the law may well refuse, for many years at least, to draw a sharp line cutting this series, in an arbitrary manner, into a cacogenic and an eugenic portion. Both the statute and its practical administration, so far as its application to sterilization is concerned, may well confine their activities to cases of mixed qualities well toward the lower end of the series, becausc in this latter region there are at present in America many cases the eugenical diagnosis and elimination of which will occupy the administrative resources of the country for many years to come.

9. The factor of environment. The physician, the anthropologist, and the psychiatrist in examining the individual, and the 
field worker in the study of the pedigree in the field, have constantly borne in upon them the necessity of separating, so far as possible, the factors of heredity and environment, in determining the causes of the character and condition of the particular individual. If this separation cannot be accomplished, then neither sociology on the one hand nor eugenics on the other can claim to be sciences. Eugenics applies to those hereditary constitutional qualities which determine the fundamental limitations and capacities of the individual. In this science as in all others, successful measurement and prediction are the criteria of practical worth. If by the study of authentic pedigrees and life histories eugenics can, to a definite degree, predict the hereditary nature of the offspring of a given person, then to just such degree is etgenical diagnosis a science.

It serves no good purpose, either to the student of heredity or of environment, to claim extraordinary potency of the particular factor which the given student represents. The first task in eugenical diagnosis, as in most of the studies of human nature, is to separate the factors of heredity and environment. Some of the clearest demonstrations of the necessity for such separation are shown in the pedigrees of persons who are diagnosed as insane. There are many persons who break down with insanity of one type or another, who their physicians declare would not have broken down had their surroundings been different, that is, had they been subjected to different istresses of life. Thus the environmental factor is equally important with the hereditary. In this case it is not the insanity, but the predisposition to it. that is inherited. Field workers report families in which there is a high incidence of a given type of insanity, and among the members of such families it is quite common to have stresses which seem most trivial given as the exciting cause in their families. On the other hand, in families in which the incidence of the mental disease is very low and the type not serious, - oftentimes a most formidable array of exciting causes is necessary in order to break down those who are potentially insane.

The task of separating the hereditary and environmental factors is difficult, but unless it be clearly accomplished, it is impossible to achieve a definite prediction concerning the hereditary potentiality of a given individual.

\section{Eugenical standards.}

(a) The biological standard. The biological standard, below which an individual falling would be classed as uneugenical because of his hereditary potentialities, is an ideal one toward which the eliminative processes of eugenics must tend if they would ultimately, achieve a purging of the race of its degenerate qualities. These biological standards are not subject to arbitrary shifting by legislation, but are determined by the practical working out of those biological laws which govern the inheritance of natural traits, and of those laws which in the social organism control mate-selection, including the differential marriage rate among individuals of varying natural social adequacy, also those biologital laws which govern differential fecundity and survival.

(b) The legal standard. But besides the theoretical eugenical standard, there must for practical purposes be a legal standard for the guidance of administrative officers in selecting individuals for the purpose of denying them the right of parenthood. 1t is clear that the legal standard must be low enough to exclude from its scope individuals of doubtful eugenical value." This exclusion should be maintained until both the science of heredity and practical etgenical administration have made considerable further advance. $B$ ut the present legal standard must nevertheless be a definite one, even if it be neither ideal nor flexible enough to fit every case. A parallel case is that of the law in placing the age of criminal responsibility at seven years. In so doing it may in some cases rate an individual as responsible who, though many years older than seven, is in fact not responsible; whereas it may exclude from responsibility an individual of five or six who by the best psychological tests may prove to be morally responsible. Until the criteria for determining moral responsibility are definitely set forth by psychologists, in rules which the law may incorporate, the best the law can do is to set forth this low arbitrary standard.

The law must first of all be practical. It must also take cognizance of advance in science, and when possible establish a flexible standard which will lend itself to adjustment to fit the facts of as many cases as possible. In the Model Law as drafted, and reported in Chapter $X V$ of this book, the standard of cacogenesis is placed low, and is as flexible as the existing knowledge of heredity will permit, so that neither individ- 
ual injustice nor social injury can be wrought by its application. With the advance of knowledge and increased experience in eugenical diagnosis and court procedure, the legal standard of cacogenesis may be both raised and made to fit more exactly a still greater percentage of the cases.

11. Types of the socially inadequate. If an individual, regardless of his hereditary constitution, could by proper training be made to serve some valuable social function and thus to contribute in some manner to the common weal, there could be no object in negative eugenics or the denial of parenthood to certain individuals, in which case eugenics would have to confine its activities to securing fit matings among its better classes. But as modern society is organized, it has to take cognizance of many individuals who, on account of defective or handicapping inheritance, or other msfortune, are unable, despite training, to maintain themselves without much social direction and help. They thus constitute a handicap to the well-being of the body politic. Specifically these social inadequates may be classed as follows:-(1) Feeble-minded; (2) Insane (including the psychopathic); (3) Criminalistic (incl. the delinquent and wayward); (4) Epileptic; (5) Inebriate (including drug habitués); (6) Diseased (including the tuberculous, the syphilitic, the leprous, and others with chronic infectious and legally segregable diseases); (7) Blind (including those with seriously impaired vision); (8) Deaf (including those with seriously impaired hearing); (9) Deformed (including the crippled); and (10) Dependent (including orphans, ne'er-do-wells, the homeless, tramps and paupers).

But it must not be thought that every member of these classes of social inadequates is such because of defective heredity. Only those individuals who, after their cases have been medically and socially diagnosed and the factors of heredity and environment duly analyzed, are shown to belong to their particular inadequate groups primarily bebecause of defective heredity, are to be rated as cacogenic. An individual who loses his sight as the result of a gun-shot wound may be of the greatest eugenical value to the state. On the other hand, an individual, though he may possess vision to a fair degree, may carry in his germ-cells the determiners for hereditary eye defect, so that if the greatest interests of the race were to be served, this individual would be denied the right of reproduction. Thê same difference persists throughout all of these groups. Doubtless in the feeble-minded class the factor of environment will be found to play a relatively small part. In insanity, epilepsy and deformity, it doubtless plays a greater part, but the problem consists not in weighing one class against another, but in each particular case in determining the hereditary factor and in diagnosing the genetical properties of its possessor.

12. Common sense and pedigree study. In the practical application of all sciences to human affairs, common sense as well as technical rules must be brought into play. After all has been said and done, the eugenicist when gauging the hereditary qualities of an individual, and applying the pedigreefacts and the demonstrated rules of inheritance to the particular case, must, besides using the plainly demonstrated rules, use judgment and common sense. The whole personality of the several members of the family-tree must be gauged and the results of such gauging must be applied in the final estimate.

Dr. H. B. Webster, of Castine, Maine, in depositing with the Eugenics Record Office the pedigree-description ${ }^{1}$ of a certain antisocial family consisting of 77 members, wrote:

"The data collected convinced me that further progeny of this breed is undesirable. In one instance (Pedigree Reference IV, 9), I have obtained consent to sterilization, on eugenic as well as personal grounds. This instance may help to combat the argument that sterilization of the defective is necessarily a cruel and unjustifiable requirement to demand of them in return for the protection and support which they obtain either by public charity, or private beneficence and tolerance.

"It is a sound eugenic tenet, that normal persons owe a debt to the community that can only be discharged by the breeding and rearing of another generation as desirable as themselves. Conversely, those defectives who are practically certain to breed principally defectives, owe a debt to the community that can be discharged only by an adequate guarantee that they shall not contribute to the next generation."

These conclusions were based upon a careful study of a compact family groupgrandparents, parents, uncles and aunts, brothers and sisters, cousins, and children. The investigator reviewed the life history

1 E. R. O. files, V. C. 11, p. 1-28, Jan., 1916. 
of each member of the group, and also made an analysis of the natural traits of each. His testimony concerning the "stock" represented by this particular family is therefore worth considering.

Commonly the physician, in rating the part that heredity is apt to play in causing a given trait or disease to appear in a certain individual, counts the total number of known kin of the patient, then counts the number of such kin who are characterized by the given trait, and divides the former number in the latter to secure a percentage or chance of incidence. According to the laws of probability, his method throws some light upon the situation, but it is not so illuminating as the method of the geneticist, who applies the demonstrated laws of heredity to the pedigree in an attempt to diagnose the hereditary make-up of the particular person. The method of the physician is valuable, but it by no means exhausts the resources accessible in such cases. Life insurance is a sound business and a sound science, and it is based upon chance of occurrence calculated in much the same manner that the physician calculates chance of incidence. This soundness is, however, based upon a wide margin of safety. If similar rules are to be applied in eugenical diagnosis, then the standard of cacogenesis must be very low indeed. It can be raised safely only by the application of genetical analysis in addition to demographic percentages.

In the case of Alice Smith, who was the subject of the test case of the eugenical sterilization law in New Jersey, the student in studying the pedigree-chart (see p. 292), and who is acquainted with the general principles of human heredity and of pedigree-selection generally in plants and animals, would not here render a judgment solely upon the basis of an exact and technical application of rules, although such application could be made; but the final judgment of degeneracy is rendered because of the persistence throughout the pedigree of degenerate human qualities from which the race must purge itself, if it is to endure. This particular person is one well toward the lower end of the series, if one arranges the personalities-complex of the American people in order of social value. She is not a borderline case presenting necessity for niceties of differential diagnosis.

Thus it seems clear that, in selecting for sterilization, the entire repertoire of heredi- tary qualities must be rated as a whole. If in the personalities of a majority of the near kin of a degenerate propositus there is a similar lack of natural value, it is, as demonstrated by many pedigree-studies, highly improbable that, in the absence of out-mating, socially valuable natural qualities would ever appear in the offspring of the propositus.

It is pertinent here to make reference to the experience of practical plant and animal breeders. Those breeders who have been most successful in improving their respective stocks have been idealists, but they have also been noted as men of sound judgment. They possessed, besides the ability to rate the qualities of an individual, that sound judgment which enabled them, by pedigree-analyses, to estimate the breeding qualities of selected individuals.

Similarly if the physician depended entirely upon hard and fast rules in diagnosis and treatment, doubtless his efforts would be of but little practical use in treating human disease. The ability to weigh symptoms and to exercise sound judgment and common sense in diagnosis enables the physician to apply also those facts and principles which medical science has so laboriously worked out.

The eugenicist, in predicting the nature of the hereditary traits which a given individual will pass on to his offspring, gains efficiency by experience to the same degree that the engineer or physician improves in expertness with training and experience. The eugenicist who has seen and andlyzed pedigrees of the particular trait or complex of traits, which he is called upon to diagnose eugenically in a given individual, stands a much better chance of making a correct diagnosis than does the analyst whose work is based upon theory alone.

\section{SUMMARY.}

1. In the administration of the eugenical sterilization laws, the task of the eugenicist is not to diagnose an individual as insane, feeble-minded, blind, or dependent-the physician, the psychologist, and the social worker do that - but it is to study the casehistory and records which the physician, psychologist and social worker provide, and then to secure, through the services of trained eugenical field workers, the pedigree and family histories of the persons alleged to be cacogenic, and finally, to determine, by applying the laws of heredity to the pedigree-fatts and family history rec 
ords, the quality of the traits of instinct, of mentality, or of physical structure, which the propositus will transmit within a definite percent-ratio to his or her offspring. In the eyes of the law the eugenicist is thus called upon to perform the function of expert witness.

2. It devolves upon the courts of law to apply, in particular cases, the determinations of the eugenicist to the standards established by the eugenical sterilization statutes.

3. The present low standards of eugenical adequacy, which characterize most of the existing sterilization statutes, render the determination of legal cacogenesis a task well within the bounds of feasibility.

4. As in the limitaton of marriage on account of hereditary degeneracy, so in eugenical sterilization, the legal standards of cacogenesis are very low. This is justified because the determination of the exact line between degeneracy and normality is very difficult to ascertain. As the science of eugenics advances, it will be possible, in keeping with the assurance of justice and general welfare, to raise both these legal and the bioligical standards.

5. At present modern pedigree analysis, as conducted by students of human heredity, offers the most satisfactory method for the definite determination of hereditary unfitness.

\section{B. LIST OF CHARACTERS IN MAN} CLASSIFIED A C CORDING TO THEIR METHOD OF INHERITANCE, AND LISTED REGARDLESS OF THEIR PERSONAL OR RACIAL VALUES. JANUARY 1, 1922.

In his constitutional make-up, man is a composite of hereditary traits. On analysis these traits are found to follow several different rules of inheritance. A few of these rules have been determined and formulated. Research continues, and slowly but surely new methods of inheritance are being found out, and additional specific qualities are being shown to follow one or the other method of transmission from parent to offspring.

It should here be emphasized that, in practical eugenical studies, those individuals who are of so unworthy or degenerate a type as to merit the denial of reproduction, in the interests of race conservation, generally show a number of specific traits which are undesirable. In these cases, in addition to demonstrating the possession of a specific genetic unity selected from the degenerate qualities of the accompanying list of good and bad traits, the high incidence of general shiftlessness, anti-social conduct and uneducability in the family is evidence of a practical nature which must weigh very heavily in determining potential parenthood of socially inadequate offspring. Thus the general social value of the "stock" from which an individual springs is practical evidence which, while not conclusive, cannot be ignored in rating the potential parenthood of socially inadequate offspring of a given person.

\section{Traits.}

Most, of the traits here listed are of no concern in the practical application of eugenical sterilization but they are of immense importance as eugenical factors in mate selection. It is not claimed that the list here presented is exhaustive. In the Trait Book (Bulletin No. 6 of the Eugenics Record Office by Charles B. Davenport) over 6,000 definite human qualities are named, but the science of human genetics is still new so that only a relatively few hereditary human traits have been listed, and definite rules of inheritance have been worked out for still fewer.

There are four published tables or lists of hereditary traits in man, recently compiled and classified on the basis of method of inheritance.

They are:

(a) The Inheritance of Family Traits, Chapter III, Heredity in Relation to Eugenics, by Chas. B. Davenport, 1911.

(b) Mendelian Heredity in Man, by Major C. C. Hurst, F. L. S., The Eugenics Review, Vol. IV, April, 1912, pp. 1-15.

c) Mendelian Inheritance in Man, (p. 301304, 2nd Ad.), Heredity and Environment in the Development of Men, by Edwin Grant Conklin, 1917.

(d) Inherited Characters in Man (table 33, pp. 240-241. Genetics and Eugenics, by W. E. Castle, 1916.

These lists have been drawn upon in preparing the present tables, but in each case credit has been given the source used. The "name and page" in the accompanying references refer to the titles just quoted, but in most cases the references given are to the source paper of the original investigator.

"Bul." refers to the Bulletins of the Eugenics Record Office.

"Carnegie" refers to the publications of the Carnegie Institution of Washington.

Credit is due Dr. Frederick L. Reichert, Miss Alice M. Hellmer and Miss Mabel L. Earle for assistance in compiling the accompanying revised lists. 


\section{HUMAN TRAITS WHICH HAVE BEEN SHOWN TO FOLLOW DEFINITE RULES OF INHERITANCE.}

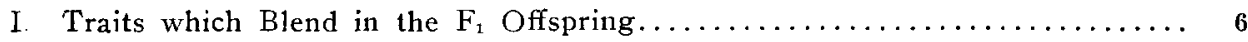

II. Traits which show Dominance or Recessiveness to the Normal Condition in the

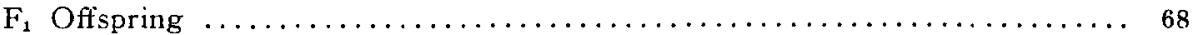

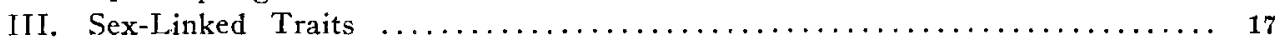

IV. Frobably Mendelian, but Dominance Imperfect or Uncertain............ 16

V. Clearly Hereditary, but Rules of Inheritance Uncertain............... 53

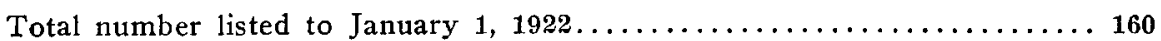

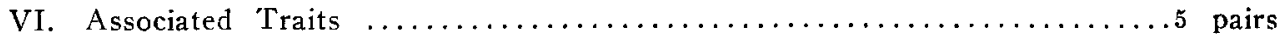

\section{Traits which Blend in the $F_{1}$ Offspring.}

1. General body size

2. Stature

3. Weight

4. Black skin color $\dagger$

5. Hair-form (round vs. flat in cross section) $\dagger$

6. Shape of head (round vs. long) $\dagger$

\author{
Reference \\ Castle $^{1}$ (p. 240) \\ Davenport (Bul. No. 18) E. R. O." \\ Castle (p. 240) \\ Davenport (Carnegie" No, 188) \\ Castle (p. 240) \\ Castle (p. 240)
}

It is possible for such traits to show segregation in subsequent generations, but it is probable that a majority of blending traits in man are polygenic in nature, behaving like the inheritance of skin-color in negro-white crosses.

II. Traits Showing Dominance of One Condition and Recessiveness of its Allelomorph in the First $\left(F_{1}\right)$ Generation of Offspring, and Segregation in the Second $\left(F_{2}\right)$ and Subsequent Generations of Offspring.

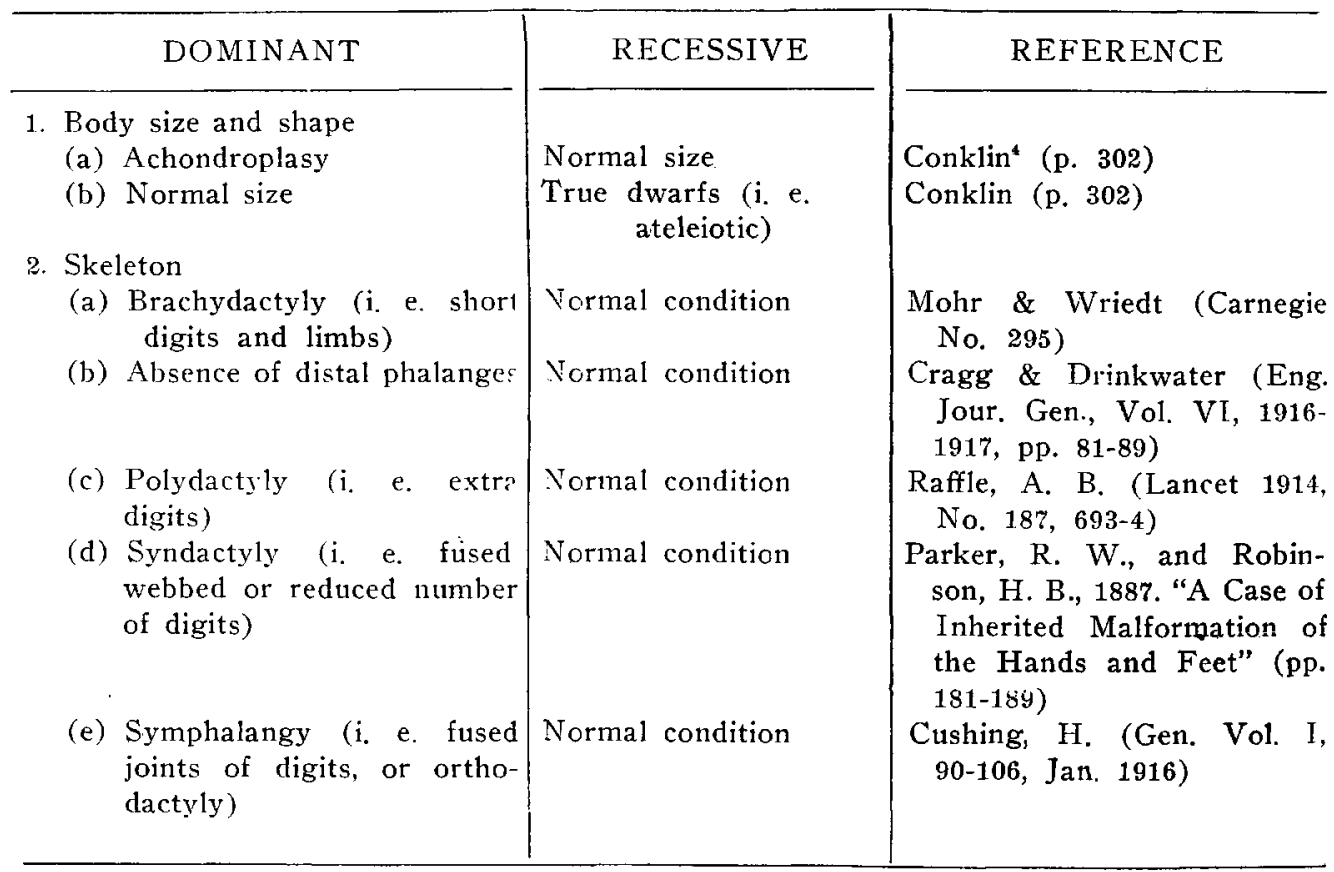

$\uparrow$ Method of inheritance not agreed upon by all investigators.

1 Castle, W. E. Genetics and Eugenics, 1916.

2 E. R. O. E'ugenics Record Office.

${ }^{s}$ Publications of the Carnegie Institution of Washington.

4 Conklin, E. G. Heredity and Environment (Revised Edition), 1916. 


\section{DOMINANT}

(f) Exostoses (i. e. abnormal outgrowths of long bones)

(g) Osteopsathyrosis (i. e. fragility of bones)

(h) Double-jointedness

(i) Radio-ulnar Synarthrosis

(j) Head form:Brachycephaly

3. Countenance

(a) Hapsburg lip

(b) Non-Jewish facial type

4. Skin
(a) Pale thick skin
(b) Brunet complexion $\dagger$

(c) Intermediate $\dagger$

(d) Normal pigmentation

(e) Spotted white (Vitiligo)

(f) Tylosis palmae et plantae

(g) Epidermolysis (i. e. excessive formation of blisters )

(h) Congenital hypertrichosis

(i) Hypotrichosis (i. e. hairlessness, associated with lack of teeth)

(j) Immunity to Poison Ivy† (Rhus toxicodendron)

(k) Ectodermal abnormalities (skin thickening, nail marking)

\begin{tabular}{|c|c|}
\hline RECESSIVE & REFERENCE \\
\hline Normal condition & $\begin{array}{l}\text { Teissier, P., and Denechan, } \\
\text { "Un cas d'exostoses osteo- } \\
\text { geniques multiples here- } \\
\text { didaires et familiales" (Bull. } \\
\text { et mem. soc. med. d'hop. de } \\
\text { Paris, 1905. 3s., XXII, pp. } \\
647-650 \text { ) }\end{array}$ \\
\hline
\end{tabular}

Normal condition

Atherton, A., 1894. "Case of Inherited Fragility of Bones" (Dominion Med. Monthly ii., pp. 1-3)

Normal condition

Dobell, Horace, 1863. "A Contribution to the Natural $\mathrm{H}$ istory of Hereditary Transmission" (Med. Chir. Trans. Lond. XLVI. pp. 25 to 28)

Vormal condition

Dolichocephaly

Normal

Tewish facial type

Colored thin skin

Intermediate and blond Davenport, Taylor, Nelson (E. R. O. Files)

Frets, G. P. "Heredity of Headform in Man," 1921 (pp. 59-61)

Woods, F. A. "Mental and Moral Heredity in Royalty" (pp. 187-189)

Coxe (Austria, 1820, Vol. I, p. 297)

Salaman (Jour. Genet., vol. 1., 1910-1911, p. 273-292) (Eug. Rev., vol. III, 191112, pp. 187-200)

Hurst, C. C. (Eug. Rev,, 191213, vol. IV, p. 14)

Davenport, Chas B. (Am. Naturalist, 1910, vol. XLIV, pp. 641-672)

Blond complexion

Albinism

Uniformly colored

Normal condition

Normal condition

Normal condition

Normal condition

Susceptibility to Poison Ivy

Normal condition
Hurst, C. C. (Eug. Rev., vol. IV, 1912, p. 13)

Stelwagon $^{1}$ (p. 638)

Stelwagon (p. 642)

Stelwagon (p. 555)

Stelwagon (p. 400)

Stelwagon (p, 1013)

Hyde, J. N. (Jour. Cut. Dis., 1909, XXVII, pp. 6-7)

Eugenics Record Office Files

Fisher, H., University Skin Clinic, Koeln, Germany (Dermat. Zeitschrift, vol. XXXII, pp. 114-142) 


\begin{tabular}{l} 
DOMINANT \\
\hline 5. Hair \\
A. Color \\
(a) White forelock \\
(b) Dark brown \\
(c) Black \\
(d) Canities (i. e. patchy gray- \\
ing of hair) \\
B. Cross Section \\
(a) Curly (i. e. flat in cross \\
section) \\
(b) Beaded (i. e. cross section \\
not uniform, or "monile- \\
thrix") \\
(c) Digital hair
\end{tabular}

6. Eyes

(a) Front of iris pigmented (i. e. brown or black eye)

(b) Hereditary cataract

(c) Glaucoma (internal pressure and swelling of eye-ball)

(d) Ectopia lentis (displaced lens)
(c. Retinitis pigmentosa (i. e. pigmentary degeneration of the retina)

(f) Congenital Aphakia

(g) Congenital Ptosis

7. Ears

(a) Normal condition

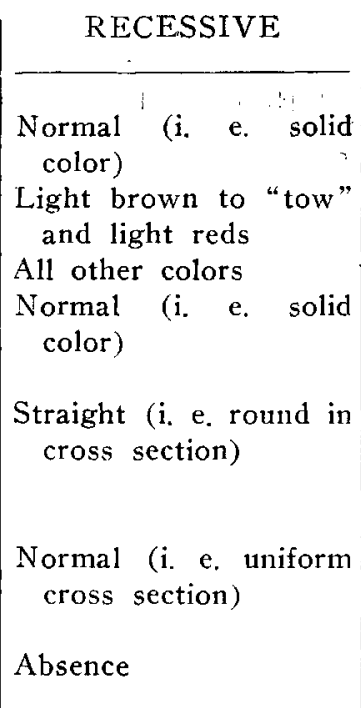

Only back of iris pigmented (blue eye)

Normal condition

Normal condition

Normal condition

Normal condition f

Normal condition

Normal condition

Deaf-mutism
REFERENCE.

Miller, N. (Jour. of Hered., 1915, vol. VI, pp. 165-169)

Conklin (p. 301)

Morgan (Brit. Med. Jour., 1890 , ii, p. 85)

Davenport, G. C. \& C. B. Heredity of Hair-form in Man" (Am. Naturalist, 1908, bs, XII, pp. 11-13)

Dtto. (pp. 138-139)

Danforth, C. H. (Am. Jour. of Phys. Anthropology, Sept. 1921)

Davenport, G. C. \& C. B (Science, N. S. XXVI, 1907, pp. 589-592

Nettleship, E., 1905. "One Heredity in the Various forms of Cataract" (Rep. Roy. Lond. Ophth. Hosp., v. 16, p. 1)

Howe, L., 1887. "A Family History of Blindness from Glaucoma" (A r ch. of Ophth., N. Y., XVI, p. 72-76)

Lewis, G. G., 1904. "Hereditary Ectopia Lentis with Report of Cases." (Arch. of Ophthal. XXXIII, No. 3 , p. 275)

Nettleship, E., 1906. "On Retinitis Pigmentosa and Allied Diseases." (Rep. Roy. Lond. Ophth. Hosp., v. 17, pts. I, II and III.)

Jones, Ralph R., Toms River, N. J. (E. R. O. files)

Briggs, H. H. (Tr. Am. Oph. Soc. 1918, XVI, pp. 255-276) Oph. Soc. 1918, XVI, pp. 255-276

(Also Am. Jour. of Ophth. 1919, 3s, ii, pp. 308-417)

St. Hilaire, E., 1900. (La surdimutite)

Politzer, A., 1907. (Geschichte der Ohrenheilkunde) 


\section{DOMINANT}

(b) Normal condition

8. Intellectual capacity $\dagger$
(a) Average
(b) Average

9. Temperament
(a) Feebly-inhibited (Hyper- kinetic)

10. Special talents
(a) Non-musical
(b) Non-artistic

11. Right-handedness

Nervots system
(a) Huntington's Chorea
(b) Muscular atrophy (i. e. pro- gressive neural muscular atrophy)
(c) Normal condition -
(d) Normal condition

(e) Normal condition

(f) Normal condition

(g) Normal condition

(h) Normal condition

(i) Normal condition

(j) Normal condition

(k) Normal condition

(l) Normal condition

\begin{tabular}{|c|} 
RECESSIVE \\
Otosclerosis \\
Very great ("genius") \\
Very small (see also \\
"Nervous System) \\
Over-inhibited (Hypo- \\
kinetic)
\end{tabular}

Musical

Artistic Left-h̆̈ndedness
ambidexterity†)

(and

Normal condition

Normal condition

Idiopathic epilepsy

Constitutional feeblemindedness

Manic depressive insanity

Dementia praecox

Paranoia

Involutional melancholia

Alcoholism

Hysteria

Friedrich's ataxia

Meniere's disease
REFERENCE

Lucae, A., 1907, "Die Chronische Progressive Schwerhoerigkeit"

Hammerschlag, V., 1905, "Zur Frage der Vererbbarkeit der Otosklerose"

Conklin (p. 301)

Conklin (p. 301)

Kraepelin, 1899, "Psychiatry." Raecke, 1903, "Transitorische Bewusstseinsstörungen der Epileptiker"

Ribot, T., 1896. "The Psychology of the Emotions"

Stanton, H. M. "Inheritance of Specific Musical Capacities" (E. R. O. Bul. No. 22, 1922)

Hurst, C. C. (Eug. Rev., vol. IV, 1912, p. 22)

Drinkwater (Eng. Journal of Genetics, vol. V, 1915-16, pp. 229-241

Hurst, C. C. (Eug. Rev., vol. IV, 1912-13, p. 16)

Davenport (E. R, O. Bul. No. 17)

Charcot and Marie (Rev: de Méd., Paris, 1886, VI, pp. 97-138)

Turner, W. Aldren "Epilepsy" (1907)

Rosanoff and Martin (Jour. Hered. 1915, vol. VI, pp. 34-35

Rosanoff \& Orr. "A Study of Heredity in Insanity in the Light of the Mendelian Theory" (Am. Jour. of Insanity, LXVIII, pp. 221 to 261)

Also E. R. O. Bul. No. 5

Rosanoff and Martin (Jour. Hered. 1915, vol. VI, pp. 355-356)

Conklin (p. 303)

Osler ${ }^{2}$ (p. 1096)

Osler $^{1}$ (p. 944)

Simon, Chas. E. (Johns Hopkins Hosp. Bul. No. 4, 1893, pp. 82-84) 


\begin{tabular}{|c|c|c|}
\hline DOMINANT & RECESSIVE & REFERENCE \\
\hline $\begin{array}{l}\text { (m) Normal condition } \\
\text { (n) Normal condition }\end{array}$ & $\begin{array}{l}\text { Sydenham's chorea (St. } \\
\text { Vitus' dance) } \\
\text { Thomson's disease (lack } \\
\text { of muscular tone) }\end{array}$ & $\begin{array}{l}\text { Jolly, F., } 1891 \text { (Neurol. Cen- } \\
\text { tralb1., Leipzig, X, 321-326) } \\
\text { Osler (p. 1131) }\end{array}$ \\
\hline $\begin{array}{l}\text { 13. Kidneys } \\
\text { (a) Diabetes insipidus } \\
\text { (b) Diabetes mellitus }\end{array}$ & $\begin{array}{l}\text { Normal condition } \\
\text { Normal condition }\end{array}$ & $\begin{array}{l}\text { Osler (p. 439) } \\
\text { Williams, John R. "A Study } \\
\text { of the Significance of } \\
\text { Heredity and Infection in } \\
\text { Diabetes Mellitus" (Amer. } \\
\text { Jour. of Med. Science, N. S., } \\
\text { vol. CLIV, pp. 396-406) }\end{array}$ \\
\hline (c) Normal condition & $\begin{array}{l}\text { Alkaptonuria (urine } \\
\text { dark after oxidation) }\end{array}$ & Osler (p. 692) \\
\hline $\begin{array}{l}\text { 14. Respiratory System } \\
\text { (a) Normal condition }\end{array}$ & Bronchial asthma & $\begin{array}{l}\text { June Adkinson (Eugenics Re- } \\
\text { search Ass'n, 1919) }\end{array}$ \\
\hline $\begin{array}{l}\text { 15. Palmaris Longus Muscle } \\
\text { 16. Teeth } \\
\text { (a) Lateral permanent incisors }\end{array}$ & $\begin{array}{l}\text { Absence } \\
\text { Absence }\end{array}$ & $\begin{array}{l}\text { Hunt, Harrison R., Univer- } \\
\text { sity of Miss. (E. R. O. } \\
\text { files) }\end{array}$ \\
\hline
\end{tabular}

III. Sex-Linked Traits.

These traits or qualities are "dominant in males and recessive in females."

1. Coloboma

2. Atrophy of optic nerve (neuritis optica) $\dagger$

3. Myopia

4. Color blindness ("Daltonism," inability to distinguish red from green)

5. Night blindness (Inability to see by faint light)

6. Nystagmus

7. Ichthyosis (scaly skin) $\dagger$

8. Pattern baldness

9. Multiple sclerosis (Differential degeneration of the nerve tissue)

\section{REFERENCE}

De Beck, D., 1886, "A Rare Family History of Congenital Coloboma" (Arch. of Ophth. XV, p. 8, and 1894, XXIII, p. 264)

Davenport $t^{1}$ (p. 110)

Oswald, A. B., "Hereditary Tendency to Defective Eyesight" (Brit. Med. Jour. Jan, 1911)

Worth, C., "Hereditary Influence in Myopia" (1905, Trans. Ophth. Soc. Lond., XXVI, pp. 141-143)

Reber, W., 1895, "Six Instances of Color Blind Women" (Med. News, XVI, pp. 95-97)

Nettleship. E. (Ophth. Soc. Trans. v. 27, p. 269-293)

Clarke, Ernest, 1903, "Hereditary Nystagmus," Ophthalmoscope (Lond. I, pp. 86-87)

Stelwagon (p. 596)

Crocker (Dis. of the Skin, 3rd Ed., p. 569)

Osborn, D. (Jour. Hered., Aug. 1916)

Merzbacher, L., 1909, "Gesetzmässigkeiten in der Vererbung und Verbreitung Verschiedener Familiärer Erkrankungen" (Arch. f. Rassen und Ges. Biologie, VI, pp. 172-198) 


\section{REFERENCE}

10. Gower's muscular atrophy (dystrophia muscularis progressiva)

11. Hemophilia

12. Wanderlust

13. Deficiency in sense of smellt

14. Thalassophilia (sea-lust)

15. Toothlessness (toothless man of India)

16. Webbed toes

17. Microphthalmia

Osler (p. 932)

Osler (pp. 755-756)

Davenport "Feebly-Inhibited, II" (Carnegie No. 236)

Glaser (Science, Dec. 27, 1918, pp. 647-648)

Davenport and Scudder (Carnegie No. 259)

Thadami (Jour. of Heredity, vol. XII, Feb. 1921, pp. 87-88)

Richard Schofield (Jour. Hered, Nov. 1920)

Ash (Brit. Med. Jour. Lond., Apr. 8, 1922)

\section{Probably Mendelian, but Dominance Imperfect or Uncertain.}

1. Defective hair and teeth

2. Extra teeth

3. Double set of permanent teeth

4. Harelip and cleft palate

5. Cryptorchism

6. Hypospadias

7. Twining trait (possibly recessive)

8. Dental agnesia (absence of certain teeth)

9. Bi-lobed ear

10. Dent in forehead (possibly dominant)

11. Human protein sensitization

12. Digital anarthrosis

13. Iso-agglutinins (as figured in blood-grouping)

14. The "Catlin mark"

15. Ankylosis (stiffening of joints)

16. Degeneracy of Cornea
Castle (p. 241)

Davenport (p. 142)

Davenport (p. 142)

Blades (Dental Cosmos, Nov, 1914). vol. LVI, pp. 1241-1245

Davenport (p. 170)

Lingard, A., 1884, "The Hereditary Transmission of Hypospadias and its Transmission by Indirect Atavism"

Wakeley, Thomas, 1895, "The Influence of Inheritance on the Tendency to have Twins"

Sergi, S. (Jour. Hered. v. V, 1914, p. 559)

Schofield, R. (Jour. Hered. v. VIII, 1917, p. 517)

Davenport (Jour. Hered., April 1915, vol. VI, pp. 163-164)

Cooke \& Vander Veer (Jour. Immunology, vol. I, June 1916, pp. 201-305)

Drinkwater, H. (Proc. Roy. Soc. Med., 1916-1917, vol. X, pp. 60-68)

Reichert, F. L. (Eng. News, June 1922, pp. 65-67)

Von Dungern \& Hirschfeld (Zeitsch, $f$, Immunitätsforsch., vol. VIII, 1911, p. 526)

Goldsmith, W. M. (Jour. of Hered., 1922, vol. XIII, No. 2, pp. 69-71)

E. R. O. Files

Davenport (pp. 112-113)

\section{Clearly Hereditary (i. e. Runs in Families), But Rule of Inheritance Uncertain.}

1. Longevity

2. Handclasp
E. R, O. Files

Hurst, C. C. (Eug. Rev., vol. IV, 1912, pp. 1-17) 
3. Diatheses to many specific diseases, as:-
(a) Pneumonia
(b) Cancer
(c) Abdominal hernia
(d) Inguinal hernia

4. Stuttering or stammering

5. Chlorosis

6. Epistaxis (nosebleed)

7. Telangiectasis

8. Splenic anemia with enlargement of the spleen (Gaucher's splenomegaly)

9. - Gout

10. Goitre

11. Exophthalmic goitre (Graves' disease)

12. Literary ability

13. Mathematical ability

14. Mechanical ability

15. Cretinism

\section{Heart defect}

17. Pernicious anaemia

18. Arteriosclerosis

19. Jaundice (hereditary form, splenomegaly with acholuric jaundice)

20. Migraine

21. Rheumatism

22. Von Recklinghausen's disease (neurofibromatosis)

23. Scoliosis

24. Raynaud's disease

25. Angio-neurotic oedema (Quincke's disease)

26. Milroy's disease (persistent hereditary oedema of the legs)
REFERENCE

Herrman, Chas. (Arch. Ped., vol. XXXIII, 1916, pp. 168-170)

Jour. Med. Research, vol. XXXII, 1915 (N. S. vol. XXVII), pp. 159-200

Couch, J. K., 1895, "A Family History of Hernia"

Davenport (p. 106)

Osler (p. 730)

Lane (Jour. Hered. 1916, vol. VII, pp. 132-134)

Weber, F. P., 1907, "Multiple Hereditary Developmental Angiomata (Telangiectasis)"

Bovaird, D., 1900, "Primary Splenomegaly" (Am. Jour. Med. Sci., vol. CXX, pp. 377-402)

Wilson, E., 1869 (Jour. Cutan Med. Lond. III, pp. 106-11\%)

Garrod, A. E., 1902, "The Incidence of Alkaptonuria"

Buschan, G., 1894, "Die Basedow'sche Krankheit" "

J. A. M. A. (Jan. 24, 1920, p. 286)

Davenport (p. 54)

Davenport (p. 59)

Davenport (pp. 55-58)

Eug. Rev., vol. II, 1910-1911, pp. 142143, and Jordan, D. S. (Eug. Rev,, vol. II, pp. 247-248)

Vierordt, K. H., 1901, "Die angeborenen Herzkrankheiten" (Spezielle Pathologie und Therapie, XV, T. I, Ab. 2)

Warfield $^{1}$ (p. 158)

Osler (p. 887)

Osler (p. 1087)

Apert, E., 1907, "Traité des maladies familiales et des maladies congénitales" (p. 235)

Cheadle, W. B., 1900, "Occasional Lectures on the Practice of Medicine"

Arnozan, X., et L. Prioleau 1883, "Annales de Dermat. et de Syph." (2s., iv, pp. 689-698)

Blumer, C., 1892, "Hereditäre Neigung zu Traumatischer Blasenbildung" (Arch. f. Dermat. und Syph. 1892, pp. 105-70)

Davenport (pp. 172-173)

Jour. Hered. IX, 1918, p. 130

Edgeworth, F. H. (Lancet, 1911, pp. 216-217)

Warfield, Louis M. Arteriosclerosis and Hypertension (3rd Edition). 
27. Mongolian imbecility (possibly recessive)

\section{REFERENCE}

Jour. Hered, vol. IX, 1918, p. 23

Herrman, C. (Arch. Ped., vol. XXXIV, 1915, pp. 494-503)

28. Amaurotic family idiocy

29. Megalophthalmus

30. Progressive Central Muscular Atrophy (infantile form, familial)

31. Hereditary spastic paraslegia

32. Marie's cerebellar hereditary ataxia

33. Paroxysmal familial paralysis

34. Hereditary tremor

35. Handwriting

36. Degeneration of macula lutea

37. Arthritis deformans

38. Spasmodic croup

39. Hereditary icterus

40. Angina pectoris

41. Cystinuria

42. General paralysis

43. Hay fever

44. Hypertrophic emphysema

45. Leprosy

46. Myxoedemạ

47. Neurasthenia

48. Obesity

49. Paramyoclonus multiplex

50. Periodical paralysis

51. Hereditary finger-print pattern

52. Memory

53. Astigmatism

54. Congenital Dislocation of Thigh-bone-

Herrman, C. (Arch. Ped., vol. XXXII, 1915, pp. 902-908)

Davenport (p. 115)

Osler (p. 928)

Osler (pp. 938-939)

Osler (p. 945)

Taylor, E. W. (Jour. Nerv. and Ment. Dis. 1898 , vol. $\mathrm{XXV}$, p. 637)

Osler (p. 1119)

Osler (p. 1066)

Davenport (p. 63)

Blue, Robert (J. A. M. A. 1919, vol. LXXIII, pp. 1328-1331

Osler (p. 1134)

Osler (pp. 557-558)

Osler (p. 837)

Osier (p. 690)

Osler (p. 922)

Osler (p. 612)

Osler (p. 646)

Osler (p. i52)

Osler (p. 875)

Osler (p. 110\%)

Osler (p. 451)

Osler (p. 11.33)

Osler (p. 1119)

Wilder, H. H. (Palm and Sole Studies Biol. Bul. 1916, vol. XXX, pp. 135172, 211-252)

Elderton, E. M. (Biometrika, Oct. 1920, pp. 57-91)

Davenport (pp. 59-60)

E. R. O. Files

Nareth 1903, "Beiträge zur Luxatio coxde congenitalis" 
VI. Associated Traits (Possibly Chromosome-Linkage).

\begin{tabular}{|c|c|c|}
\hline ONE TRAIT & $\begin{array}{c}\text { ASSOCIATED } \\
\text { TRAI'TS }\end{array}$ & REFERENCE \\
\hline 1. Brachydactylism & Shortness of stature & $\begin{array}{l}\text { Drinkwater (Eng. Journal } \\
\text { Genetics 1916-17, vol. VI, } \\
\text { p. 88) }\end{array}$ \\
\hline 2. Osteopsathyrosis & $\begin{array}{l}\text { Porcelain-blue color of } \\
\text { sclera or "whites of } \\
\text { eyes" }\end{array}$ & $\begin{array}{l}\text { Herrman, C., 1915, "Blue } \\
\text { Sclerosis IAssociated with } \\
\text { Brittle Bones" } \\
\text { Cockayne, E. A., 1914, "Case } \\
\text { of Hereditary Blue Scler- } \\
\text { osis and Brittle Bones" } \\
\text { (Proc. Roy. Soc. Med., VII, } \\
\text { No. 6, p. 101) }\end{array}$ \\
\hline 3. Hereditary nail defects & Hair defects & $\begin{array}{l}\text { Nicollé, C., and A. Halipré, } \\
1895, \text { "Maladie familiale } \\
\text { caracterisée par des alté- } \\
\text { rations des cheveux et des } \\
\text { ongles" (Ann. de Derm. et } \\
\text { Syph., VI, pp. 804-811) }\end{array}$ \\
\hline 4. Night Blindness & Myopia Strabismus & $\begin{array}{l}\text { Nettleship, E., 1907, "History } \\
\text { of Congenital Stationary } \\
\text { Night-blindness" (Ophthal. } \\
\text { Soc. Trans., vol. 27, pp. } 269 \\
\text { to 293) }\end{array}$ \\
\hline 5. Feeble-mindedness & Epilepsy & Davenport (pp. 72-76) \\
\hline
\end{tabular}


Type a. In case the defect is recessive, as in many types of manic-depressive insanity, dementia praecox, and feeble-mindedness.

\begin{tabular}{|c|c|c|c|c|c|c|c|}
\hline \multicolumn{2}{|c|}{$\begin{array}{l}\text { The Propositus. } \\
\text { (Individual affected } \\
\text { personally or in re- } \\
\text { productive qualities) }\end{array}$} & & \multicolumn{2}{|c|}{ Possible Mates } & \multicolumn{2}{|c|}{ Offspring } & Remarks \\
\hline $\begin{array}{l}\text { Germ- } \\
\text { cells }\end{array}$ & $\begin{array}{l}\text { Person- } \\
\text { ality }\end{array}$ & & $\begin{array}{l}\text { Germ- } \\
\text { cells }\end{array}$ & $\begin{array}{l}\text { Person- } \\
\text { ality }\end{array}$ & $\begin{array}{l}\text { Germ- } \\
\text { cells }\end{array}$ & $\begin{array}{c}\text { Person- } \\
\text { ality }\end{array}$ & \\
\hline $\begin{array}{l}\mathrm{Nr} \\
\text { (Simplex) }\end{array}$ & Normal & 1 & $\begin{array}{c}\mathrm{NN} \\
\text { (Duplex) } \\
\\
\text { (Simplex) }\end{array}$ & Normal & $\begin{array}{l}\left\{\begin{array}{c}50 \% \mathrm{NN} \\
\text { (Duplex) } \\
50 \% \mathrm{Nr} \\
(\text { Simplex) }\end{array}\right. \\
\left\{\begin{array}{c}25 \% \mathrm{NN} \\
\text { (Duplex) } \\
50 \% \mathrm{Nr} \\
\text { (Simplex) } \\
25 \% \mathrm{rr} \\
(\mathrm{Nulliplex})\end{array}\right. \\
\left\{\begin{array}{c}50 \% \mathrm{Nr} \\
(\text { Simplex } \\
50 \% \mathrm{rr} \\
(\mathrm{Nulliplex})\end{array}\right.\end{array}$ & \begin{tabular}{|l|} 
Normal \\
Normai \\
Normal \\
Normal \\
Affected \\
Normal \\
Affected
\end{tabular} & $\begin{array}{l}\text { Depending upon the } \\
\text { nature of the co- } \\
\text { parent. none, } 25 \% \text { or } \\
50 \% \text { of the offspring } \\
\text { of the propositus will } \\
\text { be affected. } \\
\text { If the } 3 \text { possible } \\
\text { types of matings were } \\
\text { equally frequent and } \\
\text { fertile, } 75 \% \text { of the off- } \\
\text { spring would be nor- } \\
\text { mal and } 25 \% \text { affected. }\end{array}$ \\
\hline $\begin{array}{cc}\text { b } & \text { rr } \\
& \text { (Nulliplex) }\end{array}$ & Affected & 1 & $\begin{array}{c}\mathrm{NN} \\
\text { (Duplex) } \\
\mathrm{Nr} \\
\text { (Simplex) }\end{array}$ & Normal & $\begin{array}{l}100 \% \mathrm{Nr} \\
\text { (Simplex) } \\
\left\{\begin{array}{c}50 \% \mathrm{Nr} \\
(\text { Simplex }) \\
50 \% \mathrm{rr} \\
(\mathrm{Nulliplex})\end{array}\right. \\
100 \% \mathrm{rr} \\
\text { (Nulliplex) }\end{array}$ & $\begin{array}{l}\text { Normal } \\
\text { Normal } \\
\text { Affected } \\
\text { Affected }\end{array}$ & $\begin{array}{l}\text { Diepending upon the } \\
\text { nature of the co- } \\
\text { parent, none, } 50 \% \text {, or } \\
100 \% \text { of the offspring } \\
\text { of the propositus will } \\
\text { be affected. } \\
\text { If the } 3 \text { possible } \\
\text { types of matings were } \\
\text { equally frequent and } \\
\text { fertile, half of the off- } \\
\text { spring would be nor- } \\
\text { mal and half affected. }\end{array}$ \\
\hline
\end{tabular}

C. TABLES SHOWING THE TYPES ${ }^{2}$ OF MATINGS WHICH MAY BE MADE BY PERSONS INDIVIDUALLY DEGENERATE" FROM HEREDITARY CAUSES, OR PERSONALLY NORMAL BUT CARRYING DEGENERATE GERMINAL QUALITIES, SHOWING ALSO THE PERSONAL AND GERMINAL NATURES OF THE POSSIBLE OFFSPRING OF EACH SUCH MATING, WORKED OUT IN ACCORDANCE WITH THE KNOWN LAWS OF HEREDITY.

1 There are here worked out only a few of the known methods of inheritance, but these given comprise the fundamental cases.

2 There is no essential difference between the methods of inheritance per se of desirable and undesirable traits. 
Type b. In case the defect is dominant, as in Huntingtou's cliorea, or some of the types of congenital cataract.

\begin{tabular}{|c|c|c|c|c|c|c|c|}
\hline \multicolumn{2}{|c|}{$\begin{array}{l}\text { The Propositus. } \\
\text { (Individual affected } \\
\text { personally or in re- } \\
\text { productive qualities) }\end{array}$} & \multicolumn{3}{|c|}{ Possible Mates } & \multicolumn{2}{|c|}{ Offspring } & \multirow[t]{2}{*}{ Remarks } \\
\hline $\begin{array}{l}\text { Germ- } \\
\text { cells }\end{array}$ & $\begin{array}{c}\begin{array}{c}\text { Person- } \\
\text { ality }\end{array} \\
\end{array}$ & & $\begin{array}{l}\text { Germ- } \\
\text { cells }\end{array}$ & $\begin{array}{c}\text { Person- } \\
\text { ality }\end{array}$ & $\begin{array}{l}\text { Germ- } \\
\text { cells }\end{array}$ & $\begin{array}{c}\text { Person- } \\
\text { ality }\end{array}$ & \\
\hline $\begin{array}{cc}\mathbf{a} & \overline{\mathrm{DD}} \\
& (\mathrm{Duplex})\end{array}$ & $\overline{\text { Affected }}$ & 1 & $\begin{array}{c}\text { DD } \\
\text { (Duplex) } \\
\text { Dn } \\
\text { (Simplex) } \\
\\
\text { nn } \\
\text { (Nulliplex) }\end{array}$ & $\begin{array}{l}\text { Affected } \\
\text { Affected }\end{array}$ & 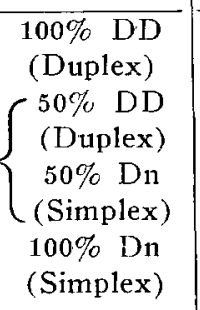 & $\begin{array}{l}\text { Affected } \\
\text { Affected } \\
\text { Affected } \\
\text { Affected }\end{array}$ & $\begin{array}{l}\text { Regardless of the } \\
\text { nature of the co- } \\
\text { parent, all of the off- } \\
\text { spring of the propo- } \\
\text { situs will be affected. }\end{array}$ \\
\hline $\begin{array}{cc}\text { b } & \text { Dn } \\
& \text { (Simplex) }\end{array}$ & Affected & 2 & $\operatorname{nn}_{\text {(Nulliplex) }}$ & Affected & $\begin{array}{l}\left\{\begin{array}{c}50 \% \text { DD } \\
\text { (Duplex) } \\
50 \% \text { Dn } \\
\text { (Simplex) }\end{array}\right. \\
\left\{\begin{array}{c}25 \% \text { DD } \\
(\text { Duplex }) \\
50 \% \text { Dn } \\
(\text { Simplex }) \\
25 \% \text { nn } \\
(\text { Nulliplex })\end{array}\right. \\
\left\{\begin{array}{c}50 \% \text { Dn } \\
(\text { Simplex }) \\
50 \% \text { nn } \\
(\text { Nulliplex })\end{array}\right.\end{array}$ & $\begin{array}{l}\text { Affected } \\
\text { Affected } \\
\text { Affected } \\
\text { Affected } \\
\text { Normal } \\
\text { Affected } \\
\text { Normal }\end{array}$ & $\begin{array}{l}\text { Depending upon the } \\
\text { nature of the co- } \\
\text { parent, all, } 75 \% \text {, or } \\
50 \% \text { of the offspring } \\
\text { of the propositus will } \\
\text { be affected. But in no } \\
\text { type of mating will } \\
\text { less than } 50 \% \text { of the } \\
\text { offspring be affected. } \\
\text { If the } 3 \text { possible } \\
\text { types of mating were } \\
\text { equally frequent and } \\
\text { fertile, } 75 \% \text { of the off- } \\
\text { spring would be af- } \\
\text { fected and } 25 \% \text { not } \\
\text { affected. }\end{array}$ \\
\hline
\end{tabular}

NOTE:-Besides the system of nomenclature here given (which was devised by Dr. Charles B. Davenport) the other system (Professor William Bateson) in vogue has its equivalents as follows: homozygous, if positive, is equivalent to duplex; homozygous, if negative, is equivalent to nulliplex; heterozygous is equivalent to simplex.

NOTE:-The six Mendelian cases are:

\section{Mating Offspring}

1. $\mathrm{DD} \times \mathrm{DD}=100 \% \mathrm{DD}$

2. $\mathrm{DD} \times \mathrm{Dr}=50 \% \mathrm{DD}+50 \% \mathrm{Dr}$

3. $\mathrm{DD} \times \mathrm{rr}=100 \% \mathrm{Dr}$

4. $\mathrm{Dr} \times \mathrm{Dr}=25 \% \mathrm{DD}+50 \% \mathrm{Dr}+25 \% \mathrm{rr}$

5. $\operatorname{Dr} \times \mathrm{rr}=50 \%+50 \% \mathrm{rr}$

6. $\mathrm{rr} \times \mathrm{rr}=100 \% \mathrm{rr}$.

A letter stands for a determiner for a given trait, in the germ-cell. Personally DD and Dr individuals possess the dominant aspect of the trait in question. DD "breeds true," but Dr cloes not. An rr individual shows the recessive aspect of the trait. and "breeds true." 
Type c. A Sex-Linked Trait. (In man the male is the heterozygous sex.)

A trait that is dominant in males but recessive in females, as Haemophilia or Colorblindness.

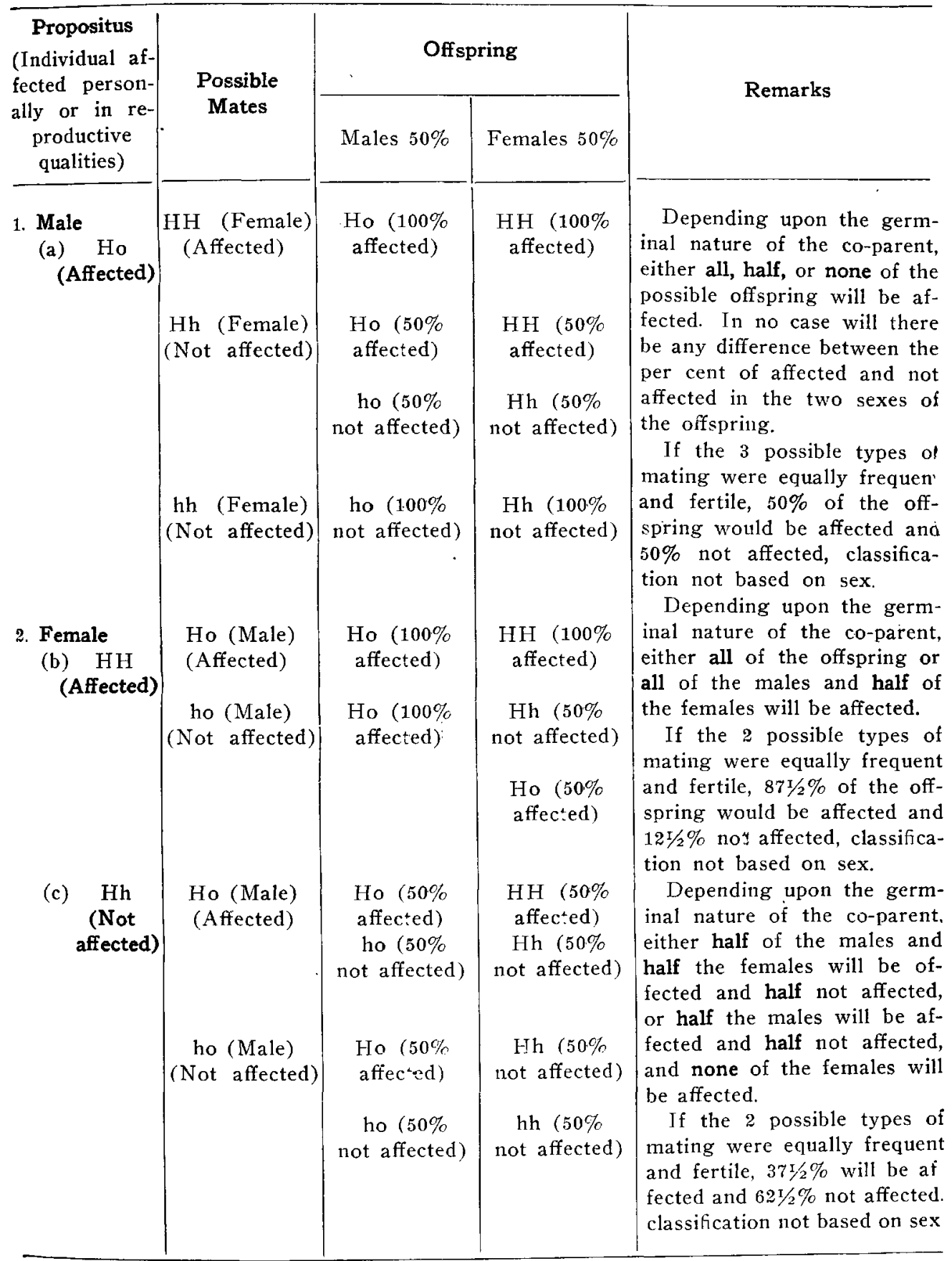

NOTE:-The typical sex-linked cases are:

1. $\mathrm{Xy} \hat{o} \times \mathrm{XX} \%=50 \% \mathrm{Xy} \hat{\alpha}+50 \% \mathrm{XX}$.

2. $\mathrm{Xy} \hat{\circ} \times \mathrm{XX} q=25 \% \mathrm{Xy} \hat{\sigma}+25 \% \mathrm{Xy} \hat{o}+25 \% \mathrm{XX} q+25 \% \mathrm{XX} q$. 
An $X y$ individual is a male unmarked by the trait in question. $X y$ is a male marked by the trait. $\mathrm{XX}$ is a female "untainted" by the trait. $\mathrm{XX}$ is a female who, while not showing the trait personally, will pass it on to one half of her sons and will "taint" one half of her daughters.

Type d. A trait that blends.

\begin{tabular}{|c|c|c|c|}
\hline $\begin{array}{l}\text { Propositus } \\
\text { (Individual af- } \\
\text { fected person- } \\
\text { ally or in re- } \\
\text { productive } \\
\text { qualities) }\end{array}$ & $\begin{array}{c}\text { Possible } \\
\text { Mates }\end{array}$ & Offspring & Remarks \\
\hline $\begin{array}{l}\text { 1. } \mathrm{Nr} \\
\text { Affected to a } \\
\text { small degree }\end{array}$ & $\begin{array}{l}\mathrm{rr} \\
\mathrm{NN}\end{array}$ & 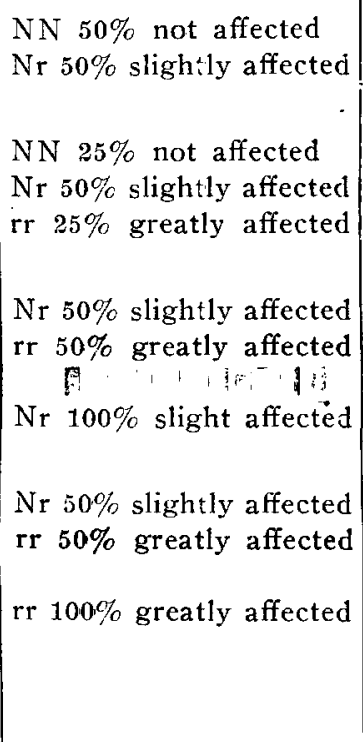 & $\begin{array}{l}\text { Depending upon the germinal nature } \\
\text { of the co-parent, either half of the possible } \\
\text { offspring will be normal and half affected; } \\
\text { or } 25 \% \text { will be normal, } 50 \% \text { only slightly } \\
\text { affected, and } 25 \% \text { greatly affected; or } 50 \% \\
\text { greatly affected and } 50 \% \text { slightly affected. } \\
\text { If the } 3 \text { possible types of matings were } \\
\text { equally frequent and fertile, } 25 \% \text { of the } \\
\text { offspring would be normal, } 50 \% \text { slightly } \\
\text { affected, and } 25 \% \text { greatly affected. } \\
\text { Depending upon the germinal nature } \\
\text { of the co-parent, either all of the possible } \\
\text { offspring will be slightly affected, or } 50 \% \\
\text { will be slightly affected and } 50 \% \text { greatly } \\
\text { affected, or all will be greatly affected. } \\
\text { If the } 3 \text { possible types of matings were } \\
\text { equally frequent and fertile, } 50 \% \text { would } \\
\text { be slightly. affected and the other } 50 \% \\
\text { greatly affected. }\end{array}$ \\
\hline
\end{tabular}


e. A Composite Trait. ${ }^{1}$ A trait which is a composite of two or more independently inherited traits.

In this particular example the composite is composed of one dominant and one recessive trait. For example, if a complex of Huntington's chorea (dominant) and manic depressive insanity (recessive), which are independently inherited, made up a medical entity (which in fact they do not), the rule of inheritance of such entity would be as follows:

\section{Propositus $^{2}$}

(Individual carrying the trait either personally or in the germ-plasm.)

(a) $\quad \mathrm{CC} n$ (Affected)

(b) $\mathrm{CC} \mathrm{Nn}$ (Not affected)

(c) $\mathrm{CC} \mathrm{NN}$ (Not affected)

(d) Cc nn (Affected)

(e) Cc Nn (Not affected)

(f) $\quad \mathrm{CcNN}$ (Not affected)

(g) cc nn (Not affected)

(h) cc Nn (Not affected)

(i) $\operatorname{cc~NN}$ (Not affected)

\section{Remarks}

Average frequency of types in offspring, provided that there is equal frequency and fertility of matings with all possible types of mates.

$50 \%$ affected

$50 \%$ not affected

$25 \%$ affected

$75 \%$ not affected

$100 \%$ not affected

$37 \% 2 \%$ affected

$621 / 2 \%$ not affected

$181 / 4 \%$ affected

$813 / 4 \%$ not affected

$100 \%$ not affected

$25 \%$ affected

$75 \%$ not affected

$121 / 2 \%$ affected

$87 \mathrm{~J} / 2 \%$ not affected

$100 \%$ not affected

See the following tables for the working out of each of these cases.

1 In this complex only two unit-traits are involved; if, as is probably the case in many characters, a larger number enter, it is at once evident that the situation becomes highly involved and consequently the possibility of analysis becomes increasingly difficult.

${ }^{2} \mathrm{C}=$ gene for Huntington's chorea; $=\mathrm{Its}$ Absence. N $\Longrightarrow$ gene not capable of developing manic depressive insanity; $m=$ gene for manic depressive insanity. 
(a)

\begin{tabular}{|c|c|c|c|c|}
\hline Propositus & Possible Mates & & Offspring & Remarks \\
\hline $\begin{array}{c}\mathrm{CC} n \mathrm{n} \\
\text { (affected) }\end{array}$ & $\begin{array}{c}\text { CC nn } \\
\text { (affected) } \\
\text { CC Nn } \\
\text { (not affected) } \\
\text { CC NN } \\
\text { (not affected) } \\
\text { Cc nn } \\
\text { (affected) } \\
\\
\text { Cc Nn } \\
\text { (not affected) } \\
\\
\text { Cc NN } \\
\text { (not affected) } \\
\text { cc nn } \\
\text { (not affected) } \\
\text { cc Nn } \\
\text { (not affected) } \\
\text { cc NN } \\
\text { (not affected) }\end{array}$ & $\begin{array}{l}\mathrm{CCnn} \\
\mathrm{CC} \mathrm{nn} \\
\mathrm{CC} \mathrm{Nn} \\
\mathrm{CC} \mathrm{Nn} \\
\mathrm{CC} \mathrm{nn} \\
\mathrm{Cc} \mathrm{nn} \\
\mathrm{CC} \mathrm{nn} \\
\mathrm{Cc} \mathrm{nn} \\
\mathrm{CC} \mathrm{Nn} \\
\mathrm{Cc} \mathrm{Nn} \\
\mathrm{CC} \mathrm{Nn} \\
\mathrm{Cc} \mathrm{Nn} \\
\mathrm{Cc} \mathrm{nn} \\
\text {. } \mathrm{nn} \\
\mathrm{Cc} \mathrm{Nn} \\
\mathrm{Cc} \mathrm{Nn}\end{array}$ & $\begin{array}{l}(100 \% \text { affected }) \\
(50 \% \text { affected }) \\
(50 \% \text { not affected } \\
(100 \% \text { not affected }) \\
(50 \% \text { affected }) \\
(50 \% \text { affected }) \\
(25 \% \text { affected }) \\
(25 \% \text { affected }) \\
(25 \% \text { not affected }) \\
(25 \% \text { not affected) } \\
(50 \% \text { not affected }) \\
(50 \% \text { not affected }) \\
(100 \% \text { affected }) \\
(50 \% \text { affected }) \\
(50 \% \text { not affected }) \\
(100 \% \text { not affected })\end{array}$ & $\begin{array}{l}\text { Depending upon the } \\
\text { germinal nature of the } \\
\text { co-parent, the offspring } \\
\text { will -be either affected } \\
\text { or not affected. } \\
\text { If the nine possible } \\
\text { types of matings were } \\
\text { equally frequent and } \\
\text { fertile, 50\% would be } \\
\text { affected and } 50 \% \text { would } \\
\text { be not affected. }\end{array}$ \\
\hline
\end{tabular}

(b)

\begin{tabular}{|c|c|c|c|c|}
\hline $\begin{array}{c}\mathrm{CC} \mathrm{Nn} \\
\text { (not affected) }\end{array}$ & $\begin{array}{c}\mathrm{CC} n \mathrm{n} \\
\text { (affected) } \\
\mathrm{CCNn} \\
\text { (not affected) } \\
\mathrm{CCNN} \\
\text { (not affected) } \\
\mathrm{Cc} n \mathrm{n} \\
\text { (affected) }\end{array}$ & 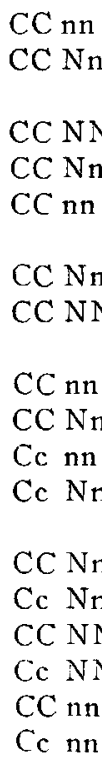 & $\begin{array}{l}(50 \% \text { affected }) \\
(50 \% \text { not affected }) \\
(25 \% \text { not affected }) \\
(50 \% \text { not affected }) \\
(25 \% \text { affected }) \\
(50 \% \text { not affected }) \\
(50 \% \text { not affected }) \\
(25 \% \text { affected) } \\
(25 \% \text { not affected }) \\
(25 \% \text { affected }) \\
(25 \% \text { not affected }) \\
(25 \% \text { not affected }) \\
(25 \% \text { not affected }) \\
(121 / 2 \% \text { not affected }) \\
(121 / 2 \% \text { not affected }) \\
(121 / 2 \% \text { affected) } \\
(121 / 2 \% \text { affected })\end{array}$ & $\begin{array}{l}\text { Depending upon the } \\
\text { germinal nature of the } \\
\text { co-parent, the offspring } \\
\text { will be either affected } \\
\text { or not affected. } \\
\text { If the nine possible } \\
\text { types of matings were } \\
\text { equally frequent and } \\
\text { fertile, } 25 \% \text { of the off- } \\
\text { spring would be af- } \\
\text { fected and } 75 \% \text { wonld } \\
\text { be not affected. }\end{array}$ \\
\hline
\end{tabular}


(b)-Continued

\begin{tabular}{|c|c|c|c|}
\hline Propositus & Possible Mates & Offspring & Remarks \\
\hline & $\begin{array}{c}\mathrm{CcNN} \\
\text { (not affected) } \\
\text { cc nn } \\
\text { (not affected) } \\
\text { cc } \mathrm{Nn} \\
\text { (not affected) } \\
\quad \text { cc } \mathrm{NN} \\
\text { (not affected) }\end{array}$ & 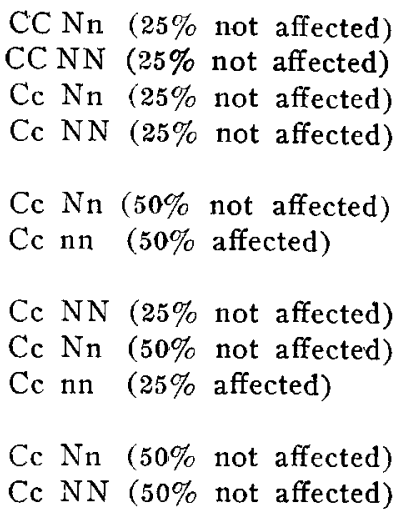 & \\
\hline
\end{tabular}

(c)

\begin{tabular}{|c|c|c|c|}
\hline $\begin{array}{c}\text { CC NN } \\
\text { (not affected) }\end{array}$ & $\begin{array}{c}\text { CC nn } \\
\text { (affected) } \\
\text { CC Nn } \\
\text { (not affected) } \\
\text { CC NN } \\
\text { (not affected) } \\
\text { Cc nn } \\
\text { (affected) } \\
\text { Cc Nn } \\
\text { (not affected) } \\
\text { Cc NN } \\
\text { (not affected) } \\
\text { cc nn } \\
\text { (not affected) } \\
\text { cc } N n \\
\text { (not affected) } \\
\text { cc } N N \\
\text { (not affected) }\end{array}$ & 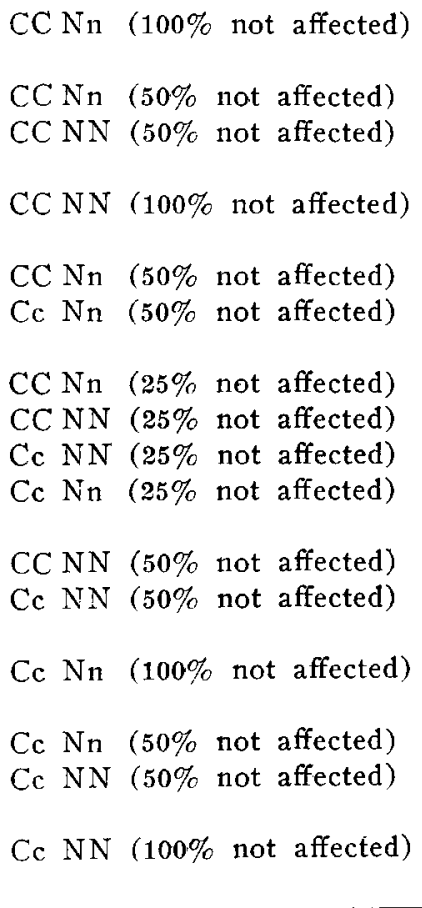 & $\begin{array}{l}\text { None of the offspring } \\
\text { will be affected, no mat- } \\
\text { ter what the character } \\
\text { of the mating, because } \\
\text { the propositus carries } \\
\text { no determiner for the n } \\
\text { (recessive) trait. }\end{array}$ \\
\hline
\end{tabular}

(d)

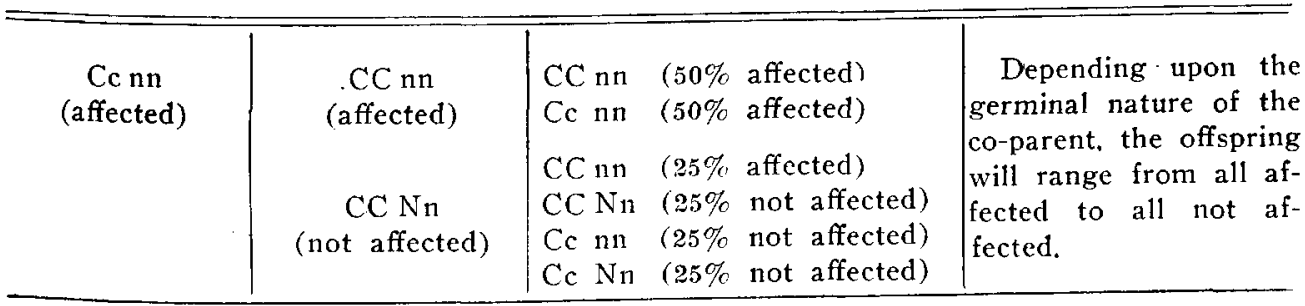


(d)-Continued

\begin{tabular}{|c|c|c|c|c|}
\hline \multirow[t]{2}{*}{ Propositus } & Possible Mates & & Offspring & Remarks \\
\hline & $\begin{array}{c}\text { CC NN } \\
\text { (not affected) } \\
\text { Cc nn } \\
\text { (affected) } \\
\\
\text { Cc Nn } \\
\text { (not affected) } \\
\text { Cc NN } \\
\text { (not affected) } \\
\text { cc nn } \\
\text { (not affected) } \\
\text { cc Nn } \\
\text { (not affected) } \\
\text { (not affected) }\end{array}$ & 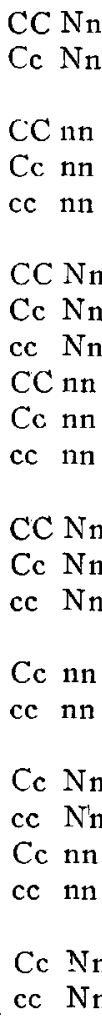 & $\begin{array}{l}(50 \% \text { not affected }) \\
(50 \% \text { not affected }) \\
(25 \% \text { affected }) \\
(50 \% \text { affected }) \\
(25 \% \text { not affected }) \\
(12 \% / 2 \% \text { not affected }) \\
(25 \% \text { not affected }) \\
(121 / 2 \% \text { not affected }) \\
(121 / 2 \% \text { affected }) \\
(25 \% \text { affected }) \\
(121 / 2 \% \text { not affected }) \\
(25 \% \text { not affected }) \\
(50 \% \text { not affected }) \\
(25 \% \text { not affected }) \\
(50 \% \text { affected }) \\
(50 \% \text { not affected }) \\
(25 \% \text { not affected }) \\
(25 \% \text { not affected }) \\
(25 \% \text { affected }) \\
(25 \% \text { not affected }) \\
(50 \% \text { not affected }) \\
(50 \% \text { not affected })\end{array}$ & $\begin{array}{l}\text { If the nine possible } \\
\text { types of matings were } \\
\text { equally frequent and } \\
\text { fertile, } 371 / 2 \% \text { of the } \\
\text { offspring would be af- } \\
\text { fected and } 621 / 2 \% \text { would } \\
\text { be not affected. }\end{array}$ \\
\hline
\end{tabular}

(e)

\begin{tabular}{|c|c|c|c|c|}
\hline $\begin{array}{c}\mathrm{Cc} \mathrm{Nn} \\
\text { (not affected) }\end{array}$ & $\begin{array}{c}\text { CC nn } \\
\text { (affected) } \\
\text { (not affected) } \\
\text { CC Nn } \\
\text { CC NN } \\
\text { (not affected) }\end{array}$ & 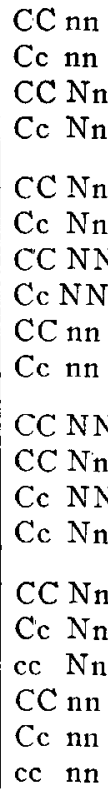 & $\begin{array}{l}(25 \% \text { affected }) \\
(25 \% \text { affected }) \\
(25 \% \text { not affected }) \\
(25 \% \text { not affected }) \\
(25 \% \text { not affected }) \\
(25 \% \text { not affected }) \\
(121 / 2 \% \text { not affected }) \\
(12 \%) \text { not affected }) \\
(121 / 2 \% \text { affected }) \\
(121 / 2 \% \text { affected }) \\
(25 \% \text { not affected }) \\
(25 \% \text { not affected }) \\
(25 \% \text { not affected }) \\
(25 \% \text { not affected }) \\
(121 / 2 \% \text { not affected }) \\
(25 \% \text { not affected }) \\
(121 / 2 \% \text { not affected }) \\
(121 / 2 \% \text { affected }) \\
(25 \% \text { affected }) \\
(12 \% / 2 \% \text { not affected })\end{array}$ & $\begin{array}{l}\text { Depending upon the } \\
\text { germinal nature of the } \\
\text { co-parent, the offspring } \\
\text { will be both affected } \\
\text { and not affected. } \\
\text { If the nine possible } \\
\text { types of matings were } \\
\text { equally frequent and } \\
\text { fertile, } 18.75 \% \text { of the } \\
\text { possible offspring, or } \\
\text { slightly less than one- } \\
\text { fifth, would be affected, } \\
\text { and } 81.25 \% \text { would be } \\
\text { not affected. }\end{array}$ \\
\hline
\end{tabular}


(e)-Continued

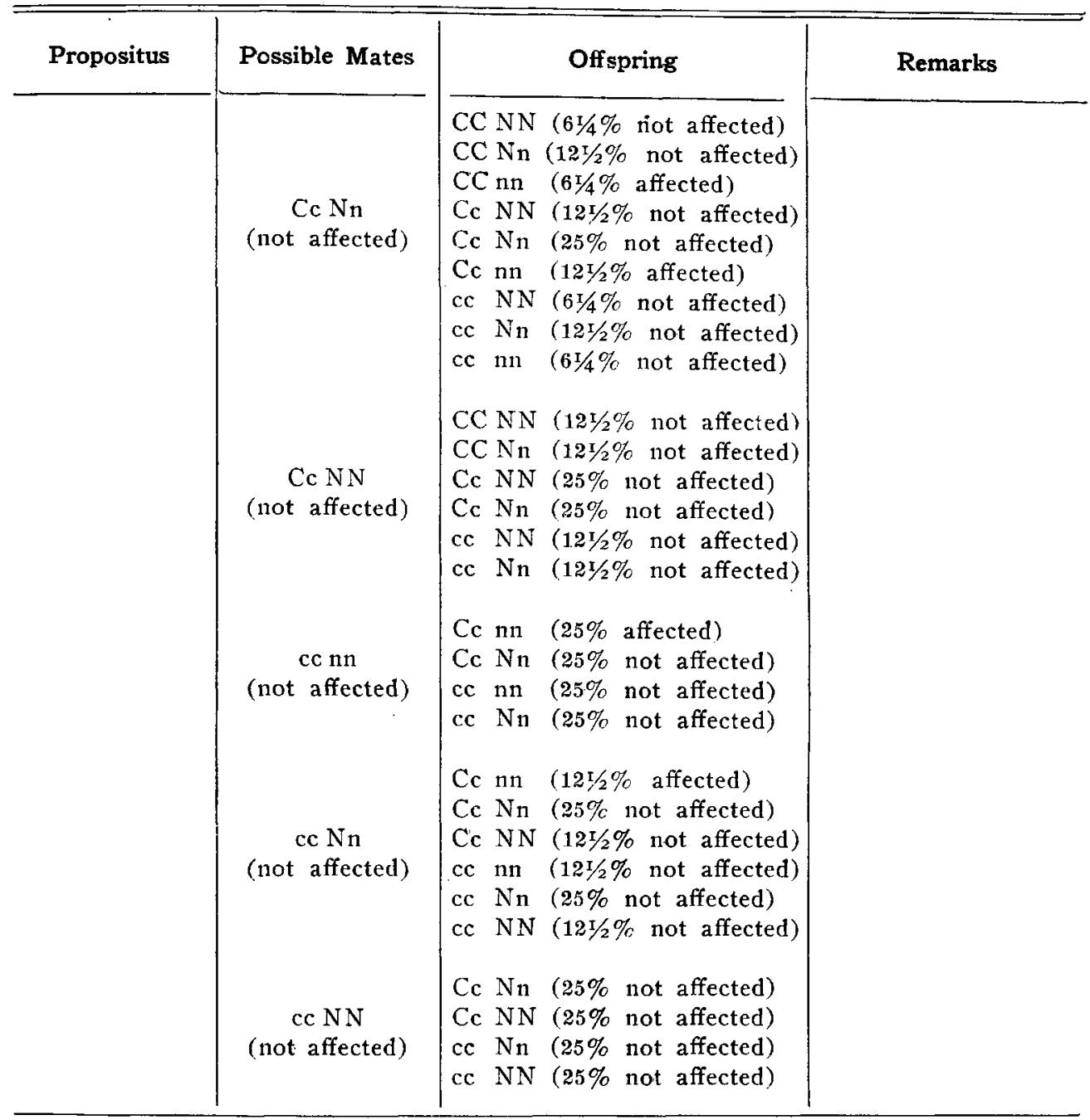

(f)

\begin{tabular}{|c|c|c|c|}
\hline $\begin{array}{c}\mathrm{CcNN} \\
\text { (not affected) }\end{array}$ & $\begin{array}{c}\mathrm{CC} \mathrm{nn} \\
\text { (affected) } \\
\text { CC Nn } \\
\text { (not affected) } \\
\text { CC NN } \\
\text { (not affected) } \\
\text { Cc nn } \\
\text { (affected) }\end{array}$ & 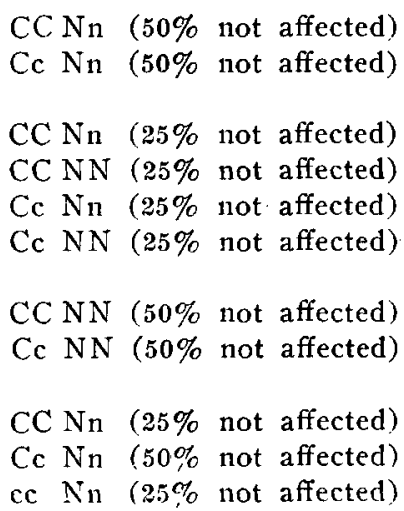 & $\begin{array}{l}\text { None of the possible } \\
\text { offspring of any mat- } \\
\text { ings made by an in- } \\
\text { dividual of this type } \\
\text { will be affected. }\end{array}$ \\
\hline
\end{tabular}


(f)-Continued

\begin{tabular}{|c|c|c|c|}
\hline Propositus & Possible Mates & Offspring & Remarks \\
\hline & $\begin{array}{c}\mathrm{CcNn} \\
\text { (not affected) } \\
\text { Cc NN } \\
\text { (nct affected) } \\
\text { cc nn } \\
\text { (not affected) } \\
\text { cc Nn } \\
\text { (not affected) } \\
\text { cc NN } \\
\text { (not affected) }\end{array}$ & 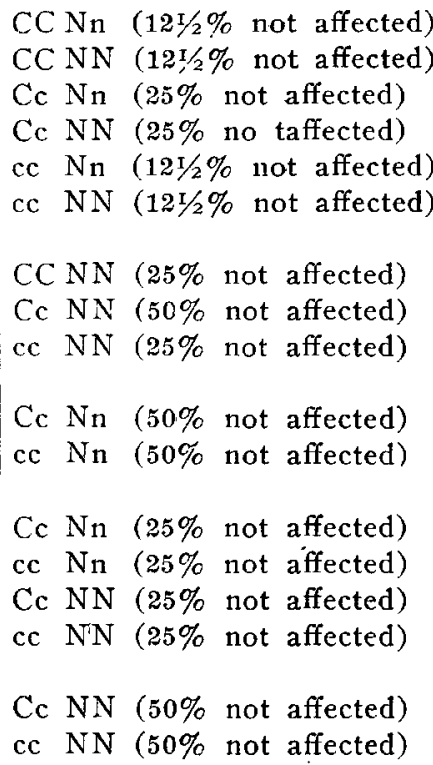 & \\
\hline
\end{tabular}

(g)

\begin{tabular}{|c|c|c|c|c|}
\hline $\begin{array}{c}\operatorname{ccnn} \\
(\text { not } \text { affected) }\end{array}$ & $\begin{array}{c}\text { CC nn } \\
\text { (affected) } \\
\text { CC Nn } \\
\text { (not affected) } \\
\text { CC NN } \\
\text { (not affected) } \\
\text { Cc nn } \\
\text { (affected) } \\
\text { Cc Nn } \\
\text { (not affected) } \\
\text { Cc NN } \\
\text { (not affected) } \\
\text { cc nn } \\
\text { (not affected) } \\
\text { cc Nn } \\
\text { (not affected) } \\
\text { cc NN } \\
\text { (not affected) }\end{array}$ & $\begin{array}{l}\text { Cc } \mathrm{nn} \\
\mathrm{Cc} \mathrm{nn} \\
\text { Cc } \mathrm{Nn} \\
\mathrm{Cc} \mathrm{Nn} \\
\mathrm{Cc} \mathrm{nn} \\
\mathrm{cc} \mathrm{nn} \\
\mathrm{Cc} \mathrm{nn} \\
\text { Cc } \mathrm{Nn} \\
\mathrm{cc} \mathrm{nn} \\
\mathrm{cc} \mathrm{Nn} \\
\text { Cc } \mathrm{Nn} \\
\mathrm{cc} \mathrm{Nn} \\
\text { cc } \mathrm{nn} \\
\mathrm{cc} \mathrm{Nn} \\
\mathrm{cc} \mathrm{nn} \\
\mathrm{cc} \mathrm{Nn}\end{array}$ & $\begin{array}{l}(100 \% \text { affected }) \\
(50 \% \text { affected }) \\
(50 \% \text { not affected }) \\
(100 \% \text { not affected }) \\
(50 \% \text { affected }) \\
(50 \% \text { not affected }) \\
(25 \% \text { affected }) \\
(25 \% \text { not affected }) \\
(25 \% \text { not affected }) \\
(25 \% \text { not affected }) \\
(50 \% \text { not affected }) \\
(50 \% \text { not affected }) \\
(100 \% \text { not affected }) \\
(50 \% \text { not affected }) \\
(50 \% \text { not affected }) \\
(100 \% \text { not affected })\end{array}$ & $\begin{array}{l}\text { Depending upon the } \\
\text { germinal nature of the } \\
\text { co-parent the offspring } \\
\text { will be either affected } \\
\text { or not affected. } \\
\text { If the nine possible } \\
\text { types of matings were } \\
\text { equally frequent and } \\
\text { fertile, } 25 \% \text { of the off- } \\
\text { spring would be affected } \\
\text { and } 75 \% \text { would be not } \\
\text { affected. }\end{array}$ \\
\hline
\end{tabular}


(h)

\begin{tabular}{|c|c|c|c|c|}
\hline Propositus & Possible Mates & & Offspring & Remarks \\
\hline $\begin{array}{c}\mathrm{ccNn} \\
\text { (not affected) }\end{array}$ & $\begin{array}{c}\mathrm{CcNn} \\
\text { (not affected) } \\
\text { Cc NN } \\
\text { (not affected) } \\
\text { cc nn } \\
\text { (not affected) } \\
\text { cc Nn } \\
\text { (not affected) } \\
\text { cc NN } \\
\text { (not affected) }\end{array}$ & 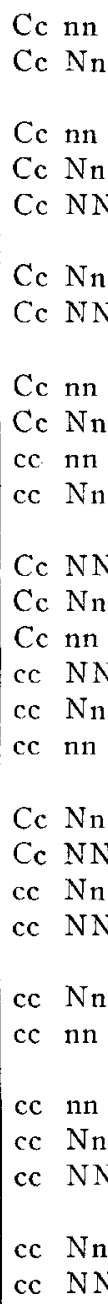 & $\begin{array}{l}(50 \% \text { affected }) \\
(50 \% \text { not affected }) \\
(25 \% \text { affected }) \\
(50 \% \text { not affected }) \\
(25 \% \text { not affected }) \\
(50 \% \text { not affected }) \\
(50 \% \text { not affected }) \\
(25 \% \text { affected }) \\
(25 \% \text { not affected }) \\
(25 \% \text { not affected }) \\
(25 \% \text { not affected }) \\
(125 \% 2 \% \text { not affected }) \\
(25 \% \text { not affected }) \\
(121 / 2 \% \text { affected }) \\
(12 \% \text { not affected }) \\
(25 \% \text { not affected }) \\
(121 / 2 \% \text { not affected }) \\
(25 \% \text { not affected }) \\
(25 \% \text { not affected }) \\
(25 \% \text { not affected }) \\
(25 \% \text { not affected }) \\
(50 \% \text { not affected }) \\
(50 \% \text { not affected }) \\
(25 \% \text { not affected }) \\
(50 \% \text { not affected }) \\
(25 \% \text { not affected }) \\
(50 \% \text { not affected }) \\
(50 \% \text { not affected })\end{array}$ & $\begin{array}{l}\text { Depending upon the } \\
\text { germinal nature of the } \\
\text { co-parent, the offspring } \\
\text { will be either affected } \\
\text { or not affected. } \\
\text { If the nine possible } \\
\text { types of matings were } \\
\text { equally frequent and } \\
\text { fertile, } 121 / 2 \% \text { of the off- } \\
\text { spring would be affected } \\
\text { and } 871 / 2 \% \text { would be } \\
\text { not affected. }\end{array}$ \\
\hline
\end{tabular}

(i)

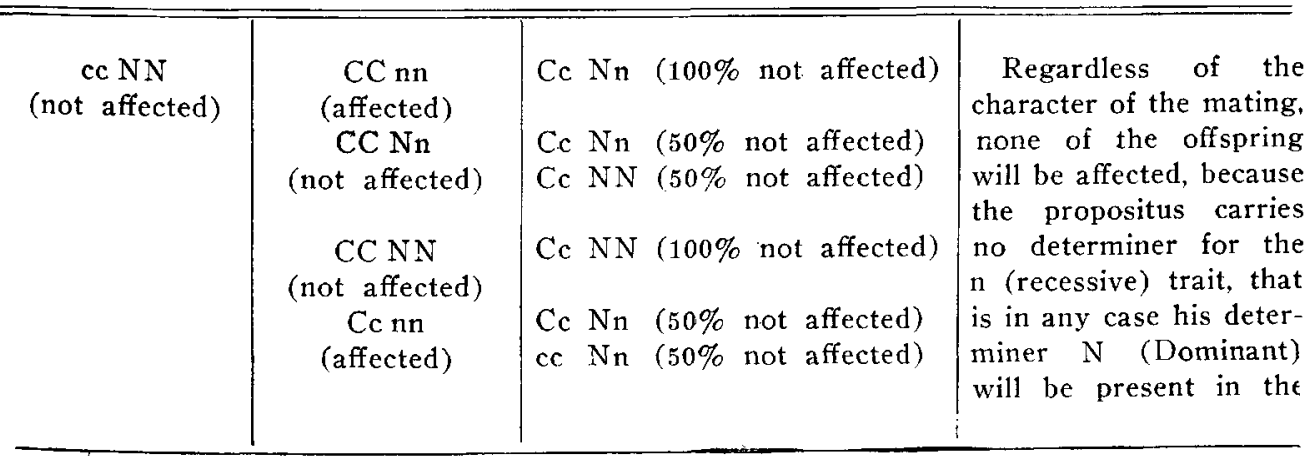


(i)-Continued

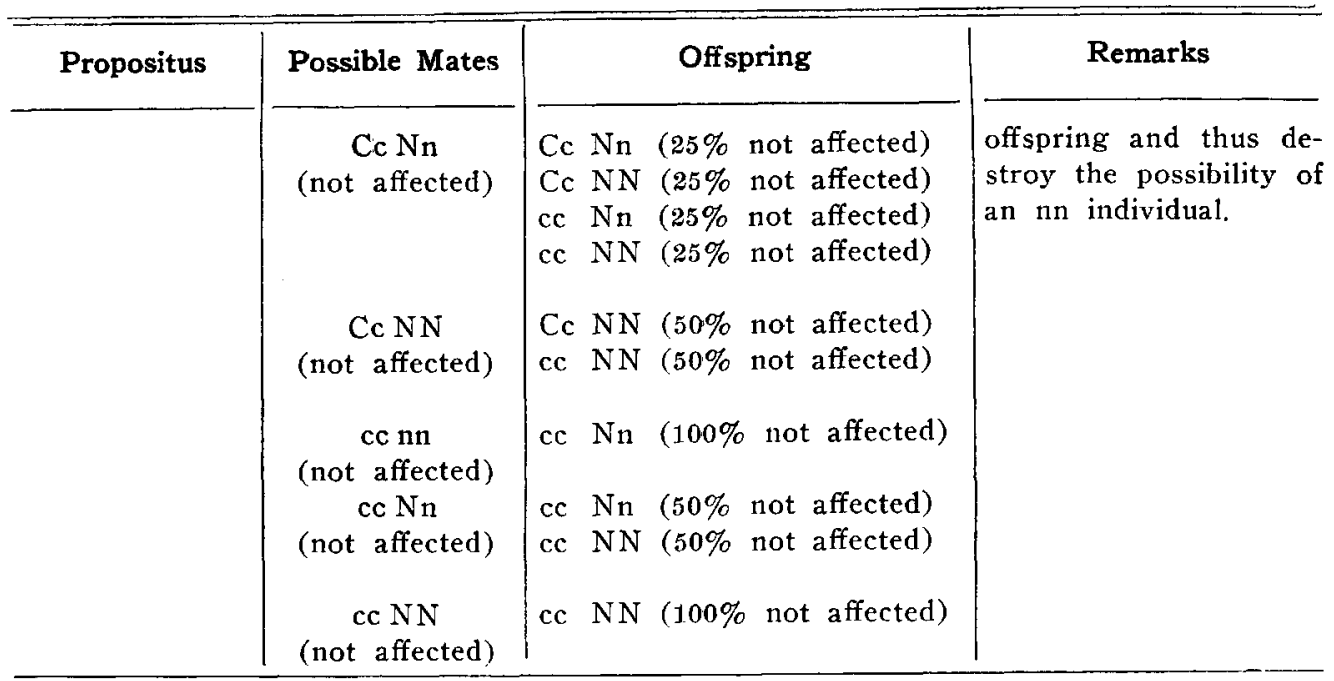

1. Research Institutions.

\section{REFERENCES}

1. Eugenics Record Office, C. B. Davenport, Director; Bulletins on the inheritance of special traits; Memoirs describing cacogenic families; Reports, Family History Schedules, etc., Cold Spring Harbor, Long Island, N. Y.

2. Galton Laboratory for National Eugenics, Karl Pearson, Director, University of London, publications for sale by Dulau \& Co., Ltd., London.

\section{Societies.}

American Genetic Association, David Fairchild, President. Research Departments for Plants. Animals, and Eugenics, Washington, D. C.

Eugenics Research Association, L. F. Barker, President, H. H. Laughlin, Sec'y, Cold Spring Harbor, Long Island, N. Y.

Eugenics Education Society, Leonard Darwin, President, London, England, (and several branches). 11 Lincoln's Inn Fields, W. C. 2, London, Mrs. A. C. Gotto, Hon. Secretary.

Société Française d'Eugénique, Lucien March, President, 97 Quai d'Orsay, Paris. France.

Deutsche Gesellschaft für Rassen-Hygiene, Dr. Alfred Ploetz, Gundelindenstrasse 5, München, Germany.

Argentine Eugenics Committee, Buenos Aires, Argentina.

Sociedade Eugenica de Sao Paulo, Brazil, Dr. Renato Kehl, Secretary, Rua Libero Badaro 119.

Galton Society, New York, N. Y., Charles B. Dąvenport, President.

Hungarian Eugenics Society, Dr. Geza von Hoffman, Acting Vice-President, Budapest.

Italian Society of Genetics and Eugenics, Dr. Ernest Pestalozza, President, Rome, Italy, Prof. Cesare Artom, Hon. Sec'y, Via Scipioni 272

Race Preservation League, University of Melbourne, Victoria, Australia.

Laboratorium f. Kemi \& Racehygiene, Kristiania-Winderen, Norway, Dr. Jon Alfred Miøen.

Eugenics Education Society of New South Wales, 136 Upper Spit Roar. Mosman, Sydney, Australia.

Eugenic Education Society of New Zealand, Dunedin, N. Z.

National Committee for Mental Hygiene, Inc., Dr. Thomas W. Salmon. Medical Director, 50 Union Square, New York, N. Y.

Race Betterment Foundation and Eugenics Registry, Dr. John Harvey Kellogg, President, Battle Creek, Mich. 
Société belge d'Eugenique, Albert Govaerts, Secretary, Maison des Medicins, 17 Grand'place, Bruxelles, Belgitum.

International Eugenics Commission, Major Leonard Darwin, Chairman, Dr. Albert Govaerts, Secretary, Brussels, Belgium.

3. Universities and colleges which offer especially active courses in Eugenics and Genetics.

Columbia University, New York, N. Y.

Harvard University, Cambridge, Mass.

Princeton University, Princeton, N. J.

Brown University, Providence, Rhode Island.

University of California, Berkeley, Cal.

University of Pennsylvania, Philadelphia, $\mathrm{Pa}$.

University of Michigan, Ann Harbor, Mich.

University of Chicago, Chicago, Ill.

University of Illinois, Urbana, Ill.

University of Kansas, Lawrence, Kans.

University of Iowa, Iowa City, Iowa.

University of Ohio, Columbus, Ohio.

Southwestern College, Winfield, Kans.

N. C. State College of Agriculture and Engineering, Raleigh. N. C.

Wilmington College, Wilmington, Ohio.

4. Custodial institutions for various types of socially inadequate, which are conducting active field studies in eugenics.

Name of Institution

Kings.Park State Hospital, Kings Park, N. Y.

State Village for Epileptics, Skillman, N. J.

State Hospital, Warren, $\mathrm{Pa}$.

Danvers State Hospital, Hathorne, Mass.

Whittier State School, Whittier, Cal.

Monson State Hospital, Palmer, Mass.

Middletown State Hospital, Middletown, Conn.

Home for Feeble-minded and Epileptic, Lapeer, Mich.

Government Hospital for the Insane, Washington

Taunton State Hospital, Taunton, Mass.

Boston State Hospital, Boston, Mass.

School for Feeble-minded and Colony for Epileptics, Faribault, Minn.

State Institution, Polk, Pa.

Letchworth Village, Thiells, N. Y.

Eastern Pennsylvania State Institution for Feeble-minded and Epileptic, Pennhurst. Pa.

Central Islip State Hospital

Bangor State Hospital

Girls Training School, Gainesville. Texas

Sleighton Farm (Girls Department), Darling, Pa.

Northern Hospital for Insane, Logansport, Ind.

Southeastern Hospital for Insane. Madison, Ind.

Indiana Girls School, Indianapolis, Ind.

Clinton Farms, N. J. State Reformatory for Women, Clinton, N. J.

Norwich State Hospital, Norwich, Conn.

State Industrial School for Girls, Lancaster, Mass.

California State Commission in Lunacy. Sacramento, Cal.

Phipps Psychiatric Clinic, Baltimore, Md.
Superintendent or Director

W. C. Garvin

David F. Weeks

H. W. Mitchell

Geo. M. Kline

Fred C. Nelles

Everett Flood

Floyd Haviland

H. A. Haynes

Wm. A. White

Arthur V. Goss

J. V. May

G. C. Hanna

J. M. Murdock

Charles S. Little

Oscar E. Thomson

G. A. Smith

Carl J. Hedin

Carrie W. Smith

M. P. Falconer

Fred $W$. Terflinger

J. W. Milligan

Kenosha Sessions

May Caughey

Henry M. Pollock

Amy F. Everall

Dr. F. W. Hatch

Dr Adolf Meyer 
5. Courts of law which have undertaken scientific engenical studies as an aid to their functions in determining the cases of personal conduct and in weighing and placing responsibilities.

Municipal Court of Chicago.

6. Journals.

Hon. Harry Olson, Chief Justice.

Dr. Wm. J. Hickson, Director of the Psychopathic Laboratory.

Archiv für Rassen- und Gesellschafts-Biologie, A. Ploetz, Editor, pubiished by B. G. Teubner, Leipzig and Berlin, Germany.

The Eugenics Review, a quarterly journal, published by the Eugenics Education Society, London; Hon. Secretary, Mrs. A. C. Gotto.

Eugenical News, a monthly periodical on eugenics, published by the Eugenics Record Office, Cold Spring Harbor, Long Island, N. Y.

Journal of Heredity, a monthly journal, published by the American Genetic Association, Washington. Oliver Olson. Acting Editor.

Journal of Genetics, a quarterly publication of the University of Cambridge Press. W. Bateson and R. C. Punnett, Editors.

Journal of the American Medical Association, Chicago, Ill. This weekly publication reports abstracts of many of the best original papers on human heredity and eugenics.

Mental Hygiene, a quarterly publication of the National Committee for Mental Hygiene, Inc, 50 Union S.quare, New York.

Genetics, bimonthly journal, Geo, H. Schull, Princeton University, Editor, published by Williams \& Wilkins Co., Baltimore.

Revue d'Eugénique, quarterly review of the Société Belge d'Eugénique, Palais d’Egmont, Maison des Médécins, Bruxelles, Belgium.

Eugénique, publication of the Société Française d'Eugénique, published by Librairie J. B. Baillière et Fils, 19, Rue Hautefeuille, Paris.

\section{Books.}

Heredity in Relation to Eugenics, by C. B. Davenport, Henry Holt \& Company New York.

Eugenics and Heredity, by Coulter, Castle, Tower and Davenport, University of Chicago Press, Chicago.

Essays in Eugenics, by Francis Galton, Eugenics Education Society, London.

English Men of Science, by Francis Galton, Eugenics Education Society, London.

Inquiries into Human Faculty and its Development, by Francis Galton, E. P. Dutton, New York.

Hereditary Genius, by Francis Galton, Macmillan Company, New York.

Natural Inheritance, by Francis Galton, Macmillan Company, N. Y.

Applied Eugenics, by Paul Popenoe and R. H. Johnson, Macmillan Company, N. Y.

Ancient Eugenics, by A. G. Roper, B. H. Blackwell Company, London.

Heredity in Royalty, by F. A. Woods. Henry Holt \& Company, New York.

The Influence of Monarchs, by F. A. Woods, Henry Holi \& Company, New York.

The Human Harvest, by David Starr Jordan, American Unitarian Association, Boston.

Is Mankind Advancing? by Mrs. John Martin, Baker \& Taylor Company, New York.

The Social Direction of Human Evolution, by W. F. Kellicott. D. Appleton \& Company. New York.

The Declining Birth Rate, by Arthur Newsholme, Moffatt, Yard \& Company, New York.

Race Suicide, by M. S. Iseman, The Cosmopolitan Press, New York.

The Jukes, by R. L. Dugdale, G. P. Putman \& Company, New York.

The Jukes, 1915, by A. H. Estabrook, Carnegie Institution of Washington.

Jukes-Edwards, by A. E. Winship, R. L. Myers \& Co., Harrisburg. 
The Kallikak Family, by H. H. Goddard, Macmillan Company, Nen York.

The Hill Folk, Report on a rural community of hereditary defectives, by Florence H. Danielson and Charles B. Davenport. Eugenics Record Office Memoir No. 1.

The Nam Family. A Study in Cacogenics. Arthur H. Estabrook and Charles B. Davenport. Eugenics Record Office Memoir No. 2.

The Dack Family, by Mrs. Anna Wendt Finlayson. Eugenics Record Office Bulletin No. 15.

Psychiatry, by Stewart Paton. J. B, Lippincott.

Human Behavior, by Stewart Paton, Charles Scribner's Sons.

Signs of Sanity, by Stewart Paton, Charles Scribner's Sons.

Manual of Psychiatry, by A. J. Rosanoff, John A. Wiley \& Sons.

Textbook of Nervous Diseases, by Charles L. Dana, William Wood and Company.

Feeble-mindedness, Its Causes and Consequences, by H. H. Goddard, Macmillan Company, New York.

Mental Deficiency (Amentia), by A. F. Tredgold, Bailliers, Tindall \& Cox, London.

A Point Scale for Measuring Mental Ability, by Yerkes, Bridges and Hardwick, Warwick \& York, Baltimore.

Physical Basis of Heredity, by T. H. Morgan, J. B. Lippincott.

Mendel's Principles of Heredity, by W. Bateson, The Cambridge University Press, New York.

The Cell in Development and Inheritance, by Edmund S. Wilson, Macmillan Company, New York.

Genetics: An Introduction to the Study of Heredity, by H. E. Walter, Macmillan Company, New York.

Heredity, by W: E. Castle, D. Appleton \& Company, New York.

Heredity and Sex, by T. H. Morgan, Macmillan Company, New York.

Heredity and Environment, by Edwin G. Conklin, Princeton University Press.

The Direction of Human Evolution, by Edwin G. Conklin, Charles Scribner's. Sons.

How to Make a Eugenical Family Study, by Charles B. Davenport and Harry H. Laughlin, Eugenics Record Office Bulletin No. 13.

Readings in Evolution, Genetics and Eugenics, by H. H. Newman, University of Chicago Press.

The Trend of the Race, by S. J. Holmes, Harcourt, Brace \& Co., New York

Statistical Directory of State Institutions for the Defective, Dependent and Delinquent Classes, by H. H. Laughlin, Bureau of the Census, Washington, D. C.

Institutional Care of the Insane in the United States and Canada (in four volumes), by Hurd, Drewry, Dewey, Pilgrim, Blumer and Burgess, John Hopkins Press.

Summaries of State Laws Relating to the Insane, prepared by John Koren. revised by S. W. Hamilton and Roy Haber, National Committee for Mental Hygiene, Inc., New York.

Summaries of State Laws Relating to the Feeble-minded and the Epileptic, prepared by Samuel W. Hamilton and Roy Haber, National Committee for Mental Hygiene, Inc. New York.

Race Decadence. by Wm. S Sadler, A. C. McClurg \& Co., Chicago

Reports and scientific papers of the International Congresses of Eugenics.

1st Congress, London, 1912. Problems in Eugenics, 2 vol. Description of the Exhibit.

and Congress, New York, 1921. Eugenics, Genetics and the Family. Eugenics in Race and State. Description of the Exhibit. 


\section{CHAPTER XII.}

\section{THE ANATOMICAL AND SURGICAL ASPECTS OF EUG்ENICAL STERILIZATION.}

Section A. Anatomy. Description of the Human Male and Female Reproductive Mechanisms and an Explanation of their Functions............ 397

a. Reproductive mechanism of the human male........................ 398

b. Reproductive mechanism of the human female.................. 402

Section B. Surgery. The principal types of surgical operations used in effect-

ing sexual sterilization.................................... 406

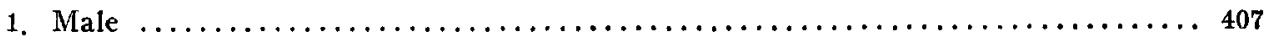

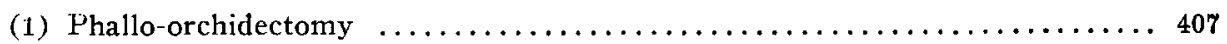

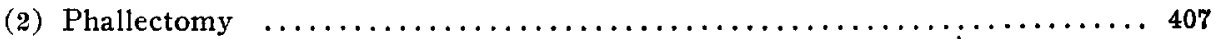

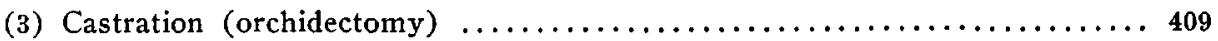

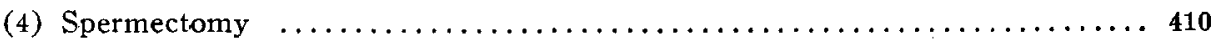

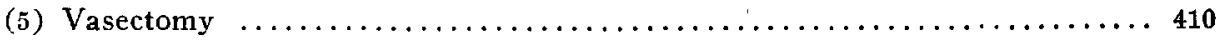

(6) Ligation of the vas deferens.............................. 411

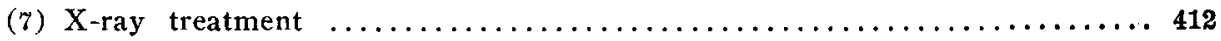

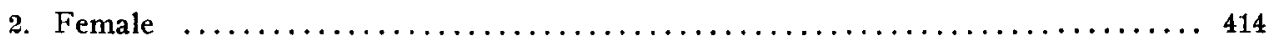

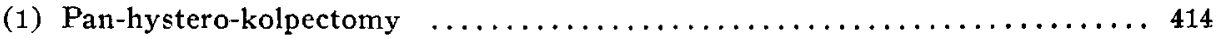

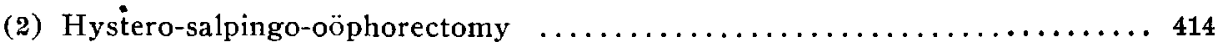

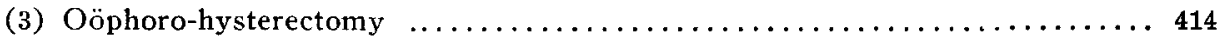

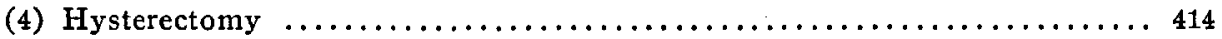

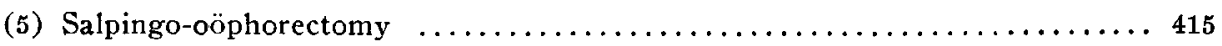

(6) Oöphorectomy (ovariectomy, oväriotomy, castration, spaying) ....... 415

(7) Curetting or cauterizing the intrauterine tubal openings............. 416

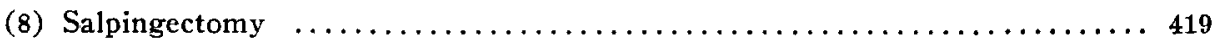

(9) Ligation of Fallopian tubes............................ 421

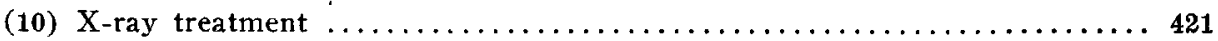

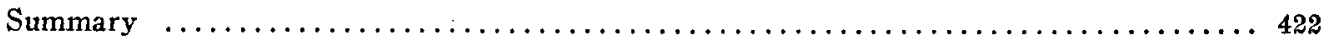

a. Types of eugenical sterilization available..................... 422

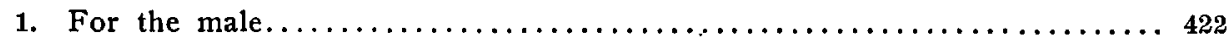

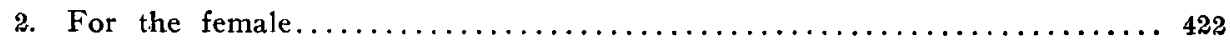

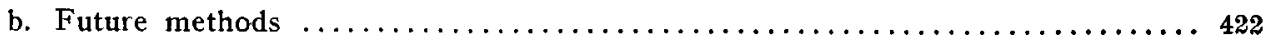

c. Weighing the matter of type of eugenical sterilization in relation to

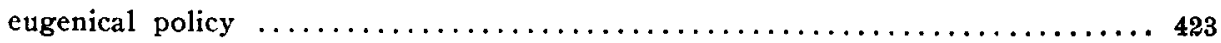

Note: Continence and Contraception............................423 
THE ANATOMICAL AND SURGICAL ASPECTS OF EUGENICAL STERILIZATION.

\section{SECTION A. DESCRIPTION OF THE} HUMAN MALE AND FEMALE MECHANISMS OF REPRODUCTION, AND AN EXPLANATION OF THEIR FUNCTIONS.

The internal organs of reproduction and, ultimately, the mature ova and spermatozoa, develop from the mesoderm. In embryonic development the first evidence of the indifferent sex-gland is found in the genital ridges which first appear at about the fifth week as small elevations of thickened cells on the Wolffian bodies. In course of development the mesothelial cells overlying the genital ridges proliferate and, at about the sixth or seventh week, by which time they comprise a tissue of several layers, begin to penetrate the tissue of the ridge. This penetrating tissue is called the germinal epithelium because it ultimately gives rise to the germinal cells or gametes, the ova or spermatozoa, as the case may be. Later, portions of the penetrating germinal epithel- ium become transformed into structures called the sex-cords, each of which includes a number of cells destined to develop into gametes.

From the sex-cord or egg column in the female germ-gland there bud off a number of parts, each of which develops into a Graafian follicle. Each of these follicles contains a cell destined ultimately to become the mature egg. In the testis the sex-cords undergo a change in which part of the tissue breaks away, leaving other portions which ultimately become the seminiferous tubules, the inner lining of which gives rise to the sex-cells which, during sexual maturity, develop into spermatozoa.

Until the fourth or fifth week in embryonic life the sex-gland is indifferent, but at this time the embryologist can distinguish the ovary and the testis from each other. It is, however, not until the ninth week of intrauterine life that the external genitals begin to show distinction.

Embryologically there is a close homology throughout the reproductive systems of the two sexes, although in mature life the analogous functions are not always performed by homologous structures. The following table ${ }^{1}$ shows this homology of structure:

HOMOLOGJES OF THE SEXUAL SYSTEM.

\begin{tabular}{|c|c|c|}
\hline FET'AL STRUCTURE & FEMALE ORGANS & MALE ORGANS \\
\hline $\begin{array}{l}\text { Indifferent sexual gland } \\
\text { Wolffian body- }\end{array}$ & Ovary & Testis \\
\hline $\begin{array}{l}\text { Its middle series of tubules } \\
\text { and }\end{array}$ & $\begin{array}{l}\text { Short tubules of parovarium } \\
\text { and }\end{array}$ & $\begin{array}{l}\text { Vasa efferentia, rete testis and } \\
\text { coni vasculosi }\end{array}$ \\
\hline $\begin{array}{l}\text { Corresponding part of Wolf- } \\
\text { fian duct }\end{array}$ & $\begin{array}{l}\text { Horizontal or long tube or } \\
\text { parovarium }\end{array}$ & Tube of epididymis \\
\hline Remainder of Wolffian duct & $\begin{array}{l}\text { Usually altogether disappears; } \\
\text { if persistent, Gartner's duct }\end{array}$ & $\begin{array}{l}\text { Vas deferens, seminal vesicle, } \\
\text { and ejaculatory duct }\end{array}$ \\
\hline $\begin{array}{l}\text { Upper series of short tubules } \\
\text { (pronephros) }\end{array}$ & Stalked hydatid of Morgagni & Stalked hydatid of Morgagni \\
\hline $\begin{array}{l}\text { Lower series of tubules } \\
\text { Duct of Müller- }\end{array}$ & Paroöphoron & $\begin{array}{l}\text { Paradidymis (organ of } \mathrm{Gi}- \\
\text { raldes) }\end{array}$ \\
\hline $\begin{array}{l}\text { Its upper extremity } \\
\text { Succeeding portion }\end{array}$ & $\begin{array}{l}\text { Fimbria of oviduct } \\
\text { Oviduct }\end{array}$ & $\begin{array}{l}\text { Sessile hydatid } \\
\text { Usually disappears; if per- } \\
\text { sistent, duct of Rathke }\end{array}$ \\
\hline $\begin{array}{l}\text { Remaining portion, by fusion } \\
\text { with its fellow }\end{array}$ & Jterus and vagina & Uterus masculinus \\
\hline
\end{tabular}

${ }^{1}$ Heisler, Jolin Clement: Text-book of Embryology, p. 263. W. B. Saunders Co., Philadelphia, 1907. 
E.XTERNAL ORGANS.

\begin{tabular}{|c|c|c|}
\hline FETAL, STRUCTURE & FEMALE ORGANS & MALE ORGANS \\
\hline $\begin{array}{l}\text { Genital eminence } \\
\text { Genital folds }\end{array}$ & $\begin{array}{l}\text { Clitoris } \\
\text { Nymphae and bulbi vestibuli }\end{array}$ & $\begin{array}{l}\text { Penis } \\
\text { Corpus spongiosum, enclosing } \\
\text { spongy part of urethra }\end{array}$ \\
\hline Genital ridge & Labia majora & Scrotum \\
\hline Urogenital sinus & $\begin{array}{l}\text { Urethra and vestibule, Glands } \\
\text { of Bartholin }\end{array}$ & $\begin{array}{l}\text { Prostatic urethra, membran- } \\
\text { ous turethra, prostate, Cow- } \\
\text { per's glands }\end{array}$ \\
\hline
\end{tabular}

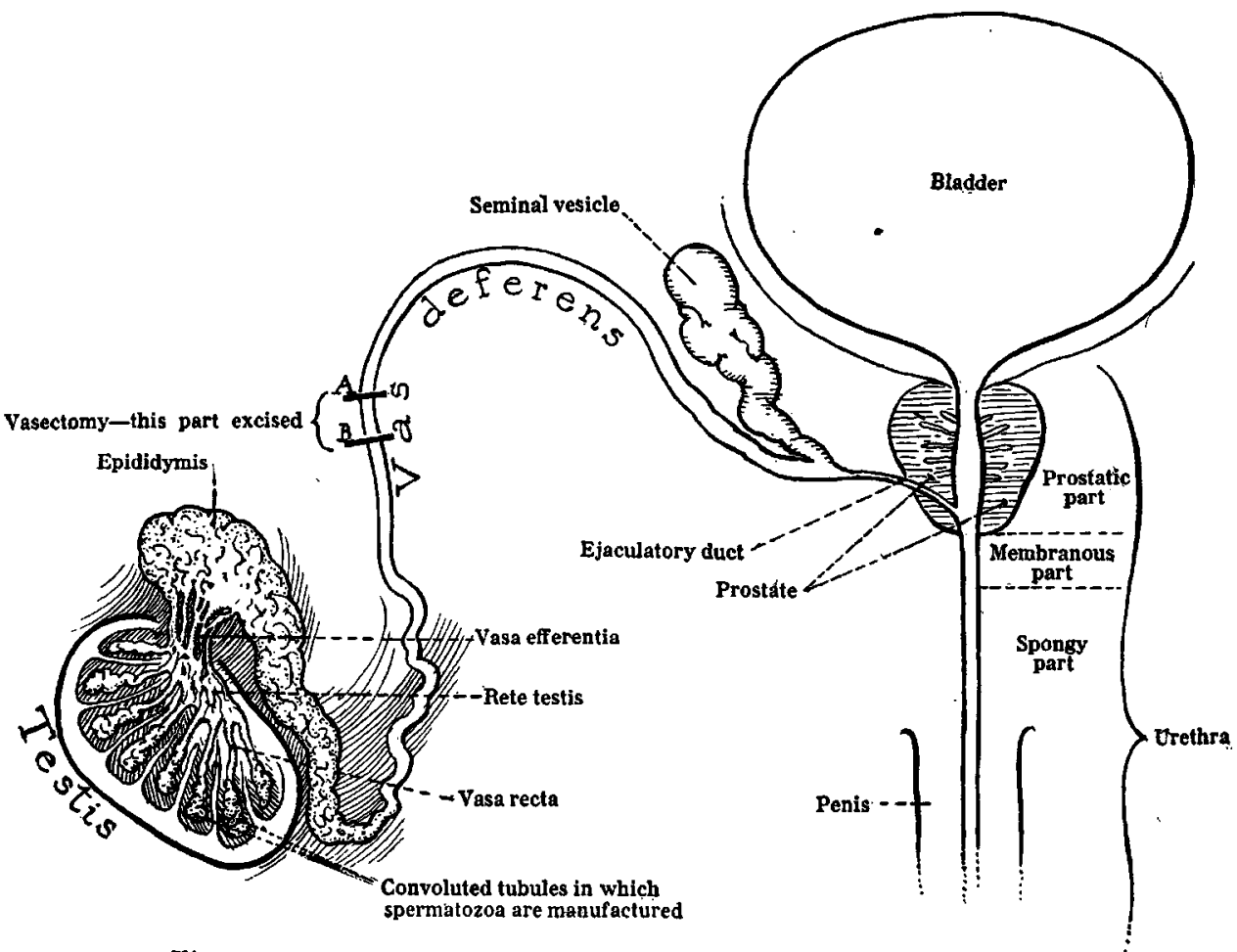

Figure r. Schematic Representation of Genital Tract in the Male

(a) The Reproductive Mechanism of the Human Male.

The essential purpose of the genital system of the male is the manufacture, storage and delivery of functioning spermatozoa. This function begins with puberty and continues until late in life.

The germ-tract. The spermatozoa are produced by indirect cell-division from a layer of cubical cells lining the basement membrane of the seminiferous tubules of the testes. The mature spermatozoa pass from the seminiferous tubules in which they are manufactured to the epididymis, which rerves as a first storage-reservoir. Thence they may pass through the vas deferens to a second storage-reservoir called the seminal vesicle (or they may shunt this storage); thence accompanied by semen, through the ejaculatory duct into the urethra, and thence to the outside. During the transit of from ten to twenty feet from the place of origin to the outside, the spermatozoa are moved along the earlier stretches of their course by the ciliary action of the lining of the germtract, during which time the spermatozoon has not yet reached maturity. From the seminal vesicles it is driven by ejaculation, which is caused by contraction of the musculature of the vasa deferentia, the ejaculat- 
ory ducts, the seminal vesicles and the prostate gland. The semen is secreted in most part by the testes, the prostate, the seminal vesicles and Cowper's glands. It is a viscid, opalescent and alkaline fluid, and contains about ten percent of solid matter. Its whitish appearance is due to the presence of spermatozoa. The purpose of the fuid is to maintain the vitality of the spermatozoa, and to convey them in their course along the seminal passages.

The Testes. The testes are a pair of glandular structures, grayish-white in color, dividuals, but the average dimension is from one and a half to two inches in length, one inch in breadth, and a trifle more in thickness. The weight varies from twenty-five to thirty grams. According to different authorities, each testis contains from two hundred to four hundred lobules or compartments. Each lobule contains several (one to three or more) seminiferous tubules. Thus in each testis there are six or eight hundred of the latter. Each tubule measures from one hundred and forty to two hundred $\mu$ in diameter, and when straightened out

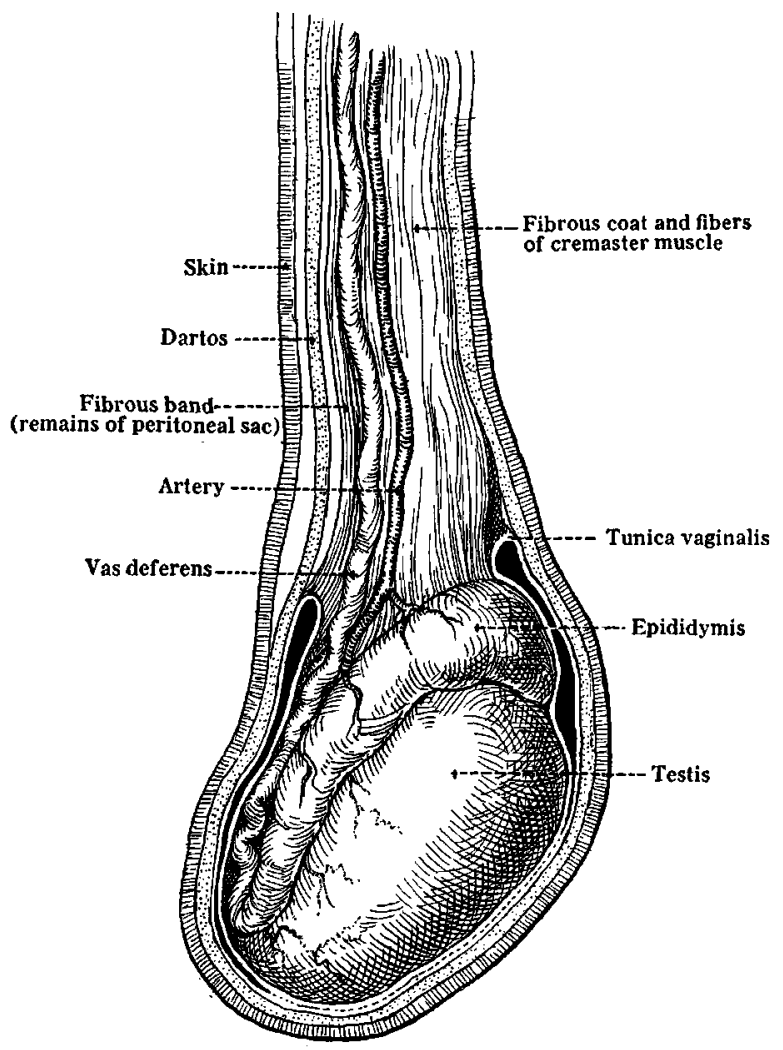

Figure 2. The Testis and Its Coverings

and resilient in consistency. The testis is suspended in the scrotum by a spermatic cord. Generally the left testis hangs somewhat lower than the right.

The spermatic cord consists of the vas deferens, blood vessels, nerves, and the ligament of Cloquet, the whole held together by connective tissue suspending the testis, and furnishing the latter gland its blood and nerve supply,: and finally conveying from it the mature spermatozoa.

In size the testes vary greatly with in- is about two fect long. At one end each of these tubules terminates blindly, but at the apex of the lobules they unite to form the short tubuli recti, which anastomose into the rete testis, which in turn branches into the vasa efferentia, of which there are from twelve to fifteen, each about one third of an inch in length. These tubules lead directly into the globus major of the epididymis. The latter structure is a much convoluted canal from fifteen to twenty feet long. The coil is held together by connective tissue. 
The Vas Deferens. The vas deferens is a tubular continuation of the epididymis. It is a cord-like duct about two feet in length if unravelled. Its lower stretches are contorted, but its upper portion is straight. It measures about three millimeters in external diameter, and its canal about five-tenths of a millimeter. Its walls have three coatsan outer fibrous, a middle of smooth muscular tissue, and an inner longitudinally folded mucus membrane. sac is pyramidal in shape and on the average measures about two inches in length and one-half inch in breadth at the base.

The ejaculatory duct is formed by the junction of the duct leading from the seminal vesicle, with the vasa deferens, and is about three-fourths of an inch in length. The ejaculatory duct from each testis empties into the urethra.

The Spermatozoon. Leeuwenhoek, the in-

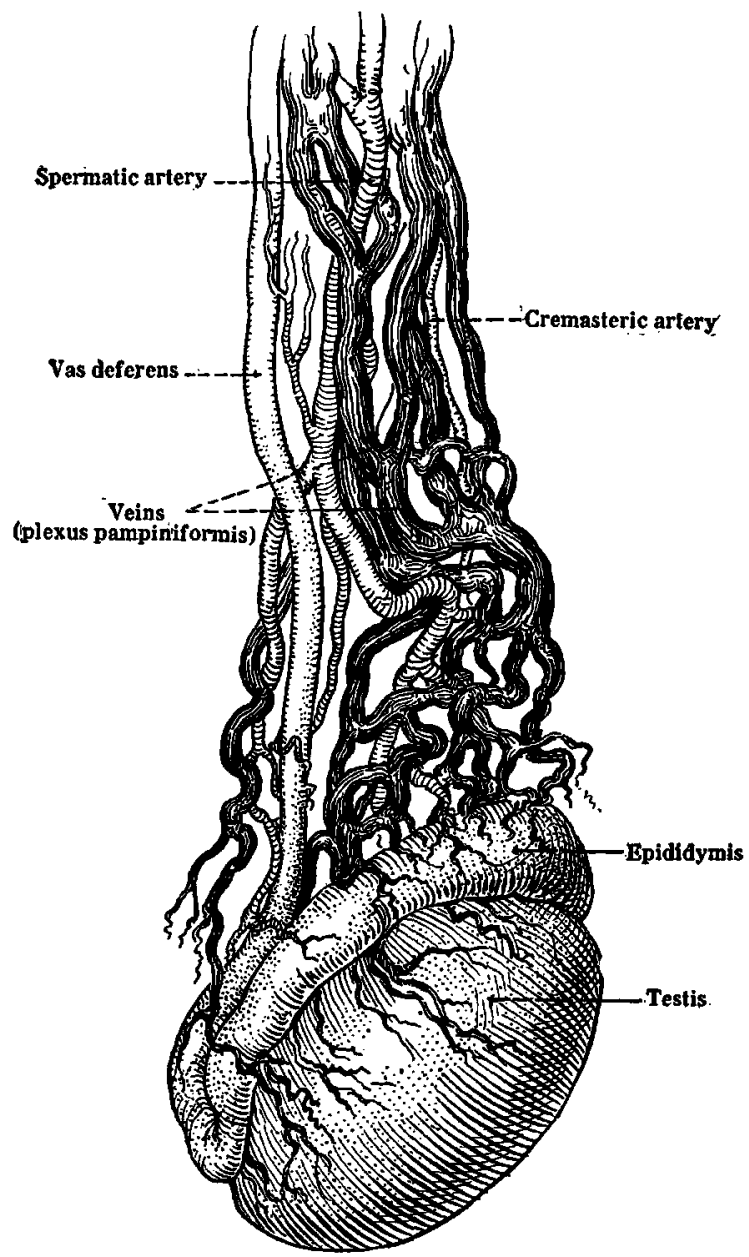

Figure 3. The Structure of the Spermatic Cord

The Seminal Vesicles. The seminal vesicles are a pair of membranous structures which branch off from the vasa deferentia. Their function is to serve as storage reservoirs for the surplus semen and spermatozoa. Each vesicle is a single tube, about five inches long and one-fifth inch in diameter, doubled on itself. They vary greatly in size and shape in different individuals, but each ventor of the microscope, and his pupil Hamm, discovered the spermatozoon in 1677 . Thence arose a school of biologists known as animalculists, who held the spermatozoon to be a complete organism in miniature. Their opponents were known as the ovists, who held that the egg contained the germ. According to these two doctrines, the theory of preformation was a sound one. It was 
also very simple, because development would, if it were proved, be simply a process of unfolding. In 1759 Wolff announced the doctrine of epigenesis, which holds that the germ is unorganized, and that the union of male and female materials is essential to reproduction. The ovists were considerably reinforced in argument when in 1762 Bonnet published the results of his work on parthogenesis. Now we know that both sperm and egg are essential to bi-sexual reproduction, that each is highly organized, and that, especially in the contribution of hereditary genes, the egg and the sperm are practically equivalent.
The spermatozoon is a highly specialized and very active single cell. Its chromosomes carry the genes for the traits transmitted by heredity, the tail drives the organism along the seminal passages in the male, and after coitus, to the place of fertilization, generally $^{2}$ in the Fallopian tube of the female. The perforator enables the sperm to enter the egg in the process of fertilization. $\mathrm{Ob}$ servers report the rate of progress of the spermatozoon to be from one and one-tenth millimeters to three and sixth-tenths millimeters per minute, and estimate that the time required for passage from the upper part of the vagina to the upper part of the

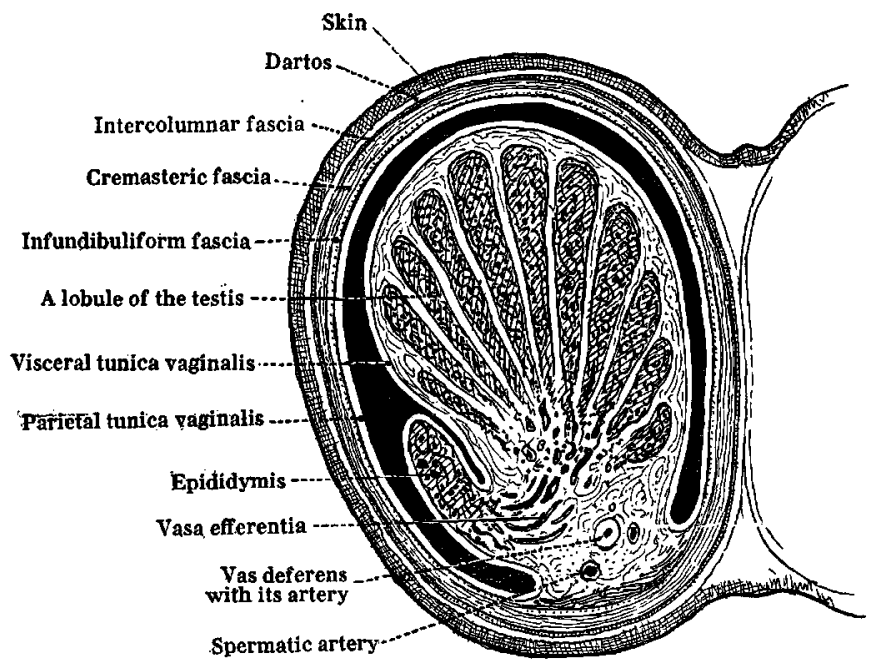

Figure 4. 4 Sectional View of the Testis

The spermatozoon is a single cell which in its gross aspect consists of a head or a nucleus, and a vibratory whip-like tail; but a more refined linear division is that into head, neck, body and tail. The human spermatozoa are small compared to those of many other mammals. On the average in man they measure ${ }^{1}$ a total length of from 51 to $58 \mu$, to which length the head contributes 4 to $6 \mu$, and the tail 41 to $53 \mu$. The width of the head is from 3 to $4 \mu$. The head is oval, but viewed in profile appears pear-shaped. At the tip of the head there is a shield of modified substance called the head-cap, or perforator. Chemical analysis shows the head to be rich in nucleic acid, and the tail high in proteins and fats. Structurally the tail, which by its vibratory motion serves as a propeller, consists of an axial filament surtounded by a shield of protoplasm.
Fallopian tube is about one and one-half hours.

The peculiar chemical composition of the semen serves the purpose of maintaining the vitality and motility of the spermatozoa. Under proper environment conditions, such as the female genital tract, the spermatozoa maintain their vitality and motility for a number of days. Comparison with other species of animals throws considerable light upon this problem. The queen bee is fertilized but once in her entire life. The turkey hen is said to be fertilized but once a season. The female bat receives the male in the fall, but ovulation and fertilization do not take place until spring.

The number of spermatozoa produced in the life-time of a single human male is very

1 Reference Handbook of the Medical Sciences, Vol. VII, p. 822 .

J. P. McMurrich: The Development of the Human Body, p. 34 . 
great. It has been found that "one cubic millimeter of human ejaculate contains 60,876 spermatozoa, a single ejaculate, therefore, containing over $200,000,000$. This would indicate that during his lifetime a man may produce 340 billions spermatozoa (Lode)." Since in each testis there is a total of seven or eight hundred linear feet of seminiferous tubules, in the two testes there are on the average approximately fifteen hundred feet of tubes of $140 \mu$ to $200 \mu$ in caliber, which are lined with spermatozoabearing epithelium (Hill). science of heredity to study progeny result. ing from crossing of differently constituted individuals and thereby to learn the rules governing the segregation and recombination of natural traits. The ancestral cells of all spermatozoa and ova have continued in unbroken descent from the germinal cells of the ancestors of the particular individual possessing them. These cells are especially important because they carry within their walls the whole hereditary endowment of their possessors, and consequently interference in human reproduction in the inter-

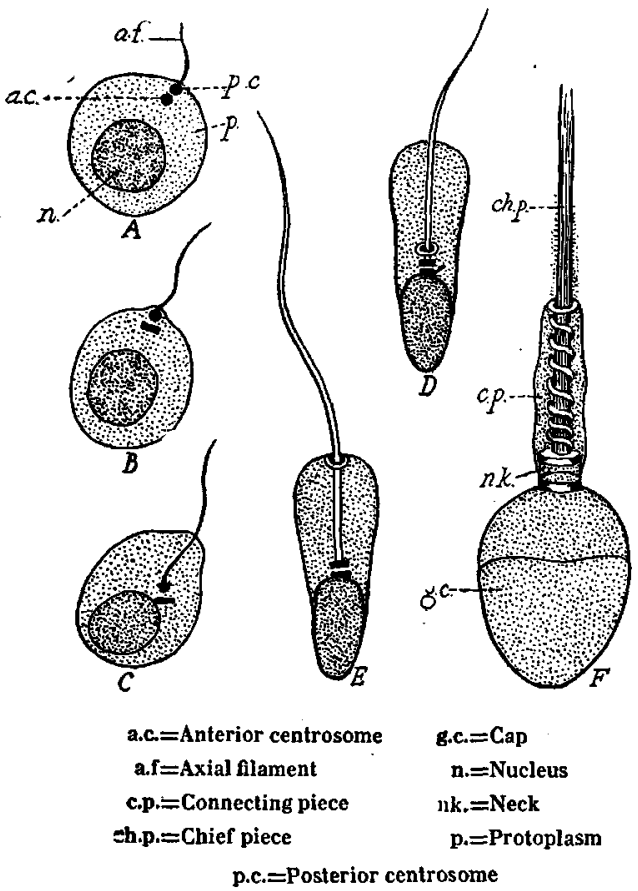

Figure 5. The Development of a Human Spermatozoon

The process of spermatogenesis is closely analogous to the maturation of the ovum. In each case the ancestral germinal cells are prepared for union by a process of reduction, as a result of which there remains in the mature germ-cell (ovum or spermatozoon) only one-half the number of chromosomes characteristic of the cells of the body tissues of the individual which produces the particular gamete. However, in normal reproduction, these chromosomes represent all of the essential characteristics of the species. Thus, an individual who is the product of the union of two such gametes possesses twice over all the essential characteristics of the race. And thus the difference in the repertoire of non-essentials permits the ests of eugenics is centered upon these particular cellular units.

\section{(b) The Reproductive Mechanism of the Human Female.}

In the human species more duties are performed by the genital mechanism of the female than by that of the male. In the female, not only must the mature germ-cell (ovum) be produced and delivered to the place of fertilization in the Fallopian tube or uterus, but the uterus must implant the zygote or fertilized egg and nourish it until the fetus is ready for birth. By the process of parturition, the female mechanism must

1 J. P. McMurrich: The Development of the Human Body, p. 19. 
deliver the child, and finally by the secretions of the mammary glands, the mother must further nourish the child for a number of months.

The Germ-tract. The ova are developed tion must intervene) is discharged from each ovary every twenty-eight days during the reproductive period. Upon being thus discharged, the ova are set free in the body cavity near the funnel-chaped openings of the

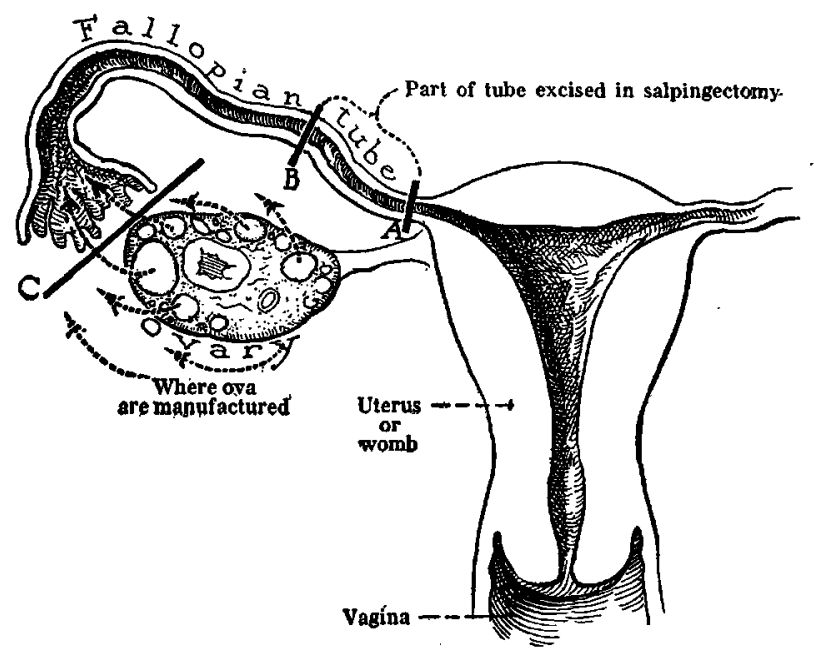

Figure 6. Schematic Representation of the Genital Tract in the Female

in the cortex of the ovaries. The cortex comprises that part of the ovary which overlies the central or medullary portion. Ova are discharged from the Graafian follicles, which are imbedded in the cortex, by the rupture of the surface (a process known as ovulation). This process is variable and periodical, but as a rule one ovum (as yet not ready for fertilization; the process of matura-
Fallopian tubes, each of which openings is provided with vibratory cilia. These cilia set up currents from the body fluids which direct the free but non-motile ovum into the tube, whence it is carried by ciliary action the entire length of this duct to its final place of fertilization near the end of the tube or in the cavity of the uterus. Ova, if not fertilized, soon degenerate, but those which

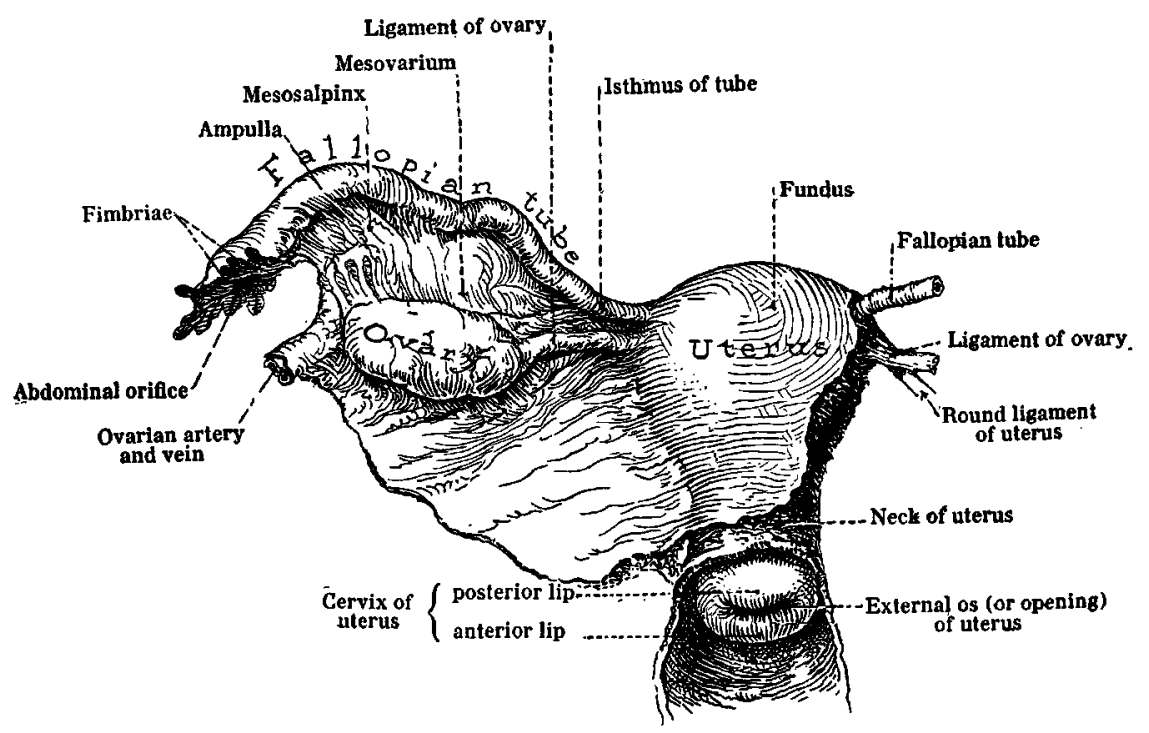

Figure 7. The Ovary, Fallopian Tube and Uterus in Place 
unite with the spermatozoa immediately begin active development.

The union of the spermatozoon and ovum is believed to take place usually in the Fallopian tube, whence the fertilized ovum, or zygote, as it is now called, normally migrates to the cavity of the uterus, where it becomes implanted. Under normal conditions, only one spermatozoon penetrates the egg or ovum; others may be present in great numbers, but they eventually perish. There is thought to be a chemical affinity between the unfertilized ovum and the spermatozoon; at any rate they are brought together by physical or chemical agencies. Immediately after fertilization, a reaction appears to establish a resistance to the penetration of long, three-fourths inch broad, and one-half inch thick. Each ovary is held in place by a suspensory ligament, which is a peritoneal fold, and by the ovarian ligament, which attaches it to the uterus. It is also steadied by the Fallopian tube. Its cortex, or outer portion, contains a number of Graafian follicles, each of which carries a potential ovum. These follicles vary in size with age and degree of development, from one-sixth inch in diameter when about ready to deliver the ovum, down to the size of pin-head, thence smaller, and finally below the range of the vision of the naked eye. As a Graafian follicle develops, the growing ovum which it contains is surrounded by small cells, and this mass, which fills only a small portion of the fol-

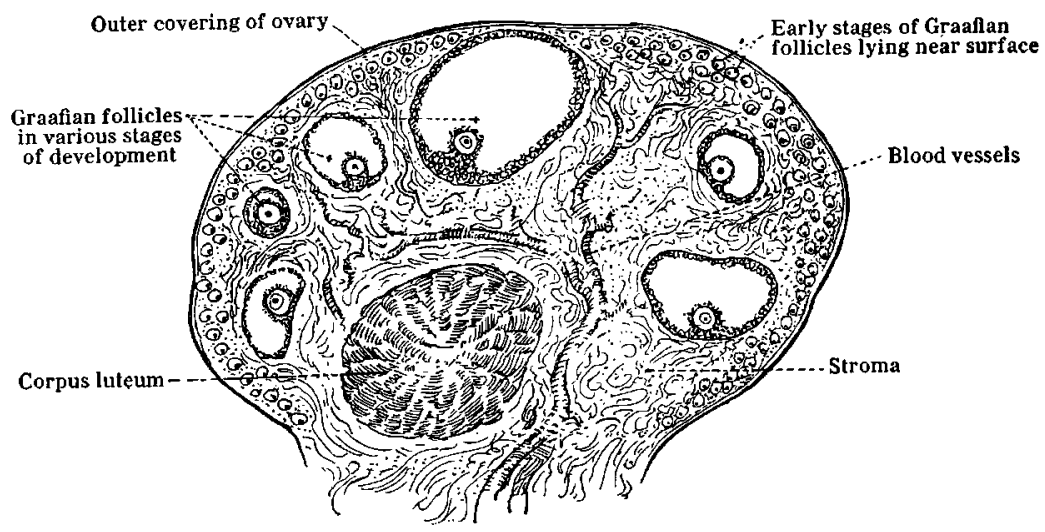

Figure 8. A Diagrammatic Section of the Human Ovary

other spermatozoa, at least by this time a definite vitelline membrane surrounds the zygote.

The Ovaries. The function of the testes was known long before the analogous female organs were identified. Galen (born $130 \mathrm{~A}$. D.) described the ovaries as testes muliebres. Willian Harvey, in 1651, laid down the dictum that the ovum is the starting point common to all animals. In $166+$ Nicolaus Steno identified the female sex-gland of mammals with that of sharks, and first named it the ovary; but it was not until 1827 that the identity of the human ovum was established. This was the work of $k$. E. von Baer.

The human ovaries are a pair of dehiscent almond-shaped glands situated one on either side of the uterus in a layer of the broad ligament and below the Fallopian tubes. In the mature adult the ovary is reddish-gray in color, and about one and a half inches licle, is attached to the inner lining of the sphere. The remainder is filled with the follicular fluid. According to different authorities, from ten to fifty Graafian follicles may be seen at one time bulging on the surface of a functioning ovary.

In childhood the surface of the ovary is smooth and even, but in adult life it becomes pitted and fibrous, due to scars caused by the rupturing of Graafian follicles.

The early differentiation of the primitive ova is a feature which deserves special attention. Before a female child is born there are perhaps 100,000 of these potential ova in each ovary, but even before birth their degeneration begins, so that at the time of birth it has been estimated that there still remain perhaps 30,000 or 40,000 potential ova; but only a few of them develop, and the rate is very slow. With puberty the process of ovulation discharges an egg from cach ovary. As a rule ovulation occurs 
generally at the time of menstruation, although it has been shown that the two processes may operate independently. Ovulation continues periodically at intervals of about twenty-eight days until the climacteric. Thus during the thirty years of active sexual maturity the human female will produce 700 or 800 mature ova. After the climacteric all of these potential egg cells degenerate, and the ovary becomes shrunken and fibrous.

After the Graafian follicle discharges its ovum, the reconstructed body which remains is known as the corpus luteum. If the ovum is not fertilized, the corpus luteum (false) reaches its maximum development within a length, and lineally consists of a constricted portion, the cord-like isthmus, which connects with the uterus (its caliber barely admits a small bristle), the softer ampulla or dilated portion, which curves over the ovary, and the infundibulum, the funnel-shaped terminal opening of the tube. The margin of the latter is irregular, due to the presence of fimbriae, one of which is attached to the ovary, the remainder being free.

While the oviduct is analogous in function to the vas deferens, embryologically these two ducts have a very different descent, the oviduct developing from the duct of Müller, and the vas deferens from the Wolffian duct.

A cross-section of the Fallopian tube

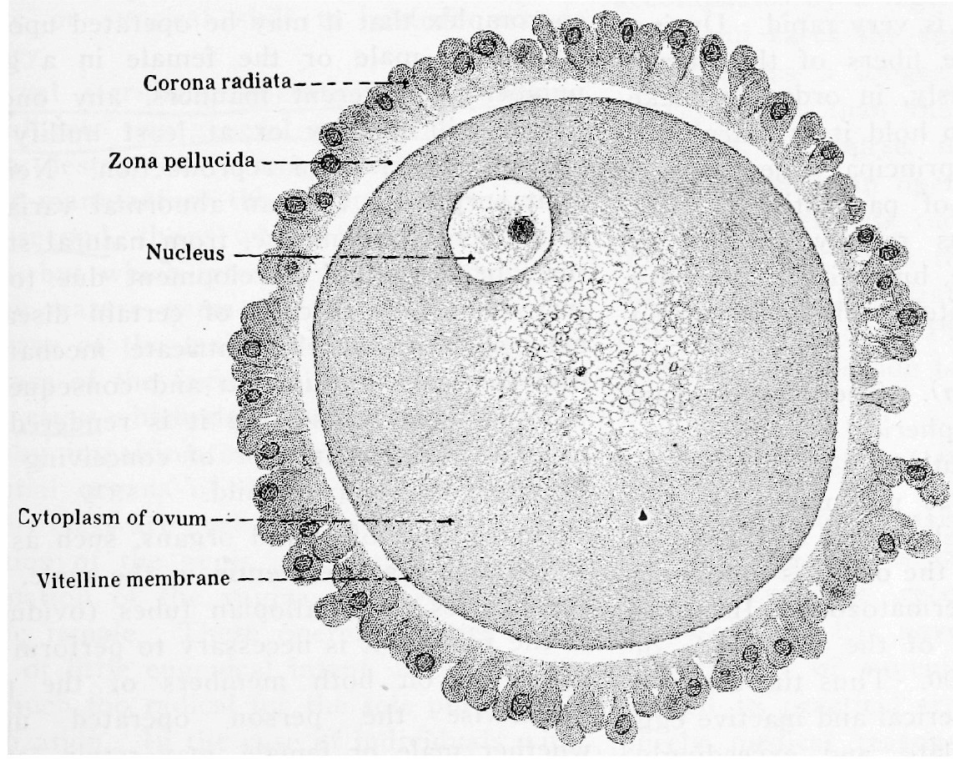

Figure 9. A Mature Human Ovum

week and then begins to shrink, and is entirely absorbed within a short time, leaving only a pitted scar. If, however, fertilization occurs, the corpus luteum (true) continues to grow for two or three months, and acquires the size of one-third to one-fourth that of the entire ovary. Finally it begins to shrink, but may not totally disappear until a month or more after labor.

The Fallopian Tubes (or Oviducts). Unlike the case in the human male, in the female the mature gamete does not have a continuous duct for its passageway. The mature egg, after being discharged into the body cavity, is taken up by the open and fimbriated end of the Fallopian tube or oviduct. This latter organ is a muscular trumpet-shaped tube about four inches in shows three coats, first, an outer peritoneal covering; second, two muscular layers (the outer with longitudinal and the inner with circular fibers); and third, a lining of mucous membrane. The latter is folded longitudinally, is ciliated, and contains numerous glands. These cilia direct currents from the peritoneal cavity to the cavity of the uterus. They thus aid the movement of the ova and impede that of the spermatozoa.

The Uterus (or Womb). The uterus is the organ of gestation. It receives, implants and supports the fertilized ovum until the latter develops into a child. It is a hollow pear-shaped organ with thick muscular walls. In non-pregnant adults it measures about three inches in length, two inches in greatest breadth, and one inch in thickness. 
It weighs from one to one and a half ounces, and is held in position by eight ligaments. The upper portion of the uterus, which lies above the entrance of the Fallopian tubes, is called the fundus. Below the tubes the gradually narrowing central portion is called the body, and the constricted portion, which is about one inch long. is called the cervix or neck. The neck protrudes into the upper anterior end of the vagina, and contains the os uteri, which connects the cavities of the uterus and vagina. It is through this opening that the spermatozoa enter, and from it that the child is delivered at parturition.

The growth of the uterus is very slow until the approach of puberty, when, for a time, its development is very rapid. During pregnancy the muscle fibers of the uterus hypertrophy enormously, in order to make room for the fetus, to hold it in place, and finally to act as the principal object of expulsion at the time of parturition. After parturition the uterus rapidly regains its normal size and shape, but neither its cavity nor the os uteri quite reaches the virgin smallness.

The Ovum (or Egg). The human ovum is a large non-motile spherical cell which, according to different authorities, ranges from 0.17 millimeters to 0.25 millimeters in diameter. and is thus barely visible to the naked eye. As in all animals, the ovum is immensely larger than the spermatozoon. In some species the size ratio of the two kinds of sex-cells is 1 to 100,000 . Thus the contrast between the large, spherical and inactive egg and the small, flagellate, and exceedingly motile spermatozoon is very great.

After the expulsion of the ovum from the Graafian follicle, an important change must take place before it is ready for fertilization. This change is called maturation, and is essentially a cell-division by which the number of chromosomes (the essential bearers of heredity) within the nucleus is reduced to one-half the number of the normal cells of the tissues of the body. Thus the egg is prepared to receive a like contribution of one-half the number of trait carrying qualities in a similarly reduced nucleus of the spermatozoon.

The ovum contains a nucleus or gerninal vesicle of relatively large size, being about one-fourth the diameter of the entire ovum. Besides the nuclens, the ovum contains deutoplasm (yolk), which is a nutritive substance, and a still larger quantity of clear cytoplasm. It is surrounded by a zona pellucida, which is a thin film giving it strength. Sometimes the remnants of the covering of smaller outer cells adhere, to which cell-group the term corona radiata is applied.

Of the seven or eight hundred ova produced by the average woman, she is of course able to use only a very few (less than a score) in the production of offspring.

\section{SECTION B. THE PRINCIPAL TYPES OF SURGICAL OPERATIONS USED IN EFFECTING SEXUAL STERIL- IZATION.}

The mechanism of human reproduction is so complex that it may be operated upon in either the male or the female in a great number of different manners, any one of which will destroy or at least nullify the essential function of reproduction. Neither is it surprising that an abnormal variation of an hereditary nature, from natural structure, or abnormal development due to in jury or to the inroads of certain diseases, may so disorder this intricate mechanism that it ceases to function and consequently the individual possessing it is rendered incapable of begetting, or of conceiving and bringing to birth, a child.

In the case of paired organs, such as the testes and vasa deferentia in the male, and the ovaries and Fallopian tubes (oviducts) in the female, it is necessary to perform the operation on both members of the pair. Otherwise the person operated upon, whether male or female, may retain sexual fertility

The matter of permanence of sterilization is equally important with that of effectiveness. Only in the case of the minor and least radical means of sterilization is there a possibility of restoring sexual fertility. Particularly in cases of ligation, whether of vasa deferentia or of Fallopian tubes, is there such a possibility by the surgical removal of the obstruction in the gametecarrying ducts. In certain types of ligation restoration is said to take place naturally without surgical or medical interference. In cases of vasectomy in which only a very small section ( $\mathrm{I} / 4$ inch or less) of vas deferens is removed, there is said to be a possibility of reanastomosing a functioning duct.

The permanency of sterilization by scarifying or cauterizing the intra-uterine tronal 
openings depends upon the skill and efficiency with which the particular operations are performed, and because of the great skill required, and the amount of guesswork involved, such operations are to be placed in the list of doubtful efficacy and permanence. The permanency of sterilization by X-rays is not proven for either sex. With the development of more extensive knowledge of this relatively new agency, a method of its use which will assure permanency may be worked out. but at present it is quite uncertain in both efficacy and permanency. All other types of sterilization here listed for both male and female are absolute and permanent, and when any one of them is properly performed, it is beyond the power of nature or surgical skill to restore sexual fertility.

Sexual sterilizing operations in common use fall into two general groups first, those which destroy or remove the sex glands which manufacture the essential germ-cells. and, second, those which leave the gonad intact, but which interfere with the delivery of the mature germ-cells to the outside in the case of the male, and to the uterus in the case of the female. But there is also a third class which destroys the sexual function by impairing or removing one of the essential organs of coitus or child-bearing. In this class are such operations as the amputation of the penis in the male, and the extirpation of the vagina or of the uterus in the female. These operations are, however, of little eugenical intent, because they are much too radical for the sole purpose of sterilization. In the case of individuals with undiseased sex-organs, the operations of vasectomy in the male and salpingectomy in the female are, under the present stage of surgical knowledge and practice, greatly to be preferred. 'The reason is that they are the least radical which produce permanent sterility.

\section{Male.}

Practically the human male nay be made sexually sterile ${ }^{1}$ by operating upon the testes, the spermatic cords, or the penis, all being esscntial organs of natural reproduction. Any of the following surgical operations or treatments, here listed in order of decreasing radicalness, will effect sexual sterility in this sex:

(1) Phallo-orchidectomy

(2) Phallectomy,

(3) Castration (Orchidectomy) ?.

4) Spermectomy.
(5) Vasectony

(6) Ligation of the vas deferens.

(r) X-ray Treatment.

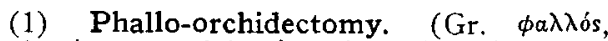
penis; ó $\chi(s$, testicle; $\dot{\kappa} \kappa \tau \mu \mu \dot{\eta}$, excision.)

This operation consists both in castration and in the amputation of the penis. It appears in historical times to have been resorted to for the purpose of producing eunuchs with no external genitals. Boys so operated on became the true castrati of the Romans. Phallo-orchidectomy is still resorted to by certain African tribes, for the purpose of supplying slaves to the Mohammedan markets. The operation when carried out with barbarous crudeness is said to be accompanied by a high death rate. Even in successful cases the surgical shock is great and requires a longer period of time for ronvalescence than the ordinary castration There is, of course, no eugenical purpose served by such an operation that cannot be found in much less radical treatment. The minimum radicalness that will produce permanent sexual sterilization serves the maximum eugenical ends. Phallo-orchidectomy is mutilation in addition to eugenically effective castration.

(2) Phallectomy. (Gr. $\phi a \lambda \lambda o ́ s, ~ p e n i s ; ~ є ̇ \kappa \tau o \mu \dot{\eta}$, excision.)

This operation consists in the amputation of the penis. It is rarely resorted to, so far as available records go, for social purposes, and has never been used for the achievement of eugenical ends. Its use is limited to practical treatment indicated for purely medical reasons, usually carcinoma.

1 In the wider sense sexual sterility means physiologically incapable, for whatever cause, of functioning as a parent; in the narrower meaning it applies only to loss of ability to produce active spermatozoa or ova. The term is here used in the wider sense.

2 "It is important to remember that there are different degrees of castration, for in current language these are seldom distinguished. The Romans recognized four different degrees. 1 . True castrati, from whom both the testicles and the penis had been removed. 2. Bpadones, from whom the testicles only had been removed. 3. Thlibiae, in whom the testicles had not been removed, but destroyed by crushing; this practice is referred to by Hippocrates. 4. Thlasiae, in whom the spermatic cord had simply been cut. Millant, from whose Paris thesis (Castration Criminelle et Maniaque, 1902): I take these definitions, points out that it was recognized that spadones remained apt for coitus if the operation was performed after puberty, a fact appreciated by many Roman ladies, ad securas libidinationes, as $\mathbf{S t}$. Jerome remarked, while Martial (lib. iv.) said of a Roman lady who sought eunuchs: "Vult futui Gallia, non parere." (See also Millant. Ies Funuques à Travers les Ages, 1909, and articles by Lipa Bey and Zambaco, SexualProbleme, Oct. and Dec., 1911.) Havelock Ellis. "The Analysis of the Sex Impulse," p. 9. 
It is a major operation and requires the usual hospital after-treatment of such operations.

The following is an account of the surgical technique given by Warbasse:

"Amputation of the penis. *** A sound or catheter is inserted into the urethra and an elastic ligature is placed about the organ at its root. *** The glans is grasped with tenaculum forceps, drawn forward, and held by an assistant. The assistant also holds the sound. A circular incision is then made through the skin $* * *$. The skin flap is dissected back far enough to provide a flap to cover the stump. The corpora cavernosa are then divided. The urethra with its surrounding spongy tissue is then dissected free and divided at a distance of about $1 \mathrm{~cm} .(1 / 3$ inch) anterior to the point of division of the cavernous bodies.

"The dorsal artery and veins" are then tied. The constricting ligature is removed. Some blood rushes out of the erectile sinuses and bleeding then usually stops. The divided surfaces of erectile tissue is sovered in by a few sutures of fine catgut passing from side to side. The urethra is then divided on its floor for about $7 \mathrm{~mm}$. ( $1 / 4$ inch). The skin is then pulled over the stump. A suture catches the urethra on either side and fastens it to the skin at the lower angle of the wound. The rest of the skin is then approximated in a vertical line. The object of longitudinal division of the mouth of the urethra is to insure against cicatricial narrowing. A catheter should be inserted into the bladder for continuous drainage for two days."

The penis is the organ of copulation, but has nothing to do with manufac ${ }^{\prime}$ uring the spermatozoa. A man whose penis has been amputated is practically incapable of procreating, but his testes may still proliferate active spermatozoa, and his asa deferentia may still deliver them to the outside. If artificial impregnation by means of the syringe, using the male semen containing active spermatozoa, ever becomes feasible in the human species, as it has proven practical with certain of the largest domestic animals, then phallectomy will not necessarily preclude a man from becoming a father

(3) Castration (L castratrio castration);

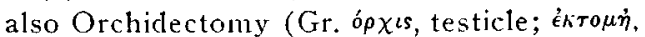
excision.)

Castration consists in the removal of both testes in their entirety. This operation may be modified by removing only a major portion of the testes (the remaining portion is called a "graft")," but by destroying their functional ducts that sterilization is effected without greatly interfering with the gland as an organ of internal secretion. There is another variation of castration, namely crushing rather than excising the testes in young boys. This operation destroys the functional use of the testes in producing spermatozoa, but apparently does not destroy the property of internal secretion. Thus, in the end results, crushing the testes is much like removing only a major portion of them. So far as information can be obtained, crushing is not resorted to today. Eugenically the most satisfactory form of castration consists in removing both the testes in their entirety. If it is desired only to accomplish sterilization without destroying the endocrine value of the testes, then vasectomy, on account of the simplicity and mildness, would appear to be preferable to removing even a major portion of the testes.

A eunuch is a man who was castrated in boyhood. This type of man was known to practically all of the ancient civilized and half-civilized peoples. Eunuchs played an important part in Egyptian, Chinese, Indian, Persian and Roman life. In Mohammedan countries they are still prized as harem attendants. In the papal choir they (soprani) were common until the accession of Leo XIII. It should be pointed out that in historic times most of the cases of castration have been performed not primarily for eugenical purposes, but for commercial or social reasons. The latter motives must be rated as shortsighted because, if a racially valuable individual is unsexed, his natural contribution to the success of the race to which he belongs ends with his own personal existence.

Neither ancient nor half-civilized peoples were acquainted with the use of general anacsthesia, but they nevertheless castrated boys and men. The operation is a severe one and today should be performed only under hospital conditions. On account of the shortness of time required, nitrous oxide (laughing gas) is recommended by some surgeons, also the operation may be per-

1 Warbasse. James Peter: Surgical Treat ment, Vol. III., p. 255 . W. B. Saunders Co. Philadelphia, 1919.

2 Proceedings of the Roy. Soc., Vol. $73, \mathrm{Nt}$ 1904. Experiments by $\mathbf{S}$. $G$. Shattock and $C$. $G$. Seligman. 
formed under a local anaesthetic. However, a general anaesthetic is usually preferred.

Castration is usually unattended by serious complications. In young boys it is even less serious surgically than in adults.

In 1886 the value of double castration in treating enlarged prostate glands was demonstrated. As stated elsewhere, vasectomy was, a decade later, proven to be just as efficacious in relieving this ailment.

Surgical Technique. (Figure 10.)

Preparation for operation. ${ }^{1}$ "Preliminary blunt dissection. The isolation of the cord should be carried as high as is necessary. In the case of malignant disease the fascial coverings of the cord should be removed with the cord, and the amputation should be made as high as possible. In ligating the cord, it is best to separate it into several smaller fasciculae and ligate each separately rather than throw a single large ligature around the whole mass. The wound in the scrotum may be closed by a subcuticular suture and compressing dressing applied."

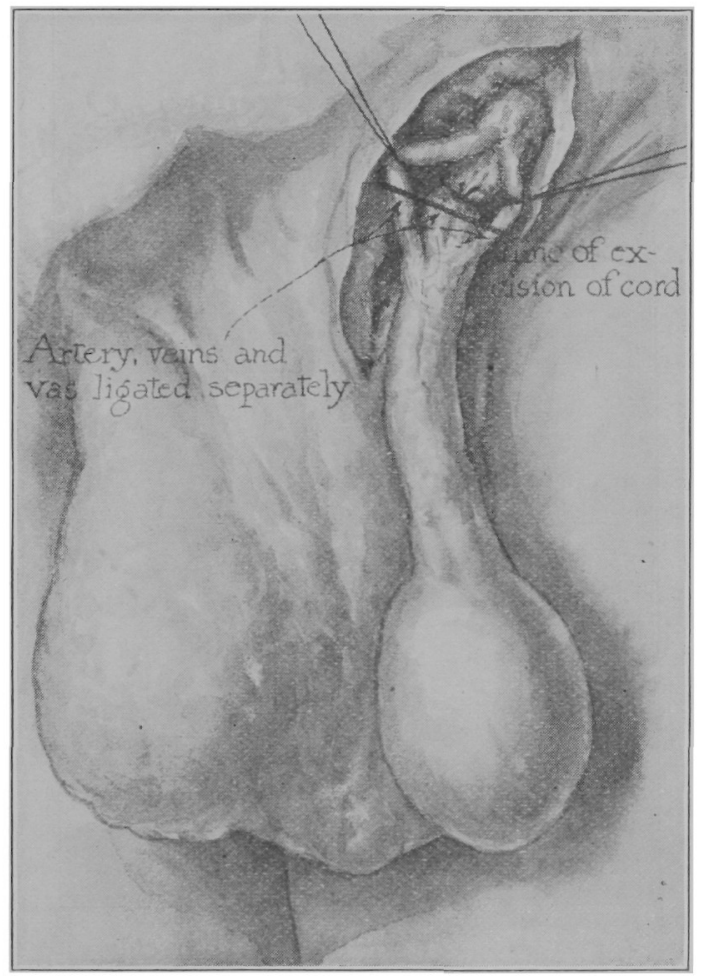

Figure Io. The Operation of Castration

cleansing of the operative regions should be repeated several times at intervals of some hours, and immediately before the operation the penis should be bandaged in sterile gauze, since it is a frequent source of infection in operations about the genitalia."

\section{The Operation. ${ }^{2}$}

"An incision is begun just below the external inguinal opening and is carried downward on the scrotum as far as the middle of the testicle. This incision should pass through the skin and the several layers of fascin down to the cord and the tunica vaginallis. The testicle with the tunica vaginalis and the cord should. be isolated by
After-treatment.

"The wound after this operation calls for no special treatment. Wounds of the scrotum, on account of the folds in the skin, are liable to sepsis. The stump of the cord, unless the precaution is taken of sewing it into the abdominal ring, may retract and bleed. Hernia is likely to make its appearance after "castration.".

\footnotetext{
${ }^{1}$ White and Martin: Genito-Urinary Surgery, 1917, p. 340.

2 Warbasse, James Peter: Surgical Treatment, Vol. III, pp. 319-320. W. B. Saunders Co., Philadelphia, 1919.

${ }^{3}$ Crandon-Ehrenfried: Surgical After-Treatment. W. B. Saunders \& Co., Philadelphla, 1912 (Second Edition).
} 
Usually the patient elects to remain in bed eight or ten days, but according to some authorities this is not necessary.

(4) Spermectomy. (Gr. $\sigma \pi \hat{\epsilon} \rho \mu a$, seed; '́ं $\kappa \tau o \mu \dot{\eta}$, excision.)

This operation consists in the ligation and excision of a section of the spermatic cord. It is, so far as sexual sterilization is concerned, the equivalent "of vasectomy; but physiologically and surgically is more radical in that in spermectomy the entire spermatic cord, including the nerves, veins and arteries cision of a section ( $1 / 4$ inch to 1 inch) of each of the vasa deferentia. The vas deferens is the tube, a part of the spermatic cord, which carries the matured spermatozoa from the testis to the epididymis. Vasectomy is the least radical operation for sexual sterilization upon the male which is sure to be effective. This operation is comparable functionally with salpingectomy in the female, because in each case the sex-germ carrying duct is severed, but anatomically and embryologically the two ducts are

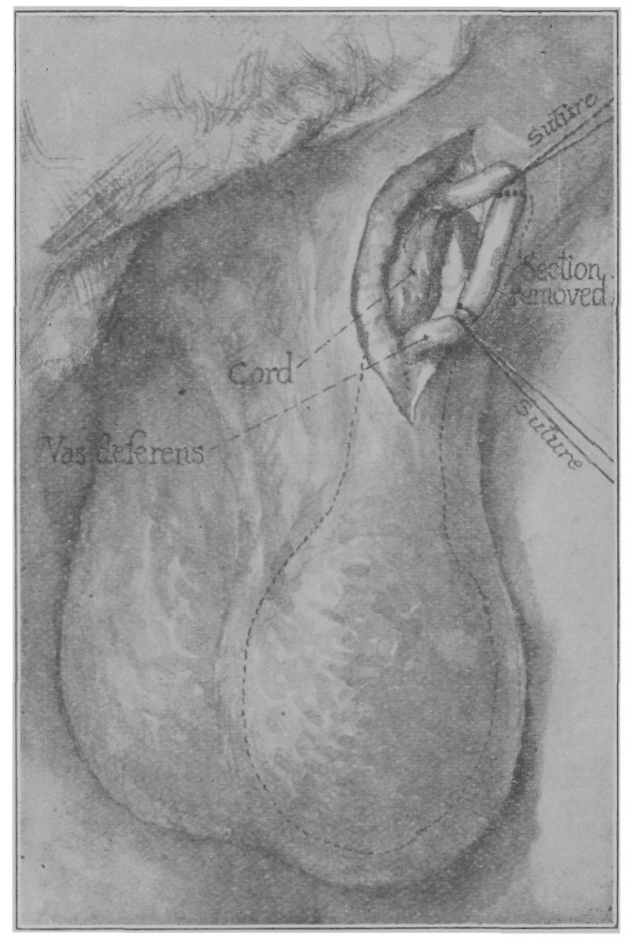

Figure II. The Operation of Vasectomy

Drawing made under the direction of Dr. Margaret H. Smyth, Stockton State Hospital, California

which supply the testes, as well as the vas deferens, which is the essential sex-duct, are excised.

Physicians found that in treating prostatic enlargement spermectomy is just as effective as castration, and still later that vasectomy is just as effective as spermectomy. The consequence is that at present there is practically no therapeutic, and absolutely no eugenical purpose served by spermectomy.

(5) Vasectomy. (L. vas, vessel; $\dot{\epsilon} \kappa \tau o \mu \dot{\eta}$, excision.)

Vasectomy, which is a refinement of spermectomy, consists in the ligation and ex- quite different, the Fallopian tube in the female being deep-seated and embryologically developed from the duct of Miller, most of which degenerates in the male fetus. On the other hand, the vas deferens in the male is much smaller in external diameter, is situated near the surface, and embryologically develops from the Wolffian duct, most of which degenerates in the female fetus.

Dr. H. C. Sharp, surgeon of the Reformatory at Jeffersonville, Indiana, appears to have been the first to use vasectomy etrenically on any scale. His operations of this nature began in $\cdot 1899$. 
Surgical Technique. (Figure 11.)

Vasectomy is a very simple operation, which is accompanied by very little shock, and may be performed without an anæsthetic, although most surgeons advise that it be done under local anæsthesia. Its pain without anæsthetic has been compared by men who were vasectomized to that experienced in the extraction of a tooth. In most of the cases reported, the preparation consisted only in a thorough cleansing of the parts with soap and water. The whole operation requires less than five minutes when executed by a skillful surgeon.

\section{VASECTOMY FOR THE PURPOSE OF STERILIZATION AS DONE AT THE STOCKTON STATE HOSPITAL.}

"Roll the vas between the thumb and index finger, separating it from the other structures of the cord. Fix it close against the skin of the scrotum with small tenaculum forceps.

At this point make incision over the vas about $1 \mathrm{~cm}$ in length down to and exposing vas. Lift up the vas with a sirong curved needle and cut out a portion $1 / 2$ inch in length.

Leave the lower end free to drop back into the sheath. Tie the upper end with fine silk ligature.

Sew up the sheath with fine catgut, leaving the upper end of the vas outside of the sheath, to prevent possible union of the cut ends of the vas.

Operation is done in a few minutes and in insane patients best done under general anæsthetic, preferably gas. Operation is practically bloodless."

\section{Dr. Margaret H. Smyth,}

Stockton State Hospital, California. May 22, 1921,

\section{According to Warbasse. ${ }^{1}$}

"It may be done under local anesthesia, first anesthetizing the skin and then, after incising the skin, infiltrating the cord with weak cocaine solution, care being taken not to puncture a vein. The skin incision begins just below the external inguinal opening and extends downward in the line of the cord for $1 \mathrm{l} / 2$ inches $(4 \mathrm{~cm}$.). The coverings of the cord are divided and pressed aside. The vas is isolated and two ligatures are tied about it. $2 \mathrm{~cm} .(3 / 4$ inch) apart. A segment of the vas $1.25 \mathrm{~cm}$. ( $\mathrm{t} / 2$ inch) in length is cut out from between the ligatures. The two stumps should not be tied together. The upper stump should be doubled back upon itself and the ligature tied around the doubled tube. This causes angulation which more securely closes the tube against the entrance of spermatozoa. The skin wound may be closed with a subcuticular suture."

$$
\text { After-care. }
$$

The patient may leave immediately. Parts may feel sore for a day or two, but the patient need not abstain from work. There have been no cases of serious post-operative complications reported from vasectomy performed for eugenical purposes.

However, in the case of enlargement of the prostate in old men, "Vasectomy done early gives a mortality of from 3 to $5 \%$. If performed later, the mortality is 10 to $15 \% . " 2$ but there is practically no relation between vasectomy of young men for eugenical and of old men for therapeutical purposes.

Permanency. Vasectomy, properly performed, causes absolute and permanent sexsterility, unless surgery is again resorted to, but even in which case restoration of function is doubtful.

Dr. G. Frank Lydston ${ }^{3}$ has described the surgery of re-anastomosis of the vas deferens in cases wherein restoration of function is desired.

Dr. $W \mathrm{~m}$. T. Belfield ${ }^{4}$ of Chicago, makes the following three statements:

(1) Vasectomy which removes over an inch of the vas offers little chance of restoration of the lumen and function of that tube.

(2) Vasectomy which removes $1 / 4$ inch, and leaves the obliquely cut ends of the tube overlapping, permits subsequent restoration of the lumen and function of this tube by a modification of the technique described by Mayo, Annals of Surgery, Jan., 1895.

(3) Restoration of an outlet after occlusion of the epididymis by gonorrhea, has been successful in a minority of the attempts made.

(6) Ligation of the vas deferens. The ligation of the whole spermatic cord, or of the vas deferens alone, has been attempted and supported as a means of attaining sexual sterilization in the male. So long as the

1 Warbasse, James Peter: Surgical Treatment, Vol. III., p. 320 . W. B. Saunders Co., Philadelphia, 1919.

2Modern Surgery: Da Costa, p. 1388. 7th Edition. 1918

3 Impotence, Sterility and Sex-Gland Implantation: Riverton Press, Chicago, 1917. Chapter VI, pp. 92-96.

Leter to author, July $29,1919$. 
vas deferens is not a functional duct, whether because a section has been excised, or because it is occluded by ligation, or inflamed following disease, the particular male will be sexually sterile. The successful ligation of the vas deferens is surgically more difficult than its excision. There is a possibility that if the ligature consists of organic substances, it is apt either to be absorbed if too thin, or to suppurate if too thick.

According to Dickinson" "a fine silk or linen ligature or silver wire is passed about it (the vas deferens) and drawn snugly enough to obliterate the caliber of the duct, but with intention not to cut it through. The ends of the ligature are cut close, the duct dropped back, and the skin closed. The ligature becomes encysted. A test made of the semen shows all other elements, and unalterated bulk, but no spermatozoa. If at some subsequent time it is desired to resume this capability for fertilization, the wound can be reopened and the little ligature cut off. But experiment has shown that, as with other ligatures, with mucous lining in apposition with mucous lining, and particularly with pressure from behind, it is difficult or impossible to shut off a canal. * * No ligature except a silver wire will last."

It is suggested that ligation in two or more places would promote permanence.

The surgical severity of the operation is about the same as that accompanying vasectomy, but in its after-effects, due to the inflammation from the ligatures, ligation appears be accompanied by more temporary discomfort than that which follows simple vasectomy.

Restoration of an occluded vas deferens by surgical interference stands a greater chance in ligation than in ordinary vasectomy. Surgeons have had some experience in such work, because in many cases the vasa deferentia are occluded by gonorrheal infection, but the principal reason for expecting restoration in the case of ligation is that it is very difficult to secure permanent occlusion "in a duct by muco-mucous apposition."

(7) X-ray treatment. Roentgen or Xrays were discovered in 1895 by W. K. Roentgen; radium in 1899 by $P$. and $M m e$. Curie. Experimentation had not continued long before it was discovered (first in guinea-pigs and rabbits, 1903, and later in man, 1904), that exposure to repeated doses of $X$-rays caused azoospermia.

Sterilization by $\mathrm{X}$-rays is the most subtle of known methods. In the male $\mathrm{X}$-radiation effects sterility by causing the destruction of the epithelial cells lining the tubuli sem- iniferi of the testes, certain of which cells in normal course develop into spermatozoa. The result is that the semen is devoid of spermatozoa.

Since X-rays cannot be felt, there is no need for an anaesthetic of any sort in connection with their application to effect sterility, neither is there any surgical shock accompanying the treatment.

If skillfully applied in proper doses, there should be no untoward results. Unskillfully applied. this treatment may result in "Roentgen burns", and thus seriously damage the tissues affected. Persons who work with $\mathrm{X}$-rays and are subjected to them for long periods of time, without proper protection, suffer greatly from tissue destruction.

Dosage and Technique. The American Roentgen Ray Society, Dr. Arthur C. Christie, President, March 17, 1921, reports as follows: "In reference to the use of X-rays for effecting sexual sterilization: (a) Apparatus needed: The ordinary 10 kilowatt outfit with Coolidge tube would be the most satisfactory for this purpose. (b) Dosage: 5 milliamperes; 8 inch spark gap; 10 inch target skin distance; each treatment $8 \mathrm{~min}-$ utes through 5 millimeters aluminum filter; both testicles being treated at once. (c) Number of applications: Three, at intervals of four weeks. (d) Physiological consequences: None other than sexual sterility."

Comment. There have been so few cases of sexual sterilization of human beings by $\mathrm{X}$-rays, in which clinical records have been kept, that physicians are only just now beginning to describe with assurance the technique of the treatment. It appears, however, that the ultimate treatment will consist in several applications each of a few minutes' duration, at intervals of a number of weeks, but the optimum number, duration and intensity of application are still matters of investigation.

The principal problems connected with this type of sterilization are those of tissue injury, of effectiveness, and of permanence. The question naturally arises whether a sexgland, having been made sterile by X-ray will have to be irradiated at certain intervals in order to maintain sterility, or whether there is a possibility of restoring fertility through surgical or medical treatment. This, too, is a matter for experimental determina-

1 Simple Sterilization of Women by Cautery Stricture at the Intra-Uterine Tubal Openings, Compared with other Methods: Surgery, Gynecology and Obstetrics, August, 1916, prs.?03214. 
tion. In order to be of certain eugenical value, it is clear, of course, that sexual sterility must be permanent.

From Colwell and Russ ${ }^{1}$ we learn that in 1903 Frieben, working with rabbits and guinea-pigs, demonstrated that prolonged exposure to rays produces sterility and atrophy of testes, and showed that sterility was due to destruction of the epithelium lining seminiferous tubules. The first human experimental work was done in 1904 by Philipp. Two men were irradiated in the perineal region for therapeutic reasons. The first was exposed to $\mathrm{X}$-rays on thirty successive days (total of 365 minutes). The second was exposed on eighteen days (total 190 minutes). Fxamination showed absence of spermatozoa in both subjects.

In 1905 Brown and Osgood ${ }^{2}$ recorded 18 cases of X-ray workers who were subjects of complete azoospermia. These men had done extensive $\mathrm{X}$-ray work for more than three years.

Dr. James A. Honeij, ${ }^{3}$ of the Yale Roentgenological Laboratory, wrote: "I feel that practical application of the X-rays to sexual sterilization should not be practiced until considerably more animal experimentation has been undertaken."

That much is yet to be learned concerning the use of $\mathrm{X}$-rays and radium in effecting sexual sterilization in man, is well set forth by the following letter from Dr. Halsey $\mathrm{J}$. Bagg, Memorial Hospital, 106th street and Central Park West, New York City, who is conducting animal experimentation with radium and $\mathrm{X}$-rays:

December 5, 1921.

"* * * The whole subject interests me greatly, especially in the light of my recent biological experiments with both $\mathrm{X}$-rays and radium on disturbances in mammalian development.

"I have conferred with our X-ray department, and they agree that the dose specified in your questionnaire (X-ray outfits commonly used by dentists) is a 'full skin dose,' but experience here has shown that individwal difference in biological reaction is so great that we do not know, how permanent the sterilization might be. I believe that, so far as we know, no scientific experiments have been conducted along these lines on the larger mammals and until such studies are made, we are not justified in drawing final conclusions.

"There is also a tendency to question the statement that the physiological effects are probably nothing more than psychomental derangement. Physicians I have spoken to suggest that more serious internal secretion changes might result from treating especially younger humans, and from a eugenic standpoint, I suppose, this is just the class you want to reach. Again only experimentation can answer the question.

"The question of sterilization by radium is also an unanswerable one at the present time. No complete data, that I know of, are available, and in the light of cases, where the reproductive function has been retained, a considerable time after radium treatment, the physicians I have spoken to, (who have had considerable experience in the use of radium) would not commit themselves so far as to suggest any possible dosage."

In a short paper urging the proper protection of X-ray workers on account of their liability to injury, and especially to sexual sterility, Dr. Alfred C. Jordan ${ }^{4}$ says:

"Considering the entirely undefended position of the testes, it is no matter for surprise that they should be affected by very small doses of $\mathrm{X}$-rays, provided the doses be repeated often enough. Wisdom suggests the advisability of inserting a small protective apron under the clothes as an additional measure. This expedient is in fairly general use, but it is merely an adjuvant, and cannot be relied upon in the absence of the other measures I have described.

"I am not aware of any reliable data bearing on the interesting question of the possibility of recovery from sterility, once it has become complete: assuming the condition to be recognized early enough, say while there are still immobile spermatozoa, it would appear possible that two or three years of completie abstinence from X-ray work might result in some degree of recovery, but I do not see how a man could expect to recover otherwise unless he were to take such extreme measures or precaution as would preclude the possibility of his doing really useful work."

It may be noted in this connection that investigators quite uniformly report that there is no change or deterioration in po-

1 Radium. X-Rays and the Living Cell. pp. 235-253.

-American Jour. of Surgery. Vol. 18, p. 147, 1905.

"Letter to the author, October 8, 1919.

+ Sterility Among X-Ray Workers: British Medical Journal, July 6, 1907, p. 15. 
tency of the men who had become sterile from X-rays.

\section{Female.}

In the female, operations having for their primary purpose the effecting of sex-sterility have not been practiced as extensively as have analogous operations on the male. The reasons are doubtless; first, that sexual impulses of the female affect social life in a less aggressive manner than those of the male; second, that radical types of sexual sterilization carried out on young girls do not cause the radical departure from the normal later development caused by analogous operations on the male; third, that the essential female genital organs are situated deeply within the abdominal cavity, and consequently their surgical treatment requires much more skill than is called for in operations upon the male. The ancients knew little concerning the homologous relations between the testis and the ovary, indeed until recent times the female was looked upon as the soil, and the male as the supplier of seed. Surgically it is only in later years (1872) that fairly skillful and safe operations for removing the ovaries were developed, consequently the use of oöphorectomy for eugenical sterilization is a relatively new agency.

The following operations and treatments will cause sex-sterility in the human female:

(1) Pan-hystero-kolpectomy.

(2) Hystero-salpingo-oöphorectomy.

(3) Oöphoro-hysterectomy.

(4) Hysterectomy.

(5) Salpingo-oöphorectomy.

(6) Ö̈phorectomy (ovariectomy, ovariotomy, castration. spaying).

(i) Curetting and Cauterizing Intra-Uterine Tubal Openings.

(8) Salpingectomy.

(9) I.igation of the Fallopian Tubes.

(10) X-ray Treatment.

This list of sex-sterilizing operations could be considerably extended, but, as is the case with several of the longer names here given, the new appellations would indicate composite operations, consisting in several simpler operations performed at one time. But, notwithstanding this limitation, the greater complexity of the female reproductive system permits a larger repertoire of operations for effecting sexual sterilization than is offered in the case of the male. However, unless there is a very urgent pathological indication, the first four operations here listed as possible for sterilizing the female are so radical that it is not necessary, nor has it ever been suggested, that they be used for purely eugenical purposes. The several other and simpler operations (numbers 5 to 9) present an ample choice for almost any conceivable case calling for eugenical sterilization.

(1) Pan-hystero-kolpectomy. (Gr. $\pi \tilde{a} s, \pi \tilde{a}$,

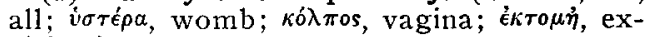
cision.)

This operation consists, as its hyphenated name indicates, in the extirpation of the womb and the vagina, and the obliteration of cavity made thereby. Obviously it is a very severe operation and is accompanied by great surgical shock. It is never carried out except for the most urgent medical reasons, and, so far as known, has never been resorted to for eugenical purposes.

(2) Hystero-salpingo-oöphorectomy. (Gr.

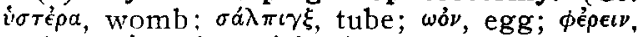

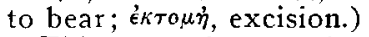

This operation consists in the removal of the uterus, the oviducts and the ovaries. (If following Caesarian section, it is called Caesarian hysterectomy or Porro's operation.)

(3) Ö̈phoro-hysterectomy. (Gr. wòv, egg; $\phi \dot{e} \rho \epsilon \iota \nu$, to bear; $\dot{v} \sigma \tau \dot{\epsilon} \rho \alpha$, womb; $\dot{\epsilon} \kappa \tau o \mu \dot{\eta}$, excision.)

This term refers to the surgical removal of the ovaries and the uterus.

(4) Hysterectomy. (Gr. i $\sigma \tau \dot{\tau} \rho a$, womb;

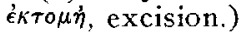

\section{Surgical Technique.}

Hysterectomy consists in the removal of the uterus. (Panhysterectomy, the removal of all of the uterus.) The following are the variations in the operation:

(a) Abdominal hysterectomy, performed through the abdominal wall.

(b) Vaginal hysterectomy, performed through the vagina.

(c) Para-vaginal hysterectomy, performed through a perineal incision.

Other operations on the uterus: 1. Supravaginal amputation of the uterus. 2. Curetting the intra-uterine tiubal openings.

Surgical Technique.

Of the above named several variations in hysterectomy the commonest is the abdoninal variety, of the surgical technique of which Kelly-Noble ${ }^{1}$ gives the following description:

"Doyen's Panhysterectomy. In this operation the myomatous uterus is pulled through the abdominal incision and swung forward and down over the pubes. The

1 Felly-Noble: Gynecology and Abdominal Surgery. $W$. B. Saunders Co., 1907, Vol. I., p. 701 . 
posterior vaginal fornix is opened through the pouch of Douglas and the cervix is caught with a tenaculum forceps. The cervix is now drawn through the posterior vaginal incision and strong traction is continued while it is cut away from the vaginal walls laterally and in front. The section is made close to the muscle of the uterus to the, inner side of the attached structures, which are under considerable tension from the traction upon the cervix. The broad ligaments and uterine vessels are clamped if necessary, tirley too radical to be mentioned among the operations executed primarily for eugenical purposes.

(5) Salpingo-oöphorectomy. (Gr. $\sigma a ́ \lambda \pi \iota \gamma \xi$,

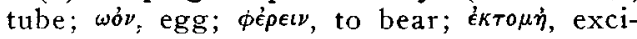
sion.)

Salpingo-oophorectomy consists in the removal of the ovaries and oviducts by operating through the abdominal wall. This is the first of the operations on the female named in the present series which has been used primarily for eugenical purposes, but

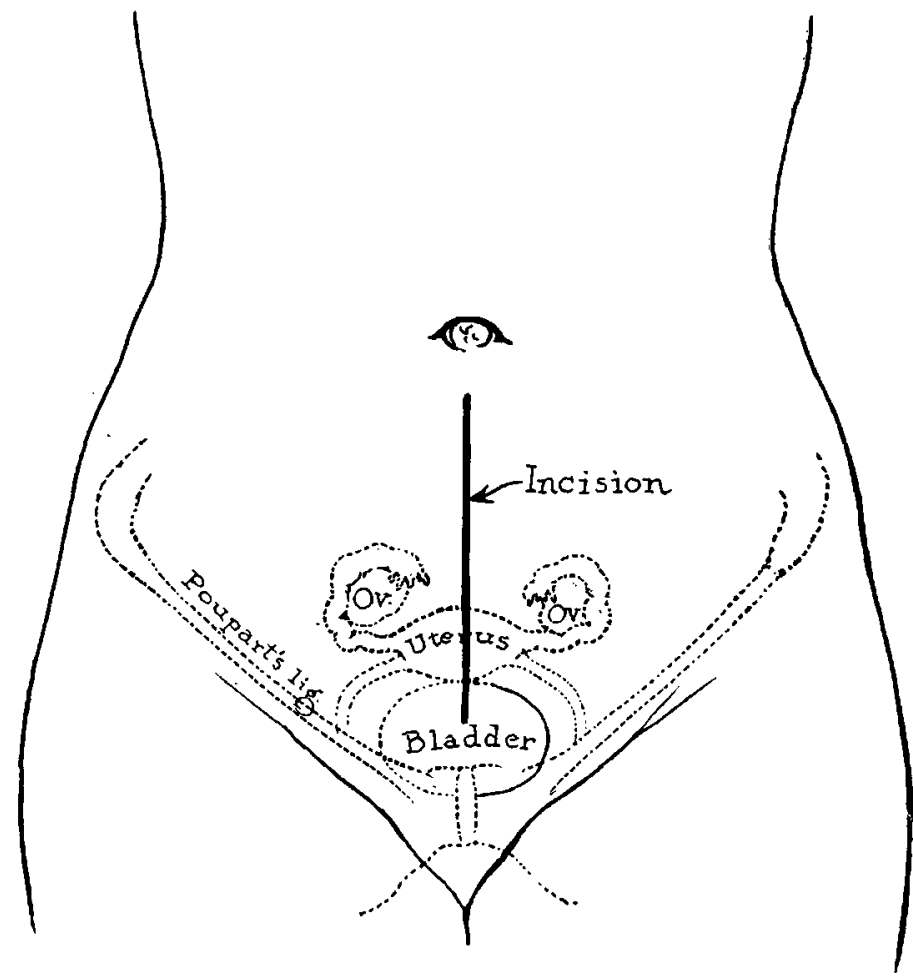

Figure 12. The Abdominal Incision Used in Salpingectomy and Oöphorectomy

and by continuous incision hugging the uterine wall the fibroid uterus is literally skinned out of its attachments. No attention is paid to the adnexa during this procedure, the line of excision passing through the insertion of the tubes and of the round ligaments at the uterine cornua. After the uterus has been removed, the adnexa are dealt with as desired and the operation is completed by sewing up the vaginal wound and uniting the peritoneum over it."

The removal of, or in fact any operation upon, the womb is a radical operation, employed for only the most urgent medical (usually cancer) or obstetrical reasons. While hysterectomy, of course, effectively sterilizes the woman operated upon, it is en- even in such cases the motive is generally a mixed one. Oftentimes surgeons in opening the abdominal cavity for the eugenical purpose of removing a section of the Fallopian tube find the conditions such that in their judgment, it is pathologically or physiologically advisable to remove both the ovaries and the entire tubes. This operation is thus looked upon as a surgical incident in eugenical sterilization, and not one which in the case of healthy, normal sex-organs, would be ordered for the purpose of effecting sexsterility.

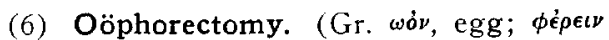
to bear; étroù, excision.)

Oöphorectomy is in the female the analogue of castration in the male, in that ir 
both cases the sex-glands are removed in their entirety.

It is accomplished through (a) a threeinch median line incision in the abdominal wall (one incision suffices for the removal of both ovaries); or (b) by operating through the vagina.

This operation is often performed in case of diseased ovaries. In 1701 a Lanarkshire physician by the name of Houston is said to have carried out a partial extirpation. But in 1809, Ephraim McDowell of Kentucky, a student of John Bell of Edinburgh, was the first to perform this operation in a successful manner. In 1872, Dr. Robert Bat-
"1. By Abdominal Section. The patient is placed in the Trendelenburg position and the abdomen opened in the middle line above the pubes for a distance of $7 \mathrm{~cm}$. (3 in.); this may be enlarged if necessary. The intestines are carcfully pushed upward from the region of the pelvis and a double or triple row of sterile gauze pads placed transversely from one iliac fossa to the other, to prevent the gut from descending into the field of operation, and to absorb blood and other discharges which may escape during manipulations. The packing serves also to prevent the radiation of heat from the intestines. The first two fingers are then

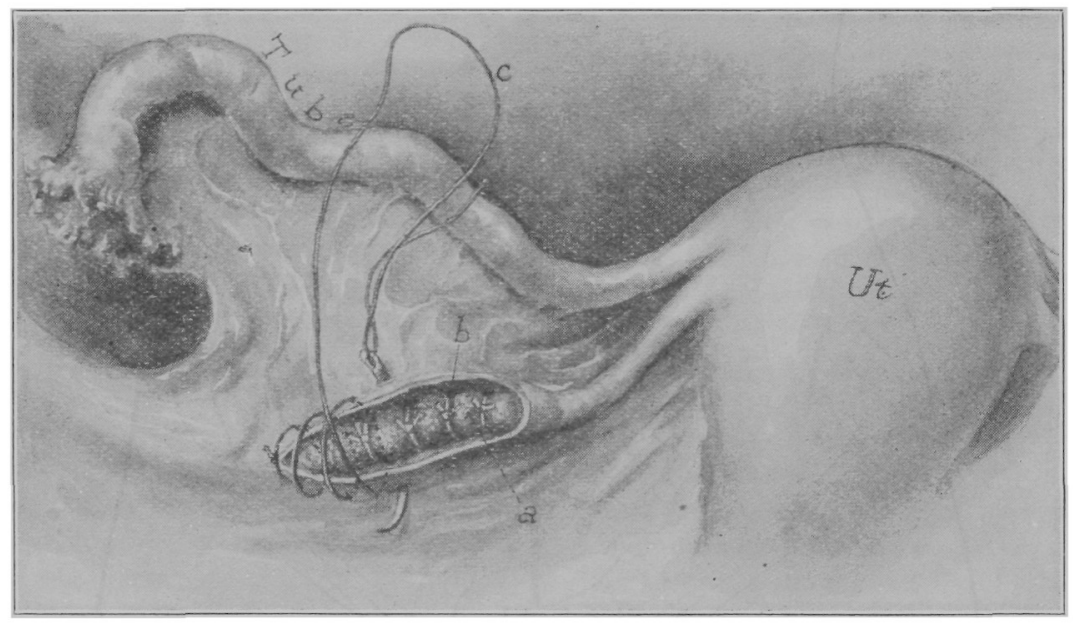

Figure 13. The Operation of Oöphorectomy

tey, of Rome, Georgia, began to perform these operations to relieve dysmenorrhea. In the following years the so-called "Battey operation" was extensively used, but physicians and surgeons do not prize its therapeutic value as highly as formerly.

Öphorectomy is a major operation, and, because it involves the opening of the abdominal cavity, it is always accompanied by considerable shock. Like all other major operations, it requires skilled surgery and the elaborate technique of the modern hospital operating room.

Surgical Technique. (Figures 12 and 13)

Kelly-Noble ${ }^{1}$ give the following description of the technique of the operation:

Oöphorectomy. Where the ovaries are healthy.

"This may be carried out by both the abdominal and vaginal routes. *** As far as statistics go, it is difficult to say which is the safer method. introduced and passed down behind the pubes until the fundus uteri is reached; they are then moved along the broad ligament until the ovary is felt. This procedure may also be carried out by first placing the fingers on the infundibulopelvic ligament and then moving them inward toward the ovary. The latter, along with the corresponding tube, is raised into the abdominal incision. The infundibulopelvic ligament and the ovarian ligament are held with forceps by an assistant, who at the same time compresses the ovarian artery. The ovary is then cut away from its attachment to the broad ligament and the denuded surface left thoroughly obliterated by a continuous catgut suture; in this way, usually, all bleeding is checked. If there should be troublesome oozing a separate ligature may be applied to the infundibulopelvic ligament so as to control the

1 Kelly-Noble: Gynecology and Abdominal Surgery. W. B. Saunders Co., 1907. Vol. I., pp. 613-614. 
ovarian artery, or one may also be applied internal to the site of the ovary to secure branches of the uterine artery anastomosing with the ovarian. The pelvis is next carefully sponged, the abdominal pads removed, and the abdominal incision closed. ***

“2. By Vaginal Section. The peritoneal cavity may be entered by an anterior or posterior colpotomy. If the ovary can be pulled down easily it may be removed by either of the procedures just described. If it cannot be brought down satisfactorily, the vaginal opening should be closed and the abdominal operation carried out. The vaginal route should not be selected when the vagina is long, narrow, rigid, or contracted, nor when the uterus cannot be pulled well down."

\section{Convalescence.}

Recovery from oöphorectomy demands from one to three or four weeks in bed. Ordinarily in uncomplicated cases the patient will be sitting up on the ninth day and out in two weeks.

The mortality rate in this operation was very high in early days, especially before the introduction of antiseptics. After this advance the rate with the best surgeons dropped to 10 or 12 per cent. At the present time it is probably about one-half or twothirds of this.

Permanence of sterilization by oöphorectomy

Double oophorectomy makes the patient absolutely and permanently sterile, but the removal of only one ovary or tube may not be successful in causing sterilization. According to Kelly-Noble: ${ }^{1}$

"The tube without the corresponding ovary is still functional and may serve to conduct an ovum from the opposite ovary to the uterus. That this is the case has been shown by experiments on animals and by observation in the human female. The ovary without the tube on its own side is of greatest value to the system because of the influence on body metabolism and because it can produce ova which may enter the uterus by way of the opposite tube and become fertilized.

"* * * it has been shown that a small portion of the ovary is as valuable to the organism as the whole structure and that a short piece of tube may be of service in conveying an ovum to the uterus."

A Substitute Operation. A recently reported eugenical substitute for oöphorectomy:
"New Operation for Sterilization, Offering the Possibility of a Return of the Ability to Conceive Later."'-Blumberg prevents the migration of the ovum into the tube by suturing the ovaries in a pocket of the broad ligament. The procedure may be done through the vagina, and its advantage lies in the present theoretical possibility of a return of the power of conception at a later date, as a result of liberation of the ovary."

Until further evidence has been presented on the subject, this report and those of many other novel sterilizing operations must be taken as purely suggestive of future fields for research.

(7) Curetting or Cauterizing the IntraUterine Tubal Openings. Occasionally reference is made to what purports to be a new or a very simple method of effecting sexual sterilization:

(a) Often the claim is made that effective sterilization can be consummated in the female by curetting the horns of the uterus, without an abdominal or vaginal incision of any sort. Recently Dr. Bernard Barrow reported a number of cases in which he used this method. He has not, however. demonstrated the effectiveness of his process to the satisfaction of the surgical world. Most of his patients were negresses who were suffering from venereal diseases, so that this complication probably destroys the validity of his tests.

(b) A second method consists in the socalled "chemical slough stricture."

Dickinson" suggests that the treatment of the inside upper uterine angles, as advised by Froriep in 1850 but not generally followed, is worthy of new study. It appears that stricture by chemical action is very painful, has often resulted in adhesions, and is not sure to be effective, and, taken as a whole, is condemned on account of its present lack of sureness, its painful procedure, and possible complications.

(c) This same surgeon (Dickinson') calls attention also to experimental closure of the intra-uterine tubal openings by electrical cautery. He says:

1 Kelly-Noble: Gynecology and Abdominal Surgery. Vol. I., p. 609. W. B. Saunders Co. 1907 .

2 Berliner Klinische Wochenschrift, April 14 1913 Reported in N. Y. Medical Journal, May 31,1913 .

3 Reported before South Side Virginia Medical Association, Dec. 10, 1912 .

4 Robert L. Dickinson: "Simple Sterilization of Women by Cautery at the Intra-Uterine Tubal Openings, Compared with Other Methods." Surgery, Gynecology and Obstetrics, Aug. 1916 , pp. $203-214$. 
"The only outlonk for a simple and sure method, and that without risk or loss of time and with but little pain, seems to be through closure of the tube, where it enters the uterus, by a stricture produced as the result of a burn with the fine-tipped cautery electrode, a procedure simple enough to be done in the office. Of course all sterilizing measures are predicated on childbearing, in any given instance, being a grave risk to life or productive of permanent ill health

Steps of procedure. Time selected, 7 to 10 days after period (for least vascularity and thickness of lining).

Location. Hospital, if the patient is sensitive: office, usually.

Technique.

(1) Loose clothing, empty bladder.

(2) Lithotomy posture (or Sims).

(3) Bimanual examination.

(4) Sims speculum, tenaculum in cervix.

(5) Injection of 5 to 10 minims 10 per cent novocaine adrenalin solution into uterus with Skene intra-uterine pipette and pressure; also application to vaginal cervix and vagina, as anæsthesia controls. After 10 minutes and due bleaching proceed to-

(6) Test the shape and length of cavity by ordinary uterine sound; this length noted.

(i) Slide on cautery sound goes to same measure.

(8) Burns of some spot on external os, with slight pressure, until wire tip is buried, to serve as a cautery control. Note time needed.

(9) If cervix is hard, burying of tip in an anæsthetized place on the vaginal wall as control. Note of required time.

(10) Cautery sound passed to cornu; held there, without pressure, the same length of time needed to bury wire tip in cervix or vagina, with same amount of current.

(11) Repeated on opposite side.

(12) Watching slough and scar form on cervix or vagina. When firmly contracted, one may be able to test the tubes for patency by the Cary method-injecing a silver solution into the uterus under pressure, and securing an $\mathrm{X}$-ray shadow of the distended uterine cavity, and also of the tubes. if they are open."

(8) Salpingectomy. (Gr, $\sigma a \dot{\lambda} \pi \iota \gamma \xi$, tube; $\dot{\epsilon} \kappa \tau \circ \mu \dot{\eta}$, excision.)

Salpingectomy is comparable functionally. but not anatomically or surgically, with vasectomy in the male. It has been used extensively in operations desiring to effect sexual sterilization only, so that in some quarters it has come to mean the equivalent of "sexual sterilization of the female," just as the expression "sterilization of the male" often connotes the specific operation of vasectomy.

Salpingectomy consists in the surgical excision of all or a portion (often about $3 / 4$ inch) of both oviducts (Fallopian tubes). According to surgical authorities, it may be achieved (a) by abdominal salpingectomy, in which the operation is executed through one median incision through the abdominal wall; (b) by vaginal salpingectomy, operating through the wall of the vagina; or (c) by salpingectomy with cuneiform resection of uterine cornu. (Neuman.)

Salpingectomy has often been performed to remove diseased tubes, and sometimes with a view to sterilization when a pregnancy would have endangered the life of the patient (as in malposition of uterus, marked tendency to toxemia, etc.). But when performed to prevent pregnancy, it has until recently ustrally been a by-product of an abdominal operation necessitated for some other reason. Only within the last decade has it been performed for purely eugenical purposes.

Surgical Technique. (Figures 14 and 15.)

However performed, salpingectomy is a serious operation and should be attempted only by skilled surgeons, under the best of modern hospital conditions.

\section{(a) Through the Abdominal Wall.}

Abdominal salpingectomy as described by Warbasse $^{1}$ is to be recommended as presenting the best available method for achieving eugenical sterilization.

"The abdomen is opened in the median line and the middle of the tube picked up with forceps. A cut is made through the tube and about $1 \mathrm{~cm}$. ( $3 / 8$ inch) into the broad ligament below the tube at the inner side of the forceps. Each cut end of the tube is grasped with fine forceps, the peritoneum not being included. The broad ligament is stripped back from it for about $1 \mathrm{~cm}$. $(3 / 8$ inch). This much of the naked tube is then tied with catgut and cut off. This is done to each of the cut segments. The tube is thus shortened about $2 \mathrm{~cm} .(3 / 4 \mathrm{inch})$. This should be done with as little injury as possible to the peritoneum. With a fine needle and catgut the peritoneum is then sultured with its raw edges turned in, so

1 Warbasse, James Peter: Surgical Treatment, Vol. III., p. 429. W. B. Saunders Co., Fhila., 1919. 
that the two stumps of the tube are covered with peritoneum. The same operation is done upon each tube."

\section{(b) Salpingectomy through Vagina.}

"An operation may be done through the vagina. A posterior colpotomy through the posterior fornix is performed, and the peritoneal cavity opened in the cul-de-sac. A tube is brought down into the opening, its fimbriated end cut off, and the stump inverted by two rows of peritoneal sutures, thus closing the passage of communication between the tube and the peritoneal cavity. Or the middle of the tube may be resected and buried under the peritoneum of the broad ligament as described for the abdominal operation. If the tube is simply ligated in two places and cut across, it is entirely possible for the lumen to become reestablished. to close the opening in the uterus with two layers of sutures; the deep sutures to approximate accurately the cut surface of the uterine muscle, the superficial ones to bring together the cut edges of the peritoneum of the broad ligament over the repaired muscle."

\section{Permanence of sterilization by salpingectomy.}

If the uterine stump of the Fallopian tube is left patent, it may still function in transmitting the ovum to the uterus. However, if skillfully performed, double salpingectomy is an effective and permanent means of sterilizing the human female.

\section{According to Williams, ${ }^{2}$}

"It was formerly believed that sterilization could be effected by ligating the proximal end of either tube; but experience has shown that the ligatures eventually cut

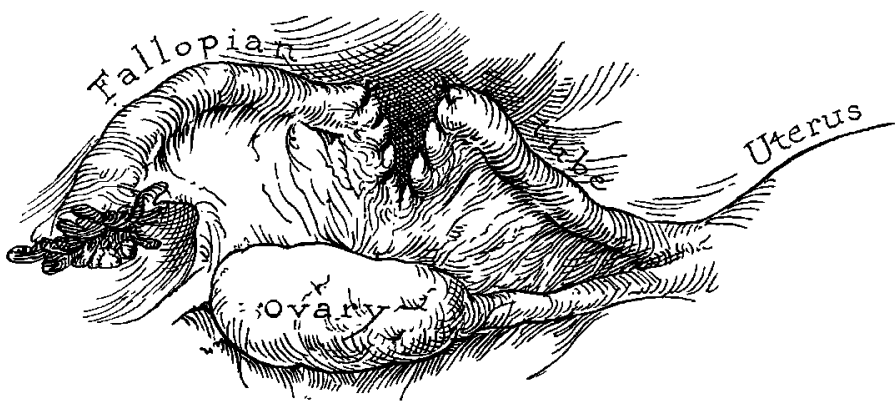

Figure I4. The Operation of Salpingectomiy

"Blumberg (Berlin, Klin. Wochenschr., Apr. 21, 1913, No. 16) buried the ovary in a pocket of the broad ligament. The abdomen is opened through the posterior fornix of the vagina. The pocket is made by dropping the ovary into that part of the broad ligament which extends between the Fallopian tube and the ligament of the ovary and suturing the free edges over it. The ovary is thus enveloped in broad ligament; it is movable in this pocket; and when desired the line of union may be separated, and the ovary released."

(c) "Bilateral salpingectomy with cuneiform resection of the uterine cornu is considered to be the surest method of producing sterility through operation upon the tubes. It was first proposed by Neuman in 1898. *** All writiers agree that in per forming the operation great care should be taken to make the wedge-shaped section of the uterine cornu deep enough to remove all of the interstitial portion of the tube and through or become absorbed, and the lumen of the tube may subsequently become restored and with it the possibility of future pregnancy. It was next suggested that the object might be accomplished by applying a double ligature to each tube and excising the portion between them; but the experiments of Fraenkel upon animals, and the experiences of $Z$ weifel, and Cripps and Williamson upon the living woman, have shown that even these measures do not insure against conception, since the ligatures may be absorbed and the cut ends of the tube become united. In order, therefore, to render a woman permanently sterile by an operation upon the tubes, their proximal ends must be buried between folds of the broad ligaments, or they must be excised by wedge-shaped incisions at the cornua of the uterus and the uterus and the wounds closed

${ }^{1}$ Heineberg, Alfred: N. Y. Med. Journ., July 15, 1916.

2 Williams, Obstetries. 4th Ed, 1917, p. 485. D. Appleton \& Co. 
by sutures. The former procedure is prefe:able, is readily effected, and I now employ it as the operation of choice, unless amputation of the uterus is indicated for some other reason."

Following the delivering of a child by Cæsarean section, “*** sterilization should not be attempted by the removal of the ovaries, for the reason that the retracting uterus may exert such tension upon the pedicles that the sutures may slip and fatal hemorrhages result, as well as for the reason that their internal secretion is necessary to the future well-being of the patient."
"Excision of a centimeter of tube was also of uncertain results. Attempts have been made to resect the tubes between two ligatures and bury the uterine stumps, closing them over with peritoneum. This did not prevent pregnancy-neither did cutting the tubes and cauterizing the cut ends effect thorough and permanent closure of the lumen. Ordinarily bilateral salpingectomy, leaving a short stump at the uterine end, gives no assurance of sterilization. In a case where the left ovary and both tubes were removed, the ends of the uterine stumps being tied with silk ligatures, the

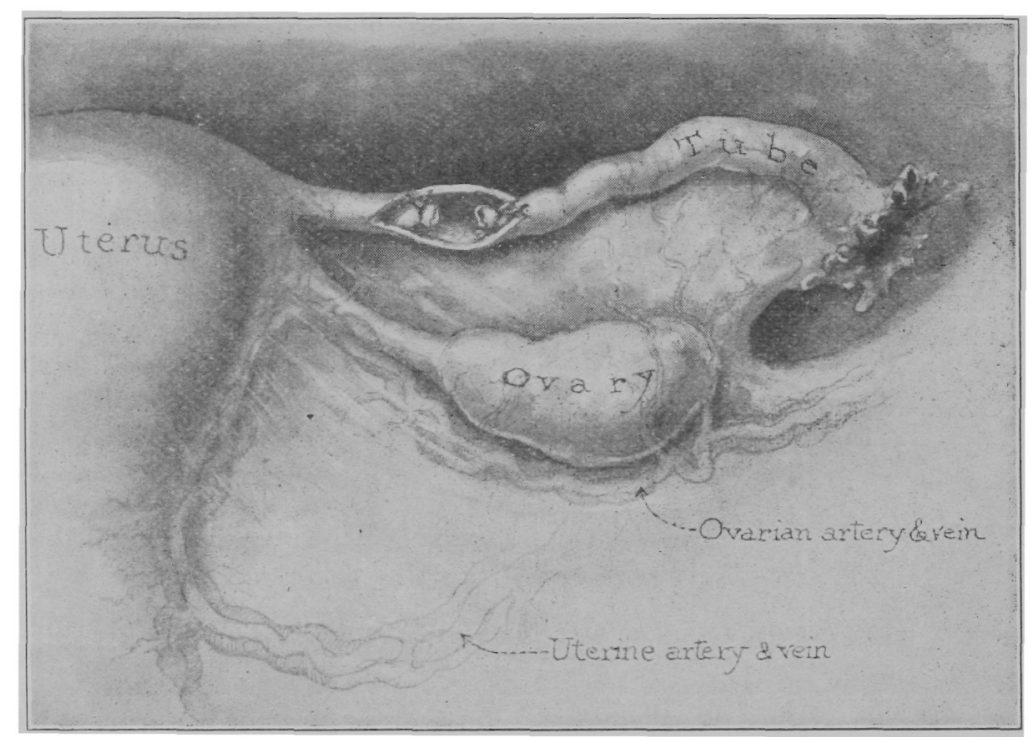

Figure 15. The Operation of Salpingectomy as practiced at the Stockton State Hospital, Cal. Drawing made under the direction of Dr. Maragaret H. Smyth, Stockton State Hospital, California

\section{Restoration of sexual functions following salpingectomy.}

According to Warbasse,

"Operations for restoring the divided tube are done (1) when the tube is accidentally severed or (2) when operation has been done to induce sterility and sterility is no longer desired.

"In operating to restore the potency of artificially closed tubes or wounded tubes, the peritoneum should be incised and the stumps exposed. The closed ends should be cut off and the two lumens brought together and sutured end-to-end. The peritoneum of the broad ligament is used to reinforce the suture line. These operations promise well for restoration of function, if nicely done."

According to Leonard, ${ }^{2}$ patient became pregnant after four years. In fact, cases of pregnancy following salpingectomy are not infrequent."

\section{SALPINGECTOMY WITH THE PUR- POSE OF STERILIZATION AS DONE AT THE STOCKTON STATE HOSPITAL}

"Incision is made in the medium line of the abdomen-one to one and a half inches in length, just above the pubic bone.

The index and middle fingers are inserted into the abdomen and the fundus of the uterus is located by touch. The tips of the

\footnotetext{
1 Warbasse. James Peter: Surgical Treatment, Vol. III., p. 429 . W. B. Saunders Co., Philadelphia, 1919 .

2 V. N. Leonard: Amer. Journ. of Obstetrics, March, 1913. The difficulty of Producing Sterility of Operations on the Fallopian Tubes.
} 
fingers are carried outward along the tube. The tube is drawn up into the incision and clamped with a small hemostat at the isthmus-this being the narrow portion of the tube and relatively free from blood vessels, making the operation practically bloodless.

An incision about $1 / 2$ inch in length is made in the serous covering exposing the tube. The tube is picked up with thumb forceps and half inch is cut out.

The uterine end of the tube is ligated with fine silk; the incision in the serous coat is closed with continuous fine catgut suture The same procedure is done on the opposite tube.

Abdominal wound is closed in layers.

General anæsthetic is preferable. Operation in ordinary conditions can be completed in 15 minutes. Patient is usually left in bed one week."

Dr. Margaret H. Smyth,

Stockton State Hospital, California. May 22, 1921.

\section{Summary.}

To sum up the matter, salpingectomy is the least radical and the most safe method now available for effecting sexual sterilization in the female.

(9) Ligation of the Fallopian Tubes. This operation seeks to effect sexual sterilization in the female by causing an occlusion of the oviducts or Fallopian tubes. Surgically it is just as serious as any other operation involving the opening of the abdominal cavity. It is subject to the same objections in reference to permanency and complications that are given for the ligation of the vas deferens; indeed, ligation of the Fallopian tubes, because of their greater external diameter, presents a more complicated situation than the analogue in the male. A1though a considerable external constrictive pressure may be applied, there is great difficulty in causing a permanent closure of a duct. The reasons appear to be, first because the tube, being lined with mucous membrane, will not readily cohere internally, and second, the ligature is apt either to be absorbed or to cut into the tissue if too tight, or to suppurate if too. loose.

Materials desirable for ligatures, in order of resistance to absorption, are as follows: Silver wire, absolutely permanent: silkwork; catgut; silk, apt to be absorbed, sometimes in a few days.
V. N. Leonard," writing on "The Difficulty of Producing Sterility by Operations on the Fallopian Tubes," says that ligation of the Fallopian tubes by tying heavy silk ligatures about the tubes in the middle has been found unsuccessful in many cases. Also tubes ligated in two places and cut between ligatures were found to reunite.

No standard technique exists for successfully and permanently sexually sterilizing a human female by ligation of the Fallopian tubes. Unless further experiments prove ligation to be permanent, and uncomplicated, it will not constitute a trustworthy or a desirable subsuitute for salpingectomy, still the field is a promising one for research.

(10) X-ray Treatment. The treatment for sterilization by $\mathrm{X}$-rays consists in both sexes of subjecting the sex-glands and, of course, the tissues covering them to irradiation. In the female X-radiation effects sterility by causing the destruction of the Graafian follicles of the ovaries.

Dosage and Technique. Dr. Arthur C. Christie, President of the American Roentgen Ray Society, reports that the dosage. strength of irradiation, intervals and number of treatments for effecting sexual sterility is the same for the male and the female (See p. 412). In the case of the female, however, each treatment requires application to four areas anteriorily and four areas posteriorily. In the female, as in the male, Dr. Christie reports no physiological dangers accompanying the proper application of $\mathrm{X}$-rays for effecting sterility.

Comment. Experiments ${ }^{2}$ on rabbits, mice, bitches and monkeys showed atrophic changes in the ovaries, with degeneration of Graatian follicles. Only one case is recorded of a human ovary. The patient was irradiated on account of menorrhagia and dysmenorrhea. The treatment was ineffectual. so an operation was performed in which the right ovary removed. This showed a few small hemorrhages and very few follicles, in which degenerative changes had begun. The changes were similar in character to those observed in lower animals.

According to Schafer," "If the testicles are exposed to the action of $X$-rays the

1 V. N. Leonard: Amer. Journ. of Obstetrics, March, 1913. The Difficulty of Producing Sterility of Operations on the Fallopian Tubes.

"Colwell \& Russ: Radium, X-Rays and the Living Cell. pp. $235-253$

${ }^{3}$ Schafer, E. A. The Fndocrine Organs. pp. 135-136; p. 137. London, 1916. 
seminiferous epithelium undergoes degeneration, although the interstitial is not, at first at any rate, attacked." *** "But the interstitial cells of the ovary do not form so distinct a tissue as those found in the testicles; they are, moreover. said to be destroyed by the X-rays, whereas those of the testicle are not so affected; they appear therefore not to be of identical nature."

The Journal of the American Medical Association, Feb. 11, 1922, quotes from the Schweizerische Medicinische Wochenschrift: "Pregnancy after Roentgen Exposures. Steiger's verdict from the evidence presented by the literature and his own experience is that with a single exposure, even with a dose large enough to bring amenorrhea, no injury need be apprehended on the ovum developing later from a follicle that has escaped the action of the rays. No injury need be apprehended if the exposure is made towards the end of a pregnancy, but there are grounds for fearing malformations in the fetus if conception has already occurred at the time of an intensive exposure."

\section{SUMMARY :}

\section{a. Types of Eugenical Sterilizing Operations}

\section{Available.}

There are a score or more of surgical operations and treatments, any one of which will cause sexual sterility, but if eugenically sexual sterility only is sought, as the matter now stands, there are available:

\section{For the Male.}

(a) A very simple and effective operation -namely, double vasectomy. This may be performed in a few minutes in a surgeon's office, with practically no more pain to the patient than one suffers in having a tooth extracted. However, a local anæsthetic is desirable. The patient requires no hospital after-treatment, but may go immediately after the operation. Under certain conditions the vas deferens, by surgical operation, may be re-anastomosed and sexual fertility reestablished. There is no general physiological or mental disturbance attributable to the operation.

(b) A more radical operation--double castration. This requires hospital facilities, but may be performed in a few minutes. Local anæsthesia or a mild general anæsthetic, such as nitrous oxide (laughing gas), may be used. But the best practice calls for a general anæsthetic,-ether or chloroform.
The patient generally chooses to remain in bed for a few days. With children and adolescents recovery is more rapid than with adults. Castration in boyhood results in halting the development of many masculine characteristics, including vigorous sexual impulses.

\section{For the Female.}

(a) A less radical operation-double salpingectomy, which in skilled hands is effective and permanent, and which does not disturb the general physiological processes of the body. This operation involves opening the abdominal cavity and is therefore a major operation, to be performed only under the best of modern hospital conditions. Cases of surgical restoration of function following salpingectomy appear to depend largely upon the specific nature of the original operation. It seems likely, however, that the more effective salpingectomy will prove very difficult or even impossible to restore by surgical means.

(b) A more radical operation-double oöphorectomy. The loss of the ovaries results in a considerable disturbance of the normal physiological functions of the body. Surgically salpingectomy and oöphorectomy are about equally difficult and serious, because each involves the opening of the abdominal cavity, with the consequent two or three weeks of post-operative hospital care.

\section{(b) Future Methods.}

Doubtless in the future other operations or systems of treatment will be devised for destroying the function of sexual fertility of the very complex human male and female reproductive systems, or at least present methods of sterilizing the female will be greatly improved. Quite naturally, the eugenicists, the lawmaker, and the surgeons will be interested in the development of effective operations of maximum simplicity and those accompanied by the least untoward effects upon the physiological and mental activities of the persons operated upon. At present, in both sexes, the ligation of the gamete-carrying ducts, and, in the female, curetting or cauterizing the intra-uterine tubal openings, offer promising fields for experimentation. But, of the several methods proposed for simplifying the achievement of permanent sexual sterilization, X-ray treatment holds out the greatest promise. If this promise is fulfilled within the next few years it will mean that, with proper hospital facilities, with very little 
trouble or expense to the state and very little inconvenience to the cacogenic individual treated, sexual sterility can be effected with the minimum amount of physiological changes other than sterility itself. This would be especially important in the case of women, because, even now, the simplest effective treatment, salpingectomy, necessitates the opening of the abdominal cavity. In the male the need of a simpler sterilization treatment is not so great because physicians have, in the operation of vasectomy, an effective treatment which, surgically, is a very minor matter. However, even in this sex, effective X-ray treatment would probably be found to be preferable to vasectomy.

More must be learned, also, about the permanency of sexual sterility effected by X-rays. If it turns out that such sterility is only temporary its use for eugenical purposes would be greatly impaired as compared with the present sure and permanent surgical methods. However, the present outlook is that permanency of sterility will probably be obtained by X-ray application. More clinical records are necessary, before a statement of effective technique can be formulated, and certain physiological results determined.

(c) Weighing the Matter of the Type of Eugenical Sterilization in Relation to Legislative Policy.

From the facts presented in this chapter it follows logically that the statute should define eugenical sterilization in general terms, amply safeguarding the individual operated upon (see Sec. 2 , Model Sterilization Law, p. 446), but should not name the specific surgical type of operation or treatment to be used in specific cases; and because of the different therapeutic needs of each case, and because of the different effects, both physiologically and mentally, of the several types of operations performed on various personality-types of each sex and of different ages, the law is wise in placing the responsibility upon a competent executive (see Section 17, Model Sterilization Law, p. 450) for determining the particular type of surgical sterilizing operation to be performed upon, or medical treatment to be given to, the particular person who by due process of law is declared cacogenic. The statute should also make due provisions to insure that this responsible official, after duly studying the particular case, and duly consulting with his medical and surgical advisors, shall decide upon that specific operation which, besides causing permanent sexual sterilization, will be most apt to affect in the most favorable manner the social. economic, marital and health reactions of the person to be sterilized.

Also, the law should be flexible enough to permit the utilization of future improvements in the type and technique of surgical or medical means of causing sexual sterilization.

\section{NOTE.}

Continence and Contraception. This subject appertains more to the applied psychology than to the letter of the present chapter, but it is here relevant because it is often suggested that sexual sterilization is not necessary in order to insure society against reproduction by particular individuals. It is said that an injunction to sex-continence, or teaching the use of mechanical contraceptives, such as the birth controllists have recently advocated, would accomplish the purpose. However, those who have studied the sex-life of the socially inadequate know that when such persons are not under the custodial care of the State in one of its better institutions, sex-intercourse takes place, and children are born to those who are sexually fertile. The only thing in favor of mechanical contraceptives is that their use appears to be simpler and less radical than surgical sterilization; but their use cannot be insured. so that when we survey the whole range of proposed preventatives, from the most radical of surgical operations to an injunction to sex-continence, the students of the problem take a logical ground and hold that for effectiveness, the least radical treatment at present consists in vasectomy in the male and salpingectony in the female. With these operations sexual sterility is sure, because they make it physiologically impossible, regardless of moral control, for persons properly operated upon to beget or to conceive offspring.

Regardless of the legal, social, economic and medical aspects of birth-control, socalled, and not considering its relations to other eugenical problems, it is clear that, if reproduction is to be forbidden to certain individuals legally declared cacogenic, these individuals must be sexually segregated or rendered physiologically incapable of pro. creation. In this case moral injunction wil! not suffice. 


\section{CHAPTER XIII.}

\section{THE PHYSIOLOGICAL AND MENTAL EFFECTS OF SEXUAL STERILIZATION.}

Introduction

1. The Normal Course of Sexual Functions.

2. Functions of the Sex-Glands, other than Reproduction.

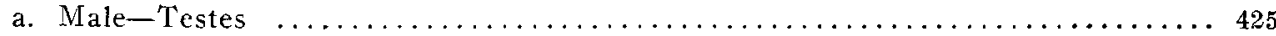

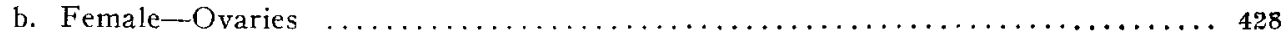

3. Classification of the Case Histories............................... 429

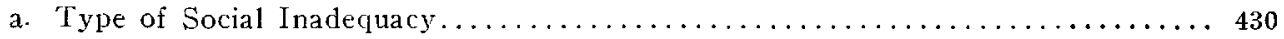

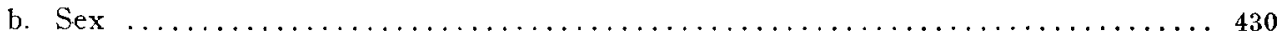

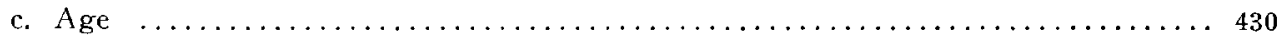

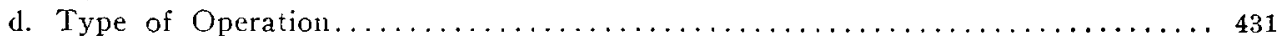

4. Testimony on the Effects of Sexual Sterilization.

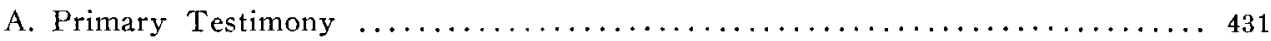

B. Supplementary Testimony
a. A. W. Wilmarth, M. D., Superintendent Wisconsin Home for

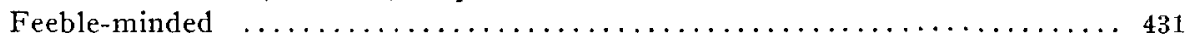
b. Havelock Ellis, in his book "The Sexual Impulse"................. 432
c. Robert Reid Rentoul, M. D., in his book, "Race Culture or Race

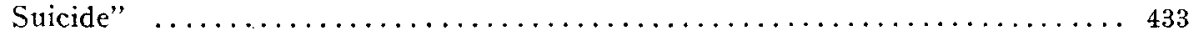
d. Martin W. Barr, M. D., in his book, "Mental Defectives"............... 433
e. F. C. Cave, M. D., Journal of Psycho-Asthenics, $1911 \ldots \ldots \ldots \ldots \ldots \ldots \ldots . \ldots \ldots 4$

5. Summary.

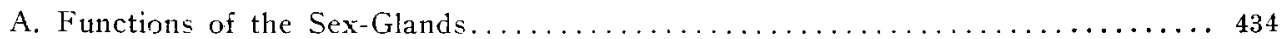

B. Effects of Sexual Sterilization............................... 434

I. Anatomical and physiological effects by sex, age, and type of operation.

(A) Male.

(a) Vasectomy or its functional equivalent.................. 434

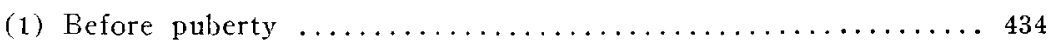

(2) During adolescent and adult life................... 435

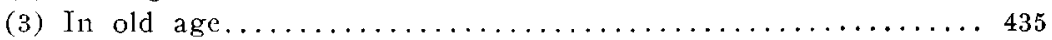

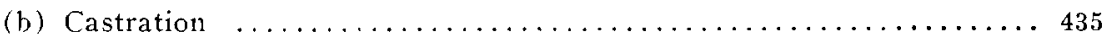

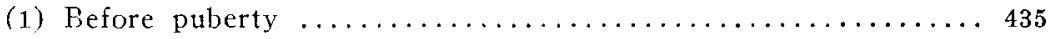

(2) During adolescent and adult life.................... 435

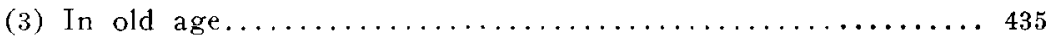

(B) Female.

(a) Salpingectomy or its functional equivalent................ 435

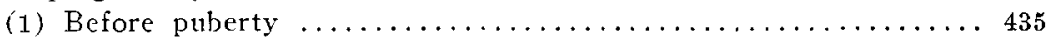

(2) During reproductive period....................... 435

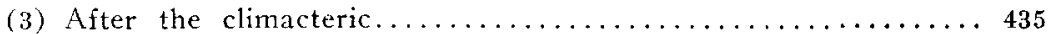

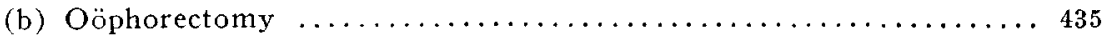

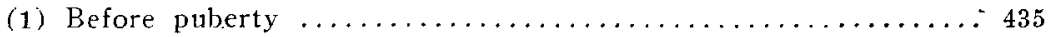

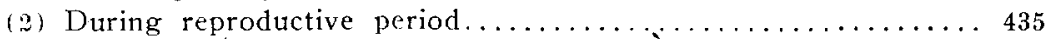

(3) After the climacteric............................ 435

II. Summary of Evidence on the Mental and Temperamental Effects

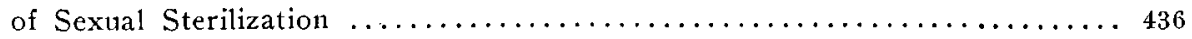

III. Summary of Fividence on Sexual Sterilization as a Therapeutic Agent........ 436 


\section{INTRODUCTION.}

In a given case it might be demonstrated by expert students of human heredity that a. given person is a potential parent of offspring a high percentage of whom would be destined by heredity to be socially inadequate of a very low and degenerate nature, and that such a given cacogenic person ought. therefore, in the interests of the general welfare, to be prohibited from reproducing. But besides all this, unless the legislative authorities of the state be acquainted with the nature of the operation proposed, and of its most probable physiological and mental effects upon the person sterilized, the balancing of the eugenical benefit to the race against a possible. physiological injury to the individual could not logically or fairly be made in statutory enactment.

Because, then, of this intimate relation between intelligent legislation on the one hand, and the physiological effects of eugenical sterilization on the other, it is deemed pertinent here to review briefly the normal course of sexual functions in human development; to describe the functions of the sexglands, other than reproduction; to set forth a basis for classifying case histories for comparative study; and finally, to review by abstract a number of authentic case histories showing the physiological and mental effects of sexual sterilization of various surgical types upon different personality-types of individuals of each sex and of different ages.

\section{THE NORMAL COURSE OF SEX- UAL FUNCTIONS.}

In man, as in all other species, the life of the race is inextricably tied up with the success of its reproductive capacities. The sexual impulse is an essential factor in the reproduction complex. In general there appears to be a close relation between the presence of normal sexual desire and the existence of sexual maturity in the particular individual. This parallelism is close, but not absolute. In tracing the rise, culmination. and decline of the sexual instincts, it is found that both the infant and very old person are devoid of strong sexual impulses. The specific quality and course of the sexual impulse and sexual fertility vary greatly with individuals, families and races, and are affected also by climate, education, mode of life, and other elements of environment.

The greater sexual activity, as well as the earlier sexual maturity, of persons and races who live in the tropics, compared with those who live in cooler regions, is generally recognized. In the same type of individual, city life, in general, appears to bring about sexual maturity about one year earlier than country life. "Heredity, however, has no small influence on libido and sexual power. Thus there are families in which, with great physical strength and longevity, great libido and virility are preserved until a great age. while in other families the vita sexualis develops late and is early extinguished... The potentia generandi ceases usually at the age of sixty-two, but potentia coeundi may be present much longer."

In the human male, puberty, which is recognizable by the deepening of the voice, the appearance of the beard and pubic hair. and occasional pollutions, takes place on the average in most civilized countries inhabited by European stock at the age of about fourteen years. On the average sexual maturity in man begins at eighteen, reaches its climax at forty, and then slowly declines.

In women, ovulation, the occurrence of which is recognizable by the beginning of the menstrual periods, begins in northern countries at about the age of twelve or fourteen years, but in certain individuals in the tropics it is said to begin as early as the ninth year. Ovulation, and with it sexual fertility, ceases with the climacteric, or menopause, after a duration of about thirty years.

With women, as with men, the factor of heredity is a very important one in determining the course of sexual fertility, not only in its duration in years, but also the perfection and rate of activity of the whole reproductive mechanism. Fertility, including frequency of reproduction, multiple births, and duration of the reproductive period, are fundamentally family traits, modified by environment.

\section{THE PHYSIOLOGICAL FUNC- TIONS OF THE SEX-GLANDS, OTHER THAN REPRODUCTION.}

\section{a) Male-Testes.}

The influence of the testes upon mental, physical and temperamental reactions in males of all species has been long recognized. Generally speaking, castration ${ }^{2}$ prevents the development of qualities which are classified as primarily masculine. The practice of castrating male infants for the purpose of rearing eunuchs has prevailed from very

11Krafft-Ebing, Psychopathia Sexualis, pp. a Millant, Les Eunuques à Tracers les Ages, 1909 . 
early times among many different nations. Until modern times, the removal of all the external genitals of male infants among certain African peoples has been practiced for the purpose of selling such children as slaves. who are much sought in the Mohammedan slave markets, where they are said to bring a price several times as high as that paid for a slave not mutilated. These eunuchs, from a race who normally are very active sexually, fail to develop beard: there is also an arrest of the development of the larynx, so that the voice fails to change with manhood from its youthful soprano quality; there is also a failure to develop the usual masculine growth of the thorax and the pelvis. There is a tendency toward a certain form of giantism, and to lay on fat. Temperamentally, the aggressive and pugnacious qualities peculiar to males are generally. lacking. The sexual impulses also are entirely wanting. All these results appear to be due to the lack of the internal secretions supplied by the normally developed and active testes. The same physiological changes take place whether the operation consists in removing: all of the external genitals, or the testes only.

Castration after puberty prevents a further development of sexual qualities, but does not undo the development which has already taken place, due to the previous activity of the internal secretion of the sex-glands. It must be remembered. however, that the maintenance of some of the qualities of each

- sex is dependent upon the continuance of sexglandular secretions. Moreover, the degree to which all of the tissue of the two testes has been removed measures in general the degree to which the physiological effects of castration are manifest. The removal of only one testis. or the leaving of a portion of the testicular tissue, results in the persistence of some of the sexual qualities which are produced by the glandular hormones.

Not only does the removal of the gonads affect the development and maintenance of the secondary sexual characteristics but the internal secretions of these glands play a part in the reaction of the organism as a whole which seems to be dependent upon the infuence of the gonad secretions upon the ductless glands. Thus according to Schafer, ${ }^{1}$ if the testes be removed, "Xlost of the ductless glands are in some way affected. the growth of the thyroid being diminished, that of the suprarenal cortex. pituitary, and thymus increased: the last named organ shows arrest of its normal retrogressive changes. If castration is performed in the mature animal, and therefore after the secondary sexual characters have become developed, there may be some retrogression of these, and such accessory generative glands as the prostate tend to undergo atrophic changes. But the effects are now mainly upon metabolism, and are shown in a tendency to increased formation of fat, although the limit of assimilation of carbohydrates is lowered and alimentary glycosuria is more easily produced. How far these effects on metabolism are direct or how far indirect, through other endocrine organs, it is not possible to say, but the fact seems to be well established that the pituitary body becomes hypertrophied after castration (Fichera, Cimorini). The increased length of limb bones which occurs when the operation is performed before adolescence may be associated with the change in the pituitary (Tandler)."

Vincent ${ }^{2}$ reviews in considerable detail the influence of the sex-glands as organs of internal secretion. He gives an account of the experiments and deductions of many investigators in reference to the effect of the sexgland upon the growth and development in both sexes of many different species.

According to this author, (Vincent), "The first result of castration before the age of puberty is the hindrance to further development of the reproductive apparatus. The vesiculae seminales and the prostate are small and atrophied. The penis does not share in the atrophy, so that in Eastern countries it is frequently considered necessary to remove this as well as the testes. The atrophy of the vesiculae seminales and the prostate after castration can also be noted experimentally in animals: and, further, if castration be performed in quite young animals, the operation prevents the development of the prostate, whereas division of the vas and the abolition of the production of semen have no arresting influence. (Steinach, Griffiths, Wallace). The atrophy of the prostate after castration has led to the introduction of this method of treating prostatic enlargement (Ramm, cited by Bied1). Castration on one side produces no effect, the retention of a single testis being sufficient to maintain the functional integrity of both prostates. It is stated, also, that

1 Schafer, E. A.: The Endocrine Organs, pp. 13t. London, 1916.

Vincent. Swale: Internal Secretion and the Ductless Glands. pp. 68-74. London, 1912. 
Cowper's glands atrophy after castration (Schneidemiihl; see however, Nagel). It is generally assumed that the growth and integrity of the prostate are determined by a hormone furnished by the testis."

In reference to the effect of castration upon the bones, Vincent continues:

** * abundant evidence has now been accumulated that the absence of the functional testis brings about abnormal growth of bony tissues. But this, according to modern views. is not due to the fact that the testis is not acting as an organ of reproduction, but to the fact that the normal internal secretion from the organ is not available for the controlling of the growth of bone in the body" ***. " **** males whose testicles are functionless are found to possess unduly long limbs. This undue length affects the radius and tibia more than the humerus and the femur. The process of ossification is unduly prolonged. He finds. a.lso, that in animals which have been castrated, there is an increase in the length and weight of the bones, and a delay in the obliteration of the epiphysical cartilages. In eunuchs there is delay in the completion of the process of endochondral ossification. Further, the long bones of the appendicular skeleton are unduly long. This excess of length is particularly remarkable in the more distal segments of the limbs. The bones are thin, smooth, and slender."

In reference to the effects of castration upon other species, Schafer" says: "In certain animals which undergo seasonal variations in sexual activity the secondary sexual characters which generally accompany these variations are also abolished or modified by castration. Thus, if a stag is castrated, the antlers either remain undeveloped or if developed are shed prematurely and are not replaced, or replaced only by incomplete growths. But structures which are common to both sexes-in species, for instance, in which both sexes possess horns-- are not modified by castration. In Arthropoda the correlation between the generative glands and the secondary sexual characters (which in many species are even more marked than in Vertebrata) does not hold good. Experiments upon caterpillars show that removal of the generative glands has no influence on the development of the male sexual characters of the imago; nor do the glands, if transplanted into individuals of the other sex, affect the secondary sexual characteis or instincts of the host. This need not be taken to mean that the secondary sexual characters in these animals are not the result of an internal secretion. but may be interpreted by supposing that some organ other than the generative glands furnishes the internal secretion which produces those characters."

"In Vertebrata, at any rate, there can be little doubt that the internal secretions of the generative glands are an important, if not the chief, factor in determining the development of the secondary sexual characters. And that this development is independent of the normal functions of the generative glands is shown by the fact that ligature of the vas deferens has no effect in preventing it. Moreover, transplanted testes and portions of testis (in which the generative cells themselves may completely disappear) have been found capable (in birds) of preventing the results of castration: the comb, wattles, spurs, etc., of the cock being developed in the usual way (Shattock and Seligmann and others). Nussbaum's experiment on the effect upon the development of the thumb-pad of grafting pieces of testis from another frog into the dorsal lymph sac of a castrated male frog also points to the existence of an internal secretion of the testicles in these animals."

"It seems certain, therefore, that the development of the secondary sexual characters in the male sex is dependent upon an internal secretion of the testicle, and it is highly probable that it is yielded not by the generative cells (gonads) but by the interstitial cells. In cryptorchids, and also after experimental ligature of the vas deferens, in both of which, as we have seen, the seminiferous epithelium is atrophied but the interstitial tissue is well developed, the secondary sexual characters and sexual desires are normal. Successful implantation of the whole or part of a testicle in a young castrated animal is also followed by development of those characters, although in most cases the seminiferous epithelium of the graft disappears. Loewy found male secondary characters developing in caponised cockerels fed with testicle-substance. Bouin and Ancel state that extract of testicle freed from all morphological elements may, when injected. produce a similar result. In support of the theory that an autacoid which affects the development of the secondary sexual organs and characters is formed by the interstitial

1 Schafer, E. A. The Endocrine Organs. pp. 134-135. London, 1916. 
cells, they have found that if one testicle is removed from a rabbit and the remaining one has the vas ligatured its interstitial tissue becomes hypertrophied."

\section{b) Female-Ovaries.}

The early removal of the ovaries (spaying) in the human female causes a much less striking change, so far as individual development is concerned, than is caused by the castration of the male. This is due doubtless to the fact that in bodily structure the female is the less specialized sex. and consequently not to be so much affected by the removal of a gland analogous to that which in the male causes the most radical changes in many sexual qualities. During adult life the removal of the ovaries causes the cessation of pregnancy, and as in the male, in the female castration seems to effect a tendency toward obesity.

The physiological reproduction complex in the female is affected by the internal secretions of all of the organs involved in this complex. According to Schafer" "Th. Sack found that if corpus luteum be added to the food of white rats it promotes retention of nitrogen, i. e. laying on of flesh, in females; in the male this result was not obtained."

It appears also that the corpora lutea are highly instrumental in the development of the mammary glands during pregnancy. An extract of corpus luteum injected subcutaneously in young virgin rabbits is known to have caused the large development of the mammae and secretion of milk. There is some evidence to show that the internal secretions of the uterus have an important bearing upon the physiology of reproduction, but in balancing the evidence Schafer ${ }^{1}$ seems to think that "the uterus contains a galactagogue hormone only at this period" (during lactation). Similarly, the internal secretions of the mammary gland and of the placenta exert influences upon the complex under consideration.

According to Vincent, ${ }^{2}$ the secretion of the ovaries appears to control. "**** the processes of the oestrus cycle, and the general condition of the female organs of generation and the mammary glands. The corpus luteum is an essential factor in maintaining the raised nutrition of the uterus during the earlier stages of the period of gestation, and so helps in the fixation of the embryo. The corpus luteum also determines by a specific internal secretion the increased growth of the mammary glands after ovulation or impregnation."
The tendency in the castrated female to develop male characters is not nearly so great as the tendency of the male to develop what appears like female characters. The reason is again that castration stops the development of secondary sexual qualities. In youth these qualities are not so highly differentiated between the two sexes. In later development the male diverges more greatly from the juvenile type. Castration in either sex causes the delay in development or the atrophy of these secondary sexual qualities. Thus the male, being castrated, would tend to resemble more closely the female, who morphologically is the more juvenile in type. But on the other hand, the castrated female, who has diverged less far from the infantile type, and not at all in the direction of the masculine type, in reverting to the juvenile stage, would not tend to resemble the male.

In discussing the effects of the removal of the ovaries in women and comparing the effects of such removal to the effects wrought by castration in the male and also in discussing the ovary as an organ of internal secretion in animals generally, Schafer" $^{3}$ says, "The effects resulting from removal of both ovaries (oöphorectomy; spaying) are externally not so striking as with the similar operation in the male sex. If the operation is performed in young animals or if the ovaries are congenitally atrophic, it is not infrequently found that characters distinctive to the male are to some extent assumed. In the human subject, as well as in animals, a constant result is that the uterus remains small: the external changes characteristic of puberty either do not occur or are greatly modified: there is absence of menstruation. A, tendency to the male type of trichosis is often also exhibited. When the operation is performed subsequently to puberty the results are less marked-but menstruation ceases, and there is sometimes atrophy of the mammae; in animals a diminution in size of the uterus and Fallopian tubes has been substantiated (Carmichael and Marshall, in rabbit; Marshall and Jolly, in white rat). According to Hatai the suprarenal capsules are diminished in size in the female white rat, whereas in the male castration causes a marked increase of those

\footnotetext{
1 Schafer, E. A. The Endocrine Organs. pp. 145-146. London, 1916.

a Vincent, Swale. Internal Secretion and the Ductless Glands, pp. 76. London, 1912.

: Schafer, F. A. The Endocrine Organs, pp. 139-140. London, 1916.
} 
organs: the same author states that although there is an increase in size of the pituitary. it is very slight as compared with the effect of castration in the male. Netabolism is affected mainly, as in males, in the direction of a tendency towards adiposity. This, however, may be indirect and through other ductless glands, which are affected much in the same way as they are in the male sex by removal of the testicles (p. 134).

"Doubtless, as in the male sex, the effects which are produced by the ovaries in determining the female secondary characters are due to an internal secretion. And reasoning from analogy one would be disposed to refer the production of this not to the generative epithelium but to special cells, like the interstitial cells above referred to. The periodical changes (heat, menstruation) which occur in the female appear to be due neither to the Graafian follicles nor to the corpora lutea. For heat in animals still occurs if the corpora lutea are destroyed, or if none are present in the ovary. Moreover. the changes which follow spaying can be prevented by ovarian grafts, and these may contain no corpora lutea."

There are, however, some instances in animals in which the records show that the tendency of castrated females is to develop masculine traits. The explanation generally given is that secondary male characters are normally present in latent form in the female, but that the secretion from the ovaries inhibits their development.

According to Morgan' ${ }^{\text {I the secondary }}$ characters of mammals, birds, crustacea and insects, rest on different physiological foundations. He concludes that "in mammals the secondary characters owe their development to the testes, ***. But in birds the ovary takes something away."

That in mammals many qualities depend upon the secretions of the sex-glands is most strikingly shown by experiments in castrating and transplanting ovaries into males, and by spaying and transplanting testes into females. Steinach ${ }^{2}$ with rats and guineapigs has shown that such exchanges result in males that develop mammary glands even to the functional stage; their bones and hair. as well as their conduct, become more feministic; while masculinized females grew large and coarse, attacked females and behaved generally in the masculine manner.

In short the physiological and mental effects of castrating or spaying the human female may be very great, but they do not tend toward masculinity to the degree that castration of the male appears to induce feministic (but in reality to preserve juvenile) qualities.

The historical and general consideration of the subject leaves no doubt that in the human species both testes and ovaries, apart from their primary functions in producing spermatozoa and ova, play very important roles as organs of internal secretion. As such their function is equally important with many other glands which exist primarily for the purpose of controlling growth, metabolism and conduct by their internal secretion.

\section{CLASSIFICATION OF CASE HISTORIES.}

The matter of classilication is always a difficult one. Indeed there are, if one will draw the line fine enough, as many classes as there are individuals to be classified; but for the immediate purpose we are interested in human beings who have been made sexually sterile as the result of surgical operations having for their purpose the effecting of such sterilization. Secondarily we must take into consideration the case histories of persons who have been made sexually sterile as the result of operations had primarily for some other purpose, but of such a nature that the reproductive function is destroyed. Similarly, sterility by traumatism and disease cannot be entirely ignored, because all of these secondary classes when described in clear histories may throw considerable light upon the main problem, namely: Given a person of known age, sex. constitutional make-up and physiological condition, who is a potential parent, and whose hereditary make-up is so defective that he or she should not be permitted to procreate offspring, what would be the probable physical, mental, temperamental, social and econonic effects of sterilizing this given individual by a given type of surgical operation? With this purpose in mind, we must classify our case histories into groups describing cases, all of which in the same group have the same complex of the principal factors considered, so that by finding out how a large number of persons of the same given complex of conditions have reacted to a given surgical operation for effecting sexual sterilization, we may predict within limits.

\footnotetext{
1 Morgan, T. H. Heredity and Sex. Columbia University Press, 1913, pp. 144, 159

2 Steinach E. Feminierung von Männchen und Maskulierung von Weibchen. Zentralli. f. Physiol. XXVII, 1913. p. 3.
} 
bounded by the extent and accuracy of the case-histories recorded, how a given operation will affect a given individual presenting a complex of conditions comparable in the main to that possessed by each member of the group previously studied.

Let us now consider the specific factors involved:

a) Type of social inadequacy in its constitutional or hereditary aspect. Since eugenical sterilization would naturally be applied only to those individuals who are carriers of defective lines of inheritance, we would, except in the case of recessive traits, confine our classes to such individuals as properly fall within the socially inadequate group. This limitation presents the following classes: (1) Feeble-minded; (2) Insane, including all types of neuropathic conditions not otherwise specifically provided for in this classification; (3) Criminalistic (including the delinquent and wayward); (4) Epileptic; (5) Inebriate; (6) Diseased (those with specific hereditary diatheses); (7) Blind; (8) Deaf; (9) Deformed; (10) Dependent (from constitutional shiftlessness).

While this is a general primary classification, still it must be recast and further shortened for the present purpose of sorting case histories into groups each of which will be numerous enough for purposes of comparison and summary. These social and biological types are five in number: (1) normal; (2) criminalistic (including the delinquent and wayward); (3) insane (including the neurotic and psychopathic, other than epileptic); (4) epileptic; (5) feeble-minded.

The persons contained in these classes are those who constitute the larger number of individuals who are subject to the operation of the several eugenical sterilization laws, and for whom in private surgical practice case-histories involving sexual sterilization are obtainable. In this table the term normal (1) refers to an individual who, on account of his or her hereditary constitutional make-up, does not belong to one of the socially inadequate classes previously listed. Most of the case-histories of this sort are from private practice, in which the motives for the operation are in the main therapeutic. The effects of sterilization upon an individual personally normal are important because pedigree studies may demonstrate in occasional cases such persons are cacogenic. The term criminalistic $(2)$ refers not only to a person who has been convicted of crime and is therefore legally a criminal, but also to one (not insane, feeble-minded, or epileptic) whose instincts and inhibitions are so anti-social that, because of them, his or her conduct is disregardful of the laws of organized society. The term insane (3) applies to all psychopathic and neuropathic cases, excepting the feeble-minded and the epileptic. It includes also the criminal-insane because in the latter class insanity rather than criminality seems to be the more fundamental defect. The term epileptic (4) as here used includes all persons who are chronically subject to convulsions. Persons who are subject to double classification, such as those who may be both crimninalistic and epileptic, or who possess any other socially inadequating qualities herein used for classifying purposes, will be grouped under the class epileptic, regardless of the other handicaps, because this is a definite and easily diagnosed condition. The term feeble-minded (5) applies to those individuals who are of such low mental order that they are unabl: to master the needs and purposes of the usual activities of life sufficiently to regulate their conduct appropriately thereto.

b) Sex. Because of the great differencr in physiological reactions, and in the con struction of their reproductive mechanisms obviously classification on the basis of sex is one of the most important for the purpose in hand.

c) Age. It is not disputed that sexual sterilization, especially the removal of the sex-gland, has very different effects when consummated before puberty than when wrought after sexual maturity. The effects of sexual sterilization in old age or beyond the reproductive period are not especially pertinent to the present investigation, because no eugenical purpose could be served by unsexing an individual who is not a potential parent. Therefore, so far as age is concerned, the accompanying case histories are divided into two groups-(a) those before puberty and (b) those after puberty.

In a complete analysis, made possible only when many more case-histories have accumulated, a more refined sub-division into the following classes will be highly useful:

A. Before puberty:

1. Infancy (birth to 4 years).

2. Childhood (4 to 10 years).

3. Early youth (10 years to puberty).

B. Reproductive period:

1. Early reproductive age (puberty to 20 years). 
2. Mid-reproductive age (20 years to 35 years).

3. Late reproductive age (35 years to climacteric in women, and to approximately 60 years in men).

\section{Past reproductive period:}

1. Early years (Climacteric to 60 years in women, and 60 to 70 years in men).

2. Sexual old age (Past 60 years in women, and past 70 years in men).

\section{d) Type of Operation.}

The classification based upon type of operation will throw the males into two classes -(1) the less radical, that is cases in which the sex-glands are not removed, but simply in which the function of their essential drainage ducts is destroyed by ligation, severing or removal, as in vasectomy; (2) the more radical, in which the sex-glands are removed. as in castration.

In the female sexual sterilization is much more serious from the surgical point of view because under practically all methods now considered efficacious the operation involves the opening of the abdominal cavity. But in the female also there are two degrees of radicalness in the operation of sexual sterilization: (1) the less radical is salpingectomy. or its equivalent, consisting of the removal of a portion or all of the Fallopian tubes, or their permanent ligation; (2) the more radical is the removal of the sex-gland, that is, ovariotomy (oöphorectomy). Equally serious with ovariotomy but rarely resorted to for eugenical motives unless also indicated as of decided therapeutic value is hysterectomy, or removal of the uterus.

Note: Other types of operations.

Other types of treatment or operation which might result in sexual sterilization, such as the application of radium or $x$-rays, or the injection of drugs or chemicals, in either sex, are so little used that case-histories of sufficient number to justify attempts at generalization are not available.

According to information under date of March 17, 1921 received from Dr. Arthur C. Christie, President of the American Roentgen Rays Society, the effects of sterilization by $\mathrm{X}$ Rays are probably nothing more than psycho-mental derangements. However, there does not seem to be uniformity of opinion on this sulject, as Dr. Halsey J. Bagg, of the Memorial Hospital, New York, in a letter to the author (December 5, 1921) states:

"*** There is also a tendency to ques tion the statement that the physiological effects are probably nothing more than psycho-mental derangements. Physicians I have spoken to suggest that more serious internal secretion changes might result from treating especially younger humans, and from a eugenic standpoint I suppose this is just the class you want to reach. Again only experimentation can answer the question."

Other operations, such as scarifying the horns of the uterus in the female, amputation of the penis in the male, and hysterectomy and pan-hysterectomy in the female are not yet developed to the degree wherein their use is of certain practicability.

\section{TESTIMONY ON THE EFFECT OF SEXUAL STERILIZATION.}

A. PRIMARY TESTIMONY

The conclusions here given in reference to the effects of sterilization are drawn primarily from a study of 694 individual case histories classified into 72 types of cases in reference to age, sex, type of operation and primary eugenical personality, Lack of available space in this book prevents the presentation of the abstracts of these histories.

\section{B. SUPPLEMENTARY TESTIMONY.}

a) From an address by A. W. Wilmarth, M. D., Superintendent of the Wisconsin Home for Feeble-Minded, before the American Association for the Study of the FeebleMinded, 1918, entitled "The Practical Working Out of Sterilization," is quoted the following:

"Of the operation it is not necessary to speak at length. It was uniform in the members of each sex, and the simplest possible to accomplish the desired effect.

"In order to give anyone, who cared to do so, time and opportunity to restrain the execution of this law, no operation was performed until nearly two years after its passage.

"I might state, incidentally, that in the sixty cases operated on, there were no complications, but recovery was prompt and complete, and no physiologic change has been evident in their life, or any apparent mental change. The sole purpose accomplished was that designed-to prevent offspring. It is believed that this has been effectively accomplished.

"In every case, notice has been served on relatives, or guardians, as required by the statute, and where onjection was made an operation was not performed in that particular case. The number who objected was surprisingly small. *** 
"We have. so far, seen no cause to regret the steps we have taken. In a number of cases we have felt safe in allowing parents to remove their children on trial, knowing that they would return them if they could not be controlled, as has already been done in one instance. In doing so, we are not oppressed with the fear that our experience in two recent cases would be repeated, when we paroled two girls who had not been operated on, to apparently competent and well-intentioned friends, to have them returned, in a short time, pregnant by their own brothers.

"As to the attitude of the public, a number of parents have voluntarily requested operation for their children; many more than have filed objections. ***"

b) Havelock Ellis in his book "The Sexual Impulse," gives the following summary of the effects of ovariotomy upon the sexual life of the patients:

"In France Jayle ("Effets physiologiques de la Castration chez la Femme," Revue de Gynecologie, 189i, pp. 403-5i) found that, among 33 patients in whom ovariotomy had been performed, in 18 sexual desire remained the same, in 3 it was diminished, in 8 abolished, in 3 increased; while pleasure in coitus remained the same in $1 \pi$, was diminished in 1 , abolished in 4 , and increased in 5 , in 6 cases sexual intercourse was very painful. In two other groups of cases-one in which both ovaries and uterus were removed and another in which the uterus alone was removed- the results were not notably different.

In Germany Gläveke (Archiv für Gynäkologie, Bd. xxxv, 1889) found that desire remained in 6 cases, was diminished in 10 . and disappeared in 11, while pleasure in intercourse remained in 8 , was diminished in 10, and was lost in 8. Pfister, again (Archiv für Gynäkologie, Bd, lvi, 1898), examined this point in 99 castrated women; he remarks that sexual desire and sexual pleasure ir intercourse were usually associated, and found the former unchanged in 19 cases. decreased in 24 , lost in 35 , never present in 21 , while the latter was unchanged in 18 cases and diminished or lost in 60 . Keppler (International Medical Congress, Berlin, 1890) found that among 46 castrated women sexual feeling was in no case abolished. Adler also, who discusses this question (Die Mangelhafte Geschlechtsempfindung des Weibes, 190t, p. $i$ et seq.), criticises Gläveke's statements and concludes that there is not strict relation between the sexual organs and the sexual feelings. Kisch, who has known several cases in which the feelings remained the same as before the operation, brings together (The Sexual Life of Women) varying opinions of numerous authors regarding the effects of removal of the ovaries on the sexual appetite.

In America Bloom (as quoted in Medical Standard, 1896. p. 121) found that in none of the cases of women investigated, in which oöphorectomy had been performed before the age of 33 , was the sexual appetite entirely lost: in most of them it had not materially diminished and in a few it was intensified. There was, however, a general consensus of opinion that the normal vaginal secretion during coitus was greatly lessened. In the cases of women over 33 , including also hysterectomies, a gradual lessening of sexual feeling and desire was found to occur most generally. Dr. Isabel Davenport records 2 cases (reported in Medical Standard, 1895, p. 346) of women between 30 and 35 years of age whose erotic tendencies were extreme; the ovaries and tubes were removed, in one case for disease, in the other with a view of removing the sexual tendencies; in neither case was there any change. Lapthorn Smith (Medical Record, vol. xlviii) has reported the case of an unmarried woman of 24 whose ovaries and tubes had been removed seven years previously for pain and enlargement, and the periods had disappeared for six years; she had had experience of sexual intercourse, and declared that she had never felt surh extreme sexual excitement and pleasure as during coitus at the end of this time.

In England Lawson Tait and Bantock British Medical Journal, October 14, 1899, p. 975) have noted that sexual passion seems sometimes to be increased even after the removal of ovaries, tubes and uterus. Lawson Tait also stated (British Gynecological Journal, Feb., 1897, p. 534) that after systematic and extensive inquiry he had not found a single instance in which, provided that sexual appetite existed before the removal of the appendages, it was abolished by that operation. A Medical Inquiry Committee appointed by the Liverpool Medical Institute (ibid., p. 617) had previously reported that a considerable number of patients stated that they had suffered a distinct loss of sexual feeling. Lawson Tait, however, throws doubts on the reliability of the Committee's results, which were based on 
the statements of unintelligent hospital patients.

I may quote the following remarks from a communication sent to me by an experienced physician in Australia: "No rule can be laid down in cases in which both ovaries have been extirpated. Some women say that, though formerly passionate, they have since become quite indifferent, but I am of opinion that the majority of women who have had prior sexual experience retain desire and gratification in an equal degree to that they had before operation."

c) Robert Reid Rentoul, M. D. "Race Culture or Race Suicide." Walter Scott Publishing Co., Lit., London, 1906, pp. 153-4.

\section{"THE EFFECTS OF STERILIZATION} UPON THE GENERAL AND MEN-

\section{TAL HEALTH."}

"No one has yet put forward any evidence to show that removal of the testes or ovaries affects the physical or mental wellbeing of the person operated upon. Veterinary surgeons have not produced any evidence from the animal world, though millions of cattle have been castrated. We know, on the other hand, that animals improve in nutrition and become more docile after castration. Again, history records the fact that eunuchs attained high social, political and military eminence, thus showing that castration did not weaken their mental powers. One sometimes hears descriptions-fables from the East, one may call them-where eunuchs are described as 'lazy,' 'treacherous,' and 'good for nothing.' I fancy a goodly number of non-castrated persons having the above peculiar traits can be found in English cities... . It is sometimes alleged-nay, gravely stated that castration of human beings causes insanity! This wild allegation has no facts to support it. The shock of any injury, of any operation, may bring latent insanity to the surface, ovariotomy and removal of the testes included; but these operations are not a cause. In the Lancet of November 4th, 1905, Dr. Albert Doran, referring to one hundred operations in which the ovaries had been removed for uterine fibroids, states that in two cases certain mental symptoms appeared, and in these it turned out, on inquiry, that one patient was of marked intemperate (alcoholic) habits, while the other was mentally affected for several years before the operation. He also quotes $\dot{D}$. Picque as stating that eightynine per cent of insane women under his care suffered from uterine or ovarian complaints.

"I have elsewhere referred to the experiments of Shattock and Seligman, which show that vasectomy does not interfere with the development of the secondary sexual characters of animals, and that castration does not interfere in any way with their health.

"Dr. Albert Doran has informed me that an Italian surgeon stated to him that just as women who suffered from mollitis ossium became stronger and larger in their bones after they had had their ovaries removed, so it was noticed that the bones of the choir 'castrati' became strongly developed after the operation."

d) Martin W. Barr, M. D., in his book on “Mental Defectives," p. 197, writes as follows:

"Dr. Everett Flood, superintendent of the Hospital for Epileptics at Palmer, Mass. reports twenty-six cases in which asexuali zation was performed, some being circum. cised at the same time, with no bad results. With twenty-four the cause for operating was epilepsy and persistent masturbation. One-half were under fourteen, two over twenty, and the remainder about fifteen years old, the mental and moral condition being good in two, fair in nine, but poor in the others. Observation for some years after operation, noted mental condition improved in only three cases, and moral conditon in only four-two kleptomaniacs reformed, one who was salacious improved, and one who was solitary acquired a more social disposition. The temper was improved in all but four cases. The sexual appetite seemed to disappear in all but two cases. and appeared in these only periodically. The effect upon the epileptics was favorable: with some the attacks ceasing altogether or returning, as in a single case, after immunity of two years.

"Pfister reports one hundred and sixteen women operated upon. The menopause followed in 94.8 per cent and molimen menstruale in 30 per cent. Sexual desire was extinguished in 52 per cent; diminished in 30 per cent; undiminished in 26 per cent. Atrophy of the uterus was constant, but of the vagina and vulva, less frequent. Atrophy of the mammary gland was noted in 29 women. The tendency to obesity was increased. For some time after the operation, the disposition was changed for the worse. but only in exceptional cases vas the change permanent. The causes for operation were 
myoma, dysmenorrhea, hysteria and hysteroepilepsy; cases suffering from the first named receiving most benefit. Results show eighteen improved, and eighty-seven cured by the operation. My own experience, although limited, has been decidedly favorable; three cases of oöphorectomy and three of testiectomy have resulted in improvement mental, moral and physical-especially marked in boys."

e) F. C. Cave, M. D., Winfield, Kansas, in an article, "Sterilization in Kansas State Home for Feeble-Minded." Journal of Psycho-Asthenics, 1911, xv., page 123, says:

Asexualization performed (oöphorectomy females, in males testiectomy) 58 cases, males 44, females 14 . Done 12 years ago. There remain now 14 girls, 22 boys. Others have been taken by death or relatives, no record of these.

Following answers to questions, submitted by Dr. Bart of Elwyn institution, based on observations of these 3 individuals:

Question $\pi$. In what proportion of inmates of your institution do you consider procreation advisable?

Answer: None.

Question 2. In what proportion of the inmates of your institution do you consider procreation possible?

Answer: $60 \%$.

Question 3. What would be the probable effect of asexualization upon their mental and moral conditions?

Answer: Mentally: I see no change in any particular. Their school work shows no marked superiority over those who are in possession of all their organs.

Morally: They are not addicted to onanism and other prevalent perversities, but this is not because their standard of morality has been elevated; it means the elimination of physical factors has caused betterment.

Question 4. What was the effect on their physical condition?

Answer: Average was 20 years. One girl has become obese. Menstruation ceased in all cases with atrophy of uterus. At time of menstruation, backache, headache and "bearing down pains" occur; some have to go to bed for few days. Breast atrophy noted in all cases. All desire for sexual intercourse and all erotic fancies apparently removed. Several were epileptic, removal of ovaries having no effect on seizures. No change in tractability. Skin more fair.
Boys. Three obese, one assumed feminine type voice, breasts increased in size, loss of hair on face, change in body contour, all desire lost.

Question 5. What operation would you advise?

Answer: Oöphorectomy and testiectomy. These operations prevent defective offspring, limit lewdness and vice. If the vas is ligated, tendency to increase sexual debaucheries, as danger of conception would be eliminated.

Question 6. At what age. is operation most effective?

Answer: Effect cannot be questioned at any age. A few were emasculated before puberty. They show no material difference from those sterilized early in adult life.

\section{SUMMARY.}

The historical and clinical evidence presented in this chapter appears to justify the following general statements:

\section{(A) FUNCTIONS OF THE SEX-}

\section{GLANDS.}

a) The primary physiological function of the sex-glands is the manufacture of spermatozoa in the male and ova in the female.

b) The internal secretions of the sex-glands govern very largely the development of the secondary sexual characteristics.

c) The male, being the more highly specialized sex, experiences the greater aberration from normal ontogeny following the early removal of the sex-glands.

d) The physiological role of the testes and ovaries (besides their influence over the primary and secondary sexual structure and functions), in governing growth, metabolism and temperamental reactions (especially sexual), is both very specific and very great.

\section{(B) EFFECTS OF SEXUAL STERIL.}

\section{IZATION.}

The wide range of the effects of eugenical sterilization is a consequence of, first, the great differences in the personality-complex of the persons operated upon-sex, age, constitutional make-up, and physiological, pathological and mental condition-and second, of the several surgical types of sterilization-operations employed.

\section{Anatomical and Physiological Effects by Sex, Age, and Type of Operation.}

\section{(A) Male.}

(a) Vasectomy or its functional equivalent.

(1) The available case-histories of males vasectomized before puberty are so few in 
number that the effect of vasectomy in early youth is not known with certainty. From the evidence given by physicians and a nimal experiments, it is believed that a boy vasectomized in carly childhood would experience an ultimate if not great atrophy of the primary sexual organs.

(2) In cases of adolescent or adult males with normal and undiseased sex-organs, vasectomy or its physiological equivalent (that is, severing or occlusion of the vas deferens) produces very little change in anatomical structure, in sexual desires or activity or in any other physiological or mental functions, other than to cause sexual sterility.

Vasectomy is reported by reputable physicians to be remedial in some cases of excessive masturbation.

(3) In old age, vasectomy is successfully resorted to as a treatment for the amelioration of the condition of men suffering from an enlargement of the prostate.

\section{(b) Castration.}

(1) A boy castrated in childhood or at least before puberty becomes an eunuch, which type of person is a familiar figure in history and literature.

The removal of both testes in early youth tends very strongly to stop further development of the secondary sexual characteristics. The beard fails to develop, neither the thorax nor pelvis assume the masculine form and, in later life, obesity and docility are developed. The infantile, or non-masculine, type of mind seems to persist in most cases. Sexual desire is entirely absent and aggressive masculinity does not appear.

(2) Castration after sexual maturity is much more serious surgically than the same operation performed earlier, but, unlike castration in childhood, it does not cause a change in secondary sexual characteristics, because these have already developed. The evidence points, however, to the fact that the absence of the sex-gland removed in adult life causes in time a slight diminution or atrophy of secondary sexual characters and activities. Males castrated during adulthood are still able to "have connection of a sort with a woman."

(3) Castration in old age has even less physiological and psychological consequence than castration in middle life. Formerly castration was resorted to in adults for the

"The so-called "Steinach Operation," ligation of the vas deferens, claims rejuvenating effects in old men. (H. Benjiman, Am. Med. N. S., Vol. XVII, pp. 435-443. Aug. 1922.) treatment of enlarged prostate, but vasectomy was later found to be equally serviceable for this purpose.

\section{(B) Female.}

(a) Salpingectomy or its functional equivalent.

(1) In girls before puherty, available cases of the removal of all or a portion of the oviducts (Fallopian tubes), or their ligation or occlusion or by other means are so few in number that authentic records are lacking in quantities sufficient to justify a general statement as to its effect. By analogy, however, to the case of salpingectomy during sexual maturity, it is reasoned that salpingectomy before puberty would not be accompanied by any great physiological disturbance or change from the normal development of physiological functions other than to stop reproduction.

(2) Salpingectomy during the period of sexual maturity in the case of women with normal and undiseased sex-organs produces practically no change upon sexual desire or activity nor upon other physiological or mental functions other than to cause sexual sterility

(3) Salpingectomy after the climacteric affects the individual only to the extent of other surgical operations of equal seriousness. It causes little or no upset or change in the emotional or physiological life.

\section{(b) Oöphorectomy.}

(1) The removal of the ovaries in young girlhood is so rarely resorted to that generalization from the records is not so well founded as in the case of castration in boys. Generally, however, in mammals, the spaying (removal of the ovaries) of young females does not effect so great a change in ontogeny as eary operation in the males brings about in the latter sex. There is a tendency, however, for adult females whose ovaries have been removed in early youth to become obese and sluggish, and to lack strong sexual impulses.

(2) Oöphorectomy during the reproductive period has been resorted to principally because of pathological conditions of the reproductive mechanism rather than for eugenical purposes. It appears to have but little effect upon the sexual feelings of the average woman operated upon, but it is often followed by a considerable physiological and psychological disturbance.

(3) Oöphorectomy after the climacteric affects the woman operated upon in a manner quite similar to that resulting from the same operation consummated during the 
reproductive period, except that in the case of the older women it appears as a rule to be followed by less serious physiological and mental disturbances, although the surgical shock may be greater. This class of cases is of interest in this connection only for comparative purposes, since no eugenical purpose is served by sexually sterilizing a woman who has passed the reproductive period.

\section{Summary of Evidence on the Mental and Temperamental Effects of Sexual Steril- ization.}

(1) The character of the sexual impulse in both the human male and female, after sterilization, is a very complex thing, depending principally upon (a) the completeness with which the genital organs, especially the sex-glands, are removed. (b) the age at which the operation is performed, and (c) the individual peculiarities, both constitutional and acquired, of the person operated upon. In general the carlier the age. the more complete the castration, and the greater the natural sexual coldness of the individual, the more certainly will the operation of sexual sterilization destroy or inhibit the development of the sexual impulse.

(2) In women to a greater extent than in men, the persistence of normal sexual emotions after sterilization depends relatively more upon the individual who is operated upon, together with her state of health and individual traits, and relatively less upon the radicalness of the operation.

(3) Among the socially more unadapted classes the knowledge of sex-sterility itself has but little influence upon sex-control, because such persons are rarely deterred from sex-relations on account of fear of parenthood. or of venereal infection. In many cases their laxity is at the maximum both before and after sterilization. Sexual sterility is desired by a certain class of sex-offenders, both male and female. Doubtless the knowledge of self-sterility enses the mind of many morally lax persons, but it is doubtful whether it determines morality or immorality. In but few cases reviewed did the patients complain of a sense of shame or regret because of the loss of sexual fertility.

(4) Vasectomy of adolescent or adult males appears to have no substantial effert either upon the sexual impulse or upon potentia coeundi.

(5) Castration (the removal of both sexglands of either sex) performed before puberty is quite certain to prevent the develop ment of the libido sexualis, and makes a eunuch of a boy, but upon a girl it has a much less decided effect. Castration in adult life has but little effect upon the sex-impulse. neither does it change greatly the secondary sexual characters.

\section{Summary of Evidence on Sexual Ster- ilization as a Therapeutic Agent.}

(1) Castration in either sex as a cure or ameliorative remedy for feeble-mindedness or epilepsy has not justified itself, but on the other hand the removal of the sex gland does not appear to destroy or prevent, to any appreciable extent, the development of purely intellectual activity to the degree indicated by the pre-operative promise of the individual. The internal secretions of the sex-glands appear much more closely related to the emotional than the intellectual functions.

2. "The attempt to cure masturbation and erotic tendencies by this operation (oöphorectomy) must be regarded as useless and unscientific. ***" Kelly-Noble: Gynecology and Abdominal Surgery. W. B. Saunders Co. 1907. Vo1. I, p. 612.

(3) In cases of persons with normal and undiseased sex-organs, the value, as a remedy for mental or nervous disorders, of sexual sterilization of any type performed upon adults of any type, of either sex, is so little that it is not indicated in the course of the psychiatric treatment.

(t) In cases of pathological sex-viciousness in children, the early removal of the sex-gland appears to be ultimately remedial of the particular ill, but at the price of eunuchism.

(5) In cases of persons with abnormal or diseased sex-organs, psychiatric and physiological benefits have been wrought by operations which incidentally involved sexual sterilization, but there appears to be relatively little of intrinsic value in the fact that the sex-organs were the seat of irritation or infection, because, in other similar cases, the removal of local troubles in other organs has rendered similar relief. 


\section{CHAPTER XIV.}

\section{THE LEGAL BIOLOGICAL AND PRACTICAL REQUIREMENTS FOR AN EFFECTIVE EUGENICAL STERILIZATION LAW.}

Introduction

A. Commonly Stated Objections to the Existing Sterilization Laws.

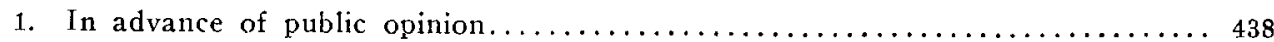

2. Violation of the Bill of Rights.............................. 438

3. Ill-adapted to their implied purposes......................... 439

4. Inadequate executive machinery ............................. 439

5. Lack of coöperation among sociologists...................... 439

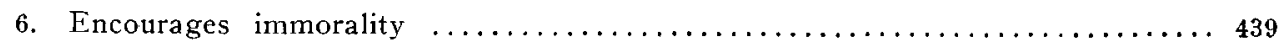

B. Requirements for an Effective Eugenical Sterilization Law.

a. Legal Requirements.

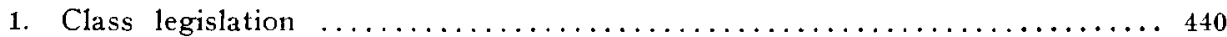

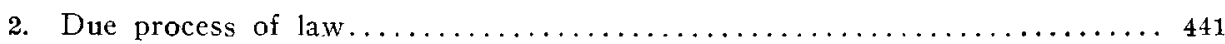

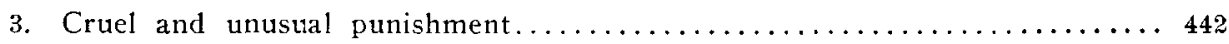

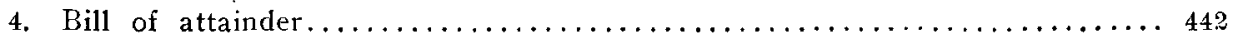

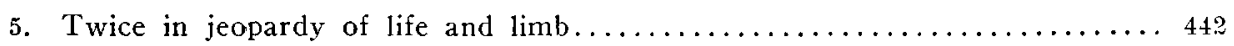

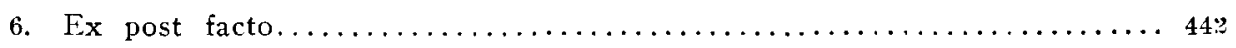

b. Biological or Eugenical Requirements.

1. Standard for legal parenthood............................ 443

2. The line of demarcation between Eugenic and Cacogenic.............. 443

3. Insurance against reproduction by cacogenic persons............... 443

4. Development of eugenic standards......................... 443

5. Suspension of order for eugenical sterilization $\ldots \ldots \ldots \ldots \ldots \ldots \ldots \ldots \ldots, \ldots \ldots \ldots$

6. Adequate evidence of cacogenesis.......................... 443

c. Practical Requirements.

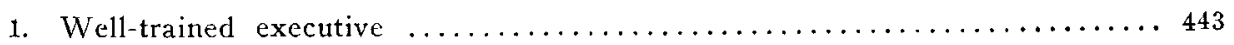

2. Due provision for prompt court procedure...................... 443

3. Ample funds for enforcement............................. 444

4. Lue provision for modern surgical work........................ 444

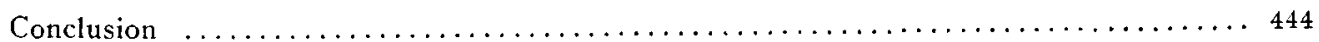




\section{INTRODUCTION.}

The twenty-three legislative enactments in reference to sexual sterilization which fifteen different American states have placed on their statute books during the past fifteen years (1907-1921) have served a valuable experimental purpose. They have provided a laboratory for working out a model law which, it is believed, can be made to function as intended, and which also will conform to sound biological, social and legal requirements.

\section{A. COMMONLY STATED OBJECTIONS TO THE EXISTING STERILIZA- TION LAWS.}

The accompanying chapters review the history and describe the principal features of the several sterilization laws which the different states have enacted; but, if the whole field is to be covered, this analysis should be supplemented by a consideration of a number of common objections based on policy and the practical working out of the laws.

\section{Ojection has been made:}

1. That the existing sterilization laws are in advance of public opinion. In a measure this is true. This could, however, hardly be set forth as a valid objection sufficient in itself to justify no further immediate efforts along this particular line of social endeavor. The law must not only follow the dictates of public opinion but in many cases legislation may well lead, or at least crystallize into statutory form, a vague idea of a possible social amelioration, and if such a statute is well grounded in truth and competency, the public will stand back of it.

2. That existing laws violate the essentials of the so-called bill of rights. Several of the sterilization laws, as drawn, have been held to run counter to Section 1, Article XIV of the Amendments to the Constitution of the United States, which guarantees to all citizens of each state the equal protection of the laws. In test cases the courts have stated that a state may, if it chooses, exercise its undoubted legislative right to improve the racial qualities of its citizens by eugenical sterilization of certain natural classes of degenerates; but, to differentiate between the members of such a natural class who are inmates of custodial institutions and those who live in the population at large is, in the opinion of at least three courts. "class legislation". The subjects of these three test cases were respectively epileptic (New Jersey), feeble-minded (New York) and feeble-minded (Michigan). Since all of those legally insane and legally criminal are theoretically under the custody of the state. a test case involving one or both of these classes will be of special interest and cori cern to eugenicists. Would the application by law of eugenical sterilization only to such insane and criminals as are in institutions constitute "class legislation"?

Objection is made that in ordering steriization. action is based upon the unproven future rather than upon the proven past, which type of procedure is contrary to the spirit of our institutions, which does not permit judicial declaration in reference to a particular individual unless the facts are proven beyond doubt. The fact which inspires a state to order eugenical, sterilization is the demonstrated proof that a given individual is of such an undesirable make-up of hereditary traits that the propagation of his kind would, beyond peradventure, constitute a serious menace to the welfare of the state. The eugenicist is now able to prove to the scientific world, to legislatures and to the courts of the land that by the application of certain pedigree principles to the pedigree findings in a particular case. it is possible to determine the hereditary potentialities of a given individual, and ihụs to demonstrate the eugenical menare of a given person.

Prevention of social menace is an essential purpose of law. Compulsory vaccination, quarantine, and the punishment of criminals as an example in stopping crime, are cases in which the law may act in order to prevent occurrences or conduct inimical to the welfare of the community. Self-preservation is the first law of nature with organized society as well as with individuals. If our society is to persist. it must purge itself of socially inadequate individua ${ }^{\prime}$ - those who do not contribute to the welfare of the social organization. If eugenical sterilization or eugenical segregation in custodial institutions will protect the race agains: degeneracy, then such measures would appear to be well within the police power of the state.

While a general application of sterilization to a natural type of defective or degenerate throughout the commonwealth seems a radical measure, still it is a condition which in the long run will make for eugenical or racia! progress, as well as for most punc- 
tilious regard for "the bill of rights. Other items of the "bill of rights" i. their rulation to eugenical sterilization are discussed uncler the subject of "The Legal Ruquircments for an Effective Eugenical Sterilization Law." (p. 440.)

3. That the statutes as drawn are illadapted to their stated or implied purposes. This is in a large measure a crue indictment; but it must be remembered that these early statutes are experimental; their practical working out will set forth weak points and will enable the legislators of the states to benefit from their study. It must be further remembered that only 1 ecently, within the last decade, have the laws of human heredity and the pedigree-method of studying anti-social families advanced to the stage of a science with practical and safe rules for predicting, within certain limits, the nature of the offspring to be expected from given matings, so that criteria for judging potential parenthood of degenerate offspring is now for the first time available. Legislators may now set standards for the natural heritable qualities of legal parenthood. There is no reason why eugenical laws may not prove as effective in improving the natural physical, mental and temperamental qualities of the human race as are the rules of breeding in conserving and developing better blood in our domestic plants and animals.

\section{That the executive machinery provided} to enforce these laws has been bad. This, also, is a true and serious objection, and there is little to be said in rebuttal. These statutes have not, as a rule, made adequate provision whereby the services of competent and honest men would be assured in executing their provisions. In most cases offcers who are busy with administrative duties of the most exacting nature were made, exofficio, the executive agents of the sterilization statutes. And, further, in many laws the chain of mandatory provisions has presented many gaps; thus, sterilization is offered as a remedy optional in the hands of certain of the state's custodians of its defective or deficient citizens. Furthermore, appropriations are in most cases quite inadequate to the service demanded. In New York the Commission appointed appears to have expended in per diem and traveling expenses practically the whole appropriation without doing any serious work as contemplated by the statute. This, however, is a matter for the chief executive officer of the state to take in hand; but if the law provides an executive agency with certain professional qualifications and with no other duties save to enforce the law, then in most states certainly the actual enforcement would be much more competent and thorough than under the political and ex-officio systems now prevalent.

5. That there is a lack of coöperation, and even considerable antagonism, between the advocates of more extensive and thorough segregation of social inadequates on the one hand, and the advocates of eugenical sterilization on the other. There can, however, be no real conflict here. Most of the present laws are at fault in providing for sterilization of inmates of institutions only. The lack of logic in this provision is obvious. It is while the individual of degenerate inheritance is in the custody of the modern institution that society is insured against reproduction by such person. Sterilization ought to, and must under the recent court decisions, apply with equal force to degenerates within custodial institutions and those in the population at large. A just method in reaching the ends sought would apply sterilization to persons in the population at large, immediately upon the official declaration of their cacogenesis, and while ordering the sterilization of the same cacogenic types in custodial institutions, in these latter cases the order for the actual operation or treatment might well be suspended until the individual is about to be released or paroled. If pending such time the particular cacogenic person died or passed the reproductive period, he or she would cease to be cacogenic, and even if still living and returned to the population at large, would not constitute an eugenical menace.

Sterilization can never take the place of segregation. Neither is there any likelihood that the support of segregation in modern institutions and colonies will be greatly interfered with, so far as the inadequates themselves are concerned, by sterilization. Sterilization and segregation are both working for social amelioration. Segregation takes the immediate problem, and should have unbounded support. Sterilization is a long-term investment and looks toward reducing the necessity in future generations of custodial care and treatment.

6. That Sexual Sterility Encourages Immorality. There is one other objection to sterilization which its opponents present. namely that the possession of sexual fertility 
on the part of both men and women, but principally on the part of women, prevents the over-indulgence in the sexual act, and thus acts as a moral stay. In reply it must be said that for the most part the persons who will come under the reach of a carefully drawn and executed sterilization law will be those who are as a rule not restrained from sexual indulgence on account of fear of parenthood. But in cases wherein this objection is valid, special pains must be taken by social agencies to remedy the situation to the greatest extent possible. And finally the eugenicist answers that this particular danger, which may exist to some degree, must be looked upon as an undesirable incident in the operation of the law, but of not sufficient moment to prevent the operation of the whole statute, from which so much future good is to be expected.

\section{B. THE REQUIREMENTS FOR AN EFFECTIVE EUGENICAL STERIL- IZATION LAW.}

All of the foregoing objections, and possibly others, should be considered and duly weighed in future legislation. In drafting the model statute an effort has been made to benefit by a careful study of the virtues and defects of the existing laws, including the above-listed objections. These pioneer and experimetal statutes have been extremely useful specifically in bringing to light the difficulties in locating socially inadequate individuals and potential parents of such. and in learning what type of executive machinery is most effective in enforcing the law, and will, at the same time, secure the greatest cooperation on the part of the individuals and families directly affected. These statutes have also furnished test cases in which the courts have clearly expounded the legal right of a state to exercise its police power in attempting to improve the racial qualities of its citizens by eugenica! sterilization.

a. Legal Requirements. The power of the state to limit, in the interest of racial betterment. the reproduction of certain individuals characterized by defective hereditary traits. is undoubted. The means used in exercising this power is a matter of legislative policy which lies with the legislative authority of the state. The only limitation which the courts have imposed, upon such authority in applying this particular social remedy. is that due regard must be had for the so-called bill of rights. Any infringement upon personal liberty, which is, of course, charac- teristic of every statute dealing with persons. must be balanced in an equitable manner by the returns in benefit to the general welfare of the people. Each of the following constitutional guarantees has, according to the courts, been violated by one or more sterilization laws, and must consequently be reckoned with in the future statutes.

1. Class Legislation. Section 1 of Article XIV of the Constitution of the United States guarantees to all citizens of all of the states the equal protection of the law. In New Jersey, New York, Michigan, and Iowa the courts have held that the statutes in each of these states were applicable to such narrow, unnatural and artificially designated classes that each constituted a violation of this general provision. This, then, appears to be the only great stumbling block from which eugenical and therapeutic-but not the punitive-sterilization statutes have fallen to their invalidity, and consequently new laws must take great pains to avoid similar disaster. The principle limitations and unnatural classifications have been as follows: First. applying the law to inmates of institutions and not to equally degenerate individuals in the population at large. Second, in applying the law to one natural class of undesirable parents, such as the feebleminded or epileptic, and not including with them all other classes of hereditarily equally defective persons. But this last objection appears not to have been emphasized so strongly by the courts as the first. Both. of them, however, are met in the model law by making all individuals of a given hereditary degeneracy, regardless of whether in institutions or in the population at large, subject to the same eugenical treatment, and second, by including in the operation of the statute all types of degenerates which modern investigations have proven to be socially ineffective primarily because of defective inheritance.

There is one other feature of class distinction in the application of eugenical laws, which should be discussed. It is contended without being confuted that the degenerate blood of the country is controlled largely by the number of degenerate women; that in the lower strains of humanity the degenerate women reproduce to full natural capacity: that if reproduction were made impossible for the degenerate members of this sex, eugenical requirements of the situation would be met. This is true to the following extent: Degenerate women may consort with 
either degenerate or normal males, but if the degenerate woman were sterile, there would, of course, be no offspring, and on the other hand, a degenerate male is limited in sexual relations to degenerate females. Thus, if the eugenical problem were one which concerned only the offspring of individuals personally degenerate, the argument for female sterilization only would be much sounder than it really is; because, as a matter of fact, not all potential parents of degenerate offspring are, themselves, personally degenerate. The matter of pedigree and the rules of the transmission of degenerate qualities must be considered, and since degeneracy, so far as possible offspring are concerned, lurks in many normal parents, the only sound method is to apply eugenical sterilization not to degenerate females alone, nor to degenerate males and females, but to all persons who are cacogenic within the legal definition, regardless of their own normal or degenerate personality. Such cacogenesis is to be determined, of course. by tue process of law upon the evidence presented by pedigree-studies.

But all this is a matter of policy. The legal question is. would it be an infringement on the constitutional provisions against "class legislation" to apply sterilization to one sex and not the other. If a state so chose, it could doubtless make such a statutory provision which would stand the tests of the courts. The reason for believing this is, that in Wisconsin the statute requiring a medical certificate showing freedom from venereal disease as a prerequisite to marriage, from the male only, and not from the female. was held (Peterson v. Widule, 15: Wis. 641) "not to constitute "class legislation," " but to be constitutionally sound, and because of the greater menace and susceptibility of the male in this particular case, to offer a benefit to the general welfare entirely commensurate to the apparent infringement on personal liberty.

The authority of the state to limit the application of eugenical sterilization to a given type or natural class of degenerates is maintained in the New Jersey law, which declares that (Section 6, Chapter 190, Laws of 1911) "If any provision of this act shall be questioned in any court, and the provisions be held to be unconstitutional and void, such determination shall not be deemed to invalidate the entire act, but only such provisions thereof with reference to the class in question as are specifically under review and particularly passed upon by the decision of the court."

The New Jersey law was tested before the courts and was attacked on the ground of "class legislation", the principal objections being that it applied to a natural class of defectives in institutions and not to the same class in the population at large. Thus theoretically the New Jersey law is still applicable to all types of defectives named in it except to epileptics, a person of this type having been the subject of the test case. This particular limitation of court purview which the statute itself provided was not discussed in the decision which declared the act unconstitutional.

Summary:-(a) It is probable that epileptics, feeble-minded, criminals, insane, or any other natural group of degenerates of a definitely described degree of degeneracy, each as a single class, could be made the subject of eugenical sterilization without infringing upon the constitutional requirement against "class legislation".

(b) Because, as previously stated, the terms "insane" and "criminal" are, in the eyes of the law, applicable only to such persons as by due process of law have been declared insane or criminal, it is probable that the judicial objection to limiting eugenical sterilization to the inmates of certain custodial institutions would lose much of its validity if laws so limited applied to the criminal or insane classes only.

(c) The legislative limitation of eugenical sterilization to one sex would probably be constitutional.

2. Due Process of Law. In enforcing any statute which calls for the regulation or modification of conduct on the part of citizens, or requires any particular behavior on their part, or applies any particular remedy to them, the application of law must itself be made with "due process of law". In cases in which the infringement upon personal liberty is small, due process of law is generally held to be satisfied by ministerial or administrative discretion; but in cases wherein the infringement is great, due process of law implies court procedure, with the right to be heard, and the decision based solely upon the law and the evidence, involving, in the most serious cases, a determination of the facts by a jury. In all such cases the burden of proving an infringement upon the law must rest with the state. It would, however, lie entirely within the au- 
thority of the state to enact a statute under which as a prerequisite to the granting of a marriage license the candidates would be required to prove to the satisfaction of a court the possession on their part of hereditary traits which are of value to the state, and which are not degenerated to the degree of cacogenesis defined by law. Such a proof might well insure the granting by the state of the right of the particular candidates to reproduce under the marriage covenant.

But, since sterilization laws will doubtless be applied to a particular class of undesirable parents which must be found in the population by officers of the state, it follows that the state must assume the burden of proving that the particular person nominated for sterilization falls within the specifications of forbidden parenthood set by the particular statute. It is clear, from the decisions rendered in the test cases, that the state will look upon eugenical sterilization as fraught with ends so fundamental in rature and so liable to abuse that in each particular compulsory case due process of law will require court procedure. with a decision based upon the law and cvidence. The legislative and court history in Iowa leads to the conclusion that a state may provide for the eugenical sterilization of certain very limited classes provided the consent of the individual or his or her family may be secured, and that in such cases due process of law will not imply court procedure. There is another reason for requiring procedure in each particular compulsory case, and that is, because sterilization, in order to be eugenically effective, need not be a matter of extreme haste, as is necessary in the case of vaccination or quarantine; but, on the other hand, the facts of the matter as determined by pedigreestudy can be learned only by considerable deliberation, especially in those cases in which the potential parenthood of degenerates is possessed by persons who thenselves are normal.

3. Cruel and Unusual Punishment. Eugenical sterilization should have absolutely no element of punishment in it. It is true that there have been attempts in this country to impose sterilization as a particularly appropriate punishment for sexual crimes, and also for cimes which seem to connote general criminal tendencies. The decision of the United States District Court in the Nevada case seems to indicate that as a rule the American states will not tolerate punitive sterilization. If as a punishment vasectomy is not cruel, it is at least unusual. A possible infringement of the provision against cruel and musual punishment is made by eliminating the punitive element, and by applying eugenical sterilization to all hereditary degenerates of types specified by iegislative enactment, that is, to all persons legally declared to be cacogenic (see p. 447), regardless of whether these particular individuals have violated the criminal law and are living in prisons, or whether they are living in the population at large. Because, then, there being no punishment in eugenical sterilization, it cannot constitute "cruel and unusual punishment."

4. Bill of Attainder. A bill of attainder applies only to punishment. It is essentially. a legislative enactment ordering a given punishment meted out to certain named individuals, or a certain named, very restricted and unnatural group of individuals. In Iowa the second sterilization law was held unconstitutional by the Federal Courts because it selected certain classes of criminals in the penitentiary, namely, those twice convicted of felony, and subjected them to sterilization as a punishment. It is obvious that this objection can be met by sterilization fundamentally eugenical, and to no degree punitive, in nature and consummation.

5. "Twice in Jeopardy of Life or Limb." In Iowa, in the case above mentioned, the statute was declared to constitute, also, placing an individual "twice in jeopardy of life or limb." Had the individual felon been ordered sterilized as a part of his original sentence at the bar, his sterilization would not then constitute placing him "twice in jeopardy of life or limb." In the state of Washington the first law was held constitutional because the order for sterilization was part of the sentence at the bar. Eugenical sterilization, being non-punitive, would not be subject to this particular objection.

6. Ex Post Facto. The Iowa statute was objected to, also, because it applied punishment to individuals for crimes at least some of which were committed before the enactment of the law, and therefore such a statute. when applied to the particular individual. would constitute an ex post facto law. Here again the matter of eugenical sterilization is not concerned, because it is not punitive. Certainly no court would hold the application of a sterilization law unconstitutional in applying it to insane persons who became insane before the enactment of the statute. 
The whole spirit of the law in avoiding ex post facto statutes is served, if observed in criminal law only.

Finally, the state must take it upon itself to prove to the satisfaction of the court or jury that the particular individual nominated for sterilization is, on account of his or her degenerate hereditary qualities, a serious menace to the racial qualities of the next generation. If in legislation and executive practice all of these foregoing requirements are met, certainly no one, from the point of view of constitutional law, could make valid legal objection to a sterilization statute enacted for purely eugcnical reasons.

(b) The Biological or Eugenical Requirements. In an effective sterilization law not only must the legal requirements be met, but the biological factors must receive due consideration.

1. The law should establish a standard of hereditary excellence in physical, mental and moral traits for legal parenthood in the state.

2. The logical line of demarcation for such purposes should be that which, due to hereditary difference, separates the socially valuable from the socially menacing. In turn the criterion for distinguishing social value from social menace is to balance an individual's life conduct and potentiality as a parent of socially valuable and socially menacing offspring. If as a whole the individual's life and his or her potential progeny are demonstrably an asset to the organized social life of the state, such individual should. if the question arose, legally be declared to be a eugenic person, the germ-plasm of whom should be conserved and proliferated as the most precious possession of the state. If, however, the resultant of such balancing demonstrates the individual and his or her possibie progeny to entail a burden upon the organized social life of the state, such person should legally be declared to be a cacogenic person, and as such should be forbidden to reproduce.

3. If, on account of hereditary degeneracy, an individual is by due process of law demonstrated to be a cacogenic person, he or she should be liable to eugenical sterilization, and actually should be made sexually sterile unless the state receives other and ample insurance against his or her reproduction.

4. The state might well set a relatively low standard at first. Later, as its executive machinery becomes more effective, and the laws of human inheritance more definitely known, and the location of degenerate families more certainly established in the particular state, the requirements could and should, in the interests of racial betterment, be raised.

5. So long as a cacogenic person is prorected against exercising his or her reproductive function, the order for sexual sterilization may, from the eugenical point of view, be held in abeyance. Such protection we find in case of inmates of our better custodial institutions, but when inmates of such institutions who shall lave been legally declared unfitted for parenthood, are about to be discharged or paroled, eugenical sterilization should be applied.

6. It is essential that potential parents of defectives of a certain qualitative and quantitative standard of degeneracy, that is those legally declared to be cacogenic persons, be sterilized, regardless of whether such individuals personally are defective mentally, physically or morally. The evidence for the legal declaration of cacogenesis should be based upon scientific pedigree-studies.

(c) Practical Requirements. An eugenical sterilization law may meet all of the requirements of constitutional law and provide all of the factors named as biologically necessary, and still be a failure. An effective law must make provision for honest and competent administration. There are many gaps in the executive chain in most of the existing statutes. In the administration of some there is evidence of dereliction, but for the most part an inadequate agency has been provided by the law for its own execution. The history of the administration of these laws points to the following legislative needs:

1. The principal officer of the law should be a trained engenicist. He should be well paid, and should be required to devote his entire time and attention to the duties of his office.

2. Due provision should be made for direct court procedure which will meet all of the legal requirements for "due process of law," and will, at the same time, insure a prompt and fair decision, whether in the particular case the nominee for sterilization is, as charged, a cacogenic person. Some of the test cases were years in reaching a final decision. This may be well enough in test cases, but in practical adninistration an expeditious decision is fundamental, not only to justice, but also to effective administration. 
Such determination should be a matter of days and weeks, not of months and years.

3. Ample funds should be provided for salaries and field expenses of trained fieldworkers skilled in analyzing human character and in tracing the descent of given traits in the family tree. The State Eugenicist should have ample funds for office maintenance, and special legislative solicitude should be given the compiling and maintenance of pedigree-records.

4. Due provision should be made for modern, skillful and humane surgical practice in executing the orders for eugenical sterilization. The State Eugenicist should be the responsible agent of the state in making contracts for surgical work involved witn competent surgeons.
Conclusion. With due heed to the legal, biological and practical considerations above listed, there is every reason to believe that the greatest benefit would accrue to the natural hereditary qualities of future generations from a law providing for the eugenical sterilization of certain hereditary degenerates and defectives.

The accompanying model statute (Chapter $\mathrm{XV}$ ) has been worked out after making a careful study of the motives, the sterilization, standards, the executive and legal processes, the legislative histories, the practical working out, general objections, and the litigation resulting from the twenty-three sterilization laws which have thus far been enacted by fifteen different states. 


\section{CHAPTER XV.}

\section{MODEL EUGENICAL STERILIZATION LAW.}

A. Principles Suggested for a Standard State Law ..................... 446

B. Full Text for a Model State Law.

Section 1. Short title.

Section 2. Definitions.

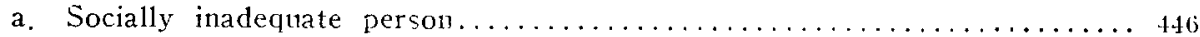

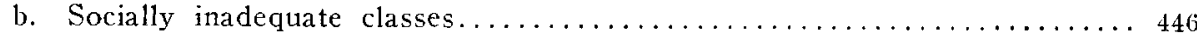

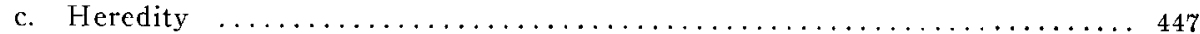

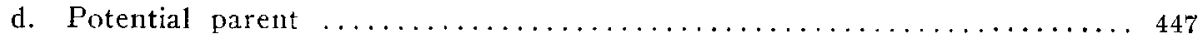

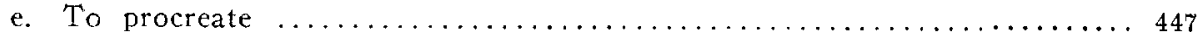

f. Potential parent of socially inadequate offspring............... 447

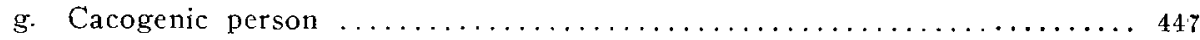

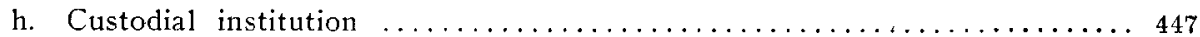

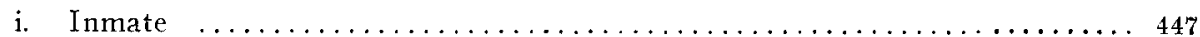

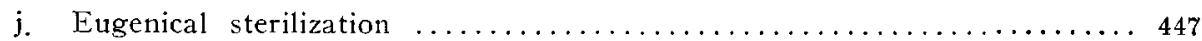

Section 3. Office of State Eugenicist......................... 447

Section 4. Qualifications of State Eugenicist....................... 447

Section 5. Term of Office, Appointment and Responsibility............... 447

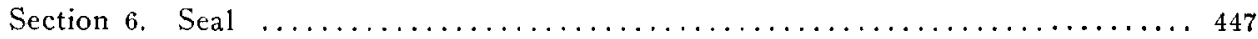

Section 7. Duties of State Eugenicist.

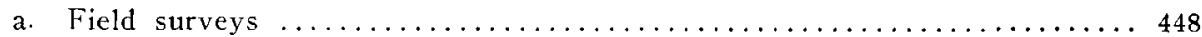

b. Further examinations ................................... 448

c. Roster custodial institutionn.............................. 448

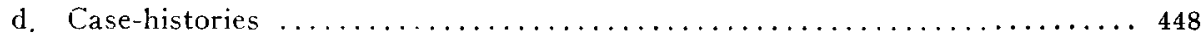

e. Records State Eugenicist's office............................ 448

f. Other duties ......................................... 448

Section 8. Coöperation by custodial institutions..................... 448

Section 9. Power to administer oaths and make arrests................ 448

Section 10. Opinion of State Eugenicist......................... 448

Section 11. Appointment of date for hearing....................... 449

Section 12. Notification of parties concerned....................... 449

Section 13. State's legal counsel............................. 449

Section 14 . Determination by jury........................... 449

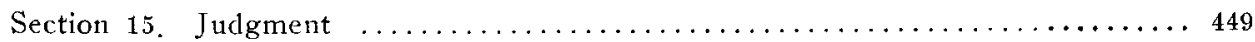

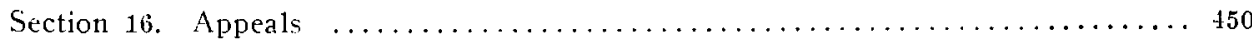

Section 17 . Type of eugenical sterilization........................ 450

Section 18. Manner of consummation........................... 450

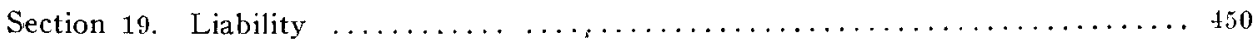

Section 20. Illegal destruction of reproductive functions................. 450

Section 21 . Punishment of responsible head of institution for dereliction........ 450

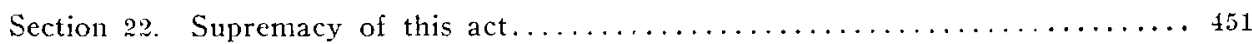

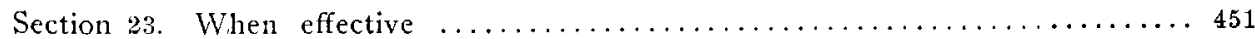

C. The Federal Government and Eugenical Sterilization.

a. Principles suggested for a Federal Statute........................ 451

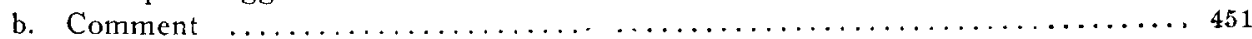




\section{A. PRINCIPLES SUGGESTED FOR A STANDARD STATE LAW.}

It may be safely stated that the experimental period for eugenical sterilization legislation has been passed so that it is now possible to enact a just and eugenically effective statute on this subject. The following outline sets forth the underlying principles which should guide such a law.

Persons Subject. All persons in the State who, because of degenerate or defective hereditary qualities are potential parents of socially inadequate offspring, regardless of whether such persons be in the population at large or inmates of custodial institutions, regardless also of the personality, sex, age, marital condition, race, or possessions of such person. Standards estabfished and terms defined by the statute.

Executive Agencies Provided. State Eugenicist who shall devote his entire time and attention to his office, aided by an ample corps of assistants, selected by appointment or civil service according to the customs of the particular state.

Basis of Selection: Procedure. 1. Investiation by State Eugenicist upon his own initiative or upon complaints lodged or information given by an official, an organization or a citizen. 2. Opinion concerning a particular individual in reference to "potential parenthood of socially inadequate offspring" rendered after scientific investigation, by State Eugenicist to Court of Record. 3. Early date set by court for hearing case. 4. Court to notify and summon interested parties. 5 . Due provision for legal counsel for the defendant and for trial by jury. 6. Judgment: Order for eugenical sterilization if the contention of the State Eugenicist is upheld. 7. Execution of the order under the supervision and responsibility of the State Eugenicist. 8. In case of inmates of institutions, execution of order may be suspended until inmate is about to be released, allowing ample time for convalescence. 9. Provision for the study of mental, moral, physiological, social and economic effects of different types of sterilization.

Type of Operation Authorized. 1. "Sur gical operation upon or medical treatment of the reproductive organs of the human male or female in consequence of which the power to procreate offspring is permanently nullified." 2. Specific type of operation or treatment in each case to be determined by the State Engenicist upon the advice of duly qualified physicians and surgeons. 3. Due provision for safe, skillful and humane operation and treatment.

State's Motive. Purely eugenic, that is, to prevent certain degenerate human stock from reproducing its kind. Absolutely no punitive element.

Appropriations Available for Enforcing the Act. Ample appropriations for the maintenance of the activities of the State Eugenicist as a permanent and effective institution.

\section{B. FULL TEXT FOR A MODEL STATE LAW.}

AN ACT to prevent the procreation of persons socially inadequate from defective inheritance, by authorizing and providing for the eugenical sterilization of certain potential parents carrying degenerate hereditary qualities.

Be It Enacted By The People Of The State of ........... that:

Section 1. Short Title. This Act shall be known as the "Eugenical Sterilization Law."

Section 2. Definitions. For the purpose of this Act, the terms (a) socially inadequate person, (b) socially inadequate classes, (c) heredity, (d) potential parent, (e) to procreate, (f) potential parent of socially inadequate offspring, $(\mathrm{g})$ cacogenic person, (h) custodial institution, (i) inmate, and ( $j$ ) eugenical sterilization, are hereby defined as follows:

(a) A socially inadequate person is one who by his or her own effort, regardless of etiology or prognosis, fails chronically in comparison with normal persons, to maintain himself or herself as a useful member of the organized social life of the state; provided that the term socially inadequate shall not be applied to any person whose individual or social ineffectiveness is due to the normally expected exigencies of youth, old age, curable injuries, or temporary physical or mental illness, in case such ineffectiveness is adequately taken care of by the particular family in which it occurs.

(b) The socially inadequate classes, regardless of etiology or prognosis, are the following: (1) Feeble-minded; (2) Insane, (including the psychopathic): (3) Criminalistic (including the delinquent and wayward); (4) Epilcptic; (5) Inebriate (including drughabitués); (6) Diseased (including the tuberculous, the syphilitic, the leprous, and others with chronic, infectious and legally segre- 
gable diseases); (\%) Blind (including those with seriously impaired vision); (8) Deaf (including those with seriously impaired hearing); (9) Deformed (including the crippled); and (10) Dependent (including orphans, ne er-do-wells, the homeless, tramps and paupers).

(c) Heredity in the human species is the transmission, through spermatozoön and ovum, of physical, physiological and psychological qualities, from parents to offspring; by extension it shall be interpreted in this Act to include also the transmission postconceptionally and ante-natally of physiological weakness, poisons or infections from parent or parents to offspring.

(d) A potential parent is a person who now, or in the future course of development, may reasonably by expected to be able to procreate offspring.

(e) To procreate means to beget or to conceive offspring, and applies equally to males and females.

(f) A potential parent of socially inadequate offspring is a person who, regardless of his or her own physical, physiological or psychological personality, and of the nature of the germ-plasm of such person's coparent, is a potential parent at least onefourth of whose possible offspring, because of the certain inheritance from said parent of one or more inferior or degenerate physical, physiological or psychological qualities would, on the average, according to the demonstrated laws of heredity, most probably function as socially inadequate persons; or at least one-half of whose possible offspring would receive from said parent, and would carry in the germ-plasm but would not necessarily show in the personality, the genes or genes-complex for one or more inferior or degenerate physical, physiological or psychological qualities, the appearance of which quality or qualities in the personality would cause the possessor therecf to function as a socially inadequate person. under the normal environment of the : tate.

(g) The term cacogenic person, as herein used, is a purely legal expression, and shall be applied only to persons declared, under the legal procedure provided by this Act, to be potential parents of socially inadequate offspring.

(h) A custodial institution is a habitation which, regardless of whether its authority or support be public or private, provides (1) food and lodging, and (2) restraint, treatment, training, care or residence for one or more socially inadequate inmates; provided that the term custodial institution shall not apply to a private household in which the socially inadequate member or members are close blood-kin or marriage relations to, or legally adopted by, an immediate member of the care-taking family.

(i) An inmate is a socially inadequate person who is a prisoner, patient, pupil, or member of, or who is otherwise held, treated. trained, cared for, or resident within a custodial institution, regardless of whether the relation of such person to such institution be voluntary or involuntary, or that of pay or charity.

(j) Eugenical Sterilization is a surgical operation upon or the medical treatment of the reproductive organs of the human male or female, in consequence of which the power to procreate offspring is surely and permanently nullified; provided, that as used in this Act the term eugenical sterilization shall imply skillful, safe and humane medical and surgical treatment of the least radical nature necessary to achieve permanent sexual sterility and the highest possible therapeutic benefits depending upon the exigencies of each particular case.

Section 3. Office of State Eugenicist. There is hereby established for the State of ........... the office of State Eugenicist. the function of which shall be to protect the state against the procreation of persons socially inadequate from degenerate or defective physical, physiological or psychological inheritance.

Section 4. Qualifications of State Eugenicist. The State Eugenicist shall be a trained student of human heredity, and shall be skilled in the modern practice of securing and analyzing human pedigrees; and he shall be required to devote his entire time and attention to the duties of his office as herein contemplated.

Se-tion 5. Term of Office, Appointment, and Responsibility. The State Eugenicist shall be appointed by the Governor, with the consent of the Senate, shall be responsible directly to the Governor, and shall hold office until removed by death, resignation, or until his successor shall have been duly appointed.

Section 6. Seal. The Governor of the State shall cause a seal to be fashioned and made for the Office of the State Eugenicist. which seal shall be duly entrusted to the State Engenicist and shall constitute the evidence of authority under this sct. 
Section 7. Duties of State Eugenicist. It shall be the duty of the State Eugenicist:

(a) To conduct field-surveys seeking firsthand data concerning the hereditary constitution of all persons in the State who are socially inadequate personally or who, although normal personally, carry degenerate or defective hereditary qualities of a socially inadequating nature, and to coöperate with, to lear the complaints of, and to seek information from individuals and public and private social-welfare, charitable and scientific organizations possessing special acquaintance with and knowledge of such persons, to the end that the State shall possess equally accurate data in reference to the personal and family histories of all persons existing in the State, who are potential parents of socially inadequate offspring, regardless of whether such potential parents be nembers of the population at large or inmates of custodial institutions, regardless also of the personality, sex, age, marital condition, race or possessions of such persons.

(b) To examine further into the natural physical, physiological and psychological traits, the environment, the personal histories, and the family-pedigrees of all persons existing in the State, whether in the population at large or as inmates of custodial institutions, who reasonably appear to be potential parents of socially inadequate offspring, with the view to determining more definitely whether in each particular case the individual is a cacogenic person within the meaning of this Act.

(c) To maintain a roster of all public and private custodial institutions in the state, and to require from the responsible head of each such institution, a record by full names and addresses, social and medical diagnosis and other pertinent data in reference to all accessions and losses of inmates as such occur from time to time; the said State Eugenicist may require a copy of any record which the particular institution may possess in reference to the case, family or institutional histories of any inmate which the State Eugenicist may name.

(d) To follow up, so far as possible, the case-histories of persons eugenically sterilized under this Act, with special reference to their social, economic, marital and health records, and to investigate the specific effects of eugenical sterilization.

(e) To preserve as property of the State complete records of all investigations and transactions of the office of State Eugeni- cist, and annually to render to the Governor in writing a true and complete report thereof.

(f) To perform such other duties as are enumerated elsewhere in this Act.

Section 8. Coöperation by Custodial Institutions. For the purpose of securing the facts essential to the determination required by this Act, the responsible head of any public or private custodial institution within the State shall, on demand, render promptly to the State Eugenicist all reports herein contemplated, and shall extend to said Officer and his duly appointed agents ready access to all records and inmates of the particular institution.

Section 9. Power to Administer Oaths and to Make Arrests. The State Eugenicist and his assistants appointed in writing by him for the purpose, shall have power to administer oaths, to subpoena and to examine witnesses under oath, and to make arrests.

Section 10. Opinion of State Eugenicist. If, after an investigation contemplated by this Act, the State Eugenicist is of the opinion that a particular subject of such investigation, which stich subject is hereinafter called the propositus, is a potential parent of socially inadequate offspring, it shall be the duty of said State Eugenicist to present such opinion in writing, to a court of record in the County wherein the particular propositus resides, sojourns, is held or is apprehended; provided that such opinion shall be accompanied by the historical and biological evidence upon which such opinion is based, and by a petition to said court praying for the legal determination of the question of fact, whether the particular propositus is, as held in the opinion, a potential parent of socially inadequate offspring; provided that in case of apparent over-sight or dereliction by the State Eugenicist, any citizen of the state over twenty-one years of age, of sound mind and respected character, may institute proceedings for the legal determination of the question in fact, whether a particular named person is, as such complaining citizen may allege, a potential parent of socially inadequate offspring, by presenting to the court of record in the county in which the particular propositus lives or sojourns, a statement duly sworn to relating the evidence tupon which the particular allegation is based, and praying for a legal determination of the above-stated question of fact, whereupon within thirty days of the filing of such petition, such court shall consider the adequacy of such evidence and, in its discretion, 
shall dismiss the case or shall command the State Eugenicist to make the eugenical investigation provided for by this Act in reference to the particular propositus, and to return his findings back to the court issuing such command, which findings shall be returned within ninety days of the issuing of such command and shall contain an opinion by the State Eugenicist as to whether the particular propositus is in fact a potential parent of socially inadequate offspring; provided that if such report presents the opinion that the particular propositus is a potential parent of socially inadequate offspring, the legal and eugenical processes in the case shall proceed as in other cases as provided by this Act; provided that if such report presents the opinion that the particular propositus is not a potential parent of socially inadequate offspring, the court may, in its discretion, dismiss the case or may order the legal and eugenical processes to proceed as in other cases provided by this Act.

Section 11. Appointment of Date for Hearing. Within ten days after the presentation of the written opinion by the State Eugenicist holding a particular propositus to be a potential parent of socially inadequate offspring, or the presentation of a negative opinion by the State Eugenicist contrarily to which opinion the court determines to proceed, it shall be the duty of the court to which such opinion is presented to appoint a time for hearing the case, which appointed time shall be within thirty days of the appointing day if the court receiving the opinion is in continuous session, and not later than the next regular session, if said court is held periodically.

Section 12. Notification of Parties Concerned. It shall be the further duty of said court to notify the propositus or the legal guardian, custodian, or next friend of said propositus, the Attorney-General of the State, and the State Eugenicist, concerning the time, place and nature of the contemplated hearing; to summon the propositus to such hearing, or if said propositus be under legal guardianship, in custody, or if, in the opinien of said court, said propositus be incapable of understanding the nature of a summons, to command the legal guardian, or custodian of said propositus, or an executive officer of said court, to present the person of said propositus before said court at the appointed time and place; to subpoena witnesses; if need be, to appoint legal counsel at the expense of the State to rep- resent the propositus; and to institute such other processes as may be necesary according to the statutes of the state and customs of the particular court, in order to insure a prompt, just and legal decision in the matter.

Section 13. The State's Legal Counsel. In all legal actions growing out of this Act. it shall be the duty of the Attorney-General of the State, assisted by the prosecuting attorney of the county in which the particular court is seated, to represent the State.

Section 14. Determination by Jury. On demand of either party to a hearing as herein contemplated, the question of fact shall be decided by a majority vote of a jury of six, summoned and conducted in accordance with the laws of the State governing trials by jury, but in case no such demand be made, the judge presiding over the court shall decide the case.

Section 15. Judgment. If, after the case has been duly heard and tried, it is the opinion of the court or the jury, as the case may be, that the particular propositus is a potential parent of socially inadequate offspring within the meaning of this Act, it shall be the duty of said court to declare the particular propositus to be a cacogenic person, and to command the State Eugenicist to arrest, if need be, such particular cacogenic person, and to cause such person to be eugenically sterilized in a skillful, safe and humane manner, and with due regard to the possible therapeutical benefits of such treatment of operation; securing. if possible, the consent and cooperation of said cacogenic person, and, if such there be, of the legal guardian, custodian or next friend of said cacogenic person; and such court shall further command that the particular cacogenic person shall not be released from the custody of the State Eugenicist until said order ha: been duly executed, but that the said particular cacogenic person be not held in the custody of the State Eugenicist longer than is necessary for the consummation of the eugenical sterilization and convalescence therefrom; and said court shall further command the State Eugenicist to report back. immediately upon the release of the person sterilized, to the court issuing the said command, a sworn statement as to the identity of the person eugenically sterilized and the place, date, nature and outcome of the particular operation or treatment; provided that in case the said cacogenic person be an inmate of a custodial institution. the court 
shall issue a supplementary order commanding the responsible head of such particular custodial institution to provide access. for the State Eugenicist and the physician and surgeon appointed by said State Eugenicist, to the person of the particular cacogenic person in the best-equipped hospital quarters which such custodial institution affords for the consummation of the particular eugenical sterilizing operation or treatment, and to aid and co-operate in such consummation; provided that in case the court is convinced that the conduct or security of said cacogenic person is such that said person will not become a parent, the court may in its discretion suspend the order for eugenical sterilization during the period of such conduct and security.

Section 16. Appeals. In litigation growing out of this Act, appeals from the decision of the court of first instance shall lie as in civil trials de novo at law, as provided by the statutes of the State.

Section 17. Type of Eugenical Sterilization. The particular type of surgical operation or medical treatment for effecting sterilization in each particular case legally ordered in consequence of this Act shall be determined upon by the State Eugenicist, after due consultation with competent medical and surgical advisors.

Section 18. Manner of Consummation. All cases of eugenical sterilization executed in consequence of this Act shall be consummated under the direct supervision and responsibility of the State Eugenicist, in a skillful, safe and humane manner, with due regard to the possible thcrapeutic benefits to be derived therefrom, and in strict accordance with modern sanitary, hospital, medical and surgical knowledge and practice: provided that the contracts for the hospital, medical and surgical services involved in such consummation shall be entered into for the State by the State Eugenicist, who shall determine the necessary and reasonable fees incident thereto, which fees shall be paid by the State from funds previously appropriated for said purpose; provided that in case the person ordered sterilized be an inmate of a custodial institution, and if in the opinion of the State Eugenicist. the hospital facilities of the particular institution are inadequate, or if time ample for eugenical sterilization and convalescence does not permit the particular operation or treatment to be consummated before the time previously set for the discharge, release or parole of the particular propositus, the order for eugenical sterilization shall not be consum mated in the custodial institution, but that the responsible head of said particular custodial institution shall at the time previously set for the discharge, release or parole of the particular propositus, so discharge, release or parole said person into the custody of the State Eugenicist, who shall then proceed to execute the order for the eugenical sterilization as in cases originating in the population at large.

Section 19. Liability. Neither the State Eugenicist, nor any other person legally participating in the execution of the provisions of this Act, shall be liable either civilly or criminally on account of said participation.

Section 20. Illegal Destruction of Reproductive Functions. Nothing in this Act shall be construed so as to prevent the medical or surgical treatment for sound therapeutic reasons of any person in this State, by a physician or surgeon licensed by this State, which treatment may incidentally involve the nullification or destruction of the reproductive functions; provided that any person in this State, except as duly ordered by the courts of law as contemplated in this Act, who wilfully, and without the aforementioned therapeutical necessity, nullifies or destroys or assists in nullifying or destroying, the reproductive functions of any person, shall be guilty of a felony, and shall be punished by not less than__-months' imprisonment or a fine of-dollars, or bjoth, or by not more than-.....months imprisonment or a fine of-dollars, or both

Section 21. Punishment of Responsible Head of Institution for Dereliction. The responsible head of any public or private custodial institution in the State who shall discharge, release or parole from his or her custody or care any inmate who has been duly ordered by a court of this State to be eugenically sterilized, before due consummation of such order as herein contemplated, unless, as herein provided, such particular inmate be discharged, released or paroled into the custody of the State Eugenicist, shall be guilty of a misdemeanor, and shall be punished by not less than___-months' imprisonment or-dollars fine, or both, or by not more than-months' imprisonment or___-dollars fine, or both. 
Section 22. Supremacy of this Act. All statutes or portions of statutes of this State contrary to this Act are hereby repealed.

Section 23. When Effective. This Act shall take effect immediately.

\section{THE FEDERAL GOVERNMENT AND EUGENICAL STERILIZATION.}

\section{a. Principles Suggested for a Federal Statute.}

Persons Subject. 1. Immigrants who are personally eligible to admission but who by the standards recommended in the model state law are potential parents of socially inadequate oftspring. 2. All persons below the standards of parenthood set in the model state law who are beyond the jurisdiction of state laws, including the inhabitants of the District of Columbia, unorganized and outlying territories. Indian reservations, inmates of federal institutions, and soldiers and sailors.

Executive Agencies Provided. Federal Eugenicist attached to Public Health Service or the Children's Bureau, aided by an ample corps of assistants.

Basis of Selection: Procedure. Same as for model state law, naming in place of state courts of record, Federal Courts of appropriate jurisdiction.

Type of Operation Authorized. Same as for model state law.

\section{United States' Motive. Purely eugenic.}

Appropiations Available for Enforcing the Act. Ample appropriations for the maintenance of the activities of the Federal Eugenicist as a permanent and effective institution.

\section{b. Comment.}

$\mathrm{Up}_{\mathrm{p}}$ to the present time, the Federal Government has not enacted any legislation bearing either directly or indirectly upon eugenical sterilization. The matter of segregating, sterilizing, or otherwise rendering non-reproductive the degenerate human strains in America is, in accordance with the spirit of our institutions, fundamentally a matter for each state to decide for itself. There is, however, a specialized field in which the Federal Government must cooperate with the several states, if the human breeding stock in our population is to be purged of its defective parenthood.

The relation between the inheritable qualities of our immigrants and the destiny of the American nation is very close. Granting that the fecundity of native and immigrant stock will run evenly, then it is clear that from generation to generation the natural qualities of our present human parenthood will more and more assume the character of the natural qualities of immigrant parents. Thus, if the American nation desires to upbuild or even to maintain its standard of natural qualities, it must forbid the addition through immigration to our human breeding stock of persons of a lower natural hereditary constitution than that which constitutes the desired standard.

If our standard of physical, mental and moral qualities for parenthood strike more heavily against one race than another, then we should be willing to enforce laws which take on the appearance of racial discrimination but which indeed would not be such, because in every race, even the very lowest, there are some individuals who through natural merit could conform to our standards of admission.

The immigration policy of the eugenicist. who has at heart the preservation, upbuilding and specialization of our better family stocks, is to base the criterion for admission of would-be immigrants primarily upon the possession of sterling natural qualities, regardless of race, language, or present social or economic condition.

It is suggested that a Federal Eugenicist. attached to the Public Health Service, or to the Children's Bureau, aided by an ample corps of assistants, would constitute an effective administrative agency for sterilization under federal authority. Some of the assistants of the office of Federal Eugenicist should be delegated to cooperate with the Immigration Service of the Department of Labor, and the Bureaus of Criminal Identification, and of Prisons, of the Department of Justice, and possibly with the Bureau of Education of the Department of the Interior. If the projected plan for examining the admissibility of immigrants in their native homes before their purchase of transportation, or even upon the steamships before landing, were adopted, it would be possible to pass satisfactorily upon the eugenical qualifications of the particular immigrant. 
This would be effected by attaching eugenicists to the medical and social staff to which would be delegated the task of determining the eugenical qualifications of each candidate for admission.

The Federal Government has exclusive jurisdiction over immigrants, and it controls interstate and foreign quarantine. It has also exclusive jurisdiction, either direct or final, over the socially inadequate, both within and not in custodial institutions, in the District of Columbia, the Indian reservations, and the territories which have not yet been admitted to statehood. It operates and controls the twenty-four federal custodial institutions for various types of the socially inadequate. Thus a Federal law would be needed in order effectually to cooperate with the eugenical efforts of the states, should the latter generally determine upon sterilization as a means for cutting down the birth rate among degenerates. The office of Federal Eugenicist attached to the Public Health Service or the Children's Bureau would constitute an appropriate executive agent of a federal sterilization statute. 


\section{CHAPTER XVI.}

\section{EXPLANATORY COMMENTS ON THE MODEL STERILIZATION LAW.}

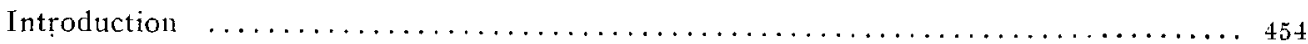

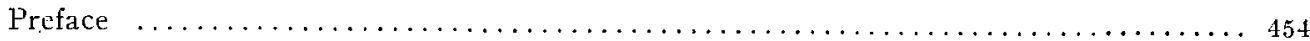

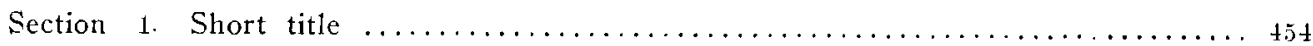

Section 2. Definitions.

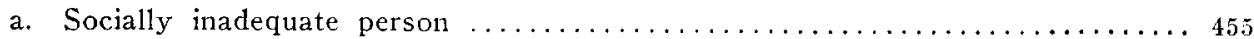

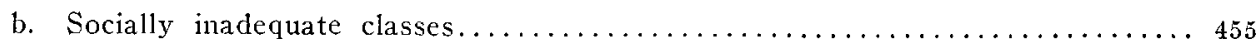

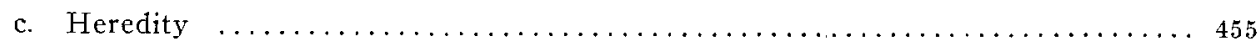

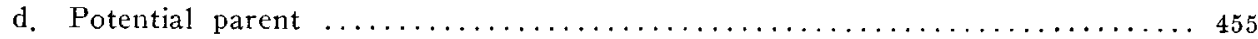

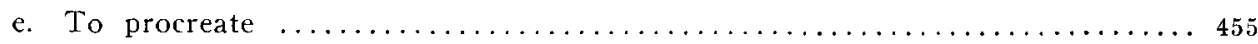

f. Potential parent of socially inadequate offspring................... 455

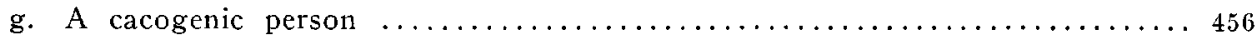

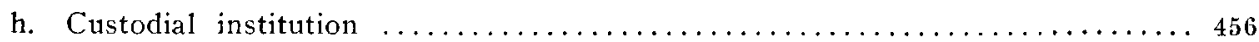

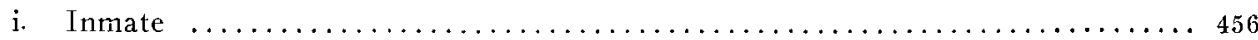

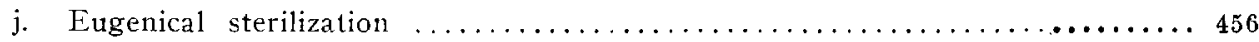

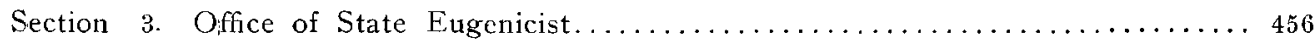

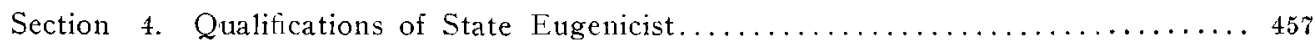

Section 5. Term of office, appointment and responsibility $\ldots \ldots \ldots \ldots \ldots \ldots \ldots \ldots+5 i$

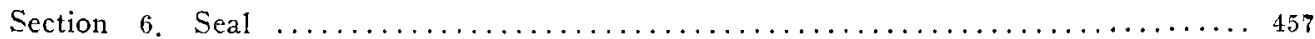

Section $\%$ Duties of State Eugenicist............................. $45 \tau$

Section 8. Coöperation by custodial institutions..................... 458

Section 9. Power to administer oaths and to make arrests................ 458

Section 10. Opinion of State Eugenicist........................... 458

Section 11. Appointment of date for hearing......................... 458

Section 12. Notification of parties concerned $\ldots \ldots \ldots \ldots \ldots \ldots \ldots \ldots \ldots \ldots \ldots \ldots \ldots$

Section 13. The State's legal counsel........................... 459

Section 14. Determination by jury............................... 459

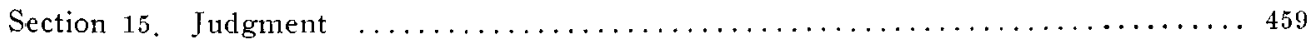

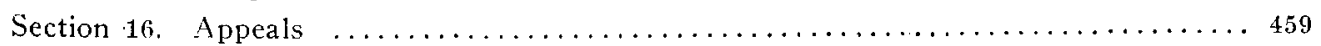

Section $1 \pi$. Type of eugenica1 sterilization............................ 459

Section 18. Manner of consummation........................... 459

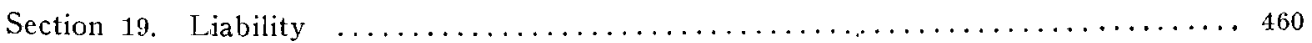

Section 20. Illegal destruction of reproductive functions................. 460

Section 21. Punishment of responsible head of institution for dereliction.......... 460

Section 22: Supremacy of this act............................. 460

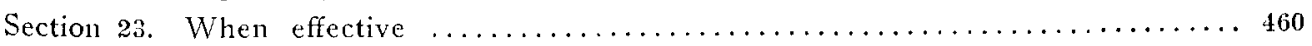

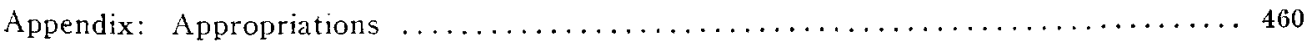




\section{INTRODUCTION.}

The lawmaker must consider eugenical sterilization in the light of the whole complex of its relationships; its legal, historical, social, economic, religious, surgical, and eugenical bearings. The evidence brought together in this book is intended to serve the legislator in his efforts to weigh the matter in its entirety. On the one hand eugenical sterilization purports to prevent the reproduction by certain definitely and legally described and located cacogenic persons. It claims that by so doing the race will be purged of some of its degenerate and defective stock. It is effective in so far as it is ain insurance against reproduction by the individuals operated upon. It may be accomplished with little or no danger to life, depending upon the legislative provisions for executing the operation "in a skillful, safe and humane manner." In some cases the operation itself may be of some therapeutic benefit, but in most cases it is neither a mental or physiological benefit nor ill. While compulsory, still in most cases it is possible to secure the cooperation of the patient or the patient's family. As a matter of fact in most. but not all, cases of legalized operations thus far consummated, such cooperation was actually secured. The cost to the state in maintaining in custodial institutions its anti-social citizens would probably be reduced considerably by eugenical sterilization, although the effects of such reduction would not be apparent until future decades. The science of eugenics has made sufficient progress to enable it. by pedigreestudies, to demonstrate the cacogenic inheritance of certain of the more patent types of mental, physical and temperamental degeneracy

On the other hand, eugenical sterilization takes away from the individual the natural ability, and by some held "the natural right," to reproduce. If a mistake be made in selecting an individual for sexual sterilization. the error cannot be rectified. It subjects the individual to compulsory surgical operation with its accompanying surgical shock. If the operation is not skillfully selected and executed, it may cause a mental or physical injury. Eugenics is a new science and has not yet a great body of history and evidence to support it, which, for example, medicine claims for itself, but effective, if not ideal, executive machinery for enforcing a justly enacted law has been put into actual operation, so that there are some authentic data upon which to base criticisms in reference to effective administration.

Thus, the lawmaker must balance evidence in favor of and against the policy of eugenical sterilization. The certain great racial and social benefit, the possible benefit to the indlividual, the ultimate great saving in money by the state must be weighed against the taking away of a natural power, a possible miscarriage of justice, a possible mistaken diagnosis, a possible surgical shock, and a possible physiological ill to the person alleged to be a potential parent of defective stock.

This model law has been drafted in accordance with the teachings of the practical working out of the existing statutes, the decisions of the courts in cases wherein the statutes have been tested, and the biological and social requirements of the case. Because of the varying eugenical needs, the different legislative customs, and the different policies in conducting the business of the state, this draft, while sound from the standpoint of constitutionality in the average state, and meeting the average biological and social requirements of the situation. should be submitted to competent eugenicists, psychiatrists, institutional executives, and lawyers, in the state in which it is proposed to enact a statute following the general principle here outlined. The active cooperation of all these specialists is needed in order to insure conformity to the special needs and policies of the particular state. It would, therefore, constitute a serious mistake to omit the advice of any one of them.

Preface. The preface contains a short statement concerning the purpose of the act. It will be noted that the actuating spirit of the model statute is eugenical. The therapeutic benefit is merely incidental, and there is absolutely no sign or suggestion of punishment. In states in which it is customary to introduce a statute in a different manner, the following introduction is suggested: "Whereas, heredity determines the natural endowments of a people, and therefore in its degenerate phases plays a most important part in the causation of feeble-mindedness, in'sanity, criminalistic tendencies, diminished vigor, susceptibility to disease, physical deformity and other individual and racial handicaps, be it enacted .............. :

Section 1. Short Title. In some states it is customary to name a statute. In naming 
this act the "lingenical Sterilization Law", it receives a designation which, together with its chapter number in the session laws of the state which enacts it, will serve the useful purpose of both legal and lay reference and description.

Section 2. Definitions. In any statute which involves the application of technica! principles, technical terms should be standardized by legislative enactment so far at least as their use in the particular statute is concerned. The principal purpose of legally defining the several terms used in eugenical pedigree-studies is to present to the exccutive agents of the law a uniform standard for action. Also such standardized definitions will prevent the confusion of terms and the use of long circumlocutions in subsequent sections of the statute.

(a) Socially inadequate person. The whole purpose of eugenical sterilization is to prevent the reproduction of persons who, because of their hereditary make-up, would be destined to become social menaces or wards of the state. The term social inadequacy covers this whole group of individuals.

(b) Socially inadequate classes. In denouncing the New Jersey statute as "class legislation", the court could see no logical boundaries to the whole group of undesirable parenthood, but had the court made a careful investigation of the classification of social handicap and degeneracy, he would have found substantially the ten classes given under section "b", which ten classes include the whole range of social inadequacy. It is therefore proper by statutory definition to draw a definite line of demarcation between the socially effective and the socially ineffective members of the communjty.

(c) Heredity. The great confusion in the notions as to what heredity is and is not necessitates a biologically sound administratively practical definition of this word to guide the executive agents of the statute.

(d) Potential parent. A child who has not yet reached the age of puberty and consequently is not able to procreate offspring, is, if his hereditary make-up be bad, a menace on account of his probable future sexual development. Women who have passed the climacteric, and very aged men, are, on account of age limits, not potential parents. Similarly men and women still in the reproductive ages, but who have lost their reproductive powers through surgical opera- tions, accident or disease, or who from defective inheritance or development are sterile, are of course not potential parents, and no eugenical purpose could be served by further operating on their reproductive organs.

(e) To procreate is here used as a general term. It saves the use of the expression "to beget or to conceive, as the case may be", throughout the statute. The justification for applying the term "to procreate" to both sexes with equal force was given by the editors of Webster's Dictionary, in a letter to the author (March 8, 1918), as follows:

Their hope to procreate children. Fenton (15\%9)

A pair of animals, producing..... two hundred offspring, of which ....... only two on an average survive to procreate their kind. Darwin (18.59).

If that be female which procreates in itself: ...... all plants female. Sir Thomas Browne, $(16+6)$.

Couples marry and procreate on the idea. not the realiry of a maintenance; they increase beyond the demand of towns and manufactures. A. Young (1792).

One of the principal ends of marriage is the procreation of children. Bouvier Law Dict. (1897).

(f) Potential parent of socially inadequate offspring. An accurate definition of a potential parent of socially inadequate offspring is very difficult to establish. Persons are socially handicapped or inadequate on ac count of physical, mental or moral qualities. Moreover many persons who them selves seem effective enough are from such mongrel stock that a large proportion of their offspring are degenerates. If the determination of undesirable parenthood is left to the judgments of boards or commissions without establishing a biologically sound criterion for making such judgment, which criterion many existing statutes have omitted, there is little likelihood that such boards or commissions will go into the matter in a scientifically thorough manner. Thus it seems eminently proper that the statute should, in accordance with the best biological teaching, establish a criterion for the determination of undesirable parenthood Section " $f$ " seeks to provide such a standard.

This standard may be raised or lowered in accordance with the radicalness with 
which the state desires to purge the hereditary stock of natural degeneracy. The specific definitions given in the law must depend also upon the existing knowledge of human heredity and the specific rules which the science of eugenics is able to demonstrate as locating definitely specific types of hereditary deficiency or degeneracy in particular individuals. In the case of most degenerate hereditary constitutions there are doubtless many of the so-called unit traits or genes involved. The working out of their rules of inheritance involves much research and is possible only by the use of many complicated formulas. But the state, regardless of such complex situations, must reserve the right to establish a definite line differentiating legally degenerate parenthood from parenthood which is not under the legal ban on account of defective inheritance.

Thus. if as a result of the expert testimony of the eugenicist, and the knowledge gained from the investigation of the hereditary qualities of a particular individual, the evidence demonstrates that a particular individual in his or her reproductive capacities falls without the boundary for socially desirable parenthood set by this statute, the particular individual may, by the courts, well be declared a potential parent of undesirable offspring, that is, a cacogenic person.

(g) A cacogenic person. In order to draw the line in a clean-cut manner, the term cacogenic person is reserved for application to an individual who, by due process of law in accordance with the standards of hereditary adequacy laid down by this particular draft, and the expert pedigree-evidence given under it, is demonstrated and declared to be a potential parent of socially inadequate offspring. Thus in the single definite legal phrase, a cacogenic person. we may describe the person definitely proven antieugenical.

(h) Custodial institution. It is becoming more customary for the states to define and to license private custodial institutions. Since the sterilization law is to apply both to inmates of custodial institutions and to persons in the population at large, a legal definition of custodial institutions is desirable. The standard of numbers may vary with the policy of the state, but if a close supervision is to be maintained over the care and treatment of the state's socially inadequate classes, or even if accurate censuses of them are to be secured from time to time, the number of inmates which a place must have in order to become a custodial institution under the law may well be the minimum, that is, one or more.

(i) Inmate. The term "inmate" in the sense here used includes prisoners, patients, pupils and members of institutions for care, treatment and punishment. It is found necessary to provide a legal meaning for the term "inmate", because many institutions, especially those for the dependent classes, and indeed for some of the institutions for delinquent and wayward girls, have objected to the term "inmate". But if given a legal definition, it need carry no connatation of shame or blame.

(j) Eugenical Sterilization. Sterilization is sometimes made synonymous with vasectomy, while the term asexualization or emasculation is often made synonymous with castration. Thus there is a necessity for a general term and definition which will cover the whole range of surgical operations, the primary purpose of which is to destroy the reproductive functions, Sterilization may be effected by simply destroying or obstructing a section of each of the vasa deferentia in the male or of the Fallopian tubes in the female, or by the more radical operations of removing the testes of the male or the ovaries of the female. In any case the operation may fittingly and legally be called sterilization, and each of the score or more of specific operations be called by their common or technical names.

In some states the existing laws call for operations which will most effectively prevent procreation. This is, of course, too indefinite; decapitation or cutting out the heart would prevent procreation, but also would kill the patient. Thus it seems wise to provide that the sexually sterilizing operation be performed upon the reproductive mechanism, and that it be of the least radical nature that will insure permanent sexual sterility.

Section 3. Office of State Eugenicist. The argument for entrusting the enforcement of the sterilization statute to a trained person rather than to a commission composed of ex officio members is given under the discussion of executive agencies. In short, we may say that the task is an arduous one which calls for special training and therefore cannot be effected by men whose principal interests lie elsewhere and whose train- 
ing may not have been directed in the fields in which the State Eugenicist must be skilled.

Section 4. Qualifications of State Eugenicist. By writing short qualifications for the State Eugenicist into the sterilization law, the state will be assured of an executive agent who will at least be competent to perform the most elementary functions of his office. It reduces to the minimum the liability to abuse through political appointment. The proven benefit to state service accruing from establishing legal qualifications for public office has established the desirability of such practice.

Section 5. Term of Office, Appointment, and Responsibility. The State Eugenicist should be assured a tenure long enough to enable him to establish and work out a definite policy and plan in enforcing the law. $\mathrm{His}$ task is too intimate to permit of frequent changes. Appointment by the Governor from a definitely qualified group ought to insure a higher class official than would be otherwise obtained, and making the State Eugenicist responsible to the Governor entails desirable responsibilities upon each. In many states it is becoming customary to reduce the number of independent officials and commissions, and to organize their activities into state executive departments comparable in some measure to the executive departments of the federal government. In such cases the direct responsibility of the State Eugenicist might well be made, not to the Governor, but to the head of the Department of Institutional Administration, or to the State Administrator of Charities and Corrections, or to whatever department is entrusted with the problem of social inadequacy.

Section 6. Seal. In order to give authority to the business transactions of the office of State Eugenicist, a seal is desirable. It is especially necessary in work which involves the preparation of documents with which special interests might care to tamper. The seal also gives the official stamp to the many orders which must be issued by the State Eugenicist. On a commission issued to a field worker, the seal gives official standing in communities in which the worker is a stranger.

\section{Section 7. Duties of State Eugenicist.}

(a) The first duty of the State Eugenicist is to comb the whole population of the state for cacogenic parents. This can of course be done only by field-studies, and by the coöperation of social welfare agencies throughout the state.

(b) Whenever a degenerate line is located. the State Eugenicist must then use persons trained in modern pedigree-studies to make further analysis of the facts. This is a logical and obvious necessity.

(c) The sterilization law applies equally to individuals in institutions and to those in the population at large. The number of the state's socially inadequate parents at large is much greater than the number of such persons who are inhabitants of institutions. Still the incidence of hereditary degeneracy among the inmates of institutions is so high that it justifies the State Eugenicist in maintaining a roster of custodial institutions, and further makes it necessary for the state to authorize this officer to require certain reports from the several custodial institutions. Until the state maintains an accurate census record of its socially inadequate in institutions and in the population at large, it cannot legislate intelligently in coping with the situation, nor can its executive agents carry on their work effectively.

(d) The business of the State Eugenicist is so important that complete reports of all transactions should be kept, and a report made annually to the Governor or the Department of Institutional Administration, if such latter exists. If provisions for such reports are not made in a statute, an incompetent appointee will be very apt to neglect the keeping of records. Especially important are complete records in eugenical investigations, because extensive field-studies have proven that the kinship between the socially inadequate strains, even in remote parts of the same state, is remarkably close. The exchange of pedigree-studies by different institutions has further demonstrated the necessity of a central archive of pedigreestudies. Such records will be valuable as long as the state must combat the problem of hereditary degeneracy.

(e) It may truly be said that no legislative. administrative or judicial work of a state is of the greatest permanent value unless records are made of such transactions, and these records are accessible to the public and properly cared for, so that their permanent preservation and care are assured. 
(f) The other duties referred to in this Act are those in connection with court procedure and the actual execution of sterilizing operations.

Section 8. Coöperation by Custodial Institutions. If the state by statute did not command a ready coöperation by custodial institutions in enforcing the sterilization statute, doubtless many of them would demur and would resent the work and inves tigation of the State Eugenicist. If, however, operation were demanded by law, the exchange of services between the State Eugenicist, especially in the use of his archives, and the custodial institutions, would be so great that the latter would soon be anxious to coöperate in the work of finding potential parents of degenerates. Under the law as written, there need be no fear on the part of advocates of extensive segregation that sterilization will take its place; there will always be work enough for both of these social agencies. The Model Law provides for the sterilization of inmates of institutions only when such inmates are to be released into the population at large while still potential parents of socially inadequate offspring.

It is not. however, to be concluded from this section that the investigations and work of the State Eugenicist are to be confined to state custodial institutions. Indeed, the principal part of his work will be in various parts of the state, dealing with local officials and the families of social inadequates. Their coöperation depends largely upon the tact of the representative of the State Eugenicist, and but little could be gained by demanding such coöperation. The authority of the State Eugenicist to administer oaths and make arrests is the power behind such diplomatic conduct which insures that the work of the field investigator will be amply backed by the law.

Section 9. Power to Administer Oaths and to Make Arrests. Under this draft the State Eugenicist and his assistants would have an official standing, and like other officers must have ample legal authority to secure the facts which the law demands that they have in hand. At least two of the existing stcrilization statutes permit their commissions to subpoena witriesses and administer oaths. The power to make arrests is that granted to all police officers and in many states is inherent in citizenship generally. But the necessity to secure evidence is so important, that the liability of losing evidence through inability to hold an individual when found would doubtless in many cases greatly handicap the investigating powers of the office of State Eugenicist. The arrest, however. in cases authorized by Section 9, would consist only in holding an individual until the legal papers could be served. Furthermore, these assistants from the State Eugenicist's office who are thus to be deputy police and who would be well acquainted with the individuals in the case might well act in the capacity of police offcers in serving the papers issued by the court.

Section 10. Opinion of State Eugenicist. The investigations of the State Eugenicist must have for their purpose the location of potential parents of socially inadequate offspring. But since the law must apply to all socially inadequate parents in the state, it is quite proper that legislative provision be made whereby any individual may in case of dereliction by the State Eugenicist institute court proceedings for the determination of degenerate parenthood on the part of a certain named individual.

In some statutes the determination by an executive officer of the existence of the fact of undesirable parenthood is sufficient to permit the same officer to order the sterilization of the particular person investigated. But the view of this model statute is that eugenical sterilization is so fraught with possibilities for error and also possibilities for abuse of power that due process of law should consist in court procedure so far as the final determination and order are concerned. Thus the State Eugenicist is commanded to present his evidence to a court of competent jurisdiction.

Section 11. Appointment of Date for Hearing. If complaint is duly filed, the court must then, according to the law, set a date for hearing the case. It is essential in such a statute, if effective and expeditious execution is desired, that the date set be not too remotely distant. This section provides for a fair hearing so far as the propositus is concerned, and for presentation of the facts of degenerate inheritance in the case in a manner adequate to a prompt determination of the question in hand.

Section 12 Notification of Parties Concerned. This section provides for the notiti. cation of the parties interested, so that all the processes of a fair trial are set in motion. 
Section 13. The State's Legal Counsel. In practically all of the states the AttorneyGeneral is required to serve the state in the capacity of legal counsel. This of course includes serving the state's executive officers in their efforts to enforce the law.

Section 14. Determination by Jury. The question of fact in sterilization cases is of sufficient seriousness to provide on the demand of either party a trial by jury. However, there would seen to be no good reason to require such a jury in every case. Doubtless in most sterilization cases both the attorneys for the propositus and for the state would agree to abide by the decision of the judge without a jury.

Section .15. Judgment. This section provides for the declaration by the courts that a given individual, demonstrated by due legal procedure to be a potential parent of socially inadequate offspring, is a cacogenic person, and in such a case provides also for ordering the actual performance of eugenical sterilization. However, until the individual is legally demonstrated to be a potential parent of socially inadequate offspring, he or she cannot, under the law, be referred to as "a cacogenic person."

The provision for sterilization in a skillful, safe and humane manner is essential to insuring a due regard for the rights of the individual sterilized. This section further provides for due authority on the part of the State Eugenicist to arrest, if need be, and to hold the individual to be sterilized, and also provides for protecting the subject's rights by making provisions against his being held for an undue period of time. Since the court must issue the order for sterilization, it is altogether fitting that a report concerning its execution be made back to the court. As an additional safeguard to the liberties and rights of the individual, in manv laws the court is given discretion to grant certain leniencies to individuals who, by due process of law, have been placed in a definite legal situation. Such authority is granted by the last clause of section 15 as a safeguard in cases of doubt, or in exceptional cases for which the written law in its insufficiently flexible manner has not definitely accounted.

Section 16. Appeals. It is obvious that decisions made by the lower courts, regardless of the special nature of their subject, must, in order to be consistent with the gen- eral judicial practice of the State, be subject to the rules governing appeals in general.

\section{Section 17. Type of Eugenical Steriliza-} tion. Bccause the specific type of sterilizing operation must in each case be decided upon, and because the definite location of responsibility is a desirable thing in the execution of laws, charging the State Eugenicist with the responsibility of deciding upon the particular type of operation is consistent with sound executive practice. It might, of course, be possible to include the designation of the type of operation in the order for sterilization, but this would involve too much court procedure; it would require the court to exercise a detail much more properly executed as a ministerial than as a judicial function. Such detail determination directly by the court. after the court has decided the main issue, would involve a study very intricate and extensive in each case, if justice were done to the therapeutic possibilities of each particular case. The selection of a specific type of operation is a thing for physicians and surgeons to advise, and for the State Eugenicist to determine upon in accordance with their advice. Such a procedure would permit also the use of possible future improvements in surgical technique, and the use of new operations which surgical science may develop for effecting sexual sterilization. Also the close coopperation between the State Eugenicist and the surgeon in the case would permit a certain surgical leewav which is desirable in case a surgeon, after beginning an operation, finds a pathological condition which indicates, in the interests of therapeutics, a modification of the operation as originally planned.

In short, the provisions of this section make doubly sure that the least physiologica! ill and the greatest therapeutic benefit shall accrie to the particular potential parents of defective offspring who are, by due process of law, ordered to be made sexually sterile.

\section{Section 18. Manner of Consummation.} This section contains further provisions for safeguarding the rights of the individual, and insures that the operation itself shall be consummated in accordance with the best knowledge and practice of the medical profession. It provides further that the State Eugenicist shall be the state's agent in contracting for such medical, surgical and hospital services as may be needed in such cases. Under this plan there would be many cases of eugenical sterilization within institutions 
of various types, but doubtless most of the eugenical sterilizing operatibns would be upon cacogenic individuals located in the population at large. It is necessary then to provide two methods of procedure-one to apply to cases within institutions, and the other to cases in the general population. Section 18 seeks to make the execution of the order sure and just in each case.

There is of course no eugenical object in sexually sterilizing an inmate who will spend the remainder of his or her sexually fertile days within the custody of a modern institution. Provision for suspending the operation in such cases is apparently an act of wisdom as well as of justice.

There is one other special case which needs attention. It is conceivable, that an individual prisoner's term might expire subsequently to the order of the court, but before the actual operation could be performed in the institution. By providing in such cases for the discharge or parole of the prisoner into the custody of the State Eugenicist, the possibility of evading the law in such particular cases is removed.

Section 19. Liability. Officers in executing the law are of course not personally liable either civilly or criminally for their official acts, if they are well within the meaning of the statute. But it is probable that a statutory protection against liability on the part of the State Eugenicist, his field-workers, and the surgeons in executing eugenical sterilization, would stop possible cases of contemplated revenge by means of attempted litigation.

Section 20. Illegal Destruction of Reproductive Functions. With the spread of knowledge of the methods of destroying the reproductive functions, many individuals will be apt to apply to physicians to be made sexually sterile in order to avoid the responsibilities of parenthood. Indeed, some of the existing sterilization commissions have been appealed to by individuals desiring sterilizing operations for such purpose. If such persons are potential parents of defectives, the State Eugenicist within the law could accommodate them by securing a court order for their sexual sterilization, but unless proper court procedure be undertaken in each case the liability of abuse of the operations of sterilization is very great. The reproductive function is attended with such potentiality for good or evil that tampering with it to avoid personal responsibility of parenthood should be forbidden by law. As seen in the analysis of the subject, many of the states in their existing statutes have seen fit to include a provision against the criminal destruction of sexual fertility. It seems a wise provision, and is therefore included in the model draft.

Section 21. Punishment of Responsible Head of Institution for Dereliction. The punishment of derelict officiats is a matter which states generally cover by special statutes. Still one state, Kansas, in its first sterilization statute, inserted a section which made it a misdemeanor for the managing officer of any institution to neglect or refuse to execute orders for the sterilization of inmates duly ordered in his particular institution. It seems to be a desirable provision, and is included in the model statute as an insurance of closer coopperation between the State Eugenicist and custodial institutions.

Section 22. Supremacy of this Act. It is customary in all legislation, especially in statutes which treat a new subject, to provide that all portions of previously enacted state laws which are contrary to the particular act be repealed. In the complex of laws relating to custodial institutions ${ }^{\circ}$ and public charities, there may be found many provisions to conflict with what the state desires to accomplish under a sterilization statute. It is doubtful, however, whether any provisions of the model draft as here given would run counter to either a State Constitution or to many legislative acts relating to the enforcement of the law or the securing of justice. The principal laws which would probably be modified by this section are those relating to the specific duties of executive officials.

Section 23. When Effective. This is of course a matter of policy on the part of the particular state. In some states the point is covered by constitutional provision. It is noticed in reading statutes that the date on which they become effective ranges from the date of signature by the governor to a number of months in the future.

\section{APPENDIX: APPROPRIATIONS.}

If an eugenical sterilization law is to be effective, it must, because it requires extensive special and expert administration, be supported by adequate appropriations. All of the items listed in the suggested outline 
of appropriations are necessary, and should be duly included in their proper places in accordance with the particular state's custom in making appropriations for maintaining permanent state activities. Since the present draft is that for a general law, it is probably true that in most states the support given by any appropriation which might accompany the law's enactment would be limited to a single fiscal year, and henceforth appropriations for continuing the work contemplated by the sterilization law would have to be con- sidered under the general appropriation bills. In states having a budget system such mixture of general legislation and appropriations would not be permitted For these reasons it seems desirable that the law defining the state's sterilization policy and organizing the machinery for its administratio' should, from the beginning, be separate from the appropriation bills.

(See page $49 \pm$ for itemized appropriations form.) 


\section{CHAPTER XVII.}

SET OF FORMS SUGGESTED FOR USE OF THE STATE EUGENICIST, THE COURTS, PRIVATE CITIZENS, AND CUSTODIAL INSTITUTIONS IN ADMINISTERING THE MODEL EUGENICAL STERILIZATION LAW. 


\section{MODEL FORMS.}

When a sterilization law becomes effectively established, the matter of forms and records will, of course, be developed in accordance with the needs of the particular case. However, the history of the execution of the existing laws on this subject demonstrates the need of a complete set of model forms for use during the early period of the law's application. The following forms are designed especially for administering the Model Sterilization Law, but they are meant also to serve as suggestions in prepar. ing a set of forms for use in the effective execution of any practical eugenical steriliza. tion statute.

1. Case record by State Eugenicist.

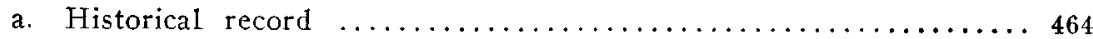

b. Record of investigation by state eugenicist................ 466

c. Report to State Eugenicist....................... 467

2. Information or complaint by private citizen to State Eugenicist.........467

3. Institutional record of individual inmate prepared for State

Eugenicist .....................................468

4. Report of State Eugenicist. (a. opinion, b. evidence, and c. peti-

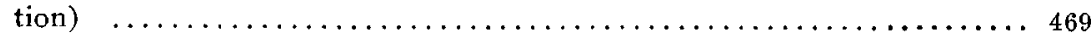

5. Action begun by private citizen............................ 470

a. Individual petition to court...................... 470

b. Order of court denying private petition................ 471

c. Order of court to State Eugenicist to investigate a par-

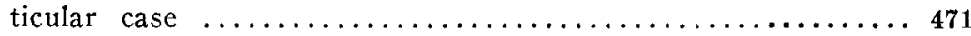

6. Hearing.

a. Proclamation appointing time and place for hearing.

b. Summons of propositus.

1. Summons to propositus in case such propositus

is not an inmate of a custodial institution and

is personally capable of understanding the nature

of a summons............................ 479

2. Order to guardian or custodian of propositus in case such propositus is an inmate of a custodial institution or lives ander guardianship in the population at large........................ 473

3. Order for arrest and presentation to court of the person of the propositus in case such propositus is neither an inmate of a custodial institution, nor living under guardianship in the population at large, nor is capable of understanding the

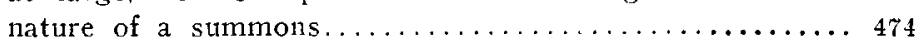

c. Notification to Attorney-General..................... 474

d. Instruction of Attorney-General to County Attorney.......... 475

e. Appointment of legal counsel for the propositus............ 475

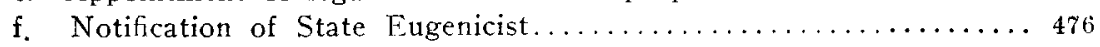

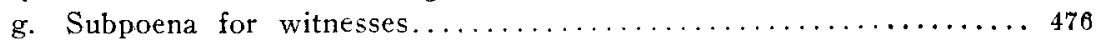

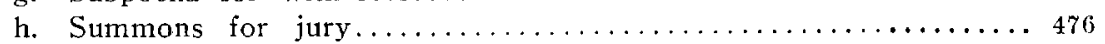

7. Judgment and Order.

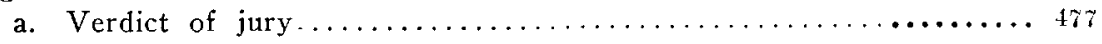

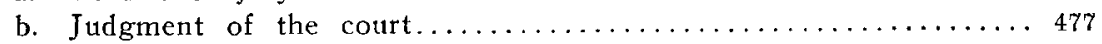

c. Order to State Eugenicist for the eugenical sterilization of a cacogenic person in the population at large.......... 4 rs

d. Order to State Eugenicist for the eugenical sterilization of a cacogenic person who is an inmate of a cus-

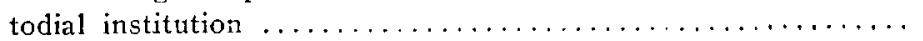


e. Order to responsible head of custodial institution............. 480

f. Order to State Eugenicist for the temporary suspension of an order for eugenical sterilization................. 481

g. Order to a cacogenic person whose eugenical sterilization has been temporarly suspended, to report periodically

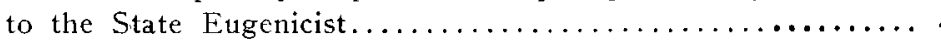

h. Order to State Eugenicist for the eugenical sterilization of a cacogenic person, the original order for whose sterilization has been temporarly suspended...............

8. Execution of Order.

a. Contract with surgeon or physician to eugenically sterilize

(1) a cacogenic person in population at large.......... 484

(2) a cacogenic person who is an inmate of a custodial institution ........................ 485

b. Report of surgeon or physician to State Eugenicist.......... 486

c. Return of State Eugenicist to court in case of the eugenical sterilization of $a_{1}$ cacogenic person in the population at large................................. 48

d. Return of State Eugenicist to court in case of the eugenical sterilization of a cacogenic person who is an inmate of a custodial institution.................... 48

e. Semi-annual return of State Eugenicist to the court in case an original order for eugenical sterilization has been temporarily suspended......................489

9. Institutional Data kept by State Eugenicist.

a. Roster of custodial institutions.................... 490

b. Monthly institutions report to State Eugenicist of accessions and losses.......................... 492

10. Record of an Individual Case of Sterilization.................... 493

a. Case record of eugenical sterilization.................. 493

11. Appropriations .................................... 494

a. Working draft of appropriations section to be inserted in the proper place in the state's appropriation bills, according to the legislative practice of the particular state

Form 1a.

\section{CASE RECORD BY STATE EUGENICIST.}

a. Historical Record.

Case number.

Investigation begun:

I. The Individual.

(Date) (If ordered, indicate when)

1. Full name (in case of a married woman record both maiden and married names) :

2. Home address:

3. Date of birth:

4. Sex:

5. Birthplace:

6. Personal identification (10 lines, and photograph)

7. Is this person an inmate of a custodial institution?

a. Name of iretitution:-

(Yes or No)

b. Address of same:

c. Inmate's institutional number reference:

d. When admitted:

e. Classification or diagnosis:

f. Name the parent, guardian, or next friend or acquaintance:

g. Address of same: 


\section{Eugenical Investigation.}

1. Name of field worker on case:-

2. History and abstract of investigation: (2 pages) (The original field notes on personal and family history together with pedigree-charts might well accompany this schedule in a separate folder, but having the same case reference number. Abstract should contain data specially pertinent to determining the potential parenthood of socially inadequate offspring and the cacogenic personality of the particular subject.)

3. Opinion of State Eugenicist:

(a) Is...

a potential parent of socially inadequate offspring, according to the definition of such given by the Eugenical Sterilization Law?

(Yes or No) Signed.

(b) Is. State Eugenicist Date signed: given by the Eugenical Sterilization Law?

.... cacogenic person, according to the definition Signed.

(Yes or No)

State Eugenielst Date signed:

\section{Court Proceedings.}

1. Name and seat of Court of Record petitioned:

2. Date petitioned: set for hearing and trial.

3. When notified by Court of date

4. Date set for hearing and trial:

5. Counsel for propositus: Address :

6. Witnesses:

\begin{tabular}{c|c|c} 
Name & \multicolumn{2}{c}{ Remarks } \\
\hline & Address & \\
& &
\end{tabular}

7. Notes on court proceedings:

8. Decision of court: Is the propositus ordered eugenically sterilized?.

9. Date of said order:.

(Yes or No)

10. Supplementary orders by the court:

(a) Was supplementary order issued to the State Eugenicist suspending the execution of the original order for eugenical sterilization and ordering semiannual reports?

(Yes or No)

(b) Was the propositus ordered to report periodically to the State Eugenicist?

(Yes or No)

If so, date of such order.

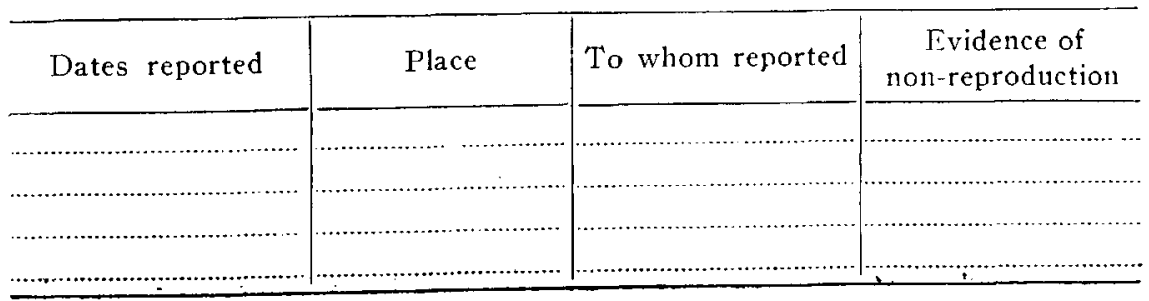


Date of return to court covering the evidence of non-reproduction.

Court. Judge. Seat.

\begin{tabular}{c|c}
\hline Dates & Substance of Return \\
\hline & \\
\hline
\end{tabular}

(c) Was an order issued by the Court to the State Eugenicist to proceed with the execution of the order previously suspended?

If so, date of such.

(d) Was the responsible head of custodial institution ordered to admit and to cooperate with State Eugenicist in enforcing the order for eugenical sterilization?.

(Yes or $\mathrm{No}$ )

Address of same:

Date of such supplementary order:

11. Additional records:

\section{Execution of Order.}

1. Name of surgeon or physician:

Address of same:

2. Type of operation ordered:

Notes in relation thereto:

3. Nature of contract with physician or surgeon:

4. Date of operation or treatment:

5. Date on which the State Eugenicist received the report of the surgeon or physician:

6. Date of return to court of affidavit of State Eugenicist, stating that the particular cacogenic person was duly sterilized eugenically, in accordance with the order of the court:

(Here file copy of the particular return.)

Form 1b.

\section{RECORD OF INVESTIGATION BY STATE EUGENICIST.}

1. Name of subject.

2. Case number:

3. Name of field worker:

4. Dates of investigation:

5. Sources of information:

\begin{tabular}{c|c|c} 
Name & Address & \multicolumn{2}{c}{ Relationship } \\
\hline & &
\end{tabular}

6. Notes on first-hand investigations of natural physical, physiological and psychological traits, personal history, and family trait-pedigree of the subject (Note:The investigations of the State Eugenicist must of necessity be primarily those of scientific inquiries into the hereditary constitution of the subject of each particular investigation under the eugenical sterilization statute. Schedules in 
the form of questions with spaces for answers are much less preferable than reports by persons trained in the scientific study of human heredity, because each report must be fitted to the particular case. It is suggested that the succeeding sheets of the form consist of blank sheets for descriptive notes and of crossruled paper for plotting pedigrees. As a typical example of effective field and pedigree investigations needed for the determination of the question of fact relative to potential parenthood of socially inadequate offspring, reference is made to the report of Dr. David F. Weeks, Superintendent of the New Jersey State Village for Epileptics, at Skillman, in the matter of his investigations into the case and family histories of one, Alice Smith, an inmate of said institution, and the subject of the test case in New Jersey. See Chapter VIII.

Form 1c.

REPORT TO STATE EUGENICIST CONCERNING NON-REPRODUCTION BY A CACOGENIC PERSON THE EUGENICAL STERILIZATION OF WHOM HAS BEEN TEMPORARILY SUSPENDED.

1. Name of Subject:

2. Case number:

3. Name of field-worker or examiner on case:

4. Date on which eugenical sterilization was ordered temporarily suspended:

5. Date of report, interview or examination:

6. Place of same:

7. Notes on report, interviews or examination: (Give names and addresses of persons interviewed or examined, or who report pertinent facts. Review evidence from testimony or examination concerning the proof of non-reproduction by the propositus.)

Form 2.

\section{INFORMATION OR COMPLAINT BY PRIVATE CITIZEN TO STATE EUGENICIST.}

1. Name of person complained against:

Case number:.

Address:

2. Name of person making complaint:

Address:

Position:

3. Reason for making complaint:

4. Affidavit:

State of:

County of:

being duly sworn, says:

I,

state of. am a citizen of the

state. I do solemnly swear that to the best of my knowledge and belief the following facts are true: (State facts tending to indicate the potential parenthood of socially inadequate offspring on the part of the particular person complained against. Give also his or her (1) name, (2) residence, (3) age, (4) sex, (5) marital condition, (6) parenthood, (7) social reactions, (8) physical, mental and temperamental qualities, and (9) family history.)

Subscribed and sworn to before

(Signed) day of. 
Form 3.

\section{RECORD OF AN INMATE OF A CUSTODIAL INSTITUTION PREPARED FOR THE USE OF THE STATE EUGENICIST IN ACCORDANCE WITH SECTION 8 OF THE MODEL EUGENICAL STERILIZATION LAW.}

Name of inmate:

Case number:

(For State Eugeniclst)

Name of institution:

Location:

Date State Eugenicist requested institution to provide data concerning the particular subject:

is requested:

Date by which the return of this schedule

Eugenicist:

Date this schedule was received by State

\section{INFORMATION.}

1. Full name of inmate: (In case of a married woman give both her maiden name and married name.).

2. Date of birth:

3. Sex:

4. Birthplace:

5. Date admitted to the Institution :

6. Institutional reference number:

7. Classification or diagnosis:

8. Personal identification: (10 lines and photograph)

9. Home address (or address from which committed or admitted):

10. Name of father:

Address, if living:

11. Name of mother:

Address, if living:

12. Name of guardian or acquaintance:

Relation:

Address:

13. Case history: (Copies of diagnosis-report and case-history in institutional records, and further data concerning individual and his or her family history. This record should be made as complete as possible, as it is necessary for determining not only the hereditary constitution of the inmate, but also for the condition of the individual before and after sterilization. It will thus aid in determining the physiological and psychological effects of the operation.) ( 2 or 3 pages should be allotted for this item.)

14. Was this individual eugenically sterilized?
a. Date:
b. Place:
(Yes or No.)
c. Surgeon:
d. Type of operation.

15. Date of discharge, release or parole of inmate from institution:.

16. Further history of case (Secure through follow-up, parole or field work with special reference to the effects of the operation. Record field notes from time to time, making sure always to date memoranda. Record general and specific morphological, pathological, physiological and psychological effects of the operation; emotional expression and control; mental, criminal, social, sexmasturbation, desire for sex relations, economic effects of the operation. Immediate and remote effects, special reference to comparison with conditions before the operation.) ( 2 pages.)

17. Remarks 
Form 4.

\section{REPORT OF STATE EUGENICIST.}

To the Court of the County of State of.

In the matter of the Opinion, Evidence and Petition of.

Eugenicist, in accordance with. Chapter.

of the Session Laws of. State of......................................., known as the Eugenical of the State Sterilization Law, presenting the opinion and evidence therefor that one, of ............................................., is a potential parent of socially inadequate offspring, and finally praying for the legal determination of the question of fact.

State of

County. being duly sworn, says:

I hold the office of State Eugenicist of the State of... and, in accordance with Chapter. of the Session Laws of. State, I herewith respectfully present the following opinion, evidence and petition:

a. Opinion: Having duly investigated the natural qualities, the environment and the pedigree of one, of..

I hold the opinion that the said. is a potential parent of socially inadequate offspring within the meaning of the aforesaid Act.

b. Evidence: The following record presents the history and biological evidence upon which the above stated opinion is based. (Here insert copy of the abstract of eugenical investigations. Detailed reports and field notes may be appended as supplementary evidence or retained for the use of the State Eugenicist or his agents in giving testimony before the court. Doubtless the principal witness for the State in most of these cases will be the Field Worker, who actually makes the pedigree-study.)

c. Petition: I respectfully pray that the Honorable Court to which this petition is addressed may act under the above named statute to the purpose that there may be a legal determination of the fact, whether the said. of......... is, as alleged in the aforesaid Opinion, a potential parent of socially inadequate offspring within the meaning of the said.. Chapter of the Session Laws of.. ..of the State of.

Subscribed and sworn to before me this. day of 
Form 5a.

\section{ACTION BEGUN BY PRIVATE CITIZEN.}

\section{INDIVIDUAL PETITION TO A COURT OF RECORD TO DETERMINE THE POTENTIAL PARENTHOOD OF SOCIALLY INADEQUATE OFFSPRING OF A CERTAIN NAMED INDIVIDUAL.}

In the matter of a petition by of... a citizen of the State of , in accordance with Section. of the Session Laws of $19 \ldots \ldots . .$. ; of the

State of. as the "Eugenical Sterilization Law." Presenting evidence that one

of. is a potential parent of socially inadequate offspring, and praying for the legal determination of the question of fact.

To the. Court of the County of

State of

State of.

County.

being duly sworn, says:

I am a citizen of the State of , and a resident of of said State. I am above twenty-one years of age, and of sound mind, and claim respected character. I do solemnly swear that to the best of my knowledge and belief the following facts are true:

a. Evidence. [State facts tending to prove that the particular person complained against is a potential parent of socially inadequate offspring. Give (1) Name, (2) Address, (3) Age, (4) Sex, (5) Marital condition, (6) Parenthood, (7) Social reactions, (8) Physical, physiological and psychological reactions, (9) Environment, and (10) Family history.]

b. Petition. In view of the foregoing facts, I firmly believe that procreation on the part of said. ..of. ..would result in the production of socially inadequate offspring, who would constitute a serious menace to the soundness of the human stock of future generations, in which soundness I and my immediate kin are vitally concerned. I therefore respectfully pray that the Honorable Court to which this petition is addressed may take action under Chapter. of the Session Laws of 19 ........of the State of. to the purpose that there may be a legal determination of the question of fact whether the aforesaid. of.. is, as alleged, a potential parent of socially inadequate offspring within the meaning of the said. Chapter of the Session Laws of 19........ of the State of

(Signed)

Complainant and Petitioner.

Subscribed and sworn to before

me this. day of

19 
Form $5 \mathrm{~b}$,

\section{ORDER OF THE COURT DENYING PRIVATE PETITION.}

State of

County.

To.

a Petitioner to this Court:

WHEREAS, the above named petitioner has presented to this Court in due form as prescribed by Chapter. of the Session Laws of $19 \ldots \ldots .$. of the State of known as the "Eugenical Sterilization Law," evidence concerning the potential parenthood of socially inadequate offspring of one. of. and further has duly petitioned this Court to determine legally the question of fact in the matter; and,

WHEREAS, this Court having duly considered the evidence presented and being of the opinion that said evidence is not sufficient to warrant further procedure in the matter, I, therefore, under the authority vested in me by the aforenamed statute of this State, do hereby deny the said petition.

GIVEN under my hand and seal this. day of. $19 \ldots \ldots$.

Form 5c.

\section{ORDER OF COURT TO STATE EUGENICIST TO INVESTIGATE A PARTICULAR CASE.}

State of.

County.

To State Eugenicist of the State of.

WHEREAS, of. has duly presented to this Court evidence concerning the potential parenthood of socially inadequate offspring of one. , of and further has duly petitioned this Court to determine legally the question of fact in the matter, all as prescribed by Chapter. of the Session Laws of 19........, known as the Eugenical Sterilization

Law; and,

WHEREAS, this Court having duly considered the evidence presented in this said petition and finding it adequate to justify further procedure, therefore, $I$, in accordance with the aforesaid statute, do command you, State Eugenicist of the State of. to make further investigation in reference to the potential parenthood of socially inadequate offspring of the aforenamed. of.. and within ninety days of the date of this order to report your findings in this matter back to this Court, together with an opinion as to whether the aforenamed. of. is in fact a potential parent of socially inadequate offspring.

WITNESS my hand this day of. 19 
Form 6a.

\section{PROCLAMATION APPOINTING A TIME AND PLACE FOR HEARING.}

In the matter of the legal determination of the potential parenthood of socially inadequate offspring of one. of..

as prescribed by Chapter. of the Session

Laws of 19 of the State of..

$$
\}
$$

State of.

County.

To Whom It May Concern:

TAKE NOTICE THAT, WHEREAS, on the. day of. 19. (Name State Eugenicist or private citizen making allegation and petition) in due form as provided by Chapter. of the Session Laws of $19 . . . . . .$. , of the State of.. has presented to this Court evidence concerning the potential parenthood of socially inadequate offspring on the part of one , of. ; and,

WHEREAS, said. has duly petitioned this Court, under the aforesaid statute, legally to determine the question of fact in the matter, I, therefore, in accordance with the aforesaid statute, do hereby appoint the day of. $19 . . . . . .$. , at. o'clock M., at the usual seat of this Court at. as the time and place for a hearing in the aforesaid matter.

WITNESS my hand this day of 19

Form 6b1.

SUMMONS TO PROPOSITUS IN CASE SUCH PROPOSITUS IS NOT AN INMATE OF A CUSTODIAL INSTITUTION AND IS PERSONALLY CAPABLE OF UNDERSTANDING THE NATURE OF A SUMMONS.

State of.

County.

To the Sheriff (or. Constable of ) of said County:

You are hereby commanded to summon ,of to appear before this Court at. on the day of. 19........, at...................... o'clock ........ M., at which time and place proceedings for the determination of the potential parenthood of socially inadequate offspring of said of....... will be duly instituted, in accordance with Chapter. of the Session Laws of 19......., of the State of........................................., known as the Eugenical Sterilization Law. You will make due return of this writ on the......................day of , 19 ...........

WITNESS my hand this day of $19 \ldots \ldots . . .$. 
Form $6 \mathrm{~b} 2$.

\section{ORDER TO GUARDIAN OR CUSTODIAN OF PROPOSITUS IN CASE SUCH PROPOSITUS IS AN INMATE OF A CUSTODIAL INSTITUTION OR LIVES UNDER GUARDIANSHIP IN THE POPULATION AT LARGE.}

State of.

County.

In the matter of the legal determination of the potential parenthood of socially inadequate offspring on the part of of.

County.

the legal guardian (or

To. of. $\int$

custodian) of

WHEREAS, on the day of. 19

(State Eugentclst of the State of of. is, under the meaning of the said statute,

a potential parent of socially inadequate offspring; and,

WHEREAS, said allegation was accompanied by supporting evidence in due form; and,

WHEREAS, this Court has duly set the day of $19 \ldots . . . .$. , at. o'clock M., at (name the seat of the Court) as the time and place for the institution of proceedings for the legal determination of the above-stated allegation;

THEREFORE, I, a Judge of. County, in accordance with the aforesaid statute, do hereby command that you, as the legal guardian (or custodian) of the said. of. appear personally, or by duly authorized agent, conveying the said before this Court at the aforesaid time and place, at which time and place proceedings for the legal determination of the question of fact in the afore-stated allegation will be duly furthered.

WITNESS my hand this day of $19 \ldots \ldots$ 
Form 6 b3.

\section{ORDER FOR THE ARREST AND PRESENTATION TO COURT OF THE \\ PERSON OF THE PROPOSITUS, IN CASE SUCH PROPOSITUS IS \\ NEITHER AN INMATE OF A CUSTODIAL INSTITUTION, NOR \\ LIVING UNDER GUARDIANSHIP IN THE POPULATION AT \\ LARGE, NOR IS CAPABLE OF UNDERSTANDING \\ THE NATURE OF A SUMMONS.}

State of.

County.

To the Sheriff (or Constable of of said County:

WHEREAS, on the day of 19

(State Eugenicist of the

State or, or............, a citizen of the State of ..........., over twenty-one years of age, and claiming

respectable character.)

duly submitted to this Court, in accordance with Chapter. of the Session Laws of $19 . . . . .$. ., in the State of. an allegation that one.

of...................................., is a potential parent of socially inadequate offspring; and,

WHEREAS, said allegation was accompanied by supporting evidence in due form; and,

WHEREAS, the.

day of. o'clock...... M., at.................................................(name seat of Court), has been duly appointed as the time and place for the institution of proceedings for the legal determination of the abovestated allegation;

THEREFORE, you are hereby commanded to arrest the said. of. and aid him (or her) safely to convoy before me at the aforesaid time and place, at which time and place proceedings for the legal determination of the question of fact in the aforesaid matter will be duly furthered.

Given under my hand this day of.. 19

Form 6c.

Judge of the. Court

\section{NOTIFICATION TO ATTORNEY-GENERAL.}

In the matter of the legal determination of the potential parenthood of socially inadequate offspring, of one of. , as prescribed by

Chapter of the Session Laws of 19......., of the State of

State of.

County.

To the Attorney-General of the State of.

You will please take notice that under Chapter. of the Session Laws of 19........, of the State of proceedings have been duly instituted in this Court for the legal determination of the question of fact whether, as alleged, one, of....................... is a potential parent of socially inadequate offspring, as defined by the above-named statute; and further that the. day of........................, 19......, at........o'clock..........., at the usual seat of this Court at..........................., have been duly appointed as the time and place for a hearing in the aforesaid matter.

This notification is made in consequence of a provision of the aforesaid Act, which makes the Attorney-General the legal counsel of the State in such matters.

WITNESS my hand this day of 19 
Form 6d.

\section{INSTRUCTIONS OF ATTORNEY-GENERAL TO COUNTY ATTORNEY.}

In the matter of the legal determination of the potential parenthood of one of. as prescribed by Chapter of the Session Laws of 19......., of the

State of.

To. Esq., the County Attorney

of County, State of

The Attorney-General of the State having been duly notified by the

Judge of the. Court of

County, that on the.

day of........................., 19...., at.........o'clock ........-at the usual seat of said Court, the hearing will be had in the matter of the legal determination of the question of fact whether, as alleged, one of.

is a potential parent of socially inadequate offspring, as defined by Chapter..................of the Sessions Laws of $19 . \ldots . . . .$. of the State of......

Pursuant to further provisions of this statute, you, as the County Attorney of said County, are hereby instructed to confer with the complaining witnesses in the case, and to aid in the capacity of legal counsel for the State in its efforts in this particular case to protect by due process of law the hereditary qualities of future generations.

Form 6e.

Attorney General of the State of

\section{APPOINTMENT OF LEGAL COUNSEL FOR THE PROPOSITUS.}

In the matter of the legal determination of the potential parenthood of socially inadequate offspring of one. of as prescribed by

Chapter. of the Session Laws of 1 of the State of. County.

WHEREAS, in accordance with Chapter. of the Session Laws of 19......., of the State of legal action having been duly instituted in the Court for the legal determination of the question of fact whether, as alleged, one.

offspring; and, of........................................, is a potential parent of socially inadequate

WHEREAS, it is the opinion of this Court that the ends of justice would be more surely served by the appointment of legal counsel to represent the aforesaid. of. aforesaid allegation, I therefore, in accordance with the aforesaid statute, and with Chapter.............. (give reference to any other statute of the State which governs the appointment of legal counsel for indigent dependents) hereby appoint.

Esq., Counselor-at-Law of the City of. to represent said. of... in the capacity of legal counsel in the aforesaid hearing. The compensation to be allowed said counsel shall be dollars a day while he is actually engaged in this matter.

I direct that this order be filed in the archives of this Court and that within ten days from this date a copy be served on said. counsel appointed to represent said. 
Form 6 .

\section{NOTIFICATION OF STATE EUGENICIST.}

in the matter of the legal determination of the potential parenthood of socially inadequate offspring by one.

as prescribed by Chapter of the Session Laws of $19 . . . . . .$. , of the

State of

State of

\section{County.}

To

State Eugenicist of the State of.

You are hereby notified that on the day of $19 \ldots . . . .$. at.........o'clock.........., at the usual seat of this Court at a hearing in the aforesaid matter will be held.

This notification is made in consequence of the provisions of Chapter of the Sessions Laws of $19 . . . . . .$. , of the State of........, that the Court before which such a hearing is held shall notify the State Eugenicist concerning the time, place and nature of such hearing.

Form 6g.

\section{SUBPOENA FOR WITNESSES.}

State of.

\section{County.}

To the Sheriff (or any Constable) of said County:

You are hereby commanded to summon. of. to be and appear before this Court at. on the. day of $19 . . . . .$. , at............o'clock.........., to testify the truth in the matter of the legal determination of the question of fact whether one.

of ................................., is, as alleged, a potential parent of socially inadequate offspring. HEREOF fail not, under penalty of the law, and have you then and there this writ. Given under my hand this day of. 19

Form 6h.

\section{SUMMONS FOR JURY.}

State of

\section{County.}

To the Sheriff (or any Constable) of said County:

You are hereby commanded to summon. to appear before this Court on the. day of.

19........, at............o'clock.........., at the usual seat of this Court at. to serve as jurors in a case pending before me, then and there to be heard. And this they shall in no wise omit. And have then and there this writ with your doings thereon.

Given under my hand this. day of. 
Form 7a.

\section{VERDICT OF JURY.}

In the matter of the legal determination of the potential parenthood of socially inadequate offspring of one

of as prescribed by Chapter. of the Session Laws of $19 . . . . .$. , of the

State of.

Court.

County.

We, the jury, duly paneled and sworn in the above entitled hearing, do find that the aforesaid. of. is (or is not), as alleged, a potential parent of socially inadequate offspring, and is (or is not), therefore, a cacogenic person.

Foreman.

Dated:

Form $7 \mathbf{b}$.

\section{JUDGMENT OF THE COURT.}

In the matter of the legal determination of the potential parenthood of socially inadequate offspring of one of as prescribed by Chapter of the Session Laws of 19........, of the State of.

State of

County.

(The Court's Review of Testimony.)

In view of the foregoing facts, I find that the aforenamed of. is (or is not), as alleged, and within the meaning of the aforesaid statute, a potential parent of socially inadequate offspring, and therefore, in accordance with this decision and the aforesaid statute, do hereby declare the aforesaid of. to be (or not to be) a

cacogenic person.

Dated: 
Form 7c.

\section{ORDER TO STATE EUGENICIST FOR THE EUGENICAL STERILIZATION OF A PERSON IN THE POPULATION AT LARGE.}

In the matter of the legal determination of the cacogenic personality of one. of. as prescribed by Chapter................ of the Session Laws of 19........, of the State of.

State of.

\section{County.}

WHEREAS, by the decision of this Court (or by verdict of a Jury duly sworn and paneled by this Court), one..... of in accordance with...............Chapter of the Session Laws of 19....... of the State of known as the "Eugenical Sterilization Law," was duly adjudged and declared to be a cacogenic person, and as such is a menace to the natural hereditary capacities of subsequent generations. THEREFORE, in accordance with the abovenamed statute and judgment, you are hereby commanded to arrest the said

and to cause the said.. to be eugenically sterilized in a skillful, safe, and humane manner, with due regard to the possible therapeutic benefits of such treatment or operation, obtaining, if possible, the consent and coöperation of said

and of his.

(or her) (custodian, parents or guardian)

You are further commanded to execute the order at a date as early as is consistent with the above-stated conditions, and at the consummation of this particular case of eugenical sterilization and the convalescence therefrom, you will release said.

from your custody, but said. shall not be released from your custody until the aforesaid order has been duly executed.

You are further commanded, upon the execution of this order, to make due return under oath of the fact to this Court, making sure to prove the identity of the individual eugenically sterilized, and to describe the time, place, type and outcome of the particular operation or treatment.

WITNESS my hand this day of $19 . . . . . .$. 
Form $7 d$.

\section{ORDER TO THE STATE EUGENICIST FOR THE EUGENICAL STERILIZA- TION OF A PERSON WHO IS AN INMATE OF A CUSTODIAL INSTITUTION.}

In the matter of the legal determination of the potential parenthood of socially inadequate offspring by one. , as prescribed by Chapter of the Session Laws of $19 . . . . .$. of the

State of

State of

County.

To.

State Eugenicist of the State of

WHEREAS, by the decision of this Court (or by verdict of a jury, duly sworn and paneled by this Court) one, , an inmate of.

a custodial institution located at in accordance with Chapter of the Session Laws of 19........ of the State of.. known as the

"Eugenical Sterilization Law," was duly adjudged to be a cacogenic person, and as such is a menace to the hereditary capacities of subsequent generations.

THEREFORE, in accordance with the above-named statute and decision, you are hereby commanded to catuse the said.. of.

to be eugenically sterilized in a skillful, safe, and humane manner, with due regard to the possible therapeutic benefits of such treatment or operation, obtaining, if possible. the consent and cooperation of said. and of..

\section{(his or her) (custodian, parent or guardian)}

This order in the normal course shall be executed before the discharge, release or parole of the aforesaid. from the custody of aforesaid institution; Provided, that if, for any cause, as contemplated by the aforesaid statute, the execution of this order is not consummated before the time previously set for the discharge, release, or parole of said. from the custody of said institution, you are hereby commanded to arrest the said................................................ at the instant of... discharge, release, or parole from the custody of (his or her) aforesaid institution, and thence to proceed with the execution of this order, to make due return under oath of the fact to this Court, making sure to prove the identity of the individual eugenically sterilized, and to describe the time, place and outcome of the particular operation or treatment.

WITNESS my hand this. day of.. $19 \ldots \ldots . . .$. 
Form 7e.

\section{ORDER TO RESPONSIBLE HEAD OF CUSTODIAL INSTITUTION.}

In the matter of the legal determination of the potential parenthood of socially inadequate offspring of of.

as prescribed by Chapter. of the Session

Laws of 19 of the State of.

State of.

County.

To the Responsible Head of

WHEREAS, one. of. , an inmate in the aforenamed custodial institution, has been declared by this Court to be a cacogenic person; and,

WHEREAS, on day of 19 the State Eugenicist of the State of. was duly commanded to cause the said to be eugenically sterilized in a skillful, safe and humane manner, in accordance with the provisions of Chapter. of the Session Laws of 19........, of the State of.

THEREFORE, in accordance with further provisions of said statute, you are hereby commanded to extend to said State Eugenicist and the physicians and surgeons appointed by him for the purpose, free access to the person of said. , an inmate of the aforesaid institution, for the purpose of executing this order, and further for said eugenical sterilizing operation or treatment to provide the hospital accommodations of said institution best adapted to such operation or treatment, and further to extend your full coöperation in the execution of said command.

You are further commanded that if, on account of lack of adequate hospital facilities in said custodial institution, or the shortness of time elapsing between the issuance of this order and the time previously set for the discharge, release or parole of said , the State Eugenicist does not execute the aforesaid order for eugenical sterilization before the time previously set for the discharge, release or parole of said. you will not fail, under penalty of the law to discharge, release or parole, as the case may be, the said. into the custody of whosoever may be the State Eugenicist of the State of. at such particular time.

WITNESS my hand this day of 19 
Form 7f.

\section{ORDER TO THE STATE EUGENICIST FOR THE TEMPORARY SUSPENSION OF AN ORDER FOR EUGENICAL STERILIZATION.}

In the matter of the legal determination of the potential parenthood of socially inadequate offspring of. , as prescribed

by Chapter of the Session Laws of 19

of the State of.

State of.

... County.

To. State Eugenicist of the State of.

WHEREAS, in accordance with the Eugenical Sterilization Law of the State of , one. was, on the day of.

19........, by due process of law in this Court, declared to be a cacogenic person in accordance with the definition of the above-named statute; and,

WHEREAS, this Court on the day of 19........, duly ordered the State Eugenicist of the State of. to cause the said. to be eugenically sterilized; and,

WHEREAS, in the opinion of this Court, the conditions are such that the state will, for the time being, be protected from reproduction by the said of.

THEREFORE, in accordance with the above-named act, and the authority by it in me vested, I hereby command the State Eugenicist of the State of.

to suspend the execution of the order for the eugenical sterilization of the said. of.........................., until further commanded by this Court.

The State Eugenicist is further commanded to keep in touch with the said. of................................, and to report to this Court on June first and December first of each year concerning the protection of the State from reproduction on the part of the said of..

WITNESS my hand this. day of. 19. 
Form $7 \mathrm{~g}$.

ORDER TO A CACOGENIC PERSON WHOSE EUGENICAL STERILIZATION HAS BEEN TEMPORARILY SUSPENDED, TO REPORT PERIODICALLY TO THE STATE EUGENICIST.

In the matter of the legal determination of the potential parenthood of socially inadequate offspring of.. , as prescribed

by Chapter. of the Session Laws of $19 . . . . . .$.

of the State of.

State of.

County.

To. of.

WHEREAS, on the day of 19......., in this Court, you, the said .of. were duly declared to be a cacogenic person, and as such were ordered eugenically sterilized; and,

WHEREAS, in further accordance with the Eugenical Sterilization Law, this Court has been duly supplied with apparently trustworthy evidence that, for the time being, the State will be protected against your reproduction; and,

WHEREAS, this Court has duly ordered the State Eugenicist to defer the execution of the order for your eugenical sterilization, and has further commanded the said State Eugenicist to report on the first day of June and the first day of December of each year to this Court concerning the validity of this protection.

THEREFORE, you are hereby commanded to report to the State Eugenicist or his duly appointed agent twice annually, at the time and place named by the State Eugenicist, and there submit to an examination, giving proof concerning the validity of this protection.

GIVEN under my hand and seal this day of. 19 
Form 7 h.

\section{ORDER TO THE STATE EUGENICIST FOR THE EUGENICAL STERILIZA- TION OF A CACOGENIC PERSON, THE ORIGINAL ORDER FOR WHOSE STERILIZATION HAS BEEN TEMPORARILY SUSPENDED.}

In the matter of the legal determination of the potential parenthood of socially inadequate offspring of. , as prescribed

by Chapter. of the Session Laws of $19 . . . . . .$.

of the State of

State of.

\section{County.}

To. State Eugenicist of the State of.

WHEREAS, in accordance with the Eugenical Sterilization Law of the State of one was, on the day of 19......., by due process of law in this Court, declared to be a cacogenic person in accordance with the definition of the above-named statute; and,

WHEREAS, this Court on the. day of $19 . . . . . . .$, duly ordered the State Eugenicist of the State of to cause the said to be eugenically sterilized; and,

WHEREAS, apparently trustworthy evidence had been presented to this Court that the State would, for the time being, be amply protected against reproduction by the said. ..; and,

WHEREAS, in accordance with said evidence, this Court temporarily suspended the order for the eugenical sterilization of the said. ; and,

WHEREAS, it now appears on the evidence presented by the State Eugenicist to this Court that the State is no longer amply protected against reproduction by the said

THEREFORE, in accordance with the above-named act and the authority by it in me vested, I hereby command the State Eugenicist of the State of.. to proceed fortwith with the execution of the original order for the eugenical sterilization of...

WITNESS my hand this. day of 19 
Form $8 \mathrm{al}$.

\section{CONTRACT WITH SURGEON OR PHYSICIAN TO STERILIZE EUGENICAL- LY AN INDIVIDUAL IN THE POPULATION AT LARGE.}

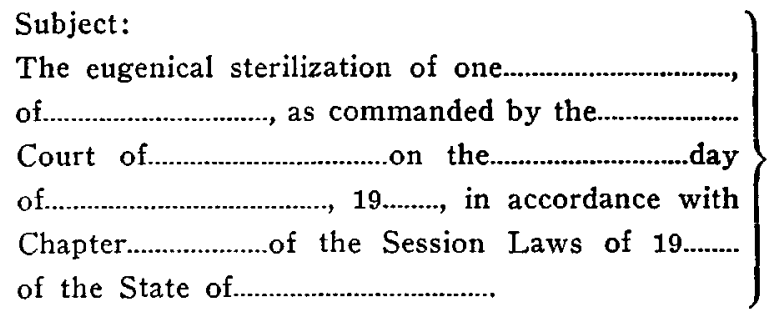

THIS AGREEMENT entered into this day of. 19 by and between the State of. represented by

State Eugenicist of said State, party of the first part, and Dr. of. physician and surgeon, duly licensed by said State, party of

the second part.

Party of the first part agrees to present the person of one of. duly ordered by the. Court of.

County, on the..................................day of....................................., 19........, in accordance with Chapter of the Session Laws of 19 . of the State of. to be eugenically sterilized, to the party of the second part (name and locate hospital or office), on or before the day of. 19.

Party of the second part agrees to perform upon said of. the operation of. which has for its primary purpose the permanent nullification of the reproductive function, said operation to be performed in a safe and humane manner, with due regard to the possible therapeutical benefits to be derived therefrom, and in full accordance with modern surgical, sanitary and hospital practice. The party of the second part further agrees to maintain said in accordance with the aforesaid modern hospital and sanitary practice to the satisfaction of the party of the first part during the period of convalescence, which period shall be terminated on the judgment and order of the party of the first part.

Party of the first part agrees to pay to the party of the second part, for the aforedescribed services, the sum of dollars, the order for said payment to be issued upon the receipt by the party of the first part of a sworn statement by the party of the second part confirming the identity of the person eugenically sterilized, describing the time, place and nature of the operation or treatment, and the outcome thereof.

If for any cause the party of the first part does not present the aforesaid subject of the order of eugenical sterilization on or before the day of $19 . . . . .$. , this contract shall become void.

IN WITNESS whereof we have hereunto set our hands this. day of.. 19

The State of

by State Eugenicist, party of the first part. M. D., party of the second part. 
Form 8a2.

\section{CONTRACT WITH SURGEON OR PHYSICIAN TO STERILIZE EUGENICAL- LY AN INDIVIDUAL INMATE OF A CUSTODIAL INSTITUTION.}

Subject:

The eugenical sterilization of one.

of. as prescribed by Chapter

State of of the Session Laws of $19 \ldots \ldots$..... of the

THIS AGREEMENT entered into this

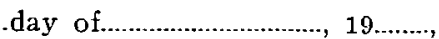
by and between the State of. by. State Eugenicist of said State, party of the first part, and Dr of. , a physician or surgeon duly licensed by said State, party of the second part,

WITNESSETH: Party of the first part agrees on or before the day of 19......., to provide access for party of the second part and his assistants to the person of one of an inmate of a custodial institution located at

said inmate having been duly ordered by the. Court of

County, on the day of. in accordance with Chapter of the Session Laws of 19 of the State of to be eugenically sterilized.

Party of the second part agrees to perform upon said of. , the operation of which has for its primary purpose the permanent nullification of the reproductive function, said operation to be performed in a skillful, safe and humane manner, with due regard to the possible therapeutical benefits to be derived therefrom, and in full accordance with modern surgical, sanitary and hospital practice.

Party of the first part agrees to furnish to the party of the second part due evidence of legal court order for the eugenical sterilization of the above-named.

of........................... and to pay to the party of the second part, for the aforedescribed services, the sum. of. dollars, said payment to be made upon the receipt by the party of the first part from the party of the second part of a sworn statement confirming the identity of the person eugenically sterilized, describing the time and place of the operation or treatment and the outcome thereof.

IN WITNESS whereof we have hereunto set our hands this. day of......................................, $19 \ldots \ldots . .$.

The State of

by State Eugenicist, party of the first part. M. D., party of the second part. 
Form sb.

\section{REPORT OF SURGEON OR PHYSICIAN TO STATE EUGENICIST.}

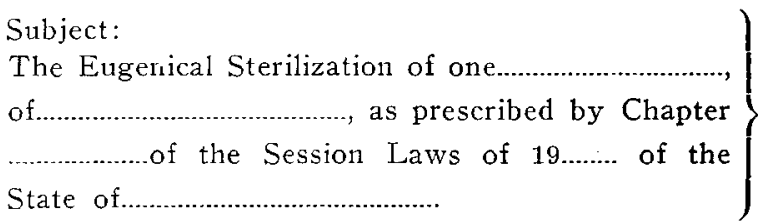

To

State Eugenicist of the State of

In accordance with a contract entered into on the day of $19 \ldots . . . . .$, by State Eugenicist of the State of.

party of the first part, and the writer of this report, party of the second part, the party of the second part hereby reports the following:

1. Name of person etrgenically sterilized:

2. Age:

3. Sex:

4. Type of operation:

5. Place of operation:

6. Time of operation:

$\%$ Record: Notes on outcome of operation and convalescence and memorandum on release of patient:

Respectfully submitted,

M. D.

being duly sworn, says that he personally performed the operation above described and that to the best of his knowledge and belief the above statements are true.

Subscribed and sworn to before me this day of. 19.

State of 
Form 8c.

\section{RETURN OF STATE EUGENICIST TO COURT IN CASE OF EUGENICAL STERILIZATION OF AN INDIVIDUAL IN THE POPULATION AT LARGE.}

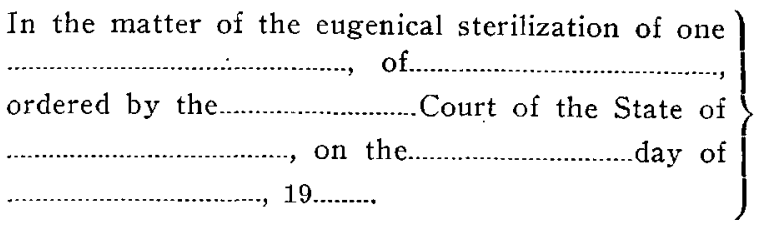

To the

Court of. State of.

Pursuant to the command of the Honorable Court aforesaid, issued on the day of 19......., to the State Eugenicist of said State, to cause the eugenical sterilization of one of the undersigned

State Eugenicist of said State respectfully makes the following return:

The aforesaid of. of whose identity I am duly convinced, was arrested by a deputy of the undersigned, on the day of. 19 at and was eugenically sterilized by the operation (or treatment) technically known as on the day of. $19 . \ldots . . . .$, at

by $\mathrm{Dr}$. , of.

by the aforesaid State. Said a physician or surgeon duly licensed convalesced as follows:

and on the. day of. 19........, was released from the custody of the State Eugenicist. All in due accordance with the aforesaid order.

Respectfully Returned,

State Eugenicist.

State of.

County.

being duly sworn, says that the statements in the above are in accordance with his first-hand knowledge and upon the official reports of his deputy and assistant and that to the best of his knowledge and belief all of said statements are true.

Subscribed and sworn to before me this day of $19 \ldots \ldots$. Notary Public, 
Form sa.

\section{RETURN OF STATE EUGENICIST TO COURT IN CASE OF EUGENICAL STERILIZATION OF AN INDIVIDUAL INMATE OF A CUSTODIAL INSTITUTION.}

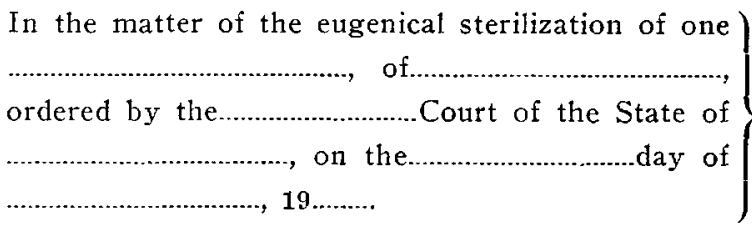

To the

Court of.

State of.

Pursuant to the command of the Honorable Court aforesaid, issued on the day of..............................., 19........, to the State Eugenicist of said State, to cause the engenical sterilization of one ố. the undersigned

State Eugenicist of said State respectfully makes the following return:

The aforesaid. of , of whose identity

I am duly convinced, was eugenically sterilized by the operation (or treatment) technically known as on the day of 19 at by $\mathrm{Dr}$ of

a physician or surgeon duly licensed by the aforesaid State. Said

remained in the custody of the aforesaid Custodial Institution and convalesced as follows:

All of which actions and reports are in due accord with the aforesaid order.

Respectfully Returned,

State Eugenicist.

State of.

County.

Subscribed and sworn to before me this day of. 19.

Notary Public,

County. 
Form 8e.

\section{SEMI-ANNUAL RETURN OF THE STATE EUGENICIST TO THE COURT IN CASE AN ORIGINAL ORDER FOR EUGENICAL STERILIZATION HAS BEEN TEMPORARILY SUSPENDED.}

Office of the State Eugenicist of the State of.

In the matter of the legal determination of the cacogenic personality of one

of. as prescribed by Chapter. of the Session Laws of 19

Date of this Return:

(June 1 or Dec. 1)

State of.

County.

To the. Court of.. State of.

In compliance with the order of the Honorable Court aforesaid, issued on the day of. 19........, I, State Eugenicist of the State of respectfully submit the following:

(Here the State Eugenicist should report the facts gathered by his field workers, or submitted by the cacogenic person at the first-hand, in reference to the assurance of nonreproduction by said cacogenic person.)

Respectfully submitted, 
Form 9.

\section{INSTITUTIONAL DATA KEPT BY STATE EUGENICIST.}

LEGAL DEFINITION OF A CUSTODIAL INSTITUTION.

From Section 2, Clause g, of Chapter. of the Sessions Laws of 19. of the State of known as the "Eugenical Sterilization Law."

"g. A custodial institution is a habitation which, regardless of whether its authority or support be public or private, provides (1) food and lodging, and (2) restraint, treatment, training, care or residence for one or more socially inadequate inmates; provided that the term custodial institution shall not apply to a private household in which the socially inadequate member or members are close blood-kin or marriage-relations to, or legally adopted by, an immediate member of the care-taking family."

Form 9a.

\section{ROSTER OF CUSTODIAL INSTITUTIONS.}

(This roster should be revised at least once a year.)

\begin{tabular}{c|c|c|c|c}
\hline Name of Institution & 2. & $\begin{array}{c}3 . \\
\text { Year } \\
\text { When } \\
\text { Opened }\end{array}$ & $\begin{array}{c}4 . \\
\text { Where Located }\end{array}$ \\
\hline I. & & & \\
\hline & & & \\
\hline
\end{tabular}

\begin{tabular}{|c|c|c|c|c|}
\hline & $\mid \begin{array}{c}5 . \\
\text { Types of Inmates, } \\
\text { Patients } \\
\text { or Pupils }\end{array}$ & $\begin{array}{c}\text { Number of Innates } \\
\text { Patients or Pupils on } \\
\text { Date of Report }\end{array}$ & $\begin{array}{c}7 . \\
\text { Exclusively for } \\
\text { Males, for Females; } \\
\text { or for Both Sexes }\end{array}$ & $\begin{array}{c}8 . \\
\text { Races Provided for }\end{array}$ \\
\hline 1. & & & & \\
\hline 2. & & & & \\
\hline 3 & & & & \\
\hline
\end{tabular}

\begin{tabular}{|c|c|c|c|c|}
\hline & $\begin{array}{l}\qquad . \\
\text { Age Limits } \\
\text { of Inmates }\end{array}$ & $\begin{array}{l}\qquad 10 . \\
\text { Territory from } \\
\text { which Inmates } \\
\text { are Drawn }\end{array}$ & $\begin{array}{l}11 . \\
\text { How Maintained. } \\
\text { Public, (State, City, } \\
\text { County or Town) } \\
\text { or Private }\end{array}$ & $\begin{array}{l}12 . \\
\text { If Private is } \\
\text { Institution } \\
\text { Licensed by } \\
\text { State? }\end{array}$ \\
\hline 1. & & & & \\
\hline 2. & & & & \\
\hline 3. & & & & \\
\hline
\end{tabular}




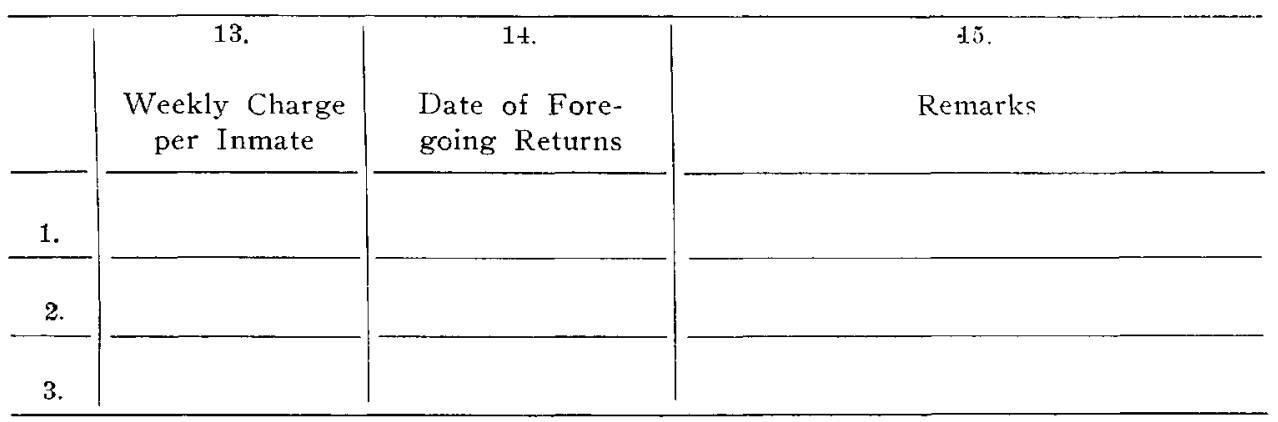

NOTE:-For suggestions on other institutional data see the reports of the more progressive Custodial Institutions, and the "Statistical Directory of State Institutions for the Defective, Dependent and Delinquent Classes." H. H. Laughlin, Bureau of the Census, 1919. 
Form 9b.

MONTHLY INSTITUTIONAL REPORT OF ACCESSIONS AND LOSSES, TO STATE EUGENICIST.

(These returns should be analyzed and summarized in other tables, following in general the systems used by the more progressive Custodial Institutions.)

Name of Institution:

Place Located:

Name of Responsible Head:

REPORT OF ACCESSIONS DURING THE MONTH OF. $19 \ldots \ldots$.

\begin{tabular}{l|c|c|c|c|c|c}
\hline 1. & $\begin{array}{c}2 . \\
\text { Institution } \\
\text { Case } \\
\text { Number }\end{array}$ & Home Address & Sex & Age & Diagnosis & $\begin{array}{c}7 . \\
\text { How } \\
\text { Admitted }\end{array}$ \\
\hline 1. & & & & & & \\
\hline 3. & & & & & & \\
\hline
\end{tabular}

8.

Remarks

$\frac{2}{3}$

3.

REPORT OF LOSSES DURING THE MONTH OF

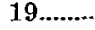

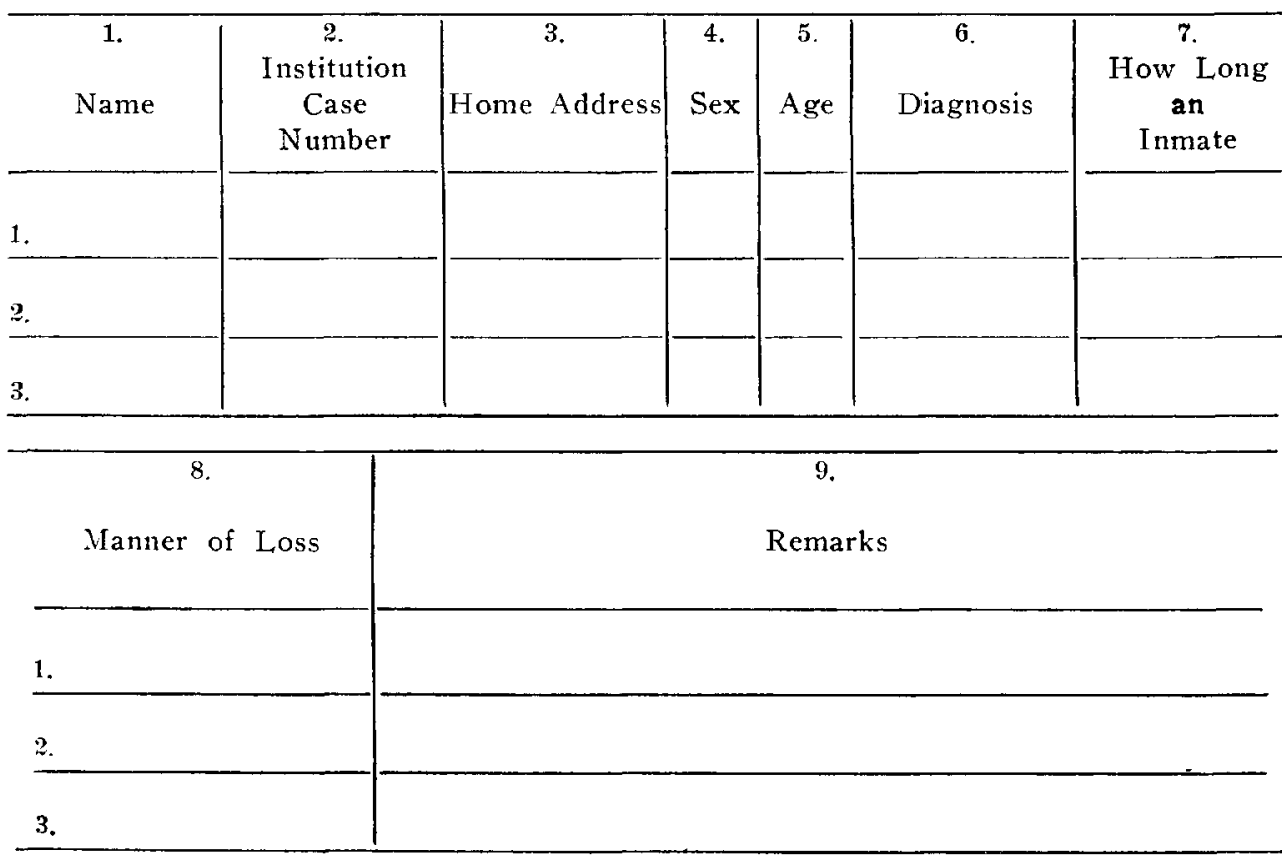

Notes on cases which are thought to be highly cacogenical:

Names of inmates concerning whom eugenical field-studies have been made: 
Form 10a.

\section{CASE RECORD OF EUGENICAL STERILIZATION.}

Case number in files of the State Eugenicist

1. Full name.

(In case of a married woman, record both maiden and married name.)

2. Sex.

3. Age when operated upon.

4. Birthplace. Present address

5. Name of court which ordered sterilization.

6. Date of court order for sterilization.

7. Attitude of individual and friends or kin toward operation

8. Type of operation ordered.

9. Names of surgeons consulted by State Eugenicist in deciding upon particular type of operation.

10. Date of operation

11. Surgeon: Name Address.

12. Condition of individual at time of operation.

13. Effects of operation. (Record general and specific morphological, pathological, physiological, psychological,-emotional expression and control,-mental, criminal, social, sex,-masturbation, desire for sexual relations, - and economic effects of the operation. Immediate and remote effects.)

NOTE: Add sheets of plain paper for the continuation of the record of this case. Entries should be made from time to time as long as examinations and reports can be secured. Each entry should be dated. 
Form 11a

\section{APPROPRIATIONS}

Adequate funds for salaries, traveling expenses, etc, will be necessary if the state is to carry out engenical sterilization in a just and effective manner.

Working draft of appropration section to be inserted in the proper place in the state's appropriation bills, according to the legislative practice of the particular state.

Section-. Appropriations. For the purpose of executing the provisions of the Eugenical Sterilization Law (Chapter...................Session...................ws..................) for the fiscal year ending .........................., the sum of \$..................is hereby appropriated, to be expended on requisition of the State Eugenicist (or the head of the department to which the State Eugenicist is directly responsible) as follows:

1. Salary of State Eugenicist.

2. Salaries of professional field-workers.

(To begin this work one such assistant will be needed for each quarter-million inhabitants of the state. Later, as the department develops, this appropriation will, of course, adjust itself to the policy of the particular state.)

Field-workers at $\$$. per annum. $\$$

3. Salaries of stenographers.

(Approximately as many stenographers and clerks as fieldworkers will be required.)

Stenographers and Clerks at $\$$. .per annum....\$

4. Traveling expenses for State Eugenicist and staff, and fees and traveling expenses of witnesses (not including court witnesses) aiding said State Eugenicist.

5 Rent for office (if ample facilities are not supplied in state owned buildings).

6. Office furniture and equipment.

7. Printing, supplies, and maintenance service. $\$$.

8. Surgical, medical and hospital charges for cases of eugenical sterilization duly ordered in accordance with the afore-mentioned Act....\$.

9. Court and notary fees (if it is customary for the particular state to make special appropriation directly to the administrative department for suck purposes; 
INDEX 



\section{INDEX}

A.

Achondroplasia, 372.

Agnew State Hospital, 55, 58. Agricultural\& Industrial School, N. Y., 85.

Ah Sun vs. Wittman, 239 .

Alabama (State), 343.

Albinism, 373.

Alcoholism, 375 .

Aldridge Case, 162, 197.

Alkaptonuria, 376.

Allen vs. Pullman Palace Car Co., 192.

Amaurotic family idiocy, 379 .

Ambidexterity, 375 .

Ambrose, Thomas L., 19.

Amendments, 1, 7, 18, 107, 111, 134, 183.

American Medico-Psychological Association, 69.

American Roentgen Ray Society, 412.

Ampulla, 405.

Anaemia (pernicious), 378 .

Analysis of laws, 6 .

Anarthrosis (digital), 377.

Anatomy, 397 .

Andrews, Charles H., 82, 144, 217.

Angina pectoris, 379 .

Angio-neurotic odema, 378 .

Animalculists, 400 .

Ankylosis, 377.

Anti-Sterílization League, 43.

Aphakia, 374.

Appeals, 135. 149, 152, 166, 198. $200,205,228,234,258,450,459$. Applegate, C. F., 56, 60, 67.

Appropriations, $6,7,8,9,10$ $11,12,13,139,439,451,460$.

Arkansas Building \& Loan Association vs. Madden, 192.

Archiv. $f$ Kriminal anthropologie, 120.

Arteriosclerosis, 378.

Arthritis deformans, 379.

Asexualization, 53, 324, 433.

Ashley, Dr. M. C., 86.

Astigmatism, 379.

Ataxia (cereballar), 379 .

Ateleiosis, 372.

Atkins vs. Kansas, 197.

Atrophy (muscular), 377, 379.

Atrophy (optic nerve), 376

Auburn State Prison, 84.

\section{B.}

Bagg, Dr. Halsey J., 413

Baer, K. E. von, 404.

Barbier vs. Connell, 239.
| Barr, Dr. Martin W., 328, 351, 433.

Barrett, Dr. Albert M., 74.

Barrow, Dr. Bernard, 418.

Bartholim, glands of, 398.

Battey, Dr. Robert, 416.

Becker, State vs., 153, 156.

Beier, Dr. A. L., 95.

Bellfield, Dr. Wm. D., 196.

Bell, Dr. Clark, 196.

Bell, Wm., 152.

Belm vs. Young, 192.

Benton vs. Budd, 192.

Bernstein, Dr. Charles, 85, 224. $330,232,235,309$.

Berry, Wm. H, 66, 143, 179 .

Berzman, State vs., 154.

Bibliography, 372, 394.

Bigelow vs. Hartford Bridge Company, 192.

Bi-lobed ears, 377.

Bill of attainder, $44 \%$.

Bingham, Judge Geo. G., 2\$T.

Biology, 104, 113, 368, 443 .

Bird. W. A. S., 30 .

Birth Control, 346, 423 .

Bissell vs. Davison, 324, 327, $32 \mathrm{~s}$.

Blackburn vs. State, 1 \$ 7 .

Blending trait, 384 .

Bliss, Dr. Geo. S., 64.

Books (see Bibliography).

Boston Chas. A., 120, 231, 336.

Brachydactylism, 372,380

Breeding, 364 .

Bronchial asthma, 376 .

Brown, Hon. R. E., 45.

Brown, Sequard, 56.

Bruce, Hortense V., 85.

Bryant, Commissioner vs. Skillman Hardware Company, 172.

Buford, Dr. J. A., 78.

Bulbi vestibuli, 398 .

Bush, Robert P., 25.

Butler, Edwin M., Senator, 18.

Butler, F. O., 56, 59, 60.

Byers, Joseph P., 164.

\section{c.}

Cacogenies, 357, 443, 447, 456.

California, $1,2,3,6,17,52,96$, $99,100,101,103,104,105,107$, $110,111,112,115,118,125$, $139,131,134,137,139$.

California State Prison, Folsom, 61 .

California State Prison, San Quentin, 60 .

Camfleld vs. United States, 173.

Cancer (diathesis), 378.

Capper, Arthur, 30.
Carmichael, Dr, F. A., 70.

Carroll, B. F., 21.

Case, J. D., 79 .

Castrati, 407, 433.

Castration, 96, 111, 324, 328, $409,425,433,435,436$.

Cataract, 874 .

Catlin mark, 377.

Cave, Dr. F. C., 70, 434 .

Chadwick, Judge, 162.

Chamberlain, Geo. E., 40, 41, 42 .

Chapman, Dr. Alma J., 79.

Charles, If W., 73 .

Charlestown vs. Werner, 238.

Charlton, G. F., 78 .

Cherokee State Hospital, 69.

Chester, Alden, Justice, 217.

Chevannes vs. Priestly, 171.

Chicago B. \& G. R. R. Company vs. Illinois, 239.

Chicago M. \& St. Paul R. R. Company rs. Westby, 239 .

Chlorosis, 378.

Christian, Frank E., 84 .

Christie, Dr. Arthur C., 412, 421.

Chromosomes, 401.

Clarinda State Hospital, 69.

Clarke, Fred P., 56.

Clarke, Geo. W., 22, 23.

Class legislation, $130,440$.

Clattenburg, H: A., 61.

Cleft palate, 377 .

Cline, Jacob, 4, 146, 271, 291 318.

Clinton State Prison, 84.

Clitoris, 398 .

Cloquet, ligament of, 399 .

Coakley, Dr., 225, 231.

Cobb, Dr. O. H., 85.

Coffey, 40.

Coloboma, 376.

Color blinaness, 376 .

Composite trait, 384.

Compton, I. H., 90, 271, 320 .

Conant, Mary C., 85.

Coni, vaseulose, 397.

Conlin, State vs., $324,327$.

Connecticut, $1,4,8,19,61,96$. $99,100,101,105,108,112,114$ $115,118,125,126,129,131$, $135,137,139$.

Connecticut Hospital, Middleton, 61 .

Connecticut Hospital, Norwich, 62.

Connecticut State Prison, Wetherfield, 61 .

Consent of patient, 110 .

Continence, 423.

Contraception, 346,423 .

Co-parent, 366 . 
Cooley's Constitutional Limita- Duryee, Dr. Chas. C., 82.

tions, 187, 197.

Cornea (degeneracy), 377.

Corona radiata, 406 .

Corpus lutcum, 405, 428 .

Corpus spongiosium, 398 .

Cosson, Geo. Adjutant-General, 184, 198.

Costill, Dr. Henry B., 164, 297.

Court Decisions, 1, 159, 174, 186, $200,213,227,234,250,257$, $269,289$.

Court procedure, 107.

Courts conducting eugenical studies, 394.

Cowper's glands, $398,399$.

Cretinism, 378 .

Criminals, 117, 328 .

Croup, 379.

Crumbacker, W. P., 68, 69.

Cryptorchism, 377.

Cummings vs. State of Missouri, 197.

Curie, P. and Mme., 412.

Custodial institution, 447, 456. Cystinuria, 379 .

\section{D.}

Daniel, Dr. F. E., 351.

Davenport, Dr. Chas. B., 225 , $\therefore 36$.

Davis, D. R., 48, 50.

Davis, Rudolph, 2, 143, 179, 291, 304.

Davis vs. Berry, 179, 198, 212, $236,239,249,252$.

Dawson, Wm. J. G., 59.

Deaf mutism, 374 .

Definitions, $446, \cdot 455$.

Degeneracy, 324, 360, 441.

Dementia praecox, 375 .

Dent in forehead, 377.

Dent vs. State of W. Va., 239.

Dental agnesia, 377 .

Dereliction in execution of law, $125,450,460$.

Deutoplasm, 406 .

Diabetes insipidus, 376 .

Diabetes mellitus, 376 .

Diagnosis, 362 .

Dickie, Wm., 54, 55.

Dickerson, D. S., 245.

Digital hair, 374.

Dinsmore vs. Southern Express Co., 201.

Distal phalanges, 372.

Dix, John A., 25.

Dominant traits, 365,382 .

Donohoe, Dr. Geo., 69.

Doran, Dr. Albert, 433.

Double-jointedness, 373.

Douglass, state vs., 154.

Dawdle, 171.

Dower, State vs., 156.

Dowden, State vs., 187.

Drake, Dr. F. I., 95.

Druckemiller, Melvin, 64.

Drum, Henry, 91, 292.

Due process of law, 132, 441.

Dubuque, Geo.'P., 92.

Duncan vs. Missouri, 190.

Dystrophia Muscularis, 377.

\section{E.}

Eastern New York Reformatory, 84.

Ectopia lentis, 374.

Effects of sexual sterilization, $425,431,434,436$.

Elliott, Margaret M., 64.

Ellis, H. Havelock, 120, 432.

Elver, Hon. Elmore T., 172.

Emasculation, 277.

Emigration, 360 .

Fngland, situation in, 355 .

Environment, 367.

Epigenesis, 401.

Epidermolysis, 373.

Epilepsy, 290, 375, 380.

Epileptics, Institutions for,

Village for Epilepties, Indiana, 64 .

State Hospital and Colony, Iowa, 69.

State Mospital for Epileptics, Kansas, 70 .

Farm Colony for Epileptics, Michigan, 74.

State Village for Epileptics, N. J., 80, 164, 292.

Craig Colony, N. Y., 85 .

Mansfield State Training School, Conn., 4, 20.

Epistaxis, 378.

Estabrook, Dr. A. H., 63, 255, $256,291,312$

Eugenical Education, 356.

Eugenical Investigators, 358 .

Eugenicist, 102, 110, 447, 456 .

Eunuch, 409, 437.

Euthanasia, 338.

Evans, Briton D., 80.

Exophthalmic goitre, 378 .

Exostoses, 373 .

Eye Color, 374, 380.

Ex post facto, 442

\section{F.}

Fallopian tubes, 111, 112, 130, $401,405,4=1$.

Family histories, 104, 291.

Farrington, Judge E. L., 247, 250 .

Fast, W. S., TS.

Federal Government, 451.

Feebleminded, the, 305 .

Feebleminded, Institutions for. Colony for Feeble Minded Males, NT. J., 80.

Home for Feeble Minded, WTis., 95.

Indiana School for Feeble Minded Youth, 64.

Indiana Farm Colony for Feeble Minded, 64.

Institution for Feeble Minded Women, N. J., so.

Institution for Feeble Minded Children, N. Y., 85.

Institution for the Feeble Minded, N. D., 87.
Institution for the Feeble Minded, Oregon, 90.

Letchworth Village, N. Y., 85.

Michigan Home and Training School, 3, 74, 203, 305.

Nebraska Institution fof Feeble Minded Youth, 77, 78.

Newark State School, N. Y. 85.

Pacific Colony, Cal., 3, 8, 19, 60.

Rome Custodial Asylum, N. Y., 85, 217, 305 .

Sonoma State Home, Cal., 7, $18,19,55,59$.

Southern Wisconsin Home for Feeble Minded, 95.

State Home for Feeble Minded, Kans., 70.

State Institution for Feeble Minded, S. D., 91.

Feeblemindedness, 375, 380 .

Feilen, Peter, 1, 123, 142, 149 , $170,171,173,188,196,212$, $215,233,236,237,249,252$, $291,292,329$,

Fenning, Frank A., 121.

Fernald, Dr. Walter E., 225, 232 , 236.

Ferris, Woodbridge N., 28.

Field surveys, 448.

Fimbriae, 405.

Finger-print pattern, 379.

Fisher Co., vs. Woods, 231.

Flood, Dr. Everett, 351.

Fogarty, Edw. J., 64.

Follicular fluid, 404.

Forms, 464.

Foster's Federal Practice, 192.

Foster, Warren F., 122, 196.

French vs. Teschermaker, 156.

Friedrich's ataxia, 375 .

Fundus, 406.

G.

Gametes, 397, 405

Garcia vs. Territory, 155 .

Garvin, Dr. Wm. C., 87.

Gedkirche, State vs., 173.

Gennat, Dr., 120 .

Germ. tract, 398, 403.

Gerngross, Dr. Friedr, Ludg., 121.

Gibson, State vs., 170.

Gillett, Governor James N., 17

Giraldes, organ of, 397.

Glands, sex, 425, tys, 434 .

Glaucoma, 374

Globus major, 400 .

Glueck, Dr. Bernard, 121.

Goitre, 378 .

Gonad, 407, 426 .

Good, Dr. A., 119.

Goodrich, James P., 63, 25̄5, 313

Gose, Judge, 162.

Gould vs. Gould, 170, 324, 327 331.

Gout, is.

Gower's muscular atrophy, 377 .

Graafian follicles, 403.

Graham vs. West Virginja, 187, 


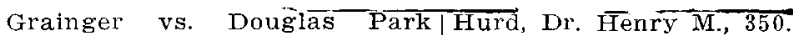
Jockey Club, 239.

Graves, Commonwealth Mass. vs., 187.

Gray, W. F., 121.

Griffiths, Dr. D. G., 78 .

Grover, Dr. O. M', 85.

Gulf, Colorado ete. R. R. Co. vs. Ellis, 176, 211.

\section{F.}

Hair, $373,374,376,377,380$.

Halgrims, Col., 22

Hamburg - Amer. - Packetfahrt. Actien Gesellschaft vs. U. S., 201.

Hamilton, Judge, J. W., 319.

Handclasp, 377.

Handwriting, $\mathbf{3 7 9}$

Hanna, L. B., 26.

Hapsburg lip, 373.

Harelip, 377.

Harvey, William, 404.

Hart, Governor L. F., 15.

Haskell, Dr. Robert H., 74.

Hatch, Dr. F. W., 52, 322.

Hathorn vs. Natural Carbonic Gas Co., 238.

Haviland, Dr. C. Floyd, 61.

Hay fever, 379.

Hay, Governor M. E., 15.

Hayes vs. Missouri, 190.

Haynes, Dr. H. A., 74, 144, 203, 305.

Heacox, Dr. Frank L., 84.

Health Department of N. Y. vs. Rector, 240.

Head form, 373.

Heart defect, 378 .

Hemenway, Dr. Henry B., 120.

Henrichs, R. B., 79.

Hemophilia, 377 .

Hennessy, John V., 82.

Heredity, 99, 363, 365, 447, 455.

Heyman, Dr. Marcus B., 87.

Hernia, 378.

Hill, John, 93.

Hilsabeck, state vs., 154.

Hinshaw, Dr. T. E., 71 .

Histories, case, $291,448$.

Hobbs vs. State, 154, 162, 197, 252.

Hoboken vs. Goodman, 172.

Hodges, Geo. H., 29.

Holden, Hon. Geo. B., 92.

Holden vs. Hardy, 230, 324, 328.

Holmes, Justice, 201.

Holt, Robert E. L., 88, 90.

Honeij, Dr. James A., 413.

Hopper vs. Stack, 172.

Hooker vs. Burr, 199.

Hormone, 427.

Hotchkiss, Dr. Wm. M., 87.

Howe, J. E., 66, 180.

Hoyt, Geo. E., 31.

Hubbard, O. S., 70.

Hugo, Francis M., 82.

Humes, Mo. P. R. Co. vs., 161.

Hunter, Joel D., 121.

Huntington's Chorea, 375.

Hurd, Dr. Arthur W., 86.

Independence, Iowa, 69 .

Ionia, Mich., 74 .
Hurtado vs. California, 325 .

Hutchinson Reformatory, 30 .

Hypertrichosis, 373 .

Hypertrophic emphysema, 379.

Hypospadias, 377.

Hypotrichosis, 373.

Hysteria, 375.

Hysterectomy 111, 414.

Hystero-salpingo-oöphorectomy, 414.

Hytatid, 397

\section{I.}

Icterus, 379.

Ichthyosis, 376 .

Idaho, 4, 48 .

Illegal use of sexual sterilization, $125,356,450,466$.

Immigration, 349,360 .

Immorality, 440 .

Indiana, $1,4,6.15,63,96,99$, $100,101,103,105,107,112$. $114,118,124,129,131,134$, $137,139,145,255,343$.

Industrial Schools.

Agricultural and Industrial School, N. Y., 85.

Farm for Boys, Valatie, N. Y., $\$ 4$

Home for Bors, N. J., 80

Indiana Boys' School, 64.

Indiana Girls' School, 64.

Industrial School for Girls, Kansas, 73.

Industrial School for Boys, Kansas, 73 .

Industrial School for Boys, Neb., 79 .

Industrial Home, Neb., 79.

Industrial School for Girls, Neb., 79 .

Industrial School for Boys, Wis., 95.

Industrial school for Girls, Wis., 95.

Preston School of Industry, Cal., 60.

Reform School at Mandan, N. D., 87 .

State Home for Girls, N. J., 80.

Training School for Girls, N. Y., 85 .

Inebriates, State Hospital for,

Iowa, 69.

Infundibulum, 405 .

Inmate, 447, 456 .

Insane, State Hospitals for.

Agnew, Cal., 55.

Ann Arbor, Mich., 74.

Binghamton, N. Y., 86 .

Buffalo, N. Y., 86 .

Central Islip, N. Y., 87

Cherokee, Inwa, 69.

Clarinda, Iowa, 69

Collins, N. Y., 86 .

Eldridge, Cal., 55.

Ingleside, $\mathrm{Neb} ., 76,78$.
Jamestown, N. D., 87.

Kalamazoo, Mich., 73.

Kings Park, N. Y., 86.

Larned, Kans., $i 1$.

Lincoln, Neb., 77,78 .

Long Island, N. Y., 87.

Manhattan, N. Y., 87.

Matteawan, N. Y., 85 .

Mendota, Wis., 95.

Middletown, Conn., 61.

Middletown, N. Y., 86.

Morris Plains, N. J., 80.

Napa, Cal., 54.

Newberry, Mich., 74.

Norfolk, Neb., 77, 78.

Norwalk, Cal., 56.

Norwich, Conn., 62.

Ogdensburg, N. Y., 86 .

Osawatomie, Kans., 70.

Patton, Cal., 55, 96.

Pendleton, Ore., 89.

Pontiac, Mich., 73.

Poughkeepsie, N. Y., 85.

Rochester, N. I., 86.

Salem, Ore., $\$ 9$.

Stockton, Cal., 54 ,

Talmage, Cal., 55.

Topeka, Kans., 70.

Traverse City, Mich., 73

Trenton, N. J., so.

Utica, N. Y., 85.

Waupun, Wis., 95.

Willard, N. Y., 85.

Winnebago, Wis., 95.

Institutions, 393.

(See also, Insane, Epileptic,

F e e b l e minded, Industrial Schools, Penitentiaries, Prisons, Reformatories.)

Intellectual capacity, 375 .

Involutional melancholia, 375 .

Iowa, $1,2,3,8,21,64,96,99$. $100,101,103,104,105,10 \mathrm{~s}$. 111. 112, 114. 115, 118, 125 , $126,129,131,135,137,14 \div$. 179.

Iowa Board of Control, 68 .

Iowa Board of Parole, 65, 67, $179, \quad 200,304$.

Ishmaels, 63 .

Iso-agglutinins, 377 .

Isthmus, 405.

\section{J.}

Jackson, 192

Jacobsen vs. Massachusetts, $171,172,238,240$.

Jaundice, 378 .

Jewish facial type, 373 .

Johnson, Hiram W.. 18

Johnston, J. A., 60.

Jones, Robert O., 50.

Jones, State of Iowa rs., 187.

Jones rs. Montague, 201.

Jordan, Dr. Alfred C., 413.

Journals, 394.

Journal of Criminal Law and ('riminology, 121, 122.

Jukes, 63,328 .

Juristisch-psychiatrische Grenzfrasen, 120 . 


\section{I.}

Kalamazoo State Hospital, 73. Kansas, 1, 3, 11, 29, 69, 96, 100, $101,102,103,104,106,109$, $110,111,113,114,116,118$, $125,126,129,132,135,136$, $138,140$.

Kansas State Penitentiary, 71. Kelcher vs. Putnam, 171.

Kelly, Judge Percy R., 287.

Kelly vs. People, 187.

Kemmler, 162, 189, 197.

Kendrick, Hon. W. R. C., 179.

Kern, W . B., 60.

Kimmish vs. Ball, 239.

Kincaid, State vs., 160.

Kutnewsky, Dr. J. K., 91.

\section{工.}

Labia majora, 398.

Labire, A. R., 34.

Lambert vs. Alcorn, 192.

Latham, Dr. C. O., 94.

Laws, 1, 6, 438 .

Laws, text of, 15 .

Laws, analysis of, 99 .

Lee, Oscar, 95.

Leeper vs. Texas, 189.

Left-handedness, 375 .

Legal counsel, 110, 449, 459.

Legal requirements, 440 .

Legislation, 15, 342, 356, 438 .

Leprosy, 379.

Lewelling, L. G., 42.

Liability, legal, 124, 450, 460 .

Libido, 425.

Lied vs. Henderson, 193.

Light, Jno. H., Attorney General, 333.

Light vs. United States, 199, 200.

Litigation, 142, 149, 164, 179, $203,217,243,256,271$.

Little, Dr. Chas. S., 85.

Little, Lura C., 43 .

Lonas vs. State, 170.

Longevity, 377.

Lowe vs. Kansas, 190.

\section{$\mathbf{M .}$}

Mackin, Dr. M. C., 69

Macomber, J. Frank, 80.

Macula lutea (degeneration). 379.

Macy, Dr. Wm. A., 86.

Magoun vs. Illinois Trust, 190. Main, Hon. John F., 152.

Main, State vs., 239, 324.

Mansel, V. H., 80.

Mansfield State Training School, 20.

Marcy, Alesc. Jr., 164.

Marriage Annulment, 345 .

Marriage-Restriction, 325, 342 , 371.

Marsha1l, Louis, 334.

Marshall, Thomas R., Governor, $6,63,146,255$.

Mason, T. R., 48.

Mathematical ability, 378 .

Mating, 381
Matthew, Railroad vs., 190.

Matthews, A. C., 54, 58, 325 .

Mecabe vs. A. T. \& S. F. Ry Company, 200.

McCauley, Chris., 92.

McCauley, State vs., 155, 197.

McCaughry, Charles C., 61.

MeCoy, Etta Joe., 73.

MeCoy, James F., 40.

McKelvie, Hon. S. R., 47.

McKenna, Justice, 329 .

McLean, Donald T., 245.

McNary, Dr. W. D., 89.

McPherson, Smith J., 181, 191.

Mechanical ability, 378 .

Meehan vs. Excise Com., 172.

Megalophythalmus, 379 .

Memory, 379.

Mendelism, 366 .

Mendocino State Hospital, 55, 58.

Menieres disease, 375.

Mesoderm, 397.

Metabolism, 426 .

Meyer, Dr. Adolph, 120.

Michigan, 1, 3, 11, 28, 73, 96, $100,102,103,104,106,108$, $110,113,114,116,118,125$, 126, $129,132,135,13 \mathrm{~s}, 140$, $143,203,343$.

Michigan Home and Training School, 74 .

Mickle, Pearly C., 2, 145, 243, $271,311$.

Microphthalmia, 377 .

Migraine, 378.

Mills vs. Green, 201.

Milroy's disease, 378

Milwaukee County Hospital for Mental Diseases, 96.

Mitchell, Dr, H. W., 39.

Mitchner. Lillian M., 73.

Model Forms, 465.

Model Law, 110, $446,454$.

Mongolian imbecility, 379 .

Moore vs. State of Missouri, 187,239 .

Moral Perverts, 292, 311, 312, 318.

Morehead, John H., 32, 48, 75.

Morgagni, hytatid of, 397 .

Morgan, 429.

Morris Plains State Hospital, 80.

Morris vs. Columbus, 171.

Morse, State vs., 238.

Mott, David C., 66, 180.

Mowrer, Dr, G. E., 63.

Wultiple sclerosis, 376

Munn vs. State of Illinois, 240.

Munson, James D., 73.

Murphey, Commonwealth vs., $155,161$.

Murphy, Chas. A., 90.

Muscular atrophy, 375 .

Myopia, 376, 380.

Myxoedema, 379 .

\section{N.}

Nail defects, 380 .

National Christian League for Promotion of Purity, 84 .
Nebraska, 1, 2, 13, 32, 46, 74, $96,100,101,102,103,104$, $106,109,111,113,117,118$, $125,129,132,135,138,140$. Nebraska Board of Examiners of Defectives, 75 .

Nelles, Fred C., 60 .

Neurasthenia, 379 .

Neurofibromatosis, 378 .

Nevada, $1,2, \quad 3,8,20,79,96$ $100,101,103,105,108,112$ $115,118,125,131,136,137$, $145,243$.

Nevin, Drr. Ethan A., 85.

New Jersey, 1, 2, 10, 23, 80, 96, $99,100,102,103,105,108$, $110,113,114,116,118,125$, $129,132,136,137,139,142$. $164,343$.

New Jersey Board of Examiners of Feeble Minded, etc., 164.

New Orleans Gas Light Co, vs. Drainage Co., 238.

New York, 1, 2, 3, 4, 10, 25, 81, $96,99,100,102,103,104,105$, $108,110,113,114,116,118$, $125,126,129,132,136,137$, $139,144,217,343$.

New York Board of Examiners of Feeble Minded, etc., 164.

Night blindness, 376,380 .

Noble State Bank vs. Haskell, $170,172$.

North Dakota, 1, 10, 26, 87, 96, $99,100,102,103,104,106$, $108,110,113,114,116,118$, $125,129,132,135,138,139$, 343.

Northrup, W. H., 26.

Nymphae, 398.

Nystagmus, 376 .

\section{o.}

Oberholzer, Dr. Emil, 120.

Obesity, 379 .

Jbjections, 438.

Odell, Arthur, 28

Oddie, Tasker, L., 21.

Ollswane, Dr. D. E., 85 .

Olson, Donald B., 91.

Olson, Hon, Harry, 322.

O'Neil vs. State of Vermont, $162,188,189,197$.

Operations, types of, 111,407 , $422,432$.

Opinions, legal, 1, 206, 222, 287, 322.

Oöphorectomy, 111, 329, 415, $416,428,434,435$.

Oöphoro-hysterectomy, 414.

Orchidectomy, 409.

Orders for sterilization, 164, $179,272$.

Oregon, 1, 2, 3, 4, 13, 33, 40, $88,96,100,101,102,104$, $106,109,110,111,113,114$, $117,118,125,130,132,136$, $138,140,146,271,343$.

Oregon State Board of Eugenics, 4, 33, 88, 146, 271.

Osawatomie State Hospital, 70. Osborn vs. Blank, 187. 
Osborn, Frank, 2, 144, 217, 291, 305.

O'Shea, 162, 197.

Osteopsathyrosis, 373,380 .

Osterreichische Zeitschrlft fur Strafrecht, 120.

Ostosclerosis, 375.

Ostrander, Dr. Herman, 73.

Os uteri, 406.

Ovaries, 404, 428.

Ovariotomy, $53,96,111,432$ 433.

Oviduct, 111, 397, 405 .

Ovists, 400.

Ovum, 397, 406.

Owens-Adair, Dr., 41, 43.

\section{F.}

Pacific Colony, Cal., 3, 8, 19, 60. Pacific Express Co. vs. Siebert, 192.

Palmaris longus, 376.

Pan-hystero-kolpectomy, 414.

Paradidymis, 397.

Paralysis, 379.

Paramyoclonus multiplex, 379.

Paranoia, $\mathbf{3 7 5}$.

Parker, Judge, 162.

Paroöphoron, 397.

Parovarium, 397.

Parsons, F. W., 86.

Parthogenesis, 401.

Passaic vs. Patterson Bill Posting Co., 172.

Patchen, State vs., 149.

Pattern baldness, 376 .

Peck, Arthur K., 33.

Pedigrees 104, 362, 369.

Penis, 398.

Penitentiaries.

(See also Prisons and $\mathbf{R e}-$ formatories.)

Iowa, 179, 304.

Kansas, 71.

Nebraska, 79.

Nevada, 79.

North Dakota, 87.

Oregon, 90, 271,318.

Washington, 91, 152.

Pennsylvania, 1, 4, 35, 39, 343.

Pennsylvania State Vaccination Commission, 341.

Pennypacker, Saml. W., 36 .

People vs. Morris, 153.

People vs. Miner, 194.

People vs. King, 238.

People vs. Budd, 238.

People vs. Hupp, 238.

People vs. Freeman, 239.

People vs. Havnar, 239.

People vs. Morse, 239.

People vs. West, 240 .

Perkins, Eli C., 21.

Perry, Dr. M. L., 70.

Phallectomy, 407.

Phallo-orchidectomy, 407.

Philpott, Austin F., 179.

Physiology, 425.

Pilcher, Dr. F. Hoyt, 351.

Pilsbury, Dr. Lawrence B., 78 Pitts, 192.

Pittsburgh, etc. Ry. Co. vs.
Board of Public Works, 192. Pituitary, 426.

Pneumonia, 378.

Poison Ivy, immunity to, 373.

Pollock, Dr. Henry M., 62.

Pollock, John C. J., 190, 191.

Polydactyly, 372.

Potentia generandi, 425 .

Potentia coeundi, 425, 436 .

Potential parent, 447, 455 .

Potter, Dr. C. A., 86.

Price, W. F., 17.

Pridgeon, U. S. vs, 160.

Prince, L. H., 95.

Prisons.

(See also penitentiaries and reformatories.)

Auburn State Prison, N. Y., 84.

California State Prison, San Quentin, 60.

California State Prison, Folsom, 61 .

Clinton State Prison, Dannemora, N. Y., 84.

Connecticut State Prison, Wethersfield, 61.

Great Meadows Prison, Comstock, N. Y, 84.

Indiana State Prison, Michigan City, 64.

Indiana Woman's Prison, Indianapolis, 64 .

Indiana State Farm, 64.

Industrial Farm for Women, Neb., 79 .

New Jersey State Prison, Trenton, 80.

Sing Sing Prison, Ossining, N. Y., 84.

State Prison, Nevada, 245.

State Prison, Waupun, Wis., 94.

Western House of Refuge for Women, N. Y., 85 .

Procreate, 447, 455.

Propositus, 362 .

Prostate. 398, 426.

Protein sensitization, 377.

Protoplasm, 401.

Ptosis, 374.

Punishment, cruel and unusual, 442.

Punitive motive, 101.

Q.

Quarantine, 133, 341, 438 .

\section{R.}

Radio-ulnar synarthrosis, 373 .

Rathke, duct of, 397 .

Raymond, P. H., 91.

Raynaud's disease, 378 .

Read, Horace D., 15 .

Recessive traits, 365,381

Records, 137, 271, 448.

Redmon, State of Wisconsin vs., 238 .

Reformatories-

(See also Penitentiaries and Prisons.)

Clinton, New Jersey, 80.
Eastern New York Reformatory, 84 .

Green Bay, Wisconsin, 94.

Industrial Home for Women, Wisconsin, 95.

Industrial Reformatory, Kansas, 73.

Jeffersonville, Indiana, $\mathbf{6 3}$ 256,312 .

Monroe, Washington, 91.

New York State Reformatory, 84.

Rahway, New Jersey, 80.

Reformatory for Women, 85 Reily, John A., 55, 58.

Rem. \& Bal. Code, 153.

Remser, W., 80.

Rentoul, Dr. R. R., 355, 433

Repeals, 1, 26.

Reports, compulsory, 357.

Research institutions, 392.

Rete testis, 397, 400.

Retinitis pigmentosa, 374 .

Reynolds, Nora, 3, 143, 144, 203 . $291,305$.

Rheumatism, 378.

Richard, John Lewis, 58.

Richards, Robert Lewis, 55 .

Right-handedness, 375 .

Robb, State vs., 239.

Roberg, Dr. David N., 89.

Robinson, Dr. C. A., 60.

Roentgen, W. K., 412.

Rosenfeld, Dr. Ernst, 120.

Ross, Dr. John R., 84.

Rudd, Honorable William P., 4. $221,222,231$.

Ruppenthal, Judge J. C., 347.

Ryon, Dr. Walter G., 85.

s.

Sadler, Dr. William S., 122

Sage, Henry M., 26.

Salpingectomy, $96,111,419,422$, 435.

Salpingo-oöphorectomy, $\mathbf{4 1 5}$.

Santa Clara County vs. So. Pacific R. R. Co., 239.

Saunders, James C., 179.

Schweizerische Zeitschrift für Strafrecht, 119

Scoliosis, 378 .

Scott, A. B., 29.

Scott, K. W., 61 .

Scrotum, 398.

Seaboard Air Line Ry. vs. R. R. Com. of Ga., 198.

Segregation, 350, 439 .

Sellers, Dr. L. R., 71

Seminal vesicles, 400

Sex-linked traits, 365,383

Shanahan, Dr. William T., 85.

Sharp, Dr. Harry C., 119, 145 ,

$156,161,196,231,237,255$ $323,328,351$,

Shelton vs. Platt, 192.

Shenango vs. Wayne, 171.

Shideler, George A. H., 256.

Shumway, H. P., 32 .

Siler vs. Louisville \& Nashville R. R., 199, 200 .

Simon vs. Craft, 240. 
Skin, 373.

Slaught, Dr. A. W., 23. Sleyster, Dr. Rock, 95.

Smith, Alfred E., 26.

Smith, Alice, 1, 2, 142, 164, 188, $206,210,215,233,236,237$, 251, 291, 292 .

Smith, Andrew C., 271.

Smith, Dr. G. A., 87.

Smith, J. J., 61.

Smith, Dr. J. N., 90, 271.

Smith, Jessie Spaulding, 121.

Smith, Walter I., 191.

Smith, Warren Wallace, 146, 255, 291, 312.

Smyth, Dr. Margaret H., 410 411, 418 .

Social inadequates, 369,430 , 446, 455.

Societies, 392.

Sonoma State Home, 7, 18, 19, $55,59$.

South Dakota, 3, 13, 34, 90, 96, $100,101,102,104,106,113$ $117,119,125,130,132,135$ 138.

Southern California State Hospital, $55,58$.

Spastic paraplegia, $\mathbf{3 7 9}$.

Spaying, 414, 428.

Spermatozoon, 397, 398, 400, 401 . 402.

Spermectomy, 410.

Splenic anemia, 378.

Sproul, William C., 39 .

St. Johnsbury, State Board of Health vs., 239.

St. Louis vs. Galt, 239

Stansbury, Ele, Attorney General, 257.

Statistics, institutional, 52.

Steinach, 429.

Steiner, Dr. R. E. Lee, 89, 271.

Steno, Nicolaus, 404.

Stephens, William D., 19.

Sterilization, $53,56,57,277$, $338,351,360,447,456$.

Stewart, R. A., 69.

Stocking, Leonard, 55.

Stockton State Hospital, 54, 56.

Stroti vs. Commonwealth, Mass. 252.

Sturtevant vs. Commonwealth, Mass, 187.

Stuttering or Stammering, 378.

Sumner, Dr. Guilford H., 69.

Suprarenal cortex, 426.

Surgery, 407.

Sydenham's Chorea (St. Vitus' dance), 375.

Smyphalangy, 372.

Syndactyly, 372 .

\section{T.}

Taber, Honorable E. J. L., Judge 243.

Talent, 375 .

Talkington, C. E., 64 .

Tappins, M. J., 94.

Teeth, 376, 377 .

Telangiectasis, 378 .

Temperament, $\mathbf{3 7 5}$.
Testes, 399, 425 .

Testes muliebres, 404 .

Testiectomy, 434 .

Thalassophilia, 377 .

Thatcher, George B., Attorney General, 248, 250.

Thayer, Ethel H., 54.

Thayer, Dr, W. N., Jr., 84.

Therapeutic purpose, 100, 127, 436.

Thigh-bones (dislocation), 379

Thomson's disease, 376 .

Thomson, Dr. Lemon, 2, 82, 144, 217,306 .

Thorn, George B., 81.

Thyroid, 426.

Thymus, 426

Todd, Arthur J., 120, 121.

Tomlinson, Wilbur F., 19.

Toothlessness, 377 .

Topeka State Hospital, 70.

Traits, list of, 365,372 .

Traverse City State Hospital, 73.

Treat, F, S., 68

Tremor, 379.

Trenton State Hospital, 80.

Tubectomy, $\mathbf{5 6}$.

Tubuli recti, 400 .

Turpin vs. Lemon, 199.

Twice in jeopardy of life and limb, 442

Twins, 377 .

Tyler vs. Judges, 199.

Tylosis palmae et plantae, 373 .

Tyrrell, Edward J., 18.

ช.

Universities, 393

Urethra, 398.

Urogenital sinus, 398.

Utah, 343 .

Uterectomy, 111.

Uterus, $397,403,405$.

\section{v.}

Vaccination, $130,133,339,438$.

Vagina, 397.

Van Wagenen, Dr. Bleeker, 225, 236.

Van Waters, State vs., 149, 154.

Vasa deferentia, 111, 397, 398, $400,405,406,408,410,411$, 422,435,

Vasa efferentia, 397,400 .

Vasectomy, $56,96,130,325,327$ $329,352,410,434$.

Venereal Diseases, 343, 345.

Vermont, 1, 43, 344.

Vetoes, $1,35,36,38,40,45,47$, 50.

Viemeister and Jacobsen vs. Commonwealth, Mass., 233, 240.

Virginia, 344.

Vita sexualis, 425 .

Vitiligo, 373 .

Voldeng, Dr. M. N., 66, 69.

Von Recklinghausen's disease 378. w.

Wagner, Dr. Charles G., 86

Walker vs. Jameson, 239.

Wanderlust, 377.

Wansboro, Dr. William J., 82 , $144,217$.

Washington, 1, 4, 6, 15, 91, 96, $99,100,101,103,104,105$, $107,110,111,112,115,118$, $124,129,131,136,137,139$, 142,344 .

Webb, U. S. Attorney General, 328.

Webbed toes, 377 .

Weeks, Dr. David F., 164, 291, 297.

Weeks, F. B., 19 .

Weems, $61,162,173,189,197$, $231,249,252$.

Werner, H. C., 95 .

West, Oswald, 42.

Western House of Refuge, N. Y., 85.

Whalen vs. Dalahsmutt, 192.

Wharton, Criminal Law, 197.

White, B. H., 23.

White, State vs., 249.

Whitten vs. State, $155,160,162$, $197,249,251,330$.

Wilcox, F. S., 62.

Wilkerson vs. Utah, 162, 197.

Williams vs. Boynton, 187.

Williams, Dr. Charles F., 146, 256.

Williams, H. W., 94.

Williams, Sidney, 152.

Williams, State vs., $155,160$. 162,197

Williams, William B. J., 206.

Wilmarth, Dr. A. W., 95.

Wilson, Woodrow, 23.

Wisconsin, 2, 12, 31, 92, 96, 100 $101,102,103,106,109,110$, $111,113,116,118,125,126$, $129,132,135,138,140,149$, 344 .

Wisconsin State Board of Contro1, 93 .

Withycombe, James, 33.

Witte, Max E., 67, 69.

Witthaus and Becker, 159 .

Wolffian bodies, 397 .

Woodbury, Egburt E., 221.

Woodruff vs. New York and New England Railroad Company, 327

Woodward, Dr. George, 36.

Woodward, State vs., 161, 330.

Worbeck, Peter, 34.

Wyatt's Case, 162, 197, 250.

Wylie, Dr. A. R. T., 87 .

x.

$\mathrm{X}$-rays, $112,119,133,407,412$ 421, 422 .

\section{$\mathbf{z}$}

Zeitschrift für die gesamte Strafrechtswissenschaft, 120. Zona pellucida, 406 .

Zuhlke, Daniel F., 205.

Zygote, 404. 



\section{Date Due}

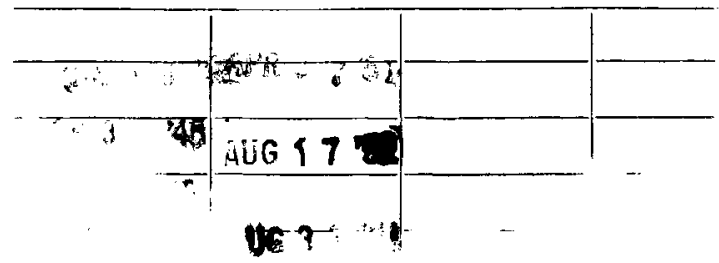




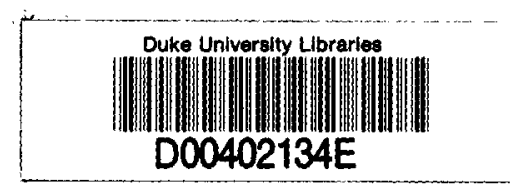
613.94
LO74E
179272 
